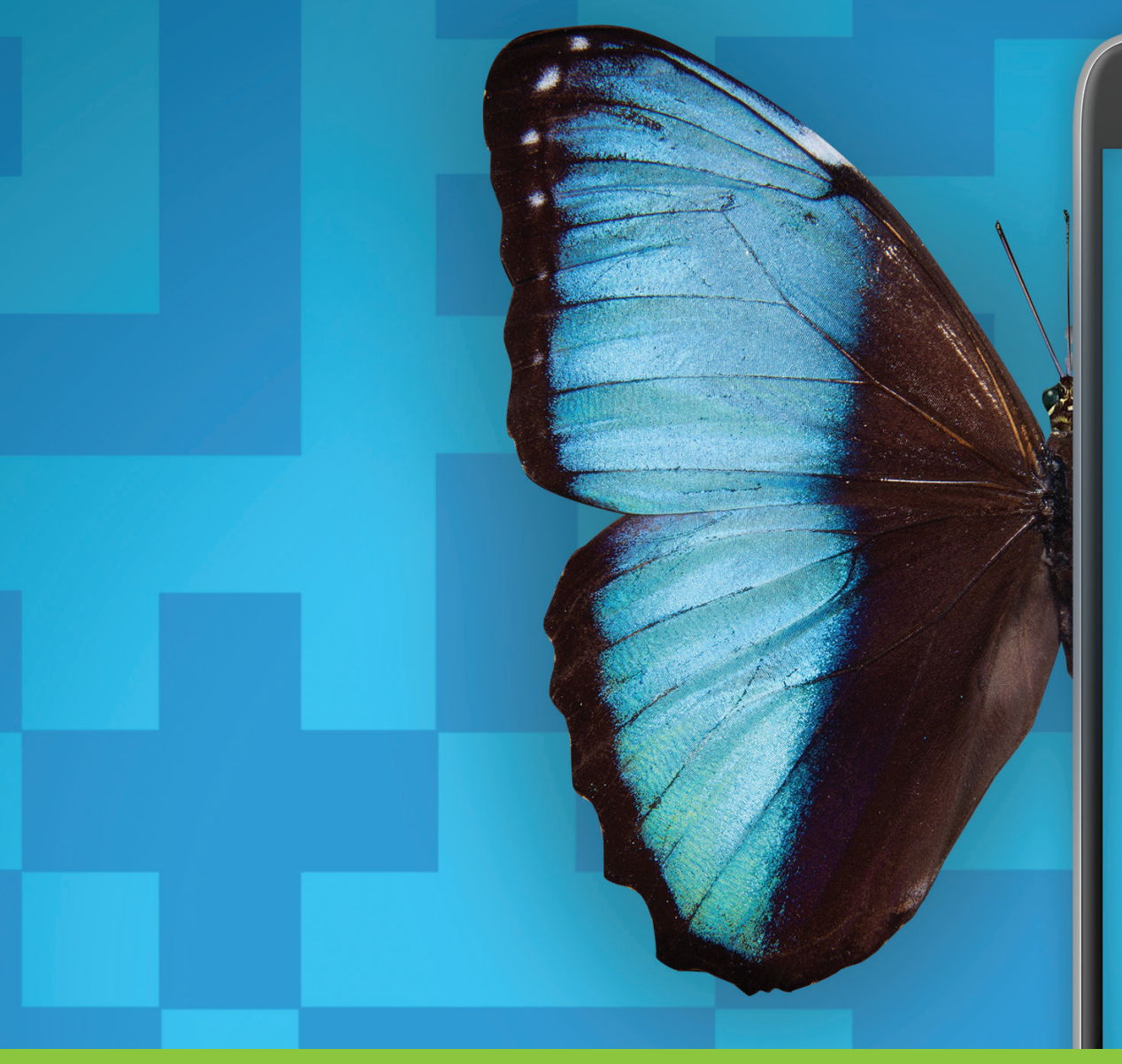

\title{
KEY INDICATORS \\ FOR ASIA AND THE PACIFIC
}

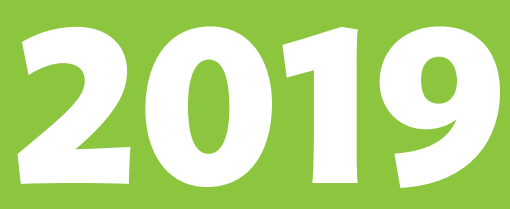

\section{TH EDITION}

SEPTEMBER 2019 


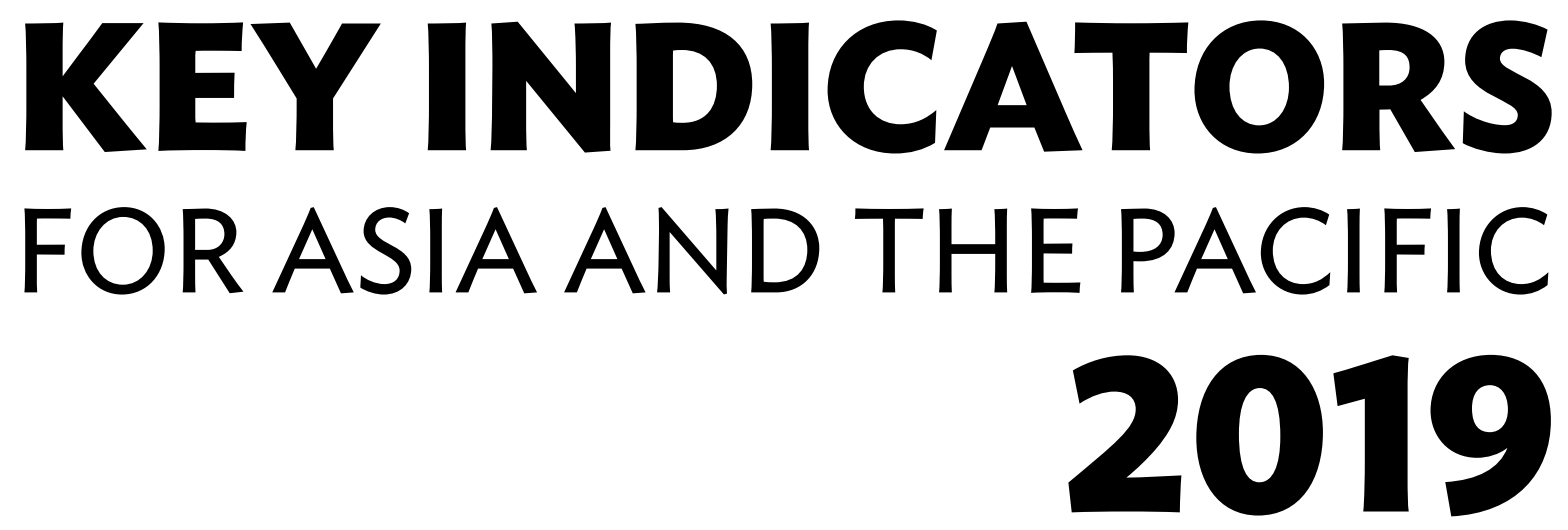

50TH EDITION 
(C) 2019 Asian Development Bank 6 ADB Avenue, Mandaluyong City, 1550 Metro Manila, Philippines

Tel +632632 4444; Fax +6326362444

www.adb.org

Some rights reserved. Published in 2019.

ISBN 978-92-9261-724-0 (print), 978-92-9261-725-7 (electronic)

ISSN $0116-3000$

Publication Stock No. FLS190428-3

DOI: http://dx.doi.org/10.22617/FLS190428-3

The views expressed in this publication are those of the authors and do not necessarily reflect the views and policies of the Asian Development Bank (ADB) or its Board of Governors or the governments they represent.

ADB does not guarantee the accuracy of the data included in this publication and accepts no responsibility for any consequence of their use. The mention of specific companies or products of manufacturers does not imply that they are endorsed or recommended by ADB in preference to others of a similar nature that are not mentioned.

By making any designation of or reference to a particular territory or geographic area, or by using the term "country" in this document, $A D B$ does not intend to make any judgments as to the legal or other status of any territory or area.

This work is available under the Creative Commons Attribution 3.0 IGO license (CC BY 3.0 IGO) https://creativecommons.org/licenses/by/3.0/igo/. By using the content of this publication, you agree to be bound by the terms of this license. For attribution, translations, adaptations, and permissions, please read the provisions and terms of use at https://www.adb.org/terms-use\#openaccess

This CC license does not apply to non-ADB copyright materials in this publication. If the material is attributed to another source, please contact the copyright owner or publisher of that source for permission to reproduce it. $A D B$ cannot be held liable for any claims that arise as a result of your use of the material.

Please contact pubsmarketing@adb.org if you have questions or comments with respect to content, or if you wish to obtain copyright permission for your intended use that does not fall within these terms, or for permission to use the ADB logo.

Notes:

In this publication, “\$” refers to US dollars.

Corrigenda to ADB publications may be found at http://www.adb.org/publications/corrigenda

Cover photo:

Cover design by Marjorie G. Ofaga. On the cover: The design for this publication is inspired by the symbolism associated with butterflies, representing transformation and change. The emergence of new technologies has spearheaded a switch from traditional methods of collecting and compiling data to a more innovative statistical ecosystem. This digital transformation has expanded the possibilities for enhanced human-data interaction, paving the way to a better understanding of our world. 


\section{Contents}

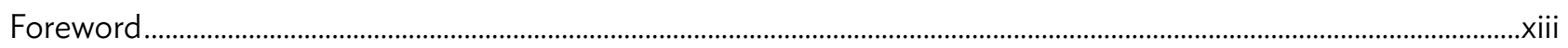

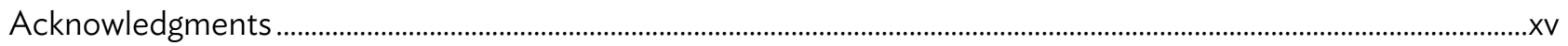

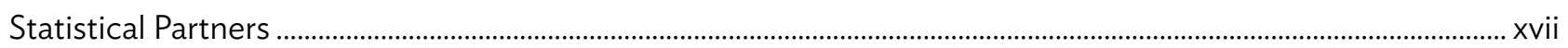

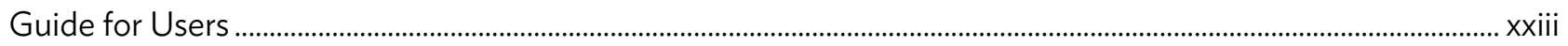

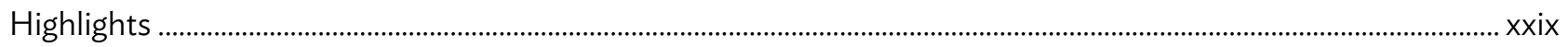

\section{PART I: Sustainable Development Goals Trends and Tables}

Sustainable Development Goals－Data Stories..........................................................................................................................

SDG 1. End poverty in all its forms everywhere ............................................................................................................... 4

SDG 2. End hunger, achieve food security and improved nutrition, and promote sustainable agriculture ..........5

SDG 3. Ensure healthy lives and promote well-being for all at all ages................................................................... 6

SDG 4. Ensure inclusive and equitable quality education and promote lifelong learning opportunities for all ..... 8

SDG 5. Achieve gender equality and empower all women and girls ........................................................................ 10

SDG 6. Ensure availability and sustainable management of water and sanitation for all...........................................11

SDG 7. Ensure access to affordable, reliable, sustainable, and modern energy for all ............................................13

SDG 8. Promote sustained, inclusive, and sustainable economic growth;

full and productive employment; and decent work for all .........................................................................14

SDG 9. Build resilient infrastructure, promote inclusive and sustainable industrialization,

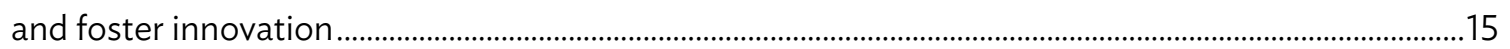

SDG 10. Reduce inequality within and among countries ..........................................................................................16

SDG 11. Make cities and human settlements inclusive, safe, resilient, and sustainable............................................18

SDG 12. Ensure sustainable consumption and production patterns ...............................................................................19

SDG 13. Take urgent action to combat climate change and its impacts ......................................................................21

SDG 14. Conserve and sustainably use the oceans, seas, and marine resources

for sustainable development ....................................................................................................................2 22

SDG 15. Protect, restore, and promote sustainable use of terrestrial ecosystems; sustainably manage forests; combat desertification; halt and reverse land degradation; and halt biodiversity loss...........................23

SDG 16. Promote peaceful and inclusive societies for sustainable development; provide access to justice for all; and build effective, accountable, and inclusive institutions at all levels ...................25

SDG 17. Strengthen the means of implementation and revitalize the Global Partnership for Sustainable

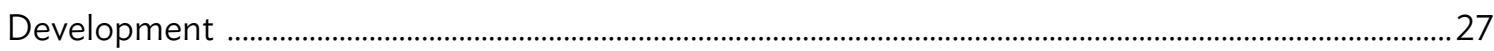

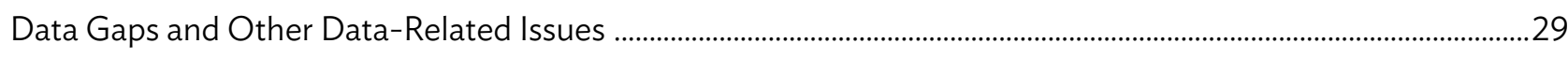

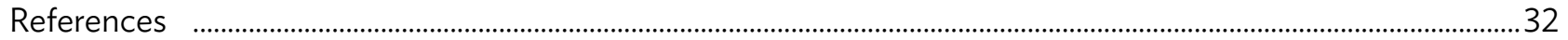

\section{Figures}

Figure 1.1.1: Proportion and Number of People Living in Extreme Poverty ................................................................... 4

Figure 1.1.2: Proportion of Employed Population Living below the International Poverty Line ..............................5

Figure 1.2.1: Prevalence of Undernourishment in Select Economies of Asia and the Pacific ................................... 6

Figure 1.2.2: Prevalence of Stunting among Children under 5 Years of Age .................................................................7 
Figure 1.3.1: Maternal Mortality Ratios and Proportion of Births Attended by Skilled Health Personnel ............7

Figure 1.3.2: Under-5 Mortality Rate by Region and Subregion of Asia and the Pacific.......................................... 8

Figure 1.4.1: Participation Rate in Preprimary Learning by Sex of Child, 2017 ............................................................. 9

Figure 1.4.2: Proportion of Teachers in Primary Education Who Have Received at Least the Minimum

Organized Teacher Training ...................................................................................................................... 10

Figure 1.5.1: Proportion of Women Who Were Married or in a Union before Age 15 or Age 18 ........................... 10

Figure 1.5.2: Proportion of Seats in National Parliament Held by Women, 2018..........................................................11

Figure 1.6.1: Proportion of the Population Using Safely Managed Drinking Water Services, 2017 ........................12

Figure 1.6.2: Proportion of Population Using Safely Managed Sanitation Services, 2017 .........................................12

Figure 1.7.1: Proportion of the Population with Access to Electricity .............................................................................13

Figure 1.7.2: Proportion of Population with Primary Reliance on Clean Fuels and Technology ...............................14

Figure 1.8.1: Unemployment Rate by Age Group, 2017 or Most Recent Year Prior ....................................................15

Figure 1.9.1: Manufacturing Value-Added per Capita........................................................................................................16

Figure 1.9.2: Carbon Dioxide Emissions per Unit of Manufacturing Value-Added ....................................................17

Figure 1.10.1: Growth Rates of Household Expenditure or Income per Capita, 2009-2017 ....................................17

Figure 1.11.1: Proportion of Urban Population Living in Slums, 2000 and 2016 .......................................................18

Figure 1.11.2: Annual Mean Levels of Fine Particulate Matter in Cities of Asia and the Pacific's Most Populous Economies, 2016 ................................................................................19

Figure 1.12.1: Material Footprint per Capita and Gross Domestic Product per Capita, 2017.................................. 20

Figure 1.12.2: Domestic Material Consumption per Capita ...............................................................................................21

Figure 1.13.1: Score Measuring Alignment of National Disaster Risk Strategy with Sendai Framework, 2018 ....22

Figure 1.14.1: Proportion of Protected Marine Area to Total Marine Area, 2018 ........................................................23

Figure 1.15.1: Proportion of Forested Area to Total Land Area, 2016 ............................................................................24

Figure 1.15.2: Red List Index Scores for Select Economies of Asia and the Pacific ....................................................25

Figure 1.16.1: Number of Victims of Intentional Homicide per 100,000 Population .................................................26

Figure 1.16.2: Proportion of Firms Experiencing at Least One Bribe Payment Request ..............................................26

Figure 1.17.1: Dollar Value of Financial and Technical Assistance Committed to Developing Countries .............27

Figure 1.17.2: Value of All Resources Made Available to Strengthen Statistical Capacity

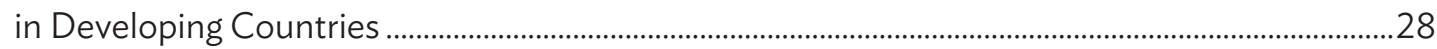

\section{Tables}

Table 1.1.1: $\quad$ Selected Indicators for Sustainable Development Goal 1-No Poverty ….............................................33

Table 1.2.1: $\quad$ Selected Indicators for Sustainable Development Goal 2-Zero Hunger .............................................35

Table 1.2.2: Selected Indicators for Sustainable Development Goal 2-Improved Agricultural Investment...36

Table 1.3.1: $\quad$ Selected Indicators for Sustainable Development Goal 3-Maternal and Child Health ..................37

Table 1.3.2: $\quad$ Selected Indicators for Sustainable Development Goal 3-Incidence

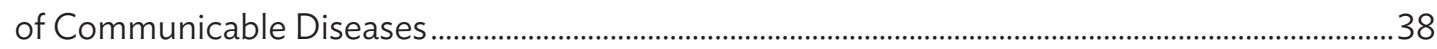

Table 1.3.3: Selected Indicators for Sustainable Development Goal 3-Mortality Rates, Health ........................39

Table 1.4.1: $\quad$ Selected Indicators for Sustainable Development Goal 4-Early Childhood Education ...................41

Table 1.4.2: Selected Indicators for Sustainable Development Goal 4-Teacher Training and Supply..............42

Table 1.5.1: $\quad$ Selected Indicators for Sustainable Development Goal 5-Early Marriage and Women in Leadership. 
Table 1.6.1: $\quad$ Selected Indicators for Sustainable Development Goal 6-Clean Water and Sanitation ...............44

Table 1.7.1: $\quad$ Selected Indicators for Sustainable Development Goal 7-Affordable and Clean Energy ............. 47

Table 1.8.1: $\quad$ Selected Indicators for Sustainable Development Goal 8-Decent Work

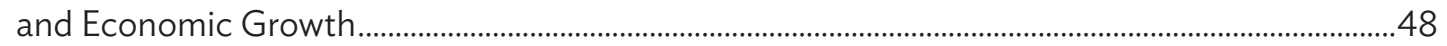

Table 1.8.2: Selected Indicators for Sustainable Development Goal 8-Unemployment .....................................49

Table 1.8.3: Selected Indicators for Sustainable Development Goal 8-Youth Participation in Education and Work, Child Labor .......................................................................................................... 52

Table 1.8.4: Selected Indicators for Sustainable Development Goal 8-Access to Banking, Insurance, and Financial Services; and Trade ........................................................................................................... 53

Table 1.9.1: Selected Indicators for Sustainable Development Goal 9-Road and Rail Transport, Passenger and Freight Volume ..................................................................................................................... 54

Table 1.9.2: Selected Indicators for Sustainable Development Goal 9-Growth in Manufacturing ...................55

Table 1.9.3: Selected Indicators for Sustainable Development Goal 9-Carbon Dioxide Emissions...................56

Table 1.9.4: Selected Indicators for Sustainable Development Goal 9-Research and Development...............57

Table 1.9.5: Selected Indicators for Sustainable Development Goal 9-Official International Support and Industry Value Added .......................................................................................................................... 58

Table 1.9.6: Selected Indicators for Sustainable Development Goal 9-Coverage by Mobile Networks..........59

Table 1.10.1: Selected Indicators for Sustainable Development Goal 10—Household Expenditure

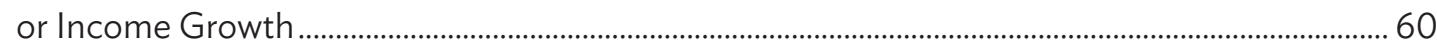

Table 1.11.1: Selected Indicators for Sustainable Development Goal 11-Sustainable Cities and Environment

Table 1.12.1: Selected Indicators for Sustainable Development Goal 12-Responsible Consumption

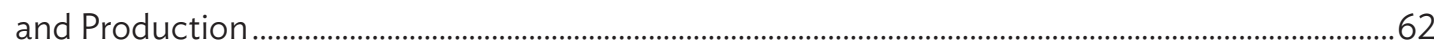

Table 1.13.1: Selected Indicators for Sustainable Development Goal 13-Impact of Disasters and Risk

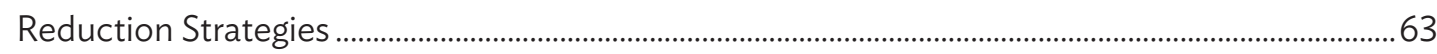

Table 1.14.1: Selected Indicators for Sustainable Development Goal 14_Life Below Water .................................64

Table 1.15.1: Selected Indicators for Sustainable Development Goal 15—Protection of Ecosystems

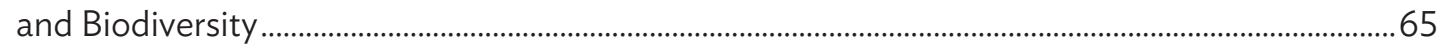

Table 1.16.1: Selected Indicators for Sustainable Development Goal 16_Peace, Justice, and Strong Institutions

Table 1.17.1: Selected Indicators for Sustainable Development Goal 17-Financial Sustainability

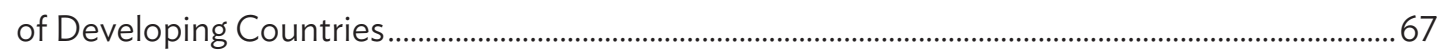

Table 1.17.2: Selected Indicators for Sustainable Development Goal 17-Statistical Capacity Building .............68

\section{PART II: Regional Trends and Tables}

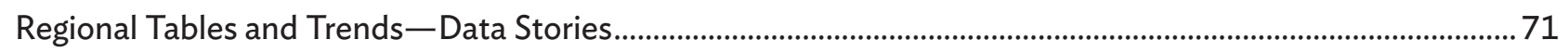

I. People

\section{Population}

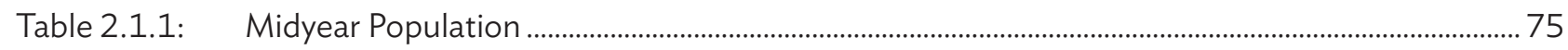

Table 2.1.2: Migration and Urbanization ...................................................................................................................... 76

Table 2.1.3: $\quad$ Proportion of Total Population Aged 0-14 Years and Aged 15-64 Years (\%)............................. 77

Table 2.1.4: $\quad$ Proportion of Total Population Aged 65 Years or Older, and Age Dependency Ratio................ 78 


\section{Labor Force and Employment}

Table 2.1.5: Labor Force Participation Rates (\%) ......................................................................................................... 79

Table 2.1.6: Employment in Agriculture, Industry, and Services (\% of total employment)................................ 80

\section{Poverty Indicators}

Table 2.1.7: Poverty and Inequality. 83

Table 2.1.8: $\quad$ Human Development Index 84

\section{Social Indicators}

Table 2.1.9: Life Expectancy at Birth (years) _....................................................................................................... 85

Table 2.1.10: $\quad$ Births, Deaths, and Fertility Rates ....................................................................................................... 86

Table 2.1.11: Primary Education Completion Rate (\%)................................................................................................ 87

Table 2.1.12: Adult (15 Years and Older) Literacy Rate (\%)................................................................................... 88

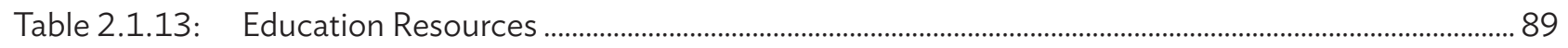

Table 2.1.14: Health Care Resources (per 1,000 population) ................................................................................... 90

Table 2.1.15: Adults Aged 15 Years and Older Living with HIV ('000)................................................................ 91

\section{Economy and Output.}

\section{National Accounts}

Table 2.2.1: $\quad$ Gross Domestic Product at Purchasing Power Parity (current international dollars, million).. 95

Table 2.2.2: Gross Domestic Product (current \$ million) .......................................................................................... 96

Table 2.2.3: $\quad$ Gross Domestic Product per Capita at Purchasing Power Parity

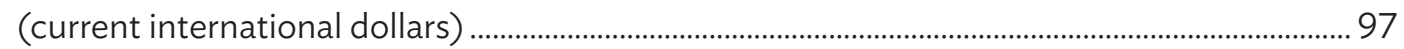

Table 2.2.4: Gross National Income per Capita, Atlas Method (current \$)........................................................... 98

Table 2.2.5: Gross Domestic Product per Capita (current \$) .................................................................................. 99

Table 2.2.6: Agriculture, Industry, and Services Value Added (\% of GDP) .........................................................100

Table 2.2.7: Household and Government Consumption Expenditure (\% of GDP)........................................101

Table 2.2.8: Gross Capital Formation and Changes in Inventories (\% of GDP) ..................................................102

Table 2.2.9: $\quad$ Exports and Imports of Goods and Services (\% of GDP) .................................................................103

Table 2.2.10: Gross Domestic Saving (\% of GDP) .........................................................................................................104

Table 2.2.11: Growth Rates of Real Gross Domestic Product (\%) ...........................................................................105

Table 2.2.12: Growth Rates of Real Gross Domestic Product per Capita (\%)........................................................106

Table 2.2.13: Growth Rates of Agriculture Real Value Added (\%) ..........................................................................107

Table 2.2.14: Growth Rates of Industry Real Value Added (\%) ....................................................................................108

Table 2.2.15: Growth Rates of Services Real Value Added (\%)...............................................................................109

Table 2.2.16: Growth Rates of Real Household Final Consumption (\%) ..............................................................110

Table 2.2.17: Growth Rates of Real Government Consumption Expenditure (\%) ...............................................111

Table 2.2.18: Growth Rates of Real Gross Capital Formation (\%) ..........................................................................112

Table 2.2.19: Growth Rates of Real Exports of Goods and Services (\%) .................................................................113

Table 2.2.20: Growth Rates of Real Imports of Goods and Services (\%) ...............................................................114

\section{Production}

Table 2.2.21: Growth Rates of Agriculture Production Index (\%) ........................................................................115

Table 2.2.22: Growth Rates of Manufacturing Production Index $(\%)$.....................................................................116 


\section{Prices}

Table 2.3.1: Growth Rates of Consumer Price Index (\%).......................................................................................120

Table 2.3.2: Growth Rates of Food and Nonalcoholic Beverages Consumer Price Index (\%)........................121

Table 2.3.3: Growth Rates of Wholesale and/or Producer Price Indexes (\%)....................................................122

Table 2.3.4: Growth Rates of Gross Domestic Product Deflator (\%) ......................................................................123

\section{Money and Finance}

Table 2.3.5: Growth Rates of Money Supply (\%) .......................................................................................................

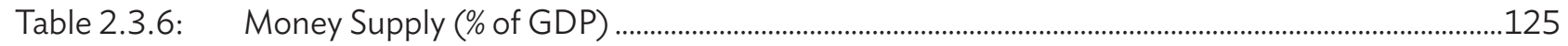

Table 2.3.7: Interest Rates on Savings and Time Deposits (\% per annum, period averages)...........................126

Table 2.3.8: Yield on Short-Term Treasury Bills and Lending Interest Rates

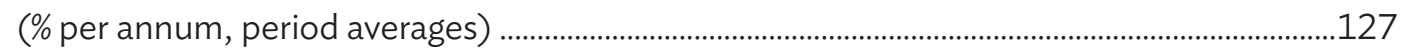

Table 2.3.9: Domestic Credit Provided by Banking Sector and Bank Nonperforming Loans.........................128

Table 2.3.10: Growth Rates of Stock Market Price Index (\%) ...............................................................................129

Table 2.3.11: Stock Market Capitalization ...........................................................................................................................

\section{Exchange Rates}

Table 2.3.12: Official Exchange Rates (local currency units per \$, period averages).

Table 2.3.13: Purchasing Power Parity Conversion Factor (local currency units per \$, period averages).....132

Table 2.3.14: Price Level Indexes (PPPs to official exchange rates, period averages,

United States $=100$ ).

IV. Globalization

\section{Balance of Payments}

Table 2.4.1: $\quad$ Trade in Goods Balance (\% of GDP) ........ . .138

Table 2.4.2: Trade in Services Balance (\% of GDP) ………………………….........................................................139

Table 2.4.3: Current Account Balance (\% of GDP) .............................................................................................140

Table 2.4.4: Workers' Remittances and Compensation of Employees, Receipts (\$ million) .........................141

Table 2.4.5: Workers' Remittances and Compensation of Employees, Receipts (\% of GDP) ........................142

Table 2.4.6: Foreign Direct Investment, Net Inflows (\$ million) ...........................................................................143

Table 2.4.7: Foreign Direct Investment, Net Inflows (\% of GDP) ..........................................................................144

\section{External Trade}

Table 2.4.8:

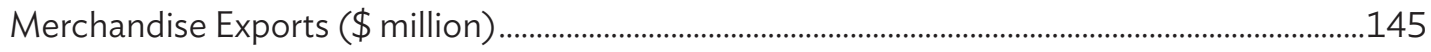

Table 2.4.9: Growth Rates of Merchandise Exports (\%) ..............................................................................................146

Table 2.4.10: Merchandise Imports (\$ million) ...........................................................................................................

Table 2.4.11: Growth Rates of Merchandise Imports (\%)...........................................................................................148

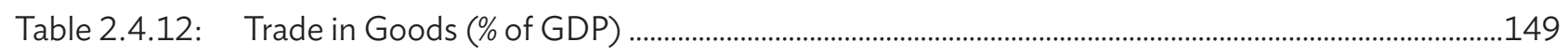

Table 2.4.13: $\quad$ Direction of Trade: Merchandise Exports (\% of total merchandise exports) .............................150

Table 2.4.14: $\quad$ Direction of Trade: Merchandise Imports (\% of total merchandise imports) ................................151 


\section{International Reserves}

Table 2.4.15: International Reserves and Ratio to Imports.

\section{Capital Flows}

Table 2.4.16: Net Official Development Assistance from All Sources to Developing Economies

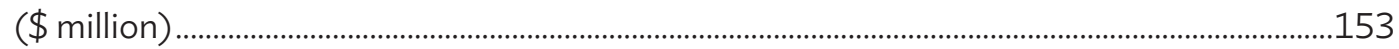

Table 2.4.17: Net Other Official Flows from All Sources to Developing Economies (\$ million) .....................154

Table 2.4.18: Net Private Flows from All Sources to Developing Economies (\$ million)..................................155

Table 2.4.19: Aggregate Net Resource Flows from All Sources to Developing Economies (\$ million)........156

\section{External Indebtedness}

Table 2.4.20: Total External Debt of Developing Economies (\$ million)...................................................................157

Table 2.4.21: Total External Debt of Developing ADB Member Economies (\% of GNI)...................................158

Table 2.4.22: Total External Debt of Developing ADB Member Economies

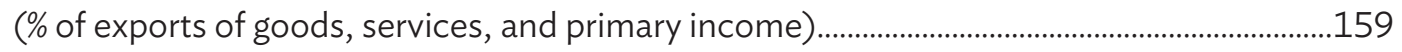

Table 2.4.23: Total Debt Service Paid by Developing ADB Member Economies .................................................160

\section{Tourism}

Table 2.4.24: International Tourist Arrivals ('000)

Table 2.4.25: International Tourism Receipts (\$ million).

\section{Transport}

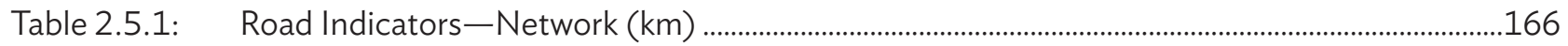

Table 2.5.2: Road Indicators_Vehicles......................................................................................................................167

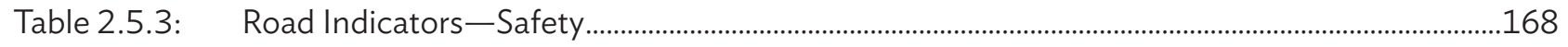

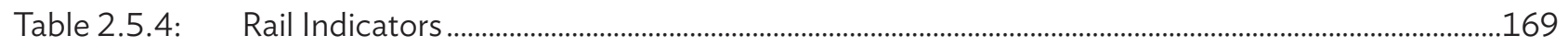

Table 2.5.5: Railways-Passengers Carried and Goods Transported.....................................................................170

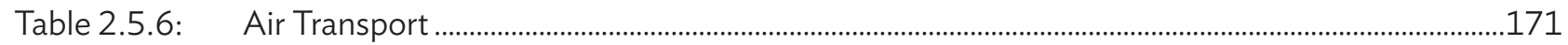

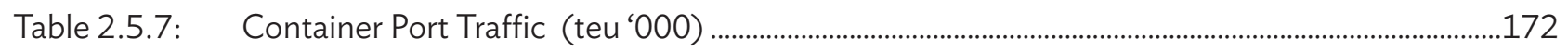

\section{Communications}

Table 2.5.8: Access to Fixed Telephone, Mobile Phones, and Internet ('000)...................................................173

Table 2.5.9: $\quad$ Access to Fixed Telephone, Mobile Phones, and Internet (per 100 people)..............................174

\section{Energy and Electricity}

\section{Electricity}

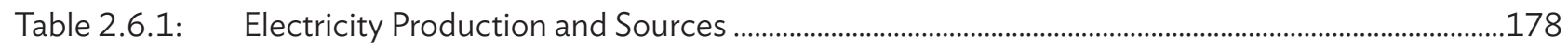

Table 2.6.2: Electric Power Consumption and Electrification ................................................................................179 


\section{Energy}

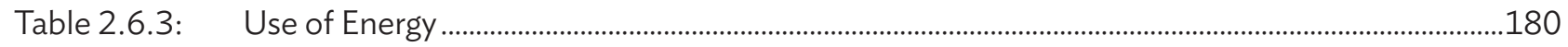

Table 2.6.4: Energy Production and Imports ..............................................................................................................

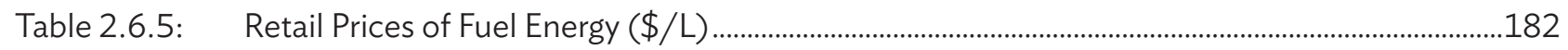

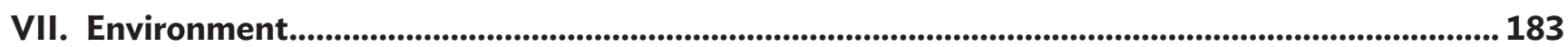

\section{Land}

Table 2.7.1: $\quad$ Agriculture Land Use (\% of total land area) .................................................................................185

\section{Pollution}

Table 2.7.2: Deforestation and Pollution ......................................................................................................................186

\section{Freshwater}

Table 2.7.3: Freshwater Resources.

VIII. Government and Governance

\section{Government Finance}

Table 2.8.1: Government Net Lending/Net Borrowing (\% of GDP)......................................................................192

Table 2.8.2: Government Taxes (\% of GDP) .................................................................................................................

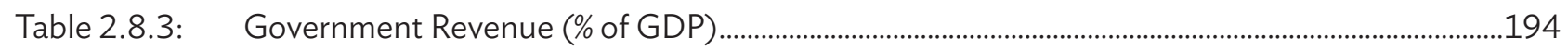

Table 2.8.4: Government Expenditure (\% of GDP) ...................................................................................................195

Table 2.8.5: Government Expenditure by Economic Activity (\% of GDP) ...............................................................196

\section{Governance}

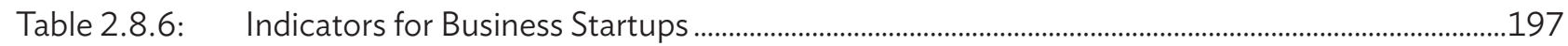

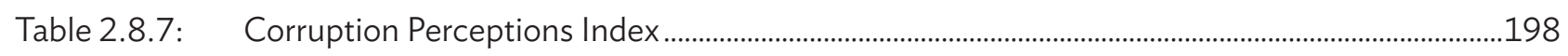

References.

\section{Figures}

Figure 2.1.1: Distribution of Population by Global Region and by Economy in Asia and the Pacific, $2018(\%)$

Figure 2.1.2: Primary Education Completion Rate, by Sex: (percentage point difference between earliest and most recently available annual data) .............................................................. 73

Figure 2.2.1: Global Distribution of Gross Domestic Product at Purchasing Power Parity (\%) ........................ 92

Figure 2.2.2: Growth Rates of Real Gross Domestic Product in Asia's Five Largest Economies (\%) ............... 93

Figure 2.3.1: Inflation Rates in Select Economies of Asia and the Pacific (\% annual change).........................117

Figure 2.3.2: Nonperforming Bank Loans in Select Economies of Asia and the Pacific (\% of total gross loans). 
Figure 2.4.1: Remittances, Foreign Direct Investment, and Official Development Assistance in ADB Developing Member Economies

Figure 2.4.2: Intraregional Merchandise Exports in Asia and the Pacific

(\% of total merchandise exports)...

Figure 2.4.3: Intraregional Merchandise Imports in Asia and the Pacific

(\% of total merchandise imports).

Figure 2.4.4: Total Merchandise Exports by Subregion within Asia and the Pacific ...

Figure 2.5.1: Air Carrier Departures by Subregion within Asia and the Pacific ('000) .163

Figure 2.5.2: Proportion of Internet Users in Select Economies of Asia and the Pacific (per 100 population)

Figure 2.6.1: Energy Use by the Five Most Populous Economies in Asia and the Pacific

(GDP per unit use of energy).

Figure 2.6.2 Energy production by global region and by economy in Asia and the Pacific, 2016

(petajoules, \%)...

Figure 2.6.3: Net Energy Imports as Share of Energy Use in Select Economies of Asia and the Pacific (\%)

Figure 2.7.1: Deforestation Rates in Select Economies of Asia and the Pacific, 2016 (\%)......

Figure 2.7.2: Change in Carbon Dioxide Emissions in Select Economies of Asia and the Pacific, 2000-2014 (t '000 per capita) .184

Figure 2.8.1: Government Taxes as a Proportion of Gross Domestic Product in Select Economies of Asia and the Pacific (\%).

Figure 2.8.2: Time Required to Start a Business in Select Economies of Asia and the Pacific (days)............190

\section{PART III: Global Value Chains}

The Evolving Dynamics of Domestic Value-Added in Asia . 202

Asia's Role in Sending and Receiving Domestic Value-Added in Exports................................................................203

Where Does Asia's Domestic Value-Added Go? .....................................................................................................204

Where Does the Domestic Value-Added Received by Asia Come From? ..................................................................205

The Evolving Dynamics of Domestic Value-Added within Asia .................................................................................205

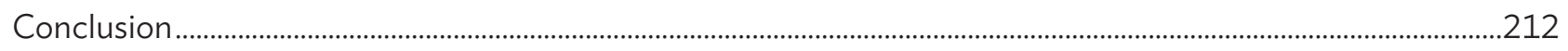

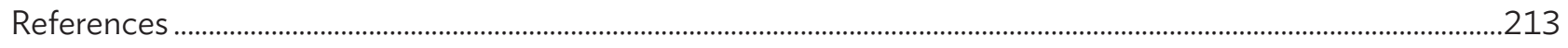

\section{Tables}

Table 3.2.1a: Value-Added Decomposition of Exports-Primary Sector ...............................................................214

Table 3.2.1b: Value-Added Decomposition of Exports-Low-Technology Manufacturing Sector ...............216

Table 3.2.1c: Value-Added Decomposition of Exports-Medium-and High-Technology

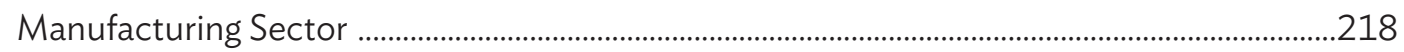

Table 3.2.1d: Value-Added Decomposition of Exports-Business Services Sector .............................................220

Table 3.2.1e: Value-Added Decomposition of Exports-Personal Services Sector..............................................222

Table 3.2.1f: Value-Added Decomposition of Exports-All Sectors .....................................................................224

Table 3.2.2a: Value-Added Exports by Various Measures - Primary Sector .............................................................226 
Table 3.2.2b:

Table 3.2.2c:

Table 3.2.2d:

Table 3.2.2e:

Table 3.2.2f:

Table 3.2.3a:

Table 3.2.3b:

Table 3.2.4.a:

Table 3.2.4.b:

Table 3.2.4.c:

Table 3.2.4.d:

Table 3.2.4.e:

Table 3.2.4.f:

Table 3.2.4.g:

Table 3.2.4.h:

Table 3.2.4.i:

Table 3.2.4.j:

Table 3.2.4.k:

Table 3.2.4.I:

Table 3.2.4.m:

Table 3.2.4.n:

Table 3.2.4.o:

Table 3.2.4.p:

Table 3.2.4.q:

Table 3.2.4.r:

Table 3.2.4.s:

Table 3.2.4.t:

Table 3.2.4.u:

Table 3.2.4.v:

Table 3.2.4.w:

Table 3.2.4.x:

Table 3.2.4.y:
Value-Added Exports by Various Measures-Low-Technology Manufacturing Sector ..........228

Value-Added Exports by Various Measures-Medium- and High-Technology

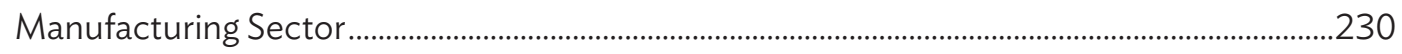

Value-Added Exports by Various Measures-Business Services Sector .......................................232

Value-Added Exports by Various Measures_-Personal Services Sector ........................................234

Value-Added Exports by Various Measures-All Sectors ..............................................................236

Revealed Comparative Advantage by Aggregate Sector (Traditional Method) ...........................238

Revealed Comparative Advantage by Aggregate Sector (Value-Added Method).....................241

Vertical Specialization, Disaggregated_Bangladesh .....................................................................2.24

Vertical Specialization, Disaggregated_Bhutan.........................................................................24

Vertical Specialization, Disaggregated-Brunei Darussalam .............................................................24

Vertical Specialization, Disaggregated-Cambodia ..........................................................................24

Vertical Specialization, Disaggregated-China, People's Republic of ...........................................245

Vertical Specialization, Disaggregated_Fiji................................................................................245

Vertical Specialization, Disaggregated_Hong Kong, China .........................................................24

Vertical Specialization, Disaggregated-India ................................................................................245

Vertical Specialization, Disaggregated - Indonesia.............................................................................24

Vertical Specialization, Disaggregated_Japan ................................................................................24

Vertical Specialization, Disaggregated_Kazakhstan ......................................................................246

Vertical Specialization, Disaggregated-Korea, Republic of .............................................................246

Vertical Specialization, Disaggregated_Kyrgyz Republic ...............................................................24

Vertical Specialization, Disaggregated-Lao People’s Democratic Republic ..............................247

Vertical Specialization, Disaggregated-Malaysia..............................................................................247

Vertical Specialization, Disaggregated-Maldives ........................................................................24

Vertical Specialization, Disaggregated-Mongolia ..............................................................................24

Vertical Specialization, Disaggregated-Nepal ............................................................................248

Vertical Specialization, Disaggregated_Pakistan.................................................................................248

Vertical Specialization, Disaggregated_Philippines .......................................................................24

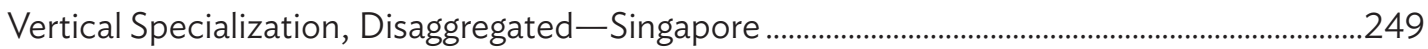

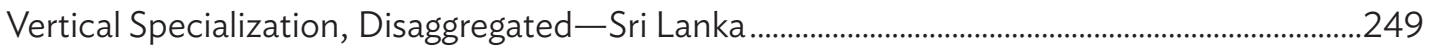

Vertical Specialization, Disaggregated-Taipei,China ..................................................................249

Vertical Specialization, Disaggregated —Thailand ..........................................................................249

Vertical Specialization, Disaggregated_Viet Nam .............................................................................250

\section{Figures}

Figure 3.1.1: Asia's Role in the Global Transfer of Domestic Value-Added in Exports ...................................203

Figure 3.1.2: Transfer of Domestic Value-Added in Exports by Region ..................................................................204

Figure 3.1.3: Intraregional Flow of Asia's Domestic Value-Added Generated in Exports, All Sectors..........206

Figure 3.1.4: Intraregional Flow of Asia's Domestic Value-Added Generated in Exports,

Primary Sector... 208

Figure 3.1.5: Intraregional Flow of Asia's Domestic Value-Added Generated in Exports, Low-Technology Industrial Sector. .209 
Figure 3.1.6: Intraregional Flow of Asia's Domestic Value-Added Generated in Exports, Medium- toHigh-Technology Industrial Sector

Figure 3.1.7. Intraregional Flow of Asia's Domestic Value-Added Generated in Exports, Business Services Sector

Figure 3.1.8: Intraregional Flow of Asia's Domestic Value-Added Generated in Exports, Personal and Public Services Sector...

\section{Definitions}

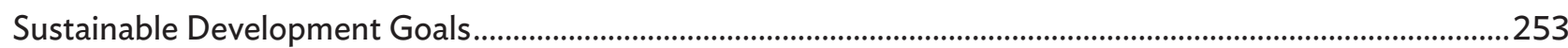

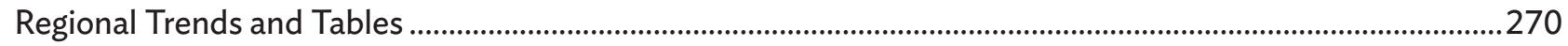

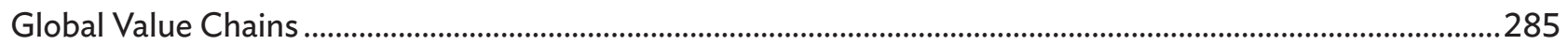




\section{Foreword}

This edition of Key Indicators for Asia and the Pacific marks 50 years of the flagship statistical publication of the Asian Development Bank (ADB). In July 1969, Key Indicators of Developing Member Countries of $A D B$ was first published as an internal reference document, providing data on each of the 17 developing economies that were ADB members at the time.

Just as we have seen many changes across our region over half a century, Key Indicators for Asia and the Pacific has reflected these changes. Today, the publication contains a comprehensive set of economic, social, and environmental statistics, including indicators of the Sustainable Development Goals (SDG). Covering the 49 regional members of ADB, Key Indicators for Asia and the Pacific now reaches out to a broad audience that includes policymakers, development practitioners, government officials, researchers, students, and the general public. Beginning this year, the publication's vitally important data will also be accessible in a user-friendly digitized format.

Data in this 2019 edition of Key Indicators for Asia and the Pacific-prepared for the first time by ADB's newly formed Statistics and Data Innovation Unit-show that development across Asia and the Pacific has been impressive on many fronts. The number of people in our region living in extreme poverty declined from 1.1 billion in 2002 to 264 million in 2015 . The maternal mortality ratio was halved in the period from 2000 to 2015, and an average of about $90 \%$ of children were enrolled in primary school in 2017. The region's share of global gross domestic product (in current United States dollars) surpassed one-third in 2018, while international trade has become a growing source of regional integration, as economies across Asia and the Pacific strengthen, broaden, and diversify their participation in global value chains.

While the region has done remarkably well, the indicators presented here also remind us of the many challenges that lie ahead. Economic growth throughout Asia and the Pacific has generally been accompanied by a rise in carbon dioxide emissions; cities are affected by air pollution; and, in some economies, more than half the urban population is living in slums or informal settlements. The proportion of elderly people in the total population reached an average of $8.6 \%$ across all ADB regional members in 2018, while the number of women participating in national parliaments is below gender parity. The SDG indicators highlight the need to expand access to safe water and sanitation facilities, and to ensure that all people have safe, nutritious, and sufficient food to eat all year round.

Effective governance depends on accurate and timely data to support evidence-based policymaking. This requires investment in data development and statistical capacity building. The special supplement to Key Indicators for Asia and the Pacific 2019 presents results from one such capacity-building initiative by ADB. It provides a quantitative assessment of the benefits of using handheld digital devices for survey data collection and management, with the traditional pen and paper interviewing method as a basis for comparison. 
In the 50th year of this publication, $\mathrm{ADB}$ again acknowledges the ongoing relationships with statistical partners in our regional member economies, who provide us with the most recent data from their official sources. We are also indebted to those international agencies from which the data in many of the publication's tables are sourced. We hope that Key Indicators for Asia and the Pacific will remain a valuable resource for data on major development issues well into the future. As always, we welcome feedback from our users on both the content and structure of the publication.

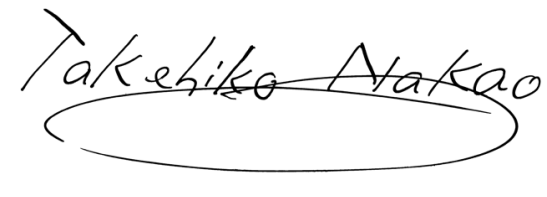

Takehiko Nakao

President Asian Development Bank 


\section{Acknowledgments}

This 50th edition of Key Indicators for Asia and the Pacific 2019 was prepared by the newly established Statistics and Data Innovation Unit (EROD-SDI) within the Economic Research and Regional Cooperation Department (ERCD) at the Asian Development Bank (ADB). The publication team was led by Stefan Schipper, under the overall direction of Kaushal Joshi. Pamela Lapitan, Melissa Pascua, and Eric Suan provided technical and coordination support in preparing the data and tables.

The statistical tables that present development indicators for ADB's regional member economies in Parts I and II of the printed publication, and the 49 tables for individual economies available online, were prepared by EROD-SDI staff and consultants, under the supervision of Kaushal Joshi, Mahinthan Joseph Mariasingham, Arturo Martinez Jr., Lakshman Nagraj Rao, and Stefan Schipper. The research team included Raymond Adofina, Nalwino Billones, Joseph Albert Nino Bulan, Ephraim Cuya, Criselda De Dios, Madeline Dumaua-Cabauatan, Anna Marie Fernando, Karen Firshan, Patricia Georgina Gonzales, Pamela Lapitan, Melissa Pascua, Lea Rotairo, Iva Sebastian, Christian Flora Mae Soco, Eric Suan, and Mic Ivan Vito Sumilang. Proofreading of statistical tables was done by Ma. Roselia Babalo, Oth Marulou Gagni, and Aileen Gatson. The analysis of Sustainable Development Goal indicators and regional trends was prepared by Kevin Donahue and Stefan Schipper. The statistical tables and analytical reports for Parts I and II were reviewed by Kaushal Joshi, Mahinthan Joseph Mariasingham, Arturo Martinez Jr., Lakshman Nagraj Rao, and Stefan Schipper. Mahinthan Joseph Mariasingham led the team comprising Kristina Baris, John Arvin Bernabe, Donald Jay Bertulfo, Marc Alvin Ermino, Krizia Anne Garay, Janine Elora Lazatin, Julieta Magallanes, Sarah Mae Manuel, Dianne Lara Monis, Clara Delos Santos, and Jonarie Vergara, which prepared the statistical tables for Part III. Monelle Capistrano and Ana Francesca Rosales provided valuable comments on the analysis of Part III, which was prepared by John Arvin Bernabe, Donald Jay Bertulfo, and Janine Elora Lazatin, under the guidance of Mahinthan Joseph Mariasingham.

We greatly appreciate the contributions from ERCD's statistical partners-ADB regional members and international organizations-who shared their data for the statistical tables on Sustainable Development Goal indicators (Part I), regional tables (Part II), global value chains (Part III), and individual economy tables. ADB resident missions in Afghanistan, Armenia, Azerbaijan, Bangladesh, Bhutan, Cambodia, Georgia, India, Indonesia, Kazakhstan, the Kyrgyz Republic, the Lao People's Democratic Republic, Myanmar, Mongolia, Nepal, Pakistan, Papua New Guinea, the People's Republic of China, Sri Lanka, Tajikistan, Thailand, Timor-Leste, Turkmenistan, Uzbekistan, and Viet Nam provided support in compiling the data from their respective countries. ADB's Japanese Representative Office, Pacific Liaison and Coordination Office, Philippines Country Office, and Pacific Subregional Office also provided help in data compilation. We greatly appreciate the continuing cooperation of the governments of ADB member economies and other international agencies. 
Paul Dent edited the publication. The cover was designed by Marjorie Ofaga, winner of the Key Indicators for Asia and the Pacific 2019 cover design contest. Rhommell Rico led the typesetting process, and provided technical support for the preparation of all promotional and awareness materials. Joseph Manglicmot assisted in typesetting. Staff from ADB's Office of Information Systems and Technology provided database management and technology support, while the Logistics Management Unit of the Office of Administrative Services facilitated the timely and smooth production of Key Indicators for Asia and the Pacific 2019. The publishing team in ADB's Department of Communications provided general guidance on production issues, and organized promotional and awareness activities.

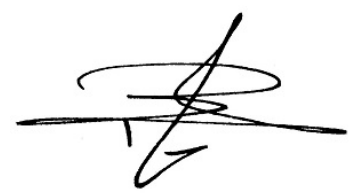

Yasuyuki Sawada Chief Economist and Director General Asian Development Bank 


\section{Statistical Partners}

The preparation and publication of Key Indicators for Asia and the Pacific 2019 would not have been possible without the support, assistance, and cooperation of partners in the regional members of the Asian Development Bank and the invaluable contributions of international, private, and nongovernment organizations. These partnerswho shared their data, knowledge, expertise, and other information-help provide the Asian Development Bank, policymakers, and other data users with a better understanding of the performance of economies across Asia and the Pacific, so that better policies can be formulated to improve the quality of life for people in this part of the world.

\section{REGIONAL MEMBERS}

Afghanistan

Armenia

Australia

Azerbaijan

Bangladesh

Bhutan

Brunei Darussalam

Cambodia
Da Afghanistan Bank (http://dab.gov.af/)

Ministry of Finance (http://mof.gov.af/en)

National Statistics and Information Authority (https://nsia.gov.af/home)

Central Bank of Armenia (http://www.cba.am/en)

Ministry of Finance (http://www.minfin.am/en/)

Statistical Committee of the Republic of Armenia (http://www.armstat.am/en)

Australian Bureau of Statistics (http://www.abs.gov.au)

Department of the Environment and Energy (http://www.environment.gov.au/)

Reserve Bank of Australia (http://www.rba.gov.au)

Central Bank of the Republic of Azerbaijan (https://www.cbar.az/en)

State Statistical Committee of the Republic of Azerbaijan

(http://www.stat.gov.az/?lang=en)

Bangladesh Bank (https://www.bb.org.bd)

Bangladesh Bureau of Statistics (http://www.bbs.gov.bd)

Ministry of Finance (https://www.mof.gov.bd/en)

Ministry of Finance (https://www.mof.gov.bt)

Ministry of Labour and Human Resources (http://www.molhr.gov.bt/molhr)

National Statistics Bureau (http://www.nsb.gov.bt/main/main.php)

Royal Monetary Authority of Bhutan (https://www.rma.org.bt)

Autoriti Monetari Brunei Darussalam (http://www.ambd.gov.bn)

Department of Economic Planning and Development

(http://www.depd.gov.bn)

Ministry of Finance and Economy (http://www.mofe.gov.bn)

Ministry of Economy and Finance (http://www.mef.gov.kh)

National Bank of Cambodia (http://www.nbc.org.kh)

National Institute of Statistics (http://www.nis.gov.kh) 
China, People's Republic of

Cook Islands

Fiji

Georgia

Hong Kong, China

India

Indonesia

Japan

Kazakhstan

Kiribati
National Bureau of Statistics of China (http://www.stats.gov.cn/english)

The People's Bank of China (http://www.pbc.gov.cn)

State Administration of Foreign Exchange (http://www.safe.gov.cn)

Cook Islands Statistics Office (http://www.mfem.gov.ck/statistics)

Ministry of Finance and Economic Management (http://www.mfem.gov.ck)

Bureau of Statistics (http://www.statsfiji.gov.fj)

Reserve Bank of Fiji (http://www.rbf.gov.fj/)

Ministry of Economy (http://www.economy.gov.fj)

Ministry of Finance of Georgia (http://mof.ge/en/)

National Bank of Georgia (http://www.nbg.gov.ge)

National Statistics Office of Georgia (http://www.geostat.ge/en)

Census and Statistics Department (http://www.censtatd.gov.hk)

Hong Kong Monetary Authority (https://www.hkma.gov.hk)

Financial Services and the Treasury Bureau (https://www.fstb.gov.hk/)

Central Statistics Office (http://mospi.nic.in)

Ministry of Finance (http://finmin.nic.in)

Reserve Bank of India (http://www.rbi.org.in)

Bank Indonesia (http://www.bi.go.id/web)

Badan Pusat Statistik-Statistics Indonesia (http://www.bps.go.id)

Ministry of Energy and Mineral Resources (http://www.esdm.go.id)

Ministry of Finance (https://www.kemenkeu.go.id)

PT Pertamina (Persero) (http://barata.com/en/)

Bank of Japan (http://www.boj.or.jp/en)

Economic and Social Research Institute (http://www.esri.go.jp)

Japan Customs (http://www.customs.go.jp/english/)

Japan Statistics Bureau (http://www.stat.go.jp/english)

Ministry of Economy, Trade and Industry (http://www.meti.go.jp)

Ministry of Finance (http://www.mof.go.jp)

The Institute of Energy Economics, Japan (http://oil-info.ieej.or.jp/)

Committee on Statistics, Ministry of National Economy of the Republic of Kazakhstan (http://www.stat.gov.kz)

Ministry of Finance of the Republic of Kazakhstan (http://www.minfin.gov.kz/) National Bank of Kazakhstan (https://nationalbank.kz)

Kiribati National Statistics Office

(http://www.mfed.gov.ki/our-work/national-statistics-office) 
Korea, Republic of

Kyrgyz Republic

Lao People's Democratic

Republic

Malaysia

Maldives

Marshall Islands

Micronesia, Federated

States of

Mongolia

Myanmar

Nauru

Nepal
Bank of Korea (https://bok.or.kr)

Ministry of Economy and Finance (formerly Ministry of Strategy and

Finance) (https://english.moef.go.kr)

Statistics Korea (http://kostat.go.kr)

National Bank of the Kyrgyz Republic (https://www.nbkr.kg)

National Statistical Committee of the Kyrgyz Republic

(http://www.stat.kg)

Bank of the Lao PDR (http://www.bol.gov.la)

Lao Statistics Bureau (http://www.lsb.gov.la)

Ministry of Finance (http://www.mof.gov.la)

Bank Negara Malaysia (http://www.bnm.gov.my)

Department of Statistics Malaysia (http://www.dosm.gov.my)

Ministry of Finance Malaysia (http://www.treasury.gov.my)

National Bureau of Statistics (http://statisticsmaldives.gov.mv/)

Maldives Monetary Authority (http://www.mma.gov.mv)

Economic Policy, Planning and Statistics Office (https://www.rmieppso.org/)

Division of Statistics (http://www.fsmstats.fm/)

States of Department of Resources and Development

(http://www.fsmrd.fm/)

Central Bank of Mongolia (https://www.mongolbank.mn/eng)

National Statistics Office of Mongolia (https://en.nso.mn)

Central Bank of Myanmar (http://www.cbm.gov.mm/)

Central Statistical Organization (https://www.csostat.gov.mm)

Ministry of National Planning and Economic Development

(https://www.mnped.gov.mm)

Ministry of Finance and Economic Planning (http://www.naurugov.nr)

Nauru Bureau of Statistics (https://nauru.prism.spc.int)

Central Bureau of Statistics (https://cbs.gov.np)

Ministry of Energy, Water Resources and Irrigation

(http://www.moewri.gov.np/en/)

Ministry of Finance (https://www.mof.gov.np)

Nepal Rastra Bank (https://www.nrb.org.np) 
New Zealand

Niue

Pakistan

Palau

Papua New Guinea

Philippines

Samoa

Singapore

Solomon Islands

Sri Lanka
Ministry of Business, Innovation and Employment https://www.mbie.govt.nz)

Reserve Bank of New Zealand (https://www.rbnz.govt.nz/)

Stats NZ Tatauranga Aotearoa (https://www.stats.govt.nz/)

Statistics Niue (https://niue.prism.spc.int/)

Ministry of Finance (http://www. finance.gov.pk)

Pakistan Bureau of Statistics (http://www.pbs.gov.pk)

State Bank of Pakistan (http://www.sbp.org.pk)

Bureau of Budget and Planning, Ministry of Finance

(http://palaugov.pw/budgetandplanning/)

Bank of Papua New Guinea (https://www.bankpng.gov.pg)

Department of Treasury (http://www.treasury.gov.pg)

National Statistical Office (https://www.nso.gov.pg)

Bangko Sentral ng Pilipinas (http://www.bsp.gov.ph)

Bureau of Local Government Finance (http://www.blgf.gov.ph)

Bureau of the Treasury (http://www.treasury.gov.ph)

Department of Budget and Management

(http://www.dbm.gov.ph)

Department of Energy (https://www.doe.gov.ph)

Philippine Statistics Authority (http://www.psa.gov.ph)

Samoa Bureau of Statistics (http://www.sbs.gov.ws)

Central Bank of Samoa (https://www.cbs.gov.ws)

Department of Statistics (http://www.singstat.gov.sg)

Enterprise Singapore (formerly International Enterprise Singapore)

(http://www.enterprisesg.gov.sg)

Ministry of Finance (http://www.mof.gov.sg)

Ministry of Manpower (http://www.mom.gov.sg)

Ministry of Trade and Industry (http://www.mti.gov.sg)

Monetary Authority of Singapore (http://www.mas.gov.sg)

Central Bank of Solomon Islands (http://www.cbsi.com.sb)

Solomon Islands National Statistics Office (https://www.statistics.gov.sb)

Central Bank of Sri Lanka (https://www.cbsl.gov.lk)

Department of Census and Statistics (http://www.statistics.gov.lk) 
Taipei,China

Tajikistan

Thailand

Timor-Leste

Tonga

Turkmenistan

Tuvalu

Uzbekistan

Vanuatu

Viet Nam
Central bank of Taipei,China (https://www.cbc.gov.tw)

Directorate-General of Budget, Accounting and Statistics

(https://eng.dgbas.gov.tw)

Ministry of Finance (https://www.mof.gov.tw)

National Bank of Tajikistan (http://www.nbt.tj)

Agency on Statistics under President of the Republic of Tajikistan (https://www.stat.tj)

Bank of Thailand (http://www.bot.or.th)

Ministry of Finance (http://www2.mof.go.th)

National Economic and Social Development Board (http://www.nesdb.go.th/nesdb_en)

National Statistical Office (http://web.nso.go.th)

Central Bank of Timor-Leste (http://www.bancocentral.tl) Ministry of Finance (http://www.mof.gov.tl)

General Directorate of Statistics (http://www.statistics.gov.tl)

Ministry of Finance and National Planning (http://www.finance.gov.to)

National Reserve Bank of Tonga (http://www.reservebank.to)

Department of Statistics (http://www.spc.int/prism/tonga)

Central Bank of Turkmenistan (http://www.cbt.tm/en/)

Ministry of Finance and Economy of Turkmenistan (http://www.minfin.gov.tm/)

State Committee of Turkmenistan on Statistics (formerly the National Institute of State Statistics and Information of Turkmenistan) (http://www.stat.gov.tm)

Central Statistics Division (https://tuvalu.prism.spc.int)

Cabinet of Ministers (https://www.gov.uz/en/pages/executive_office)

Central Bank of Uzbekistan (http://www.cbu.uz)

Ministry of Finance of the Republic of Uzbekistan (http://www.mf.gov.uz)

State Statistical Committee of the Republic of Uzbekistan(http://www.stat.uz)

Department of Finance and Treasury (https://doft.gov.vu)

Reserve Bank of Vanuatu (http://www.rbv.gov.vu)

Vanuatu National Statistics Office (http://www.vnso.gov.vu)

General Statistics Office (http://www.gso.gov.vn)

Ministry of Finance (http://www.mof.gov.vn)

State Bank of Viet Nam (http://www.sbv.gov.vn) 


\title{
INTERNATIONAL, PRIVATE, AND NONGOVERNMENT ORGANIZATIONS
}

\author{
Association of Southeast Asian Nations \\ Food and Agriculture Organization of the United Nations \\ International Labour Organization \\ International Monetary Fund \\ International Telecommunication Union \\ Interstate Statistical Committee of the Commonwealth of Independent States \\ Joint United Nations Programme on HIV/AIDS \\ Organisation for Economic Co-operation and Development \\ Secretariat of the Pacific Community \\ Transparency International \\ UNESCO Institute for Statistics \\ United Nations Children's Fund \\ United Nations Conference on Trade and Development \\ United Nations Department of Economic and Social Affairs \\ United Nations Development Programme \\ United Nations Economic Commission for Europe \\ United Nations Economic and Social Commission for Asia and the Pacific \\ United Nations Educational, Scientific and Cultural Organization \\ United Nations Environment Programme \\ United Nations Human Settlements Programme \\ United Nations Office on Drugs and Crime \\ United Nations Population Division \\ United Nations Statistics Division \\ United Nations World Tourism Organization \\ United States Census Bureau \\ World Bank \\ World Health Organization \\ WHO/UNICEF Joint Monitoring Programme for Water Supply, Sanitation and Hygiene \\ World Trade Organization
}


Key Indicators for Asia and the Pacific 2019 begins with a Highlights section that presents key messages from various parts of the publication.

Part I comprises the data tables and brief analyses of trends of select indicators for the Sustainable Development Goals (SDGs) for which data are available. The indicators are presented according to the United Nations SDG global indicator framework.

Part II explores trends in social, economic, and environmental developments in member economies of the Asian Development Bank (ADB) across Asia and the Pacific. These assessments are grouped into eight themes: People; Economy and Output; Money, Finance, and Prices; Globalization; Transport and Communications; Energy and Electricity; Environment; and Government and Governance. Each theme is further analyzed by specific indicators, which are presented in the 100 regional tables that are incorporated into Part II of the publication.

The 17 SDGs in Part I and the 8 themes in Part II start with a short commentary, complemented by figures and charts describing the status of economies with respect to key trends of select targets and indicators. The scales used in some figures and charts are adjusted to show very small numbers. In addition, figures and charts appearing in this publication are also provided with a digital object identifier to facilitate easier access to data. Both Part I and Part II also present discussion boxes on how to approach important measurement issues for select indicators.

The SDGs and regional tables presented in Part I and II cover 49 national economies across Asia and the Pacific, all of which are members of ADB. The term "country," used interchangeably with economy, is not intended to make any judgment as to the legal or other status of any territory or area. The 49 economies have been broadly grouped into developing ADB member economies and developed ADB member economies. The term "developing Asia" refers to the 46 developing member economies of $A D B$, including Niue as new member of ADB in 2019. The developed economies refer to Australia, Japan, and New Zealand. Based on ADB's geographic operations, the 46 developing ADB member economies are divided into 5 subregions within the Asia and Pacific region. These subregions are Central and West Asia, East Asia, the Pacific, South Asia, and Southeast Asia. Economies are listed alphabetically within each subregion. The term "regional members", often used interchangeably with Asia and the Pacific, refers to all 49 ADB members, both developing and developed. Indicators are shown for the most recent year (usually 2018) or period for which data are available and, in most tables, for a starting year or period (usually 2000). Depending on available data, the starting point may be a year from 2000 to 2008 (usually the year closest to 2000), and the most recent year may be a year from 2009 to 2018 (usually the year closest to 2018). There may, however, be some exceptions to these general principles. In the tables, aggregates for subregions include economies with available data and are shown if the indicator is available for more than half of the economies and if more than two-thirds of the reference population is represented.

Part III contains select indicators for depicting participation by economies of Asia and the Pacific in global value chains (GVCs), and the sectorspecific comparative advantage of each economy in terms of exports. Typical indicators of international trade, which mainly refer to the value of exports and imports of goods and services, can be traced back to the traditional trading of final goods across borders. Today's globalization has made many economies more open to trade, providing opportunities for firms to scale up production and allocate their resources more efficiently by moving production chains across borders where there is comparative advantage. GVC analysis provides detailed cross-border trading transactions of 
inputs used in different stages of production-from raw materials, to intermediate inputs, to the final products purchased by the end consumers.

This publication is also available on ADB's website at www.kidb.adb.org, along with individual statistical tables for each of the 49 ADB regional members, and time series for the indicators presented in Part I and II. Data for the SDG indicators, regional tables, and individual member tables are mainly obtained from two sources: (i) ADB's statistical partners linked to regional member economies, and (ii) international statistical agencies, particularly from the United Nations SDG Indicators Global Database, a master set of data prepared by the Department of Economic and Social Affairs of the United Nations Secretariat. The term "economy source", cited as a source in some tables, refers to data provided by the statistical partners linked to the ADB regional member economies.

The data presented for indicators in Part I are from either official country sources, the SDG Indicators Global Database, or databases maintained by international agencies that, based on their areas of expertise, prepared one or more of the series of statistical indicators included in the SDG Indicators Global Database. The data presented in Part III are mainly drawn from the ADB Multiregion InputOutput Tables Database.

Data produced and disseminated by international agencies are generally based on data produced and disseminated by an individual economy (including data adjusted by the economy to meet international standards). However, it should be noted that national data may be compiled using national standards and practices and, as such, international agencies often adjust the data for international comparability. In such cases, data disseminated by the international agencies may differ from data available from national sources. In other cases, when data for a specific year, or set of years, are not available; or they are available from multiple national sources (surveys, administrative data sources, and other sources); or when there are data quality issues; the relevant international agency may estimate the data. Some indicators are regularly produced for the purpose of global monitoring by the designated agency and there are no corresponding data at the national level (e.g., population living on less than $\$ 1.90$ at 2011 purchasing power parity). In other cases, the differences between data from national and international agencies may be because the most recent and/or revised data available at the national level are not yet available with the relevant international agency. Some data gaps are filled by supplementing or deriving data collected through sample surveys financed and carried out by international agencies. For example, many of the health indicators are estimated using data from the Multiple Indicator Cluster Surveys and Demographic and Health Surveys.

ADB exercises due care and caution in collecting data before publication. Nevertheless, data from international sources presented in this publication may differ from those available within individual member economies. Thus, for a detailed description of how the indicators are compiled by the international agencies, readers may refer to the metadata available from databases of the individual international agencies, or the SDG Indicators Global Database website for metadata of SDG indicators. Comparable and standardized national data gathered through a robust data-reporting mechanism of the international agencies should be the basis for all data in the global monitoring databases, and global indicators should be produced in full consultation with national statistical agencies.

Data obtained from ADB member economies are comparable to the extent that the ADB members follow standard statistical concepts, definitions, and estimation methods recommended by the United Nations and other applicable international agencies. Nevertheless, member economies invariably develop and use their own concepts, definitions, and estimation methodologies to suit their individual 
circumstances, and these may not necessarily comply with recommended international standards. Therefore, even though attempts are made to present the data in a comparable and uniform format, the data are subject to variations in the statistical methods used by individual economies, so full comparability may not be possible. These variations are reflected in the footnotes of the statistical tables, or noted in the Data Issues and Comparability sections. Moreover, the aggregates shown in some tables for the developing $A D B$ member economies and $A D B$ regional members are treated as approximations of the actual total or average, or growth rates, due to missing data from the primary source. No attempt has been made to impute the missing data.

The data published by ADB do not constitute any form of advice or recommendation. For answers to any questions on the data, users of this publication are requested to seek advice from the relevant data source or organization. 


\section{Fiscal Year}

There are 24 regional members of the Asian Development Bank with fiscal years that do not coincide with the calendar year. Whenever statistical series (for example, national accounts or government finance) are compiled on the basis of a fiscal year, these series are presented in the column for the single-year during which most of the fiscal year occurred. The 24 fiscal year definitions for 2018 are outlined below.

\section{Regional Member}

Afghanistan
(fiscal year since 2013)
Brunei Darussalam
(fiscal year since 2002)
Hong Kong, China
India
Japan
Myanmar
New Zealand
Singapore

Fiji

Australia
Bangladesh
Bhutan
Cook Islands
Kiribati
Nauru
Pakistan
Samoa
Tonga

Nepal

Lao People's Democratic Republic Marshall Islands

Micronesia, Federated States of

Palau

Thailand
Fiscal Year

21 December 2017 to 20 December 2018

2018

1 April 2018 to 31 March 2019

2018

1 August 2017 to 31 July 2018

2018

1 July 2017 to 30 June 2018

2018

16 July 2017 to 15 July 2018

2018

1 October 2017 to 30 September 2018

Year Caption

8




\section{Key Symbols}

$\begin{array}{ll}\ldots & \begin{array}{l}\text { data not available } \\ \text { magnitude equals zero }\end{array} \\ (-/+) 0 \text { or } 0.0 & \text { magnitude is less than half of unit employed } \\ * & \text { provisional/preliminary/estimate/budget figure } \\ \text { I } & \text { marks break in series } \\ > & \text { greater than } \\ < & \text { less than } \\ > & \text { greater than or equal to } \\ < & \text { less than or equal to } \\ \text { n.a. } & \text { not applicable } \\ \% & \text { percentage }\end{array}$

\section{Units of Measurement}

$\begin{array}{ll}\mathrm{kg} & \text { kilogram } \\ \mathrm{kl} & \text { kiloliter } \\ \mathrm{km} & \text { kilometer } \\ \mathrm{km}^{2} & \text { square kilometer } \\ \mathrm{kWh} & \text { kilowatt-hour } \\ \mathrm{kt} & \text { kiloton } \\ \mathrm{ktoe} & \text { kiloton of oil equivalent } \\ \mathrm{L} & \text { liter } \\ \mathrm{m}^{3} & \text { cubic meter } \\ \mathrm{mj} & \text { megajoule } \\ \mathrm{PM} & \text { particulate matter } \\ \mathrm{teu} & \text { twenty-foot equivalent unit } \\ \mathrm{t} & \text { metric ton } \\ \mathrm{tj} & \text { terajoule } \\ \mu \mathrm{gg} / \mathrm{m}^{3} & \text { micrograms per cubic meter }\end{array}$




\section{Abbreviations}

\begin{tabular}{|c|c|}
\hline$A D B$ & Asian Development Bank \\
\hline BPM5 & Balance of Payments Manual (Fifth Edition) \\
\hline BPM6 & Balance of Payments and International Investment Position Manual (Sixth Edition) \\
\hline $\mathrm{CIF}$ & cost, insurance, and freight \\
\hline $\mathrm{CO}_{2}$ & carbon dioxide \\
\hline $\mathrm{CPI}$ & consumer price index \\
\hline DHS & Demographic and Health Survey \\
\hline ESCAP & Economic and Social Commission for Asia and the Pacific \\
\hline FAO & Food and Agriculture Organization of the United Nations \\
\hline FDI & foreign direct investment \\
\hline FOB & free on board \\
\hline FVA & foreign value added \\
\hline GDP & gross domestic product \\
\hline GNI & gross national income \\
\hline GVC & global value chain \\
\hline IDA & International Development Association \\
\hline ILO & International Labour Organization \\
\hline IMF & International Monetary Fund \\
\hline ISIC & International Standard Industrial Classification \\
\hline MICS & Multiple Indicator Cluster Surveys \\
\hline MMR & maternal mortality ratio \\
\hline MOF & Ministry of Finance \\
\hline NPL & nonperforming loan \\
\hline NSO & national statistics office; national statistical office \\
\hline NSS & national statistical service \\
\hline ODA & official development assistance \\
\hline OECD & Organisation for Economic Co-operation and Development \\
\hline PLI & price level index \\
\hline PPP & purchasing power parity \\
\hline UN & United Nations \\
\hline UNDESA & United Nations Department of Economic and Social Affairs \\
\hline UNICEF & United Nations Children's Fund \\
\hline UNSD & United Nations Statistics Division \\
\hline
\end{tabular}

Unless otherwise indicated, “\$” refers to United States dollars. 


\section{HIGHLIGHTS}

\section{Part I. Sustainable Development Goals}

The 17 Sustainable Development Goals (SDGs) to be achieved by 2030, along with their 232 related indicators, provide a global policy framework toward ending all forms of poverty, fighting inequality, and tackling climate change, while ensuring that no person is left behind as economies of the world grow and prosper. A summary of trends for selected SDG indicators across economies in Asia and the Pacific is presented here.

- In developing Asia, the proportion of people living on less than $\$ 1.90$ a day (at 2011 purchasing power parity) fell from $33.7 \%$ in 2002 to $7.0 \%$ in 2015 . In absolute terms, this represented a decline in people living in extreme poverty from 1.11 billion to 264 million.

- Poor food security can result in cases of severe malnutrition, which in turn can lead to stunting (i.e., being too short for one's age). Since 2000, the prevalence of stunting in children below the age of 5 years has fallen in 26 of the $30 \mathrm{ADB}$ developing member economies with available data for this indicator.

- The number of women in Asia and the Pacific dying during pregnancy or childbirth, or soon after childbirth, fell from 264 per 100,000 live births in 2000 to 123 per 100,000 live births in 2015. All subregions within the Asia and Pacific region experienced a reduction in maternal deaths during the review period, with South Asia reporting the largest drop.

- The under-5 mortality rate across Asia and the Pacific declined from 69 deaths per 1,000 live births in 2000 to 31 deaths per 1,000 live births in 2017. This rate fell in 46 of the 47 economies with available data for the review period.

- In Asia and the Pacific, significant gaps persist in ensuring women's full participation in political leadership. The threshold of $20 \%$ women's representation in national parliaments was surpassed in only one-third of economies with available data in 2018 .

- Since 2000, there has been an increase in the proportion of people with access to safely managed drinking water services in 21 of the 25 economies with available data for this indicator. However, the proportion of the population using safely managed drinking water services exceeded $90 \%$ in only 8 economies in 2017, and urban-rural disparities persisted in 9 of the 10 economies with disaggregated data available.

- Of the 14 economies with available data on sanitation from 2000 to 2017, the share of the population benefiting from safely managed sanitation services increased in 11 economies, decreased in 2 economies, and remained unchanged at 100\% in Singapore. In 2017, 4 of the 14 economies had more than $90 \%$ of the population using safely managed sanitation services, but another 4 economies reported usage of such services at below $50 \%$ of the population.

- The proportion of the population across Asia and the Pacific with access to electricity exceeded $90 \%$ in 38 of the 48 economies with available data for 2017 , compared with only 20 economies in 2000. 
- Of the 30 developing member economies with available data on unemployment in 2017 (or the most recent year), all but 1 had a higher rate of unemployment among people aged 15-24 years than among people aged 25 years and older. Of these, 13 economies had an employment gap between the two age groups that exceeded 10 percentage points.

- Household expenditure (or income) per capita rose for the bottom $40 \%$ of the total population in 17 of the 18 developing member economies with available data during the most recent 5-year assessment period. The average annual growth rates in the per capita household expenditure of the bottom $40 \%$ outpaced the per capita household expenditure growth of the total population in 11 of the 18 reporting economies.

- In 2016, air pollution-as measured by the annual mean of the daily concentrations of fine suspended particles equal to or less than 2.5 microns in diameter-exceeded the maximum recommended value by the World Health Organization in urban areas in all but 4 of the 43 economies with available data. Among Asia and the Pacific's 10 largest economies in terms of population in 2016, the highest levels of air pollution in urban areas were found in India, Bangladesh, and Pakistan.

- Domestic material consumption measures the total amount of material directly used in production processes within an economy. Economies in Asia and the Pacific more than doubled their aggregate domestic material consumption from 23.7 billion metric tons in 2000 to 53.6 billion metric tons in 2017. The region's highest per capita domestic material consumption in 2017 were found in Australia, Mongolia, and Singapore.

- The Sendai Framework helps governments substantially reduce disaster risk and minimize the loss of lives, livelihoods, and health experienced as a result of natural disasters. Self-assessment on the alignment of national disaster risk reduction strategies with the Sendai Framework in 2017 and 2018 showed that 3 of the 16 economies in Asia and the Pacific with such strategies were in comprehensive alignment with the framework, while another 8 economies had at least a moderate alignment.

- From 2000 to 2018, 46 of the 48 regional economies with available data reported a decline in their respective score on the Red List Index, a measure of change in aggregate extinction risk across groups of species. Nepal and Niue each experienced a marginal increase in their scores during the review period.

- For 2000-2004 and 2011-2017, the number of victims of intentional homicide per 100,000 people fell in 29 of the 37 regional economies with available data. The largest declines in the intentional homicide rate occurred in Kazakhstan, Mongolia, and Thailand.

- The aggregate value of annual financial and technical assistance increased in 35 of the 41 developing economies with available data for 2000-2008 and 2009-2017. The largest amounts of average annual financial and technical assistance during 2009-2017 went to Afghanistan (\$1,405 million), Indonesia ( $\$ 1,310$ million), and Pakistan (\$894 million).

- The financial resources devoted to statistical capacity building increased in 17 of the 41 developing member economies with available data for the decade preceding 2016. The largest increases in resources dedicated to statistical capacity building (in current dollars) were observed in in Uzbekistan ( $\$ 1.73$ million), the Solomon Islands (\$1.28 million), and Nepal (\$1.01 million). 


\section{Part II. Region at a Glance}

Each year, ADB presents data on social, economic, and environmental developments in its member economies from across the Asia and Pacific region. These indicators are grouped into eight themes: People; Economy and Output; Money, Finance, and Prices; Globalization; Transport and Communications; Energy and Electricity; Environment; and Government and Governance. Each of these themes has a brief analysis of key trends of select indicators highlighting important recent developments in Asia and the Pacific.

\section{People}

- The combined population of the 49 regional members of ADB reached 4,180 million in 2018 , accounting for nearly $55 \%$ of the global population. Among the world's 10 most populous national economies in 2018, there were 6 in Asia and the Pacific: the People's Republic of China (PRC) with 1,395 million people, India with 1,332 million, Indonesia with 265 million, Pakistan with 213 million, Bangladesh with 165 million, and Japan with 127 million.

- The region's population is gradually aging amid increased life expectancy and decreasing fertility rates. In 2018, the average ratio of the elderly population (65 years and older) to the total population reached $8.6 \%$ across all ADB regional members, up from $5.9 \%$ in 2000.

- Economies in the region are increasing access to primary education. In 2017 (or the most recent year for which data are available), 30 of the $35 \mathrm{ADB}$ developing member economies with available data had a primary education attainment ratio that met or exceeded $90 \%$ for both boys and girls. By comparison, in 2000 (or the earliest year for which data are available), only 20 of the 35 economies had achieved this same measure of primary education attainment. Of the economies reporting in 2017, showing an improvement in primary education attainment compared to 2000 (or the earliest year available), and having data for both boys and girls, more than two-thirds reported that the gain for girls exceeded that for boys.

\section{Economy and Output}

- Asia and the Pacific's share of global gross domestic product (GDP) at purchasing power parity increased from $30.3 \%$ in 2000 to $42.8 \%$ in 2018. Whereas when measured in terms of current United States dollars, the region's share of global GDP surpassed one-third in 2018.

- In 2018, the five largest economies in Asia and the Pacific in terms of GDP at purchasing power parity were the PRC, India, Japan, Indonesia, and the Republic of Korea. All five economies experienced positive GDP growth each year from 2016 to 2018, with India having the highest growth rate in each of the 3 years.

- Capital formation comprises fixed investment in the form of buildings, civil engineering, machinery, and equipment, as well as changes in inventories. In 2018, of the 37 economies with available data, 21 reported capital formation that was more than a quarter of GDP.

\section{Money, Finance, and Prices}

- In 25 of 47 reporting economies across Asia and the Pacific, consumer price inflation accelerated from 2017 to 2018, while in 22 economies it decelerated. Rising oil prices and falling exchange rates contributed to an acceleration in inflation in some developing member economies, while falling prices for food and nonalcoholic beverages slowed inflation in others.

- In 2018, the money supply expanded on an annual basis in 38 of the 39 economies with available data. 
- During and after the global financial crisis, the value of nonperforming bank loans-as well as the percentage of nonperforming loans as a share of total gross loans-rose across the region. Subsequent years have seen a gradual recovery. From 2010 to 2017, the percentage of nonperforming loans as a share of total gross loans fell in 22 of the 31 economies with available data.

\section{Globalization}

- The aggregate of remittances to developing member economies in Asia and the Pacific reached $\$ 297.1$ billion in 2018, up significantly from $\$ 35.5$ billion in 2000. Among the region's top recipients of remittances, India, the PRC, and the Philippines were ranked first, second, and fourth in the world, respectively. In 2018, remittances accounted for at least $10 \%$ of GDP in one-quarter of ADB's developing member economies.

- Foreign direct investment in Asia and the Pacific totaled $\$ 541.9$ billion in 2017 , up more than threefold since 2000. The region's aggregate foreign direct investment in 2017 accounted for $29.2 \%$ of the global total, compared with $12.4 \%$ in 2000 .

- Economies in Asia and the Pacific are exporting an increasing share of their goods to other economies within the region. Among the 48 regional economies, 40 increased their intraregional share of merchandise exports from 2000 to 2018. On an aggregate basis, intraregional exports as a share of the region's total exports rose from $50.8 \%$ in 2000 to $57.7 \%$ in 2018 .

- Merchandise exports from Asia and the Pacific rose to $\$ 7$ trillion in 2018. The region's share of total global merchandise exports was $36.1 \%$ in 2018 , up from $28.7 \%$ in 2000.

\section{Transport and Communications}

- Asia and the Pacific is extending its lead as the busiest region in the world in terms of passenger air traffic, accounting for about $34 \%$ of the global total in 2017. In 29 of the 35 developing economies with available data, air carrier departures increased from 2000 to 2017. By economy, the most air carrier departures in 2017 were in the PRC (4.36 million); India (1.03 million); Indonesia (0.92 million); Taipei,China (0.51 million); and the Republic of Korea (0.50 million).

- The proportion of households in Asia and the Pacific with internet access rose from about $28 \%$ in 2010 to more than $48 \%$ in 2017 . The corresponding internet penetration rates for males and females were $47.9 \%$ and $39.7 \%$, respectively, signaling that a digital gender divide persists.

\section{Energy and Electricity}

- From 2000 to 2016, Asia and the Pacific's five most populous economies all increased their energy efficiency, as measured by the amount of GDP per unit use of energy (i.e., one petajoule). The largest increases in GDP per petajoule were in India (\$76.1 million per petajoule) and Bangladesh (\$73.7 million per petajoule).

- The region's aggregate energy production increased to $33.7 \%$ of the global total in 2016, compared with $24.6 \%$ in 2000 . In 2016 , the PRC contributed $49.3 \%$ of the region's energy production. The region's next largest energy producers and their respective regional production shares in 2016 were India (12.1\%), Indonesia (9.8\%), and Australia (8.5\%). 
- Of the 44 regional economies with available data for 2016, 29 were net energy importers. Compared with their respective positions in 2000 (or the earliest year for which data are available), the Lao People's Democratic Republic, Mongolia, and Timor-Leste had all switched from being net energy importers to being net energy exporters by 2016.

\section{Environment}

- In 2016, 15 of 46 reporting economies in Asia and the Pacific increased their total forested land, 14 economies experienced a decrease, and 17 experienced no change. The region's highest rates of reforestation in 2016 occurred in the Philippines (3.0\%), Azerbaijan (2.3\%), and the Lao People's Democratic Republic (1.0\%).

- Economic growth in the region has been accompanied by a rise in carbon dioxide $\left(\mathrm{CO}_{2}\right)$ emissions. In 2014, Asia and the Pacific accounted for nearly half of all global $\mathrm{CO}_{2}$ emissions. The top five emitters-the PRC, India, Japan, the Republic of Korea, and Indonesia-together accounted for more than $90 \%$ of the region's total. From 2000 to 2014 , only 7 of the 47 regional economies with available data were successful in reducing $\mathrm{CO}_{2}$ emissions on a per capita basis.

\section{Government and Governance}

- The ratio of government taxes to GDP rose between 2017 and 2018 in 13 of the 23 reporting economies. In eight economies, a decrease in the government taxes-to-GDP ratio occurred, and in 2 regional economies the government taxes-toGDP ratio remained unchanged between 2017 and 2018. The largest increases were observed in Tonga (4.9 percentage points), Mongolia (2.6 percentage points), and Uzbekistan (2.4 percentage points). The largest decreases were observed in Nauru ( -5.4 percentage points), Bangladesh ( -1.7 percentage points), and the Maldives ( -1.1 percentage points).

- Comparing 2018 with 2005, there were 30 economies in Asia and the Pacific with available data that reduced the number of days required to start a business, 4 economies in which there was an increase, and 3 economies with no change. The high-income economies of New Zealand (0.5 days); Hong Kong, China (1.5 days); and Singapore (1.5 days) had the shortest times required to start a business among all regional members in 2018.

\section{Part III. Global Value Chains}

ADB utilizes global value chain statistics derived from multi-regional input-output tables to describe the role of Asia and the Pacific in global production networks. This year, Key Indicators for Asia and the Pacific features the flow of domestic value-added via forward linkages to depict the evolving dynamics of production networks across Asia. Domestic valueadded via forward linkages measures the amount of domestic value-added that is generated from the production of total exports.

- Asia has been growing as a source of, and destination for, domestic value-added in exports. In $2000,23.0 \%$ of the world's total domestic value-added via forward linkages came from Asia, while $19.7 \%$ of the world's total domestic valueadded was received by Asia. By 2018, Asia was contributing $30.2 \%$ to the world's total domestic value-added generation and absorbing $26.0 \%$ of the total domestic value-added sent around the world.

- Intraregional trade remains important for Asia, especially as its dependence on North America (defined here as the United States and Canada) as a trade partner appears to be diminishing. Up to $33.5 \%$ of domestic value-added generated in Asia stayed within the region in 2018, while $39.0 \%$ 
of total domestic value-added absorbed in Asia originated from within the region. Comparing 2000 to 2018, Asia sent a smaller share of its generated domestic value-added to North America, while North America's contribution to total domestic value-added flowing into Asia also declined.

- When assessing all sectors, the People's Republic of China (PRC) had overtaken Japan as the largest source of intraregional domestic value-added outflows by 2018, while the subregion comprising Southeast Asia plus Fiji had become the largest destination for total intraregional domestic valueadded inflows. In 2000, Japan was the largest source of intraregional domestic value-added, while East Asia was the largest destination for domestic value-added.

- In the primary sector, Southeast Asia plus Fiji was the largest source of intraregional domestic value-added in 2000, while Japan was the largest destination. By 2018, the PRC had become the leading source of intraregional domestic valueadded in the primary sector, generating $46.3 \%$ of intraregional domestic value-added outflows. Meanwhile, Southeast Asia plus Fiji became the top destination for primary sector intraregional domestic value-added in 2018, with the PRC being its major source.

- In the low-technology industrial sector, intraregional domestic value-added in 2000 was more or less evenly generated by the PRC, Japan, East Asia, and Southeast Asia plus Fiji. However, by 2018, the PRC had emerged as the region's source hub for the sector, followed by Southeast Asia plus Fiji. In terms of destinations for intraregional domestic value-added in this sector, Southeast Asia plus Fiji had replaced Japan as the region's largest by 2018. Also noticeable was the rise of India and economies in South Asia and Central \& West Asia as destinations for low-technology industrial sector intraregional domestic valueadded.

- In the medium- to high-technology industrial sector, Japan was Asia's largest source of intraregional domestic value-added in 2000, but East Asia had surpassed it by 2018. Meanwhile, the PRC rose to become the region's largest destination of intraregional domestic value-added flows for the sector in 2018, exceeding those going to East Asia and Southeast Asia plus Fiji, which were the region's leading destinations in 2000. India, South Asia, and Central \& West Asia were also receiving increased volumes of medium- to high-technology industrial sector domestic valueadded inflows by 2018, with most of the inflows coming from the PRC.

- In the business services sectors, the PRC and Southeast Asia plus Fiji were the largest sources of intraregional domestic value added in 2018, replacing Japan and East Asia. While East Asia and Southeast Asia plus Fiji remained the destination hubs for the sector's intraregional domestic valueadded flows, the share of inflows to the PRC also increased as East Asia's and Japan's shares declined.

- In the personal and public services sector, the PRC had surpassed Japan as the region's leading source of intraregional domestic value-added by 2018 . While the PRC replaced East Asia as the region's destination hub, the destinations for the sector's intraregional flows in 2018 were more diversified than those in 2000, with flows from India to the PRC representing the single highest movement of total intraregional domestic value-added. 
PART I

Sustainable Development Goals Trends and Tables 



\section{Sustainable Development Goals-Data Stories}

The United Nations (UN) Sustainable Development Goals (SDGs) were adopted in September 2015 to set targets for global development that would be achieved by 2030. Economies in Asia and the Pacific are working toward achieving the 17 goals and 169 targets that comprise the SDG framework. A total of 232 statistical indicators are used to track the progress of individual economies toward meeting the SDGs. ${ }^{1}$

The SDGs were developed through a participatory process. ${ }^{2}$ A key feature of the SDGs, when compared with the Millennium Development Goals, is their increased emphasis on level of disaggregation by income, sex, age, race, ethnicity, migratory status, and disability status. Responses to a 2017 survey conducted by the Asian Development Bank (ADB) and the United Nations Economic and Social Commission for Asia and the Pacific (UNESCAP) suggested that, while disaggregation by location was available for several SDG indicators, disaggregation was less common by sex and often absent for disabled persons and indigenous peoples. ${ }^{3}$

The SDG indicator framework comprises a three-tier classification system based on data availability and whether the methodology is well established. Tier I indicators are those with a clearly established methodology and where data are being regularly collected by many economies. Tier II indicators are those with an established methodology, but where data are not regularly collected by many economies. Tier III indicators have neither established standards nor estimation methodologies. Of the 232 SDG indicators, 82 belong to Tier I, 61 belong to Tier II, and 84 belong to Tier III. The remaining 5 indicators fall under multiple tiers.

Data availability is an area of concern for tracking progress in achieving the SDGs. It is also vital to the design, implementation, and monitoring of national development plans. A lack of resources devoted to the development of statistics at the economy level is often a primary constraint to sufficient data being available (PARIS21 2017). The Cape Town Global Action Plan for Sustainable Development Data, which was adopted by the UN Statistical Commission in March 2017, appeals for a commitment from governments to provide the funding necessary to upgrade national statistical systems, use a combination of traditional and innovative data sources, and harness strategic partnerships with an array of stakeholders (UN 2017).

Part I of Key Indicators for Asia and the Pacific 2019 seeks to contribute to improved data availability in Asia and the Pacific. It provides a status update for ADB's 49 regional member economies on their progress toward achievement of the Sustainable Development Agenda. In addition to the data tables, the discussions for select SDG indicators are accompanied by supporting data stories and charts. Most of the statistics presented in the tables and charts are presented for two data points from 2000 to 2018. Data gaps and other data-related issues are also considered to inform any related policy actions.

1 In May 2018, the UN Statistical Commission approved the revised list of 232 indicators, which is the framework in place today for tracking progress toward achievement of the SDGs. Further refinements to the SDG indicators are expected.

2 As an example of this participatory process, the UN conducted an online survey asking citizens of the world to identify areas that they would like to see addressed in the SDGs.

3 In 2017, ADB and UNESCAP undertook a survey of 22 selected national statistics offices from ADB and UNESCAP member economies on their experience with SDG data compilation. 


\section{SDG 1. End poverty in all its forms everywhere

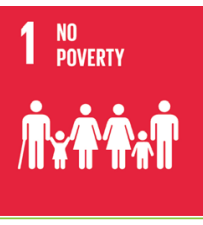

\section{Developing Asia has made major gains in reducing extreme poverty since 2002, but more than one- quarter of a billion people still live in extreme poverty.}

Eradicating extreme poverty throughout Asia and the Pacific has been one of region's greatest challenges. Those mired in such conditions struggle to meet basic needs, and often lack access to appropriate healthcare, education, clean water, and sanitation.

In developing Asia, the percentage of people living in extreme poverty-as measured by surviving on less than $\$ 1.90$ per day at 2011 purchasing power parity-fell significantly in the early part of the new millennium, from $33.7 \%$ in 2002 to $7.0 \%$ in 2015 (Figure 1.1.1). In absolute terms, this represented a decline from 1.11 billion people in extreme poverty to 264 million. The overwhelming majority of this decline occurred in East Asia (from 409 million people to 10 million) and South Asia (from 505 million to 202 million).

Extreme poverty fell in every subregion of Asia and the Pacific over the review period: Central and West Asia (from $29.3 \%$ in 2002 to $5.5 \%$ in 2015), East Asia (from $31.9 \%$ to $0.7 \%$ ), the Pacific (from $45.6 \%$ to $25.0 \%$ ), South Asia (from $39.7 \%$ to $13.3 \%$ ), and Southeast Asia (from $24.7 \%$ to $5.5 \%$ ).

The proportion of the world's population living in extreme poverty fell from $25.6 \%$ in 2002 to $10.0 \%$ in 2015 , largely due to the reduction in extreme poverty in developing Asia.

Figure 1.1.1: Proportion and Number of People Living in Extreme Poverty

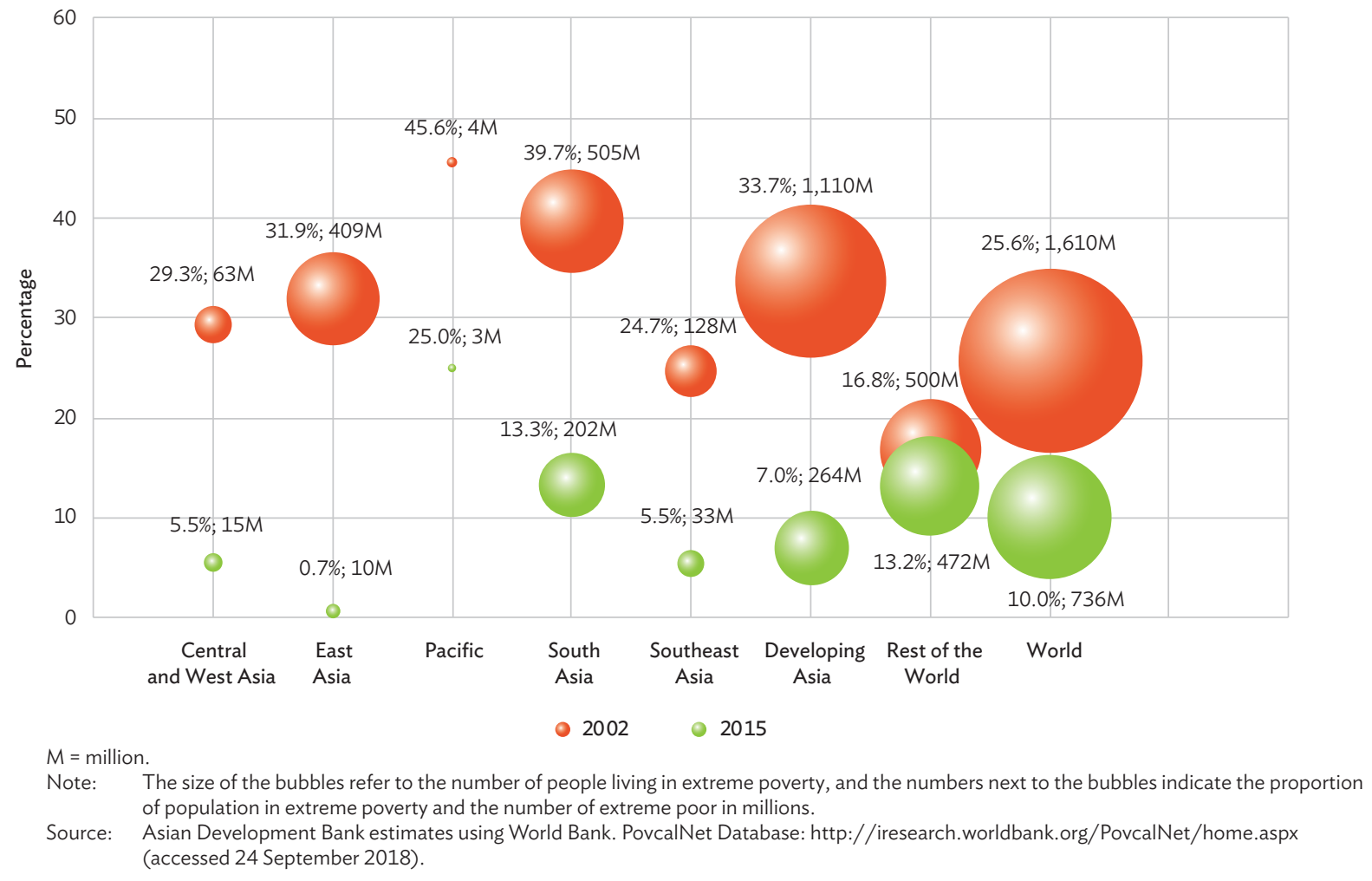




\section{Proportion of the "working poor" to total population falling throughout developing Asia}

Across developing Asia in 2018, the proportion of the employed population living in extreme poverty (i.e., the "working poor") was less than $5 \%$ in 15 of the 27 economies with available data for this indicator. The share of the working poor as a percentage of the total population exceeded $20 \%$ in 6 economies (Figure 1.1.2). The smallest proportions of the employed population living in extreme poverty in 2018 were found in Azerbaijan (0.02\%), Mongolia (0.12\%), and Sri Lanka (0.15\%). The largest shares were observed in Afghanistan (37.6\%), Uzbekistan (27.1\%), and Papua New Guinea (PNG) (26.3\%).

Figure 1.1.2: Proportion of Employed Population Living below the International Poverty Line

(\%)

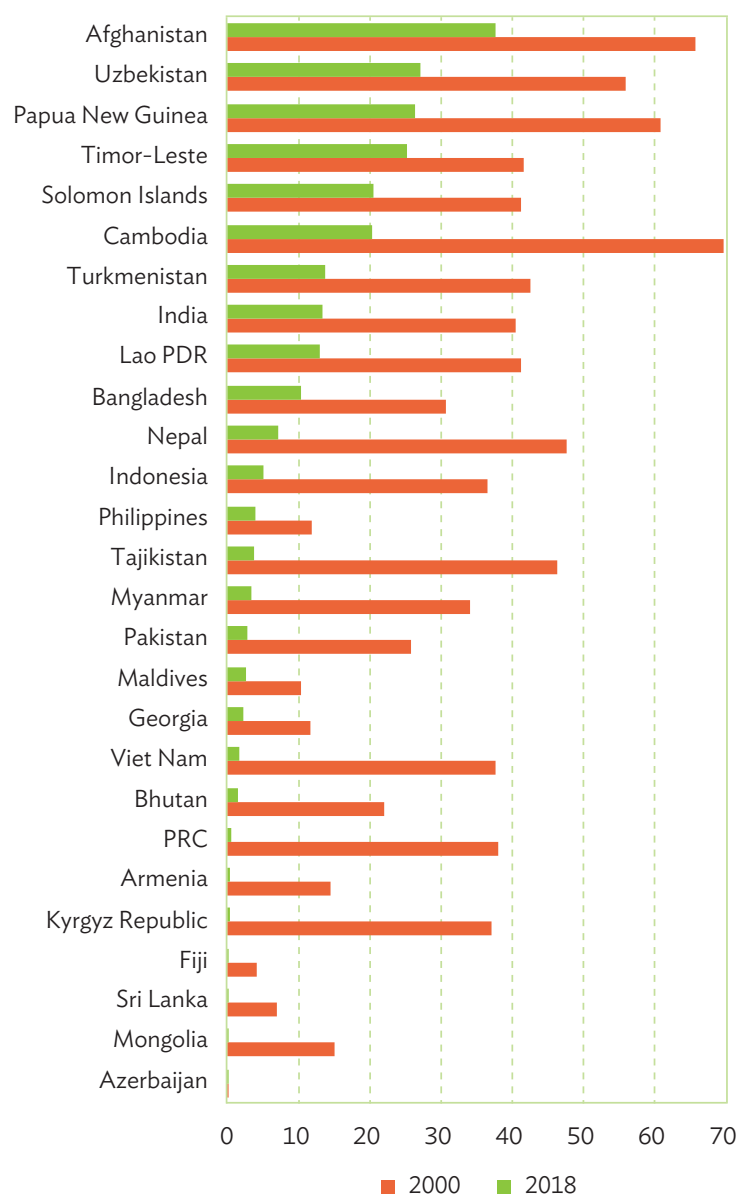

Lao PDR= Lao People's Democratic Republic, PRC= People's Republic of China.

Note: Only economies with values greater than zero for both years are included. Source: $\quad$ ILOSTAT. International Labour Organisation (accessed 18 July 2019).
From 2000 to 2018, the share of the working poor as a percentage of the total population fell in all of the 27 reporting economies. The largest declines occurred in Cambodia (49.3 percentage points), Tajikistan (42.4 percentage points), and Nepal (40.3 percentage points).

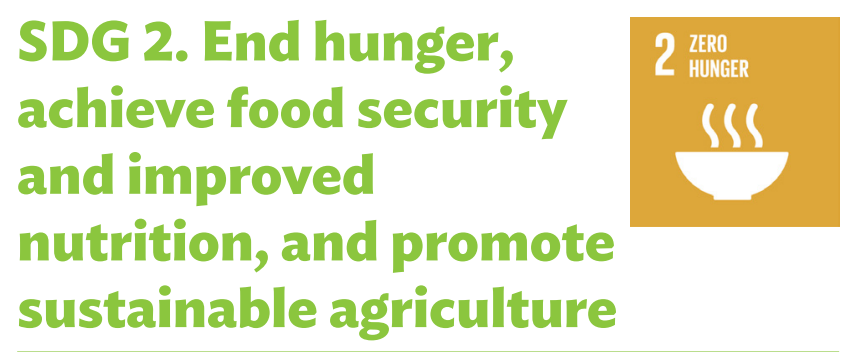

In spite of reductions in undernourishment in more than four-fifths of economies in Asia and the Pacific since 2000, hunger persists in the region

According to the UN, the rates of reducing undernourishment in Asia and the Pacific have slowed significantly in recent years, risking progress toward the SDG target to eradicate hunger by 2030 (FAO 2018). Investments in agriculture are needed to increase productivity and sustainability in food production systems.

Of the 37 regional economies with available data, 31 experienced a decline in the prevalence of undernourishment in the total population from 2000 to 2017 (Figure 1.2.1). The largest reductions during the review period occurred in Myanmar (37.7 percentage points), Mongolia (21.7 percentage points), and the Lao People's Democratic Republic (21.2 percentage points).

In 2017, the prevalence of undernourishment in the total population was below $10.0 \%$ in 26 of the 37 reporting economies, compared with only 14 of 37 in 2000. The prevalence of undernourishment was lowest-at a rate of $2.5 \%$ or below-in Australia; Azerbaijan; Hong Kong, China; Japan; Kazakhstan; Malaysia; New Zealand; and the Republic of Korea. The highest rates of undernourishment in 2017 were observed in Afghanistan (29.8\%), Timor-Leste (24.9\%), and Pakistan (20.3\%). 
Figure 1.2.1: Prevalence of Undernourishment in Select

Economies of Asia and the Pacific

(\% of total population)

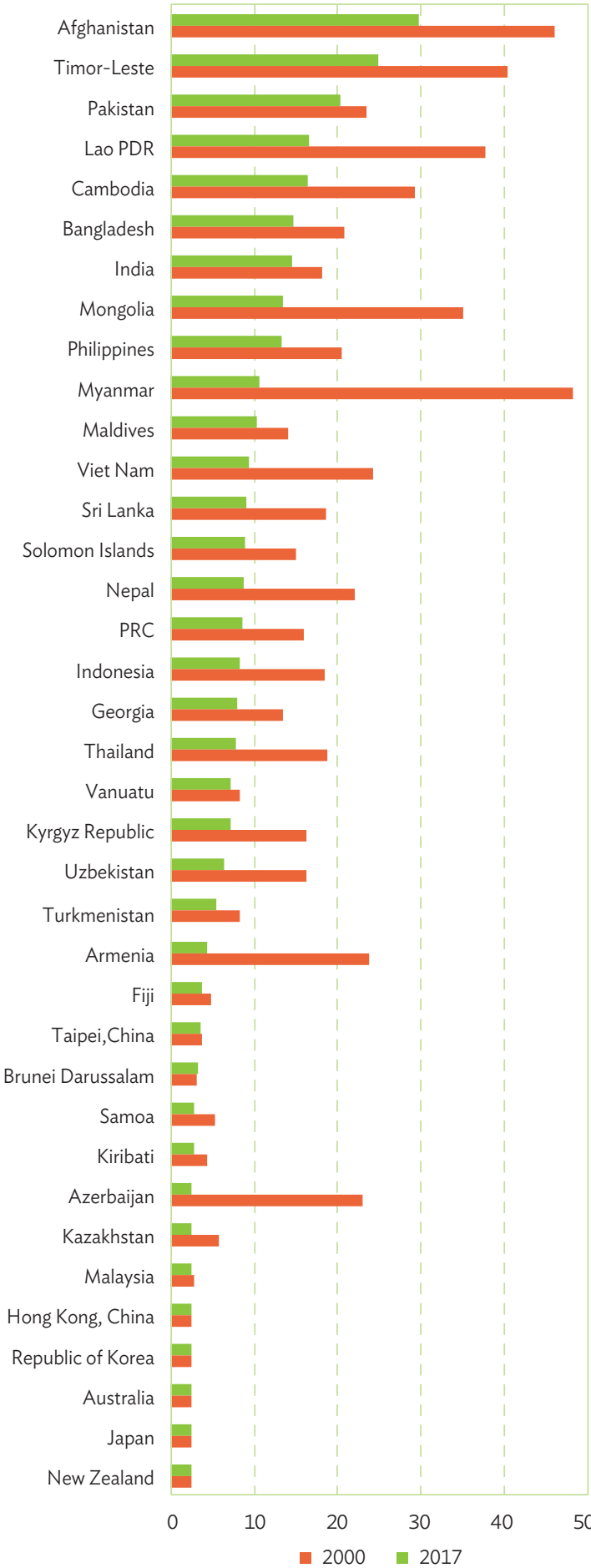

Lao PDR = Lao People's Democratic Republic, PRC = People's Republic of China Note: $\quad 2000$ values refer to 3-year average for 1999-2001; 2017 values refer to 3-year average for 2016-2018; and data with values smaller than 2.5\% are presented as $2.5 \%$.

Source: Table 1.2.1, Key Indicators for Asia and the Pacific 2019.
The prevalence of stunting has fallen since 2000 in more than $85 \%$ of developing member economies for which data are available

Poor food security and severe malnutrition have led to millions of Asian and Pacific islander children being stunted (i.e., too short for their age). The prevalence of stunting in children below the age of 5 years exceeded $25 \%$ in 15 of the 30 developing member economies with available data for 2016 (or another recent year)(Figure 1.2.2). The highest rates of stunting were found in Timor-Leste (50.9\%), PNG (49.5\%), and the Lao PDR (44.2\%).

The prevalence of stunting in children below the age of 5 years fell in 26 of the 30 reporting economies that had two data points available for comparison (ranging from 2000 to 2008 and 2009 to 2016). The 3 economies in which the prevalence of stunting increased over the review period were PNG (5.6 percentage points), Malaysia (3.5 percentage points), and Vanuatu (2.8 percentage points), while there was no change to this indicator in the Republic of Korea.

\section{SDG 3. Ensure healthy lives and promote well-being for all at all ages}

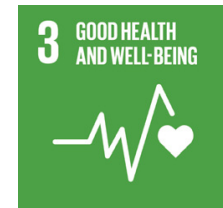

\section{Maternal mortality more than halved across Asia and the Pacific}

In Asia and the Pacific, the ratio of women dying during pregnancy, childbirth, or soon after fell from 264 deaths per 100,000 live births in 2000 to 123 deaths per 100,000 live births in 2015. This compares with world averages of 341 and 216 in 2000 and 2015, respectively (Table 1.3.1).

All subregions of Asia and the Pacific experienced a reduction in the maternal mortality ratio (MMR) from 2000 to 2015. South Asia reported 
Figure 1.2.2: Prevalence of Stunting among Children under 5 Years of Age

(\%)

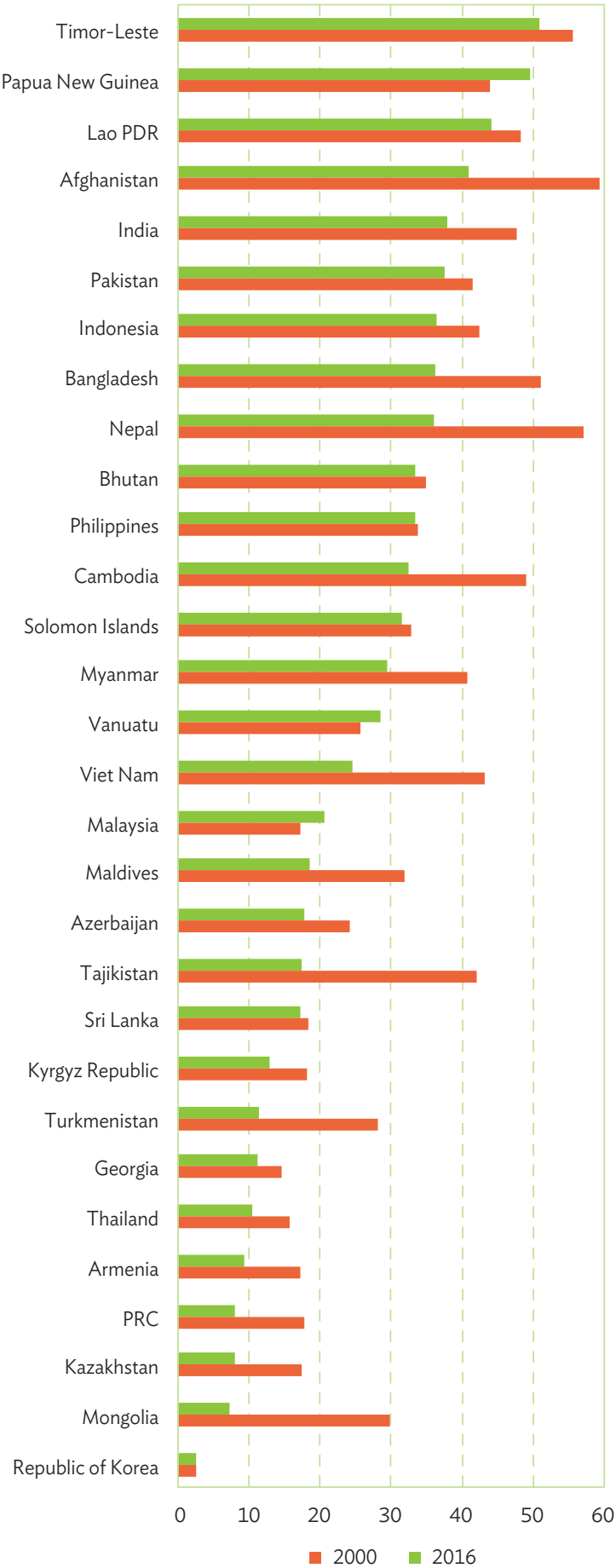

Lao PDR = Lao People's Democratic Republic, PRC = People's Republic of China.

Note: 2000 values refer to available data between 2000 and 2008; and 2016 values refer to available data between 2009 and 2018. Only economies with data for both years 2000 and 2016 are included. "Stunting" is when a child is too short compared to the average height for his or her age.

Source: Table 1.2.1, Key Indicators for Asia and the Pacific 2019. the largest drop (203 fewer maternal deaths per 100,000 live births), followed by Central and West Asia (192) and the Pacific (154) (Table 1.3.1).

From 2000 to 2015, the MMR decreased in 39 of the 43 regional economies with available data (Table 1.3.1). The exceptions were in the Kyrgyz Republic (from 74 maternal deaths per 100,000 live births in 2000 to 76 in 2015); Taipei,China (from 8 to 10); Tonga (from 97 to 124); and Uzbekistan (from 34 to 36).

Afghanistan experienced the largest decline in its MMR, with 704 fewer maternal deaths per 100,000 live births in 2015 than in 2000. It was followed by Timor-Leste (479), the Lao PDR (349), and Cambodia (323), Nepal (290) and Bhutan (275). Economies with fewer than 20 maternal deaths per 100,000 live births in 2015 included Hong Kong, China (2); Japan (5); Australia (6); Singapore (10); Taipei,China (10); the Republic of Korea (11); New Zealand (11); and Kazakhstan (12) (Table 1.3.1).

In economies where maternal deaths were low, there was a high proportion of births attended by skilled health personnel. Conversely, in those economies where maternal deaths were high, there was a low proportion of births attended by medical professionals (Figure 1.3.1).

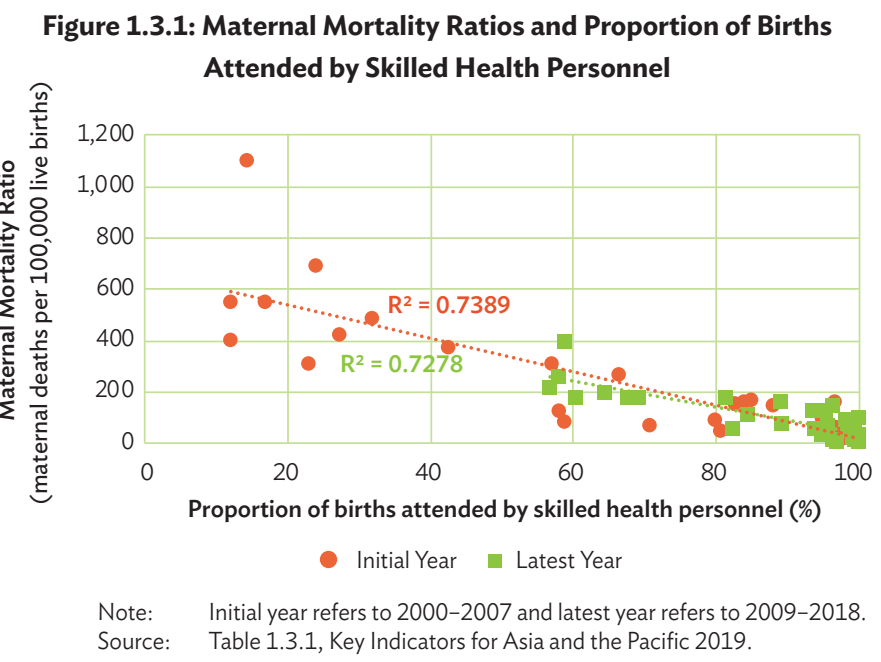


The under-5 mortality rate fell in 46 out of 47 economies between 2000 and 2017.

The under-5 mortality rate in Asia and the Pacific fell from 69 deaths per 1,000 live births in 2000 to 31 deaths per 1,000 live births in 2017. This compares with world averages of 77 and 39 in 2000 and 2017, respectively.

By subregion, South Asia experienced the largest decline in under-5 mortality (52 fewer deaths per 1,000 live births), followed by Central and West Asia (41), East Asia (27), the Pacific (24), and Southeast Asia (22) as shown in Figure 1.3.2. For the 3 developed economies in Asia and the Pacific, the average decline during the review period was 2 fewer deaths per 1,000 live births.

The under-5 mortality rate fell during the review period in 46 out of the 47 regional economies with available data. The largest reductions occurred in Cambodia (78 fewer deaths per 1,000 live births), Afghanistan (61), Timor-Leste (60), and Bangladesh (55) as can be observed in Table 1.3.1. Fiji was the only economy in which the under-5 mortality rate increased, from 23 deaths per 1,000 live births in 2000 to 25 in 2017.

Figure 1.3.2: Under-5 Mortality Rate by Region and Subregion of Asia and the Pacific (per 1,000 live births)

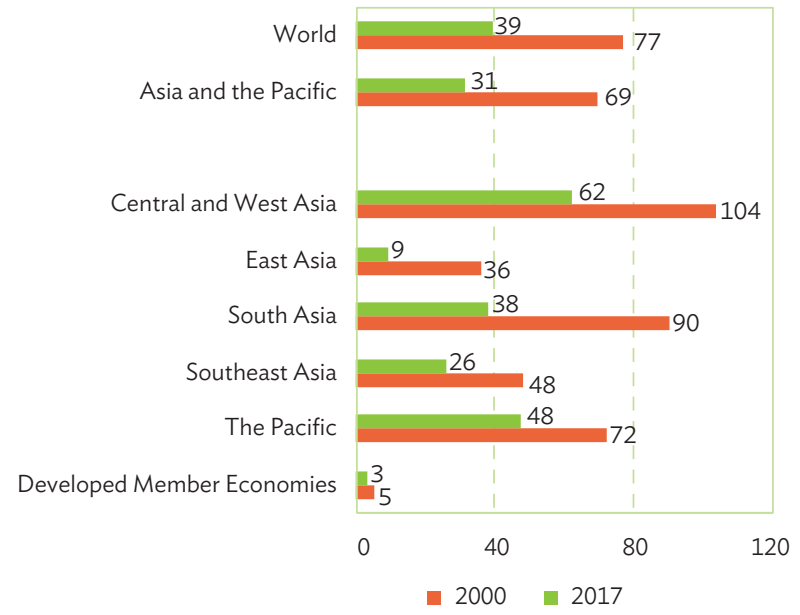

Source:

Table 1.3.1, Key Indicators for Asia and the Pacific 2019
SDG 4. Ensure inclusive and equitable quality education and 4 QUALTYY promote lifelong learning opportunities for all

Participation rates in pre-primary education for both boys and girls exceed $90 \%$ in two-fifths of developing member economies

Early childhood education is critical to laying a strong foundation for future development and lifelong learning. Among the developing economies of Asia and the Pacific, 14 of the 32 economies with available data for 2017 (or another recent year) had at least $90 \%$ of both boys and girls participating in organized learning 1 year before the official entrance age to primary school (Figure 1.4.1). For boys in developing economies, $100 \%$ participation rates in preprimary education were observed in Hong Kong, China; Palau; and Viet Nam. For girls, 100\% preprimary participation rates were observed in the Cook Islands, Indonesia, Niue, and Tuvalu.

Participation rates below $50 \%$ for both boys and girls were found in 6 of the 32 economies reporting for 2017 (or the most recent year for which data are available). These economies, and their respective preprimary participation rates for each sex, were Bangladesh (35.3\% for boys and 35.4\% for girls), Cambodia (42.5\% and 43.6\%), Samoa (34.9\% and $39.1 \%$ ), Tajikistan (13.4\% and $11.6 \%$ ), Timor-Leste (32.8\% and 33.5\%), and Uzbekistan (37.4\% and 36.4\%). 
Figure 1.4.1: Participation Rate in Preprimary Learning ${ }^{\mathrm{a}}$ by Sex of Child, 2017 ${ }^{\mathrm{b}}$

(\%)

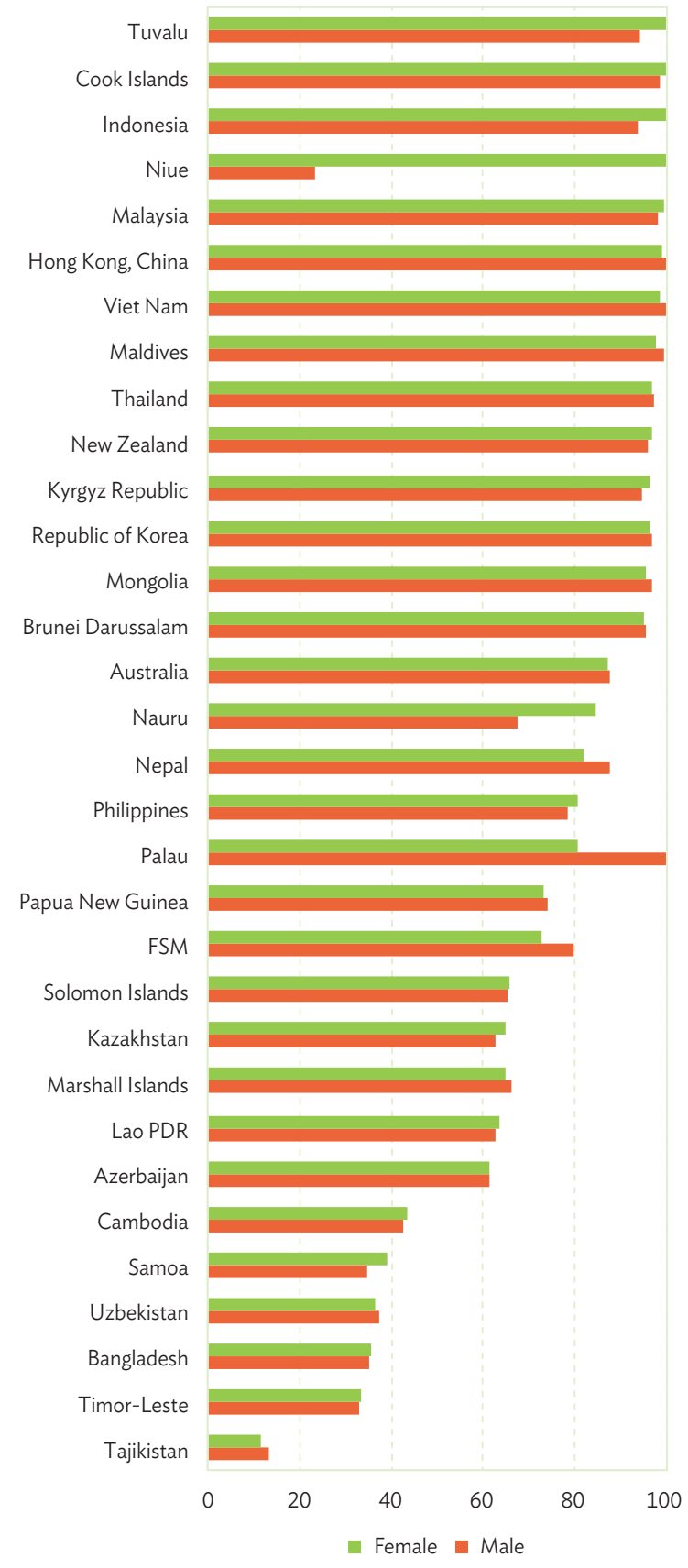

FSM = Federated States of Micronesia, Lao PDR = Lao People's Democratic Republic. a Participation in organized learning 1 year before the official entrance age to primary school.

b For Kazakhstan, data refer to 2018; for the Cook Islands, the Republic of Korea, the Marshall Islands, Nauru, Papua New Guinea, the Philippines, and Tuvalu data refer to 2016; for Niue, Malaysia, the FSM, and Solomon Islands, data refer to 2015; for Palau, data refer to 2014; for Cambodia, data refer to 2012; and for Bangladesh, data refer to 2010.

Source: Table 1.4.1, Key Indicators for Asia and the Pacific 2019.
In 15 of the 32 reporting economies, the preprimary participation rate for girls lagged behind that of boys. The biggest gaps were found in Palau (19.6 percentage points), the Federated States of Micronesia (7.0 percentage points), and Nepal (5.5 percentage points).

\section{Providing qualified primary school teachers is a priority in most economies}

Primary school teachers play a key role in ensuring the quality of children's education. While national minimum training requirements can vary widely across economies, all primary education teachers should receive adequate and relevant pedagogical training, both pre-service and in-service, required for teaching at the relevant level.

Comparing 2000 (or another early year) with 2017 (or another recent year), 15 of the 23 regional economies with available data increased the proportion of primary education teachers receiving the minimum organized training. The largest increases in this proportion over the review period were achieved in Nepal (from $15.4 \%$ to $97.3 \%$ ), Kyrgyz Republic (from 52.0\% to 95.4\%), and Myanmar (from $62.7 \%$ to $97.8 \%$ ). The largest declines in the proportion of primary education teachers receiving the minimum organized training were in Kiribati (from $93.9 \%$ to $72.7 \%$ ), Fiji (from $97.8 \%$ to $90.1 \%$ ), and Bangladesh (from $53.4 \%$ to $50.4 \%$ ).

In 2017 (or the most recent year for which data are available), the proportion of primary education teachers receiving the minimum organized training exceeded $90 \%$ in 19 of the 23 reporting economies with available data for both 2000 and 2017 (Figure 1.4.2). This compares favorably with 2000 (or the earliest year for which data are available), when only 10 of the 23 economies met the $90 \%$ threshold. 
Figure 1.4.2: Proportion of Teachers in Primary Education Who Have Received at Least the Minimum Organized Teacher Training (\%)

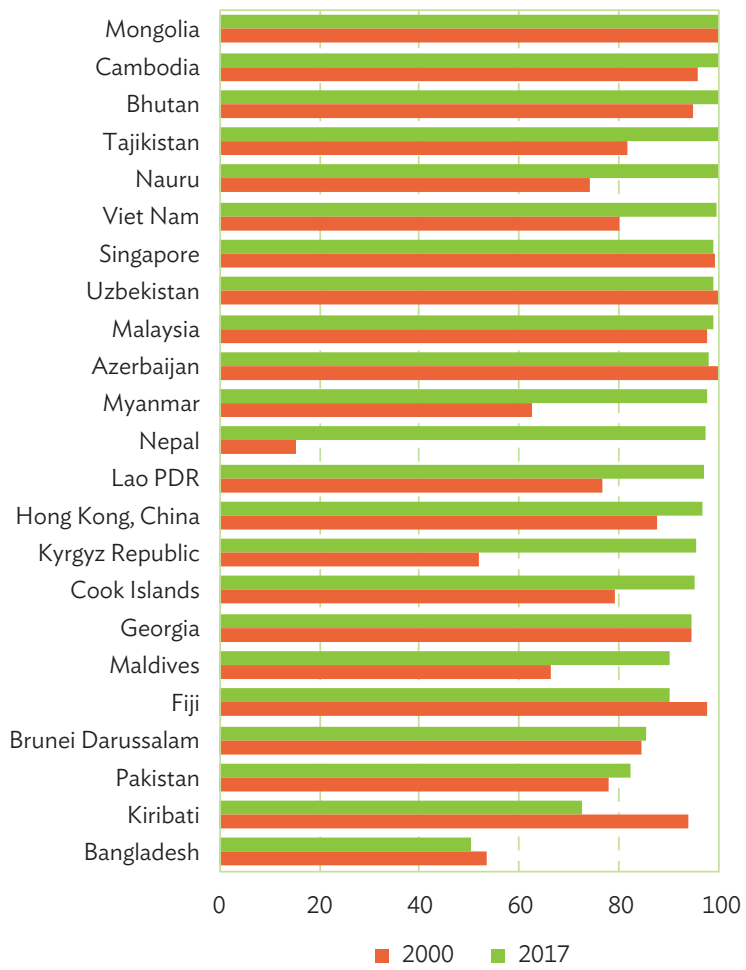

Lao PDR = Lao People's Democratic Republic

Note: $\quad 2000$ values refer to available data between 2000 and 2008; and 2017 values refer to available data between 2009 and 2018. Only economies with data for both years 2000 and 2017 are included.

Source: Table 1.4.2, Key Indicators for Asia and the Pacific 2019

Click here for figure data

\section{SDG 5. Achieve gender equality and empower all women and girls}

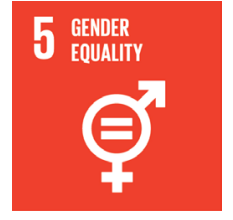

\section{At least 20\% of women aged 20-24 years old were married or in a union before the age of 18 in 11 of 29 regional economies}

Early-age marriage can compromise the education outcomes of a girl or young woman. It can impact her employment prospects; the type, arrangements, and conditions of her future work; her overall well-being; and the health of her offspring (Nour 2009).
In 11 of the 29 regional economies with available data, at least $20 \%$ of women between the ages of 20 and 24 years had been married or in a union before the age of 18 (Table 1.5.1). Bangladesh (58.6\%) reported the largest proportion of women aged 20-24 being married or in a union before the age of 18 (Figure 1.5.1). More than a quarter of women between the ages of 20 and 24 years were married or in a union before the age of 18 in Nepal (39.5\%), Afghanistan (34.8\%), the Lao PDR (32.7\%), India (27.3\%), and Bhutan (25.8\%).

\section{Women's representation in the national parliament exceeds $30 \%$ in only 3 economies}

Sustainable development and societies in general can be strengthened by providing women and girls with equal access to education, health care,

Figure 1.5.1: Proportion of Women Who Were Married or in a Union before Age 15 or Age 18 (\% of all women aged $20-24$ years)

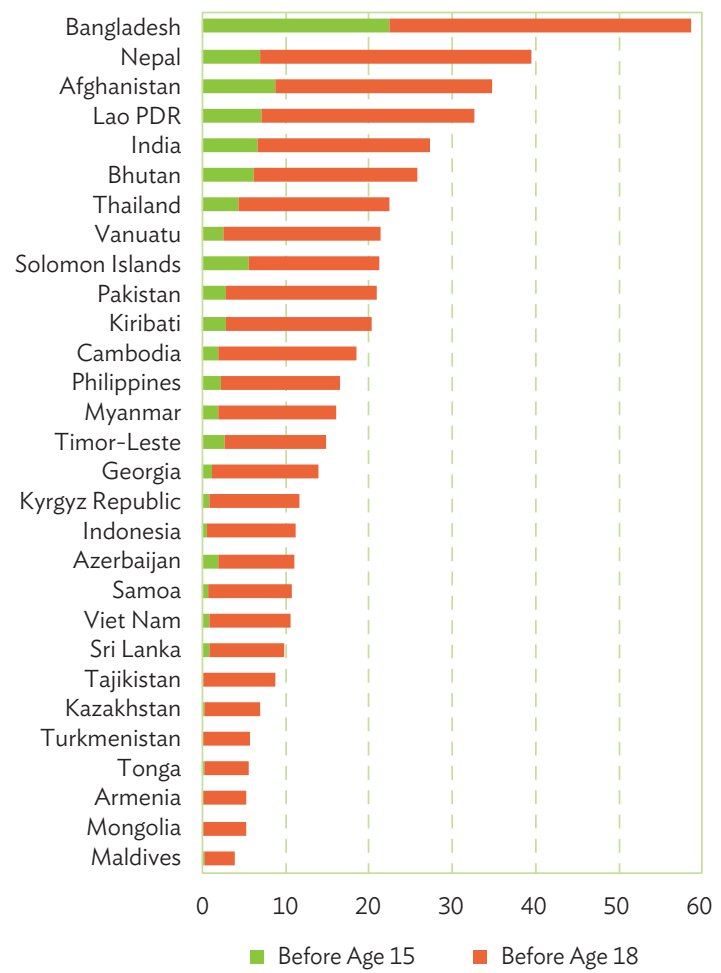

Lao PDR = Lao People's Democratic Republic

Note: The percentages shown are based on economy data for the most recent year from 2009 to 2018.

Source: Table 1.5.1, Key Indicators for Asia and the Pacific 2019. 
decent work, and representation in political and economic decision-making processes. Unfortunately, no economy in Asia and the Pacific was even remotely close to $50 \%$ representation of women in their national parliaments in 2018 (Figure 1.5.2). In fact, only 3 of the 45 economies with available data had female parliamentary representation exceeding 30\%: New Zealand (38.3\%), Nepal (32.7\%), and Timor-Leste (32.3\%). A threshold of $15 \%$ for women's representation was surpassed in only 25 of the 45 economies reporting in 2018, while 13 economies failed to achieve a $10 \%$ threshold.

Figure 1.5.2: Proportion of Seats in National Parliament Held by Women, 2018

(\%)

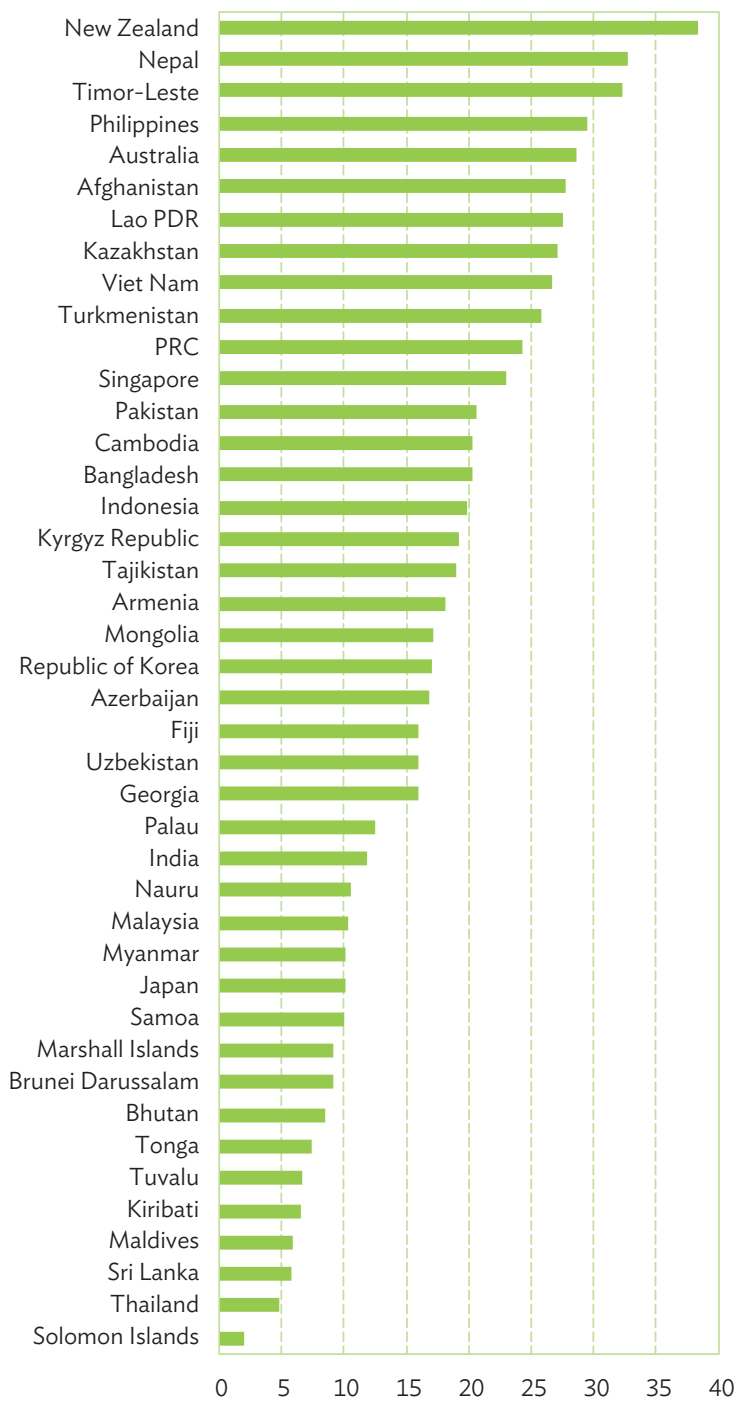

Lao PDR = Lao People's Democratic Republic, PRC= People's Republic of China.

Note: $\quad$ The Federated States of Micronesia, Papua New Guinea, and Vanuatu have zero representation and are not shown in the figure.

Source: Table 1.5.1, Key Indicators for Asia and the Pacific 2019
A UN assessment of female participation in local governance in Asia and the Pacific showed that, as with national level data, female participation at the local level is far below gender parity levels. A shortage of women in elected local leadership posts implies that fewer women will continue into higher elected offices, at both the local and national level (ADB and UN Women 2018).

\section{SDG 6. Ensure availability and sustainable} management of water and sanitation for all

\section{Economies are doing more to provide safe drinking water, but rural areas still lag}

There is sufficient fresh water on the planet to provide clean water for all. Yet, millions of people die every year from diseases associated with inadequate water supply, sanitation, and hygiene. Proper management of water and sanitation services is needed to reduce the risk of contracting preventable diseases.

In 2017, the proportion of the population using safely managed drinking water services exceeded $90 \%$ in only 8 of the 25 regional economies with available data (Figure 1.6.1). Among these 8 economies, the proportion reached $100 \%$ in Hong Kong, China; New Zealand; and Singapore. Conversely, the proportion of the population using safely managed drinking water services was below $50 \%$ in 9 economies.

Since 2000, all but 3 of the 25 reporting economies have made progress in providing safely managed drinking water services. Over the review period, the largest increases in the proportion of the population using such services were in Armenia (56.9 percentage points), Kazakhstan (32.0 percentage points), and Turkmenistan (28.0 percentage points). 
Among the 10 reporting economies with data disaggregated into urban and rural areas, 9 had a higher share of the population using safely managed drinking water services in urban areas than in rural areas. The biggest discrepancies were observed in Uzbekistan (urban coverage 55.0 percentage points higher than rural coverage), Cambodia (39.9 percentage points), and the Kyrgyz Republic (39.6 percentage points). The exception was Bangladesh, where rural areas had greater access to safely managed drinking water services than did urban areas (by a difference of 16.9 percentage points).

The share of the population receiving safely managed sanitation services increased in 11 of 14 reporting economies between 2000 and 2017

\section{Figure 1.6.1: Proportion of the Population Using Safely Managed Drinking Water Services, 2017}

(\%)

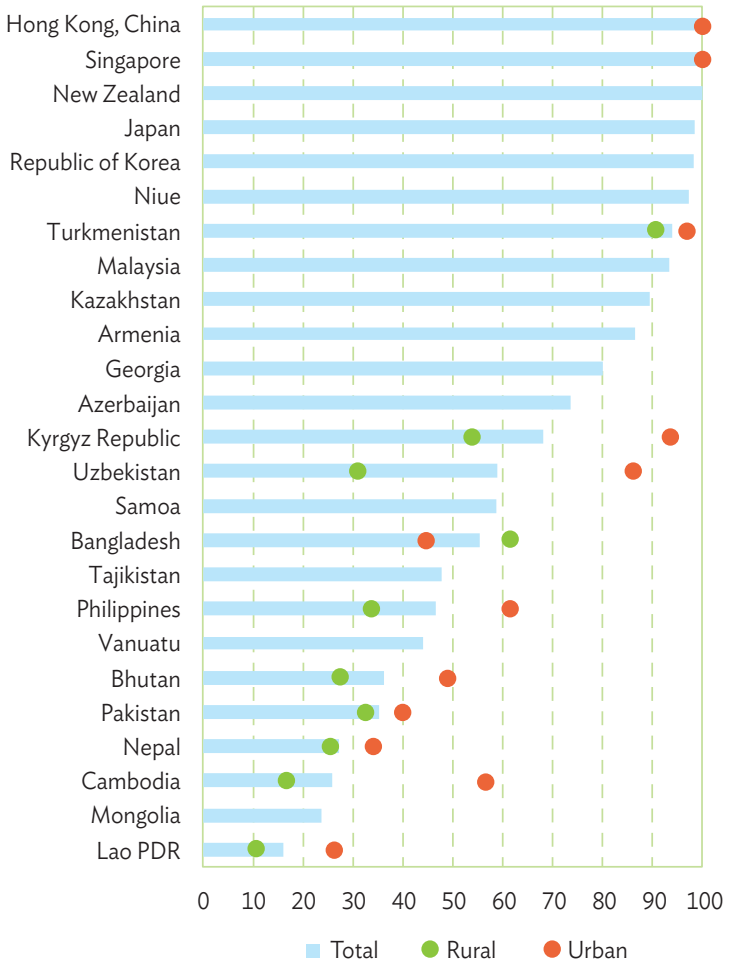

Lao PDR = Lao People's Democratic Republic.

Note: This figure excludes economies that provided only urban and/or rural data, with no national totals provided.

Source: Table 1.6.1, Key Indicators for Asia and the Pacific 2019.
Inadequate sanitation can negatively impact food security, livelihood choices, and educational opportunities. Only 4 of the 14 regional economies with available data for 2017 had more than $90 \%$ of the population using safely managed sanitation services. Coverage of such services reached or approached $100 \%$ in Singapore (100.0\%), the Republic of Korea (99.9\%), and Japan (98.8\%) as shown in Figure 1.6.2. However, the share of the population accessing safely managed sanitation services in 2017 was below $50 \%$ in 4 of the 14 reporting economies.

From 2000 to 2017, 11 of the 14 economies increased the share of the population benefiting from safely managed sanitation services, 2 experienced a decline, and 1 remain unchanged (Singapore's

\section{Figure 1.6.2: Proportion of Population Using Safely Managed Sanitation Services, 2017}

(\%)

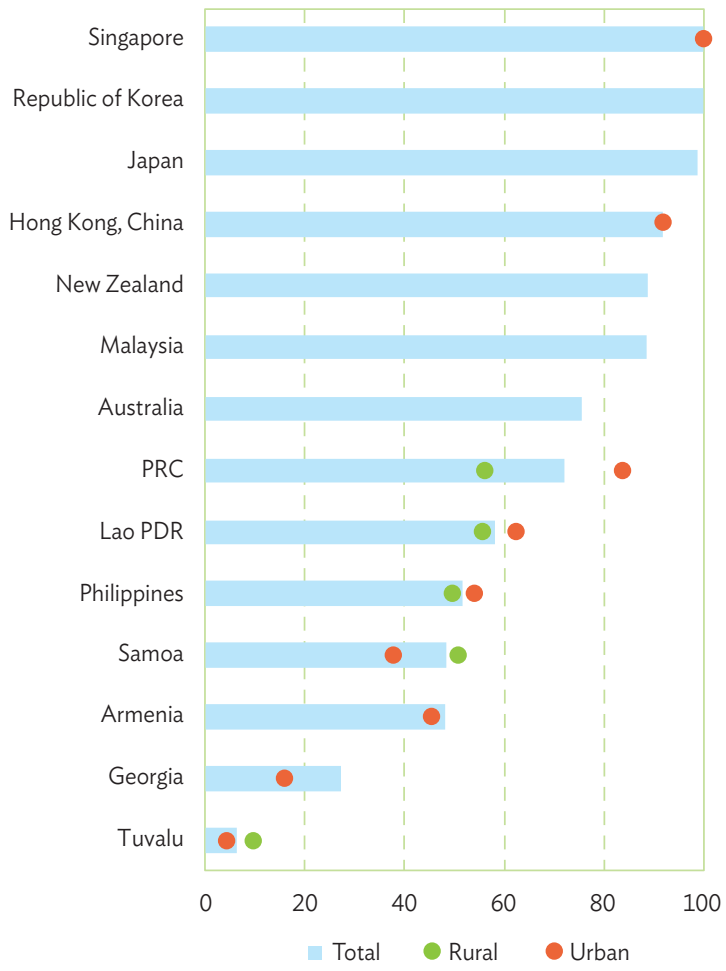

PRC = People's Republic of China, Lao PDR = Lao People's Democratic Republic.

Note: This figure excludes economies that provided only urban and/or rural data, with no national totals provided.

Source: Table 1.6.1, Key Indicators for Asia and the Pacific 2019. 
sanitation coverage was stable at $100 \%$.). The largest increases during the review period were in the People's Republic of China (PRC) (45.5 percentage points), the Lao PDR (36.2 percentage points), and the Republic of Korea (14.0 percentage points).

Among the 5 reporting economies with data disaggregated into urban and rural areas, 3 had a higher share of the population using safely managed sanitation services in urban areas, while 2 had a higher share in rural areas. The biggest discrepancy in sanitation services coverage in favor of urban areas was observed in the PRC (27.6 percentage points). The biggest discrepancy in favor of rural areas was in Samoa (13.2 percentage points).

\section{SDG 7. Ensure}

\section{access to affordable, reliable, sustainable, and modern energy for all}

\section{Economies in Asia and the Pacific have significantly expanded access to electricity since 2000.}

Universal access to energy, improved energy efficiency, and the increased use of renewable energy support the development of sustainable and inclusive communities, while also strengthening resilience to climate change and other environmental hazards. Public and private investments in energy generation and distribution are needed globally, and greater emphasis should be placed on equitable regulatory frameworks and innovative business models.

Across economies of Asia and the Pacific, the proportion of the population with access to electricity exceeded $90 \%$ in 38 of the 48 economies with available data for 2017. This compares with 20 of 46 economies in 2000 (Table 1.7.1). No economy had electricity coverage below $50 \%$ of the population in 2017, compared with 12 economies in 2000.

From 2000 to 2017, the largest gains in expanding access to electricity across the population occurred in Afghanistan (74.7 percentage points), Cambodia (72.5 percentage points), and Nepal (68.4 percentage points) as shown in Figure 1.7.1.

Figure 1.7.1: Proportion of the Population with Access to Electricity

(\%)

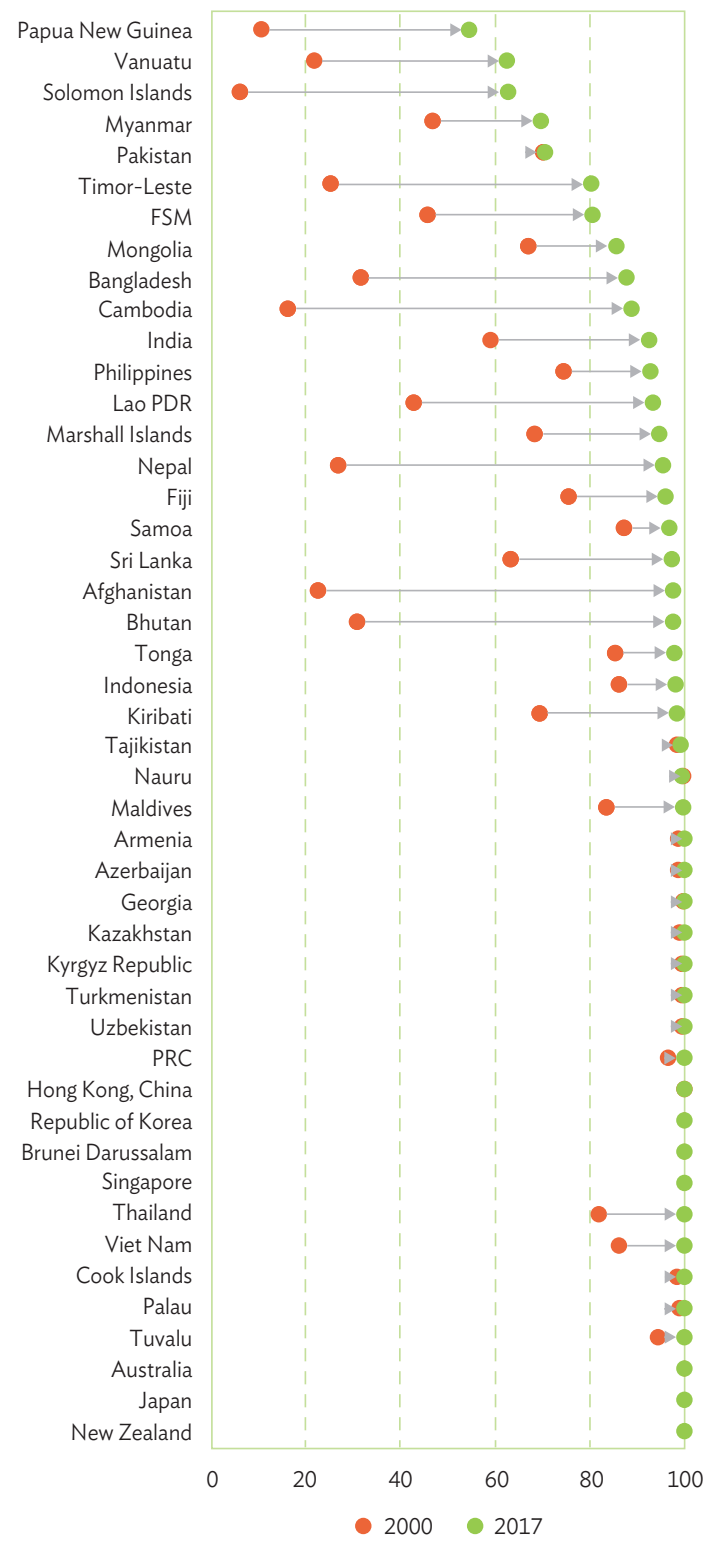

FSM = Federated States of Micronesia, Lao PDR = Lao People's Democratic Republic, PRC = People's Republic of China.

Source: Table 1.7.1, Key Indicators for Asia and the Pacific 2019. 
Access to clean fuels and technology has broadly risen across the region since 2000, with a handful of economies lagging behind

In 16 of the 47 regional economies with available data on clean energy in 2017 , more than $90 \%$ of the population had access to clean fuels and technology for cooking, heating, or lighting (Figure 1.7.2). This compares with 9 economies in 2000.

Figure 1.7.2: Proportion of Population with Primary Reliance on Clean Fuels and Technology

(\%)

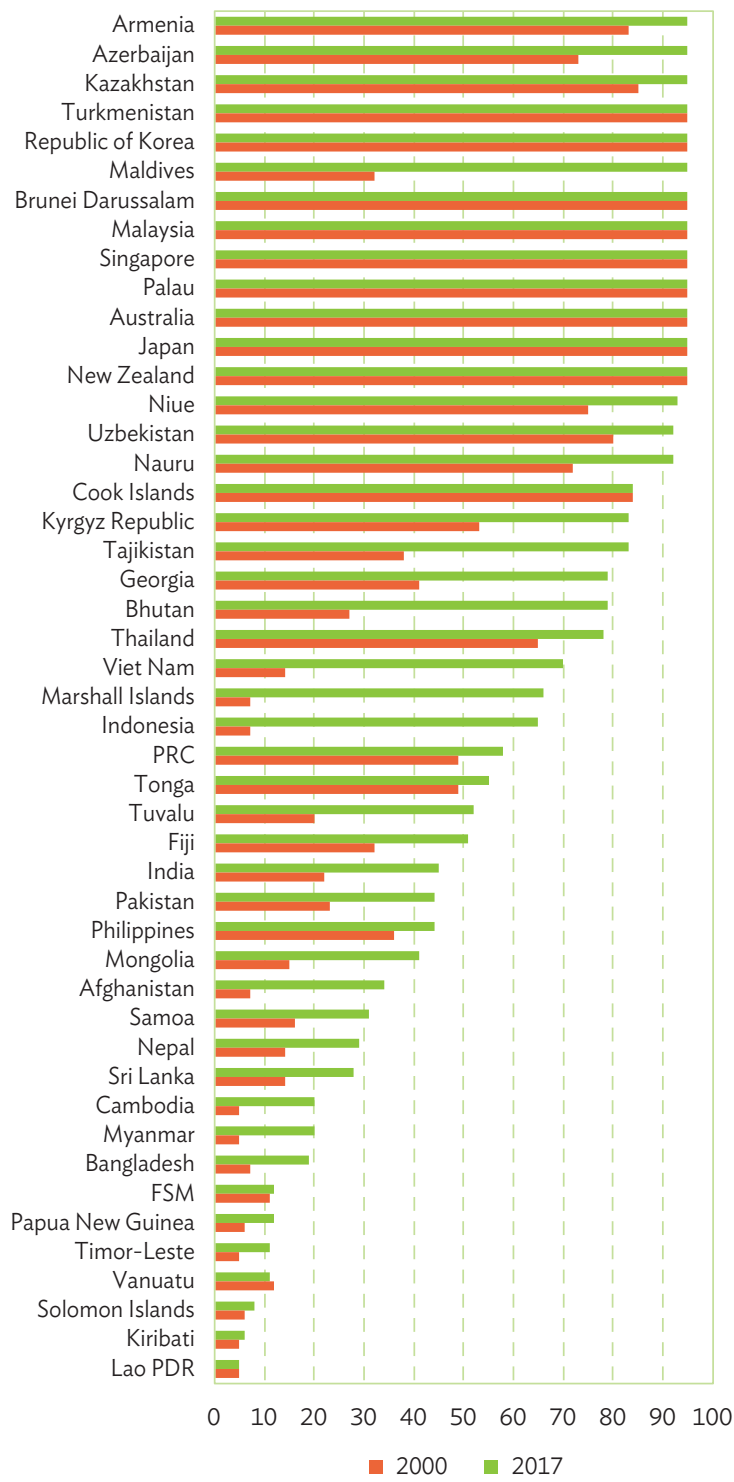

FSM = Federated States of Micronesia, Lao PDR = Lao People's Democratic Republic, PRC = People's Republic of China

Note: Data with values greater than $95 \%$ are presented as $95 \%$ and values smaller than $5 \%$ are presented as $5 \%$.

Source: Table 1.7.1, Key Indicators for Asia and the Pacific 2019
From 2000 to 2017, the largest increases in the share of the population with access to clean energy occurred in Maldives (63.0 percentage points), the Marshall Islands (59.0 percentage points), and Indonesia (58.0 percentage points).

Conversely, the share of the population with access to clean energy was below $20 \%$ in 8 of the 46 reporting economies.

\section{SDG 8. Promote sustained, inclusive, and sustainable economic growth; full and productive employment; and decent work for all}

\section{Age and gender gaps persist in job markets across Asia and the Pacific}

Employment provides individuals with income and (in many cases) access to social protection coverage, unemployment benefits, pensions, and maternity leave. Yet, those in vulnerable forms of employment, such as the self-employed and contributing family workers, generally lack access to these benefits (ILO 2018).

Of the 30 economies with available data for 2017 (or another recent year), all but 1 (Kazakhstan) had a higher rate of unemployment among the population aged 15-24 years than among the population aged 25 years and older (Figure 1.8.1). Moreover, there were 13 economies with an employment gap between the two age groups that exceeded 10 percentage points. The most significant gaps were in Kiribati (33.1 percentage points), Armenia (22.7 percentage points), and Samoa (21.9 percentage points).

Among the population aged 15 years and older, there was a gender gap in unemployment in favor 
of males in 19 of the 34 economies with available data for 2017 (or another recent year) (Table 1.8.2). In economies where there was a gender gap in unemployment in favor of girls and women in 2017 (or another recent year), the largest gaps were in the Lao PDR (3.0 percentage points), Turkmenistan (3.0 percentage points), and Georgia (2.3 percentage points).

Figure 1.8.1: Unemployment Rate by Age Group, 2017 or Most Recent Year Prior

(\%)

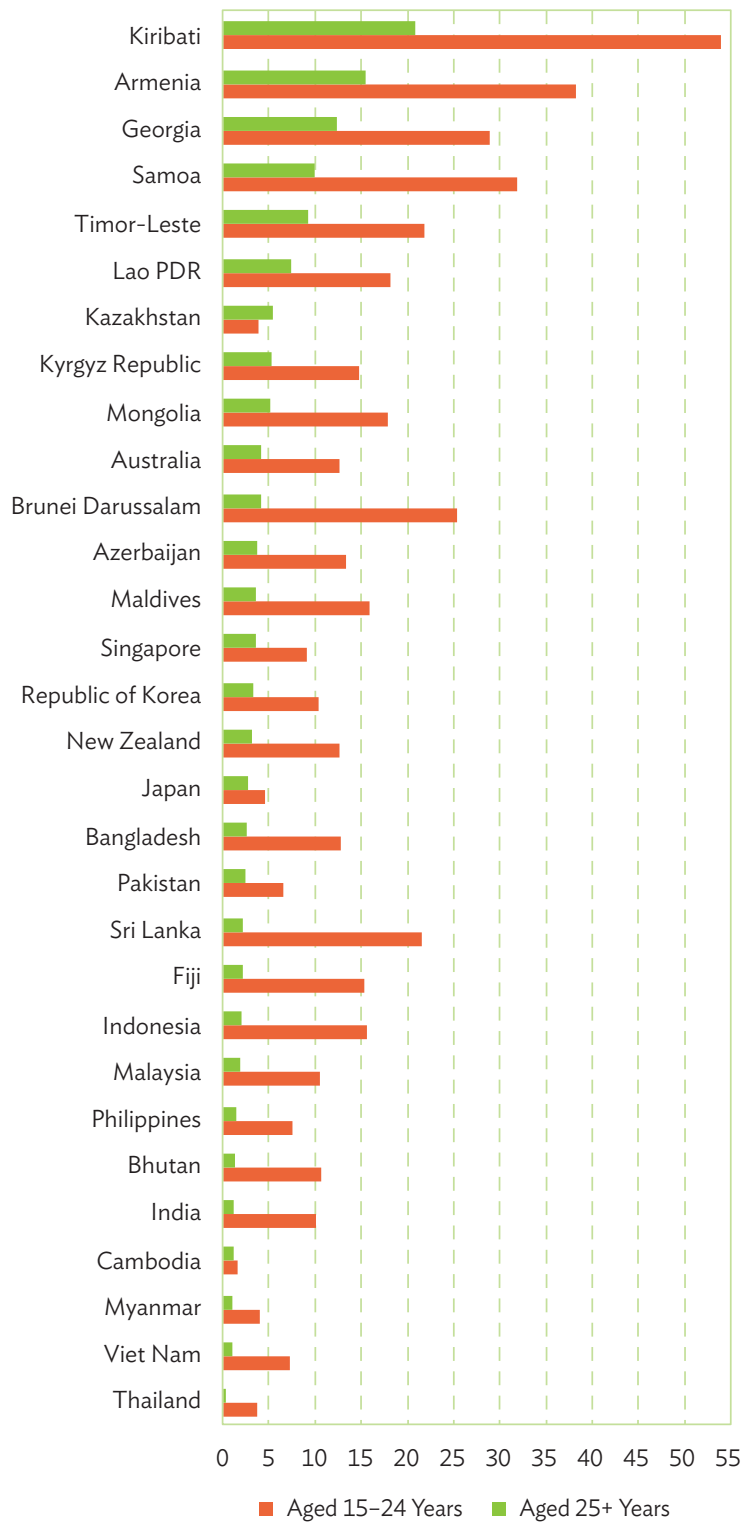

Lao PDR = Lao People's Democratic Republic.

Note: $\quad$ For Fiji, Malaysia, Maldives, Singapore, and Sri Lanka, data refer to 2016; for Azerbaijan, Bhutan, and Pakistan, data refer to 2015; for Brunei Darussalam, data refers to 2014; for Kazakhstan and Timor-Leste, data refer to 2013; for Cambodia and India, data refer to 2012; for Kiribati, data refers to 2010

Source: Table 1.8.2, Key Indicators for Asia and the Pacific 2019.
Closing the age and gender gaps in employment will require investments in youth education, increasing opportunities for girls and women to enroll in education and enter labor markets, promoting efficient school-to-work transition programs, and creating decent jobs (ILO 2017).

\section{SDG 9. Build resilient infrastructure, promote inclusive and sustainable industrialization, and foster innovation}

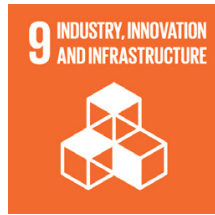

Manufacturing value added per capita increased in around 75\% of economies in Asia and the Pacific since 2000, signaling progress in industrialization across most of the region.

Manufacturing value-added is used to assess an economy's level of industrialization. Its share as a percentage of gross domestic product (GDP) reflects manufacturing's significance in an economy, as the jobs created by an expanding manufacturing sector can support an economy's overall development.

From 2000 to 2018, an increase in manufacturing value-added per capita was observed in 34 of the 46 economies with available data (Figure 1.9.1). Among the developing economies, the biggest gains (in constant 2010 United States dollars) occurred in the Republic of Korea ( $\$ 4,371$ per capita), Singapore $(\$ 2,348)$, and Turkmenistan $(\$ 2,118)$. The largest declines occurred in Brunei Darussalam (\$1,499); Hong Kong, China (\$389); and Samoa (\$120).

In 2018, manufacturing value-added per capita exceeded \$1,000 (in constant 2010 United States dollars) in 9 developing economies, led by Singapore (\$9,358), the Republic of Korea (\$7,769), and Brunei Darussalam (\$4,738). Conversely, manufacturing value-added per capita was below $\$ 100$ in 8 economies. 
Figure 1.9.1: Manufacturing Value-Added per Capita (constant 2010 \$)

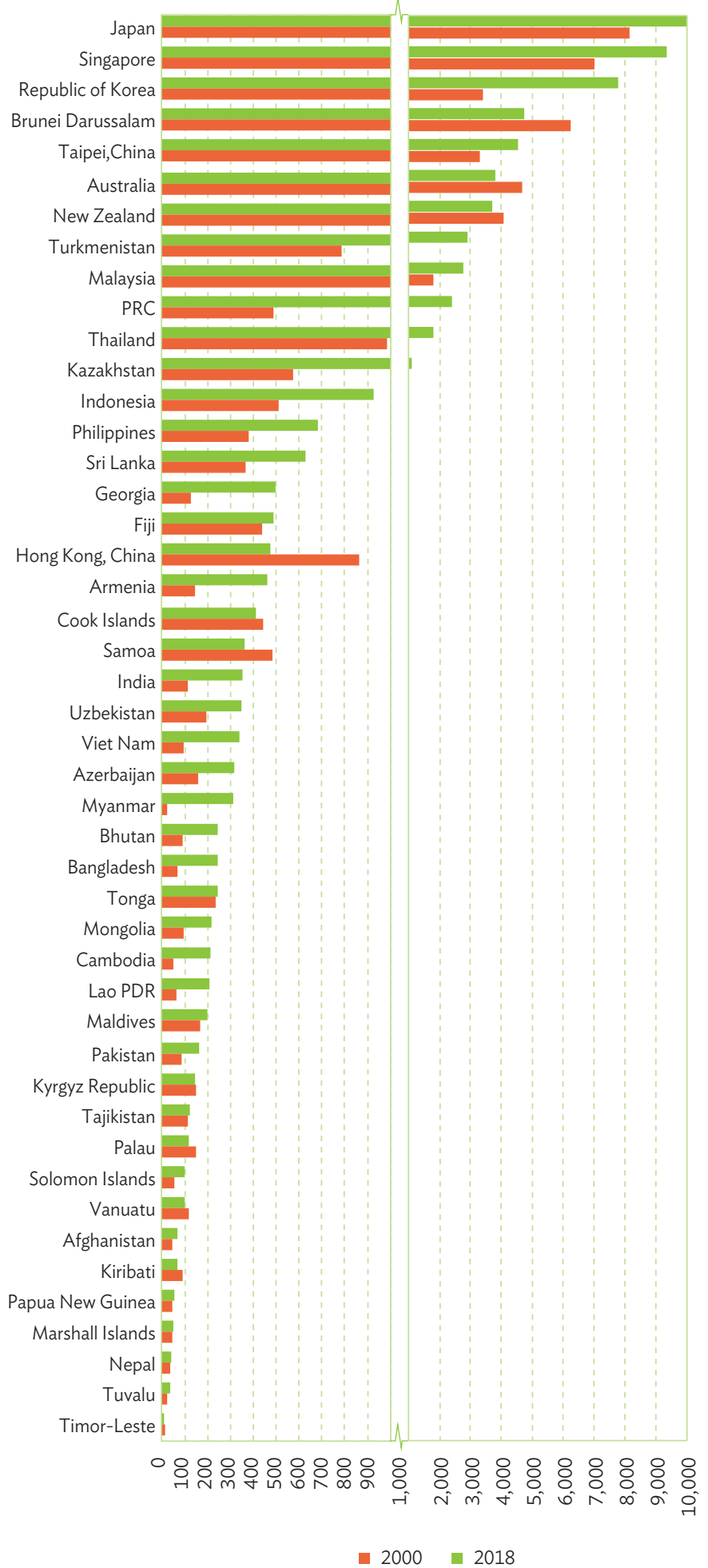

\$ = United States dollars, Lao PDR = Lao People's Democratic Republic, PRC $=$ People's Republic of China.

Note: $\quad$ For 2000, data for Taipei, China refer to 2001. Only economies with data for both years 2000 and 2018 are included.

Source: $\quad$ Table 1.9.2, Key Indicators for Asia and the Pacific 2019.
While Asia and the Pacific's aggregate carbon dioxide $\left(\mathrm{CO}_{2}\right)$ emissions have risen, $\mathrm{CO}_{2}$ emissions per unit of manufacturing value added declined in a majority of regional economies between 2000 and 2016.

The adoption of clean and environmentally sound technologies and industrial processes promotes resource-use efficiency and reduces carbon dioxide $\left(\mathrm{CO}_{2}\right)$ emissions.

Across Asia and the Pacific, emissions-in term of kilograms $(\mathrm{kg})$ of $\mathrm{CO}_{2}$ equivalent-per unit of manufacturing value-added declined in 18 of the 30 regional economies with data available for both 2000 and 2016 (Figure 1.9.2). The biggest declines per unit of manufacturing value-added (in 2010 constant United States dollars) occurred in Uzbekistan $(2.2 \mathrm{~kg}$ of $\mathrm{CO}_{2}$ equivalent), Myanmar $(2.0 \mathrm{~kg})$, and Armenia $(1.3 \mathrm{~kg})$. The largest increases were in Nepal (1.4 kg of $\mathrm{CO}_{2}$ equivalent); Hong Kong, China (1.2 kg); and Viet Nam (0.5 kg).

In 2016, the economies with the highest levels of $\mathrm{CO}_{2}$ emissions per unit of manufacturing value-added were $\mathrm{Nepal}$ ( $2.6 \mathrm{~kg}$ of $\mathrm{CO}_{2}$ equivalent), Viet Nam (2.3 kg), and Kazakhstan (2.2 kg). In 2000, the three highest emitters in terms of $\mathrm{CO}_{2}$ equivalent per unit of manufacturing value-added were Uzbekistan (3.2 kg of $\mathrm{CO}_{2}$ equivalent), Mongolia (2.2 $\mathrm{kg})$, and Kazakhstan (2.1 kg).

\section{SDG 10. Reduce inequality within and among countries}

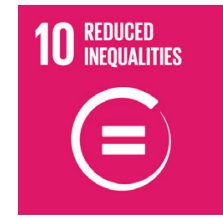

Household expenditure on the rise among the bottom 40\% low-income sections of the population

Growth in household expenditure (or income) per capita was assessed over varying periods for each economy, usually periods of 5 or 6 years falling within 2008 and 2017. 
Figure 1.9.2: Carbon Dioxide

Emissions per Unit of Manufacturing Value-Added

( $\mathrm{kg}$ of $\mathrm{CO}_{2}$ per constant $2010 \$$ )

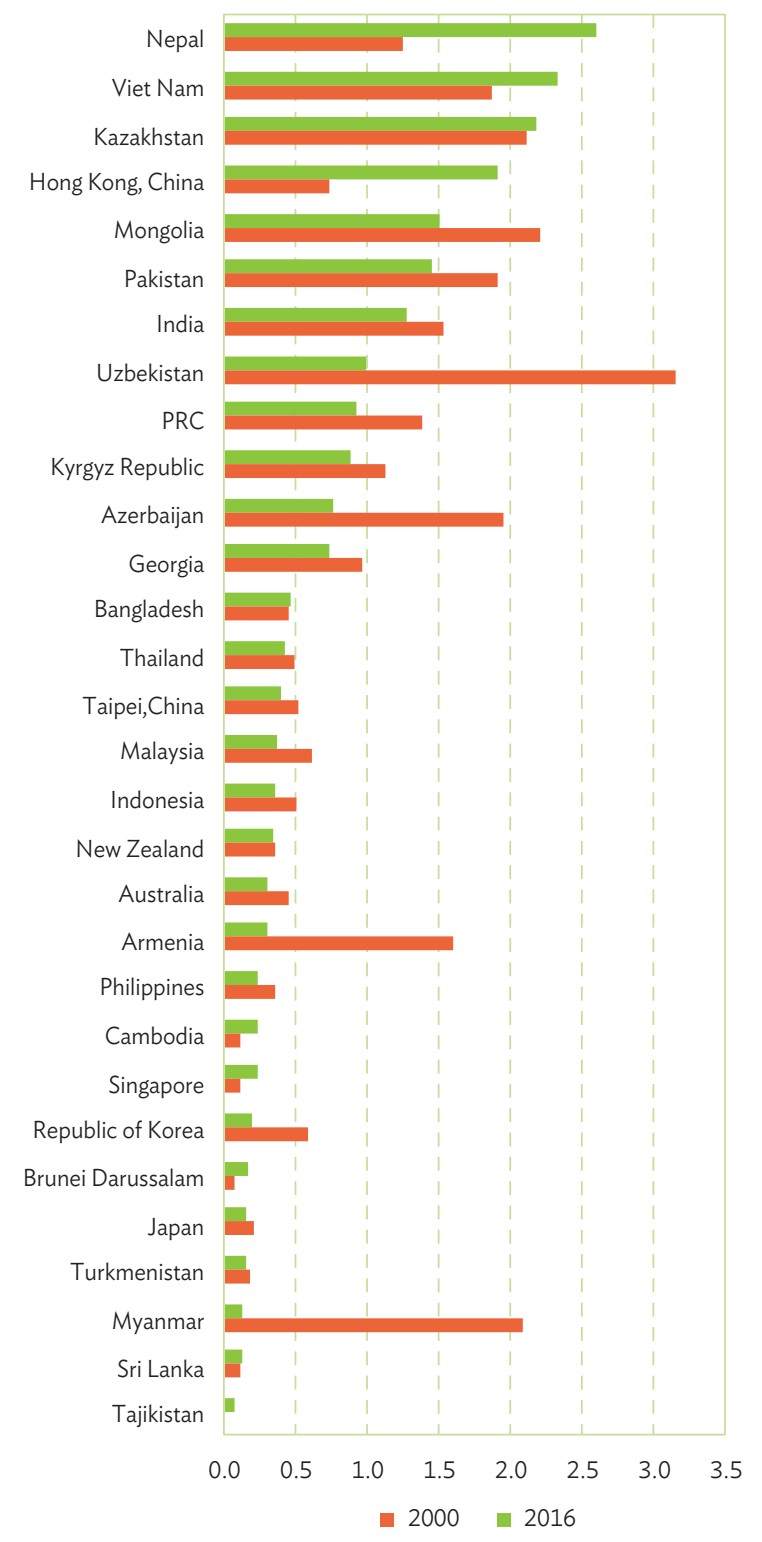

$\$=$ United States dollars, $\mathrm{CO}_{2}=$ carbon dioxide, $\mathrm{kg}=$ kilogram,

PRC = People's Republic of China.

Note: Only economies with available data for both years 2000 and 2016 are included.

Source: Table 1.9.3, Key Indicators for Asia and the Pacific 2019.

Click here for figure data

Of the 18 developing economies with available data, household expenditure (or income) per capita rose for the bottom $40 \%$ of the total population in 17 economies (Figure 1.10.1). Kazakhstan was the exception, with a negligible average annual decline of $0.02 \%$. The biggest gains during the review period were in the PRC (9.1\% average annual growth), Malaysia (8.3\%), and the Philippines (5.1\%).
Figure 1.10.1: Growth Rates of Household

Expenditure or Income per Capita, 2009-2017

(\%)

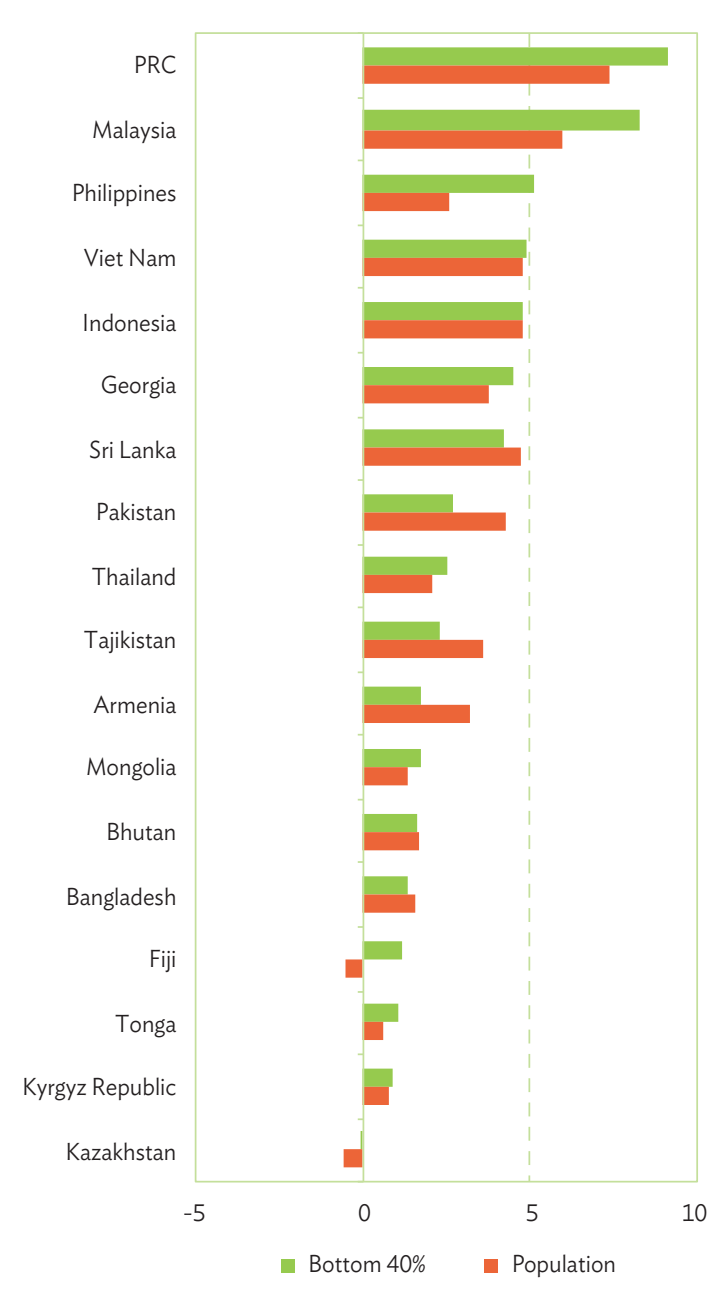

PRC $=$ People's Republic of China.

Note: "Bottom $40 \%$ " refers to individuals within the lowest 40 percentile band in terms of income. Growth in household expenditure or income per capita is assessed over varying periods for each economy, usually periods of 5 or 6 years falling within 2009 and 2017. Growth rates refer to latest available data for over about a five-year period. Only economies with data for both the bottom $40 \%$ and the total population are included.

Source: Table 1.10.1, Key Indicators for Asia and the Pacific 2019.

Click here for figure data

Over the review period, average annual growth rates in household expenditure (or income) per capita among the bottom $40 \%$ outpaced the annual growth rates for the total population in 11 of the 18 reporting economies. The largest increases in favor of the bottom $40 \%$ occurred in the Philippines (2.6 percentage points), Malaysia (2.4 percentage points), the PRC (1.7 percentage points), and Fiji (1.7 percentage points). 
The economies in which the average annual growth rates in household expenditure (or income) per capita among the bottom $40 \%$ lagged behind the growth rates for the total population were Armenia ( -1.5 percentage points), Pakistan ( -1.5 percentage points), and Tajikistan (-1.3 percentage points).

\section{SDG 11. Make cities and human settlements inclusive, safe, resilient, and sustainable}

\section{Individual economies have made majorgains since 2000 in reducing the share of the urban population living in slums}

Lack of access to basic services is a common constraint in informal settlements and slums, contributing to the persistence of poverty and posing a challenge for sustainable and inclusive urbanization. The UN estimates that about one-quarter of all urban residents, or 1 billion people, live in slums, with an additional 600 million living in inadequate housing (UN-Habitat 2016).

Among the 13 developing economies with data available for both 2000 (or 2005) and 2016 (or 2014), those with the highest rates of the urban population living in slums, informal settlements, or inadequate housing in 2016 were Myanmar (56.6\%), Nepal (51.0\%), and Bangladesh (49.4\%) as shown in Figure 1.11.1.

Among the 13 reporting economies, the largest reductions in the percentage of the urban population living in slums, informal settlements, or inadequate housing over the review period were in the Lao PDR (58.5 percentage points), Viet Nam (34.4 percentage points), and Cambodia (31.2 percentage points), with an increase of 11.0 percentage points noted in Myanmar.

Figure 1.11.1: Proportion of Urban Population Living in Slums, 2000 and 2016

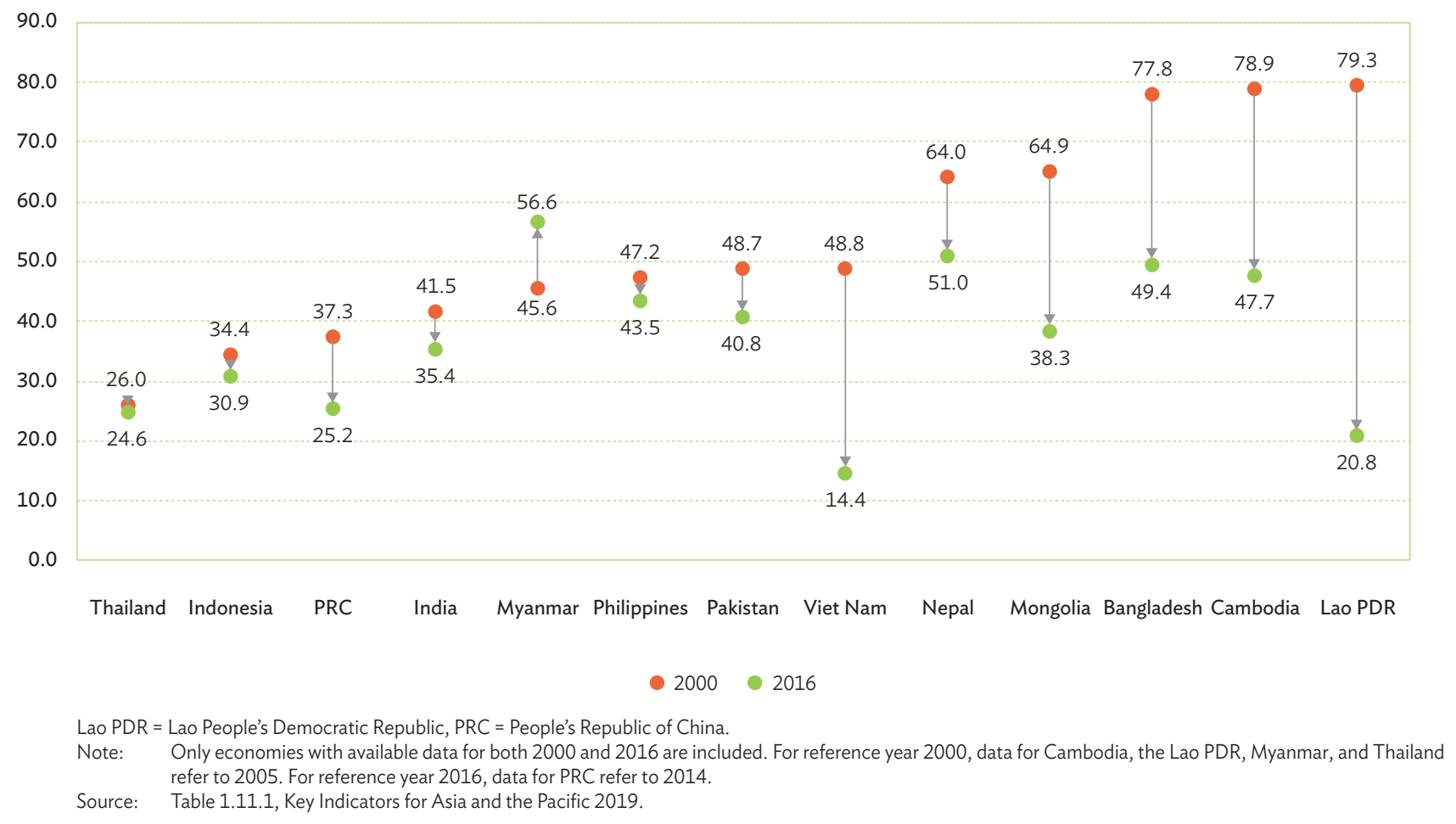




\section{Air pollution is dangerously high in urban areas of highly populated economies}

Particulate matter with a diameter equal to or less than 2.5 microns $\left(\mathrm{PM}_{2.5}\right)$ is the most commonly used pollutant in studies on health effects caused by exposure to air pollution. The primary sources of particulate matter include the combustion of fossil fuels for industry, transportation, and power generation, as well as household activities such as heating, cooking, and lighting (WHO 2018).

In 2016, the annual mean of the daily concentrations of fine suspended particles equal to or less than $\mathrm{PM}_{2.5}$ in urban areas exceeded 10 micrograms per cubic meter $\left[\mu \mathrm{g} / \mathrm{m}^{3}\right]-$ the maximum recommended value by the World Health Organization (WHO 2018) -in all but 4 of the 43 economies in Asia and the Pacific with available data (Table 1.11.1). These 4 economies, and their respective annual means, were Brunei Darussalam $\left(5.8\left[\mu \mathrm{g} / \mathrm{m}^{3}\right]\right)$, New Zealand $\left(5.8 \mu \mathrm{g} / \mathrm{m}^{3}\right)$, Australia $\left(7.3 \mu \mathrm{g} / \mathrm{m}^{3}\right)$, and Maldives $\left(7.7 \mu \mathrm{g} / \mathrm{m}^{3}\right)$. The regional economies with the highest annual means of daily concentrations of $\mathrm{PM}_{2.5}$ in urban areas were Nepal $\left(99.5 \mu \mathrm{g} / \mathrm{m}^{3}\right)$, India $\left(68.0 \mu \mathrm{g} / \mathrm{m}^{3}\right)$, and Afghanistan $\left(59.9 \mu \mathrm{g} / \mathrm{m}^{3}\right)$.

When considering the 10 largest economies in Asia and the Pacific in terms of population, 4 of the 5 most populous had the highest annual means of daily concentrations of $\mathrm{PM}_{2.5}$ in urban areas in 2016: India $\left(68.0 \mu \mathrm{g} / \mathrm{m}^{3}\right)$, Bangladesh $\left(58.6 \mu \mathrm{g} / \mathrm{m}^{3}\right)$, Pakistan $\left(56.2 \mu \mathrm{g} / \mathrm{m}^{3}\right)$, and the PRC $\left(51.0 \mu \mathrm{g} / \mathrm{m}^{3}\right)$ as shown in Figure 1.11.2. In 9 of the region's 10 most populous economies, air pollution levels in urban areas exceeded the economy's overall level of air pollution. Myanmar was the exception, as its annual mean of daily concentrations of $\mathrm{PM}_{2.5}$ in urban areas $\left(34.6 \mu \mathrm{g} / \mathrm{m}^{3}\right)$ was just slightly below the level for all of Myanmar $\left(34.7 \mu \mathrm{g} / \mathrm{m}^{3}\right)$.
Figure 1.11.2: Annual Mean Levels of Fine Particulate Matter in Cities of Asia and the Pacific's Most Populous Economies, 2016 $\left(\mu \mathrm{g} / \mathrm{m}^{3}\right)$

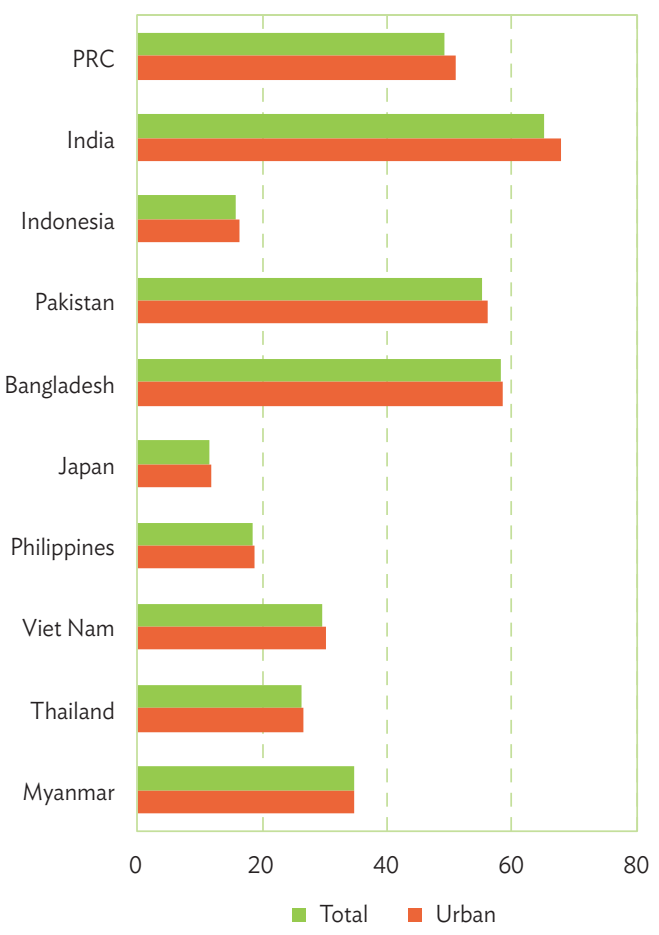

$\mu g=$ microgram, $\mathrm{m}^{3}=$ cubic meter, $\mathrm{PRC}=$ People's Republic of China.

Note: $\quad$ Fine particulate matter is classified as matter with a diameter equal to or less than 2.5 microns in diameter (PM2.5). The graph covers cities in the 10 most populous economies of Asia and the Pacific.

Sources: Table 1.11.1 and Table 2.1.1, Key Indicators for Asia and the Pacific 2019

\section{SDG 12. Ensure sustainable consumption and production patterns}

There is a strong correlation in Asia and the Pacific between an economy's material footprint per capita and GDP per capita.

Material footprint is the quantity of material extraction that is required to meet the consumption of an economy. Therefore, an economy's total material footprint is the sum of the material footprint for biomass, fossil fuels, metal ores, and nonmetal ores. 
The aggregate material footprint of economies in Asia and the Pacific more than doubled from 2000 to 2017 , rising from 20.7 billion metric tons ( $\mathrm{t}$ ) to 47.0 billion $t$ (Table 1.12.1). The regional economies with the largest material footprints in 2017 were the PRC (27.7 billion $\mathrm{t}$ ), India (6.1 billion $\mathrm{t}$ ), and Japan (3.1 billion $\mathrm{t}$ ).

Figure 1.12.1 shows a strong correlation between material footprint per capita and GDP per capita in 2017. The economies with the largest material footprint per capita in 2017 were the high-income economies of Singapore (73.0 t), Australia (43.0 t), and the Republic of Korea (26.4 $\mathrm{t}$ ). The economies with the smallest material footprints on a per capita basis in 2017 were Afghanistan (1.2 t), Myanmar (1.5 t), and Bangladesh (2.4 t).

Of the 36 regional economies with data available for both 2000 and 2017, only Japan showed a reduction in its material footprint per capita, decreasing from $27.8 \mathrm{t}$ in 2000 to $24.6 \mathrm{t}$ in 2017.
Aggregate domestic material consumption has more than doubled in Asia and the Pacific since 2000, although about one-fifth of the region's economies have reduced their domestic material consumption on a per capita basis.

Domestic material consumption measures the total amount of material directly used in production processes within an economy.

On an aggregate basis, domestic material consumption in Asia and the Pacific more than doubled from 23.7 billion metric tons $(t)$ in 2000 to 53.6 billion $\mathrm{t}$ in 2017 (Table 1.12.1). The region's most populous economy, the PRC, accounted for half the region's total in 2000 and about two-thirds of it in 2017.

On a per capita basis, 3 regional economies had a domestic material consumption over $30 \mathrm{t}$ in 2017: Australia (37.9 t), Mongolia (34.5 t), and Singapore $(32.6 \mathrm{t})$ as shown in Figure 1.12.2. The lowest levels of domestic material consumption per capita were in Tuvalu (1.1 t), Palau (1.2 t), and Afghanistan (1.9 t).

Figure 1.12.1: Material Footprint per Capita and Gross Domestic Product per Capita, 2017

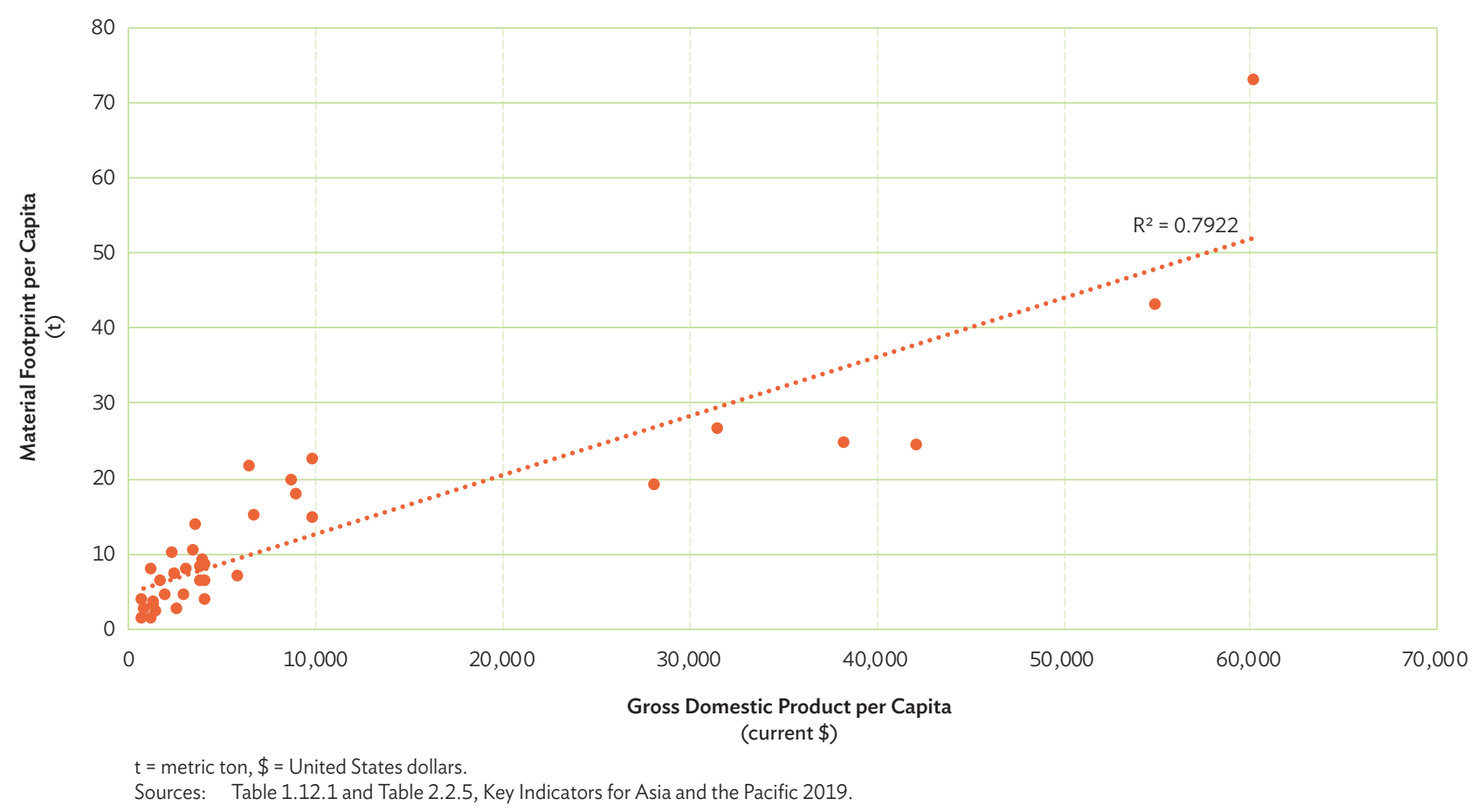


Figure 1.12.2: Domestic Material Consumption per Capita

(t)

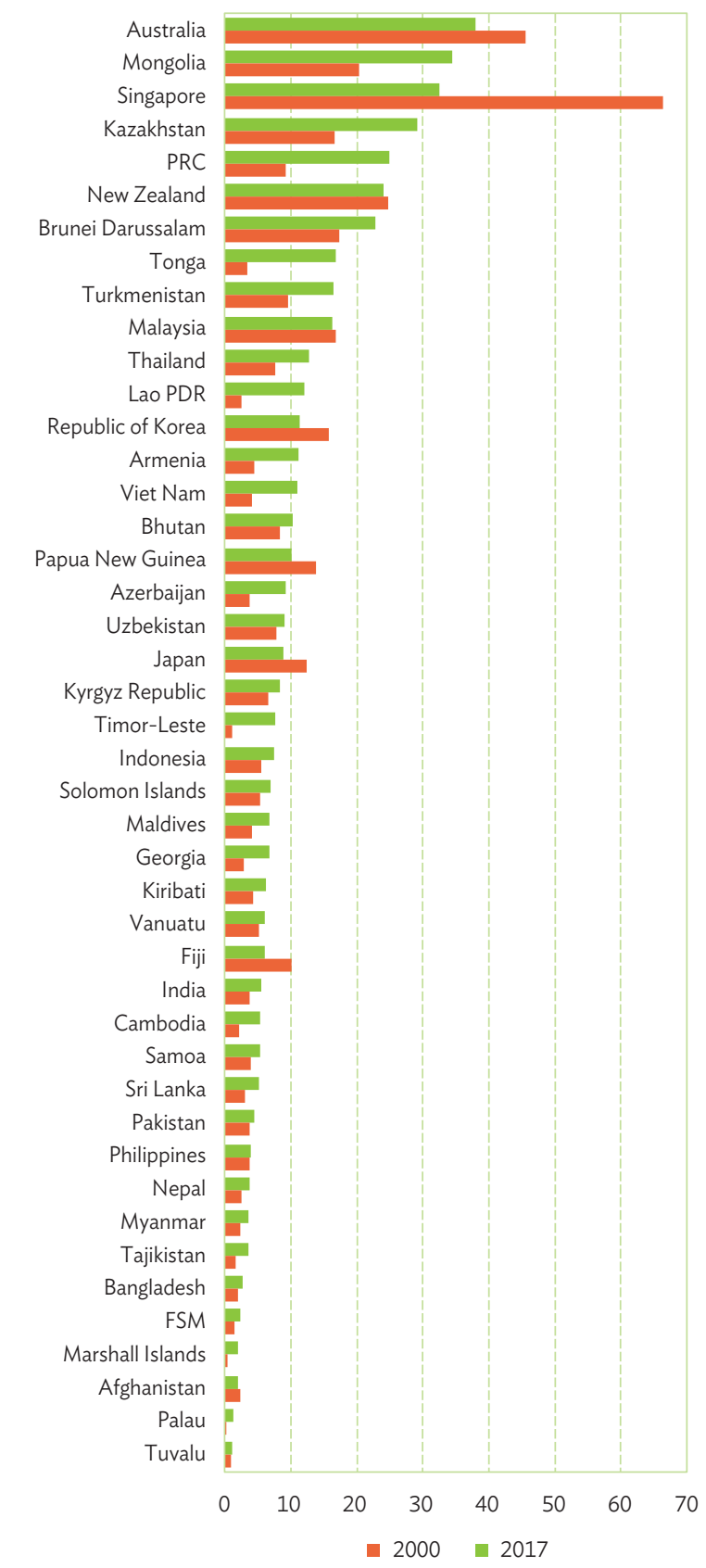

FSM = Federated States of Micronesia, Lao PDR = Lao People's Democratic Republic, PRC $=$ People's Republic of China, $t=$ metric ton .

Source: Table 1.12.1, Key Indicators for Asia and the Pacific 2019.

Click here for figure data

From 2000 to 2017, the largest increases in domestic material consumption per capita occurred in the PRC (15.7 t), Mongolia (14.1 t), and Tonga (13.5 t). Reductions in domestic material consumption per capita over the review period were realized in 9 of the 44 economies with available data. The economies with reductions were led by Singapore $(-33.8 \mathrm{t})$, Australia (-7.6 t), and the Republic of Korea (-4.4t).

\section{SDG 13. Take urgent action to combat climate change and its impacts}

\section{Economies across Asia and the Pacific are developing sound disaster risk reduction strategies}

The Sendai Framework for Disaster Risk Reduction, 2015-2030 recognizes the state (central government) as having primary responsibility for reducing disaster risk, while also sharing this responsibility with local governments, the private sector, and other stakeholders. The framework can help governments substantially reduce disaster risk and minimize the loss of lives, livelihoods, and health as may be experienced as a result of natural disasters. ${ }^{4}$

Figure 1.13.1 outlines the results of selfassessments conducted by 16 economies in Asia and the Pacific on how well their national disaster risk reduction strategies align with the Sendai Framework. The results show that, in 2018 (or the most recent year for which data are available), 3 of the 15 economies achieved a score of 1.0, indicating comprehensive alignment with the framework. These economies were Armenia, Georgia, Japan, the Republic of Korea, and Mongolia. Another 8 economies had a score of 0.5 or higher, reflecting at least a moderate alignment with the framework. Note that Malaysia's self-assessment returned a score of 0 , so it is not included in Figure 1.13.1. 
Figure 1.13.1: Score Measuring Alignment of National Disaster Risk Strategy with Sendai Framework, 2018

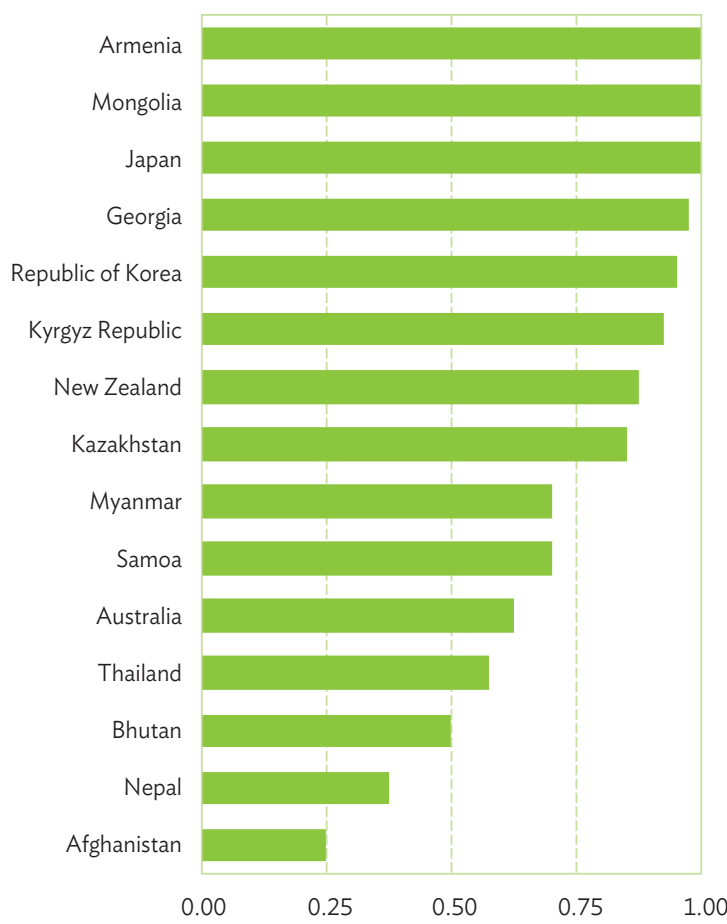

Notes: The economies shown have undertaken adoption and implementation of national disaster risk reduction strategies in line with the Sendai Framework. Scores indicate the compliance of alignment with the framework, based on self-assessments of the economy using 10 criteria for monitoring the progress of national national disaster risk reduction strategies. The score ranges are as follows: $1=$ comprehensive alignment, 0.75 = substantial alignment, $0.50=$ moderate alignment, $0.25=$ limited alignment, 0 = no alignment. Malaysia has a score of "0" and not shown in the figure. For Afghanistan, Armenia, Mongolia, Myanmar, and the Republic of Korea, data refer to 2017.

Source: Table 1.13.1, Key Indicators for Asia and the Pacific 2019. play a critical role in our planet's overall health, our existence is threatened by the deterioration of seas and oceans as a result of overexploitation, pollution, and the impacts of climate change. SDG 14 stresses that careful environmental management is needed to curtail (and ultimately reverse) declines in biodiversity, rebuild depleted fish stocks, and reduce ocean acidification in order to ensure the long-term, sustainable use of marine resources. ${ }^{5}$

Some economies in Asia and the Pacific have taken bold measures to protect their marine resources. In 2018, the proportion of protected area to total marine area exceeded $80 \%$ in the Cook Islands (100.0\%) and Palau (83.0\%) as shown in Figure 1.14.1. The next highest proportions of protected marine resources were in Australia (40.6\%), New Zealand (29.7\%), and Kiribati (11.8\%).

However, of the 37 regional economies with available data on marine areas in 2018, 32 had protected areas covering less than the SDG target of $10 \%$, which is to be met in 2020. More alarmingly, 19 economies had extended protection to less than $1 \%$ of their total marine area in 2018.

Click here for figure data

\section{SDG 14. Conserve and sustainably use the oceans, seas, and marine resources for

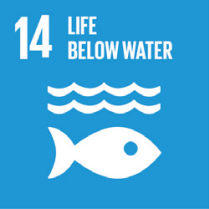 sustainable development}

\section{More than half of all reporting economies protect less than $1 \%$ of their total marine areas}

About 71 percent of the Earth's surface is covered by water, and the oceans hold about 96.5\% of all Earth's water (USGS 2019). As they

5 For more information on SDG 14 and its associated targets, go to https://www.un.org/sustainabledevelopment/oceans/. 
Figure 1.14.1: Proportion of Protected Marine Area to Total Marine Area, 2018

(\%)

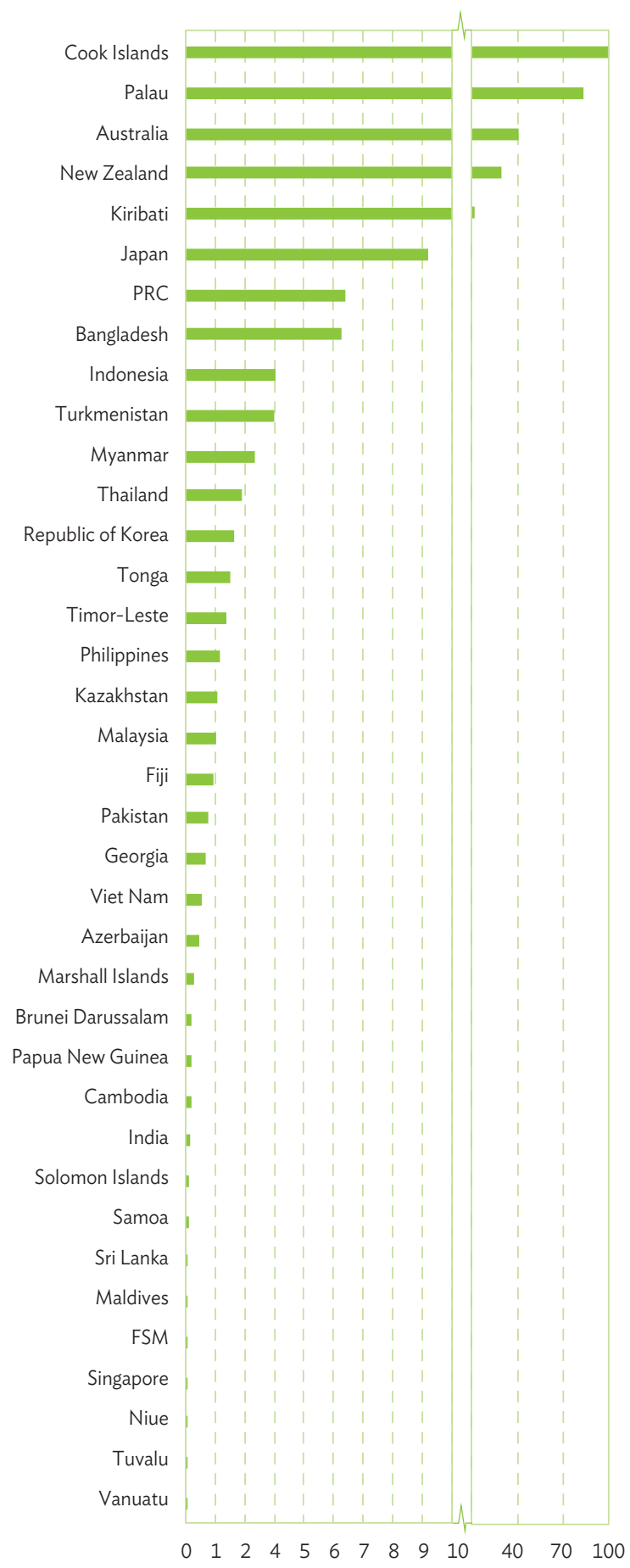

FSM = Federated States of Micronesia, $P R C=$ People's Republic of China Source: Table 1.14.1, Key Indicators for Asia and the Pacific 2019.

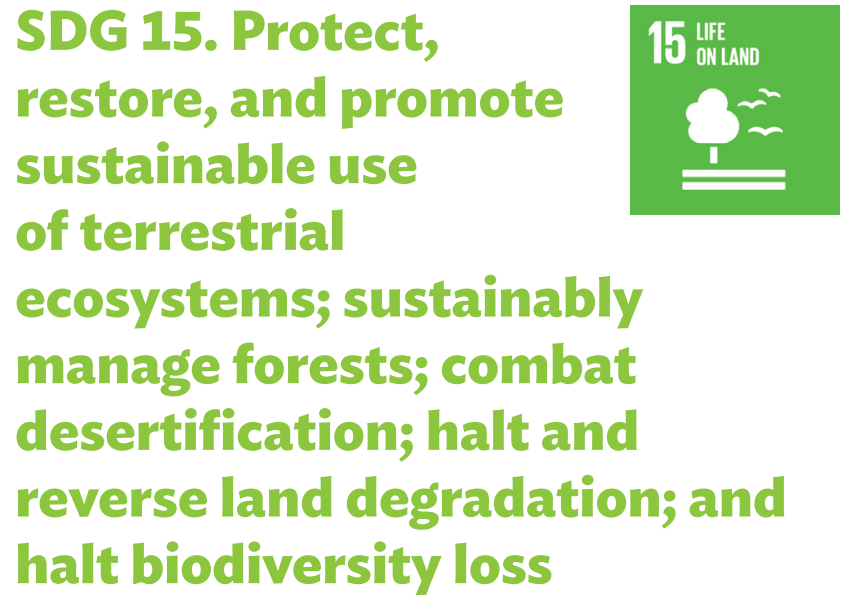

Overexploitation of forest resources remains a risk for a number of regional economies

Forests cover more than $30 \%$ of the Earth's land surface. They are on the front line in the struggle against climate change-absorbing and storing massive amounts of carbon dioxide $\left(\mathrm{CO}_{2}\right)$-and their preservation is key to protecting biodiversity. ${ }^{6}$

Forested areas as a proportion of an economy's total land exceeded $30 \%$ in 25 of the 46 economies of Asia and the Pacific with available data for 2016 (Figure 1.15.1). The highest proportions were in the FSM (91.9\%), Palau (87.6\%), and the Lao PDR (82.1\%) as shown in Figure 1.15.1. Conversely, the economies with the lowest proportions of forested land to total land in 2016 were Nauru (0.0\%), Kazakhstan (1.2\%), and Pakistan (1.9\%).

From 2000 to 2016, 17 of the 46 reporting economies experienced an increase in the proportion of forested land to total land, with the largest gains occurring in the Lao PDR (10.5 percentage points), Viet Nam (10.4 percentage points), and Bhutan (7.0 percentage points). The biggest decreases occurred in Cambodia (-12.6 percentage points), TimorLeste (-12.1 percentage points), and Myanmar (-9.7 percentage points) (Table1.15.1). 
Figure 1.15.1: Proportion of Forested

Area to Total Land Area, 2016

(\%)

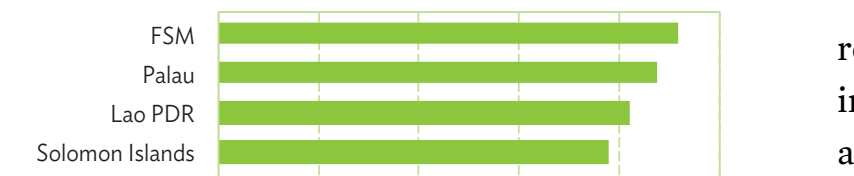

Papua New Guinea

Bhutan

Brunei Darussalam

Marshall Islands

Japan

Malaysia

Republic of Korea

Taipei,China

Samoa

Fiji

Cambodia

Indonesia

Viet Nam

Timor-Leste

Myanmar

Georgia

New Zealand

Vanuatu

Tuvalu

Sri Lanka

Thailand

Philippines

Nepal

India

Singapore

PRC

Australia

Kiribati

Azerbaijan

Tonga

Armenia

Bangladesh

Turkmenistan

Mongolia

Uzbekistan

Maldives

Kyrgyz Republic

Tajikistan

Afghanistan

Pakistan

Kazakhstan

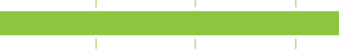

产
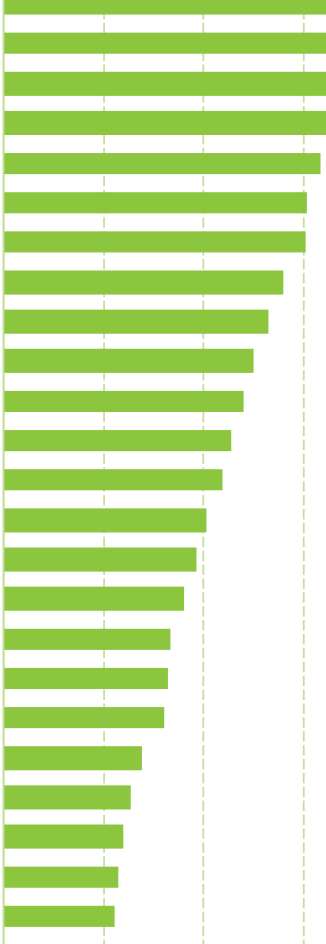

.
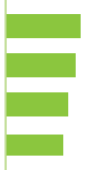

.

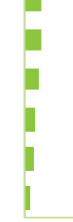

$0 \quad 20$

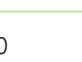

FSM = Federated States of Micronesia, Lao PDR = Lao People's Democratic Republic, PRC = People's Republic of China.

Note: Nauru has 0 forest area and is not included in the figure. For Taipei,China, data refer to 2017.

Source: Table 1.15.1, Key Indicators for Asia and the Pacific 2019.

\section{Extinction risks rising in almost every economy of Asia and the Pacific}

The Red List Index is a composite measure representing aggregate survival probability (the inverse of extinction risk) for all birds, mammals, amphibians, corals, and cycads occurring within an economy, weighted by the fraction of each species' distribution occurring within that economy. Index values can range from 0.0 (indicating all species are categorized as "extinct") to 1.0 (indicating all species are categorized as "least concern").

In 2018,26 of the 48 regional economies with available data garnered a score of at least 0.8 on the Red List Index, down from 37 economies in 2000 (Figure 1.15.2). The highest Red List Index scores in 2018 were recorded in the Central Western economies of Tajikistan (0.99), the Kyrgyz Republic (0.98), Turkmenistan (0.97), and Uzbekistan (0.97).

There were 8 economies that scored 0.7 or lower on the Red List Index in 2018: the FSM (0.69), India (0.68), Malaysia (0.68), Fiji (0.67), Vanuatu (0.66), the Philippines (0.64), New Zealand (0.63), and Sri Lanka (0.56).

Over the review period, all 48 reporting economies, apart from Nepal (0.82 to 0.83) and Niue (0.76 to 0.77), experienced a decline in their scores. The largest declines were recorded in Palau (0.91 to 0.73), Malaysia (0.83 to 0.68), and Sri Lanka (0.66 to $0.56)$. 
Figure 1.15.2: Red List Index Scores

for Select Economies of Asia and the Pacific

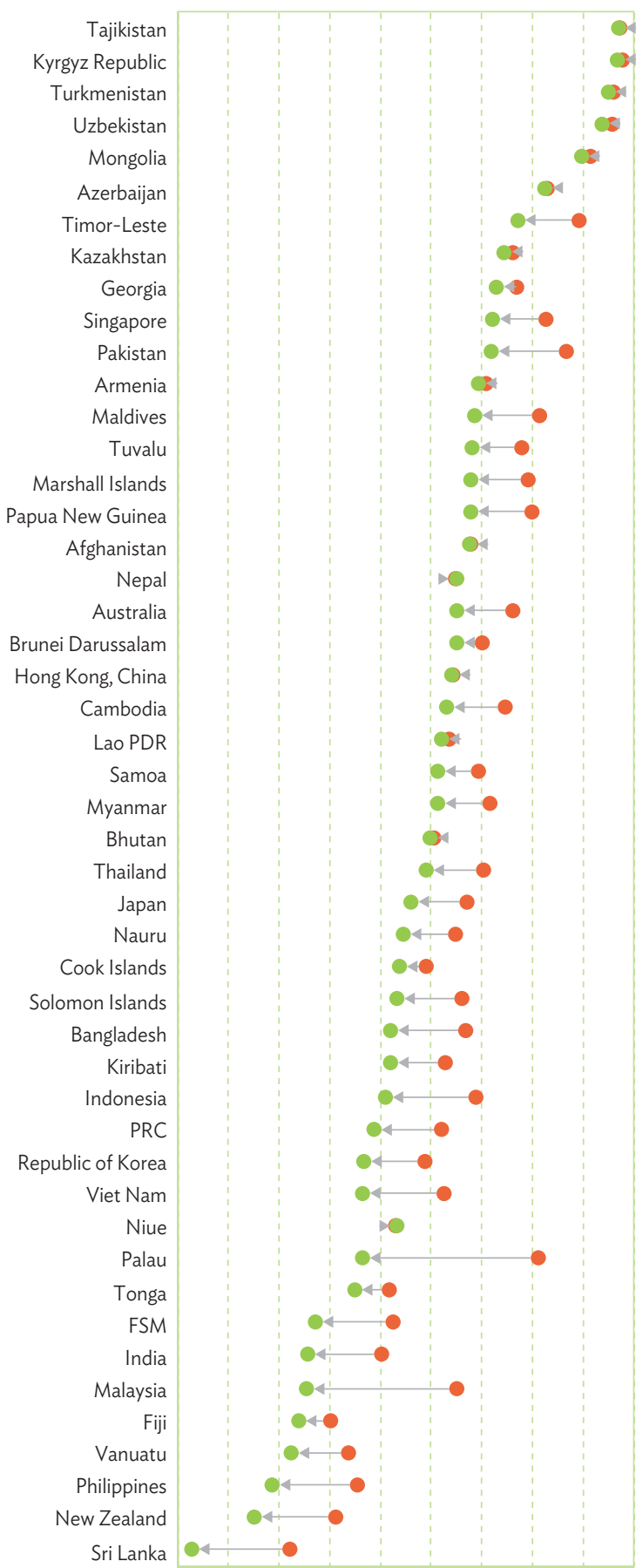

$\begin{array}{llllllllll}0.55 & 0.60 & 0.65 & 0.70 & 0.75 & 0.80 & 0.85 & 0.90 & 0.95 & 1.00\end{array}$

- $2000 \quad 2018$
SDG 16. Promote

peaceful and

inclusive societies

for sustainable

development; provide access

to justice for all; and build

effective, accountable, and

inclusive institutions at all

levels

\section{Intentional homicide reduced in around $80 \%$ of Asian and Pacific economies}

Effective, transparent, and accountable institutions are needed at all levels to promote peaceful and inclusive societies, including the reduction of intentional homicides.

Comparing 2000-2004 with 2011-2017, the number of victims of intentional homicide per 100,000 people fell in 29 of the 37 regional economies with available data (Figure 1.16.1). The largest declines in the intentional homicide rate occurred in Kazakhstan $^{7}$ (-10.4), Mongolia (-7.7), and Thailand $(-5.0)$. The largest increases were in the Pacific economies of Tuvalu (18.6) ${ }^{8}$, Kiribati (3.9), PNG (1.7), and Timor-Leste (1.6).

In 2017 (or the most recent year for which data are available), the lowest rates of intentional homicide per 100,000 people were in Japan (0.2); Singapore (0.2); and Hong Kong, China (0.3). The highest rates were in Tuvalu (18.6), PNG (10.0), and the Philippines (8.4).

\footnotetext{
FSM = Federated States of Micronesia, Lao PDR = Lao People's Democratic Republic, PRC $=$ People's Republic of China.

Note: Index values range from 0.0 (indicating all species are categorized as "extinct") to 1.0 (indicating all species are categorized as "least concern").

Table 1.15.1, Key Indicators for Asia and the Pacific 2019
}

7 Per the UN Office on Drugs and Crime, counting rules changes in the time series are not specified. The changes in methodology were not accounted for in the statement.

8 The population of Tuvalu in 2017 was around 11,000 people. The indicator is presented per 100,000 population. Therefore, one victim of intentional homicide could lead to a spike in the rate for Tuvalu. 
More than 20\% of firms in 19 of 32 developing member economies reported being solicited for a bribe by a public official within the most recent year for which data are available.

Figure 1.16.1: Number of Victims of Intentional Homicide per 100,000 Population

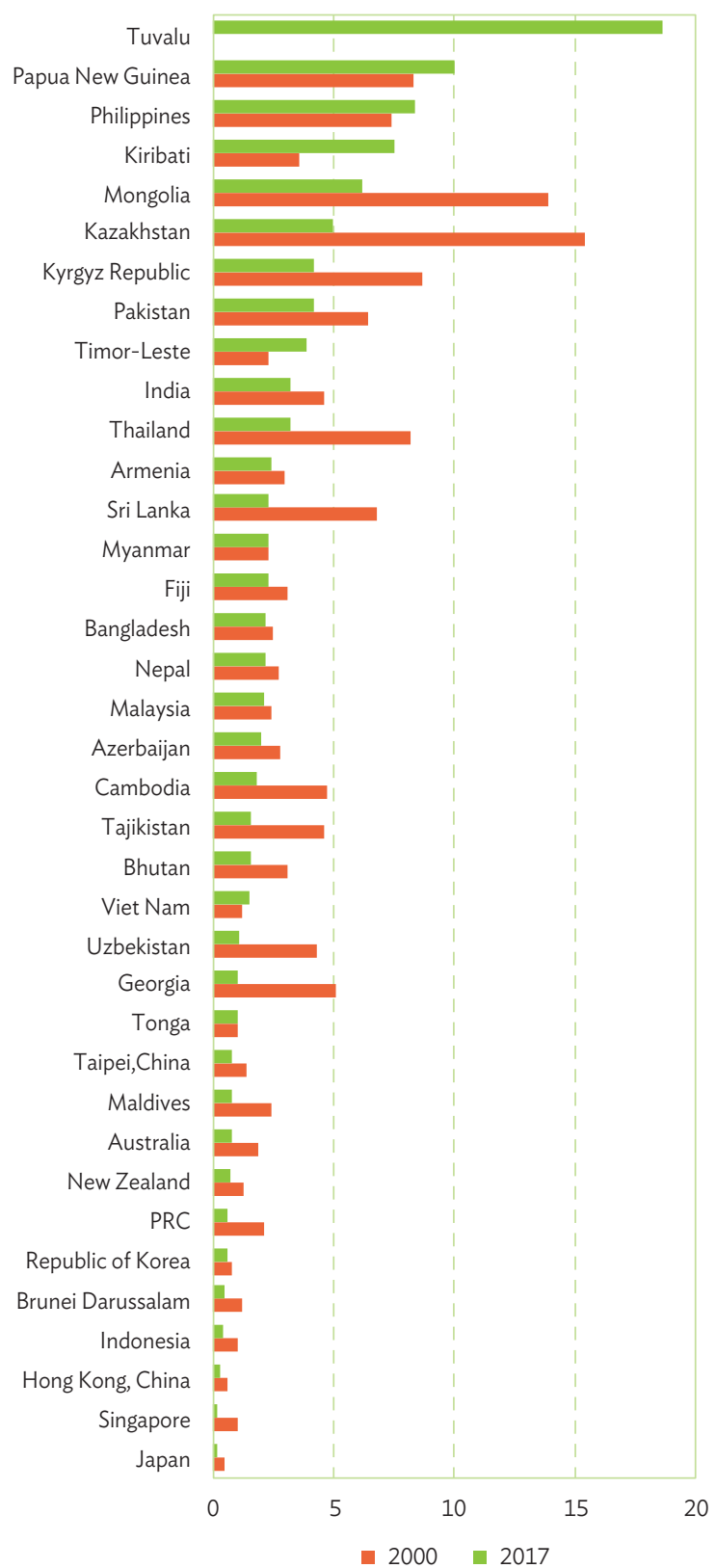

PRC = People's Republic of China.

Note: $\quad$ This chart includes economies with available data for both 2000 and 2017. For 2000, data included are for 2000 to 2004. For 2017, data included are for 2011 to 2017. For 2000, Tuvalu has zero recorded data for the number of victims of intentional homicide.

Source: Table 1.16.1, Key Indicators for Asia and the Pacific 2019.
Corruption can be challenging to assess and quantify. As one measure, the World Bank asks firms if they have been solicited by public officials for gifts or informal payments. By doing so, the World Bank seeks to determine the bribery prevalence rate in an economy in the context of service delivery and other transactions.

Across a review period in which the most recent year of available data ranged from 2009 to 2018, the proportion of firms reporting that they had been solicited by public officials for gifts or informal payments exceeded $20 \%$ in 19 of 32 economies (Figure 1.16.2). The lowest levels of reported bribery solicitations occurred in Bhutan (0.9\%), Georgia (2.2\%), and the FSM (4.5\%).

\section{Figure 1.16.2: Proportion of Firms Experiencing at Least One Bribe Payment Request}

(\%)

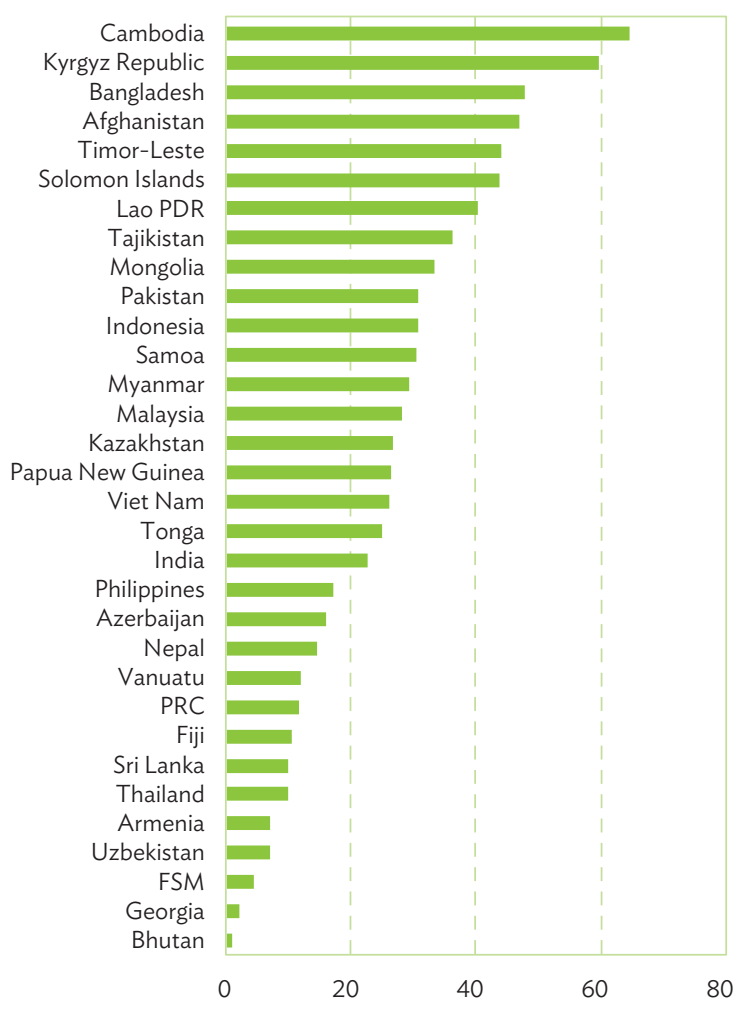

FSM = Federated States of Micronesia, Lao PDR = Lao People's Democratic Republic, PRC $=$ People's Republic of China.

Note: The percentages shown are based on economy data for the most recent year from 2009 to 2018.

Source: Table 1.16.1, Key Indicators for Asia and the Pacific 2019. 
SDG 17. Strengthen the means of implementation and revitalize the Global Partnership for Sustainable Development

\section{Financial and technical assistance doubled in one- third of reporting economies}

Helping the most vulnerable communities requires partnerships between governments, the private sector, and civil society to efficiently mobilize and redirect public and private resources to deliver on sustainable development objectives.

When comparing annual averages of the periods 2000-2008 and 2009-2017, the value (in constant 2017 United States dollars) of financial and technical assistance increased in 35 of the 41 developing economies of Asia and the Pacific with available data (Figure 1.17.1). The largest amounts of average annual financial and technical assistance during 2009-2017 went to Afghanistan ( $\$ 1,405$ million), Indonesia (\$1,310 million), and Pakistan (\$894 million).

From 2000-2008 to 2009-2017, the value of average financial and technical assistance more than doubled in 14 of the 41 reporting economies. In absolute (constant 2017 United States dollars) terms, the largest increases occurred in Afghanistan (\$843 million), Indonesia (\$669 million), and Pakistan (\$529 million). The largest absolute declines were in the FSM ( $\$ 17$ million), the Solomon Islands (\$11 million), and the Marshall Islands (\$9 million).
Figure 1.17.1: Dollar Value of Financial and Technical Assistance Committed to Developing Countries (constant 2017 \$ million)

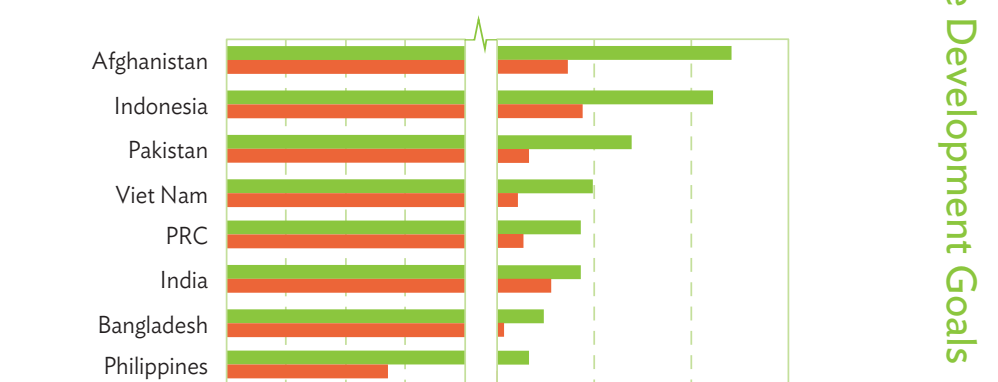


High-quality statistical data is imperative for improving development effectiveness, yet the amount of all resources made available to strengthen statistical capacity increased only in about $40 \%$ of regional economies over the past decade

Financing better-quality statistical data, and increasing transparency in monitoring and accountability, will help improve development effectiveness. However, many developing economies in Asia and the Pacific need support from partners to build institutional capacity and improve data collection activities.

In 2016, the highest levels of financial resources (in current United States dollars) dedicated to statistical capacity building were observed in Cambodia (\$2.22 million), Uzbekistan (\$2.00 million), and Myanmar ( $\$ 1.84$ million) as shown in Figure 1.17.2.

From 2006 (or the earliest year for which data are available) to 2016, the dollar value of all resources made available for strengthening statistical capacity increased in only 17 of the 41 developing economies with available data. The largest increases (in current United States dollars) were in Uzbekistan ( $\$ 1.73$ million), the Solomon Islands ( $\$ 1.28$ million), and Nepal (\$1.01 million).

\subsection{2: Value of All Resources Made Available to Strengthen Statistical Capacity in Developing Countries (current \$)}

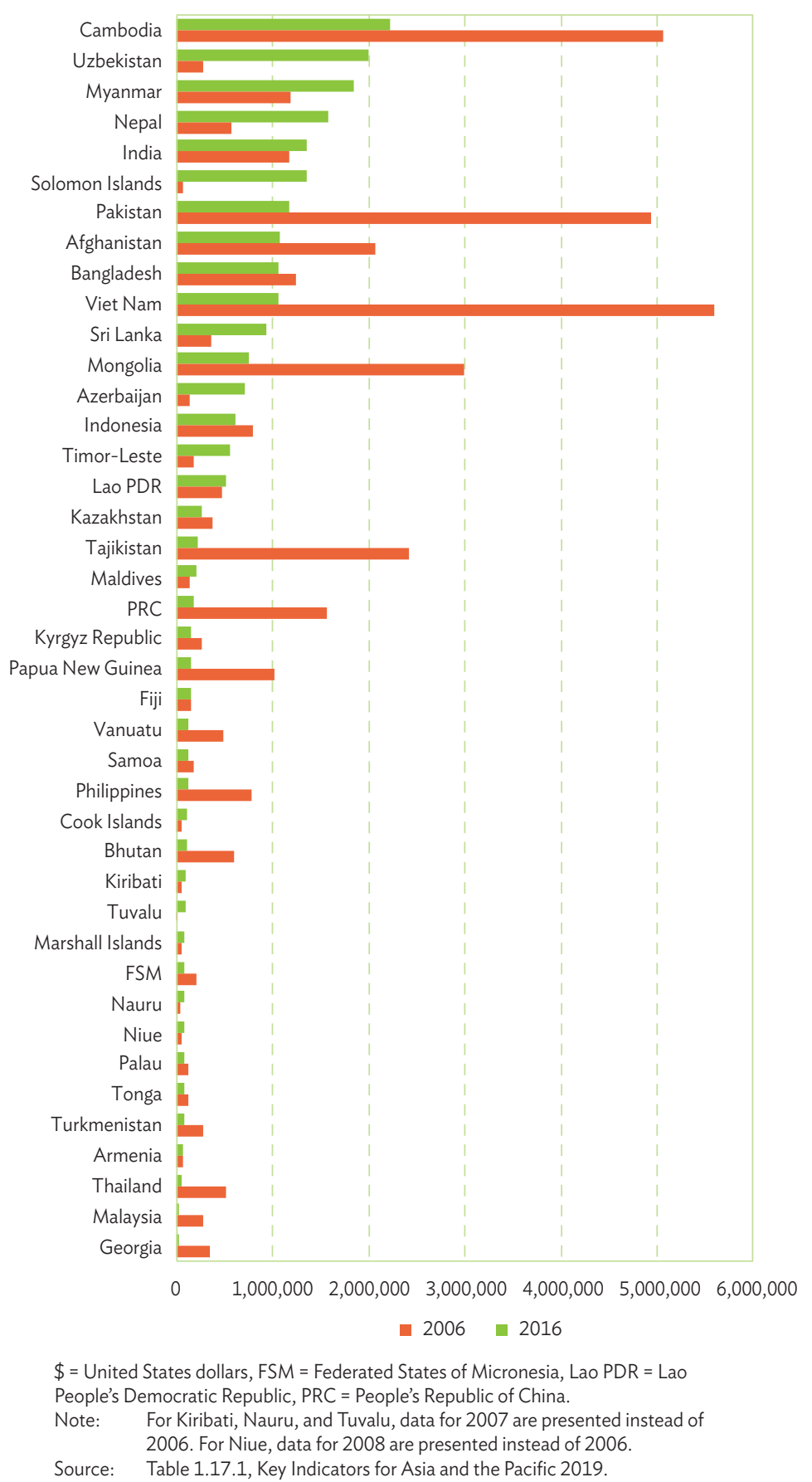


New and huge data demands. The approved framework for global monitoring of the SDGs consists of 232 indicators with greater disaggregation than the Millennium Development Goals and across a wider spectrum of topics. This requires national statistical systems and the global statistical system to work closely with each other to identify strategies to produce more disaggregated and better-quality data. Currently, national statistical systems, with the assistance of their governments and the development community, are working toward addressing these data demands across all tiers of the SDG indicators.

Limited data availability for SDG indicators. Since the launch of the SDGs in 2015, significant progress has been made toward closing the gap in data and their timely availability. However, there is scope for further improvement. An assessment undertaken by ADB and the United Nations Economic and Social Commission for Asia and the Pacific (UNESCAP) on the extent of data availability for the SDG indicators across Asia and the Pacific revealed that only $52 \%$ of the SDG indicators had some data (ADB and UNESCAP 2017). Moreover, an assessment made by UNESCAP revealed that $11 \%$ of Tier I indicators, 34\% of Tier II indicators, and 93\% of Tier III indicators do not have any data available. Only $26 \%$ of all SDG indicators are amenable to trend analysis at the regional level, with two or more data points available for these indicators for $50 \%$ or more economies in Asia and the Pacific.

There may be disparities in data availability for SDG indicators across economic, social, and environmental dimensions as national statistics offices prioritize data production on economic indicators. Further, SDG indicators with social dimensions that overlap with indicators for the Millennium Development Goals would be expected to have relatively good data availability. Most national statistics offices across Asia and the Pacific conduct population and housing censuses every decade, and such sources provide baseline data for socioeconomic information requirements, including SDG indicators with economic and social dimensions. Aside from censuses, data (and updates) on SDG indicators are sourced from household surveys-such as labor force surveys, household income and expenditure surveys, demographic and health surveys, establishment surveys, and agriculture surveys-as well as from administrative reporting systems, but the frequency of data on SDG indicators would depend on the regularity of these data collection activities.

Gaps in data granularity. Since the principle of the SDGs is to leave no one behind, many of the SDG indicators require disaggregation by location, sex, gender, age, income, ethnicity, migration status, disability status, and other relevant dimensions. Granular data can illustrate disparities within and across economies. However, the extent to which specific groups are disproportionately at risk-for example, to lack of housing and security of tenure in slums-is currently difficult to decipher given the lack of data disaggregation and interlinkages across indicators. Sex disaggregations, even for basic indicators such as extreme poverty rates based on the $\$ 1.90$ a day (at 2011 purchasing power parity) level, are not currently available. Similarly, poverty numbers are currently unavailable for vulnerable groups, such as persons with disabilities or indigenous peoples, since the sample surveys that form the basis for poverty calculations are only designed to obtain an overall picture of welfare conditions. To obtain poverty data for groups that have a small share of the total population, investments in population registers and/ or special surveys need to be made.

With the growing use of information and communication technology, innovative data sources such as big data and crowdsourced data can potentially address gaps in data granularity in monitoring the SDGs. Unlike censuses, sample surveys, and administrative reporting systems (all 
of which have well-defined target populations), some types of big data may not represent underlying populations of interest. Careful attention is needed when complementing surveys and other conventional data sources with big data to ensure that reliable statistical inferences can be made (Cox, Kartsonaki, and Keogh 2018).

Lack of data comparability. SDG indicators, such as the proportion of the urban population living in slums or the proportion of the population with access to safely managed sanitation services, require data on housing conditions that may not be fully comparable across economies due to differences in definitions. Comparisons across economies are likewise difficult for urban-rural disaggregation of SDG indicators due to variations in the definition of "urban" and "rural" across time and economies.

\section{Sparse data and irregular frequency.} Indicators that provide a useful description of income inequality, such as the growth in household income of those in the bottom 40th percentile of income distribution in relation to national averages, are only currently available for a few economies. Indicators on material footprint and domestic material consumption, which are widely accepted as strategic sustainability indicators of production and consumption, are not produced annually. Data to monitor progress made toward addressing climate change are sparse.

Frequency is also of concern. For example, data on the coverage of protected areas in relation to total marine areas are not collected regularly, alongside other challenges such as the difficulty in determining whether a site conforms to the definition of a protected area. Further, some protected areas are not assigned management categories. While access to remote-sensing data has improved in recent years, these data have their own limitations in assessing land use. For example, forest regrowth cannot easily be detected with remote-sensing techniques.
Data limitations. While the indicators included in the framework for monitoring the SDGs are carefully chosen, they may have some limitations. The labor share in GDP, for instance, does not include the income of the self-employed, and yet a sizeable proportion of the employed population in developing Asia is made up of people who are self-employed. Current measures of poverty used by economies are largely based on income or consumption data, while the SDG indicators include a multidimensional poverty measure, which has yet to be tested on a wider scale.

Cities face many challenges in relation to pollution, traffic, and inadequate housing for the poor, and these challenges are further fueled by migration and population growth, changes in family structures, inequalities of opportunity for excluded groups, and rising insecurity. The interconnectedness of these issues is not easy to explore using currently available data.

With regard to the Red List Index, since the composite index is aggregated across multiple taxonomic groups, it can be updated annually, but the index does not adequately capture the deteriorating status of common species that are abundant and widespread although declining gradually. Other indicators for monitoring many targets under SDG 15 are also sparsely available. The absence of a framework for monitoring terrestrial ecosystems, low data availability, and the lack of good-quality data all have ecological implications and these issues must be carefully addressed.

Measurement errors. The quality of data for all the SDG indicators needs to be considered when uncovering trends and patterns, as data are subject to measurement issues. Farmer self-reports of land area and production are known to have significant biases (Dillon and Rao 2018). The calculation of mortality rates in children under the age of 5 years requires complete counts of live births and 
child deaths by a precise age, which are not always available due to lacking civil registration systems in some developing economies of Asia and the Pacific. Maternal deaths are likewise not always accounted for given incomplete or inaccurate records on causes of death. The measurement of quality education is a challenge given the lack of standard definitions for minimum competency. Anthropometric measures of malnutrition (including stunted heights) are subject to measurement errors and issues around reference standards (i.e., local versus international standards). Access to safely managed drinking water services, access to safely managed sanitation, and information on hygiene crucially depend on more and better data, particularly administrative data sources (WHO and UNICEF 2017).

As far as international support for statistics development is concerned, full coverage of all statistical capacity development programs cannot be guaranteed in the data compiled by PARIS21 for measuring the dollar-value of such support. Double counting of projects may happen. The data may also be inflated by including project totals for multisector projects. Further, donor-side commitments do not necessarily translate to actual disbursements to the economies slated for official development assistance.

Reliability of data on SDG indicators depends on the quality of the underlying data sources. Economies need to increase investment, look for innovative data sources, and form strategic partnerships with a range of stakeholders to ensure that data quality, comparability, measurement, and timeliness can be enhanced. The result will be good development data that can be used for evidence-based policymaking, which will in turn translate into better outcomes in sustainable development. 


\section{References}

Asian Development Bank (ADB) and the United Nations Economic and Social Commission for Asia and the Pacific (UNESCAP). 2017. AsiaPacific Sustainable Development Goals Outlook. http://sdgasiapacific.net/download/AP_SDG_ Outlook.pdf.

ADB and United Nations (UN) Women. 2018. Gender Equality and the Sustainable Development Goals in Asia and the Pacific: Baseline and Pathways for Transformative Change by 2030. Bangkok.

D.R. Cox, C. Kartsonaki, and R. H.Keogh. 2018. Big Data: Some Statistical Issues. Statistics $\mathcal{E}$ Probability Letters Volume 136, May 2018, pp. 111-115.

A. Dillon and L.N. Rao. 2018. Land Measurement Bias: Comparisons from Global Positioning System, Self-Reports, and Satellite Data. Asian Development Bank, Economics Working Paper Series. No. 540.

European Union and United Nations Human Settlements Programme (UN-Habitat). 2016. The State of European Cities: Cities Leading the Way to a Better Future. Brussels, Belgium: European Commission.

Food and Agriculture Organization of the United Nations (FAO). 2018. The State of Food Security. Rome.

International Labour Organization (ILO). 2017. Global Employment Trends for Youth 2017: Paths To a Better Working Future. Geneva.
International Labour Organization (ILO). 2018. World Employment and Social Outlook: Trends 2018. Geneva, Switzerland: ILO.

N.M. Nour. 2009. Child Marriage: A Silent Health and Human Rights. Reviews in Obstetrics \& Gynecology. 2 (1). pp. 51-56.

Secretariat of the Partnership in Statistics for Development in the 21st Century (PARIS21). 2017. Partner Report on Support to Statistics PRESS 2017. Paris, France: PARIS21.

United Nations Statistical Commission (UNSC). 2017. Cape Town Global Action Plan for Sustainable Development Data. New York. https://unstats. un.org/sdgs/hlg/Cape_Town_Global_Action_ Plan_for_Sustainable_Development_Data.pdf.

United States Geological Survey (USGS). 2019. How Much Water is There on Earth?. Reston, Virginia. https://www.usgs.gov/special-topic/ water-science-school/science/how-muchwater-there-earth?qt-science_center objects $=0 \#$ qt-science_center_objects.

World Health Organization (WHO) and United Nations Children's Fund (UNICEF). 2017. Progress on Drinking Water, Sanitation and Hygiene: 2017 Update and SDG Baselines. Geneva.

World Health Organization (WHO). 2018. Ambient (Outdoor) Air Quality and Health. Geneva. https://www.who.int/news-room/fact-sheets/ detail/ambient-(outdoor)-air-quality-andhealth. 
Table 1.1.1: Selected Indicators for Sustainable Development Goal 1-No Poverty

\begin{tabular}{|c|c|c|c|c|c|c|c|c|c|}
\hline \multirow{6}{*}{ ADB Regional Member } & \multicolumn{9}{|c|}{$\begin{array}{l}\text { Target 1.1: By 2030, eradicate extreme poverty for all people everywhere, measured as people living below the } \\
\text { international poverty line of } \$ 1.90 \text { a day (2011 PPP) }\end{array}$} \\
\hline & \multicolumn{4}{|c|}{$\begin{array}{l}\text { 1.1.1a: Proportion of Population Living below } \\
\text { the } \$ 1.90 \text { a Day (2011 PPP) Poverty Line }{ }^{\mathrm{a}, \mathrm{b}} \\
(\%)\end{array}$} & \multirow{2}{*}{\multicolumn{5}{|c|}{$\begin{array}{l}\text { 1.1.1b: Proportion of Employed Population Living below the } \\
\text { International Poverty Line, by Age Group and Sex }{ }^{b, c} \\
(\%) \\
2018\end{array}$}} \\
\hline & \multirow{4}{*}{\multicolumn{2}{|c|}{2000}} & \multirow{4}{*}{\multicolumn{2}{|c|}{2017}} & & & & & \\
\hline & & & & & \multicolumn{5}{|c|}{ Age Group } \\
\hline & & & & & \multicolumn{3}{|c|}{$15+$} & $15-24$ & $25+$ \\
\hline & & & & & Total & Female & Male & & \\
\hline \multicolumn{10}{|l|}{ Developing ADB Member Economies } \\
\hline \multicolumn{10}{|l|}{ Central and West Asia } \\
\hline Afghanistan & & & $\ldots$ & & 37.6 & 39.99 & 36.3 & 39.2 & 36.9 \\
\hline Armenia & 19.3 & (2001) & 1.4 & & 0.4 & 0.5 & 0.4 & 0.6 & 0.4 \\
\hline Azerbaijand & 2.7 & $(2001)$ & & & 0.0 & 0.0 & 0.0 & 0.0 & 0.0 \\
\hline Georgia & 19.4 & & 5.0 & & 2.2 & 2.0 & 2.4 & 2.9 & 2.2 \\
\hline Kazakhstan & 10.3 & (2001) & 0.0 & & 0.0 & 0.0 & 0.0 & 0.0 & 0.0 \\
\hline Kyrgyz Republic & 42.1 & & 1.5 & & 0.3 & 0.2 & 0.4 & 0.3 & 0.3 \\
\hline Pakistan & 28.6 & (2001) & 3.9 & (2015) & 2.8 & 3.4 & 2.7 & 3.1 & 2.8 \\
\hline Tajikistan & 30.8 & (2003) & 4.8 & (2015) & 3.8 & 3.6 & 3.9 & 3.6 & 3.9 \\
\hline Turkmenistan & & & $\ldots$ & & 13.7 & 10.6 & 16.1 & 15.6 & 13.4 \\
\hline Uzbekistand $^{d}$ & 62.0 & & & & 27.1 & 23.5 & 29.7 & 27.7 & 27.0 \\
\hline \multicolumn{10}{|l|}{ East Asia } \\
\hline China, People's Republic of & 31.7 & $(2002)$ & 0.7 & (2015) & 0.6 & 0.6 & 0.6 & 0.8 & 0.6 \\
\hline Hong Kong, China ${ }^{f}$ & & & & & - & - & - & - & - \\
\hline Korea, Republic of ${ }^{-}$ & 0.2 & $(2006)$ & 0.2 & $(2012)$ & - & - & - & - & - \\
\hline Mongolia & 9.7 & (2002) & 0.6 & (2016) & 0.1 & 0.1 & 0.1 & 0.2 & 0.1 \\
\hline Taipei, China & & & & & 0.0 & 0.0 & 0.0 & 0.1 & 0.0 \\
\hline \multicolumn{10}{|l|}{ South Asia } \\
\hline Bangladesh & 34.8 & & 14.8 & (2016) & 10.4 & 11.9 & 9.8 & 11.8 & 10.1 \\
\hline Bhutan & 17.6 & $(2003)$ & 1.5 & & 1.6 & 2.0 & 1.3 & 2.8 & 1.4 \\
\hline India & 38.2 & (2004) & 21.2 & (2011) & 13.4 & 15.2 & 12.9 & 17.4 & 12.8 \\
\hline Maldives & 10.0 & (2002) & 7.3 & (2009) & 2.7 & 3.6 & 2.4 & 3.6 & 2.6 \\
\hline Nepal & 46.1 & (2003) & 15.0 & (2010) & 7.2 & 7.2 & 7.2 & 7.2 & 7.2 \\
\hline Sri Lanka & 8.3 & $(2002)$ & 0.8 & $(2016)$ & 0.2 & 0.1 & 0.2 & 0.2 & 0.1 \\
\hline \multicolumn{10}{|l|}{ Southeast Asia } \\
\hline Brunei Darussalam & & & & & - & - & - & - & - \\
\hline Cambodia & & & & & 20.3 & 20.3 & 20.3 & 23.4 & 19.4 \\
\hline Indonesia & 39.3 & & 5.7 & & 5.2 & 5.2 & 5.2 & 5.3 & 5.1 \\
\hline Lao People's Democratic Republic & 33.8 & (2002) & 22.7 & (2012) & 13.1 & 12.3 & 13.8 & 17.8 & 11.7 \\
\hline Malaysia & 0.4 & (2004) & 0.0 & (2015) & 0.0 & 0.0 & 0.0 & 0.0 & 0.0 \\
\hline Myanmar & & & 6.2 & (2015) & 3.3 & 3.6 & 3.2 & 4.2 & 3.1 \\
\hline Philippines & 14.5 & & 7.8 & (2015) & 4.1 & 3.3 & 4.5 & 5.1 & 3.8 \\
\hline Singapore & & & $\ldots$ & & - & - & - & - & - \\
\hline Thailand & 2.5 & & 0.0 & & 0.0 & 0.0 & 0.0 & 0.0 & 0.0 \\
\hline Viet Nam & 38.0 & $(2002)$ & 2.0 & $(2016)$ & 1.6 & 1.7 & 1.5 & 3.1 & 1.4 \\
\hline The Pacific & & & & & & & & & \\
\hline Cook Islands & & & & & & & & & \\
\hline Fiji & 4.9 & $(2002)$ & 1.4 & $(2013)$ & 0.2 & 0.3 & 0.2 & 0.3 & 0.2 \\
\hline Kiribati & 12.9 & (2006) & $\ldots$ & & $\ldots$ & $\ldots$ & $\ldots$ & $\ldots$ & $\ldots$ \\
\hline Marshall Islands & & & & & & $\ldots$ & $\ldots$ & $\ldots$ & \\
\hline Micronesia, Federated States of & 8.1 & $(2005)$ & 15.4 & $(2013)$ & $\ldots$ & $\ldots$ & $\ldots$ & $\ldots$ & $\ldots$ \\
\hline Nauru & & & & & & $\ldots$ & $\ldots$ & & \\
\hline Niue & & & & & & & & & \\
\hline Palau & & & & & & & & & \\
\hline Papua New Guinea & & & 38.0 & (2009) & 26.3 & 28.1 & 24.6 & 30.9 & 25.0 \\
\hline Samoa & 2.0 & $(2002)$ & 1.1 & (2013) & & & & & \\
\hline Solomon Islands & 45.6 & (2005) & 25.1 & (2013) & 20.6 & 20.8 & 20.5 & 25.0 & 19.0 \\
\hline Timor-Leste & 46.0 & (2001) & 30.7 & (2014) & 25.2 & 24.6 & 25.4 & 31.0 & 24.3 \\
\hline Tonga & 2.8 & (2001) & 1.0 & (2015) & $\ldots$ & $\ldots$ & $\ldots$ & & $\ldots$ \\
\hline Tuvalu & $\ldots$ & & 3.3 & (2010) & & & & & \\
\hline Vanuatu & & & 13.1 & $(2010)$ & & & & & \\
\hline Developed ADB Member Economies & & & & & & & & & \\
\hline Australia & & & & & & & & & \\
\hline Japan & & & $\cdots$ & & & & & & \\
\hline New Zealand & & & & & & & & & \\
\hline
\end{tabular}


Table 1.1.1: Selected Indicators for Sustainable Development Goal 1-No Poverty (continued)

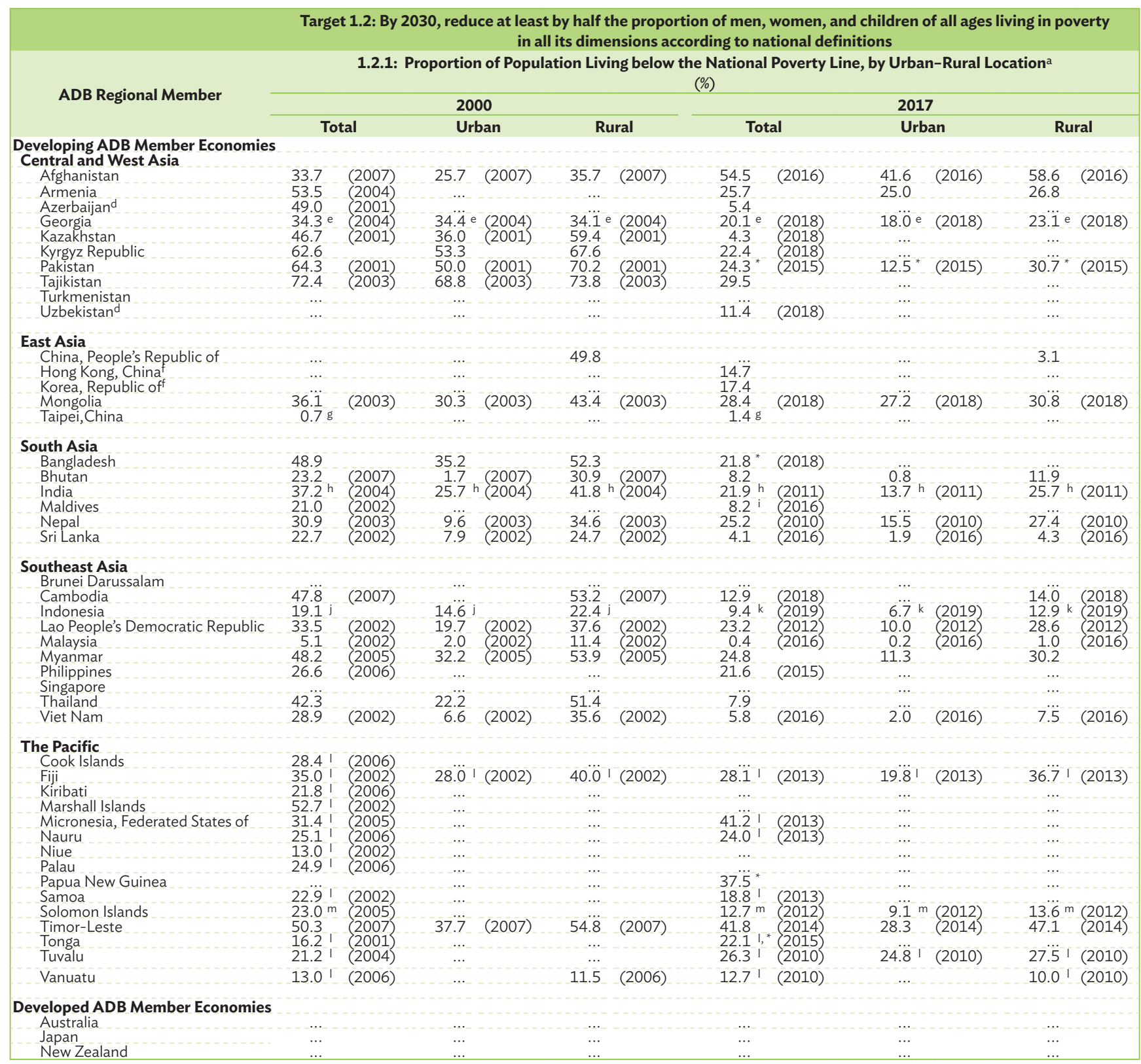

$\ldots=$ data not available ${ }^{*}=$ provisional $/$ preliminary/estimate $/$ budget figure, $0.0=$ magnitude is less than half of unit employed or true zero, $A D B=$ Asian Development Bank,

PPP = purchasing power parity.

a For indicator 1.1.1a and indicator 1.2.1, the year indicated in the table refers to the year when the household survey data were collected. For economies in which the household survey data collection period bridged 2 calendar years, the table reports the first year.

b For indicator 1.1.1a, data are consumption-based, except for Malaysia, where data are income-based. For indicator 1.1.1a and indicator 1.1.1b, the estimates are based on the international poverty line of $\$ 1.90$ a day (2011 PPP).

c Data are taken from International Labour Organization modelled estimates and projections.

d For Indicator 1.1.1a, the latest available estimate for Azerbaijan is for 2005: 0.0\%. For Uzbekistan, the latest available estimate is for 2003: 62.1\%.

e Refers to absolute poverty or the share of the population under the absolute poverty line.

f For indicator 1.2.1, the earliest available estimate for Hong Kong, China is for 2009: 16.0\%. For the Republic of Korea, the earliest available estimate is for 2012: 18.6\%. For Hong Kong, China, data refer to the poverty rate after policy intervention (recurrent cash). For the Republic of Korea, data refer to the relative poverty rate.

g Refers to the percentage of the low-income population to the total population.

h Based on Tendulkar methodology, using mixed reference period.

i Based on half the median of total consumption expenditure equivalent to Maldivian Rufiyaa 74.

j Reference period is February 2000.

k Reference period is March 2019.

I Data refer to the percentage of the population living below the basic-needs poverty line.

$m$ Refers to the poverty headcount ratio using the upper poverty line.

Sources: $\quad$ For indicator 1.1.1a: World Bank. PovcalNet Database. http://iresearch.worldbank.org/PovcalNet/povDuplicateWB.aspx (accessed 3 June 2019); and United Nations Statistics Division. Sustainable Development Goals (SDGs), SDG Indicators, Global Database. http://unstats.un.org/sdgs/indicators/database/ (accessed 13 July 2019). For indicator 1.1.1b: International Labour Organisation. ILOSTAT. http://www.ilo.org/ilostat (accessed 18 July 2019). For indicator 1.2.1: Economy sources; World Bank. World Development Indicators. http://databank.worldbank.org/data/reports.aspx?source=world-development-indicators (accessed 3 June 2019); and Secretariat of the Pacific Community. National Minimum Development Indicators. https://www.spc.int/nmdi/ (accessed 15 July 2019). 
Table 1.2.1: Selected Indicators for Sustainable Development Goal 2-Zero Hunger

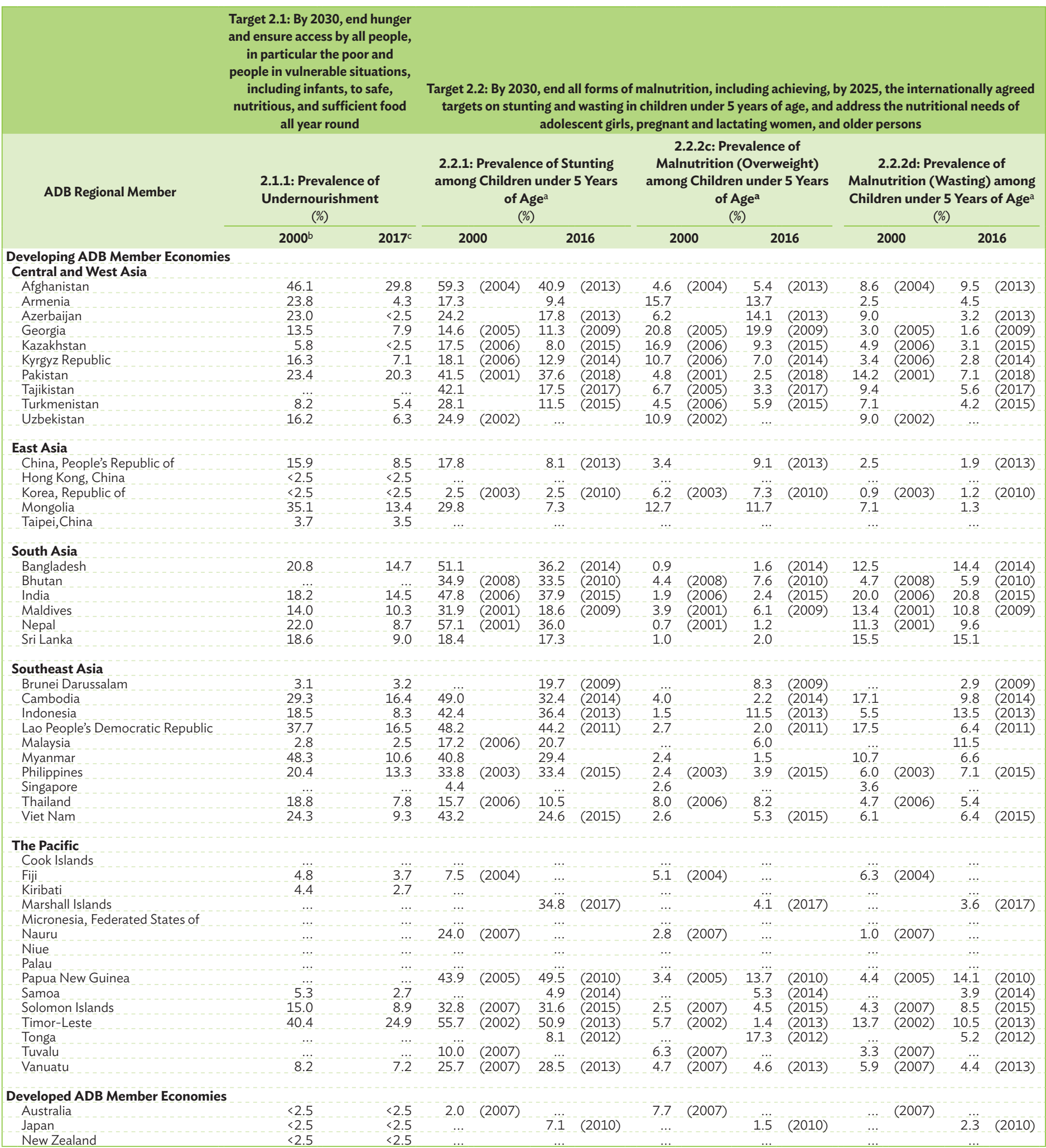

$\ldots=$ data not available, $<=$ less than, $\mathrm{ADB}=$ Asian Development Bank.

a According to the World Health Organization, for some economies the estimates were adjusted where necessary to be nationally representative and to cover the age range 0-5 years, which might result in slight differences in prevalence from the survey results reported. Estimates for some economies are also "pending reanalysis." Details can be found in the "Notes" column of the joint child malnutrition dataset.

b Data refer to 3-year average for 1999-2001.

c Data refer to 3-year average for 2016-2018.

Sources: $\quad$ For Indicator 2.1.1: Food and Agriculture Organization of the United Nations. FAOSTAT. http://www.fao.org/faostat/ (accessed 24 July 2019). For Indicator 2.2.1, Indicator 2.2.2c, and Indicator 2.2.2d: United Nations Statistics Division. Sustainable Development Goals (SDGs), SDG Indicators, Global Database. https://unstats.un.org/sdgs/indicators/ database/ (accessed 8 July 2019) 
Table 1.2.2: Selected Indicators for Sustainable Development Goal 2-Improved Agricultural Investment

\begin{tabular}{|c|c|c|c|c|c|c|c|}
\hline \multirow{3}{*}{ ADB Regional Member } & \multicolumn{7}{|c|}{$\begin{array}{l}\text { Target 2.a: Increase investment, including through enhanced international cooperation, in rural infrastructure, } \\
\text { agricultural research and extension services, technology development, and plant and livestock gene banks in order to } \\
\text { enhance agricultural productive capacity in developing countries, in particular least developed countries }\end{array}$} \\
\hline & \multicolumn{4}{|c|}{$\begin{array}{l}\text { 2.a.1: The Agriculture Orientation Index for } \\
\text { Government Expenditures }\end{array}$} & \multicolumn{3}{|c|}{$\begin{array}{l}\text { 2.a.2: Total Official Flows to the Agriculture Sector } \\
\text { (constant } 2017 \$ \text { million) }\end{array}$} \\
\hline & \multicolumn{2}{|c|}{2001} & \multicolumn{2}{|c|}{2017} & \multicolumn{2}{|c|}{2000} & 2017 \\
\hline \multicolumn{8}{|l|}{ Developing ADB Member Economies } \\
\hline \multicolumn{8}{|l|}{ Central and West Asia } \\
\hline Afghanistan & 0.1 & (2003) & 0.2 & (2015) & 4.3 & & 324.8 \\
\hline Armenia & & & 0.2 & & 15.1 & & 112.7 \\
\hline Azerbaijan & 0.4 & (2008) & 0.5 & $(2015)$ & 74.3 & & 10.7 \\
\hline Georgia & 0.1 & $(2003)$ & 0.3 & & 36.5 & & 51.6 \\
\hline Kazakhstan & 0.4 & & 0.4 & & 3.6 & & 43.8 \\
\hline Kyrgyz Republic & 0.1 & & 0.1 & $(2016)$ & 80.9 & & 21.7 \\
\hline Pakistan & 0.0 & & 0.0 & $(2016)$ & 58.1 & & 275.3 \\
\hline Tajikistan & & & & & 23.2 & & 29.3 \\
\hline Turkmenistan & $\ldots$ & & & & 0.0 & & 1.1 \\
\hline Uzbekistan & & & 0.6 & & 0.2 & & 110.7 \\
\hline \multicolumn{8}{|l|}{ East Asia } \\
\hline China, People's Republic of & 0.3 & (2007) & 0.3 & & 327.6 & & 447.2 \\
\hline \multicolumn{8}{|l|}{ Hong Kong, China } \\
\hline Korea, Republic of & 1.5 & & 2.1 & (2016) & & & \\
\hline Mongolia & 0.2 & & 0.1 & $(2015)$ & 4.3 & & 33.0 \\
\hline \multicolumn{8}{|l|}{ Taipei,China } \\
\hline \multicolumn{8}{|l|}{ South Asia } \\
\hline Bangladesh & 0.2 & & 0.4 & (2016) & 333.6 & & 280.0 \\
\hline Bhutan & 0.3 & & 0.8 & & 5.8 & & 19.5 \\
\hline India & 0.2 & & 0.3 & $(2016)$ & 221.1 & & 632.4 \\
\hline Maldives & 0.2 & & 0.0 & & 0.0 & & 4.9 \\
\hline Nepal & 0.2 & (2002) & 0.4 & & 69.5 & & 135.1 \\
\hline Sri Lanka & 0.4 & & 0.7 & & 51.9 & & 53.6 \\
\hline \multicolumn{8}{|l|}{ Southeast Asia } \\
\hline \multicolumn{8}{|l|}{ Brunei Darussalam } \\
\hline Cambodia & & & & & 158.8 & & 106.3 \\
\hline Indonesia & 0.2 & (2004) & 0.1 & (2013) & 194.1 & & 355.9 \\
\hline Lao People's Democratic Republic & & & & & 27.9 & & 86.4 \\
\hline Malaysia & 0.4 & & 0.3 & & 8.6 & & 3.7 \\
\hline Myanmar & & & 0.1 & & 2.1 & & 193.8 \\
\hline Philippines & 0.3 & & 0.3 & & 355.4 & & 150.0 \\
\hline Singapore & 2.0 & & 11.4 & & & & \\
\hline Thailand & 0.9 & & 0.7 & & 28.0 & & 7.4 \\
\hline Viet Nam & 0.1 & $(2006)$ & 0.2 & $(2014)$ & 103.8 & & 297.1 \\
\hline \multicolumn{8}{|l|}{ The Pacific } \\
\hline Cook Islands & 0.4 & $(2005)$ & 0.4 & $(2013)$ & 0.0 & & 0.2 \\
\hline Fiji & 0.3 & (2005) & 0.4 & (2016) & 1.0 & & 17.3 \\
\hline Kiribati & $\ldots$ & & $\ldots$ & & 7.7 & & 4.2 \\
\hline Marshall Islands & 0.1 & (2008) & 0.1 & & 3.3 & & 1.2 \\
\hline Micronesia, Federated States of & & & 0.2 & & 9.7 & & 2.1 \\
\hline Nauru & $\ldots$ & & $\ldots$ & & 0.2 & (2003) & 0.4 \\
\hline Niue & & & & & 0.0 & (2002) & 0.1 \\
\hline Palau & 0.1 & (2008) & 0.2 & & 0.2 & & 3.0 \\
\hline Papua New Guinea & 0.1 & & & & 58.6 & & 22.4 \\
\hline Samoa & & & 0.7 & & 2.7 & & 13.3 \\
\hline Solomon Islands & & & 0.1 & (2015) & 3.4 & & 13.9 \\
\hline Timor-Leste & 1.2 & (2008) & 0.2 & (2015) & 8.8 & & 32.5 \\
\hline Tonga & $=$ & & $=$ & & 0.2 & & 1.7 \\
\hline Tuvalu & & & & & 7.3 & (2001) & 7.7 \\
\hline Vanuatu & 0.1 & $(2005)$ & 0.2 & $(2012)$ & 3.7 & & 8.4 \\
\hline Developed ADB Member Economie & & & & & & & \\
\hline Australia & 0.2 & & 0.2 & & & & \\
\hline Japan & & & & & $\ldots$ & & \\
\hline New Zealand & 0.3 & (2004) & & & & & \\
\hline
\end{tabular}

$\ldots=$ data not available, $0.0=$ magnitude is less than half of unit employed, $\$=$ United States dollars, $A D B=$ Asian Development Bank.

a Total official flows refer to official development assistance plus other official flows. Data refer to gross disbursements.

Sources: $\quad$ Food and Agriculture Organization of the United Nations. FAOSTAT. http://www.fao.org/faostat/ (accessed 1 August 2019); and United Nations Statistics Division. Sustainable Development Goals (SDGs), SDG Indicators, Global Database. https://unstats.un.org/sdgs/indicators/database/ (accessed 8 July 2019). 
Goal 3. Ensure healthy lives and promote well-being for all at all ages

Table 1.3.1: Selected Indicators for Sustainable Development Goal 3-Maternal and Child Health

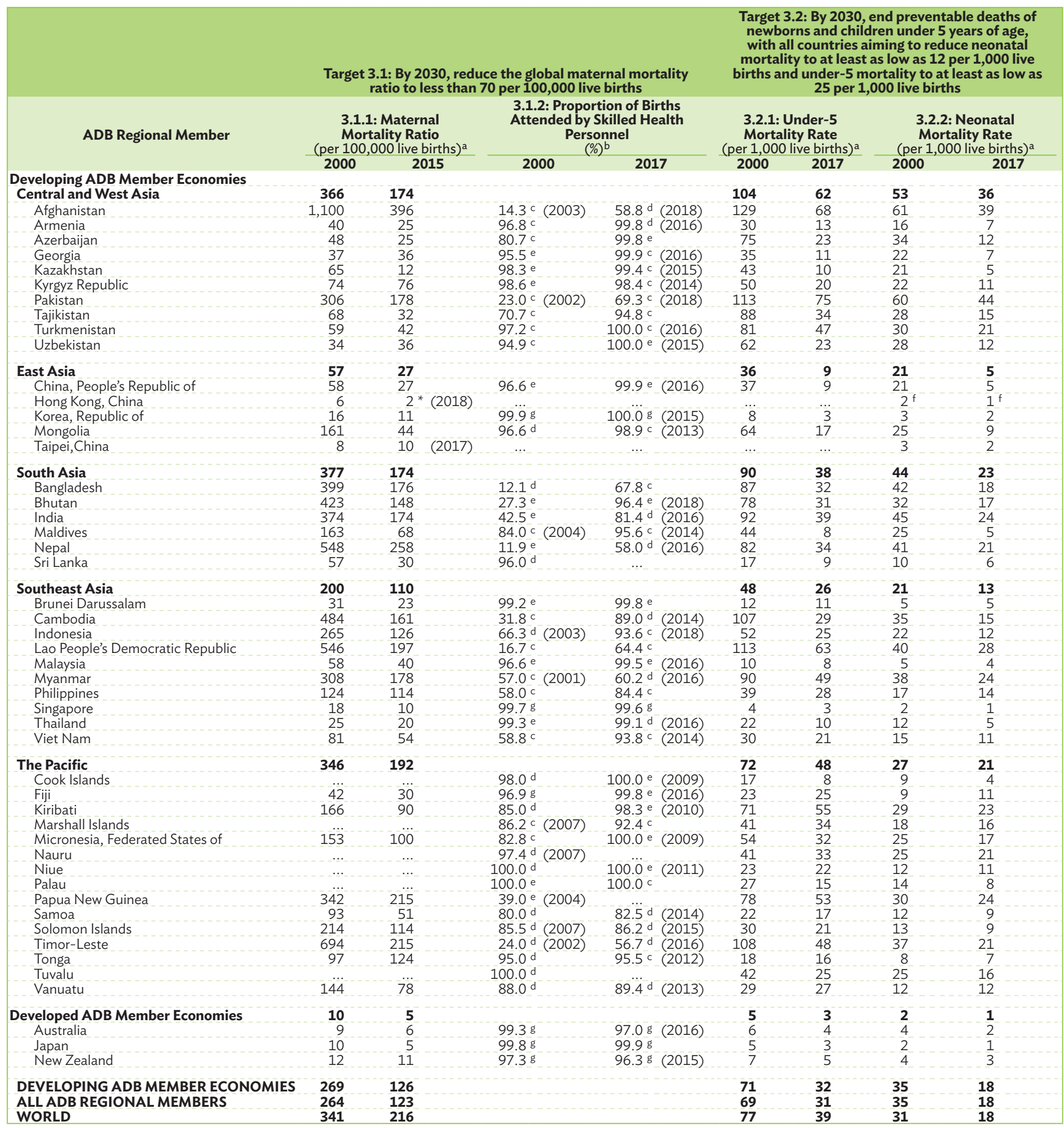

$\ldots=$ data not available, ${ }^{*}=$ provisional, preliminary, $\mathrm{ADB}=$ Asian Development Bank.

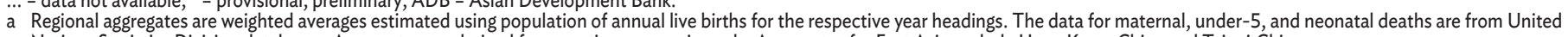
Nations Statistics Division databases. Aggregates are derived for reporting economies only. Aggregates for East Asia exclude Hong Kong, China and Taipei,China.

b Based on population-based national household survey data and routine health systems.

c Estimates are aligned with the standard definition of doctor, nurse, and/or midwife.

d Includes other health personnel not in alignment with the standard definition.

e No clear definition of health personnel.

$f$ Calculated based on known births and deaths.

$g$ Institutional birth including all deliveries that occurred at a health facility.

Sources: For Indicator 3.1.1: United Nations Statistics Division. Sustainable Development Goals (SDGs), SDG Indicators, Global Database. https://unstats.un.org/sdgs/indicators/database/ (accessed 8 July 2019). For Hong Kong, China: Government of the Hong Kong Special Administrative Region of the People's Republic of China, Centre for Health Protection. https://www. chp.gov.hk/en/statistics/data/10/27/110.html (accessed 22 July 2019); and Department of Health. Annual Report 2014/2015. https://www.dh.gov.hk/english/pub_rec/pub_rec_ar/ pdf/1415/supplementary_table2014.pdf (accessed 22 July 2019). For Taipei,China: Government of Taipei,China, Directorate-General of Budget, Accounting and Statistics. https://eng. dgbas.gov.tw/public/data/dgbas03/bs2/yearbook_eng/Yearbook2017.pdf (accessed 22 July 2019). For Indicators 3.1.2 and 3.2.1: United Nations Statistics Division. SDGs, SDG Indicators, Global Database. https://unstats.un.org/sdgs/indicators/database/ (accessed 8 July 2019). For Indicator 3.2.2: United Nations Statistics Division. SDGs, SDG Indicators, Global Database. https://unstats.un.org/sdgs/indicators/database/ (accessed 8 July 2019). For Hong Kong, China: Government of the Hong Kong Special Administrative Region of the People's Republic of China, Department of Health. Annual Report 2014/2015. https://www.chp.gov.hk/en/statistics/data/10/27/110.html (accessed 22 July 2019); and Health Facts of Hong Kong 2018 Edition. https://www.dh.gov.hk/english/statistics/statistics_hs/files/Health_Statistics_pamphlet_E.pdf (accessed 22 July 2019). For Taipei,China: Government of Taipei,China, Ministry of Health and Welfare. 2017 Statistics of Causes of Deaths. https://www.mohw.gov.tw/cp-3961-42866-2.html accessed 22 July 2019). 
Table 1.3.2: Selected Indicators for Sustainable Development Goal 3-Incidence of Communicable Diseases

\begin{tabular}{|c|c|c|c|c|c|c|}
\hline \multirow{3}{*}{ ADB Regional Member } & \multicolumn{6}{|c|}{$\begin{array}{l}\text { Target 3.3: By 2030, end the epidemics of AIDS, tuberculosis, malaria, and neglected tropical diseases; and comba } \\
\text { hepatitis, water-borne diseases, and other communicable diseases }\end{array}$} \\
\hline & \multicolumn{2}{|c|}{$\begin{array}{l}\text { 3.3.1: Number of New HIV Infections } \\
\text { (per 1,000 uninfected population) }\end{array}$} & \multicolumn{2}{|c|}{$\begin{array}{l}\text { 3.3.2: Tuberculosis Incidence } \\
\text { (per 100,000 population) }\end{array}$} & \multicolumn{2}{|c|}{$\begin{array}{l}\text { 3.3.3: Malaria Incidence } \\
\text { (per 1,000 population) }\end{array}$} \\
\hline & 2000 & 2018 & 2000 & 2017 & 2000 & 2017 \\
\hline \multirow{2}{*}{\multicolumn{7}{|c|}{$\begin{array}{l}\text { Developing ADB Member Economies } \\
\text { Central and West Asia }\end{array}$}} \\
\hline & & & & & & \\
\hline Afghanistan & 0.01 & 0.02 & 190.0 & 189.0 & 92.6 & 23.0 \\
\hline Armenia & 0.10 & 0.06 & 54.0 & 36.0 & 0.0 & - \\
\hline Azerbaijan & 0.05 & $0.08 \quad(2017)$ & 80.0 & 67.0 & 8.2 & - \\
\hline Georgia & 0.06 & 0.18 & 254.0 & 86.0 & 5.2 & - \\
\hline Kazakhstan & 0.02 & 0.14 & 166.0 & 66.0 & - & - \\
\hline Kyrgyz Republic & 0.03 & 0.09 & 244.0 & 144.0 & 0.0 & - \\
\hline Pakistan & $<0.01$ & 0.11 & 275.0 & 267.0 & 6.9 & 4.9 \\
\hline Tajikistan & 0.08 & 0.09 & 219.0 & 85.0 & 9.2 & - \\
\hline Turkmenistan & & & 112.0 & 43.0 & 0.0 & - \\
\hline Uzbekistan & 0.08 & 0.16 & 99.0 & 73.0 & 0.1 & - \\
\hline \multicolumn{7}{|l|}{ East Asia } \\
\hline China, People's Republic of & & $\ldots$ & 109.0 & 63.0 & 0.0 & - \\
\hline Hong Kong, China & & $\ldots$ & 104.0 & 67.0 & $\ldots$ & $\cdots$ \\
\hline Korea, Republic of & & & 49.0 & 70.0 & 1.3 & 0.1 \\
\hline Mongolia & 0.01 & 0.01 & 428.0 & 428.0 & & \\
\hline Taipei, China & & $\ldots$ & $\ldots$ & $\ldots$ & 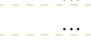 & $\cdots$ \\
\hline \multicolumn{7}{|l|}{ South Asia } \\
\hline Bangladesh & $<0.01$ & 0.01 & 221.0 & 221.0 & 5.6 & 1.9 \\
\hline Bhutan & 0.25 & 0.11 & 249.0 & 134.0 & 14.0 & 0.0 \\
\hline India & 0.19 & 0.10 & 289.0 & 204.0 & 22.8 & 7.7 \\
\hline Maldives & & & 59.0 & 39.0 & - & \\
\hline Nepal & 0.19 & 0.03 & 163.0 & 152.0 & 7.4 & 0.5 \\
\hline Sri Lanka & 0.02 & 0.01 & 66.0 & 64.0 & 48.6 & - \\
\hline \multicolumn{7}{|l|}{ Southeast Asia } \\
\hline Brunei Darussalam & & & 106.0 & 64.0 & & \\
\hline Cambodia & 0.88 & 0.05 & 575.0 & 326.0 & 100.5 & 18.4 \\
\hline Indonesia & 0.11 & 0.17 & 370.0 & 319.0 & 8.3 & 5.8 \\
\hline Lao People's Democratic Republic & 0.16 & 0.08 & 330.0 & 168.0 & 62.7 & 5.8 \\
\hline Malaysia & 0.27 & 0.18 & 75.0 & 93.0 & 13.7 & 0.1 \\
\hline Myanmar & 0.58 & 0.20 & 411.0 & 358.0 & 49.3 & 3.7 \\
\hline Philippines & $<0.01$ & 0.13 & 590.0 & 554.0 & 2.7 & 0.3 \\
\hline Singapore & 0.09 & 0.04 & 51.0 & 47.0 & & \\
\hline Thailand & 0.64 & 0.09 & 241.0 & 156.0 & 6.6 & 0.8 \\
\hline Viet Nam & 0.30 & 0.06 & 197.0 & 129.0 & 3.5 & 0.1 \\
\hline \multicolumn{7}{|l|}{ The Pacific } \\
\hline Cook Islands & & $\ldots$ & 6.3 & - & $\ldots$ & $\cdots$ \\
\hline Fiji & & $\ldots$ & 22.0 & 49.0 & $\ldots$ & $\ldots$ \\
\hline Kiribati & $\ldots$ & $\ldots$ & 373.0 & 413.0 & $\ldots$ & $\ldots$ \\
\hline Marshall Islands & & & 81.0 & 480.0 & $\ldots$ & \\
\hline Micronesia, Federated States of & $\ldots$ & $\ldots$ & 106.0 & 165.0 & $\ldots$ & $\ldots$ \\
\hline Nauru & $\ldots$ & $\ldots$ & 46.0 & 91.0 & $\ldots$ & $\ldots$ \\
\hline Nive & & & - & 71.0 & & \\
\hline Palau & $\ldots$ & $\ldots$ & 65.0 & 106.0 & $\ldots$ & $\ldots$ \\
\hline Papua New Guinea & 0.84 & 0.26 & 432.0 & 432.0 & 273.5 & 181.9 \\
\hline Samoa & & & 28.0 & 18.0 & & \\
\hline Solomon Islands & $\ldots$ & ... & 91.0 & 76.0 & 623.2 & 171.0 \\
\hline Timor-Leste & $\ldots$ & & 498.0 & (2002) & 214.7 & 0.1 \\
\hline Tonga & & & 28.0 & 12.0 & & \\
\hline Tuvalu & & & 195.0 & 236.0 & & \\
\hline Vanuatu & & & 110.0 & 51.0 & 125.4 & 8.2 \\
\hline \multicolumn{7}{|l|}{ Developed ADB Member Economies } \\
\hline Australia & 0.05 & 0.04 & 6.3 & 6.8 & & \\
\hline Japan & 0.01 & 0.01 & 36.0 & 15.0 & & \\
\hline New Zealand & 0.03 & 0.03 & 10.0 & 7.5 & $\ldots$ & $\ldots$ \\
\hline
\end{tabular}

$\ldots=$ data not available, $<=$ less than, $-=$ magnitude equals zero, $0.0=$ magnitude is less than half of unit employed, $A D B=$ Asian Development Bank.

Sources: $\quad$ For Indicator 3.3.1: The Joint United Nations Programme on HIV/AIDS. http://aidsinfo.unaids.org/ (accessed 18 July 2019). For Azerbaijan and India: United Nations Statistics Division. Sustainable Development Goals (SDGs), SDG Indicators, Global Database. http://unstats.un.org/sdgs/indicators/database/ (accessed 8 July 2019). For Indicators 3.3.2 and 3.3.3: United Nations Statistics Division. SDGs, SDG Indicators, Global Database. http://unstats.un.org/sdgs/indicators/database/ (accessed 8 July 2019). 
Goal 3. Ensure healthy lives and promote well-being for all at all ages

Table 1.3.3: Selected Indicators for Sustainable Development Goal 3-Mortality Rates, Health

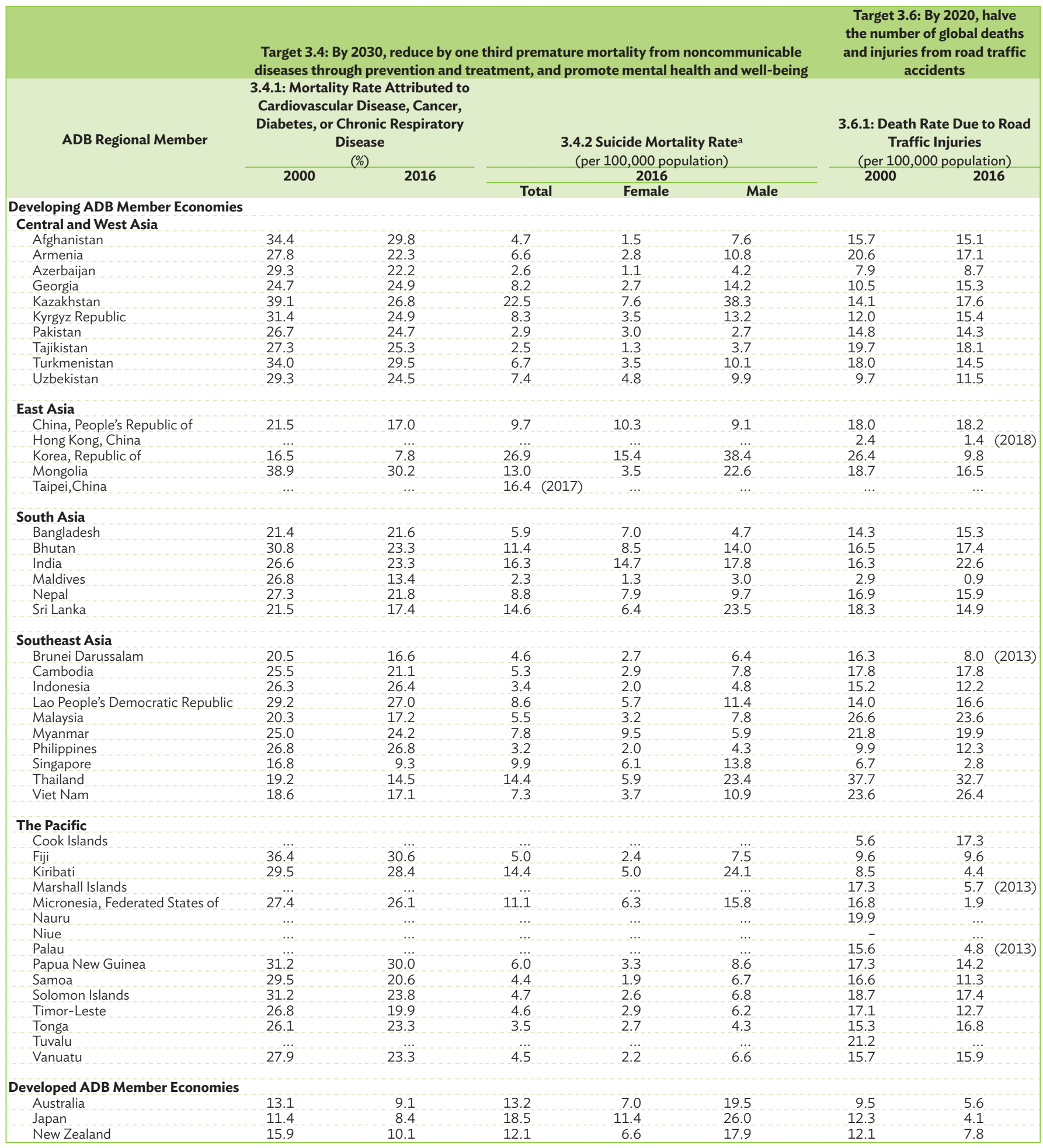


Table 1.3.3: Selected Indicators for Sustainable Development Goal 3-Mortality Rates, Health (continued)

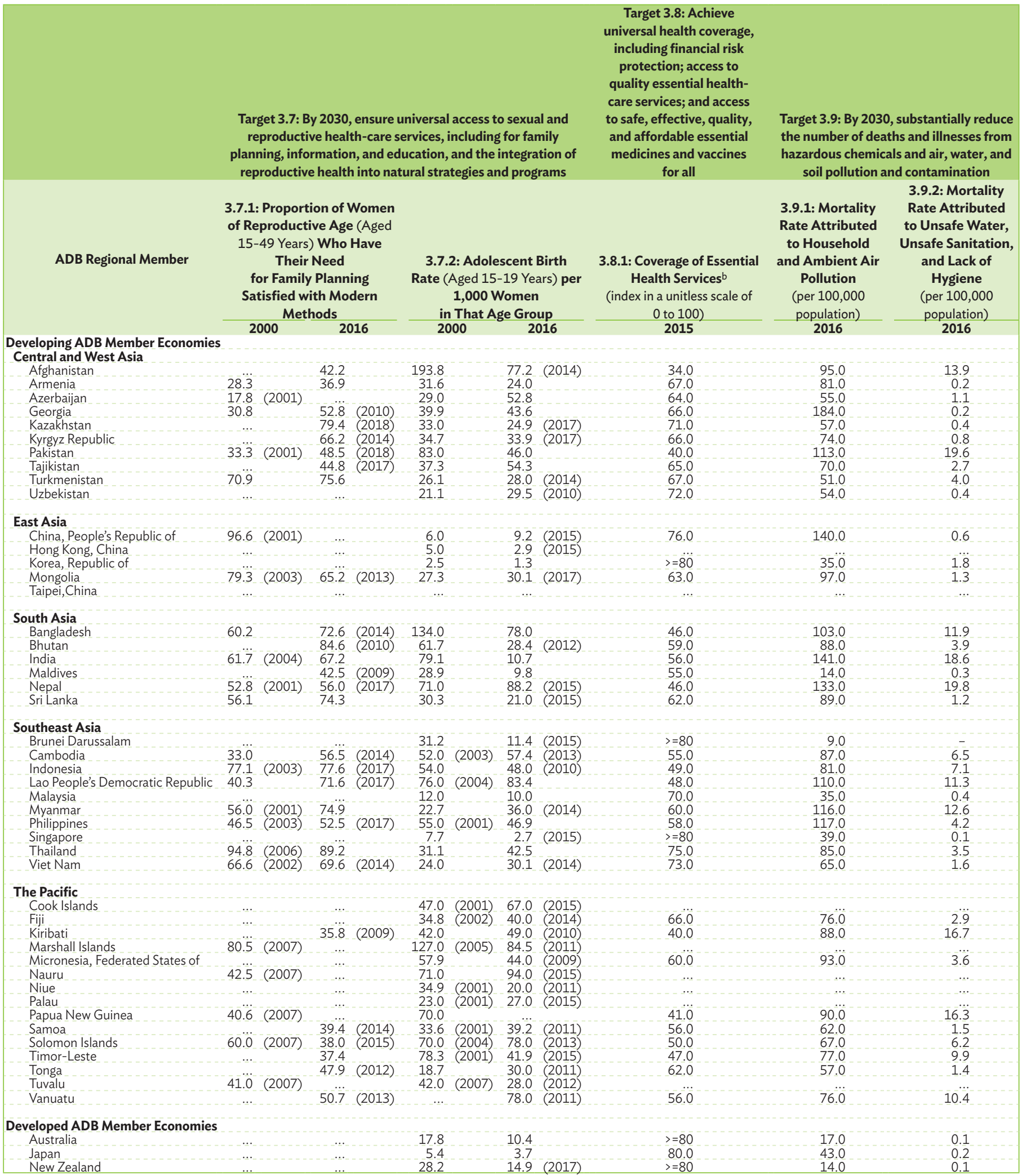

$\ldots=$ data not available, $\geq=$ greater than or equal to, $-=$ magnitude equals zero, $A D B=$ Asian Development Bank.

a Data refers to crude suicide rates (per 100,000 population).

b The universal health coverage service coverage index is a single indicator that is calculated based on tracer indicators (some of which are proxies of service coverage) to monitor coverage of essential health services. For presentation purposes, index values of 80 and over are reported as " $\geq 80$ " to avoid comparisons that are not meaningful. This should not be interpreted as a of essential health services. For presentation purposes, index values of 80 and over are reported as " $\geq 80$ " to avoid comparisons that are not meaningful. This should not be interpreted
target.

Sources: $\quad$ For Indicators 3.4.1, 3.4.2, 3.7.1, 3.7.2, 3.8.1, and 3.9.2: United Nations Statistics Division. Sustainable Development Goals (SDGs), SDG Indicators, Global Database. https://unstats.un.org/sdgs/indicators/database/ (accessed 8 July 2019). For Indicator 3.4.2 for Taipei, China: Government of Taipei,China. Cause of Death Statistics. https://www.mohw.gov.tw/lp-3961-2.html (accessed 22 July 2019). For Indicator 3.6.1: For 2000: United Nations Statistics Division. Sustainable Development Goals (SDGs), SDG Indicators, Global Database. https://unstats.un.org/sdgs/indicators/database/ (accessed 8 July 2019). For 2016: World Health Organization. Global Health Observatory Data Repository. http://apps.who.int/gho/data/node.main.A997?lang=en (accessed 22 July 2019). For Hong Kong, China: Government of the Hong Kong Special Administrative Region of the People's Republic of China. Road Traffic Accident Statistics. https://www.td.gov.hk/en/road_safety/road_traffic_accident_statistics/ accident_trend_since_1953/index.html (accessed 22 July 2019). 
Goal 4. Ensure inclusive and equitable quality education and promote lifelong learning opportunities for all

Table 1.4.1: Selected Indicators for Sustainable Development Goal 4-Early Childhood Education

\begin{tabular}{|c|c|c|c|c|c|c|c|c|c|c|c|c|}
\hline \multirow{3}{*}{ ADB Regional Member } & \multicolumn{12}{|c|}{$\begin{array}{c}\text { Target 4.2: By 2030, ensure that all girls and boys have access to quality early childhood development, care, } \\
\text { and preprimary education, so that they are ready for primary education }\end{array}$} \\
\hline & \multicolumn{4}{|c|}{2000} & \multirow{2}{*}{\multicolumn{2}{|c|}{ Male }} & \multicolumn{4}{|c|}{2017} & \multirow{2}{*}{\multicolumn{2}{|c|}{ Male }} \\
\hline & \multicolumn{2}{|c|}{ Total } & \multicolumn{2}{|c|}{ Female } & & & \multicolumn{2}{|c|}{ Total } & \multicolumn{2}{|c|}{ Female } & & \\
\hline Developing ADB Member Economies & & & & & & & & & & & & \\
\hline Central and West Asia & & & & & & & & & & & & \\
\hline Afghanistan & & & & & & & & & & & & \\
\hline Armenia & & & & & & & & & & & & \\
\hline Azerbaijan & 15.8 & & 16.1 & & 15.6 & & 61.3 & & 61.4 & & 61.2 & \\
\hline Georgia & 46.1 & (2004) & 49.1 & (2004) & 43.4 & (2004) & & & & & & \\
\hline Kazakhstan & & & & & & & 63.9 & (2018) & 65.0 & $(2018)$ & 62.7 & $(2018)$ \\
\hline Kyrgyz Republic & 42.4 & & 43.2 & & 41.6 & & 95.4 & & 96.3 & & 94.5 & \\
\hline Pakistan & & & & & $\ldots$ & & & & & & & \\
\hline Tajikistan & $\ldots$ & & $\ldots$ & & $\ldots$ & & 12.5 & & 11.6 & & 13.4 & \\
\hline Turkmenistan & & & & & & & & & & & $\ldots$ & \\
\hline Uzbekistan & & & . & & & & 36.9 & & 36.4 & & 37.4 & \\
\hline East Asia & & & & & & & & & & & & \\
\hline China, People's Republic of & & & & & & & & & & & & \\
\hline Hong Kong, China & & & & & & & 99.5 & & 99.0 & & 100.0 & \\
\hline Korea, Republic of & 49.6 & (2005) & 49.6 & $(2005)$ & 49.6 & $(2005)$ & 96.4 & $(2016)$ & 96.1 & $(2016)$ & 96.6 & (2016) \\
\hline Mongolia & 96.5 & $(2007)$ & 100.0 & $(2007)$ & 93.1 & (2007) & 96.0 & & 95.5 & & 96.6 & \\
\hline Taipei,China & & & & & & & & & & & & \\
\hline South Asia & & & & & & & & & & & & \\
\hline Bangladesh & $\ldots$ & & $\ldots$ & & $\ldots$ & & 35.3 & $(2010)$ & 35.4 & $(2010)$ & 35.3 & $(2010)$ \\
\hline Bhutan & & & & & & & & & $\ldots$ & & $\ldots$ & \\
\hline India & & & & & & & & & & & & \\
\hline Maldives & 69.5 & & 70.0 & & 69.1 & & 98.5 & & 97.4 & & 99.5 & \\
\hline Nepal & & & $\ldots$ & & $\ldots$ & & 84.9 & & 82.1 & & 87.6 & \\
\hline Sri Lanka & & & $\ldots$ & & $\cdots$ & & $\ldots$ & & $\ldots$ & & $\ldots$ & \\
\hline Southeast Asia & & & & & & & & & & & & \\
\hline Brunei Darussalam & 97.5 & $(2006)$ & 95.0 & (2006) & 100.0 & (2006) & 95.1 & & 94.8 & & 95.3 & \\
\hline Cambodia & 26.6 & (2006) & 27.2 & (2006) & 26.0 & (2006) & 43.0 & (2012) & 43.6 & (2012) & 42.5 & (2012) \\
\hline Indonesia & $\ldots$ & & $\ldots$ & & $\ldots$ & & 96.8 & & 100.0 & & 93.7 & \\
\hline Lao People's Democratic Republic & & & $\ldots$ & & 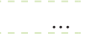 & & 63.1 & & 63.6 & & 62.6 & \\
\hline Malaysia & 76.9 & $(2002)$ & 79.3 & $(2002)$ & 74.6 & $(2002)$ & 98.6 & $(2015)$ & 99.3 & (2015) & 98.0 & (2015) \\
\hline Myanmar & & & & & & & & & & & & \\
\hline Philippines & 24.0 & (2001) & 23.8 & (2001) & 24.1 & (2001) & 79.6 & (2016) & 80.7 & (2016) & 78.6 & (2016) \\
\hline Singapore & & & & & & & & & & & & \\
\hline Thailand & 98.9 & $(2006)$ & 100.0 & (2006) & 97.9 & (2006) & 97.0 & & 96.8 & & 97.1 & \\
\hline Viet Nam & 78.7 & (2006) & $\ldots$ & & $\ldots$ & & 99.3 & & 98.5 & & 100.0 & \\
\hline The Pacific & & & & & & & & & & & & \\
\hline Cook Islands & & & & & & & 99.1 & (2016) & 100.0 & (2016) & 98.3 & (2016) \\
\hline Fiji & 48.6 & $(2004)$ & 50.2 & $(2004)$ & 47.1 & $(2004)$ & $\ldots$ & & $\ldots$ & & $\ldots$ & \\
\hline Kiribati & $\ldots$ & & $\ldots$ & & $\ldots$ & & $\ldots$ & & - & & $\ldots$ & \\
\hline Marshall Islands & $\ldots$ & & & & & & 65.6 & (2016) & 64.8 & (2016) & 66.4 & (2016) \\
\hline Micronesia, Federated States of & & & & & & & 76.4 & $(2015)$ & 72.8 & (2015) & 79.8 & $(2015)$ \\
\hline Nauru & 89.4 & (2007) & 78.5 & (2007) & 100.0 & (2007) & 74.8 & (2016) & 84.3 & (2016) & 67.3 & (2016) \\
\hline Niue & $\ldots$ & & $\ldots$ & & $\ldots$ & & 55.7 & (2015) & 100.0 & (2015) & 23.2 & (2015) \\
\hline Palau & & & & & & & 90.4 & (2014) & 80.4 & (2014) & 100.0 & (2014) \\
\hline Papua New Guinea & & & & & & & 73.5 & (2016) & 73.1 & (2016) & 73.9 & (2016) \\
\hline Samoa & $\ldots$ & & & & & & 36.9 & & 39.1 & & 34.9 & \\
\hline Solomon Islands & & & & & & & 65.4 & (2015) & 65.7 & (2015) & 65.1 & (2015) \\
\hline Timor-Leste & & & & & & & 33.1 & & 33.5 & & 32.8 & \\
\hline Tonga & & & $\ldots$ & & 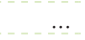 & & & & & & & \\
\hline Tuvalu & . & & $\ldots$ & & 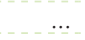 & & 97.0 & $(2016)$ & 100.0 & $(2016)$ & 94.2 & $(2016)$ \\
\hline Vanuatu & 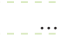 & & $\cdots$ & & $\cdots$ & & $\ldots$ & &.- & & $\ldots$ & \\
\hline Developed ADB Member Econ & & & & & & & & & & & & \\
\hline Australia & 52.6 & (2001) & 53.3 & $(2001)$ & 52.0 & $(2001)$ & 87.4 & & 87.1 & & 87.7 & \\
\hline Japan & & & & & & & & & & & & \\
\hline New Zealand & & & & & & & 96.2 & & 96.5 & & 95.8 & \\
\hline
\end{tabular}

$\ldots=$ data not available, $\mathrm{ADB}=$ Asian Development Bank.

a Covers participation in early childhood education and primary education.

b The indicator measures the exposure of children to organized learning, but not to the intensity of the learning programs.

Source: $\quad$ United Nations Statistics Division. Sustainable Development Goals (SDGs), SDG Indicators, Global Database. https://unstats.un.org/sdgs/indicators/database/ (accessed 8 July 2019). 
Goal 4. Ensure inclusive and equitable quality education and promote lifelong learning opportunities for all

\section{Table 1.4.2: Selected Indicators for Sustainable Development Goal 4-Teacher Training and Supply}

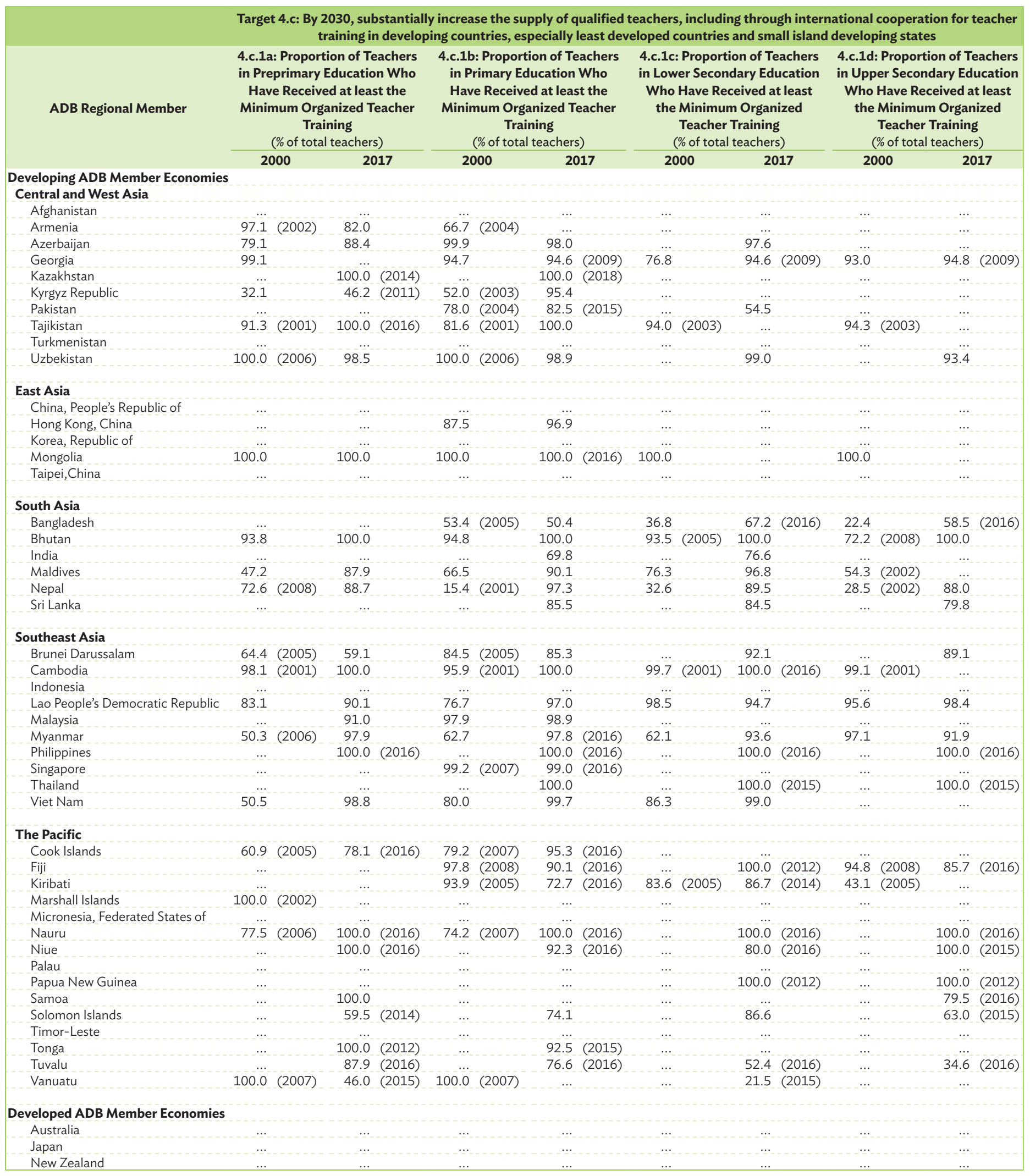

$\ldots=$ data not available, $\mathrm{ADB}=$ Asian Development Bank.

Source: $\quad$ United Nations Statistics Division. Sustainable Development Goals (SDGs), SDG Indicators, Global Database. https://unstats.un.org/sdgs/indicators/database/ (accessed 8 July 2019). 
Table 1.5.1: Selected Indicators for Sustainable Development Goal 5-Early Marriage and Women in Leadership

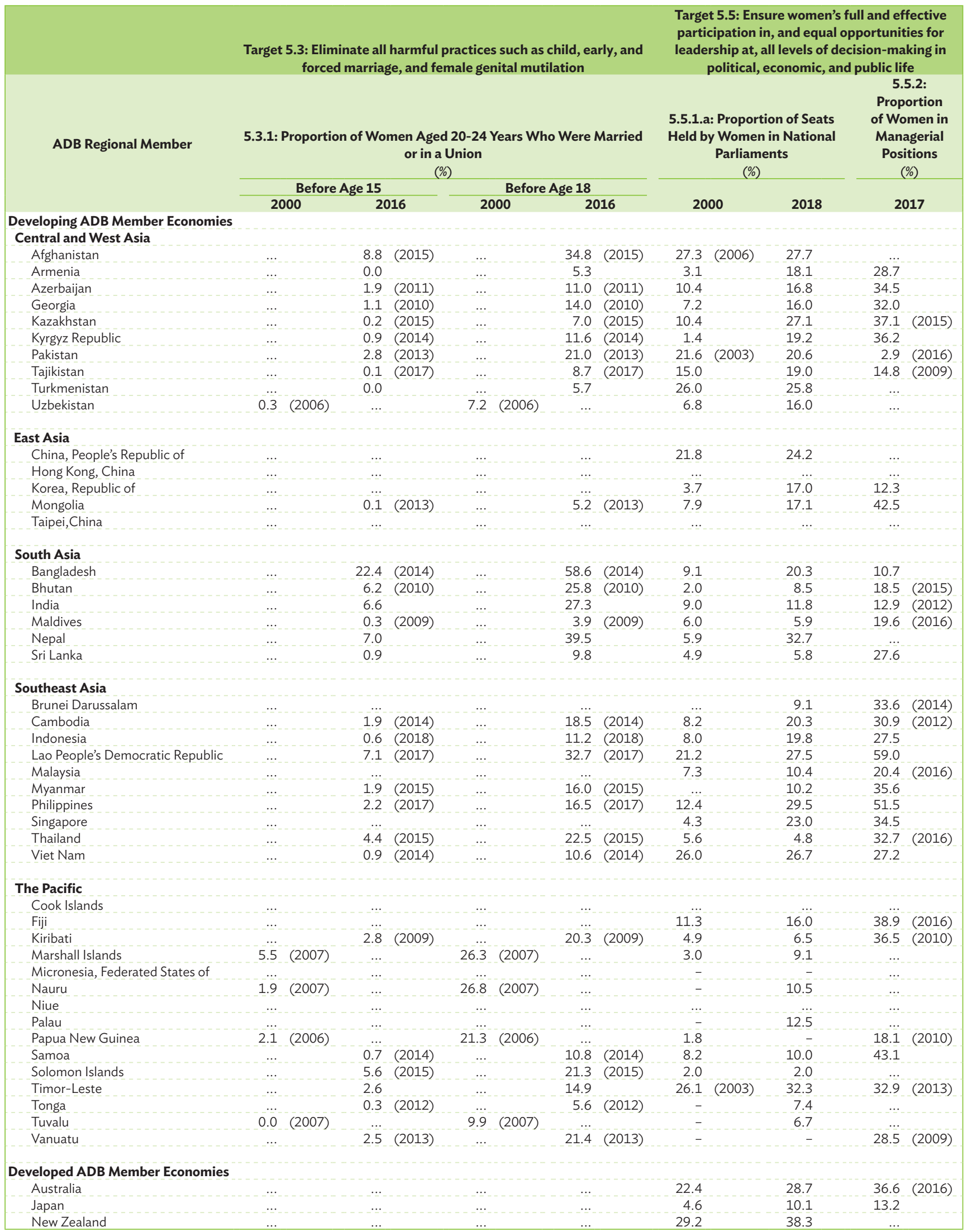

$\ldots=$ data not available, $-=$ magnitude equals zero, $0.0=$ magnitude is less than half of unit employed, $A D B=$ Asian Development Bank.

Sources: United Nations Statistics Division. Sustainable Development Goals (SDGs), SDG Indicators, Global Database. https://unstats.un.org/sdgs/indicators/database (accessed 8 July 2019). For Tajikistan for indicator 5.5.1a: Inter-Parliamentary Union. Women in National Parliaments. http://archive.ipu.org/wmn-e/classif-arc.htm (accessed 24 July 2019). 
Goal 6. Ensure availability and sustainable management of water and sanitation for all

Table 1.6.1: Selected Indicators for Sustainable Development Goal 6-Clean Water and Sanitation

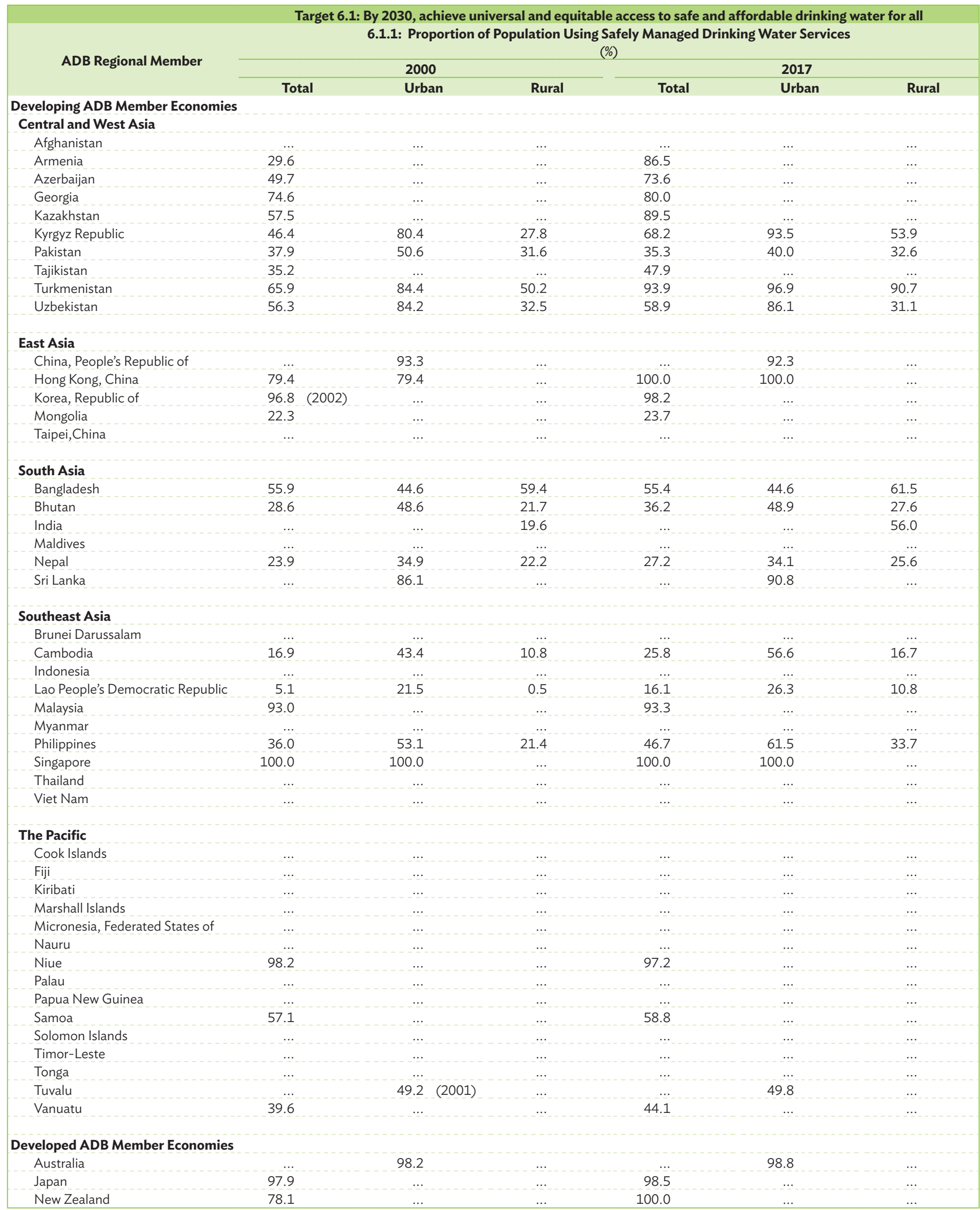


Goal 6. Ensure availability and sustainable management of water and sanitation for all

Table 1.6.1: Selected Indicators for Sustainable Development Goal 6-Clean Water and Sanitation (continued)




Table 1.6.1: Selected Indicators for Sustainable Development Goal 6-Clean Water and Sanitation (continued)

\begin{tabular}{|c|c|c|c|c|}
\hline \multirow{3}{*}{ ADB Regional Member } & \multicolumn{2}{|c|}{$\begin{array}{l}\text { Target 6.4: By } 2030 \text {, substantially increase water-use } \\
\text { efficiency across all sectors and ensure sustainable } \\
\text { withdrawals and supply of freshwater to address water } \\
\text { scarcity and substantially reduce the number of people } \\
\text { suffering from water scarcity }\end{array}$} & \multicolumn{2}{|c|}{$\begin{array}{l}\text { Target 6.a: By 2030, expand international cooperation } \\
\text { and capacity-building support to developing countries } \\
\text { in water- and sanitation-related activities and } \\
\text { programmes, including water harvesting, desalination, } \\
\text { water efficiency, wastewater treatment, and recycling } \\
\text { and reuse technologies }\end{array}$} \\
\hline & \multicolumn{2}{|c|}{$\begin{array}{l}\text { 6.4.2: Level of Water Stress, Freshwater Withdrawal as a } \\
\text { Proportion of Available Freshwater Resources } \\
(\%)\end{array}$} & \multicolumn{2}{|c|}{$\begin{array}{l}\text { 6.a.1: Amount of Water- and Sanitation-Related } \\
\text { Official Development Assistance Part of a Government- } \\
\text { Coordinated Spending Plan } \\
(\$ \text { million })\end{array}$} \\
\hline & 2000 & 2015 & 2000 & 2017 \\
\hline \multicolumn{5}{|l|}{$\begin{array}{l}\text { Developing ADB Member Economies } \\
\text { Central and West Asia }\end{array}$} \\
\hline Afghanistan & 54.8 & & 4.3 & 93.5 \\
\hline Armenia & & 64.2 & 12.9 & 79.2 \\
\hline Azerbaijan & & 56.4 & 49.5 & 84.2 \\
\hline Georgia & & $5.9(2010)$ & 0.8 & 68.4 \\
\hline Kazakhstan & & 27.7 (2010) & 7.2 & 0.7 \\
\hline Kyrgyz Republic & $50.0 \quad(2005)$ & & 13.9 & 11.9 \\
\hline Pakistan & & $112.5 \quad(2010)$ & 14.8 & 263.1 \\
\hline Tajikistan & $73.9(2005)$ & & 15.5 & 24.5 \\
\hline Turkmenistan & $143.6 \quad(2005)$ & & 0.0 & $0.2 \quad(2011)$ \\
\hline Uzbekistan & & 136.9 & 2.2 & 64.2 \\
\hline \multicolumn{5}{|l|}{ East Asia } \\
\hline $\begin{array}{l}\text { China, People's Republic of } \\
\text { Hong Kong, China }\end{array}$ & $\cdots$ & $\begin{array}{r}43.4 \\
\ldots\end{array}$ & $\begin{array}{r}971.4 \\
\ldots\end{array}$ & 90.4 \\
\hline Korea, Republic of & $84.8 \quad(2005)$ & & & \\
\hline Mongolia & & 3.4 & 0.3 & 10.8 \\
\hline Taipei,China & & & $-\ldots$ & $\cdots$ \\
\hline \multicolumn{5}{|l|}{ South Asia } \\
\hline Bangladesh & & $5.7 \quad(2010)$ & 84.4 & 283.5 \\
\hline Bhutan & & 1.4 (2010) & 5.7 & 11.8 \\
\hline India & & $66.5(2010)$ & 172.7 & 659.4 \\
\hline Maldives & & 15.7 (2010) & $0.6 \quad(2001)$ & 3.2 \\
\hline Nepal & $8.3(2005)$ & $\ldots$ & 59.0 & 179.4 \\
\hline Sri Lanka & $90.8 \quad(2005)$ & & 32.0 & 144.5 \\
\hline \multicolumn{5}{|l|}{ Southeast Asia } \\
\hline Cambodia & $1.0(2005)$ & & 23.3 & 162.3 \\
\hline Indonesia & & 28.0 & 84.1 & 121.8 \\
\hline Lao People's Democratic Republic & $2.3(2005)$ & & 37.3 & 65.8 \\
\hline Malaysia & $5.7 \quad(2005)$ & & 526.1 & 1.7 \\
\hline Myanmar & 5.8 & & 1.4 & 74.6 \\
\hline Philippines & & 26.0 & 20.0 & 70.4 \\
\hline \multicolumn{5}{|l|}{ Singapore } \\
\hline Thailand & $23.0 \quad(2005)$ & & 77.9 & 2.6 \\
\hline Viet Nam & 18.1 (2005) & $\ldots$ & 224.9 & 533.2 \\
\hline \multicolumn{5}{|l|}{ The Pacific } \\
\hline Cook Islands & & & 0.4 & 3.5 \\
\hline Fiji & $0.5 \quad(2005)$ & $\cdots$ & 0.4 & 2.7 \\
\hline Kiribati & $\ldots$ & $\ldots$ & 0.1 & 10.1 \\
\hline Marshall Islands & & .. & 0.1 & 2.0 \\
\hline Micronesia, Federated States of & & & $0.0 \quad(2003)$ & 1.2 \\
\hline Nauru & & & 0.1 & 0.1 \\
\hline Niue & & & $0.1 \quad(2002)$ & 0.0 \\
\hline Palau & & & $0.0 \quad(2003)$ & 5.2 \\
\hline Papua New Guinea & $0.1 \quad(2005)$ & & 12.8 & 28.0 \\
\hline Samoa & $\ldots$ & & 0.3 & 14.4 \\
\hline Solomon Islands & & & 2.2 & 10.6 \\
\hline Timor-Leste & $28.3(2005)$ & & 3.9 & 5.9 \\
\hline Tonga & & & 10.3 & 2.4 \\
\hline Tuvalu & & & 0.1 & 1.0 \\
\hline Vanuatu & & $\ldots$ & 0.1 & 2.2 \\
\hline \multicolumn{5}{|l|}{ Developed ADB Member Economies } \\
\hline Australia & & 6.2 & & \\
\hline Japan & & $37.3(2010)$ & & \\
\hline New Zealand & $\ldots$ & $4.2(2010)$ & $\ldots$ & \\
\hline
\end{tabular}

$\ldots=$ data not available, 0.0 = magnitude is less than half of unit employed, $\$=$ United States dollars, ADB = Asian Development Bank.

Source: $\quad$ United Nations Statistics Division. Sustainable Development Goals (SDGs), SDG Indicators, Global Database. https://unstats.un.org/sdgs/indicators/database/ (accessed 8 July 2019). 
Table 1.7.1: Selected Indicators for Sustainable Development Goal 7-Affordable and Clean Energy

\begin{tabular}{|c|c|c|c|c|c|c|c|c|c|c|c|c|}
\hline \multirow{4}{*}{ ADB Regional Member } & \multicolumn{8}{|c|}{$\begin{array}{l}\text { Target 7.1: By 2030, ensure universal access to affordable, reliable, and } \\
\text { modern energy services }\end{array}$} & \multicolumn{2}{|c|}{$\begin{array}{c}\text { Target 7.2: By } \\
\text { 2030, increase } \\
\text { substantially the } \\
\text { share of renewable } \\
\text { energy in the } \\
\text { global energy mix }\end{array}$} & \multicolumn{2}{|c|}{$\begin{array}{l}\text { Target 7.3: By } \\
\text { 2030, double the } \\
\text { global rate of } \\
\text { improvement in } \\
\text { energy efficiency }\end{array}$} \\
\hline & \multicolumn{6}{|c|}{$\begin{array}{c}\text { 7.1.1: Proportion of Population } \\
\text { with Access to Electricity } \\
(\%)\end{array}$} & \multirow{2}{*}{\multicolumn{2}{|c|}{$\begin{array}{c}\text { 7.1.2: Proportion } \\
\text { of Population } \\
\text { with Primary } \\
\text { Reliance on } \\
\text { Clean Fuels and } \\
\text { Technology } \\
(\%)\end{array}$}} & \multirow{2}{*}{\multicolumn{2}{|c|}{$\begin{array}{l}\text { 7.2.1: Renewable } \\
\text { Energy Share in } \\
\text { Total Final Energy } \\
\text { Consumption } \\
(\%)\end{array}$}} & \multicolumn{2}{|c|}{$\begin{array}{c}\text { 7.3.1: Energy } \\
\text { Intensity } \\
\text { Measured in } \\
\text { Terms of Primary } \\
\text { Energy and GDP } \\
(\mathrm{MJ} / \$ 2011 \text { PPP } \\
\text { GDP) }\end{array}$} \\
\hline & To & & Urb & & Ru & & & & & & & \\
\hline & 2000 & 2017 & 2000 & 2017 & 2000 & 2017 & 2000 & 2017 & 2000 & 2016 & 2000 & 2016 \\
\hline $\begin{array}{l}\text { Developing ADB Member Economies } \\
\text { Central and West Asia } \\
\text { Afghanistan } \\
\text { Armenia } \\
\text { Azerbaijan } \\
\text { Georgia } \\
\text { Kazakhstan } \\
\text { Kyrgyz Republic } \\
\text { Pakistan } \\
\text { Tajikistan } \\
\text { Turkmenistan } \\
\text { Uzbekistan }\end{array}$ & $\begin{array}{l}23.0^{\mathrm{a}} \\
98.9 \\
98.9 \\
99.9 \mathrm{~b} \\
99.1 \\
99.7 \\
70.4 \\
98.5 \\
99.6 \\
99.6\end{array}$ & $\begin{array}{r}97.7 \\
100.0 \\
100.0 \\
100.0 \\
100.0 \\
100.0 \\
70.8 \\
99.3 \\
100.0 \\
100.0\end{array}$ & $\begin{array}{c}74.0^{\mathrm{a}} \\
99.1 \\
99.7 \\
100.0^{\mathrm{b}} \\
99.7 \\
99.9 \\
93.8 \\
99.7 \\
99.7 \\
99.9\end{array}$ & $\begin{array}{r}99.5 \\
100.0 \\
100.0 \\
100.0 \\
100.0 \\
100.0 \\
100.0 \\
99.2 \\
100.0 \\
100.0\end{array}$ & $\begin{array}{l}8.0^{\mathrm{a}} \\
98.5^{-} \\
98.1^{\mathrm{b}} \\
99.8^{\mathrm{b}} \\
98.3^{-} \\
99.6^{-} \\
58.9^{-} \\
98.0^{-} \\
99.5 \\
99.3\end{array}$ & $\begin{array}{r}97.1 \\
100.0 \\
100.0 \\
100.0 \\
100.0 \\
100.0 \\
54.1 \\
99.3 \\
100.0 \\
100.0\end{array}$ & $\begin{array}{r}7.0 \\
83.0 \\
73.0 \\
41.0 \\
85.0 \\
53.0 \\
23.0 \\
38.0 \\
>95 \\
80.0\end{array}$ & $\begin{array}{r}34.0 \\
>95 \\
>95 \\
79.0 \\
>95 \\
83.0 \\
44.0 \\
83.0 \\
>95 \\
92.0\end{array}$ & $\begin{array}{r}54.2 \\
7.2 \\
2.1 \\
47.3 \\
2.5 \\
35.2 \\
51.0 \\
62.4 \\
0.1 \\
1.2\end{array}$ & $\begin{array}{r}20.8 \\
14.0 \\
1.9 \\
28.1 \\
2.0 \\
21.9 \\
45.6 \\
43.9 \\
0.1 \\
3.2\end{array}$ & $\begin{array}{r}1.7 \\
9.4 \\
13.2 \\
8.3 \\
10.1 \\
9.6 \\
5.5 \\
12.3 \\
25.9 \\
34.5 \\
\end{array}$ & $\begin{array}{r}2.3 \\
5.3 \\
3.8 \\
5.8 \\
8.2 \\
8.0 \\
4.3 \\
5.0 \\
13.0 \\
8.2\end{array}$ \\
\hline $\begin{array}{l}\text { Asia } \\
\text { China, People's Republic of } \\
\text { Hong Kong, China } \\
\text { Korea, Republic of } \\
\text { Mongolia } \\
\text { Taipei, China }\end{array}$ & $\begin{array}{r}96.6 \\
100.0 \\
100.0 \\
67.3\end{array}$ & $\begin{array}{r}100.0 \\
100.0 \\
100.0 \\
85.9\end{array}$ & $\begin{array}{r}100.0 \\
100.0 \\
99.2\end{array}$ & $\begin{array}{r}100.0 \\
100.0 \\
100.0 \\
99.8 \\
\cdots\end{array}$ & $\begin{array}{r}94.7 \\
100.0 \\
100.0 \\
24.8 \\
\cdots\end{array}$ & $\begin{array}{r}100.0 \\
100.0 \\
100.0 \\
55.7 \\
\cdots\end{array}$ & $\begin{array}{r}49.0 \\
\ldots \\
>95 \\
15.0 \\
\ldots\end{array}$ & $\begin{array}{r}58.0 \\
\quad \cdots \\
495 \\
41.0 \\
\cdots\end{array}$ & $\begin{array}{r}29.6 \\
0.6 \\
0.7 \\
5.7 \\
1.3\end{array}$ & $\begin{array}{r}12.6 \\
0.8 \\
2.6 \\
3.3 \\
2.1\end{array}$ & $\begin{array}{r}10.1 \\
2.5 \\
8.1 \\
9.0\end{array}$ & $\begin{array}{l}6.2 \\
1.5 \\
6.6 \\
6.0\end{array}$ \\
\hline $\begin{array}{l}\text { South Asia } \\
\text { Bangladesh } \\
\text { Bhutan } \\
\text { India } \\
\text { Maldives } \\
\text { Nepal } \\
\text { Sri Lanka }\end{array}$ & $\begin{array}{l}32.0 \\
31.2 \\
59.4 \\
83.8 \\
27.2 \\
63.6\end{array}$ & $\begin{array}{l}88.0 \\
97.7 \\
92.6 \\
99.8 \\
95.5 \\
97.5\end{array}$ & $\begin{array}{l}81.2 \\
96.7 \\
88.7 \\
99.7 \\
83.9 \\
85.3\end{array}$ & $\begin{array}{r}99.5 \\
99.1 \\
99.2 \\
99.7 \\
98.7 \\
100.0\end{array}$ & $\begin{array}{r}16.7 \\
8.8 \\
48.1 \\
77.7 \\
18.4 \\
58.7\end{array}$ & $\begin{array}{l}81.3 \\
96.8 \\
89.3 \\
99.9 \\
94.7 \\
97.0\end{array}$ & $\begin{array}{r}7.0 \\
27.0 \\
22.0 \\
32.0 \\
14.0 \\
14.0\end{array}$ & $\begin{array}{r}19.0 \\
79.0 \\
45.0 \\
>95 \\
29.0 \\
28.0\end{array}$ & $\begin{array}{r}59.0 \\
91.4 \\
51.8 \\
2.3 \\
88.3 \\
64.2\end{array}$ & $\begin{array}{r}34.0 \\
84.8 \\
34.0 \\
1.1 \\
79.2 \\
50.9\end{array}$ & $\begin{array}{r}3.6 \\
21.8 \\
7.0 \\
2.4 \\
9.3 \\
3.4\end{array}$ & $\begin{array}{r}3.1 \\
10.0 \\
4.5 \\
3.4 \\
8.1 \\
2.0\end{array}$ \\
\hline $\begin{array}{l}\text { Southeast Asia } \\
\text { Brunei Darussalam } \\
\text { Cambodia } \\
\text { Indonesia } \\
\text { Lao People's Democratic Republic } \\
\text { Malaysia } \\
\text { Myanmar } \\
\text { Philippines } \\
\text { Singapore } \\
\text { Thailand } \\
\text { Viet Nam }\end{array}$ & $\begin{array}{r}100.0 \\
16.6 \\
86.3 \\
43.1 \\
\ldots \\
47.0 \\
74.8 \\
100.0 \\
82.1 \\
86.3\end{array}$ & $\begin{array}{r}100.0 \\
89.1 \\
98.1 \\
93.6 \\
100.0 \\
69.8 \\
93.0 \\
100.0 \\
100.0 \\
100.0\end{array}$ & $\begin{array}{r}100.0 \\
60.6 \\
95.4 \\
96.0 \\
\ldots \\
83.4 \mathrm{~b} \\
89.7 \\
100.0 \\
99.9 \\
99.0\end{array}$ & $\begin{array}{r}100.0 \\
99.1 \\
100.0 \\
99.5 \\
100.0 \\
92.6 \\
96.4 \\
100.0 \\
100.0 \\
100.0\end{array}$ & $\begin{array}{r}100.0 \\
6.6 \\
79.5 \\
28.2 \\
\ldots \\
33.3 \mathrm{~b} \\
61.9 \\
100.0 \\
74.0 \\
82.2\end{array}$ & $\begin{array}{r}100.0 \\
86.1 \\
95.7 \\
90.5 \\
100.0 \\
59.9 \\
90.0 \\
100.0 \\
100.0 \\
100.0\end{array}$ & $\begin{array}{r}>95 \\
<5 \\
7.0 \\
<5 \\
>95 \\
<5 \\
36.0 \\
>95 \\
65.0 \\
14.0\end{array}$ & $\begin{array}{r}>95 \\
20.0 \\
65.0 \\
<5 \\
>95 \\
20.0 \\
44.0 \\
>95 \\
78.0 \\
70.0\end{array}$ & $\begin{array}{r}81 . \overline{1} \\
45.6 \\
81.6 \\
6.7 \\
80.2 \\
34.9 \\
0.3 \\
22.0 \\
58.0\end{array}$ & $\begin{array}{r}0.0 \\
62.7 \\
37.2 \\
51.9 \\
6.2 \\
68.0 \\
24.0 \\
0.7 \\
21.8 \\
32.7\end{array}$ & $\begin{array}{l}3.7 \\
8.5 \\
5.3 \\
4.4 \\
5.4 \\
8.9 \\
5.1 \\
3.8 \\
5.2 \\
5.9\end{array}$ & $\begin{array}{l}4.1 \\
5.8 \\
3.4 \\
5.9 \\
4.7 \\
2.9 \\
3.1 \\
2.5 \\
5.4 \\
6.1\end{array}$ \\
\hline $\begin{array}{l}\text { The Pacific } \\
\text { Cook Islands } \\
\text { Fiji } \\
\text { Kiribati } \\
\text { Marshall Islands } \\
\text { Micronesia, Federated States of } \\
\text { Nauru } \\
\text { Niue } \\
\text { Palau } \\
\text { Papua New Guinea } \\
\text { Samoa } \\
\text { Solomon Islands } \\
\text { Timor-Leste } \\
\text { Tonga } \\
\text { Tuvalu } \\
\text { Vanuatu }\end{array}$ & $\begin{array}{r}98.6 \\
75.8 \\
69.7 \\
68.5 \\
46.0 \\
99.8 \\
\ldots \\
98.9 \\
11.2 \\
87.3 \\
6.6 \\
25.6 \\
85.4 \\
94.6 \\
22.3\end{array}$ & $\begin{array}{r}100.0 \\
96.0 \\
98.6 \\
94.8 \\
80.8 \\
99.6 \\
100.0 \\
100.0 \\
54.4 \\
96.8 \\
62.9 \\
80.4 \\
98.0 \\
100.0 \\
62.8\end{array}$ & $\begin{array}{r}98.5 \\
91.4 \\
93.6 \\
89.2 \\
70.0 \\
98.1 \\
\ldots \\
99.7 \\
63.1 \\
98.6 \\
59.1 \\
70.9 \\
97.0 \\
95.4 \\
78.4\end{array}$ & $\begin{array}{r}100.0 \\
99.9 \\
88.7 \\
95.6 \\
93.7 \\
99.7 \\
100.0 \\
100.0 \\
81.0 \\
100.0 \\
73.8 \\
100.0 \\
98.9 \\
100.0 \\
92.7\end{array}$ & $\begin{array}{r}- \\
61.4 \\
51.2 \\
23.3 \\
39.1 \\
98.1 \\
\ldots \\
97.0 \\
3.3 \\
84.2 \\
0.0 \\
10.8 \\
81.9 \\
94.0 \\
6.8\end{array}$ & $\begin{array}{r}-\overline{1} \\
91.1 \\
100.0 \\
91.8 \\
77.0 \\
99.7 \\
0.0 \\
100.0 \\
50.4 \\
96.1 \\
59.6 \\
71.9 \\
97.7 \\
100.0 \\
52.7\end{array}$ & $\begin{array}{r}84.0 \\
32.0 \\
<5 \\
7.0 \\
11.0 \\
72.0 \\
75.0 \\
>95 \\
6.0 \\
16.0 \\
6.0 \\
<5 \\
49.0 \\
20.0 \\
12.0\end{array}$ & $\begin{array}{r}84.0 \\
51.0 \\
6.0 \\
66.0 \\
12.0 \\
92.0 \\
93.0 \\
>95 \\
12.0 \\
31.0 \\
8.0 \\
11.0 \\
55.0 \\
52.0 \\
11.0\end{array}$ & $\begin{array}{r}52 . \\
56.5 \\
19.6 \\
1.2 \\
16.4 \\
0.6 \\
- \\
66.4 \\
42.5 \\
66.9 \\
48.3 \\
2.5 \\
- \\
48.7\end{array}$ & $\begin{array}{r}1.9 \\
24.4 \\
45.4 \\
11.8 \\
1.6 \\
31.4 \\
22.1 \\
0.0 \\
50.3 \\
27.3 \\
65.7 \\
19.2 \\
2.0 \\
11.8 \\
33.7\end{array}$ & $\begin{array}{r}4.0 \\
5.5 \\
10.5 \\
5.6 \\
17.1 \\
\ldots . \\
12.2 \\
6.5 \\
4.2 \\
7.3 \\
1.3 \\
3.2 \\
3.4 \\
4.0\end{array}$ & $\begin{array}{r}4.4 \\
6.5 \\
11.2 \\
6.3 \\
4.1 \\
\ldots . \\
10.4 \\
6.0 \\
4.1 \\
4.4 \\
0.8 \\
3.2 \\
3.8 \\
4.0\end{array}$ \\
\hline $\begin{array}{l}\text { Developed ADB Member Economies } \\
\text { Australia } \\
\text { Japan } \\
\text { New Zealand }\end{array}$ & $\begin{array}{l}100.0 \\
100.0 \\
100.0\end{array}$ & $\begin{array}{l}100.0 \\
100.0 \\
100.0\end{array}$ & $\begin{array}{l}100.0 \\
100.0 \\
100.0\end{array}$ & $\begin{array}{l}100.0 \\
100.0 \\
100.0\end{array}$ & $\begin{array}{l}100.0 \\
100.0 \\
100.0\end{array}$ & $\begin{array}{l}100.0 \\
100.0 \\
100.0\end{array}$ & $\begin{array}{l}>95 \\
>95 \\
>95\end{array}$ & $\begin{array}{l}>95 \\
>95 \\
>95\end{array}$ & $\begin{array}{r}8.4 \\
3.9 \\
29.0\end{array}$ & $\begin{array}{r}9.3 \\
6.6 \\
32.8\end{array}$ & $\begin{array}{l}6.7 \\
5.0 \\
6.7\end{array}$ & $\begin{array}{l}5.0 \\
3.7 \\
5.2\end{array}$ \\
\hline
\end{tabular}

$\ldots=$ data not available, $-=$ magnitude equals zero, $0.0=$ magnitude is less than half of unit employed, $\$=$ United States dollars, $A D B=$ Asian Development Bank,

$\mathrm{GDP}=$ gross domestic product, $\mathrm{MJ}=$ megajoule, $\mathrm{PPP}=$ purchasing power parity.

a Data is for 2005.

b Data is for 2002 .

c Data is for 2015 .

d Data is for 2001.

e Data is for 2006 .

Sources: $\quad$ United Nations Statistics Division. Sustainable Development Goals (SDGs), SDG Indicators, Global Database. http://unstats.un.org/sdgs/indicators/database/ (accessed 8 July 2019). For Taipei,China: World Bank. Sustainable Energy for All Database. http://databank.worldbank.org/data/source/sustainable-energy-for-all\# (accessed 19 July 2019). 
Goal 8. Promote sustained, inclusive, and sustainable economic growth; full and productive employment; and decent work for all

Table 1.8.1: Selected Indicators for Sustainable Development Goal 8-Decent Work and Economic Growth

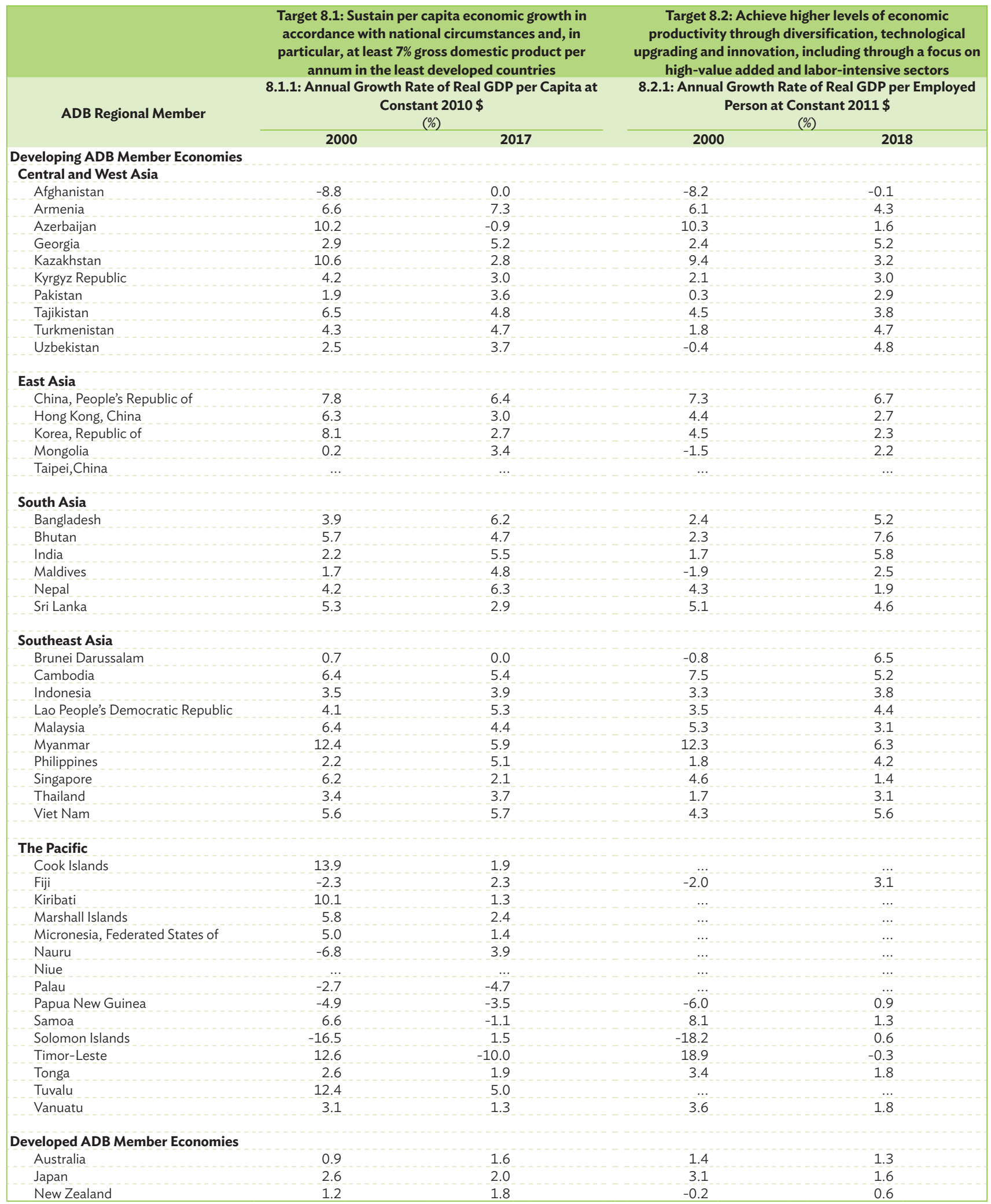

$\ldots=$ data not available, 0.0 or $-0.0=$ magnitude is less than half of unit employed, $\$=$ United States dollars, $A D B=$ Asian Development Bank, GDP = gross domestic product Source: $\quad$ United Nations Statistics Division. Sustainable Development Goals (SDGs), SDG Indicators, Global Database. http://unstats.un.org/sdgs/indicators/database/ (accessed 8 July 2019). 
Goal 8. Promote sustained, inclusive, and sustainable economic growth; full and productive employment; and decent work for all

Table 1.8.2: Selected Indicators for Sustainable Development Goal 8-Unemployment

\begin{tabular}{|c|c|c|c|c|c|c|c|c|c|c|c|c|}
\hline \multirow{4}{*}{ ADB Regional Member } & \multicolumn{12}{|c|}{$\begin{array}{c}\text { Target 8.5: By 2030, achieve full and productive employment and decent work for all women and men, including for } \\
\text { young people and persons with disabilities, and equal pay for work of equal value }\end{array}$} \\
\hline & \multicolumn{12}{|c|}{$\begin{array}{l}\text { 8.5.2a: Unemployment Rate for Age Group } 15+\text {, by Sex } \\
(\%)\end{array}$} \\
\hline & \multirow{2}{*}{\multicolumn{4}{|c|}{2000}} & \multirow{2}{*}{\multicolumn{2}{|c|}{ Male }} & \multicolumn{6}{|c|}{2017} \\
\hline & & & & & & & \multicolumn{2}{|c|}{ Total } & \multicolumn{2}{|c|}{ Female } & \multicolumn{2}{|c|}{ Male } \\
\hline \multicolumn{13}{|l|}{ Developing ADB Member Economies } \\
\hline \multicolumn{13}{|l|}{$\begin{array}{l}\text { Central and West Asia } \\
\text { Afghanistan }\end{array}$} \\
\hline Armenia & 9.8 & $(2007)$ & 9.8 & $(2007)$ & 9.9 & $(2007)$ & 17.7 & & 17.5 & & 17.9 & \\
\hline Azerbaijan & 11.8 & & 12.7 & & 10.9 & & 5.0 & & 5.9 & & 4.1 & \\
\hline Georgia & 10.8 & & 10.5 & & 11.1 & & 13.9 & & 12.7 & & 15.0 & \\
\hline Kazakhstan & 12.8 & & 12.1 & (2001) & 8.9 & (2001) & 4.9 & & 5.9 & (2013) & 4.6 & (2013) \\
\hline Kyrgyz Republic & 7.5 & & 14.3 & (2002) & 11.2 & (2002) & 6.9 & & 8.9 & & 5.6 & \\
\hline Pakistan & 0.6 & $(2006)$ & 0.3 & $(2006)$ & 0.6 & $(2006)$ & 3.6 & $(2015)$ & 6.1 & $(2015)$ & 2.8 & $(2015)$ \\
\hline Tajikistan & & & & & $=1$ & & 11.5 & (2009) & 10.5 & (2009) & 12.3 & (2009) \\
\hline Turkmenistan & & & & & & & 4.0 & (2010) & 2.3 & (2010) & 5.3 & (2010) \\
\hline Uzbekistan & 5.0 & $(2007)$ & & & & & 5.2 & $(2016)$ & $\ldots$ & & - & \\
\hline East Asia & & & & & & & & & & & & \\
\hline $\begin{array}{l}\text { China, People's Republic of } \\
\text { Hong Kong, China }\end{array}$ & $\ldots$ & & & & & & & & $\ldots$ & & & \\
\hline Korea, Republic of & 4.4 & & 3.6 & & 5.0 & & 3.7 & & 3.6 & & 3.8 & \\
\hline Mongolia & 6.8 & (2003) & 6.4 & (2003) & 7.1 & (2003) & 6.4 & & 5.7 & & 7.0 & \\
\hline Taipei,China & $\ldots$ & & $\ldots$ & & $\ldots$ & & $\ldots$ & & $\ldots$ & & $\ldots$ & \\
\hline South Asia & & & & & & & & & & & & \\
\hline Bangladesh & 3.3 & & 3.3 & & 3.2 & & 4.4 & & 6.7 & & 3.3 & \\
\hline Bhutan & 1.9 & (2001) & 3.2 & (2001) & 1.3 & (2001) & 2.5 & (2015) & 3.2 & (2015) & 1.8 & (2015) \\
\hline India & 2.7 & & 2.4 & & 2.9 & & 2.7 & (2012) & 3.7 & (2012) & 2.4 & (2012) \\
\hline Maldives & 2.0 & & 2.7 & & 1.6 & & 6.1 & $(2016)$ & 5.6 & $(2016)$ & 6.4 & (2016) \\
\hline Nepal & 1.3 & (2008) & 1.1 & (2008) & 1.6 & (2008) & & & & & & \\
\hline Sri Lanka & 7.7 & & 11.4 & & 5.9 & & 4.2 & & 7.0 & $(2016)$ & 2.9 & $(2016)$ \\
\hline Southeast Asia & & & & & & & & & & & & \\
\hline Brunei Darussalam & & & & & & & 7.0 & (2014) & 7.9 & (2014) & 6.3 & (2014) \\
\hline Cambodia & 2.5 & & 2.8 & & 2.1 & & 0.2 & (2014) & 0.2 & (2014) & 0.2 & (2014) \\
\hline Indonesia & $\ldots$ & & $\ldots$ & & $\ldots$ & & 4.2 & & 3.9 & & 4.4 & \\
\hline Lao People's Democratic Republic & & & & & -1 & & 9.4 & & 7.8 & & 10.8 & \\
\hline Malaysia & 3.0 & & 3.1 & & 3.0 & & 3.4 & & 3.9 & (2016) & 3.1 & (2016) \\
\hline Myanmar & & & & & & & 1.6 & & 2.0 & & 1.2 & \\
\hline Philippines & 3.7 & (2001) & 4.0 & (2001) & 3.5 & (2001) & 2.6 & & 2.7 & & 2.5 & \\
\hline Singapore & 3.7 & & 3.5 & & 3.9 & & 4.1 & (2016) & 4.5 & (2016) & 3.8 & (2016) \\
\hline Thailand & 2.4 & & 2.3 & & 2.4 & & 0.7 & (2016) & 0.7 & (2016) & 0.7 & (2016) \\
\hline Viet Nam & 2.3 & & 2.1 & & 2.4 & & 1.9 & & 1.7 & & 2.1 & \\
\hline The Pacific & & & & & & & & & & & & \\
\hline Cook Islands & & & & & & & & & & & & \\
\hline Fiji & 4.7 & $(2004)$ & 6.0 & (2004) & 4.1 & $(2004)$ & 4.3 & (2016) & 5.5 & (2016) & 3.7 & (2016) \\
\hline Kiribati & 14.7 & (2005) & 18.2 & (2005) & 12.3 & (2005) & 30.6 & (2010) & 34.1 & (2010) & 27.6 & (2010) \\
\hline Marshall Islands & 25.4 & $(2005)$ & & & $\ldots$ & & $\ldots$ & (et) & $\ldots$ & & $\ldots$ & \\
\hline Micronesia, Federated States of & $\ldots$ & & & & & & & & & & & \\
\hline Nauru & & & & & & & 23.0 & $(2011)$ & 25.5 & $(2011)$ & 21.4 & $(2011)$ \\
\hline Niue & & & & & & & $\ldots$ & & $\ldots$ & & $\ldots$ & \\
\hline Palau & 3.3 & & 3.5 & & 3.1 & & & & & & & \\
\hline Papua New Guinea & 2.9 & & & & & & & & & & & \\
\hline Samoa & 5.0 & $(2001)$ & 6.2 & $(2001)$ & 4.4 & $(2001)$ & 14.5 & & 21.3 & & 10.6 & \\
\hline Solomon Islands & $\ldots$ & & $\ldots$ & & $\ldots$ & & 2.0 & $(2009)$ & 1.8 & (2009) & 2.3 & (2009) \\
\hline Timor-Leste & & & & & & & 11.0 & $(2013)$ & 10.6 & $(2013)$ & 11.2 & $(2013)$ \\
\hline Tonga & 5.2 & $(2003)$ & 7.4 & (2003) & 3.8 & (2003) & $\ldots$ & & $\ldots$ & & $\ldots$ & \\
\hline Tuvalu & 6.5 & $(2002)$ & 8.6 & $(2002)$ & 5.0 & $(2002)$ & & & & & & \\
\hline Vanuatu & $\ldots$ & & $\ldots$ & & $\ldots$ & & & & $\cdots$ & & $\cdots$ & \\
\hline Developed ADB Member Economies & & & & & & & & & & & & \\
\hline Australia & 6.3 & & 6.1 & & 6.5 & & 5.6 & & 5.7 & & 5.5 & \\
\hline Japan & 4.7 & & 4.5 & & 4.9 & & 2.8 & & 2.7 & & 3.0 & \\
\hline New Zealand & 6.1 & & 6.0 & & 6.3 & & 4.7 & & 5.2 & & 4.3 & \\
\hline
\end{tabular}


Goal 8. Promote sustained, inclusive, and sustainable economic growth; full and productive employment; and decent work for all

Table 1.8.2: Selected Indicators for Sustainable Development Goal 8-Unemployment (continued)

\begin{tabular}{|c|c|c|c|c|c|c|c|c|c|c|c|c|}
\hline \multirow{5}{*}{ ADB Regional Member } & \multicolumn{12}{|c|}{$\begin{array}{c}\text { Target 8.5: By 2030, achieve full and productive employment and decent work for all women and men, including for } \\
\text { young people and persons with disabilities, and equal pay for work of equal value }\end{array}$} \\
\hline & \multicolumn{12}{|c|}{$\begin{array}{l}\text { 8.5.2b: Unemployment Rate for Age Group 15-24, by Sex } \\
(\%)\end{array}$} \\
\hline & \multicolumn{4}{|c|}{2000} & \multirow{2}{*}{\multicolumn{2}{|c|}{ Male }} & \multicolumn{4}{|c|}{2017} & \multirow{2}{*}{\multicolumn{2}{|c|}{ Male }} \\
\hline & \multicolumn{2}{|c|}{ Total } & \multicolumn{2}{|c|}{ Female } & & & \multicolumn{2}{|c|}{ Total } & \multicolumn{2}{|c|}{ Female } & & \\
\hline & & & & & & & & & & & & \\
\hline Central and West Asia & & & & & & & & & & & & \\
\hline Afghanistan & & & & & & & & & & & & \\
\hline Armenia & 11.7 & $(2007)$ & 10.1 & $(2007)$ & 12.6 & $(2007)$ & 38.2 & & 44.8 & & 32.8 & \\
\hline Azerbaijan & 14.0 & (2007) & 10.5 & (2007) & 18.2 & (2007) & 13.4 & (2015) & 15.8 & (2015) & 11.4 & (2015) \\
\hline Georgia & 21.1 & & 20.5 & & 21.6 & & 28.9 & & 32.8 & & 26.3 & \\
\hline Kazakhstan & 17.3 & $(2002)$ & 19.3 & $(2002)$ & 15.7 & $(2002)$ & 3.9 & $(2013)$ & 4.3 & (2013) & 3.6 & (2013) \\
\hline Kyrgyz Republic & 20.1 & (2002) & 21.2 & (2002) & 19.3 & (2002) & 14.8 & & 21.0 & & 11.7 & \\
\hline Pakistan & 0.9 & (2006) & 0.6 & (2006) & 1.0 & (2006) & 6.6 & (2015) & 9.4 & (2015) & 5.7 & (2015) \\
\hline Tajikistan & & & & & & & - & & $\ldots$ & & & \\
\hline Turkmenistan & & & & & & & & & & & & \\
\hline Uzbekistan & & & & & & & & & & & & \\
\hline East Asia & & & & & & & & & & & & \\
\hline China, People's Republic of & $\ldots$ & & $\ldots$ & & & & & & & & & \\
\hline Hong Kong, China & & & & & & & & & & & & \\
\hline Korea, Republic of & 10.8 & & 9.0 & & 13.6 & & 10.4 & & 9.7 & & 11.3 & \\
\hline Mongolia & 9.8 & (2008) & 8.8 & (2008) & 10.6 & (2008) & 17.9 & & 22.6 & & 15.0 & \\
\hline Taipei,China & $\ldots$ & & $\ldots$ & & $\ldots$ & & $\ldots$ & & $\ldots$ & & $\ldots$ & \\
\hline South Asia & & & & & & & & & & & & \\
\hline Bangladesh & 10.7 & & 10.3 & & 11.1 & & 12.8 & & 16.8 & & 10.8 & \\
\hline Bhutan & & & & & & & 10.7 & (2015) & 12.7 & (2015) & 8.2 & (2015) \\
\hline India & 8.1 & & 7.0 & & 8.4 & & 10.1 & (2012) & 12.0 & (2012) & 9.5 & (2012) \\
\hline Maldives & 4.4 & & 5.1 & & 4.0 & & 15.9 & (2016) & 12.1 & (2016) & 19.1 & (2016) \\
\hline Nepal & 2.2 & $(2008)$ & 1.6 & $(2008)$ & 2.9 & $(2008)$ & & & & & & \\
\hline Sri Lanka & 23.7 & & 30.8 & & 19.9 & & 21.6 & $(2016)$ & 29.2 & $(2016)$ & 17.1 & (2016) \\
\hline Southeast Asia & & & & & & & & & & & & \\
\hline Brunei Darussalam & & & & & & & 25.4 & (2014) & 28.1 & (2014) & 23.5 & (2014) \\
\hline Cambodia & & & & & & & 1.6 & (2012) & 1.4 & (2012) & 1.8 & (2012) \\
\hline Indonesia & & & & & & & 15.6 & & 15.6 & & 15.6 & \\
\hline Lao People's Democratic Republic & & & & & & & 18.2 & & 15.5 & & 20.8 & \\
\hline Malaysia & 10.9 & (2007) & 11.5 & $(2007)$ & 10.5 & $(2007)$ & 10.5 & (2016) & 11.4 & $(2016)$ & 9.8 & $(2016)$ \\
\hline Myanmar & & & & & & & 4.0 & & 4.8 & & 3.3 & \\
\hline Philippines & 9.7 & (2001) & 12.8 & (2001) & 7.9 & (2001) & 7.5 & & 8.9 & & 6.6 & \\
\hline Singapore & 7.7 & (2001) & 10.7 & (2001) & 5.1 & (2001) & 9.1 & (2016) & 12.5 & (2016) & 6.2 & (2016) \\
\hline Thailand & 6.6 & & 6.0 & & 7.0 & & 3.7 & (2016) & 4.7 & (2016) & 3.0 & (2016) \\
\hline Viet Nam & 4.6 & $(2004)$ & 4.9 & $(2004)$ & 4.4 & $(2004)$ & 7.3 & & 7.3 & & 7.3 & \\
\hline The Pacific & & & & & & & & & & & & \\
\hline Cook Islands & & & & & & & & & & & & \\
\hline Fiji & 9.8 & (2005) & 16.0 & (2005) & 7.1 & (2005) & 15.4 & (2016) & 22.4 & (2016) & 11.9 & (2016) \\
\hline Kiribati & 39.3 & $(2005)$ & 41.6 & $(2005)$ & 37.2 & (2005) & 54.0 & (2010) & 61.8 & $(2010)$ & 47.6 & (2010) \\
\hline Marshall Islands & $\ldots$ & & $\ldots$ & & $\ldots$ & & $\ldots$ & & $\ldots$ & & $\ldots$ & \\
\hline Micronesia, Federated States of & $\ldots$ & & & & & & & & & & & \\
\hline Nauru & 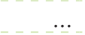 & & & & & & & & & & & \\
\hline Niue & & & & & & & & & & & & \\
\hline Palau & 9.6 & & 10.6 & & 8.8 & & & & & & & \\
\hline Papua New Guinea & 5.3 & & & & & & & & & & & \\
\hline Samoa & 12.2 & (2001) & 15.5 & (2001) & 10.6 & (2001) & 31.9 & & 43.4 & & 24.6 & \\
\hline Solomon Islands & & & & & & & & & & & & \\
\hline Timor-Leste & $\cdots$ & & & & & & 21.8 & $(2013)$ & 16.7 & $(2013)$ & 25.1 & $(2013)$ \\
\hline Tonga & $\ldots$ & & & & & & $\ldots$ & & $\ldots$ & & $\ldots$ & \\
\hline Tuvalu & & & & & & & & & & & & \\
\hline Vanuatu & $\cdots$ & & $\ldots$ & & & & $\ldots$ & & $\ldots$ & & & \\
\hline Developed ADB Member Economies & & & & & & & & & & & & \\
\hline Australia & 12.1 & & 11.2 & & 12.9 & & 12.6 & & 11.5 & & 13.7 & \\
\hline Japan & 9.1 & & 7.9 & & 10.2 & & 4.6 & & 4.5 & & 4.7 & \\
\hline New Zealand & 13.5 & & 12.4 & & 14.5 & & 12.7 & & 13.0 & & 12.4 & \\
\hline
\end{tabular}


Goal 8. Promote sustained, inclusive, and sustainable economic growth; full and productive employment; and decent work for all

Table 1.8.2: Selected Indicators for Sustainable Development Goal 8-Unemployment (continued)

\begin{tabular}{|c|c|c|c|c|c|c|c|c|c|c|c|c|}
\hline \multirow{5}{*}{ ADB Regional Member } & \multicolumn{12}{|c|}{$\begin{array}{l}\text { Target 8.5: By 2030, achieve full and productive employment and decent work for all women and men, including for } \\
\text { young people and persons with disabilities, and equal pay for work of equal value }\end{array}$} \\
\hline & \multicolumn{12}{|c|}{$\begin{array}{l}\text { 8.5.2c: Unemployment Rate for Age Group 25+, by Sex } \\
(\%)\end{array}$} \\
\hline & \multirow{2}{*}{\multicolumn{4}{|c|}{$\begin{array}{r}2000 \\
\text { Female }\end{array}$}} & \multirow{2}{*}{\multicolumn{2}{|c|}{ Male }} & \multicolumn{4}{|c|}{2017} & \multirow{2}{*}{\multicolumn{2}{|c|}{ Male }} \\
\hline & & & & & & & \multicolumn{2}{|c|}{ Total } & \multicolumn{2}{|c|}{ Female } & & \\
\hline & \multicolumn{12}{|c|}{ Developing ADB Member Economies } \\
\hline $\begin{array}{l}\text { Central and West Asia } \\
\text { Afghanistan }\end{array}$ & & & & & & & & & & & & \\
\hline Armenia & 9.6 & $(2007)$ & 9.7 & $(2007)$ & 9.5 & (2007) & 15.5 & & 14.7 & & 16.2 & \\
\hline Azerbaijan & 5.2 & (2007) & 4.3 & (2007) & 6.1 & (2007) & 3.8 & (2015) & 4.6 & (2015) & 3.0 & (2015) \\
\hline Georgia & 9.7 & & 9.5 & & 9.8 & & 12.4 & & 11.0 & & 13.7 & \\
\hline Kazakhstan & 7.9 & $(2002)$ & 9.9 & (2002) & 6.0 & (2002) & 5.4 & (2013) & 6.1 & (2013) & 4.7 & (2013) \\
\hline Kyrgyz Republic & 10.4 & (2002) & 12.4 & (2002) & 8.8 & (2002) & 5.3 & & 6.9 & & 4.2 & \\
\hline Pakistan & 0.4 & (2006) & 0.2 & (2006) & 0.5 & (2006) & 2.5 & (2015) & 4.8 & (2015) & 1.8 & (2015) \\
\hline Tajikistan & & & & & $\ldots$ & & & & $\ldots$ & & $\ldots$ & \\
\hline Turkmenistan & & & & & & & & & & & & \\
\hline Uzbekistan & & & & & & & & & & & & \\
\hline East Asia & & & & & & & & & & & & \\
\hline $\begin{array}{l}\text { China, People's Republic of } \\
\text { Hong Kong, China }\end{array}$ & $\ldots$ & & & &.- & & & & & & $\ldots$ & \\
\hline Korea, Republic of & 3.7 & & 2.7 & & 4.3 & & 3.3 & & 3.0 & & 3.5 & \\
\hline Mongolia & 4.7 & $(2008)$ & 4.6 & (2008) & 4.9 & (2008) & 5.2 & & 4.3 & & 6.1 & \\
\hline Taipei,China & . & & & & & & & & & & $\ldots$ & \\
\hline South Asia & & & & & & & & & & & & \\
\hline Bangladesh & 0.9 & & 0.7 & & 1.0 & & 2.6 & & 4.4 & & 1.8 & \\
\hline Bhutan & & & & & & & 1.3 & (2015) & 1.6 & (2015) & 1.1 & (2015) \\
\hline India & 1.2 & & 1.1 & & 1.3 & & 1.2 & (2012) & 2.1 & (2012) & 0.9 & (2012) \\
\hline Maldives & 1.1 & & 1.8 & & 0.8 & & 3.6 & (2016) & 3.7 & (2016) & 3.6 & (2016) \\
\hline Nepal & 1.0 & (2008) & 0.9 & (2008) & 1.1 & $(2008)$ & & & & & & \\
\hline Sri Lanka & 3.5 & & 6.2 & & 2.2 & & 2.2 & $(2016)$ & 4.1 & $(2016)$ & 1.1 & $(2016)$ \\
\hline Southeast Asia & & & & & & & & & & & & \\
\hline Brunei Darussalam & $\ldots$ & & & & $\ldots$ & & 4.1 & (2014) & 4.9 & (2014) & 3.5 & (2014) \\
\hline Cambodia & $\ldots$ & & & & . & & 1.2 & (2012) & 1.0 & (2012) & 1.3 & (2012) \\
\hline Indonesia & - & & & & & & 2.0 & & 1.7 & & 2.2 & \\
\hline Lao People's Democratic Republic & $\ldots$ & & & & $\ldots$ & & 7.4 & & 5.9 & & 8.6 & \\
\hline Malaysia & 1.4 & (2007) & 1.3 & (2007) & 1.5 & (2007) & 1.9 & (2016) & 2.3 & (2016) & 1.7 & (2016) \\
\hline Myanmar & & & & & & & 1.0 & & 1.3 & & 0.7 & \\
\hline Philippines & 2.0 & (2001) & 1.7 & (2001) & 2.2 & (2001) & 1.5 & & 1.5 & & 1.5 & \\
\hline Singapore & 3.3 & (2001) & 3.0 & (2001) & 3.5 & (2001) & 3.6 & (2016) & 3.7 & (2016) & 3.6 & (2016) \\
\hline Thailand & 1.5 & & 1.5 & & 1.4 & & 0.3 & (2016) & 0.3 & (2016) & 0.4 & (2016) \\
\hline Viet Nam & 1.5 & $(2004)$ & 1.8 & $(2004)$ & 1.1 & $(2004)$ & 1.0 & & 0.9 & & 1.2 & \\
\hline The Pacific & & & & & & & & & & & & \\
\hline Cook Islands & & & & & & & & & & & & \\
\hline Fiji & 2.6 & $(2005)$ & 2.7 & $(2005)$ & 2.5 & (2005) & 2.2 & (2016) & 2.4 & (2016) & 2.2 & $(2016)$ \\
\hline Kiribati & 7.9 & (2005) & 10.1 & (2005) & 6.5 & (2005) & 20.9 & (2010) & 22.8 & (2010) & 19.2 & (2010) \\
\hline Marshall Islands & $\ldots$ & & 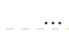 & & $\ldots$ & & $\ldots$ & & $\ldots$ & & $\ldots$ & \\
\hline Micronesia, Federated States of & $\ldots$ & & & & $\ldots$ & & $\ldots$ & & & & $\ldots$ & \\
\hline Nauru & $\ldots$ & & & & & & & & & & .. & \\
\hline Nive & & & & & & & & & & & $\ldots$ & \\
\hline Palau & 2.6 & & 2.8 & & 2.5 & & & & & & & \\
\hline Papua New Guinea & 2.1 & & & & & & & & & & & \\
\hline Samoa & 2.7 & $(2001)$ & 3.0 & $(2001)$ & 2.6 & $(2001)$ & 10.0 & & 15.1 & & 7.3 & \\
\hline Solomon Islands & $\ldots$ & & $\ldots$ & & & & & & & & & \\
\hline Timor-Leste & $\ldots$ & & & & & & 9.3 & (2013) & 9.5 & (2013) & 9.3 & (2013) \\
\hline Tonga & $\ldots$ & & & & & & $\ldots$ & & $\ldots$ & & $\ldots$ & \\
\hline Tuvalu & & & & & & & & & & & & \\
\hline Vanuatu & & & & & & & & & & & -1 & \\
\hline Developed ADB Member Economies & & & & & & & & & & & & \\
\hline Australia & 4.9 & & 4.7 & & 5.1 & & 4.2 & & 4.5 & & 4.0 & \\
\hline Japan & 4.2 & & 3.9 & & 4.3 & & 2.7 & & 2.5 & & 2.8 & \\
\hline New Zealand & 4.6 & & 4.6 & & 4.6 & & 3.2 & & 3.8 & & 2.7 & \\
\hline
\end{tabular}

... = data not available, $\mathrm{ADB}=$ Asian Development Bank.

Source: $\quad$ United Nations Statistics Division. Sustainable Development Goals (SDGs), SDG Indicators, Global Database. https://unstats.un.org/sdgs/indicators/database/ (accessed 8 July 2019). 
Goal 8. Promote sustained, inclusive, and sustainable economic growth; full and productive employment; and decent work for all

Table 1.8.3: Selected Indicators for Sustainable Development Goal 8-Youth Participation in Education and Work, Child Labor

\begin{tabular}{|c|c|c|c|c|c|c|c|c|}
\hline \multirow{3}{*}{ ADB Regional Member } & \multicolumn{3}{|c|}{$\begin{array}{l}\text { Target 8.6: By 2020, substantially reduce } \\
\text { the proportion of youth not in employment, } \\
\text { education, or training }\end{array}$} & \multicolumn{5}{|c|}{$\begin{array}{l}\text { Target 8.7: Take immediate and effective measures to } \\
\text { eradicate forced labor, end modern slavery and human } \\
\text { trafficking, and secure the prohibition and elimination of the } \\
\text { worst forms of child labor, including recruitment and use of } \\
\text { child soldiers; and, by 2025, end child labor in all its forms }\end{array}$} \\
\hline & \multicolumn{3}{|c|}{$\begin{array}{l}\text { 8.6.1: Proportion of Youth (Aged 15-24 Years) } \\
\text { not in Education, Employment, or Training } \\
(\%)\end{array}$} & \multicolumn{5}{|c|}{$\begin{array}{l}\text { 8.7.1: Proportion of Children (Aged 5-17 Years) } \\
\text { Engaged in Child Labor, } 2015 \\
(\%)\end{array}$} \\
\hline & 2000 & \multicolumn{2}{|c|}{2017} & \multicolumn{2}{|c|}{ Total } & Female & \multicolumn{2}{|c|}{ Male } \\
\hline \multicolumn{9}{|l|}{ Developing ADB Member Economies } \\
\hline \multicolumn{9}{|l|}{ Central and West Asia } \\
\hline Afghanistan & & & & 16.6 & (2013) & 12.6 & 20.3 & (2013) \\
\hline Armenia & & 36.6 & & 3.9 & & 2.7 & 4.9 & \\
\hline \multicolumn{9}{|l|}{ Azerbaijan } \\
\hline Georgia & & & & 1.5 & & 0.9 & 2.1 & \\
\hline Kazakhstan & 18.6 (2001) & 9.5 & (2016) & & & & & \\
\hline Kyrgyz Republic & & 21.0 & & 15.3 & (2014) & 13.8 (2014) & 17.3 & (2014) \\
\hline Pakistan & 36.2 (2006) & 30.4 & (2015) & & & & 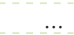 & \\
\hline Tajikistan & & 42.2 & (2009) & & & & & \\
\hline Turkmenistan & .. & $\ldots$ & & 0.3 & & 0.1 & 0.4 & \\
\hline Uzbekistan & & & & $-=$ & & $\cdots$ & $\cdots$ & \\
\hline \multicolumn{9}{|l|}{ East Asia } \\
\hline \multicolumn{9}{|l|}{$\begin{array}{l}\text { China, People's Republic of } \\
\text { Hong Kong, China }\end{array}$} \\
\hline \multicolumn{9}{|l|}{ Korea, Republic of } \\
\hline Mongolia & 18.5 (2006) & 19.8 & & 9.4 & (2013) & 7.2 (2013) & 11.5 & (2013) \\
\hline Taipei,China & & & & $\cdots$ & & $\cdots$ & $\ldots$ & \\
\hline South Asia & & & & & & & & \\
\hline Bangladesh & $31.0 \quad(2005)$ & 27.4 & & 5.9 & (2013) & 5.2 (2013) & 6.4 & (2013) \\
\hline Bhutan & & & & 1.7 & (2010) & 1.7 (2010) & 1.6 & (2010) \\
\hline India & 32.2 & 27.5 & (2012) & 4.3 & (2012) & 3.1 (2012) & 5.3 & (2012) \\
\hline Maldives & & 23.5 & (2016) & & & & & \\
\hline Nepal & 23.4 (2008) & & & 19.0 & (2014) & 19.3 & 19.2 & (2014) \\
\hline Sri Lanka & $\ldots$ & 27.7 & $(2014)$ & $\ldots$ & & $\ldots$ & $\ldots$ & \\
\hline Southeast Asia & & & & & & & & \\
\hline Brunei Darussalam & & 17.2 & (2014) & & & & & \\
\hline Cambodia & & 12.7 & (2012) & 11.5 & (2012) & 12.2 & 10.8 & (2012) \\
\hline Indonesia & 29.4 & 21.5 & & & & & & \\
\hline Lao People's Democratic Republic & & 42.1 & & 11.4 & $(2010)$ & $12.9(2010)$ & 9.9 & (2010) \\
\hline Malaysia & $\ldots$ & 11.7 & $(2016)$ & & & $\ldots$ & $\ldots$ & \\
\hline Myanmar & & 17.4 & & & & & & \\
\hline Philippines & $24.7 \quad(2006)$ & 21.7 & & 4.3 & (2011) & 3.5 (2011) & 5.1 & (2011) \\
\hline Singapore & & 4.3 & & $\ldots$ & & ... & $\ldots$ & \\
\hline Thailand & & 15.0 & (2016) & & & & & \\
\hline Viet Nam & 10.6 (2007) & 9.7 & $(2014)$ & 12.1 & $(2014)$ & $12.5(2014)$ & 11.9 & (2014) \\
\hline $\begin{array}{l}\text { The Pacific } \\
\text { Cook Islands }\end{array}$ & & & & & & & & \\
\hline $\begin{array}{l}\text { Cook Islands } \\
\text { Fiji }\end{array}$ & $20.6(2005)$ & 20.1 & (2016) & $\begin{array}{l}\cdots \\
\cdots\end{array}$ & & $\begin{array}{l}\cdots \\
\ldots\end{array}$ & $\begin{array}{l}\cdots \\
\ldots\end{array}$ & \\
\hline Kiribati & ... & $\ldots$ & $-1=0+0$ & & & $\ldots$ & $\ldots$ & \\
\hline Marshall Islands & $\ldots$ & & & & & & & \\
\hline Micronesia, Federated States of & $\ldots$ & $\ldots$ & & & & $\ldots$ & $\ldots$ & \\
\hline Nauru & $\ldots$ & $\ldots$ & & $\ldots$ & & $\ldots$ & $\ldots$ & \\
\hline Nive & & & & & & & & \\
\hline Palau & 27.2 & & & $\ldots$ & & $\ldots$ & $\ldots$ & \\
\hline Papua New Guinea & $\ldots$ & 27.7 & (2010) & $\ldots$ & & $\ldots$ & $\ldots$ & \\
\hline Samoa & & 37.9 & & & & & & \\
\hline Solomon Islands & 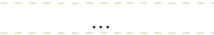 & & & 13.8 & & 13.8 & 13.8 & \\
\hline Timor-Leste & & 24.3 & (2013) & $\ldots$ & & $\ldots$ & $\ldots$ & \\
\hline Tonga & & & & & & & & \\
\hline Tuvalu & 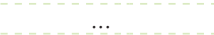 & & & & & & & \\
\hline Vanuatu & $\ldots$ & & & 15.0 & $(2013)$ & $15.8 \quad(2013)$ & 14.2 & (2013) \\
\hline Developed ADB Member Economies & & & & & & & & \\
\hline Australia & & 9.8 & (2015) & & & & & \\
\hline Japan & & 3.3 & & & & & & \\
\hline New Zealand & 10.8 (2004) & 11.8 & & & & & & \\
\hline
\end{tabular}

$\ldots=$ data not available, $A D B=$ Asian Development Bank.

Source: United Nations Statistics Division. Sustainable Development Goals (SDGs), SDG Indicators, Global Database. https://unstats.un.org/sdgs/indicators/database/ (accessed 8 July 2019). 
Goal 8. Promote sustained, inclusive, and sustainable economic growth; full and productive employment; and decent work for all

Table 1.8.4: Selected Indicators for Sustainable Development Goal 8-Access to Banking, Insurance, and Financial Services; and Trade

\begin{tabular}{|c|c|c|c|c|c|c|}
\hline \multirow{4}{*}{ ADB Regional Member } & \multicolumn{6}{|c|}{$\begin{array}{l}\text { Target 8.10: Strengthen the capacity of domestic financial institutions to encourage and expand access to banking, } \\
\text { insurance, and financial services for all }\end{array}$} \\
\hline & \multicolumn{4}{|c|}{$\begin{array}{l}\text { 8.10.1: Number of Commercial Bank Branches } \\
\text { and ATMs per 100,000 Adults }\end{array}$} & \multirow{2}{*}{\multicolumn{2}{|c|}{$\begin{array}{l}\text { 8.10.2: Proportion of Adults } \\
\text { (15 Years and Older) with } \\
\text { an Account at a Bank or } \\
\text { Other Financial Institution } \\
\text { or with a Mobile- } \\
\text { Money Service Provider } \\
(\%)\end{array}$}} \\
\hline & \multicolumn{2}{|c|}{ Commercial Bank Branches } & \multicolumn{2}{|c|}{ ATMs } & & \\
\hline & 2004 & 2017 & 2004 & 2017 & 2011 & 2017 \\
\hline \multicolumn{7}{|l|}{ Developing ADB Member Economies } \\
\hline \multicolumn{7}{|l|}{ Central and West Asia } \\
\hline Afghanistan & 0.4 & 2.1 & 0.0 & 1.3 & 9.0 & 14.9 \\
\hline Armenia & 10.8 & 23.1 & 3.0 & 63.7 & 17.5 & 47.8 \\
\hline Azerbaijan & 6.5 & $10.7 \quad(2015)$ & 17.1 (2006) & 32.1 & 14.9 & 28.6 \\
\hline Georgia & 9.5 & 33.2 & 2.0 & 75.9 & 33.0 & 61.2 \\
\hline Kazakhstan & 3.7 & 2.8 & 10.0 & 74.6 & 42.1 & 58.7 \\
\hline Kyrgyz Republic & 5.1 & 8.1 & 0.6 & 33.4 & 3.8 & 39.9 \\
\hline Pakistan & 7.7 & 10.6 & 0.8 & 10.4 & 10.3 & 21.3 \\
\hline Tajikistan & 4.9 & 6.5 (2013) & $0.6(2005)$ & 10.3 (2013) & 2.5 & 47.0 \\
\hline Turkmenistan & & & & & 0.4 & 40.6 \\
\hline Uzbekistan & 39.2 & 38.2 & 0.9 & 24.1 & 22.5 & 37.1 \\
\hline \multicolumn{7}{|l|}{ East Asia } \\
\hline China, People's Republic of & & 8.8 & $9.6(2006)$ & 84.2 & 63.8 & 80.2 \\
\hline Hong Kong, China & 23.6 & 21.1 & & $50.7 \quad(2016)$ & 88.7 & 95.3 \\
\hline Korea, Republic of & 16.8 & 15.5 & 208.2 & $271.9(2016)$ & 93.1 & 94.9 \\
\hline Mongolia & 40.0 & $70.4 \quad(2016)$ & 9.9 (2008) & $88.6(2016)$ & 77.7 & 93.0 \\
\hline \multicolumn{7}{|l|}{ Taipei, China } \\
\hline \multicolumn{7}{|l|}{ South Asia } \\
\hline Bangladesh & 6.9 & 8.6 & 0.1 & 8.1 & 31.7 & 50.1 \\
\hline Bhutan & 14.4 & 17.0 & 0.5 & 36.6 & & 33.7 \\
\hline India & 9.0 & 14.7 & $2.3(2005)$ & 22.1 & 35.2 & 79.9 \\
\hline Maldives & 10.1 & 15.6 & 7.2 & 35.0 & & \\
\hline Nepal & 2.6 & 11.4 & $\ldots$ & 10.3 & 25.3 & 45.4 \\
\hline Sri Lanka & 8.8 & $18.6 \quad(2015)$ & 9.4 (2007) & $17.2(2015)$ & 68.5 & 73.7 \\
\hline \multicolumn{7}{|l|}{ Southeast Asia } \\
\hline Brunei Darussalam & 21.0 & 18.2 & 34.9 & 68.5 & & \\
\hline Cambodia & $2.3(2006)$ & 7.5 & $0.0 \quad(2005)$ & 16.7 & 3.7 & 21.7 \\
\hline Indonesia & 5.2 & 16.9 & 8.6 & 55.6 & 19.6 & 48.9 \\
\hline Lao People's Democratic Republic & & 3.1 & $2.6(2008)$ & 26.1 & 26.8 & 29.1 \\
\hline Malaysia & 14.1 & 10.1 & 27.1 & 46.8 & 66.2 & 85.3 \\
\hline Myanmar & 1.8 & 4.7 & & 4.4 & $\ldots$ & 26.0 \\
\hline Philippines & 8.2 & 9.1 & 10.3 & 28.3 & 26.6 & 34.5 \\
\hline Singapore & 11.7 & 8.5 & 47.9 & 65.2 & 98.2 & 97.9 \\
\hline Thailand & 7.8 & 11.9 & 19.9 & 117.3 & 72.7 & 81.6 \\
\hline Viet Nam & $3.3(2008)$ & 3.4 & 1.4 & 24.3 & 21.4 & 30.8 \\
\hline The Pacific & & & & & & \\
\hline Cook Islands & & & & & & \\
\hline Fiji & 9.3 & 11.6 & 19.0 & 50.2 & $\cdots$ & \\
\hline Kiribati & & 5.7 (2013) & & 14.3 (2013) & $\cdots$ & \\
\hline Marshall Islands & 11.8 & $20.3 \quad(2016)$ & $2.9(2007)$ & $5.8(2016)$ & $\cdots$ & $\cdots$ \\
\hline Micronesia, Federated States of & 12.3 & 14.2 & 3.1 & 14.2 & & \\
\hline Nauru & & & & & & . \\
\hline Niue & & $\cdots$ & $\ldots$ & & & \\
\hline Palau & & & $30.9 \quad(2007)$ & 45.8 & $\cdots$ & \\
\hline Papua New Guinea & 1.8 & 1.5 & 3.8 & 8.8 & $\ldots$ & $\ldots$ \\
\hline Samoa & 17.6 & 22.5 & 12.1 & 49.8 & $\ldots$ & $\ldots$ \\
\hline Solomon Islands & 7.5 & 4.3 & 1.5 & 12.0 & $\ldots$ & $\ldots$ \\
\hline Timor-Leste & 1.2 & 5.3 & $2.1 \quad(2008)$ & 12.6 & $\ldots$ & $\ldots$ \\
\hline Tonga & 24.2 & 28.9 & 22.5 & 36.1 & $\cdots$ & \\
\hline Tuvalu & & $\ldots$ & $\ldots$ & $\ldots$ & $\ldots$ & \\
\hline Vanuatu & 19.6 & $21.4 \quad(2015)$ & 4.9 & $39.9(2015)$ & $\cdots$ & \\
\hline Developed ADB Member Economie & & & & & & \\
\hline Australia & 30.7 & 29.6 & 139.6 & 162.0 & 99.1 & 99.5 \\
\hline Japan & 34.6 & 34.0 & 124.4 & 127.8 & 96.4 & 98.2 \\
\hline New Zealand & 35.0 & 27.3 & 59.0 & 65.9 & 99.4 & 99.2 \\
\hline
\end{tabular}

$\ldots=$ data not available, 0.0 = magnitude is less than half of unit employed, $A D B=$ Asian Development Bank.

Source: $\quad$ United Nations Statistics Division. Sustainable Development Goals (SDGs), SDG Indicators, Global Database. http://unstats.un.org/sdgs/indicators/database/ (accessed 8 July 2019). 
Goal 9. Build resilient infrastructure, promote inclusive and sustainable industrialization, and foster innovation

\section{Table 1.9.1: Selected Indicators for Sustainable Development Goal 9-Road and Rail Transport, Passenger and Freight Volume}

\begin{tabular}{|c|c|c|c|c|}
\hline \multirow{3}{*}{ ADB Regional Member } & \multicolumn{4}{|c|}{$\begin{array}{l}\text { Target 9.1: Develop quality, reliable, sustainable and resilient infrastructure, including regional and transborder } \\
\text { infrastructure, to support economic development and human well-being, with a focus on affordable } \\
\text { and equitable access for all }\end{array}$} \\
\hline & $\begin{array}{l}\text { 9.1.2: Passenger Volume, } \\
\text { by Road Transport } \\
\text { (passenger-km million) }\end{array}$ & $\begin{array}{l}\text { 9.1.2: Freight Volume, } \\
\text { by Road Transport } \\
\text { (t-km million) }\end{array}$ & $\begin{array}{l}\text { 9.1.2: Passenger Volume, } \\
\text { by Rail Transport } \\
\text { (passenger-km million) }\end{array}$ & $\begin{array}{l}\text { 9.1.2: Freight Volume, } \\
\text { by Rail Transport } \\
\text { ( } \mathrm{t}-\mathrm{km} \text { million) }\end{array}$ \\
\hline & 2017 & 2017 & 2017 & 2017 \\
\hline \multicolumn{5}{|l|}{ Developing ADB Member Economies } \\
\hline \multicolumn{5}{|l|}{ Central and West Asia } \\
\hline Afghanistan & $28,050.6$ & $8,060.3$ & 0.4 & - \\
\hline Armenia & $14,587.2$ & $1,736.6$ & 43.2 & 343.8 \\
\hline Azerbaijan & $63,138.7$ & $10,993.7$ & 912.1 & $10,996.5$ \\
\hline Georgia & $20,283.5$ & $1,741.6$ & 51.4 & $2,270.2$ \\
\hline Kazakhstan & $65,242.3$ & $191,652.1$ & 413.2 & $259,481.0$ \\
\hline Kyrgyz Republic & $10,445.6$ & $4,765.5$ & 2.7 & 154.3 \\
\hline Pakistan & $442,575.6$ & $341,086.4$ & 84.3 & $56,418.3$ \\
\hline Tajikistan & $13,908.4$ & $2,847.9$ & 1.3 & 73.6 \\
\hline Turkmenistan & $31,283.4$ & $6,095.0$ & 0.3 & $11,734.0$ \\
\hline Uzbekistan & $84,312.2$ & $33,062.2$ & 705.6 & $21,618.6$ \\
\hline \multicolumn{5}{|l|}{ East Asia } \\
\hline China, People's Republic of & $4,053,259.5$ & $7,168,249.2$ & $1,305,450.5$ & $2,543,045.7$ \\
\hline Hong Kong, China & $38,636.6$ & $10,665.7$ & $2,630.9$ & $11,295.2$ \\
\hline Korea, Republic of & $379,629.5$ & $198,410.5$ & $140,776.1$ & $11,726.6$ \\
\hline Mongolia & $7,360.9$ & $14,393.4$ & $17,162.8$ & $22,662.5$ \\
\hline Taipei, China & 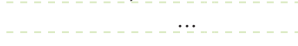 & & $-\cdots$ & $-\cdots$ \\
\hline \multicolumn{5}{|l|}{ South Asia } \\
\hline Bangladesh & $214,466.5$ & $21,894.1$ & $82,290.9$ & $7,889.0$ \\
\hline Bhutan & 748.3 & $1,207.6$ & $5,419.4$ & - \\
\hline India & $2,123,246.4$ & $2,204,061.9$ & $705,580.9$ & $573,788.2$ \\
\hline Maldives & $2,113.6$ & 53.4 & $2,978.2$ & - \\
\hline Nepal & $18,293.4$ & $6,528.6$ & $3,489.8$ & - \\
\hline Sri Lanka & $24,113.9$ & $9,343.4$ & $115,991.7$ & 437.5 \\
\hline \multicolumn{5}{|l|}{ Southeast Asia } \\
\hline Brunei Darussalam & 49.6 & 891.2 & $7,131.3$ & - \\
\hline Cambodia & $14,900.7$ & $9,699.8$ & $21,769.7$ & $1,566.5$ \\
\hline Indonesia & $228,384.2$ & $329,869.7$ & $593,963.0$ & $5,539.5$ \\
\hline Lao People's Democratic Republic & $8,024.4$ & $19,084.2$ & $14,513.9$ & - \\
\hline Malaysia & $44,529.0$ & $98,324.7$ & $168,479.1$ & $6,527.0$ \\
\hline Myanmar & $51,442.9$ & $14,517.0$ & $27,094.8$ & $4,057.2$ \\
\hline Philippines & $154,173.2$ & $47,828.8$ & $274,605.5$ & - \\
\hline Singapore & $22,522.6$ & 567.7 & $103,818.6$ & 662.5 \\
\hline Thailand & $120,694.3$ & $184,681.1$ & $332,528.2$ & $23,477.7$ \\
\hline Viet Nam & $122,902.0$ & $118,524.8$ & $186,146.3$ & $3,358.0$ \\
\hline \multicolumn{5}{|l|}{ The Pacific } \\
\hline Cook Islands & 87.0 & - & 3.4 & - \\
\hline Fiji & $2,672.7$ & 442.7 & 317.0 & - \\
\hline Kiribati & 326.7 & 19.5 & 11.8 & - \\
\hline Marshall Islands & 679.4 & - & 8.7 & - \\
\hline Micronesia, Federated States of & 536.7 & 34.2 & 37.4 & - \\
\hline Nauru & 41.4 & - & 1.6 & - \\
\hline Niue & 4.1 & - & 0.2 & - \\
\hline Palau & 194.4 & 24.6 & 120.4 & - \\
\hline Papua New Guinea & $15,871.6$ & $3,954.1$ & 816.6 & - \\
\hline Samoa & $1,213.0$ & 1.3 & 115.7 & - \\
\hline Solomon Islands & $1,932.7$ & 0.4 & 89.8 & - \\
\hline Timor-Leste & 156.5 & - & - & - \\
\hline Tonga & 736.2 & 54.5 & 82.1 & $=$ \\
\hline Tuvalu & 54.6 & 3.1 & 4.3 & - \\
\hline Vanuatu & $1,687.2$ & 1.5 & 157.1 & - \\
\hline \multicolumn{5}{|l|}{ Developed ADB Member Economies } \\
\hline Australia & $98,606.9$ & $262,176.7$ & $21,698.8$ & $418,843.4$ \\
\hline Japan & $869,989.0$ & $209,997.1$ & $428,851.8$ & $28,708.0$ \\
\hline New Zealand & $18,602.1$ & $16,717.1$ & $5,367.2$ & $10,316.8$ \\
\hline
\end{tabular}

$\ldots=$ data not available, $\mathrm{ADB}=\mathrm{Asian}$ Development Bank, $\mathrm{km}=$ kilometer $\mathrm{t}=$ metric ton.

Source: United Nations Statistics Division. Sustainable Development Goals (SDGs), SDG Indicators, Global Database. http://unstats.un.org/sdgs/indicators/database/ (accessed 8 July 2019). 
Goal 9. Build resilient infrastructure, promote inclusive and sustainable industrialization, and foster innovation

Table 1.9.2: Selected Indicators for Sustainable Development Goal 9-Growth in Manufacturing

\begin{tabular}{|c|c|c|c|c|c|c|c|c|}
\hline \multirow{4}{*}{ ADB Regional Member } & \multicolumn{8}{|c|}{$\begin{array}{l}\text { Target 9.2: Promote inclusive and sustainable industrialization; and, by } 2030 \text {, significantly raise industry's share of } \\
\text { employment and GDP, in line with national circumstances, and double its share in least developed countries }\end{array}$} \\
\hline & \multicolumn{5}{|c|}{ 9.2.1: Manufacturing Value Addeda } & \multirow{2}{*}{\multicolumn{3}{|c|}{$\begin{array}{c}\text { 9.2.2: Manufacturing Employment as } \\
\text { a Proportion of Total Employment } \\
(\%)\end{array}$}} \\
\hline & \multicolumn{2}{|c|}{$\begin{array}{l}\text { As a Proportion of GDP } \\
(\%)\end{array}$} & \multicolumn{3}{|c|}{$\begin{array}{c}\text { Per Capita } \\
\text { (at constant } 2010 \$)\end{array}$} & & & \\
\hline & 2000 & 2018 & 200 & & 2018 & 2000 & \multicolumn{2}{|c|}{2017} \\
\hline \multirow{2}{*}{\multicolumn{9}{|c|}{$\begin{array}{l}\text { Developing ADB Member Economies } \\
\text { Central and West Asia }\end{array}$}} \\
\hline & & & & & & & & \\
\hline Afghanistan & 17.2 & 11.0 & 46.3 & & 68.8 & $4.6 \quad(2008)$ & 6.8 & $(2012)$ \\
\hline Armenia & 9.9 & 9.7 & 146.2 & & 459.0 & $10.7 \quad(2002)$ & 9.1 & \\
\hline Azerbaijan & 9.6 & 5.5 & 158.1 & & 315.9 & 4.6 & 5.2 & \\
\hline Georgia & 9.6 & 11.5 & 128.6 & & 495.2 & 5.9 & 5.9 & \\
\hline Kazakhstan & 13.0 & 10.0 & 575.1 & & $1,110.2$ & $7.7 \quad(2001)$ & 6.4 & $(2015)$ \\
\hline Kyrgyz Republic & 23.2 & 13.2 & 151.0 & & 145.8 & 6.4 & 10.1 & \\
\hline Pakistan & 10.1 & 13.2 & 83.9 & & 164.8 & 11.5 & 15.3 & $(2016)$ \\
\hline Tajikistan & 27.1 & 12.1 & 113.4 & & 120.7 & $4.7 \quad(2004)$ & 5.5 & (2009) \\
\hline Turkmenistan & 33.0 & 38.0 & 786.1 & & $2,904.5$ & & $\ldots$ & \\
\hline Uzbekistan & 24.1 & 16.6 & 195.6 & & 350.1 & & $\cdots$ & \\
\hline \multicolumn{9}{|l|}{ East Asia } \\
\hline China, People's Republic of & 28.2 & 31.2 & 489.3 & & $2,383.3$ & & & \\
\hline Hong Kong, China & 3.8 & 1.2 & 862.6 & & 473.3 & & & \\
\hline Korea, Republic of & 22.7 & 28.8 & $3,397.6$ & & $7,769.0$ & 20.3 & 16.9 & \\
\hline Mongolia & 5.9 & 5.1 & 93.9 & & 215.8 & 6.8 & 7.5 & \\
\hline Taipei,China & 24.6 & 21.4 & $3,314.8$ & (2001) & $4,530.6$ & $27.7 \quad(2001)$ & 26.8 & (2018) \\
\hline \multicolumn{9}{|l|}{ South Asia } \\
\hline Bangladesh & 13.5 & 21.1 & 67.4 & & 244.2 & 7.3 & 14.4 & \\
\hline Bhutan & 7.6 & 7.9 & 90.8 & & 245.3 & $2.0 \quad(2005)$ & 6.5 & $(2015)$ \\
\hline India & 15.2 & 17.0 & 114.0 & & 353.0 & 10.7 & 12.5 & $(2012)$ \\
\hline Maldives & 2.9 & 2.3 & 165.4 & & 200.6 & 12.9 & 11.0 & $(2016)$ \\
\hline Nepal & 8.1 & 5.5 & 37.5 & & 42.9 & $\ldots$ & $\ldots$ & \\
\hline Sri Lanka & 20.1 & 15.5 & 366.2 & & 630.0 & 16.5 (2002) & 19.3 & \\
\hline \multicolumn{9}{|l|}{ Southeast Asia } \\
\hline Brunei Darussalam & 17.4 & 14.9 & $6,237.5$ & & $4,738.3$ & & 3.7 & (2014) \\
\hline Cambodia & 11.5 & 17.7 & 49.3 & & 212.1 & 7.0 & 17.4 & (2012) \\
\hline Indonesia & 23.8 & 21.6 & 510.5 & & 928.0 & 13.0 & 14.1 & \\
\hline Lao People's Democratic Republic & 9.1 & 11.1 & 61.7 & & 207.0 & & 7.9 & \\
\hline Malaysia & 25.8 & 23.3 & $1,807.8$ & & $2,768.3$ & 22.8 & 16.9 & $(2016)$ \\
\hline Myanmar & 8.5 & 23.9 & 24.5 & & 314.1 & & 10.5 & \\
\hline Philippines & 23.7 & 22.6 & 380.2 & & 684.4 & 10.0 & 8.6 & \\
\hline Singapore & 20.4 & 17.2 & $7,010.3$ & & $9,358.1$ & 20.7 & 14.4 & $(2015)$ \\
\hline Thailand & 28.5 & 27.7 & 985.1 & & $1,784.8$ & $14.7 \quad(2002)$ & 16.7 & $(2016)$ \\
\hline Viet Nam & 12.8 & 17.5 & 95.9 & & 338.7 & 9.2 & 17.4 & \\
\hline \multicolumn{9}{|l|}{ The Pacific } \\
\hline Cook Islands & 3.5 & 2.4 & 441.5 & & 410.9 & & & \\
\hline Fiji & 13.3 & 11.2 & 439.8 & & 490.1 & $13.7 \quad(2005)$ & 5.6 & $(2016)$ \\
\hline Kiribati & 5.1 & 4.0 & 91.8 & & 67.7 & 1.6 & 13.2 & $(2010)$ \\
\hline Marshall Islands & 1.8 & 1.3 & 47.6 & & 48.0 & $\ldots$ & 0.7 & $(2010)$ \\
\hline Micronesia, Federated States of & & & $\ldots$ & & & & $\cdots$ & \\
\hline Nauru & $\ldots$ & & $\ldots$ & & & & $\ldots$ & \\
\hline Niue & $\ldots$ & $\ldots$ & $\ldots$ & & $\ldots$ & $\ldots$ & $\ldots$ & \\
\hline Palau & 1.5 & 1.2 & 150.9 & & 118.8 & 0.7 & $\ldots$ & \\
\hline Papua New Guinea & 2.5 & 2.4 & 43.9 & & 54.2 & 1.1 & 1.8 & $(2010)$ \\
\hline Samoa & 16.9 & 9.0 & 481.8 & & 362.1 & & 6.8 & \\
\hline Solomon Islands & 4.9 & 6.8 & 52.4 & & 101.3 & & $\ldots$ & \\
\hline Timor-Leste & 1.9 & 0.3 & 15.0 & & 7.1 & $\ldots$ & 5.5 & (2013) \\
\hline Tonga & 7.1 & 6.1 & 234.6 & & 242.2 & $24.7 \quad(2003)$ & $\ldots$ & \\
\hline Tuvalu & 0.8 & 1.0 & 24.1 & & 36.2 & $\ldots$ & $\ldots$ & \\
\hline Vanuatu & 4.3 & 3.2 & 117.2 & & 97.5 & & 1.9 & $(2009)$ \\
\hline \multicolumn{9}{|l|}{ Developed ADB Member Economies } \\
\hline Australia & 9.3 & 5.9 & $4,677.3$ & & $3,809.9$ & 12.1 & 7.2 & \\
\hline Japan & 19.4 & 21.2 & $8,154.7$ & & $10,366.1$ & 20.5 & 16.1 & \\
\hline New Zealand & 14.1 & 9.6 & $4,081.3$ & & $3,712.8$ & 15.8 & 9.8 & \\
\hline
\end{tabular}

$\ldots=$ data not available, $\$=$ United States dollars, ADB = Asian Development Bank, GDP = gross domestic product.

a United Nations Statistics Division data used for indicator 9.2.1 were calculated from GDP, manufacturing value added, and population data.

Sources: United Nations Statistics Division. Sustainable Development Goals (SDGs), SDG Indicators, Global Database. https://unstats.un.org/sdgs/indicators/database/ (accessed 8 July 2019); and United Nations Industrial Development Organization. Statistics Data Portal. https://stat.unido.org/SDG (accessed 22 July 2019 ). 


\section{Table 1.9.3: Selected Indicators for Sustainable Development Goal 9-Carbon Dioxide Emissions}

\begin{tabular}{|c|c|c|c|c|}
\hline \multirow{5}{*}{ ADB Regional Member } & \multirow{2}{*}{\multicolumn{4}{|c|}{$\begin{array}{l}\text { Target 9.4: By 2030, upgrade infrastructure and retrofit industries to make them sustainable, with increased } \\
\text { resource-use efficiency and greater adoption of clean and environmentally sound technologies and industria } \\
\text { processes, with all countries taking action in accordance with their respective capabilities } \\
\text { 9.4.1: Carbon Dioxide Emissions }{ }^{a}\end{array}$}} \\
\hline & & & & \\
\hline & \multirow{2}{*}{\multicolumn{2}{|c|}{$\begin{array}{c}\text { Per Unit of GDP (PPP) } \\
\text { ( } \mathrm{kg} \text { of } \mathrm{CO}_{2} \text { equivalent per constant } 2010 \$ \text { ) }\end{array}$}} & \multirow{2}{*}{\multicolumn{2}{|c|}{$\begin{array}{l}\text { Per Unit of Manufacturing Value Added } \\
\text { (kg of } \mathrm{CO}_{2} \text { equivalent per constant } 2010 \$ \text { ) }\end{array}$}} \\
\hline & & & & \\
\hline & 2000 & 2016 & 2000 & 2016 \\
\hline \multicolumn{5}{|c|}{ Developing ADB Member Economies } \\
\hline \multirow{2}{*}{\multicolumn{5}{|c|}{$\begin{array}{l}\text { Central and West Asia } \\
\text { Afghanistan }\end{array}$}} \\
\hline & & & & \\
\hline Armenia & 0.4 & 0.2 & 1.6 & 0.3 \\
\hline Azerbaijan & 0.8 & 0.2 & 2.0 & 0.8 \\
\hline Georgia & 0.3 & 0.3 & 1.0 & 0.7 \\
\hline Kazakhstan & 0.8 & 0.6 & 2.1 & 2.2 \\
\hline Kyrgyz Republic & 0.5 & 0.5 & 1.1 & 0.9 \\
\hline Pakistan & 0.2 & 0.2 & 1.9 & 1.5 \\
\hline Tajikistan & 0.3 & 0.2 & - & 0.1 \\
\hline Turkmenistan & 1.6 & 0.8 & 0.2 & 0.2 \\
\hline Uzbekistan & 1.9 & 0.5 & 3.2 & 1.0 \\
\hline \multicolumn{5}{|l|}{ East Asia } \\
\hline China, People's Republic of & 0.7 & 0.5 & 1.4 & 0.9 \\
\hline Hong Kong, China & 0.2 & 0.1 & 0.7 & 1.9 \\
\hline Korea, Republic of & 0.4 & 0.3 & 0.6 & 0.2 \\
\hline Mongolia & 0.8 & 0.5 & 2.2 & 1.5 \\
\hline Taipei, China & & & 0.5 & 0.4 \\
\hline \multicolumn{5}{|l|}{ South Asia } \\
\hline Bangladesh & 0.1 & 0.1 & 0.5 & 0.5 \\
\hline Bhutan & & & & \\
\hline India & 0.3 & 0.3 & 1.5 & 1.3 \\
\hline Maldives & & & & \\
\hline Nepal & 0.1 & 0.1 & 1.3 & 2.6 \\
\hline Sri Lanka & 0.1 & 0.1 & 0.1 & 0.1 \\
\hline \multicolumn{5}{|l|}{ Southeast Asia } \\
\hline Brunei Darussalam & 0.2 & 0.2 & 0.1 & 0.2 \\
\hline Cambodia & 0.1 & 0.2 & 0.1 & 0.2 \\
\hline Indonesia & 0.2 & 0.2 & 0.5 & 0.4 \\
\hline \multicolumn{5}{|l|}{ Lao People's Democratic Republic } \\
\hline Malaysia & 0.3 & 0.3 & 0.6 & 0.4 \\
\hline Myanmar & 0.2 & 0.1 & 2.1 & 0.1 \\
\hline Philippines & 0.2 & 0.2 & 0.4 & 0.2 \\
\hline Singapore & 0.2 & 0.1 & 0.1 & 0.2 \\
\hline Thailand & 0.3 & 0.2 & 0.5 & 0.4 \\
\hline Viet Nam & 0.2 & 0.4 & 1.9 & 2.3 \\
\hline \multicolumn{5}{|l|}{ The Pacific } \\
\hline \multicolumn{5}{|l|}{ Cook Islands } \\
\hline \multicolumn{5}{|l|}{ Fiji } \\
\hline \multicolumn{5}{|l|}{ Kiribati } \\
\hline \multicolumn{5}{|l|}{ Marshall Islands } \\
\hline \multicolumn{5}{|l|}{ Micronesia, Federated States of } \\
\hline Nauru & $\ldots$ & & & \\
\hline Niue & $\ldots$ & $\ldots$ & $\ldots$ & $\ldots$ \\
\hline Palau & $\ldots$ & & $\ldots$ & \\
\hline Papua New Guinea & $\ldots$ & $\ldots$ & $\ldots$ & $\ldots$ \\
\hline Samoa & & & & \\
\hline Solomon Islands & $\ldots$ & $\ldots$ & $\ldots$ & $\ldots$ \\
\hline Timor-Leste & & & & \\
\hline Tonga & $\ldots$ & $\ldots$ & $\ldots$ & $\ldots$ \\
\hline Tuvalu & & & & \\
\hline Vanuatu & 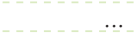 & 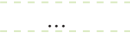 & 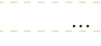 & \\
\hline Developed ADB Member Econon & & & & \\
\hline Australia & 0.5 & 0.4 & 0.5 & 0.3 \\
\hline Japan & 0.3 & 0.2 & 0.2 & 0.2 \\
\hline New Zealand & 0.3 & 0.2 & 0.4 & 0.4 \\
\hline
\end{tabular}

$\ldots=$ data not available, $-=$ magnitude equals zero, $\$=$ United States dollar, $\mathrm{ADB}=\mathrm{Asian}$ Development $\mathrm{Bank}, \mathrm{CO}_{2}=$ carbon dioxide, $\mathrm{GDP}=$ gross domestic product, $\mathrm{kg}=$ kilogram, $\mathrm{PPP}=$ purchasing power parity.

a Refers to carbon dioxide emissions from fuel combustion.

Sources: $\quad$ United Nations Statistics Division. Sustainable Development Goals (SDGs), SDG Indicators, Global Database. https://unstats.un.org/sdgs/indicators/database/ (accessed 8 July 2019); and United Nations Industrial Development Organization. Statistics Data Portal. https://stat.unido.org/SDG (accessed 23 July 2019). 
Goal 9. Build resilient infrastructure, promote inclusive and sustainable industrialization, and foster innovation

Table 1.9.4: Selected Indicators for Sustainable Development Goal 9-Research and Development

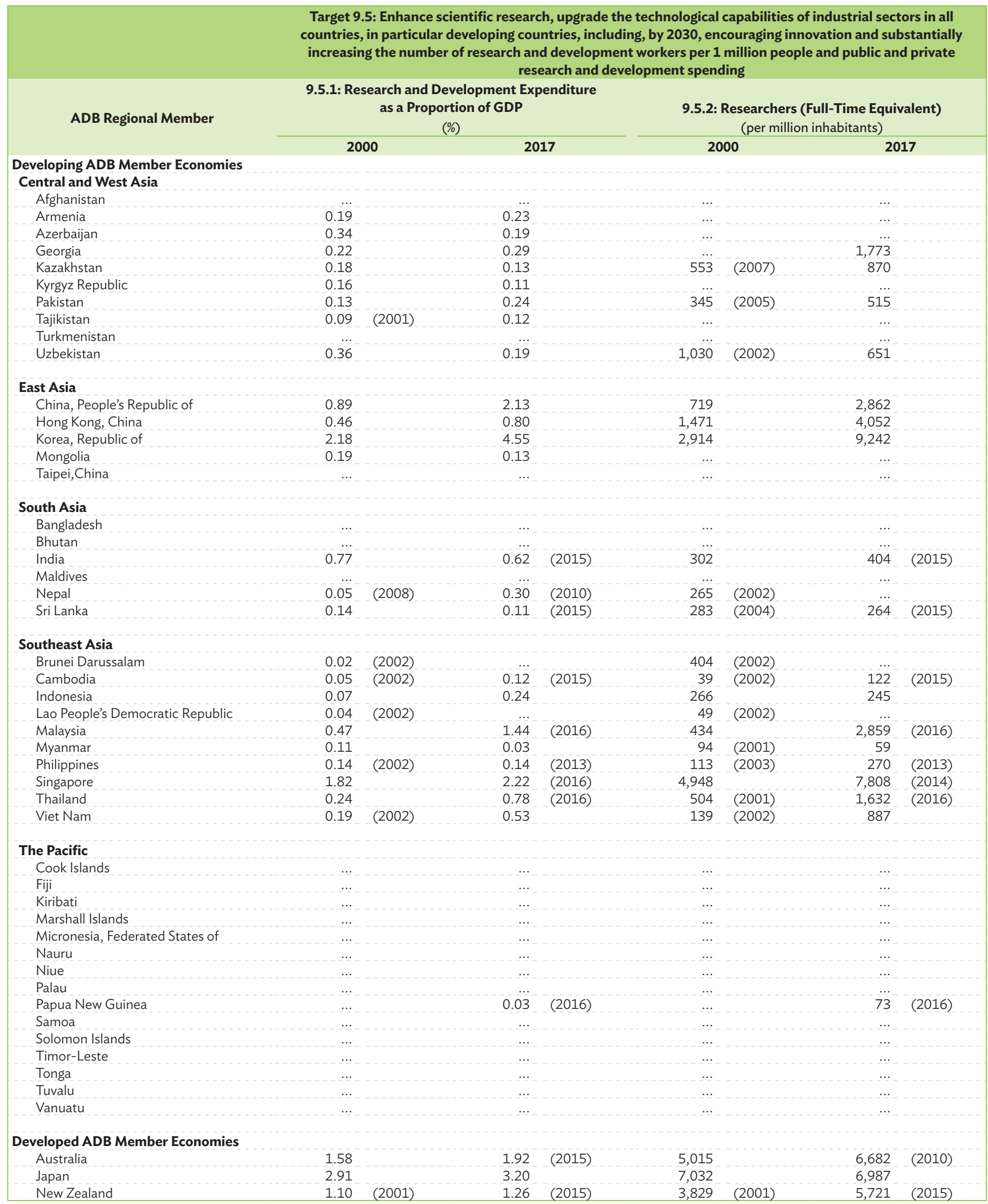

$\ldots=$ data not available, $\mathrm{ADB}=$ Asian Development Bank, GDP = gross domestic product.

Sources: United Nations Statistics Division. Sustainable Development Goals (SDGs), SDG Indicators, Global Database. https://unstats.un.org/sdgs/indicators/database/ (accessed 8 July 2019); and United Nations Educational, Scientific and Cultural Organization Institute for Statistics. Sustainable Development Goals. http://data.uis.unesco.org/\# (accessed 29 July 2019). 
Goal 9. Build resilient infrastructure, promote inclusive and sustainable industrialization, and foster innovation

\section{Table 1.9.5: Selected Indicators for Sustainable Development Goal 9-Official International Support and Industry Value Added}

\begin{tabular}{|c|c|c|c|c|}
\hline \multirow{3}{*}{ ADB Regional Member } & \multirow{2}{*}{\multicolumn{2}{|c|}{$\begin{array}{l}\text { Target 9.a: Facilitate sustainable and resilient } \\
\text { infrastructure development in developing countries } \\
\text { through enhanced financial, technological, and } \\
\text { technical support to African countries, least } \\
\text { developed countries, landlocked developing } \\
\text { countries, and small-island developing States } \\
\text { 9.a.1: Total Official International Support } \\
\text { to Infrastructure } \\
\text { (constant } 2016 \$ \text { million) }\end{array}$}} & \multicolumn{2}{|c|}{$\begin{array}{l}\text { Target 9.b: Support domestic technology development, } \\
\text { research and innovation in developing countries, } \\
\text { including by ensuring a conducive policy environment for, } \\
\text { inter alia, industrial diversification, and value addition to } \\
\text { commodities }\end{array}$} \\
\hline & & & \multicolumn{2}{|c|}{$\begin{array}{l}\text { 9.b.1: Proportion of Medium and High-Tech Industry } \\
\text { Value Added in Total Value Added } \\
(\%)\end{array}$} \\
\hline & 2000 & 2017 & 2000 & 2016 \\
\hline \multicolumn{5}{|l|}{ Developing ADB Member Economies } \\
\hline \multicolumn{5}{|l|}{ Central and West Asia } \\
\hline Afghanistan & 0.4 & 500.5 & 13.6 & 9.5 \\
\hline Armenia & 134.0 & 290.1 & 9.5 & 4.5 \\
\hline Azerbaijan & 24.1 & $1,160.1$ & 16.5 & 20.3 \\
\hline Georgia & 141.7 & 422.6 & 21.4 & 11.5 \\
\hline Kazakhstan & 239.8 & 392.6 & 5.2 & 14.2 \\
\hline Kyrgyz Republic & 92.2 & 118.5 & 5.9 & 3.0 \\
\hline Pakistan & 477.7 & $1,755.4$ & 25.2 & 24.6 \\
\hline Tajikistan & 16.5 & 143.8 & 2.7 & 2.2 \\
\hline Turkmenistan & 1.8 & 10.8 & $\ldots$ & $\ldots$ \\
\hline Uzbekistan & 47.1 & 582.6 & & \\
\hline \multicolumn{5}{|l|}{ East Asia } \\
\hline China, People's Republic of & $2,283.4$ & $2,401.5$ & 42.9 & 41.5 \\
\hline Hong Kong, China & & & 39.5 & 37.4 \\
\hline Korea, Republic of & & & 58.9 & 63.7 \\
\hline Mongolia & 115.2 & 402.9 & 2.5 & 5.6 \\
\hline Taipei,China & $\ldots$ & $\ldots$ & 56.2 & 68.9 \\
\hline \multicolumn{5}{|l|}{ South Asia } \\
\hline Bangladesh & 626.1 & $2,207.7$ & 21.1 & 9.8 \\
\hline Bhutan & 30.8 & 39.3 & & \\
\hline India & $2,996.7$ & $6,277.5$ & 41.3 & 38.8 \\
\hline Maldives & 11.5 & 23.3 & 2.6 & 2.6 \\
\hline Nepal & 114.3 & 324.4 & 12.1 & 8.4 \\
\hline Sri Lanka & 75.5 & 465.5 & 9.4 & 7.6 \\
\hline \multicolumn{5}{|l|}{ Southeast Asia } \\
\hline Brunei Darussalam & & & 3.3 & 3.3 \\
\hline Cambodia & 44.4 & 371.0 & 0.3 & 0.3 \\
\hline Indonesia & 108.7 & $2,513.3$ & 35.7 & 35.1 \\
\hline Lao People's Democratic Republic & 73.4 & 150.4 & 13.6 & 13.6 \\
\hline Malaysia & 568.5 & 4.3 & 51.2 & 44.1 \\
\hline Myanmar & 0.0 & 400.3 & 12.4 & 6.6 \\
\hline Philippines & 781.8 & 292.1 & 38.1 & 44.7 \\
\hline Singapore & & & 78.5 & 78.1 \\
\hline Thailand & 693.1 & 429.1 & 37.9 & 40.7 \\
\hline Viet Nam & $1,111.3$ & $2,325.3$ & 23.5 & 37.8 \\
\hline \multicolumn{5}{|l|}{ The Pacific } \\
\hline Cook Islands & 1.0 & 7.7 & & $\ldots$ \\
\hline Fiji & 0.2 & 16.9 & 8.5 & 7.1 \\
\hline Kiribati & 1.5 & 24.5 & & \\
\hline Marshall Islands & 3.2 & 100.9 & $\ldots$ & $\ldots$ \\
\hline Micronesia, Federated States of & 5.0 & 8.6 & $\ldots$ & \\
\hline Nauru & $0.0(2002)$ & 4.5 & $\ldots$ & $\ldots$ \\
\hline Niue & 0.5 & 2.3 & $\ldots$ & $\ldots$ \\
\hline Palau & 0.2 & 12.3 & & \\
\hline Papua New Guinea & 218.4 & 196.7 & 12.6 & 12.6 \\
\hline Samoa & 3.2 & 60.5 & $\ldots$ & $\ldots$ \\
\hline Solomon Islands & 9.1 & 44.7 & $\ldots$ & \\
\hline Timor-Leste & 2.5 & 62.1 & & \\
\hline Tonga & 5.0 & 34.5 & 1.6 & 1.6 \\
\hline Tuvalu & $0.0(2002)$ & 9.8 & & \\
\hline Vanuatu & 9.7 & 54.5 & & \\
\hline \multicolumn{5}{|l|}{ Developed ADB Member Economies } \\
\hline Australia & & & 27.2 & 27.0 \\
\hline Japan & & & 52.0 & 56.2 \\
\hline New Zealand & & & 12.5 & 18.5 \\
\hline
\end{tabular}

$\ldots=$ data not available, $0.0=$ magnitude is less than half of unit employed, $\$=$ United States dollars, $A D B=$ Asian Development Bank.

a Gross disbursements of total official development assistance and other official flows from all donors in support of infrastructure.

Sources: $\quad$ United Nations Statistics Division. Sustainable Development Goals (SDGs), SDG Indicators, Global Database. http://unstats.un.org/sdgs/indicators/database/ (accessed 8 July 2019); and United Nations Industrial Development Organization. Statistics Data Portal. https://stat.unido.org/SDG (accessed 23 July 2019). 
Goal 9. Build resilient infrastructure, promote inclusive and sustainable industrialization, and foster innovation

Table 1.9.6: Selected Indicators for Sustainable Development Goal 9-Coverage by Mobile Networks

\begin{tabular}{|c|c|c|c|c|c|c|c|c|c|}
\hline \multirow{3}{*}{ ADB Regional Member } & \multicolumn{9}{|c|}{$\begin{array}{l}\text { Target 9.c: Significantly increase access to information and communications technology and strive to provide } \\
\text { universal and affordable access to the Internet in least developed countries by } 2020\end{array}$} \\
\hline & \multicolumn{3}{|c|}{$\begin{array}{c}\text { 9.c.1a: Proportion of Population } \\
\text { Covered by } 2 \mathrm{G} \text { Mobile Networks } \\
\text { (\%) }\end{array}$} & \multicolumn{3}{|c|}{$\begin{array}{c}\text { 9.c.1b: Proportion of Population } \\
\text { Covered by 3G Mobile Networks } \\
\text { (\%) }\end{array}$} & \multicolumn{3}{|c|}{$\begin{array}{c}\text { 9.c.1c: Proportion of Population } \\
\text { Covered by LTE Mobile Networks } \\
(\%)\end{array}$} \\
\hline & \multicolumn{2}{|c|}{2000} & 2017 & \multicolumn{2}{|c|}{2008} & 2017 & \multicolumn{2}{|c|}{2012} & 2017 \\
\hline \multirow{2}{*}{\multicolumn{10}{|c|}{ Developing ADB Member Economies }} \\
\hline Central and West Asia & & & & & & & & & \\
\hline Afghanistan & 72.0 & $(2007)$ & 90.0 & & & 46.0 & - & (2014) & 5.0 \\
\hline Armenia & 38.0 & $(2001)$ & 100.0 & 81.1 & (2009) & 100.0 & 17.5 & & 90.1 \\
\hline Azerbaijan & 93.5 & & 100.0 & 32.2 & (2009) & 96.3 & 6.7 & & 42.0 \\
\hline Georgia & 79.0 & (2001) & 100.0 & $\ldots$ & & 100.0 & 8.9 & (2013) & 99.7 \\
\hline Kazakhstan & 94.0 & (2001) & 96.6 & & & 87.5 & 2.7 & & 72.5 \\
\hline Kyrgyz Republic & 5.2 & $(2004)$ & 99.1 & $\cdots$ & & 75.0 & 0.5 & (2014) & 50.0 \\
\hline Pakistan & 27.1 & $(2001)$ & 88.0 & & & 72.0 & - & & 67.0 \\
\hline Tajikistan & - & (2001) & 90.0 & & & 90.0 & 8.4 & & 80.0 \\
\hline Turkmenistan & 12.4 & (2001) & 95.8 & & & 75.8 & 6.0 & (2013) & 67.0 \\
\hline Uzbekistan & 75.0 & (2002) & 98.4 & & & 75.0 & 1.0 & (2014) & 43.0 \\
\hline \multicolumn{10}{|l|}{ East Asia } \\
\hline China, People's Republic of & 50.0 & $(2001)$ & 99.5 & & & 98.0 & 10.0 & (2013) & 98.0 \\
\hline Hong Kong, China & 100.0 & & 100.0 & 99.0 & (2009) & 99.0 & 91.7 & & 99.0 \\
\hline Korea, Republic of & 99.0 & & 99.9 & 99.0 & (2007) & 99.9 & 99.0 & (2014) & 99.9 \\
\hline Mongolia & 58.0 & & 99.0 & 39.9 & & 95.0 & $\ldots$ & & 21.0 \\
\hline Taipei,China & $\ldots$ & & $\ldots$ & $\ldots$ & & $\ldots$ & & & $\ldots$ \\
\hline \multicolumn{10}{|l|}{ South Asia } \\
\hline Bangladesh & 40.0 & $(2001)$ & 99.5 & & & 92.8 & 59.0 & (2014) & 67.0 \\
\hline Bhutan & 5.4 & (2005) & 98.0 & 15.0 & (2010) & 88.0 & 5.0 & (2013) & 55.0 \\
\hline India & 21.1 & $(2001)$ & 97.0 & - & $(2007)$ & 88.0 & 2.0 & $(2014)$ & 88.0 \\
\hline Maldives & 40.0 & & 100.0 & 41.8 & (2009) & 100.0 & 11.4 & (2013) & 100.0 \\
\hline Nepal & 10.0 & (2006) & 92.5 & 20.4 & (2009) & 54.1 & - & (2014) & 15.5 \\
\hline Sri Lanka & 57.9 & $(2001)$ & 99.7 & & & 88.0 & 5.0 & & 48.0 \\
\hline \multicolumn{10}{|l|}{ Southeast Asia } \\
\hline Brunei Darussalam & & & 99.3 & & & 92.7 & 5.0 & $(2013)$ & 90.0 \\
\hline Cambodia & 80.0 & & 99.0 & 43.0 & (2009) & 83.9 & 9.0 & (2014) & 57.5 \\
\hline Indonesia & 89.0 & & 98.6 & $\ldots$ & & 93.8 & 5.0 & (2013) & 90.4 \\
\hline Lao People's Democratic Republic & 55.0 & (2005) & 98.0 & - & (2007) & 78.0 & 2.0 & (2014) & 9.0 \\
\hline Malaysia & 95.0 & (2001) & 96.2 & 74.0 & (2009) & 96.2 & 15.0 & (2013) & 92.0 \\
\hline Myanmar & 10.0 & (2006) & 90.5 & & & 90.5 & - & (2014) & 29.5 \\
\hline Philippines & 70.0 & & 95.0 & 69.0 & (2009) & 93.0 & 6.0 & & 80.0 \\
\hline Singapore & 100.0 & & 100.0 & 99.8 & (2007) & 100.0 & 99.0 & (2014) & 100.0 \\
\hline Thailand & 25.9 & $(2005)$ & 98.0 & $\ldots$ & & 98.0 & - & (2014) & 98.0 \\
\hline Viet Nam & 70.0 & $(2006)$ & 99.5 & & & 98.0 & - & $(2014)$ & 95.0 \\
\hline The Pacific & & & & & & & & & \\
\hline Cook Islands & & & 100.0 & & & 55.0 & & & 55.0 \\
\hline $\mathrm{Fiji}$ & 40.0 & & 96.0 & & & 96.0 & 15.0 & (2014) & 96.0 \\
\hline Kiribati & $\ldots$ & & 45.0 & & & 48.0 & 10.0 & (2013) & 45.0 \\
\hline Marshall Islands & & & 65.0 & & & & $\ldots$ & & \\
\hline Micronesia, Federated States of & - & & 80.0 & & & 15.0 & $\ldots$ & & - \\
\hline Nauru & $\ldots$ & & 98.0 & 98.0 & $(2010)$ & 98.0 & $\because$ & (2014) & 30.0 \\
\hline Nive & & & & $\ldots$ & & $-(2$ & $\ldots$ & & $\ldots$ \\
\hline Palau & 30.0 & (2005) & 98.0 (2015) & & & $88.0 \quad(2$ & & & \\
\hline Papua New Guinea & 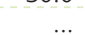 & & 89.0 & & & 64.4 & 7.0 & (2014) & 50.0 \\
\hline Samoa & & & 97.0 & & & 91.0 & $\ldots$ & & 49.0 \\
\hline Solomon Islands & 35.0 & & 94.0 & & & 25.0 & & & 19.0 \\
\hline Timor-Leste & 38.0 & (2003) & 96.5 & & & 96.5 & & & 20.0 \\
\hline Tonga & 70.0 & (2001) & 98.0 & 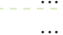 & & 95.0 & $\cdots$ & $(2014)$ & 65.0 \\
\hline Tuvalu & 15.0 & $(2004)$ & 48.0 & . & & 48.0 & $\ldots$ & & - \\
\hline Vanuatu & 20.0 & $(2002)$ & 98.0 & & & 98.0 & & & 33.0 \\
\hline Developed ADB Member Economies & & & & & & & & & \\
\hline Australia & 95.6 & & 99.4 & 98.8 & & 99.4 & 52.2 & & 99.0 \\
\hline Japan & 99.0 & & 99.9 & & & 99.9 & 84.0 & & 99.0 \\
\hline New Zealand & 97.0 & & 98.0 & 97.0 & & 98.0 & 50.0 & (2014) & 94.0 \\
\hline
\end{tabular}

$\ldots=$ data not available, - = magnitude equals zero, $\mathrm{ADB}=$ Asian Development Bank, $\mathrm{LTE}=$ Long-Term Evolution.

Source: United Nations Statistics Division. Sustainable Development Goals (SDGs), SDG Indicators, Global Database. http://unstats.un.org/sdgs/indicators/database/ (accessed 8 July 2019). 
Table 1.10.1: Selected Indicators for Sustainable Development Goal 10-Household Expenditure or Income Growth

\begin{tabular}{|c|c|c|c|c|}
\hline \multirow[b]{2}{*}{ ADB Regional Member } & \multicolumn{4}{|c|}{$\begin{array}{c}\text { Target 10.1: By 2030, progressively achieve and sustain income growth of the bottom } 40 \% \text { of the population } \\
\text { at a rate higher than the national average }\end{array}$} \\
\hline & \multicolumn{2}{|c|}{$\begin{array}{l}\text { 10.1.1a: Growth Rates of Household Expenditure } \\
\text { or Income per Capita among the Bottom } 40 \% \text { of the } \\
\text { Populationa,b } \\
(\%)\end{array}$} & \multicolumn{2}{|c|}{$\begin{array}{l}\text { 10.1.1b: Growth Rates of Household Expenditure } \\
\text { or Income per Capita }{ }^{\mathrm{a}, \mathrm{b}} \\
(\%)\end{array}$} \\
\hline \multicolumn{5}{|l|}{ Developing ADB Member Economies } \\
\hline \multicolumn{5}{|l|}{ Central and West Asia } \\
\hline \multicolumn{5}{|l|}{ Afghanistan } \\
\hline Armenia & 1.8 & $(2012-2017)$ & 3.2 & $(2012-2017)$ \\
\hline \multicolumn{5}{|l|}{ Azerbaijan } \\
\hline Georgia & 4.5 & $(2012-2017)$ & 3.8 & $(2012-2017)$ \\
\hline Kazakhstan & -0.0 & $(2012-2017)$ & -0.6 & $(2012-2017)$ \\
\hline Kyrgyz Republic & 0.9 & $(2012-2017)$ & 0.8 & $(2012-2017)$ \\
\hline Pakistan & 2.7 & $(2010-2015)$ & 4.3 & $(2010-2015)$ \\
\hline Tajikistan & 2.3 & $(2009-2015)$ & 3.6 & $(2009-2015)$ \\
\hline \multicolumn{5}{|l|}{ Turkmenistan } \\
\hline \multicolumn{5}{|l|}{ Uzbekistan } \\
\hline \multicolumn{5}{|l|}{ East Asia } \\
\hline China, People's Republic of & 9.1 & $(2013-2015)$ & 7.4 & $(2013-2015)$ \\
\hline \multirow{2}{*}{\multicolumn{5}{|c|}{ Hong Kong, China }} \\
\hline & & & & \\
\hline Mongolia & 1.7 & $(2010-2016)$ & 1.3 & $(2010-2016)$ \\
\hline \multicolumn{5}{|l|}{ Taipei,China } \\
\hline \multicolumn{5}{|l|}{ South Asia } \\
\hline Bangladesh & 1.4 & $(2010-2016)$ & 1.5 & $(2010-2016)$ \\
\hline Bhutan & 1.6 & $(2012-2017)$ & 1.7 & $(2012-2017)$ \\
\hline \multicolumn{5}{|l|}{ India } \\
\hline \multicolumn{5}{|l|}{ Maldives } \\
\hline \multicolumn{5}{|l|}{ Nepal } \\
\hline Sri Lanka & 4.2 & $(2012-2016)$ & 4.7 & $(2012-2016)$ \\
\hline \multicolumn{5}{|l|}{ Southeast Asia } \\
\hline Brunei Darussalam & & & $\ldots$ & \\
\hline Cambodia & & & & \\
\hline Indonesia & 4.8 & $(2015-2017)$ & 4.8 & $(2015-2017)$ \\
\hline Lao People's Democratic Republic & & & & \\
\hline Malaysia & 8.3 & $(2011-2015)$ & 6.0 & $(2011-2015)$ \\
\hline Myanmar & & & & \\
\hline Philippines & 5.1 & $(2012-2015)$ & 2.6 & $(2012-2015)$ \\
\hline Singapore & & & & \\
\hline Thailand & 2.5 & $(2014-2017)$ & 2.1 & $(2014-2017)$ \\
\hline Viet Nam & 4.9 & $(2012-2016)$ & 4.8 & $(2012-2016)$ \\
\hline The Pacific & & & & \\
\hline Cook Islands & & & & \\
\hline Fiji & 1.2 & $(2008-2013)$ & -0.5 & $(2008-2013)$ \\
\hline Kiribati & & & $\ldots$ & \\
\hline Marshall Islands & $\ldots$ & & $\ldots$ & \\
\hline Micronesia, Federated States of & & & & \\
\hline Nauru & $\ldots$ & & $\ldots$ & \\
\hline Nive & & & & \\
\hline Palau & & & & \\
\hline Papua New Guinea & & & $\ldots$ & \\
\hline Samoa & & & & \\
\hline Solomon Islands & . & & .. & \\
\hline Timor-Leste & & & & \\
\hline Tonga & 1.0 & $(2009-2015)$ & 0.6 & $(2009-2015)$ \\
\hline Tuvalu & & & & \\
\hline Vanuatu & & & & \\
\hline Developed ADB Member Economies & & & & \\
\hline Australia & $\ldots$ & & $\ldots$ & \\
\hline Japan & & & & \\
\hline New Zealand & & & & \\
\hline
\end{tabular}

$\ldots=$ data not available, $-0.0=$ magnitude is less than half of unit employed, $A D B=A$ sian Development Bank

a Based on real mean per capita consumption or income measured at 2011 purchasing power parity, using the PovcalNet database (http://iresearch.worldbank.org/PovcalNet). Data reported are based on consumption, except for Malaysia and the Philippines, which are based on income.

b For the data collection periods, the initial year refers to the nearest survey collected 5 years before the most recent survey available; only surveys collected between 3 and 7 years before the most recent survey are considered. The final year refers to the most recent survey available between 2014 and 2018.

Source: United Nations Statistics Division. Sustainable Development Goals (SDGs), SDG Indicators, Global Database. https://unstats.un.org/sdgs/indicators/database/ (accessed 8 July 2019). 
Table 1.11.1: Selected Indicators for Sustainable Development Goal 11-Sustainable Cities and Environment

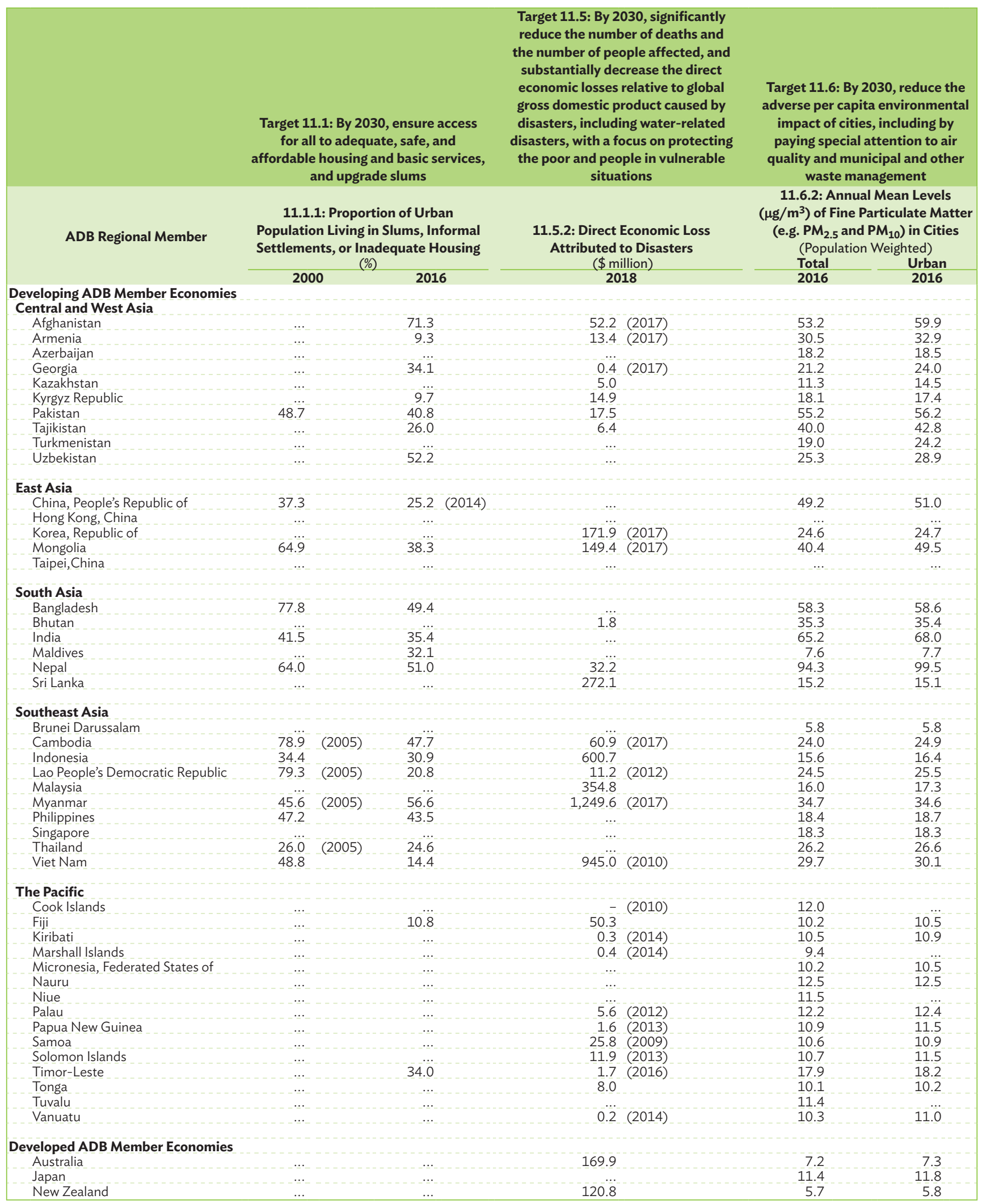

$\ldots=$ data not available, $-=$ magnitude equals zero, $\$=$ United States dollars, $\mathrm{ADB}=$ Asian Development Bank, $\mathrm{m}^{3}=$ cubic meter, $\mathrm{PM}=$ particulate matter, $\mu \mathrm{g}=$ microgram.

Source: United Nations Statistics Division. Sustainable Development Goals (SDGs), SDG Indicators, Global Database. https://unstats.un.org/sdgs/indicators/database/ (accessed 8 July 2019). 
Table 1.12.1: Selected Indicators for Sustainable Development Goal 12-Responsible Consumption and Production

\begin{tabular}{|c|c|c|c|c|c|c|c|c|}
\hline \multirow{4}{*}{ ADB Regional Member } & \multicolumn{8}{|c|}{ Target 12.2: By 2030, achieve the sustainable management and efficient use of natural resources } \\
\hline & \multicolumn{4}{|c|}{ 12.2.1: Material Footprint } & \multicolumn{4}{|c|}{ 12.2.2: Domestic Material Consumption } \\
\hline & \multicolumn{2}{|c|}{$\begin{array}{c}\text { All } \\
\text { (t million) }\end{array}$} & \multicolumn{2}{|c|}{$\begin{array}{c}\text { Per Capita } \\
(\mathrm{t})\end{array}$} & \multicolumn{2}{|c|}{$\begin{array}{l}\text { All } \\
\text { (t million) }\end{array}$} & \multicolumn{2}{|c|}{$\begin{array}{c}\text { Per Capita } \\
(\mathrm{t})\end{array}$} \\
\hline & 2000 & 2017 & 2000 & 2017 & 2000 & 2017 & 2000 & 2017 \\
\hline \multicolumn{9}{|l|}{$\begin{array}{l}\text { Developing ADB Member Economies } \\
\text { Central and West Asia }\end{array}$} \\
\hline Afghanistan & 11.9 & 42.6 & 0.6 & 1.2 & 46.0 & 67.9 & 2.3 & 1.9 \\
\hline Armenia & 7.2 & 24.0 & 2.3 & 8.2 & 13.8 & 32.5 & 4.5 & 11.1 \\
\hline Azerbaijan & 20.4 & 61.8 & 2.5 & 6.3 & 30.1 & 90.1 & 3.7 & 9.2 \\
\hline Georgia & 14.2 & 35.6 & 3.0 & 9.1 & 13.3 & 26.5 & 2.8 & 6.8 \\
\hline Kazakhstan & 172.8 & 325.2 & 11.5 & 17.9 & 249.3 & 530.4 & 16.6 & 29.1 \\
\hline Kyrgyz Republic & 29.2 & 48.1 & 5.9 & 8.0 & 32.0 & 50.6 & 6.5 & 8.4 \\
\hline Pakistan & 354.7 & 627.0 & 2.6 & 3.2 & 514.2 & 875.8 & 3.7 & 4.4 \\
\hline Tajikistan & 4.5 & 33.3 & 0.7 & 3.7 & 10.2 & 31.2 & 1.6 & 3.5 \\
\hline Turkmenistan & 45.0 & 124.3 & 10.0 & 21.6 & 43.4 & 94.9 & 9.6 & 16.5 \\
\hline Uzbekistan & 115.4 & 197.4 & 4.6 & 6.2 & 195.5 & 289.2 & 7.9 & 9.1 \\
\hline \multicolumn{9}{|l|}{ East Asia } \\
\hline China, People's Republic of & $8,864.7$ & $27,670.5$ & 6.9 & 19.6 & $11,782.8$ & $35,101.0$ & 9.2 & 24.9 \\
\hline Hong Kong, China & & & & & $\ldots$ & $\ldots$ & $\ldots$ & $\ldots$ \\
\hline Korea, Republic of & $1,056.5$ & $1,346.1$ & 22.3 & 26.4 & 746.1 & 576.9 & 15.7 & 11.3 \\
\hline Mongolia & 9.1 & 42.6 & 3.8 & 13.9 & 49.0 & 106.2 & 20.4 & 34.5 \\
\hline Taipei, China & & & & $\cdots$ & $\ldots$ & $\ldots$ & $\ldots$ & $\ldots$ \\
\hline \multicolumn{9}{|l|}{ South Asia } \\
\hline Bangladesh & 228.2 & 387.7 & 1.7 & 2.4 & 254.4 & 435.7 & 1.9 & 2.6 \\
\hline Bhutan & 2.6 & 8.4 & 4.5 & 10.4 & 4.7 & 8.4 & 8.3 & 10.4 \\
\hline India & $2,941.9$ & $6,135.9$ & 2.8 & 4.6 & $3,866.5$ & $7,403.2$ & 3.7 & 5.5 \\
\hline Maldives & 1.8 & 6.4 & 6.3 & 14.6 & 1.2 & 3.0 & 4.1 & 6.8 \\
\hline Nepal & 30.3 & 79.2 & 1.3 & 2.7 & 61.7 & 111.6 & 2.6 & 3.8 \\
\hline Sri Lanka & 37.0 & 79.7 & 2.0 & 3.8 & 57.9 & 107.4 & 3.1 & 5.1 \\
\hline \multicolumn{9}{|l|}{ Southeast Asia } \\
\hline Brunei Darussalam & 4.2 & 8.2 & 12.6 & 19.1 & 5.8 & 9.8 & 17.3 & 22.9 \\
\hline Cambodia & 20.2 & 57.2 & 1.7 & 3.6 & 26.9 & 84.6 & 2.2 & 5.3 \\
\hline Indonesia & 711.4 & $1,643.6$ & 3.4 & 6.2 & $1,156.3$ & $1,972.5$ & 5.5 & 7.5 \\
\hline Lao People's Democratic Republic & 6.7 & 50.6 & 1.3 & 7.4 & 13.7 & 82.2 & 2.6 & 12.0 \\
\hline Malaysia & 445.0 & 714.9 & 19.2 & 22.6 & 387.9 & 517.8 & 16.7 & 16.4 \\
\hline Myanmar & 24.5 & 79.9 & 0.5 & 1.5 & 106.9 & 187.6 & 2.3 & 3.5 \\
\hline Philippines & 311.9 & 455.5 & 4.0 & 4.3 & 295.0 & 415.7 & 3.8 & 4.0 \\
\hline Singapore & 200.2 & 417.0 & 51.1 & 73.0 & 259.8 & 186.1 & 66.4 & 32.6 \\
\hline Thailand & 487.8 & $1,029.0$ & 7.7 & 14.9 & 477.3 & 879.1 & 7.6 & 12.7 \\
\hline Viet Nam & 274.9 & 956.6 & 3.4 & 10.0 & 332.2 & $1,049.5$ & 4.1 & 11.0 \\
\hline \multicolumn{9}{|l|}{ The Pacific } \\
\hline \multicolumn{9}{|l|}{ Cook Islands } \\
\hline Fiji & 4.4 & 6.4 & 5.4 & 7.0 & 8.1 & 5.5 & 10.0 & 6.1 \\
\hline Kiribati & -1 & & $\ldots$ & & 0.4 & 0.7 & 4.2 & 6.3 \\
\hline Marshall Islands & $\ldots$ & & $\ldots$ & $\ldots$ & 0.0 & 0.1 & 0.4 & 2.0 \\
\hline Micronesia, Federated States of & $\ldots$ & $\ldots$ & $\ldots$ & $\ldots$ & 0.2 & 0.2 & 1.4 & 2.3 \\
\hline \multicolumn{9}{|l|}{ Nauru } \\
\hline Niue & & & & & $\cdots$ & $\ldots$ & & \\
\hline Palau & & & & & 0.0 & 0.0 & 0.2 & 1.2 \\
\hline Papua New Guinea & 11.6 & 21.3 & 2.1 & 2.6 & 76.9 & 83.8 & 13.8 & 10.2 \\
\hline Samoa & 0.7 & 1.7 & 4.1 & 8.4 & 0.7 & 1.0 & 4.0 & 5.3 \\
\hline Solomon Islands & & & & & 2.2 & 4.3 & 5.4 & 7.0 \\
\hline Timor-Leste & & & $\ldots$ & $\ldots$ & 0.9 & 10.0 & 1.1 & 7.7 \\
\hline Tonga & & & & & 0.3 & 1.8 & 3.4 & 16.9 \\
\hline Tuvalu & & & $\ldots$ & $\ldots$ & 0.0 & 0.0 & 0.9 & 1.1 \\
\hline Vanuatu & 0.6 & 2.2 & 3.4 & 7.9 & 1.0 & 1.7 & 5.3 & 6.1 \\
\hline Developed ADB Member Economies & & & & & & & & \\
\hline Australia & 643.6 & $1,050.7$ & 33.8 & 43.0 & 868.2 & 927.3 & 45.5 & 37.9 \\
\hline Japan & $3,539.6$ & $3,138.5$ & 27.8 & 24.6 & $1,571.5$ & $1,139.9$ & 12.3 & 8.9 \\
\hline New Zealand & 82.0 & 114.5 & 21.2 & 24.3 & 95.7 & 113.3 & 24.8 & 24.1 \\
\hline
\end{tabular}

$\ldots=$ data not available, $0.0=$ magnitude is less than half of unit employed, $\mathrm{ADB}=$ Asian Development Bank, $\mathrm{t}=$ metric ton.

Source: $\quad$ For Indicator 12.2.1: Organisation for Economic Co-operation and Development. OECD Statistics - Material Resources. hhttps://stats.oecd.org/ (accessed 22 July 2019). For Indicator 12.2.2: United Nations Statistics Division. Sustainable Development Goals (SDGs), SDG Indicators, Global Database. https://unstats.un.org/sdgs/indicators/database/ (accessed 8 July 2019). 
Table 1.13.1: Selected Indicators for Sustainable Development Goal 13-Impact of Disasters and Risk Reduction Strategies

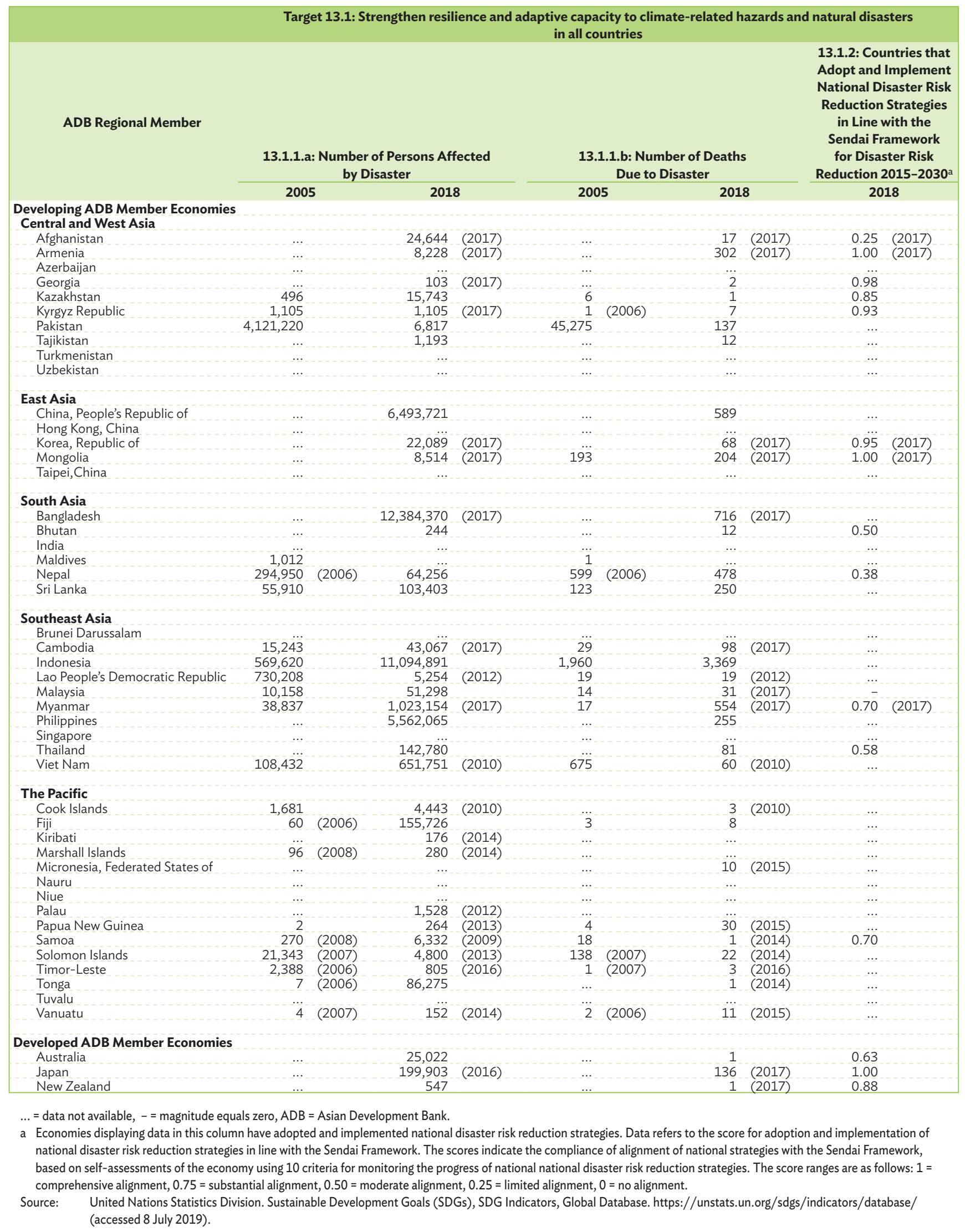


Goal 14. Conserve and sustainably use the oceans, seas, and marine resources for sustainable development

Table 1.14.1: Selected Indicators for Sustainable Development Goal 14-Life Below Water

\begin{tabular}{|c|c|c|c|}
\hline \multirow{3}{*}{ ADB Regional Member } & \multicolumn{3}{|c|}{$\begin{array}{l}\text { Target 14.5: By 2020, conserve at least 10\% of coastal and marine areas, consistent with national and international law } \\
\text { and based on the best available scientific information }\end{array}$} \\
\hline & $\begin{array}{c}\text { 14.5.1.a: Average Proportion of } \\
\text { Marine Key Biodiversity Areas } \\
\text { Covered by Protected Areas } \\
(\%)\end{array}$ & $\begin{array}{l}\text { 14.5.1.b: Coverage of Protected } \\
\text { Areas in Relation to Marine Areas } \\
\text { (Exclusive Economic Zones) } \\
(\%)\end{array}$ & $\begin{array}{l}\text { 14.5.1.c: Protected Marine Areas } \\
\text { (Exclusive Economic Zones) } \\
\left(\mathrm{km}^{2}\right)\end{array}$ \\
\hline & 2018 & 2018 & 2018 \\
\hline \\
\hline \multirow{2}{*}{\multicolumn{4}{|c|}{$\begin{array}{l}\text { Central and West Asia } \\
\text { Afghanistan }\end{array}$}} \\
\hline & & & \\
\hline \multicolumn{4}{|l|}{ Armenia } \\
\hline Azerbaijan & & 0.4 & 345.4 \\
\hline Georgia & 26.5 & 0.7 & 153.0 \\
\hline Kazakhstan & & 1.0 & $1,249.5$ \\
\hline \multicolumn{4}{|l|}{ Kyrgyz Republic } \\
\hline Pakistan & 39.3 & 0.8 & $1,707.4$ \\
\hline \multicolumn{4}{|l|}{ Tajikistan } \\
\hline Turkmenistan & ... & 3.0 & $2,331.8$ \\
\hline \multicolumn{4}{|l|}{ Uzbekistan } \\
\hline \multicolumn{4}{|l|}{ East Asia } \\
\hline China, People's Republic of & 21.7 & 5.4 & $47,502.6$ \\
\hline Hong Kong, China & 43.6 & & 62.8 \\
\hline Korea, Republic of & 24.2 & 1.6 & $5,308.8$ \\
\hline \multicolumn{4}{|l|}{ Mongolia } \\
\hline \multicolumn{4}{|l|}{ Taipei,China } \\
\hline \multicolumn{4}{|l|}{ South Asia } \\
\hline Bangladesh & 34.5 & 5.3 & $4,458.4$ \\
\hline \multicolumn{4}{|l|}{ Bhutan } \\
\hline India & 37.7 & 0.2 & $3,962.3$ \\
\hline Maldives & - & 0.1 & 474.9 \\
\hline \multicolumn{4}{|l|}{ Nepal } \\
\hline Sri Lanka & 43.4 & 0.1 & 398.6 \\
\hline \multicolumn{4}{|l|}{ Southeast Asia } \\
\hline Brunei Darussalam & 60.9 & 0.2 & 51.6 \\
\hline Cambodia & 19.2 & 0.2 & 89.1 \\
\hline Indonesia & 23.4 & 3.1 & $181,846.6$ \\
\hline \multicolumn{4}{|l|}{ Lao People's Democratic Republic } \\
\hline Malaysia & 28.5 & 1.0 & $4,709.0$ \\
\hline Myanmar & 21.4 & 2.3 & $11,964.4$ \\
\hline Philippines & 44.2 & 1.2 & $21,267.4$ \\
\hline Singapore & 3.3 & 0.0 & 0.1 \\
\hline Thailand & 60.4 & 1.9 & $5,773.8$ \\
\hline Viet Nam & 44.2 & 0.6 & $3,630.3$ \\
\hline \multicolumn{4}{|l|}{ The Pacific } \\
\hline Cook Islands & 28.3 & 100.0 & $1,972,774.8$ \\
\hline Fiji & 15.9 & 0.9 & $11,959.0$ \\
\hline Kiribati & 40.2 & 11.8 & $408,793.3$ \\
\hline Marshall Islands & 12.3 & 0.3 & $5,388.4$ \\
\hline Micronesia, Federated States of & 1.6 & 0.0 & 475.1 \\
\hline \multicolumn{4}{|l|}{ Nauru } \\
\hline Niue & & 0.0 & 36.9 \\
\hline Palau & $\ldots$ & 83.0 & $504,690.9$ \\
\hline Papua New Guinea & 1.9 & 0.2 & $4,585.5$ \\
\hline Samoa & 11.9 & 0.1 & 114.8 \\
\hline Solomon Islands & 9.4 & 0.1 & $1,900.4$ \\
\hline Timor-Leste & 18.8 & 1.4 & 584.1 \\
\hline Tonga & 5.9 & 1.5 & $10,055.2$ \\
\hline Tuvalu & & 0.0 & 62.1 \\
\hline Vanuatu & 4.7 & 0.0 & 47.5 \\
\hline Developed ADB Member Economi & & & \\
\hline Australia & 66.0 & 40.6 & $3,014,642.6$ \\
\hline Japan & 73.5 & 8.2 & $331,976.8$ \\
\hline New Zealand & 44.6 & 29.7 & $1,221,615.5$ \\
\hline
\end{tabular}

$\ldots=$ data not available, - = magnitude equals zero, $0.0=$ magnitude is less than half of unit employed, $\mathrm{ADB}=$ Asian Development Bank, $\mathrm{km}^{2}=\mathrm{square}$ kilometer.

Source: United Nations Statistics Division. Sustainable Development Goals (SDGs), SDG Indicators, Global Database. https://unstats.un.org/sdgs/indicators/database/ (accessed 8 July 2019). 
Goal 15. Protect, restore, and promote sustainable use of terrestrial ecosystems; sustainably manage forests; combat desertification and halt and reverse land degradation; and halt biodiversity loss

Table 1.15.1: Selected Indicators for Sustainable Development Goal 15-Protection of Ecosystems and Biodiversity

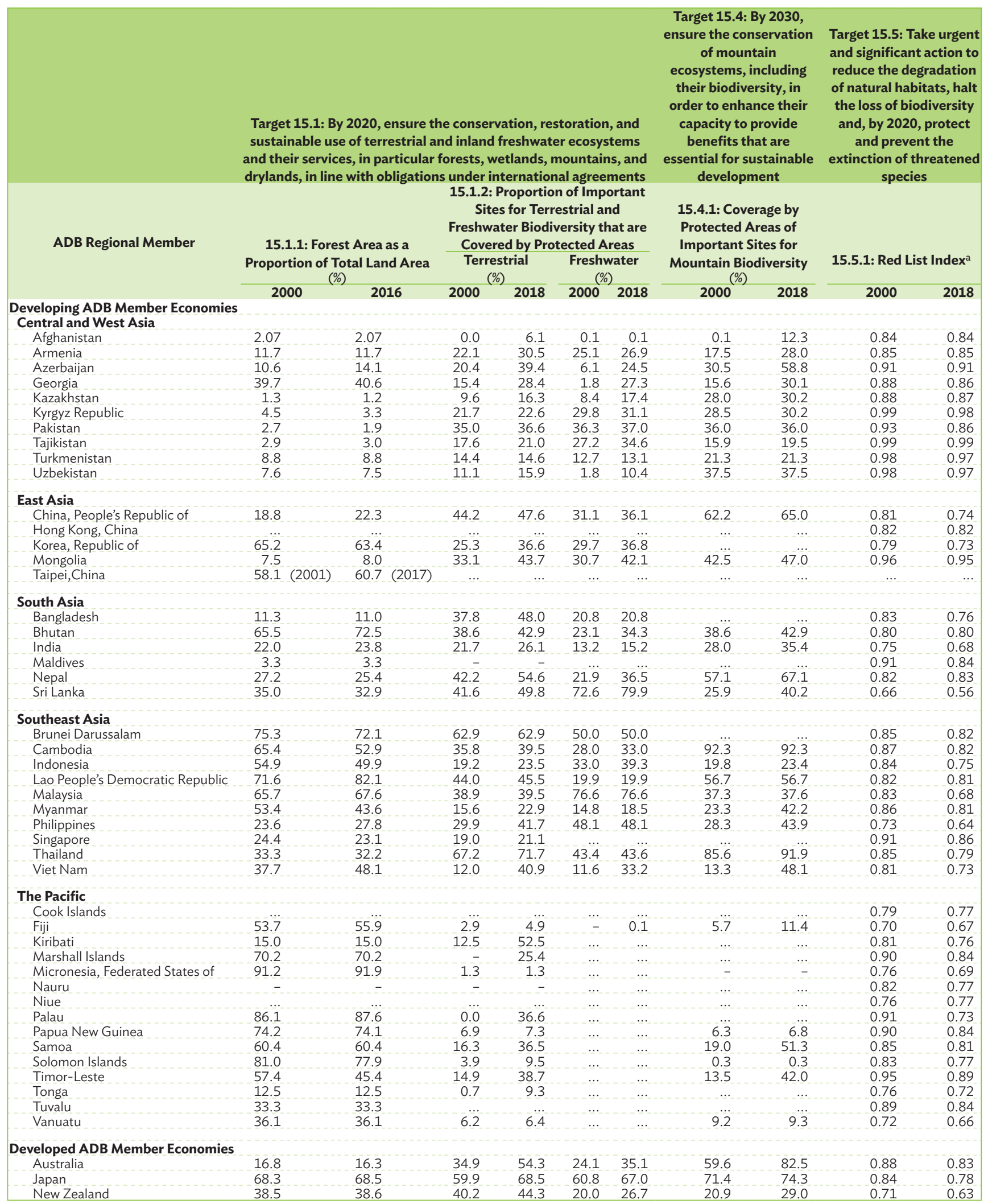

... = data not available, 0.0 = magnitude is less than half of unit employed, - = magnitude equals zero, $A D B=$ Asian Development Bank.

a The Red List Index midpoint value ranges from 1, which means all species are categorized as 'Least Concern' hence that none are expected to go extinct in the near future, to 0 meaning all species are categorized as 'Extinct'. The index therefore indicates how far the set of species has moved overall towards extinction.

Source: $\quad$ For Indicator 15.1.1, Indicator 15.1.2, and Indicator 15.4.1: United Nations Environment Programme. Environment Live Statistics. https://environmentlive.unep.org/ statistics (accessed 7 August 2019). For Indicator 15.1.1 for Taipei,China: Directorate-General of Budget, Accounting and Statistics. https://eng.stat.gov.tw/ (accessed 22 July 2019). For Indicator 15.5.1: United Nations Statistics Division. Sustainable Development Goals (SDGs), SDG Indicators, Global Database. https://unstats. un.org/sdgs/indicators/database/ (accessed 8 July 2019). 
Goal 16. Promote peaceful and inclusive societies for sustainable development; provide access to justice for all; and build effective, accountable, and inclusive institutions at all levels

\section{Table 1.16.1: Selected Indicators for Sustainable Development Goal 16-Peace, Justice, and Strong Institutions}

\begin{tabular}{|c|c|c|c|c|c|c|c|c|c|c|}
\hline \multirow{3}{*}{ ADB Regional Member } & \multicolumn{4}{|c|}{$\begin{array}{l}\text { Target 16.1: Significantly reduce } \\
\text { all forms of violence and related } \\
\text { death rates everywhere }\end{array}$} & \multicolumn{2}{|c|}{$\begin{array}{l}\text { Target 16.3: Promote the } \\
\text { rule of law at the national } \\
\text { and international levels } \\
\text { and ensure equal access } \\
\text { to justice for all }\end{array}$} & \multicolumn{2}{|c|}{$\begin{array}{c}\text { Target 16.5: } \\
\text { Substantially reduce } \\
\text { corruption and bribery } \\
\text { in all their forms }\end{array}$} & \multicolumn{2}{|c|}{$\begin{array}{l}\text { Target 16.9: By 2030, } \\
\text { provide legal identity } \\
\text { for all, including birth } \\
\text { registration }\end{array}$} \\
\hline & \multicolumn{4}{|c|}{$\begin{array}{l}\text { 16.1.1: Number of Victims of } \\
\text { Intentional Homicide } \\
\text { (per } 100,000 \text { population) }\end{array}$} & \multicolumn{2}{|c|}{$\begin{array}{c}\text { 16.3.2: Unsentenced } \\
\text { Detainees as a Proportion } \\
\text { of Overall Prison } \\
\text { Population } \\
(\%)\end{array}$} & \multirow{2}{*}{\multicolumn{2}{|c|}{$\begin{array}{c}\text { 16.5.2: Proportion of } \\
\text { Firms Experiencing } \\
\text { at least One Bribe } \\
\text { Payment Request } \\
(\%) \\
2013\end{array}$}} & \multicolumn{2}{|c|}{$\begin{array}{l}\text { 16.9.1: Proportion of } \\
\text { Children Under } 5 \text { Years } \\
\text { of Age Whose Births } \\
\text { have been Registered } \\
\text { with a Civil Authority } \\
(\%)\end{array}$} \\
\hline & & & & & $2005^{b}$ & $2017^{c}$ & & & & \\
\hline \multicolumn{11}{|l|}{$\begin{array}{l}\text { Developing ADB Member Economies } \\
\text { Central and West Asia }\end{array}$} \\
\hline Afghanistan & & & 7.1 & & 81.0 & 30.8 & 46.8 & (2014) & 42.3 & (2015) \\
\hline Armenia & 3.0 & & 2.4 & & 28.1 & 32.1 & 7.1 & & 99.3 & (2016) \\
\hline Azerbaijan & 2.8 & & 2.0 & & 12.0 & 17.2 & 15.9 & & & \\
\hline Georgia & 5.1 & & 1.0 & (2016) & 52.9 & 13.1 & 2.2 & & 99.6 & (2015) \\
\hline Kazakhstan & $15.4^{d}$ & & $5.0^{\circ}$ & & 15.6 & 15.1 & 26.7 & & 99.7 & (2015) \\
\hline Kyrgyz Republic & 8.7 & & 4.2 & & 16.2 & 18.4 & 59.8 & & 97.7 & (2014) \\
\hline Pakistan & 6.4 & & 4.2 & & 57.8 & 67.0 & 30.8 & & 33.6 & (2013) \\
\hline Tajikistan & 4.6 & & 1.6 & (2011) & & $\ldots$ & 36.3 & & 95.8 & \\
\hline Turkmenistan & 5.9 & & & & $\ldots$ & & & & 99.6 & (2016) \\
\hline Uzbekistan & 4.3 & & 1.1 & & & & 7.0 & & & \\
\hline \multicolumn{11}{|l|}{ East Asia } \\
\hline China, People's Republic of & 2.1 & & 0.6 & & & & 11.6 & (2012) & & \\
\hline Hong Kong, China & 0.6 & & 0.3 & & 11.5 & 20.3 & & & & \\
\hline Korea, Republic of & 0.8 & & 0.6 & & 34.2 & 35.7 & & & & \\
\hline Mongolia & 13.9 & (2003) & 6.2 & & 18.8 & 19.8 & 33.4 & & 99.3 & (2013) \\
\hline Taipei,China & 1.4 & (2001) & 0.8 & (2015) & & $\cdots$ & $\cdots$ & & 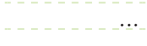 & \\
\hline \multicolumn{11}{|l|}{ South Asia } \\
\hline Bangladesh & 2.5 & & 2.2 & & 64.0 & 78.5 & 47.7 & & 20.2 & (2014) \\
\hline Bhutan & 3.1 & & 1.6 & & & & 0.9 & (2015) & 99.9 & $(2010)$ \\
\hline India & 4.6 & & 3.2 & (2016) & 67.9 & 67.2 & 22.7 & (2014) & 79.7 & (2016) \\
\hline Maldives & 2.4 & (2001) & 0.8 & (2013) & & & & & 92.5 & (2009) \\
\hline Nepal & 2.7 & & 2.2 & (2016) & & & 14.4 & & 56.2 & (2016) \\
\hline Sri Lanka & $6.8^{d}$ & (2003) & 2.30 & & 52.4 & 55.3 & 10.0 & (2011) & & \\
\hline \multicolumn{11}{|l|}{ Southeast Asia } \\
\hline Brunei Darussalam & 1.2 & & 0.5 & (2013) & 7.2 & 7.1 & & & & \\
\hline Cambodia & 4.7 & & 1.8 & (2011) & 32.6 & 28.3 & 64.7 & (2016) & 73.3 & (2014) \\
\hline Indonesia & 1.0 & & 0.4 & & 46.6 & 32.0 & 30.6 & (2015) & 71.9 & (2018) \\
\hline Lao People's Democratic Republic & & & & & & & 40.3 & (2018) & 73.0 & \\
\hline Malaysia & 2.4 & & 2.1 & (2013) & 33.8 & 29.3 & 28.2 & (2015) & & \\
\hline Myanmar & 2.3 & & 2.3 & (2016) & & & 29.3 & (2016) & 81.3 & (2016) \\
\hline Philippines & $7.4^{d}$ & & $8.4^{\mathrm{C}}$ & & 66.7 & 73.0 & 17.2 & (2015) & 91.8 & \\
\hline Singapore & 1.0 & & 0.2 & & 4.1 & 10.9 & & & & \\
\hline Thailand & 8.2 & & 3.2 & (2016) & 24.6 & 18.2 & 9.9 & (2016) & 99.5 & (2016) \\
\hline Viet Nam & 1.2 & (2001) & 1.5 & (2011) & & & 26.1 & (2015) & 96.1 & (2014) \\
\hline \multicolumn{11}{|l|}{ The Pacific } \\
\hline Cook Islands & & & 3.5 & (2012) & 3.7 & 17.7 & & & & \\
\hline Fiji & 3.1 & $(2003)$ & 2.3 & (2014) & 8.7 & 28.0 & 10.5 & (2009) & & \\
\hline Kiribati & 3.6 & & 7.5 & (2012) & 2.6 & 5.1 & & & 93.5 & (2009) \\
\hline Marshall Islands & $\ldots$ & & $\ldots$ & & $\ldots$ & $\ldots$ & & & 83.8 & \\
\hline Micronesia, Federated States of & $\ldots$ & & $\ldots$ & & & & 4.5 & (2009) & & \\
\hline Nauru & $\ldots$ & & $\ldots$ & & $-t$ & . & $\ldots$ & - & 95.9 & (2013) \\
\hline Niue & -1 & & & & & & & & & \\
\hline Palau & & & & & & & & & & \\
\hline Papua New Guinea & 8.3 & & 10.0 & (2010) & 31.3 & 38.1 & 26.4 & (2015) & & \\
\hline Samoa & & & 3.1 & (2013) & & & 30.5 & (2009) & 58.6 & (2014) \\
\hline Solomon Islands & 4.4 & (2004) & & & 35.4 & 50.2 & 43.8 & (2015) & 88.0 & (2015) \\
\hline Timor-Leste & 2.3 & (2004) & 3.9 & (2015) & 64.7 & 24.0 & 44.2 & (2015) & 60.4 & (2016) \\
\hline Tonga & 1.0 & & 1.0 & (2012) & 2.6 & 7.4 & 24.9 & (2009) & 93.4 & (2012) \\
\hline Tuvalu & - & (2002) & 18.6 & (2012) & & & & & & \\
\hline Vanuatu & $\ldots$ & & $\ldots$ & & 22.5 & 20.4 & 11.9 & (2009) & 43.4 & (2013) \\
\hline \multicolumn{11}{|l|}{ Developed ADB Member Economies } \\
\hline Australia & 1.9 & & 0.8 & & 20.4 & 30.1 & & & 100.0 & (2013) \\
\hline Japan & 0.5 & & 0.2 & & 15.0 & 11.1 & & & 100.0 & (2013) \\
\hline New Zealand & $1.3^{d}$ & & $0.7 \mathrm{~d}$ & & 18.4 & 22.3 & & & 100.0 & (2014) \\
\hline
\end{tabular}

$\ldots$... data not available, - = magnitude equals zero, $\mathrm{ADB}=$ Asian Development Bank.

a Changes in the definition of birth registration were made from the second and third rounds of Multiple Indicator Cluster Surveys (MICS2 and MICS3) to the fourth round (MICS4). In order to allow for comparability with the latter round, data from MICS2 and MICS3 on birth registration were recalculated according to the MICS4 indicator definition. Therefore, the recalculated data presented here may differ from estimates included in MICS2 and MICS3 national reports.

b For 2005, data refer to a 3-year average for 2003-2005.

c For 2017, data refer to a 3-year average for 2015-2017.

d For Kazakhstan, the Philippines, and Sri Lanka: Changes in definitions and/or counting rules are reported by the Member State to indicate a break in the time series. For New Zealand: For 2000-2006, data refer to offences; for 2007 onward, data refer to victims of intentional homicide.

Sources: $\quad$ For Indicator 16.1.1: United Nations Office on Drugs and Crime. Statistics Online. https://dataunodc.un.org/ (accessed 24 July 2019). For Indicators 16.3.2, 16.5.2, and 16.9.1: United Nations Statistics Division. Sustainable Development Goals (SDGs), SDG Indicators, Global Database. https://unstats.un.org/sdgs/indicators/ database/ (accessed 8 July 2019). 
Goal 17. Strengthen the means of implementation and revitalize the Global Partnership for Sustainable Development

Table 1.17.1: Selected Indicators for Sustainable Development Goal 17-Financial Sustainability of Developing Countries

\begin{tabular}{|c|c|c|c|c|}
\hline \multirow{3}{*}{ ADB Regional Member } & \multicolumn{2}{|c|}{$\begin{array}{l}\text { Target 17.4: Assist developing countries in attaining long-term } \\
\text { debt sustainability through coordinated policies aimed at } \\
\text { fostering debt financing, debt relief, and debt restructuring, as } \\
\text { appropriate, and address the external debt of highly indebted } \\
\text { poor countries to reduce debt distress }\end{array}$} & \multicolumn{2}{|c|}{$\begin{array}{l}\text { Target 17.9: Enhance international support for } \\
\text { implementing effective and targeted capacity- } \\
\text { building in developing countries to support } \\
\text { national plans to implement all the Sustainable } \\
\text { Development Goals, including through North- } \\
\text { South, South-South, and triangular cooperation }\end{array}$} \\
\hline & \multicolumn{2}{|c|}{$\begin{array}{l}\text { 17.4.1: Debt Service as a Proportion of Exports } \\
\text { of Goods and Services } \\
\text { (\%) }\end{array}$} & \multicolumn{2}{|c|}{$\begin{array}{l}\text { 17.9.1: Dollar Value of Financial and } \\
\text { Technical Assistance Committed } \\
\text { to Developing Countries }{ }^{\mathrm{a}} \\
\text { (constant } 2017 \$ \text { million) }\end{array}$} \\
\hline & 2000 & 2017 & $\begin{array}{c}\text { Average, } \\
2000-2008\end{array}$ & $\begin{array}{l}\text { Average, } \\
\text { 2009-2017 }\end{array}$ \\
\hline \multicolumn{5}{|l|}{$\begin{array}{l}\text { Developing ADB Member Economies } \\
\text { Central and West Asia }\end{array}$} \\
\hline Afghanistan & $0.5 \quad(2008)$ & 3.8 & 562.1 & $1,404.7$ \\
\hline Armenia & 8.2 & 5.3 & 64.9 & 94.0 \\
\hline Azerbaijan & 5.5 & 7.6 & 32.1 & 95.7 \\
\hline Georgia & 12.2 & 6.7 & 80.5 & 130.6 \\
\hline Kazakhstan & 8.8 & 3.3 & 55.7 & 303.5 \\
\hline Kyrgyz Republic & 9.8 & 6.1 & 50.9 & 90.5 \\
\hline Pakistan & 21.1 & 20.1 & 364.7 & 893.9 \\
\hline Tajikistan & 9.1 (2002) & 6.5 & 29.8 & 40.5 \\
\hline Turkmenistan & $\ldots-2-2$ & $\ldots$ & 6.1 & 6.2 \\
\hline Uzbekistan & & & 37.1 & 145.6 \\
\hline \multicolumn{5}{|l|}{ East Asia } \\
\hline China, People's Republic of & 7.1 & 0.6 & 332.4 & 630.6 \\
\hline $\begin{array}{l}\text { Hong Kong, China } \\
\text { Korea, Republic of }\end{array}$ & $\cdots$ & $\cdots$ & $\ldots$ & \\
\hline Mongolia & 6.5 & 4.2 & 38.2 & 169.0 \\
\hline Taipei,China & & & & \\
\hline \multicolumn{5}{|l|}{ South Asia } \\
\hline Bangladesh & 10.3 & 3.5 & 235.7 & 439.8 \\
\hline Bhutan & $2.5 \quad(2006)$ & 10.1 & 15.1 & 22.4 \\
\hline India & 15.4 & 2.9 & 477.9 & 627.9 \\
\hline Maldives & 4.0 & 2.4 & 3.6 & 9.2 \\
\hline Nepal & 7.4 & 7.4 & 79.4 & 163.8 \\
\hline Sri Lanka & 10.9 & 19.3 & 111.3 & 112.5 \\
\hline \multicolumn{5}{|l|}{ Southeast Asia } \\
\hline Brunei Darussalam & & & & \\
\hline Cambodia & 0.7 & 1.3 & 87.2 & 124.5 \\
\hline Indonesia & 11.2 & 9.2 & 641.1 & $1,310.1$ \\
\hline Lao People's Democratic Republic & 7.9 & 8.9 & 47.1 & 76.5 \\
\hline Malaysia & & & 17.7 & 14.0 \\
\hline Myanmar & 1.0 & 5.1 & 15.7 & 171.1 \\
\hline Philippines & 14.6 & 5.3 & 135.0 & 362.8 \\
\hline Singapore & & & & \\
\hline Thailand & 5.8 & 0.2 & 46.1 & 66.2 \\
\hline Viet Nam & 7.2 & 1.4 & 305.9 & 690.2 \\
\hline \multicolumn{5}{|l|}{ The Pacific } \\
\hline Cook Islands & & & 2.3 & 4.4 \\
\hline Fiji & 2.5 & 2.3 & 16.6 & 16.9 \\
\hline Kiribati & & & 8.6 & 8.8 \\
\hline Marshall Islands & $\ldots$ & $\ldots$ & 18.4 & 9.2 \\
\hline Micronesia, Federated States of & $\ldots$ & & 39.3 & 22.6 \\
\hline Nauru & $\ldots$ & $\ldots$ & 9.2 & 8.8 \\
\hline Niue & $\ldots$ & $\ldots$ & 1.7 & 6.7 \\
\hline Palau & & & 1.7 & 3.2 \\
\hline Papua New Guinea & 8.0 & 1.3 & 95.2 & 162.0 \\
\hline Samoa & $5.5 \quad(2004)$ & 8.9 & 15.7 & 33.6 \\
\hline Solomon Islands & 2.8 & 1.5 & 80.2 & 69.0 \\
\hline Timor-Leste & $-(2006)$ & 0.1 & 53.9 & 47.4 \\
\hline Tonga & $9.8 \quad(2001)$ & 9.9 & 10.6 & 14.4 \\
\hline Tuvalu & & & 3.3 & 4.0 \\
\hline Vanuatu & 1.4 & $2.0 \quad(2016)$ & 13.3 & 19.4 \\
\hline \multicolumn{5}{|l|}{$\begin{array}{l}\text { Developed ADB Member Economies } \\
\text { Australia } \\
\text { Japan } \\
\text { New Zealand }\end{array}$} \\
\hline
\end{tabular}

... = data not available, $\$=$ United States dollars, $A D B=$ Asian Development Bank.

a Technical assistance includes assistance through North-South, South-South, and triangular cooperation. United Nations Statistics Division dataset and metadata refer to this indicator as total official development assistance (gross disbursements) for technical cooperation.

Sources: $\quad$ For Indicator 17.4.1: World Bank. World Development Indicators. https://data.worldbank.org (accessed 19 July 2019). For Indicator 17.9.1: United Nations Statistics Division. Sustainable Development Goals (SDGs), SDG Indicators, Global Database. http://unstats.un.org/sdgs/indicators/database/ (accessed 8 July 2019). 
Goal 17. Strengthen the means of implementation and revitalize the Global Partnership for Sustainable Development

\section{Table 1.17.2: Selected Indicators for Sustainable Development Goal 17-Statistical Capacity Building}

\begin{tabular}{|c|c|c|c|c|}
\hline \multirow[b]{2}{*}{ ADB Regional Member } & $\begin{array}{l}\text { Target 17.18: By 2020, enhance capacity- } \\
\text { building support to developing countries, } \\
\text { including for least developed countries and } \\
\text { small island developing states, to increase } \\
\text { significantly the availability of high-quality, } \\
\text { timely, and reliable data disaggregated } \\
\text { by income, gender, age, race, ethnicity, } \\
\text { migratory status, disability, geographic } \\
\text { location, and other characteristics relevant } \\
\text { in national contexts }\end{array}$ & \multicolumn{2}{|c|}{$\begin{array}{l}\text { Target 17.19: By 2030, build on existing initiatives to develop } \\
\text { measurements of progress on sustainable development that } \\
\text { complement gross domestic product and support statistical capacity- } \\
\text { building in developing countries }\end{array}$} & \multirow{2}{*}{$\begin{array}{l}\text { tives to develop } \\
\text { evelopment that } \\
\text { t statistical capacity- } \\
\text { es } \\
\text { 17.19.2: Countries } \\
\text { that Have } \\
\text { Conducted at Least } \\
\text { One Population and } \\
\text { Housing Census in } \\
\text { the Past } 10 \text { Years } \\
\text { b } \\
\end{array}$} \\
\hline & $\begin{array}{c}\text { 17.18.3: Availability of National } \\
\text { Statistical Plan } \\
2018\end{array}$ & $\begin{array}{l}\text { 17.19.1: Valu } \\
\text { to Strengthen } \\
2006\end{array}$ & $\begin{array}{l}\text { of All Resources Made Available } \\
\text { Statistical Capacity in Developing } \\
\text { Countries } \\
\text { (current \$) }\end{array}$ & \\
\hline \multicolumn{5}{|l|}{$\begin{array}{l}\text { Developing ADB Member Economies } \\
\text { Central and West Asia }\end{array}$} \\
\hline Afghanistan & B & $2,069,400.0$ & $1,068,881.9$ & \\
\hline Armenia & $A, B, C, D$ & $56,731.7$ & $62,246.8$ & 2011 \\
\hline Azerbaijan & & $140,534.9$ & $712,524.1$ & 2009 \\
\hline Georgia & $A, \mathbb{B}, C$ & $342,978.7$ & $20,550.5$ & 2014 \\
\hline Kazakhstan & A, B, C & $372,625.0$ & $257,878.3$ & 2009 \\
\hline Kyrgyz Republic & $A, B, C, D$ & $260,060.6$ & $154,417.3$ & 2009 \\
\hline Pakistan & A, B, C & $4,933,085.6$ & $1,172,347.8$ & 2017 \\
\hline Tajikistan & $C, D, E$ & $2,411,705.8$ & $219,524.2$ & 2010 \\
\hline Turkmenistan & & $279,722.6$ & $73,769.5$ & 2012 \\
\hline Uzbekistan & $A, B, C, D, E$ & $272,261.8$ & $2,002,363.0$ & $\ldots$ \\
\hline \multicolumn{5}{|l|}{ East Asia } \\
\hline China, People's Republic of & $A, B, C$ & $1,568,187.0$ & $180,924.5$ & 2010 \\
\hline $\begin{array}{l}\text { Hong Kong, China } \\
\text { Korea Republic of }\end{array}$ & $A, B, C$ & $-\ldots$ & 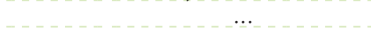 & 2016 \\
\hline $\begin{array}{l}\text { Korea, Republic of } \\
\text { Mongolia }\end{array}$ & $A, B, C, D$ & $2,994,147.0$ & $754,892.8$ & $\begin{array}{l}2015 \\
2010\end{array}$ \\
\hline Taipei,China & & & 年 & 2010 \\
\hline \multicolumn{5}{|l|}{ South Asia } \\
\hline Bangladesh & $A, B, C, D$ & $1,245,957.7$ & $1,057,761.7$ & 2011 \\
\hline Bhutan & $A, B, D$ & $598,515.6$ & $105,675.9$ & 2016 \\
\hline India & $B, C$ & $1,171,518.6$ & $1,355,733.6$ & 2011 \\
\hline Maldives & $B, C$ & $136,444.6$ & $208,525.1$ & 2014 \\
\hline Nepal & $B, C, D$ & $568,917.5$ & $1,582,385.8$ & 2011 \\
\hline Sri Lanka & D & $361,402.2$ & $938,315.0$ & 2012 \\
\hline \multicolumn{5}{|l|}{ Southeast Asia } \\
\hline Brunei Darussalam & A, C & & $4,978.0$ & 2011 \\
\hline Cambodia & C, D & $5,058,884.8$ & $2,219,806.6$ & 2008 \\
\hline Indonesia & & $795,895.3$ & $615,634.0$ & 2010 \\
\hline Lao People's Democratic Republic & B & $468,513.1$ & $507,017.1$ & 2015 \\
\hline Malaysia & & $274,242.8$ & $21,288.2$ & 2010 \\
\hline Myanmar & B & $1,187,054.1$ & $1,843,609.9$ & 2014 \\
\hline Philippines & B & $773,000.7$ & $114,773.8$ & 2015 \\
\hline Singapore & $A, B, C$ & & & 2010 \\
\hline Thailand & A, B, C & $510,883.2$ & $43,542.2$ & 2010 \\
\hline Viet Nam & B & $5,598,915.4$ & $1,055,629.5$ & 2009 \\
\hline \multicolumn{5}{|l|}{ The Pacific } \\
\hline Cook Islands & B & $43,363.3$ & $108,442.6$ & 2016 \\
\hline Fiji & & $151,154.8$ & $147,500.5$ & 2017 \\
\hline Kiribati & & $50,302.5$ & $92,853.0$ & 2015 \\
\hline Marshall Islands & $\cdots$ & $53,283.3$ & $79,617.9$ & 2011 \\
\hline Micronesia, Federated States of & & $210,191.8$ & $79,617.9$ & 2010 \\
\hline Nauru & & $34,046.5$ & $79,617.9$ & 2011 \\
\hline Niue & $\ldots$ & $44,967.1$ & $79,617.9$ & 2011 \\
\hline Palau & & $120,972.2$ & $79,617.9$ & 2015 \\
\hline Papua New Guinea & & $1,018,702.0$ & $150,531.7$ & 2011 \\
\hline Samoa & B & $174,911.1$ & $118,212.8$ & 2016 \\
\hline Solomon Islands & B & $66,377.7$ & $1,348,830.7$ & 2009 \\
\hline Timor-Leste & B & $172,795.8$ & $553,476.0$ & 2015 \\
\hline Tonga & $\cdots$ & $123,480.6$ & $79,617.9$ & 2016 \\
\hline Tuvalu & & $7,618.0$ & $89,360.3$ & 2012 \\
\hline Vanuatu & C & $489,116.6$ & $125,678.4$ & 2016 \\
\hline \multicolumn{5}{|l|}{ Developed ADB Member Economies } \\
\hline Australia & $A, B, C$ & & & 2016 \\
\hline Japan & & & & 2015 \\
\hline New Zealand & $\mathrm{A}, \mathrm{B}, \mathrm{C}, \mathrm{E}$ & & & 2013 \\
\hline
\end{tabular}

$\ldots=$ data not available, $\$=$ United States dollars, ADB = Asian Development Bank.

a $A=$ a national statistical plan fully funded, $B=$ a national statistical plan under implementation, $C=$ a national statistical plan with funding from government, $D=$ a national statistical plan with funding from donors, $\mathrm{E}=\mathrm{a}$ national statistical plan with funding from others.

b Refers to the most recent year in which a population and housing census was conducted.

Sources: United Nations Statistics Division. Sustainable Development Goals (SDGs), SDG Indicators, Global Database. http://unstats.un.org/sdgs/indicators/database/ (accessed 8 July 2019). For Taipei,China: Government of Taipei,China. Directorate-General of Budget, Accounting and Statistics. https://eng.stat.gov.tw/ (accessed 19 July 2019). 
PART II

\section{Regional Trends and Tables}



Part II of Key Indicators for Asia and the Pacific 2019 contains 100 tables depicting social, economic, and environmental trends and developments in the 49 member economies of the Asian Development Bank (ADB) located in the Asia and the Pacific region. These statistical tables are grouped into eight themes, each with a short commentary highlighting important recent developments regarding select indicators. Each theme concludes with a section on data issues and comparability, wherein issues surrounding the collection and presentation of indicators are detailed.

The eight themes are People; Economy and Output; Money, Finance, and Prices; Globalization; Transport and Communications; Energy and Electricity; Environment; and Government and Governance.

Data patterns for the key indicators are summarized and/or visualized through charts and figures. These charts and figures compare indicators across ADB member economies and depict the most recent year for which data are available, which is generally 2018. In some cases, the most recent year for which data are available is compared to either the previous year (e.g., 2017) or an earlier year (e.g., 2000 or 2005). Such comparisons help the reader identify regional, subregional, and economy-level trends. 


\section{People}

People brings together standard demographic indicators such as population size and age structure, as well as primary education attainment levels. The regional tables in this section present data on birth, death, and fertility rates; age dependency ratios; urbanization and employment; poverty and inequality; health and education resources; international migration; and the Human Development Index.

\section{Pace of population growth slows across Asia and the Pacific}

The total population of the Asia and Pacific region reached 4,180 million in 2018, up from 3,435 million in 2000. The region's share of the global population gradually decreased from $55.9 \%$ in 2000 to $54.8 \%$ in 2018, as annual population growth rates over the review period slowed in all the subregions within Asia and the Pacific, except in Central and West Asia (Figure 2.1.1).

In 2018, annual population growth rates in the Pacific (2.6\%), Central and West Asia (2.5\%), and South Asia (1.2\%) exceeded the global average (1.1\%), while annual population growth was $1.1 \%$ in Southeast Asia and $0.4 \%$ in East Asia. Populations in developed $\mathrm{ADB}$ member economies expanded at an average of only $0.1 \%$ in 2018 .

The most populous subregion in 2018 was South Asia (1,549 million). This was followed by East Asia (1,481 million), Southeast Asia (649 million), Central and West Asia (332 million), and the Pacific (13 million). In 2018, the aggregate population of the region's three developed member economiesAustralia, Japan, and New Zealand-was 156 million.
According to the United Nations (UN), India is projected to overtake the People's Republic of China (PRC) as the world's most populous economy by 2027 (UN 2019a). Together, the two economies' populations comprised $35.7 \%$ of the global total in 2018. Among the world's 10 most populous countries in 2018, 6 were located in Asia and the Pacific: the PRC (1,395 million), India (1,332 million), Indonesia (265 million), Pakistan (213 million), Bangladesh (165 million), and Japan (127 million). The ADB member economies with the smallest populations in 2018 were all located in the Pacific: Niue (1,700), Nauru (11,400), and Tuvalu (11,600).

\section{Girls are benefitting from education expansion across the region}

In the 1970s, Asia and the Pacific was home to twothirds of the world's out-of-school children. Today, about $90 \%$ of children, on average, are enrolled at the primary school level in economies across the region. ${ }^{1}$

In 2017 (or the most recent year for which data are available), 30 of the $35 \mathrm{ADB}$ developing member economies with available data had a primary education attainment ratio that met or exceeded $90 \%$ for both boys and girls. ${ }^{2}$ By comparison, in 2000 (or

For more information on education issues in Asia and the Pacific, go to https://www.adb.org/sectors/education/issues.

2 The primary education attainment ratios for boys and girls are defined as the gross intake levels for the last grade of primary education for both males and females. These calculations include all new entrants, by sex, regardless of age. Therefore, the ratios for boys and girls can exceed $100 \%$ due to inclusion in the numerator, but not in the denominator, of overaged and underaged children who enter school late or early, and/or repeat grades. For the full definition and data specifications, go to http://uis.unesco.org/en/glossary-term/gross-intake-ratio-last-grade-primary-education. 
Figure 2.1.1: Distribution of Population by Global Region and by Economy in Asia and the Pacific, 2018

(\%)

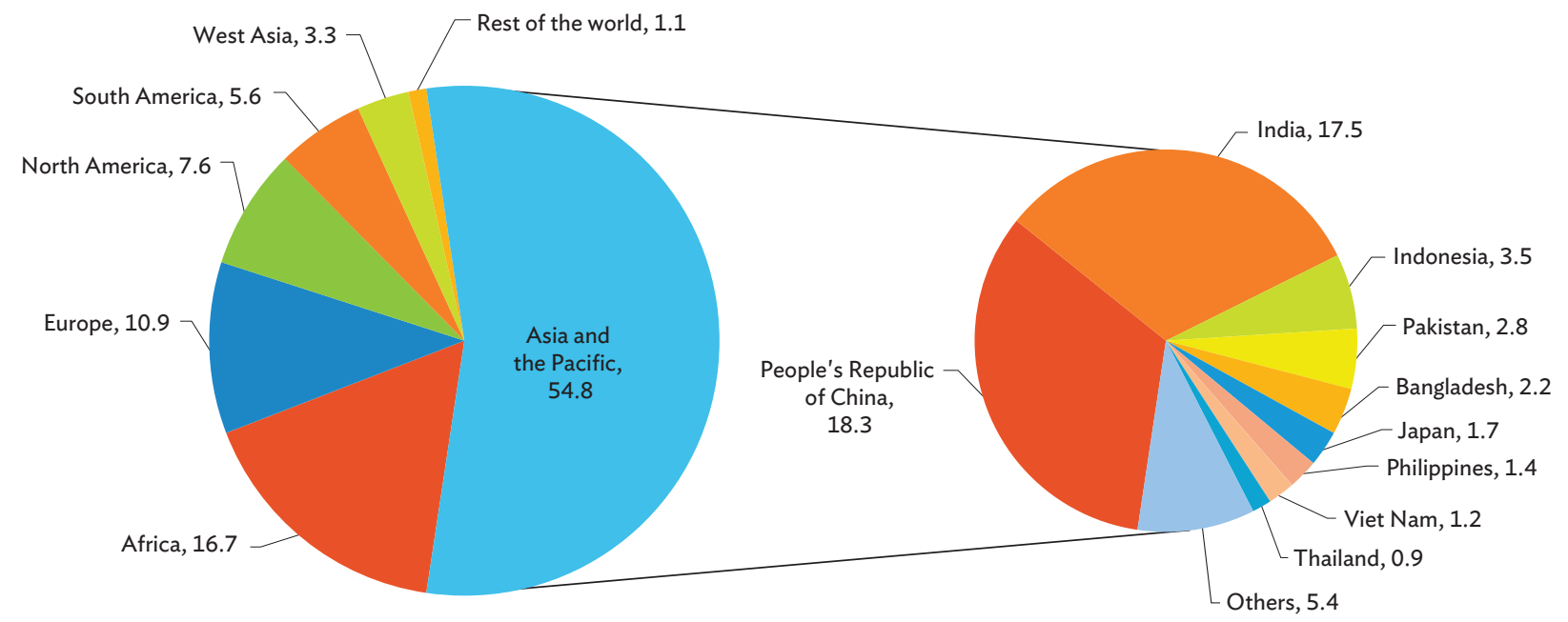

Note: $\quad$ The aggregate for the West Asia region was adjusted to exclude Armenia, Azerbaijan, and Georgia, which are included in the total for Asia and the Pacific. Source: $\quad$ Table 2.1.1, Key Indicators for Asia and the Pacific 2019.

Click here for figure data

the earliest year for which data are available), only 20 of the 35 economies had achieved this same measure of primary education attainment (Table 2.1.11).

During the review period, 28 economies increased their overall primary education attainment level (Table 2.1.11). Of these, 19 economies reported that the increase for girls exceeded that for boys, for which data are available. The largest gains in primary education attainment for girls, achieved over the review period, were observed in Nepal (60.9 percentage points), Bangladesh (56.2 percentage points), and Bhutan (53.4 percentage points) (Figure 2.1.2).

\section{Data Issues and Comparability}

Demographic data are based on vital registration records, censuses, and surveys. Since vital registration records in many ADB developing member economies are incomplete, they cannot be used for statistical purposes. In most economies, population censuses, which are used to provide more accurate estimates of population sizes, are conducted every 10 years. Population numbers in between census years are
Figure 2.1.2: Primary Education Completion Rate, by Sex: (percentage point difference between earliest and most recently available annual data)

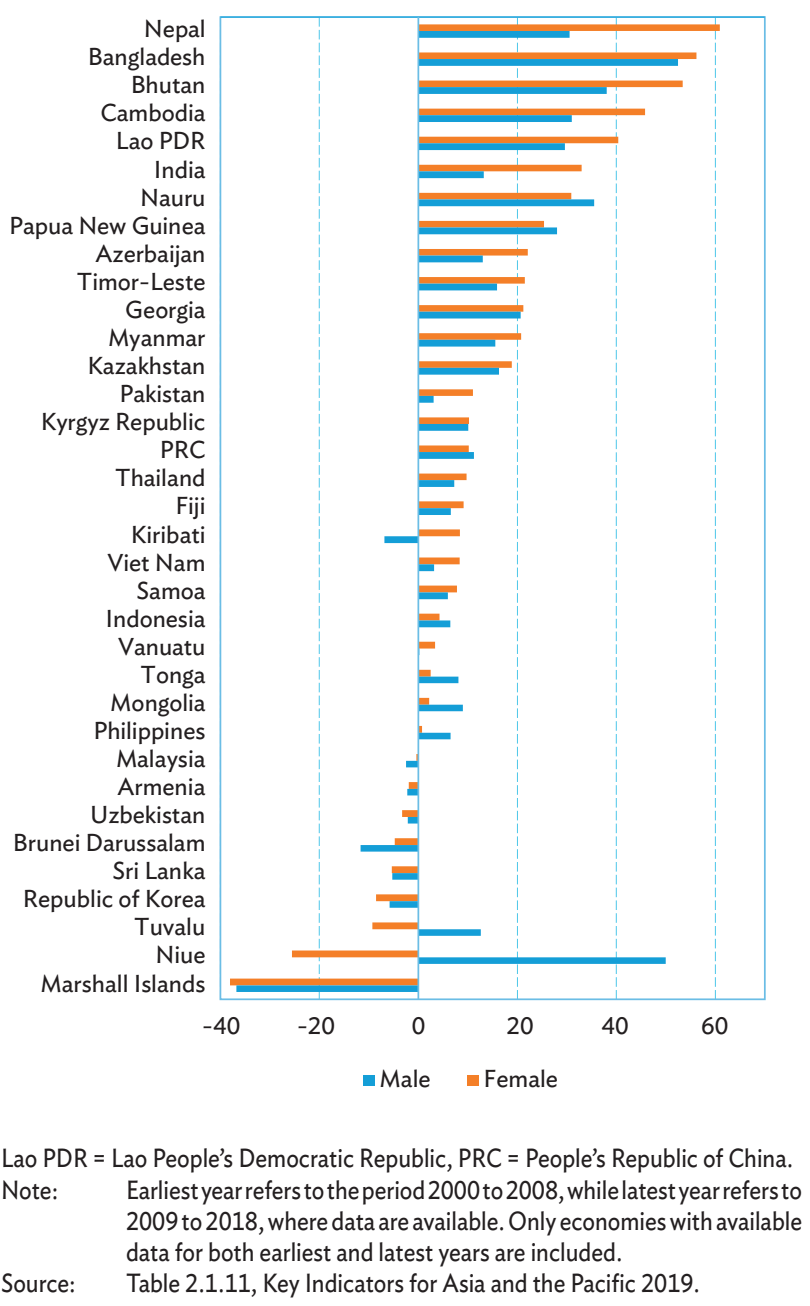


products of imputation methods that use various population distributional assumptions.

The UN Department of Economics and Social Affairs' Population Division uses future trends on fertility, mortality, and international migration to project population numbers through to 2100 . The medium-fertility variant included in World Population Prospects 2019 Revision assumes, over the remainder of the century, a decline of fertility in economies where large families are still prevalent, a slight increase of fertility in several economies where women have fewer than two live births on average over a lifetime, and continued reductions in mortality at all ages.

Urban population statistics are compiled according to each economy's national definition, as there is no agreed international standard for defining an urban area, which poses constraints in the comparability of urban and city indicators across economies. Data from World Urbanization Prospects are used when national estimates are not available.
Household surveys, which are the best source of labor force data, are not carried out in all economies on a regular basis. Some economies rely on census data supplemented by enterprise surveys and unemployment registration records, which are often incomplete and may refer only to formal employment. Furthermore, a breakdown by economic activities also may not be available. An initiative is underway to adopt new standards for work and employment statistics, following the recommendations of the 19th International Conference of Labour Statisticians in 2013, which included the need for more in-depth statistics on forced labor, cooperatives, and labor migration, as well as guidelines on a statistical definition of employment in the environment sector. The conceptual definitions used here are, however, based on the traditional framework. 
Table 2.1.1: Midyear Population

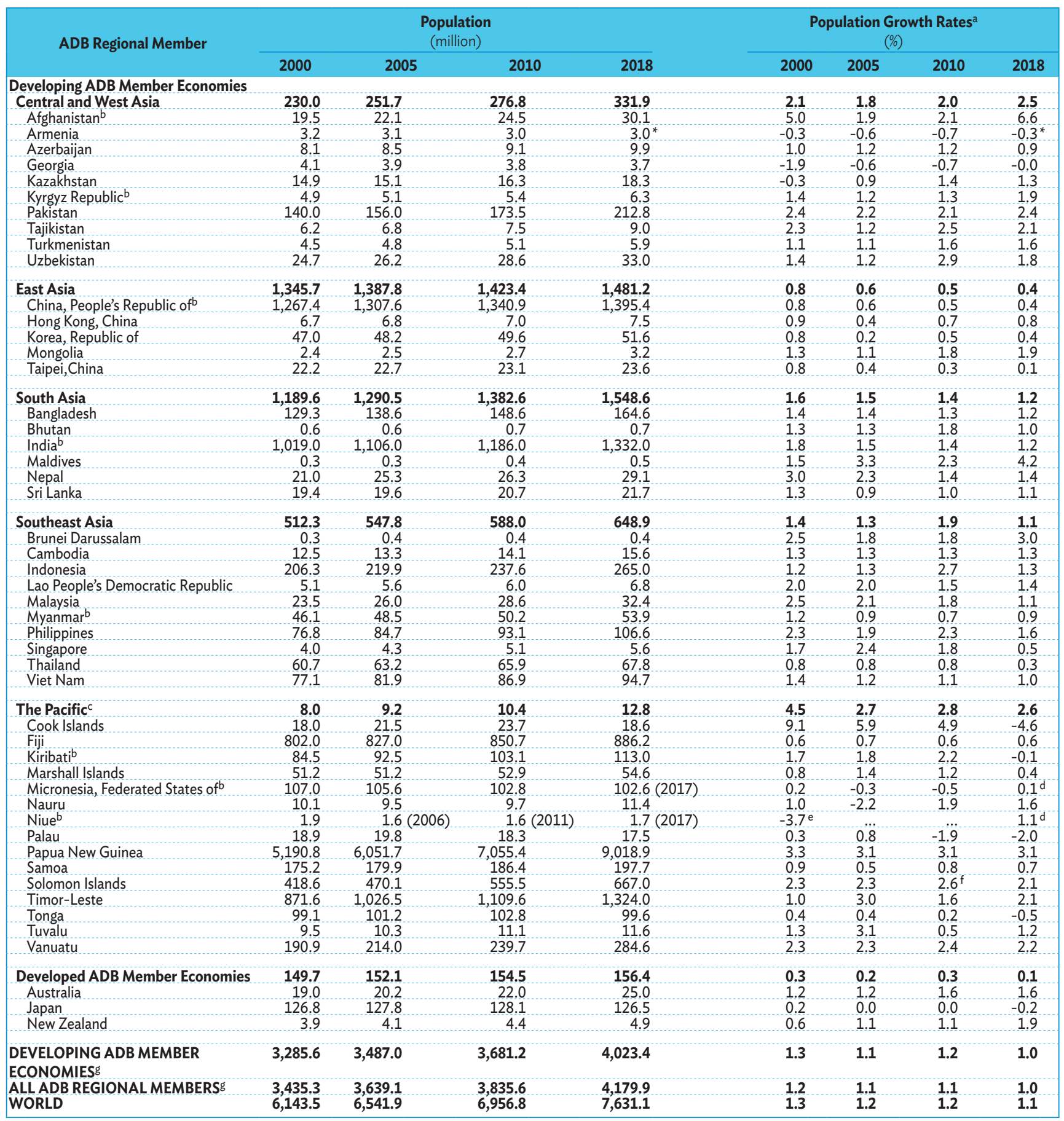

$0.0=$ magnitude is less than half of unit employed, ${ }^{*}=$ preliminary, $A D B=$ Asian Development Bank.

a The annual population growth rate is calculated as the percentage change in population when comparing the reference year with the year prior. For example, the population growth rates under the column heading "2018" refer to population growth from 2017 to 2018.

b Estimates of population size are as of 1 January for the Kyrgyz Republic; 11 March for Niue; 10 June for Afghanistan; 1 April for 2000, 4 April for 2010, and 30 September for 2005 and 2017 for the Federated States of Micronesia; 1 October for India and Myanmar; 7 November for Kiribati; and 31 December for the People's Republic of China.

c Estimates of population size for ADB developing member economies in the Pacific are expressed in thousands, while the total population for the Pacific region is expressed in millions.

d Refers to 2017 annual population growth rate.

e Refers to 2001 annual population growth rate.

$f$ Refers to 2011 annual population growth rate.

g For reporting economies only.

Sources: Economy sources; and United Nations. World Population Prospects 2019. https://population.un.org/wpp/Download/Standard/Population/ (accessed22 July2019). 
Table 2.1.2: Migration and Urbanization

\begin{tabular}{|c|c|c|c|c|c|c|c|c|}
\hline \multirow[t]{2}{*}{ ADB Regional Member } & \multicolumn{4}{|c|}{$\begin{array}{l}\text { Net International Migration Rate } \\
\text { (per } 1,000 \text { population) }\end{array}$} & \multicolumn{4}{|c|}{$\begin{array}{l}\text { Urban Population } \\
\text { (\% of total population) }\end{array}$} \\
\hline & $2000-2005$ & 2005-2010 & 2010-2015 & 2015-2020 & 2000 & 2005 & 2010 & 2018 \\
\hline \multicolumn{9}{|l|}{ Developing ADB Member Economies } \\
\hline \multicolumn{9}{|l|}{ Central and West Asia } \\
\hline Afghanistan & 6.4 & -7.6 & 3.3 & -1.7 & 21.3 & 21.5 & 23.2 & 25.0 \\
\hline Armenia & -10.6 & -12.5 & -2.1 & -1.7 & 64.8 & 64.0 & 63.5 & 63.8 \\
\hline Azerbaijan & 0.9 & 1.2 & 0.2 & 0.1 & 51.1 & 52.5 & 53.0 & 52.9 \\
\hline Georgia & -6.9 & -5.8 & -4.7 & -2.5 & 55.1 & 56.5 & 56.5 & 58.5 \\
\hline Kazakhstan & 0.6 & -0.4 & 1.9 & -1.0 & 56.5 & 57.1 & 54.5 & 58.0 \\
\hline Kyrgyz Republic & -6.9 & -2.9 & -3.3 & -0.6 & 34.7 & 34.8 & 34.1 & 33.9 \\
\hline Pakistan & -0.9 & -0.4 & -1.1 & -1.1 & 33.0 & 34.6 & 36.3 & 36.4 \\
\hline Tajikistan & -4.5 & -4.1 & -3.4 & -2.2 & 26.6 & 26.4 & 26.4 & 27.1 \\
\hline Turkmenistan & -5.4 & -2.5 & -1.9 & -0.9 & 45.9 & 47.1 & 48.5 & 51.6 \\
\hline Uzbekistan & -1.9 & -1.0 & -0.4 & -0.3 & 37.2 & 36.1 & 51.3 & 50.6 \\
\hline \multicolumn{9}{|l|}{ East Asia } \\
\hline China, People's Republic of & -0.3 & -0.3 & -0.2 & -0.2 & 36.2 & 43.0 & 50.0 & 59.6 \\
\hline Hong Kong, China & 1.9 & 2.6 & 2.1 & 4.0 & 100.0 & 100.0 & 100.0 & 100.0 \\
\hline Korea, Republic of & 0.3 & -0.6 & 1.6 & 0.2 & 79.6 & 81.3 & 81.9 & 81.5 \\
\hline Mongolia & -1.2 & -0.8 & -0.3 & -0.3 & 56.6 & 61.9 & 69.2 & 67.9 \\
\hline Taipei,China & 1.8 & 2.2 & 1.5 & 1.3 & 55.8 & 57.7 & 59.3 & 62.5 \\
\hline \multicolumn{9}{|l|}{ South Asia } \\
\hline Bangladesh & -2.2 & -4.5 & -3.0 & -2.3 & 23.1 & 24.2 & 25.9 & 36.6 \\
\hline Bhutan & 2.0 & -3.3 & 0.1 & 0.4 & 21.0 & 30.9 & 34.8 & 40.9 \\
\hline India & -0.3 & -0.4 & -0.4 & -0.4 & 27.7 & 28.8 & 29.9 & 34.0 \\
\hline Maldives & 11.6 & 10.5 & 28.4 & 22.8 & 27.7 & 33.8 & 36.4 & 39.8 \\
\hline Nepal & -6.2 & -7.4 & -15.1 & 1.5 & 14.1 & 14.6 & 16.6 & 20.8 \\
\hline Sri Lanka & -4.7 & -5.2 & -4.7 & -4.6 & 18.4 & 18.3 & 18.2 & 18.5 \\
\hline \multicolumn{9}{|l|}{ Southeast Asia } \\
\hline Brunei Darussalam & 0.2 & -1.2 & -0.4 & - & 71.2 & 73.2 & 75.0 & 77.6 \\
\hline Cambodia & -0.6 & -4.3 & -2.0 & -1.9 & 18.6 & 19.2 & 20.3 & 23.4 \\
\hline Indonesia & -1.1 & -1.1 & -0.4 & -0.4 & 42.0 & 45.9 & 49.9 & 50.2 \\
\hline Lao People's Democratic Republic & -5.3 & -3.7 & -3.5 & -2.1 & 22.0 & 27.2 & 30.1 & 35.0 \\
\hline Malaysia & 5.5 & 5.7 & 1.7 & 1.6 & 62.0 & 66.5 & 71.0 & 75.6 \\
\hline Myanmar & -5.1 & -5.4 & -2.0 & -3.1 & 27.0 & 27.9 & 28.9 & 30.0 \\
\hline Philippines & -3.0 & -3.4 & -1.7 & -0.6 & 46.1 & 45.7 & 45.3 & 46.9 \\
\hline Singapore & 4.5 & 30.7 & 11.8 & 4.7 & 100.0 & 100.0 & 100.0 & 100.0 \\
\hline Thailand & 1.2 & 0.2 & 0.5 & 0.3 & 31.1 & 32.5 & 43.4 & 50.1 \\
\hline Viet Nam & -1.6 & -1.9 & -0.9 & -0.8 & 24.2 & 27.1 & 30.5 & 35.7 \\
\hline \multicolumn{9}{|l|}{ The Pacific } \\
\hline Cook Islands & & & & & 65.2 & 71.0 & 73.3 & 75.1 \\
\hline Fiji & -14.4 & -5.6 & -12.0 & -7.0 & 47.9 & 49.9 & 52.2 & 56.9 \\
\hline Kiribati & -4.4 & -0.6 & -7.7 & -6.9 & 43.0 & 43.6 & 47.4 & 54.1 \\
\hline Marshall Islands & & & & & 68.6 & 71.1 & 73.6 & 77.0 \\
\hline Micronesia, Federated States of & -23.0 & -23.5 & -5.7 & -5.4 & 22.3 & 22.3 & 22.3 & $22.6(2017)$ \\
\hline Nauru $\quad-$ & $\ldots$ & $\ldots$ & $\ldots$ & $\ldots$ & 100.0 & 100.0 & 100.0 & 100.0 \\
\hline Niue & $\ldots$ & $\ldots$ & $\ldots$ & $\ldots$ & 33.1 & 35.2 & 38.7 & 44.8 \\
\hline Palau & & & & & 69.5 & 77.4 & 77.0 & $78.7(2015)$ \\
\hline Papua New Guinea & -2.7 & 1.1 & -0.1 & -0.1 & 13.2 & 13.1 & 13.0 & 13.2 \\
\hline Samoa & -17.7 & -16.5 & -12.8 & -14.3 & 20.0 & 22.1 & 21.0 & 19.0 \\
\hline Solomon Islands & -3.8 & -5.7 & -2.8 & -2.5 & 15.8 & 17.8 & 20.0 & 23.7 \\
\hline Timor-Leste & -5.9 & -7.3 & -4.9 & -4.3 & 24.3 & 26.0 & 27.7 & 30.6 \\
\hline Tonga & -15.8 & -15.2 & -25.4 & -7.7 & 23.0 & 23.2 & 23.4 & 22.8 \\
\hline Tuvalu & & & & & 46.0 & 49.7 & 54.8 & 62.4 \\
\hline Vanuatu & -2.6 & -2.9 & 1.4 & 0.4 & 21.8 & 23.2 & 24.4 & 25.0 \\
\hline \multicolumn{9}{|l|}{ Developed ADB Member Economies } \\
\hline Australia & 6.0 & 11.4 & 8.6 & 6.4 & $84.1(2001)$ & 84.6 & 85.7 & 86.8 \\
\hline Japan & 0.3 & 0.4 & 0.6 & 0.6 & 78.6 & 86.0 & 90.8 & 91.6 \\
\hline New Zealand & 6.7 & 2.9 & 4.0 & 3.2 & 83.5 & 83.8 & 83.7 & 84.1 \\
\hline
\end{tabular}

... = data not available, - = magnitude equals zero, $\mathrm{ADB}=$ Asian Development Bank.

a Refers to annual average. The United Nations' population estimates and projections are based on all available sources of data on population size, and levels of fertility, mortality, and international migration. Statistics on international migration are sourced from population registers and other administrative sources. These estimates and projections are made for 235 distinct national economies or areas comprising the total population of the world.

b For urban population, refers to localities of 100,000 or more inhabitants.

Sources: Economy sources; United Nations. World Urbanization Prospects: The 2018 Revision - Data Query. https://esa.un.org/unpd/wup/DataQuery/ (accessed 20 July 2019); and United Nations. World Population Prospects 2019. https://population.un.org/wpp/Download/Standard/Migration/ (accessed 20 July 2019). 
Table 2.1.3: Proportion of Total Population Aged 0-14 Years and Aged 15-64 Years ${ }^{\mathrm{a}}$ $(\%)$

\begin{tabular}{|c|c|c|c|c|c|c|c|c|}
\hline \multirow{2}{*}{ ADB Regional Member } & \multicolumn{4}{|c|}{ Population Aged 0-14 Years } & \multicolumn{4}{|c|}{ Population Aged 15-64 Years } \\
\hline & 2000 & 2005 & 2010 & 2018 & 2000 & 2005 & 2010 & 2018 \\
\hline \multicolumn{9}{|l|}{ Developing ADB Member Economies } \\
\hline Central and West Asia & 39.9 & 37.7 & 35.9 & 34.4 & 55.6 & 57.7 & 59.7 & 61.1 \\
\hline Afghanistan & 48.9 & 47.9 & 48.2 & 43.1 & 48.8 & 49.9 & 49.5 & 54.3 \\
\hline Armenia & 25.8 & 21.5 & 19.5 & 20.6 & 64.2 & 66.6 & 69.5 & 68.1 \\
\hline Azerbaijan & 31.1 & 26.2 & 22.8 & 23.4 & 63.0 & 67.2 & 71.3 & 70.4 \\
\hline Georgia & 20.8 & 19.0 & 18.0 & 19.8 & 66.2 & 66.5 & 67.8 & 65.3 \\
\hline Kazakhstan & 27.5 & 24.5 & 24.1 & 28.5 & 65.6 & 67.8 & 69.1 & 64.1 \\
\hline Kyrgyz Republic & 34.9 & 31.0 & 29.9 & 32.4 & 59.6 & 63.4 & 65.6 & 63.2 \\
\hline Pakistan & 42.0 & 40.0 & 37.7 & 35.3 & 54.0 & 55.9 & 58.1 & 60.4 \\
\hline Tajikistan & 42.5 & 38.0 & 35.7 & 36.8 & 53.9 & 58.2 & 61.0 & 60.2 \\
\hline Turkmenistan & 36.3 & 32.6 & 29.5 & 30.8 & 59.5 & 62.8 & 66.3 & 64.8 \\
\hline Uzbekistan & 37.3 & 32.6 & 29.1 & 28.7 & 58.1 & 62.6 & 66.4 & 66.9 \\
\hline East Asia & 24.6 & 20.3 & 18.5 & 17.6 & 68.6 & 72.2 & 73.3 & 71.3 \\
\hline China, People's Republic of & 24.8 & 20.4 & 18.7 & 17.9 & 68.4 & 72.2 & 73.3 & 71.2 \\
\hline Hong Kong, China & 16.9 & 14.3 & 11.9 & 11.9 & 72.1 & 73.4 & 75.1 & 71.2 \\
\hline Korea, Republic of & 20.6 & 18.8 & 16.1 & 13.0 & 72.2 & 72.3 & 73.2 & 72.6 \\
\hline Mongolia & 34.8 & 28.9 & 27.0 & 30.4 & 61.5 & 67.3 & 69.2 & 65.5 \\
\hline Taipei,China & 21.2 & 19.0 & 15.9 & 12.9 & 70.0 & 71.3 & 73.4 & 72.7 \\
\hline South Asia & 35.0 & 32.9 & 31.0 & 27.1 & 60.7 & 62.4 & 64.0 & 66.7 \\
\hline Bangladesh & 37.0 & 34.4 & 32.0 & 27.7 & 59.2 & 61.3 & 63.2 & 67.1 \\
\hline Bhutan & 39.8 & 35.1 & 31.2 & 25.8 & 56.3 & 60.5 & 63.7 & 68.2 \\
\hline India & 34.7 & 32.7 & 30.8 & 27.1 & 60.9 & 62.5 & 64.1 & 66.8 \\
\hline Maldives & 40.5 & 31.5 & 25.3 & 20.1 & 55.8 & 64.1 & 70.2 & 76.1 \\
\hline Nepal & 41.0 & 39.3 & 36.3 & 30.4 & 55.3 & 56.4 & 58.7 & 63.9 \\
\hline Sri Lanka & 26.8 & 25.6 & 25.4 & 24.2 & 67.0 & 67.6 & 67.2 & 65.3 \\
\hline Southeast Asia & 31.7 & 29.9 & 27.9 & 25.7 & 63.4 & 65.0 & 66.6 & 67.7 \\
\hline Brunei Darussalam & 30.7 & 27.8 & 26.0 & 23.0 & 67.0 & 69.2 & 70.7 & 72.1 \\
\hline Cambodia & 41.6 & 37.1 & 33.3 & 31.2 & 55.3 & 59.5 & 62.9 & 64.2 \\
\hline Indonesia & 30.7 & 29.9 & 28.8 & 26.6 & 64.6 & 65.3 & 66.2 & 67.6 \\
\hline Lao People's Democratic Republic & 43.4 & 40.3 & 36.4 & 32.6 & 53.1 & 56.0 & 59.9 & 63.3 \\
\hline Malaysia & 33.4 & 30.5 & 28.0 & 24.0 & 62.7 & 65.1 & 67.1 & 69.3 \\
\hline Myanmar & 32.5 & 31.2 & 30.0 & 26.4 & 63.0 & 64.2 & 65.1 & 67.8 \\
\hline Philippines & 38.5 & 37.1 & 34.0 & 31.0 & 58.3 & 59.4 & 61.9 & 63.9 \\
\hline Singapore & 18.7 & 17.2 & 14.0 & 12.3 & 74.9 & 75.6 & 78.7 & 76.3 \\
\hline Thailand & 24.0 & 21.3 & 19.2 & 17.1 & 69.5 & 71.0 & 71.9 & 71.0 \\
\hline Viet Nam & 31.6 & 27.1 & 23.6 & 23.2 & 62.0 & 66.4 & 69.9 & 69.6 \\
\hline The Pacific & 40.0 & 39.1 & 38.0 & 35.8 & 56.8 & 57.6 & 58.4 & 60.4 \\
\hline Cook Islands & 34.7 & 31.4 & 27.9 & 26.0 & 59.1 & 61.3 & 63.8 & 63.6 \\
\hline Fiji & 35.0 & 30.5 & 29.0 & 29.5 & 61.6 & 65.4 & 66.2 & 65.0 \\
\hline Kiribati & 40.0 & 36.9 & 36.1 & 35.5 & 56.7 & 59.5 & 60.3 & 60.5 \\
\hline Marshall Islands & 42.3 & 41.3 & 41.8 & 38.2 & 55.5 & 56.5 & 55.9 & 58.4 \\
\hline Micronesia, Federated States of & 40.4 & 38.9 & 35.7 & 31.7 & 56.0 & 57.3 & 61.1 & 64.3 \\
\hline Nauru & 40.1 & 37.1 & 35.6 & 39.9 & 58.6 & 61.2 & 63.1 & 57.9 \\
\hline Niue & 30.0 & 25.5 & 24.8 & 21.6 & 60.8 & 64.0 & 63.0 & 64.3 \\
\hline Palau & 23.9 & 24.1 & 20.3 & 20.0 & 70.7 & 70.2 & 73.2 & 71.2 \\
\hline Papua New Guinea & 39.8 & 39.2 & 38.3 & 35.8 & 57.2 & 57.6 & 58.4 & 60.7 \\
\hline Samoa & 40.8 & 39.6 & 38.3 & 38.3 & 54.8 & 55.6 & 56.7 & 56.9 \\
\hline Solomon Islands & 41.9 & 41.3 & 40.8 & 40.2 & 55.2 & 55.7 & 55.9 & 56.2 \\
\hline Timor-Leste & 44.9 & 44.7 & 42.5 & 37.8 & 51.7 & 51.6 & 53.4 & 57.9 \\
\hline Tonga & 38.5 & 38.2 & 37.4 & 35.4 & 55.9 & 55.9 & 56.9 & 58.6 \\
\hline Tuvalu & 37.1 & 34.3 & 32.0 & 31.3 & 57.0 & 60.1 & 62.7 & 62.3 \\
\hline Vanuatu & 41.5 & 39.7 & 38.2 & 38.8 & 55.2 & 57.1 & 57.9 & 57.5 \\
\hline Developed ADB Member Economies & 15.8 & 14.8 & 14.4 & 13.9 & 68.0 & 66.6 & 64.7 & 60.7 \\
\hline Australia & 20.9 & 19.8 & 19.0 & 19.2 & 66.8 & 67.3 & 67.6 & 65.2 \\
\hline Japan & 14.8 & 13.8 & 13.4 & 12.7 & 68.2 & 66.5 & 64.1 & 59.7 \\
\hline New Zealand & 22.7 & 21.5 & 20.5 & 19.7 & 65.5 & 66.4 & 66.4 & 64.7 \\
\hline DEVELOPING ADB MEMBER ECONOMIES & 30.6 & 27.8 & 26.1 & 24.0 & 64.0 & 66.3 & 67.6 & 68.1 \\
\hline ALL ADB REGIONAL MEMBERS & 30.0 & 27.3 & 25.6 & 23.6 & 64.1 & 66.3 & 67.5 & 67.8 \\
\hline WORLD & 30.1 & 28.1 & 27.0 & 25.8 & 63.0 & 64.6 & 65.5 & 65.4 \\
\hline
\end{tabular}

$\mathrm{ADB}=$ Asian Development Bank.

a The estimates are based on all available sources of data on population size and levels of fertility, mortality, and international migration for 235 distinct national economies or areas comprising the total population of the world.

Sources: $\quad$ United Nations. World Population Prospects, The 2019 Revision. https://population.un.org/wpp/ (accessed 1 July 2019 ). For the Cook Islands, the Marshall Islands, Nauru, Niue, Palau, and Tuvalu: The Pacific Community, Statistics for Development Division. Official communication, 3 July 2019. 
Table 2.1.4: Proportion of Total Population Aged 65 Years or Oldera, and Age Dependency Ratio

\begin{tabular}{|c|c|c|c|c|c|c|c|c|}
\hline \multirow[t]{2}{*}{ ADB Regional Member } & \multicolumn{4}{|c|}{$\begin{array}{l}\text { Population Aged } 65 \text { Years and Older } \\
\text { (\% of total population) }\end{array}$} & \multicolumn{4}{|c|}{ Age Dependency Ratio for Total Population } \\
\hline & 2000 & 2005 & 2010 & 2018 & 2000 & 2005 & 2010 & 2018 \\
\hline \multicolumn{9}{|l|}{ Developing ADB Member Economies } \\
\hline Central and West Asia & 4.4 & 4.6 & 4.5 & 4.5 & 79.7 & 73.3 & 67.6 & 63.6 \\
\hline Afghanistan & 2.3 & 2.2 & 2.3 & 2.6 & 104.9 & 100.3 & 102.0 & 84.1 \\
\hline Armenia & 10.0 & 11.9 & 11.0 & 11.3 & 55.8 & 50.1 & 43.8 & 46.8 \\
\hline Azerbaijan & 5.8 & 6.6 & 5.9 & 6.2 & 58.7 & 48.8 & 40.3 & 42.0 \\
\hline Georgia & 12.9 & 14.5 & 14.2 & 14.9 & 51.0 & 50.4 & 47.5 & 53.0 \\
\hline Kazakhstan & 6.8 & 7.7 & 6.8 & 7.4 & 52.4 & 47.4 & 44.6 & 55.9 \\
\hline Kyrgyz Republic & 5.5 & 5.6 & 4.5 & 4.5 & 67.9 & 57.7 & 52.5 & 58.3 \\
\hline Pakistan & 4.0 & 4.1 & 4.2 & 4.3 & 85.0 & 78.8 & 72.2 & 65.5 \\
\hline Tajikistan & 3.6 & 3.8 & 3.3 & 3.0 & 85.6 & 71.9 & 63.9 & 66.1 \\
\hline Turkmenistan & 4.3 & 4.6 & 4.1 & 4.4 & 68.2 & 59.2 & 50.7 & 54.4 \\
\hline Uzbekistan & 4.6 & 4.8 & 4.5 & 4.4 & 72.1 & 59.8 & 50.7 & 49.5 \\
\hline East Asia & 6.9 & 7.6 & 8.2 & 11.1 & 45.9 & 38.6 & 36.5 & 40.3 \\
\hline China, People's Republic of & 6.8 & 7.5 & 8.1 & 10.9 & 46.2 & 38.6 & 36.5 & 40.4 \\
\hline Hong Kong, China & 11.0 & 12.2 & 12.9 & 16.9 & 38.7 & 36.2 & 33.1 & 40.4 \\
\hline Korea, Republic of & 7.2 & 8.9 & 10.7 & 14.4 & 38.5 & 38.3 & 36.6 & 37.7 \\
\hline Mongolia & 3.7 & 3.7 & 3.8 & 4.1 & 62.5 & 48.5 & 44.6 & 52.7 \\
\hline Taipei,China & 8.7 & 9.7 & 10.7 & 14.4 & 42.8 & 40.3 & 36.2 & 37.6 \\
\hline South Asia & 4.3 & 4.7 & 5.1 & 6.1 & 64.7 & 60.4 & 56.3 & 49.8 \\
\hline Bangladesh & 3.9 & 4.3 & 4.8 & 5.2 & 69.0 & 63.0 & 58.1 & 49.0 \\
\hline Bhutan & 3.9 & 4.4 & 5.1 & 6.0 & 77.7 & 65.3 & 57.0 & 46.6 \\
\hline India & 4.4 & 4.7 & 5.1 & 6.2 & 64.2 & 59.9 & 56.0 & 49.8 \\
\hline Maldives & 3.8 & 4.4 & 4.6 & 3.7 & 79.3 & 56.0 & 42.5 & 31.3 \\
\hline Nepal & 3.8 & 4.3 & 5.0 & 5.7 & 80.9 & 77.2 & 70.4 & 56.6 \\
\hline Sri Lanka & 6.2 & 6.8 & 7.4 & 10.5 & 49.2 & 48.0 & 48.8 & 53.1 \\
\hline Southeast Asia & 4.9 & 5.1 & 5.5 & 6.6 & 57.8 & 53.9 & 50.1 & 47.7 \\
\hline Brunei Darussalam & 2.4 & 3.0 & 3.4 & 4.9 & 49.3 & 44.5 & 41.5 & 38.7 \\
\hline Cambodia & 3.1 & 3.4 & 3.7 & 4.6 & 80.7 & 67.9 & 58.9 & 55.7 \\
\hline Indonesia & 4.7 & 4.8 & 5.0 & 5.9 & 54.8 & 53.1 & 51.0 & 47.9 \\
\hline Lao People's Democratic Republic & 3.6 & 3.7 & 3.7 & 4.1 & 88.4 & 78.5 & 67.0 & 57.9 \\
\hline Malaysia & 3.9 & 4.4 & 4.9 & 6.7 & 59.4 & 53.5 & 49.0 & 44.2 \\
\hline Myanmar & 4.5 & 4.6 & 4.8 & 5.8 & 58.7 & 55.8 & 53.5 & 47.4 \\
\hline Philippines & 3.3 & 3.5 & 4.1 & 5.1 & 71.6 & 68.2 & 61.6 & 56.5 \\
\hline Singapore & 6.4 & 7.2 & 7.3 & 11.5 & 33.5 & 32.3 & 27.0 & 31.1 \\
\hline Thailand & 6.5 & 7.8 & 8.9 & 11.9 & 43.9 & 40.9 & 39.0 & 40.8 \\
\hline Viet Nam & 6.4 & 6.5 & 6.5 & 7.3 & 61.3 & 50.7 & 43.1 & 43.8 \\
\hline The Pacific & 3.2 & 3.4 & 3.6 & 3.8 & 76.0 & 73.7 & 71.2 & 65.6 \\
\hline Cook Islands & 6.2 & 7.3 & 8.2 & 10.4 & 69.3 & 63.1 & 56.7 & 57.2 \\
\hline Fiji & 3.4 & 4.1 & 4.8 & 5.4 & 62.5 & 53.0 & 51.1 & 53.8 \\
\hline Kiribati & 3.3 & 3.5 & 3.6 & 4.0 & 76.3 & 68.0 & 65.7 & 65.3 \\
\hline Marshall Islands & 2.1 & 2.2 & 2.3 & 3.5 & 80.0 & 76.9 & 78.8 & 71.3 \\
\hline Micronesia, Federated States of & 3.6 & 3.9 & 3.2 & 4.0 & 78.6 & 74.7 & 63.7 & 55.5 \\
\hline Nauru & 1.3 & 1.7 & 1.3 & 2.2 & 70.7 & 63.4 & 58.5 & 72.7 \\
\hline Niue & 9.2 & 10.5 & 12.1 & 14.1 & 64.6 & 56.4 & 58.7 & 55.5 \\
\hline Palau & 5.4 & 5.7 & 6.5 & 8.8 & 41.4 & 42.5 & 36.7 & 40.5 \\
\hline Papua New Guinea & 3.1 & 3.2 & 3.3 & 3.4 & 74.9 & 73.5 & 71.3 & 64.6 \\
\hline Samoa & 4.4 & 4.8 & 5.0 & 4.8 & 82.3 & 79.7 & 76.3 & 75.8 \\
\hline Solomon Islands & 2.9 & 3.0 & 3.3 & 3.6 & 81.1 & 79.6 & 78.9 & 78.1 \\
\hline Timor-Leste & 3.4 & 3.7 & 4.0 & 4.3 & 93.3 & 93.7 & 87.2 & 72.7 \\
\hline Tonga & 5.6 & 5.9 & 5.7 & 6.0 & 78.9 & 78.9 & 75.8 & 70.6 \\
\hline Tuvalu & 5.9 & 5.6 & 5.3 & 6.4 & 75.4 & 66.5 & 59.5 & 60.6 \\
\hline Vanuatu & 3.3 & 3.3 & 3.9 & 3.6 & 81.1 & 75.3 & 72.8 & 73.9 \\
\hline Developed ADB Member Economies & 16.3 & 18.6 & 20.9 & 25.3 & 47.1 & 50.1 & 54.5 & 64.6 \\
\hline Australia & 12.3 & 12.9 & 13.4 & 15.7 & 49.7 & 48.6 & 47.9 & 53.5 \\
\hline Japan & 17.0 & 19.7 & 22.5 & 27.6 & 46.6 & 50.3 & 55.9 & 67.4 \\
\hline New Zealand & 11.8 & 12.1 & 13.1 & 15.7 & 52.7 & 50.6 & 50.5 & 54.6 \\
\hline DEVELOPING ADB MEMBER ECONOMIES & 5.5 & 5.9 & 6.3 & 7.9 & 56.4 & 50.9 & 47.9 & 46.9 \\
\hline ALL ADB REGIONAL MEMBERS & 5.9 & 6.4 & 6.9 & 8.6 & 55.9 & 50.8 & 48.1 & 47.5 \\
\hline WORLD & 6.9 & 7.3 & 7.6 & 8.9 & 58.7 & 54.8 & 52.8 & 53.0 \\
\hline
\end{tabular}

$\mathrm{ADB}=$ Asian Development Bank.

a The estimates are based on all available sources of data on population size and levels of fertility, mortality, and international migration for 235 distinct national economies or areas comprising the total population of the world.

Sources: $\quad$ For Population Aged 65 Years and Older: United Nations. World Population Prospects, The 2019 Revision. https://population.un.org/wpp/ (accessed 1 July 2019); and for the Cook Islands, the Marshall Islands, Nauru, Niue, Palau, and Tuvalu: The Pacific Community, Statistics for Development Division. Official communication, 3 July 2019. For Age Dependency Ratio for Total Population: Asian Development Bank estimates using data from the United Nations. 
Table 2.1.5: $\quad$ Labor Force Participation Rates ${ }^{a}$

$(\%)$

\begin{tabular}{|c|c|c|c|c|c|c|c|c|c|}
\hline ADB Regional Member & 2000 & 2005 & 2010 & 2013 & 2014 & 2015 & 2016 & 2017 & 2018 \\
\hline \multirow{2}{*}{\multicolumn{10}{|c|}{$\begin{array}{l}\text { Developing ADB Member Economies } \\
\text { Central and West Asia }\end{array}$}} \\
\hline & & & & & & & & & \\
\hline Afghanistan & & & $49.8(2011)$ & 55.4 & & & 53.9 & & \\
\hline Armenia & 61.4 & 57.7 & $61.2^{1201}$ & 63.4 & 63.1 & 62.5 & 61.0 & 60.9 & $63.6^{*}$ \\
\hline Azerbaijan & 77.6 & 68.4 & 64.8 & 64.7 & 65.1 & 65.4 & 66.0 & 66.2 & 66.3 \\
\hline Georgia & 65.2 & 62.7 & 63.3 & 65.2 & 65.5 & 66.8 & 66.3 & 65.8 & 63.9 \\
\hline Kazakhstan & 66.0 & 69.4 & 71.2 & 71.7 & 70.7 & 69.7 & 70.0 & 69.7 & 70.0 \\
\hline Kyrgyz Republic & $64.4(2002)$ & 64.8 & 64.2 & 62.5 & 62.4 & 62.4 & 61.5 & 60.1 & 59.8 \\
\hline Pakistan & 42.8 & 43.7 & 45.9 & 45.7 & 45.5 & 45.2 & & & 44.3 \\
\hline Tajikistan & 56.3 & 55.0 & 50.3 & 48.6 & 47.8 & 47.7 & 46.7 & 46.2 & \\
\hline Turkmenistan & 63.2 & 63.3 & 64.0 & 64.8 & 65.0 & 65.2 & 65.3 & 65.2 & 65.1 \\
\hline Uzbekistan & 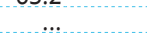 & $\ldots$ & $\ldots$ & $0 . . .$. & 71.3 & 71.9 & 72.5 & 73.5 & 0.1 \\
\hline \multicolumn{10}{|l|}{ East Asia } \\
\hline China, People's Republic of & 77.2 & 73.4 & 71.0 & 70.4 & 70.2 & 69.9 & 69.6 & 69.2 & 68.7 \\
\hline Hong Kong, China & 61.4 & 60.9 & 59.6 & 61.2 & 61.1 & 61.1 & 61.1 & 61.1 & 61.2 \\
\hline Korea, Republic of & 61.2 & 62.2 & 61.1 & 61.7 & 62.7 & 62.8 & 62.9 & 63.2 & 63.1 \\
\hline Mongolia & 62.9 & 63.5 & 61.6 & 61.9 & 62.1 & 61.5 & 60.5 & 61.1 & 61.0 \\
\hline Taipei,China & 57.7 & 57.8 & 58.1 & 58.4 & 58.5 & 58.7 & 58.7 & 58.8 & 59.0 \\
\hline \multicolumn{10}{|l|}{ South Asia } \\
\hline Bangladesh & 54.9 & $58.5(2006)$ & 59.3 & 57.1 & & & 58.5 & 58.2 & \\
\hline Bhutan & 56.5 (2001) & 60.4 & 68.6 & 65.3 & 62.6 & 63.1 & 62.2 & 63.3 & 62.6 \\
\hline India & 37.6 & 39.2 & 36.4 (2011) & $\ldots$ & & $\ldots$ & & $\ldots \ldots$ & $\ldots$ \\
\hline Maldives ${ }^{c}$ & 47.7 & 57.7 (2006) & 52.1 & $\cdots$ & 63.8 & $\ldots$ & 57.6 & $\ldots$ & . \\
\hline Nepal & & $77.2(2004)$ & $74.3(2012)$ & 77.2 & 72.2 & & & & 38.5 \\
\hline Sri Lanka & 50.3 & 49.3 & 48.6 & 53.7 & 53.2 & 53.8 & 53.8 & 54.1 & 51.8 \\
\hline \multicolumn{10}{|l|}{ Southeast Asia } \\
\hline Brunei Darussalam & $67.9(2001)$ & & $68.9(2011)$ & & 65.6 & $\ldots$ & $\ldots$ & 62.7 & $\ldots$ \\
\hline Cambodia & 65.2 & $74.6(2004)$ & 87.0 & 83.0 & 82.6 & $\cdots$ & $\cdots$ & & \\
\hline Indonesia & 67.8 & 66.8 & 67.7 & 66.8 & 66.6 & 65.8 & 66.3 & 66.7 & 67.3 \\
\hline Lao People's Democratic Republice & 79.9 (2001) & 66.6 & 79.2 & & & 0 & 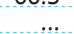 & 40.8 & \\
\hline Malaysia & 65.4 & 63.3 & 63.7 & 67.3 & 67.6 & 67.9 & 67.7 & 68.0 & 68.3 \\
\hline Myanmar & & & & & 67.0 & 64.7 & & 61.5 & 62.0 \\
\hline Philippines & 64.9 & 65.1 & 64.1 & 63.9 & 64.6 & 63.7 & 63.5 & 61.2 & 60.9 \\
\hline Singapore ${ }^{f}$ & 63.2 & 63.0 & 66.2 & 66.7 & 67.0 & 68.3 & 68.0 & 67.7 & 67.7 \\
\hline Thailands & 71.5 & 72.5 & 72.3 & 71.1 & 70.3 & 69.8 & 68.8 & 68.1 & 68.3 \\
\hline Viet Nam & $\ldots$ & 74.7 (2007) & 77.4 & 77.5 & 77.7 & 77.8 & 77.3 & 76.7 & 76.8 \\
\hline \multicolumn{10}{|l|}{ The Pacific } \\
\hline Cook Islands & $69.0(2001)$ & $70.2(2006)$ & $71.0(2011)$ & $\ldots$ & & $\ldots$ & & $\ldots$ & $\ldots$ \\
\hline Fiji & & & & & 55.2 & & 58.3 & 57.1 & $\cdots$ \\
\hline Kiribati & 80.9 & 63.6 & 59.3 & $\ldots$ & $\ldots$ & 66.0 & $\ldots \ldots$ & $\ldots \ldots$ & $\ldots$ \\
\hline Marshall Islands & 51.1 & 51.1 & 41.7 (2011) & & $\ldots$ & $\ldots$ & $\ldots \ldots$ & $\ldots \ldots$ & $\ldots$ \\
\hline Micronesia, Federated States of & 58.6 & & 57.3 & 49.3 & $\ldots$ & $\ldots \ldots$ & $\ldots \ldots$ & $\ldots \ldots$ & $\ldots$ \\
\hline Nauruh & & & $64.0(2011)$ & 60.8 & $\ldots$ & & $\ldots$ & & $\ldots$ \\
\hline Niue & $78.7(2001)$ & $78.0(2006)$ & $68.9(2011)$ & & $\ldots$ & $\ldots$ & . & 68.6 & .... \\
\hline Palau & 67.5 & 69.1 & $68.1(2012)$ & & & 77.4 & & & \\
\hline Papua New Guinea & 72.0 & 61.0 & 48.2 & 48.0 & 47.5 & 47.1 & 47.1 & 47.1 & 46.8 \\
\hline Samoad & $50.6(2001)$ & $49.8(2006)$ & $41.3(2011)$ & $\ldots$ & $\ldots$ & $\ldots \ldots$ & 47.4 & 43.3 & $\ldots$ \\
\hline Solomon Islands & & & $62.9(2009)$ & & & & & & $\ldots$ \\
\hline Timor-Leste & $56.0(2001)$ & $60.2(2004)$ & 41.7 & 30.6 & & $\ldots$ & $\ldots$ & $\ldots$ & $\ldots$ \\
\hline Tonga & & $94.8(2003)$ & & & & 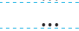 & 63.7 & $\ldots$ & $\ldots$ \\
\hline Tuvalu & $58.2(2002)$ & & $59.4(2012)$ & & & & 52.3 & & \\
\hline Vanuatu & 69.6 & 70.3 & 70.4 & 70.4 & 70.4 & 70.6 & 70.5 & 70.5 & 70.5 \\
\hline \multicolumn{10}{|l|}{ Developed ADB Member Economies } \\
\hline Australia & 63.1 & 64.4 & 65.4 & 64.9 & 64.7 & 65.0 & 64.9 & 65.2 & 65.6 \\
\hline Japan & 62.4 & 60.4 & 59.6 & 59.3 & 59.4 & 59.6 & 60.0 & 60.5 & 61.5 \\
\hline New Zealand & 65.2 & 67.7 & 68.0 & 67.8 & 68.7 & 68.7 & 69.8 & 70.7 & 70.7 \\
\hline
\end{tabular}

$\ldots=$ data not available, ${ }^{*}=$ preliminary, $\mathrm{ADB}=$ Asian Development Bank.

a Based on varying concepts and definitions of "labor force" across economies.

b For 2005 and 2017, data are from censuses of population. For all other years, data are from labor force surveys. Thus, data prior to and after the census years may not be directly comparable with 2005 and 2017 data.

c Includes local population only.

d Figures for different years may not be directly comparable with each other due to changes in methodology and labor concepts adopted.

e For 2017, the figure is based on the 2017 Labour Force Survey conducted using the concepts defined at the 19th International Conference of Labour Statisticians and hence is not directly comparable with figures from the 2005 Census of Population and Housing and the 2010 Report on the National Child Labour Survey of the Lao People's Democratic Republic.

$f$ Refers to Singapore residents only.

$g$ Includes seasonally inactive labor force.

h For 2011, the figure is from the 2011 census. For 2013, the figure refers to preliminary data from the Nauru Household Income and Expenditure Survey 2012/2013. Thus, data for 2011 and 2013 may not be directly comparable.

Sources: Economy sources. For Papua New Guinea, the People's Republic of China, Turkmenistan, and Vanuatu: International Labour Organization. ILOSTAT. http:// www.ilo.org/ilostat/ (accessed 23 July 2019). For the Lao People's Democratic Republic for 2001: International Labour Organization. ILOSTAT. http://www. ilo.org/ilostat/ (accessed July 2016). For the Federated States of Micronesia and Tuvalu: Secretariat of the Pacific Community. National Minimum Development Indicator Database. http://www.spc.int/nmdi/ (accessed 23 July 2019). For Timor-Leste for 2001: United Nations Development Programme. East Timor Human Development Report 2002. http://www.tl.undp.org/content/timor_leste/en/home/library/poverty/human-development-report-2002-timor-leste. html (accessed 23 July 2018). 
Table 2.1.6: Employment in Agriculture, Industry, and Services ${ }^{a}$ (\% of total employment)

\begin{tabular}{|c|c|c|c|c|}
\hline \multirow{2}{*}{ ADB Regional Member } & \multicolumn{4}{|c|}{ Agriculture } \\
\hline & 2000 & 2005 & 2010 & 2018 \\
\hline \multirow{2}{*}{\multicolumn{5}{|c|}{ Developing ADB Member Economies }} \\
\hline & \multicolumn{4}{|c|}{ Central and West Asia } \\
\hline Afghanistan & $69.6(2001)$ & $69.6(2004)$ & & $39.5(2016)$ \\
\hline Armenia & 44.4 & 46.2 & 38.6 & $31.3(2017)$ \\
\hline Azerbaijan & 39.1 & 38.7 & 38.2 & 36.3 \\
\hline Georgiab & $52.8(2001)$ & 50.0 & 48.0 & 43.1 (2017) \\
\hline Kazakhstan & 31.4 & 31.9 & 28.3 & 14.1 \\
\hline Kyrgyz Republic & 53.1 & 38.5 & 31.2 & 20.3 \\
\hline Pakistanc & 48.4 & 43.0 & 45.0 & 38.5 \\
\hline Tajikistan & 65.0 & 67.5 & 65.9 & $60.9(2017)$ \\
\hline Turkmenistan & 47.6 & & & \\
\hline Uzbekistan & 34.4 & 29.1 & 26.8 & $27.2(2017)$ \\
\hline \multicolumn{5}{|l|}{ East Asia } \\
\hline China, People's Republic of ${ }^{d}$ & 50.0 & 44.8 & 36.7 & 26.1 \\
\hline Hong Kong, China ${ }^{\mathrm{e}}$ & 0.3 & 0.3 & - & - \\
\hline Korea, Republic of ${ }^{f}$ & 10.7 & 8.0 & 6.6 & 5.0 \\
\hline Mongolia & 48.6 & 39.9 & 33.5 & 26.7 \\
\hline Taipei, China & 7.8 & 5.9 & 5.2 & 4.9 \\
\hline \multicolumn{5}{|l|}{ South Asia } \\
\hline Bangladesh & 50.8 & $48.1(2006)$ & 47.5 & $40.6(2017)$ \\
\hline Bhutans & $46.5(2001)$ & 43.6 & 59.4 & 54.0 \\
\hline India & 59.9 & 56.1 & $53.2(2009)$ & \\
\hline Maldives ${ }^{\mathrm{h}}$ & 13.7 & $15.9(2007)$ & 4.3 & $9.0(2016)$ \\
\hline Nepal & & & $64.0(2011)$ & 21.5 \\
\hline Sri Lanka & 36.0 & 32.8 & 32.5 & 25.5 \\
\hline \multicolumn{5}{|l|}{ Southeast Asia } \\
\hline Brunei Darussalam & & & & \\
\hline Cambodia & 73.7 & 60.3 & 72.3 & $64.3(2014)$ \\
\hline Indonesia & 45.3 & 44.0 & 38.3 & 28.8 \\
\hline Lao People's Democratic Republic & & 76.3 & 72.2 & $31.3(2017)$ \\
\hline Malaysiaj & 16.7 & 14.6 & 13.6 & 10.6 \\
\hline Myanmar & & & & 47.6 \\
\hline Philippines & 37.1 & 35.7 & 33.2 & 24.3 \\
\hline Singapore ${ }^{k}$ & 0.1 & 0.1 & 0.2 & 0.1 \\
\hline Thailand & 44.2 & 38.6 & 38.2 & 32.1 \\
\hline Viet $\mathrm{Nam}$ & 65.1 & 55.1 & 49.5 & 37.7 \\
\hline \multicolumn{5}{|l|}{ The Pacific } \\
\hline Cook Islands $\mathrm{s}^{\mathrm{m}}$ & $7.2(2001)$ & $4.9(2006)$ & $4.3(2011)$ & $5.3(2016)$ \\
\hline $\mathrm{Fijij}^{n}$ & 1.5 & 1.1 & 1.7 & $19.2(2016)$ \\
\hline Kiribatio & & 2.7 & 22.1 & $24.3(2015)$ \\
\hline Marshall Islands & 6.4 & 3.1 & 13.9 & $6.4(2017)$ \\
\hline Micronesia, Federated States of & 52.2 & $\ldots$ & $\ldots$ & $\ldots$ \\
\hline Nauru & & & & \\
\hline Nive & $9.0(2001)$ & $15.9(2006)$ & $10.4(2011)$ & $8.7(2017)$ \\
\hline Palaup & 7.1 & 7.8 & $\ldots$ & $6.4(2015)$ \\
\hline \multicolumn{5}{|l|}{ Papua New Guinea } \\
\hline Samoa & $39.9(2001)$ & $35.4(2006)$ & $37.0(2011)$ & 21.9 (2017) \\
\hline Solomon Islands 9 & & & $41.5(2009)$ & \\
\hline Timor-Leste & $\ldots$ & & 51.0 & $40.5(2013)$ \\
\hline Tonga & $\ldots$ & $27.9(2006)$ & $\ldots$ & $24.1(2016)$ \\
\hline Tuvalu & $\ldots$ & $\ldots$ & $\ldots$ & $\ldots-\ldots$ \\
\hline Vanuatu & $\ldots$ & $\ldots$ & $\ldots$ & $\ldots$ \\
\hline \multicolumn{5}{|l|}{ Developed ADB Member Economies } \\
\hline Australia & 4.8 & 3.6 & 3.2 & 2.6 \\
\hline Japan & 5.1 & 4.4 & 4.0 & 3.4 \\
\hline New Zealand ${ }^{r}$ & 8.8 & 6.9 & 6.7 & 5.8 \\
\hline
\end{tabular}


Table 2.1.6: Employment in Agriculture, Industry, and Services ${ }^{a}$ (continued) (\% of total employment)

\begin{tabular}{|c|c|c|c|c|}
\hline \multirow{2}{*}{ ADB Regional Member } & \multicolumn{4}{|c|}{ Industry } \\
\hline & 2000 & 2005 & 2010 & 2018 \\
\hline \multicolumn{5}{|l|}{ Developing ADB Member Economies } \\
\hline \multicolumn{5}{|l|}{ Central and West Asia } \\
\hline Afghanistan & $6.2(2001)$ & $6.2(2004)$ & & $14.8(2016)$ \\
\hline Armenia & 20.6 & 15.9 & 17.4 & $16.7(2017)$ \\
\hline Azerbaijan & 12.1 & 12.4 & 13.7 & 14.6 \\
\hline Georgia $^{b}$ & $5.8(2001)$ & 7.5 & 7.2 & $13.2(2017)$ \\
\hline Kazakhstan & 18.2 & 17.9 & 18.7 & 19.9 \\
\hline Kyrgyz Republic & 10.5 & 17.6 & 21.1 & 24.8 \\
\hline Pakistanc & 11.5 & 20.3 & 20.9 & 24.6 \\
\hline Tajikistan & 9.1 & 8.7 & 7.9 & $9.1(2017)$ \\
\hline Turkmenistan & 13.0 & & & \\
\hline Uzbekistan & 12.7 & 13.2 & 22.7 & $23.1(2017)$ \\
\hline \multicolumn{5}{|l|}{ East Asia } \\
\hline China, People's Republic of & 22.5 & 23.8 & 28.7 & 27.6 \\
\hline Hong Kong, China ${ }^{\mathrm{e}}$ & 19.6 & 14.4 & 11.2 & 11.6 \\
\hline Korea, Republic of ${ }^{-}$ & 20.4 & 26.7 & 25.0 & 25.2 \\
\hline Mongolia & 14.1 & 16.8 & 16.2 & 20.6 \\
\hline Taipei,China & 28.1 & 36.4 & 35.9 & 35.7 \\
\hline \multicolumn{5}{|l|}{ South Asia } \\
\hline Bangladesh & 13.1 & $14.6(2006)$ & 17.6 & $20.4(2017)$ \\
\hline Bhutan' & $5.6(2001)$ & 17.2 & 6.6 & 13.1 \\
\hline India & 16.3 & 18.8 & $21.5(2009)$ & \\
\hline Maldives ${ }^{h}$ & 19.0 & $27.9(2007)$ & 9.4 & $18.4(2016)$ \\
\hline Nepal & & & $9.5(2011)$ & 30.8 \\
\hline Sri Lanka & 23.6 & 25.4 & 24.6 & 27.9 \\
\hline \multicolumn{5}{|l|}{ Southeast Asia } \\
\hline Brunei Darussalam & & & & \\
\hline Cambodia & 7.0 & 9.7 & 9.2 & $9.0(2014)$ \\
\hline Indonesia & 17.4 & 18.8 & 19.3 & 23.2 \\
\hline Lao People's Democratic Republic & & & 8.1 & $14.1(2017)$ \\
\hline Malaysia & 32.5 & 29.7 & 27.8 & 27.1 \\
\hline Myanmar & & & & 17.8 \\
\hline Philippines & 16.2 & 15.4 & 15.0 & 19.1 \\
\hline Singapore ${ }^{k}$ & 25.7 & 21.7 & 21.8 & 15.9 \\
\hline Thailand & 20.2 & 22.4 & 20.8 & 22.8 \\
\hline Viet $\mathrm{Nam}^{\prime}$ & 13.1 & 17.6 & 21.0 & 26.8 \\
\hline \multicolumn{5}{|l|}{ The Pacific } \\
\hline Cook Islands $\mathrm{m}^{\mathrm{m}}$ & $6.0(2001)$ & $14.2(2006)$ & $11.7(2011)$ & $10.1(2016)$ \\
\hline $\mathrm{Fiji}^{\mathrm{n}}$ & 30.8 & 30.8 & 23.9 & $14.4(2016)$ \\
\hline Kiribatio & & 3.2 & 16.1 & $18.2(2015)$ \\
\hline Marshall Islands & 8.5 & 9.6 & 9.0 & $10.3(2017)$ \\
\hline Micronesia, Federated States of & $\ldots$ & $\ldots$ & $\ldots$ & $\ldots$ \\
\hline Nauru & & & & \\
\hline Niue & $20.4(2001)$ & $17.1(2006)$ & $14.2(2011)$ & $14.2(2017)$ \\
\hline \multirow{2}{*}{\multicolumn{5}{|c|}{ Papua New Guinea }} \\
\hline & & & & \\
\hline Samoa & $19.7(2001)$ & $21.8(2006)$ & $12.2(2011)$ & $15.4(2017)$ \\
\hline Solomon Islands 9 & $\ldots$ & & $13.0(2009)$ & \\
\hline Timor-Leste & $\ldots$ & & 8.8 & $12.7(2013)$ \\
\hline Tonga & $\ldots$ & $27.8(2006)$ & $\ldots$ & $25.6(2016)$ \\
\hline Tuvalu & $\ldots$ & $\ldots$ & $\ldots$ & $\ldots$ \\
\hline Vanuatu & $\ldots$ & $\ldots$ & $\ldots$ & $\ldots \ldots$ \\
\hline \multicolumn{5}{|l|}{ Developed ADB Member Economies } \\
\hline Australia & 21.5 & 21.1 & 21.0 & 19.7 \\
\hline Japan & 31.2 & 27.5 & 25.4 & 23.9 \\
\hline New Zealand ${ }^{r}$ & 12.6 & 22.4 & 20.6 & 19.8 \\
\hline
\end{tabular}


Table 2.1.6: Employment in Agriculture, Industry, and Services ${ }^{\mathrm{a}}$ (continued) (\% of total employment)

\begin{tabular}{|c|c|c|c|c|}
\hline \multirow{2}{*}{ ADB Regional Member } & \multicolumn{4}{|c|}{ Services } \\
\hline & 2000 & 2005 & 2010 & 2018 \\
\hline \multirow{2}{*}{\multicolumn{5}{|c|}{$\begin{array}{l}\text { Developing ADB Member Economies } \\
\text { Central and West Asia }\end{array}$}} \\
\hline & & & & \\
\hline Afghanistan & $24.2(2001)$ & $24.2(2004)$ & & $45.7(2016)$ \\
\hline Armenia & 35.0 & 37.8 & 44.0 & 51.9 (2017) \\
\hline Azerbaijan & 48.7 & 48.8 & 48.1 & 49.1 \\
\hline Georgia $^{\mathrm{b}}$ & $41.4(2001)$ & 42.5 & 44.8 & $43.7(2017)$ \\
\hline Kazakhstan & 50.5 & 50.2 & 53.0 & 66.0 \\
\hline Kyrgyz Republic & 36.5 & 43.9 & 47.7 & 54.9 \\
\hline Pakistanc & 40.0 & 36.7 & 34.2 & 39.8 \\
\hline Tajikistan & 26.0 & 23.9 & 26.3 & $30.0(2017)$ \\
\hline Turkmenistan & 39.4 & & & \\
\hline Uzbekistan & 52.8 & 57.7 & 50.5 & $49.8(2017)$ \\
\hline \multicolumn{5}{|l|}{ East Asia } \\
\hline China, People's Republic of & 27.5 & 31.4 & 34.6 & 46.3 \\
\hline Hong Kong, China & 79.8 & 85.1 & 88.9 & 87.9 \\
\hline Korea, Republic off & 68.9 & 65.4 & 68.4 & 69.8 \\
\hline Mongolia & 37.2 & 43.3 & 50.2 & 52.7 \\
\hline Taipei,China & 64.1 & 57.7 & 58.8 & 59.4 \\
\hline \multicolumn{5}{|l|}{ South Asia } \\
\hline Bangladesh & 36.2 & $37.6(2006)$ & 35.3 & $38.9(2017)$ \\
\hline Bhutang & $47.9(2001)$ & 39.2 & 33.7 & 32.9 \\
\hline India & 23.7 & 25.1 & $25.3(2009)$ & \\
\hline Maldives & 67.3 & $56.2(2007)$ & 86.3 & $72.6(2016)$ \\
\hline Nepal & & & $25.7(2011)$ & 47.7 \\
\hline Sri Lanka & 40.3 & 41.8 & 42.9 & 46.6 \\
\hline \multirow{2}{*}{\multicolumn{5}{|c|}{ Southeast Asia }} \\
\hline Brunei Darussalam & & & & \\
\hline Cambodia & 19.3 & 30.0 & 18.6 & 26.6 (2014) \\
\hline Indonesia & 37.3 & 37.3 & 42.3 & 48.0 \\
\hline Lao People's Democratic Republic & & & 19.7 & 54.6 (2017) \\
\hline Malaysia & 50.8 & 55.6 & 58.7 & 62.3 \\
\hline Myanmar & & & & \\
\hline Philippines & 46.7 & 48.1 & 51.8 & 56.6 \\
\hline Singapore ${ }^{k}$ & 74.2 & 78.2 & 77.9 & 83.9 \\
\hline Thailand & 35.6 & 39.0 & 41.0 & 45.1 \\
\hline Viet $\mathrm{Nam}^{\mathrm{T}}$ & 21.8 & 27.3 & 29.5 & 36.2 \\
\hline \multicolumn{5}{|l|}{ The Pacific } \\
\hline Cook Islands & $86.7(2001)$ & $80.9(2006)$ & $84.0(2011)$ & $84.6(2016)$ \\
\hline $\mathrm{Fiji}^{\mathrm{n}}$ & 67.7 & 68.1 & 74.4 & $66.4(2016)$ \\
\hline Kiribatio & & 30.7 & 61.8 & $57.5(2015)$ \\
\hline Marshall Islands & 85.1 & 87.3 & 77.1 & $83.3(2017)$ \\
\hline Micronesia, Federated States of & & & & \\
\hline Nauru & & & & \\
\hline Niue & $70.6(2001)$ & $66.9(2006)$ & $75.4(2011)$ & 77.1 (2017) \\
\hline Palaup & 92.2 & 89.6 & $\ldots \ldots$ & $82.0(2015)$ \\
\hline Papua New Guinea & & & & \\
\hline Samoa & $40.4(2001)$ & $42.8(2006)$ & $50.9(2011)$ & $62.7(2017)$ \\
\hline Solomon Islands ${ }^{9}$ & $\ldots \ldots$ & & $44.8(2009)$ & \\
\hline Timor-Leste & $\ldots$ & & 39.8 & 46.7 (2013) \\
\hline Tonga & $\ldots$ & $44.3(2006)$ & $\ldots \ldots$ & $50.3(2016)$ \\
\hline Tuvalu & & & $\ldots$ & \\
\hline Vanuatu & $\ldots \ldots$ & $\ldots . . .$. & $\ldots \ldots$ & $\ldots$ \\
\hline \multicolumn{5}{|l|}{ Developed ADB Member Economies } \\
\hline Australia & 73.7 & 75.3 & 75.9 & 77.6 \\
\hline Japan & 63.7 & 68.1 & 70.5 & 72.7 \\
\hline New Zealand ${ }^{r}$ & 66.3 & 70.7 & 72.6 & 74.4 \\
\hline
\end{tabular}

... = data not available; - = magnitude equals zero, $\mathrm{ADB}=$ Asian Development Bank.

a Data are based on varying labor force concepts and definitions adopted by different economies. Some values may not add up to $100 \%$ due to limitations on data availability.

b Prior to 2017, employment in services includes people who were engaged in construction industries.

c For 2000 , employment in services includes people who were engaged in electricity, gas, and water industries.

d Refers to persons engaged in social labor and receiving remuneration or earning business income.

e Employment in services includes people who are engaged in the following sectors: electricity and gas supply; water supply; sewerage, waste management, and remediation activities.

$f$ For 2000, employment in services includes people who are engaged in electricity, gas, water, and construction industries.

g For 2005 and 2017, data are from the census of population. For other years, data are from labor force surveys. Data prior to and after the census years may not be directly comparable to data for 2005 and 2017

h Figures include local population only. For 2010, employment in services includes people who were engaged in industries other than agriculture, forestry, and fishing; mining and quarrying; or manufacturing industries.

i Some data may not add up because (i) for 2005 and 2011-2013, data cover all islands; (ii) for 2003, data exclude the Northern Province; (iii) for 2004, data exclude Mullaitivu and Kilinochchi districts; and (iv) for 2006-2010 and years prior to 2003, data exclude northern and eastern provinces.

j For 2005, employment in services includes people who were engaged in water supply; sewerage, waste management, and remediation activities.

k Refers to Singapore residents only.

I Refers to total number of persons engaged in any activity, regardless of age.

$\mathrm{m}$ Covers all wage and salary earners from all islands. For 2001, employment in services includes people who were engaged in electricity, gas, water, and construction industries.

n Refers to paid employment as of end of June, except for 2000 and 2005, which refer to end of December.

o Refers to cash work and unpaid village work. For 2005, employment figures by industry include only paid (cash work) workers, and as such, the number of employed for all industries may not add up to the total number of employed, which includes both cash workers and unpaid village workers. For 2010, employment in agriculture includes people who were engaged in mining and quarrying.

p For 2000 and 2005, employment in services includes people who were engaged in electricity, gas, water, and construction industries.

q For 2009, the figure refers to paid employment.

$r$ For 2000, employment in services includes people who were engaged in industries other than agriculture, forestry, and fishing or manufacturing industries.

Source: Asian Development Bank estimates using data from economy sources. 
Table 2.1.7: $\quad$ Poverty and Inequality ${ }^{\mathrm{a}}$

\begin{tabular}{|c|c|c|c|c|c|c|c|c|}
\hline \multirow[t]{2}{*}{ ADB Regional Member } & \multicolumn{2}{|c|}{$\begin{array}{l}\text { Proportion of Population } \\
\text { Living on Less Than \$1.90 a } \\
\text { Day (2011 PPP) } \\
(\%)\end{array}$} & \multicolumn{2}{|c|}{$\begin{array}{l}\text { Proportion of Population } \\
\text { Living on Less Than } \$ 3.20 \text { a } \\
\text { Day (2011 PPP) } \\
(\%)\end{array}$} & \multicolumn{2}{|c|}{$\begin{array}{c}\text { Income Ratio of Highest } 20 \% \\
\text { to Lowest } 20 \% \mathrm{~b}\end{array}$} & \multicolumn{2}{|c|}{$\begin{array}{c}\text { Gini } \\
\text { Coefficient }\end{array}$} \\
\hline & 2000 & 2017 & 2000 & 2017 & 2000 & 2017 & 2000 & 2017 \\
\hline \multicolumn{9}{|l|}{$\begin{array}{l}\text { Developing ADB Member Economies } \\
\text { Central and West Asia }\end{array}$} \\
\hline Afghanistan & & & & & & & & \\
\hline Armenia & $19.3(2001)$ & 1.4 & $55.6(2001)$ & 12.3 & $5.7(2001)$ & 5.0 & $0.354(2001)$ & 0.336 \\
\hline $\begin{array}{l}\text { Azerbaljan } \\
\text { Georgia }\end{array}$ & 19.4 & 5.0 & $\begin{array}{l}17.6 \\
44.8\end{array}$ & 16.3 & & 7.1 & $\begin{array}{l}0.365(2001) \\
0.405\end{array}$ & 0.379 \\
\hline Kazakhstan & $10.3(2001)$ & 0.0 & $32.3(2001)$ & 0.4 & $6.4(2001)$ & 3.8 & $0.360(2001)$ & 0.275 \\
\hline Kyrgyz Republic & 42.1 & 1.5 & 77.6 & 19.6 & & 3.8 & 0.310 & 0.273 \\
\hline Pakistand ${ }^{d}$ & $28.6(2001)$ & $3.9(2015)$ & $72.4(2001)$ & $34.7(2015)$ & $4.3(2001)$ & $4.8(2015)$ & $0.304(2001)$ & $0.335(2015)$ \\
\hline Tajikistan & $30.8(2003)$ & $4.8(2015)$ & $66.8(2003)$ & $20.3(2015)$ & $5.2(2003)$ & $5.6(2015)$ & $0.327(2003)$ & $0.340(2015)$ \\
\hline Turkmenistan & & & & & & & & \\
\hline Uzbekistane & 62.0 & & 86.7 & & 6.2 & & 0.361 & \\
\hline \multicolumn{9}{|l|}{ East Asia } \\
\hline $\begin{array}{l}\text { China, People's Republic of } \\
\text { Hons Kons China }\end{array}$ & $31.7(2002)$ & $0.7(2015)$ & $57.7(2002)$ & $7.0(2015)$ & $8.6(2002)$ & $7.1(2015)$ & $0.421(2002)$ & $0.386(2015)$ \\
\hline Korea, Republic of & $0.2(2006)$ & $0.2(2012)$ & $0.5(2006)$ & $0.5(2012)$ & $5.4(2006)$ & $5.3(2012)$ & $0.317(2006)$ & $0.316(2012)$ \\
\hline Mongolia & $9.7(2002)$ & $0.6(2016)$ & $33.6(2002)$ & $6.9(2016)$ & $5.4(2002)$ & $5.1(2016)$ & $0.329(2002)$ & 0.323 (2016) \\
\hline Taipei, China $^{f}$ & $\ldots$ & & & & & & 0.294 & 0.277 \\
\hline \multicolumn{9}{|l|}{ South Asia } \\
\hline Bangladesh & 34.8 & $14.8(2016)$ & 72.7 & $52.9(2016)$ & 5.0 & $4.8(2016)$ & 0.334 & $0.324(2016)$ \\
\hline Bhutan & $17.6(2003)$ & 1.5 & $45.2(2003)$ & 12.0 & $7.4(2003)$ & & $0.409(2003)$ & 0.374 \\
\hline India ${ }^{-}$ & $38.2(2004)$ & $21.2(2011)$ & $75.2(2004)$ & $60.4(2$ & $5.1(2004)$ & $5.5(2$ & $0.344(2004)$ & 0.357 (2011) \\
\hline Maldives ${ }^{d}$ & $10.0(2002)$ & $7.3(2009)$ & $39.2(2002)$ & $24.4(2009)$ & $7.2(2002)$ & $7.0(2009)$ & $0.413(2002)$ & $0.384(2009)$ \\
\hline Nepald & $46.1(2003)$ & $15.0(2010)$ & $75.5(2003)$ & 50.8( & $7.9(2003)$ & $5.0(2010)$ & $0.438(2003)$ & $0.328(2010)$ \\
\hline Sri Lanka & $8.3(2002)$ & $0.8(2016)$ & $36.0(2002)$ & $10.1(2016)$ & $7.1(2002)$ & $6.8(2016)$ & $0.410(2002)$ & $0.398(2016)$ \\
\hline \multicolumn{9}{|l|}{ Southeast Asia } \\
\hline Brunei Darussalam & . & .... & $\ldots$ & . & $\ldots$ & ... & $\ldots$ & 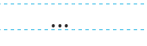 \\
\hline Indonesia & 39.3 & 5.7 & 79.9 & 27.3 & 4.0 & & 0.285 & 0.381 \\
\hline Lao People's Democratic Republicd & $33.8(2002)$ & $22.7(2012)$ & $72.1(2002)$ & 58.7( & 4.8( & 5.9 & $0.326(2002)$ & $0.364(20$ \\
\hline Malay & $0.4(2004)$ & $0.0(2015)$ & $2.6(2004)$ & $0.2(2015)$ & $10.9(2004)$ & $8.2(2015)$ & 0.461 (2004) & $0.410(2015)$ \\
\hline Myan & & $6.2(2015)$ & & $29.5(2015)$ & & $6.3(2015)$ & & $0.381(2015)$ \\
\hline Philippines & 14.5 & $7.8(2015)$ & 43.1 & $32.6(2015)$ & 8.0 & $7.2(2015)$ & 0.428 & 0.401 (2015) \\
\hline Singapc & & & & & & & & \\
\hline Thailand & 2.5 & 0.0 & & 0.5 & 8.0 & 6.0 & 0.428 & 0.365 \\
\hline Viet Nam & $38.0(2002)$ & $2.0(2016)$ & $70.8(2002)$ & $8.4(2016)$ & $6.1(2002)$ & $6.2(2016)$ & $0.370(2002)$ & $0.353(2016)$ \\
\hline \multirow{2}{*}{\multicolumn{9}{|c|}{ The Pacific }} \\
\hline & & & & & & & & \\
\hline Fijid & $4.9(2002)$ & $1.4(2013)$ & $21.8(2002)$ & $14.1(2013)$ & $6.8(2002)$ & $6.0(2013)$ & $0.381(2002)$ & $0.367(2013)$ \\
\hline Kiribati & $12.9(2006)$ & & $34.6(2006)$ & & $6.7(2006)$ & & $0(2006)$ & \\
\hline \multicolumn{9}{|l|}{ Marshall Islands } \\
\hline Micronesia, Federated States of & $8.1(2005)$ & $15.4(2013)$ & $24.6(2005)$ & $38.7(2013)$ & $8.7(2005)$ & $8.4(2013)$ & $0.424(2005)$ & $0.401(2013)$ \\
\hline Nauru & $\ldots$ & $\ldots \ldots$ & $\ldots$ & $\ldots \ldots$ & & $\ldots \ldots$ & & $\ldots$ \\
\hline Nive & $\ldots . .$. & - & $\ldots \ldots$ & $\ldots \ldots$ & $\ldots \ldots$ & $=0$ & $\ldots$ & . \\
\hline Palau & 10 & & & & & & & \\
\hline Papua New Guinead & & $38.0(2009)$ & & $65.6(2009)$ & & $9.3(2009)$ & & $0.419(2009)$ \\
\hline Samoad & $2.0(2002)$ & $1.1(2013)$ & $11.9(2002)$ & $9.6(2013)$ & $7.6(2002)$ & 6.8( & $0.407(2002)$ & $0.387(2013)$ \\
\hline Solomon Islands & $45.6(2005)$ & $25.1(2013)$ & $70.6(2005)$ & $58.8(2013)$ & $10.4(2005)$ & $6.4(2013)$ & 0.461 (2005) & 0.371 (2013) \\
\hline Timor-Leste & 46.0 (2001) & $30.7(2014)$ & $75.7(2001)$ & $73.3(2014)$ & $6.0(2001)$ & $4.1(2014)$ & $0.359(2001)$ & $0.287(2014)$ \\
\hline Tong & $2.8(2001)$ & $1.0(2015)$ & $8.4(2001)$ & $7.5(2015)$ & $7.1(2001)$ & $6.7(2015)$ & $0.377(2001)$ & $0.376(2015)$ \\
\hline Tuvalu & & $3.3(2010)$ & & $17.6(2010)$ & & $7.0(2010)$ & & $0.391(2010)$ \\
\hline Vanuatu. & . & $13.1(2010)$ & 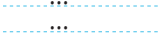 & $39.2(2010)$ & . & $6.7(2010)$ & & $0.376(2010)$ \\
\hline \multicolumn{9}{|l|}{ Developed ADB Member Economies } \\
\hline Australia &. & & & & $5.5(2001)$ & $6.3(2014)$ & $0.335(2001)$ & $0.358(2014)$ \\
\hline Japan & $\ldots$ & $\ldots$ & $\ldots$ & $\ldots$ & $5.4(2008)$ & $\ldots \ldots$ & $0.321(2008)$ & \\
\hline New Zealands & ... & $\ldots$ & $\ldots$ & $\ldots$ & ... & $\ldots$ & $\ldots$ & $0.349(2014)$ \\
\hline
\end{tabular}

$\ldots=$ Data not available, 0.0 = magnitude is less than half the unit employed, $\mathrm{ADB}=$ Asian Development Bank, $\mathrm{PPP}=$ purchasing power parity.

a Poverty and inequality estimates are consumption-based except for Malaysia, which is income-based. For New Zealand, the Gini coefficient data are based on disposable income post taxes and transfers. For Taipei,China, the estimates for the Gini coefficient are based on per capita disposable income.

b Derived from income or expenditure shares of the highest $20 \%$ and lowest $20 \%$ groups.

c For Azerbaijan, the latest available data are for 2005 : 0.0\% for proportion of population below $\$ 1.90$ a day (2011 PPP); $0.0 \%$ for proportion of population below $\$ 3.20$ a day (2011 PPP); 3.5 for income ratio of highest $20 \%$ to lowest $20 \%$; and 0.266 for Gini coefficient.

d Household income and expenditure surveys for these economies were conducted in overlappingyears. The table adopts the approach of the World Bank's World Development Indicators, using the initial year of the survey as the reference period for the poverty estimates.

e For Uzbekistan, the latest available data are for 2003 : $62.1 \%$ for proportion of population below $\$ 1.90$ a day (2011 PPP); $86.4 \%$ for proportion of population below $\$ 3.20$ a day (2011 PPP); 5.9 for income ratio of highest $20 \%$ to lowest $20 \%$; and 0.353 for Gini coefficient.

$f$ For Taipei,China, the Gini coefficient reflected in the table refers to the coefficient using per capita disposable income. The estimates using disposable income of households are 0.326 for 2000 and 0.337 for 2017 .

g Using the new income definition for New Zealand, the earliest available figure for the Gini coefficient is 0.323 for 2011.

Sources: World Bank. World Development Indicators. http://data.worldbank.org/data-catalog/world-development-indicators (accessed 3 June 2019); Organisation for Economic Co-operation and Development. Income Distribution and Poverty. /stats.oecd.org/index.aspx? queryid=66670 (accessed 3 June 2019 ). For Taipei,China: Government of Taipei,China, Directorate-General of Budget, Accounting and Statistics. http://eng.dgbas.gov.tw/mp.asp?mp=2 (accessed 3 June 2019 ). 
Table 2.1.8: $\quad$ Human Development Index ${ }^{a}$

\begin{tabular}{|c|c|c|c|c|c|c|c|c|c|}
\hline ADB Regional Member & 2000 & 2005 & 2010 & 2013 & 2014 & 2015 & 2016 & 2017 & Rank in 2017b \\
\hline \multicolumn{10}{|l|}{ Developing ADB Member Economies } \\
\hline Central and West Asia & 0.604 & 0.620 & 0.657 & 0.675 & 0.680 & 0.683 & 0.686 & 0.689 & \\
\hline Afghanistan & & 0.408 & 0.463 & 0.487 & 0.491 & 0.493 & 0.494 & 0.498 & 168 \\
\hline Armenia & 0.647 & 0.693 & 0.728 & 0.742 & 0.745 & 0.748 & 0.749 & 0.755 & 83 \\
\hline Azerbaijan & 0.640 & 0.679 & 0.740 & 0.752 & 0.758 & 0.758 & 0.757 & 0.757 & 80 \\
\hline Georgia & 0.673 & 0.712 & 0.735 & 0.757 & 0.765 & 0.771 & 0.776 & 0.780 & 70 \\
\hline Kazakhstan & 0.685 & 0.747 & 0.765 & 0.788 & 0.793 & 0.797 & 0.797 & 0.800 & 58 \\
\hline Kyrgyz Republic & 0.594 & 0.616 & 0.636 & 0.658 & 0.663 & 0.666 & 0.669 & 0.672 & 122 \\
\hline Pakistan & 0.450 & 0.500 & 0.526 & 0.538 & 0.548 & 0.551 & 0.560 & 0.562 & 150 \\
\hline Tajikistan & 0.550 & 0.593 & 0.634 & 0.646 & 0.645 & 0.645 & 0.647 & 0.650 & 127 \\
\hline Turkmenistan & & & 0.673 & 0.692 & 0.697 & 0.701 & 0.705 & 0.706 & 108 \\
\hline Uzbekistan & 0.595 & 0.628 & 0.666 & 0.690 & 0.695 & 0.698 & 0.703 & 0.710 & 105 \\
\hline East Asia & 0.707 & 0.774 & 0.812 & 0.830 & 0.835 & 0.838 & 0.845 & 0.847 & \\
\hline China, People's Republic of & 0.594 & 0.647 & 0.706 & 0.729 & 0.738 & 0.743 & 0.748 & 0.752 & 86 \\
\hline Hong Kong, China & 0.827 & 0.871 & 0.901 & 0.915 & 0.923 & 0.927 & 0.930 & 0.933 & 7 \\
\hline Korea, Republic of & 0.817 & 0.855 & 0.884 & 0.893 & 0.896 & 0.898 & 0.900 & 0.903 & 22 \\
\hline Mongolia & 0.589 & 0.650 & 0.697 & 0.729 & 0.734 & 0.737 & 0.743 & 0.741 & 92 \\
\hline Taipei,China & & 0.846 & 0.873 & 0.882 & 0.882 & 0.885 & 0.903 & 0.907 & $\ldots$ \\
\hline South Asia & 0.540 & 0.562 & 0.606 & 0.630 & 0.638 & 0.644 & 0.649 & 0.654 & \\
\hline Bangladesh & 0.468 & 0.505 & 0.545 & 0.575 & 0.583 & 0.592 & 0.597 & 0.608 & 136 \\
\hline Bhutan & & 0.510 & 0.566 & 0.589 & 0.599 & 0.603 & 0.609 & 0.612 & 134 \\
\hline India & 0.493 & 0.535 & 0.581 & 0.607 & 0.618 & 0.627 & 0.636 & 0.640 & 130 \\
\hline Maldives & 0.606 & 0.631 & 0.671 & 0.696 & 0.705 & 0.710 & 0.712 & 0.717 & 101 \\
\hline Nepal & 0.446 & 0.475 & 0.529 & 0.554 & 0.560 & 0.566 & 0.569 & 0.574 & 149 \\
\hline Sri Lanka & 0.685 & 0.718 & 0.745 & 0.759 & 0.763 & 0.766 & 0.768 & 0.770 & 76 \\
\hline Southeast Asia & 0.614 & 0.650 & 0.684 & 0.703 & 0.707 & 0.711 & 0.715 & 0.719 & \\
\hline Brunei Darussalam & $\begin{array}{l}0.014 \\
0.819\end{array}$ & 0.838 & 0.042 & 0.853 & 0.853 & 0.852 & 0.852 & 0.853 & 39 \\
\hline Cambodia & 0.420 & 0.490 & 0.537 & 0.560 & 0.566 & 0.571 & 0.576 & 0.582 & 146 \\
\hline Indonesia & 0.606 & 0.632 & 0.661 & 0.681 & 0.683 & 0.686 & 0.691 & 0.694 & 116 \\
\hline Lao People's Democratic Republic & 0.466 & 0.506 & 0.546 & 0.579 & 0.586 & 0.593 & 0.598 & 0.601 & 139 \\
\hline Malaysia & 0.725 & 0.731 & 0.772 & 0.785 & 0.790 & 0.795 & 0.799 & 0.802 & 57 \\
\hline Myanmar & 0.431 & 0.477 & 0.530 & 0.558 & 0.564 & 0.569 & 0.574 & 0.578 & 148 \\
\hline Philippines & 0.624 & 0.650 & 0.665 & 0.685 & 0.689 & 0.693 & 0.696 & 0.699 & 113 \\
\hline Singapore & 0.819 & 0.868 & 0.909 & 0.923 & 0.928 & 0.929 & 0.930 & 0.932 & 9 \\
\hline Thailand & 0.649 & 0.693 & 0.724 & 0.728 & 0.735 & 0.741 & 0.748 & 0.755 & 83 \\
\hline Viet Nam & 0.579 & 0.616 & 0.654 & 0.675 & 0.678 & 0.684 & 0.689 & 0.694 & 116 \\
\hline The Pacific & 0.584 & 0.602 & 0.632 & 0.644 & 0.645 & 0.652 & 0.653 & 0.658 & \\
\hline Cook Islands & & & & & & & & & \\
\hline Fiji & 0.683 & 0.695 & 0.711 & 0.727 & 0.730 & 0.738 & 0.738 & 0.741 & 92 \\
\hline Kiribati & 0.552 & 0.585 & 0.590 & 0.609 & 0.616 & 0.621 & 0.610 & 0.612 & 134 \\
\hline Marshall Islands & & & & $\begin{array}{l}0.00 \\
\ldots\end{array}$ & & & & 0.708 & 106 \\
\hline Micronesia, Federated States of & 0.552 & 0.582 & 0.608 & 0.619 & 0.618 & 0.627 & 0.627 & 0.627 & 131 \\
\hline Nauru & & & $\ldots$ & $\ldots$ & $\ldots$ & $\ldots$ & $\ldots$ & $\ldots$ & $\ldots$ \\
\hline Niue & & & & & & & & & $\ldots$ \\
\hline Palau & 0.743 & 0.760 & 0.769 & 0.780 & 0.786 & 0.793 & 0.798 & 0.798 & 60 \\
\hline Papua New Guinea & 0.449 & 0.479 & 0.520 & 0.534 & 0.536 & 0.542 & 0.543 & 0.544 & 153 \\
\hline Samoa & 0.647 & 0.673 & 0.693 & 0.700 & 0.703 & 0.706 & 0.711 & 0.713 & 104 \\
\hline Solomon Islands & 0.450 & 0.487 & 0.507 & 0.539 & 0.539 & 0.546 & 0.543 & 0.546 & 152 \\
\hline Timor-Leste & 0.507 & 0.496 & 0.619 & 0.614 & 0.610 & 0.630 & 0.631 & 0.625 & 132 \\
\hline Tonga & 0.673 & 0.693 & 0.712 & 0.716 & 0.717 & 0.721 & 0.724 & 0.726 & 98 \\
\hline Tuvalu & & & & & & & & & \\
\hline Vanuatu & & 0.572 & 0.591 & 0.597 & 0.598 & 0.599 & 0.600 & 0.603 & 138 \\
\hline Developed ADB Member Economies & 0.874 & 0.890 & 0.902 & 0.912 & 0.915 & 0.918 & 0.920 & 0.922 & \\
\hline Australia & 0.898 & 0.908 & 0.923 & 0.931 & 0.933 & 0.936 & 0.938 & 0.939 & 3 \\
\hline Japan & 0.855 & 0.873 & 0.885 & 0.899 & 0.903 & 0.905 & 0.907 & 0.909 & 19 \\
\hline New Zealand & 0.869 & 0.888 & 0.899 & 0.907 & 0.910 & 0.914 & 0.915 & 0.917 & 16 \\
\hline
\end{tabular}

$\ldots=$ data not available, $\mathrm{ADB}=$ Asian Development Bank.

a The regional indexes are calculated as simple averages of the indexes for their member economies.

b Rank among the 189 national economies presented in Human Development Report 2018 of the United Nations Development Programme.

Sources: $\quad$ United Nations Development Programme. Human Development Data (1990-2017). http://hdr.undp.org/en/data\# (accessed 4 June 2019). For Taipei,China: Government of Taipei,China, Directorate-General of Budget, Accounting and Statistics. https://eng.stat.gov.tw/ct.asp? $x$ Item=25280\&ctNode=6032\&mp=5 (accessed 4 June 2019). 
Table 2.1.9: $\quad$ Life Expectancy at Birth

(years)

\begin{tabular}{|c|c|c|c|c|c|c|}
\hline \multirow{2}{*}{ ADB Regional Member } & \multicolumn{2}{|c|}{ Both Sexes } & \multicolumn{2}{|c|}{ Female } & \multicolumn{2}{|r|}{ Male } \\
\hline & 2000 & 2017 & 2000 & 2017 & 2000 & 2017 \\
\hline \multirow{2}{*}{\multicolumn{7}{|c|}{$\begin{array}{l}\text { Developing ADB Member Economies } \\
\text { Central and West Asia }\end{array}$}} \\
\hline & & & & & & \\
\hline Afghanistan & 55.5 & 64.0 & 56.7 & 65.4 & 54.4 & 62.8 \\
\hline Armenia & 71.4 & 74.8 & 74.5 & 77.8 & 68.1 & 71.4 \\
\hline Azerbaijan & 66.8 & 72.1 & 69.9 & 75.2 & 63.6 & 69.1 \\
\hline Georgia & 71.9 & 73.4 & 75.4 & 77.6 & 68.1 & 69.2 \\
\hline Kazakhstan & 65.5 & 73.0 & 71.1 & 76.9 & 60.2 & 68.7 \\
\hline Kyrgyz Republic & 68.6 & 71.2 & 72.4 & 75.4 & 64.9 & 67.2 \\
\hline Pakistan & 62.7 & 66.6 & 63.6 & 67.7 & 62.0 & 65.6 \\
\hline Tajikistan & 65.5 & 71.2 & 68.8 & 74.4 & 62.5 & 68.4 \\
\hline Turkmenistan & 63.6 & 68.0 & 67.7 & 71.4 & 59.6 & 64.5 \\
\hline Uzbekistan & 67.2 & 71.4 & 70.4 & 74.2 & 64.0 & 68.6 \\
\hline \multicolumn{7}{|l|}{ East Asia } \\
\hline China, People's Republic of & 72.0 & 76.4 & 73.7 & 78.0 & 70.4 & 74.9 \\
\hline Hong Kong, China & 80.9 & 84.7 & 83.9 & 87.6 & 78.0 & 81.9 \\
\hline Korea, Republic of & 75.9 & 82.6 & 79.7 & 85.7 & 72.3 & 79.7 \\
\hline Mongolia & 62.9 & 69.5 & 65.9 & 73.7 & 60.1 & 65.4 \\
\hline Taipei,China & 76.5 & 80.4 & 79.6 & 83.7 & 73.8 & 77.3 \\
\hline \multicolumn{7}{|l|}{ South Asia } \\
\hline Bangladesh & 65.3 & 72.8 & 65.7 & 74.6 & 65.0 & 71.2 \\
\hline Bhutan & 60.8 & 70.6 & 60.9 & 70.9 & 60.6 & 70.3 \\
\hline India & 62.6 & 68.8 & 63.4 & 70.4 & 61.8 & 67.3 \\
\hline Maldives & 69.9 & 77.6 & 71.1 & 78.8 & 69.2 & 76.7 \\
\hline Nepal & 62.4 & 70.6 & 63.4 & 72.2 & 61.3 & 69.0 \\
\hline Sri Lanka & 71.0 & 75.5 & 74.9 & 78.8 & 67.5 & 72.1 \\
\hline \multicolumn{7}{|l|}{ Southeast Asia } \\
\hline Brunei Darussalam & 75.2 & 77.4 & 76.9 & 79.1 & 73.7 & 75.8 \\
\hline Cambodia & 58.4 & 69.3 & 60.6 & 71.3 & 56.2 & 67.1 \\
\hline Indonesia & 66.3 & 69.4 & 68.0 & 71.6 & 64.6 & 67.3 \\
\hline Lao People's Democratic Republic & 58.9 & 67.0 & 60.3 & 68.6 & 57.5 & 65.4 \\
\hline $\begin{array}{l}\text { Malaysia } \\
\text { a p }\end{array}$ & 72.8 & 75.5 & 75.0 & 77.9 & 70.8 & 73.3 \\
\hline Myanmar & 62.1 & 66.7 & 64.2 & 69.1 & 60.1 & 64.4 \\
\hline Philippines & 67.2 & 69.2 & 70.3 & 72.8 & 64.2 & 65.9 \\
\hline Singapore & 78.0 & 82.9 & 80.0 & 85.2 & 76.0 & 80.7 \\
\hline Thailand & 70.6 & 75.5 & 74.5 & 79.3 & 66.9 & 71.8 \\
\hline Viet Nam & 73.3 & 76.5 & 78.1 & 81.0 & 68.4 & 71.8 \\
\hline \multicolumn{7}{|l|}{ The Pacific } \\
\hline Cook Islands & 71.9 & $76.2(2018)$ & 74.7 & $79.2(2018)$ & 69.2 & $73.4(2018)$ \\
\hline Fiji & 67.6 & 70.4 & 70.2 & 73.6 & 65.2 & 67.5 \\
\hline Kiribati & 64.0 & 66.5 & 67.0 & 69.8 & 61.1 & 63.2 \\
\hline Marshall Islands & 68.4 & $73.6(2018)$ & 70.4 & $76.0(2018)$ & 66.6 & $71.4(2018)$ \\
\hline Micronesia, Federated States of & 67.3 & 69.3 & 67.9 & 70.5 & 66.7 & 68.1 \\
\hline Nauru & 60.9 & $67.8(2018)$ & 64.5 & $71.2(2018)$ & 57.4 & $63.6(2018)$ \\
\hline Niue & $70.1(2001)$ & $73.9(2006-2011)^{a}$ & $71.2(2001)$ & $75.2(2006-2011)^{a}$ & $69.8(2001)$ & $72.5(2006-2011)^{a}$ \\
\hline Palau & 68.5 & $73.6(2018)$ & 71.7 & $77.0(2018)$ & 65.4 & $70.4(2018)$ \\
\hline Papua New Guinea & 61.8 & 65.7 & 64.4 & 68.3 & 59.5 & 63.3 \\
\hline Samoa & 69.3 & 75.2 & 72.8 & 78.5 & 66.3 & 72.3 \\
\hline Solomon Islands & 63.1 & 71.0 & 64.0 & 72.6 & 62.3 & 69.5 \\
\hline Timor-Leste & 59.4 & 69.2 & 60.6 & 71.1 & 58.1 & 67.4 \\
\hline Tonga & 70.8 & 73.2 & 72.8 & 76.2 & 68.8 & 70.2 \\
\hline Tuvalu & 61.6 & $67.2(2018)$ & 63.6 & $69.5(2018)$ & 59.7 & $65.0(2018)$ \\
\hline Vanuatu & 67.4 & 72.3 & 69.3 & 74.7 & 65.9 & 70.2 \\
\hline \multicolumn{7}{|l|}{ Developed ADB Member Economies } \\
\hline Australia & 79.2 & 82.5 & 82.0 & 84.7 & 76.6 & 80.4 \\
\hline Japan & 81.1 & 84.1 & 84.6 & 87.3 & 77.7 & 81.1 \\
\hline New Zealand & 78.6 & 81.7 & 81.3 & 83.4 & 76.1 & 80.0 \\
\hline WORLD & 67.7 & 72.2 & 69.9 & $\mathbf{7 4 . 5}$ & 65.6 & 70.1 \\
\hline
\end{tabular}

$\mathrm{ADB}=$ Asian Development Bank.

a Refers to multiyear average for the intercensal years 2006-2011. Estimates are derived through an indirect technique, by applying the United Nations Mortpak.4.1 software program (MATCH), which calculates the Coale-Demeny WEST model life tables.

Sources: World Bank. World Development Indicators. http://databank.worldbank.org/data/source/world-development-indicators/preview/on\# (accessed 19 June 2019). For the Cook Islands, the Marshall Islands, Nauru, Palau, and Tuvalu: United States Census Bureau Online. https://www.census.gov/data-tools/demo/ idb/informationGateway.php (accessed 19 June 2019). For Niue: Statistics Niue, Department of Finance, Planning and Statistics. https://niue.prism.spc.int/ andhttp://prism.spc.int/images/census_reports/Niue_2011_Population_Households_Census.pdf(accessed 19 June 2019). For Taipei,China:Government of Taipei,China, Directorate-General of Budget, Accounting and Statistics. http://eng.dgbas.gov.tw/mp.asp? mp=2 (accessed 19 June 2019 ). 
Table 2.1.10: Births, Deaths, and Fertility Rates

\begin{tabular}{|c|c|c|c|c|c|c|}
\hline \multirow[t]{2}{*}{ ADB Regional Member } & \multicolumn{2}{|c|}{$\begin{array}{l}\text { Crude Birth Rate } \\
\text { (per 1,000 people) }\end{array}$} & \multicolumn{2}{|c|}{$\begin{array}{l}\text { Crude Death Rate } \\
\text { (per 1,000 people) }\end{array}$} & \multicolumn{2}{|c|}{$\begin{array}{l}\text { Total Fertility Rate } \\
\text { (births per woman) }\end{array}$} \\
\hline & 2000 & 2017 & 2000 & 2017 & 2000 & 2017 \\
\hline \multicolumn{7}{|l|}{ Developing ADB Member Economies } \\
\hline \multicolumn{7}{|l|}{ Central and West Asia } \\
\hline Afghanistan & 48.4 & 32.5 & 12.0 & 6.6 & 7.5 & 4.5 \\
\hline Armenia & 12.9 & 13.1 & 8.6 & 9.7 & 1.6 & 1.6 \\
\hline Azerbaijan & 14.5 & 14.6 & 5.8 & 5.8 & 2.0 & 1.9 \\
\hline Georgia & 12.0 & 13.2 & 9.9 & 13.2 & 1.6 & 2.0 \\
\hline Kazakhstan & 14.9 & 21.6 & 10.1 & 7.2 & 1.8 & 2.7 \\
\hline Kyrgyz Republic & 19.8 & 24.8 & 7.0 & 5.4 & 2.4 & 3.0 \\
\hline Pakistan & 32.0 & 27.7 & 8.7 & 7.2 & 4.6 & 3.4 \\
\hline Tajikistan & 30.2 & 28.3 & 7.0 & 5.1 & 3.9 & 3.3 \\
\hline Turkmenistan & 23.6 & 24.6 & 7.8 & 7.1 & 2.8 & 2.8 \\
\hline Uzbekistan & 21.4 & 22.1 & 5.5 & 5.0 & 2.6 & 2.5 \\
\hline \multicolumn{7}{|l|}{ East Asia } \\
\hline China, People's Republic of & 14.0 & 12.4 & 6.5 & 7.1 & 1.5 & 1.6 \\
\hline Hong Kong, China & 8.1 & 7.7 & 5.1 & 6.3 & 1.0 & 1.1 \\
\hline Korea, Republic of & 13.3 & 7.0 & 5.2 & 5.6 & 1.5 & 1.1 \\
\hline Mongolia & 19.3 & 23.1 & 7.7 & 6.3 & 2.1 & 2.7 \\
\hline Taipei,China & 13.8 & $7.7(2018)$ & 5.7 & $7.3(2018)$ & 1.7 & $1.1(2018)$ \\
\hline \multicolumn{7}{|l|}{ South Asia } \\
\hline Bangladesh & 27.6 & 18.6 & 6.9 & 5.3 & 3.2 & 2.1 \\
\hline Bhutan & 28.0 & 17.9 & 8.5 & 6.0 & 3.6 & 2.0 \\
\hline India & 26.5 & 18.8 & 8.7 & 7.3 & 3.3 & 2.3 \\
\hline Maldives & 22.6 & 17.7 & 4.7 & 3.3 & 2.9 & 2.1 \\
\hline Nepal & 32.1 & 19.5 & 8.5 & 6.2 & 4.0 & 2.1 \\
\hline Sri Lanka & 18.5 & 15.0 & 7.0 & 7.0 & 2.2 & 2.0 \\
\hline \multicolumn{7}{|l|}{ Southeast Asia } \\
\hline Brunei Darussalam & 21.4 & 15.6 & 2.9 & 3.6 & 2.2 & 1.9 \\
\hline Cambodia & 28.1 & 22.9 & 9.4 & 6.0 & 3.8 & 2.5 \\
\hline Indonesia & 21.8 & 18.6 & 7.3 & 7.2 & 2.5 & 2.3 \\
\hline Lao People's Democratic Republic & 31.8 & 23.4 & 9.8 & 6.6 & 4.3 & 2.6 \\
\hline Malaysia & 22.0 & 17.0 & 4.5 & 5.0 & 2.8 & 2.0 \\
\hline Myanmar & 24.5 & 17.6 & 9.1 & 8.2 & 2.9 & 2.2 \\
\hline Philippines & 29.6 & 23.0 & 6.0 & 6.5 & 3.8 & 2.9 \\
\hline Singapore & 13.7 & 8.9 & 4.5 & 5.0 & 1.6 & 1.2 \\
\hline Thailand & 14.5 & 10.1 & 6.9 & 8.0 & 1.7 & 1.5 \\
\hline Viet Nam & 17.5 & 16.5 & 5.5 & 5.8 & 2.0 & 2.0 \\
\hline \multicolumn{7}{|l|}{ The Pacific } \\
\hline Cook Islands & 23.1 & $13.7(2018)$ & 6.3 & $8.6(2018)$ & 3.2 & $2.2(2018)$ \\
\hline Fiji & 24.7 & 19.0 & 6.1 & 7.2 & 3.1 & 2.5 \\
\hline Kiribati & 30.6 & 27.9 & 7.6 & 7.0 & 4.1 & 3.6 \\
\hline Marshall Islands & 35.0 & $23.8(2018)$ & 5.3 & $4.2(2018)$ & 4.4 & $3.0(2018)$ \\
\hline Micronesia, Federated States of & 29.9 & 23.8 & 6.3 & 6.2 & 4.3 & 3.1 \\
\hline Nauru & 27.9 & $23.2(2018)$ & 7.2 & $5.9(2018)$ & 3.5 & $2.8(2018)$ \\
\hline Niue & $18.5(2001)$ & $18.4(2006-2011)^{a}$ & $7.8(2001)$ & $8.9(2006-2011)^{\mathrm{a}}$ & $3.0(2001)$ & $2.2(2006-2011)^{\mathrm{a}}$ \\
\hline Palau & 14.5 & 12.4 & 6.5 & 10.3 & 1.8 & $2.2(2015)$ \\
\hline Papua New Guinea & 34.0 & 27.3 & 8.3 & 7.1 & 4.5 & 3.6 \\
\hline Samoa & 30.6 & 24.3 & 6.1 & 5.0 & 4.5 & 3.9 \\
\hline Solomon Islands & 35.6 & 28.2 & 7.5 & 4.7 & 4.7 & 3.8 \\
\hline Timor-Leste & 43.5 & 34.6 & 9.4 & 5.4 & 7.1 & 5.4 \\
\hline Tonga & 28.2 & 23.6 & 6.2 & 6.0 & 4.3 & 3.6 \\
\hline Tuvalu & 24.6 & $23.7(2018)$ & 10.8 & $8.4(2018)$ & 3.6 & $2.9(2018)$ \\
\hline Vanuatu & 32.4 & 25.5 & 6.2 & 4.8 & 4.4 & 3.2 \\
\hline \multicolumn{7}{|l|}{ Developed ADB Member Economies } \\
\hline Australia & 13.0 & 12.4 & 6.7 & 6.5 & 1.8 & 1.8 \\
\hline Japan & 9.4 & 7.6 & 7.7 & 10.8 & 1.4 & 1.4 \\
\hline New Zealand & 14.7 & 12.4 & 6.9 & 7.0 & 2.0 & 1.8 \\
\hline WORLD & 21.6 & 18.7 & 8.5 & 7.6 & 2.7 & 2.4 \\
\hline
\end{tabular}

$\mathrm{ADB}=$ Asian Development Bank.

a Refers to a multiyear average for the intercensal years 2006-2011. Crude birth rate and crude death rate are calculated by dividing the average annual number of births and deaths of the intercensal period 2006-2011 by the midperiod population size of the intercensal period. For total fertility rate, the estimate is based on the average registered number of children born, by age of mother, of the intercensal period 2006-2011, and the estimated midperiod number of women of childbearing age.

Sources: World Bank. World Development Indicators. http://databank.worldbank.org/data/source/world-development-indicators/preview/on (accessed 18 June 2019). For the Cook Islands, the Marshall Islands, Nauru, and Tuvalu: United States Census Bureau Online. http://www.census.gov/ (accessed 18 June 2019). For Niue: Statistics Niue, Department of Finance, Planning and Statistics. https://niue.prism.spc.int/ and http://prism.spc.int/images/census_reports/ Niue_2011_Population_Households_Census.pdf (accessed 18 June 2019). For Taipei,China: Government of Taipei,China, Directorate-General of Budget, Accounting and Statistics. http://eng.dgbas.gov.tw/mp.asp?mp=2 (accessed 18 June 2019). 
Table 2.1.11: Primary Education Completion Rate ${ }^{a}$

(\%)

\begin{tabular}{|c|c|c|c|c|c|c|}
\hline \multirow{2}{*}{ ADB Regional Member } & \multicolumn{2}{|c|}{ Both Sexes } & \multicolumn{2}{|c|}{ Female } & \multicolumn{2}{|c|}{ Male } \\
\hline & 2000 & 2017 & 2000 & 2017 & 2000 & 2017 \\
\hline \multirow{2}{*}{\multicolumn{7}{|c|}{$\begin{array}{l}\text { Developing ADB Member Economies } \\
\text { Central and West Asia }\end{array}$}} \\
\hline & & & & & & \\
\hline \multicolumn{7}{|l|}{ Afghanistan } \\
\hline Armenia & $93.7(2002)$ & 91.6 & $94.1(2002)$ & 92.2 & $93.3(2002)$ & 91.1 \\
\hline Azerbaijan & 89.5 & 107.2 & 85.5 & 107.6 & 93.8 & 106.8 \\
\hline Georgia & 96.2 & 117.1 & 96.4 & 117.6 & 96.0 & 116.7 \\
\hline Kazakhstan & 92.1 & $109.7(2018)$ & 92.0 & $110.9(2018)$ & 92.2 & $108.5(2018)$ \\
\hline Kyrgyz Republic & 93.7 & 103.8 & 93.2 & 103.4 & 94.1 & 104.1 \\
\hline Pakistan & $64.3(2005)$ & $71.3(2016)$ & $53.5(2005)$ & $64.6(2016)$ & $74.5(2005)$ & $77.6(2016)$ \\
\hline Tajikistan & 92.7 & 92.4 & 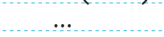 & 92.0 & & 92.7 \\
\hline \multicolumn{7}{|l|}{ Turkmenistan } \\
\hline Uzbekistan & $100.4(2001)$ & 97.7 & $100.3(2001)$ & 97.0 & $100.5(2001)$ & 98.4 \\
\hline \multicolumn{7}{|l|}{ East Asia } \\
\hline China, People's Republic of & $89.1(2006)$ & $99.9(2013)$ & $89.0(2006)$ & $99.2(2013)$ & $89.2(2006)$ & $100.5(2013)$ \\
\hline Hong Kong, China & & 102.2 & & 100.7 & & 103.6 \\
\hline Korea, Republic of & 103.2 & $96.1(2016)$ & 105.0 & $96.5(2016)$ & 101.6 & $95.8(2016)$ \\
\hline Mongolia & 87.0 & 92.6 & 89.3 & 91.5 & 84.6 & 93.6 \\
\hline Taipei,China & - & $\ldots$ & $\ldots$ & $\ldots$ & $\ldots$ & $\ldots$ \\
\hline \multicolumn{7}{|l|}{ South Asia } \\
\hline Bangladesh & $64.3(2005)$ & 118.6 & $66.8(2005)$ & 123.0 & $61.9(2005)$ & 114.3 \\
\hline Bhutan & 49.5 & 95.1 & 46.1 & 99.5 & 52.9 & 90.9 \\
\hline India & 71.8 & 94.5 & 63.5 & 96.6 & 79.4 & 92.6 \\
\hline Maldives & & 94.7 & & 91.5 & & 97.8 \\
\hline Nepal & 67.3 & 112.8 & 57.2 & 118.1 & 77.0 & 107.6 \\
\hline Sri Lanka & $107.3(2001)$ & 101.9 & $106.6(2001)$ & 101.2 & $108.0(2001)$ & 102.7 \\
\hline \multicolumn{7}{|l|}{ Southeast Asia } \\
\hline Brunei Darussalam & 114.8 & 106.5 & 109.9 & 105.2 & 119.5 & 107.8 \\
\hline Cambodia & $51.3(2001)$ & 89.6 & $46.1(2001)$ & 91.9 & $56.3(2001)$ & 87.3 \\
\hline Indonesia & $93.8(2001)$ & 99.2 & $94.2(2001)$ & 98.5 & $93.4(2001)$ & 99.8 \\
\hline Lao People's Democratic Republic & 67.3 & 102.2 & 61.4 & 101.8 & 73.0 & 102.6 \\
\hline Malaysia & 100.6 & 99.2 & 100.7 & 100.3 & 100.5 & 98.1 \\
\hline Myanmar & 78.2 & 96.4 & 75.9 & 96.7 & 80.6 & 96.1 \\
\hline Philippines & $100.3(2001)$ & $104.0(2016)$ & $105.4(2001)$ & $106.1(2016)$ & $95.5(2001)$ & $102.0(2016)$ \\
\hline Singapore & & $99.8(2016)$ & & $99.2(2016)$ & & $100.4(2016)$ \\
\hline Thailand & 84.9 & 93.4 & 84.3 & 94.1 & 85.4 & 92.7 \\
\hline Viet Nam & 99.0 & $104.8(2016)$ & 96.6 & $105.0(2016)$ & 101.3 & $104.5(2016)$ \\
\hline \multicolumn{7}{|l|}{ The Pacific } \\
\hline Cook Islands & $112.0(2007)$ & $108.9(2016)$ & & $102.1(2016)$ & & $115.9(2016)$ \\
\hline Fiji & 95.0 & $102.8(2016)$ & 93.9 & $103.1(2016)$ & 96.0 & $102.6(2016)$ \\
\hline Kiribati & 99.0 & $99.5(2016)$ & 95.1 & $103.5(2016)$ & 102.7 & $95.8(2016)$ \\
\hline Marshall Islands & $114.3(2002)$ & $76.9(2016)$ & $118.1(2002)$ & $80.0(2016)$ & $110.8(2002)$ & $74.0(2016)$ \\
\hline \multicolumn{7}{|l|}{ Micronesia, Federated States of } \\
\hline Nauru & $87.0(2001)$ & $120.4(2016)$ & $90.1(2001)$ & $121.0(2016)$ & $84.3(2001)$ & $119.8(2016)$ \\
\hline Niue & $105.0(2001)$ & $111.5(2016)$ & $105.6(2001)$ & $80.0(2016)$ & $104.5(2001)$ & $154.5(2016)$ \\
\hline Palau & $104.5(2004)$ & $95.9(2014)$ & 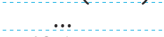 & $94.7(2014)$ & & $96.9(2014)$ \\
\hline Papua New Guinea & 52.5 & $79.3(2016)$ & 48.1 & $73.5(2016)$ & 56.7 & $84.7(2016)$ \\
\hline Samoa & 94.0 & 100.9 & 95.5 & 103.2 & 92.7 & 98.7 \\
\hline Solomon Islands & & 87.2 & & 89.5 & & 85.0 \\
\hline Timor-Leste & $76.6(2008)$ & $95.3(2016)$ & $76.1(2008)$ & $97.6(2016)$ & $77.2(2008)$ & $93.1(2016)$ \\
\hline Tonga & $105.5(2001)$ & $111.0(2013)$ & $104.0(2001)$ & $106.5(2013)$ & $107.0(2001)$ & $115.1(2013)$ \\
\hline Tuvalu & $101.7(2001)$ & $104.0(2016)$ & $108.3(2001)$ & $98.9(2016)$ & $96.1(2001)$ & $108.7(2016)$ \\
\hline Vanuatu & 92.1 & $93.8(2013)$ & 94.4 & $97.8(2013)$ & 89.9 & $90.2(2013)$ \\
\hline \multicolumn{7}{|l|}{ Developed ADB Member Economies } \\
\hline Australia & & & & & $\ldots$ & \\
\hline Japan & & $100.5(2016)$ & & $100.7(2016)$ & & $100.3(2016)$ \\
\hline New Zealand & $\ldots$ & $\ldots$ & $\cdots$ & $\cdots$ & $\cdots$ & $\cdots$ \\
\hline
\end{tabular}

$\ldots=$ data not available, $\mathrm{ADB}=$ Asian Development Bank.

a Represented by the total number of new entrants in the last grade of primary education, regardless of age, expressed as a percentage of the population at the theoretical age to enter the last grade of primary education.

Source: $\quad$ United Nations Educational, Scientific and Cultural Organization, Institute for Statistics Database. UIS.Stat. http://data.uis.unesco.org/ (accessed 20 July 2019). 
Table 2.1.12: Adult (15 Years and Older) Literacy Rate

(\%)

\begin{tabular}{|c|c|c|c|c|c|c|}
\hline \multirow{2}{*}{ ADB Regional Member } & \multicolumn{2}{|c|}{ Both Sexes } & \multicolumn{2}{|c|}{ Female } & \multicolumn{2}{|c|}{ Male } \\
\hline & 2000 & 2016 & 2000 & 2016 & 2000 & 2016 \\
\hline \multirow{2}{*}{\multicolumn{7}{|c|}{$\begin{array}{l}\text { Developing ADB Member Economies } \\
\text { Central and West Asia }\end{array}$}} \\
\hline & & & & & & \\
\hline Afghanistan & & $31.7(2011)$ & & $17.6(2011)$ & & $45.4(2011)$ \\
\hline Armenia & $99.4(2001)$ & $99.7(2011)$ & $99.2(2001)$ & $99.7(2011)$ & $99.7(2001)$ & $99.8(2011)$ \\
\hline Azerbaijan & $99.6(2007)$ & 99.8 & 99.4 (2007) & 99.7 & $99.8(2007)$ & 99.9 \\
\hline Georgia & $99.7(2002)$ & $99.6(2014)$ & $99.6(2002)$ & $99.5(2014)$ & $99.8(2002)$ & $99.7(2014)$ \\
\hline Kazakhstan & $\ldots$ & $99.8(2010)$ & $\ldots$ & $99.7(2010)$ & $\ldots$ & $99.8(2010)$ \\
\hline Kyrgyz Republic & & $99.2(2009)$ & & $99.0(2009)$ & & $99.5(2009)$ \\
\hline Pakistan & $49.9(2005)$ & $57.0(2014)$ & $35.4(2005)$ & $44.3(2014)$ & $64.1(2005)$ & $69.1(2014)$ \\
\hline Tajikistan & 99.5 & $99.8(2014)$ & 99.2 & $99.7(2014)$ & 99.7 & $99.8(2014)$ \\
\hline Turkmenistan & & $99.7(2014)$ & & $99.6(2014)$ & & $99.8(2014)$ \\
\hline Uzbekistan & 98.6 & 100.0 & 98.1 & 100.0 & 99.2 & 100.0 \\
\hline \multicolumn{7}{|l|}{ East Asia } \\
\hline China, People's Republic of & 90.9 & $95.1(2010)$ & 86.5 & $92.7(2010)$ & 95.1 & $97.5(2010)$ \\
\hline Hong Kong, China & $\ldots$ & & $\ldots$ & & ont & $\ldots$ \\
\hline Korea, Republic of & & & & & & \\
\hline Mongolia & 97.8 & $98.3(2010)$ & 97.5 & $98.3(2010)$ & 98.0 & $98.2(2010)$ \\
\hline Taipei,China & $\ldots$ & $\ldots$ & $\ldots$ & $\ldots$ & $\ldots$ & $\ldots$ \\
\hline \multicolumn{7}{|l|}{ South Asia } \\
\hline Bangladesh & $47.5(2001)$ & $72.9(2017)$ & $40.8(2001)$ & $70.1(2017)$ & $53.9(2001)$ & 75.7 (2017) \\
\hline Bhutan & $52.8(2005)$ & $57.0(2012)$ & $38.7(2005)$ & $48.0(2012)$ & $65.0(2005)$ & $66.0(2012)$ \\
\hline India & $61.0(2001)$ & $69.3(2011)$ & $47.8(2001)$ & $59.3(2011)$ & $73.4(2001)$ & 78.9 (2011) \\
\hline Maldives & $98.4(2006)$ & $98.6(2014)$ & $98.4(2006)$ & $98.7(2014)$ & $98.4(2006)$ & $98.5(2014)$ \\
\hline Nepal & $48.6(2001)$ & $59.6(2011)$ & $34.9(2001)$ & $48.8(2011)$ & $62.7(2001)$ & $71.7(2011)$ \\
\hline Sri Lanka & $90.7(2001)$ & $91.9(2017)$ & $89.1(2001)$ & $91.0(2017)$ & $92.3(2001)$ & $93.0(2017)$ \\
\hline \multicolumn{7}{|l|}{ Southeast Asia } \\
\hline Brunei Darussalam & $92.7(2001)$ & $96.1(2011)$ & $90.2(2001)$ & $94.7(2011)$ & $95.2(2001)$ & $97.4(2011)$ \\
\hline Cambodia & $73.6(2004)$ & $80.5(2015)$ & $64.1(2004)$ & $75.0(2015)$ & $84.7(2004)$ & $86.5(2015)$ \\
\hline Indonesia & $90.4(2004)$ & 95.4 & $86.8(2004)$ & 93.6 & $94.0(2004)$ & 97.2 \\
\hline Lao People's Democratic Republic & 69.6 & $84.7(2015)$ & 58.5 & $79.4(2015)$ & 81.4 & $90.0(2015)$ \\
\hline 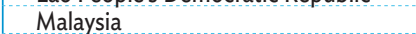 & 88.7 & 93.7 & 85.4 & 91.1 & 92.0 & 96.3 \\
\hline Myanmar & 89.9 & 75.6 & 86.4 & 71.8 & 93.9 & 80.0 \\
\hline Philippines & 92.6 & $96.4(2013)$ & 92.7 & $96.8(2013)$ & 92.5 & $96.0(2013)$ \\
\hline Singapore & 92.5 & 97.0 & 88.6 & 95.4 & 96.6 & 98.7 \\
\hline Thailand & 92.6 & $92.9(2015)$ & 90.5 & $91.2(2015)$ & 94.9 & $94.7(2015)$ \\
\hline Viet Nam & 90.2 & $93.5(2009)$ & 86.6 & $91.4(2009)$ & 93.9 & $95.8(2009)$ \\
\hline \multicolumn{7}{|l|}{ The Pacific } \\
\hline Cook Islands & $\ldots$ & $\ldots$ & $\ldots$ & $\ldots$ & $\ldots$ & $\ldots \ldots$ \\
\hline Fiji & $\ldots$ & $\ldots$ & $\ldots$ & $\ldots$ & $\ldots \ldots$ & $\ldots \ldots$ \\
\hline Kiribati & $\ldots$ & & $\ldots$ & & $\ldots$ & \\
\hline Marshall Islands & $\ldots$ & $98.3(2011)$ & $\ldots$ & $98.2(2011)$ & $\ldots$ & $98.3(2011)$ \\
\hline Micronesia, Federated States of & $\ldots$ & $\ldots$ & $\ldots$ & $\ldots$ & $\ldots$ & $\ldots$ \\
\hline Nauru & $\ldots$ & $\ldots$ & $\ldots$ & $\ldots$ & $\ldots$ & $\ldots$ \\
\hline Nive & $\ldots$ & & $\ldots$ & & $\ldots$ & $\ldots$ \\
\hline Palau & $\ldots$ & $96.6(2015)$ & $\ldots$ & $96.3(2015)$ & $\cdots$ & $96.8(2015)$ \\
\hline Papua New Guinea & 57.3 & $61.6(2010)$ & 50.9 & $57.9(2010)$ & 63.4 & $65.3(2010)$ \\
\hline Samoa & $\ldots$ & $99.0(2011)$ & $\ldots$ & $99.1(2011)$ & $\ldots$ & $98.9(2011)$ \\
\hline \multicolumn{7}{|l|}{ Solomon Islands } \\
\hline Timor-Leste & $37.6(2001)$ & $58.3(2010)$ & $30.0(2001)$ & $53.0(2010)$ & $45.3(2001)$ & $63.6(2010)$ \\
\hline Tonga & $99.0(2006)$ & $99.4(2011)$ & $99.1(2006)$ & $99.4(2011)$ & $99.0(2006)$ & $99.3(2011)$ \\
\hline \multicolumn{7}{|l|}{ Tuvalu } \\
\hline Vanuatu & $78.4(2004)$ & $84.7(2014)$ & $76.2(2004)$ & $83.2(2014)$ & $80.5(2004)$ & $86.2(2014)$ \\
\hline \multicolumn{7}{|l|}{ Developed ADB Member Economies } \\
\hline Australia & $\ldots$ & $\ldots$ & $\ldots$ & $\ldots$ & $\ldots$ & $\ldots$ \\
\hline Japan & & & & & $\ldots$ & \\
\hline New Zealand & & $\ldots$ & $\ldots$ & $\ldots$ & $\ldots$ & $\ldots$ \\
\hline WORLD & 81.5 & 86.2 & 76.4 & 82.7 & 86.6 & 89.8 \\
\hline
\end{tabular}

$\ldots$... data not available, $\mathrm{ADB}=$ Asian Development Bank.

Source: United Nations Educational, Scientific and Cultural Organization, Institute for Statistics Database. UIS.Stat. http://data.uis.unesco.org/ (accessed 20 July 2019). 
Table 2.1.13: Education Resources

\begin{tabular}{|c|c|c|c|c|c|}
\hline \multirow{2}{*}{ ADB Regional Member } & \multicolumn{2}{|c|}{ Primary Pupil-Teacher Ratio } & \multicolumn{3}{|c|}{ Secondary Pupil-Teacher Ratio } \\
\hline & 2000 & 2017 & 2000 & 2017 & \\
\hline \multicolumn{6}{|l|}{ Developing ADB Member Economies } \\
\hline \multicolumn{6}{|l|}{ Central and West Asia } \\
\hline Afghanistan & $42.3(2006)$ & 44.0 & $31.6(2007)$ & 38.7 & \\
\hline Armenia & $20.3(2001)$ & $\ldots$ & $\ldots$ & $\ldots$ & \\
\hline Azerbaijan & 18.7 & 15.5 & $\ldots$ & $\ldots$ & \\
\hline Georgia & 16.8 & 9.0 & 7.5 & 7.4 & \\
\hline Kazakhstan & $18.7(2001)$ & $19.6(2018)$ & $\ldots$ & 7.0 & (2018) \\
\hline Kyrgyz Republic & 24.1 & 24.9 & 13.3 & 10.4 & \\
\hline Pakistan & 33.0 & 44.8 & $24.2(2003)$ & 19.4 & \\
\hline Tajikistan & 21.8 & 22.3 & 16.4 & 15.4 & (2011) \\
\hline \multicolumn{6}{|l|}{ Turkmenistan } \\
\hline Uzbekistan & 21.4 & 21.2 & 11.5 & 10.3 & \\
\hline \multicolumn{6}{|l|}{ East Asia } \\
\hline China, People's Republic of & $22.2(2001)$ & 16.6 & 17.1 & 13.3 & \\
\hline Hong Kong, China & 21.5 & 13.8 & $18.8(2001)$ & 11.5 & \\
\hline Korea, Republic of & 32.1 & $16.3(2016)$ & 21.0 & 13.8 & (2016) \\
\hline Mongolia & 32.6 & 30.4 & 19.9 & 14.5 & $(2010)$ \\
\hline Taipei,China & 19.0 & $12.1(2018)$ & 17.6 & $12.8^{\circ}$ & $(2018)$ \\
\hline \multicolumn{6}{|l|}{ South Asia } \\
\hline Bangladesh & $47.0(2005)$ & 30.1 & 38.4 & 34.0 & \\
\hline Bhutan & 41.1 & 34.6 & $28.1(2005)$ & 11.0 & \\
\hline India & 40.0 & $35.2(2016)$ & 33.6 & 28.5 & (2016) \\
\hline Maldives & 22.7 & 10.2 & 15.3 & 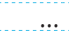 & \\
\hline Nepal & 38.0 & 20.9 & 30.2 & 28.8 & \\
\hline Sri Lanka & $26.3(2001)$ & 22.9 & $\ldots$ & 17.4 & \\
\hline \multicolumn{6}{|l|}{ Southeast Asia } \\
\hline Brunei Darussalam & 13.7 & 10.2 & 10.9 & 8.7 & \\
\hline Cambodia & 50.1 & 41.7 & 18.5 & $\ldots$ & \\
\hline Indonesia & 22.1 & 16.1 & 14.6 & 15.3 & \\
\hline Lao People's Democratic Republic & 30.1 & 22.3 & 21.3 & 18.1 & \\
\hline Malaysia & 19.6 & 11.7 & 18.4 & 12.3 & \\
\hline Myanmar & 32.8 & 23.0 & 31.9 & 26.4 & \\
\hline Philippines & 35.3 & $29.0(2016)$ & $36.4(2001)$ & 23.5 & (2016) \\
\hline Singapore & $21.1(2007)$ & $15.1(2016)$ & $17.8(2007)$ & 11.7 & (2016) \\
\hline Thailand & 20.8 & 16.2 & $24.0(2001)$ & 24.2 & \\
\hline Viet Nam & 29.5 & 19.6 & $\ldots$ & $\ldots$ & \\
\hline \multicolumn{6}{|l|}{ The Pacific } \\
\hline Cook Islands & 17.8 & $17.4(2016)$ & 13.9 & 15.7 & (2016) \\
\hline Fiji & 28.1 & $19.7(2016)$ & 20.2 & 19.3 & $(2012)$ \\
\hline Kiribati & 31.7 & 25.5 & $21.0(2001)$ & $\ldots$ & \\
\hline Marshall Islands & $16.9(2002)$ & & $16.7(2002)$ & $\ldots$ & \\
\hline Micronesia, Federated States of & & $19.7(2015)$ & a & n & \\
\hline Nauru & 21.5 & $40.2(2016)$ & 17.4 & 24.8 & (2016) \\
\hline Niue & 14.7 & $15.5(2016)$ & 7.8 & 7.9 & $(2015)$ \\
\hline Palau & 15.7 & & 15.1 & $\ldots$ & \\
\hline Papua New Guinea & 35.4 & $35.5(2016)$ & $\ldots$ & 34.3 & (2016) \\
\hline Samoa & 24.0 & $30.2(2010)$ & 21.2 & 27.7 & (2016) \\
\hline Solomon Islands & & 25.8 & 10.1 & 25.9 & $(2012)$ \\
\hline Timor-Leste & $61.9(2001)$ & $31.4(2011)$ & $28.0(2001)$ & 24.3 & (2011) \\
\hline Tonga & 22.1 & $21.6(2015)$ & 14.6 & 14.5 & $(2015)$ \\
\hline Tuvalu & 19.7 & $17.2(2016)$ & $\ldots$ & 8.4 & $(2016)$ \\
\hline Vanuatu & 22.5 & $26.6(2015)$ & 24.7 & 20.6 & $(2015)$ \\
\hline \multicolumn{6}{|l|}{ Developed ADB Member Economies } \\
\hline Australia & $\cdots$ & $\ldots$ & $\ldots$ & $\ldots$ & \\
\hline Japan & $\ldots$ & $15.9(2016)$ & $\ldots$ & 11.2 & (2016) \\
\hline New Zealand & 18.4 & 14.9 & 15.5 & 13.6 & \\
\hline
\end{tabular}

$\ldots=$ data not available, $\mathrm{ADB}=$ Asian Development Bank.

a Includes those for vocational secondary schools.

Sources: $\quad$ United Nations Educational, Scientific and Cultural Organization, Institute for Statistics Database. UIS.Stat. http://data.uis.unesco.org/ (accessed 24 May 2019). For Taipei,China: Government of Taipei,China, Directorate-General of Budget, Accounting and Statistics. Social Indicators. http://eng.dgbas.gov.tw/ mp.asp?mp=2 (accessed 24 May 2019). 
Table 2.1.14: Health Care Resources

(per 1,000 population)

\begin{tabular}{|c|c|c|c|c|}
\hline \multirow{2}{*}{ ADB Regional Member } & \multicolumn{2}{|c|}{ Physicians } & \multicolumn{2}{|c|}{ Hospital Beds } \\
\hline & 2000 & 2017 & 2000 & 2017 \\
\hline \multirow{2}{*}{\multicolumn{5}{|c|}{$\begin{array}{l}\text { Developing ADB Member Economies } \\
\text { Central and West Asia }\end{array}$}} \\
\hline & & & & \\
\hline Afghanistan & $0.20(2001)$ & $0.28(2016)$ & 0.3 & $0.5(2015)$ \\
\hline Armenia & 2.99 & $2.90(2014)$ & 6.4 & $4.2(2015)$ \\
\hline Azerbaijan & 3.61 & $3.45(2014)$ & 8.7 & 4.7 (2013) \\
\hline Georgia & $4.67(2008)$ & $5.10(2015)$ & 4.8 & $2.6(2013)$ \\
\hline Kazakhstan & 3.29 & $3.25(2014)$ & 7.2 & 6.7 (2013) \\
\hline Kyrgyz Republic & $2.48(2008)$ & $1.88(2014)$ & 7.0 & $4.5(2013)$ \\
\hline Pakistan & 0.66 & $0.98(2015)$ & 0.7 & $0.6(2014)$ \\
\hline Tajikistan & 2.17 & $1.70(2014)$ & 6.5 & 4.8 (2013) \\
\hline Turkmenistan & $4.35(2002)$ & $2.22(2014)$ & 9.1 & 7.4 (2013) \\
\hline Uzbekistan & 2.95 & $2.37(2014)$ & 5.3 & $4.0(2013)$ \\
\hline \multicolumn{5}{|l|}{ East Asia } \\
\hline China, People's Republic of & 1.24 & $1.79(2015)$ & 2.5 & $4.2(2012)$ \\
\hline Hong Kong, China & & & & \\
\hline Korea, Republic of & $1.69(2004)$ & 2.37 & 6.1 & $11.5(2015)$ \\
\hline Mongolia & $2.75(2002)$ & $2.89(2016)$ & $7.5(2002)$ & $7.0(2012)$ \\
\hline Taipei,China & $1.54(2001)$ & 2.25 & $5.7(2001)$ & 7.0 \\
\hline \multicolumn{5}{|l|}{ South Asia } \\
\hline Bangladesh & $0.24(2001)$ & 0.53 & $0.3(2001)$ & $0.8(2015)$ \\
\hline Bhutan & $0.18(2004)$ & 0.37 & $1.6(2001)$ & 1.7 (2012) \\
\hline India & 0.53 & 0.78 & $0.7(2002)$ & 0.7 (2011) \\
\hline Maldives & $0.97(2004)$ & $1.04(2016)$ & 1.7 & $4.3(2009)$ \\
\hline Nepal & $0.21(2004)$ & 0.65 & $0.2(2001)$ & $0.3(2012)$ \\
\hline Sri Lanka & 0.42 & 0.96 & 2.9 & $3.6(2012)$ \\
\hline \multicolumn{5}{|l|}{ Southeast Asia } \\
\hline Brunei Darussalam & 1.01 & $1.77(2015)$ & 2.6 & $2.7(2015)$ \\
\hline Cambodia & 0.17 & $0.17(2014)$ & $0.6(2001)$ & $0.8(2015)$ \\
\hline Indonesia & $0.13(2003)$ & 0.38 & $0.6(2002)$ & $1.2(2015)$ \\
\hline Lao People's Democratic Republic & 0.28 & $0.50(2014)$ & $0.9(2002)$ & 1.5 (2012) \\
\hline Malaysia & 0.70 & $1.51(2015)$ & $1.8(2001)$ & 1.9 (2015) \\
\hline Myanmar & $0.37(2004)$ & 0.86 & 0.7 & $0.9(2012)$ \\
\hline Philippines & 1.22 & $1.28(2010)$ & $1.0(2001)$ & $1.0(2011)$ \\
\hline Singapore & $1.43(2001)$ & $2.31(2016)$ & $2.9(2001)$ & $2.4(2015)$ \\
\hline Thailand & $0.30(2001)$ & 0.81 & 2.2 & $2.1(2010)$ \\
\hline Viet Nam & $0.52(2001)$ & $0.82(2016)$ & $2.4(2001)$ & $2.6(2014)$ \\
\hline \multicolumn{5}{|l|}{ The Pacific } \\
\hline Cook Islands & $0.77(2001)$ & $1.42(2014)$ & $6.3(2005)$ & \\
\hline Fiji & $0.47(2003)$ & $0.84(2015)$ & $2.1(2004)$ & $2.3(2011)$ \\
\hline Kiribati & $0.25(2008)$ & $0.20(2013)$ & $1.5(2004)$ & 1.9 (2015) \\
\hline Marshall Islands & $0.60(2007)$ & $0.46(2012)$ & & $2.7(2010)$ \\
\hline Micronesia, Federated States of & 0.60 & $0.19(2009)$ & 2.8 & $3.2(2009)$ \\
\hline Nauru & $0.99(2004)$ & $1.24(2015)$ & $3.5(2004)$ & $5.0(2010)$ \\
\hline Niue & $2.22(2003)$ & & $5.2(2006)$ & \\
\hline Palau & $1.30(2006)$ & $1.18(2014)$ & $5.9(2006)$ & $4.8(2010)$ \\
\hline Papua New Guinea & 0.05 & $0.05(2010)$ & & \\
\hline Samoa & $0.28(2003)$ & $0.34(2016)$ & 3.3 & \\
\hline Solomon Islands & $0.13(2003)$ & $0.20(2016)$ & $2.2(2003)$ & $1.4(2012)$ \\
\hline Timor-Leste & $0.08(2004)$ & 0.72 & & $5.9(2010)$ \\
\hline Tonga & $0.36(2001)$ & $0.52(2013)$ & $3.2(2001)$ & $2.6(2010)$ \\
\hline Tuvalu & $0.63(2002)$ & $0.92(2014)$ & $5.6(2001)$ & $\ldots$ \\
\hline Vanuatu & $0.15(2004)$ & $0.17(2016)$ & $3.1(2001)$ & \\
\hline \multicolumn{5}{|l|}{ Developed ADB Member Economies } \\
\hline Australia & $2.48(2001)$ & $3.59(2016)$ & 7.8 & $3.8(2014)$ \\
\hline Japan & 2.01 & $2.41(2016)$ & 14.7 & $13.4(2012)$ \\
\hline New Zealand & $2.31(2001)$ & $3.03(2016)$ & $6.2(2002)$ & $2.8(2013)$ \\
\hline
\end{tabular}

... = data not available, $\mathrm{ADB}=$ Asian Development Bank.

Sources: For number of physicians per 1,000 population: World Health Organization. Global Health Observatory. http://apps.who.int/gho/data/node.main. HWFGRP_0020?lang=en (accessed 27 May 2019); and for initial year data of Armenia, Azerbaijan, Kazakhstan, Timor-Leste, and Uzbekistan: World Bank. World Development Indicators. https://data.worldbank.org/indicator/SH.MED.PHYS.ZS (accessed 27 May 2019). For number of hospital beds per 1,000 population: World Bank. World Development Indicators. https://data.worldbank.org/indicator/SH.MED.BEDS.ZS (accessed 27 May 2019); and for initial year data of Cook Islands and Niue: World Health Organization. Global Health Observatory. http://apps.who.int/gho/data/view.main.HS07v (accessed 27 May 2019). For Taipei,China: Government of Taipei,China, Directorate-General of Budget, Accounting and Statistics. Statistical Yearbook of the Republic of China 2017. https://eng.dgbas.gov.tw/lp.asp?ctNode=2351\&CtUnit=1072\&BaseDSD=36\&MP=2 (accessed 27 May 2019). 
Table 2.1.15: Adults Aged 15 Years and Older Living with HIV ('000)

\begin{tabular}{|c|c|c|c|c|}
\hline \multirow{2}{*}{ ADB Regional Member } & \multicolumn{2}{|c|}{ All Adults } & \multicolumn{2}{|c|}{ Women } \\
\hline & 2000 & 2018 & 2000 & 2018 \\
\hline \multirow{2}{*}{\multicolumn{5}{|c|}{$\begin{array}{l}\text { Developing ADB Member Economies } \\
\text { Central and West Asia }\end{array}$}} \\
\hline & & & & \\
\hline Afghanistan & 1.5 & 6.9 & $<0.5$ & 2.0 \\
\hline Armenia & $<1.0$ & 3.5 & $<0.5$ & 1.2 \\
\hline \multicolumn{5}{|l|}{ Azerbaijan } \\
\hline Georgia & $<1.0$ & 9.3 & $<0.5$ & 3.0 \\
\hline Kazakhstan & 1.1 & 25.0 & $<0.5$ & 9.2 \\
\hline Kyrgyz Republic & $<1.0$ & 8.2 & $<0.2$ & 2.7 \\
\hline Pakistan & $<0.5$ & 160.0 & $<0.2$ & 48.0 \\
\hline Tajikistan & 1.4 & 12.0 & $<0.5$ & 3.5 \\
\hline \multicolumn{5}{|l|}{ Turkmenistan } \\
\hline Uzbekistan & 14.0 & 46.0 & 4.2 & 16.0 \\
\hline \multicolumn{5}{|l|}{ East Asia } \\
\hline \multicolumn{5}{|l|}{$\begin{array}{l}\text { China, People's Republic of } \\
\text { Hono Kons China }\end{array}$} \\
\hline Hong Kong, China & $\ldots$ & $\ldots$ & $\ldots$ & $\ldots$ \\
\hline \multicolumn{5}{|l|}{ Korea, Republic of } \\
\hline Mongolia & $<0.1$ & $<1.0$ & $<0.1$ & $<0.2$ \\
\hline \multicolumn{5}{|l|}{ Taipei,China } \\
\hline \multicolumn{5}{|l|}{ South Asia } \\
\hline Bangladesh & $<1.0$ & 13.0 & $<0.5$ & 4.8 \\
\hline Bhutan & $<1.0$ & 1.3 & $<0.2$ & $<0.5$ \\
\hline \multicolumn{5}{|l|}{ India } \\
\hline \multicolumn{5}{|l|}{ Maldives } \\
\hline Nepal & 15.0 & 29.0 & 2.4 & 12.0 \\
\hline Sri Lanka & 2.1 & 3.4 & $<0.5$ & 1.0 \\
\hline \multicolumn{5}{|l|}{ Southeast Asia } \\
\hline \multicolumn{5}{|l|}{ Brunei Darussalam } \\
\hline Cambodia & 78.0 & 70.0 & 33.0 & 37.0 \\
\hline Indonesia & 80.0 & 620.0 & 15.0 & 220.0 \\
\hline \multicolumn{5}{|l|}{ Lao People's Democratic Republic } \\
\hline Malaysia & 55.0 & 87.0 & 11.0 & 15.0 \\
\hline Myanmar & 150.0 & 230.0 & 34.0 & 87.0 \\
\hline Philippines & 1.0 & 77.0 & $<0.2$ & 4.6 \\
\hline Singapore & 2.9 & 7.9 & $<0.5$ & $<1.0$ \\
\hline Thailand & 720.0 & 480.0 & 260.0 & 210.0 \\
\hline Viet Nam & 120.0 & 220.0 & 24.0 & 74.0 \\
\hline \multicolumn{5}{|l|}{ The Pacific } \\
\hline \multicolumn{5}{|l|}{ Cook Islands } \\
\hline Fiji & $\ldots$ & $\ldots$ & $\ldots$ & $\ldots$ \\
\hline Kiribati & $\ldots$ & $\ldots$ & $\ldots$ & $\ldots$ \\
\hline Marshall Islands & $\ldots$ & $\ldots$ & $\ldots$ & $\ldots$ \\
\hline Micronesia, Federated States of & $\ldots$ & $\cdots$ & $\cdots$ & $\ldots$ \\
\hline Nauru & $\ldots$ & $\ldots$ & $\ldots$ & $\cdots$ \\
\hline Niue & $\ldots$ & $\ldots$ & $\ldots$ & $\ldots$ \\
\hline Palau & $\ldots$ & $\cdots$ & $\cdots$ & $\cdots$ \\
\hline Papua New Guinea & 19.0 & 42.0 & 10.0 & 25.0 \\
\hline Samoa & & $\ldots$ & $\ldots$ & $\ldots$ \\
\hline Solomon Islands & $\cdots$ & $\ldots$ & $\ldots$ & $\ldots$ \\
\hline Timor-Leste & $\ldots$ & $\ldots$ & $\ldots$ & $\ldots$ \\
\hline Tonga & $\ldots$ & $\ldots$ & $\ldots$ & $\ldots$ \\
\hline Tuvalu & 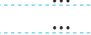 & $\ldots$ & $\ldots$ & $\ldots$ \\
\hline Vanuatu & $\ldots$ & $\ldots$ & $\ldots$ & $\ldots$ \\
\hline Developed ADB Member Economies & & & & \\
\hline Australia & 13.0 & 28.0 & 1.3 & 3.3 \\
\hline Japan & 6.1 & 30.0 & $<1.0$ & 2.8 \\
\hline New Zealand & 1.3 & 3.6 & $<0.5$ & $<1.0$ \\
\hline
\end{tabular}

... = data not available, $<=$ less than, $\mathrm{ADB}=$ Asian Development Bank.

a The modeled HIV estimates are calculated by the Joint United Nations Programme on HIV/AIDS (UNAIDS) using the software Spectrum developed by Avenir Health (www.avenirhealth.org), and the Estimates and Projections Package developed by the East-West Center (www.eastwestcenter.org). The UNAIDS Reference Group on Estimates, Modelling and Projections (www.epidem.org) provides technical guidance on the development of the HIV component of the software.

Source: Joint United Nations Programme on HIV/AIDS (UNAIDS). UNAIDS Database. http://aidsinfo.unaids.org/ (accessed 20 July 2019) 


\section{Economy and Output}

Economy and Output presents figures comparing the relative size of economies, both within the Asia and Pacific region and across the world, using data on gross domestic product (GDP) expressed at purchasing power parity (PPP) and current United States (US) dollars. Regional members' economic growth rates are also discussed. Statistical tables generated from the national accounts, include GDP, value added, consumption expenditure, capital formation, exports and imports, and gross domestic saving. Other tables present production indicators and trends in external trade and domestic consumption.

\section{Asia and the Pacific's share of global GDP at PPP exceeds that of Europe and North America combined.}

Asia and the Pacific's share of global GDP at PPP has increased steadily, from $30.3 \%$ in 2000 to $37.0 \%$ in 2010 and $42.8 \%$ in 2018 (Figure 2.2.1). In fact, the region's share of global GDP in 2018 exceeded the combined share of Europe and North America. Europe's global GDP share fell from 27.2\% in 2000 to $22.4 \%$ in 2018, while North America's declined from $25.3 \%$ in 2000 to $18.3 \%$ in 2018 .
Across other regions of the world, the global GDP shares in 2018 of South America (5.1\%), Africa (4.9\%), West Asia (4.7\%), and economies not belonging to any specified region (1.8\%) were little changed from the respective shares of these regions in 2000 and 2010. Among these regions, the largest change during the review period occurred in South America, where global GDP share fell from $6.1 \%$ in 2000 to $5.1 \%$ in 2018 .

In 2018, the five largest economies in Asia and the Pacific in terms of GDP at PPP together

Figure 2.2.1: Global Distribution of Gross Domestic Product at Purchasing Power Parity

(\%)

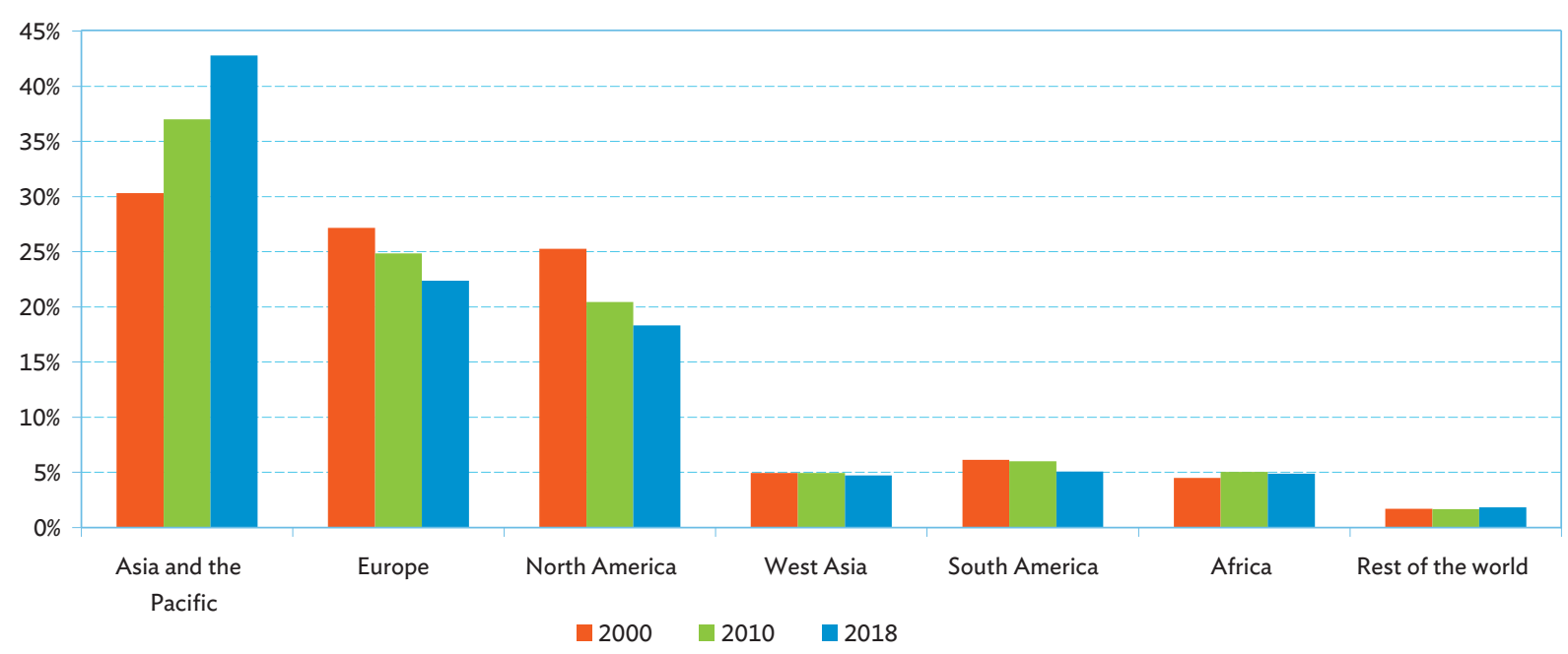

Sources: Table 2.2.1, Key Indicators for Asia and the Pacific 2019; and World Bank. World Development Indicators. http//data.worldbank.org/ (accessed 3 August 2019). 
accounted for $79.7 \%$ of the region's total output. This contribution was led by the PRC (43.0\%), followed by India (17.8\%), Japan (9.3\%), Indonesia (5.9\%), and the Republic of Korea (3.8\%). In 2000, these five economies accounted for $75.3 \%$ of the region's GDP at PPP, led by the PRC (24.8\%) and followed by Japan (22.7\%), India (15.5\%), Indonesia (6.5\%), and the Republic of Korea (5.8\%).

\section{India was the region's fastest-growing large economy over the last 3 years}

In 2018, the five largest economies in Asia and the Pacific in terms of GDP at PPP were the PRC, India, Japan, Indonesia, and the Republic of Korea.

All five of these Asian economies posted positive GDP growth each year from 2016 to 2018, but their growth rates varied widely (Figure 2.2.2). India had the highest growth rates over the 3 years, with $8.2 \%$ in $2016,7.2 \%$ in 2017 , and $6.8 \%$ in 2018 , while the high-income economies of Japan and the Republic of Korea had the lowest.
In Japan, marginal GDP growth of $0.6 \%$ was achieved in 2016 . This rose to $1.9 \%$ in 2017 , before falling to $0.8 \%$ in 2018. The Republic of Korea experienced moderate growth of $2.9 \%$ in $2016,3.2 \%$ in 2017 , and $2.7 \%$ in 2018.

The largest economy in the Asia and Pacific region-and, indeed, in the world-in terms of GDP at PPP was the PRC. It expanded at rates of $6.7 \%$ in $2016,6.8 \%$ in 2017 , and $6.6 \%$ in 2018 . Indonesia's economy grew $5.0 \%, 5.1 \%$, and $5.2 \%$ in 2016,2017 , and 2018, respectively.

\section{Data Issues and Comparability}

Indicators in this theme are derived from national accounts statistics compiled in accordance with the UN System of National Accounts. As national statistics offices gradually adopt the latest 2008 System of National Accounts framework with regard to data compilation frameworks and methodologies, these indicators will become more consistent across economies. Currently, economies in the region have

Figure 2.2.2: Growth Rates of Real Gross Domestic Product in Asia's Five Largest Economies

(\%)

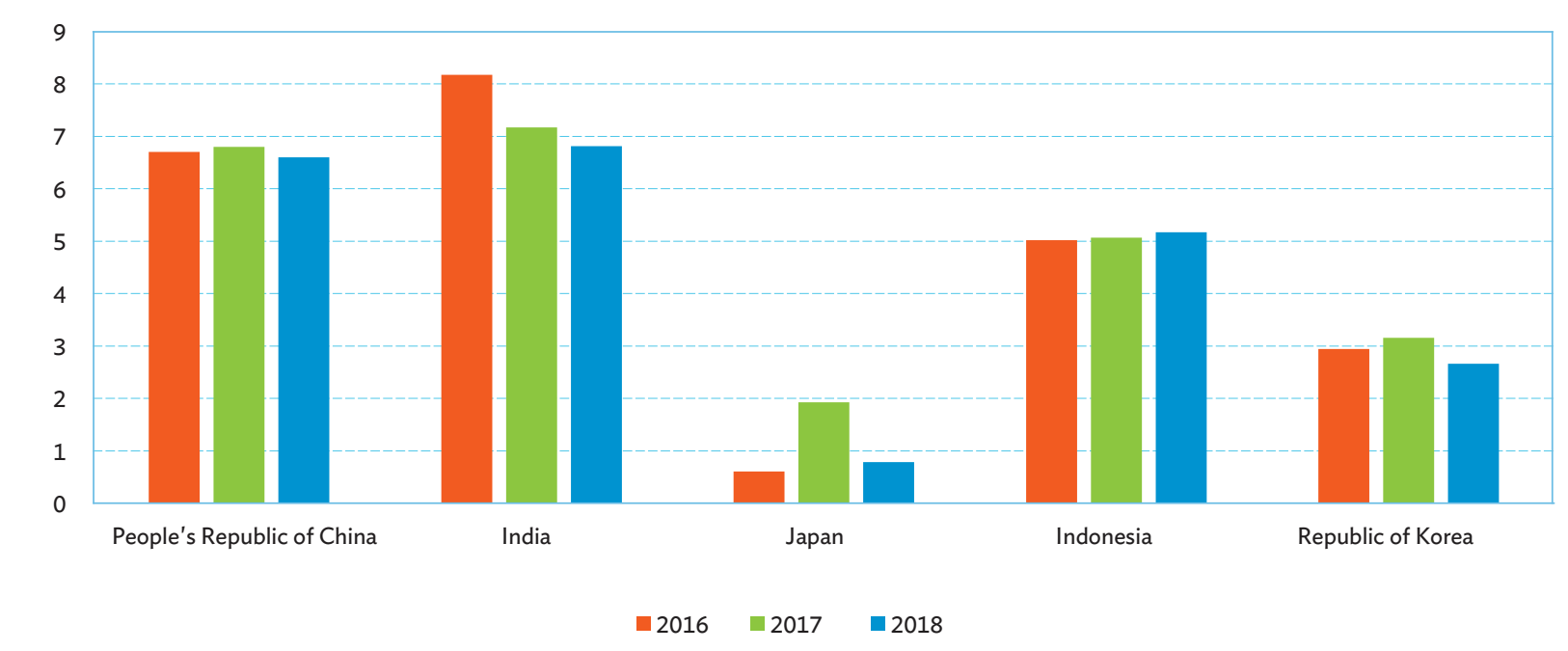

Note: Largest economies are determined in terms of gross domestic product at purchasing power parity in 2018.

Source: Table 2.2.11, Key Indicators for Asia and the Pacific 2019. 
varying reference periods (e.g., calendar year versus fiscal year) and price valuation methods. Due to a lack of reliable data and limited technical and financial resources dedicated to national accounts compilation, some economies with small statistics offices are not able to provide timely estimates, while some are dependent on the estimates of external institutions. 
Table 2.2.1: Gross Domestic Product at Purchasing Power Parity

(current international dollars, million)

\begin{tabular}{|c|c|c|c|c|c|c|c|c|c|}
\hline ADB Regional Member & 2000 & 2005 & 2010 & 2013 & 2014 & 2015 & 2016 & 2017 & 2018 \\
\hline \multirow{2}{*}{\multicolumn{10}{|c|}{ Developing ADB Member Economies }} \\
\hline & & & & & & & & & \\
\hline Afghanistan & $21,094(2002)$ & 26,719 & 49,145 & 63,573 & 65,723 & 66,906 & 70,126 & 74,664 & 76,585 \\
\hline Armenia & 7,144 & 14,228 & 18,892 & 23,190 & 24,479 & 25,532 & 25,863 & 28,331 & 30,477 \\
\hline Azerbaijan & 29,486 & 61,179 & 143,821 & 162,121 & 169,809 & 173,428 & 169,953 & 172,695 & 179,085 \\
\hline Georgia & 11,444 & 18,237 & 25,896 & 32,322 & 34,456 & 35,828 & 37,251 & 39,793 & 42,611 \\
\hline Kazakhstan & 117,863 & 216,123 & 321,302 & 405,853 & 430,900 & 440,733 & 450,454 & 477,836 & 515,810 \\
\hline Kyrgyz Republic & 8,086 & 10,902 & 14,890 & 18,486 & 19,590 & 20,571 & 21,691 & 23,142 & 24,492 \\
\hline Pakistan & 427,259 & 603,400 & 715,663 & 841,247 & 897,233 & 949,730 & $1,013,179$ & $1,091,293$ & $1,176,498$ \\
\hline Tajikistan & 5,863 & 10,410 & 15,766 & 20,837 & 22,808 & 24,108 & 26,047 & 28,564 & 31,341 \\
\hline Turkmenistan & 18,823 & 27,514 & 49,544 & 73,661 & 82,712 & 89,245 & 95,668 & 103,824 & 122,022 \\
\hline Uzbekistan & 49,421 & 71,785 & 140,800 & 190,092 & 173,576 & 188,499 & 202,174 & 215,208 & 231,358 \\
\hline \multicolumn{10}{|l|}{ East Asia } \\
\hline China, People's Republic of & $3,707,488$ & $6,624,265$ & $12,445,651$ & $16,779,114$ & $18,344,523$ & $19,820,982$ & $21,387,607$ & $23,266,769$ & $25,361,730$ \\
\hline Hong Kong, China & 180,414 & 248,418 & 331,004 & 385,147 & 403,274 & 417,319 & 431,064 & 456,170 & 480,086 \\
\hline Korea, Republic of & 872,060 & $1,213,618$ & $1,572,870$ & $1,726,903$ & $1,792,600$ & $1,933,849$ & $2,018,179$ & $2,119,722$ & $2,220,605$ \\
\hline Mongolia & 8,881 & 13,612 & 20,483 & 31,897 & 35,063 & 36,281 & 37,107 & 39,789 & 43,446 \\
\hline Taipei,China & 482,934 & 658,932 & 893,856 & $1,024,653$ & $1,086,022$ & $1,106,470$ & $1,135,554$ & $1,192,709$ & $1,251,717$ \\
\hline \multicolumn{10}{|l|}{ South Asia } \\
\hline Bangladesh & 151,802 & 214,078 & 364,054 & 463,397 & 500,782 & 539,303 & 583,983 & 638,430 & 704,165 \\
\hline Bhutan & 1,615 & 2,646 & 4,576 & 5,609 & 5,988 & 6,514 & 7,114 & 7,585 & 7,933 \\
\hline India & $2,318,667$ & $3,546,543$ & $5,487,141$ & $6,727,353$ & $7,362,570$ & $8,036,327$ & $8,787,915$ & $9,596,835$ & $10,474,334$ \\
\hline Maldives & 2,179 & 2,635 & 4,287 & 5,419 & 5,926 & 6,162 & 6,684 & 7,282 & 7,897 \\
\hline Nepal & 29,088 & 38,478 & 52,569 & 62,803 & 67,824 & 70,827 & 72,023 & 80,150 & 86,755 \\
\hline Sri Lanka & 84,781 & 112,660 & 168,758 & 218,576 & 233,759 & 248,090 & 262,055 & 276,168 & 291,459 \\
\hline \multicolumn{10}{|l|}{ Southeast Asia } \\
\hline Brunei Darussalam & 21,758 & 26,993 & 30,667 & 33,269 & 33,102 & 33,266 & 32,801 & 33,869 & 34,650 \\
\hline Cambodia & 13,306 & 23,284 & 35,361 & 46,181 & 50,415 & 54,540 & 59,013 & 64,353 & 70,753 \\
\hline Indonesia & 977,310 & $1,378,538$ & $2,003,476$ & $2,520,498$ & $2,696,763$ & $2,858,510$ & $3,035,213$ & $3,249,635$ & $3,494,762$ \\
\hline Lao People's Democratic Republic & 9,981 & 15,860 & 24,421 & 34,455 & 37,779 & 40,959 & 44,315 & 48,233 & 52,543 \\
\hline Malaysia & 300,920 & 424,707 & 581,232 & 715,486 & 772,812 & 833,902 & 877,990 & 945,875 & $1,011,337$ \\
\hline Myanmar & 47,921 & 98,268 & 182,822 & 237,852 & 261,718 & 283,014 & 302,881 & 329,498 & 357,819 \\
\hline Philippines & 262,156 & 367,351 & 513,839 & 644,115 & 696,633 & 746,796 & 806,934 & 877,180 & 952,967 \\
\hline Singapore & 167,813 & 238,071 & 363,321 & 447,490 & 473,741 & 492,656 & 512,797 & 541,878 & 571,494 \\
\hline Thailand & 460,361 & 671,842 & 887,868 & $1,043,881$ & $1,074,101$ & $1,119,607$ & $1,169,841$ & $1,240,047$ & $1,320,504$ \\
\hline Viet Nam & 163,686 & 255,824 & 382,022 & 476,764 & 514,852 & 555,113 & 596,038 & 648,742 & 711,219 \\
\hline \multirow{2}{*}{\multicolumn{10}{|c|}{$\begin{array}{l}\text { The Pacific } \\
\text { Cook Islands }\end{array}$}} \\
\hline & & & & & & & & & \\
\hline $\mathrm{Fiji}$ & 4,293 & 5,391 & 6,193 & 7,152 & 7,696 & 8,141 & 8,448 & 9,054 & 9,722 \\
\hline Kiribati & 134 & 161 & 177 & 207 & 210 & 234 & 249 & 254 & 265 \\
\hline Marshall Islands & 122 & 153 & 182 & 205 & 208 & 209 & 217 & 230 & 241 \\
\hline Micronesia, Federated States of & 267 & 308 & 335 & 345 & 344 & 365 & 373 & 421 & 437 \\
\hline Nauru & $\ldots$ & & 65 & 113 & 157 & 163 & 182 & 194 & 189 \\
\hline \multicolumn{10}{|l|}{ Niue } \\
\hline Palau & 190 & 247 & 241 & 269 & 287 & 309 & 324 & 319 & 317 \\
\hline Papua New Guinea & 12,171 & 15,167 & 22,222 & 25,847 & 29,892 & 33,081 & 34,814 & 38,352 & 39,419 \\
\hline Samoa & 534 & 798 & 1,038 & 1,043 & 1,092 & 1,189 & 1,278 & 1,288 & 1,310 \\
\hline Solomon Islands & 392 & 728 & 989 & 1,122 & 1,162 & 1,200 & 1,250 & 1,319 & 1,394 \\
\hline Timor-Leste & 2,297 & 5,764 & 9,646 & 10,629 & 8,025 & 9,783 & 9,960 & 9,220 & 9,694 \\
\hline Tonga & 360 & 449 & 508 & 541 & 563 & 584 & 623 & 683 & 713 \\
\hline Tuvalu & 23 & 26 & 30 & 35 & 36 & 40 & 45 & 48 & 50 \\
\hline Vanuatu & 418 & 487 & 682 & 759 & 791 & 817 & 851 & 920 & 971 \\
\hline \multicolumn{10}{|l|}{ Developed ADB Member Economies } \\
\hline Australia & 504,273 & 664,362 & 866,385 & $1,061,628$ & 0,545 & 1,971 & $1,145,491$ & $1,221,574$ & $1,288,228$ \\
\hline Japan & $3,404,300$ & $4,045,734$ & $4,480,784$ & $4,967,052$ & $4,986,566$ & $5,136,019$ & $5,221,770$ & $5,319,800$ & $5,484,024$ \\
\hline New Zealand & 83,024 & 106,148 & 135,972 & 160,892 & 168,034 & 172,225 & 183,610 & 193,557 & 203,421 \\
\hline DEVELOPING ADB MEMBER & $10,982,800$ & $17,266,798$ & $27,888,305$ & $35,510,511$ & $38,421,997$ & $41,311,186$ & $44,338,129$ & $47,978,571$ & $52,003,175$ \\
\hline $\begin{array}{l}\text { ECONOMIES } \\
\text { ALADB REGIONAL MEMBERSa }\end{array}$ & & & & 700002 & 11677112 & 701401 & & & \\
\hline ALL ADB REGIONAL MEMBERS ${ }^{a}$ & $14,974,398$ & $22,083,042$ & $33,371,446$ & L,700,082 & 44,677,142 & 47,721,401 & $0,889,000$ & $1,713,503$ & 3,978,848 \\
\hline
\end{tabular}

... = data not available, $\mathrm{ADB}=$ Asian Development Bank.

a For reporting economies only.

Source: Asian Development Bank estimates. 
Table 2.2.2: $\quad$ Gross Domestic Product ${ }^{a}$

(current \$ million)

\begin{tabular}{|c|c|c|c|c|c|c|c|c|c|}
\hline ADB Regional Member & 2000 & 2005 & 2010 & 2013 & 2014 & 2015 & 2016 & 2017 & 2018 \\
\hline \multirow{2}{*}{\multicolumn{10}{|c|}{ Developing ADB Member Economies }} \\
\hline & \multicolumn{9}{|c|}{ Central and West Asia } \\
\hline Afghanistan & $4,285(2002)$ & 6,622 & 16,078 & 21,610 & 21,330 & 20,607 & 20,231 & 21,499 & 20,514 \\
\hline Armenia & 1,912 & 4,900 & 9,260 & 11,121 & 11,610 & 10,553 & 10,546 & 11,527 & 12,433 \\
\hline Azerbaijan & 5,273 & 13,245 & 52,906 & 74,161 & 75,239 & 53,076 & 37,867 & 40,867 & 46,939 \\
\hline $\begin{array}{l}\text { Georgia } \\
\text { a }\end{array}$ & 3,058 & 6,411 & 11,638 & 16,141 & 16,510 & 13,993 & 14,378 & 15,081 & 16,210 \\
\hline Kazakhstan & 18,292 & 57,124 & 148,047 & 236,635 & 221,416 & 184,388 & 137,278 & 162,887 & 172,941 \\
\hline Kyrgyz Republic & 1,370 & 2,460 & 4,794 & 7,335 & 7,468 & 6,678 & 6,813 & 7,703 & 8,093 \\
\hline Pakistan & 79,097 & 119,739 & 174,508 & 220,269 & 248,949 & 267,035 & 277,521 & 303,092 & 282,346 \\
\hline Tajikistan & 861 & 2,312 & 5,642 & 8,506 & 9,237 & 7,855 & 6,953 & 7,158 & 7,523 \\
\hline Turkmenistan & 4,932 & 17,174 & 22,582 & 39,198 & 43,486 & 35,855 & 36,180 & 37,926 & 44,114 \\
\hline Uzbekistan & 13,759 & 14,396 & 46,909 & 68,997 & 76,659 & 81,847 & 81,779 & 59,160 & 50,500 \\
\hline \multicolumn{10}{|l|}{ East Asia } \\
\hline China, People's Republic of & $1,211,332$ & $2,285,960$ & $6,087,192$ & $9,570,468$ & $10,438,478$ & $11,015,560$ & $11,137,979$ & $12,143,563$ & $13,608,139$ \\
\hline Hong Kong, China & 171,669 & 181,569 & 228,639 & 275,697 & 291,460 & 309,386 & 320,863 & 341,685 & 362,682 \\
\hline Korea, Republic of & 576,179 & 934,901 & $1,144,067$ & $1,370,795$ & $1,484,318$ & $1,465,773$ & $1,500,112$ & $1,623,901$ & $1,720,489$ \\
\hline Mongolia & 1,137 & 2,523 & 7,189 & 12,582 & 12,227 & 11,750 & 11,187 & 11,426 & $\quad 12,980$ \\
\hline Taipei,China & 331,503 & 375,920 & 446,217 & 511,614 & 530,554 & 525,759 & 531,478 & 574,959 & 589,501 \\
\hline \multicolumn{10}{|l|}{ South Asia } \\
\hline Bangladesh & 45,468 & 57,627 & 114,508 & 153,505 & 173,062 & 194,466 & 220,837 & 245,633 & 269,628 \\
\hline Bhutan & 439 & 819 & 1,585 & 1,798 & 1,959 & 2,060 & 2,220 & 2,528 & \\
\hline India & 484,498 & 837,499 & $1,702,346$ & $1,917,054$ & $2,042,939$ & $2,146,759$ & $2,286,229$ & $2,625,091$ & $2,779,692$ \\
\hline Maldives & 624 & 1,163 & 2,588 & 3,295 & 3,697 & 4,109 & 4,414 & 4,866 & \\
\hline Nepal & 5,338 & 8,259 & 16,281 & 18,209 & 20,138 & 20,801 & 20,982 & 25,590 & 27,825 \\
\hline Sri Lanka & 16,717 & 24,406 & 56,726 & 74,318 & 79,356 & 80,604 & 82,401 & 88,020 & 88,942 \\
\hline \multicolumn{10}{|l|}{ Southeast Asia } \\
\hline Brunei Darussalam & 6,001 & 9,531 & 13,707 & 18,094 & 17,098 & 12,930 & 11,400 & 12,128 & 13,567 \\
\hline Cambodia & 3,667 & 6,293 & 11,242 & 15,228 & 16,703 & 18,050 & 20,017 & 22,177 & 24,572 \\
\hline Indonesia & 165,021 & 285,869 & 755,094 & 912,524 & 890,815 & 860,854 & 931,877 & $1,015,423$ & $1,042,173$ \\
\hline Lao People's Democratic Republic & 1,638 & 2,717 & 6,744 & 11,942 & 13,268 & 14,390 & 15,806 & 16,847 & 17,954 \\
\hline Malaysia & 93,790 & 143,534 & 255,017 & 323,276 & 338,066 & 301,355 & 301,255 & 318,955 & 358,579 \\
\hline Myanmar & & & & 62,140 & 66,300 & 62,543 & 64,590 & 66,491 & \\
\hline Philippines & 81,026 & 103,072 & 199,591 & 271,836 & 284,585 & 292,774 & 304,898 & 313,620 & 330,910 \\
\hline Singapore & 96,077 & 127,808 & 239,808 & 307,576 & 314,864 & 307,997 & 318,057 & 338,399 & 364,146 \\
\hline Thailand & 126,392 & 189,318 & 341,105 & 420,334 & 407,339 & 401,296 & 412,353 & 455,275 & 505,042 \\
\hline Viet Nam & 31,173 & 57,633 & 115,932 & 171,222 & 186,205 & 193,241 & 205,276 & 223,780 & 245,214 \\
\hline \multicolumn{10}{|l|}{ The Pacific } \\
\hline Cook Islands & 92 & 183 & 241 & 289 & 319 & 302 & 310 & 346 & 374 \\
\hline Fiji & 1,678 & 2,981 & 3,140 & 4,190 & 4,857 & 4,682 & 4,927 & 5,270 & \\
\hline Kiribati & 68 & 112 & 156 & 185 & 180 & 171 & 178 & 186 & \\
\hline Marshall Islands & 112 & 140 & 168 & 192 & 185 & 181 & 198 & 208 & \\
\hline Micronesia, Federated States of & 233 & 250 & 297 & 316 & 318 & 315 & 331 & 363 & \\
\hline Nauru & & 31 & 51 & 102 & 115 & 90 & 104 & 116 & 113 \\
\hline Niue & 8 & 14 & 18 & 25 & 27 & 24 & 25 & 26 & 30 \\
\hline Palau & 146 & 184 & 183 & 223 & 243 & 280 & 300 & 286 & 284 \\
\hline Papua New Guinea & 3,499 & 4,866 & 14,251 & 21,261 & 23,211 & 21,723 & 20,759 & 23,716 & 25,111 \\
\hline Samoa & 231 & 434 & 692 & 764 & 781 & 787 & 822 & 825 & 833 \\
\hline Solomon Islands & 286 & 428 & 696 & 1,015 & 1,047 & 1,027 & 1,093 & & $\ldots$ \\
\hline Timor-Leste & 440 & 1,814 & 3,999 & 5,638 & 4,042 & 3,093 & 2,504 & 2,487 & \\
\hline Tonga & 189 & 264 & 374 & 440 & 436 & 398 & 406 & 457 & 476 \\
\hline Tuvalu & 14 & 22 & 31 & 37 & 37 & 35 & 40 & 44 & \\
\hline Vanuatu & 273 & 395 & 701 & 802 & 815 & 760 & 804 & 880 & . \\
\hline \multicolumn{10}{|l|}{ Developed ADB Member Economies } \\
\hline Australia & 383,318 & 704,385 & $1,193,596$ & $1,483,151$ & $1,440,948$ & $1,220,347$ & $1,235,745$ & $1,352,365$ & $1,380,500$ \\
\hline Japan & $4,887,520$ & $4,755,410$ & $5,700,098$ & $5,155,717$ & $4,850,414$ & $\quad 4,389,475$ & $4,926,667$ & $4,859,951$ & $4,970,075$ \\
\hline New Zealand & 54,444 & 114,723 & 146,584 & 190,786 & 200,835 & 177,207 & 187,853 & 202,276 & \\
\hline $\begin{array}{l}\text { DEVELOPING ADB MEMBER } \\
\text { ECONOMIES }\end{array}$ & $3,589,796$ & 92,925 & $12,262,941$ & $17,162,959$ & 381,945 & 958,217 & $19,366,576$ & $21,172,468$ & $23,050,869$ \\
\hline ALL ADB REGIONAL MEMBERS ${ }^{\mathrm{b}}$ & $8,915,077$ & $11,467,442$ & $19,303,219$ & $23,992,612$ & $24,874,141$ & $24,745,247$ & $25,716,842$ & $27,587,060$ & $29,401,444$ \\
\hline
\end{tabular}

$\ldots=$ data not available, $\$=$ United States dollars, $\mathrm{ADB}=$ Asian Development Bank.

a Gross domestic product at local currency units are obtained from economy sources and are converted to United States dollars using the official exchange rates from the International Monetary Fund. The exchange rates used are expressed as the average rate for a period of time (average of period), calculated as annual averages based on the monthly averages (local currency units relative to the United States dollar).

b For reporting economies only.

Source: Asian Development Bank estimates. 
Table 2.2.3: Gross Domestic Product per Capita at Purchasing Power Parity (current international dollars)

\begin{tabular}{|c|c|c|c|c|c|c|c|c|c|}
\hline ADB Regional Member & 2000 & 2005 & 2010 & 2013 & 2014 & 2015 & 2016 & 2017 & 2018 \\
\hline \multirow{2}{*}{\multicolumn{10}{|c|}{$\begin{array}{l}\text { Developing ADB Member Economies } \\
\text { Central and West Asia }\end{array}$}} \\
\hline & & & & & & & & & \\
\hline Afghanistan & $1,039(2002)$ & 1,209 & 2,007 & 2,443 & 2,475 & 2,469 & 2,536 & 2,645 & 2,546 \\
\hline Armenia & 2,218 & 4,522 & 6,205 & 7,674 & 8,122 & 8,498 & 8,643 & 9,509 & 10,257 \\
\hline Azerbaijan & 3,652 & 7,197 & 15,884 & 17,216 & 17,809 & 17,973 & 17,417 & 17,525 & 18,017 \\
\hline Georgia & 2,807 & 4,673 & 6,839 & 8,694 & 9,264 & 9,618 & 9,993 & 10,674 & 11,434 \\
\hline Kazakhstan & 7,919 & 14,268 & 19,685 & 23,824 & 24,924 & 25,123 & 25,315 & 26,491 & 28,223 \\
\hline Kyrgyz Republic & 1,659 & 2,123 & 2,748 & 3,264 & 3,391 & 3,490 & 3,603 & 3,769 & 3,914 \\
\hline Pakistan & 3,053 & 3,867 & 4,125 & 4,563 & 4,772 & 4,954 & 5,185 & 5,252 & 5,528 \\
\hline Tajikistan & 946 & 1,535 & 2,097 & 2,581 & 2,762 & 2,853 & 3,012 & 3,232 & 3,472 \\
\hline Turkmenistan & 4,168 & 5,787 & 9,739 & 13,726 & 15,131 & 16,036 & 16,895 & 18,032 & 20,855 \\
\hline Uzbekistan & 2,005 & 2,743 & 4,930 & 6,285 & 5,643 & 6,023 & 6,348 & 6,645 & 7,020 \\
\hline \multicolumn{10}{|l|}{ East Asia } \\
\hline China, People's Republic of & 2,925 & 5,066 & 9,281 & 12,331 & 13,412 & 14,419 & 15,468 & 16,738 & 18,176 \\
\hline Hong Kong, China & 27,069 & 36,461 & 47,123 & 53,650 & 55,782 & 57,235 & 58,755 & 61,714 & 64,432 \\
\hline Korea, Republic of & 18,551 & 25,187 & 31,740 & 34,244 & 35,357 & 37,919 & 39,418 & 41,203 & 43,029 \\
\hline Mongolia & 3,718 & 5,367 & 7,479 & 11,003 & 11,833 & 11,987 & 12,013 & 12,636 & 13,543 \\
\hline Taipei,China & 21,769 & 28,990 & 38,627 & 43,892 & 46,404 & 47,158 & 48,289 & 50,634 & 53,084 \\
\hline \multicolumn{10}{|l|}{ South Asia } \\
\hline Bangladesh & 1,174 & 1,545 & 2,450 & 2,995 & 3,194 & 3,394 & 3,632 & 3,924 & 4,278 \\
\hline Bhutan & 2,713 & 4,166 & 6,576 & 7,653 & 8,037 & 8,605 & 9,256 & 10,431 & 10,803 \\
\hline India & 2,275 & 3,207 & 4,627 & 5,378 & 5,811 & 6,264 & 6,765 & 7,292 & 7,864 \\
\hline Maldives & 8,069 & 7,781 & 10,891 & 12,641 & 13,544 & 13,560 & 14,148 & 14,812 & 15,422 \\
\hline Nepal & 1,382 & 1,521 & 2,002 & 2,308 & 2,459 & 2,534 & 2,542 & 2,791 & 2,981 \\
\hline Sri Lanka & 4,379 & 5,735 & 8,171 & 10,621 & 11,254 & 11,833 & 12,359 & 12,879 & 13,450 \\
\hline \multicolumn{10}{|l|}{ Southeast Asia } \\
\hline Brunei Darussalam & 66,988 & 75,294 & 79,283 & 82,491 & 81,212 & 80,665 & 78,611 & 78,856 & 78,324 \\
\hline Cambodia & 1,068 & 1,748 & 2,503 & 3,147 & 3,392 & 3,623 & 3,870 & 4,167 & 4,523 \\
\hline Indonesia & 4,738 & 6,270 & 8,431 & 10,130 & 10,694 & 11,190 & 11,732 & 12,408 & 13,188 \\
\hline Lao People's Democratic Republic & 1,962 & 2,821 & 4,042 & 5,462 & 5,903 & 6,309 & 6,728 & 7,219 & 7,751 \\
\hline Malaysia & 12,811 & 16,306 & 20,331 & 23,692 & 25,173 & 26,728 & 27,784 & 29,559 & 31,214 \\
\hline Myanmar & 1,040 & 2,027 & 3,645 & 4,623 & 5,034 & 5,396 & 5,724 & 6,172 & 6,644 \\
\hline Philippines & 3,415 & 4,338 & 5,517 & 6,559 & 6,975 & 7,353 & 7,816 & 8,362 & 8,940 \\
\hline Singapore & 41,663 & 55,809 & 71,566 & 82,881 & 86,612 & 89,007 & 91,452 & 96,552 & 101,352 \\
\hline Thailand & 7,588 & 10,623 & 13,469 & 15,638 & 16,031 & 16,652 & 17,343 & 18,329 & 19,468 \\
\hline Viet Nam & 2,123 & 3,123 & 4,394 & 5,312 & 5,675 & 6,053 & 6,430 & 6,925 & 7,510 \\
\hline \multicolumn{10}{|l|}{ The Pacific } \\
\hline Cook Islands & & & & & & & & & \\
\hline Fiji & 5,353 & 6,518 & 7,280 & 8,297 & 8,890 & 9,364 & 9,675 & 10,232 & 10,970 \\
\hline Kiribati & 1,587 & 1,741 & 1,714 & 1,933 & 1,930 & 2,125 & 2,229 & 2,249 & 2,348 \\
\hline Marshall Islands & 2,377 & 2,982 & 3,444 & 3,834 & 3,875 & 3,883 & 4,014 & 4,224 & 4,410 \\
\hline Micronesia, Federated States of & 2,492 & 2,919 & 3,257 & 3,380 & 3,368 & 3,566 & 3,642 & 4,106 & \\
\hline Nauru & & & 6,659 & 10,472 & 14,759 & 15,085 & 16,566 & 17,304 & 16,663 \\
\hline \multicolumn{10}{|l|}{ Niue } \\
\hline Palau & 10,011 & 12,447 & 13,154 & 15,455 & 16,510 & 17,505 & 18,134 & 17,813 & 18,098 \\
\hline Papua New Guinea & 2,345 & 2,506 & 3,150 & 3,341 & 3,747 & 4,022 & 4,104 & 4,385 & 4,371 \\
\hline Samoa & 3,049 & 4,434 & 5,568 & 5,469 & 5,687 & 6,147 & 6,519 & 6,559 & 6,627 \\
\hline Solomon Islands & 935 & 1,549 & 1,780 & 1,877 & 1,899 & 1,918 & 1,955 & 2,019 & 2,091 \\
\hline Timor-Leste & 2,636 & 5,615 & 8,693 & 8,975 & 6,616 & 7,883 & 7,853 & 7,113 & 7,321 \\
\hline Tonga & 3,630 & 4,439 & 4,943 & 5,290 & 5,540 & 5,773 & 6,188 & 6,823 & 7,152 \\
\hline Tuvalu & 2,407 & 2,480 & 2,726 & 3,198 & 3,253 & 3,549 & 4,004 & 4,192 & 4,342 \\
\hline Vanuatu & 2,188 & 2,275 & 2,846 & 2,956 & 3,013 & 3,040 & 3,124 & 3,303 & 3,411 \\
\hline \multicolumn{10}{|l|}{ Developed ADB Member Economies } \\
\hline Australia & 26,501 & 32,927 & 39,324 & 45,902 & 46,880 & 46,270 & 47,352 & 49,654 & 51,544 \\
\hline Japan & 26,839 & 31,663 & 34,987 & 38,974 & 39,179 & 40,396 & 41,118 & 41,959 & 43,342 \\
\hline New Zealand & 21,521 & 25,677 & 31,253 & 36,220 & 37,261 & 37,475 & 39,123 & 40,376 & 41,638 \\
\hline & 3,343 & 4,952 & 7,576 & 9,307 & 9,967 & 10,608 & 11,269 & 12,044 & 12,925 \\
\hline ALL ADB REGIONAL MEMBERS ${ }^{a}$ & 4,359 & 6,068 & 8,700 & 10,503 & 11,141 & 11,783 & 12,441 & 13,217 & 14,111 \\
\hline
\end{tabular}

$\ldots=$ data not available, $\mathrm{ADB}=$ Asian Development Bank.

a For reporting economies only.

Source: Asian Development Bank estimates. 
Table 2.2.4: Gross National Income per Capita, Atlas Method (current \$)

\begin{tabular}{|c|c|c|c|c|c|c|c|c|}
\hline ADB Regional Member & 2000 & 2005 & 2010 & 2014 & 2015 & 2016 & 2017 & 2018 \\
\hline \multicolumn{9}{|l|}{ Developing ADB Member Economies } \\
\hline \multicolumn{9}{|l|}{ Central and West Asia } \\
\hline Afghanistan & & & 510 & 630 & 600 & 570 & 550 & 550 \\
\hline Armenia & 660 & 1,540 & 3,470 & 4,140 & 4,020 & 3,750 & 3,970 & 4,230 \\
\hline Azerbaijan & 610 & 1,270 & 5,400 & 7,740 & 6,570 & 4,760 & 4,070 & 4,050 \\
\hline Georgia & 810 & 1,520 & 3,110 & 4,500 & 4,110 & 3,830 & 3,760 & 4,130 \\
\hline Kazakhstan & 1,260 & 2,950 & 7,440 & 12,090 & 11,420 & 8,800 & 7,960 & 7,830 \\
\hline Kyrgyz Republic & 280 & 450 & 850 & 1,250 & 1,180 & 1,110 & 1,110 & 1,220 \\
\hline Pakistan & 480 & 700 & 1,030 & 1,320 & 1,360 & 1,420 & 1,500 & 1,580 \\
\hline Tajikistan & 170 & 320 & 920 & 1,360 & 1,250 & 1,110 & 1,000 & 1,010 \\
\hline Turkmenistan & 600 & 1,590 & 4,070 & 7,200 & 7,030 & 6,820 & 6,380 & 6,740 \\
\hline Uzbekistan & 630 & 530 & 1,340 & 2,210 & 2,440 & 2,660 & 2,350 & 2,020 \\
\hline \multicolumn{9}{|l|}{ East Asia } \\
\hline China, People's Republic of & 940 & 1,760 & 4,340 & 7,500 & 7,910 & 8,210 & 8,630 & 9,470 \\
\hline Hong Kong, China & 26,930 & 28,890 & 33,620 & 40,240 & 41,180 & 42,970 & 46,420 & 50,310 \\
\hline Korea, Republic of & 10,740 & 17,790 & 21,260 & 26,800 & 27,250 & 27,690 & 28,380 & 30,600 \\
\hline Mongolia & 470 & 900 & 2,000 & 4,210 & 3,820 & 3,500 & 3,230 & 3,580 \\
\hline Taipei,China & 13,922 & 17,644 & 20,034 & 23,369 & 23,075 & 23,039 & 23,895 & 25,371 \\
\hline \multicolumn{9}{|l|}{ South Asia } \\
\hline Bangladesh & 440 & 550 & 800 & 1,110 & 1,220 & 1,370 & 1,520 & 1,750 \\
\hline Bhutan & 740 & 1,230 & 2,090 & 2,530 & 2,600 & 2,730 & 2,890 & 3,080 \\
\hline India & 440 & 710 & 1,220 & 1,560 & 1,600 & 1,690 & 1,830 & 2,020 \\
\hline Maldives & 2,070 & 3,460 & 5,960 & 7,320 & 7,650 & 8,140 & 8,670 & 9,310 \\
\hline Nepal & 230 & 310 & 540 & 770 & 780 & 770 & 850 & 960 \\
\hline Sri Lanka & 870 & 1,210 & 2,410 & 3,640 & 3,760 & 3,810 & 3,880 & 4,060 \\
\hline \multicolumn{9}{|l|}{ Southeast Asia } \\
\hline Brunei Darussalam & 14,680 & 23,090 & 33,300 & 43,130 & 38,830 & 33,160 & 29,890 & 31,020 \\
\hline Cambodia & 300 & 460 & 750 & 1,020 & 1,060 & 1,140 & 1,230 & 1,380 \\
\hline Indonesia & 580 & 1,220 & 2,530 & 3,620 & 3,430 & 3,400 & 3,530 & 3,840 \\
\hline Lao People's Democratic Republic & 280 & 460 & 1,000 & 1,820 & 1,970 & 2,120 & 2,240 & 2,460 \\
\hline Malaysia & 3,460 & 5,270 & 8,260 & 11,140 & 10,610 & 10,030 & 9,810 & 10,460 \\
\hline Myanmar & $170(2002)$ & 270 & 850 & 1,230 & 1,200 & 1,200 & 1,200 & 1,310 \\
\hline Philippines & 1,220 & 1,430 & 2,460 & 3,450 & 3,510 & 3,570 & 3,650 & 3,830 \\
\hline Singapore & 23,680 & 28,820 & 44,930 & 56,370 & 53,120 & 52,520 & 54,200 & 58,770 \\
\hline Thailand & 1,980 & 2,790 & 4,580 & 5,760 & 5,710 & 5,690 & 5,950 & 6,610 \\
\hline Viet Nam & 410 & 630 & 1,250 & 1,880 & 1,970 & 2,080 & 2,190 & 2,400 \\
\hline \multicolumn{9}{|l|}{ The Pacific } \\
\hline Cook Islands & 6,129 & 8,475 & 9,349 & 17,088 & 17,157 & 18,347 & 17,360 & 20,026 \\
\hline Fiji & 2,240 & 3,590 & 3,650 & 5,020 & 5,200 & 5,360 & 5,430 & 5,860 \\
\hline Kiribati & 1,330 & 1,730 & 2,050 & 3,250 & 3,460 & 3,190 & 3,070 & 3,140 \\
\hline Marshall Islands & 2,930 & 3,380 & 3,520 & 4,160 & 4,360 & 4,250 & 4,430 & 4,740 \\
\hline Micronesia, Federated States of & 2,210 & 2,550 & 2,900 & 3,140 & 3,490 & 3,390 & 3,430 & 3,580 \\
\hline Nauru & & & 5,810 & 14,730 & 11,830 & 10,730 & 10,820 & 11,240 \\
\hline Niue & & $8,728(2006)$ & $10,896(2011)$ & & & & 14,546 & \\
\hline Palau & $7,420(2002)$ & 9,240 & 10,300 & 12,870 & 14,340 & 15,260 & 15,500 & 16,910 \\
\hline Papua New Guinea & 570 & 650 & 1,730 & 2,970 & 2,900 & 2,670 & 2,500 & 2,530 \\
\hline Samoa & $1,520(2002)$ & 2,310 & 3,200 & 4,050 & 4,080 & 4,130 & 4,120 & 4,190 \\
\hline Solomon Islands & 1,010 & 890 & 900 & 1,840 & 1,870 & 1,820 & 1,830 & 2,000 \\
\hline Timor-Leste & $800(2002)$ & 740 & 2,850 & 2,960 & 3,080 & 2,370 & 1,810 & 1,820 \\
\hline Tonga & 2,050 & 2,450 & 3,570 & 4,570 & 4,520 & 4,300 & 4,250 & 4,300 \\
\hline Tuvalu & $2,710(2001)$ & 3,630 & 4,400 & 4,670 & 5,440 & 5,070 & 4,810 & 5,430 \\
\hline Vanuatu & 1,430 & 1,780 & 2,690 & 3,110 & 2,790 & 2,780 & 2,810 & 2,970 \\
\hline \multicolumn{9}{|l|}{ Developed ADB Member Economies } \\
\hline Australia & 21,120 & 30,310 & 46,630 & 65,170 & 60,560 & 54,190 & 51,630 & 53,190 \\
\hline Japan & 36,230 & 40,560 & 43,440 & 43,950 & 38,840 & 37,880 & 38,470 & 41,340 \\
\hline New Zealand & 14,080 & 25,440 & 29,690 & 41,650 & 40,600 & 39,410 & 38,470 & 40,820 \\
\hline
\end{tabular}

... = data not available, $\$=$ United States dollars, $\mathrm{ADB}=$ Asian Development Bank.

a Refers to a conversion factor that averages the exchange rate for a given year and the 2 preceding years, adjusted for differences in rates of inflation between the member economy and the $\mathrm{G} 5$ economies.

Sources: World Bank. World Development Indicators Online. http://data.worldbank.org (accessed 18 July 2019). For the Cook Islands; Niue; and Taipei,China: Asian Development Bank estimates using Atlas method based on economy sources. 
Table 2.2.5: Gross Domestic Product per Capita (current \$)

\begin{tabular}{|c|c|c|c|c|c|c|c|c|c|}
\hline ADB Regional Member & 2000 & 2005 & 2010 & 2013 & 2014 & 2015 & 2016 & 2017 & 2018 \\
\hline \multirow{2}{*}{\multicolumn{10}{|c|}{ Developing ADB Member Economies }} \\
\hline & \multicolumn{9}{|c|}{ Central and West Asia } \\
\hline Afghanistan & $211(2002)$ & 300 & 657 & 830 & 803 & 760 & 732 & 762 & 682 \\
\hline Armenia & 593 & 1,557 & 3,041 & 3,680 & 3,852 & 3,512 & 3,524 & 3,869 & 4,184 \\
\hline Azerbaijan & 653 & 1,558 & 5,843 & 7,875 & 7,891 & 5,501 & 3,881 & 4,147 & 4,722 \\
\hline Georgia & 750 & 1,643 & 3,073 & 4,342 & 4,439 & 3,756 & 3,857 & 4,045 & 4,350 \\
\hline Kazakhstan & 1,229 & 3,771 & 9,070 & 13,891 & 12,807 & 10,511 & 7,715 & 9,030 & 9,462 \\
\hline Kyrgyz Republic & 281 & 479 & 885 & 1,295 & 1,293 & 1,133 & 1,132 & 1,255 & 1,293 \\
\hline Pakistan & 565 & 767 & 1,006 & 1,195 & 1,324 & 1,393 & 1,420 & 1,459 & 1,327 \\
\hline Tajikistan & 139 & 341 & 750 & 1,053 & 1,119 & 929 & 804 & 810 & 833 \\
\hline Turkmenistan & 1,092 & 3,612 & 4,439 & 7,304 & 7,955 & 6,443 & 6,390 & 6,587 & 7,540 \\
\hline Uzbekistan & 558 & 550 & 1,642 & 2,281 & 2,492 & 2,615 & 2,568 & 1,827 & 1,532 \\
\hline \multicolumn{10}{|l|}{ East Asia } \\
\hline China, People's Republic of & 956 & 1,748 & 4,540 & 7,033 & 7,631 & 8,014 & 8,055 & 8,736 & 9,752 \\
\hline Hong Kong, China & 25,757 & 26,650 & 32,550 & 38,404 & 40,315 & 42,432 & 43,735 & 46,225 & 48,676 \\
\hline Korea, Republic of & 12,257 & 19,403 & 23,087 & 27,183 & 29,276 & 28,741 & 29,299 & 31,565 & 33,339 \\
\hline Mongolia & 476 & 995 & 2,625 & 4,340 & 4,126 & 3,882 & 3,622 & 3,628 & 4,046 \\
\hline Taipei,China & 14,943 & 16,539 & 19,283 & 21,916 & 22,670 & 22,408 & 22,601 & 24,409 & 25,000 \\
\hline \multicolumn{10}{|l|}{ South Asia } \\
\hline Bangladesh & 352 & 416 & 771 & 992 & 1,104 & 1,224 & 1,373 & 1,510 & 1,638 \\
\hline Bhutan & 738 & 1,290 & 2,279 & 2,453 & 2,629 & 2,721 & 2,888 & 3,477 & \\
\hline India & 475 & 757 & 1,435 & 1,532 & 1,612 & 1,673 & 1,760 & 1,995 & 2,087 \\
\hline Maldives & 2,311 & 3,436 & 6,576 & 7,687 & 8,450 & 9,043 & 9,343 & 9,898 & \\
\hline Nepal & 254 & 326 & 620 & 669 & 730 & 744 & 741 & 891 & 956 \\
\hline Sri Lanka & 863 & 1,242 & 2,747 & 3,611 & 3,821 & 3,845 & 3,886 & 4,105 & 4,104 \\
\hline \multicolumn{10}{|l|}{ Southeast Asia } \\
\hline Brunei Darussalam & 18,477 & 26,587 & 35,437 & 44,865 & 41,947 & 31,354 & 27,322 & 28,238 & 30,667 \\
\hline Cambodia & 294 & 472 & 796 & 1,038 & 1,124 & 1,199 & 1,313 & 1,436 & 1,571 \\
\hline Indonesia & 800 & 1,300 & 3,177 & 3,667 & 3,533 & 3,370 & 3,602 & 3,877 & 3,933 \\
\hline Lao People's Democratic Republic & 322 & 483 & 1,116 & 1,893 & 2,073 & 2,217 & 2,400 & 2,521 & 2,649 \\
\hline Malaysia & 3,993 & 5,511 & 8,920 & 10,705 & 11,012 & 9,659 & 9,533 & 9,967 & 11,067 \\
\hline Myanmar & & & & 1,208 & 1,275 & 1,192 & 1,221 & 1,245 & \\
\hline Philippines & 1,055 & 1,217 & 2,143 & 2,768 & 2,849 & 2,883 & 2,953 & 2,990 & 3,104 \\
\hline Singapore & 23,853 & 29,961 & 47,237 & 56,967 & 57,565 & 55,645 & 56,722 & 60,296 & 64,580 \\
\hline Thailand & 2,083 & 2,994 & 5,174 & 6,297 & 6,079 & 5,968 & 6,113 & 6,730 & 7,446 \\
\hline Viet Nam & 404 & 704 & 1,334 & 1,908 & 2,052 & 2,107 & 2,215 & 2,389 & 2,589 \\
\hline \multicolumn{10}{|l|}{ The Pacific } \\
\hline Cook Islands & 5,091 & 8,491 & 10,160 & 15,548 & 17,362 & 16,422 & 17,773 & 17,724 & 20,099 \\
\hline Fiji & 2,093 & 3,604 & 3,692 & 4,861 & 5,610 & 5,386 & 5,642 & 5,956 & \\
\hline Kiribati & 799 & 1,212 & 1,515 & 1,726 & 1,654 & 1,554 & 1,598 & 1,641 & \\
\hline Marshall Islands & 2,195 & 2,741 & 3,180 & 3,591 & 3,445 & 3,363 & 3,653 & 3,822 & \\
\hline Micronesia, Federated States of & 2,179 & 2,370 & 2,886 & 3,096 & 3,113 & 3,080 & 3,235 & 3,536 & \\
\hline Nauru & & 3,291 & 5,275 & 9,465 & 10,778 & 8,329 & 9,463 & 10,341 & 9,926 \\
\hline Niue & 4,107 & $8,197(2006)$ & $13,021(2011)$ & & & & & 15,197 & \\
\hline Palau & 7,718 & 9,303 & 10,034 & 12,839 & 14,007 & 15,875 & 16,782 & 15,995 & 16,195 \\
\hline Papua New Guinea & 674 & 804 & 2,020 & 2,748 & 2,910 & 2,641 & 2,447 & 2,712 & 2,784 \\
\hline Samoa & 1,319 & 2,413 & 3,713 & 4,007 & 4,065 & 4,067 & 4,193 & 4,200 & 4,215 \\
\hline Solomon Islands & 682 & 911 & 1,253 & 1,698 & 1,711 & 1,642 & 1,709 & & $\ldots$ \\
\hline Timor-Leste & 504 & 1,767 & 3,604 & 4,760 & 3,332 & 2,492 & 1,974 & 1,919 & \\
\hline Tonga & 1,907 & 2,607 & 3,636 & 4,310 & 4,291 & 3,935 & 4,032 & 4,562 & 4,777 \\
\hline Tuvalu & 1,450 & 2,108 & 2,816 & 3,401 & 3,331 & 3,135 & 3,497 & 3,837 & \\
\hline Vanuatu & 1,432 & 1,846 & 2,923 & 3,124 & 3,104 & 2,828 & 2,952 & 3,161 & $\ldots$ \\
\hline \multicolumn{10}{|l|}{ Developed ADB Member Economies } \\
\hline Australia & 20,144 & 34,911 & 54,176 & 64,128 & 61,380 & 51,241 & 51,083 & 54,970 & 55,236 \\
\hline Japan & 38,532 & 37,218 & 44,508 & 40,454 & 38,109 & 34,524 & 38,794 & 38,332 & 39,280 \\
\hline New Zealand & 14,113 & 27,752 & 33,692 & 42,949 & 44,534 & 38,559 & 40,027 & 42,194 & \\
\hline $\begin{array}{l}\text { DEVELOPING ADB MEMBER } \\
\text { ECONOMIES }^{a}\end{array}$ & 1,108 & 1,714 & 3,377 & 4,498 & 4,768 & 4,868 & 4,922 & 5,315 & 5,729 \\
\hline ADB REGIONAL MEMBERS ${ }^{a}$ & 2,630 & 3,194 & 5,099 & 6,043 & 6,203 & 6,110 & 6,287 & 6,664 & 7,034 \\
\hline
\end{tabular}

... = data not available, $\$$ = United States dollars, $\mathrm{ADB}=$ Asian Development Bank.

a For reporting economies only.

Source: Asian Development Bank estimates using economy sources and official exchange rates from the International Monetary Fund. 
Table 2.2.6: Agriculture, Industry, and Services Value Added (\% of GDPa)

\begin{tabular}{|c|c|c|c|c|c|c|c|c|c|c|c|c|}
\hline \multirow{2}{*}{ ADB Regional Member } & \multicolumn{4}{|c|}{ Agriculture } & \multicolumn{4}{|c|}{ Industry } & \multicolumn{4}{|c|}{ Services } \\
\hline & 2000 & 2005 & 2010 & 2018 & 2000 & 2005 & 2010 & 2018 & 2000 & 2005 & 2010 & 2018 \\
\hline \multicolumn{13}{|l|}{ Developing ADB Member Economies } \\
\hline \multicolumn{13}{|l|}{ Central and West Asia } \\
\hline Afghanistan & $43.7(2002)$ & 35.2 & 28.8 & 21.4 & $21.7(2002)$ & 26.0 & 21.3 & 24.6 & $34.6(2002)$ & 38.8 & 49.8 & 54.0 \\
\hline Armenia & 25.1 & 20.6 & 18.8 & 15.0 & 38.3 & 44.7 & 36.3 & 27.4 & 36.5 & 34.6 & 45.0 & 57.6 \\
\hline Azerbaijan & 17.1 & 9.8 & 5.9 & 5.7 & 45.3 & 63.3 & 64.3 & 56.6 & 37.5 & 26.9 & 29.8 & 37.7 \\
\hline Georgia & 21.9 & 16.7 & 8.4 & 7.7 & 22.4 & 26.8 & 22.2 & 26.3 & 55.7 & 56.5 & 69.4 & 66.0 \\
\hline Kazakhstan & 8.6 & 6.6 & 4.7 & 4.6 & 40.1 & 39.2 & 41.9 & 36.9 & 51.3 & 54.2 & 53.4 & 58.6 \\
\hline Kyrgyz Republic & 36.6 & 31.3 & 18.8 & 13.1 & 31.3 & 22.0 & 28.2 & 30.9 & 32.1 & 46.7 & 53.1 & 56.0 \\
\hline Pakistan & 27.4 & 24.4 & 24.3 & 24.0 & 18.8 & 21.1 & 20.6 & 19.3 & 53.8 & 54.5 & 55.1 & 56.8 \\
\hline Tajikistan & 27.3 & 23.8 & 21.8 & 20.9 & 38.4 & 30.7 & 27.9 & 30.1 & 34.3 & 45.6 & 50.3 & 49.0 \\
\hline Turkmenistan & 22.9 & 18.8 & 11.5 & $\ldots$ & 41.8 & 37.6 & 60.0 & & 35.2 & 43.6 & 28.5 & \\
\hline Uzbekistan & 34.4 & 29.5 & 32.9 & 32.4 & 23.1 & 29.1 & 25.9 & 32.0 & 42.5 & 41.4 & 41.1 & 35.6 \\
\hline \multicolumn{13}{|l|}{ East Asia } \\
\hline China, People's Republic of & 14.7 & 11.6 & 9.3 & 7.2 & 45.5 & 47.0 & 46.5 & 40.7 & 39.8 & 41.3 & 44.2 & 52.2 \\
\hline Hong Kong, China & 0.1 & 0.1 & 0.1 & $0.1(2017)$ & 12.6 & 8.7 & 7.0 & $7.5(2017)$ & 87.3 & 91.3 & 93.0 & $92.4(2017)$ \\
\hline Korea, Republic of & 4.3 & 2.9 & 2.4 & 2.0 & 38.5 & 37.7 & 37.5 & 37.3 & 57.2 & 59.4 & 60.1 & 60.7 \\
\hline Mongolia & 27.4 & 19.8 & 11.6 & 10.8 & 26.0 & 34.9 & 36.1 & 41.6 & 46.6 & 45.3 & 52.3 & 47.6 \\
\hline Taipei,China & 2.0 & 1.6 & 1.6 & 1.6 & 31.3 & 32.3 & 33.8 & 35.2 & 66.7 & 66.1 & 64.6 & 63.2 \\
\hline \multicolumn{13}{|l|}{ South Asia } \\
\hline Bangladesh & 25.5 & 20.1 & 17.8 & 13.8 & 25.3 & 27.2 & 26.1 & 30.2 & 49.2 & 52.6 & 56.0 & 56.0 \\
\hline Bhutan & 27.4 & 23.2 & 17.5 & $18.3(2017)$ & 36.0 & 37.3 & 44.6 & 42.7 (2017) & 36.6 & 39.5 & 37.9 & 39.1 (2017) \\
\hline India & 23.0 & 18.8 & 18.2 & 16.1 & 26.0 & 28.1 & 27.2 & 29.6 & 51.0 & 53.1 & 54.6 & 54.3 \\
\hline Maldives & $6.9(2001)$ & 8.7 & 6.1 & $6.6(2017)$ & $13.2(2001)$ & 13.2 & 10.2 & $14.9(2017)$ & 79.9 (2001) & 78.1 & 83.8 & 78.5 (2017) \\
\hline Nepal & 39.6 & 35.2 & 35.4 & 28.1 & 21.5 & 17.1 & 15.1 & 14.9 & 38.9 & 47.7 & 49.5 & 57.0 \\
\hline Sri Lanka & 17.6 & 11.8 & 9.5 & 8.6 & 29.9 & 30.2 & 29.7 & 29.4 & 52.5 & 58.0 & 60.9 & 62.0 \\
\hline \multicolumn{13}{|l|}{ Southeast Asia } \\
\hline Brunei Darussalam & 1.0 & 0.9 & 0.7 & 1.0 & 63.7 & 71.6 & 67.4 & 62.2 & 35.3 & 27.5 & 31.9 & 36.7 \\
\hline Cambodia & 37.8 & 32.4 & 36.0 & 23.5 & 23.0 & 26.4 & 23.3 & 34.4 & 39.1 & 41.2 & 40.7 & 42.1 \\
\hline Indonesia & 15.6 & 13.1 & 14.3 & 13.3 & 45.9 & 46.5 & 43.9 & 41.4 & 38.5 & 40.3 & 41.8 & 45.2 \\
\hline Lao People's Democratic Republic & 48.5 & 36.7 & 30.6 & 17.7 & 19.1 & 23.5 & 29.8 & 35.5 & 32.4 & 39.8 & 39.6 & 46.8 \\
\hline Malaysia & 8.3 & 8.4 & 10.2 & 7.6 & 46.8 & 46.9 & 40.9 & 38.8 & 44.9 & 44.7 & 48.9 & 53.6 \\
\hline Myanmar & 57.2 & 46.7 & 36.9 & $23.3(2017)$ & 9.7 & 17.5 & 26.5 & $36.3(2017)$ & 33.1 & 35.8 & 36.7 & $40.4(2017)$ \\
\hline Philippines & 14.0 & 12.7 & 12.3 & 9.3 & 34.5 & 33.8 & 32.6 & 30.8 & 51.5 & 53.5 & 55.1 & 59.9 \\
\hline Singapore & 0.1 & 0.1 & 0.0 & 0.0 & 34.8 & 32.9 & 28.2 & 26.6 & 65.1 & 67.1 & 71.8 & 73.3 \\
\hline Thailand ${ }^{\mathrm{b}}$ & 8.5 & 9.2 & 10.5 & 8.1 & 33.7 & 35.5 & 37.1 & 32.4 & 57.8 & 55.3 & 52.4 & 59.5 \\
\hline Viet Nam & 24.5 & 19.3 & 21.0 & 16.3 & 36.7 & 38.1 & 36.7 & 38.0 & 38.7 & 42.6 & 42.2 & 45.7 \\
\hline \multicolumn{13}{|l|}{ The Pacific } \\
\hline Cook Islands & 10.3 & 6.9 & 3.4 & 3.8 & 8.3 & 9.6 & 7.9 & 7.3 & 81.4 & 83.5 & 88.7 & 88.9 \\
\hline Fiji & 16.5 & 14.1 & 11.0 & $12.9(2017)$ & 21.6 & 19.2 & 20.9 & $20.0(2017)$ & 61.9 & 66.8 & 68.1 & 67.1 (2017) \\
\hline Kiribati & 20.0 & 21.8 & 24.2 & $28.9(2017)$ & 12.2 & 9.3 & 11.9 & $11.6(2017)$ & 67.8 & 68.9 & 63.9 & 59.5 (2017) \\
\hline Marshall Islands & 10.5 & 9.3 & 15.7 & $16.9(2017)$ & 12.3 & 10.3 & 12.7 & $13.9(2017)$ & 77.1 & 80.5 & 71.6 & $69.3(2017)$ \\
\hline Micronesia, Federated States of & 25.3 & 24.2 & 26.7 & $28.8(2016)$ & 8.7 & 5.7 & 7.8 & $6.5(2016)$ & 66.0 & 70.1 & 65.5 & $64.8(2016)$ \\
\hline Nauru & & 5.2 & 6.3 & & & 9.1 & 32.7 & & & 85.7 & 61.0 & \\
\hline Niue & 22.2 & 23.3 & 23.0 & 19.1 & 3.9 & 4.5 & 4.0 & 3.7 & 73.9 & 72.2 & 73.0 & 77.2 \\
\hline Palau & 4.3 & 4.2 & 4.2 & 3.5 & 16.1 & 15.2 & 11.0 & 8.8 & 79.7 & 80.5 & 84.8 & 87.6 \\
\hline Papua New Guinea & 35.2 & 34.0 & 20.2 & 17.9 & 40.7 & 44.3 & 34.2 & 40.5 & 24.1 & 21.7 & 45.5 & 41.6 \\
\hline Samoa & 16.7 & 12.3 & 9.1 & 9.4 & 26.8 & 30.6 & 18.1 & 14.6 & 56.6 & 57.2 & 72.8 & 75.9 \\
\hline Solomon Islands & & 32.4 & 30.3 & $27.3(2016)$ & & 9.5 & 13.3 & $14.7(2016)$ & & 58.0 & 56.4 & $58.0(2016)$ \\
\hline Timor-Leste & 24.2 & 7.4 & 5.7 & $10.4(2017)$ & 31.7 & 76.1 & 79.1 & $45.6(2017)$ & 44.1 & 16.5 & 15.2 & 44.0 (2017) \\
\hline Tonga & 22.2 & 20.0 & 18.2 & 19.5 & 20.7 & 19.0 & 20.0 & 18.7 & 57.1 & 61.0 & 61.8 & 61.8 \\
\hline Tuvalu & 20.4 & 22.2 & 27.3 & $20.0(2017)$ & 7.4 & 8.3 & 5.7 & $17.8(2017)$ & 72.2 & 69.4 & 67.0 & $62.2(2017)$ \\
\hline Vanuatu & 25.4 & 24.1 & 21.9 & $23.1(2017)$ & 12.2 & 8.5 & 13.0 & $11.0(2017)$ & 62.3 & 67.4 & 65.0 & $65.9(2017)$ \\
\hline \multicolumn{13}{|l|}{ Developed ADB Member Economies } \\
\hline Australia & 3.1 & 2.9 & 2.2 & 2.6 & 24.6 & 24.6 & 25.2 & 24.0 & 72.2 & 72.5 & 72.7 & 73.4 \\
\hline Japan & 1.5 & 1.1 & 1.1 & $1.2(2017)$ & 32.7 & 30.1 & 28.5 & $29.3(2017)$ & 65.8 & 68.8 & 70.4 & 69.5 (2017) \\
\hline New Zealand & 8.3 & 4.9 & 7.1 & $6.2(2016)$ & 25.3 & 25.8 & 23.0 & $22.0(2016)$ & 66.4 & 69.3 & 69.9 & 71.8 (2016) \\
\hline
\end{tabular}

$\ldots=$ data not available, $0.0=$ magnitude is less than half of the unit employed, $A D B=$ Asian Development Bank, GDP $=$ gross domestic product.

a Calculated as a share of GDP at current prices.

b For Thailand, value added for construction is included under services.

Source: Economy sources. 
Table 2.2.7: Household and Government Consumption Expenditure (\% of GDPa)

\begin{tabular}{|c|c|c|c|c|c|c|c|c|}
\hline \multirow{2}{*}{ ADB Regional Member } & \multicolumn{4}{|c|}{ Household Consumption } & \multicolumn{4}{|c|}{ Government Consumption } \\
\hline & 2000 & 2005 & 2010 & 2018 & 2000 & 2005 & 2010 & 2018 \\
\hline \multirow{2}{*}{\multicolumn{9}{|c|}{$\begin{array}{l}\text { ADB Developing Member Economies } \\
\text { Central and West Asia }\end{array}$}} \\
\hline & & & & & & & & \\
\hline Afghanistan & $111.2(2002)$ & 115.7 & 97.4 & 78.8 & $7.7(2002)$ & 10.0 & 14.0 & 12.4 \\
\hline Armenia ${ }^{\mathrm{b}}$ & 97.1 & 75.5 & 82.0 & 79.9 & 11.8 & 10.6 & 13.1 & 12.8 \\
\hline Azerbaijan & 63.0 & 41.6 & 38.9 & 52.8 & 15.2 & 10.4 & 10.9 & 10.2 \\
\hline Georgia & 80.5 & 64.6 & 72.3 & 59.3 & 8.5 & 17.3 & 21.1 & 16.6 \\
\hline Kazakhstan & 61.9 & 49.9 & 45.4 & 51.4 & 12.1 & 11.2 & 10.8 & 8.7 \\
\hline Kyrgyz Republic ${ }^{b}$ & 65.7 & 84.5 & 84.6 & 82.7 & 20.0 & 17.5 & 18.1 & 16.5 \\
\hline Pakistan ${ }^{b}$ & 75.5 & 78.4 & 79.7 & 82.1 & 8.1 & 7.5 & 10.3 & 12.4 \\
\hline Tajikistan ${ }^{\mathrm{b}}$ & 87.7 & 81.1 & 84.7 & $77.9(2017)$ & 11.6 & 14.6 & 11.3 & $14.3(2017)$ \\
\hline Turkmenistan & 37.1 & 46.6 & 5.0 & & 14.5 & 13.2 & 9.3 & \\
\hline Uzbekistan & 61.9 & 46.7 & 57.0 & 54.5 & 18.7 & 17.6 & 13.3 & 15.0 \\
\hline \multicolumn{9}{|l|}{ East Asia } \\
\hline China, People's Republic of & 46.7 & 39.8 & 35.6 & 39.4 & 16.6 & 13.9 & 12.9 & 14.9 \\
\hline Hong Kong, China ${ }^{b}$ & 58.6 & 57.5 & 61.4 & 68.3 & 9.4 & 9.2 & 8.9 & 9.9 \\
\hline Korea, Republic of & 53.3 & 51.0 & 49.1 & 46.2 & 10.9 & 12.9 & 14.2 & 16.1 \\
\hline Mongolia & 75.1 & 55.2 & 55.2 & 48.4 & 15.3 & 12.1 & 12.7 & 11.8 \\
\hline Taipei, China & 55.1 & 56.1 & 53.1 & 53.7 & 15.7 & 15.3 & 14.9 & 14.5 \\
\hline \multicolumn{9}{|l|}{ South Asia } \\
\hline Bangladesh & 77.5 & 74.4 & 74.1 & 70.8 & 4.6 & 5.5 & 5.1 & 6.4 \\
\hline Bhutan ${ }^{b}$ & 47.7 & 40.4 & 46.6 & $52.8(2017)$ & 21.9 & 21.9 & 20.0 & 16.4 (2017) \\
\hline Indiab & 64.6 & 58.3 & 56.0 & 59.4 & 12.6 & 10.9 & 11.4 & 11.2 \\
\hline Maldives & & & & & & & $\ldots$ & $\ldots$ \\
\hline Nepalb & 75.9 & 79.5 & 78.6 & 70.5 & 8.9 & 8.9 & 10.0 & 11.7 \\
\hline Sri Lanka & 70.9 & 69.0 & 68.5 & 69.8 & 13.7 & 13.1 & 8.5 & 9.0 \\
\hline \multicolumn{9}{|l|}{ Southeast Asia } \\
\hline Brunei Darussalamb & 24.8 & 22.5 & 14.7 & 19.5 & 25.8 & 18.4 & 22.2 & 24.1 \\
\hline Cambodiab & 88.8 & 84.3 & 81.3 & 70.6 & 5.2 & 4.1 & 6.3 & 4.9 \\
\hline Indonesiac & 61.7 & 64.4 & 56.2 & 57.0 & 6.5 & 8.1 & 9.0 & 9.0 \\
\hline Lao People's Democratic Republic & & & & & & & & \\
\hline Malaysiac & 43.8 & 44.2 & 48.1 & 57.4 & 10.2 & 11.5 & 12.6 & 12.0 \\
\hline Myanmar & 87.7 & 86.9 & 67.3 & $71.3(2017)$ & & & & \\
\hline Philippines ${ }^{\mathrm{b}}$ & 72.2 & 75.0 & 71.6 & 73.8 & 11.4 & 9.0 & 9.7 & 11.9 \\
\hline Singapore & 41.9 & 39.8 & 36.3 & 34.9 & 10.5 & 9.9 & 9.7 & 10.5 \\
\hline Thailand & 53.1 & 54.9 & 51.2 & 47.8 & 13.6 & 13.7 & 15.8 & 16.2 \\
\hline Viet Nam & 66.5 & 65.5 & 66.6 & 67.6 & 6.4 & 5.5 & 6.0 & 6.5 \\
\hline \multicolumn{9}{|l|}{ The Pacific } \\
\hline Cook Islands & & & & & & & & \\
\hline $\mathrm{Fiji}^{\mathrm{b}}$ & 57.2 & 73.3 & 70.3 & $63.7(2017)$ & 17.3 & 15.9 & 15.0 & $19.8(2017)$ \\
\hline \multicolumn{9}{|l|}{ Kiribati } \\
\hline Marshall Islands & $\ldots$ & 71.8 & 73.0 & $71.5(2017)$ & $\ldots$ & 58.0 & 54.8 & $57.1(2017)$ \\
\hline Micronesia, Federated States of & $\ldots$ & $\ldots$ & $\ldots$ & $\ldots$ & $\ldots$ & $\ldots$ & $\ldots$ & $\ldots$ \\
\hline Nauru & $\ldots$ & $\ldots$ & $\ldots$ & $\ldots$ & $\cdots$ & $\ldots$ & $\ldots$ & $\ldots$ \\
\hline Niue & $\ldots$ & & $\ldots$ & $\ldots$ & $\ldots$ & $\ldots$ & $\ldots$ & $\ldots$ \\
\hline Palau & $\cdots$ & 63.6 & 67.7 & 66.6 & $\cdots$ & 31.3 & 37.5 & 32.4 \\
\hline Papua New Guinea & 44.6 & 48.0 & & 00.0 & 16.6 & 16.1 & 10. & 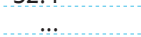 \\
\hline \multicolumn{9}{|l|}{ Samoa } \\
\hline Solomon Islands & & 62.6 & 60.2 & $58.5(2016)$ & & 45.3 & 40.7 & $29.7(2016)$ \\
\hline Timor-Leste & 70.7 & 22.6 & 15.1 & $39.8(2017)$ & 111.3 & 13.4 & 22.8 & $35.2(2017)$ \\
\hline Tonga & 87.3 & 93.0 & 91.3 & 99.6 & 18.2 & 15.5 & 18.1 & 18.8 \\
\hline \multicolumn{9}{|l|}{ Tuvalu } \\
\hline Vanuatu & 62.4 & 65.8 & 60.6 & $60.5(2017)$ & 16.4 & 13.2 & 17.5 & $17.4(2017)$ \\
\hline \multicolumn{9}{|l|}{ ADB Developed Member Economies } \\
\hline Australia & 58.1 & 57.6 & 56.2 & 56.5 & 17.8 & 17.6 & 18.0 & 18.7 \\
\hline Japan & 54.4 & 55.6 & 57.8 & 55.6 & 16.9 & 18.1 & 19.5 & 19.7 \\
\hline New Zealand & 58.0 & 58.2 & 58.1 & 58.1 & 17.0 & 17.9 & 19.5 & 18.2 \\
\hline
\end{tabular}

.... = data not available, $\mathrm{ADB}=$ Asian Development Bank, $\mathrm{GDP}=$ gross domestic product.

a Calculated as a share of GDP at current prices.

b Data for household consumption includes nonprofit institutions serving households.

c Prior to 2010, data for household consumption includes nonprofit institutions serving households.

d Data for household consumption includes government consumption.

Source: Economy sources. 
Table 2.2.8: Gross Capital Formation and Changes in Inventories (\% of GDPa)

\begin{tabular}{|c|c|c|c|c|c|c|c|c|}
\hline \multirow{2}{*}{ ADB Regional Member } & \multicolumn{4}{|c|}{ Gross Capital Formation } & \multicolumn{4}{|c|}{ Changes in Inventories } \\
\hline & 2000 & 2005 & 2010 & 2018 & 2000 & 2005 & 2010 & 2018 \\
\hline \multicolumn{9}{|l|}{ Developing ADB Member Economies } \\
\hline \multicolumn{9}{|l|}{ Central and West Asia } \\
\hline Afghanistan b,c & $11.3(2002)$ & 21.8 & 17.5 & 22.0 & & & 5.3 & 21.4 \\
\hline Armenia & 18.6 & 30.5 & 32.9 & 22.4 & 0.2 & 0.7 & -0.6 & 5.7 \\
\hline Azerbaijan & 20.7 & 41.5 & 18.1 & 20.1 & -2.5 & 0.2 & -0.1 & -0.6 \\
\hline Georgia & 26.6 & 33.5 & 21.6 & 33.3 & 1.1 & 5.4 & 2.3 & 3.9 \\
\hline Kazakhstan & 18.1 & 31.0 & 25.4 & 24.7 & 0.8 & 3.0 & 1.0 & 3.3 \\
\hline Kyrgyz Republic & 18.3 & 16.2 & 28.1 & 31.7 & 1.7 & 0.2 & -0.7 & 3.8 \\
\hline Pakistan & 17.6 & 17.7 & 15.8 & 16.4 & 1.6 & 1.6 & 1.6 & 1.6 \\
\hline Tajikistan & 9.4 & 11.6 & 23.8 & $27.2(2017)$ & 2.0 & 0.5 & -0.6 & $0.6(2017)$ \\
\hline Turkmenistan & 35.4 & 22.9 & 51.9 & & & & & \\
\hline Uzbekistan & 19.6 & 26.5 & 26.5 & 40.2 & -4.4 & 4.5 & 2.4 & 10.4 \\
\hline \multicolumn{9}{|l|}{ East Asia } \\
\hline China, People's Republic of & 34.4 & 41.4 & 47.7 & 44.1 & 1.0 & 0.9 & 2.6 & 1.8 \\
\hline Hong Kong, China & 27.6 & 21.1 & 23.9 & 21.7 & 1.1 & -0.3 & 2.1 & 0.2 \\
\hline Korea, Republic of & 32.9 & 32.5 & 32.6 & 31.3 & 1.1 & 2.0 & 2.3 & 0.9 \\
\hline Mongolia & 29.0 & 37.5 & 42.1 & 43.1 & 3.8 & 9.6 & 7.6 & 13.4 \\
\hline Taipei,China & 27.2 & 24.5 & 25.0 & 21.3 & 0.9 & 0.3 & 1.3 & 0.3 \\
\hline \multicolumn{9}{|l|}{ South Asia } \\
\hline Bangladesh ${ }^{\mathrm{b}}$ & 23.0 & 24.5 & 26.2 & 31.2 & & & & $\cdots$ \\
\hline Bhutan & 48.7 & 52.0 & 61.7 & $51.3(2017)$ & -1.8 & -0.0 & 0.5 & $-0.1(2017)$ \\
\hline India & 24.3 & 34.7 & 36.5 & 31.3 & 0.7 & 2.8 & 3.5 & 1.0 \\
\hline Maldives & & & & & & & & \\
\hline Nepal & 24.3 & 26.5 & 38.3 & 55.2 & 5.0 & 6.5 & 16.1 & 20.5 \\
\hline Sri Lanka & 25.4 & 26.1 & 30.4 & 28.6 & 0.6 & 2.8 & 5.9 & 2.2 \\
\hline \multicolumn{9}{|l|}{ Southeast Asia } \\
\hline Brunei Darussalam & 13.1 & 11.4 & 23.7 & 41.1 & 0.1 & 0.0 & 0.2 & 0.2 \\
\hline Cambodia & 17.5 & 20.2 & 17.4 & 23.4 & -0.8 & 1.3 & 1.2 & 0.9 \\
\hline Indonesia & 22.2 & 25.1 & 32.9 & 34.6 & 2.4 & 1.4 & 1.9 & 2.3 \\
\hline \multicolumn{9}{|l|}{ Lao People's Democratic Republic } \\
\hline Malaysia $^{c}$ & 26.9 & 22.4 & 23.4 & 23.6 & 1.6 & 0.1 & 1.0 & -0.6 \\
\hline Myanmar & 12.4 & 13.2 & 23.2 & $34.1(2017)$ & 0.7 & 0.5 & 0.3 & $1.3(2017)$ \\
\hline Philippines & 18.4 & 21.6 & 20.5 & 27.0 & -3.7 & 1.6 & 0.0 & 0.2 \\
\hline Singapore & 35.2 & 21.5 & 27.7 & 26.6 & 2.8 & -1.7 & 2.1 & 2.5 \\
\hline Thailand & 22.3 & 30.4 & 25.4 & 25.0 & 0.7 & 2.7 & 1.4 & 2.1 \\
\hline Viet Nam & 29.6 & 33.8 & 35.7 & 26.5 & 2.0 & 2.5 & 3.0 & 2.7 \\
\hline \multicolumn{9}{|l|}{ The Pacific } \\
\hline \multicolumn{9}{|l|}{ Cook Islands } \\
\hline Fiji & 17.3 & 21.0 & 18.7 & $18.1(2017)$ & 1.9 & 1.4 & 2.9 & $-(2017)$ \\
\hline Kiribati & $\ldots$ & & & & $\ldots$ & & & \\
\hline Marshall Islands & $\ldots$ & 19.1 & 42.9 & $22.1(2017)$ & $\ldots$ & 0.2 & 0.1 & $-0.1(2017)$ \\
\hline Micronesia, Federated States of & $\ldots$ & $\ldots \ldots$ & $\ldots$ & $\ldots$ & $\ldots$ & ...... & $\ldots \ldots$ & $\ldots$ \\
\hline Nauru & & & & $\ldots$ & $\ldots$ & $\ldots$ & $\ldots$ & $\ldots \ldots$ \\
\hline Niue & $\ldots$ & & & & & & & 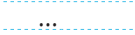 \\
\hline Palau & & 42.9 & 24.6 & 26.7 & & 0.4 & 0.7 & 1.2 \\
\hline Papua New Guinea & 21.9 & 17.5 & $\ldots$ & $\ldots$ & 1.5 & 1.0 & $\ldots$ & $\ldots$ \\
\hline \multirow{2}{*}{\multicolumn{9}{|c|}{ Solomon Islands }} \\
\hline & & & & & & & & \\
\hline Timor-Leste & 28.0 & 4.0 & 12.0 & $22.5(2017)$ & -3.7 & 0.0 & 0.0 & $1.0(2017)$ \\
\hline Tonga & 20.7 & 22.3 & 30.1 & 27.3 & 0.5 & 0.3 & 0.5 & 0.3 \\
\hline Tuvalu & & & & & & & & \\
\hline Vanuatu & 22.9 & 24.1 & 34.7 & $27.9(2017)$ & 0.5 & 0.7 & 0.8 & $0.7(2017)$ \\
\hline \multicolumn{9}{|l|}{ Developed ADB Member Economies } \\
\hline Australia & 26.3 & 27.6 & 26.9 & 24.3 & 0.3 & 0.5 & -0.2 & 0.1 \\
\hline Japan & 27.3 & 24.7 & 21.3 & 24.4 & -0.1 & 0.1 & -0.0 & 0.2 \\
\hline New Zealand & 22.0 & 25.4 & 20.1 & 23.7 & 1.2 & 0.7 & 0.4 & 0.3 \\
\hline
\end{tabular}

$\ldots=$ data not available, -0.0 or $0.0=$ magnitude is less than half of unit employed, $-=$ magnitude equals zero, $A D B=$ Asian Development $B$ ank, $G D P=$ gross domestic product.

a Computed as a share of GDP at current prices.

b Refers to gross fixed capital formation and includes data on changes in inventories.

c Changes in inventories include statistical discrepancy.

Source: Economy sources. 
Table 2.2.9: Exports and Imports of Goods and Services (\% of GDPa)

\begin{tabular}{|c|c|c|c|c|c|c|c|c|}
\hline \multirow{2}{*}{ ADB Regional Member } & \multicolumn{4}{|c|}{ Exports of Goods and Services } & \multicolumn{4}{|c|}{ Imports of Goods and Services } \\
\hline & 2000 & 2005 & 2010 & 2018 & 2000 & 2005 & 2010 & 2018 \\
\hline \multicolumn{9}{|l|}{$\begin{array}{l}\text { Developing ADB Member Economies } \\
\text { Central and West Asia }\end{array}$} \\
\hline Afghanistan & $29.7(2002)$ & 26.0 & 9.8 & 8.1 & $59.8(2002)$ & 73.6 & 43.9 & 42.8 \\
\hline Armenia & 23.4 & 28.8 & 20.8 & 37.5 & 50.5 & 43.2 & 45.3 & 52.9 \\
\hline Azerbaijan & 40.2 & 62.9 & 54.3 & 54.3 & 38.4 & 52.9 & 20.7 & 37.7 \\
\hline Georgia & 23.0 & 33.7 & 35.0 & 55.1 & 39.7 & 51.6 & 52.8 & 66.7 \\
\hline Kazakhstan & 56.6 & 53.2 & 44.2 & 38.9 & 49.1 & 44.6 & 29.9 & 26.2 \\
\hline Kyrgyz Republic & 41.8 & 38.3 & 51.6 & 32.7 & 47.6 & 56.8 & 81.7 & 68.4 \\
\hline Pakistan & 12.1 & 14.3 & 13.5 & 8.5 & 13.2 & 17.8 & 19.4 & 19.4 \\
\hline Tajikistan & 92.4 & 54.3 & 26.8 & $15.7(2017)$ & 100.2 & 72.8 & 59.0 & $40.9(2017)$ \\
\hline Turkmenistan & 97.2 & 65.0 & 76.3 & & 82.4 & 47.8 & 44.5 & \\
\hline Uzbekistan & 26.5 & 37.9 & 27.9 & 29.1 & 26.7 & 28.7 & 19.7 & 38.7 \\
\hline \multicolumn{9}{|l|}{ East Asia } \\
\hline China, People's Republic of & 20.8 & 33.5 & 26.4 & 19.8 & 18.5 & 28.1 & 22.7 & 19.0 \\
\hline Hong Kong, China & 126.0 & 177.5 & 205.3 & 188.3 & 121.6 & 165.2 & 199.4 & 188.2 \\
\hline Korea, Republic of & 33.9 & 35.3 & 47.1 & 41.6 & 32.2 & 33.0 & 44.3 & 37.0 \\
\hline Mongolia & 54.0 & 58.8 & 46.7 & 61.5 & 67.9 & 63.6 & 56.7 & 64.8 \\
\hline Taipei,China & 51.9 & 60.6 & 70.9 & 66.8 & 49.9 & 56.4 & 63.9 & 56.3 \\
\hline \multicolumn{9}{|l|}{ South Asia } \\
\hline Bangladesh & 14.0 & 16.6 & 16.0 & 14.8 & 19.2 & 23.0 & 21.8 & 23.4 \\
\hline Bhutan & 29.4 & 38.2 & 42.5 & $29.1(2017)$ & 48.3 & 64.4 & 70.7 & $49.6(2017)$ \\
\hline India & 12.8 & 19.3 & 22.0 & 19.7 & 13.7 & 22.0 & 26.3 & 23.6 \\
\hline Maldives & & & & & & & & $\ldots$ \\
\hline Nepal & 23.3 & 14.6 & 9.6 & 8.9 & 32.4 & 29.5 & 36.4 & 46.3 \\
\hline Sri Lanka & 38.2 & 32.3 & 19.6 & 22.8 & 48.4 & 41.3 & 26.8 & 30.1 \\
\hline \multicolumn{9}{|l|}{ Southeast Asia } \\
\hline Brunei Darussalam & 67.4 & 70.2 & 67.4 & 51.9 & 35.8 & 27.3 & 28.0 & 42.0 \\
\hline Cambodia & 49.8 & 64.1 & 54.1 & 61.6 & 61.8 & 72.7 & 59.5 & 63.3 \\
\hline Indonesia & 41.0 & 34.1 & 24.3 & 21.0 & 30.5 & 29.9 & 22.4 & 22.1 \\
\hline \multicolumn{9}{|l|}{ Lao People's Democratic Republic } \\
\hline Malaysia & 119.8 & 112.9 & 86.9 & 68.8 & 100.6 & 91.0 & 71.0 & 61.7 \\
\hline Myanmar & 0.5 & 0.2 & 19.6 & $20.0(2017)$ & 0.6 & 0.1 & 15.1 & $28.0(2017)$ \\
\hline Philippines & 51.4 & 46.1 & 34.8 & 31.7 & 53.4 & 51.7 & 36.6 & 44.4 \\
\hline Singapore & 188.4 & 225.2 & 198.0 & 176.4 & 176.0 & 195.3 & 171.7 & 149.8 \\
\hline Thailand & 64.8 & 68.4 & 66.5 & 66.8 & 56.5 & 69.5 & 60.8 & 56.5 \\
\hline Viet Nam & 55.0 & 63.7 & 72.0 & 105.8 & 57.5 & 67.0 & 80.2 & 102.5 \\
\hline \multicolumn{9}{|l|}{ The Pacific } \\
\hline Cook Islands & & & & & & & & \\
\hline Fiji & 65.4 & 54.1 & 57.4 & $50.8(2017)$ & 70.5 & 63.7 & 63.8 & $56.1(2017)$ \\
\hline \multicolumn{9}{|l|}{ Kiribati } \\
\hline Marshall Islands & $\ldots$ & 36.7 & 44.0 & $47.4(2017)$ & $\ldots$ & 92.7 & 107.1 & $90.7(2017)$ \\
\hline Micronesia, Federated States of & $\ldots$ & $\ldots$ & $\ldots$ & 12 & $\cdots$ & $\ldots$ & $\ldots$ & 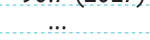 \\
\hline Nauru & $\ldots$ & $\ldots$ & $\ldots$ & $\ldots$ & $\ldots$ & $\ldots$ & $\ldots$ & $\ldots$ \\
\hline Niue & $\cdots$ & $\ldots$ & $\ldots$ & $\ldots$ & $\ldots$ & $\ldots$ & $\ldots$ & $\ldots$ \\
\hline Palau & $\cdots$ & 47.2 & 50.0 & 46.7 & $\cdots$ & 78.6 & 77.1 & 76.7 \\
\hline Papua New Guinea & 66.2 & 74.5 & 0.0 & 10. & 49.2 & 56.1 & & $\ldots$ \\
\hline Samoa & & & & & & & & \\
\hline Solomon Islands & & 33.0 & 47.4 & $50.1(2016)$ & & 45.2 & 78.7 & $57.3(2016)$ \\
\hline Timor-Leste & 27.2 & 82.8 & 100.2 & $61.1(2017)$ & 139.5 & 23.7 & 50.7 & $59.9(2017)$ \\
\hline Tonga & 15.4 & 17.7 & 13.2 & 21.6 & 46.8 & 57.8 & 57.9 & 66.7 \\
\hline \multicolumn{9}{|l|}{ Tuvalu } \\
\hline Vanuatu & 34.7 & 45.4 & 46.6 & $47.7(2017)$ & 43.7 & 54.8 & 52.7 & $57.9(2017)$ \\
\hline \multicolumn{9}{|l|}{ Developed ADB Member Economies } \\
\hline Australia & 19.4 & 18.3 & 19.8 & 21.8 & 21.6 & 21.0 & 20.8 & 21.4 \\
\hline Japan & 10.6 & 14.0 & 15.0 & 18.5 & 9.2 & 12.5 & 13.6 & 18.2 \\
\hline New Zealand & 35.7 & 28.3 & 30.3 & 28.3 & 32.8 & 29.7 & 28.0 & 28.3 \\
\hline
\end{tabular}

.... = data not available, $\mathrm{ADB}=$ Asian Development Bank, $\mathrm{GDP}=$ gross domestic product .

a Computed as a share of GDP at current prices.

Source: Economy sources. 
Table 2.2.10: Gross Domestic Saving (\% of GDPa)

\begin{tabular}{|c|c|c|c|c|c|c|c|c|c|}
\hline ADB Regional Member & 2000 & 2005 & 2010 & 2013 & 2014 & 2015 & 2016 & 2017 & 2018 \\
\hline \multicolumn{10}{|l|}{ Developing ADB Member Economies } \\
\hline \multicolumn{10}{|l|}{ Central and West Asia } \\
\hline Afghanistan & $-18.8(2002)$ & -25.8 & -11.4 & 7.8 & 7.9 & 5.0 & 8.2 & 12.0 & 8.7 \\
\hline Armenia & -8.9 & 14.0 & 4.9 & 0.9 & 2.4 & 8.8 & 9.2 & 7.7 & 7.3 \\
\hline Azerbaijan & 20.4 & 47.5 & 49.8 & 47.8 & 43.7 & 30.9 & 28.5 & 31.1 & 36.7 \\
\hline Georgia & 9.9 & 15.7 & 3.8 & 11.8 & 12.3 & 14.0 & 17.0 & 20.4 & 21.7 \\
\hline Kazakhstan & 26.0 & 38.9 & 43.8 & 39.9 & 40.8 & 34.6 & 33.8 & 37.2 & \\
\hline Kyrgyz Republic & 14.3 & -2.1 & -2.7 & -15.6 & -13.5 & -8.3 & -0.2 & 0.8 & \\
\hline Pakistan & 16.5 & 14.2 & 10.0 & 8.2 & 8.2 & 9.3 & 8.7 & 6.8 & 5.5 \\
\hline Tajikistan & 0.6 & 4.3 & 4.0 & -13.6 & -12.7 & 2.5 & 7.1 & 7.8 & $\ldots$ \\
\hline Turkmenistan & 48.4 & 40.2 & 85.6 & 81.6 & & $\ldots$ & $\ldots$ & $\ldots$ & $\cdots$ \\
\hline Uzbekistan & 19.4 & 35.7 & 29.6 & 25.9 & 26.0 & 24.3 & 22.1 & 26.9 & 30.5 \\
\hline \multicolumn{10}{|l|}{ East Asia } \\
\hline China, People's Republic of & 36.8 & 46.8 & 51.4 & 50.0 & 49.7 & 49.1 & 46.7 & 46.1 & 44.9 \\
\hline Hong Kong, China & 32.0 & 33.3 & 29.8 & 24.6 & 24.0 & 23.9 & 23.8 & 23.1 & 21.8 \\
\hline Korea, Republic of & 34.6 & 34.8 & 35.4 & 34.5 & 34.8 & 36.4 & 36.8 & 37.0 & 35.9 \\
\hline Mongolia & 9.6 & 32.7 & 32.1 & 30.7 & 30.4 & 27.4 & 30.5 & 33.7 & 40.8 \\
\hline Taipei,China & 29.4 & 29.1 & 31.7 & 30.7 & 32.2 & 33.5 & 32.9 & 33.3 & 32.2 \\
\hline \multicolumn{10}{|l|}{ South Asia } \\
\hline Bangladesh & 17.9 & 20.0 & 20.8 & 22.0 & 22.1 & 22.2 & 25.0 & 25.3 & 22.8 \\
\hline Bhutan & 29.7 & 25.9 & 33.4 & 24.1 & 21.7 & 17.9 & 29.5 & 22.1 & $\ldots$ \\
\hline India & $\ldots$ & $\ldots$ & $\ldots$ & $\ldots$ & $\ldots$ & $\ldots$ & $\ldots$ & $\ldots$ & $\ldots$ \\
\hline Maldives & & & & & & & & & \\
\hline Nepal & 15.2 & 11.6 & 11.5 & 10.6 & 11.9 & 9.2 & 4.1 & 13.4 & 17.8 \\
\hline Sri Lanka & 15.4 & 17.9 & 23.1 & 24.6 & 24.2 & 23.6 & 27.4 & 29.0 & 21.2 \\
\hline \multicolumn{10}{|l|}{ Southeast Asia } \\
\hline Brunei Darussalam & 49.4 & 59.1 & 63.1 & 64.6 & 63.1 & 55.2 & 52.6 & 53.0 & 56.3 \\
\hline Cambodia & 8.1 & 14.0 & 14.5 & 17.7 & 18.9 & 19.6 & 20.4 & 23.2 & 26.0 \\
\hline Indonesia & 31.8 & 27.5 & 34.8 & 33.7 & 33.4 & 32.8 & 32.7 & 33.6 & $\ldots$ \\
\hline \multicolumn{10}{|l|}{ Lao PDR } \\
\hline Malaysia & 46.1 & 44.3 & 39.3 & 34.5 & 34.3 & 33.0 & 32.6 & 32.4 & 30.6 \\
\hline Myanmar & 12.3 & 13.1 & 32.7 & 33.8 & 22.9 & 23.4 & 24.6 & 25.3 & $\ldots$ \\
\hline Philippines & 16.4 & 15.9 & 18.7 & 15.8 & 16.9 & 15.3 & 15.1 & 15.3 & 14.2 \\
\hline Singapore & 47.5 & 51.4 & 54.0 & 53.1 & 52.9 & 52.7 & 53.4 & 53.2 & 53.2 \\
\hline Thailand & 31.7 & 30.3 & 32.0 & 31.3 & 31.8 & 34.9 & 36.7 & 37.7 & 36.3 \\
\hline Viet Nam & 27.1 & 29.0 & 27.4 & 28.4 & 27.9 & 25.7 & 24.9 & 25.5 & 26.0 \\
\hline \multicolumn{10}{|l|}{ The Pacific } \\
\hline Cook Islands & $\cdots$ & & & & & & & & $\ldots$ \\
\hline Fiji & 25.6 & 7.1 & 12.7 & 15.0 & 17.2 & 18.3 & 14.1 & 13.9 & $\ldots$ \\
\hline \multicolumn{10}{|l|}{ Kiribati } \\
\hline Marshall Islands & $\ldots$ & 19.1 & 42.9 & 23.1 & 20.0 & 18.7 & 20.0 & 22.1 & $\cdots$ \\
\hline Micronesia, Federated States of & $\ldots$ & $\ldots$ & $\ldots$ & $\ldots$ & $\ldots$ & $\ldots$ & $\ldots$ & $\ldots$ & $\ldots$ \\
\hline Nauru & $\ldots$ & $\cdots$ & $\ldots$ & & $\cdots$ & $\ldots$ & $\ldots$ & $\cdots$ & \\
\hline \multicolumn{10}{|l|}{ Niue } \\
\hline Palau & $\ldots$ & 3.1 & -7.4 & -6.1 & -3.0 & 5.3 & 5.3 & 0.1 & -1.8 \\
\hline Papua New Guinea & 38.8 & 35.9 & $\ldots$ & $\ldots$ & $\ldots$ & $\ldots$ & $\ldots$ & $\ldots$ & $\ldots$ \\
\hline Samoa & $\ldots$ & $\ldots$ & $\ldots$ & $\ldots$ & $\ldots$ & $\ldots$ & $\ldots$ & $\ldots$ & $\ldots$ \\
\hline Solomon Islands & & & & & & & & & $\ldots$ \\
\hline Timor-Leste & -84.4 & 63.1 & 61.5 & 68.6 & 53.3 & 39.6 & 23.4 & 23.7 & $\ldots$ \\
\hline Tonga & -10.0 & -16.3 & -16.1 & -19.7 & -21.3 & & & & \\
\hline Tuvalu & $\ldots$ & & & & $\ldots$ & $\ldots$ & $\ldots$ & $\cdots$ & $\ldots$ \\
\hline Vanuatu & 21.2 & 13.9 & 27.0 & 23.3 & 24.0 & $\ldots$ & $\ldots$ & $\ldots$ & $\ldots$ \\
\hline \multicolumn{10}{|l|}{ Developed ADB Member Economies } \\
\hline Australia & 24.1 & 24.8 & 25.8 & 26.6 & 26.3 & 24.7 & 23.1 & 24.7 & 24.8 \\
\hline Japan & 29.0 & 26.8 & 22.9 & 20.9 & 21.4 & 23.3 & 24.2 & 24.9 & $\ldots$ \\
\hline New Zealand & 25.0 & 24.0 & 22.4 & 23.6 & 23.7 & 24.1 & 24.2 & 24.3 & $\ldots$ \\
\hline
\end{tabular}

.... = data not available, $\mathrm{ADB}=$ Asian Development Bank, $\mathrm{GDP}=$ gross domestic product.

a Computed as a share of GDP at current prices.

Sources: Economy sources. 
Table 2.2.11: Growth Rates of Real Gross Domestic Product (\%)

\begin{tabular}{|c|c|c|c|c|c|c|c|c|c|}
\hline ADB Regional Member & 2000 & 2005 & 2010 & 2013 & 2014 & 2015 & 2016 & 2017 & 2018 \\
\hline \multicolumn{10}{|l|}{ Developing ADB Member Economies } \\
\hline \multicolumn{10}{|l|}{ Central and West Asia } \\
\hline Afghanistan & & 9.9 & 3.2 & 6.5 & 3.1 & -1.8 & 3.5 & 7.1 & -0.2 \\
\hline Armenia & 5.9 & 13.9 & 2.2 & 3.3 & 3.6 & 3.2 & 0.2 & 7.5 & 5.2 \\
\hline Azerbaijan & 11.1 & 26.4 & 5.0 & 5.8 & 2.8 & 1.1 & -3.1 & 0.2 & 1.4 \\
\hline Georgia & 1.8 & 9.6 & 6.2 & 3.4 & 4.6 & 2.9 & 2.8 & 4.8 & 4.7 \\
\hline Kazakhstan & 9.8 & 9.7 & 7.3 & 6.0 & 4.2 & 1.2 & 1.1 & 4.1 & 1.4 \\
\hline Kyrgyz Republic & 5.4 & -0.2 & -0.5 & 10.9 & 4.0 & 3.9 & 4.3 & 4.7 & 3.5 \\
\hline Pakistan & $3.6(2001)$ & 6.5 & 1.6 & 4.4 & 4.7 & 4.7 & 4.6 & 5.4 & 5.8 \\
\hline Tajikistan & 8.3 & 6.7 & 6.5 & 7.4 & 6.7 & 6.0 & 6.9 & 7.1 & \\
\hline Turkmenistan & 5.5 & 13.0 & 9.2 & 10.2 & 10.3 & 6.5 & 6.2 & 6.5 & 6.2 \\
\hline Uzbekistan & 4.0 & 7.0 & 7.3 & 7.6 & 7.2 & 7.4 & 6.1 & 4.5 & 5.1 \\
\hline \multicolumn{10}{|l|}{ East Asia } \\
\hline China, People's Republic of & 8.5 & 11.4 & 10.6 & 7.8 & 7.3 & 6.9 & 6.7 & 6.8 & 6.6 \\
\hline Hong Kong, China & 7.7 & 7.4 & 6.8 & 3.1 & 2.8 & 2.4 & 2.2 & 3.8 & 3.0 \\
\hline Korea, Republic of & $4.9(2001)$ & 4.3 & 6.8 & 3.2 & 3.2 & 2.8 & 2.9 & 3.2 & 2.7 \\
\hline Mongolia & 1.1 & 7.3 & $17.3(2011)$ & 11.6 & 7.9 & 2.4 & 1.2 & 5.3 & 6.9 \\
\hline Taipei,China & 6.4 & 5.4 & 10.6 & 2.2 & 4.0 & 0.8 & 1.5 & 3.1 & 2.6 \\
\hline \multicolumn{10}{|l|}{ South Asia } \\
\hline Bangladesh & 6.0 & 6.0 & 5.6 & 6.0 & 6.1 & 6.6 & 7.1 & 7.3 & 7.9 \\
\hline Bhutan & 6.9 & 7.1 & 11.7 & 2.1 & 5.7 & 6.6 & 8.0 & 4.6 & $\ldots$ \\
\hline India & 3.8 & 9.3 & 10.3 & 6.4 & 7.4 & 8.0 & 8.2 & 7.2 & 6.8 \\
\hline Maldives & 3.8 & -13.1 & 7.3 & 7.3 & 7.3 & 2.9 & 7.3 & 6.9 & 6.1 \\
\hline Nepal & 6.0 & 3.5 & 4.8 & 4.1 & 6.0 & 3.3 & 0.6 & 8.2 & 6.7 \\
\hline Sri Lanka & 6.0 & 6.2 & 8.0 & 3.4 & 5.0 & 5.0 & 4.5 & 3.4 & 3.2 \\
\hline \multicolumn{10}{|l|}{ Southeast Asia } \\
\hline Brunei Darussalam & 2.8 & 0.4 & $3.7(2011)$ & -2.1 & -2.5 & -0.4 & -2.5 & 1.3 & 0.1 \\
\hline Cambodia & 10.7 & 13.3 & 6.0 & 7.4 & 7.1 & 7.0 & 7.0 & 7.0 & 7.5 \\
\hline Indonesia & 4.9 & 5.7 & 6.2 & 5.6 & 5.0 & 4.9 & 5.0 & 5.1 & 5.2 \\
\hline Lao People's Democratic Republic & 6.3 & 6.8 & 8.1 & 8.0 & 7.6 & 7.3 & 7.0 & 6.9 & 6.3 \\
\hline Malaysia & 8.9 & 5.3 & 7.4 & 4.7 & 6.0 & 5.1 & 4.4 & 5.7 & 4.7 \\
\hline Myanmar & 13.7 & 13.6 & 9.6 & 8.4 & 8.0 & 7.0 & 5.9 & 6.8 & $\ldots$ \\
\hline Philippines & 4.4 & 4.8 & 7.6 & 7.1 & 6.1 & 6.1 & 6.9 & 6.7 & 6.2 \\
\hline Singapore & 9.0 & 7.4 & 14.5 & 4.8 & 3.9 & 2.9 & 3.0 & 3.7 & 3.1 \\
\hline Thailand & 4.5 & 4.2 & 7.5 & 2.7 & 1.0 & 3.1 & 3.4 & 4.0 & 4.1 \\
\hline Viet Nam & 6.8 & 7.5 & 6.4 & 5.4 & 6.0 & 6.7 & 6.2 & 6.8 & 7.1 \\
\hline \multicolumn{10}{|l|}{ The Pacific } \\
\hline Cook Islands & 13.9 & -1.1 & -3.0 & -1.4 & 6.2 & 4.0 & 5.7 & 1.9 & 6.6 \\
\hline Fiji & -1.7 & -1.3 & 3.0 & 4.7 & 5.6 & 4.7 & 2.6 & 5.2 & $\ldots$ \\
\hline Kiribati & 5.3 & $-0.0(2006)$ & -0.9 & 4.2 & -0.7 & 10.4 & 5.1 & 0.3 & $\ldots$ \\
\hline Marshall Islands & 6.0 & 3.6 & 7.1 & 2.8 & -0.7 & -0.6 & 1.8 & 4.5 & \\
\hline Micronesia, Federated States of & 4.9 & 2.1 & 2.0 & -3.9 & -2.2 & 5.0 & 0.7 & 2.4 & \\
\hline Nauru & $\ldots$ & -0.6 & 13.6 & 34.2 & 36.5 & 2.8 & $\ldots$ & 4.0 & -4.0 \\
\hline Niue & & 8.9 & 0.6 & 6.0 & 4.1 & 4.0 & 3.5 & 2.4 & 6.5 \\
\hline Palau & $6.4(2001)$ & 4.1 & 0.3 & -1.4 & 4.4 & 10.1 & 0.8 & -3.5 & 1.7 \\
\hline Papua New Guinea & -2.5 & 3.9 & 10.1 & 3.8 & 13.5 & 9.5 & 4.1 & 1.1 & 0.3 \\
\hline Samoa & 8.6 & 4.7 & 2.4 & 0.8 & 2.6 & 6.7 & 3.7 & -0.6 & 0.7 \\
\hline Solomon Islands & -14.2 & 7.4 & 9.7 & 2.8 & 1.8 & 2.6 & 3.4 & & $\ldots$ \\
\hline Timor-Leste & $9.2(2001)$ & 35.9 & -1.2 & -11.1 & -25.9 & 20.6 & 0.7 & -9.2 & $\ldots$ \\
\hline Tonga & -0.8 & 1.6 & 3.3 & -3.1 & 1.9 & 3.1 & 4.8 & 5.4 & 0.2 \\
\hline Tuvalu & $1.5(2001)$ & -4.1 & -3.3 & 4.9 & 1.2 & 9.2 & 5.9 & 5.9 & $\ldots$. \\
\hline Vanuatu & 5.9 & 5.3 & 1.6 & 2.0 & 2.3 & 0.2 & 3.5 & 4.4 & $\ldots$ \\
\hline \multicolumn{10}{|l|}{ Developed ADB Member Economies } \\
\hline Australia & 3.9 & 3.2 & 2.1 & 2.6 & 2.6 & 2.3 & 2.8 & 2.3 & 2.8 \\
\hline Japan & 2.8 & 1.7 & 4.2 & 2.0 & 0.4 & 1.2 & 0.6 & 1.9 & 0.8 \\
\hline New Zealand & 2.9 & 3.3 & 1.5 & 2.6 & 3.7 & 3.6 & 3.6 & 3.2 & 2.7 \\
\hline
\end{tabular}

$\ldots$ = data not available, $-0.0=$ magnitude is less than half of unit employed, $\mathrm{ADB}=$ Asian Development Bank.

Source: Economy sources. 
Table 2.2.12: Growth Rates of Real Gross Domestic Product per Capita

\begin{tabular}{|c|c|c|c|c|c|c|c|c|c|}
\hline ADB Regional Member & 2000 & 2005 & 2010 & 2013 & 2014 & 2015 & 2016 & 2017 & 2018 \\
\hline \multicolumn{10}{|l|}{ Developing ADB Member Economies } \\
\hline \multicolumn{10}{|l|}{ Central and West Asia } \\
\hline Afghanistan & $\ldots$ & 7.8 & 1.2 & 4.3 & 1.0 & -3.8 & 1.5 & 4.9 & -6.3 \\
\hline Armenia & 6.2 & 14.5 & 2.9 & 3.3 & 3.9 & 3.6 & 0.6 & 8.0 & 5.5 \\
\hline Azerbaijan & 10.0 & 24.9 & 3.8 & 4.5 & 1.5 & -0.1 & -4.2 & -0.8 & 0.5 \\
\hline Georgia & 3.8 & 10.3 & 7.0 & 3.7 & 4.6 & 2.7 & 2.8 & 4.8 & 4.8 \\
\hline Kazakhstan & 10.2 & 8.7 & 5.7 & 4.4 & 2.7 & -0.3 & -0.3 & 2.7 & 0.1 \\
\hline Kyrgyz Republic & 4.0 & -1.4 & -1.8 & 8.7 & 2.0 & 1.8 & 2.2 & 2.7 & 1.5 \\
\hline Pakistan & $1.5(2001)$ & 4.2 & -0.5 & 2.3 & 2.6 & 2.7 & 2.6 & 2.9 & 3.3 \\
\hline Tajikistan & 5.8 & 5.5 & 3.9 & 5.1 & 4.3 & 3.5 & 4.5 & 4.8 & \\
\hline Turkmenistan & 4.3 & 11.8 & 7.5 & 8.2 & 8.3 & 4.6 & 4.4 & 4.7 & 4.5 \\
\hline Uzbekistan & 2.6 & 5.7 & 4.3 & 5.9 & 5.4 & 5.6 & 4.3 & 2.7 & 3.3 \\
\hline \multicolumn{10}{|l|}{ East Asia } \\
\hline China, People's Republic of & 7.7 & 10.7 & 10.1 & 7.3 & 6.7 & 6.4 & 6.1 & 6.2 & 6.2 \\
\hline Hong Kong, China & 6.8 & 6.9 & 6.0 & 2.7 & 2.1 & 1.5 & 1.6 & 3.0 & 2.2 \\
\hline Korea, Republic of & & 4.1 & 6.3 & 2.7 & 2.6 & 2.3 & 2.4 & 2.8 & 2.3 \\
\hline Mongolia & -0.2 & 6.1 & $15.3(2011)$ & 9.4 & 5.6 & 0.2 & -0.8 & 3.3 & 4.9 \\
\hline Taipei,China & 5.6 & 5.0 & 10.3 & 2.0 & 3.8 & 0.6 & 1.3 & 2.9 & 2.5 \\
\hline \multicolumn{10}{|l|}{ South Asia } \\
\hline Bangladesh & 4.5 & 4.5 & 4.2 & 4.6 & 4.6 & 5.1 & 5.8 & 6.0 & 6.6 \\
\hline Bhutan & 5.6 & 5.7 & 9.7 & 0.4 & 4.0 & 5.0 & 6.4 & 3.3 & \\
\hline India & 2.0 & 7.7 & 8.8 & 5.1 & 6.1 & 6.7 & 6.9 & 5.8 & 5.5 \\
\hline Maldives & 2.3 & -15.9 & 4.9 & 4.4 & 5.2 & -0.9 & 3.2 & 2.7 & 1.8 \\
\hline Nepal & 2.9 & 1.2 & 3.4 & 2.7 & 4.5 & 1.9 & -0.8 & 6.8 & 5.2 \\
\hline Sri Lanka & 4.6 & 5.3 & 7.0 & 2.6 & 4.0 & 4.0 & 3.3 & 2.2 & 2.1 \\
\hline \multicolumn{10}{|l|}{ Southeast Asia } \\
\hline Brunei Darussalam & 0.3 & -1.3 & $2.0(2011)$ & -3.2 & -3.5 & -1.6 & -3.6 & -1.5 & -2.9 \\
\hline Cambodia & 9.2 & 11.7 & 4.6 & 6.0 & 5.8 & 5.7 & 5.7 & 5.7 & 6.1 \\
\hline Indonesia & 3.7 & 4.3 & 3.4 & 4.1 & 3.6 & 3.5 & 3.7 & 3.7 & 3.8 \\
\hline Lao People's Democratic Republic & 4.2 & 4.7 & 6.6 & 6.5 & 6.1 & 5.7 & 5.5 & 5.3 & 4.8 \\
\hline Malaysia & 6.2 & 3.2 & 5.5 & 2.3 & 4.3 & 3.5 & 3.0 & 4.5 & 3.6 \\
\hline Myanmar & 12.4 & 12.6 & 8.9 & 7.5 & 7.0 & 6.1 & 4.9 & 5.8 & \\
\hline Philippines & 2.0 & 2.8 & 5.2 & 5.3 & 4.4 & 4.3 & 5.2 & 5.0 & 4.5 \\
\hline Singapore & 7.2 & 4.8 & 12.5 & 3.2 & 2.6 & 1.7 & 1.6 & 3.6 & 2.6 \\
\hline Thailand & 3.6 & 3.3 & 6.6 & 2.3 & 0.6 & 2.8 & 3.0 & 3.7 & 3.9 \\
\hline Viet Nam & 5.3 & 6.3 & 5.3 & 4.3 & 4.9 & 5.5 & 5.1 & 5.7 & 6.0 \\
\hline \multicolumn{10}{|l|}{ The Pacific } \\
\hline Cook Islands & 4.4 & -6.7 & -7.5 & 3.4 & 7.3 & 4.0 & & $\ldots$ & 11.7 \\
\hline Fiji & -2.3 & -2.0 & 2.3 & 4.2 & 5.2 & 4.2 & 2.2 & 4.6 & 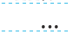 \\
\hline Kiribati & 3.5 & $-2.2(2006)$ & -3.0 & 2.8 & -2.0 & 8.9 & 3.7 & -1.0 & \\
\hline Marshall Islands & 5.2 & 2.1 & 5.8 & 2.4 & -1.1 & -1.0 & 1.4 & 4.2 & \\
\hline Micronesia, Federated States of & 4.6 & 2.3 & 2.6 & -3.8 & -2.2 & 4.8 & 0.6 & 2.4 & \\
\hline Nauru & $\ldots$ & 1.6 & 11.4 & 28.0 & 34.2 & 1.1 & $\ldots$ & 2.4 & -5.5 \\
\hline Niue & $3.9(2001)$ & & & $\ldots$ & & $\ldots$ & & 1.3 & \\
\hline Palau & $4.9(2001)$ & 3.2 & 2.2 & -0.2 & 4.7 & 8.1 & -0.3 & -3.7 & 3.8 \\
\hline Papua New Guinea & -5.5 & 0.8 & 6.8 & 0.7 & 10.1 & 6.2 & 0.9 & -2.0 & -2.8 \\
\hline Samoa & 7.6 & 4.2 & 1.6 & 0.0 & 1.9 & 6.0 & 2.4 & -0.8 & -0.1 \\
\hline Solomon Islands & -16.2 & 4.9 & & 0.4 & -0.5 & 0.3 & 1.2 & & \\
\hline Timor-Leste & $6.6(2001)$ & 31.9 & -2.7 & -13.2 & -27.6 & 17.9 & -1.5 & -11.1 & \\
\hline Tonga & -0.8 & 1.6 & 3.3 & -3.1 & 1.9 & 3.1 & 4.8 & 5.4 & 0.2 \\
\hline Tuvalu & $1.1(2001)$ & -7.0 & -3.8 & 3.7 & -0.0 & 7.9 & 4.6 & 4.7 & $\ldots$ \\
\hline Vanuatu & 3.5 & 2.9 & -0.8 & -0.3 & 0.0 & -2.1 & 2.0 & 2.2 & \\
\hline \multicolumn{10}{|l|}{ Developed ADB Member Economies } \\
\hline Australia & 2.8 & 2.0 & 0.5 & 0.9 & 1.0 & 0.9 & 1.3 & 0.6 & 1.2 \\
\hline Japan & 2.6 & 1.7 & 4.2 & 2.1 & 0.5 & 1.3 & 0.7 & 2.1 & 1.0 \\
\hline New Zealand & 2.3 & 2.2 & 0.4 & 1.8 & 2.2 & 1.6 & 1.5 & 1.0 & 0.8 \\
\hline
\end{tabular}

$\ldots=$ data not available, -0.0 or $0.0=$ magnitude is less than half of unit employed, $A D B=$ Asian Development Bank.

Source: $\quad$ Asian Development Bank estimates using economy sources. 
Table 2.2.13: Growth Rates of Agriculture Real Value Added $(\%)$

\begin{tabular}{|c|c|c|c|c|c|c|c|c|c|}
\hline ADB Regional Member & 2000 & 2005 & 2010 & 2013 & 2014 & 2015 & 2016 & 2017 & 2018 \\
\hline \multirow{2}{*}{\multicolumn{10}{|c|}{$\begin{array}{l}\text { Developing ADB Member Economies } \\
\text { Central and West Asia }\end{array}$}} \\
\hline & \multicolumn{9}{|c|}{ Central and West Asia } \\
\hline Afghanistan & & 12.2 & -18.0 & 8.3 & 3.7 & -16.9 & 12.4 & 21.4 & -10.3 \\
\hline Armenia & -1.0 & 11.2 & -16.0 & 7.6 & 6.1 & 13.2 & -5.0 & -5.1 & -8.5 \\
\hline Azerbaijan & 12.1 & 6.7 & -4.7 & 4.9 & -2.6 & 6.6 & 2.6 & 4.2 & 4.6 \\
\hline Georgia & -12.0 & 11.7 & -4.2 & 11.3 & 1.6 & 1.5 & 0.3 & -3.8 & 0.7 \\
\hline Kazakhstan & -3.2 & 7.1 & -12.9 & 11.2 & 1.3 & 3.5 & 5.4 & 2.8 & \\
\hline Kyrgyz Republic & 2.6 & -4.2 & -2.6 & 2.7 & -0.5 & 6.2 & 2.9 & 2.2 & 2.7 \\
\hline Pakistan & $-0.7(2001)$ & 7.0 & 0.2 & 2.7 & 2.5 & 2.1 & 0.2 & 2.1 & 3.8 \\
\hline Tajikistan & $8.0(2001)$ & 2.8 & 6.8 & 7.7 & 9.2 & 3.4 & 5.2 & 7.6 & $\ldots$ \\
\hline Turkmenistan & -2.6 & 14.1 & 17.7 & 9.9 & 1.7 & $\ldots$ & & $\ldots$ & \\
\hline Uzbekistan & 3.2 & 5.9 & 6.1 & 6.4 & 6.0 & 6.1 & 6.2 & 1.2 & 0.3 \\
\hline \multicolumn{10}{|l|}{ East Asia } \\
\hline China, People's Republic of & 2.3 & 5.1 & 4.3 & 3.8 & 4.1 & 3.9 & 3.3 & 4.0 & 3.5 \\
\hline Hong Kong, China ${ }^{\mathrm{a}}$ & $0.3(2001)$ & -0.2 & 3.9 & 4.9 & -6.0 & -6.8 & -2.0 & -5.2 & -1.5 \\
\hline Korea, Republic of & $0.4(2001)$ & 0.6 & -3.6 & 4.2 & 5.1 & -0.2 & -5.6 & 2.3 & 1.5 \\
\hline Mongolia & -16.3 & 11.3 & & 19.2 & 13.7 & 10.7 & 6.2 & 1.8 & 4.5 \\
\hline Taipei,China & 1.8 & -3.9 & 2.3 & 1.4 & 1.6 & -8.4 & -10.1 & 8.4 & 2.0 \\
\hline \multicolumn{10}{|l|}{ South Asia } \\
\hline Bangladesh & 7.4 & 2.2 & 6.2 & 2.5 & 4.4 & 3.3 & 2.8 & 3.0 & 4.2 \\
\hline Bhutan & 5.4 & 1.1 & 0.9 & 2.4 & 2.4 & 4.9 & 3.9 & 3.4 & \\
\hline India & -0.0 & 5.1 & 8.6 & 5.6 & -0.2 & 0.6 & 6.3 & 5.0 & 2.9 \\
\hline Maldives & -0.8 & 11.4 & -3.5 & 6.9 & -0.3 & -0.4 & 1.5 & 8.2 & 5.8 \\
\hline Nepal & 4.9 & 3.5 & 2.0 & 1.1 & 4.5 & 1.1 & 0.2 & 5.2 & 2.8 \\
\hline Sri Lanka & 2.3 & 1.8 & 7.0 & 3.2 & 4.6 & 4.7 & -3.7 & -0.4 & 4.8 \\
\hline \multicolumn{10}{|l|}{ Southeast Asia } \\
\hline Brunei Darussalam & 6.6 & 1.3 & $-2.6(2011)$ & -1.2 & 4.7 & 6.4 & -3.6 & -1.6 & -1.6 \\
\hline Cambodia & 2.5 & 15.7 & 4.0 & 1.6 & 0.3 & 0.2 & 1.3 & 1.7 & 1.2 \\
\hline Indonesia & 1.9 & 2.7 & 3.0 & 4.2 & 4.2 & 3.8 & 3.4 & 3.9 & 3.9 \\
\hline Lao People's Democratic Republic & 4.2 & 0.7 & 3.2 & 2.8 & 4.1 & 3.6 & 2.8 & 2.9 & 1.3 \\
\hline Malaysia & 6.1 & 2.6 & 2.4 & 2.0 & 2.0 & 1.4 & -3.7 & 5.7 & 0.1 \\
\hline Myanmar & 11.0 & 12.1 & 4.7 & 3.6 & 2.8 & 3.4 & -0.5 & 1.3 & \\
\hline Philippines & 3.4 & 2.2 & -0.2 & 1.2 & 1.7 & 0.1 & -1.2 & 4.0 & 0.9 \\
\hline Singapore ${ }^{\mathrm{a}}$ & -6.0 & 6.9 & 2.7 & 3.5 & 3.3 & -0.5 & -0.5 & -11.3 & -1.4 \\
\hline Thailand & 6.8 & -0.1 & -0.5 & 0.7 & -0.3 & -6.5 & -1.3 & 3.7 & 5.1 \\
\hline Viet Nam & 4.6 & 4.2 & 0.5 & 2.6 & 3.4 & 2.4 & 1.4 & 2.9 & 3.8 \\
\hline \multicolumn{10}{|l|}{ The Pacific } \\
\hline Cook Islands & 0.1 & -3.5 & 1.9 & 3.9 & 8.5 & -1.5 & 3.5 & -13.9 & -4.0 \\
\hline Fiji & -1.2 & 0.9 & -2.6 & 6.7 & 1.9 & 2.9 & -10.8 & 8.3 & $\ldots$ \\
\hline Kiribati & -7.2 & $10.4(2006)$ & -3.9 & -0.7 & 5.9 & 1.3 & 10.7 & 9.0 & \\
\hline Marshall Islands & 22.6 & -9.2 & 28.4 & 3.4 & -1.5 & 0.5 & -2.4 & 5.3 & \\
\hline Micronesia, Federated States of & 7.1 & 4.4 & -3.9 & -6.4 & 6.0 & 10.7 & -7.3 & $\ldots$ & \\
\hline Nauru & $\ldots$ & 0.3 & 3.7 & 5.3 & 9.5 & 5.2 & & 1.6 & \\
\hline Niue & & 8.6 & -0.4 & 7.0 & 0.2 & 2.0 & 1.2 & 3.5 & 1.7 \\
\hline Palau & $0.6(2001)$ & 4.3 & -5.0 & 2.8 & -5.9 & -3.7 & 7.8 & 8.4 & -5.2 \\
\hline Papua New Guinea & 2.1 & 5.6 & 2.8 & 4.7 & 3.4 & -2.6 & 2.7 & 7.5 & 3.3 \\
\hline Samoa & 8.1 & 2.4 & -9.0 & 6.4 & 0.7 & 1.9 & 7.1 & 7.1 & -12.4 \\
\hline Solomon Islands & -17.1 & -1.5 & 14.8 & -1.3 & 5.8 & 2.5 & 5.8 & $\ldots$ & \\
\hline Timor-Leste & $-1.0(2001)$ & 2.2 & 4.2 & -5.4 & -3.6 & -5.2 & -1.3 & -3.2 & \\
\hline Tonga & -2.5 & -2.1 & 0.5 & 3.7 & 3.1 & -2.7 & 0.5 & 1.3 & -1.0 \\
\hline Tuvalu & $-2.2(2001)$ & -1.1 & 12.8 & -2.7 & -0.5 & -1.8 & 2.9 & 0.8 & \\
\hline Vanuatu & 4.3 & 2.3 & 4.8 & 4.8 & 4.2 & -15.8 & 5.1 & 0.4 & \\
\hline \multicolumn{10}{|l|}{ Developed ADB Member Economies } \\
\hline Australia & 6.7 & 4.3 & -0.7 & -0.7 & 1.1 & 1.4 & -7.9 & 9.6 & -5.1 \\
\hline Japan & 7.3 & -0.0 & -5.8 & 0.3 & -3.1 & -4.5 & -7.6 & -1.7 & \\
\hline New Zealand & 3.6 & 5.2 & -7.9 & -2.6 & 5.5 & 2.6 & 1.3 & 1.0 & 3.1 \\
\hline
\end{tabular}

$\ldots$ = data not available, $-0.0=$ magnitude is less than half of unit employed, $\mathrm{ADB}=$ Asian Development Bank.

a Refers to other goods industries comprising agriculture, forestry, and fishing; and mining and quarrying.

Source: Economy sources. 
Table 2.2.14: Growth Rates of Industry Real Value Added

(\%)

\begin{tabular}{|c|c|c|c|c|c|c|c|c|c|}
\hline ADB Regional Member & 2000 & 2005 & 2010 & 2013 & 2014 & 2015 & 2016 & 2017 & 2018 \\
\hline \multirow{2}{*}{\multicolumn{10}{|c|}{ Developing ADB Member Economies }} \\
\hline & \\
\hline Afghanistan & & 13.0 & 6.3 & 4.5 & 2.4 & 4.5 & -1.8 & 0.9 & 7.6 \\
\hline Armenia & 12.8 & 14.8 & 5.7 & 0.5 & -2.3 & 2.8 & -0.3 & 9.0 & 4.4 \\
\hline Azerbaijan & 5.7 & 43.6 & 3.7 & 4.3 & 0.4 & -3.4 & -5.7 & -3.6 & -0.7 \\
\hline Georgia & 4.9 & 9.6 & 8.2 & 2.4 & 4.6 & 4.1 & 6.2 & 6.5 & 1.0 \\
\hline Kazakhstan & 15.3 & 10.7 & 9.5 & 3.1 & 1.5 & -0.4 & 1.1 & 6.3 & \\
\hline Kyrgyz Republic & 8.8 & -9.8 & 2.5 & 30.2 & 5.7 & 2.9 & 7.1 & 8.6 & 6.2 \\
\hline Pakistan & $5.8(2001)$ & 6.5 & 3.4 & 0.8 & 4.5 & 5.2 & 5.7 & 5.4 & 5.8 \\
\hline Tajikistan & $15.6(2001)$ & 7.7 & 5.6 & 4.0 & 14.9 & 16.3 & 22.2 & 7.3 & \\
\hline Turkmenistan & 1.0 & 10.6 & 6.0 & 8.0 & 11.6 & & & & \\
\hline Uzbekistan & 1.8 & 5.3 & 5.5 & 9.8 & 7.4 & 8.3 & 5.9 & 5.4 & 10.5 \\
\hline \multicolumn{10}{|l|}{ East Asia } \\
\hline China, People's Republic of & 9.5 & 12.1 & 12.7 & 8.0 & 7.4 & 6.2 & 6.3 & 5.9 & 5.8 \\
\hline Hong Kong, China ${ }^{a}$ & $-3.8(2001)$ & -1.4 & 7.7 & 1.5 & 7.4 & 2.4 & 3.0 & -0.7 & 0.3 \\
\hline Korea, Republic of & $3.5(2001)$ & 4.4 & 9.6 & 2.8 & 2.9 & 2.4 & 3.1 & 4.2 & 2.2 \\
\hline Mongolia & 1.5 & 4.2 & $8.8(2011)$ & 14.6 & 12.7 & 9.9 & -0.4 & 0.7 & 5.8 \\
\hline Taipei,China ${ }^{\mathrm{a}}$ & 7.1 & 7.6 & 20.8 & 1.7 & 7.2 & -0.5 & 2.8 & 4.6 & 3.3 \\
\hline \multicolumn{10}{|l|}{ South Asia } \\
\hline Bangladesh & 6.2 & 8.3 & 7.0 & 9.6 & 8.2 & 9.7 & 11.1 & 10.2 & 12.1 \\
\hline Bhutan & 7.3 & 3.8 & 12.5 & 3.9 & 3.7 & 8.2 & 6.9 & 2.4 & \\
\hline India & 6.0 & 9.7 & 7.6 & 3.8 & 7.0 & 9.6 & 7.7 & 5.9 & 6.9 \\
\hline Maldives & -3.8 & 14.3 & 7.3 & -6.0 & 16.2 & 18.1 & 12.3 & 10.9 & 9.8 \\
\hline Nepal & 8.6 & 3.0 & 4.0 & 2.7 & 7.1 & 1.4 & -6.4 & 12.4 & 9.6 \\
\hline Sri Lanka & 9.0 & 8.0 & 8.4 & 4.1 & 4.7 & 2.2 & 5.7 & 4.1 & 0.9 \\
\hline \multicolumn{10}{|l|}{ Southeast Asia } \\
\hline Brunei Darussalam & 3.0 & -1.8 & $3.2(2011)$ & -5.6 & -4.4 & -0.0 & -2.9 & 1.5 & -0.4 \\
\hline Cambodia & 31.2 & 12.7 & 13.6 & 10.7 & 10.1 & 11.7 & 10.9 & 9.8 & 11.6 \\
\hline Indonesia & 5.9 & 4.7 & 4.9 & 4.3 & 4.2 & 3.0 & 3.8 & 4.1 & 4.3 \\
\hline Lao People's Democratic Republic & 9.3 & 10.6 & 17.5 & 7.7 & 7.3 & 7.0 & 12.0 & 11.6 & 7.8 \\
\hline Malaysia & 13.6 & 3.6 & 8.4 & 3.6 & 5.9 & 5.2 & 4.3 & 4.7 & 3.2 \\
\hline Myanmar & 21.3 & 19.9 & 18.6 & 11.4 & 12.1 & 8.3 & 8.9 & 9.4 & \\
\hline Philippines & 6.5 & 4.2 & 11.6 & 9.2 & 7.8 & 6.4 & 8.0 & 7.1 & 6.7 \\
\hline Singapore ${ }^{a, b}$ & 11.1 & 7.9 & 24.0 & 1.9 & 3.7 & -2.7 & 2.7 & 5.6 & 4.9 \\
\hline Thailand $\mathrm{d}^{\mathrm{a}, \mathrm{c}}$ & 4.0 & 4.9 & 10.6 & 1.7 & 0.1 & 1.9 & 2.2 & 2.2 & 2.7 \\
\hline Viet Nam & 10.1 & 8.4 & -9.9 & 5.1 & 6.4 & 9.6 & 7.6 & 8.0 & 8.9 \\
\hline \multicolumn{10}{|l|}{ The Pacific } \\
\hline Cook Islands & 18.2 & -6.3 & -8.4 & -6.3 & -13.5 & -10.2 & 8.1 & 24.2 & 7.0 \\
\hline Fiji & -5.5 & -6.7 & 6.5 & 4.4 & 1.2 & 6.9 & 7.6 & 4.4 & $\ldots$ \\
\hline Kiribati & -6.4 & $15.0(2006)$ & 9.5 & 16.0 & -2.6 & 23.6 & -2.4 & -15.8 & $\ldots$ \\
\hline Marshall Islands & -14.6 & 10.1 & 0.1 & 5.8 & -12.9 & -4.0 & 16.3 & 13.2 & 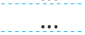 \\
\hline Micronesia, Federated States of & 6.6 & -2.9 & 18.0 & -19.5 & -29.0 & -6.1 & 6.9 & & $\ldots$ \\
\hline Nauru & $\ldots$ & 16.1 & 39.4 & -28.5 & -3.6 & -17.1 & & 3.1 & \\
\hline Niue & & 81.4 & 14.4 & 9.7 & 6.1 & 0.9 & 2.3 & -4.7 & 90.4 \\
\hline Palau & $29.5(2001)$ & 7.0 & 5.2 & -11.8 & 3.1 & 30.3 & 13.1 & -8.4 & 3.0 \\
\hline Papua New Guinea & -0.8 & 4.1 & 12.0 & 2.0 & 39.1 & 35.3 & 8.1 & -2.5 & -4.2 \\
\hline Samoa & 14.4 & 4.7 & 7.7 & -2.0 & 1.6 & 8.7 & -2.6 & -9.7 & -5.3 \\
\hline Solomon Islands & -29.7 & -3.1 & 15.4 & -2.0 & -13.0 & -5.0 & 0.9 & & $\ldots$ \\
\hline Timor-Leste & $-14.3(2001)$ & 73.9 & -6.3 & -14.8 & -44.5 & 41.7 & -1.1 & -17.3 & \\
\hline Tonga & -0.4 & -2.8 & 11.6 & -14.5 & 1.6 & 7.9 & 9.5 & 10.8 & -5.8 \\
\hline Tuvalu & $5.0(2001)$ & -18.2 & -41.6 & 40.5 & -5.8 & 36.7 & 20.2 & 21.1 & \\
\hline Vanuatu & 46.4 & 5.3 & 12.6 & 9.8 & 3.2 & 35.3 & 4.3 & 7.1 & \\
\hline \multicolumn{10}{|l|}{ Developed ADB Member Economies } \\
\hline Australia & $\ldots$ & $\ldots$ & $\ldots$ & $\ldots$ & $\ldots$ & $\ldots$ & $\ldots$ & $\ldots$ & $\ldots$ \\
\hline Japana & $\ldots$ & $\ldots$ & $\ldots$ & $\ldots$ & $\ldots$ & $\ldots$ & $\ldots$ & $\ldots$ & $\ldots$ \\
\hline New Zealand ${ }^{a}$ & $\ldots$ & $\ldots$ & $\cdots$ & $\ldots$ & $\ldots$ & $\ldots$ & $\ldots$ & $\ldots$ & $\ldots$ \\
\hline \multicolumn{10}{|c|}{$\ldots=$ data not available, $-0.0=$ magnitude is less than half of unit employed, $A D B=$ Asian Development Bank. } \\
\hline \multirow{2}{*}{\multicolumn{10}{|c|}{$\begin{array}{l}\text { a National accounts are compiled using chain volume measures. } \\
\text { b Industry refers to manufacturing, construction, and utilities. }\end{array}$}} \\
\hline & & \multicolumn{8}{|c|}{ b Industry refers to manufacturing, construction, and utilities. } \\
\hline \multicolumn{10}{|c|}{$\begin{array}{l}\text { c Industry refers to mining and quarrying; manufacturing; electricity, gas, steam, and air-conditioningsupply; water supply; and sewerage, waste management, and remediation } \\
\text { activities. }\end{array}$} \\
\hline
\end{tabular}


Table 2.2.15: Growth Rates of Services Real Value Added

(\%)

\begin{tabular}{|c|c|c|c|c|c|c|c|c|c|}
\hline ADB Regional Member & 2000 & 2005 & 2010 & 2013 & 2014 & 2015 & 2016 & 2017 & 2018 \\
\hline \multicolumn{10}{|l|}{ Developing ADB Member Economies } \\
\hline \multicolumn{10}{|l|}{ Central and West Asia } \\
\hline Afghanistan & & 5.4 & 18.1 & 6.4 & 4.0 & 1.4 & 2.3 & 3.3 & 1.2 \\
\hline Armenia & 3.1 & 14.7 & 4.7 & 2.8 & 6.7 & 1.0 & 3.4 & 10.4 & 9.4 \\
\hline Azerbaijan & 9.6 & 9.6 & 8.8 & 8.6 & 7.6 & 6.8 & -0.8 & 3.5 & 3.2 \\
\hline Georgia & 5.5 & 6.5 & 8.2 & 3.6 & 4.5 & 3.0 & 2.1 & 5.0 & 6.6 \\
\hline Kazakhstan & 8.4 & 10.4 & 6.0 & 6.9 & 5.7 & 3.1 & 0.9 & 2.7 & \\
\hline Kyrgyz Republic & 5.8 & 8.4 & -1.3 & 4.8 & 4.5 & 3.5 & 3.2 & 3.3 & 2.1 \\
\hline Pakistan & $5.1(2001)$ & 8.1 & 3.2 & 5.1 & 4.5 & 4.4 & 5.7 & 6.5 & 6.4 \\
\hline Tajikistan & $3.9(2001)$ & 7.7 & 7.1 & 9.4 & 1.7 & 1.9 & -1.5 & 6.2 & $\ldots$ \\
\hline Turkmenistan & 18.0 & 27.1 & 13.8 & -9.2 & -13.2 & & $\ldots$ & $\ldots$ & $\ldots$ \\
\hline Uzbekistan & 5.4 & 7.6 & 10.6 & 7.5 & 8.3 & 8.3 & 6.3 & 6.4 & 5.4 \\
\hline \multicolumn{10}{|l|}{ East Asia } \\
\hline China, People's Republic of & 9.8 & 12.4 & 9.7 & 8.3 & 7.8 & 8.2 & 7.7 & 7.9 & 7.6 \\
\hline Hong Kong, China ${ }^{\mathrm{a}}$ & $1.8(2001)$ & 7.8 & 6.9 & 2.7 & 2.5 & 1.7 & 2.3 & 3.6 & 3.4 \\
\hline Korea, Republic of a & $5.6(2001)$ & 4.1 & 4.6 & 3.0 & 2.7 & 2.7 & 3.1 & 2.7 & 3.4 \\
\hline Mongolia & 10.5 & 9.7 & $17.8(2011)$ & 7.8 & 7.8 & 0.6 & 1.1 & 7.7 & 5.5 \\
\hline Taipei,China $^{\mathrm{a}}$ & 6.5 & 4.1 & 6.3 & 2.3 & 3.3 & 1.2 & 1.3 & 2.5 & 2.6 \\
\hline \multicolumn{10}{|l|}{ South Asia } \\
\hline Bangladesh & 5.5 & 6.4 & 5.5 & 5.5 & 5.6 & 5.8 & 6.3 & 6.7 & 6.4 \\
\hline Bhutan & 8.7 & 14.8 & 12.1 & 1.6 & 8.2 & 8.5 & 9.8 & 6.7 & $\ldots$ \\
\hline India & 5.1 & 10.9 & 9.7 & 7.7 & 9.8 & 9.4 & 8.4 & 8.1 & 7.5 \\
\hline Maldives & 5.1 & -17.7 & 7.3 & 8.8 & 7.0 & 2.4 & 6.7 & 5.2 & 4.7 \\
\hline Nepal & 5.9 & 3.3 & 5.8 & 5.7 & 6.2 & 4.6 & 2.4 & 8.1 & 7.2 \\
\hline Sri Lanka & 6.1 & 6.4 & 8.0 & 3.8 & 4.8 & 6.0 & 4.8 & 3.6 & 4.7 \\
\hline \multicolumn{10}{|l|}{ Southeast Asia } \\
\hline Brunei Darussalam & 2.5 & 4.1 & $4.9(2011)$ & 4.7 & 0.6 & -1.1 & -1.7 & 1.1 & 0.8 \\
\hline Cambodia & 8.9 & 13.1 & 3.3 & 8.7 & 8.7 & 7.1 & 6.8 & 7.0 & 6.7 \\
\hline Indonesia & 5.2 & 7.9 & 8.4 & 6.4 & 6.0 & 5.5 & 5.7 & 5.7 & 5.8 \\
\hline Lao People's Democratic Republic & 6.9 & 10.8 & 7.6 & 9.7 & 8.1 & 8.0 & 4.7 & 4.4 & 6.9 \\
\hline Malaysia & 6.0 & 7.3 & 7.4 & 6.0 & 6.8 & 5.3 & 5.7 & 6.4 & 6.9 \\
\hline Myanmar & 13.4 & 13.1 & 9.5 & 10.3 & 9.1 & 8.7 & 8.1 & 8.3 & $\ldots$ \\
\hline Philippines & 3.3 & 5.8 & 7.2 & 7.0 & 6.0 & 6.9 & 7.5 & 6.9 & 6.8 \\
\hline Singapore ${ }^{a, b}$ & 7.9 & 6.9 & 10.9 & 6.5 & 4.2 & 4.1 & 2.3 & 2.9 & 3.0 \\
\hline Thailand $\mathrm{a}, \mathrm{c}$ & 4.4 & 4.5 & 6.9 & 3.7 & 1.8 & 5.6 & 4.7 & 5.1 & 4.8 \\
\hline Viet Nam & 5.3 & 8.6 & -7.7 & 6.7 & 6.2 & 6.3 & 7.0 & 7.4 & 7.0 \\
\hline \multicolumn{10}{|l|}{ The Pacific } \\
\hline Cook Islands & 15.4 & -0.3 & -2.6 & -0.6 & 7.6 & 5.4 & 6.6 & 0.6 & 4.0 \\
\hline Fiji & 0.8 & -17.0 & 2.9 & 4.5 & 7.4 & 3.3 & 0.3 & 3.6 & $\ldots$ \\
\hline Kiribati & 1.7 & $0.9(2006)$ & -0.1 & 2.6 & -0.3 & 7.2 & 6.6 & 3.3 & $\ldots$ \\
\hline Marshall Islands & 6.8 & 3.5 & 3.6 & 1.7 & 2.1 & 1.1 & 0.9 & 3.4 & $\ldots$ \\
\hline Micronesia, Federated States of & 3.3 & 0.7 & 2.4 & -0.8 & -1.2 & 3.0 & 2.3 & & $\ldots$ \\
\hline Nauru & $\ldots$ & -2.1 & 4.2 & 60.7 & 41.9 & 11.6 & $\ldots$ & 3.9 & $\ldots$ \\
\hline Niue & $\ldots$ & 0.8 & 0.4 & 5.7 & 5.2 & 4.6 & 4.2 & 2.4 & 4.7 \\
\hline Palau & $2.6(2001)$ & 2.4 & -0.5 & -0.4 & 5.7 & 8.6 & -0.7 & -2.8 & 2.9 \\
\hline Papua New Guinea & -12.7 & 3.6 & 12.4 & 4.3 & 0.9 & -2.3 & 2.3 & 1.5 & 3.8 \\
\hline Samoa & 6.2 & 5.2 & 3.0 & 0.7 & 3.2 & 6.9 & 4.8 & 0.4 & 3.8 \\
\hline Solomon Islands & -5.7 & 19.4 & 6.4 & 7.6 & 3.9 & 5.0 & 3.3 & & $\ldots$ \\
\hline Timor-Leste & $42.2(2001)$ & 4.3 & 13.7 & 1.3 & 7.8 & 4.7 & 5.7 & 2.7 & $\ldots$ \\
\hline Tonga & 0.0 & 3.6 & 1.0 & -0.5 & 1.4 & 2.7 & 5.7 & 4.0 & 2.7 \\
\hline Tuvalu & $-0.5(2001)$ & -4.9 & 2.3 & 0.0 & 2.4 & 7.1 & 2.0 & 3.2 & $\ldots$ \\
\hline Vanuatu & 2.2 & 6.6 & 3.0 & 0.1 & 2.4 & 2.0 & 2.9 & 2.9 & $\ldots$ \\
\hline \multicolumn{10}{|l|}{ Developed ADB Member Economies } \\
\hline Australia & $\ldots$ & $\ldots$ & $\ldots$ & $\ldots$ & $\ldots$ & $\ldots$ & $\ldots$ & $\ldots$ & $\ldots$ \\
\hline Japan & $\ldots$ & $\ldots$ & $\ldots$ & $\ldots$ & $\ldots$ & $\ldots$ & $\ldots$ & $\ldots$ & $\ldots$ \\
\hline New Zealand ${ }^{\mathrm{a}}$ & $\ldots$ & $\ldots$ & $\cdots$ & $\cdots$ & $\ldots$ & $\ldots$ & $\ldots$ & $\ldots$ & $\ldots$ \\
\hline \multicolumn{10}{|c|}{$\ldots=$ data not available, $0.0=$ magnitude is less than half of unit employed, $\mathrm{ADB}=$ Asian Development Bank. } \\
\hline \multicolumn{10}{|c|}{ a National accounts are compiled using chain volume measures. } \\
\hline \multicolumn{10}{|c|}{ b Services refers to services-producing industries, including ownership of dwellings. } \\
\hline \multicolumn{10}{|l|}{ c Services includes construction. } \\
\hline
\end{tabular}


Table 2.2.16: Growth Rates of Real Household Final Consumption

(\%)

\begin{tabular}{|c|c|c|c|c|c|c|c|c|c|}
\hline ADB Regional Member & 2000 & 2005 & 2010 & 2013 & 2014 & 2015 & 2016 & 2017 & 2018 \\
\hline \multicolumn{10}{|l|}{ Developing ADB Member Economies } \\
\hline \multicolumn{10}{|l|}{ Central and West Asia } \\
\hline \multicolumn{10}{|l|}{ Afghanistan } \\
\hline Armenia & 8.3 & 8.8 & 3.9 & 0.9 & 1.0 & -7.7 & -1.0 & 12.4 & 4.8 \\
\hline Azerbaijana & 10.0 & 13.2 & 10.8 & 8.6 & 8.1 & 8.5 & 1.7 & 0.9 & $\ldots$ \\
\hline Georgia $^{\mathrm{a}}$ & $\ldots$ & & $6.7(2011)$ & -0.1 & 3.2 & 0.1 & -0.6 & 1.3 & \\
\hline Kazakhstan & 1.2 & 10.7 & 11.5 & 18.7 & 1.1 & 1.8 & 1.2 & 1.2 & 5.3 \\
\hline Kyrgyz Republic ${ }^{\mathrm{a}}$ & -5.0 & 8.3 & 2.7 & 8.0 & 3.0 & -0.9 & -0.6 & 6.3 & 3.7 \\
\hline Pakistan ${ }^{\mathrm{a}}$ & $3.5(2001)$ & 10.8 & 2.2 & 2.1 & 5.6 & 2.9 & 7.6 & 8.7 & 6.3 \\
\hline Tajikistan ${ }^{\mathrm{a}}$ & $8.6(2001)$ & 20.6 & 10.5 & 9.3 & 1.8 & -15.1 & 6.4 & - & $\ldots$ \\
\hline Turkmenistan & -48.3 & -15.2 & -61.3 & & & & & & \\
\hline Uzbekistan & & - & 51.7 & 10.1 & 10.7 & 11.9 & 9.4 & 3.9 & 4.4 \\
\hline \multicolumn{10}{|l|}{ East Asia } \\
\hline China, People's Republic of & $\ldots$ & 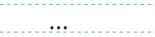 & 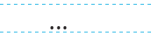 & $\ldots$ & $\cdots$ & $\ldots$ & $\ldots$ & $\ldots$ & \\
\hline Hong Kong, China ${ }^{\mathrm{a}}$ & 4.5 & 3.5 & 6.1 & 4.6 & 3.3 & 4.8 & 2.0 & 5.6 & 5.5 \\
\hline Korea, Republic of & $5.8(2001)$ & 4.7 & 4.6 & 1.3 & 2.0 & 2.2 & 2.3 & 2.8 & 2.7 \\
\hline Mongolia & 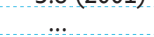 & $12.4(2006)$ & $15.8(2011)$ & 15.4 & 6.3 & 8.1 & -2.6 & 5.5 & -1.8 \\
\hline Taipei,China & 5.1 & 3.3 & 3.8 & 2.4 & 3.2 & 2.9 & 2.4 & 2.6 & $\ldots$ \\
\hline \multicolumn{10}{|l|}{ South Asia } \\
\hline Bangladesh & 4.1 & 3.9 & 4.6 & 5.1 & 4.0 & 5.8 & 3.0 & 7.4 & 11.0 \\
\hline Bhutan ${ }^{\mathrm{a}}$ & 0.4 & 1.3 & 5.5 & 58.0 & -6.4 & 12.6 & -5.6 & 5.1 & \\
\hline India ${ }^{a}$ & 3.4 & 8.6 & 8.7 & 7.3 & 6.4 & 7.9 & 8.2 & 7.4 & 8.1 \\
\hline \multicolumn{10}{|l|}{ Maldives } \\
\hline Nepala & $\ldots$ & 4.7 & 6.2 & 2.7 & 4.2 & 2.9 & -0.7 & 2.6 & 2.5 \\
\hline Sri Lanka & 4.0 & 1.7 & $9.9(2011)$ & 7.8 & 3.7 & 7.5 & 7.4 & 2.5 & 2.3 \\
\hline \multicolumn{10}{|l|}{ Southeast Asia } \\
\hline Brunei Darussalama & -7.0 & -0.6 & $5.4(2011)$ & 6.0 & -3.7 & 5.2 & -1.3 & 4.7 & 2.4 \\
\hline Cambodia & 4.9 & 12.2 & 8.8 & 5.8 & 4.5 & 6.0 & 6.8 & 4.6 & 4.6 \\
\hline Indonesiab & 1.6 & 4.0 & 4.7 & 5.5 & 5.3 & 4.8 & 5.0 & 5.0 & 5.1 \\
\hline \multicolumn{10}{|l|}{ Lao People's Democratic Republic } \\
\hline Malaysiab & 13.0 & 9.1 & 6.9 & 7.2 & 7.0 & 6.0 & 5.9 & 6.9 & 8.0 \\
\hline Myanmarc & 4.3 & 14.6 & 2.6 & 13.7 & 11.1 & 4.7 & 2.2 & 4.3 & \\
\hline Philippines $^{\mathrm{a}}$ & 5.2 & 4.4 & 3.4 & 5.6 & 5.6 & 6.3 & 7.1 & 5.9 & 5.6 \\
\hline Singapore & 13.6 & 4.1 & 4.4 & 2.8 & 3.6 & 5.2 & 2.7 & 3.4 & 2.7 \\
\hline Thailand ${ }^{\mathrm{a}}$ & 7.0 & 4.2 & 5.5 & 0.9 & 0.8 & 2.3 & 2.9 & 3.0 & 4.6 \\
\hline Viet Nam & 3.1 & 5.8 & 8.2 & 5.2 & 6.1 & 9.3 & 7.3 & 7.3 & 7.3 \\
\hline \multicolumn{10}{|l|}{ The Pacific } \\
\hline Cook Islands & $\ldots$ & $\ldots$ & $\ldots$ & $\ldots$ & $\cdots$ & $\ldots$ & $\ldots$ & $\ldots$ & $\ldots$ \\
\hline $\mathrm{Fiji}$ & $\ldots$ & $\ldots$ & $\ldots$ & $\ldots$ & $\ldots$ & $\ldots$ & $\ldots$ & $\cdots$ & $\ldots$ \\
\hline \multicolumn{10}{|l|}{ Kiribati } \\
\hline Marshall Islands & $\ldots$ & 1.3 & 2.1 & -3.5 & 0.2 & 1.2 & 6.3 & 9.2 & $\cdots$ \\
\hline Micronesia, Federated States of & $\ldots$ & $\ldots$ & $\ldots$ & $\ldots$ & $\ldots$ & $\ldots$ & $\ldots$ & $\ldots$ & $\ldots$ \\
\hline \multirow{2}{*}{\multicolumn{10}{|c|}{ Niue }} \\
\hline & & & & & & & & & \\
\hline Palau & & $0.5(2006)$ & -2.3 & 1.0 & 2.5 & 5.4 & 6.1 & -0.5 & 0.2 \\
\hline Papua New Guinea ${ }^{a}$ & -28.5 & 9.8 & $\ldots$ & $\ldots$ & $\ldots$ & $\ldots$ & $\ldots$ & $\ldots$ & $\ldots$ \\
\hline Samoa & $\ldots$ & $\ldots$ & & $\ldots$ & & $\ldots$ & & $\ldots$ & $\ldots$ \\
\hline Solomon Islands & & 9.3 & 8.7 & 4.8 & 4.8 & 4.4 & 2.2 & $\cdots$ & $\ldots$ \\
\hline Timor-Leste & $12.9(2001)$ & -1.2 & 5.2 & 3.1 & 6.2 & 2.1 & 6.5 & 4.1 & \\
\hline Tonga & 3.5 & 2.2 & -1.3 & 4.9 & 2.7 & 5.0 & 5.0 & 4.6 & 5.4 \\
\hline Tuvalu & $\ldots$ & $\ldots$ & $\ldots$ & $\ldots$ & $\ldots$ & $\ldots$ & $\ldots$ & $\ldots$ & $\ldots$ \\
\hline Vanuatu & $\ldots$ & 2.4 & 2.6 & 3.5 & 3.9 & 1.3 & 8.9 & -1.9 & $\ldots$ \\
\hline \multicolumn{10}{|l|}{ Developed ADB Member Economies } \\
\hline Australia & 4.3 & 4.5 & 3.3 & 1.8 & 2.4 & 2.3 & 2.8 & 2.4 & 2.8 \\
\hline Japan & 1.8 & 1.2 & 2.3 & 2.4 & -0.8 & -0.4 & -0.3 & 1.1 & 0.3 \\
\hline New Zealand & 1.4 & 4.6 & 2.3 & 3.7 & 3.0 & 3.9 & 5.8 & 4.1 & 3.3 \\
\hline
\end{tabular}

... = data not available, - = magnitude equals zero, $\mathrm{ADB}=$ Asian Development Bank.

a Includes expenditure of nonprofit institutions serving households.

b Prior to 2010, includes expenditure of nonprofit institutions serving households.

c Includes government final consumption expenditure.

Source: Economy sources. 
Table 2.2.17: Growth Rates of Real Government Consumption Expenditure (\%)

\begin{tabular}{|c|c|c|c|c|c|c|c|c|c|}
\hline ADB Regional Member & 2000 & 2005 & 2010 & 2013 & 2014 & 2015 & 2016 & 2017 & 2018 \\
\hline \multicolumn{10}{|l|}{ Developing ADB Member Economies } \\
\hline \\
\hline Afghanistan & & & & - & & .... & . & 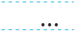 & $\cdots$ \\
\hline Armenia & 2.8 & 19.0 & 3.9 & 7.6 & -1.2 & 4.7 & -2.4 & -2.1 & 7.4 \\
\hline Azerbaijan & 2.3 & 3.4 & 3.4 & 3.6 & 3.7 & 1.3 & 6.8 & 1.1 & $\ldots$ \\
\hline Georgia & & & $1.0(2011)$ & 4.3 & 11.2 & 22.1 & 6.5 & 2.0 & \\
\hline Kazakhstan & 15.0 & 10.8 & 2.7 & 1.7 & 9.8 & 2.4 & 2.3 & 1.9 & -14.0 \\
\hline Kyrgyz Republic & 5.9 & -2.7 & -1.1 & -0.4 & -0.5 & 0.9 & 1.5 & 1.3 & -0.1 \\
\hline Pakistan & $-6.7(2001)$ & 3.4 & -0.6 & 10.1 & 1.5 & 8.1 & 8.2 & 5.3 & 14.2 \\
\hline Tajikistan & $10.8(2001)$ & 0.4 & 0.9 & 2.3 & 4.1 & 3.3 & 3.9 & 9.4 & $\ldots$ \\
\hline Turkmenistan & 28.0 & 17.9 & 3.8 & $\ldots$ & $\ldots$ & $\ldots$ & & $\ldots$ & $\ldots$ \\
\hline Uzbekistan & $\ldots$ & $\ldots$ & 7.0 & 8.6 & 8.4 & 6.7 & 2.7 & 1.5 & 3.1 \\
\hline \multicolumn{10}{|l|}{ East Asia } \\
\hline China, People's Republic of & $\cdots$ & $\cdots$ & & & & $\cdots$ & $\because$ & $\ldots$ & \\
\hline Hong Kong, China & 2.4 & -2.6 & 3.4 & 2.7 & 3.1 & 3.4 & 3.4 & 2.8 & 4.2 \\
\hline Korea, Republic of & $6.5(2001)$ & 5.3 & 5.6 & 4.8 & 4.3 & 3.8 & 4.4 & 3.9 & 5.6 \\
\hline Mongolia & & & $15.3(2011)$ & 15.8 & 12.2 & -4.7 & 10.6 & -1.8 & 0.5 \\
\hline Taipei,China & 0.6 & 0.4 & 1.1 & -0.8 & 3.7 & -0.1 & 3.6 & -0.6 & 3.5 \\
\hline \multicolumn{10}{|l|}{ South Asia } \\
\hline Bangladesh & 0.9 & 7.7 & 6.8 & 5.8 & 7.9 & 8.8 & 8.4 & 7.8 & 15.4 \\
\hline Bhutan & - & 2.8 & 7.5 & -10.1 & 2.4 & 10.8 & 4.2 & 4.4 & $\ldots$ \\
\hline India & 1.4 & 8.9 & 5.8 & 0.6 & 7.6 & 7.5 & 5.8 & 15.0 & 9.2 \\
\hline Maldives & $\ldots$ & & & & & $\ldots$ & & & $\ldots$ \\
\hline Nepal & $7.8(2002)$ & 1.2 & 1.3 & -6.7 & 10.0 & 7.4 & -0.4 & 10.5 & 13.4 \\
\hline Sri Lanka & 5.3 & 12.0 & $-2.1(2011)$ & 0.1 & 6.0 & 10.2 & 2.3 & -5.4 & -5.5 \\
\hline \multicolumn{10}{|l|}{ Southeast Asia } \\
\hline Brunei Darussalam & 7.7 & -1.0 & $5.3(2011)$ & 3.6 & 1.9 & -3.6 & -6.5 & 7.4 & 1.6 \\
\hline Cambodia & 12.4 & 2.9 & 12.5 & 5.2 & 2.4 & 4.4 & 5.7 & 6.5 & 6.5 \\
\hline Indonesia & -0.9 & 6.6 & 0.3 & 6.7 & 1.2 & 5.3 & -0.1 & 2.1 & 4.8 \\
\hline \multicolumn{10}{|l|}{ Lao People's Democratic Republic } \\
\hline Malaysia & 1.6 & 6.5 & 3.4 & 5.8 & 4.4 & 4.5 & 1.1 & 5.5 & 3.3 \\
\hline \multicolumn{10}{|l|}{ Myanmar } \\
\hline Philippines & -1.0 & 2.1 & 4.0 & 5.0 & 3.3 & 7.6 & 9.0 & 6.2 & 13.0 \\
\hline Singapore & 18.3 & 4.0 & 10.2 & 11.7 & 0.6 & 8.9 & 3.7 & 4.5 & 4.1 \\
\hline Thailand & 2.8 & 8.0 & 8.9 & 1.5 & 2.8 & 2.5 & 2.2 & 0.1 & 1.8 \\
\hline Viet Nam & 5.0 & 8.2 & 12.3 & 7.3 & 7.0 & 7.0 & 7.5 & 7.4 & 6.3 \\
\hline \multicolumn{10}{|l|}{ The Pacific } \\
\hline Cook Islands & $\ldots$ & $\ldots$ & $\ldots$ & $\ldots$ & $\ldots$ & $\ldots$ & $\ldots$ & $\ldots$ & $\ldots$ \\
\hline Fiji & $\ldots$ & $\ldots$ & $\ldots$ & $\ldots$ & $\ldots$ & $\ldots$ & $\ldots$ & $\ldots$ & $\ldots$ \\
\hline \multicolumn{10}{|l|}{ Kiribati } \\
\hline Marshall Islands & $\ldots$ & 2.1 & 0.3 & 0.3 & -1.7 & 7.3 & 6.0 & 1.6 & $\ldots$ \\
\hline Micronesia, Federated States of & $\ldots$ & $\ldots$ & $\ldots$ & $\ldots$ & $\cdots$ & $\ldots$ & $\cdots$ & $\ldots$ & $\ldots$ \\
\hline Nauru & $\ldots$ & $\ldots$ & $\ldots$ & $\ldots$ & $\ldots$ & $\ldots$ & $\cdots$ & $\ldots$ & $\ldots$ \\
\hline \multicolumn{10}{|l|}{ Niue } \\
\hline Palau & $\ldots$ & $5.9(2006)$ & -1.5 & 1.0 & 1.4 & 1.3 & 4.1 & -0.6 & 4.4 \\
\hline Papua New Guinea & 3.7 & 1.1 & $\ldots$ & $\ldots$ & $\ldots$ & $\ldots$ & $\ldots$ & $\ldots$ & $\ldots$ \\
\hline Samoa & $\ldots$ & $\ldots$ & $\ldots$ & $\ldots$ & $\ldots$ & $\ldots$ & $\ldots$ & $\ldots$ & $\ldots$ \\
\hline Solomon Islands & $\ldots$ & 80.6 & 10.0 & 14.7 & 8.2 & -1.4 & 2.0 & & $\ldots$ \\
\hline Timor-Leste & $33.8(2001)$ & -28.1 & 2.1 & -15.8 & 11.8 & 3.6 & -1.2 & -5.8 & $\cdots$ \\
\hline Tonga & -2.8 & -1.5 & -8.6 & 2.0 & -2.3 & 5.6 & -0.7 & 5.4 & 2.7 \\
\hline \multicolumn{10}{|l|}{ Tuvalu } \\
\hline Vanuatu & $\ldots$ & -0.1 & 4.3 & 2.2 & -3.7 & 16.9 & -1.4 & 19.5 & $\ldots$ \\
\hline \multicolumn{10}{|l|}{ Developed ADB Member Economies } \\
\hline Australia & 3.1 & 3.2 & 1.7 & 0.3 & 1.5 & 2.4 & 4.3 & 5.0 & 3.7 \\
\hline Japan & 3.9 & 0.8 & 1.9 & 1.5 & 0.5 & 1.5 & 1.4 & 0.3 & 0.8 \\
\hline New Zealand & 1.3 & 7.2 & 1.9 & 2.0 & 3.3 & 2.3 & 2.1 & 2.8 & 1.9 \\
\hline
\end{tabular}

$\ldots$ = data not available, - = magnitude equals zero, $\mathrm{ADB}=$ Asian Development Bank.

Source: Economy sources. 
Table 2.2.18: Growth Rates of Real Gross Capital Formation

(\%)

\begin{tabular}{|c|c|c|c|c|c|c|c|c|c|}
\hline ADB Regional Member & 2000 & 2005 & 2010 & 2013 & 2014 & 2015 & 2016 & 2017 & 2018 \\
\hline \multicolumn{10}{|l|}{ Developing ADB Member Economies } \\
\hline \multicolumn{10}{|l|}{ Central and West Asia } \\
\hline Afghanistan & & & & & & & & & \\
\hline Armenia & 5.2 & 26.9 & 0.5 & -9.1 & -3.0 & -1.2 & -8.7 & 15.4 & 26.8 \\
\hline Azerbaijan & 2.6 & 5.8 & 2.0 & 4.5 & -1.7 & -11.1 & -19.0 & -1.0 & $\ldots$ \\
\hline Georgia & & & $28.0(2011)$ & -11.7 & 26.9 & 9.3 & 8.1 & -1.1 & \\
\hline Kazakhstan & 10.7 & 35.0 & 2.0 & 6.7 & 8.6 & 5.5 & 2.5 & 2.3 & -1.3 \\
\hline Kyrgyz Republic & 22.1 & 13.7 & -5.2 & 5.1 & 15.7 & -2.3 & 8.1 & 6.9 & 11.3 \\
\hline Pakistan & $2.5(2001)$ & 13.2 & -6.5 & 2.8 & 2.8 & 14.6 & 7.3 & 9.5 & 5.7 \\
\hline Tajikistan & $39.2(2001)$ & 2.6 & 7.5 & 15.1 & 17.6 & 25.2 & 19.1 & -0.9 & $\ldots$ \\
\hline Turkmenistan & -6.0 & 12.4 & 21.6 & $\ldots$ & $\ldots$ & $\ldots$ & $\ldots$ & $\ldots$ & $\ldots$ \\
\hline Uzbekistan & $\ldots$ & $\ldots$ & $\ldots$ & $\ldots$ & $\cdots$ & $\ldots$ & $\ldots$ & $\ldots$ & $\ldots$ \\
\hline \multicolumn{10}{|l|}{ East Asia } \\
\hline China, People's Republic of & & $\ldots$ & & & $\ldots$ & $\ldots$ & $\ldots$ & $\ldots$ & $\ldots$ \\
\hline Hong Kong, China & 16.1 & - & 11.3 & 3.1 & 1.6 & -8.1 & 4.0 & 5.2 & 1.3 \\
\hline Korea, Republic of & $1.7(2001)$ & 2.2 & 17.1 & 1.0 & 3.6 & 6.5 & 6.3 & 10.9 & -1.8 \\
\hline Mongolia & & $15.0(2006)$ & $62.8(2011)$ & 1.4 & -30.1 & -26.5 & 2.1 & 34.6 & 41.3 \\
\hline Taipei,China & 9.0 & 1.3 & 35.8 & 3.2 & 4.4 & 1.5 & 0.6 & -0.8 & 6.1 \\
\hline \multicolumn{10}{|l|}{ South Asia } \\
\hline Bangladesh & 7.3 & 10.7 & 8.6 & 5.4 & 9.9 & 7.1 & 8.9 & 10.1 & 10.5 \\
\hline Bhutan & 26.5 & -12.2 & 46.1 & -35.7 & 24.4 & 16.5 & 12.0 & -0.1 & \\
\hline India & -5.5 & 16.2 & 14.1 & -4.6 & 7.7 & 4.7 & 3.6 & 10.4 & 9.0 \\
\hline Maldives & & & & & & & & & \\
\hline Nepal & $-14.0(2002)$ & 9.5 & 34.4 & 23.5 & 22.8 & 9.4 & 10.7 & 37.8 & 23.2 \\
\hline Sri Lanka & 8.7 & 9.4 & $20.2(2011)$ & -8.8 & 11.5 & 3.8 & 5.0 & 8.2 & 6.6 \\
\hline \multicolumn{10}{|l|}{ Southeast Asia } \\
\hline Brunei Darussalam & $6.7(2001)$ & 0.5 & $37.0(2011)$ & 11.9 & -31.2 & 6.6 & -11.1 & 8.0 & 28.1 \\
\hline $\begin{array}{l}\text { Cambodia } \\
\text { amb }\end{array}$ & 12.7 & 30.7 & -7.9 & 14.1 & 8.8 & 9.9 & 10.0 & 6.0 & 6.0 \\
\hline Indonesia & 12.9 & 12.4 & 8.8 & 2.8 & 5.7 & 3.0 & 5.0 & 5.3 & 8.9 \\
\hline \multicolumn{10}{|l|}{ Lao People's Democratic Republic } \\
\hline Malaysia & 29.2 & -2.5 & 25.3 & 4.9 & 2.5 & 6.7 & 4.4 & 6.2 & -3.2 \\
\hline Myanmar & 11.3 & 29.8 & 34.6 & 12.3 & 7.5 & 16.1 & 4.3 & 6.8 & \\
\hline Philippines & 1.1 & 3.0 & 31.6 & 27.9 & 4.2 & 18.4 & 24.6 & 9.4 & 13.2 \\
\hline Singapore & 23.6 & 1.3 & 20.0 & 4.9 & 0.8 & -8.6 & 10.2 & 11.6 & -2.1 \\
\hline Thailand & 8.0 & 21.7 & 32.0 & 3.2 & -12.3 & 2.1 & -3.7 & 11.2 & \\
\hline Viet Nam & 10.1 & 11.2 & 10.4 & 5.5 & 8.9 & 9.0 & 9.7 & 9.8 & 8.2 \\
\hline \multicolumn{10}{|l|}{ The Pacific } \\
\hline Cook Islands & $\ldots$ & $\ldots$ & $\ldots$ & $\ldots$ & $\ldots$ & $\ldots$ & $\ldots$ & $\ldots$ & $\ldots$ \\
\hline Fiji & $\ldots$ & $\ldots$ & $\ldots$ & $\ldots$ & $\ldots$ & $\ldots$ & $\ldots$ & $\ldots$ & $\ldots$ \\
\hline Kiribati & $\ldots$ & & & & 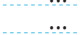 & $\ldots$ & 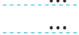 & $\ldots$ & $\ldots$ \\
\hline Marshall Islands & $\ldots$ & 20.8 & 23.9 & 81.4 & -17.7 & -2.5 & 18.9 & 14.8 & $\ldots$ \\
\hline Micronesia, Federated States of & $\ldots$ & $\ldots$ & $\ldots$ & $\ldots$ & $\ldots$ & $\ldots$ & $\ldots$ & $\ldots$ & $\ldots$ \\
\hline Nauru & $\ldots$ & $\ldots$ & $\ldots$ & $\ldots$ & $\ldots$ & $\ldots$ & $\ldots$ & $\ldots$ & $\ldots$ \\
\hline Niue & $\ldots$ & $\ldots$ & ….. & & & & & & $\ldots$ \\
\hline Palau & & $-11.0(2006)$ & 3.3 & -12.9 & 37.1 & 0.3 & 9.8 & 2.5 & -5.0 \\
\hline Papua New Guinea & 36.8 & -9.8 & $\ldots$ & $\ldots$ & $\ldots$ & $\ldots$ & $\ldots$ & $\ldots$ & $\ldots$ \\
\hline Samoa & & & & & & & & & \\
\hline Solomon Islands & & 71.1 & 88.7 & 1.9 & 3.3 & 10.2 & -5.0 & & $\ldots$ \\
\hline Timor-Leste & $10.5(2001)$ & -7.8 & -4.5 & -20.1 & 3.4 & -10.3 & 15.4 & -15.0 & \\
\hline Tonga & 1.3 & 4.7 & 11.7 & -34.8 & 9.3 & 15.0 & 14.7 & 30.3 & -10.2 \\
\hline Tuvalu & & & & & & & & & \\
\hline Vanuatu & $\ldots$ & 7.7 & -5.2 & 17.0 & 9.0 & 33.2 & -21.5 & 15.9 & $\ldots$ \\
\hline \multicolumn{10}{|l|}{ Developed ADB Member Economies } \\
\hline Australia & & & & & & & & & \\
\hline Japan & 3.1 & 2.3 & 3.1 & 3.2 & 3.4 & 2.9 & -0.9 & 2.8 & 1.7 \\
\hline New Zealand & -3.8 & 4.0 & 7.4 & 8.0 & 8.4 & 2.3 & 4.2 & 3.8 & 2.9 \\
\hline
\end{tabular}

... = data not available, - = magnitude equals zero, $\mathrm{ADB}=$ Asian Development Bank.

Source: Economy sources. 
Table 2.2.19: Growth Rates of Real Exports of Goods and Services (\%)

\begin{tabular}{|c|c|c|c|c|c|c|c|c|c|}
\hline ADB Regional Member & 2000 & 2005 & 2010 & 2013 & 2014 & 2015 & 2016 & 2017 & 2018 \\
\hline \multicolumn{10}{|l|}{ Developing ADB Member Economies } \\
\hline \\
\hline Afghanistan & & & & .... & & $\ldots$ & & . & . \\
\hline Armenia & 19.0 & 15.9 & 26.5 & 8.6 & 6.4 & 4.9 & 19.1 & 18.7 & 4.6 \\
\hline Azerbaijan & 15.4 & 52.8 & 9.1 & 2.1 & -1.9 & -0.1 & 11.4 & -2.2 & $\ldots$ \\
\hline Georgia & & & $15.5(2011)$ & 20.3 & 0.4 & 6.0 & 7.7 & 10.3 & \\
\hline Kazakhstan & 27.9 & 0.4 & 3.1 & 2.7 & -2.5 & -4.1 & -4.5 & 6.4 & 11.5 \\
\hline Kyrgyz Republic & 10.5 & -11.0 & -11.7 & 12.3 & -6.2 & -5.6 & -3.8 & 6.1 & -1.8 \\
\hline Pakistan & $12.2(2001)$ & 11.7 & 15.7 & 13.6 & -1.5 & -6.3 & -1.6 & -0.8 & 9.9 \\
\hline Tajikistan & $-20.8(2001)$ & 2.9 & 23.0 & -10.0 & - & - & - & - & $\ldots$ \\
\hline Turkmenistan & 82.7 & 19.2 & 11.7 & & & $\ldots$ & $\ldots$ & $\ldots$ & $\ldots$ \\
\hline Uzbekistan & $\ldots$ & $\ldots$ & 2.1 & 11.1 & -7.5 & 2.3 & 11.1 & 1.3 & 10.7 \\
\hline \multicolumn{10}{|l|}{ East Asia } \\
\hline China, People's Republic of & $\cdots$ & & & $\cdots$ & & $\cdots$ & & $\cdots$ & \\
\hline Hong Kong, China & 16.9 & 12.2 & 17.6 & 7.8 & 1.0 & -1.4 & 0.7 & 5.9 & 3.8 \\
\hline Korea, Republic of & $-1.8(2001)$ & 7.9 & 13.0 & 3.8 & 2.1 & 0.2 & 2.4 & 2.5 & 3.5 \\
\hline Mongolia & & $6.1(2006)$ & $18.2(2011)$ & 12.8 & 53.2 & 0.1 & 13.8 & 14.8 & 14.1 \\
\hline Taipei,China & 18.0 & 7.6 & 25.7 & 3.5 & 5.9 & -0.4 & 1.9 & 7.4 & 3.7 \\
\hline \multicolumn{10}{|l|}{ South Asia } \\
\hline Bangladesh & 14.4 & 15.6 & 0.9 & 2.5 & 3.2 & -2.8 & 2.2 & -2.3 & 8.1 \\
\hline Bhutan & 3.3 & 34.3 & 7.5 & 3.9 & -5.8 & -3.5 & -9.1 & 11.6 & \\
\hline India & 18.2 & 26.1 & 19.6 & 7.8 & 1.8 & -5.6 & 5.1 & 4.7 & 12.5 \\
\hline \multicolumn{10}{|l|}{ Maldives } \\
\hline Nepal & $-23.2(2002)$ & -3.0 & -10.4 & 10.3 & 18.8 & 6.8 & -13.7 & 11.3 & 7.8 \\
\hline Sri Lanka & 17.1 & 6.6 & $10.2(2011)$ & 6.6 & 4.3 & 4.7 & -0.7 & 7.6 & 0.5 \\
\hline \multicolumn{10}{|l|}{ Southeast Asia } \\
\hline Brunei Darussalam & 11.9 & -1.3 & $-3.0(2011)$ & -5.7 & -0.1 & -9.9 & -1.9 & -5.3 & 5.7 \\
\hline Cambodia & 30.3 & 16.4 & 20.6 & 14.0 & 11.3 & 7.2 & 8.6 & 5.3 & 5.3 \\
\hline Indonesia & 26.5 & 16.6 & 15.3 & 4.2 & 1.1 & -2.1 & -1.7 & 8.9 & 6.5 \\
\hline \multicolumn{10}{|l|}{ Lao People's Democratic Republic } \\
\hline Malaysia & 16.1 & 8.3 & 11.1 & 0.3 & 5.0 & 0.3 & 1.3 & 8.7 & 2.2 \\
\hline Myanmar & 79.3 & 3.6 & 10.9 & 12.9 & 18.7 & 15.1 & -0.4 & 19.0 & \\
\hline Philippines & 13.7 & 5.0 & 21.0 & -1.0 & 12.6 & 8.5 & 11.6 & 19.7 & 13.4 \\
\hline Singapore & 14.3 & 12.8 & 17.8 & 6.1 & 3.6 & 5.0 & 0.0 & 5.7 & 5.1 \\
\hline Thailand & 15.8 & 7.8 & 14.2 & 2.7 & 0.3 & 1.6 & 2.8 & 5.4 & 4.2 \\
\hline Viet Nam & $11.0(2002)$ & 7.8 & 14.6 & 17.4 & 11.6 & 12.6 & 13.9 & 16.7 & 14.3 \\
\hline \multicolumn{10}{|l|}{ The Pacific } \\
\hline Cook Islands & $\ldots$ & $\ldots$ & $\ldots$ & $\ldots$ & $\ldots$ & $\ldots$ & $\ldots$ & $\ldots$ & $\ldots$ \\
\hline Fiji & $\ldots$ & $\ldots$ & $\ldots$ & $\ldots$ & $\ldots$ & $\ldots$ & $\ldots$ & $\ldots$ & $\ldots$ \\
\hline Kiribati & & 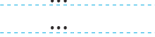 & $\ldots$ & $\ldots$ & $\ldots$ & $\ldots$ & $\ldots$ & $\ldots$ & $\ldots$ \\
\hline Marshall Islands & $\ldots$ & 14.6 & 22.4 & 8.3 & 1.4 & 8.2 & -8.8 & 8.9 & $\ldots$ \\
\hline Micronesia, Federated States of & $\ldots$ & $\cdots$ & $\cdots$ & $\ldots$ & $\ldots$ & $\cdots$ & $\cdots$ & $\ldots$ & $\ldots$ \\
\hline Nauru & $\ldots$ & $\ldots$ & $\ldots$ & $\ldots$ & $\cdots$ & $\ldots$ & $\cdots$ & $\ldots$ & $\ldots$ \\
\hline \multicolumn{10}{|l|}{ Niue } \\
\hline Palau & $\ldots$ & $0.2(2006)$ & 5.5 & -3.4 & 9.6 & 11.9 & -4.1 & -9.1 & -7.1 \\
\hline Papua New Guinea & 7.1 & 6.8 & $\ldots$ & $\ldots$ & $\ldots$ & $\ldots$ & $\ldots$ & $\ldots$ & $\ldots$ \\
\hline Samoa & $\ldots$ & $\ldots$ & $\ldots$ & $\ldots$ & $\ldots$ & $\ldots$ & $\ldots$ & $\ldots$ & $\ldots$ \\
\hline Solomon Islands & & 10.5 & 34.8 & -4.8 & -8.9 & 1.8 & 3.6 & & $\ldots$ \\
\hline Timor-Leste & $-19.2(2001)$ & 74.0 & -6.7 & -13.4 & -26.4 & 12.8 & -9.4 & -9.1 & $\ldots$ \\
\hline Tonga & -14.7 & -2.8 & -8.8 & 19.7 & -21.5 & 7.8 & 34.3 & -0.1 & -6.6 \\
\hline \multicolumn{10}{|l|}{ Tuvalu } \\
\hline Vanuatu & & 7.1 & 0.4 & 4.2 & -0.7 & 4.9 & 19.5 & -1.1 & $\ldots$ \\
\hline \multicolumn{10}{|l|}{ Developed ADB Member Economies } \\
\hline Australia & 9.9 & 3.5 & 4.7 & 5.3 & 6.0 & 6.8 & 6.8 & 5.5 & 4.1 \\
\hline Japan & 12.7 & 7.2 & 24.9 & 0.8 & 9.3 & 2.9 & 1.7 & 6.8 & 3.3 \\
\hline New Zealand & 6.1 & -0.4 & 2.8 & 0.1 & 4.6 & 5.9 & 1.3 & 3.0 & 3.6 \\
\hline
\end{tabular}

$\ldots$ = data not available, 0.0 = magnitude is less than half of unit employed, - = magnitude equals zero, $A D B=$ Asian Development Bank .

Source: Economy sources. 
Table 2.2.20: Growth Rates of Real Imports of Goods and Services

(\%)

\begin{tabular}{|c|c|c|c|c|c|c|c|c|c|}
\hline ADB Regional Member & 2000 & 2005 & 2010 & 2013 & 2014 & 2015 & 2016 & 2017 & 2018 \\
\hline \multicolumn{10}{|l|}{ Developing ADB Member Economies } \\
\hline \multicolumn{10}{|l|}{ Central and West Asia } \\
\hline \multicolumn{10}{|l|}{ Afghanistan } \\
\hline Armenia & 7.2 & 14.3 & 12.8 & -2.1 & -1.0 & -15.1 & 7.6 & 24.6 & 12.7 \\
\hline Azerbaijan & 17.3 & 19.8 & 12.4 & 1.1 & -2.1 & -0.5 & 11.3 & -1.6 & \\
\hline Georgia & $\ldots$ & $\ldots$ & $17.9(2011)$ & 2.9 & 11.1 & 10.4 & 6.3 & 0.9 & \\
\hline Kazakhstan & 28.0 & 12.1 & 2.9 & 7.8 & -4.0 & -0.1 & -2.0 & -1.4 & 3.2 \\
\hline Kyrgyz Republic & 0.4 & 6.5 & -6.9 & 4.1 & 1.6 & -13.2 & -1.1 & 7.4 & 6.7 \\
\hline Pakistan & $2.2(2001)$ & 39.5 & 4.3 & 1.8 & 0.3 & -1.6 & 16.0 & 21.0 & 17.5 \\
\hline Tajikistan & $-14.5(2001)$ & 16.5 & 8.0 & 1.1 & 1.0 & - & - & - & $\ldots$ \\
\hline Turkmenistan & 4.1 & -9.3 & 7.4 & & & & & & \\
\hline Uzbekistan & & 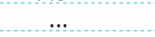 & -6.6 & 8.8 & 0.3 & -11.2 & -2.2 & 15.5 & 39.4 \\
\hline \multicolumn{10}{|l|}{ East Asia } \\
\hline China, People's Republic of & & $\cdots$ & & & $\ldots$ & $\cdots$ & $\ldots$ & $\ldots$ & \\
\hline Hong Kong, China & 17.1 & 9.3 & 18.2 & 8.3 & 1.0 & -1.8 & 0.9 & 6.6 & 4.6 \\
\hline Korea, Republic of & $-3.5(2001)$ & 7.8 & 17.5 & 1.6 & 1.3 & 2.1 & 5.2 & 8.9 & 0.8 \\
\hline Mongolia & & $6.7(2006)$ & $49.5(2011)$ & 7.6 & 6.8 & -11.4 & 12.7 & 24.8 & 21.4 \\
\hline Taipei,China & 14.9 & 2.9 & 28.0 & 3.4 & 5.7 & 1.1 & 3.1 & 5.3 & 4.9 \\
\hline \multicolumn{10}{|l|}{ South Asia } \\
\hline Bangladesh & 10.2 & 19.1 & 0.7 & 1.2 & 1.2 & 3.2 & -7.1 & 2.9 & 27.0 \\
\hline Bhutan & 4.2 & 13.0 & 28.7 & -1.8 & -3.2 & 16.2 & -12.4 & 3.7 & \\
\hline India & 4.6 & 32.6 & 15.6 & -8.1 & 0.9 & -5.9 & 4.4 & 17.6 & 15.4 \\
\hline \multicolumn{10}{|l|}{ Maldives } \\
\hline Nepal & $-15.1(2002)$ & 6.9 & 28.3 & 14.1 & 21.0 & 9.6 & 2.8 & 27.2 & 19.0 \\
\hline Sri Lanka & 14.8 & 2.7 & $23.6(2011)$ & -1.5 & 9.6 & 10.6 & 7.9 & 7.1 & 1.8 \\
\hline \multicolumn{10}{|l|}{ Southeast Asia } \\
\hline Brunei Darussalam & -6.2 & 10.2 & 33.7 (2011) & 14.5 & -22.9 & -8.9 & -10.8 & 1.3 & 28.1 \\
\hline Cambodia & 23.7 & 17.3 & 16.8 & 15.1 & 10.1 & 6.5 & 8.6 & 4.1 & 4.1 \\
\hline Indonesia & 25.9 & 17.8 & 17.3 & 1.9 & 2.1 & -6.2 & -2.4 & 8.1 & 12.0 \\
\hline \multicolumn{10}{|l|}{ Lao People's Democratic Republic } \\
\hline Malaysia & 24.4 & 8.9 & 15.6 & 1.7 & 4.0 & 0.8 & 1.4 & 10.2 & 1.3 \\
\hline Myanmar & -8.0 & 2.2 & 51.9 & 54.4 & 22.3 & 21.6 & -11.4 & 9.4 & \\
\hline Philippines & 11.8 & 3.3 & 22.5 & 4.4 & 9.9 & 14.6 & 20.2 & 18.1 & 16.0 \\
\hline Singapore & 20.0 & 11.6 & 16.3 & 6.5 & 2.8 & 3.4 & 0.1 & 7.5 & 4.7 \\
\hline Thailand & 26.0 & 16.2 & 23.0 & 1.7 & -5.3 & 0.0 & -1.0 & 6.2 & 8.6 \\
\hline Viet Nam & $15.8(2002)$ & 5.9 & 13.7 & 17.3 & 12.8 & 18.1 & 15.3 & 17.5 & 12.8 \\
\hline \multicolumn{10}{|l|}{ The Pacific } \\
\hline Cook Islands & $\cdots$ & $\ldots$ & $\ldots$ & $\ldots$ & $\ldots$ & $\ldots$ & $\ldots$ & $\ldots$ & $\cdots$ \\
\hline Fiji & $\ldots$ & $\ldots$ & $\ldots$ & $\ldots$ & $\cdots$ & $\ldots$ & $\ldots$ & $\ldots$ & $\ldots$ \\
\hline Kiribati & $\ldots$ & $\ldots$ & $\ldots$ & $\ldots$ & $\ldots$ & $\ldots$ & $\ldots$ & $\cdots$ & . \\
\hline Marshall Islands & $\cdots$ & 9.6 & 7.6 & 12.0 & -9.2 & 9.9 & 7.0 & 10.7 & \\
\hline Micronesia, Federated States of & $\ldots$ & $\ldots$ & $\ldots$ & $\ldots$ & $\ldots$ & $\ldots$ & $\ldots$ & $\ldots$ & $\ldots$ \\
\hline Nauru & $\cdots$ & $\ldots$ & $\ldots$ & $\ldots$ & $\cdots$ & $\ldots$ & $\ldots$ & & $\ldots$ \\
\hline \multicolumn{10}{|l|}{ Niue } \\
\hline Palau & $\cdots$ & $2.0(2006)$ & 1.1 & 1.2 & 11.8 & 2.6 & 8.0 & -1.4 & -5.5 \\
\hline Papua New Guinea & -4.7 & 4.7 & $\ldots$ & $\ldots$ & $\ldots$ & $\ldots$ & $\ldots$ & $\ldots$ & $\ldots$ \\
\hline Samoa & $\ldots$ & $\ldots$ & & & $\ldots$ & $\ldots$ & & $\cdots$ & $\ldots$ \\
\hline Solomon Islands & & 14.0 & 51.7 & 6.6 & -5.9 & 3.9 & 1.2 & & $\ldots$ \\
\hline Timor-Leste & $26.7(2001)$ & -19.1 & -6.6 & -13.8 & 19.4 & -15.4 & -5.1 & -3.3 & \\
\hline Tonga & -0.6 & 1.8 & -4.5 & -2.5 & 0.2 & 23.2 & 9.4 & 5.6 & 1.0 \\
\hline \multicolumn{10}{|l|}{ Tuvalu } \\
\hline Vanuatu & $\ldots$ & 2.9 & -2.2 & 6.5 & 0.2 & 26.2 & 2.3 & 3.3 & $\cdots$ \\
\hline \multicolumn{10}{|l|}{ Developed ADB Member Economies } \\
\hline Australia & 12.0 & 12.5 & 7.1 & 0.3 & -2.3 & 1.0 & -0.1 & 4.7 & 7.1 \\
\hline Japan & 9.3 & 6.1 & 11.2 & 3.3 & 8.3 & 0.8 & -1.6 & 3.5 & 3.4 \\
\hline New Zealand & -1.1 & 4.9 & 11.5 & 8.1 & 7.4 & 2.3 & 5.1 & 7.1 & 4.1 \\
\hline
\end{tabular}

... = data not available, 0.0 = magnitude is less than half of unit employed, $-=$ magnitude equals zero, $A D B=$ Asian Development Bank.

Source: Economy sources. 
Table 2.2.21: Growth Rates of Agriculture Production Index (\%)

\begin{tabular}{|c|c|c|c|c|c|c|c|c|c|}
\hline ADB Regional Member & 2000 & 2005 & 2010 & 2013 & 2014 & 2015 & 2016 & 2017 & 2018 \\
\hline \multicolumn{10}{|l|}{ Developing ADB Member Economies } \\
\hline \multicolumn{10}{|l|}{ Central and West Asia } \\
\hline Afghanistan & -15.9 & 10.7 & -0.8 & -2.2 & 3.6 & -3.7 & 5.3 & $\ldots$ & $\ldots$ \\
\hline Armenia & 4.7 & 36.9 & -18.3 & 4.3 & 0.3 & 6.1 & -10.0 & & $\ldots$ \\
\hline Azerbaijan & 10.1 & 15.8 & -0.7 & 1.9 & -3.4 & 6.4 & 1.9 & $\because$ & $\ldots$ \\
\hline Georgia & -13.7 & 17.1 & -6.2 & 19.2 & -15.7 & 2.1 & -5.2 & $\ldots$ & $\ldots$ \\
\hline Kazakhstan & -4.4 & 7.1 & -10.4 & 9.7 & 1.0 & 3.4 & 5.4 & 3.0 & 3.2 \\
\hline Kyrgyz Republic & 2.6 & -4.2 & -2.6 & 2.7 & -0.5 & 6.2 & 3.1 & 2.4 & 2.7 \\
\hline Pakistan & 1.3 & -2.6 & -1.9 & 5.5 & 7.4 & -4.8 & 2.6 & 11.5 & 5.8 \\
\hline Tajikistan & 12.6 & -6.8 & 1.1 & 10.4 & -1.8 & 6.0 & -2.7 & $\ldots$ & $\ldots$ \\
\hline Turkmenistan & 7.4 & 3.4 & 2.8 & 6.2 & -4.0 & -5.2 & 3.2 & & $\ldots$ \\
\hline Uzbekistan & 3.1 & 5.0 & 4.5 & 5.9 & -2.2 & 6.1 & 6.1 & 1.2 & 0.3 \\
\hline \multicolumn{10}{|l|}{ East Asia } \\
\hline China, People's Republic of & 5.1 & 3.8 & 2.4 & 1.5 & 1.4 & 2.9 & 2.2 & $\ldots$ & $\ldots$ \\
\hline Hong Kong, China & 2.4 & 13.5 & 0.0 & 0.0 & -5.9 & 0.0 & 0.0 & 6.3 & 5.9 \\
\hline Korea, Republic of & 0.8 & 0.6 & -5.9 & 4.3 & 2.5 & -1.7 & -1.4 & $\ldots$ & ... \\
\hline Mongolia & -1.8 & -7.1 & -20.2 & 9.4 & 8.6 & -1.9 & 5.6 & $\ldots$ & $\ldots$ \\
\hline Taipei,China & 2.2 & -5.7 & 2.1 & -1.2 & 1.1 & -3.4 & -3.6 & 5.4 & 2.8 \\
\hline \multicolumn{10}{|l|}{ South Asia } \\
\hline Bangladesh & 6.1 & 13.0 & 5.9 & 1.7 & 4.3 & 0.7 & 2.3 & $\ldots$ & $\ldots$ \\
\hline Bhutan & -10.2 & 23.5 & 4.5 & -4.2 & 2.1 & 0.1 & 3.4 & $\ldots$ & $\ldots$ \\
\hline India & -1.1 & 5.7 & 8.6 & 3.8 & 2.7 & -1.2 & 2.3 & $\ldots$ & $\ldots$ \\
\hline Maldives & 5.9 & -20.0 & -3.9 & -3.2 & 3.9 & 2.4 & 0.2 & $\ldots$ & $\ldots$ \\
\hline Nepal & 5.1 & 2.0 & 1.0 & -6.6 & 4.3 & -0.2 & 1.4 & $\ldots$ & $\ldots$ \\
\hline Sri Lanka & 2.3 & 8.7 & 10.5 & 9.5 & -9.5 & 4.5 & 0.6 & $\ldots$ & $\ldots$ \\
\hline \multicolumn{10}{|l|}{ Southeast Asia } \\
\hline Brunei Darussalam & 13.0 & -26.6 & 4.9 & 8.4 & -0.2 & 2.1 & -0.3 & $\ldots$ & $\ldots$ \\
\hline Cambodia & 1.8 & 26.7 & 8.7 & 1.5 & 0.3 & 1.4 & 5.0 & $\ldots$ & $\ldots$ \\
\hline Indonesia & 3.3 & 2.7 & 2.6 & 0.9 & 2.0 & 2.2 & 0.5 & $\ldots$ & $\ldots$ \\
\hline Lao People's Democratic Republic & 14.3 & 4.0 & 6.9 & 4.4 & 17.1 & 11.0 & 4.0 & $\ldots$ & $\ldots$ \\
\hline Malaysia & 3.5 & 4.6 & 0.5 & 1.9 & -0.8 & 0.9 & 0.6 & $\cdots$ & $\cdots$ \\
\hline Myanmar & 10.3 & 7.2 & 2.1 & 2.0 & 1.3 & 2.3 & -0.8 & 0.1 & $\cdots$ \\
\hline Philippines & 2.7 & 2.2 & -0.8 & 0.9 & -3.3 & -1.3 & -2.2 & $\ldots$ & $\ldots$ \\
\hline Singapore & -59.2 & -22.8 & 0.5 & 6.7 & -0.3 & -2.0 & 4.9 & $\ldots$ & $\ldots$ \\
\hline Thailand & 8.5 & $6.3(2006)$ & 0.9 & -0.7 & 0.3 & -3.9 & 0.0 & 7.0 & 6.8 \\
\hline Viet Nam & 3.2 & 3.7 & 2.7 & 1.5 & 2.2 & 2.4 & -1.5 & $\ldots$ & $\ldots$ \\
\hline \multicolumn{10}{|l|}{ The Pacific } \\
\hline Cook Islands & -3.3 & 3.3 & -2.5 & 3.4 & -0.5 & -0.2 & -1.8 & $\ldots$ & $\ldots$ \\
\hline Fiji & -0.1 & 1.6 & -6.9 & 12.1 & 2.2 & -3.3 & -2.1 & $\cdots$ & $\cdots$ \\
\hline Kiribati & -5.5 & 1.1 & -48.4 & -0.9 & 0.7 & 0.1 & -0.2 & $\cdots$ & $\ldots$ \\
\hline Marshall Islands & -74.9 & 15.2 & -5.0 & 6.1 & 0.0 & -4.3 & -5.6 & $\ldots$ & $\ldots$ \\
\hline Micronesia, Federated States of & -0.0 & -3.5 & -0.4 & 6.1 & 12.2 & 13.1 & -20.8 & $\cdots$ & $\cdots$ \\
\hline Nauru & 0.8 & 1.2 & 1.0 & 2.1 & 0.9 & 1.0 & 0.7 & $\ldots$ & $\cdots$ \\
\hline \multicolumn{10}{|l|}{ Niue } \\
\hline Palau & & & & & & & & $\ldots$ & $\ldots$ \\
\hline Papua New Guinea & 3.2 & 1.8 & -1.4 & 2.3 & 1.2 & 0.8 & 1.1 & $\ldots$ & $\ldots$ \\
\hline Samoa & 3.1 & 2.1 & 0.0 & 1.5 & 1.1 & 4.1 & -1.1 & $\ldots$ & $\ldots$ \\
\hline Solomon Islands & 2.9 & 12.2 & 2.9 & 2.6 & 1.7 & -0.8 & -3.1 & $\ldots$ & $\ldots$ \\
\hline Timor-Leste & 6.0 & 6.0 & -0.7 & -3.4 & -0.4 & 0.2 & -1.3 & $\ldots$ & $\ldots$ \\
\hline Tonga & -3.3 & -0.2 & -1.4 & -1.0 & 0.8 & 3.6 & -1.5 & $\ldots$ & $\ldots$ \\
\hline Tuvalu & 6.1 & 1.4 & -1.3 & 2.3 & -0.4 & 0.9 & 1.0 & $\cdots$ & $\cdots$ \\
\hline Vanuatu & -4.6 & 1.9 & 24.0 & 6.0 & -8.8 & 0.2 & 1.0 & $\ldots$ & $\ldots$ \\
\hline \multicolumn{10}{|l|}{ Developed ADB Member Economies } \\
\hline Australia & -1.4 & -0.4 & -2.0 & -1.0 & -0.3 & 0.5 & -3.5 & $\ldots$ & $\ldots$ \\
\hline Japan & -0.5 & 1.0 & -2.4 & -0.4 & -0.2 & -1.1 & -3.8 & $\ldots$ & $\ldots$ \\
\hline New Zealand & 6.9 & -2.1 & 1.2 & 0.5 & 5.8 & 1.9 & -0.8 & $\cdots$ & $\cdots$ \\
\hline
\end{tabular}

$\ldots=$ data not available, -0.0 or $0.0=$ magnitude is less than half of unit employed, $A D B=$ Asian Development Bank.

Sources: $\quad$ Food and Agriculture Organization of the United Nations. FAOSTAT. http://foastat3.fao.org (accessed 1 July 2019 ). For Kazakhstan; the Kyrgyz Republic; Pakistan; Uzbekistan (2014-2018); Hong Kong, China; Taipei,China; Myanmar (2010-2017); and Thailand (2005-2018): Economy sources. 
Table 2.2.22: Growth Rates of Manufacturing Production Index

(\%)

\begin{tabular}{|c|c|c|c|c|c|c|c|c|c|}
\hline ADB Regional Member & 2000 & 2005 & 2010 & 2013 & 2014 & 2015 & 2016 & 2017 & 2018 \\
\hline \multicolumn{10}{|l|}{ Developing ADB Member Economies } \\
\hline \\
\hline Afghanistan & $\ldots$ & $\ldots$ & $\ldots$ & $\ldots$ & $\ldots$ & $\ldots$ & $\ldots$ & $\ldots$ & $\ldots$ \\
\hline Armenia & $\ldots$ & $\ldots$ & $\ldots$ & $\ldots$ & $\ldots$ & $\ldots$ & $\ldots$ & $\ldots$ & $\ldots$ \\
\hline Azerbaijan & $\ldots$ & $\ldots$ & $\ldots$ & $\ldots$ & $\ldots$ & $\ldots$ & $\ldots$ & $\ldots$ & \\
\hline Georgia & $34.6(2002)$ & 40.6 & 18.5 & -0.3 & 6.0 & 6.0 & 3.3 & 5.9 & 3.2 \\
\hline Kazakhstan & 17.3 & 15.9 & 15.1 & 1.9 & 1.1 & 0.2 & 0.6 & 5.1 & 3.8 \\
\hline Kyrgyz Republic & 3.4 & -19.4 & 19.4 & 96.5 & -33.5 & -4.9 & 14.3 & & \\
\hline Pakistan & $1.0(2001)$ & 18.2 & 0.5 & 4.4 & 5.4 & 3.4 & 3.1 & 5.8 & 5.2 \\
\hline Tajikistan & 12.0 & 10.5 & $-6.2(2009)$ & $\ldots$ & $\ldots$ & $\ldots$ & $\ldots$ & $\ldots$ & $\ldots$ \\
\hline Turkmenistan & 13.4 & & $\ldots$ & & $\ldots$ & $\ldots$ & $\ldots$ & $\ldots$ & $\ldots$ \\
\hline Uzbekistan & 7.1 & $10.2(2004)$ & & & 8.2 & 5.9 & 6.9 & 4.2 & 6.4 \\
\hline \multicolumn{10}{|l|}{ East Asia } \\
\hline China, People's Republic of & $\ldots$ & $18.2(2006)$ & 16.6 & 10.5 & 9.4 & 7.0 & 6.8 & 7.2 & 6.5 \\
\hline Hong Kong, China & -0.5 & 3.0 & 3.6 & 0.1 & -0.4 & -1.5 & -0.5 & 0.4 & 1.3 \\
\hline Korea, Republic of & 10.4 & 3.3 & 7.9 & 1.7 & 2.9 & -0.3 & 2.3 & 2.2 & 1.2 \\
\hline Mongolia & & & & . & & $\ldots$ & $\ldots$ & $\ldots$ & \\
\hline Taipei,China & 7.8 & 3.2 & 29.7 & 3.4 & 6.8 & -1.2 & 1.9 & 5.3 & 3.9 \\
\hline \multicolumn{10}{|l|}{ South Asia } \\
\hline Bangladesh & 4.9 & 8.5 & 6.3 & 11.6 & 9.2 & 10.7 & 13.5 & 11.2 & 15.0 \\
\hline Bhutan & $\ldots$ & $\ldots$ & $\ldots$ & $\ldots$ & $\ldots$ & $\ldots$ & $\ldots$ & $\ldots$ & $\ldots$ \\
\hline India & 5.3 & 10.3 & 9.0 & 3.6 & 3.8 & 3.0 & 4.1 & 4.6 & 3.6 \\
\hline \multicolumn{10}{|l|}{ Maldives } \\
\hline Nepal & 6.5 & 2.6 & -2.3 & 4.0 & 7.0 & 0.3 & -13.3 & 17.1 & 10.0 \\
\hline \multicolumn{10}{|l|}{ Sri Lanka } \\
\hline \multicolumn{10}{|l|}{ Southeast Asia } \\
\hline Brunei Darussalam & $\ldots$ & $\ldots$ & $\ldots$ & $\ldots$ & $\ldots$ & $\ldots$ & $\ldots$ & $\ldots$ & $\therefore$ \\
\hline Cambodia & 48.8 & & $\ldots$ & & & & & & \\
\hline Indonesia & 3.6 & 1.3 & 4.8 & 6.0 & 4.8 & 4.8 & 4.0 & 4.7 & 4.0 \\
\hline \multicolumn{10}{|l|}{ Lao People's Democratic Republic } \\
\hline Malaysia & 24.9 & 5.1 & 11.0 & 4.2 & 6.0 & 4.9 & 4.3 & 6.1 & 4.8 \\
\hline Myanmar & $\ldots$ & $\ldots$ & $10.1(2011)$ & 8.8 & 9.4 & 10.2 & 9.1 & 9.8 & \\
\hline Philippines & 16.0 & 1.1 & 23.3 & 15.2 & 6.2 & 2.4 & 14.5 & -2.8 & 7.0 \\
\hline Singapore & 15.3 & 9.5 & 29.7 & 1.7 & 2.7 & -5.1 & 3.7 & 10.4 & 7.0 \\
\hline Thailand & 6.9 & 5.0 & 14.2 & 1.9 & -4.0 & 0.1 & 12.5 & 1.8 & 3.6 \\
\hline Viet Nam & $\ldots$ & $\ldots$ & $\ldots$ & 2.0 & 1.0 & 1.6 & 0.8 & 2.9 & -2.0 \\
\hline \multicolumn{10}{|l|}{ The Pacific } \\
\hline Cook Islands & $\ldots$ & &.. & & $\ldots$ & $\ldots$ & $\ldots$ & $\ldots$ & \\
\hline Fiji & -5.6 & $2.3(2006)$ & 7.6 & 5.2 & -2.8 & 8.9 & 2.1 & 1.5 & 6.1 \\
\hline \multirow{2}{*}{\multicolumn{10}{|c|}{$\begin{array}{l}\text { Kiribati } \\
\text { Marshall Islands }\end{array}$}} \\
\hline & & & $\ldots$ & $\ldots$ & $\ldots$ & $\ldots$ & $\ldots$ & $\ldots$ & $\ldots$ \\
\hline Micronesia, Federated States of & $\cdots$ & $\cdots$ & $\cdots$ & $\ldots$ & $\cdots$ & $\ldots$ & $\ldots$ & $\ldots$ & $\ldots$ \\
\hline Nauru & $\ldots$ & $\ldots$ & $\ldots$ & $\ldots$ & $\cdots$ & $\ldots$ & $\ldots$ & $\ldots$ & $\ldots$ \\
\hline \multicolumn{10}{|l|}{ Niue } \\
\hline \multicolumn{10}{|l|}{ Palau } \\
\hline \multicolumn{10}{|l|}{ Papua New Guinea } \\
\hline Samoa ${ }^{a}$ & 2.8 & - & 15.2 & 3.2 & $\ldots$ & $\ldots$ & $\ldots$ & $\ldots$ & $\ldots$ \\
\hline Solomon Islands & $\ldots$ & $\ldots$ & $\ldots$ & $\ldots$ & $\ldots$ & $\ldots$ & $\ldots$ & $\ldots$ & $\ldots$ \\
\hline Timor-Leste & $\ldots$ & $\ldots$ & $\ldots$ & $\ldots$ & $\ldots$ & $\ldots$ & $\ldots$ & $\ldots$ & $\ldots$ \\
\hline \multicolumn{10}{|l|}{ Tonga } \\
\hline \multicolumn{10}{|l|}{ Tuvalu } \\
\hline \multicolumn{10}{|l|}{ Vanuatu } \\
\hline Developed ADB Member Economies & & & & & & & & & \\
\hline Australia & 1.3 & -1.0 & 0.5 & -3.2 & -1.1 & -1.6 & -2.2 & -1.0 & 3.1 \\
\hline Japan & 5.7 & 1.3 & 15.6 & -0.8 & 1.9 & -1.1 & - & 3.1 & 1.1 \\
\hline New Zealand & 3.5 & 0.3 & 3.7 & 0.5 & 3.1 & 1.6 & 1.3 & 2.3 & 0.8 \\
\hline
\end{tabular}

... = data not available, - = magnitude equals zero, $\mathrm{ADB}=$ Asian Development Bank.

a Refers to volume indices of industrial production.

Sources: Economy sources. 


\section{Money, Finance, and Prices}

Money, Finance, and Prices summarizes the latest statistics on consumer price inflation, the money supply, and nonperforming loans. Other monetary and financial statistics include producer price inflation, interest rates, bank lending, official exchange rates, and stock market capitalization and growth rates.

\section{Inflation accelerated in 25 economies and decelerated in 22 economies in 2018.}

In 25 of 47 economies across Asia and the Pacific with available data, consumer price inflation accelerated from 2017 to 2018, while in 22 economies it decelerated (Figure 2.3.1). Rising oil prices and falling exchange rates contributed to an acceleration in inflation among some developing member economies (ADB 2019). The largest inflation gains from 2017 to 2018 occurred in Turkmenistan (5.5 percentage points), Niue (5.1 percentage points), Uzbekistan (3.7 percentage points), and Solomon Islands (3.0 percentage points). In Turkmenistan, subsidy cuts fueled inflation at the same time as foreign exchange pressures drove up prices for imported goods (ADB 2019). In Uzbekistan, inflation reflected the ongoing impact of foreign exchange liberalization, utility price increases, the removal of price controls for bread and other basic goods, higher wages and pensions, and rapid credit growth (ADB 2019). The increase observed in Solomon Islands was driven by a reversal in the consumer price index (CPI) for food and nonalcoholic beverages, from $-0.7 \%$ in 2017 to $1.9 \%$ in 2018 .

The largest decreases in inflation from 2017 to 2018 were observed in Azerbaijan (-10.6 percentage points), Afghanistan (-7.0 percentage points), and Nauru ( -4.0 percentage points). In Azerbaijan, a decline of 15.2 percentage points in the CPI for
Figure 2.3.1: Inflation Rates in Select Economies of Asia and the Pacific (\% annual change)

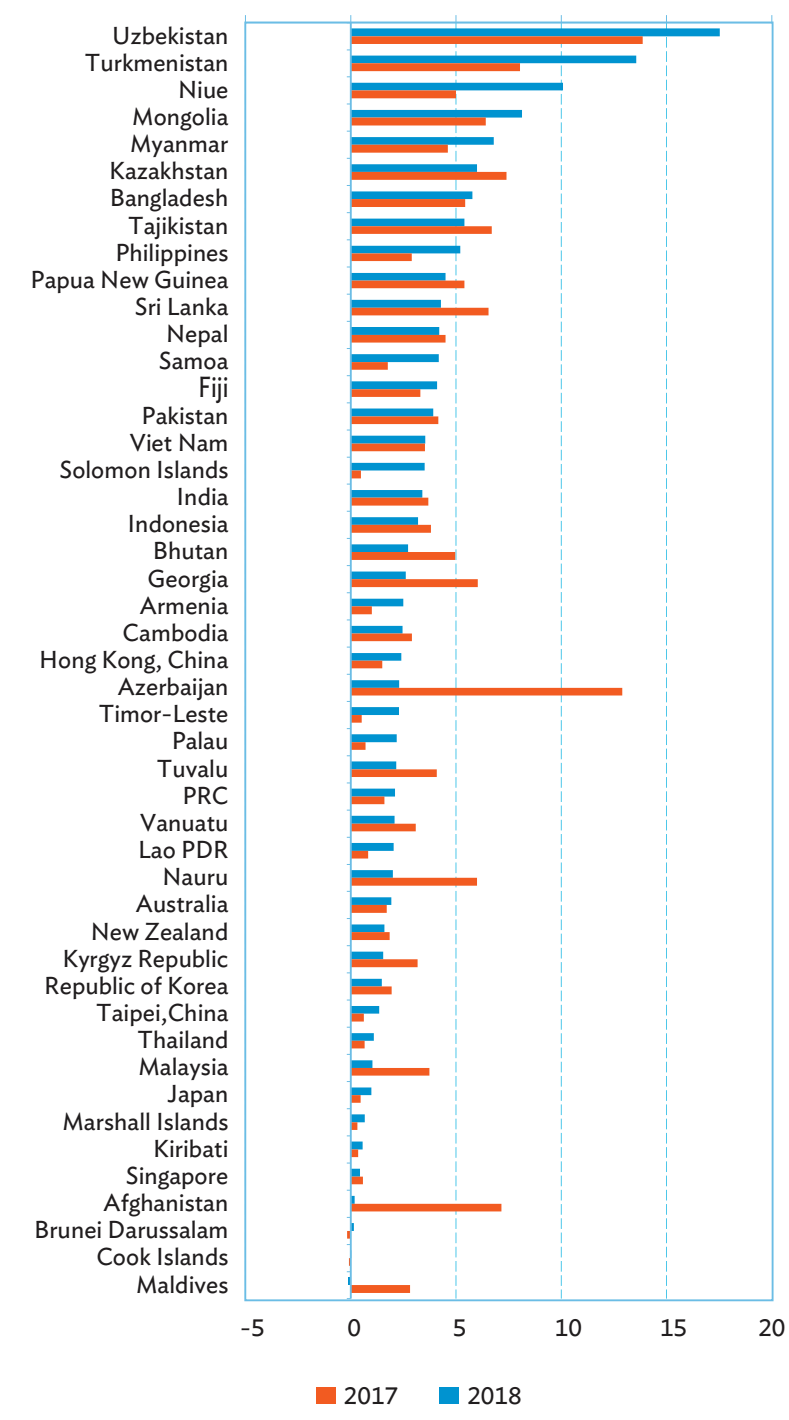

Lao PDR = Lao People's Democratic Republic, PRC = People's Republic of China.

Note: This chart includes economies with available data for both 2017 and 2018.

Source: $\quad$ Table 2.3.1, Key Indicators for Asia and the Pacific 2019. 
food and nonalcoholic beverages lowered consumer price inflation from $12.9 \%$ in 2017 to $2.3 \%$ in 2018 . In Afghanistan, the CPI for food and nonalcoholic beverages fell by 11.6 percentage points, leading to a drop in overall inflation from $7.2 \%$ in 2017 to $0.2 \%$ in 2018.

\section{Banks' balance sheets bounce back from the global financial crisis}

The global financial crisis of 2007-2008 strained the financial systems of many economies in Asia and the Pacific. During and after the crisis, the value of nonperforming bank loans-as well as the percentage of nonperforming loans as a share of total gross loans-rose across the region before gradually recovering in subsequent years.

From 2010 to 2017, the percentage of nonperforming loans as a share of total gross loans fell in 22 of the 31 economies with available data (Figure 2.3.2). The biggest improvements were seen in Afghanistan (-37.7 percentage points), Kazakhstan (-11.6 percentage points), and Maldives (-10.5 percentage points).

The largest increases from 2010 to 2017 were observed in Tajikistan (12.9 percentage points), Vanuatu (10.3 percentage points), and India (7.3 percentage points).

\section{Data Issues and Comparability}

Not all reporting economies meet the standards and classifications of the International Monetary Fund (IMF) on the compilation of monetary and financial statistics available on the fund's Dissemination Standards Bulletin Board. ${ }^{3}$

CPI coverage differs across economies. Most economies try to follow the Classification of

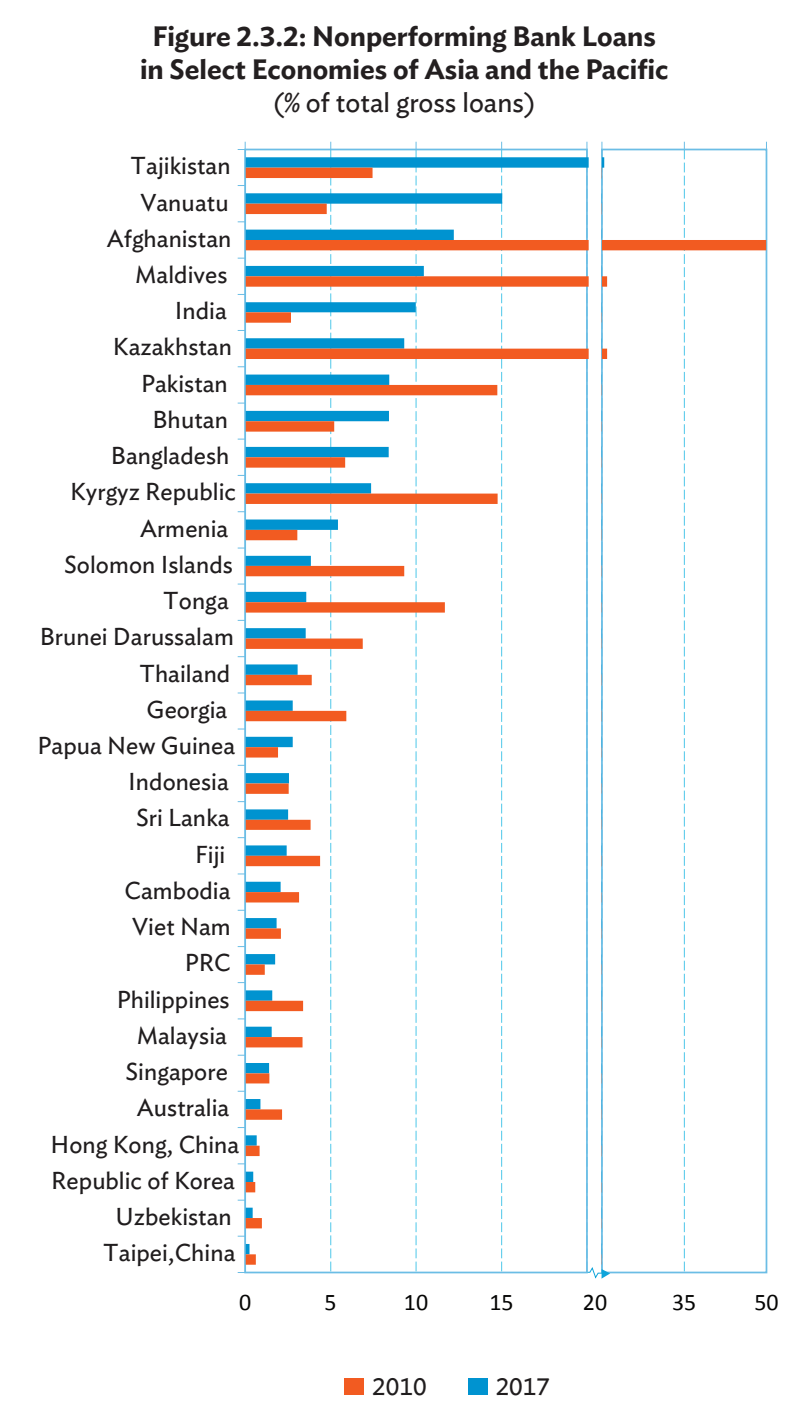

PRC $=$ People's Republic of China

Note: $\quad$ This chart includes economies with available data for both 2010 and 2017. For 2010, data included are for 2010 to 2012. For 2017, data included are for 2015 to 2017.

Source: Table 2.3.9, Key Indicators for Asia and the Pacific 2019.

Individual Consumption by Purpose guidelines, but the implementation varies across economies. In some instances, the basket of goods and services in the index is outdated or represents only urban areas (or the capital city). Other price measurements, such as the wholesale price index and the producer price index, are not available in Pacific economies.

3 For more information on the IMF's standards and classifications on the compilation of monetary and financial statistics, go to http://dsbb.imf. org/Pages/SDDS/StatMethod.aspx. 
Broad money supply in most economies relates to M2, which includes cash, checking deposits, savings deposits, money market securities, mutual funds, and other time deposits. However, 12 of the 44 economies with available data reported M3, thereby posing limits to comparability as M3 also includes less liquid financial assets. Not all economies publish the same types of aggregates, and, even when aggregates have the same name (i.e., M1, M2, M3, etc.), their asset composition often differs significantly. For example, the definition of M2 in one economy may include time deposits with maturities of 1 year or less, whereas another economy's M2 definition may include time deposits with maturities of 2 years or less.

Finally, some economies use the central bank policy rate, while others use commercial bank rates in measuring banks' average deposit and lending rates. 
Prices

Table 2.3.1: $\quad$ Growth Rates of Consumer Price Index ${ }^{a}$

(\%)

\begin{tabular}{|c|c|c|c|c|c|c|c|c|c|}
\hline ADB Regional Member & 2000 & 2005 & 2010 & 2013 & 2014 & 2015 & 2016 & 2017 & 2018 \\
\hline \multicolumn{10}{|l|}{ Developing ADB Member Economies } \\
\hline \multicolumn{10}{|l|}{ Central and West Asia } \\
\hline Afghanistan & & 11.9 & -4.5 & 6.4 & 5.6 & -0.6 & 4.0 & 7.2 & 0.2 \\
\hline Armenia & -0.8 & 0.6 & 8.2 & 5.8 & 3.0 & 3.7 & -1.4 & 1.0 & 2.5 \\
\hline Azerbaijan & 1.8 & 9.6 & 5.7 & 2.4 & 1.4 & 4.0 & 12.4 & 12.9 & 2.3 \\
\hline Georgia & 4.0 & 8.2 & 7.1 & -0.5 & 3.1 & 4.0 & 2.1 & 6.0 & 2.6 \\
\hline Kazakhstan & 13.2 & 7.6 & 7.1 & 5.8 & 6.7 & 6.6 & 14.6 & 7.4 & 6.0 \\
\hline Kyrgyz Republic & 18.7 & 4.3 & 8.0 & 6.6 & 7.5 & 6.5 & 0.4 & 3.2 & 1.5 \\
\hline Pakistan & 3.6 & 9.3 & 10.1 & 7.4 & 8.6 & 4.5 & 2.9 & 4.2 & 3.9 \\
\hline Tajikistan & 60.6 & 7.1 & 9.8 & 3.7 & 7.4 & 5.1 & 6.1 & 6.7 & 5.4 \\
\hline Turkmenistan & 8.0 & 10.7 & 4.4 & 6.8 & 6.0 & 7.4 & 3.6 & 8.0 & 13.6 \\
\hline Uzbekistan ${ }^{\mathrm{b}}$ & 24.9 & 6.4 & 7.6 & 7.0 & 6.4 & 5.5 & 9.5 & 13.9 & 17.5 \\
\hline \multicolumn{10}{|l|}{ East Asia } \\
\hline China, People's Republic of & 0.4 & 1.8 & 3.3 & 2.6 & 2.0 & 1.4 & 2.0 & 1.6 & 2.1 \\
\hline Hong Kong, China & -3.7 & 0.8 & 2.3 & 4.3 & 4.4 & 3.0 & 2.4 & 1.5 & 2.4 \\
\hline Korea, Republic of & 2.3 & 2.8 & 2.9 & 1.3 & 1.3 & 0.7 & 1.0 & 1.9 & 1.5 \\
\hline Mongolia & $8.0(2001)$ & 9.5 & 12.9 & 12.5 & 11.0 & 1.9 & 1.3 & 6.4 & 8.1 \\
\hline Taipei,China & 1.3 & 2.3 & 1.0 & 0.8 & 1.2 & -0.3 & 1.4 & 0.6 & 1.4 \\
\hline \multicolumn{10}{|l|}{ South Asia } \\
\hline Bangladesh & 2.8 & 6.5 & 6.8 & 6.8 & 7.3 & 6.4 & 5.9 & 5.4 & 5.8 \\
\hline Bhutan & 4.0 & 5.3 & 7.0 & 8.8 & 8.3 & 4.5 & 3.2 & 5.0 & 2.7 \\
\hline India & 3.7 & 4.2 & 10.4 & 12.2 & 5.8 & 4.9 & 4.6 & 3.7 & 3.4 \\
\hline Maldives & -1.2 & 1.3 & 6.1 & 3.8 & 2.1 & 1.0 & 0.5 & 2.8 & -0.1 \\
\hline Nepal & 3.4 & 4.6 & 9.5 & 9.9 & 9.1 & 7.2 & 9.9 & 4.5 & 4.2 \\
\hline Sri Lankac & 6.2 & 11.0 & 6.2 & 6.9 & 5.1 & 2.2 & 4.0 & 6.5 & 4.3 \\
\hline \multicolumn{10}{|l|}{ Southeast Asia } \\
\hline Brunei Darussalam & 1.2 & 1.1 & 0.4 & 0.4 & -0.2 & -0.4 & -0.7 & -0.2 & 0.1 \\
\hline Cambodiac & -0.8 & 5.8 & 4.0 & 2.9 & 3.9 & 1.2 & 3.0 & 2.9 & 2.5 \\
\hline Indonesiad & 3.8 & 10.5 & 5.1 & 7.0 & 6.4 & 6.4 & 3.5 & 3.8 & 3.2 \\
\hline Lao People's Democratic Republic & 23.2 & 7.2 & 6.0 & 6.4 & 4.1 & 1.3 & 1.6 & 0.8 & 2.0 \\
\hline Malaysia & 1.5 & 2.9 & 1.7 & 2.1 & 3.2 & 2.1 & 2.1 & 3.7 & 1.0 \\
\hline Myanmar & -0.2 & 9.4 & 7.7 & 8.9 & 5.0 & 9.5 & 6.9 & 4.6 & 6.8 \\
\hline Philippines & 6.7 & 6.5 & 3.8 & 2.6 & 3.6 & 0.7 & 1.3 & 2.9 & 5.2 \\
\hline Singapore & 1.3 & 0.5 & 2.8 & 2.4 & 1.0 & -0.5 & -0.5 & 0.6 & 0.4 \\
\hline Thailand & 1.6 & 4.4 & 3.3 & 2.2 & 1.9 & -0.9 & 0.2 & 0.7 & 1.1 \\
\hline Viet Nam & $-0.3(2001)$ & 8.3 & 9.2 & 6.6 & 4.8 & 0.6 & 2.7 & 3.5 & 3.5 \\
\hline \multicolumn{10}{|l|}{ The Pacific } \\
\hline Cook Islands & 3.2 & 2.5 & -0.3 & 1.9 & 2.1 & 1.9 & -0.3 & -0.1 & 0.0 \\
\hline Fiji & 1.1 & $2.5(2006)$ & 3.7 & 2.9 & 0.6 & 1.4 & 3.9 & 3.3 & 4.1 \\
\hline Kiribatic & 0.4 & -0.3 & -3.0 & -1.5 & 2.1 & 0.6 & 1.9 & 0.4 & 0.6 \\
\hline Marshall Islands ${ }^{c}$ & 0.9 & 3.5 & 1.8 & 1.9 & 1.1 & -2.2 & -1.5 & 0.3 & 0.7 \\
\hline Micronesia, Federated States of & 1.8 & 4.1 & 3.6 & 2.1 & 0.7 & 0.0 & -1.0 & 0.2 & \\
\hline Nauru & 2.3 & 9.8 & -3.1 & 4.1 & 0.3 & 9.8 & 8.2 & 6.0 & 2.0 \\
\hline Niue & & 0.8 & 5.3 & -1.2 & 0.4 & 1.8 & 1.3 & 5.0 & 10.1 \\
\hline Palau & $-1.8(2001)$ & 3.9 & 1.4 & 3.4 & 4.2 & 0.9 & -1.0 & 0.7 & 2.2 \\
\hline Papua New Guinea & 15.6 & 1.8 & $4.4(2011)$ & 5.0 & 5.2 & 6.0 & 6.7 & 5.4 & 4.5 \\
\hline Samoa & 0.9 & 1.9 & 0.8 & 0.6 & -0.4 & 0.7 & 1.3 & 1.8 & 4.2 \\
\hline Solomon Islands ${ }^{\mathrm{c}}$ & 7.1 & 7.2 & 0.9 & 5.4 & 5.2 & -0.6 & 0.5 & 0.5 & 3.5 \\
\hline Timor-Leste & & 1.6 & 5.2 & 9.5 & 0.8 & 0.6 & -1.5 & 0.5 & 2.3 \\
\hline Tonga & 6.3 & 8.7 & 3.5 & 0.8 & 2.5 & -1.1 & 2.6 & 7.4 & \\
\hline Tuvalu & 3.9 & 3.2 & -1.9 & 2.0 & 1.1 & 3.2 & 3.5 & 4.1 & 2.2 \\
\hline Vanuatu & 2.5 & 0.8 & 2.8 & 1.5 & 0.8 & 2.5 & 0.8 & 3.1 & 2.1 \\
\hline \multicolumn{10}{|l|}{ Developed ADB Member Economies } \\
\hline Australia & 2.4 & 2.4 & 2.3 & 2.3 & 2.7 & 1.7 & 1.4 & 1.7 & 1.9 \\
\hline Japan & -0.7 & -0.3 & -0.7 & 0.3 & 2.8 & 0.8 & -0.1 & 0.5 & 1.0 \\
\hline New Zealand & 2.6 & 3.0 & 2.3 & 1.1 & 1.2 & 0.3 & 0.6 & 1.9 & 1.6 \\
\hline \multicolumn{10}{|c|}{$\ldots=$ data not available, $0.0=$ magnitude is less than half of unit employed, $A D B=$ Asian Development Bank. } \\
\hline \multicolumn{10}{|c|}{ a Data refer to the whole economy, unless otherwise indicated. } \\
\hline \multirow{2}{*}{\multicolumn{10}{|c|}{$\begin{array}{l}\text { b Prior to } 2016 \text {, values were calculat } \\
\text { c Data refer to capital city. }\end{array}$}} \\
\hline & & & & & & & & & \\
\hline d For 2000-2002, consumer price i & er to the consum & r price indexes & 43 cities; for & $03-200$ & 5 cities; & $2008-2$ & 66 citi & nd for 2 & $-2018,82$ \\
\hline
\end{tabular}


Table 2.3.2: Growth Rates of Food and Nonalcoholic Beverages Consumer Price Index (\%)

\begin{tabular}{|c|c|c|c|c|c|c|c|c|c|}
\hline ADB Regional Member & 2000 & 2005 & 2010 & 2013 & 2014 & 2015 & 2016 & 2017 & 2018 \\
\hline \multicolumn{10}{|l|}{ Developing ADB Member Economies } \\
\hline \multicolumn{10}{|l|}{ Central and West Asia } \\
\hline Afghanistan & & 9.1 & -9.1 & 5.2 & 10.0 & -0.6 & 4.9 & 10.0 & -1.6 \\
\hline Armenia & -5.9 & 0.8 & 9.4 & 5.8 & 1.7 & 3.1 & -3.3 & 4.1 & 2.3 \\
\hline Azerbaijan & $\ldots$ & $12.4(2006)$ & 7.5 & 2.0 & 0.7 & 4.8 & 13.7 & 17.2 & 2.0 \\
\hline Georgia & & 8.9 & 11.7 & -0.7 & 5.1 & 4.2 & 1.6 & 6.8 & 2.2 \\
\hline Kazakhstan & 16.4 & 8.8 & 5.9 & 4.0 & 5.8 & 5.7 & 12.9 & 8.5 & 4.7 \\
\hline Kyrgyz Republic ${ }^{\mathrm{b}}$ & 18.5 & 7.0 & 6.5 & 5.3 & 8.2 & 3.7 & -6.5 & 2.5 & -2.2 \\
\hline Pakistanc & $2.5(2002)$ & 12.5 & 12.6 & 6.7 & 8.6 & 2.6 & 1.0 & 3.3 & 2.8 \\
\hline Tajikistan & & & & 3.1 & 10.0 & 3.8 & 6.5 & 7.8 & 4.9 \\
\hline \multicolumn{10}{|l|}{ Turkmenistan } \\
\hline Uzbekistan & 30.0 & 4.3 & 4.9 & 4.8 & 3.7 & 2.7 & 7.9 & 18.1 & 20.1 \\
\hline \multicolumn{10}{|l|}{ East Asia } \\
\hline China, People's Republic of & -2.6 & 2.9 & 7.2 & 4.7 & 3.1 & 2.3 & 4.6 & -1.4 & 1.8 \\
\hline Hong Kong, China & & $2.4(2006)$ & 3.5 & 4.3 & 3.6 & 3.3 & 3.6 & 1.1 & 4.3 \\
\hline Korea, Republic of & 0.8 & 3.1 & 6.4 & 0.9 & 0.3 & 1.6 & 2.3 & 3.4 & 2.8 \\
\hline Mongolia & $8.8(2001)$ & 15.6 & 18.6 & 13.3 & 6.6 & -4.8 & 1.7 & 7.3 & 9.1 \\
\hline Taipei, China & 0.2 & 10.3 & 1.1 & 1.1 & 4.0 & 3.9 & 7.9 & -1.8 & 0.6 \\
\hline \multicolumn{10}{|l|}{ South Asia } \\
\hline Bangladeshe & & & $7.7(2012)$ & 5.2 & 8.6 & 6.7 & 4.9 & 6.0 & 7.1 \\
\hline Bhutan & & 5.3 & 9.4 & 8.1 & 10.1 & 3.3 & 4.0 & 7.5 & 4.9 \\
\hline India & & & & & 6.1 & 4.7 & 4.4 & 1.9 & 0.4 \\
\hline Maldives ${ }^{f}$ & -4.8 & 7.8 & 7.5 & 7.2 & 0.7 & 0.5 & 0.6 & 5.6 & -1.1 \\
\hline Nepals & 0.6 & 3.8 & 15.3 & 9.5 & 11.6 & 9.6 & 10.9 & 1.9 & 2.7 \\
\hline Sri Lankah & 4.5 & 11.4 & 6.9 & 7.9 & 4.3 & 5.5 & 6.1 & 9.2 & 3.4 \\
\hline \multicolumn{10}{|l|}{ Southeast Asia } \\
\hline Brunei Darussalam & $\ldots$ & $\therefore$ & $-0.0(2011)$ & 0.1 & -0.2 & 0.8 & -0.9 & 0.3 & 1.9 \\
\hline Cambodia ${ }^{\mathrm{h}}$ & & & $4.3^{-1}$ & 3.9 & 4.9 & 4.0 & 5.6 & 3.4 & 2.5 \\
\hline Indonesia ${ }^{\mathrm{i}}$ & -4.8 & 10.0 & 9.4 & 12.0 & & 7.2 & 7.2 & 2.1 & 4.2 \\
\hline Lao People's Democratic Republic & & & $5.6(2012)$ & 12.6 & 6.9 & 4.5 & 4.3 & -0.1 & 1.2 \\
\hline Malaysia & 2.1 & 3.7 & 2.5 & 3.6 & 3.3 & 3.6 & 3.8 & 3.9 & 1.7 \\
\hline Myanmar & & $18.7(2007)$ & 7.4 & 6.8 & 6.9 & 13.1 & 9.2 & 4.4 & 6.6 \\
\hline Philippines & $3.7(2001)$ & 6.4 & 4.0 & 2.5 & 5.9 & 1.8 & 1.6 & 3.0 & 6.8 \\
\hline Singapore & 0.5 & 2.0 & 2.3 & 2.3 & 3.0 & 1.2 & 2.3 & 1.3 & 1.3 \\
\hline Thailand & -1.1 & 4.8 & 5.4 & 3.4 & 3.9 & 1.1 & 1.6 & - & 0.4 \\
\hline Viet Nam & $-1.3(2001)$ & 11.2 & 10.7 & 2.7 & 4.0 & 1.5 & 2.5 & -1.1 & 3.2 \\
\hline \multicolumn{10}{|l|}{ The Pacific } \\
\hline Cook Islands $\mathrm{h}^{\mathrm{j}}$ & 3.4 & 1.1 & 2.9 & 2.6 & 3.3 & -0.1 & 1.3 & 0.3 & 0.5 \\
\hline Fiji & -3.2 & $1.8(2006)$ & 4.1 & 3.5 & 1.9 & 4.7 & 6.0 & -2.1 & 3.4 \\
\hline Kiribatik & & $6.1(2007)$ & -4.6 & -3.5 & 0.6 & -0.6 & 1.7 & 1.8 & -1.1 \\
\hline Marshall Islands ${ }^{\mathrm{h},}$ & -0.8 & 0.3 & -1.5 & 2.6 & 2.0 & 2.3 & -1.4 & -0.3 & 1.5 \\
\hline Micronesia, Federated States of & 1.1 & 3.4 & 2.2 & 2.6 & 0.8 & 0.8 & -1.2 & -1.6 & \\
\hline Nauru & $\ldots$ & & 0.4 & & & & & & \\
\hline Niue $^{m}$ & & 1.1 & 8.2 & -0.5 & - & 2.7 & -0.2 & 3.4 & 0.6 \\
\hline Palau & $-2.4(2001)$ & -1.5 & 1.8 & 3.2 & 1.5 & 1.7 & -3.0 & 1.6 & 3.9 \\
\hline Papua New Guinea & 13.6 & 3.5 & $-1.0(2011)$ & -0.9 & 4.8 & 4.9 & 5.1 & 2.8 & 0.8 \\
\hline Samoa & & 0.2 & -6.6 & 0.7 & -3.4 & 3.3 & 5.9 & 1.4 & 5.6 \\
\hline Solomon Islands $\mathrm{h}, \mathrm{n}$ & $\ldots$ & $\ldots$ & -2.6 & 2.6 & 3.1 & -2.8 & 0.5 & -0.7 & 1.9 \\
\hline Timor-Leste & $\ldots$ & - & 6.4 & 12.0 & 0.7 & 0.3 & -2.1 & 0.9 & 1.7 \\
\hline Tonga & 0.4 & 6.0 & 3.0 & 1.8 & 3.7 & 1.9 & 1.3 & 8.6 & \\
\hline Tuvalu & 1.1 & 5.5 & -5.9 & 0.1 & 0.6 & 4.0 & 3.4 & 4.5 & 3.3 \\
\hline Vanuatu & 2.0 & 0.5 & 4.5 & 1.5 & 1.7 & 3.6 & 2.3 & 6.8 & 3.5 \\
\hline \multicolumn{10}{|l|}{ Developed ADB Member Economies } \\
\hline Australia & 2.1 & 1.6 & 1.6 & 0.5 & 1.3 & 2.1 & 0.1 & 1.8 & -0.0 \\
\hline Japan & -2.4 & -1.3 & -0.3 & -0.2 & 4.3 & 3.6 & 2.1 & 0.7 & 1.6 \\
\hline New Zealand & 1.5 & 1.2 & 1.0 & 0.4 & 0.3 & - & -0.6 & 2.1 & -0.2 \\
\hline
\end{tabular}

$\ldots$ = data not available, $-=$ magnitude equals zero, -0.0 or $0.0=$ magnitude is less than half of unit employed, $A D B=A s i a n$ Development Bank.

a Data refer to the whole economy, unless otherwise indicated.

b For 2000-2002, refers to food and drinks, which includes alcoholic beverages.

c For 2002-2008, growth rates were calculated using price indexes for food, nonalcoholic beverages, alcoholic beverages, tobacco, and narcotics. For 2009 onward, growth rates were calculated using price indexes for food and nonalcoholic beverages only.

d For 2016 onward, excludes nonalcoholic beverages.

e Refers to food, nonalcoholic and alcoholic beverages, and tobacco.

f Prior to 2012, national and capital city consumer price indexes have the same values because the series for Maldives was linked to a previously published series for Malé. From June 2012 onward, national and capital city consumer price indexes have been compiled separately. Refers to food (including fish) and nonalcoholic beverages. Prior to 2004, also includes tobacco and narcotics.

$g$ Refers to food and beverages. Includes nonalcoholic and alcoholic beverages.

h Refers to capital city.

i Consumer price index (CPI) data of Indonesia for 2000-2002 refer to CPI for 43 cities; for 2003-2007, 45 cities; for 2008-2013, 66 cities; and for 2014-2018, 82 cities. Refers to Indonesia's CPI group "Foodstuff” consisting of cereals, cassava, and related products; meat and related products; fresh fish; preserved fish; eggs, milk, and related products; vegetables; beans and nuts; fruits; spices; fats and oils; and other food items. The group does not include nonalcoholic and alcoholic beverages.

j Refers to fruits and vegetables; meat, poultry and fish; cereal products; soft drink and sweets; farm products, fats and oils; other food; and prepared food.

k For 2006 onward, refers to the Tarawa Retail Price Index. The index is collected data on South Tarawa, which represents data for all of Kiribati. Data refer to the weighted average of food and nonalcoholic drinks price indexes.

I Refers to food.

m For 2003-2011, data refers to food.

n For 2008-2017, excludes nonalcoholic beverages.

o Includes restaurant meals and take away and fast foods.

Source: Economy sources. 


\section{Prices}

Table 2.3.3: Growth Rates of Wholesale and/or Producer Price Indexes

$(\%)$

\begin{tabular}{|c|c|c|c|c|c|c|c|c|c|}
\hline ADB Regional Member & 2000 & 2005 & 2010 & 2013 & 2014 & 2015 & 2016 & 2017 & 2018 \\
\hline \multicolumn{10}{|l|}{ Developing ADB Member Economies } \\
\hline \multicolumn{10}{|l|}{ Central and West Asia } \\
\hline \multicolumn{10}{|l|}{ Afghanistan } \\
\hline Armenia & 0.8 & 7.7 & 22.6 & 4.7 & 8.5 & -0.8 & 1.5 & 3.9 & 1.6 \\
\hline Azerbaijan & $3.3(2001)$ & 17.3 & 30.5 & -3.9 & -5.1 & -30.6 & 27.5 & 36.8 & 26.0 \\
\hline Georgia & 5.8 & 7.5 & 11.3 & -2.0 & 2.9 & 7.5 & -0.1 & 11.0 & 6.1 \\
\hline Kazakhstan & 38.0 & 23.7 & 25.2 & -0.3 & 9.5 & -20.5 & 16.8 & 15.3 & 19.0 \\
\hline Kyrgyz Republic & 29.6 & 2.8 & 22.8 & -2.1 & 1.5 & 8.8 & 6.4 & 1.7 & 1.5 \\
\hline Pakistan & 1.8 & 6.8 & 13.8 & 7.4 & 8.2 & -0.3 & -1.0 & 4.0 & 3.5 \\
\hline Tajikistan & 39.2 & 10.4 & 27.2 & 2.1 & 4.7 & 3.0 & 14.7 & 1.6 & 1.8 \\
\hline \multicolumn{10}{|l|}{ Turkmenistan } \\
\hline Uzbekistan & 60.9 & 25.6 & 15.6 & 11.7 & 13.6 & 13.5 & 14.8 & 17.5 & 31.8 \\
\hline \multicolumn{10}{|l|}{ East Asia } \\
\hline China, People's Republic of & 2.8 & 4.9 & 5.5 & -1.9 & -1.9 & -5.2 & -1.4 & 6.3 & 3.5 \\
\hline Hong Kong, China & 0.2 & 0.8 & 6.0 & -3.1 & -1.7 & -2.7 & 1.3 & 3.8 & 2.0 \\
\hline Korea, Republic of & 2.1 & 2.1 & 3.8 & -1.6 & -0.5 & -4.0 & -1.8 & 3.5 & 1.9 \\
\hline Mongolia & $\ldots$ & $\ldots$ & $\ldots$ & $\ldots$ & $\ldots$ & $\ldots$ & 11.3 & 17.5 & -8.1 \\
\hline Taipei,China & 1.8 & 0.6 & 5.5 & -2.4 & -0.6 & -8.9 & -3.0 & 0.9 & 3.6 \\
\hline \multicolumn{10}{|l|}{ South Asia } \\
\hline Bangladesh & -0.4 & 3.4 & & & & & & & \\
\hline Bhutan & & & $5.8(2012)$ & 2.7 & 3.0 & 0.6 & 1.2 & 5.8 & 4.7 \\
\hline India & 7.2 & 4.5 & 9.6 & 5.2 & 1.3 & -3.7 & 1.7 & 2.9 & 4.3 \\
\hline Maldives & $-2.4(2002)$ & 4.6 & 3.9 & 0.3 & 2.1 & -2.4 & & & \\
\hline Nepal & $1.3(2001)$ & 7.4 & 12.2 & 9.0 & 8.3 & 6.1 & 6.3 & 2.7 & 1.7 \\
\hline Sri Lanka & 1.7 & 11.5 & 2.6 & 9.2 & 3.2 & 1.0 & 4.2 & 7.4 & 3.4 \\
\hline \multicolumn{10}{|l|}{ Southeast Asia } \\
\hline Brunei Darussalam & $\ldots$ & $\ldots$ & $\ldots$ & $\ldots$ & $\ldots$ & $\ldots$ & $\ldots$ & $\ldots$ & $\ldots$ \\
\hline \multicolumn{10}{|l|}{ Cambodia } \\
\hline Indonesia ${ }^{b}$ & 12.5 & 15.3 & 4.9 & -1.6 & 5.4 & 4.4 & 7.9 & 4.6 & 5.5 \\
\hline \multicolumn{10}{|l|}{ Lao People's Democratic Republic } \\
\hline Malaysia & $-1.8(2001)$ & $3.8(2006)$ & $12.3(2011)$ & -2.7 & 1.5 & -7.4 & -1.1 & 6.7 & -1.1 \\
\hline \multicolumn{10}{|l|}{ Myanmar } \\
\hline Philippines & 5.8 & 11.4 & 5.9 & 1.6 & 2.7 & -3.9 & 1.2 & 4.4 & 7.0 \\
\hline Singapore & 10.0 & 9.6 & 4.7 & -2.7 & -3.3 & -15.3 & -6.9 & 7.0 & 6.3 \\
\hline Thailand & 3.9 & 9.1 & 9.4 & 0.3 & 0.1 & -4.1 & -1.2 & 0.7 & 0.4 \\
\hline Viet Nam & -0.2 & 4.4 & 12.6 & 5.3 & 3.3 & -0.6 & -0.6 & 2.8 & 3.1 \\
\hline \multicolumn{10}{|l|}{ The Pacific } \\
\hline Cook Islands & $\ldots$ & $\ldots$ & $\ldots$ & $\cdots$ & $\cdots$ & $\ldots$ & $\ldots$ & $\ldots$ & $\ldots$ \\
\hline Fiji & $\ldots$ & $\ldots$ & $\ldots$ & $\ldots$ & $\ldots$ & $\ldots$ & $\ldots$ & $\ldots$ & $\ldots$ \\
\hline Kiribati & $\ldots$ & $\cdots$ & $\cdots$ & $\ldots$ & $\ldots$ & $\ldots$ & $\ldots$ & $\ldots$ & $\ldots$ \\
\hline Marshall Islands & $\ldots$ & $\ldots$ & $\ldots$ & $\ldots$ & $\ldots$ & $\ldots$ & (n) & $\ldots$ & $\ldots$ \\
\hline Micronesia, Federated States of & $\ldots$ & $\cdots$ & $\ldots$ & $\ldots$ & $\ldots$ & $\ldots$ & 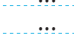 & $\ldots$ & $\ldots$ \\
\hline Nauru & $\ldots$ & $\ldots$ & $\ldots$ & $\ldots$ & $\ldots$ & $\ldots$ & $\ldots$ & $\ldots$ & $\ldots$ \\
\hline Niue & $\ldots$ & $\ldots$ & $\ldots$ & $\cdots$ & $\ldots$ & $\ldots$ & $\ldots$ & $\ldots$ & $\ldots$ \\
\hline Palau & $\ldots$ & $\ldots$ & $\ldots$ & $\ldots$ & $\ldots$ & $\ldots$ & $\ldots$ & $\ldots$ & $\ldots$ \\
\hline Papua New Guinea & $\ldots$ & $\ldots$ & $\ldots$ & $\ldots$ & $\ldots$ & $\ldots$ & $\ldots$ & $\ldots$ & $\ldots$ \\
\hline Samoa & $\ldots$ & $\ldots$ & $\ldots$ & $\ldots$ & $\ldots$ & $\ldots$ & $\ldots$ & $\ldots$ & $\ldots$ \\
\hline Solomon Islands & $\ldots$ & $\ldots$ & $\ldots$ & $\ldots$ & $\ldots$ & $\ldots$ & $\ldots$ & $\ldots$ & $\ldots$ \\
\hline Timor-Leste & $\ldots$ & $\ldots$ & $\ldots$ & $\ldots$ & $\ldots$ & $\ldots$ & $\ldots$ & $\ldots$ & $\ldots$ \\
\hline Tonga & $\ldots$ & $\ldots$ & $\ldots$ & $\ldots$ & $\ldots$ & $\ldots$ & $\ldots$ & $\ldots$ & $\ldots$ \\
\hline Tuvalu & $\ldots$ & $\ldots$ & $\ldots$ & $\ldots$ & $\ldots$ & $\ldots$ & $\ldots$ & $\ldots$ & $\ldots$ \\
\hline Vanuatu & $\ldots$ & $\ldots$ & $\ldots$ & $\ldots$ & $\ldots$ & $\ldots$ & $\ldots$ & $\ldots$ & $\ldots$ \\
\hline \multicolumn{10}{|l|}{ Developed ADB Member Economies } \\
\hline Australia & 2.6 & 3.6 & -0.1 & 1.2 & 2.1 & 1.0 & 1.5 & 1.0 & 1.6 \\
\hline Japan & 0.0 & 1.6 & -0.1 & 1.3 & 1.1 & -3.0 & -3.5 & 2.3 & 2.6 \\
\hline New Zealand & 5.2 & 3.4 & 2.3 & 2.2 & 1.1 & -1.3 & 0.8 & 4.8 & 3.4 \\
\hline
\end{tabular}

$\ldots=$ data not available, $0.0=$ magnitude is less than half of unit employed, $A D B=$ Asian Development Bank.

a For agricultural and industrial products only.

b For 2013, change of the wholesale price index was estimated by rebasing January-October 2013 and 2012 data to 2005.

Source: Economy sources. 
Table 2.3.4: Growth Rates of Gross Domestic Product Deflator

(\%)

\begin{tabular}{|c|c|c|c|c|c|c|c|c|c|}
\hline ADB Regional Member & 2000 & 2005 & 2010 & 2013 & 2014 & 2015 & 2016 & 2017 & 2018 \\
\hline \multicolumn{10}{|l|}{ Developing ADB Member Economies } \\
\hline \multicolumn{10}{|l|}{ Central and West Asia } \\
\hline Afghanistan & & 11.6 & 14.3 & 3.5 & -1.0 & 5.1 & 5.2 & -0.5 & 2.7 \\
\hline Armenia & -1.4 & 3.2 & 7.8 & 3.4 & 2.3 & 1.2 & 0.3 & 2.1 & 2.5 \\
\hline Azerbaijan & 12.5 & 16.1 & 13.6 & 0.4 & -1.3 & -8.9 & 14.7 & 16.2 & 11.9 \\
\hline Georgia & 4.7 & 7.9 & 8.5 & -0.8 & 3.8 & 5.9 & 4.2 & 6.1 & 3.6 \\
\hline Kazakhstan & 17.4 & 17.9 & 19.6 & 9.5 & 5.8 & 1.9 & 13.6 & 8.6 & 6.4 \\
\hline Kyrgyz Republic & 27.2 & 7.1 & 10.0 & 3.2 & 8.4 & 3.4 & 6.1 & 6.3 & 1.5 \\
\hline Pakistan & $5.3(2001)$ & 7.8 & 10.9 & 7.0 & 7.4 & 4.1 & 0.4 & 4.0 & 2.1 \\
\hline Tajikistan & 22.7 & 9.5 & 12.4 & 4.3 & 5.5 & 0.2 & 5.2 & 4.9 & \\
\hline Turkmenistan & 21.3 & 7.0 & 2.3 & 1.2 & 0.6 & -4.9 & -5.0 & -1.6 & 7.8 \\
\hline Uzbekistan & 47.1 & 21.4 & 18.9 & 11.7 & 14.3 & 10.4 & 8.7 & 19.4 & 28.1 \\
\hline \multicolumn{10}{|l|}{ East Asia } \\
\hline China, People's Republic of & 2.0 & 3.8 & 6.7 & 2.2 & 0.8 & 0.1 & 1.1 & & $\ldots$ \\
\hline Hong Kong, China & -3.4 & -0.2 & 0.3 & 1.8 & 2.9 & 3.6 & 1.6 & 3.0 & 3.6 \\
\hline Korea, Republic of & $3.5(2001)$ & 1.0 & 2.7 & 1.0 & 0.9 & 3.2 & 2.0 & 2.2 & 0.5 \\
\hline Mongolia & 12.0 & 20.1 & $15.1(2011)$ & 2.9 & 7.4 & 1.7 & 2.2 & 10.6 & 8.7 \\
\hline Taipei,China & 7.6 & -1.5 & -1.5 & 1.5 & 1.7 & 3.3 & 0.9 & -1.2 & -1.0 \\
\hline \multicolumn{10}{|l|}{ South Asia } \\
\hline Bangladesh & 1.9 & 5.1 & 7.1 & 7.2 & 5.7 & 5.9 & 6.7 & 6.3 & 5.6 \\
\hline Bhutan & 3.7 & 5.9 & 6.0 & 5.9 & 7.3 & 3.6 & 4.5 & 5.5 & \\
\hline India & 3.6 & 4.2 & 9.0 & 6.2 & 3.3 & 2.1 & 3.5 & 3.1 & 4.7 \\
\hline Maldives & 36.7 (2001) & 9.2 & 2.9 & 6.4 & 4.6 & 7.9 & 0.1 & 3.2 & $\ldots$ \\
\hline Nepal & 4.6 & 5.8 & 14.4 & 6.1 & 9.0 & 5.1 & 5.0 & 9.1 & 5.4 \\
\hline Sri Lanka & 6.7 & 10.4 & 7.3 & 6.2 & 2.9 & 0.6 & 4.8 & 8.2 & 4.3 \\
\hline \multicolumn{10}{|l|}{ Southeast Asia } \\
\hline Brunei Darussalam & 29.0 & 18.8 & 5.3 & -2.8 & -1.8 & -17.6 & -9.2 & 5.0 & 9.2 \\
\hline Cambodia & -4.9 & 6.1 & 3.1 & 0.8 & 2.6 & 1.7 & 3.4 & 3.3 & 3.1 \\
\hline Indonesia & 9.6 & 14.3 & 8.2 & 5.0 & 5.4 & 4.0 & 2.4 & 4.2 & 3.8 \\
\hline Lao People's Democratic Republic & 21.8 & 7.8 & 3.1 & 6.5 & 5.7 & 2.3 & 3.0 & 1.8 & 2.0 \\
\hline Malaysia & $-1.6(2001)$ & $4.0(2006)$ & $5.4(2011)$ & 0.2 & 2.5 & -0.4 & 1.7 & 3.8 & 0.7 \\
\hline Myanmar & 2.5 & 19.2 & 7.0 & 4.4 & 4.2 & 4.1 & 3.6 & 6.3 & $\ldots$ \\
\hline Philippines & 5.7 & 5.8 & 4.2 & 2.0 & 3.2 & -0.6 & 1.7 & 2.3 & 3.8 \\
\hline Singapore & 3.9 & 1.9 & 1.1 & -0.4 & -0.3 & 3.2 & 0.8 & 2.6 & 1.8 \\
\hline Thailand & 1.3 & 5.1 & 4.1 & 1.8 & 1.4 & 0.9 & 2.4 & 2.3 & 1.0 \\
\hline Viet Nam & 3.4 & 9.0 & 12.1 & 4.8 & 3.7 & -0.2 & 1.1 & 4.1 & 3.4 \\
\hline \multicolumn{10}{|l|}{ The Pacific } \\
\hline Cook Islands & 2.2 & -2.6 & 1.9 & -5.0 & 3.6 & 6.4 & -2.1 & -0.2 & 4.2 \\
\hline Fiji & -2.4 & 3.1 (2006) & 2.5 & 2.3 & 4.1 & 3.7 & 4.9 & 0.1 & $\ldots$ \\
\hline Kiribati & 3.2 & 5.5 & 1.2 & 0.1 & 4.1 & 2.9 & 7.3 & -4.9 & $\ldots$ \\
\hline Marshall Islands & -2.9 & 2.0 & 1.5 & 0.3 & -3.0 & -1.4 & 7.1 & 0.5 & $\ldots$ \\
\hline Micronesia, Federated States of & 1.1 & 2.1 & 3.8 & 0.8 & 2.8 & -5.5 & 4.7 & 6.9 & $\ldots$ \\
\hline Nauru & $\ldots$ & -6.9 & -18.2 & -21.7 & -11.8 & -8.3 & 5.7 & 3.6 & 1.2 \\
\hline Niue & & 0.5 & 7.6 & 4.0 & 1.6 & -0.3 & 0.5 & 1.9 & 11.2 \\
\hline Palau & $0.8(2001)$ & 7.5 & -0.2 & 7.3 & 4.3 & 4.8 & 6.2 & -1.1 & -2.5 \\
\hline Papua New Guinea & 13.1 & 7.9 & 9.9 & 3.6 & 5.4 & -3.9 & 3.9 & 8.3 & 8.6 \\
\hline Samoa & 1.1 & 5.1 & -0.0 & 1.2 & 0.5 & 3.7 & 0.9 & 0.6 & 1.7 \\
\hline Solomon Islands & 6.9 & 8.8 & 1.8 & 6.8 & 1.9 & 4.0 & 2.9 & $\ldots$ & $\ldots$ \\
\hline Timor-Leste & $7.8(2001)$ & 23.8 & 26.5 & -4.8 & -3.2 & -36.6 & -19.6 & 9.4 & \\
\hline Tonga & 7.4 & 6.7 & 3.7 & 0.8 & 0.9 & 1.4 & 1.7 & 3.0 & \\
\hline Tuvalu & $6.1(2001)$ & 0.7 & 2.5 & 2.0 & 4.9 & 4.6 & 7.7 & 1.7 & $\cdots$ \\
\hline Vanuatu & 2.4 & 0.4 & 2.6 & 2.7 & 2.0 & 4.5 & 1.8 & 4.2 & $\ldots$ \\
\hline \multicolumn{10}{|l|}{ Developed ADB Member Economies } \\
\hline Australia & 2.5 & 3.7 & 1.1 & -0.1 & 1.5 & -0.7 & -0.5 & 3.7 & 1.8 \\
\hline Japan & -1.4 & -1.0 & -1.9 & -0.3 & 1.7 & 2.1 & 0.3 & -0.2 & -0.1 \\
\hline New Zealand & 3.5 & 2.1 & 3.7 & 4.9 & 0.5 & 0.7 & 2.4 & 2.8 & 1.1 \\
\hline
\end{tabular}

$\ldots=$ data not available; 0.0 = magnitude is less than half of unit employed, $\mathrm{ADB}=$ Asian Development Bank.

Source: Economy sources. 
Table 2.3.5: $\quad$ Growth Rates of Money Supply ${ }^{a}$

\author{
$(\%)$
}

\begin{tabular}{|c|c|c|c|c|c|c|c|c|c|}
\hline ADB Regional Member & 2000 & 2005 & 2010 & 2013 & 2014 & 2015 & 2016 & 2017 & 2018 \\
\hline \multicolumn{10}{|l|}{ Developing ADB Member Economies } \\
\hline \multicolumn{10}{|l|}{ Central and West Asia } \\
\hline Afghanistan & & $38.3(2006)$ & 39.3 & 7.1 & 6.0 & 3.7 & 5.5 & 10.4 & 2.6 \\
\hline Armenia & 38.6 & 27.8 & 11.8 & 14.8 & 8.3 & 10.8 & 17.5 & 18.5 & 7.4 \\
\hline Azerbaijan ${ }^{b}$ & 21.8 & 22.3 & 24.3 & 15.0 & 11.8 & -1.3 & -1.9 & 9.0 & 5.7 \\
\hline Georgiab $^{b}$ & 39.2 & 27.9 & 30.1 & 24.5 & 13.8 & 19.3 & 20.2 & 14.8 & 14.7 \\
\hline Kazakhstan & 45.0 & 25.2 & 13.3 & 10.2 & 10.4 & 33.8 & 15.6 & -1.7 & 7.0 \\
\hline Kyrgyz Republic & 12.1 & 9.9 & 21.1 & 22.8 & 3.0 & 14.9 & 14.6 & 17.9 & 5.5 \\
\hline Pakistan & 9.4 & 19.8 & 13.0 & 16.9 & 12.6 & 12.8 & 14.5 & 13.9 & 9.5 \\
\hline Tajikistan & 43.3 & 62.9 & 17.6 & 18.6 & 3.5 & 12.2 & 56.7 & 36.6 & 10.0 \\
\hline Turkmenistan & 94.6 & 5.6 & 74.2 & 26.0 & 10.0 & 18.0 & & & $\ldots$ \\
\hline Uzbekistan & 37.1 & 54.4 & 52.4 & 23.0 & 14.9 & 25.2 & 23.5 & 40.2 & 14.4 \\
\hline \multicolumn{10}{|l|}{ East Asia } \\
\hline China, People's Republic of & 12.3 & 16.5 & 19.7 & 13.6 & 11.0 & 13.3 & 11.3 & 9.0 & 8.1 \\
\hline Hong Kong, China & 7.8 & 5.1 & 8.1 & 12.4 & 9.5 & 5.5 & 7.7 & 10.0 & 4.3 \\
\hline Korea, Republic of & 5.2 & 7.0 & 6.0 & 4.6 & 8.1 & 8.2 & 7.1 & 5.1 & 6.7 \\
\hline Mongolia & 17.6 & 34.6 & 62.5 & 24.2 & 12.5 & -5.5 & 21.0 & 30.5 & 22.8 \\
\hline Taipei,China & 6.5 & 6.6 & 5.5 & 5.8 & 6.1 & 5.8 & 3.6 & 3.6 & 2.7 \\
\hline \multicolumn{10}{|l|}{ South Asia } \\
\hline Bangladesh & 18.6 & 16.7 & 22.4 & 16.7 & 16.1 & 12.4 & 16.3 & 10.9 & 9.2 \\
\hline Bhutan & 16.1 & 13.2 & 16.5 & 3.3 & 26.0 & 3.8 & 23.0 & 17.4 & 6.5 \\
\hline India ${ }^{b}$ & 16.8 & 21.1 & 16.1 & 13.4 & 10.9 & 10.1 & 10.1 & 9.2 & 10.5 \\
\hline Maldives & 4.2 & 10.6 & 14.6 & 18.4 & 14.9 & 12.1 & -0.2 & 5.2 & 3.4 \\
\hline Nepal & 21.8 & 8.3 & 14.1 & 16.4 & 19.1 & 19.9 & 19.5 & 15.5 & 19.4 \\
\hline Sri Lanka & 13.0 & 19.6 & 18.0 & 18.0 & 13.1 & 17.2 & 18.9 & 17.5 & 13.5 \\
\hline \multicolumn{10}{|l|}{ Southeast Asia } \\
\hline Brunei Darussalam & $1.9(2002)$ & -4.5 & 4.8 & 1.5 & 3.2 & -1.8 & 1.5 & -0.4 & 2.8 \\
\hline Cambodia & 26.9 & 16.1 & 20.0 & 14.6 & 30.0 & 14.7 & 17.9 & 23.8 & 24.0 \\
\hline Indonesia & 15.6 & 16.3 & 15.4 & 12.8 & 11.9 & 9.0 & 10.0 & 8.3 & 6.3 \\
\hline Lao People's Democratic Republic & 45.9 & 8.2 & 39.5 & 17.0 & 25.2 & 14.7 & 10.9 & 12.2 & 8.4 \\
\hline Malaysiab & 5.1 & 8.3 & 6.8 & 7.3 & 7.3 & 3.0 & 3.2 & 4.9 & 8.0 \\
\hline Myanmar & 42.2 & 27.3 & 42.5 & 31.4 & 21.0 & 30.7 & 17.4 & 20.5 & 14.6 \\
\hline Philippines ${ }^{b}$ & 4.6 & 16.8 & 10.0 & 31.8 & 11.2 & 9.4 & 12.8 & 11.9 & 9.5 \\
\hline Singapore & -2.0 & 6.2 & 8.6 & 4.3 & 3.3 & 1.5 & 8.0 & 3.2 & 3.9 \\
\hline Thailand & 4.0 & 6.1 & 10.9 & 7.3 & 4.7 & 4.4 & 4.2 & 5.0 & 4.7 \\
\hline Viet Nam & 56.2 & 29.7 & 33.3 & 18.8 & 17.7 & 16.2 & 18.4 & 15.0 & 12.4 \\
\hline \multicolumn{10}{|l|}{ The Pacific } \\
\hline Cook Islands & $12.2(2001)$ & -0.9 & 0.1 & -18.3 & -1.0 & 9.5 & 0.1 & 6.4 & 9.9 \\
\hline $\mathrm{Fiji}^{\mathrm{b}}$ & -2.1 & 15.2 & 3.5 & 19.0 & 10.1 & 14.3 & 4.8 & 8.2 & $\ldots$ \\
\hline \multicolumn{10}{|l|}{ Kiribati } \\
\hline Marshall Islands & 16.6 & -0.8 & 9.4 & 6.8 & 31.0 & 28.6 & 19.9 & 27.8 & $\ldots$ \\
\hline Micronesia, Federated States of & $\ldots$ & $\ldots$ & $\ldots$ & $\ldots$ & $\ldots$ & $\ldots$ & $\ldots$ & $\ldots$ & $\ldots$ \\
\hline Nauru & $\cdots$ & $\ldots$ & $\ldots$ & $\ldots$ & $\cdots$ & $\ldots$ & $\cdots$ & $\ldots$ & $\cdots$ \\
\hline Niue & & & & & & & & & $\ldots$ \\
\hline Palau & & & 0.6 & 8.8 & 27.0 & 29.4 & 14.5 & & $\ldots$ \\
\hline Papua New Guineab & 5.4 & 29.5 & 11.4 & 6.7 & 3.4 & 8.0 & 10.9 & -0.7 & -4.0 \\
\hline Samoa & 16.4 & 15.6 & 6.4 & 6.4 & 9.6 & 6.0 & 9.2 & 15.2 & 8.8 \\
\hline Solomon Islands & 0.4 & 46.1 & 13.3 & 12.4 & 5.1 & 15.5 & 13.4 & 3.5 & 6.8 \\
\hline Timor-Leste & $155.5(2001)$ & 17.6 & 18.2 & 22.9 & 19.9 & 7.1 & 14.2 & 12.1 & 3.1 \\
\hline Tonga & 8.3 & 12.1 & 5.1 & 5.2 & 7.3 & 9.3 & 16.7 & 13.7 & 7.6 \\
\hline Tuvalu & & & & $\ldots$ & $\ldots$ & $\ldots$ & & $\ldots$ & $\ldots$ \\
\hline Vanuatu & 5.5 & 11.6 & -6.0 & -5.6 & 8.5 & 11.4 & 10.7 & 9.3 & $\ldots$ \\
\hline \multicolumn{10}{|l|}{ Developed ADB Member Economies } \\
\hline Australiab & 7.3 & 8.9 & 4.5 & 6.5 & 7.0 & 6.7 & 5.8 & 7.8 & 1.9 \\
\hline Japanc & 1.9 & 0.4 & 1.9 & 3.4 & 2.8 & 2.5 & 3.2 & 2.9 & 2.2 \\
\hline New Zealand & 6.6 & 7.8 & 3.2 & 5.0 & 6.3 & 8.1 & 7.7 & 7.3 & 6.4 \\
\hline
\end{tabular}

... = data not available, $\mathrm{ADB}=$ Asian Development Bank.

a Data are based on money supply M2 (M2), unless otherwise stated.

b Refers to money supply M3 (M3).

c Refers to M3, except for 2000 (M2).

d Refers to M3, except for 2016-2018 (M2).

Source: Economy sources. 
Table 2.3.6: Money Supplya (\% of GDP)

\begin{tabular}{|c|c|c|c|c|c|c|c|c|c|}
\hline ADB Regional Member & 2000 & 2005 & 2010 & 2013 & 2014 & 2015 & 2016 & 2017 & 2018 \\
\hline \multicolumn{10}{|l|}{ Developing ADB Member Economies } \\
\hline \multicolumn{10}{|l|}{ Central and West Asia } \\
\hline Afghanistan & $11.0(2002)$ & 17.9 & 30.3 & 28.5 & 29.6 & 29.7 & 28.8 & 29.8 & 32.9 \\
\hline Armenia & 14.7 & 16.3 & 26.3 & 33.9 & 34.7 & 36.8 & 43.0 & 46.4 & 46.2 \\
\hline Azerbaijan & 10.8 & 14.7 & 24.8 & 33.2 & 36.5 & 39.1 & 34.6 & 32.4 & 30.2 \\
\hline Georgiab $^{b}$ & 10.1 & 16.9 & 29.9 & 36.6 & 38.4 & 42.0 & 47.2 & 48.7 & 51.4 \\
\hline Kazakhstan & 15.3 & 27.2 & 38.9 & 32.2 & 32.3 & 41.9 & 42.2 & 36.6 & 35.4 \\
\hline Kyrgyz Republic & 11.3 & 21.1 & 31.4 & 34.0 & 31.1 & 33.3 & 34.4 & 36.5 & 36.6 \\
\hline Pakistan & 33.0 & 41.6 & 37.8 & 38.8 & 38.9 & 40.2 & 43.5 & 45.0 & 45.8 \\
\hline Tajikistan & 5.8 & 11.2 & 12.0 & 13.9 & 12.8 & 13.5 & 18.8 & 22.9 & 22.3 \\
\hline Turkmenistan & 19.4 & 10.5 & 17.3 & 41.7 & 41.4 & 48.2 & & & \\
\hline Uzbekistan & 12.2 & 14.4 & 18.9 & 20.3 & 19.1 & 20.1 & 21.5 & 24.2 & 20.5 \\
\hline \multicolumn{10}{|l|}{ East Asia } \\
\hline China, People's Republic of & 134.2 & 158.0 & 176.1 & 186.6 & 191.6 & 203.0 & 209.5 & 205.9 & 202.9 \\
\hline Hong Kong, China & 272.9 & 310.1 & 401.7 & 470.3 & 487.2 & 484.4 & 502.2 & 516.6 & 504.3 \\
\hline Korea, Republic of & 108.6 & 106.7 & 125.5 & 128.0 & 132.9 & 135.5 & 138.3 & 137.8 & 142.6 \\
\hline Mongolia & 21.1 & 37.5 & 48.0 & 49.3 & 47.8 & 43.4 & 50.8 & 56.9 & 60.5 \\
\hline Taipei,China & 182.6 & 201.9 & 219.2 & 233.2 & 234.0 & 237.8 & 240.5 & 244.4 & 247.0 \\
\hline \multicolumn{10}{|l|}{ South Asia } \\
\hline Bangladesh & 31.5 & 40.9 & 45.5 & 50.3 & 52.1 & 52.0 & 52.9 & 51.4 & 49.3 \\
\hline Bhutan & 50.8 & 57.8 & 70.5 & 55.2 & 61.4 & 57.7 & 63.0 & 65.6 & 71.2 \\
\hline India ${ }^{b}$ & 60.3 & 73.6 & 83.6 & 84.7 & 84.6 & 84.4 & 83.3 & 81.7 & 81.0 \\
\hline Maldives & 41.1 & 45.2 & 47.9 & 46.8 & 47.8 & 48.3 & 44.9 & 42.8 & 40.1 \\
\hline Nepal & 49.0 & 51.0 & 60.3 & 77.6 & 79.7 & 88.2 & 99.6 & 96.9 & 102.1 \\
\hline Sri Lanka & 32.2 & 33.6 & 28.3 & 31.9 & 33.4 & 37.1 & 40.2 & 42.2 & 44.5 \\
\hline \multicolumn{10}{|l|}{ Southeast Asia } \\
\hline Brunei Darussalam & $77.8(2001)$ & 57.8 & 67.3 & 62.6 & 67.5 & 80.8 & 92.6 & 86.7 & 81.6 \\
\hline Cambodia & 13.0 & 19.5 & 41.4 & 53.4 & 63.2 & 66.6 & 70.9 & 79.4 & 88.8 \\
\hline Indonesia & 53.8 & 43.4 & 36.0 & 39.1 & 39.5 & 39.5 & 40.4 & 39.9 & 38.8 \\
\hline Lao People's Democratic Republic & 17.4 & 18.7 & 38.0 & 44.5 & 49.0 & 51.2 & 51.5 & 53.1 & 53.1 \\
\hline Malaysiab & 128.6 & 123.8 & 132.2 & 142.6 & 140.8 & 136.3 & 132.5 & 126.6 & 129.6 \\
\hline Myanmar & 32.7 & 21.6 & 23.6 & 36.8 & 39.5 & 46.4 & 49.7 & 52.8 & \\
\hline Philippines ${ }^{b}$ & 39.9 & 41.8 & 49.8 & 60.0 & 61.0 & 63.3 & 65.6 & 67.3 & 66.8 \\
\hline Singapore & 103.2 & 103.3 & 123.3 & 128.9 & 128.4 & 122.9 & 127.9 & 124.1 & 122.7 \\
\hline Thailand & 122.4 & 104.1 & 109.0 & 124.4 & 127.0 & 127.7 & 125.9 & 124.3 & 123.2 \\
\hline Viet Nam & 50.5 & 75.6 & 129.3 & 122.8 & 131.5 & 143.6 & 158.3 & 163.7 & 166.2 \\
\hline \multicolumn{10}{|l|}{ The Pacific } \\
\hline Cook Islands & 50.1 & 56.4 & 83.1 & 67.2 & 60.9 & 59.3 & 57.7 & 56.2 & 55.6 \\
\hline $\mathrm{Fiji}^{\mathrm{b}}$ & 42.4 & 58.9 & 67.6 & 74.2 & 74.7 & 68.9 & 73.3 & 75.0 & \\
\hline \multicolumn{10}{|l|}{ Kiribati } \\
\hline Marshall Islands & 54.6 & 52.9 & 60.7 & 47.2 & 64.2 & 84.3 & 92.7 & 112.8 & \\
\hline Micronesia, Federated States of & $\ldots$ & $\ldots$ & $\ldots$ & $\ldots$ & & & $\ldots$ & & $\cdots$ \\
\hline Nauru & & & $\ldots$ & $\ldots$ & $\ldots$ & $\ldots$ & $\ldots$ & $\ldots$ & $\cdots$ \\
\hline Niue & & & & & & & & & \\
\hline Palau & & & 54.9 & 65.2 & 76.1 & 85.5 & 91.4 & & \\
\hline Papua New Guinea ${ }^{b}$ & 31.2 & 33.6 & 34.0 & 37.9 & 32.8 & 33.6 & 34.5 & 29.4 & 25.9 \\
\hline Samoa & 33.5 & 35.7 & 44.2 & 42.3 & 45.0 & 43.1 & 45.0 & 51.9 & 55.1 \\
\hline Solomon Islands & 32.0 & 29.2 & 37.0 & 46.5 & 46.9 & 51.4 & 54.6 & 53.8 & 53.2 \\
\hline Timor-Leste & 4.6 & 4.2 & 7.4 & 8.9 & 14.8 & 20.8 & 29.3 & 33.1 & $\ldots$ \\
\hline Tonga & 29.2 & 39.0 & 40.9 & 44.0 & 45.8 & 48.1 & 52.3 & 53.1 & \\
\hline Tuvalu & & & & & & & & & \\
\hline Vanuatu & 89.7 & 98.6 & 83.3 & 70.9 & 73.7 & 78.5 & 82.5 & 82.9 & 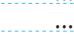 \\
\hline \multicolumn{10}{|l|}{ Developed ADB Member Economies } \\
\hline Australiab & 65.4 & 73.5 & 94.5 & 101.5 & 104.3 & 109.6 & 113.3 & 115.0 & 111.9 \\
\hline Japanc & 123.4 & 198.7 & 218.8 & 236.0 & 237.4 & 235.5 & 240.8 & 243.7 & 247.3 \\
\hline New Zealand ${ }^{d}$ & 86.3 & 98.7 & 110.5 & 114.5 & 116.9 & 120.1 & 102.7 & 103.7 & 106.2 \\
\hline
\end{tabular}

$\ldots=$ data not available, $\mathrm{ADB}=$ Asian Development Bank, $\mathrm{GDP}=$ gross domestic product.

a Refers to money supply $M 2(M 2)$, unless otherwise stated.

b Refers to money supply M3 (M3).

c Refers to M3, except for 2000 (M2).

d Refers to M3, except for 2016-2018 (M2).

Source: Economy sources. 
Table 2.3.7: Interest Rates on Savings and Time Deposits

(\% per annum, period averages)

\begin{tabular}{|c|c|c|c|c|c|c|c|c|}
\hline \multirow{2}{*}{ ADB Regional Member } & \multicolumn{4}{|c|}{ Savings Deposits } & \multicolumn{4}{|c|}{ Time Deposits $^{\mathrm{a}}$} \\
\hline & 2000 & 2005 & 2010 & 2018 & 2000 & 2005 & 2010 & 2018 \\
\hline \multicolumn{9}{|l|}{ Developing ADB Member Economies } \\
\hline \multicolumn{9}{|l|}{ Central and West Asia } \\
\hline Afghanistan & $\ldots$ & $4.26(2006)$ & 5.42 & 1.60 & $\ldots$ & $4.72(2006)$ & 8.18 & 2.29 \\
\hline Armenia & $\ldots$ & $\ldots$ & $\ldots$ & $\ldots$ & 20.72 & 6.66 & 10.70 & 9.38 \\
\hline Azerbaijan & $\ldots$ & $\ldots$ & & $\ldots$ & 10.40 & 9.38 & 10.96 & 9.79 \\
\hline Georgiab & 10.98 & 6.79 & 8.71 & 4.28 & 9.85 & 10.23 & 11.60 & 5.82 \\
\hline Kazakhstan & $\ldots$ & $\ldots$ & $\ldots$ & $\ldots$ & 7.53 & 10.29 & 9.84 & 10.60 \\
\hline Kyrgyz Republic c & $\ldots$ & $\ldots$ & $\ldots$ & $\ldots$ & 28.07 & 9.78 & 11.47 & 10.34 \\
\hline Pakistan ${ }^{\mathrm{b}}$ & 5.75 & 1.24 & 5.02 & 4.14 & 7.37 & 4.21 & 7.21 & 4.63 \\
\hline Tajikistan & $5.28(2002)$ & 3.63 & 3.83 & 1.10 & $14.84(2002)$ & 20.16 & 17.78 & 14.60 \\
\hline Turkmenistan & $\ldots$ & $\ldots$ & $\ldots$ & $\ldots$ & $\ldots$ & $\ldots$ & $\ldots$ & $\ldots$ \\
\hline Uzbekistand & $\ldots$ & $\cdots$ & $\ldots$ & 15.94 & $\ldots$ & $\cdots$ & $\ldots$ & 16.36 \\
\hline \multicolumn{9}{|l|}{ East Asia } \\
\hline China, People's Republic of & 0.99 & 0.72 & 0.36 & 0.35 & 2.25 & 2.25 & 2.33 & 1.50 \\
\hline Hong Kong, China & 4.50 & 0.97 & 0.01 & 0.04 & 5.40 & 1.73 & 0.16 & 0.20 \\
\hline Korea, Republic of & 7.08 & 3.57 & 3.18 & 1.84 & 7.94 & 3.72 & 3.86 & 2.03 \\
\hline Mongolia & 13.80 & 12.60 & 10.70 & 11.20 & & $\ldots$ & & \\
\hline Taipei,China & 3.50 & 0.55 & 0.24 & 0.23 & 4.98 & 1.77 & 1.03 & 1.05 \\
\hline \multicolumn{9}{|l|}{ South Asia } \\
\hline Bangladesh & 5.81 & 4.19 & 4.88 & 3.26 & 8.97 & 8.31 & 9.00 & 7.44 \\
\hline Bhutane & 6.00 & 4.50 & 4.75 & 5.25 & 9.50 & 6.50 & 6.75 & 7.75 \\
\hline India & 4.00 & 3.50 & 3.50 & $4.00(2016)$ & 7.10 & 5.32 & 7.50 & $5.49(2016)$ \\
\hline Maldives ${ }^{f}$ & 5.50 & 2.25 & 2.25 & 1.50 & 6.50 & 4.50 & 3.75 & 4.39 \\
\hline Nepal & 5.25 & 3.38 & 7.00 & 4.63 & 6.88 & 3.63 & 8.13 & 10.42 \\
\hline Sri Lanka & 8.40 & 5.00 & 5.00 & 4.00 & 15.00 & 9.00 & 8.50 & 10.50 \\
\hline \multicolumn{9}{|l|}{ Southeast Asia } \\
\hline Brunei Darussalam & $\ldots$ & 1.01 & 0.47 & 0.35 & $\ldots$ & 1.61 & 0.75 & 0.77 \\
\hline Cambodia & 6.13 & 2.08 & 1.18 & 1.14 & 7.20 & 6.83 & 6.58 & 6.11 \\
\hline Indonesia & 8.86 & 4.32 & 3.92 & 1.25 & 12.17 & 10.95 & 7.88 & 6.51 \\
\hline \multicolumn{9}{|l|}{ Lao People's Democratic Republic } \\
\hline Malaysia & 2.72 & 1.41 & 0.94 & 1.04 & 4.24 & 3.70 & 2.81 & 3.31 \\
\hline Myanmar & $\ldots$ & & & $\ldots$ & $\ldots$ & $\ldots$ & $\ldots$ & $\ldots$ \\
\hline Philippines 8 & 7.40 & 3.80 & 1.60 & 0.90 & 10.50 & 6.00 & 2.07 & 3.46 \\
\hline Singapore & 1.30 & 0.24 & 0.14 & 0.16 & 2.45 & 0.76 & 0.48 & 0.45 \\
\hline Thailand & 2.50 & 1.88 & 0.50 & 0.50 & 3.50 & 3.00 & 1.55 & 1.40 \\
\hline Viet Nam & 0.20 & 3.00 & 3.00 & 0.54 & 6.24 & 8.40 & 11.50 & 7.09 \\
\hline \multicolumn{9}{|l|}{ The Pacific } \\
\hline Cook Islands & $\ldots$ & $\ldots$ & $\ldots$ & $\ldots$ & $\ldots$ & $\ldots$ & $\ldots$ & $\ldots$ \\
\hline $\mathrm{Fiji}$ & $\ldots$ & $\ldots$ & $\ldots$ & $\ldots$ & $\ldots$ & $\ldots$ & $\ldots$ & $\ldots$ \\
\hline Kiribati & $\ldots$ & $\ldots$ & $\ldots$ & $\ldots$ & $\ldots$ & $\ldots$ & $\ldots$ & $\ldots$ \\
\hline Marshall Islands & 2.50 & 1.23 & 0.50 & $\ldots$ & 6.75 & 3.54 & 3.50 & $\ldots$ \\
\hline Micronesia, Federated States of & $\ldots$ & $\ldots$ & $\ldots$ & $\cdots$ & $\ldots$ & $\cdots$ & $\ldots$ & $\ldots$ \\
\hline Nauru & $\ldots$ & $\ldots$ & & $\ldots$ & $\ldots$ & $\cdots$ & $\ldots$ & $\ldots$ \\
\hline Niue & $\ldots$ & $\ldots$ & $\ldots$ & $\ldots$ & $\ldots$ & $\cdots$ & $\ldots$ & $\ldots$ \\
\hline Palau & $\ldots$ & $\ldots$ & 0.95 & 0.11 & $\ldots$ & $\ldots$ & 0.84 & 0.38 \\
\hline Papua New Guinea & 3.88 & 1.80 & 1.00 & 0.67 & 9.38 & 1.30 & 4.80 & 2.00 \\
\hline Samoa & 3.00 & 2.75 & 0.88 & 1.00 & 7.35 & 6.38 & 2.25 & 2.90 \\
\hline \multicolumn{9}{|l|}{ Solomon Islands } \\
\hline Timor-Leste & $0.20(2002)$ & 0.75 & 0.75 & 0.42 & $-(2002)$ & 1.28 & 1.33 & 0.67 \\
\hline Tonga & 3.15 & 3.36 & 1.52 & 2.42 & 5.13 & 5.93 & 2.97 & 5.24 \\
\hline Tuvalu & $\ldots$ & $\ldots$ & $\ldots$ & $\ldots$ & $\ldots$ & $\ldots$ & $\ldots$ & $\ldots$ \\
\hline Vanuatu & $\ldots$ & $\ldots$ & $\ldots$ & $\ldots$ & $\ldots$ & $\ldots$ & $\ldots$ & $\ldots$ \\
\hline \multicolumn{9}{|l|}{ Developed ADB Member Economies } \\
\hline Australia & $\cdots$ & 5.40 & 4.50 & 1.00 & 5.90 & 4.55 & 6.00 & 2.20 \\
\hline Japan h & 0.09 & 0.01 & 0.04 & 0.00 & 0.24 & 0.03 & 0.10 & 0.03 \\
\hline New Zealand ${ }^{i}$ & $\ldots$ & $\ldots$ & $\ldots$ & $\ldots$ & 6.49 & 6.90 & 4.72 & 3.26 \\
\hline
\end{tabular}

$\ldots=$ data not available, - = magnitude equals zero, 0.00 = magnitude is less than half of unit employed, $A D B=$ Asian Development Bank.

a Refers to interest rate on time deposits of 12 months, unless otherwise indicated.

b Refers to interest rate on time deposits of over 12 months.

c Rates for time deposits refer to interest rates of commercial banks in national currency for 6-12 months.

d Refers to time deposits from 181 days to 365 days.

e Rates for time deposits refer to rates for fixed deposits of 1 year to less than 3 years.

$f$ Refers to interest rate on time deposits of 2-3 years.

g Rates for time deposits refer to rates charged on interest-bearing deposits with maturities of over 1 year.

$\mathrm{h}$ Refers to time deposits from 12 months to less than 2 years, calculated as the arithmetic average of the monthly figures.

i Refers to interest rate on time deposits of 6 months.

Sources: Economy sources. For the People's Republic of China: CEIC Database. https://www.ceicdata.com/en (accessed 22 July 2019 ). 
Table 2.3.8: Yield on Short-Term Treasury Bills and Lending Interest Rates

(\% per annum, period averages)

\begin{tabular}{|c|c|c|c|c|c|c|c|c|}
\hline \multirow{2}{*}{ ADB Regional Member } & \multicolumn{4}{|c|}{ Yield on Short-Term Treasury Bills ${ }^{a}$} & \multicolumn{4}{|c|}{ Lending Interest Rates } \\
\hline & 2000 & 2005 & 2010 & 2018 & 2000 & 2005 & 2010 & 2018 \\
\hline \multirow{2}{*}{\multicolumn{9}{|c|}{$\begin{array}{l}\text { Developing ADB Member Economies } \\
\text { Central and West Asia }\end{array}$}} \\
\hline & & & & & & & & \\
\hline Afghanistan & & & & & & $18.0(2006)$ & 15.6 & $14.8(2017)$ \\
\hline Armenia & $20.6(2001)$ & 4.1 & 10.6 & 6.2 & 31.6 & 18.0 & 19.2 & 12.8 \\
\hline Azerbaijan & 16.7 & 7.5 & 1.8 & $14.3(2017)$ & 19.7 & 17.0 & 20.7 & 17.4 \\
\hline Georgia & $29.9(2001)$ & 12.6 & 9.6 & 7.3 & & 17.6 & 15.8 & 11.1 \\
\hline Kazakhstan & & & & & & & & \\
\hline Kyrgyz Republic & 32.3 & 4.4 & 10.4 & 5.6 & 57.0 & 21.7 & 23.7 & 19.5 \\
\hline Pakistanc & 8.4 & 7.2 & 12.5 & $6.0(2017)$ & & 9.1 & 14.0 & 8.5 \\
\hline Tajikistand & $\ldots$ & $\ldots$ & 6.7 & $1.0(2017)$ & 1.6 & 23.3 & 23.4 & $29.6(2017)$ \\
\hline Turkmenistan & $\ldots$ & $\ldots$ & $\ldots$ & $\ldots$ & $\ldots$ & $\ldots \ldots$ & $\ldots$ & $\ldots$ \\
\hline Uzbekistan & $\ldots$ & $\ldots$ & $\ldots$ & $\ldots$ & $\ldots$ & $\ldots$ & $\ldots \ldots$ & $\ldots . .$. \\
\hline \multicolumn{9}{|l|}{ East Asia } \\
\hline China, People's Republic ofe & 2.6 & 1.9 & 2.6 & & 5.9 & 5.6 & 5.8 & 4.4 \\
\hline Hong Kong, China & 5.9 & 2.7 & 0.2 & 1.3 & 9.3 & 6.2 & 5.0 & 5.0 \\
\hline Korea, Republic of & 7.1 & 3.6 & 2.7 & 1.4 & 8.5 & 5.6 & 5.5 & 3.7 \\
\hline Mongolias & & 13.7 & $12.9(2012)$ & $13.9(2017)$ & 37.0 & 30.6 & 20.1 & 17.7 \\
\hline Taipei, China ${ }^{\mathrm{h}}$ & $\cdots$ & 1.3 & 0.3 & 0.3 & 7.7 & 3.8 & 2.7 & 2.6 \\
\hline \multicolumn{9}{|l|}{ South Asia } \\
\hline Bangladeshd & 6.3 & 6.7 & 2.2 & 3.9 & 12.8 & 10.6 & 12.2 & 9.7 \\
\hline Bhutan $^{d}$ & 7.3 & 3.5 & 2.0 & 2.5 & 16.0 & 14.5 & 13.9 & 14.0 \\
\hline India $a^{\mathrm{d}, \mathrm{i}}$ & 9.0 & 5.7 & 6.2 & 6.6 & 12.3 & 10.8 & 8.3 & 9.5 \\
\hline Maldives ${ }^{j}$ & & $5.0(2006)$ & 4.9 & 3.5 & 13.0 & 13.0 & 10.4 & 10.7 \\
\hline Nepald & 5.3 & 3.0 & 6.9 & 3.6 & & & & \\
\hline Sri Lanka & $13.7(2001)$ & 9.0 & 8.6 & $10.1(2017)$ & $14.3(2001)$ & 10.8 & 10.2 & $11.6(2017)$ \\
\hline \multicolumn{9}{|l|}{ Southeast Asia } \\
\hline Brunei Darussalam & $\ldots$ & $\ldots$ & $\ldots$ & $\ldots$ & 5.5 & 5.5 & 5.5 & 5.5 \\
\hline Cambodia & $\ldots$ & $\ldots$ & $\ldots$ & & & & & \\
\hline Indonesia & $\cdots$ & & $\cdots$ & $\ldots$ & 18.5 & 14.1 & 13.3 & 10.5 \\
\hline Lao People's Democratic Republic & 29.9 & 18.6 & 8.0 & & 32.0 & 26.8 & 22.6 & \\
\hline Malaysia & 2.9 & 2.5 & 2.6 & $2.8(2016)$ & 7.7 & 6.0 & 5.0 & 4.9 \\
\hline Myanmar & & & & & 15.3 & 15.0 & 17.0 & 13.0 \\
\hline Philippines $^{\mathrm{d}}$ & 9.9 & 6.1 & 3.5 & 3.6 & 10.9 & 10.2 & 7.7 & 6.1 \\
\hline Singapore & 2.2 & 2.1 & 0.3 & & 5.8 & 5.3 & 5.4 & 5.3 \\
\hline Thailand ${ }^{d}$ & $2.3(2001)$ & 2.7 & 1.4 & 1.3 & 7.8 & 4.7 & 4.3 & 4.1 \\
\hline Viet $\mathrm{Nam}^{\mathrm{m}}$ & 5.4 & 6.1 & 11.1 & $\begin{array}{l}1.2 \\
\ldots\end{array}$ & 10.6 & 11.0 & 13.1 & 7.4 \\
\hline \multicolumn{9}{|l|}{ The Pacific } \\
\hline Cook Islands & & & & & & & $\ldots$ & \\
\hline Fiji & 3.5 & 1.9 & 3.4 & $1.4(2017)$ & 8.4 & 6.8 & 7.5 & $5.7(2017)$ \\
\hline \multicolumn{9}{|l|}{ Kiribati } \\
\hline Marshall Islands & $\ldots . .$. & $\ldots . .$. & $\ldots . .$. & $\ldots . .$. & $\ldots$ & $\cdots$ & & $\ldots$ \\
\hline Micronesia, Federated States of & $\ldots$ & $\ldots$ & $\ldots$ & $\ldots$ & 15.3 & 16.4 & 15.1 & $16.1(2017)$ \\
\hline Nauru & $\ldots$ & $\ldots$ & $\ldots$ & $\ldots$ & $\ldots$ & $\ldots$ & $\ldots$ & $\ldots$ \\
\hline Nive & $\ldots$ & $\ldots$ & $\ldots$ & $\ldots \ldots$ & $\ldots \ldots$ & $\ldots \ldots$ & $\ldots$ & $\ldots \ldots$ \\
\hline \multicolumn{9}{|l|}{ Palau } \\
\hline Papua New Guinean & 17.0 & 3.8 & 4.6 & $4.7(2017)$ & 17.5 & 11.5 & 10.4 & $8.4(2017)$ \\
\hline Samoa & & & & & $11.6(2001)$ & 11.4 & 10.7 & 9.0 \\
\hline Solomon Islands & 7.0 & 4.5 & 3.7 & 0.5 & 10.3 & 9.3 & 14.4 & 10.7 \\
\hline Timor-Leste & & & & $\ldots$ & 17.4 (2002) & 16.7 & 11.0 & 13.5 \\
\hline Tonga & $\ldots$ & $\ldots$ & $\ldots$ & $\ldots$ & 11.3 & 11.4 & 11.5 & 8.0 \\
\hline Tuvalu & $\ldots$ & & & & & & & \\
\hline Vanuatu & $\ldots$ & $\ldots \ldots$ & $\ldots$ & $\ldots$ & 9.9 & 7.5 & 5.5 & 2.7 \\
\hline \multicolumn{9}{|l|}{ Developed ADB Member Economies } \\
\hline Australia $^{\circ}$ & 6.0 & & 4.4 & & 7.7 & 7.3 & 7.3 & 5.3 \\
\hline Japan & 0.2 & 0.0 & 0.1 & $-0.2(2017)$ & 2.1 & 1.7 & 1.6 & $1.0(2017)$ \\
\hline New Zealand & 6.4 & 6.5 & 2.8 & 1.7 & 7.8 & 7.8 & 6.3 & $4.8(2017)$ \\
\hline
\end{tabular}

$\ldots=$ data not available, $0.0=$ magnitude is less than half of unit employed, $\mathrm{ADB}=$ Asian Development Bank.

a Refers to 3-month Treasury bills, unless otherwise indicated.

b Refers to average yield on 9-month to 12-month Treasury bills since March 2001.

c Refers to weighted average yield on 6-month Treasury securities.

d Refers to 91-day Treasury bills.

e Refers to 3-month Treasury bonds trading rate.

$f$ Refers to 91-day certificates of deposit.

g Refers to weighted average rate on Treasury bills of all maturities. From December 2012 onward, refers to yield on 12-week Treasury bills.

$\mathrm{h}$ Refers to prime lending rates.

i Figures are for fiscal year ending March.

j Refers to rate on 28-day Treasury bills.

$k$ Refers to weighted average rate on the last monthly issuance of 364-day Treasury bills since December 2001.

I Refers to weighted average auction rate for 12 -month Treasury bills.

$\mathrm{m}$ Refers to average monthly yield on 360-day Treasury bills sold at auction.

$\mathrm{n}$ Refers to rate on 182-day Treasury bills.

- Refers to estimated closing yield in the secondary market on 13-week Treasury notes.

Sources: International Monetary Fund. International Financial Statistics. http://data.imf.org/ (accessed 5 August 2019); and Organisation for Economic Co-operation and Development. Main Economic Indicators. http://dx.doi.org/10.1787/data-00043-en (accessed7 June2019). For Bangladesh; Bhutan; India; and Taipei,China: Economy sources. 
Table 2.3.9: Domestic Credit Provided by Banking Sector and Bank Nonperforming Loans

\begin{tabular}{|c|c|c|c|c|c|c|}
\hline \multirow[t]{2}{*}{ ADB Regional Member } & \multicolumn{4}{|c|}{$\begin{array}{l}\text { Domestic Credit Provided by Banking Sector }{ }^{\mathrm{a}} \\
\text { (\% of GDP) }\end{array}$} & \multicolumn{2}{|c|}{$\begin{array}{l}\text { Bank Nonperforming Loans }{ }^{b} \\
\text { (\% of total gross loans) }\end{array}$} \\
\hline & 2000 & 2005 & 2010 & 2018 & 2010 & 2017 \\
\hline \multicolumn{7}{|l|}{ Developing ADB Member Economies } \\
\hline \multicolumn{7}{|l|}{ Central and West Asia } \\
\hline Afghanistan & & $-4.9(2006)$ & 4.8 & -5.3 & 49.9 & 12.2 \\
\hline Armenia & 11.5 & 8.8 & 27.8 & 62.5 & 3.0 & 5.4 \\
\hline Azerbaijan & 9.6 & 11.2 & 23.0 & 13.2 & & \\
\hline Georgia & 21.5 & 21.6 & 35.5 & 71.9 & 5.9 & 2.8 \\
\hline Kazakhstan & 12.3 & 39.0 & 45.4 & 38.2 & 20.9 & 9.3 \\
\hline Kyrgyz Republic & 12.2 & 13.8 & 12.5 & 22.4 & 14.8 & 7.4 \\
\hline Pakistan & 41.6 & 46.5 & 46.2 & 58.3 & 14.7 & 8.4 \\
\hline Tajikistan & 17.9 & 13.0 & 7.6 & 15.6 & 7.4 & $\ldots$ \\
\hline Turkmenistan & $\ldots$ & $\ldots$ & $\ldots . .$. & $\ldots$ & $\ldots . .$. & $\ldots$ \\
\hline Uzbekistan & $\ldots$ & $\ldots$ & $\ldots . .$. & $\ldots$ & 1.0 & $0.4(2016)$ \\
\hline \multicolumn{7}{|l|}{ East Asia } \\
\hline China, People's Republic of & 118.4 & 132.6 & 142.5 & 218.3 & 1.1 & 1.7 \\
\hline Hong Kong, China & 134.0 & 139.8 & 195.4 & 252.0 & 0.8 & 0.7 \\
\hline Korea, Republic of & 70.9 & 125.5 & 151.0 & 176.9 & 0.6 & $0.5(2016)$ \\
\hline Mongolia & 9.0 & 26.6 & 25.7 & 65.5 & & \\
\hline Taipei,China & 1.8 & 1.9 & 0.9 & $\ldots$ & 0.6 & 0.2 \\
\hline \multicolumn{7}{|l|}{ South Asia } \\
\hline Bangladesh & 30.2 & 47.7 & 57.4 & 64.1 & $5.8(2011)$ & $8.4(2015)$ \\
\hline Bhutan & 2.9 & 21.8 & 45.6 & 64.0 & 5.2 & 8.4 \\
\hline India & 52.1 & 59.3 & 73.4 & $72.1(2016)$ & 2.7 (2011) & 10.0 \\
\hline Maldives & 34.8 & 47.0 & 76.9 & 64.9 & $20.9(2012)$ & 10.5 \\
\hline Nepal & 40.8 & 42.2 & 67.4 & 102.2 & & 1.7 \\
\hline Sri Lanka & 43.7 & 43.5 & 35.5 & $71.3(2016)$ & $3.8(2011)$ & 2.5 \\
\hline \multicolumn{7}{|l|}{ Southeast Asia } \\
\hline Brunei Darussalam & 38.6 & 10.4 & 22.7 & 28.4 & 6.9 & 3.5 \\
\hline Cambodia & 6.4 & 7.2 & 22.7 & 85.7 & 3.1 & 2.1 \\
\hline Indonesia & 60.7 & 46.2 & 34.2 & 47.2 & 2.5 & 2.6 \\
\hline Lao People's Democratic Republic & 9.0 & 8.1 & 26.7 & & $\ldots$ & \\
\hline Malaysia & 138.4 & 117.7 & 123.3 & 143.1 & 3.4 & 1.5 \\
\hline Myanmar & 31.2 & 23.1 & 25.2 & $42.5(2017)$ & & \\
\hline Philippines & 58.3 & 47.2 & 49.2 & 69.1 & 3.4 & 1.6 \\
\hline Singapore & 76.5 & 61.0 & 79.6 & 136.6 & 1.4 & 1.4 \\
\hline Thailand & 134.3 & 111.0 & 133.4 & 167.0 & 3.9 & 3.1 \\
\hline Viet Nam & 35.1 & 65.4 & 124.7 & 141.9 & 2.1 & 1.8 \\
\hline \multicolumn{7}{|l|}{ The Pacific } \\
\hline Cook Islands & & & & & 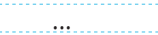 & 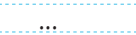 \\
\hline Fiji & 37.9 & 111.6 & 132.3 & $116.2(2017)$ & 4.4 & 2.4 \\
\hline Kiribati & $\ldots$ & $\ldots$ & $\ldots \ldots$ & $\ldots$ & & $\ldots . .$. \\
\hline Marshall Islands & & & & & $\ldots$ & $\ldots$ \\
\hline Micronesia, Federated States of & -42.3 & -24.5 & -14.7 & $-46.8(2017)$ & $\ldots$ & $\ldots . .$. \\
\hline Nauru & $\ldots$ & $\ldots$ & $\ldots$ & $\ldots$ & $\ldots$ & $\ldots$ \\
\hline \multirow{2}{*}{\multicolumn{7}{|c|}{ Palau }} \\
\hline & & & & & & \\
\hline Papua New Guinea & 28.2 & 22.2 & 23.7 & 37.5 & 1.9 & 2.8 \\
\hline Samoa & 18.3 & 31.8 & 63.4 & 76.5 & & 5.3 \\
\hline Solomon Islands & 26.5 & 29.4 & 26.8 & 27.9 & 9.3 & $3.8(2016)$ \\
\hline Timor-Leste & $-7.6(2002)$ & -2.5 & -5.5 & -10.9 & & \\
\hline Tonga & 38.8 & 48.3 & 39.9 & 31.6 & $11.7(2012)$ & 3.6 \\
\hline Tuvalu & & & & & & \\
\hline Vanuatu & 35.6 & 44.5 & 63.7 & 52.7 & 4.8 & 15.0 \\
\hline \multicolumn{7}{|l|}{ Developed ADB Member Economies } \\
\hline Australia & 93.4 & 113.3 & 153.8 & 176.8 & 2.1 & 0.9 \\
\hline Japan & 295.0 & 296.7 & 313.8 & $348.6(2016)$ & $\ldots$ & $\ldots$ \\
\hline New Zealand & 108.0 & 126.4 & 150.7 & 154.8 & $\ldots$ & $\ldots$ \\
\hline
\end{tabular}

$\ldots=$ data not available, $\mathrm{ADB}=$ Asian Development Bank, $\mathrm{GDP}=$ gross domestic product.

a Domestic credit provided by the financial sector includes all credit to various sectors on a gross basis, with the exception of credit to the central government, which is net. The financial sector includes monetary authorities and deposit money banks, as well as other financial corporations where data are available (including corporations that do not accept transferable deposits, but do incur such liabilities as time and savings deposits). Examples of other financial corporations are finance and leasing companies, money lenders, insurance corporations, pension funds, and foreign exchange companies.

b Bank nonperforming loans to total gross loans are the value of nonperforming loans divided by the total value of the loan portfolio (including nonperforming loans before the deduction of specific loan-loss provisions). The loan amount recorded as nonperforming should be the gross value of the loan as recorded on the balance sheet, not just the amount that is overdue.

Sources: $\quad$ World Bank. World Development Indicators Online. http://data.worldbank.org/ (accessed 5 August 2019). For Taipei,China: Central bank of Taipei,China. http://www.cbc.gov.tw (accessed 5 August 2019). 
Table 2.3.10: Growth Rates of Stock Market Price Index ${ }^{a}$

(\%)

\begin{tabular}{|c|c|c|c|c|c|c|c|c|c|}
\hline ADB Regional Member & 2000 & 2005 & 2010 & 2013 & 2014 & 2015 & 2016 & 2017 & 2018 \\
\hline \multicolumn{10}{|l|}{ Developing ADB Member Economies } \\
\hline \multicolumn{10}{|l|}{ Central and West Asia } \\
\hline \multicolumn{10}{|l|}{ Afghanistan } \\
\hline \multicolumn{10}{|l|}{ Armenia } \\
\hline \multicolumn{10}{|l|}{ Azerbaijan } \\
\hline \multicolumn{10}{|l|}{ Georgia } \\
\hline \multicolumn{10}{|l|}{ Kazakhstan } \\
\hline \multicolumn{10}{|l|}{ Kyrgyz Republic } \\
\hline Pakistan & 7.0 & 53.7 & 28.2 & 49.4 & 27.2 & 2.1 & 45.7 & & $\ldots$ \\
\hline \multicolumn{10}{|l|}{ Tajikistan } \\
\hline \multicolumn{10}{|l|}{ Turkmenistan } \\
\hline \multicolumn{10}{|l|}{ Uzbekistan } \\
\hline \multicolumn{10}{|l|}{ East Asia } \\
\hline China, People's Republic of & 37.3 & -22.1 & 3.4 & -1.1 & 1.5 & 66.0 & -19.0 & 6.7 & 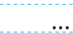 \\
\hline Hong Kong, China & 26.5 & 11.1 & 19.3 & 10.4 & 2.7 & 4.8 & -12.0 & 22.3 & 10.2 \\
\hline Korea, Republic of & -8.7 & 28.5 & 23.6 & 1.5 & 1.1 & 1.4 & -1.2 & 16.5 & 0.5 \\
\hline Mongolia & $\ldots$ & 18.7 & 88.7 & -21.0 & 4.2 & -14.6 & -14.0 & 33.5 & 30.5 \\
\hline Taipei,China & 5.7 & 1.0 & 23.1 & 8.2 & 11.1 & -0.4 & -2.2 & 16.5 & 4.0 \\
\hline \multicolumn{10}{|l|}{ South Asia } \\
\hline Bangladesh & 31.8 & -14.9 & 82.8 & 1.1 & 14.0 & -4.8 & 8.8 & 24.0 & -13.8 \\
\hline \multicolumn{10}{|l|}{ Bhutan } \\
\hline India & 11.2 & 32.6 & 29.8 & 11.4 & 25.2 & 10.9 & -3.6 & 8.6 & $\ldots$ \\
\hline Maldives & $\ldots$ & 51.8 & -20.4 & -5.3 & -4.8 & 8.9 & 4.8 & 7.4 & 6.8 \\
\hline \multicolumn{10}{|l|}{ Nepal } \\
\hline Sri Lankab & $\cdots$ & 27.6 & 96.0 & 4.8 & 23.4 & -5.5 & -9.7 & & $\cdots$ \\
\hline \multicolumn{10}{|l|}{ Southeast Asia } \\
\hline Brunei Darussalam & $\ldots$ & & & $\therefore$ & $\ldots$ & $\ldots$ & $\ldots$ & $\ldots$ & $\ldots$ \\
\hline Cambodia & & & & & & & & & \\
\hline Indonesiab & -38.5 & 16.2 & 46.1 & -1.0 & 22.3 & -12.1 & 15.3 & 20.0 & -2.5 \\
\hline Lao People's Democratic Republic & & & & & $\ldots$ & $\ldots$ & $\ldots$ & $\ldots$ & $\ldots$ \\
\hline Malaysia & 21.4 & 6.4 & 27.1 & 8.7 & 5.5 & -6.1 & -3.8 & 5.0 & 2.2 \\
\hline Myanmar & & & & & & $\ldots$ & & & \\
\hline Philippines & -6.3 & 17.5 & 43.1 & 16.0 & 1.8 & 5.5 & 0.9 & 8.0 & 0.1 \\
\hline Singapore & 8.6 & 16.7 & 30.3 & 7.6 & 1.2 & -2.5 & -11.6 & 10.3 & \\
\hline Thailand & -18.7 & 4.2 & 45.6 & 21.3 & -0.2 & 0.2 & -2.1 & 12.7 & 6.6 \\
\hline Viet Nam ${ }^{b}$ & $\ldots$ & 8.3 & 12.2 & 22.1 & 8.1 & 6.1 & 14.8 & $\ldots$ & $\ldots$ \\
\hline The Pacific & & & & & & & & & \\
\hline Cook Islands & $\ldots$ & & & $\ldots$ & $\ldots$ & 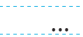 & & & $\ldots$ \\
\hline Fiji & $\ldots$ & 13.5 & -11.1 & 2.6 & 0.5 & 20.8 & 27.6 & 22.4 & $\ldots$ \\
\hline Kiribati & $\ldots$ & $\ldots$ & $\ldots$ & $\ldots$ & $\ldots$ & $\ldots$ & $\ldots$ & $\ldots$ & $\ldots$ \\
\hline Marshall Islands & $\ldots$ & $\ldots$ & $\ldots$ & $\ldots$ & $\ldots$ & $\ldots$ & $\ldots$ & $\ldots$ & $\ldots$ \\
\hline Micronesia, Federated States of & $\ldots$ & $\ldots$ & $\ldots$ & $\ldots$ & $\cdots$ & $\ldots$ & $\ldots$ & $\ldots$ & $\ldots$ \\
\hline Nauru & $\ldots$ & $\ldots$ & $\ldots$ & $\ldots$ & $\ldots$ & $\ldots$ & $\ldots$ & $\ldots$ & $\ldots$ \\
\hline Niue & $\cdots$ & $\ldots$ & & $\ldots$ & $\ldots$ & $\ldots$ & $\ldots$ & $\ldots$ & $\ldots$ \\
\hline Palau & $\ldots$ & & & & & & $\ldots$ & $\ldots$ & $\ldots$ \\
\hline Papua New Guinea & $\ldots$ & 52.5 & 26.2 & -15.3 & -12.3 & -6.3 & $\ldots$ & & $\ldots$ \\
\hline Samoa & $\ldots$ & $\ldots$ & $\ldots$ & $\ldots$ & $\ldots$ & $\ldots$ & $\ldots$ & $\ldots$ & $\ldots$ \\
\hline Solomon Islands & $\ldots$ & $\ldots$ & $\ldots$ & $\ldots$ & $\ldots$ & $\ldots$ & $\ldots$ & $\ldots$ & $\ldots$ \\
\hline Timor-Leste & $\ldots$ & $\ldots$ & $\ldots$ & $\ldots$ & $\ldots$ & $\ldots$ & $\ldots$ & $\ldots$ & $\ldots$ \\
\hline Tonga & $\ldots$ & & & $\ldots$ & $\ldots$ & $\ldots$ & $\ldots$ & $\ldots$ & $\ldots$ \\
\hline Tuvalu & $\ldots$ & $\ldots$ & $\ldots$ & $\cdots$ & $\ldots$ & $\cdots$ & $\ldots$ & $\cdots$ & $\ldots$ \\
\hline Vanuatu & $\ldots$ & $\ldots$ & $\ldots$ & $\ldots$ & $\ldots$ & $\ldots$ & $\ldots$ & $\ldots$ & $\ldots$ \\
\hline Developed ADB Member Economies & & & & & & & & & \\
\hline Australiab & 1.7 & 17.6 & -2.6 & 15.1 & 1.1 & -2.1 & 7.0 & 7.0 & -6.9 \\
\hline Japan & 11.6 & 13.5 & 2.0 & 46.0 & 12.6 & 22.7 & -12.6 & & $\ldots$ \\
\hline New Zealand & 2.3 & 19.4 & 9.7 & 25.5 & 14.1 & 12.7 & 17.4 & 11.1 & 14.8 \\
\hline
\end{tabular}

$\ldots$.. data not available, $\mathrm{ADB}=$ Asian Development Bank.

a Refers to growth rates of stock market prices (period average), unless otherwise indicated.

b Refers to growth rates of end of period stock market prices.

Sources: International Monetary Fund. International Financial Statistics. http://data.imf.org/IFS (accessed 8 July 2019 ). For Taipei,China: Annual statistics from the stock exchange corporation in Taipei,China. http://www.twse.com.tw/en/statistics/ (accessed 8 July 2019). 
Table 2.3.11: Stock Market Capitalization

\begin{tabular}{|c|c|c|c|c|c|c|c|c|}
\hline \multirow[t]{2}{*}{ ADB Regional Member } & \multicolumn{4}{|c|}{$\begin{array}{l}\text { Stock Market Capitalization } \\
\text { (\$ million) }\end{array}$} & \multicolumn{4}{|c|}{$\begin{array}{c}\text { Stock Market Capitalization } \\
(\% \text { of GDP) }\end{array}$} \\
\hline & 2000 & 2005 & 2010 & 2018 & 2000 & 2005 & 2010 & 2018 \\
\hline \multicolumn{9}{|l|}{ Developing ADB Member Economies } \\
\hline \multicolumn{9}{|l|}{ Central and West Asia } \\
\hline Afghanistan & $\ldots$ & $\ldots$ & $\ldots$ & $\ldots$ & $\ldots$ & $\ldots$ & $\ldots$ & $\ldots$ \\
\hline Armenia & $\ldots$ & $\ldots$ & $\ldots$ & $\ldots . .$. & $\ldots$ & $\ldots$ & $\ldots$ & $\ldots$ \\
\hline Azerbaijan & $\ldots$ & $\ldots$ & $\ldots$ & $\ldots$ & $\ldots$ & & $\ldots$ & $\ldots$ \\
\hline \multicolumn{9}{|l|}{ Georgia } \\
\hline Kazakhstan & 802 & 10,529 & 26,673 & 37,005 & 4.4 & 18.4 & 18.0 & 21.7 \\
\hline \multicolumn{9}{|l|}{ Kyrgyz Republic } \\
\hline Pakistan & 6,625 & 45,317 & 38,007 & $91,864(2016)$ & 9.0 & 41.4 & 21.4 & $33.0(2016)$ \\
\hline Tajikistan & $\ldots$ & $\ldots$ & $\ldots$ & $\ldots$ & $\ldots$ & $\ldots$ & $\ldots$ & $\ldots$. \\
\hline Turkmenistan & $\ldots . .$. & $\ldots . .$. & $\ldots . .$. & $\ldots \ldots$ & $\ldots$ & $\ldots \ldots$ & $\ldots$ & $\ldots \ldots$ \\
\hline Uzbekistan & $\ldots$ & $\ldots$ & $\ldots$ & $\ldots$ & $\ldots$ & $\ldots$ & $\ldots$ & $\ldots$ \\
\hline \multicolumn{9}{|l|}{ East Asia } \\
\hline China, People's Republic of & & 401,852 & $4,027,840$ & $6,324,880$ & & 17.6 & 66.2 & 46.5 \\
\hline Hong Kong, China & 623,398 & $1,054,999$ & $2,711,316$ & $3,819,215$ & 363.1 & 581.0 & $1,185.9$ & $1,052.1$ \\
\hline Korea, Republic of & 171,262 & 718,011 & $1,091,911$ & $1,413,717$ & 30.5 & 79.9 & 99.8 & 87.3 \\
\hline \multicolumn{9}{|l|}{ Mongolia } \\
\hline Taipei,China & 262,295 & 485,825 & 752,335 & 972,097 & 79.1 & 129.3 & 168.6 & 164.8 \\
\hline \multicolumn{9}{|l|}{ South Asia } \\
\hline Bangladesh & 2,192 & 3,300 & 41,617 & 77,391 & 4.1 & 4.8 & 36.1 & 28.2 \\
\hline Bhutan & 53 & 101 & 219 & 393 (2017) & 12.0 & 12.4 & 13.8 & $15.5(2017)$ \\
\hline India & $\ldots$ & 553,074 & $1,631,830$ & $2,083,483$ & $\ldots$ & 67.4 & 97.4 & 76.4 \\
\hline Maldives & $\ldots$ & $\ldots$ & $-1,-1, \ldots$ & $-2, \quad \ldots$ & $\ldots$ & $\ldots$ & $\ldots$ & $\ldots$ \\
\hline Nepal & & & & & & & & \\
\hline Sri Lanka & 1,074 & 5,720 & 19,924 & 15,575 & 6.6 & 23.4 & 35.1 & 17.5 \\
\hline \multicolumn{9}{|l|}{ Southeast Asia } \\
\hline \multirow{2}{*}{\multicolumn{9}{|c|}{$\begin{array}{l}\text { Brunei Darussalam } \\
\text { Cambodia }\end{array}$}} \\
\hline & & & & & & & & \\
\hline Indonesia & 26,813 & 81,428 & 360,388 & 486,766 & 16.2 & 28.5 & 47.7 & 46.7 \\
\hline \multicolumn{9}{|l|}{ Lao People's Democratic Republic } \\
\hline Malaysia & 113,156 & 180,518 & 408,689 & 398,019 & 120.6 & 125.8 & 160.3 & 112.3 \\
\hline \multicolumn{9}{|l|}{ Myanmar } \\
\hline Philippines & 25,981 & 39,799 & 157,321 & 258,156 & 32.1 & 38.6 & 78.8 & 78.0 \\
\hline Singapore & 152,826 & 257,340 & 647,226 & 687,257 & 159.1 & 201.3 & 269.9 & 188.7 \\
\hline Thailand & 29,217 & 123,885 & 277,732 & 500,741 & 23.1 & 65.4 & 81.4 & 99.2 \\
\hline Viet Nam & $\ldots$ & $\ldots$ & 36,855 & 132,653 & $\ldots$ & $\ldots$ & 31.8 & 54.2 \\
\hline \multicolumn{9}{|l|}{ The Pacific } \\
\hline Cook Islands & $\ldots$ & $\ldots$ & $\ldots$ & $\ldots$ & $\ldots$ & $\ldots$ & $\ldots$ & $\ldots$ \\
\hline Fiji & $\ldots$ & $\ldots$ & & $\ldots$ & $\ldots$ & $\ldots$ & $\ldots$ & \\
\hline Kiribati & $\ldots$ & $\ldots$ & $\ldots$ & $\ldots . .$. & $\ldots$ & $\ldots$ & $\ldots$ & $\ldots$ \\
\hline Marshall Islands & & $\ldots$ & $\ldots$ & $\ldots$ & $\ldots$ & $\ldots$ & $\ldots$ & \\
\hline Micronesia, Federated States of & $\ldots$ & $\ldots$ & $\ldots$ & $\ldots . .$. & $\ldots$ & $\ldots$ & $\ldots$ & $\ldots$ \\
\hline Nauru & & $\ldots \ldots$ & $\ldots \ldots$ & $\ldots$ & $\ldots$ & $\ldots \ldots$ & $\ldots \ldots$ & $\ldots \ldots$ \\
\hline Niue & $\ldots$ & $\ldots$ & $\ldots$ & $\ldots \ldots$ & $\ldots$ & $\ldots \ldots$ & $\ldots \ldots$ & $\ldots \ldots$ \\
\hline Palau & & & & $\ldots$ & $\ldots$ & & $\ldots \ldots$ & $\ldots$ \\
\hline Papua New Guinea & $\ldots$ & 6,138 & 11,027 & $\ldots$ & $\ldots$ & 126.2 & 77.4 & $\ldots$ \\
\hline Samoa & $\ldots$ & $\ldots$ & $\ldots$ & $\ldots$ & $\ldots$ & $\ldots$ & $\ldots$ & $\ldots$ \\
\hline Solomon Islands & $\ldots$ & $\ldots$ & $\ldots$ & $\ldots$ & $\ldots$ & $\ldots$ & $\ldots$ & $\ldots$ \\
\hline Timor-Leste & $\ldots$ & $\ldots$ & $\ldots$ & $\ldots$ & $\ldots$ & $\ldots$ & $\ldots$ & $\ldots$ \\
\hline Tonga & $\ldots$ & $\ldots$ & $\ldots$ & $\ldots$ & $\ldots$ & $\ldots$ & $\ldots$ & $\ldots$ \\
\hline Tuvalu & $\ldots$ & $\ldots$ & $\ldots$ & & $\ldots$ & $\ldots$ & $\ldots$ & $\ldots$. \\
\hline Vanuatu & $\ldots$ & $\ldots \ldots$ & $\ldots \ldots$ & $\ldots \ldots$ & $\ldots$ & $\ldots \ldots$ & $\ldots . .$. & $\ldots \ldots$ \\
\hline \multicolumn{9}{|l|}{ Developed ADB Member Economies } \\
\hline Australia & 372,794 & 804,015 & $1,454,491$ & $1,262,800$ & 89.8 & 116.0 & 126.9 & 88.2 \\
\hline Japan & $3,157,222$ & $4,572,901$ & $3,827,774$ & $5,296,811$ & 64.6 & 96.2 & 67.2 & 106.6 \\
\hline New Zealand & 18,613 & 40,592 & 43,516 & 86,133 & 35.4 & 35.4 & 29.7 & 42.0 \\
\hline
\end{tabular}

... = data not available, $\$=$ United States dollars, $\mathrm{ADB}=$ Asian Development Bank, GDP = gross domestic product.

Sources: World Bank. World Development Indicators Online. http://databank.worldbank.org/data (accessed 18 July 2019). For Bhutan and Taipei,China: Asian Development Bank estimates using data from economy sources. 
Table 2.3.12: $\quad$ Official Exchange Rates

(local currency units per $\$$, period averages)

\begin{tabular}{|c|c|c|c|c|c|c|c|c|c|}
\hline ADB Regional Member & 2000 & 2005 & 2010 & 2013 & 2014 & 2015 & 2016 & 2017 & 2018 \\
\hline \multicolumn{10}{|l|}{ Developing ADB Member Economies } \\
\hline \multicolumn{10}{|l|}{ Central and West Asia } \\
\hline Afghanistan & 47.36 & 49.49 & 46.45 & 55.38 & 57.25 & 61.14 & 67.87 & 68.03 & 72.08 \\
\hline Armenia & 539.53 & 457.69 & 373.66 & 409.63 & 415.92 & 477.92 & 480.49 & 482.72 & 482.99 \\
\hline Azerbaijan & 0.89 & 0.95 & 0.80 & 0.78 & 0.78 & 1.02 & 1.60 & 1.72 & 1.70 \\
\hline Georgia & 1.98 & 1.81 & 1.78 & 1.66 & 1.77 & 2.27 & 2.37 & 2.51 & 2.53 \\
\hline Kazakhstan & 142.13 & 132.88 & 147.36 & 152.13 & 179.19 & 221.73 & 342.16 & 326.00 & 344.71 \\
\hline Kyrgyz Republic & 47.70 & 41.01 & 45.96 & 48.44 & 53.65 & 64.46 & 69.91 & 68.87 & 68.84 \\
\hline Pakistan & 53.65 & 59.51 & 85.19 & 101.63 & 101.10 & 102.77 & 104.77 & 105.46 & 121.82 \\
\hline Tajikistan & 2.08 & 3.12 & 4.38 & 4.76 & 4.94 & 6.16 & 7.84 & 8.55 & 9.15 \\
\hline Turkmenistan & 1.04 & 1.04 & 2.85 & 2.85 & 2.85 & 3.50 & 3.50 & 3.50 & 3.50 \\
\hline Uzbekistan a & 236.61 & $1,106.10$ & $1,578.42$ & $2,094.99$ & $2,310.95$ & $2,567.99$ & $2,965.25$ & $5,113.88$ & $8,069.61$ \\
\hline \multicolumn{10}{|l|}{ East Asia } \\
\hline China, People's Republic of & 8.28 & 8.19 & 6.77 & 6.20 & 6.14 & 6.23 & 6.64 & 6.76 & 6.62 \\
\hline Hong Kong, China & 7.79 & 7.78 & 7.77 & 7.76 & 7.75 & 7.75 & 7.76 & 7.79 & 7.84 \\
\hline Korea, Republic of & $1,130.96$ & $1,024.12$ & $1,156.06$ & $1,094.85$ & $1,052.96$ & $1,131.16$ & $1,160.43$ & $1,130.42$ & $1,100.56$ \\
\hline Mongolia & $1,076.67$ & $1,205.25$ & $1,357.06$ & $1,523.93$ & $1,817.94$ & $1,970.31$ & $2,140.29$ & $2,439.78$ & $2,472.48$ \\
\hline Taipei,China & 31.23 & 32.17 & 31.64 & 29.77 & 30.37 & 31.90 & 32.32 & 30.44 & 30.16 \\
\hline \multicolumn{10}{|l|}{ South Asia } \\
\hline Bangladesh & 52.14 & 64.33 & 69.65 & 78.10 & 77.64 & 77.95 & 78.47 & 80.44 & 83.47 \\
\hline Bhutan & 44.94 & 44.10 & 45.73 & 58.60 & 61.03 & 64.15 & 67.20 & 65.12 & 68.39 \\
\hline India & 44.94 & 44.10 & 45.73 & 58.60 & 61.03 & 64.15 & 67.20 & 65.12 & 68.39 \\
\hline Maldives & 11.77 & 12.80 & 12.80 & 15.37 & 15.38 & 15.37 & 15.37 & 15.39 & 15.39 \\
\hline Nepal & 71.09 & 71.37 & 73.26 & 93.08 & 97.55 & 102.41 & 107.38 & 104.51 & 108.93 \\
\hline Sri Lanka & 77.01 & 100.50 & 113.06 & 129.07 & 130.56 & 135.86 & 145.58 & 152.45 & 162.46 \\
\hline \multicolumn{10}{|l|}{ Southeast Asia } \\
\hline Brunei Darussalam & 1.72 & 1.66 & 1.36 & 1.25 & 1.27 & 1.37 & 1.38 & 1.38 & 1.35 \\
\hline Cambodia & $3,840.75$ & $4,092.50$ & $4,184.92$ & $4,027.25$ & $4,037.50$ & $4,067.75$ & $4,058.69$ & $4,050.58$ & $4,051.17$ \\
\hline Indonesia & $8,421.78$ & $9,704.74$ & $9,090.43$ & $10,461.24$ & $11,865.21$ & $13,389.41$ & $13,308.33$ & $13,380.83$ & $14,236.94$ \\
\hline Lao People's Democratic Republic & $7,887.64$ & $10,655.17$ & $8,258.77$ & $7,860.14$ & $8,048.96$ & $8,147.91$ & $8,179.27$ & $8,351.53$ & $8,489.24$ \\
\hline Malaysia & 3.80 & 3.79 & 3.22 & 3.15 & 3.27 & 3.91 & 4.15 & 4.30 & 4.04 \\
\hline Myanmarb & 6.52 & 5.82 & 5.63 & 933.57 & 984.35 & $1,162.62$ & $1,234.87$ & $1,360.36$ & $1,429.81$ \\
\hline Philippines & 44.19 & 55.09 & 45.11 & 42.45 & 44.40 & 45.50 & 47.49 & 50.40 & 52.66 \\
\hline Singapore & 1.72 & 1.66 & 1.36 & 1.25 & 1.27 & 1.37 & 1.38 & 1.38 & 1.35 \\
\hline Thailand & 40.11 & 40.22 & 31.69 & 30.73 & 32.48 & 34.25 & 35.30 & 33.94 & 32.31 \\
\hline Viet Nam & $14,167.75$ & $15,858.92$ & $18,612.92$ & $20,933.42$ & $21,148.00$ & $21,697.57$ & $21,935.00$ & $22,370.09$ & $22,602.05$ \\
\hline \multicolumn{10}{|l|}{ The Pacific } \\
\hline Cook Islands & 2.20 & 1.42 & 1.39 & 1.22 & 1.21 & 1.43 & 1.44 & 1.41 & 1.45 \\
\hline Fiji & 2.13 & 1.69 & 1.92 & 1.84 & 1.89 & 2.10 & 2.09 & 2.07 & 2.09 \\
\hline Kiribati & 1.72 & 1.31 & 1.09 & 1.04 & 1.11 & 1.33 & 1.35 & 1.30 & 1.34 \\
\hline Marshall Islands ${ }^{\mathrm{C}}$ & 1.00 & 1.00 & 1.00 & 1.00 & 1.00 & 1.00 & 1.00 & 1.00 & 1.00 \\
\hline Micronesia, Federated States of c & 1.00 & 1.00 & 1.00 & 1.00 & 1.00 & 1.00 & 1.00 & 1.00 & 1.00 \\
\hline Nauru & 1.72 & 1.31 & 1.09 & 1.04 & 1.11 & 1.33 & 1.35 & 1.30 & 1.34 \\
\hline Niue & 2.20 & 1.42 & 1.39 & 1.22 & 1.21 & 1.43 & 1.44 & 1.41 & 1.45 \\
\hline Palauc & 1.00 & 1.00 & 1.00 & 1.00 & 1.00 & 1.00 & 1.00 & 1.00 & 1.00 \\
\hline Papua New Guinea & 2.78 & 3.10 & 2.72 & 2.24 & 2.46 & 2.77 & 3.13 & 3.19 & 3.28 \\
\hline Samoa & 3.29 & 2.71 & 2.48 & 2.31 & 2.33 & 2.56 & 2.56 & 2.55 & 2.59 \\
\hline Solomon Islands & 5.09 & 7.53 & 8.06 & 7.30 & 7.38 & 7.91 & 7.95 & 7.89 & 7.95 \\
\hline Timor-Leste ${ }^{c}$ & 1.00 & 1.00 & 1.00 & 1.00 & 1.00 & 1.00 & 1.00 & 1.00 & 1.00 \\
\hline Tonga & 1.76 & 1.94 & 1.91 & 1.77 & 1.85 & 2.11 & 2.22 & 2.21 & 2.24 \\
\hline Tuvalu & 1.72 & 1.31 & 1.09 & 1.04 & 1.11 & 1.33 & 1.35 & 1.30 & 1.34 \\
\hline Vanuatu & 137.64 & 109.25 & 96.91 & 94.54 & 97.07 & 108.99 & 108.48 & 107.82 & 108.78 \\
\hline \multicolumn{10}{|l|}{ Developed ADB Member Economies } \\
\hline Australia & 1.72 & 1.31 & 1.09 & 1.04 & 1.11 & 1.33 & 1.35 & 1.30 & 1.34 \\
\hline Japan & 107.77 & 110.22 & 87.78 & 97.60 & 105.94 & 121.04 & 108.79 & 112.17 & 110.42 \\
\hline New Zealand & 2.20 & 1.42 & 1.39 & 1.22 & 1.21 & 1.43 & 1.44 & 1.41 & 1.45 \\
\hline
\end{tabular}

$\$=$ United States (US) dollars, ADB = Asian Development Bank.

a Data show weighted averages of the official, bank, and parallel market rates.

b From 1 April 2012 onward, the Central Bank of Myanmar adopted the managed float exchange rate regime for kyat vis-à-vis the US dollar.

c Unit of currency is the US dollar.

Sources: International Monetary Fund. International Financial Statistics. http://data.imf.org/ (accessed 26 June 2019). For Turkmenistan for 2000-2009: United Nations National Accounts Main Aggregates Database. https://unstats.un.org/unsd/snaama/resCountry.asp (accessed 22 May 2019); and for 2010-2018: Interstate Statistical Committee of the Commonwealth of Independent States. http://www.cisstat.org/eng/index.htm (accessed 6 June 2019 ). For Uzbekistan for 2000-2009: United Nations National Accounts Main Aggregates Database. http://unstats.un.org/unsd/snaama/resCountry.asp (accessed June 2013); for 2010-2012: Interstate Statistical Committee of the Commonwealth of Independent States. http://www.cisstat.com (accessed 15 July 2015); and for 2013-2018: Central Bank ofUzbekistan. http://cbu.uz/en/statistics/(accessed 23 July 2019). For Taipei,China:Central bank of Taipei,China. http://www.cbc.gov.tw (accessed 26 June 2019). 
Table 2.3.13: Purchasing Power Parity Conversion Factor ${ }^{\mathrm{a}}$

(local currency units per $\$$, period averages)

\begin{tabular}{|c|c|c|c|c|c|c|c|c|c|}
\hline ADB Regional Member & 2000 & 2005 & 2010 & 2013 & 2014 & 2015 & 2016 & 2017 & 2018 \\
\hline \multirow{2}{*}{\multicolumn{10}{|c|}{ Developing ADB Member Economies }} \\
\hline & & & & & & & & & \\
\hline Afghanistan & $9.60(2002)$ & 12.27 & 15.20 & 18.82 & 18.58 & 18.83 & 19.58 & 19.59 & 19.31 \\
\hline Armenia & 144.36 & 157.63 & 183.16 & 196.45 & 197.26 & 197.54 & 195.93 & 196.41 & 197.04 \\
\hline Azerbaijan & 0.16 & 0.20 & 0.30 & 0.36 & 0.35 & 0.31 & 0.36 & 0.41 & 0.45 \\
\hline Georgia & 0.53 & 0.64 & 0.80 & 0.83 & 0.85 & 0.89 & 0.91 & 0.95 & 0.96 \\
\hline Kazakhstan & 22.06 & 35.12 & 67.90 & 88.70 & 92.08 & 92.76 & 104.28 & 111.13 & 115.57 \\
\hline Kyrgyz Republic & 8.08 & 9.25 & 14.80 & 19.22 & 20.45 & 20.93 & 21.96 & 22.92 & 22.75 \\
\hline Pakistan & 9.93 & 11.81 & 20.77 & 26.61 & 28.05 & 28.90 & 28.70 & 29.29 & 29.24 \\
\hline Tajikistan & 0.30 & 0.69 & 1.57 & 1.94 & 2.00 & 2.01 & 2.09 & 2.14 & 2.20 \\
\hline Turkmenistan & 0.27 & 0.65 & 1.30 & 1.52 & 1.50 & 1.41 & 1.32 & 1.28 & 1.27 \\
\hline Uzbekistan & 65.87 & 221.82 & 525.87 & 760.41 & $1,020.61$ & $1,115.04$ & $1,199.44$ & $1,405.79$ & $1,761.40$ \\
\hline \multicolumn{10}{|l|}{ East Asia } \\
\hline China, People's Republic of & 2.70 & 2.83 & 3.31 & 3.53 & 3.50 & 3.46 & 3.46 & 3.53 & 3.55 \\
\hline Hong Kong, China & 7.41 & 5.68 & 5.37 & 5.55 & 5.60 & 5.75 & 5.78 & 5.84 & 5.92 \\
\hline Korea, Republic of & 747.24 & 788.92 & 840.89 & 869.08 & 871.88 & 857.37 & 862.55 & 866.01 & 852.69 \\
\hline Mongolia & 137.83 & 223.43 & 476.33 & 601.13 & 633.91 & 638.08 & 645.24 & 700.60 & 738.70 \\
\hline Taipei,China & 21.43 & 18.35 & 15.80 & 14.86 & 14.84 & 15.16 & 15.13 & 14.67 & 14.20 \\
\hline \multicolumn{10}{|l|}{ South Asia } \\
\hline Bangladesh & 15.62 & 17.32 & 21.91 & 25.87 & 26.83 & 28.11 & 29.67 & 30.95 & 31.96 \\
\hline Bhutan & 12.22 & 13.65 & 15.84 & 18.79 & 19.96 & 20.28 & 20.97 & 21.71 & 21.85 \\
\hline India & 9.39 & 10.41 & 14.19 & 16.70 & 16.93 & 17.14 & 17.48 & 17.81 & 18.15 \\
\hline Maldives & 3.37 & 5.65 & 7.73 & 9.34 & 9.60 & 10.25 & 10.15 & 10.28 & 10.28 \\
\hline Nepal & 13.05 & 15.32 & 22.69 & 26.99 & 28.97 & 30.08 & 31.28 & 33.37 & 34.94 \\
\hline Sri Lanka & 15.18 & 21.77 & 38.01 & 43.88 & 44.32 & 44.14 & 45.78 & 48.59 & 49.58 \\
\hline \multicolumn{10}{|l|}{ Southeast Asia } \\
\hline Brunei Darussalam & 0.48 & 0.59 & 0.61 & 0.68 & 0.65 & 0.53 & 0.48 & 0.49 & 0.53 \\
\hline Cambodia & $1,058.37$ & $1,106.11$ & $1,330.50$ & $1,327.98$ & $1,337.63$ & $1,346.23$ & $1,376.69$ & $1,395.91$ & $1,406.93$ \\
\hline Indonesia & $1,422.04$ & $2,012.48$ & $3,426.11$ & $3,787.40$ & $3,919.40$ & $4,032.29$ & $4,085.95$ & $4,181.15$ & $4,245.60$ \\
\hline Lao People's Democratic Republic & $1,294.15$ & $1,825.20$ & $2,280.56$ & $2,724.36$ & $2,826.89$ & $2,862.67$ & $2,917.29$ & $2,917.02$ & $2,900.76$ \\
\hline Malaysia & 1.18 & 1.28 & 1.41 & 1.42 & 1.43 & 1.41 & 1.42 & 1.45 & 1.43 \\
\hline Myanmar & 53.27 & 125.03 & 217.57 & 243.90 & 249.36 & 256.93 & 263.34 & 274.51 & 290.68 \\
\hline Philippines & 13.66 & 15.46 & 17.52 & 17.91 & 18.14 & 17.84 & 17.94 & 18.02 & 18.29 \\
\hline Singapore & 0.99 & 0.89 & 0.90 & 0.86 & 0.84 & 0.86 & 0.86 & 0.86 & 0.86 \\
\hline Thailand & 11.01 & 11.33 & 12.17 & 12.37 & 12.32 & 12.28 & 12.44 & 12.46 & 12.36 \\
\hline Viet Nam & $2,698.14$ & $3,572.77$ & $5,648.44$ & $7,517.89$ & $7,648.53$ & $7,553.17$ & $7,554.44$ & $7,716.43$ & $7,792.72$ \\
\hline \multicolumn{10}{|l|}{ The Pacific } \\
\hline Cook Islands & & & & & & & & & \\
\hline Fiji & 0.83 & 0.93 & 0.97 & 1.08 & 1.19 & 1.21 & 1.22 & 1.20 & 1.18 \\
\hline Kiribati & 0.87 & 0.91 & 0.96 & 0.92 & 0.95 & 0.97 & 0.96 & 0.95 & 0.95 \\
\hline Marshall Islands & 0.92 & 0.92 & 0.92 & 0.94 & 0.89 & 0.87 & 0.91 & 0.90 & 0.89 \\
\hline Micronesia, Federated States of & 0.87 & 0.81 & 0.89 & 0.92 & 0.92 & 0.86 & 0.89 & 0.86 & 0.85 \\
\hline Nauru & & & 0.86 & 0.94 & 0.81 & 0.73 & 0.77 & 0.78 & 0.77 \\
\hline \multicolumn{10}{|l|}{ Nive } \\
\hline Palau & 0.77 & 0.75 & 0.76 & 0.83 & 0.85 & 0.91 & 0.93 & 0.90 & 0.89 \\
\hline Papua New Guinea & 0.80 & 1.00 & 1.74 & 1.85 & 1.91 & 1.82 & 1.87 & 1.97 & 2.09 \\
\hline Samoa & 1.42 & 1.48 & 1.66 & 1.69 & 1.67 & 1.69 & 1.65 & 1.64 & 1.65 \\
\hline Solomon Islands & 3.71 & 4.43 & 5.68 & 6.61 & 6.64 & 6.78 & 6.95 & 7.00 & 7.14 \\
\hline Timor-Leste & 0.19 & 0.31 & 0.41 & 0.53 & 0.50 & 0.32 & 0.25 & 0.27 & 0.27 \\
\hline Tonga & 0.92 & 1.14 & 1.40 & 1.44 & 1.43 & 1.44 & 1.44 & 1.47 & 1.49 \\
\hline Tuvalu & 1.04 & 1.11 & 1.13 & 1.10 & 1.14 & 1.18 & 1.17 & 1.19 & 1.23 \\
\hline Vanuatu & 90.06 & 88.64 & 99.53 & 99.91 & 100.00 & 101.40 & 102.49 & 103.17 & 103.05 \\
\hline \multicolumn{10}{|l|}{ Developed ADB Member Economies } \\
\hline Australia & 1.31 & 1.39 & 1.50 & 1.45 & 1.45 & 1.47 & 1.45 & 1.44 & 1.43 \\
\hline Japan & 154.72 & 129.55 & 111.67 & 101.30 & 103.05 & 103.45 & 102.64 & 102.47 & 100.07 \\
\hline New Zealand & 1.44 & 1.54 & 1.50 & 1.45 & 1.44 & 1.48 & 1.47 & 1.47 & 1.45 \\
\hline
\end{tabular}

Sources: World Bank. World Development Indicators. http://databank.worldbank.org/data/home.aspx (accessed 23 July 2019). For Taipei,China: Asian Development Bank estimates using data from economy sources and World Bank data. 
Table 2.3.14: Price Level Indexes

(PPPs to official exchange rates, period averages, United States $=100$ )

\begin{tabular}{|c|c|c|c|c|c|c|c|c|c|}
\hline ADB Regional Member & 2000 & 2005 & 2010 & 2013 & 2014 & 2015 & 2016 & 2017 & 2018 \\
\hline \multicolumn{10}{|l|}{ Developing ADB Member Economies } \\
\hline \multicolumn{10}{|l|}{ Central and West Asia } \\
\hline Afghanistan & $20.31(2002)$ & 24.78 & 32.72 & 33.99 & 32.45 & 30.80 & 28.85 & 28.80 & 26.79 \\
\hline Armenia & 26.76 & 34.44 & 49.02 & 47.96 & 47.43 & 41.33 & 40.78 & 40.69 & 40.80 \\
\hline Azerbaijan & 17.88 & 21.65 & 36.79 & 45.74 & 44.31 & 30.60 & 22.28 & 23.66 & 26.21 \\
\hline Georgia & 26.72 & 35.15 & 44.94 & 49.94 & 47.91 & 39.06 & 38.60 & 37.90 & 38.04 \\
\hline Kazakhstan & 15.52 & 26.43 & 46.08 & 58.31 & 51.38 & 41.84 & 30.48 & 34.09 & 33.53 \\
\hline Kyrgyz Republic & 16.94 & 22.57 & 32.20 & 39.68 & 38.12 & 32.46 & 31.41 & 33.29 & 33.04 \\
\hline Pakistan & 18.51 & 19.84 & 24.38 & 26.18 & 27.75 & 28.12 & 27.39 & 27.77 & 24.00 \\
\hline Tajikistan & 14.68 & 22.21 & 35.79 & 40.82 & 40.50 & 32.58 & 26.69 & 25.06 & 24.00 \\
\hline Turkmenistan & 26.20 & 62.42 & 45.58 & 53.21 & 52.57 & 40.18 & 37.82 & 36.53 & 36.15 \\
\hline Uzbekistan & 27.84 & 20.05 & 33.32 & 36.30 & 44.16 & 43.42 & 40.45 & 27.49 & 21.83 \\
\hline \multicolumn{10}{|l|}{ East Asia } \\
\hline China, People's Republic of & 32.67 & 34.51 & 48.91 & 57.04 & 56.90 & 55.58 & 52.08 & 52.19 & 53.66 \\
\hline Hong Kong, China & 95.15 & 73.09 & 69.07 & 71.58 & 72.27 & 74.14 & 74.44 & 74.90 & 75.55 \\
\hline Korea, Republic of & 66.07 & 77.03 & 72.74 & 79.38 & 82.80 & 75.80 & 74.33 & 76.61 & 77.48 \\
\hline Mongolia & 12.80 & 18.54 & 35.10 & 39.45 & 34.87 & 32.38 & 30.15 & 28.72 & 29.88 \\
\hline Taipei,China & 68.64 & 57.05 & 49.92 & 49.93 & 48.85 & 47.52 & 46.80 & 48.21 & 47.10 \\
\hline \multicolumn{10}{|l|}{ South Asia } \\
\hline Bangladesh & 29.95 & 26.92 & 31.45 & 33.13 & 34.56 & 36.06 & 37.82 & 38.47 & 38.29 \\
\hline Bhutan & 27.20 & 30.95 & 34.65 & 32.06 & 32.71 & 31.62 & 31.20 & 33.33 & 31.95 \\
\hline India & 20.90 & 23.61 & 31.02 & 28.50 & 27.75 & 26.71 & 26.02 & 27.35 & 26.54 \\
\hline Maldives & 28.65 & 44.16 & 60.38 & 60.81 & 62.39 & 66.69 & 66.04 & 66.82 & 66.77 \\
\hline Nepal & 18.35 & 21.46 & 30.97 & 28.99 & 29.69 & 29.37 & 29.13 & 31.93 & 32.07 \\
\hline Sri Lanka & 19.72 & 21.66 & 33.61 & 34.00 & 33.95 & 32.49 & 31.44 & 31.87 & 30.52 \\
\hline \multicolumn{10}{|l|}{ Southeast Asia } \\
\hline Brunei Darussalam & 27.58 & 35.31 & 44.70 & 54.39 & 51.65 & 38.87 & 34.76 & 35.81 & 39.15 \\
\hline Cambodia & 27.56 & 27.03 & 31.79 & 32.97 & 33.13 & 33.10 & 33.92 & 34.46 & 34.73 \\
\hline Indonesia & 16.89 & 20.74 & 37.69 & 36.20 & 33.03 & 30.12 & 30.70 & 31.25 & 29.82 \\
\hline Lao People's Democratic Republic & 16.41 & 17.13 & 27.61 & 34.66 & 35.12 & 35.13 & 35.67 & 34.93 & 34.17 \\
\hline Malaysia & 31.17 & 33.80 & 43.88 & 45.18 & 43.74 & 36.14 & 34.31 & 33.72 & 35.46 \\
\hline Myanmara & 7.67 & 20.15 & 36.21 & 26.13 & 25.33 & 22.10 & 21.33 & 20.18 & 20.33 \\
\hline Philippines & 30.91 & 28.06 & 38.84 & 42.20 & 40.85 & 39.20 & 37.78 & 35.75 & 34.72 \\
\hline Singapore & 57.25 & 53.68 & 66.00 & 68.73 & 66.46 & 62.52 & 62.02 & 62.45 & 63.72 \\
\hline Thailand & 27.46 & 28.18 & 38.42 & 40.27 & 37.92 & 35.84 & 35.25 & 36.71 & 38.25 \\
\hline Viet Nam & 19.04 & 22.53 & 30.35 & 35.91 & 36.17 & 34.81 & 34.44 & 34.49 & 34.48 \\
\hline \multicolumn{10}{|l|}{ The Pacific } \\
\hline \multicolumn{10}{|l|}{ Cook Islands } \\
\hline Fiji & 39.09 & 55.29 & 50.71 & 58.58 & 63.11 & 57.52 & 58.32 & 58.21 & 56.36 \\
\hline Kiribati & 50.34 & 69.60 & 88.39 & 89.28 & 85.67 & 73.10 & 71.68 & 72.97 & 70.98 \\
\hline Marshall Islands & 92.36 & 91.91 & 92.34 & 93.66 & 88.89 & 86.62 & 91.00 & 90.49 & 89.45 \\
\hline Micronesia, Federated States of & 87.47 & 81.22 & 88.59 & 91.58 & 92.43 & 86.39 & 88.82 & 86.13 & 85.06 \\
\hline Nauru & & & 79.20 & 90.38 & 73.03 & 55.21 & 57.12 & 59.76 & 59.57 \\
\hline \multicolumn{10}{|l|}{ Niue } \\
\hline Palau & 77.10 & 74.74 & 76.28 & 83.07 & 84.84 & 90.69 & 92.55 & 89.79 & 89.49 \\
\hline Papua New Guinea & 28.75 & 32.08 & 64.13 & 82.26 & 77.65 & 65.67 & 59.63 & 61.84 & 63.70 \\
\hline Samoa & 43.25 & 54.43 & 66.69 & 73.27 & 71.48 & 66.16 & 64.31 & 64.04 & 63.60 \\
\hline Solomon Islands & 72.94 & 58.83 & 70.40 & 90.46 & 90.10 & 85.63 & 87.41 & 88.79 & 89.76 \\
\hline Timor-Leste & 19.14 & 31.47 & 41.46 & 53.04 & 50.37 & 31.61 & 25.14 & 26.98 & 26.63 \\
\hline Tonga & 52.52 & 58.73 & 73.55 & 81.47 & 77.45 & 68.16 & 65.16 & 66.85 & 66.80 \\
\hline Tuvalu & 60.24 & 84.98 & 103.30 & 106.36 & 102.40 & 88.35 & 87.34 & 91.52 & 91.55 \\
\hline Vanuatu & 65.43 & 81.14 & 102.70 & 105.67 & 103.01 & 93.03 & 94.49 & 95.69 & 94.74 \\
\hline \multicolumn{10}{|l|}{ Developed ADB Member Economies } \\
\hline Australia & 76.01 & 106.02 & 137.77 & 139.71 & 130.93 & 110.74 & 107.88 & 110.71 & 107.16 \\
\hline Japan & 143.57 & 117.54 & 127.21 & 103.80 & 97.27 & 85.46 & 94.35 & 91.36 & 90.63 \\
\hline New Zealand & 65.58 & 108.08 & 107.80 & 118.58 & 119.52 & 102.89 & 102.31 & 104.50 & 100.63 \\
\hline
\end{tabular}

$\ldots=$ data not available, $\mathrm{ADB}=$ Asian Development Bank, $\mathrm{PPP}=$ purchasing power parity.

a The Central Bank of Myanmar devalued the local currency effective 1 April 2012. To achieve a consistent price series, the exchange rate used for estimating the price level index in prior years was extrapolated using the predevaluation exchange rate series.

Source: Asian Development Bank estimates using data from economy sources and World Bank data. 


\section{Globalization}

Globalization focuses on trends in remittances, foreign direct investment, and merchandise exports. The statistical tables cover balance of payments, external trade, international reserves, capital flows, external indebtedness, and tourism.

\section{Remittances remain a significant and stable source of regional revenue}

The aggregate of remittances to ADB developing member economies flatlined from 2014 to 2015 and actually declined in 2016 (Figure 2.4.1). However, aggregate remittances resumed their upward trend in 2017, reaching $\$ 272.2$ billion, then increased again in 2018 to reach $\$ 297.1$ billion. This total represents a significant rise on the $\$ 35.5$ billion in aggregate remittances in 2000.

The region's top five recipients of remittances in 2018 were India ( $\$ 78.6$ billion), the PRC ( $\$ 67.4$ billion), the Philippines ( $\$ 33.8$ billion), Pakistan
( $\$ 21.0$ billion), and Viet Nam ( $\$ 15.9$ billion). On a global basis, India, the PRC, and the Philippines were ranked first, second, and fourth, respectively, in 2018 (World Bank 2019). Remittances accounted for at least $10.0 \%$ of GDP in 8 of the 32 economies with available data for 2018 (Table 2.4.5). These economies were led by Tonga with remittances accounting for $34.6 \%$ of GDP, the Kyrgyz Republic (33.2\%), and Tajikistan (30.2\%).

In comparison with remittance flows, official development assistance to economies in Asia and the Pacific has remained relatively low since 2000, totaling only $\$ 24.5$ billion in 2017 (less than $10 \%$ of the region's aggregate remittances in the same year).

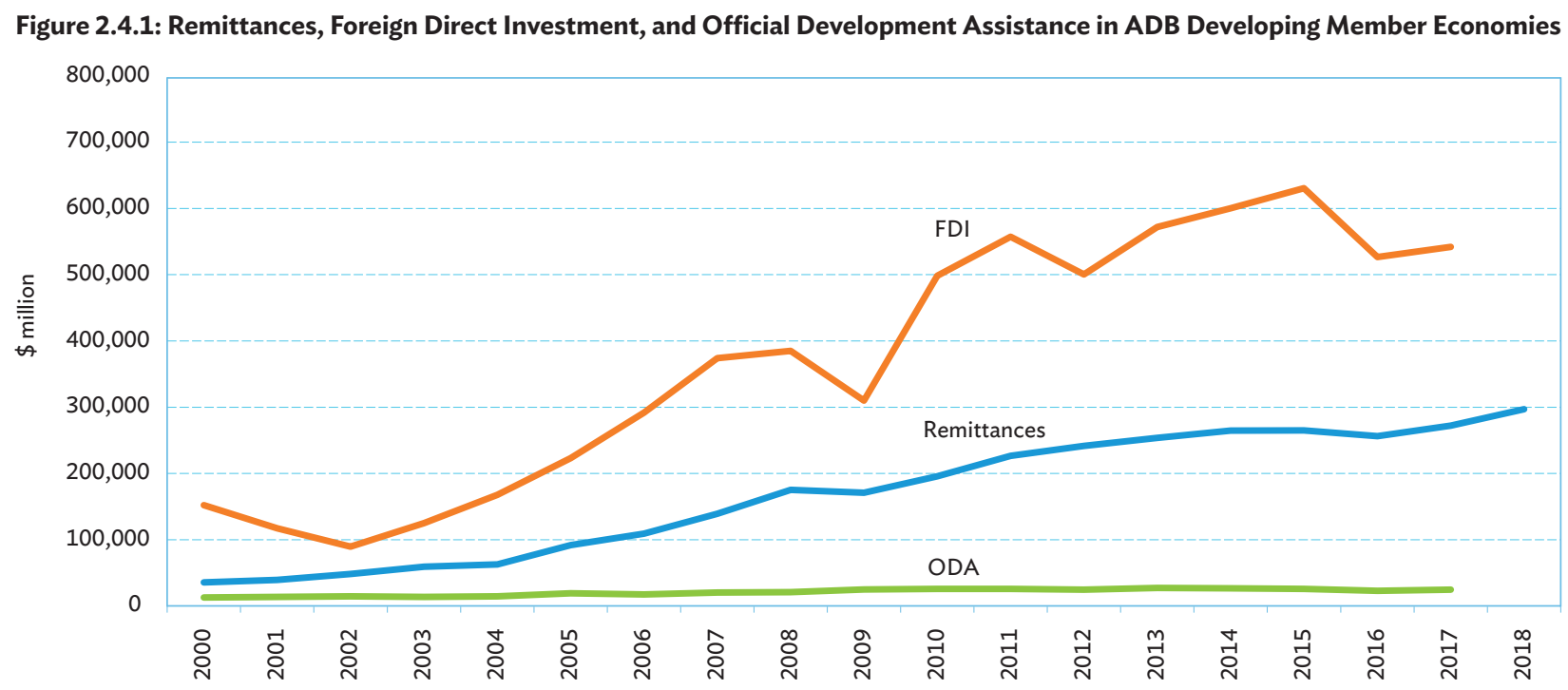

$\$=$ United States dollars, $\mathrm{ADB}=$ Asian Development Bank, FDI = Foreign Direct Investment, Net Inflows; ODA = Net Official Development Assistance; Remittances = Workers' Remittances and Compensation of Employees, Receipts.

Sources: $\quad$ Table 2.4.4, Table 2.4.6, Table 2.4.16, Key Indicators for Asia and the Pacific 2019. 
Foreign direct investment (FDI) in Asia and the Pacific climbed to $\$ 541.9$ billion in 2017 , more than tripling the amount of FDI in 2000. However, FDI flows were much more volatile than remittance flows during the review period, with declines observed in 2001-2002, 2009, 2012, and 2016.

The region's aggregate FDI in 2017 accounted for $29.2 \%$ of the world's total FDI, up significantly from only $12.4 \%$ in 2000 . The PRC was comfortably largest recipient of FDI in Asia and the Pacific for 2018 , receiving a total of $\$ 203.5$ billion. It was followed by Hong Kong, China ( $\$ 86.5$ billion); Singapore (\$82.0 billion); and Australia (\$58.1 billion). These 4 economies were also among the global top 10 recipients of FDI in 2018, ranking second, fifth, sixth, and eighth, respectively (UN 2019b).

\section{Between 2000 and 2018, economies in Asia and the Pacific exported an increasing share of their goods to other economies within the region.}

Asia and Pacific's intraregional exports as a share of the region's total exports rose from $50.8 \%$ in 2000 to $57.7 \%$ in 2018 (Table 2.4.13). As a result, the region's exports to North America declined from 25.9\% in 2000 to $17.5 \%$ in 2018, while exports to Europe declined from $17.6 \%$ to $16.1 \%$ over the same period.

Among 48 economies in Asia and the Pacific, 40 increased the share of merchandise exports that remained within the region (Figure 2.4.2). On the other hand, the region's largest exporter, the PRC, saw the percentage of its intraregional exports as a share of total exports fall from $51.8 \%$ in 2000 to $45.5 \%$ in 2018. The regions of the world receiving increased shares of the PRC's merchandise exports included Africa (from $1.7 \%$ in 2000 to $3.7 \%$ in 2018), South America (from $1.4 \%$ to $3.4 \%$ ), the Middle East (from $2.9 \%$ to $4.5 \%$ ), and Europe (from $18.4 \%$ to $19.8 \%$ ).
Asia and the Pacific also received a greater share of the world's total merchandise exports, rising from $24.5 \%$ in 2000 to $33.6 \%$ in 2018 . This gain occurred mainly at the expense of global exports to North America and Europe, which fell from 25.2\% to $18.1 \%$ and from $42.4 \%$ to $38.1 \%$, respectively, over the review period.

Figure 2.4.2: Intraregional Merchandise Exports in Asia and the Pacific (\% of total merchandise exports)

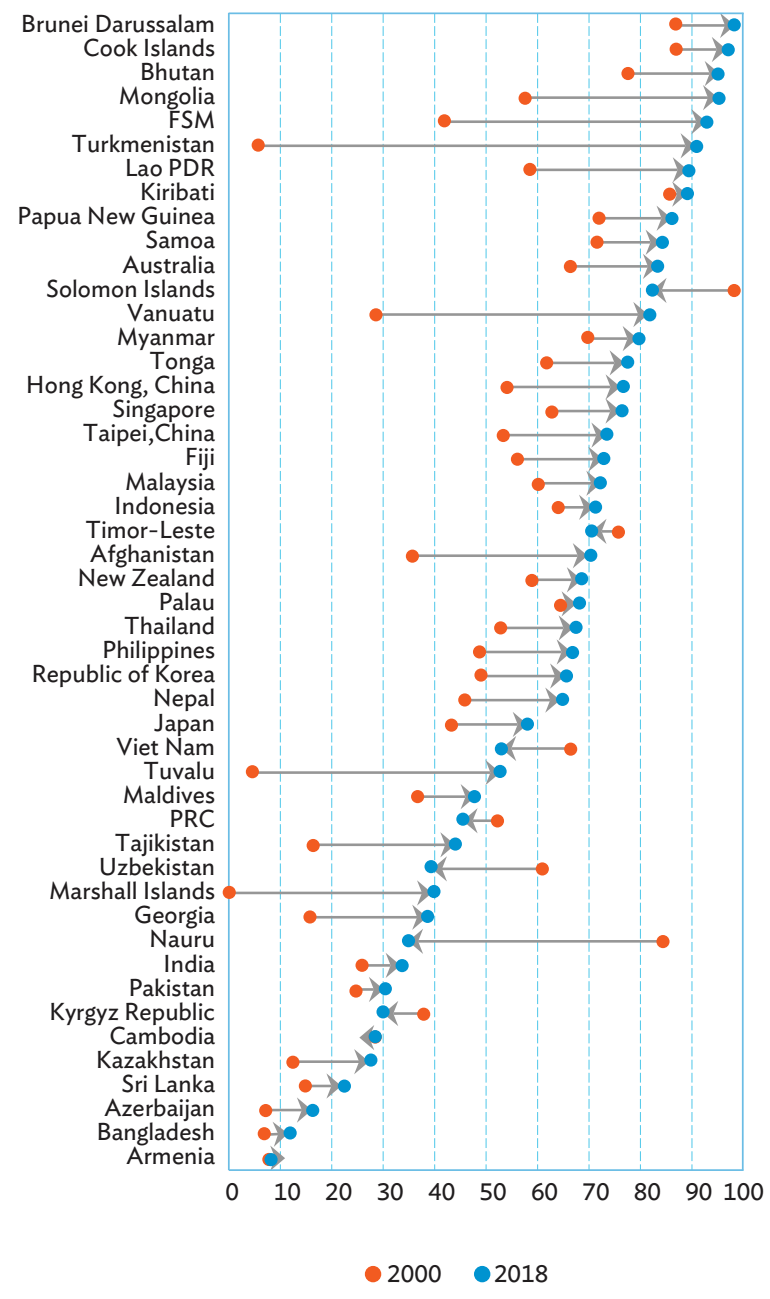

FSM = Federated States of Micronesia, Lao PDR = Lao People's Democratic Republic, PRC $=$ People's Republic of China.

Source: Table 2.4.13, Key Indicators for Asia and the Pacific 2019. 


\section{Three-quarters of Asia and Pacific economies increased their share of intra-regional imports between 2000 and 2018}

Among 48 economies in Asia and the Pacific, 36 increased the share of imports received from within the region from 2000 to 2018 (Figure 2.4.3). On an aggregate basis, Asia and the Pacific's intraregional merchandise imports accounted for $57.1 \%$ of total imports in 2018, up from $56.6 \%$ in 2000.

Figure 2.4.3: Intraregional Merchandise Imports in Asia and the Pacific (\% of total merchandise imports)

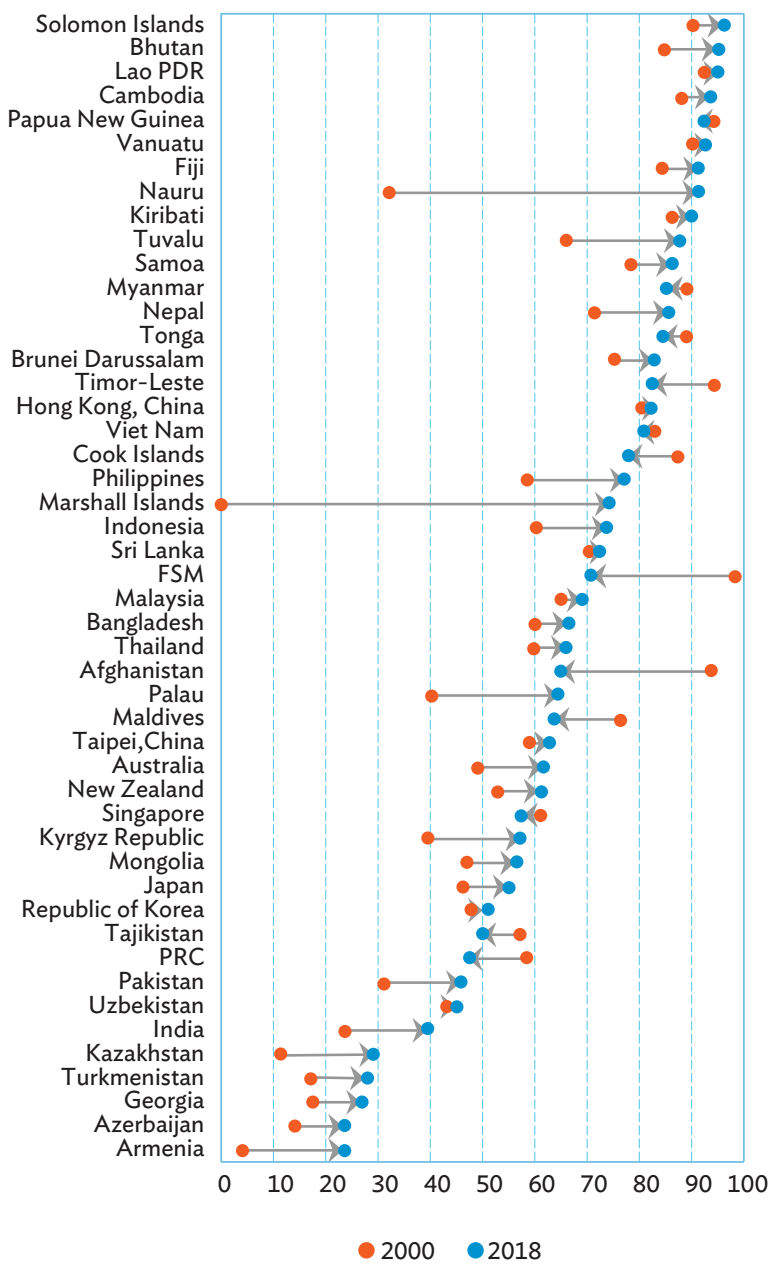

FSM = Federated States of Micronesia, Lao PDR = Lao People's Democratic Republic, PRC $=$ People's Republic of China

Source: $\quad$ Table 2.4.14, Key Indicators for Asia and the Pacific 2019.
Bucking the upward trend was the region's largest importer, the PRC, whose share of imports from within Asia and the Pacific fell from $58.2 \%$ in 2000 to $47.2 \%$ in 2018 . Over this period, the PRC increased its share of imports from South America (from $2.1 \%$ in 2000 to $6.6 \%$ in 2018), economies not belonging to any specified region (from $3.2 \%$ to $6.9 \%$ ), the Middle East (from $4.5 \%$ to $7.6 \%$ ), Africa (from $2.4 \%$ to $4.3 \%$ ), and Europe (from $17.7 \%$ to $17.9 \%$ ).

Afghanistan's intraregional merchandise imports as a share of its total imports also declined significantly from 2000 to 2018 , falling from $93.4 \%$ to $64.9 \%$ over the review period. This decline was accounted for almost entirely by a rise of merchandise imports from the Middle East, with the proportion of total increasing from only $3.0 \%$ in 2000 to $28.3 \%$ in 2018 .

Asia and the Pacific accounted for $35.7 \%$ of the world's total merchandise imports in 2018, up from $29.2 \%$ in 2000 . This increase generated corresponding declines in the shares of the world's total merchandise imports by North America and Europe, which fell from $19.9 \%$ to $13.6 \%$ and from $40.6 \%$ to $38.6 \%$, respectively, over the review period.

\section{Total merchandise exports from Asia and the Pacific have recovered strongly}

For the first time since 2009, total merchandise exports from Asia and the Pacific contracted in 2015 , falling to $\$ 6.0$ trillion from $\$ 6.5$ trillion in 2014 (Figure 2.4.4). The region's exports fell further to $\$ 5.8$ trillion in 2016, before recovering to $\$ 6.4$ trillion in 2017 and rising again to $\$ 7.0$ trillion in 2018. The slowdown across 2015 and 2016, along with the subsequent recovery across 2017 and 2018, mirrored the global trend in merchandise exports from 2015 to 2018 .

From 2000 to 2018, merchandise exports from Asia and the Pacific experienced significant growth (Figure 2.4.4). By subregion, the following average 


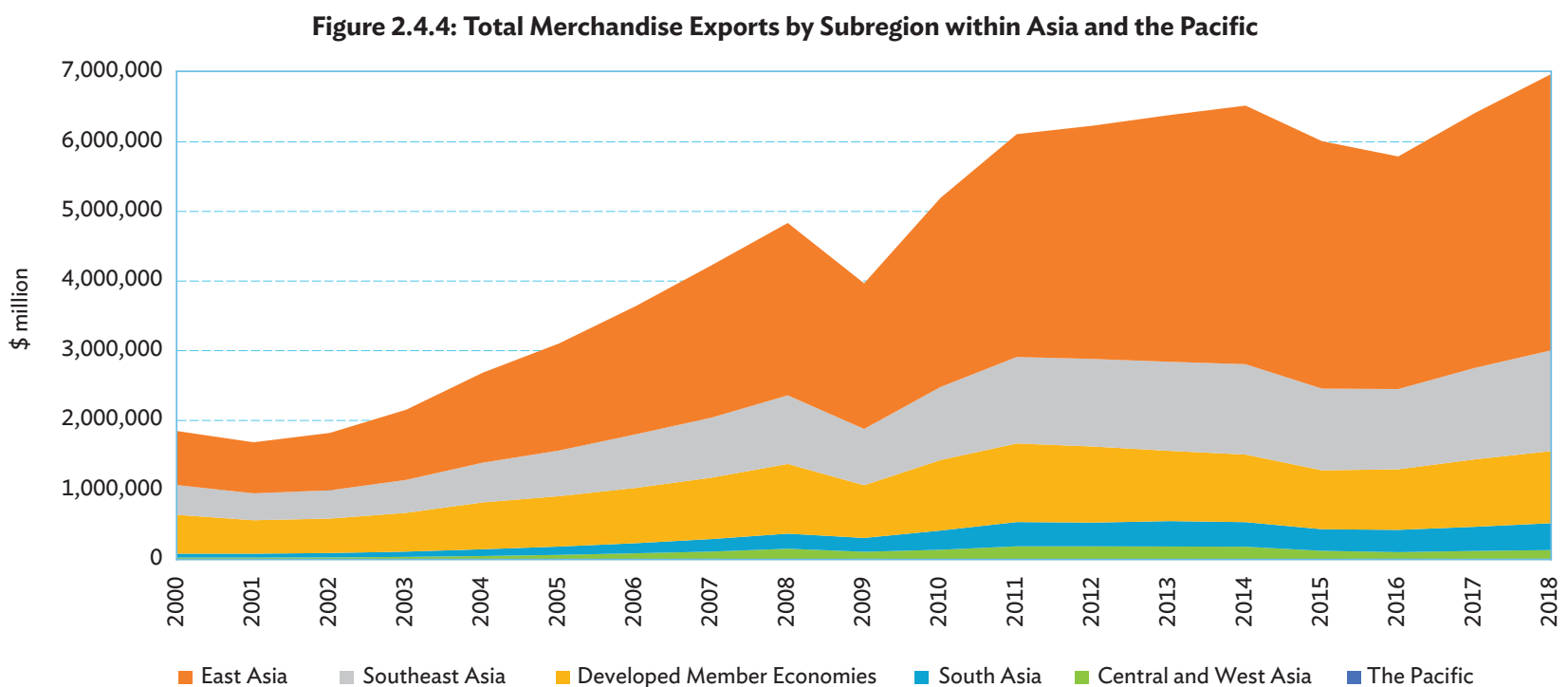

$\$=$ United States dollars.

Source: Table 2.4.8, Key Indicators for Asia and the Pacific 2019.

annual growth rates were achieved: South Asia (32.4\%), East Asia (22.9\%), Central and West Asia (20.5\%), the Pacific (17.7\%), Southeast Asia (13.2\%), and developed member economies (4.8\%).

Among individual economies, Asia and the Pacific's largest exporters in 2018 were the PRC (35.7\% of the regional total), Japan (10.6\%), and the Republic of Korea (8.7\%) as seen in Table 2.4.8. In 2000, the top three exporters, and their respective shares of regional merchandise exports, were Japan (26.0\%); the PRC (13.5\%); and Hong Kong, China $(10.9 \%)$.

Asia and the Pacific generated $36.1 \%$ of global merchandise exports in 2018, up from $28.7 \%$ in 2000.

\section{Data Issues and Comparability}

Most of the data on international transactions presented in this section are taken from balanceof-payments statistics as reported by individual economies. IMF guidelines are followed by most governments in compiling these statistics. However, authorities have difficulty accurately recording nonofficial transactions such as migrant workers' remittances and private capital flows, which is one of the reasons for updating the IMF's Balance of Payments Manual (BPM) to the sixth edition (BPM6) in 2009, and for aligning the BPM to the System of National Accounts 2008. A majority of economies have shifted to BPM6 while a few others continue to use either BPM5 or BPM4. This affects the comparability of data across economies.

The World Trade Organization and other international agencies closely monitor international trade statistics. Common definitions are used by all economies, with the larger economies across Asia and the Pacific using standard forms and procedures for data processing.

Data on official development assistance, other official flows, and private direct investment and other private capital are compiled by the Organisation for Economic Co-operation and Development's Development Assistance Committee. These data are standardized on a calendar-year basis for all donors, but may have discrepancies for some economies owing to the fiscal-year data available in budget documents. Donor-side commitments do not necessarily translate to actual disbursements to recipient economies of official development assistance. 
Table 2.4.1: $\quad$ Trade in Goods Balance

(\% of GDP)

\begin{tabular}{|c|c|c|c|c|c|c|c|c|c|}
\hline ADB Regional Member & 2000 & 2005 & 2010 & 2013 & 2014 & 2015 & 2016 & 2017 & 2018 \\
\hline \multicolumn{10}{|l|}{ Developing ADB Member Economies } \\
\hline \multicolumn{10}{|l|}{ Central and West Asia } \\
\hline Afghanistan ${ }^{\mathrm{a}}$ & $-28.4(2002)$ & -65.5 & -28.7 & -39.9 & -30.8 & -36.3 & -30.2 & -31.4 & -30.3 \\
\hline Armenia & -24.4 & -13.0 & -22.3 & -19.7 & -17.7 & -11.2 & -9.0 & -11.9 & -14.2 \\
\hline Azerbaijan & 6.1 & 24.9 & 37.3 & 28.8 & 25.2 & 11.0 & 11.1 & 15.0 & 21.0 \\
\hline Georgia & -17.5 & -19.0 & -22.6 & -21.7 & -26.0 & -28.2 & -27.0 & -25.2 & -25.4 \\
\hline Kazakhstan & 12.2 & 18.1 & 19.3 & 15.2 & 16.5 & 6.3 & 6.7 & 10.3 & 15.5 \\
\hline Kyrgyz Republic ${ }^{\mathrm{a}}$ & 0.3 & -17.0 & -25.1 & -37.9 & -38.1 & -34.3 & -31.1 & -30.9 & -34.4 \\
\hline Pakistana & -1.8 & -3.7 & -6.6 & -7.0 & -6.7 & -6.5 & -6.9 & -8.8 & -11.0 \\
\hline Tajikistan ${ }^{\mathrm{a}}$ & -9.5 & -34.1 & -43.9 & -46.9 & -33.2 & -29.2 & -27.1 & -21.2 & -25.1 \\
\hline Turkmenistan & & 11.6 & 9.9 & 10.3 & 9.5 & -5.3 & -15.6 & -6.3 & 9.4 \\
\hline Uzbekistan ${ }^{b}$ & 3.6 & 10.1 & 6.4 & 0.5 & -0.6 & 0.1 & -0.1 & 1.5 & -4.2 \\
\hline \multicolumn{10}{|l|}{ East Asia } \\
\hline China, People's Republic of & 2.5 & 5.4 & 3.9 & 3.8 & 4.2 & 5.2 & 4.4 & 3.9 & 2.9 \\
\hline Hong Kong, China & 11.9 & 17.1 & 1.4 & -10.1 & -11.1 & -7.4 & -5.2 & -6.7 & -8.9 \\
\hline Korea, Republic of & 2.7 & 3.5 & 4.2 & 5.9 & 5.8 & 8.2 & 7.8 & 7.0 & 6.5 \\
\hline Mongolia & -6.4 & -3.9 & -2.4 & -20.7 & 1.5 & 4.8 & 12.0 & 13.0 & 5.2 \\
\hline Taipei,China & 5.8 & 6.5 & 8.3 & 10.7 & 11.3 & 13.9 & 13.3 & 14.1 & 11.5 \\
\hline \multicolumn{10}{|l|}{ South Asia } \\
\hline Bangladesh & -4.0 & -5.5 & -4.5 & -4.7 & -3.9 & -3.6 & -2.9 & -3.8 & -6.7 \\
\hline Bhutan ${ }^{\mathrm{a}}$ & -15.6 & -30.7 & -17.3 & -19.7 & -20.3 & -20.2 & -25.1 & -18.9 & -15.1 \\
\hline India ${ }^{a}$ & -2.7 & -6.2 & -7.4 & -7.9 & -7.1 & -6.2 & -4.9 & -6.0 & -6.6 \\
\hline Maldives & -37.4 & -42.4 & -40.9 & -41.8 & -45.0 & -40.4 & -41.8 & -39.3 & -45.3 \\
\hline Nepalc & -14.4 & -14.6 & -25.5 & -27.2 & -30.4 & -31.3 & -30.3 & -33.9 & -37.7 \\
\hline Sri Lanka & -10.8 & -10.3 & -8.5 & -10.2 & -10.4 & -10.4 & -10.9 & -11.0 & -11.6 \\
\hline \multicolumn{10}{|l|}{ Southeast Asia } \\
\hline Brunei Darussalama & $45.4(2001)$ & 50.7 & 45.3 & 38.2 & 43.5 & 22.4 & 18.9 & 19.8 & \\
\hline Cambodia & -14.7 & -16.1 & -23.9 & -23.9 & -23.1 & -21.9 & -19.2 & -19.3 & -23.8 \\
\hline Indonesia & 15.2 & 6.2 & 4.1 & 0.6 & 0.8 & 1.6 & 1.6 & 1.9 & -0.0 \\
\hline Lao People's Democratic Republic ${ }^{\mathrm{a}}$ & -12.5 & -12.1 & -4.7 & -6.6 & -12.8 & -14.1 & -7.1 & -4.7 & -4.8 \\
\hline Malaysia ${ }^{\mathrm{a}}$ & 22.2 & 23.9 & 15.1 & 9.5 & 10.2 & 9.3 & 8.2 & 8.5 & 8.2 \\
\hline Myanmara,d & -0.1 & 0.1 & 0.1 & 0.2 & -2.8 & -6.1 & -5.5 & -9.0 & \\
\hline Philippines $^{\mathrm{a}}$ & -7.4 & -11.8 & -8.4 & -6.5 & -6.1 & -8.0 & -11.7 & -12.8 & -14.8 \\
\hline Singapore & 16.4 & 37.3 & 26.4 & 25.6 & 27.5 & 30.1 & 27.4 & 27.3 & 27.0 \\
\hline Thailand & 4.3 & 1.8 & 7.8 & 0.0 & 4.2 & 6.7 & 8.9 & 7.5 & 4.4 \\
\hline Viet $\mathrm{Nam}^{\mathrm{a}}$ & 1.2 & -4.2 & -4.4 & 5.1 & 6.5 & 3.8 & 5.4 & 4.8 & 6.7 \\
\hline \multicolumn{10}{|l|}{ The Pacific } \\
\hline Cook Islands & & & -25.2 & -39.6 & -37.2 & -44.9 & -49.6 & -46.2 & \\
\hline $\mathrm{Fiji}^{\mathrm{a}}$ & -14.0 & -23.0 & -23.5 & -27.7 & -21.2 & -19.5 & -20.2 & -20.7 & \\
\hline Kiribatia & -52.2 & -62.8 & -40.9 & -52.4 & -52.2 & -52.4 & -53.5 & -52.9 & \\
\hline Marshall Islandsc & -54.0 & -39.7 & -54.0 & -40.6 & -39.3 & -36.2 & -34.1 & -34.6 & \\
\hline Micronesia, Federated States of & -38.2 & -42.8 & -43.3 & -40.7 & -37.0 & -40.6 & -33.3 & -33.1 & \\
\hline Nauru & $\ldots$ & $\cdots$ & $33.6(2012)$ & 4.3 & -27.1 & -43.0 & -37.7 & -40.7 & -41.6 \\
\hline Niue & & $-33.4(2007)$ & -60.3 & -43.7 & -42.1 & -40.2 & -35.7 & -43.6 & -41.4 \\
\hline Palau & -79.1 & -49.7 & -45.8 & -56.0 & -62.4 & -48.8 & -44.7 & -48.7 & -48.6 \\
\hline Papua New Guinea ${ }^{\mathrm{d}}$ & 31.4 & 36.8 & 15.6 & 1.1 & 20.6 & 27.0 & 29.5 & 29.1 & 29.7 \\
\hline Samoa ${ }^{\mathrm{a}}$ & -107.5 & -28.4 & -35.0 & -39.5 & -40.4 & -35.0 & -35.3 & -36.3 & -37.5 \\
\hline Solomon Islands ${ }^{\mathrm{a}}$ & -8.1 & -5.6 & -19.7 & -1.7 & -0.1 & -0.2 & 0.2 & 0.1 & 0.0 \\
\hline Timor-Leste ${ }^{\mathrm{a}}$ & & $-3.9(2006)$ & -7.0 & -11.0 & -14.9 & -20.5 & -21.5 & -24.7 & \\
\hline Tonga & -44.8 & -65.6 & -52.6 & -56.4 & -56.4 & -71.3 & -74.6 & -75.2 & -81.1 \\
\hline Tuvalua & -64.9 & $-40.5(2006)$ & -54.3 & -45.0 & -47.0 & -121.0 & -61.0 & -61.0 & $\ldots$ \\
\hline Vanuatu & -18.2 & -23.3 & -27.1 & -27.4 & -24.8 & -34.9 & -32.5 & -28.7 & \\
\hline \multicolumn{10}{|l|}{ Developed ADB Member Economies } \\
\hline Australia & -1.9 & -2.6 & -0.7 & -0.2 & 0.6 & -0.8 & -1.7 & 0.8 & 0.7 \\
\hline Japan & 2.4 & 2.2 & 1.9 & -1.7 & -2.0 & -0.2 & 1.0 & 0.9 & 0.2 \\
\hline New Zealand & 1.6 & -3.0 & 1.4 & 1.2 & -0.2 & -1.0 & -1.1 & -0.9 & $\ldots$ \\
\hline
\end{tabular}

$\ldots=$ data not available $\mid$ | = marks break in series due to change in compilation methodology, 0.0 = magnitude is less than half of unit employed, $A D B=A s i a n$ Development Bank, GDP = gross domestic product.

a Change in compilation methodology from the International Monetary Fund's Balance of Payments Manual (fifth edition) [BPM5] to the International Monetary Fund's Balance of Payments and International Investment Position Manual (sixth edition) [BPM6].

b Based on the International Monetary Fund's Balance of Payments Manual (fourth edition) [BPM4].

c Based on BPM5.

d Change in compilation methodology from BPM4 to BPM5.

e Change in compilation methodology from BPM4 to BPM6.

Source: Economy sources. 
Table 2.4.2: Trade in Services Balance (\% of GDP)

\begin{tabular}{|c|c|c|c|c|c|c|c|c|c|}
\hline ADB Regional Member & 2000 & 2005 & 2010 & 2013 & 2014 & 2015 & 2016 & 2017 & 2018 \\
\hline \multicolumn{10}{|l|}{ Developing ADB Member Economies } \\
\hline \multicolumn{10}{|l|}{ Central and West Asia } \\
\hline Afghanistan ${ }^{a}$ & $-3.6(2002)$ & -8.2 & 6.3 & -3.2 & -0.2 & -1.0 & -2.1 & -3.4 & -2.5 \\
\hline Armenia & -3.4 & -3.0 & -2.8 & -1.1 & -1.0 & -0.9 & -0.7 & -0.2 & -1.2 \\
\hline Azerbaijan & -4.3 & -14.9 & -3.3 & -5.6 & -8.1 & -8.0 & -8.3 & -8.3 & -4.4 \\
\hline Georgia & 2.4 & 1.6 & 4.7 & 8.8 & 7.9 & 10.0 & 11.0 & 13.4 & 13.8 \\
\hline Kazakhstan & -5.3 & -9.5 & -4.9 & -3.4 & -3.1 & -2.6 & -2.7 & -2.2 & -2.7 \\
\hline Kyrgyz Republic a & -12.2 & -4.9 & -4.2 & -0.7 & -4.4 & -2.8 & -3.0 & -1.2 & -1.7 \\
\hline Pakistan ${ }^{\mathrm{a}}$ & -3.5 & -2.8 & -1.0 & -0.7 & -1.1 & -1.1 & -1.2 & -1.4 & -2.0 \\
\hline Tajikistan ${ }^{\mathrm{a}}$ & -1.7 & -4.6 & -0.5 & -5.0 & -3.1 & -2.7 & -2.0 & -1.7 & -2.9 \\
\hline \multicolumn{10}{|l|}{ Turkmenistan } \\
\hline Uzbekistan b,c & -0.5 & -1.1 & -1.2 & -0.3 & -0.1 & 1.3 & 1.4 & 3.1 & \\
\hline \multicolumn{10}{|l|}{ East Asia } \\
\hline China, People's Republic of & -0.1 & 0.0 & -0.2 & -1.3 & -2.0 & -2.0 & -2.1 & -2.1 & -2.1 \\
\hline Hong Kong, China & -7.5 & -4.9 & 4.4 & 10.7 & 11.3 & 9.8 & 7.5 & 7.8 & 9.0 \\
\hline Korea, Republic of & -0.1 & -1.0 & -1.2 & -0.5 & -0.2 & -1.0 & -1.2 & -2.3 & -1.7 \\
\hline Mongolia & -7.5 & 0.5 & -4.2 & -10.4 & -10.5 & -6.1 & -12.0 & -10.6 & -15.2 \\
\hline Taipei,China & -3.8 & -3.8 & -2.5 & -3.0 & -2.2 & -2.0 & -1.9 & -1.5 & -1.2 \\
\hline \multicolumn{10}{|l|}{ South Asia } \\
\hline Bangladesh & -1.4 & -1.5 & -1.1 & -2.1 & -2.4 & -1.6 & -1.2 & -1.3 & -1.7 \\
\hline Bhutan $^{\mathrm{a}}$ & -1.8 & -4.8 & -4.4 & -3.0 & -3.3 & -3.3 & -2.8 & -2.0 & \\
\hline India ${ }^{a}$ & 0.3 & 2.8 & 2.6 & 3.8 & 3.7 & 3.2 & 3.0 & 3.0 & 2.9 \\
\hline Maldives ${ }^{\mathrm{a}}$ & 33.4 & 6.8 & 34.8 & 57.1 & 59.6 & 49.4 & 40.5 & 35.3 & \\
\hline Nepald & 7.2 & -0.4 & -1.3 & 0.5 & 1.1 & 1.3 & 0.4 & 0.1 & 0.1 \\
\hline Sri Lanka & 0.2 & 1.4 & 1.2 & 1.6 & 2.4 & 2.9 & 3.5 & 3.8 & 4.2 \\
\hline \multicolumn{10}{|l|}{ Southeast Asia } \\
\hline Brunei Darussalama & $11.0(2001)$ & 0.6 & -5.9 & -13.1 & -9.5 & -7.8 & -9.8 & -5.7 & \\
\hline Cambodia & -0.6 & 2.9 & 9.0 & 11.2 & 10.3 & 9.5 & 8.0 & 8.4 & 9.9 \\
\hline Indonesia & -11.1 & -3.2 & -1.3 & -1.3 & $\begin{array}{l}10.3 \\
-1.1\end{array}$ & -1.0 & -0.8 & $\begin{array}{l}0.4 \\
-0.7\end{array}$ & -0.7 \\
\hline Lao People's Democratic Republic a & 5.1 & 2.5 & 2.4 & -2.3 & -2.9 & -1.6 & -1.2 & -2.0 & -1.3 \\
\hline Malaysia ${ }^{a}$ & -11.1 & -2.0 & 0.8 & -0.9 & -1.0 & -1.8 & -1.5 & -1.7 & -1.2 \\
\hline Myanmara,e & -0.0 & -0.1 & -0.0 & 0.4 & 1.4 & 2.2 & 2.0 & 1.8 & \\
\hline Philippines $^{\mathrm{a}}$ & -2.3 & 2.1 & 2.9 & 2.6 & 1.6 & 1.9 & 2.3 & 2.8 & 3.2 \\
\hline Singapore & -4.1 & -7.4 & -0.1 & -2.5 & -4.1 & -2.8 & -0.8 & -2.3 & -0.5 \\
\hline Thailand & 3.7 & -3.6 & -2.1 & 2.7 & 2.5 & 4.8 & 5.9 & 6.3 & 5.7 \\
\hline Viet Nama & -1.8 & -0.5 & -2.1 & -1.8 & -2.1 & -2.5 & -2.1 & -1.8 & -1.5 \\
\hline \multicolumn{10}{|l|}{ The Pacific } \\
\hline Cook Islands & $\cdots$ & & 41.4 & 33.9 & 32.5 & 37.6 & 44.5 & 43.1 & $\cdots$ \\
\hline $\mathrm{Fiji}^{\mathrm{a}}$ & 7.1 & 13.4 & 17.1 & 15.0 & 27.8 & 32.8 & 33.6 & 31.9 & \\
\hline Kiribatia & -27.4 & -30.3 & -25.4 & -29.4 & -37.1 & -39.4 & -36.8 & -36.0 & \\
\hline Marshall Islands & -20.1 & -21.8 & -19.7 & -21.5 & -19.1 & -19.8 & -18.9 & -21.8 & \\
\hline Micronesia, Federated States of & -16.5 & -16.3 & -15.4 & -12.9 & -11.3 & -11.7 & -12.4 & -10.3 & \\
\hline Nauru & $\ldots$ & $\ldots$ & $-13.5(2012)$ & -7.4 & -23.5 & -13.4 & -15.1 & -15.2 & -20.9 \\
\hline Niue & $\ldots$ & $-17.5(2007)$ & -40.5 & 4.8 & 8.4 & 13.0 & 13.6 & 16.5 & 21.1 \\
\hline Palau & 13.2 & 16.6 & 19.3 & 27.8 & 32.2 & 32.3 & 25.5 & 21.4 & 19.3 \\
\hline Papua New Guineae & -21.2 & -17.8 & -17.2 & -16.4 & -9.0 & -5.4 & -4.6 & -5.5 & -4.6 \\
\hline Samoa ${ }^{a}$ & 44.1 & 15.6 & 10.4 & 15.3 & 15.8 & 15.8 & 15.1 & 19.0 & 20.5 \\
\hline Solomon Islands a & -8.2 & 1.5 & -13.8 & -12.0 & -10.6 & -7.4 & -8.4 & & $\ldots$ \\
\hline Timor-Leste ${ }^{\mathrm{a}}$ & & $-10.8(2006)$ & -24.0 & -7.6 & -14.7 & -18.8 & -21.0 & -13.8 & \\
\hline Tonga ${ }^{f}$ & 1.7 & -7.3 & -2.1 & 1.4 & -0.7 & 1.2 & 4.3 & 5.9 & 6.8 \\
\hline Tuvalua & -51.2 & $5.6(2006)$ & -3.8 & -73.0 & -74.0 & -95.0 & -74.0 & -80.0 & $\ldots$ \\
\hline Vanuatu ${ }^{\mathrm{a}}$ & 17.1 & 14.9 & 17.6 & 23.3 & 22.7 & 13.5 & 21.7 & 21.8 & \\
\hline \multicolumn{10}{|l|}{ Developed ADB Member Economies } \\
\hline Australia & -0.2 & -0.2 & -0.3 & -1.1 & -1.1 & -0.7 & -0.6 & -0.2 & -0.3 \\
\hline Japan & -0.2 & $\begin{array}{l}-0.2 \\
-0.8\end{array}$ & -0.5 & $\begin{array}{l}-1.1 \\
-0.7\end{array}$ & $\begin{array}{l}-1.1 \\
-0.6\end{array}$ & -0.4 & $\begin{array}{l}-0.0 \\
-0.2\end{array}$ & $\begin{array}{l}-0.2 \\
-0.1\end{array}$ & $\begin{array}{l}-0.3 \\
-0.1\end{array}$ \\
\hline New Zealand & 1.4 & 1.5 & 0.9 & 0.5 & 1.0 & 1.9 & 1.9 & 1.8 & $\begin{array}{l}0.1 \\
\ldots\end{array}$ \\
\hline
\end{tabular}

$\ldots=$ data not available, $\mid$ = marks break in series due to change in compilation methodology, $0.0=$ magnitude is less than half of the unit employed, $A D B=A$ sian Development Bank, GDP = gross domestic product.

a Change in compilation methodology from the International Monetary Fund's Balance of Payments Manual (fifth edition) [BPM5] to the International Monetary Fund's Balance of Payments and International Investment Position Manual (sixth edition) [BPM6].

b Based on the International Monetary Fund's Balance of Payments Manual (fourth edition) [BPM4].

c For 2005 onward, includes other goods and income.

d Based on BPM5.

e Change in compilation methodology from BPM4 to BPM5.

$f$ Change in compilation methodology from BPM4 to BPM6.

Source: Economy sources. 
Table 2.4.3: Current Account Balance (\% of GDP)

\begin{tabular}{|c|c|c|c|c|c|c|c|c|c|}
\hline ADB Regional Member & 2000 & 2005 & 2010 & 2013 & 2014 & 2015 & 2016 & 2017 & 2018 \\
\hline \multirow{2}{*}{\multicolumn{10}{|c|}{ Developing ADB Member Economies }} \\
\hline & & & & & & & & & \\
\hline Afghanistan ${ }^{a}$ & $-3.5(2002)$ & -2.71 & -10.5 & -27.5 & -19.1 & -24.1 & -16.5 & -20.9 & -20.4 \\
\hline Armenia & -15.8 & -2.5 & -13.6 & -7.3 & -7.6 & -2.6 & -2.3 & -2.4 & -9.1 \\
\hline Azerbaijan & -3.2 & 1.3 & 28.4 & 17.6 & 13.9 & -0.4 & -3.6 & 4.1 & 12.9 \\
\hline Georgia & -5.8 & -10.9 & -10.3 & -5.9 & -10.8 & -12.6 & -13.1 & -8.8 & -7.7 \\
\hline Kazakhstan & 2.0 & -1.8 & 0.9 & 0.8 & 2.8 & -3.3 & -5.9 & -3.1 & -0.0 \\
\hline Kyrgyz Republic ${ }^{\mathrm{a}}$ & -5.5 & $-1.4 \mid$ & -6.6 & -13.9 & -17.2 & -16.2 & -11.5 & -6.2 & -8.7 \\
\hline Pakistan $^{\mathrm{a}}$ & -0.31 & -1.3 & -2.3 & -1.1 & -1.3 & -1.0 & -1.8 & -4.2 & -6.7 \\
\hline Tajikistan $^{\mathrm{a}}$ & -7.2 & -12.8 & -10.3 & -10.4 & -3.4 & -6.1 & -4.2 & 2.2 & -5.0 \\
\hline Turkmenistan & 8.4 & 5.1 & -12.9 & -7.3 & -6.1 & -15.6 & -20.2 & -10.3 & 3.1 \\
\hline Uzbekistan $\mathrm{b}$ & 1.6 & 13.5 & 5.1 & 2.9 & 3.4 & 1.7 & 1.8 & 5.2 & $\ldots .1$ \\
\hline \multicolumn{10}{|l|}{ East Asia } \\
\hline China, People's Republic of & 1.7 & 5.8 & 3.9 & 1.5 & 2.3 & 2.8 & 1.8 & 1.6 & 0.4 \\
\hline Hong Kong, China & 4.4 & 11.9 & 7.0 & 1.5 & 1.4 & 3.3 & 4.0 & 4.7 & 4.3 \\
\hline Korea, Republic of & 1.8 & 1.3 & 2.4 & 5.6 & 5.6 & 7.2 & 6.5 & 4.6 & 4.4 \\
\hline Mongolia & -6.1 & 3.5 & -12.3 & -37.6 & -15.8 & -8.1 & -6.3 & -10.1 & -17.0 \\
\hline Taipei,China & 2.5 & 4.0 & 8.3 & 9.7 & 11.4 & 14.2 & 13.7 & 14.4 & 11.6 \\
\hline \multicolumn{10}{|l|}{ South Asia } \\
\hline Bangladesh & -0.9 & -1.0 & 3.7 & 1.6 & 0.8 & 1.8 & 1.9 & -0.5 & -3.6 \\
\hline Bhutan $^{\mathrm{a}}$ & -9.4 & -29.0 & -20.4 & -24.4 & -25.2 & -25.9 & -29.1 & -21.8 & -17.7 \\
\hline India ${ }^{a}$ & -0.6 & -1.2 & -2.8 & -1.7 & -1.3 & -1.1 & -0.6 & -1.8 & -2.1 \\
\hline Maldives ${ }^{\mathrm{a}}$ & -8.2 & -23.5 & -13.8 & -3.9 & -3.2 & -7.4 & -23.5 & -21.8 & -25.0 \\
\hline Nepalc & -2.2 & 2.0 & -2.3 & 3.4 & 4.6 & 5.1 & 6.2 & -0.4 & -8.2 \\
\hline Sri Lanka ${ }^{\mathrm{a}}$ & -6.4 & -2.7 & -1.9 & -3.4 & -2.5 & -2.3 & -2.1 & -2.6 & -3.2 \\
\hline \multicolumn{10}{|l|}{ Southeast Asia } \\
\hline Brunei Darussalam ${ }^{a}$ & $51.5(2001)$ & 47.31 & 36.5 & 20.9 & 30.7 & 16.6 & 12.9 & 16.4 & \\
\hline Cambodia $^{\mathrm{a}}$ & -2.7 & -3.6 & -8.7 & -8.4 & -8.5 & -8.7 & -8.4 & -7.9 & -11.3 \\
\hline Indonesia ${ }^{a}$ & $4.8 \mid$ & 0.1 & 0.7 & -3.2 & -3.1 & -2.0 & -1.8 & -1.6 & -3.0 \\
\hline Lao People's Democratic Republic ${ }^{a}$ & -0.3 & -7.1 & 0.41 & -7.9 & -14.5 & -15.8 & -8.8 & -7.5 & -7.9 \\
\hline Malaysia ${ }^{\mathrm{a}}$ & 9.0 & 14.4 & 10.1 & 3.5 & 4.4 & 3.0 & 2.4 & 2.8 & 2.1 \\
\hline Myanmara, d & -0.1 & 0.0 & 0.01 & -0.8 & -2.9 & -4.3 & -2.2 & -8.6 & \\
\hline Philippines $^{\mathrm{a}}$ & -2.7 & 1.9 & 3.6 & 4.2 & 3.8 & 2.5 & -0.4 & -0.7 & -2.4 \\
\hline Singapore & 11.1 & 23.3 & 22.9 & 15.7 & 18.0 & 17.2 & 17.5 & 16.4 & 17.9 \\
\hline Thailand & 7.4 & -4.0 & 3.4 & -1.2 & 3.7 & 8.0 & 11.7 & 11.0 & 7.0 \\
\hline Viet Nam ${ }^{a}$ & 4.2 & -1.0 & -3.7 & 4.5 & 4.6 & 0.1 & 3.0 & 2.1 & 2.3 \\
\hline \multicolumn{10}{|l|}{ The Pacific } \\
\hline Cook Islands & & & 15.5 & -6.2 & -1.7 & -0.8 & 1.4 & 2.6 & $\ldots$ \\
\hline Fijia & -1.6 & -7.0 & -4.7 & -9.7 & -6.1 & -3.8 & -3.9 & -7.1 & $\ldots$ \\
\hline Kiribati $^{\mathrm{a}}$ & -3.2 & $-32.4]$ & 0.1 & -4.5 & 31.3 & 32.8 & 10.5 & 38.0 & $\ldots$ \\
\hline Marshall Islandsc & -10.9 & 7.6 & -17.9 & -10.7 & -1.7 & 14.4 & 9.7 & 4.8 & $\ldots$ \\
\hline Micronesia, Federated States of & -13.5 & -9.1 & -15.7 & -10.4 & 1.1 & 2.6 & 3.6 & 7.5 & \\
\hline Nauru & $\ldots$ & & $38.1(2012)$ & 18.8 & -13.5 & -9.5 & 1.7 & 0.5 & -1.8 \\
\hline Niue & & $-8.0(2007)$ & -53.9 & 16.2 & 8.2 & 11.1 & 17.6 & 14.9 & 15.7 \\
\hline Palau & -49.7 & -23.0 & -8.8 & -14.2 & -17.9 & -8.7 & -13.6 & -19.1 & -16.6 \\
\hline Papua New Guinead & 10.1 & 13.3 & -4.4 & -1.5 & 10.4 & 20.2 & 25.0 & 22.5 & 24.3 \\
\hline $\mathrm{Samoa}^{\mathrm{a}}$ & -2.9 & -6.0 & -8.4 & -5.9 & -5.9 & -1.6 & -5.0 & -0.8 & 3.0 \\
\hline Solomon Islands $\mathrm{s}^{\mathrm{a}}$ & -12.9 & -1.9 & -20.8 & -3.8 & -0.6 & -0.4 & -0.6 & -0.7 & -0.5 \\
\hline Timor-Leste ${ }^{\mathrm{a}}$ & & $20.5(2006)$ & 42.0 & 43.6 & 27.0 & 6.4 & -20.9 & -11.4 & \\
\hline Tonga ${ }^{e}$ & -8.4 & -4.2 & -8.7 & -15.1 & -9.1 & -9.1 & 5.2 & 7.0 & 4.4 \\
\hline Tuvalua & 54.5 & $-1.6(2006)$ & -3.8 & -7.0 & 3.0 & -53.0 & 23.0 & 6.0 & $\ldots$ \\
\hline Vanuatua & -5.0 & -3.5 & -5.8 & -3.2 & 2.3 & -5.3 & -3.0 & -9.2 & $\ldots$ \\
\hline \multicolumn{10}{|l|}{ Developed ADB Member Economies } \\
\hline Australia & -5.1 & -6.6 & -5.0 & -3.9 & -3.2 & -3.7 & -4.7 & -2.2 & -2.7 \\
\hline Japan & 2.7 & 3.6 & 3.9 & 0.9 & 0.8 & 3.1 & 4.0 & 4.1 & 3.5 \\
\hline New Zealand & -2.3 & -7.8 & -2.8 & -2.5 & -3.4 & -2.6 & -2.6 & -3.0 & $\ldots$ \\
\hline
\end{tabular}

$\ldots=$ data not available, $\mid=$ marks break in series due to change in compilation methodology, $0.0=$ magnitude is less than half of the unit employed, $A D B=A$ sian Development Bank, GDP = gross domestic product.

a Change in compilation methodology from the International Monetary Fund's Balance of Payments Manual (fifth edition) [BPM5] to the International Monetary Fund's Balance of Payments and International Investment Position Manual (sixth edition) [BPM6].

b Based on the International Monetary Fund's Balance of Payments Manual (fourth edition) [BPM4].

c Based on the methodology in BPM5.

d Change in compilation methodology from BPM4 to BPM5.

e Change in compilation methodology from BPM4 to BPM6.

Source: Economy sources. 
Table 2.4.4: Workers' Remittances and Compensation of Employees, Receipts ${ }^{a}$ (\$ million)

\begin{tabular}{|c|c|c|c|c|c|c|c|c|c|}
\hline ADB Regional Member & 2000 & 2005 & 2010 & 2013 & 2014 & 2015 & 2016 & 2017 & 2018 \\
\hline \multicolumn{10}{|l|}{ Developing ADB Member Economies } \\
\hline Central and West Asia & 1,643 & 8,018 & 20,721 & 33,741 & 34,944 & 31,083 & 30,609 & 33,514 & 35,501 \\
\hline Afghanistan & & & 362 & 329 & 250 & 341 & 368 & 378 & 384 \\
\hline Armenia & 87 & 915 & 1,669 & 2,192 & 2,079 & 1,491 & 1,382 & 1,539 & 1,512 \\
\hline Azerbaijan & 57 & 623 & 1,410 & 1,733 & 1,846 & 1,270 & 643 & 1,133 & 1,272 \\
\hline Georgia & 210 & 446 & 1,184 & 1,945 & 1,986 & 1,459 & 1,521 & 1,794 & 2,034 \\
\hline Kazakhstan & 122 & 62 & 226 & 207 & 229 & 194 & 275 & 355 & 419 \\
\hline Kyrgyz Republic & 9 & 313 & 1,266 & 2,278 & 2,243 & 1,688 & 1,995 & 2,486 & 2,690 \\
\hline Pakistan & 1,080 & 4,280 & 9,690 & 14,629 & 17,244 & 19,306 & 19,808 & 19,689 & 21,014 \\
\hline Tajikistan & 79 (2002) & 467 & 2,021 & 3,698 & 3,384 & 2,259 & 1,867 & 2,237 & 2,275 \\
\hline Turkmenistan & $\ldots$ & $14(2006)$ & 35 & 40 & 30 & 16 & 8 & 2 & 2 \\
\hline Uzbekistan & $\ldots$ & $898(2006)$ & 2,858 & 6,689 & 5,653 & 3,059 & 2,741 & 3,901 & 3,899 \\
\hline East Asia & 6,042 & 29,601 & 59,401 & 67,356 & 70,370 & 71,944 & 69,160 & 71,977 & 76,525 \\
\hline China, People's Republic of & 758 & 23,626 & 52,460 & 59,491 & 62,332 & 63,938 & 61,000 & 63,860 & 67,414 \\
\hline Hong Kong, China & 136 & 297 & 340 & 360 & 372 & 387 & 399 & 437 & 469 \\
\hline Korea, Republic of & 4,862 & 5,178 & 5,836 & 6,455 & 6,551 & 6,444 & 6,504 & 6,224 & 6,703 \\
\hline Mongolia & 12 & 177 & 266 & 257 & 255 & 261 & 260 & 273 & 441 \\
\hline Taipei,China & 274 & 323 & 500 & 792 & 860 & 915 & 997 & 1,183 & 1,499 \\
\hline South Asia & 16,092 & 29,959 & 71,929 & 95,864 & 98,319 & 97,958 & 90,231 & 96,631 & 109,685 \\
\hline Bangladesh & 1,969 & 4,642 & 10,850 & 13,867 & 14,988 & 15,296 & 13,574 & 13,498 & 15,496 \\
\hline Bhutan & & $2(2006)$ & 8 & 12 & 14 & 20 & 34 & 43 & 48 \\
\hline India & 12,845 & 22,125 & 53,480 & 69,970 & 70,389 & 68,910 & 62,744 & 68,967 & 78,609 \\
\hline Maldives & 2 & 2 & 3 & 3 & 3 & 4 & 4 & 4 & 4 \\
\hline Nepal & 112 & 1,212 & 3,464 & 5,589 & 5,889 & 6,730 & 6,612 & 6,928 & 8,064 \\
\hline Sri Lanka & 1,163 & 1,976 & 4,123 & 6,422 & 7,036 & 7,000 & 7,262 & 7,190 & 7,464 \\
\hline Southeast Asia & 11,752 & 24,900 & 42,983 & 56,157 & 60,501 & 63,376 & 65,658 & 69,302 & 74,556 \\
\hline \multicolumn{10}{|l|}{ Brunei Darussalam } \\
\hline Cambodia & 121 & 164 & 557 & 1,003 & 1,103 & 1,185 & 1,200 & 1,295 & 1,411 \\
\hline Indonesia & 1,190 & 5,420 & 6,916 & 7,614 & 8,551 & 9,659 & 8,907 & 9,011 & 11,237 \\
\hline Lao People's Democratic Republic & 1 & 1 & 42 & 170 & 188 & 189 & 189 & 253 & 271 \\
\hline Malaysia & 342 & 1,117 & 1,103 & 1,423 & 1,580 & 1,644 & 1,604 & 1,648 & 1,663 \\
\hline Myanmar & 102 & 129 & 115 & 1,644 & 1,864 & 2,005 & 2,346 & 2,565 & 2,754 \\
\hline Philippines & 6,957 & 13,733 & 21,557 & 26,717 & 28,691 & 29,799 & 31,142 & 32,810 & 33,827 \\
\hline \multicolumn{10}{|l|}{ Singapore } \\
\hline Thailand & 1,700 & 1,187 & 4,433 & 6,585 & 6,524 & 5,895 & 6,270 & 6,720 & 7,459 \\
\hline Viet Nam & 1,340 & 3,150 & 8,260 & 11,000 & 12,000 & 13,000 & 14,000 & 15,000 & 15,934 \\
\hline The Pacific & $\ldots$ & 420 & 616 & 653 & 652 & 720 & 724 & 772 & 802 \\
\hline \multicolumn{10}{|l|}{ Cook Islands } \\
\hline Fiji & 44 & 203 & 176 & 204 & 221 & 251 & 269 & 274 & 288 \\
\hline Kiribati & $\ldots$ & $13(2006)$ & 16 & 17 & 17 & 16 & 17 & 17 & 18 \\
\hline Marshall Islands & $\ldots$ & 24 & 22 & 25 & 26 & 27 & 28 & 28 & 30 \\
\hline Micronesia, Federated States of & $\ldots$ & $\ldots$ & 18 & 22 & 23 & 23 & 23 & 23 & 24 \\
\hline Nauru & $\ldots$ & $\ldots$ & $\ldots$ & $\ldots$ & $\ldots$ & $\ldots$ & $\ldots$ & $\ldots$ & $\ldots$ \\
\hline Niue & $\ldots$ & $\ldots$ & & & & & & & \\
\hline Palau & $\ldots$ & 1 & 2 & 2 & 2 & 2 & 2 & 2 & 2 \\
\hline Papua New Guinea & 7 & 7 & 3 & 14 & 10 & 10 & 3 & 4 & 4 \\
\hline Samoa & $\ldots$ & 82 & 139 & 165 & 141 & 131 & 131 & 138 & 142 \\
\hline Solomon Islands & 4 & 7 & 14 & 21 & 16 & 19 & 20 & 16 & 17 \\
\hline Timor-Leste & & $4(2006)$ & 137 & 34 & 44 & 62 & 80 & 87 & 88 \\
\hline Tonga & $53(2001)$ & 69 & 74 & 123 & 119 & 150 & 126 & 159 & 165 \\
\hline Tuvalu & $\ldots$ & 5 & 4 & 4 & 4 & 4 & 4 & 4 & 4 \\
\hline Vanuatu & 35 & 5 & 12 & 24 & 28 & 24 & 19 & 19 & 19 \\
\hline Developed ADB Member Economies & 3,514 & 2,197 & 3,919 & 5,212 & 6,331 & 5,783 & 6,160 & 6,594 & 7,610 \\
\hline Australia & 1,904 & 940 & 1,864 & 2,389 & 2,292 & 2,173 & 2,055 & 2,002 & 1,818 \\
\hline Japan & 1,374 & 905 & 1,684 & 2,364 & 3,734 & 3,325 & 3,830 & 4,440 & 5,634 \\
\hline New Zealand & 236 & 352 & 371 & 459 & 305 & 285 & 274 & 152 & 158 \\
\hline DEVELOPING ADB MEMBER ECONOMIES & 35,530 & 92,899 & 195,650 & 253,770 & 264,786 & 265,082 & 256,381 & 272,196 & 297,070 \\
\hline ALL ADB REGIONAL MEMBERS & 39,044 & 95,096 & 199,570 & 258,983 & 271,116 & 270,865 & 262,541 & 278,790 & 304,679 \\
\hline WORLD & 119,051 & 284,762 & 469,852 & 580,511 & 603,224 & 595,831 & 589,369 & 632,727 & 689,404 \\
\hline
\end{tabular}

... = data not available, $\$=$ United States dollars, $\mathrm{ADB}=$ Asian Development Bank.

a For 2005 onward, figures are based on the IMF's Balance of Payments and International Investment Position Manual (sixth edition). Prior to 2005, figures are based on the IMF's Balance of Payments Manual (fifth edition).

b For reporting economies only.

Sources: World Bank. Migration and Remittances Data. http://www.worldbank.org/en/topic/migrationremittancesdiasporaissues/brief/migration-remittances-data (accessed 3 June 2019). For Taipei,China: Central bank of Taipei,China. https://www.cbc.gov.tw/ct.asp?xltem=1061\&ctNode=535\&mp=2 (accessed 3 June 2019). 
Table 2.4.5: Workers' Remittances and Compensation of Employees, Receipts (\% of GDP)

\begin{tabular}{|c|c|c|c|c|c|c|c|c|c|}
\hline ADB Regional Member & 2000 & 2005 & 2010 & 2013 & 2014 & 2015 & 2016 & 2017 & 2018 \\
\hline \multicolumn{10}{|l|}{ Developing ADB Member Economies } \\
\hline \multicolumn{10}{|l|}{ Central and West Asia } \\
\hline Afghanistan & $\ldots$ & & 2.3 & 1.5 & 1.2 & 1.7 & 1.8 & 1.8 & 1.9 \\
\hline Armenia & 4.6 & 18.7 & 18.0 & 19.7 & 17.9 & 14.1 & 13.1 & 13.3 & 12.2 \\
\hline Azerbaijan & 1.1 & 4.7 & 2.7 & 2.3 & 2.5 & 2.4 & 1.7 & 2.8 & 2.7 \\
\hline Georgia & 6.9 & 7.0 & 10.2 & 12.1 & 12.0 & 10.4 & 10.6 & 11.9 & 12.6 \\
\hline Kazakhstan & 0.7 & 0.1 & 0.2 & 0.1 & 0.1 & 0.1 & 0.2 & 0.2 & 0.2 \\
\hline Kyrgyz Republic & 0.6 & 12.7 & 26.4 & 31.1 & 30.0 & 25.3 & 29.3 & 32.3 & 33.2 \\
\hline Pakistan & 1.4 & 3.6 & 5.6 & 6.6 & 6.9 & 7.2 & 7.1 & 6.5 & 7.4 \\
\hline Tajikistan & $6.4(2002)$ & 20.2 & 35.8 & 43.5 & 36.6 & 28.8 & 26.9 & 31.2 & 30.2 \\
\hline Turkmenistan & $\ldots$ & $0.1(2006)$ & 0.2 & 0.1 & 0.1 & 0.0 & 0.0 & 0.0 & 0.0 \\
\hline Uzbekistan & 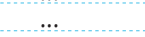 & $5.2(2006)$ & 6.1 & 9.7 & 7.4 & 3.7 & 3.4 & 6.6 & 7.7 \\
\hline \multicolumn{10}{|l|}{ East Asia } \\
\hline China, People's Republic of & 0.1 & 1.0 & 0.9 & 0.6 & 0.6 & 0.6 & 0.5 & 0.5 & 0.5 \\
\hline Hong Kong, China & 0.1 & 0.2 & 0.1 & 0.1 & 0.1 & 0.1 & 0.1 & 0.1 & 0.1 \\
\hline Korea, Republic of & 0.8 & 0.6 & 0.5 & 0.5 & 0.4 & 0.4 & 0.4 & 0.4 & 0.4 \\
\hline Mongolia & 1.1 & 7.0 & 3.7 & 2.0 & 2.1 & 2.2 & 2.3 & 2.4 & 3.4 \\
\hline Taipei,China & 0.1 & 0.1 & 0.1 & 0.2 & 0.2 & 0.2 & 0.2 & 0.2 & 0.3 \\
\hline \multicolumn{10}{|l|}{ South Asia } \\
\hline Bangladesh & 4.3 & 8.1 & 9.5 & 9.0 & 8.7 & 7.9 & 6.1 & 5.5 & 5.7 \\
\hline Bhutan & & $0.2(2006)$ & 0.5 & 0.7 & 0.7 & 1.0 & 1.5 & 1.7 & $\ldots$ \\
\hline India & 2.7 & 2.6 & 3.1 & 3.6 & 3.4 & 3.2 & 2.7 & 2.6 & 2.8 \\
\hline Maldives & 0.4 & 0.2 & 0.1 & 0.1 & 0.1 & 0.1 & 0.1 & 0.1 & \\
\hline Nepal & 2.1 & 14.7 & 21.3 & 30.7 & 29.2 & 32.4 & 31.5 & 27.1 & 29.0 \\
\hline Sri Lanka & 7.0 & 8.1 & 7.3 & 8.6 & 8.9 & 8.7 & 8.8 & 8.2 & 8.4 \\
\hline \multicolumn{10}{|l|}{ Southeast Asia } \\
\hline Brunei Darussalam & $\cdots$ & 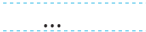 & & & & & & & .. \\
\hline Cambodia & 3.3 & 2.6 & 5.0 & 6.6 & 6.6 & 6.6 & 6.0 & 5.8 & 5.7 \\
\hline Indonesia & 0.7 & 1.9 & 0.9 & 0.8 & 1.0 & 1.1 & 1.0 & 0.9 & 1.1 \\
\hline Lao People's Democratic Republic & 0.0 & 0.0 & 0.6 & 1.4 & 1.4 & 1.3 & 1.2 & 1.5 & 1.5 \\
\hline Malaysia & 0.4 & 0.8 & 0.4 & 0.4 & 0.5 & 0.5 & 0.5 & 0.5 & 0.5 \\
\hline Myanmar & & & & 2.6 & 2.8 & 3.2 & 3.6 & 3.9 & $\ldots$ \\
\hline Philippines & 8.6 & 13.3 & 10.8 & 9.8 & 10.1 & 10.2 & 10.2 & 10.5 & 10.2 \\
\hline Singapore & & & & & & & & $\ldots$ & $\ldots$ \\
\hline Thailand & 1.3 & 0.6 & 1.3 & 1.6 & 1.6 & 1.5 & 1.5 & 1.5 & 1.5 \\
\hline Viet Nam & 4.3 & 5.5 & 7.1 & 6.4 & 6.4 & 6.7 & 6.8 & 6.7 & 6.5 \\
\hline \multicolumn{10}{|l|}{ The Pacific } \\
\hline Cook Islands & $\cdots$ & & & & & & & & $\ldots$ \\
\hline Fiji & 2.6 & 6.8 & 5.6 & 4.9 & 4.5 & 5.4 & 5.5 & 5.2 & $\ldots$ \\
\hline Kiribati & $\ldots$ & $11.8(2006)$ & 10.0 & 9.3 & 9.3 & 9.4 & 9.8 & 9.4 & $\cdots$ \\
\hline Marshall Islands & $\ldots$ & 16.9 & 13.2 & 12.8 & 14.1 & 15.1 & 14.3 & 13.6 & $\cdots$ \\
\hline Micronesia, Federated States of & $\ldots$ & $\ldots$ & 6.1 & 7.0 & 7.3 & 7.4 & 7.0 & 6.4 & $\cdots$ \\
\hline Nauru & $\ldots$ & $\ldots$ & $\ldots$ & $\ldots$ & $\ldots$ & $\ldots$ & $\ldots$ & $\ldots$ & $\ldots$ \\
\hline \multicolumn{10}{|l|}{ Niue } \\
\hline Palau & & 0.8 & 0.9 & 1.1 & 0.9 & 0.8 & 0.8 & 0.8 & 0.9 \\
\hline Papua New Guinea & 0.2 & 0.1 & 0.0 & 0.1 & 0.0 & 0.0 & 0.0 & 0.0 & 0.0 \\
\hline Samoa & & 18.8 & 20.0 & 21.5 & 18.0 & 16.7 & 15.9 & 16.7 & 17.0 \\
\hline Solomon Islands & 1.5 & 1.7 & 2.1 & 2.0 & 1.6 & 1.8 & 1.9 & & $\ldots$ \\
\hline Timor-Leste & $\ldots$ & $0.1(2006)$ & 3.4 & 0.6 & 1.1 & 2.0 & 3.2 & 3.5 & $\ldots$ \\
\hline Tonga & $31.5(2001)$ & 26.1 & 19.8 & 27.9 & 27.3 & 37.6 & 31.1 & 34.7 & 34.6 \\
\hline Tuvalu & & 22.7 & 12.5 & 10.9 & 11.0 & 11.6 & 10.3 & 9.2 & $\ldots$ \\
\hline Vanuatu & 12.7 & 1.3 & 1.7 & 3.0 & 3.5 & 3.2 & 2.3 & 2.1 & $\ldots$ \\
\hline \multicolumn{10}{|l|}{ Developed ADB Member Economies } \\
\hline Australia & 0.5 & 0.1 & 0.2 & 0.2 & 0.2 & 0.2 & 0.2 & 0.1 & 0.1 \\
\hline Japan & 0.0 & 0.0 & 0.0 & 0.0 & 0.1 & 0.1 & 0.1 & 0.1 & 0.1 \\
\hline New Zealand & 0.4 & 0.3 & 0.3 & 0.2 & 0.2 & 0.2 & 0.1 & 0.1 & $\ldots$ \\
\hline DEVELOPING ADB MEMBER ECONOMIES & 1.0 & 1.6 & 1.6 & 1.5 & 1.4 & 1.4 & 1.3 & 1.3 & 1.3 \\
\hline ALL ADB REGIONAL MEMBERS & 0.4 & 0.8 & 1.0 & 1.1 & 1.1 & 1.1 & 1.0 & 1.0 & 1.0 \\
\hline
\end{tabular}

... = data not available, 0.0 = magnitude is less than half of unit employed, $\mathrm{ADB}=$ Asian Development Bank, GDP $=$ gross domestic product.

a For reporting economies only.

Sources: Economy sources; and World Bank. Migration and Remittances Data. http://www.worldbank.org/en/topic/migrationremittancesdiasporaissues/brief/ migration-remittances-data (accessed 3 June 2019). 
Table 2.4.6: $\quad$ Foreign Direct Investment, Net Inflows (\$ million)

\begin{tabular}{|c|c|c|c|c|c|c|c|c|c|}
\hline ADB Regional Member & 2000 & 2005 & 2010 & 2013 & 2014 & 2015 & 2016 & 2017 & 2018 \\
\hline \multicolumn{10}{|l|}{ Developing ADB Member Economies } \\
\hline Central and West Asia & 2,271 & 10,946 & 20,287 & 19,777 & 21,128 & 18,960 & 30,977 & 16,853 & $\ldots$ \\
\hline Afghanistan & 0 & 271 & 191 & 48 & 43 & 169 & 94 & 52 & \\
\hline Armenia & 104 & 292 & 529 & 346 & 404 & 178 & 338 & 250 & 254 \\
\hline Azerbaijan & 130 & 4,476 & 3,353 & 2,619 & 4,430 & 4,048 & 4,500 & 2,867 & 1,403 \\
\hline Georgia & 131 & 453 & 900 & 1,028 & 1,818 & 1,659 & 1,571 & 1,830 & 1,184 \\
\hline Kazakhstan & 1,371 & 2,546 & 7,456 & 10,011 & 7,308 & 6,578 & 17,221 & 4,713 & 208 \\
\hline Kyrgyz Republic & -2 & 43 & 473 & 612 & 343 & 1,144 & 619 & -107 & \\
\hline Pakistan & 308 & 2,201 & 2,022 & 1,333 & 1,868 & 1,621 & 2,488 & 2,952 & 2,778 \\
\hline Tajikistan & 24 & 54 & 94 & 283 & 327 & 454 & 242 & 186 & 221 \\
\hline Turkmenistan & 131 & 418 & 3,632 & 2,861 & 3,830 & 3,043 & 2,243 & 2,314 & \\
\hline Uzbekistan & 75 & 192 & 1,636 & 635 & 757 & 66 & 1,663 & 1,797 & 624 \\
\hline East Asia & 129,082 & 160,528 & 340,093 & 386,210 & 410,384 & 430,126 & 325,218 & 314,499 & 313,606 \\
\hline China, People's Republic of & 42,095 & 104,109 & 243,703 & 290,928 & 268,097 & 242,489 & 174,750 & 166,084 & 203,492 \\
\hline Hong Kong, China & 70,496 & 40,963 & 82,709 & 76,857 & 129,847 & 181,047 & 133,259 & 125,717 & 86,463 \\
\hline Korea, Republic of & 11,509 & 13,643 & 9,497 & 12,767 & 9,274 & 4,104 & 12,104 & 17,913 & 14,479 \\
\hline Mongolia & 54 & 188 & 1,691 & 2,060 & 338 & 94 & $-4,156$ & 1,494 & 2,174 \\
\hline Taipei,China & 4,928 & 1,625 & 2,492 & 3,598 & 2,828 & 2,391 & 9,261 & 3,291 & 6,998 \\
\hline South Asia & 4,062 & 8,364 & 29,486 & 32,144 & 38,397 & 47,877 & 48,263 & 44,165 & \\
\hline Bangladesh & 280 & 761 & 1,232 & 2,603 & 2,539 & 2,831 & 2,333 & 2,151 & \\
\hline Bhutan & $2(2002)$ & 6 & 75 & 20 & 24 & $\begin{array}{r}6,00 \\
6\end{array}$ & 12 & $\begin{array}{l}-17 \\
-17\end{array}$ & 4 \\
\hline India & 3,584 & 7,269 & 27,397 & 28,153 & 34,577 & 44,009 & 44,459 & 39,966 & 43,302 \\
\hline Maldives & 22 & 53 & 216 & 361 & 333 & 298 & 457 & 493 & \\
\hline Nepal & -0 & 2 & 88 & 74 & 30 & 52 & 106 & 196 & \\
\hline Sri Lanka & 173 & 272 & 478 & 933 & 894 & 680 & 897 & 1,375 & \\
\hline Southeast Asia & 21,371 & 43,002 & 108,136 & 133,321 & 129,818 & 132,933 & 121,793 & 166,093 & ... \\
\hline Brunei Darussalam & $61(2001)$ & 175 & 481 & 776 & 568 & 171 & -151 & 468 & \\
\hline Cambodia & 118 & 379 & 1,404 & 2,068 & 1,853 & 1,823 & 2,476 & 2,788 & 3,103 \\
\hline Indonesia & $\begin{array}{r}110 \\
-4,550\end{array}$ & 8,336 & $\begin{array}{r}1,404 \\
15,292\end{array}$ & 23,282 & $\begin{array}{r}1,035 \\
25,121\end{array}$ & $\begin{array}{r}1,023 \\
19,779\end{array}$ & 4,542 & 20,510 & 20,171 \\
\hline Lao People's Democratic Republic & 34 & 28 & 279 & 681 & 868 & 1,078 & 935 & 1,599 & \\
\hline Malaysia & 3,788 & 3,925 & 10,886 & 11,296 & 10,619 & 9,857 & 13,470 & 9,512 & \\
\hline Myanmar & 255 & 235 & 901 & 2,255 & 2,175 & 4,084 & 3,278 & 4,002 & \\
\hline Philippines & 1,487 & 1,664 & 1,070 & 3,737 & 5,740 & 5,639 & 8,280 & 10,256 & 9,802 \\
\hline Singapore & 15,515 & 18,090 & 55,076 & 64,390 & 68,698 & 69,775 & 73,553 & 94,811 & 82,039 \\
\hline Thailand & 3,366 & 8,216 & 14,747 & 15,936 & 4,975 & 8,928 & 2,810 & 8,046 & 13,248 \\
\hline Viet Nam & 1,298 & 1,954 & 8,000 & 8,900 & 9,200 & 11,800 & 12,600 & 14,100 & \\
\hline The Pacific & 259 & 240 & 459 & 503 & 524 & 584 & 459 & 308 & \\
\hline Cook Islands & $\ldots$ & $\ldots$ & $\ldots$ & $\ldots$ & $\ldots$ & & & & \\
\hline Fiji & 1 & 173 & 178 & 244 & 378 & 205 & 392 & 388 & 342 \\
\hline Kiribati & 1 & 3 & -7 & 1 & 3 & -1 & 2 & 1 & \\
\hline Marshall Islands & 126 & 3 & -9 & 33 & 9 & -5 & -3 & 0 & \\
\hline Micronesia, Federated States of & $-0(2001)$ & 0 & 1 & 1 & 20 & 1 & $\ldots$ & $\ldots$ & \\
\hline Nauru & 1 & 1 & $1(2009)$ & $\ldots$ & $\ldots$ & $\ldots$ & $\cdots$ & $\cdots$ & \\
\hline Niue & & & $\ldots$ & $\cdots$ & $\cdots$ & & & & \\
\hline Palau & 3 & 4 & 3 & 18 & 40 & 35 & 35 & 27 & \\
\hline Papua New Guinea & 96 & 32 & 29 & 18 & -30 & 203 & -40 & -180 & \\
\hline Samoa & -1 & 4 & -1 & 14 & 23 & 27 & 3 & 9 & \\
\hline Solomon Islands & 2 & 1 & 166 & 53 & 21 & 32 & 37 & 37 & \\
\hline Timor-Leste & $1(2002)$ & 1 & 30 & 56 & 34 & 43 & 5 & 7 & \\
\hline Tonga & 9 & 6 & 5 & 6 & 13 & 13 & 6 & -6 & 15 \\
\hline Tuvalu & $-0(2001)$ & -0 & 0 & 0 & 0 & 0 & 0 & 0 & \\
\hline Vanuatu & 20 & 13 & 63 & 59 & 13 & 31 & 22 & 25 & \\
\hline Developed ADB Member Economies & 24,073 & $-17,727$ & 42,938 & 64,576 & 86,197 & 50,230 & 82,275 & 67,044 & 85,400 \\
\hline Australia & 14,893 & $-25,093$ & 35,211 & 53,997 & 63,195 & 45,051 & 39,226 & 44,480 & 58,048 \\
\hline Japan & 10,688 & 5,460 & 7,441 & 10,648 & 19,752 & 5,252 & 40,954 & 20,420 & 25,877 \\
\hline New Zealand & $-1,508$ & 1,907 & 286 & -70 & 3,249 & -74 & 2,096 & 2,144 & 1,475 \\
\hline Developing ADB Member Economies & 157,045 & 223,080 & 498,461 & 571,956 & 600,251 & 630,481 & 526,710 & 541,917 & $\ldots$ \\
\hline All ADB Regional Members ${ }^{\mathrm{a}}$ & 181,118 & 205,353 & 541,399 & 636,532 & 686,447 & 680,710 & 608,985 & 608,961 & $\ldots$ \\
\hline World & $1,460,994$ & $1,546,409$ & $1,857,433$ & $2,134,350$ & $1,838,186$ & $2,394,019$ & $2,480,344$ & $2,085,130$ & ... \\
\hline
\end{tabular}

$\ldots=$ data not available, -0 or 0 = magnitude is less than half of unit employed, $\$=$ United States dollars, $A D B=$ Asian Development Bank.

a For reporting economies only.

Sources: $\quad$ World Bank. World Development Indicators. http://data.worldbank.org/indicator/BX.KLT.DINV.CD.WD?locations=MH (accessed 24 July 2019). For Taipei,China: Central bank of Taipei,China. https://www.cbc.gov.tw/ct.asp?xitem=1061\&ctnode=535\&mp=2 (accessed 24 July 2019 ). 
Table 2.4.7: $\quad$ Foreign Direct Investment, Net Inflows (\% of GDP)

\begin{tabular}{|c|c|c|c|c|c|c|c|c|c|}
\hline ADB Regional Member & 2000 & 2005 & 2010 & 2013 & 2014 & 2015 & 2016 & 2017 & 2018 \\
\hline \multicolumn{10}{|l|}{ Developing ADB Member Economies } \\
\hline \multicolumn{10}{|l|}{ Central and West Asia } \\
\hline Afghanistan & $1.2(2002)$ & 4.1 & 1.2 & 0.2 & 0.2 & 0.8 & 0.5 & 0.2 & $\cdots$ \\
\hline Armenia & 5.5 & 6.0 & 5.7 & 3.1 & 3.5 & 1.7 & 3.2 & 2.2 & 2.0 \\
\hline Azerbaijan & 2.5 & 33.8 & 6.3 & 3.5 & 5.9 & 7.6 & 11.9 & 7.0 & 3.0 \\
\hline Georgia & 4.3 & 7.1 & 7.7 & 6.4 & 11.0 & 11.9 & 10.9 & 12.1 & 7.3 \\
\hline Kazakhstan & 7.5 & 4.5 & 5.0 & 4.2 & 3.3 & 3.6 & 12.5 & 2.9 & 0.1 \\
\hline Kyrgyz Republic & -0.2 & 1.7 & 9.9 & 8.3 & 4.6 & 17.1 & 9.1 & -1.4 & \\
\hline Pakistan & 0.4 & 1.8 & 1.2 & 0.6 & 0.8 & 0.6 & 0.9 & 1.0 & 1.0 \\
\hline Tajikistan & 2.7 & 2.4 & 1.7 & 3.3 & 3.5 & 5.8 & 3.5 & 2.6 & 2.9 \\
\hline Turkmenistan & 2.7 & 2.4 & 16.1 & 7.3 & 8.8 & 8.5 & 6.2 & 6.1 & \\
\hline Uzbekistan & 0.5 & 1.3 & 3.5 & 0.9 & 1.0 & 0.1 & 2.0 & 3.0 & 1.2 \\
\hline \multicolumn{10}{|l|}{ East Asia } \\
\hline China, People's Republic of & 3.5 & 4.6 & 4.0 & 3.0 & 2.6 & 2.2 & 1.6 & 1.4 & 1.5 \\
\hline Hong Kong, China & 41.1 & 22.6 & 36.2 & 27.9 & 44.6 & 58.5 & 41.5 & 36.8 & 23.8 \\
\hline Korea, Republic of & 2.0 & 1.5 & 0.8 & 0.9 & 0.6 & 0.3 & 0.8 & 1.1 & 0.8 \\
\hline Mongolia & 4.7 & 7.4 & 23.5 & 16.4 & 2.8 & 0.8 & -37.2 & 13.1 & 16.7 \\
\hline Taipei,China & 1.5 & 0.4 & 0.6 & 0.7 & 0.5 & 0.5 & 1.7 & 0.6 & 1.2 \\
\hline \multicolumn{10}{|l|}{ South Asia } \\
\hline Bangladesh & 0.6 & 1.3 & 1.1 & 1.7 & 1.5 & 1.5 & 1.1 & 0.9 & $\cdots$ \\
\hline Bhutan & $0.5(2002)$ & 0.8 & 4.7 & 1.1 & 1.2 & 0.3 & 0.5 & -0.7 & $\cdots$ \\
\hline India & 0.7 & 0.9 & 1.6 & 1.5 & 1.7 & 2.1 & 1.9 & 1.5 & 1.6 \\
\hline Maldives & 3.6 & 4.6 & 8.4 & 11.0 & 9.0 & 7.3 & 10.3 & 10.1 & $\ldots$ \\
\hline Nepal & -0.0 & 0.0 & 0.5 & 0.4 & 0.2 & 0.2 & 0.5 & 0.8 & \\
\hline Sri Lanka & 1.0 & 1.1 & 0.8 & 1.3 & 1.1 & 0.8 & 1.1 & 1.6 & $\ldots$ \\
\hline \multicolumn{10}{|l|}{ Southeast Asia } \\
\hline Brunei Darussalam & $1.1(2001)$ & 1.8 & 3.5 & 4.3 & 3.3 & 1.3 & -1.3 & 3.9 & $\ldots$ \\
\hline Cambodia & 3.2 & 6.0 & 12.5 & 13.6 & 11.1 & 10.1 & 12.4 & 12.6 & 12.6 \\
\hline Indonesia & -2.8 & 2.9 & 2.0 & 2.6 & 2.8 & 2.3 & 0.5 & 2.0 & 1.9 \\
\hline Lao People's Democratic Republic & 2.1 & 1.0 & 4.1 & 5.7 & 6.5 & 7.5 & 5.9 & 9.5 & $\ldots$ \\
\hline Malaysia & 4.0 & 2.7 & 4.3 & 3.5 & 3.1 & 3.3 & 4.5 & 3.0 & $\ldots$ \\
\hline Myanmar & & & & 3.6 & 3.3 & 6.5 & 5.1 & 6.0 & $\cdots$ \\
\hline Philippines & 1.8 & 1.6 & 0.5 & 1.4 & 2.0 & 1.9 & 2.7 & 3.3 & 3.0 \\
\hline Singapore & 16.1 & 14.2 & 23.0 & 20.9 & 21.8 & 22.7 & 23.1 & 28.0 & 22.5 \\
\hline Thailand & 2.7 & 4.3 & 4.3 & 3.8 & 1.2 & 2.2 & 0.7 & 1.8 & 2.6 \\
\hline Viet Nam & 4.2 & 3.4 & 6.9 & 5.2 & 4.9 & 6.1 & 6.1 & 6.3 & $\ldots$ \\
\hline \multicolumn{10}{|l|}{ The Pacific } \\
\hline Cook Islands & & & & $\ldots$ & $\ldots$ & $\ldots$ & $\ldots$ & $\ldots$ & $\ldots$ \\
\hline Fiji & 0.0 & 5.8 & 5.7 & 5.8 & 7.8 & 4.4 & 7.9 & 7.4 & $\ldots$ \\
\hline Kiribati & 1.1 & 2.3 & -4.2 & 0.5 & 1.5 & -0.5 & 1.0 & 0.4 & $\ldots$ \\
\hline Marshall Islands & 111.8 & 2.3 & -5.6 & 16.9 & 4.9 & -3.0 & -1.5 & 0.1 & $\cdots$ \\
\hline Micronesia, Federated States of & $-0.1(2001)$ & 0.0 & 0.3 & 0.3 & 6.4 & 0.3 & $\ldots$ & $\ldots$ & $\cdots$ \\
\hline Nauru & 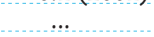 & 3.2 & $3.0(200$ & $\ldots$ & $\ldots$ & $\ldots$ & $\cdots$ & $\ldots$ & $\ldots$ \\
\hline \multicolumn{10}{|l|}{ Niue } \\
\hline Palau & 2.2 & 2.2 & 1.5 & 8.1 & 16.4 & 12.3 & 11.7 & 9.6 & $\ldots$ \\
\hline Papua New Guinea & 2.8 & 0.7 & 0.2 & 0.1 & -0.1 & 0.9 & -0.2 & -0.8 & $\ldots$ \\
\hline Samoa & -0.5 & 0.9 & -0.2 & 1.8 & 2.9 & 3.4 & 0.3 & 1.1 & $\ldots$ \\
\hline Solomon Islands & 0.7 & 0.1 & 23.8 & 5.3 & 2.0 & 3.1 & 3.4 & & $\ldots$ \\
\hline Timor-Leste & $0.2(2002)$ & 0.1 & 0.8 & 1.0 & 0.8 & 1.4 & 0.2 & 0.3 & $\ldots$ \\
\hline Tonga & 4.9 & 2.3 & 1.2 & 1.4 & 3.0 & 3.2 & 1.4 & -1.2 & 3.2 \\
\hline Tuvalu & $-0.1(2001)$ & -0.1 & 1.4 & 0.9 & 0.8 & 0.9 & 0.8 & 0.7 & $\ldots$ \\
\hline Vanuatu & 7.4 & 3.4 & 9.0 & 7.4 & 1.6 & 4.1 & 2.7 & 2.8 & $\ldots$ \\
\hline \multicolumn{10}{|l|}{ Developed ADB Member Economies } \\
\hline Australia & 3.9 & -3.6 & 2.9 & 3.6 & 4.4 & 3.7 & 3.2 & 3.3 & 4.2 \\
\hline Japan & 0.2 & 0.1 & 0.1 & 0.2 & 0.4 & 0.1 & 0.8 & 0.4 & 0.5 \\
\hline New Zealand & -2.8 & 1.7 & 0.2 & -0.0 & 1.6 & -0.0 & 1.1 & 1.1 & $\ldots$ \\
\hline DEVELOPING ADB MEMBER ECONOMIES & 4.4 & 3.8 & 4.1 & 3.3 & 3.3 & 3.3 & 2.7 & 2.6 & 2.1 \\
\hline ALL ADB REGIONAL MEMBERS & 2.0 & 1.8 & 2.8 & 2.7 & 2.8 & 2.8 & 2.4 & 2.2 & 2.0 \\
\hline
\end{tabular}

... = data not available, 0.0 = magnitude is less than half of the unit employed, $\mathrm{ADB}=$ Asian Development Bank, GDP = gross domestic product.

a For reporting economies with data available for both foreign direct investment and GDP.

Sources: $\quad$ World Bank. World Development Indicators. http://data.worldbank.org/indicator/BX.KLT.DINV.CD.WD?locations=MH (accessed 24 July 2019). For Taipei,China: Central bank of Taipei,China. https://www.cbc.gov.tw/ct.asp?xltem=1061\&ctNode=535\&mp=2 (accessed 24 July 2019 ). 
Table 2.4.8: Merchandise Exports

(\$ million)

\begin{tabular}{|c|c|c|c|c|c|c|c|c|c|}
\hline ADB Regional Member & 2000 & 2005 & 2010 & 2013 & 2014 & 2015 & 2016 & 2017 & 2018 \\
\hline \multicolumn{10}{|l|}{ Developing ADB Member Economies } \\
\hline Central and West Asia & 26,716 & 64,110 & 134,665 & 181,036 & 174,603 & 116,374 & 97,395 & 113,221 & 125,443 \\
\hline Afghanistan & 137 & 384 & 388 & 515 & 571 & 571 & 596 & 723 & 875 \\
\hline Armenia & 300 & 974 & 1,041 & 1,479 & 1,547 & 1,485 & 1,792 & 2,238 & 2,412 \\
\hline Azerbaijan & 1,745 & 7,649 & 26,374 & 31,703 & 28,260 & 15,586 & 13,211 & 15,152 & 20,794 \\
\hline Georgia & 324 & 865 & 1,677 & 2,910 & 2,861 & 2,205 & 2,113 & 2,735 & 3,355 \\
\hline Kazakhstan & 8,812 & 27,849 & 60,271 & 84,700 & 79,460 & 45,956 & 36,737 & 48,503 & 60,956 \\
\hline Kyrgyz Republic & 505 & 674 & 1,756 & 2,007 & 1,884 & 1,483 & 1,573 & 1,764 & 1,765 \\
\hline Pakistan & 8,335 & 14,453 & 19,261 & 23,383 & 25,715 & 23,526 & 20,859 & 20,566 & 21,296 \\
\hline Tajikistan & 784 & 909 & 1,195 & 1,162 & 977 & 891 & 899 & 1,198 & \\
\hline Turkmenistan & 2,508 & 4,944 & 9,679 & 18,854 & 19,782 & 12,164 & 7,520 & 7,788 & \\
\hline Uzbekistan & 3,265 & 5,409 & 13,023 & 14,323 & 13,546 & 12,508 & 12,095 & 12,554 & 13,991 \\
\hline East Asia & 775,319 & $1,536,567$ & $2,714,594$ & $3,542,100$ & $3,713,254$ & $3,553,456$ & $3,339,763$ & $3,657,920$ & $3,965,543$ \\
\hline China, People's Republic of & 249,203 & 761,953 & $1,577,754$ & $2,209,004$ & $2,342,293$ & $2,273,468$ & $2,097,631$ & $2,263,371$ & $2,487,401$ \\
\hline Hong Kong, China & 201,855 & 289,325 & 390,134 & 458,959 & 473,654 & 465,092 & 462,269 & 497,340 & 530,472 \\
\hline Korea, Republic of & 172,268 & 284,419 & 466,384 & 559,632 & 572,665 & 526,757 & 495,426 & 573,694 & 604,860 \\
\hline Mongolia & 536 & 1,064 & 2,909 & 4,269 & 5,774 & 4,669 & 4,916 & 6,201 & 7,012 \\
\hline Taipei,China & 151,458 & 199,807 & 277,413 & 310,236 & 318,869 & 283,470 & 279,521 & 317,313 & 335,798 \\
\hline South Asia & 56,445 & 119,305 & 276,096 & 364,634 & 353,306 & 310,212 & 320,174 & 346,730 & 385,742 \\
\hline Bangladesh & 4,780 & 8,259 & 16,099 & 27,619 & 29,807 & 30,588 & 33,352 & 33,462 & 35,612 \\
\hline Bhutan & 103 & 214 & 535 & 511 & 539 & 561 & 488 & 566 & 604 \\
\hline India & 45,297 & 103,496 & 249,951 & 325,099 & 310,742 & 267,550 & 275,233 & 300,440 & 336,879 \\
\hline Maldives & 109 & 162 & 62 & 166 & 144 & 144 & 139 & 199 & \\
\hline Nepal & 701 & 823 & 830 & 826 & 943 & 833 & 653 & 699 & 745 \\
\hline Sri Lanka & 5,456 & 6,351 & 8,618 & 10,413 & 11,130 & 10,536 & 10,309 & 11,364 & 11,901 \\
\hline Southeast Asia & 427,409 & 655,385 & $1,048,737$ & $1,279,250$ & $1,297,458$ & $1,172,817$ & $1,152,310$ & $1,313,489$ & $1,446,072$ \\
\hline Brunei Darussalam & 3,906 & 6,247 & 8,887 & 11,436 & 10,601 & 6,338 & 4,917 & 5,585 & 6,575 \\
\hline Cambodia & 1,397 & 2,908 & 3,903 & 7,044 & 8,170 & 9,336 & 10,273 & 11,224 & 12,963 \\
\hline Indonesia & 62,124 & 85,660 & 157,779 & 182,552 & 175,981 & 150,366 & 145,186 & 168,811 & 180,215 \\
\hline Lao People's Democratic Republic & 330 & 553 & 1,746 & 2,264 & 3,276 & 3,653 & 4,245 & 4,873 & 5,295 \\
\hline Malaysia & 98,229 & 141,595 & 198,325 & 228,503 & 233,868 & 199,041 & 189,708 & 217,403 & 247,397 \\
\hline Myanmar & 1,756 & 3,836 & 8,872 & 11,233 & 11,452 & 11,432 & 11,837 & 13,878 & 16,672 \\
\hline Philippines & 38,078 & 41,255 & 51,498 & 56,698 & 62,102 & 58,827 & 57,406 & 68,713 & 69,307 \\
\hline Singapore & 137,954 & 230,523 & 352,553 & 419,969 & 415,191 & 357,729 & 337,962 & 372,938 & 411,958 \\
\hline Thailand & 69,152 & 110,360 & 192,937 & 227,518 & 226,601 & 214,077 & 214,195 & 234,947 & 252,207 \\
\hline Viet Nam & 14,483 & 32,447 & 72,237 & 132,033 & 150,217 & 162,017 & 176,581 & 215,119 & 243,483 \\
\hline The Pacific & 2,813 & 4,304 & 7,010 & 7,803 & 10,721 & 10,052 & 9,924 & 11,645 & 11,793 \\
\hline Cook Islands & 9 & 5 & 5 & 11 & 18 & 14 & 14 & 20 & 17 \\
\hline Fiji & 543 & 705 & 837 & 1,151 & 1,220 & 982 & 931 & 985 & 1,016 \\
\hline Kiribati & 4 & 4 & 4 & 7 & 10 & 9 & $\ldots$ & $\ldots$ & \\
\hline Marshall Islands & 25 & 34 & & & & & & & \\
\hline Micronesia, Federated States of & 17 & 13 & 30 & 35 & 32 & 40 & 49 & 46 & \\
\hline Naurua & & 0 & 32 & 48 & 22 & 14 & 26 & 25 & \\
\hline Niue & 0 & & 1 & 1 & 1 & 1 & 1 & 2 & 2 \\
\hline Palau & 12 & 14 & 16 & 21 & 19 & 18 & & & \\
\hline Papua New Guinea & 2,089 & 3,311 & 5,737 & 5,951 & 8,794 & 8,425 & 8,202 & 9,958 & 10,060 \\
\hline Samoa & 14 & 12 & 23 & 24 & 27 & 34 & 36 & 37 & 42 \\
\hline Solomon Islands & 65 & 105 & 227 & 448 & 455 & 421 & 432 & 469 & 534 \\
\hline Timor-Leste & & 43 & 42 & 53 & 39 & 38 & 162 & 24 & 46 \\
\hline Tonga & 9 & 10 & 8 & 14 & 19 & 18 & 21 & 19 & 13 \\
\hline Tuvalu & 0 & 0 & 1 & 0 & 0 & 0 & 0 & 0 & \\
\hline Vanuatu & 26 & 46 & 48 & 39 & 63 & 39 & 50 & 60 & 64 \\
\hline Developed ADB Member Economies & 557,173 & 723,803 & $1,012,107$ & $1,008,852$ & 970,204 & 846,261 & 869,790 & 967,697 & $1,035,712$ \\
\hline Australia & 63,980 & 106,211 & 212,027 & 252,894 & 239,708 & 187,525 & 192,140 & 230,950 & 257,436 \\
\hline Japan & 479,320 & 595,696 & 767,825 & 714,931 & 689,916 & 624,681 & 643,753 & 697,951 & 737,877 \\
\hline New Zealand & 13,873 & 21,896 & 32,255 & 41,026 & 40,579 & 34,054 & 33,897 & 38,797 & 40,399 \\
\hline DEVELOPING ADB MEMBER ECONOMIES & $1,288,702$ & $2,379,671$ & $4,181,101$ & $5,374,823$ & $5,549,341$ & $5,162,911$ & $4,919,565$ & $5,443,006$ & $5,934,593$ \\
\hline ALL ADB REGIONAL MEMBERS & $1,845,875$ & $3,103,474$ & $5,193,208$ & $6,383,675$ & $6,519,545$ & $6,009,172$ & $5,789,355$ & $6,410,703$ & $6,970,305$ \\
\hline WORLD & $6,439,934$ & $10,433,968$ & $15,142,190$ & $18,699,578$ & $18,797,999$ & $16,400,565$ & $15,845,543$ & $17,518,078$ & $19,324,970$ \\
\hline
\end{tabular}

$\ldots=$ data not available, 0 = magnitude is less than half of unit employed, $\$=$ United States dollars, $A D B=$ Asian Development Bank.

a For 2002-2015, data were taken from the media release on International Merchandise Trade Statistics (IMTS Release No. 01/2016) of the Nauru Bureau of Statistics, published on 3 November 2016.

b For reporting economies only.

Sources: $\quad$ Economy sources; and International Monetary Fund. International Financial Statistics. http://data.imf.org/ (accessed 27 March 2019). For world merchandise exports: International Monetary Fund. Direction of Trade Statistics. http://data.imf.org/?sk=9D6028D4-F14A-464C-A2F2-59B2CD424B85 (accessed 20 May 2019). 
Table 2.4.9: $\quad$ Growth Rates of Merchandise Exports ${ }^{a}$

(\%)

\begin{tabular}{|c|c|c|c|c|c|c|c|c|c|}
\hline ADB Regional Member & 2000 & 2005 & 2010 & 2013 & 2014 & 2015 & 2016 & 2017 & 2018 \\
\hline \multicolumn{10}{|l|}{ Developing ADB Member Economies } \\
\hline \multicolumn{10}{|l|}{ Central and West Asia } \\
\hline Afghanistan & -17.4 & 25.9 & -3.7 & 24.4 & 10.9 & - & 4.5 & 21.2 & 21.1 \\
\hline Armenia & 29.7 & 34.7 & 46.6 & 7.1 & 4.6 & -4.0 & 20.6 & 24.9 & 7.8 \\
\hline Azerbaijan & 87.7 & $\ldots$ & 25.3 & -2.1 & -10.9 & -44.8 & -15.2 & 14.7 & 37.2 \\
\hline Georgia & 36.1 & 33.8 & 48.0 & 22.5 & -1.7 & -22.9 & -4.2 & 29.5 & 22.6 \\
\hline Kazakhstan & 50.1 & 38.6 & 39.5 & -2.0 & -6.2 & -42.2 & -20.1 & 32.0 & 25.7 \\
\hline Kyrgyz Republic & 11.2 & -6.5 & 5.0 & 4.1 & -6.1 & -21.3 & 6.1 & 12.1 & 0.0 \\
\hline Pakistan & 4.8 & 14.9 & 12.0 & 2.6 & 10.0 & -8.5 & -11.3 & -1.4 & 3.6 \\
\hline Tajikistan & 13.9 & -0.7 & 18.3 & -14.4 & -15.9 & -8.9 & 0.9 & 33.3 & $\ldots$ \\
\hline Turkmenistan & 115.5 & 28.3 & 3.8 & -5.7 & 4.9 & -38.5 & -38.2 & 3.6 & \\
\hline Uzbekistan & 0.9 & 11.5 & 10.6 & 5.3 & -5.4 & -7.7 & -3.3 & 3.8 & 11.4 \\
\hline \multicolumn{10}{|l|}{ East Asia } \\
\hline China, People's Republic of & 27.8 & 28.4 & 31.3 & 7.8 & 6.0 & -2.9 & -7.7 & 7.9 & 9.9 \\
\hline Hong Kong, China & 16.1 & 11.6 & 22.5 & 3.7 & 3.2 & -1.8 & -0.6 & 7.6 & 6.7 \\
\hline Korea, Republic of & 19.9 & 12.0 & 28.3 & 2.1 & 2.3 & -8.0 & -5.9 & 15.8 & 5.4 \\
\hline Mongolia & 18.0 & 22.4 & 54.3 & -2.6 & 35.3 & -19.1 & 5.3 & 26.1 & 13.1 \\
\hline Taipei,China & 22.6 & 8.6 & 35.1 & 1.3 & 2.8 & -11.1 & -1.4 & 13.5 & 5.8 \\
\hline \multicolumn{10}{|l|}{ South Asia } \\
\hline Bangladesh & 12.5 & 11.3 & 3.7 & 17.5 & 7.9 & 2.6 & 9.0 & 0.3 & 6.4 \\
\hline Bhutan & -11.3 & 35.8 & 6.5 & -11.9 & 5.5 & 4.1 & -13.0 & 16.0 & 6.6 \\
\hline India & 22.2 & 25.0 & 43.1 & 6.3 & -4.4 & -13.9 & 2.9 & 9.2 & 12.1 \\
\hline Maldives & 18.8 & -10.5 & -63.6 & 2.8 & -13.0 & -0.6 & -3.2 & 43.0 & \\
\hline Nepal & 34.0 & 12.4 & -4.9 & -5.2 & 14.1 & -11.6 & -21.6 & 7.0 & 6.6 \\
\hline Sri Lanka & 18.5 & 10.1 & 21.7 & 6.7 & 6.9 & -5.3 & -2.2 & 10.2 & 4.7 \\
\hline \multicolumn{10}{|l|}{ Southeast Asia } \\
\hline Brunei Darussalam & 53.1 & 23.3 & 23.9 & -11.9 & -7.3 & -40.2 & -22.4 & 13.6 & 17.7 \\
\hline Cambodia & 23.6 & 12.3 & 24.4 & 23.9 & 16.0 & 14.3 & 10.0 & 9.3 & 15.5 \\
\hline Indonesia & 27.7 & 19.7 & 35.4 & -3.9 & -3.6 & -14.6 & -3.4 & 16.3 & 6.8 \\
\hline Lao People's Democratic Republic & 9.6 & 52.2 & 65.9 & 3.3 & 44.7 & 11.5 & 16.2 & 14.8 & 8.7 \\
\hline Malaysia & 16.1 & 11.8 & 26.5 & 0.4 & 2.3 & -14.9 & -4.7 & 14.6 & 13.8 \\
\hline Myanmar & 53.1 & 61.8 & 32.4 & 26.2 & 1.9 & -0.2 & 3.5 & 17.2 & 20.1 \\
\hline Philippines & 8.7 & 4.0 & 34.0 & 8.8 & 9.5 & -5.3 & -2.4 & 19.7 & 0.9 \\
\hline Singapore & 20.3 & 15.7 & 30.5 & 1.1 & -1.1 & -13.8 & -5.5 & 10.3 & 10.5 \\
\hline Thailand & 18.0 & 14.6 & 27.3 & -0.1 & -0.4 & -5.5 & 0.1 & 9.7 & 7.3 \\
\hline Viet Nam & 25.5 & 22.5 & 26.5 & 15.3 & 13.8 & 7.9 & 9.0 & 21.8 & 13.2 \\
\hline \multicolumn{10}{|l|}{ The Pacific } \\
\hline Cook Islands & 154.4 & -26.9 & 88.0 & 100.6 & 65.8 & -20.3 & -2.9 & 48.9 & -14.2 \\
\hline Fiji & -12.1 & 1.4 & 24.9 & -5.6 & 6.0 & -19.5 & -5.1 & 5.8 & 3.1 \\
\hline Kiribati & -59.1 & 58.2 & -38.0 & -4.9 & 51.9 & -11.0 & $\ldots$ & $\ldots$ & $\ldots$ \\
\hline Marshall Islands & 48.7 & 14.0 & 5.6 & & & & & $\ldots$ & \\
\hline Micronesia, Federated States of & $\ldots$ & -7.3 & 63.5 & -33.3 & -7.8 & 23.0 & 23.3 & -5.6 & \\
\hline Nauru & & -69.8 & 249.5 & -33.4 & -53.4 & -39.4 & $\ldots$ & -4.1 & $\begin{array}{l}\cdots \\
\cdots\end{array}$ \\
\hline Niue & & & 1.0 & 47.7 & 1.4 & -20.2 & 8.8 & 23.0 & 12.8 \\
\hline Palau & 65.9 & 116.9 & 15.9 & -0.5 & -8.7 & -5.3 & $\ldots$ & $\ldots$ & $\ldots$ \\
\hline Papua New Guinea & 7.3 & 26.8 & 30.9 & -5.9 & 47.8 & -4.2 & -2.6 & 21.4 & 1.0 \\
\hline Samoa & -24.9 & 0.6 & 114.4 & -23.2 & 14.7 & 23.8 & 6.3 & 3.1 & 13.5 \\
\hline Solomon Islands & -48.1 & 22.3 & 37.4 & -8.3 & 1.7 & -7.6 & 2.7 & 8.6 & 13.7 \\
\hline Timor-Leste & & -58.9 & 20.7 & -30.7 & -26.7 & -1.7 & 321.2 & -85.1 & 91.5 \\
\hline Tonga & -27.1 & -35.2 & 7.1 & -9.2 & 34.2 & -6.5 & 21.1 & -12.1 & -31.2 \\
\hline Tuvalu & -91.5 & -54.0 & 76.5 & 4.4 & 464.8 & -12.0 & 7.2 & -8.1 & \\
\hline Vanuatu & 2.8 & -6.5 & -14.8 & -29.4 & 62.6 & -38.0 & 28.8 & 20.2 & 5.8 \\
\hline \multicolumn{10}{|l|}{ Developed ADB Member Economies } \\
\hline Australia & 14.1 & 22.6 & 38.3 & -1.4 & -5.2 & -21.8 & 2.5 & 20.2 & 11.5 \\
\hline Japan & 14.8 & 5.4 & 32.6 & -10.5 & -3.5 & -9.5 & 3.1 & 8.4 & 5.7 \\
\hline New Zealand & 11.2 & 6.3 & 30.5 & 9.7 & -1.1 & -16.1 & -0.5 & 14.5 & 4.1 \\
\hline DEVELOPING ADB MEMBER ECONOMIES ${ }^{b}$ & 21.0 & 18.4 & 30.2 & 4.6 & 3.2 & -7.0 & -4.7 & 10.6 & 9.0 \\
\hline ALL ADB REGIONAL MEMBERS & 19.0 & 15.7 & 30.9 & 2.4 & 2.1 & -7.8 & -3.7 & 10.7 & 8.7 \\
\hline WORLD & 13.7 & 13.6 & 22.2 & 2.2 & 0.5 & -12.8 & -3.4 & 10.6 & 10.3 \\
\hline
\end{tabular}

... = data not available, - = magnitude equals zero, $\mathrm{ADB}=$ Asian Development Bank.

a Growth rates are based on the value of exports in United States dollars.

b For reporting economies only.

Sources: Economy sources; and International Monetary Fund. International Financial Statistics. http://data.imf.org/ (accessed 27 March 2019). 
Table 2.4.10: Merchandise Imports (\$ million)

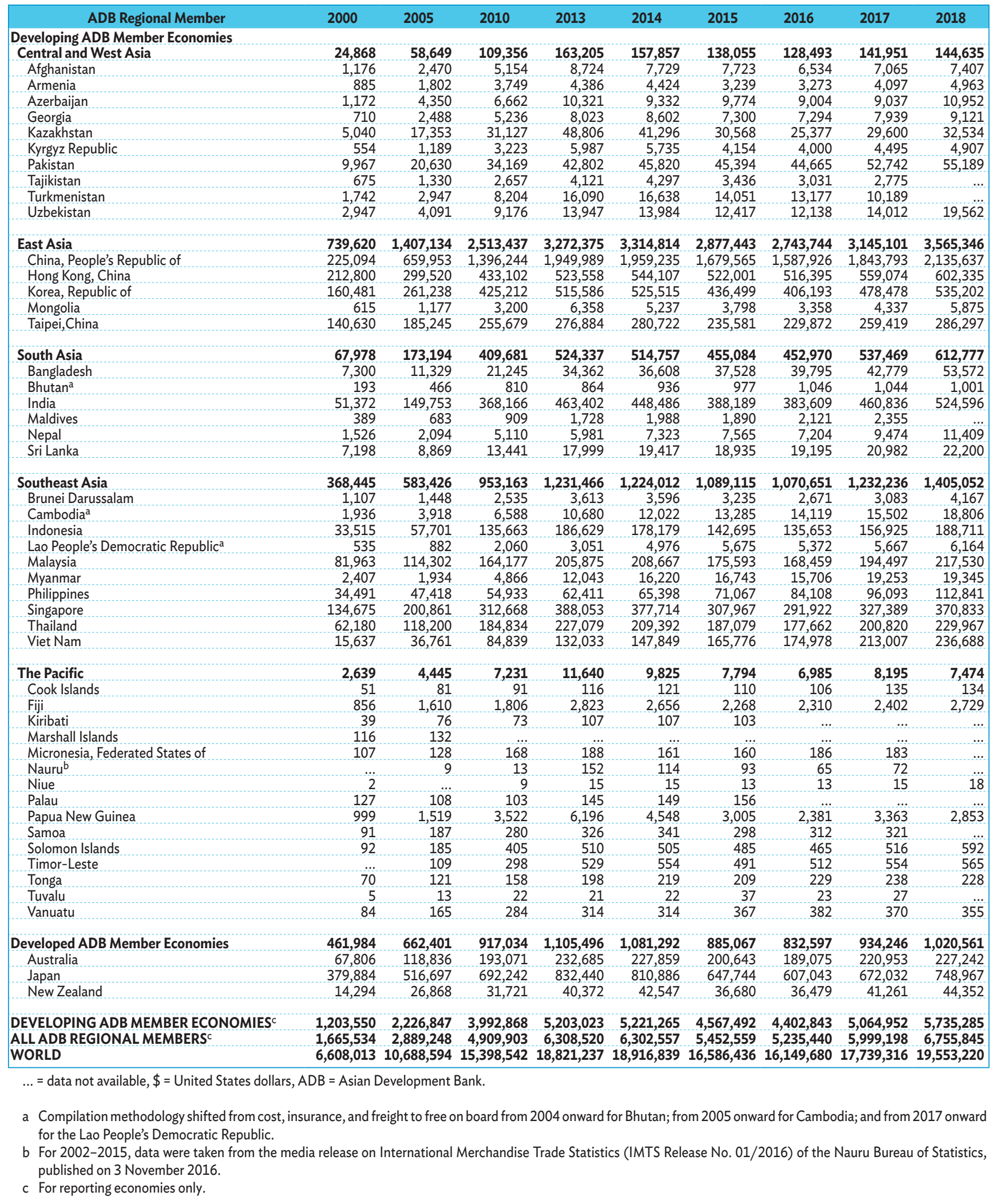

Sources: Economy sources; and International Monetary Fund. International Financial Statistics. http://data.imf.org/ (accessed 27 March 2019). For world merchandise exports: International Monetary Fund. Direction of Trade Statistics. http://data.imf.org/?sk=9D6028D4-F14A-464C-A2F2-59B2CD424B85 (accessed 20 May 2019). 
Table 2.4.11: Growth Rates of Merchandise Imports ${ }^{a}$

$(\%)$

\begin{tabular}{|c|c|c|c|c|c|c|c|c|c|}
\hline ADB Regional Member & 2000 & 2005 & 2010 & 2013 & 2014 & 2015 & 2016 & 2017 & 2018 \\
\hline \multirow{2}{*}{\multicolumn{10}{|c|}{ Developing ADB Member Economies }} \\
\hline & & & & & & & & & \\
\hline Afghanistan & 16.2 & 13.5 & 54.5 & -2.3 & -11.4 & -0.1 & -15.4 & 8.1 & 4.8 \\
\hline Armenia & 9.1 & 33.4 & 12.9 & 2.9 & 0.9 & -26.8 & 1.1 & 25.2 & 21.1 \\
\hline Azerbaijan & 13.1 & & 6.9 & 1.3 & -9.6 & 4.7 & -7.9 & 0.4 & 21.2 \\
\hline Georgia & 2.9 & 34.9 & 17.0 & -0.4 & 7.2 & -15.1 & -0.1 & 8.8 & 14.9 \\
\hline Kazakhstan & 37.9 & 35.8 & 9.6 & 5.3 & -15.4 & -26.0 & -17.0 & 16.6 & 9.9 \\
\hline Kyrgyz Republic & -7.6 & 25.5 & 6.0 & 7.4 & -4.2 & -27.6 & -3.7 & 12.4 & 9.2 \\
\hline Pakistan & 5.7 & 33.7 & 2.5 & -0.4 & 7.1 & -0.9 & -1.6 & 18.1 & 4.6 \\
\hline Tajikistan & 1.8 & 11.7 & 3.4 & 9.1 & 4.3 & -20.1 & -11.8 & -8.4 & \\
\hline Turkmenistan & 26.8 & -6.4 & -8.8 & 13.8 & 3.4 & -15.5 & -6.2 & -22.7 & \\
\hline Uzbekistan & -5.2 & 7.2 & -2.8 & 8.8 & 0.3 & -11.2 & -2.2 & 15.4 & 39.6 \\
\hline \multicolumn{10}{|l|}{ East Asia } \\
\hline China, People's Republic of & 35.8 & 17.6 & 38.8 & 7.2 & 0.5 & -14.3 & -5.5 & 16.1 & 15.8 \\
\hline Hong Kong, China & 18.5 & 10.5 & 24.7 & 3.8 & 3.9 & -4.1 & -1.1 & 8.3 & 7.7 \\
\hline Korea, Republic of & 34.0 & 16.4 & 31.6 & -0.8 & 1.9 & -16.9 & -6.9 & 17.8 & 11.9 \\
\hline Mongolia & 19.8 & 15.5 & 49.7 & -5.6 & -17.6 & -27.5 & -11.6 & 29.2 & 35.5 \\
\hline Taipei,China & 26.3 & 7.8 & 44.3 & -0.1 & 1.4 & -16.1 & -2.4 & 12.9 & 10.4 \\
\hline \multicolumn{10}{|l|}{ South Asia } \\
\hline Bangladesh & 3.3 & 16.3 & 5.1 & 6.8 & 6.5 & 2.5 & 6.0 & 7.5 & 25.2 \\
\hline Bhutan & 2.9 & 77.2 & 40.7 & -9.2 & 8.3 & 4.4 & 7.0 & -0.1 & -4.1 \\
\hline India & 2.8 & 35.4 & 30.7 & -7.2 & -3.2 & -13.4 & -1.2 & 20.1 & 13.8 \\
\hline Maldives & -3.4 & 21.3 & -5.6 & 11.2 & 15.0 & -4.9 & 12.2 & 11.1 & \\
\hline Nepal & 19.0 & 13.2 & 39.3 & 10.4 & 22.4 & 3.3 & -4.8 & 31.5 & 20.4 \\
\hline Sri Lanka & 20.5 & 10.7 & 31.8 & -5.9 & 7.9 & -2.5 & 1.4 & 9.3 & 5.8 \\
\hline \multicolumn{10}{|l|}{ Southeast Asia } \\
\hline Brunei Darussalam & -16.7 & 1.5 & 5.6 & 1.4 & -0.5 & -10.0 & -17.4 & 15.4 & 35.2 \\
\hline Cambodia & 21.6 & & 35.0 & 15.9 & 12.6 & 10.5 & 6.3 & 9.8 & 21.3 \\
\hline Indonesia & 39.6 & 24.0 & 40.1 & -2.6 & -4.5 & -19.9 & -4.9 & 15.7 & 20.3 \\
\hline Lao People's Democratic Republic & -3.4 & 23.8 & 41.0 & 0.1 & 63.1 & 14.1 & -5.3 & 5.5 & 8.8 \\
\hline Malaysia & 25.3 & 8.7 & 33.1 & 4.8 & 1.4 & -15.9 & -4.1 & 15.5 & 11.8 \\
\hline Myanmar & 3.3 & -11.6 & 11.0 & 30.9 & 34.7 & 3.2 & -6.2 & 22.6 & 0.5 \\
\hline Philippines & 5.9 & 7.7 & 27.5 & 0.5 & 4.8 & 8.7 & 18.3 & 14.2 & 17.4 \\
\hline Singapore & 21.3 & 15.4 & 26.9 & 0.6 & -2.7 & -18.5 & -5.2 & 12.1 & 13.3 \\
\hline Thailand & 23.3 & 25.1 & 37.7 & -0.2 & -7.8 & -10.7 & -5.0 & 13.0 & 14.5 \\
\hline Viet Nam & 33.2 & 15.0 & 21.3 & 16.0 & 12.0 & 12.1 & 5.6 & 21.7 & 11.1 \\
\hline \multicolumn{10}{|l|}{ The Pacific } \\
\hline Cook Islands & 21.9 & 7.0 & 11.2 & 3.9 & 4.1 & -9.3 & -3.0 & 26.9 & -0.4 \\
\hline Fiji & -8.3 & 11.5 & 16.9 & 25.4 & -5.9 & -14.6 & 1.9 & 4.0 & 13.6 \\
\hline Kiribati & -4.2 & 28.7 & 5.4 & -1.2 & 0.0 & -3.7 & $\ldots$ & $\ldots$ & $\ldots$ \\
\hline Marshall Islands & 16.7 & 15.3 & 15.0 & & & & & & $\ldots$ \\
\hline Micronesia, Federated States of & $\ldots$ & -3.2 & -1.8 & -3.1 & -14.3 & -0.3 & 16.0 & -1.4 & $\ldots$ \\
\hline Nauru & $\ldots$ & -27.0 & -47.3 & 283.2 & -25.3 & -18.0 & & 10.4 & \\
\hline Niue & & & 28.5 & 16.8 & 1.4 & -15.4 & 5.2 & 13.1 & 17.8 \\
\hline Palau & -5.7 & 0.7 & 9.3 & 6.7 & 3.1 & 4.4 & & & \\
\hline Papua New Guinea & -7.0 & 4.5 & 23.0 & 30.3 & -26.6 & -33.9 & -20.8 & 41.3 & -15.2 \\
\hline Samoa & -21.7 & 20.7 & 36.6 & 5.6 & 4.8 & -12.7 & 4.8 & 2.7 & \\
\hline Solomon Islands & -16.1 & 52.4 & 51.2 & 2.7 & -1.0 & -4.1 & -4.1 & 11.1 & 14.8 \\
\hline Timor-Leste & & -25.3 & 1.0 & -21.1 & 4.7 & -11.3 & 4.2 & 8.2 & 2.1 \\
\hline Tonga & -3.8 & 15.3 & 10.3 & -0.5 & 10.4 & -4.4 & 9.5 & 3.7 & -4.0 \\
\hline Tuvalu & -36.0 & 13.3 & 59.2 & -1.2 & 7.0 & 66.4 & -36.2 & 13.1 & \\
\hline Vanuatu & -12.6 & 22.4 & -2.5 & 5.8 & -0.0 & 17.0 & 4.0 & -3.1 & -4.0 \\
\hline \multicolumn{10}{|l|}{ Developed ADB Member Economies } \\
\hline Australia & 3.5 & 14.4 & 23.4 & -7.1 & -2.1 & -11.9 & -5.8 & 16.9 & 2.8 \\
\hline Japan & 22.7 & 13.6 & 25.8 & -6.0 & -2.6 & -20.1 & -6.3 & 10.7 & 11.4 \\
\hline New Zealand & -0.4 & 14.4 & 27.9 & 6.7 & 5.4 & -13.8 & -0.5 & 13.1 & 7.5 \\
\hline DEVELOPING ADB MEMBER ECONOMIES & 24.4 & 16.3 & 32.7 & 2.9 & 0.4 & -12.5 & -3.6 & 15.0 & 13.2 \\
\hline ALL ADB REGIONAL MEMBERS & 22.7 & 15.7 & 31.2 & 1.3 & -0.1 & -13.5 & -4.0 & 14.6 & 12.6 \\
\hline WORLD & 13.6 & 13.2 & 21.4 & 1.5 & 0.5 & -12.3 & -2.6 & 9.8 & 10.2 \\
\hline
\end{tabular}

$\ldots=$ data not available, -0.0 or $0.0=$ magnitude is less than half of unit employed, $A D B=$ Asian Development Bank.

a Growth rates are based on the value of imports in United States dollars.

b For reporting economies only.

Sources: Economy sources; and International Monetary Fund. International Financial Statistics. http://data.imf.org/ (accessed 27 March 2019). 
Table 2.4.12: Trade in Goods ${ }^{a}$

(\% of GDP)

\begin{tabular}{|c|c|c|c|c|c|c|c|c|c|}
\hline ADB Regional Member & 2000 & 2005 & 2010 & 2013 & 2014 & 2015 & 2016 & 2017 & 2018 \\
\hline \multicolumn{10}{|l|}{ Developing ADB Member Economies } \\
\hline \multicolumn{10}{|l|}{ Central and West Asia } \\
\hline Afghanistan & & 43.1 & 34.5 & 42.8 & 38.9 & 40.2 & 35.2 & 36.2 & 40.4 \\
\hline Armenia & 62.0 & 56.6 & 51.7 & 52.7 & 51.4 & 44.8 & 48.0 & 55.0 & 59.3 \\
\hline Azerbaijan & 55.3 & 90.6 & 62.4 & 56.7 & 50.0 & 47.8 & 58.7 & 59.2 & 67.6 \\
\hline Georgia & 33.8 & 52.3 & 59.4 & 67.7 & 69.4 & 67.9 & 65.4 & 70.8 & 77.0 \\
\hline Kazakhstan & 75.7 & 79.1 & 61.7 & 56.4 & 54.5 & 41.5 & 45.2 & 47.9 & 54.1 \\
\hline Kyrgyz Republic & 77.3 & 75.7 & 103.8 & 109.0 & 102.0 & 84.4 & 81.8 & 81.3 & 82.4 \\
\hline Pakistan & 23.1 & 29.3 & 30.6 & 30.0 & 28.7 & 25.8 & 23.6 & 24.2 & 27.1 \\
\hline Tajikistan & 169.6 & 96.8 & 68.3 & 62.1 & 57.1 & 55.1 & 56.5 & 55.5 & $\ldots$ \\
\hline Turkmenistan & 86.2 & 45.9 & 79.2 & 89.1 & 83.8 & 73.1 & 57.2 & 47.4 & \\
\hline Uzbekistan & 45.1 & 66.0 & 47.3 & 41.0 & 35.9 & 30.5 & 29.6 & 44.9 & 66.4 \\
\hline \multicolumn{10}{|l|}{ East Asia } \\
\hline China, People's Republic of & 39.2 & 62.2 & 48.9 & 43.5 & 41.2 & 35.9 & 33.1 & 33.8 & 34.0 \\
\hline Hong Kong, China & 241.5 & 324.3 & 360.1 & 356.4 & 349.2 & 319.0 & 305.0 & 309.2 & 312.3 \\
\hline Korea, Republic of & 57.8 & 58.4 & 77.9 & 78.4 & 74.0 & 65.7 & 60.1 & 64.8 & 66.3 \\
\hline Mongolia & 101.2 & 88.8 & 85.0 & 84.5 & 90.1 & 72.1 & 74.0 & 92.2 & 99.3 \\
\hline Taipei,China & 88.1 & 102.4 & 119.5 & 114.8 & 113.0 & 98.7 & 95.8 & 100.3 & 105.5 \\
\hline \multicolumn{10}{|l|}{ South Asia } \\
\hline Bangladesh & 26.6 & 34.0 & 32.6 & 40.4 & 38.4 & 35.0 & 33.1 & 31.0 & 33.1 \\
\hline Bhutan & 67.3 & 83.1 & 84.9 & 76.5 & 75.3 & 74.7 & 69.1 & 63.7 & \\
\hline India & 20.0 & 30.2 & 36.3 & 41.1 & 37.2 & 30.5 & 28.8 & 29.0 & 31.0 \\
\hline Maldives & 79.7 & 72.6 & 37.5 & 57.5 & 57.7 & 49.5 & 51.2 & 52.5 & \\
\hline Nepal & 41.7 & 35.3 & 36.5 & 37.4 & 41.0 & 40.4 & 37.4 & 39.8 & 43.7 \\
\hline Sri Lanka & 75.7 & 62.4 & 38.9 & 38.2 & 38.5 & 36.6 & 35.8 & 36.7 & 38.3 \\
\hline \multicolumn{10}{|l|}{ Southeast Asia } \\
\hline Brunei Darussalam & 83.5 & 80.7 & 83.3 & 83.2 & 83.0 & 74.0 & 66.6 & 71.5 & 79.2 \\
\hline Cambodiab & 90.9 & 108.5 & 93.3 & 116.4 & 120.9 & 125.3 & 121.9 & 120.5 & 129.3 \\
\hline Indonesia & 58.0 & 50.1 & 38.9 & 40.5 & 39.8 & 34.0 & 30.1 & 32.1 & 35.4 \\
\hline Lao People's Democratic Republic & 52.9 & 52.8 & 56.5 & 44.5 & 62.2 & 64.8 & 60.8 & 62.6 & 63.8 \\
\hline Malaysia & 192.1 & 178.3 & 142.1 & 134.4 & 130.9 & 124.3 & 118.9 & 129.1 & 129.7 \\
\hline Myanmar & $\ldots$ & $\ldots$ & & 37.5 & 41.7 & 45.0 & 42.6 & 49.8 & \\
\hline Philippines & 89.6 & 86.0 & 53.3 & 43.8 & 44.8 & 44.4 & 46.4 & 52.5 & 55.0 \\
\hline Singaporec & 283.8 & 337.5 & 277.4 & 262.7 & 251.8 & 216.1 & 198.0 & 207.0 & 215.0 \\
\hline Thailand & 103.9 & 120.7 & 110.7 & 108.2 & 107.0 & 100.0 & 95.0 & 95.7 & 95.5 \\
\hline Viet Nam & 96.6 & 120.1 & 135.5 & 154.2 & 160.1 & 169.6 & 171.3 & 191.3 & 195.8 \\
\hline \multicolumn{10}{|l|}{ The Pacific } \\
\hline Cook Islands & 65.3 & 47.3 & 39.8 & 43.8 & 43.4 & 40.9 & 38.7 & 44.9 & 40.6 \\
\hline Fiji & 83.3 & 77.7 & 84.2 & 94.9 & 79.8 & 69.4 & 65.8 & 64.3 & $\ldots$ \\
\hline Kiribati & 63.6 & 72.0 & 49.3 & 61.5 & 65.3 & 65.6 & $\ldots$ & $\ldots$ & \\
\hline Marshall Islands & 125.4 & 118.1 & & & & & & & $\ldots$ \\
\hline Micronesia, Federated States of & 53.0 & 56.5 & 66.7 & 70.4 & 60.7 & 63.4 & 70.8 & 63.2 & $\ldots$ \\
\hline Nauru & & 30.4 & 86.3 & 196.1 & 118.5 & 118.4 & 86.8 & 83.1 & \\
\hline Niue & 28.9 & $\ldots$ & 56.5 & 64.2 & 60.8 & 58.7 & 59.7 & 63.9 & 65.0 \\
\hline Palau & 95.2 & 66.2 & 64.7 & 74.1 & 69.2 & 62.0 & & & \\
\hline Papua New Guinea & 88.3 & 99.3 & 65.0 & 57.1 & 57.5 & 52.6 & 51.0 & 56.2 & 51.4 \\
\hline Samoa & 45.1 & 45.9 & 43.7 & 45.8 & 47.2 & 42.2 & 42.4 & 43.4 & $\ldots$ \\
\hline Solomon Islands & 55.1 & 67.7 & 90.8 & 94.4 & 91.8 & 88.1 & 82.1 & & \\
\hline Timor-Leste & & 8.4 & 8.5 & 10.3 & 14.7 & 17.1 & 26.9 & 23.2 & \\
\hline Tonga & 41.9 & 49.6 & 44.6 & 48.2 & 54.5 & 57.0 & 61.7 & 56.1 & 50.6 \\
\hline Tuvalu & 37.3 & 59.8 & 72.7 & 55.9 & 60.8 & 105.7 & 60.0 & 61.0 & $\ldots$ \\
\hline Vanuatu & 40.5 & 53.5 & 47.4 & 43.9 & 46.2 & 53.4 & 53.7 & 48.9 & \\
\hline \multicolumn{10}{|l|}{ Developed ADB Member Economies } \\
\hline Australia & 34.4 & 31.9 & 33.9 & 32.7 & 32.4 & 31.8 & 30.8 & 33.4 & 35.1 \\
\hline Japan & 17.6 & 23.4 & 25.6 & 30.0 & 30.9 & 29.0 & 25.4 & 28.2 & 29.9 \\
\hline New Zealand & 51.7 & 42.5 & 43.6 & 42.7 & 41.4 & 39.9 & 37.5 & 39.6 & $\cdots$ \\
\hline DEVELOPING ADB MEMBER ECONOMIES ${ }^{d}$ & 69.5 & 78.2 & 66.7 & 61.6 & 58.6 & $\mathbf{5 1 . 3}$ & 48.1 & 49.6 & 50.6 \\
\hline ALL ADB REGIONAL MEMBERS & 39.4 & 52.3 & 52.3 & 52.9 & 51.5 & 46.3 & 42.9 & 45.0 & 46.7 \\
\hline
\end{tabular}

$\ldots$ = data not available, $\mathrm{ADB}=$ Asian Development Bank, $\mathrm{GDP}=$ gross domestic product.

a The sum of merchandise exports and imports valued in United States dollars.

b The compilation methodology shifted from cost, insurance, and freight to free on board from 2004 onward for Bhutan, from 2005 onward for Cambodia, and from 2017

onward for the Lao People's Democratic Republic.

c Prior to 2003, data excludes Indonesia.

d For reporting economies only.

Sources: Economy sources; and International Monetary Fund. International Financial Statistics. http://data.imf.org/ (accessed 27 March 2019). 
Table 2.4.13: Direction of Trade: Merchandise Exports (\% of total merchandise exports)

\begin{tabular}{|c|c|c|c|c|c|c|c|c|c|c|c|c|c|c|}
\hline \multirow{2}{*}{$\begin{array}{c}\text { To } \\
\text { From } \\
\text { ADB Regional Member }\end{array}$} & \multicolumn{2}{|c|}{$\begin{array}{l}\text { Asia and } \\
\text { the Pacific }\end{array}$} & \multicolumn{2}{|c|}{ Europe } & \multicolumn{2}{|c|}{$\begin{array}{c}\text { North and } \\
\text { Central } \\
\text { America }\end{array}$} & \multicolumn{2}{|c|}{ Middle East } & \multicolumn{2}{|c|}{$\begin{array}{c}\text { South } \\
\text { America }\end{array}$} & \multicolumn{2}{|c|}{ Africa } & \multicolumn{2}{|c|}{$\begin{array}{c}\text { Rest of } \\
\text { the World }\end{array}$} \\
\hline & 2000 & 2018 & 2000 & 2018 & 2000 & 2018 & 2000 & 2018 & 2000 & 2018 & 2000 & 2018 & 2000 & 2018 \\
\hline \multirow{2}{*}{\multicolumn{15}{|c|}{$\begin{array}{l}\text { Developing ADB Member Economies } \\
\text { Central and West Asia }\end{array}$}} \\
\hline & & & & & & & & & & & & & & \\
\hline Afghanistan & 35.8 & 69.7 & 50.3 & 2.5 & 2.7 & 1.0 & 8.7 & 26.5 & 2.2 & 0.0 & 0.3 & 0.2 & 0.0 & 0.0 \\
\hline Armenia & 8.0 & 8.4 & 56.5 & 71.3 & 12.9 & 3.4 & 12.5 & 16.0 & 0.0 & 0.0 & 0.0 & 0.1 & 10.1 & 0.8 \\
\hline Azerbaijan & 7.4 & 16.1 & 82.4 & 70.5 & 0.5 & 4.8 & 8.6 & 7.2 & 0.4 & 0.4 & 0.6 & 1.0 & 0.1 & 0.0 \\
\hline Georgia & 16.1 & 38.5 & 75.5 & 50.2 & 2.7 & 5.3 & 4.0 & 4.9 & 0.1 & 0.6 & 1.4 & 0.5 & 0.3 & 0.0 \\
\hline Kazakhstan & 12.4 & 27.2 & 48.9 & 68.1 & 14.8 & 1.8 & 2.5 & 2.1 & 0.1 & 0.1 & 0.1 & 0.6 & 21.2 & 0.0 \\
\hline Kyrgyz Republic & 37.6 & 30.0 & 58.7 & 68.4 & 0.6 & 0.1 & 1.6 & 1.4 & 0.0 & 0.0 & 1.5 & 0.0 & 0.0 & 0.0 \\
\hline Pakistan & 24.8 & 30.1 & 29.7 & 36.7 & 28.1 & 18.0 & 12.4 & 8.1 & 1.2 & 1.2 & 3.6 & 5.9 & 0.1 & 0.0 \\
\hline Tajikistan & 16.6 & 44.0 & 80.1 & 48.4 & 0.1 & 0.3 & 1.7 & 5.3 & 0.7 & 0.1 & 0.8 & 1.9 & 0.0 & 0.0 \\
\hline Turkmenistan & 6.0 & 90.7 & 81.2 & 7.5 & 1.1 & 0.1 & 10.2 & 1.5 & 0.0 & 0.1 & 0.2 & 0.0 & 1.3 & 0.0 \\
\hline Uzbekistan & 60.5 & 39.5 & 30.4 & 25.0 & 0.0 & 0.1 & 8.9 & 2.3 & 0.1 & 0.1 & 0.0 & 0.0 & 0.0 & 33.0 \\
\hline \multicolumn{15}{|l|}{ East Asia } \\
\hline China, People's Republic of & 51.8 & 45.4 & 18.4 & 19.8 & 23.5 & 23.1 & 2.9 & 4.5 & 1.4 & 3.4 & 1.7 & 3.7 & 0.3 & 0.1 \\
\hline Hong Kong, China & 53.9 & 76.1 & 16.7 & 10.6 & 26.1 & 9.4 & 1.4 & 2.3 & 1.1 & 0.8 & 0.7 & 0.8 & 0.1 & 0.0 \\
\hline Korea, Republic of & 49.1 & 65.3 & 16.2 & 12.2 & 26.4 & 15.9 & 4.3 & 3.6 & 2.2 & 1.7 & 1.5 & 1.3 & 0.2 & 0.0 \\
\hline Mongolia & 57.7 & 95.0 & 17.6 & 4.8 & 24.6 & 0.2 & 0.1 & 0.0 & 0.0 & 0.0 & 0.0 & 0.0 & 0.0 & 0.0 \\
\hline Taipei,China & 53.6 & 73.3 & 15.7 & 9.4 & 26.1 & 13.6 & 1.7 & 1.8 & 1.1 & 0.8 & 0.9 & 0.6 & 0.8 & 0.4 \\
\hline \multicolumn{15}{|l|}{ South Asia } \\
\hline Bangladesh & 6.9 & 11.5 & 41.5 & 51.9 & 33.8 & 15.3 & 2.4 & 1.8 & 0.2 & 0.9 & 0.6 & 0.5 & 14.6 & 18.1 \\
\hline Bhutan & 77.9 & 95.4 & 6.5 & 4.5 & 4.3 & 0.1 & 0.0 & 0.0 & 0.8 & 0.0 & 10.2 & 0.0 & 0.2 & 0.0 \\
\hline India & 26.2 & 33.3 & 28.5 & 20.9 & 23.8 & 18.5 & 12.2 & 16.6 & 1.3 & 2.4 & 4.3 & 7.4 & 3.6 & 0.8 \\
\hline Maldives & 36.9 & 47.9 & 18.6 & 42.0 & 44.4 & 9.5 & 0.0 & 0.4 & 0.0 & 0.0 & 0.0 & 0.2 & 0.0 & 0.0 \\
\hline Nepal & 46.2 & 64.4 & 24.1 & 17.8 & 28.0 & 12.2 & 0.1 & 1.8 & 0.0 & 0.0 & 0.0 & 0.1 & 1.6 & 3.7 \\
\hline Sri Lanka & 14.8 & 21.9 & 30.6 & 35.4 & 43.5 & 29.7 & 7.7 & 9.1 & 0.6 & 1.8 & 0.7 & 1.5 & 2.1 & 0.8 \\
\hline Southeast Asia & & & & & & & & & & & & & & \\
\hline Brunei Darussalam & 87.0 & 98.3 & 0.5 & 0.4 & 12.4 & 0.9 & 0.1 & 0.1 & 0.0 & 0.0 & 0.0 & 0.2 & 0.0 & 0.0 \\
\hline Cambodia & 28.2 & 28.1 & 17.3 & 39.3 & 54.4 & 30.1 & 0.0 & 1.0 & 0.0 & 0.8 & 0.0 & 0.3 & 0.0 & 0.4 \\
\hline Indonesia & 64.1 & 70.9 & 15.1 & 11.3 & 15.1 & 11.6 & 3.4 & 2.9 & 0.9 & 1.2 & 1.4 & 2.1 & 0.1 & 0.0 \\
\hline Lao People's Democratic Republic & 58.3 & 89.1 & 38.1 & 6.0 & 3.2 & 3.9 & 0.1 & 0.8 & 0.0 & 0.1 & 0.3 & 0.1 & 0.0 & 0.0 \\
\hline Malaysia & 60.0 & 72.3 & 14.5 & 12.3 & 22.3 & 10.0 & 2.0 & 2.8 & 0.6 & 0.7 & 0.6 & 1.8 & 0.0 & 0.0 \\
\hline Myanmar & 69.8 & 79.4 & 8.0 & 15.0 & 21.0 & 2.9 & 0.6 & 0.8 & 0.3 & 0.2 & 0.3 & 1.6 & 0.0 & 0.0 \\
\hline Philippines & 48.8 & 66.6 & 18.7 & 13.8 & 31.7 & 17.5 & 0.5 & 1.1 & 0.2 & 0.7 & 0.1 & 0.4 & 0.0 & 0.0 \\
\hline Singapore & 62.8 & 76.1 & 14.6 & 10.2 & 19.2 & 10.1 & 1.7 & 1.9 & 0.4 & 0.4 & 1.1 & 1.4 & 0.2 & 0.0 \\
\hline Thailand & 53.0 & 67.0 & 17.6 & 12.0 & 23.3 & 13.2 & 3.1 & 3.3 & 0.6 & 1.8 & 1.7 & 2.6 & 0.7 & 0.3 \\
\hline Viet Nam & 65.9 & 52.9 & 23.1 & 19.6 & 6.1 & 22.0 & 2.9 & 3.0 & 0.3 & 1.6 & 0.8 & 0.7 & 0.9 & 0.0 \\
\hline The Pacific & & & & & & & & & & & & & & \\
\hline Cook Islands & 87.1 & 96.7 & 0.0 & 0.0 & 7.8 & 0.1 & 0.0 & 0.0 & 0.0 & 0.0 & 0.0 & 0.0 & 5.1 & 3.2 \\
\hline Fiji & 56.0 & 72.7 & 20.2 & 4.4 & 23.7 & 22.4 & 0.0 & 0.3 & 0.1 & 0.0 & 0.0 & 0.2 & 0.0 & 0.0 \\
\hline Kiribati & 85.3 & 89.0 & 2.8 & 1.8 & 0.1 & 9.0 & 0.0 & 0.0 & 11.8 & 0.0 & 0.0 & 0.1 & 0.0 & 0.0 \\
\hline Marshall Islands & 0.0 & 39.4 & 42.3 & 34.8 & 57.7 & 3.4 & 0.0 & 19.0 & 0.0 & 1.1 & 0.0 & 2.2 & 0.0 & 0.0 \\
\hline Micronesia, Federated States of & 42.1 & 92.7 & 0.3 & 0.2 & 57.4 & 5.3 & 0.0 & 0.0 & 0.0 & 1.7 & 0.0 & 0.0 & 0.2 & 0.0 \\
\hline Nauru & 84.0 & 34.8 & 1.3 & 0.9 & 7.5 & 10.7 & 0.0 & 2.8 & 0.1 & 0.1 & 7.1 & 50.8 & 0.0 & 0.0 \\
\hline Niue & & & & & & & $\ldots$ & & & & & & $\ldots$ & \\
\hline Palau & 64.6 & 67.5 & 6.8 & 8.5 & 12.2 & 22.3 & 0.0 & 0.0 & 1.2 & 1.4 & 14.8 & 0.2 & 0.3 & 0.1 \\
\hline Papua New Guinea & 72.0 & 86.0 & 19.9 & 11.4 & 6.9 & 1.5 & 0.2 & 0.1 & 0.0 & 0.9 & 1.1 & 0.1 & 0.0 & 0.1 \\
\hline Samoa & 71.4 & 83.9 & 1.6 & 2.8 & 26.6 & 8.4 & 0.2 & 0.1 & 0.0 & 4.5 & 0.1 & 0.3 & 0.0 & 0.0 \\
\hline Solomon Islands & 98.0 & 82.2 & 0.8 & 16.0 & 0.0 & 0.9 & 0.0 & 0.0 & 0.0 & 0.4 & 1.1 & 0.5 & 0.0 & 0.1 \\
\hline Timor-Leste & 75.5 & 70.5 & 17.1 & 11.5 & 6.7 & 16.6 & 0.0 & 0.5 & 0.0 & 0.0 & 0.6 & 0.8 & 0.0 & 0.0 \\
\hline Tonga & 61.7 & 76.9 & 1.2 & 8.1 & 21.5 & 14.3 & 0.1 & 0.1 & 0.0 & 0.0 & 15.5 & 0.3 & 0.1 & 0.4 \\
\hline Tuvalu & 4.8 & 52.8 & 78.8 & 3.9 & 0.6 & 6.1 & 0.0 & 0.3 & 8.4 & 33.0 & 5.6 & 3.9 & 1.7 & 0.1 \\
\hline Vanuatu & 28.7 & 81.5 & 68.5 & 3.9 & 2.5 & 7.1 & 0.0 & 0.0 & 0.1 & 6.7 & 0.0 & 0.8 & 0.1 & 0.0 \\
\hline Developed Member Economies & & & & & & & & & & & & & & \\
\hline Australia & 66.4 & 83.4 & 12.4 & 5.8 & 11.6 & 4.5 & 5.1 & 2.8 & 0.8 & 0.6 & 1.9 & 0.9 & 1.7 & 2.0 \\
\hline Japan & 43.4 & 58.1 & 17.9 & 13.5 & 34.3 & 23.0 & 2.3 & 3.2 & 1.2 & 1.3 & 0.9 & 1.0 & 0.1 & 0.0 \\
\hline New Zealand & 59.0 & 68.6 & 16.7 & 11.1 & 18.0 & 12.0 & 2.8 & 4.3 & 1.5 & 0.9 & 0.9 & 2.2 & 1.1 & 1.0 \\
\hline $\begin{array}{l}\text { DEVELOPING ADB MEMBER } \\
\text { ECONOMIES }\end{array}$ & 52.8 & 56.5 & 17.8 & 16.9 & 23.6 & 17.4 & 2.9 & 4.2 & 1.1 & 2.1 & 1.3 & 2.6 & 0.6 & 0.3 \\
\hline ALL ADB REGIONAL MEMBERS & 50.8 & $\mathbf{5 7 . 7}$ & 17.6 & 16.1 & 25.9 & 17.5 & 2.8 & 4.0 & 1.1 & 2.0 & 1.2 & 2.4 & 0.5 & 0.3 \\
\hline WORLD & 24.5 & 33.6 & 42.4 & 38.1 & 25.2 & 18.1 & 3.0 & 4.1 & 2.2 & 2.5 & 1.8 & 2.6 & 0.9 & 1.1 \\
\hline
\end{tabular}

$0.0=$ magnitude is less than half of unit employed, $A D B=$ Asian Development Bank.

a For 2000 , data refer to 2004 .

Sources: International Monetary Fund. Direction of Trade Statistics. http://data.imf.org/?sk=9D6028D4-F14A-464C-A2F2-59B2CD424B85 (accessed 20 May 2019). For the Cook Islands and Taipei,China: Economy sources. 
Table 2.4.14: Direction of Trade, Merchandise Imports (\% of total merchandise imports)

\begin{tabular}{|c|c|c|c|c|c|c|c|c|c|c|c|c|c|c|}
\hline \multirow{2}{*}{$\begin{array}{c}\text { From } \\
\text { To } \\
\text { ADB Regional Member }\end{array}$} & \multicolumn{2}{|c|}{$\begin{array}{l}\text { Asia and the } \\
\text { Pacific }\end{array}$} & \multicolumn{2}{|c|}{ Europe } & \multicolumn{2}{|c|}{$\begin{array}{l}\text { North and } \\
\text { Central } \\
\text { America }\end{array}$} & \multicolumn{2}{|c|}{ Middle East } & \multicolumn{2}{|c|}{$\begin{array}{l}\text { South } \\
\text { America }\end{array}$} & \multicolumn{2}{|c|}{ Africa } & \multicolumn{2}{|c|}{$\begin{array}{l}\text { Rest of } \\
\text { the World }\end{array}$} \\
\hline & 2000 & 2018 & 2000 & 2018 & 2000 & 2018 & 2000 & 2018 & 2000 & 2018 & 2000 & 2018 & 2000 & 2018 \\
\hline \multirow{2}{*}{\multicolumn{15}{|c|}{$\begin{array}{l}\text { Developing ADB Member Economies } \\
\text { Central and West Asia }\end{array}$}} \\
\hline & & & & & & & & & & & & & & \\
\hline Afghanistan & 93.4 & 64.9 & 3.3 & 4.2 & 0.1 & 1.4 & 3.0 & 28.3 & 0.0 & 0.2 & 0.2 & 0.9 & 0.0 & 0.0 \\
\hline Armenia & 4.3 & 23.2 & 60.4 & 60.2 & 14.6 & 4.5 & 15.4 & 8.1 & 0.0 & 1.8 & 0.0 & 1.0 & 5.3 & 1.0 \\
\hline Azerbaijan & 14.4 & 23.3 & 65.1 & 61.7 & 10.5 & 6.6 & 7.3 & 4.4 & 0.5 & 2.0 & 2.1 & 1.5 & 0.1 & 0.5 \\
\hline Georgia & 17.8 & 26.7 & 66.7 & 62.6 & 10.2 & 4.2 & 4.2 & 4.2 & 0.9 & 2.0 & 0.1 & 0.4 & 0.1 & 0.0 \\
\hline Kazakhstan & 11.7 & 29.2 & 78.5 & 63.6 & 6.3 & 5.2 & 1.1 & 1.0 & 1.0 & 0.5 & 0.5 & 0.4 & 0.8 & 0.0 \\
\hline Kyrgyz Republic & 39.8 & 57.2 & 45.5 & 39.0 & 11.7 & 3.0 & 2.9 & 0.6 & 0.1 & 0.2 & 0.0 & 0.1 & 0.0 & 0.0 \\
\hline Pakistan & 31.2 & 45.8 & 19.8 & 12.6 & 7.0 & 6.1 & 38.3 & 28.6 & 1.0 & 1.2 & 2.7 & 5.7 & 0.0 & 0.0 \\
\hline Tajikistan & 56.5 & 49.8 & 40.6 & 38.4 & 0.1 & 1.5 & 1.6 & 9.5 & 0.0 & 0.8 & 1.1 & 0.0 & 0.0 & 0.0 \\
\hline Turkmenistan & 17.5 & 27.4 & 58.9 & 64.9 & 3.5 & 4.8 & 13.5 & 2.1 & 0.1 & 0.9 & 0.0 & 0.0 & 6.4 & 0.0 \\
\hline Uzbekistan & 43.4 & 44.8 & 47.3 & 46.2 & 1.5 & 7.8 & 5.0 & 0.9 & 2.6 & 0.3 & 0.1 & 0.0 & 0.0 & 0.0 \\
\hline \multicolumn{15}{|l|}{ East Asia } \\
\hline China, People's Republic of & 58.2 & 47.2 & 17.7 & 17.9 & 11.8 & 9.4 & 4.5 & 7.6 & 2.1 & 6.6 & 2.4 & 4.3 & 3.2 & 6.9 \\
\hline Hong Kong, China & 80.5 & 82.1 & 10.3 & 9.5 & 7.6 & 5.6 & 0.8 & 1.4 & 0.5 & 0.8 & 0.3 & 0.6 & 0.0 & 0.0 \\
\hline Korea, Republic of & 48.1 & 50.6 & 12.5 & 16.1 & 20.0 & 13.2 & 15.9 & 15.6 & 1.6 & 2.4 & 1.8 & 1.6 & 0.0 & 0.4 \\
\hline Mongolia & 47.1 & 56.2 & 47.8 & 39.1 & 4.8 & 4.1 & 0.2 & 0.2 & 0.0 & 0.3 & 0.0 & 0.1 & 0.0 & 0.0 \\
\hline Taipei,China & 58.9 & 62.6 & 13.6 & 12.1 & 19.3 & 13.4 & 4.8 & 9.6 & 1.0 & 1.3 & 2.3 & 0.9 & 0.0 & 0.0 \\
\hline \multicolumn{15}{|l|}{ South Asia } \\
\hline Bangladesh & 60.1 & 66.1 & 12.4 & 9.8 & 3.7 & 4.1 & 5.2 & 6.5 & 1.4 & 3.4 & 0.9 & 3.0 & 16.4 & 7.0 \\
\hline Bhutan & 84.9 & 94.7 & 14.3 & 1.1 & 0.4 & 3.1 & 0.0 & 0.4 & 0.3 & 0.0 & 0.0 & 0.0 & 0.0 & 0.7 \\
\hline India & 23.6 & 39.4 & 28.9 & 16.3 & 7.2 & 8.3 & 9.4 & 23.7 & 1.4 & 4.0 & 6.1 & 7.8 & 23.4 & 0.5 \\
\hline Maldives & 76.0 & 63.8 & 10.6 & 13.1 & 3.7 & 2.3 & 8.9 & 19.7 & 0.1 & 0.6 & 0.4 & 0.5 & 0.4 & 0.0 \\
\hline Nepal & 71.6 & 85.4 & 12.8 & 5.6 & 2.0 & 3.0 & 5.8 & 2.3 & 0.8 & 1.5 & 0.1 & 0.3 & 7.0 & 2.0 \\
\hline Sri Lanka & 70.4 & 71.9 & 14.2 & 12.2 & 4.6 & 3.7 & 9.4 & 10.1 & 0.5 & 0.4 & 0.5 & 1.7 & 0.2 & 0.0 \\
\hline Southeast Asia & & & & & & & & & & & & & & \\
\hline Brunei Darussalam & 75.1 & 82.7 & 12.7 & 7.3 & 11.2 & 8.9 & 0.3 & 0.3 & 0.1 & 0.5 & 0.0 & 0.1 & 0.5 & 0.1 \\
\hline Cambodia & 88.5 & 93.4 & 8.3 & 4.5 & 2.8 & 1.6 & 0.1 & 0.2 & 0.1 & 0.1 & 0.0 & 0.1 & 0.2 & 0.1 \\
\hline Indonesia & 60.5 & 73.6 & 14.1 & 9.6 & 12.3 & 6.5 & 8.4 & 5.1 & 1.5 & 1.9 & 2.3 & 3.2 & 0.9 & 0.0 \\
\hline Lao People's Democratic Republic & 92.2 & 94.5 & 7.0 & 5.1 & 0.7 & 0.4 & 0.0 & 0.0 & 0.0 & 0.0 & 0.0 & 0.0 & 0.0 & 0.0 \\
\hline Malaysia & 65.2 & 68.9 & 12.6 & 15.4 & 17.3 & 7.5 & 2.0 & 4.6 & 0.6 & 2.2 & 0.4 & 1.2 & 1.9 & 0.2 \\
\hline Myanmar & 88.7 & 85.5 & 8.9 & 5.6 & 2.3 & 3.7 & 0.0 & 4.4 & 0.0 & 0.4 & 0.0 & 0.3 & 0.0 & 0.0 \\
\hline Philippines & 58.4 & 77.2 & 10.8 & 9.3 & 19.4 & 7.7 & 10.5 & 4.7 & 0.7 & 0.9 & 0.2 & 0.2 & 0.0 & 0.0 \\
\hline Singapore & 60.7 & 57.8 & 14.2 & 17.7 & 15.8 & 12.5 & 8.2 & 10.5 & 0.3 & 0.8 & 0.4 & 0.7 & 0.4 & 0.0 \\
\hline Thailand & 60.2 & 65.8 & 12.7 & 13.0 & 12.6 & 7.5 & 10.2 & 9.3 & 1.1 & 1.5 & 1.3 & 1.4 & 2.0 & 1.4 \\
\hline Viet Nam & 82.9 & 81.0 & 11.8 & 7.5 & 2.6 & 6.3 & 1.3 & 2.3 & 0.4 & 2.2 & 0.3 & 0.6 & 0.7 & 0.0 \\
\hline The Pacific & & & & & & & & & & & & & & \\
\hline Cook Islands & 87.0 & 77.8 & 0.2 & 0.0 & 8.6 & 13.1 & 0.0 & 0.0 & 0.0 & 0.0 & 0.0 & 0.0 & 4.3 & 9.1 \\
\hline Fiji & 84.6 & 91.2 & 3.8 & 4.6 & 5.5 & 3.2 & 0.1 & 0.6 & 0.3 & 0.1 & 0.2 & 0.2 & 5.5 & 0.2 \\
\hline Kiribati & 86.3 & 89.8 & 2.3 & 2.2 & 11.4 & 6.5 & 0.0 & 0.0 & 0.0 & 1.3 & 0.0 & 0.2 & 0.0 & 0.0 \\
\hline Marshall Islands & 0.1 & 74.2 & 99.8 & 21.3 & 0.0 & 2.3 & 0.0 & 1.2 & 0.0 & 0.6 & 0.0 & 0.4 & 0.0 & 0.0 \\
\hline Micronesia, Federated States of & 98.0 & 70.9 & 1.7 & 0.3 & 0.0 & 18.3 & 0.0 & 0.0 & 0.0 & 0.1 & 0.0 & 0.2 & 0.2 & 10.3 \\
\hline Nauru & 32.3 & 91.0 & 7.9 & 0.3 & 10.6 & 0.8 & 0.0 & 0.0 & 0.0 & 0.1 & 49.2 & 7.7 & 0.0 & 0.0 \\
\hline Nive & & & & & & & & & & & & & & \\
\hline Palau & 40.4 & 64.5 & 0.7 & 2.5 & 59.0 & 32.5 & 0.0 & 0.0 & 0.0 & 0.4 & 0.0 & 0.0 & 0.0 & 0.0 \\
\hline Papua New Guinea & 94.1 & 92.5 & 3.2 & 3.4 & 2.3 & 3.4 & 0.0 & 0.2 & 0.2 & 0.1 & 0.1 & 0.4 & 0.0 & 0.0 \\
\hline Samoa & 78.5 & 86.0 & 0.7 & 2.2 & 20.5 & 11.1 & 0.0 & 0.1 & 0.2 & 0.2 & 0.0 & 0.0 & 0.0 & 0.4 \\
\hline Solomon Islands & 90.6 & 95.8 & 3.0 & 1.4 & 6.1 & 2.4 & 0.0 & 0.0 & 0.1 & 0.0 & 0.2 & 0.3 & 0.0 & 0.0 \\
\hline Timor-Leste ${ }^{\mathrm{a}}$ & 94.0 & 82.5 & 5.3 & 5.7 & 0.6 & 8.3 & 0.0 & 0.4 & 0.1 & 2.9 & 0.0 & 0.1 & 0.0 & 0.1 \\
\hline Tonga & 88.8 & 84.6 & 0.7 & 1.5 & 10.3 & 13.0 & 0.0 & 0.1 & 0.2 & 0.8 & 0.1 & 0.1 & 0.0 & 0.1 \\
\hline Tuvalu & 66.0 & 87.4 & 32.4 & 3.2 & 0.2 & 6.5 & 0.0 & 0.3 & 1.0 & 0.9 & 0.0 & 1.6 & 0.4 & 0.0 \\
\hline Vanuatu & 90.5 & 92.5 & 7.8 & 3.8 & 0.7 & 3.1 & 0.0 & 0.2 & 0.3 & 0.2 & 0.5 & 0.1 & 0.3 & 0.1 \\
\hline Developed ADB Member Economies & & & & & & & & & & & & & & \\
\hline Australia & 49.5 & 61.5 & 23.5 & 20.1 & 22.1 & 12.2 & 2.8 & 2.0 & 0.8 & 0.8 & 0.9 & 1.2 & 0.4 & 2.3 \\
\hline Japan & 46.4 & 54.7 & 15.1 & 15.4 & 22.2 & 13.8 & 13.0 & 12.3 & 2.0 & 2.6 & 1.3 & 1.1 & 0.1 & 0.0 \\
\hline New Zealand & 53.1 & 60.6 & 18.8 & 19.4 & 19.6 & 12.1 & 5.6 & 5.9 & 1.1 & 1.2 & 1.2 & 0.5 & 0.5 & 0.3 \\
\hline DEVELOPING ADB MEMBER ECONOMIES & & 57.2 & 14.8 & 15.5 & 13.5 & 9.0 & 6.7 & 9.1 & 1.1 & 3.6 & 1.5 & 2.9 & 2.1 & 2.8 \\
\hline ALL ADB REGIONAL MEMBERS & 56.6 & 57.1 & 15.3 & 15.6 & 15.9 & 9.6 & 7.9 & 9.1 & 1.3 & 3.4 & 1.4 & 2.6 & 1.5 & 2.4 \\
\hline WORLD & 29.2 & 35.7 & 40.6 & 38.6 & 19.9 & 13.6 & 4.2 & 5.2 & 2.6 & 3.0 & 2.2 & 2.5 & 1.3 & 1.3 \\
\hline
\end{tabular}

$0.0=$ magnitude is less than half of unit employed, $A D B=$ Asian Development Bank.

a For 2000 , data refer to 2004 .

Sources: International Monetary Fund. Direction of Trade Statistics. http://data.imf.org/?sk=9D6028D4-F14A-464C-A2F2-59B2CD424B85 (accessed 20 May 2019). For the Cook Islands and Taipei,China: Economy sources. 
Table 2.4.15: International Reserves and Ratio to Imports

\begin{tabular}{|c|c|c|c|c|c|c|c|c|c|}
\hline \multirow[t]{2}{*}{ ADB Regional Member } & \multicolumn{5}{|c|}{$\begin{array}{l}\text { International Reserves } \\
(\$ \text { million })\end{array}$} & \multicolumn{4}{|c|}{$\begin{array}{l}\text { Ratio to Imports } \\
\text { (months) }\end{array}$} \\
\hline & 2000 & 2005 & 2010 & 2018 & & 2000 & 2005 & 2010 & 2018 \\
\hline \multicolumn{10}{|l|}{ Developing ADB Member Economies } \\
\hline \multicolumn{10}{|l|}{ Central and West Asia } \\
\hline Afghanistan & $7(2002)$ & 0 & 5,147 & 8,191 & & $0.0(2002)$ & 0.0 & 12.5 & 14.2 \\
\hline Armenia & 314 & 669 & 1,866 & 2,249 & & 4.8 & 4.8 & 6.9 & 6.2 \\
\hline Azerbaijan & 680 & 1,178 & 6,409 & 6,666 & & 5.3 & 3.2 & 11.5 & 7.3 \\
\hline Georgia & 116 & 479 & 2,264 & 3,289 & & 1.4 & 2.2 & 5.4 & 4.6 \\
\hline Kazakhstan & 2,096 & 7,070 & 28,275 & 30,927 & & 3.6 & 4.7 & 10.3 & 11.2 \\
\hline Kyrgyz Republic & 262 & 612 & 1,720 & 2,156 & & 6.2 & 6.6 & 6.9 & 5.6 \\
\hline Pakistan & 2,056 & 10,948 & 17,210 & 11,709 & & 2.6 & 6.9 & 6.6 & 2.5 \\
\hline Tajikistan & 94 & 189 & 403 & 1,284 & & 1.2 & 2.0 & 1.7 & 5.6 \\
\hline Turkmenistan & 1,808 & 4,457 & & & & 15.8 & 18.1 & & \\
\hline Uzbekistan & 1,273 & 2,900 & 14,600 & 28,077 & (2017) & 6.3 & 10.5 & 22.0 & $25.8(2017)$ \\
\hline \multicolumn{10}{|l|}{ East Asia } \\
\hline China, People's Republic of & 168,855 & 825,588 & $2,872,090$ & $3,168,212$ & & 10.8 & 17.5 & 27.8 & 18.8 \\
\hline Hong Kong, China & 107,560 & 124,278 & 268,743 & 424,630 & & 7.9 & 6.1 & 8.4 & 8.5 \\
\hline Korea, Republic of & 96,198 & 210,391 & 291,571 & 403,575 & & 7.5 & 10.0 & 8.4 & 9.4 \\
\hline Mongolia & 202 & 333 & 2,288 & 3,549 & & 4.0 & 3.4 & 8.9 & 7.2 \\
\hline Taipei,China & 111,370 & 257,952 & 387,207 & 466,792 & & 9.7 & 17.0 & 18.4 & 19.6 \\
\hline \multicolumn{10}{|l|}{ South Asia } \\
\hline Bangladesh & 1,516 & 2,825 & 11,178 & 32,019 & & 2.4 & 2.9 & 6.3 & 7.1 \\
\hline Bhutan & 318 & 467 & 1,002 & 1,206 & (2017) & 20.6 & 12.2 & 15.1 & $14.1(2017)$ \\
\hline India & 40,155 & 136,026 & 296,730 & 396,115 & & 8.3 & 10.4 & 9.3 & 9.2 \\
\hline Maldives & 123 & 189 & 364 & 768 & & 4.3 & 3.5 & 3.5 & 3.3 \\
\hline Nepal & 952 & 1,504 & 2,939 & 8,079 & & 7.3 & 8.9 & 7.2 & 8.3 \\
\hline Sri Lanka & 1,147 & 2,735 & 7,196 & 7,959 & (2017) & 1.9 & 3.7 & 6.4 & 4.6 (2017) \\
\hline \multicolumn{10}{|l|}{ Southeast Asia } \\
\hline Brunei Darussalam & $382(2001)$ & 492 & 1,563 & 3,488 & (2017) & $4.2(2001)$ & 4.2 & 7.3 & $13.6(2017)$ \\
\hline Cambodia & 611 & 1,159 & 3,802 & 14,628 & & 3.8 & 3.5 & 6.9 & 9.3 \\
\hline Indonesia & 29,268 & 34,731 & 96,211 & 120,654 & & 8.7 & 6.5 & 9.7 & 8.0 \\
\hline Lao People's Democratic Republic & 140 & 239 & 713 & 1,270 & (2017) & 3.1 & 3.3 & 4.2 & 2.7 (2017) \\
\hline Malaysia & 28,624 & 70,152 & 106,525 & 101,444 & & 4.4 & 7.8 & 8.6 & 6.9 \\
\hline Myanmar & 234 & 782 & 5,729 & 5,214 & (2017) & 1.3 & 5.3 & 16.0 & $4.0(2017)$ \\
\hline Philippines & 15,063 & 18,494 & 62,373 & 79,193 & & 4.2 & 5.9 & 14.0 & 9.4 \\
\hline Singapore & 80,170 & 116,172 & 225,715 & 287,678 & & 6.9 & 7.2 & 8.7 & 9.6 \\
\hline Thailand & 32,661 & 52,065 & 172,129 & 205,641 & & 6.3 & 5.9 & 12.4 & 10.7 \\
\hline Viet Nam & 3,510 & 9,216 & 12,926 & 49,497 & (2017) & 3.0 & 3.2 & 2.0 & $2.9(2017)$ \\
\hline \multirow{2}{*}{\multicolumn{10}{|c|}{ The Pacific }} \\
\hline Cook Islands & & & & & & & & & \\
\hline Fiji & 412 & 321 & 721 & 947 & & 6.4 & 2.8 & 5.6 & 2.3 \\
\hline Kiribati & 0 & 0 & 8 & 8 & (2017) & 0.0 & 0.0 & 1.4 & $0.8(2017)$ \\
\hline Marshall Islands & 0 & 0 & 5 & 5 & (2017) & 0.0 & 0.0 & 0.5 & 0.5 (2017) \\
\hline Micronesia, Federated States of & 113 & 50 & 56 & 204 & (2017) & 12.4 & 4.8 & 4.2 & $13.9(2017)$ \\
\hline Nauru & $\ldots$ & $\ldots$ & $\ldots$ & 1 & & $\ldots$ & $\ldots$ & $\ldots$ & 0.2 \\
\hline Niue & & & & 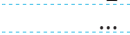 & & & 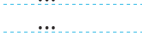 & 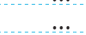 & \\
\hline Palau & 0 & 0 & 5 & 4 & & 0.0 & 0.0 & 0.6 & 0.3 \\
\hline Papua New Guinea & $343(2002)$ & 749 & 3,092 & 2,213 & & $3.8(2002)$ & 5.9 & 10.5 & 10.3 \\
\hline Samoa & $57(2001)$ & 77 & 189 & 170 & & $5.7(2001)$ & 5.0 & 8.1 & 6.1 \\
\hline Solomon Islands & 32 & 95 & 266 & 616 & & 4.2 & 9.4 & 8.9 & 13.9 \\
\hline Timor-Leste & $43(2002)$ & $84(2006)$ & 406 & 674 & & & $8.9(2006)$ & 15.9 & 13.2 \\
\hline Tonga & 25 & 47 & 105 & 227 & & 2.9 & 2.8 & 6.0 & 6.7 \\
\hline Tuvalu & 0 & $0(2006)$ & 3 & 2 & (2017) & 0.0 & $0.0(2006)$ & 1.8 & 1.1 (2017) \\
\hline Vanuatu & 39 & 67 & 161 & 395 & (2017) & 6.1 & 6.2 & 8.1 & $15.2(2017)$ \\
\hline \multicolumn{10}{|l|}{ Developed ADB Member Economies } \\
\hline Australia & 18,817 & 43,257 & 42,268 & 53,875 & & 3.5 & 4.5 & 2.6 & 2.9 \\
\hline Japan & 361,639 & 846,896 & $1,096,185$ & $1,270,466$ & & 12.9 & 21.9 & 21.0 & 21.0 \\
\hline New Zealand & 3,952 & 8,893 & 16,723 & 20,684 & (2017) & 3.7 & 4.2 & 6.5 & $6.0(2017)$ \\
\hline DEVELOPING ADB MEMBER & 728,826 & $1,895,784$ & $4,911,905$ & $5,881,627$ & & 7.7 & 11.1 & 15.8 & 12.8 \\
\hline \multirow{2}{*}{$\begin{array}{l}\text { DEVELOPING ADB MEMBER } \\
\text { ECONOMIESc } \\
\text { ALL ADB REGIONAL MEMBERSc }\end{array}$} & & & & & & & & & \\
\hline & $1,113,234$ & $2,794,830$ & $6,067,080$ & $7,226,652$ & & 8.7 & 12.7 & 15.9 & 13.5 \\
\hline
\end{tabular}

$\ldots=$ data not available, 0 or $0.0=$ magnitude is less than half of the unit employed, $\$=$ United States dollars, $A D B=$ Asian Development Bank.

a Data refer to international reserves with gold at national valuation, unless otherwise specified, end of year. For Afghanistan (up to 2007), Bhutan, Kiribati, Nauru, Palau, Samoa, Solomon Islands (up to 2011), Tonga, Turkmenistan, and Vanuatu, data refer to international reserves without gold.

b Merchandise imports from the balance of payments were used in the calculation.

c For reporting economies only.

Sources: For international reserves: International Monetary Fund. International Financial Statistics. http://data.imf.org/ (accessed 27 March 2019); for Taipei,China: economy source. For the reserves-to-imports ratio: Asian Development Bank estimates using data from the International Monetary Fund's International Financial Statistics and economy sources. 
Table 2.4.16: Net Official Development Assistance from All Sources to Developing Economies ${ }^{a}$ (\$ million)

\begin{tabular}{|c|c|c|c|c|c|c|c|c|c|}
\hline ADB Regional Member & 2000 & 2005 & 2010 & 2012 & 2013 & 2014 & 2015 & 2016 & 2017 \\
\hline \multicolumn{10}{|l|}{ Developing ADB Member Economies } \\
\hline \multicolumn{10}{|l|}{ Central and West Asia } \\
\hline Afghanistan & 136 & 2,815 & 6,235 & 6,667 & 5,153 & 4,943 & 4,267 & 4,069 & 3,804 \\
\hline Armenia & 216 & 173 & 320 & 271 & 280 & 267 & 347 & 326 & 256 \\
\hline Azerbaijan & 141 & 210 & 156 & 287 & -71 & 217 & 70 & 78 & 116 \\
\hline Georgia & 172 & 293 & 589 & 659 & 646 & 564 & 449 & 463 & 446 \\
\hline Kazakhstan & 185 & 225 & 212 & 132 & 91 & 93 & 83 & 64 & 59 \\
\hline Kyrgyz Republic & 193 & 238 & 372 & 470 & 539 & 627 & 770 & 516 & 461 \\
\hline Pakistan & 550 & 1,477 & 2,933 & 2,017 & 2,194 & 3,616 & 3,754 & 2,950 & 2,283 \\
\hline Tajikistan & 112 & 226 & 388 & 394 & 391 & 356 & 427 & 343 & 317 \\
\hline Turkmenistan & 36 & 29 & 44 & 38 & 36 & 34 & 24 & 33 & 29 \\
\hline Uzbekistan & 185 & 169 & 198 & 256 & 295 & 325 & 448 & 457 & 638 \\
\hline \multicolumn{10}{|l|}{ East Asia } \\
\hline China, People's Republic of & 1,749 & 1,798 & 672 & -181 & -657 & -947 & -332 & -792 & $-1,045$ \\
\hline Hong Kong, China & $-2 \ldots$ & $\ldots$ & $\ldots$ & $\ldots$ & $\ldots$ & $\ldots$ & & & \\
\hline Korea, Republic of & & & & & & & & & \\
\hline Mongolia & 186 & 195 & 287 & 447 & 431 & 317 & 236 & 326 & 764 \\
\hline Taipei,China & $\ldots$ & $\ldots$ & $\ldots$ & $\cdots$ & $\ldots$ & $\cdots$ & $\ldots$ & $\ldots$ & $\ldots$ \\
\hline \multicolumn{10}{|l|}{ South Asia } \\
\hline Bangladesh & 976 & 1,252 & 1,327 & 2,154 & 2,634 & 2,423 & 2,570 & 2,505 & 3,758 \\
\hline Bhutan & 47 & 79 & 97 & 162 & 137 & 131 & 97 & 52 & 119 \\
\hline India & 1,383 & 1,876 & 2,831 & 1,682 & 2,456 & 2,992 & 3,174 & 2,679 & 3,161 \\
\hline Maldives & 18 & 72 & 88 & 57 & 22 & 23 & 27 & 27 & 43 \\
\hline Nepal & 311 & 407 & 767 & 770 & 873 & 884 & 1,225 & 1,063 & 1,268 \\
\hline Sri Lanka & 222 & 1,040 & 559 & 491 & 403 & 492 & 427 & 357 & 297 \\
\hline \multicolumn{10}{|l|}{ Southeast Asia } \\
\hline Brunei Darussalam & & & & & & & & & \\
\hline Cambodia & 346 & 453 & 681 & 808 & 808 & 803 & 679 & 728 & 856 \\
\hline Indonesia & 1,645 & 2,489 & 1,324 & 69 & 69 & -382 & -33 & -111 & 277 \\
\hline Lao People's Democratic Republic & 234 & 241 & 389 & 411 & 423 & 474 & 471 & 399 & 480 \\
\hline Malaysia & 49 & 29 & -6 & 18 & -113 & 20 & -1 & -52 & -29 \\
\hline Myanmar & 106 & 145 & 355 & 505 & 3,936 & 1,384 & 1,169 & 1,537 & 1,543 \\
\hline Philippines & 553 & 588 & 582 & -3 & 192 & 677 & 515 & 284 & 160 \\
\hline Singapore & & & & & & & $\ldots$ & $\ldots$ & \\
\hline Thailand & 701 & -165 & -20 & -131 & 29 & 355 & 59 & 228 & 250 \\
\hline Viet Nam & 1,485 & 1,693 & 2,770 & 4,113 & 4,086 & 4,216 & 3,157 & 2,895 & 2,392 \\
\hline \multicolumn{10}{|l|}{ The Pacific } \\
\hline Cook Islands & 4 & 7 & 14 & 21 & 16 & 28 & 26 & 17 & 19 \\
\hline Fiji & 29 & 66 & 76 & 105 & 91 & 94 & 102 & 117 & 146 \\
\hline Kiribati & 17 & 27 & 24 & 66 & 65 & 81 & 65 & 61 & 77 \\
\hline Marshall Islands & 47 & 56 & 25 & 84 & 94 & 56 & 57 & 13 & 73 \\
\hline Micronesia, Federated States of & 97 & 105 & 64 & 143 & 143 & 117 & 81 & 51 & 98 \\
\hline Nauru & 4 & 9 & 28 & 36 & 29 & 23 & 31 & 23 & 26 \\
\hline Niue & 3 & 21 & 15 & 20 & 18 & 14 & 20 & 14 & 15 \\
\hline Palau & 39 & 24 & 29 & 15 & 35 & 23 & 14 & 18 & 22 \\
\hline Papua New Guinea & 275 & 268 & 514 & 670 & 657 & 582 & 591 & 532 & 533 \\
\hline Samoa & 29 & 43 & 124 & 117 & 113 & 94 & 94 & 89 & 131 \\
\hline Solomon Islands & 68 & 197 & 333 & 305 & 290 & 201 & 190 & 176 & 187 \\
\hline Timor-Leste & 231 & 185 & 290 & 284 & 259 & 250 & 212 & 224 & 232 \\
\hline Tonga & 16 & 33 & 66 & 78 & 81 & 80 & 68 & 83 & 87 \\
\hline Tuvalu & 4 & 9 & 14 & 25 & 28 & 34 & 50 & 24 & 27 \\
\hline Vanuatu & 35 & 40 & 109 & 102 & 91 & 100 & 187 & 129 & 132 \\
\hline DEVELOPING ADB MEMBER ECONOMIES & 12,837 & 19,139 & 25,876 & 24,633 & 27,294 & 26,678 & 25,867 & 22,992 & 24,506 \\
\hline DEVELOPING ECONOMIES WORLDWIDEC & 48,993 & 107,452 & 129,264 & 133,752 & 151,138 & 161,730 & 153,220 & 158,218 & 163,144 \\
\hline
\end{tabular}

$\ldots=$ data not available, $\$=$ United States dollars, $\mathrm{ADB}=$ Asian Development Bank.

a Net official development assistance refers to concessional flows to developing economies and multilateral institutions provided by official agencies, including state and local governments, or by their executing agencies, administered with the objective of promoting the economic development and welfare of developing economies, and containing a grant element of at least $25 \%$. Net flow takes into account principal repayments for loans, offsetting entries for forgiven debt, and recoveries made on grants. b For reporting economies only.

c Includes data for all developing economies as reported in the Organisation for Economic Co-operation and Development's OECD.Stat database.

Source: Organisation for Economic Co-operation and Development. OECD.Stat. http://stats.oecd.org (accessed 22 April 2019 ). 
Table 2.4.17: Net Other Official Flows from All Sources to Developing Economies ${ }^{\mathrm{a}}$ (\$ million)

\begin{tabular}{|c|c|c|c|c|c|c|c|c|c|}
\hline ADB Regional Member & 2000 & 2005 & 2010 & 2012 & 2013 & 2014 & 2015 & 2016 & 2017 \\
\hline \multicolumn{10}{|l|}{ Developing ADB Member Economies } \\
\hline \multicolumn{10}{|l|}{ Central and West Asia } \\
\hline Afghanistan & & 56.9 & 71.2 & 29.1 & 60.5 & -24.2 & 127.4 & 97.2 & 56.1 \\
\hline Armenia & 16.9 & 7.8 & 288.3 & 133.4 & 112.1 & 103.6 & 111.1 & 197.2 & 157.6 \\
\hline Azerbaijan & 314.3 & 226.5 & 179.9 & 411.8 & 391.0 & 630.1 & 801.8 & $1,114.7$ & $1,738.5$ \\
\hline Georgia & 62.7 & 86.3 & 250.2 & 146.6 & -0.7 & 2.9 & 342.4 & 486.6 & 262.1 \\
\hline Kazakhstan & -41.7 & -502.3 & $2,247.2$ & 606.9 & $1,548.0$ & 549.5 & $1,256.7$ & 441.4 & -853.7 \\
\hline Kyrgyz Republic & -4.0 & 56.3 & 18.3 & 73.7 & 69.7 & 16.5 & 0.4 & -43.2 & -6.0 \\
\hline Pakistan & -592.9 & 127.4 & 345.3 & 414.3 & -236.7 & -97.1 & -343.9 & $1,102.3$ & 377.7 \\
\hline Tajikistan & 0.7 & 22.8 & 6.4 & 9.2 & 6.6 & -5.5 & 68.1 & 13.6 & 15.6 \\
\hline Turkmenistan & 130.3 & -74.1 & 647.4 & -333.2 & 135.4 & $1,143.9$ & $2,356.6$ & 926.1 & 532.3 \\
\hline Uzbekistan & 272.1 & -48.7 & 16.0 & 122.9 & 754.6 & 743.9 & 530.5 & $1,204.2$ & 383.0 \\
\hline \multicolumn{10}{|l|}{ East Asia } \\
\hline China, People's Republic of & $-1,782.4$ & 423.1 & $3,196.3$ & $1,474.0$ & 742.1 & 343.0 & $1,215.8$ & 139.9 & $1,227.3$ \\
\hline Hong Kong, China & & & & & & $\ldots$ & $\cdots$ & $\ldots$ & \\
\hline Korea, Republic of & & & & & & & & & \\
\hline Mongolia & -8.5 & -14.6 & 159.3 & 283.9 & 255.0 & 509.8 & 213.3 & 756.4 & -210.6 \\
\hline Taipei,China & $\ldots$ & $\ldots$ & $\ldots$ & $\ldots$ & $\ldots$ & $\cdots$ & $\cdots$ & $\ldots$ & $\ldots$ \\
\hline \multicolumn{10}{|l|}{ South Asia } \\
\hline Bangladesh & -30.5 & 186.8 & 35.1 & 129.3 & 187.7 & 247.0 & 417.9 & $1,421.5$ & $2,337.4$ \\
\hline Bhutan & -1.1 & 4.8 & 24.0 & 3.7 & -5.0 & -6.0 & -2.8 & 8.0 & 3.1 \\
\hline India & -196.4 & $2,322.3$ & $5,967.5$ & $4,011.4$ & $3,010.8$ & $4,029.7$ & $1,811.5$ & $1,935.6$ & $1,188.9$ \\
\hline Maldives & -4.8 & 44.0 & -33.9 & -105.3 & 13.3 & -3.7 & -8.1 & -24.7 & -23.8 \\
\hline Nepal & 23.7 & -8.3 & -6.9 & 3.9 & 16.2 & -2.4 & -7.4 & 0.7 & -2.3 \\
\hline Sri Lanka & -22.7 & 39.8 & 189.3 & 491.3 & 436.0 & 350.5 & 320.8 & 312.6 & 132.3 \\
\hline \multicolumn{10}{|l|}{ Southeast Asia } \\
\hline Brunei Darussalam & & & & & & & & & \\
\hline Cambodia & -0.4 & 7.6 & -5.0 & 33.4 & 89.3 & 96.3 & 84.6 & -12.3 & 84.1 \\
\hline Indonesia & 100.1 & $1,443.8$ & $1,783.7$ & $-2,036.8$ & 120.8 & $-1,715.7$ & $3,775.4$ & $3,708.7$ & $2,934.5$ \\
\hline Lao People's Democratic Republic & -8.8 & 59.4 & -120.5 & 29.7 & 4.6 & 194.8 & 73.1 & 38.6 & 74.7 \\
\hline Malaysia & 519.9 & $-1,369.3$ & 159.2 & 552.9 & -126.4 & $1,339.4$ & -231.8 & $-1,494.5$ & -739.8 \\
\hline Myanmar & 20.1 & -31.5 & 30.9 & -32.7 & 227.2 & 107.6 & 427.5 & 100.6 & 96.4 \\
\hline Philippines & 499.6 & -945.9 & -680.3 & 603.5 & $-1,245.5$ & $1,029.6$ & $1,148.5$ & 203.1 & -32.2 \\
\hline Singapore & & & & & & & & & \\
\hline Thailand & $-2,112.2$ & $1,629.6$ & -71.5 & $1,474.9$ & $2,454.4$ & -349.0 & 138.7 & -39.3 & $-1,051.6$ \\
\hline Viet Nam & -546.4 & 248.4 & $2,815.4$ & $2,005.8$ & $4,828.3$ & $2,133.3$ & $2,782.1$ & 580.6 & $-1,345.9$ \\
\hline \multicolumn{10}{|l|}{ The Pacific } \\
\hline Cook Islands & -0.2 & -0.3 & 9.7 & 7.1 & 4.9 & -1.3 & -0.6 & -1.2 & 1.8 \\
\hline Fiji & -11.8 & 1.2 & 14.2 & 20.3 & 73.6 & 66.1 & -11.4 & 40.6 & 48.3 \\
\hline Kiribati & $0.1(2002)$ & 0.2 & 0.5 & 0.8 & 0.6 & 0.2 & 0.2 & 0.3 & 0.1 \\
\hline Marshall Islands & -0.2 & -0.1 & -0.6 & -57.2 & -21.1 & 146.2 & 7.6 & 36.7 & 17.1 \\
\hline Micronesia, Federated States of & -0.1 & 0.3 & 0.8 & 3.5 & & 1.1 & 0.2 & 2.3 & 1.5 \\
\hline Nauru & -5.6 & 0.2 & 0.3 & 0.3 & -0.1 & & $\ldots$ & 62.5 & 19.4 \\
\hline Niue & 7.5 & $\ldots$ & $\ldots$ & $\ldots$ & $\ldots$ & $\ldots$ & & 0.0 & \\
\hline Palau & -1.5 & -2.1 & $0.1(2008)$ & 14.7 & 6.4 & -11.1 & 0.3 & 6.6 & 9.9 \\
\hline Papua New Guinea & 85.4 & -9.1 & $4,892.3$ & 843.2 & $1,025.2$ & $-2,991.6$ & 19.4 & -320.7 & -267.2 \\
\hline Samoa & 0.4 & -0.1 & 4.1 & -5.7 & 4.2 & -0.9 & -1.3 & 5.6 & 1.3 \\
\hline Solomon Islands & 1.2 & -11.7 & 59.2 & 0.6 & 37.4 & 25.0 & 0.7 & 19.1 & 0.5 \\
\hline Timor-Leste & 417.8 & 1.1 & 4.6 & 2.0 & 5.7 & 9.9 & 7.8 & 24.8 & 11.8 \\
\hline Tonga & 0.0 & 0.4 & 0.3 & 1.0 & 0.3 & 0.0 & 2.1 & 2.5 & 1.2 \\
\hline Tuvalu & & $0.5(2006)$ & -0.1 & 0.2 & 0.2 & 0.2 & 0.2 & 0.2 & 0.1 \\
\hline Vanuatu & -16.2 & 0.8 & 1.3 & 2.6 & 1.7 & 0.8 & 0.7 & 0.9 & 2.1 \\
\hline DEVELOPING ADB MEMBER ECONOMIES & $-2,915.4$ & $3,980.2$ & $22,499.3$ & $11,370.6$ & $14,987.2$ & $8,612.3$ & $17,436.0$ & $13,055.7$ & 7,183.3 \\
\hline DEVELOPING ECONOMIES WORLDWIDE & $9,856.9$ & $9,605.9$ & $70,855.8$ & $38,758.7$ & $38,935.3$ & $22,461.4$ & $50,604.3$ & $29,589.4$ & $21,222.0$ \\
\hline
\end{tabular}

... = data not available, 0.0 = magnitude is less than half of unit employed, $\$=$ United States dollars, $A D B=$ Asian Development Bank.

a Net other official flows refer to official sector transactions with economies on the Development Assistance Committee List of Official Development Assistance Recipients, which do not meet the conditions for eligibility as official development assistance, either because they are not primarily aimed at development or because they have a grant element of less than 25\%. The Development Assistance Committee List of Official Development Assistance Recipients is available at http://www.oecd.org/dac/ financing-sustainable-development/development-finance-standards/daclist.htm. Also includes net export credits. Net flow takes into account principal repayments for loans, offsetting entries for forgiven debt, and recoveries made on grants.

b For reporting economies only.

c Includes data for all developing economies as reported in the Organisation for Economic Co-operation and Development's OECD.Stat database.

Source: Organisation for Economic Co-operation and Development. OECD.Stat. http://stats.oecd.org (accessed 22 April 2019). 
Table 2.4.18: Net Private Flows from All Sources to Developing Economies ${ }^{a}$ (\$ million)

\begin{tabular}{|c|c|c|c|c|c|c|c|c|c|}
\hline ADB Regional Member & 2000 & 2005 & 2010 & 2012 & 2013 & 2014 & 2015 & 2016 & 2017 \\
\hline \multicolumn{10}{|l|}{ Developing ADB Member Economies } \\
\hline \multicolumn{10}{|l|}{ Central and West Asia } \\
\hline Afghanistan & 21 & -14 & -21 & -12 & 26 & 32 & -5 & -5 & 3 \\
\hline Armenia & -21 & 35 & -69 & -91 & 208 & -0 & 57 & 179 & 85 \\
\hline Azerbaijan & 219 & 1,082 & 798 & 326 & 869 & -129 & 436 & 404 & 107 \\
\hline Georgia & 23 & -32 & 22 & 182 & 52 & -59 & 1,249 & 190 & 360 \\
\hline Kazakhstan & 603 & 2,252 & $-1,511$ & 194 & 2,947 & 1,251 & 3,090 & -86 & $-3,041$ \\
\hline Kyrgyz Republic & 12 & 7 & 23 & 15 & 18 & 10 & 6 & -23 & 4 \\
\hline Pakistan & 60 & 833 & -75 & 298 & -172 & 155 & 131 & 192 & 707 \\
\hline Tajikistan & -8 & -1 & 18 & 15 & 47 & 4 & -8 & -2 & -42 \\
\hline Turkmenistan & 124 & 1 & -46 & 43 & 103 & 42 & -11 & 285 & 106 \\
\hline Uzbekistan & -10 & -84 & 39 & 153 & -117 & -478 & 110 & 108 & 435 \\
\hline \multicolumn{10}{|l|}{ East Asia } \\
\hline China, People's Republic of & 923 & 21,125 & 46,301 & 17,987 & 53,925 & 61,702 & 17,154 & 42,121 & 36,602 \\
\hline Hong Kong, China & $\ldots$ & $\ldots$ & $\ldots$ & & $\ldots$ & $\ldots$ & $\ldots$ & & \\
\hline Korea, Republic of & & $\cdots$ & & & & & & & \\
\hline Mongolia & 3 & -2 & 22 & 417 & 511 & 42 & 216 & 586 & 66 \\
\hline Taipei,China & $\ldots$ & $\ldots$ & $\ldots$ & $\ldots$ & $\ldots$ & $\ldots$ & $\ldots$ & $\ldots$ & $\ldots$ \\
\hline \multicolumn{10}{|l|}{ South Asia } \\
\hline Bangladesh & 93 & 186 & -3 & 858 & -105 & 249 & 100 & -380 & 230 \\
\hline Bhutan & -8 & 1 & 18 & 107 & -163 & 9 & 16 & -0 & -1 \\
\hline India & 1,099 & 4,548 & 19,976 & 14,426 & 6,292 & 10,655 & 7,288 & 14,813 & 18,564 \\
\hline Maldives & -4 & 8 & 38 & 38 & -16 & 100 & 112 & 17 & -1 \\
\hline Nepal & -4 & -2 & -11 & 78 & 115 & 7 & -3 & 6 & 53 \\
\hline Sri Lanka & 98 & 35 & 218 & 199 & 447 & 427 & 387 & 482 & 387 \\
\hline \multicolumn{10}{|l|}{ Southeast Asia } \\
\hline Brunei Darussalam & $\ldots$ & $\ldots$ & $\ldots$ & & & & & & \\
\hline Cambodia & 9 & 9 & 256 & 276 & 310 & 399 & 380 & 403 & 412 \\
\hline Indonesia & 606 & 4,012 & 3,348 & 10,084 & 7,291 & 13,343 & 9,678 & 10,235 & 11,158 \\
\hline Lao People's Democratic Republic & 14 & 0 & 172 & 363 & 59 & 50 & -19 & 44 & 72 \\
\hline Malaysia & -872 & 2,064 & 6,573 & 9,684 & 9,719 & 6,165 & 3,689 & 2,134 & 2,839 \\
\hline Myanmar & -70 & 17 & 260 & 357 & 534 & 566 & 865 & 356 & 452 \\
\hline Philippines & 330 & 3,496 & 2,424 & 4,785 & 2,510 & 4,839 & 1,908 & 2,738 & 4,121 \\
\hline \multicolumn{10}{|l|}{ Singapore } \\
\hline Thailand & 32 & 10,944 & 6,394 & 5,356 & 6,096 & 10,076 & $-2,337$ & 2,760 & 1,304 \\
\hline Viet Nam & 237 & 224 & 2,038 & 3,412 & 5,002 & 3,467 & 2,790 & 4,758 & 4,515 \\
\hline \multicolumn{10}{|l|}{ The Pacific } \\
\hline Cook Islands & -31 & -29 & -0 & -1 & 3 & -2 & -2 & -1 & 0 \\
\hline Fiji & 6 & 51 & -3 & 163 & 2 & 49 & 53 & -15 & 45 \\
\hline Kiribati & 0 & 1 & -0 & 0 & 0 & 3 & 3 & -9 & -1 \\
\hline Marshall Islands & 108 & 2,737 & 974 & 2,179 & $-1,048$ & -365 & 2,245 & 9 & 570 \\
\hline Micronesia, Federated States of & $-0(2001)$ & 0 & 3 & 4 & 93 & 320 & 798 & 714 & 453 \\
\hline Nauru & 4 & 2 & $2(2009)$ & $\ldots$ & $\ldots$ & $\ldots$ & $\ldots$ & -0 & 0 \\
\hline Niue & 12 & -1 & $\ldots$ & -0 & $\cdots$ & 0 & 0 & 0 & 0 \\
\hline Palau & 18 & 1 & 3 & 7 & 2 & 6 & 7 & 9 & 10 \\
\hline Papua New Guinea & -27 & 238 & -40 & 3,063 & 879 & 65 & $-2,931$ & 211 & 134 \\
\hline Samoa & 1 & 30 & 17 & 14 & -36 & 37 & 3 & 8 & 6 \\
\hline Solomon Islands & -15 & -17 & 3 & -463 & 4 & 23 & 11 & -1 & -8 \\
\hline Timor-Leste & $54(2001)$ & 0 & -3 & 3 & 25 & 2 & 17 & -41 & 15 \\
\hline Tonga & -7 & 2 & -10 & 0 & 1 & 1 & -1 & -0 & 0 \\
\hline Tuvalu & -4 & -1 & $\ldots$ & -0 & -2 & -1 & 0 & 0 & 0 \\
\hline Vanuatu & 41 & 11 & 31 & 86 & 43 & 15 & -5 & 1 & -1 \\
\hline DEVELOPING ADB MEMBER ECONOMIES & 3,668 & 53,771 & 88,180 & 74,604 & 96,474 & 113,076 & 47,476 & 83,201 & 80,720 \\
\hline DEVELOPING ECONOMIES WORLDWIDE & 75,170 & 173,009 & 324,145 & 300,041 & 251,386 & 414,308 & 116,530 & 128,651 & 229,598 \\
\hline
\end{tabular}

$\ldots$.. data not available, -0 or 0 = magnitude is less than half of unit employed, $\$=$ United States dollars, ADB = Asian Development Bank.

a Net private flows refer to the sum of direct investments and portfolio investments.

b For reporting economies only.

c Includes data for all developing economies as reported in the Organisation for Economic Co-operation and Development's OECD.Stat database.

Source: Organisation for Economic Co-operation and Development. OECD.Stat. http://stats.oecd.org (accessed 22 April 2019 ). 
Table 2.4.19: Aggregate Net Resource Flows from All Sources to Developing Economies ${ }^{a}$ (\$ million)

\begin{tabular}{|c|c|c|c|c|c|c|c|c|c|}
\hline ADB Regional Member & 2000 & 2005 & 2010 & 2012 & 2013 & 2014 & 2015 & 2016 & 2017 \\
\hline \multicolumn{10}{|l|}{ Developing ADB Member Economies } \\
\hline \multicolumn{10}{|l|}{ Central and West Asia } \\
\hline Afghanistan & 157 & 2,858 & 6,285 & 6,684 & 5,239 & 4,951 & 4,389 & 4,162 & 3,863 \\
\hline Armenia & 211 & 216 & 539 & 313 & 600 & 371 & 515 & 703 & 498 \\
\hline Azerbaijan & 673 & 1,519 & 1,135 & 1,024 & 1,189 & 718 & 1,308 & 1,596 & 1,961 \\
\hline Georgia & 258 & 347 & 861 & 987 & 698 & 508 & 2,040 & 1,139 & 1,069 \\
\hline Kazakhstan & 746 & 1,975 & 948 & 933 & 4,586 & 1,893 & 4,430 & 419 & $-3,836$ \\
\hline Kyrgyz Republic & 201 & 302 & 413 & 559 & 627 & 653 & 776 & 450 & 459 \\
\hline Pakistan & 17 & 2,437 & 3,203 & 2,730 & 1,786 & 3,673 & 3,541 & 4,244 & 3,368 \\
\hline Tajikistan & 105 & 248 & 413 & 418 & 444 & 355 & 487 & 354 & 290 \\
\hline Turkmenistan & 290 & -44 & 645 & -253 & 274 & 1,220 & 2,370 & 1,244 & 667 \\
\hline Uzbekistan & 447 & 37 & 253 & 532 & 933 & 590 & 1,089 & 1,770 & 1,456 \\
\hline \multicolumn{10}{|l|}{ East Asia } \\
\hline China, People's Republic of & 889 & 23,346 & 50,169 & 19,280 & 54,011 & 61,098 & 18,037 & 41,469 & 36,784 \\
\hline Hong Kong, China & $\ldots$ & & & $\ldots$ & & & & & \\
\hline Korea, Republic of & & & & & & & & & \\
\hline Mongolia & 180 & 179 & 468 & 1,147 & 1,196 & 869 & 665 & 1,668 & 619 \\
\hline Taipei,China & $\ldots$ & $\cdots$ & $\ldots$ & $\cdots$ & $\cdots$ & $\ldots$ & $\ldots$ & $\ldots$ & $\ldots$ \\
\hline \multicolumn{10}{|l|}{ South Asia } \\
\hline Bangladesh & 1,039 & 1,625 & 1,360 & 3,141 & 2,717 & 2,918 & 3,088 & 3,546 & 6,325 \\
\hline Bhutan & 38 & 85 & 140 & 273 & -32 & 133 & 110 & 60 & 121 \\
\hline India & 2,286 & 8,746 & 28,774 & 20,120 & 11,760 & 17,676 & 12,274 & 19,428 & 22,914 \\
\hline Maldives & 10 & 124 & 93 & -10 & 19 & 119 & 131 & 19 & 18 \\
\hline Nepal & 331 & 397 & 749 & 851 & 1,005 & 888 & 1,215 & 1,070 & 1,319 \\
\hline Sri Lanka & 298 & 1,115 & 966 & 1,181 & 1,286 & 1,269 & 1,135 & 1,152 & 816 \\
\hline \multicolumn{10}{|l|}{ Southeast Asia } \\
\hline Brunei Darussalam & & & & & & & & & \\
\hline Cambodia & 354 & 470 & 932 & 1,117 & 1,207 & 1,298 & 1,144 & 1,120 & 1,352 \\
\hline Indonesia & 2,352 & 7,945 & 6,456 & 8,116 & 7,481 & 11,245 & 13,420 & 13,833 & 14,369 \\
\hline Lao People's Democratic Republic & 239 & 301 & 441 & 803 & 487 & 719 & 526 & 482 & 627 \\
\hline Malaysia & -304 & 724 & 6,726 & 10,255 & 9,480 & 7,524 & 3,457 & 588 & 2,070 \\
\hline Myanmar & 56 & 131 & 646 & 829 & 4,697 & 2,058 & 2,460 & 1,993 & 2,091 \\
\hline Philippines & 1,383 & 3,138 & 2,326 & 5,385 & 1,457 & 6,546 & 3,572 & 3,225 & 4,249 \\
\hline Singapore & & & & & & & & & \\
\hline Thailand & $-1,380$ & 12,409 & 6,302 & 6,700 & 8,579 & 10,081 & $-2,139$ & 2,949 & 502 \\
\hline Viet Nam & 1,176 & 2,166 & 7,623 & 9,531 & 13,916 & 9,816 & 8,729 & 8,233 & 5,561 \\
\hline \multicolumn{10}{|l|}{ The Pacific } \\
\hline Cook Islands & -27 & -23 & 23 & 28 & 23 & 25 & 23 & 15 & 20 \\
\hline Fiji & 24 & 118 & 87 & 289 & 166 & 210 & 144 & 143 & 239 \\
\hline Kiribati & 17 & 28 & 24 & 67 & 66 & 84 & 68 & 52 & 77 \\
\hline Marshall Islands & 156 & 2,793 & 998 & 2,205 & -975 & -163 & 2,309 & 58 & 660 \\
\hline Micronesia, Federated States of & 97 & 105 & 68 & 150 & 236 & 438 & 879 & 767 & 552 \\
\hline Nauru & 2 & 12 & 28 & 36 & 29 & 23 & 31 & 85 & 45 \\
\hline Niue & 23 & 20 & 15 & 20 & 18 & 14 & 20 & 14 & 15 \\
\hline Palau & 55 & 22 & 32 & 37 & 44 & 18 & 21 & 33 & 42 \\
\hline Papua New Guinea & 333 & 498 & 5,366 & 4,576 & 2,562 & $-2,344$ & $-2,320$ & 422 & 400 \\
\hline Samoa & 30 & 73 & 145 & 126 & 81 & 130 & 95 & 103 & 139 \\
\hline Solomon Islands & 55 & 169 & 395 & -158 & 331 & 249 & 202 & 194 & 179 \\
\hline Timor-Leste & 649 & 186 & 292 & 288 & 290 & 262 & 238 & 207 & 259 \\
\hline Tonga & 10 & 35 & 57 & 79 & 83 & 82 & 70 & 85 & 88 \\
\hline Tuvalu & -0 & 8 & 14 & 26 & 26 & 34 & 50 & 25 & 27 \\
\hline Vanuatu & 60 & 52 & 142 & 191 & 136 & 117 & 182 & 131 & 134 \\
\hline DEVELOPING ADB MEMBER ECONOMIES & 13,536 & 76,890 & 136,553 & 110,607 & 138,756 & 148,366 & 90,779 & 119,248 & 112,409 \\
\hline DEVELOPING ECONOMIES WORLDWIDE ${ }^{\mathrm{C}}$ & 134,020 & 290,067 & 524,265 & 472,551 & 441,459 & 598,499 & 320,354 & 316,459 & 413,964 \\
\hline
\end{tabular}

$\ldots=$ data not available, -0 or $0=$ magnitude is less than half of unit employed, $\$=$ United States dollars, $A D B=$ Asian Development Bank.

a Aggregate net resource flows refer to the sum of net official development assistance, net other official flows, and net private flows.

b For reporting economies only.

c Includes data for all developing economies as reported in the Organisation for Economic Co-operation and Development's OECD.Stat database.

Source: Organisation for Economic Co-operation and Development. OECD.Stat. http://stats.oecd.org (accessed 22 April 2019). 
Table 2.4.20: Total External Debt of Developing Economies ${ }^{a}$ (\$ million)

\begin{tabular}{|c|c|c|c|c|c|c|c|c|}
\hline \multirow{2}{*}{ ADB Regional Member } & \multicolumn{4}{|c|}{ Total External Debt } & \multicolumn{4}{|c|}{ External Debt, Public and Publicly Guaranteed } \\
\hline & 2000 & 2005 & 2010 & 2017 & 2000 & 2005 & 2010 & 2017 \\
\hline \multicolumn{9}{|l|}{ Developing ADB Member Economies } \\
\hline \multicolumn{9}{|l|}{ Central and West Asia } \\
\hline Afghanistan & 0 & 979 (2006) & 2,436 & 2,552 & 0 & $920(2006)$ & 1,976 & 1,982 \\
\hline Armenia & 1,018 & 1,970 & 6,307 & 10,335 & 684 & 924 & 2,560 & 5,228 \\
\hline Azerbaijan & 1,585 & 2,247 & 7,279 & 15,254 & 794 & 1,491 & 3,839 & 12,663 \\
\hline Georgia & 1,826 & 2,151 & 8,790 & 15,756 & 1,274 & 1,531 & 3,274 & 6,054 \\
\hline Kazakhstan & 12,890 & 43,857 & 119,145 & 167,485 & 3,623 & 2,177 & 3,845 & 21,295 \\
\hline Kyrgyz Republic & 1,938 & 2,257 & 4,118 & 8,161 & 1,220 & 1,665 & 2,446 & 3,908 \\
\hline Pakistan & 33,022 & 34,018 & 62,801 & 84,523 & 27,192 & 30,089 & 43,403 & 60,049 \\
\hline Tajikistan & 1,141 & 1,125 & 3,561 & 5,881 & 755 & 829 & 1,806 & 3,092 \\
\hline Turkmenistan & 2,627 & 1,153 & 529 & 781 & 2,271 & 878 & 359 & 226 \\
\hline Uzbekistan & 4,948 & 4,632 & 7,802 & 17,708 & 3,766 & 3,626 & 3,423 & 8,208 \\
\hline \multicolumn{9}{|l|}{ East Asia } \\
\hline China, People's Republic of & 145,666 & 283,310 & 734,465 & $1,710,235$ & 94,489 & 84,212 & 94,003 & 201,724 \\
\hline Hong Kong, China & 208,260 & 470,288 & 879,034 & $1,692,317(2018)$ & & & & $\ldots$ \\
\hline Korea, Republic of & 135,208 & 161,956 & 355,911 & $440,599(2018)$ & 52,128 & 39,665 & 120,636 & $\ldots$ \\
\hline Mongolia & 960 & 1,396 & 5,928 & 28,199 & 833 & 1,267 & 1,782 & 7,492 \\
\hline Taipei,China & 34,757 & 86,732 & 101,581 & $191,161(2018)$ & 23 & 222 & 8,035 & $168(2018)$ \\
\hline \multicolumn{9}{|l|}{ South Asia } \\
\hline Bangladesh & 15,603 & 18,506 & 26,881 & 47,155 & 14,992 & 17,441 & 21,453 & 31,367 \\
\hline Bhutan & 212 & 657 & 935 & 2,636 & 202 & 636 & 919 & 2,565 \\
\hline India & 101,131 & 121,195 & 290,428 & 513,209 & 81,196 & 54,726 & 100,563 & 196,176 \\
\hline Maldives & 203 & 362 & 917 & 1,365 & 185 & 300 & 628 & 1,260 \\
\hline Nepal & 2,878 & 3,191 & 3,789 & 4,963 & 2,826 & 3,112 & 3,509 & 4,299 \\
\hline Sri Lanka & 9,250 & 11,300 & 21,684 & 50,142 & 7,945 & 9,658 & 16,430 & 32,575 \\
\hline \multicolumn{9}{|l|}{ Southeast Asia } \\
\hline Brunei Darussalam & & & & & & & & \\
\hline Cambodia & 1,946 & 2,769 & 3,825 & 11,898 & 1,853 & 2,666 & 2,874 & 6,380 \\
\hline Indonesia & 144,032 & 142,120 & 198,269 & 354,352 & 70,025 & 77,705 & 103,388 & 195,691 \\
\hline Lao People's Democratic Republic & 2,531 & 3,279 & 6,554 & 14,498 & 2,474 & 2,354 & 3,751 & 8,374 \\
\hline Malaysia & 41,946 & 64,911 & 133,800 & $200,364(2016)$ & 19,125 & 34,387 & 61,858 & $65,721(2016)$ \\
\hline Myanmar & 6,239 & 7,288 & 10,187 & 16,139 & 5,692 & 6,429 & 8,616 & 14,837 \\
\hline Philippines & 58,456 & 58,693 & 65,358 & 73,080 & 33,744 & 35,364 & 45,094 & 35,440 \\
\hline Singapore & 220,298 & 300,359 & & & . & & & \\
\hline Thailand & 79,830 & 58,467 & 106,358 & 129,765 & 29,462 & 12,602 & 15,929 & 24,458 \\
\hline Viet Nam & 12,785 & 18,530 & 44,902 & 104,079 & 11,584 & 16,219 & 32,764 & 51,782 \\
\hline \multicolumn{9}{|l|}{ The Pacific } \\
\hline Cook Islands & 59 & 68 & 99 & $70(2018)$ & & & & \\
\hline Fiji & 195 & 303 & 607 & 899 & 174 & 185 & 426 & 753 \\
\hline Kiribati & 8 & 11 & 14 & $42(2018)$ & $\ldots$ & $\ldots$ & $\ldots$ & $\ldots$ \\
\hline Marshall Islands & 105 & 92 & 105 & 83 & $\ldots$ & $\ldots$ & $\ldots$ & $\ldots$ \\
\hline Micronesia, Federated States of & 63 & 62 & 86 & $80(2016)$ & $\ldots$ & $\ldots$ & $\ldots$ & $\ldots$ \\
\hline Nauru & $\ldots$ & $\ldots$ & $\ldots$ & $\ldots$ & $\ldots$ & $\ldots \ldots$ & $\ldots$ & $\ldots .$. \\
\hline Niue & & $\ldots$ & $\ldots$ & $\ldots$ & $\ldots$ & $\ldots$ & $\ldots$ & $\ldots$ \\
\hline Palau & 58 & 60 & 66 & $88(2018)$ & ...... & & & \\
\hline Papua New Guinea & 2,325 & 1,871 & 5,987 & 17,367 & 1,454 & 1,264 & 1,042 & 2,299 \\
\hline Samoa & 139 & 169 & 325 & 443 & 138 & 167 & 299 & 416 \\
\hline Solomon Islands & 156 & 167 & 231 & 350 & 121 & 144 & 125 & 97 \\
\hline Timor-Leste & 0 & 0 & 77 (2012) & 50 & 0 & 0 & 0 & 36 \\
\hline Tonga & 74 & 89 & 154 & 169 & 65 & 80 & 144 & 159 \\
\hline Tuvalu & 4 & $10(2006)$ & 16 & 26 & & & & \\
\hline Vanuatu & 112 & 100 & 178 & 393 & 73 & 72 & 102 & 287 \\
\hline $\begin{array}{l}\text { DEVELOPING ADB MEMBER } \\
\text { ECONOMIES }\end{array}$ & $1,024,241$ & $1,547,430$ & $3,087,716$ & $5,734,288$ & 453,258 & 410,618 & 649,443 & 941,342 \\
\hline $\begin{array}{l}\text { DEVELOPING ECONOMIES } \\
\text { WORLDWIDE }^{c}\end{array}$ & $2,269,263$ & $3,043,004$ & $5,591,470$ & $9,383,642$ & $1,206,268$ & $1,223,350$ & $1,656,407$ & $2,639,996$ \\
\hline
\end{tabular}

$\ldots$... data not available, $\$=$ United States dollars, $\mathrm{ADB}=$ Asian Development Bank.

a Refers to the sum of public and publicly guaranteed long-term debt, private nonguaranteed long-term debt, use of International Monetary Fund credit, and estimated short-term debt.

b For reporting economies only.

c Refers to all low- and middle-income countries as classified by the World Bank. For developing member economies not covered by the World Bank, data are from economy sources.

Sources: $\quad$ World Bank. International Debt Statistics Online. http://data.worldbank.org/data-catalog/international-debt-statistics (accessed 19 July 2019); and Asian Development Bank estimates using economy sources. 


\section{External Indebtness}

Table 2.4.21: Total External Debt of Developing ADB Member Economies $(\%$ of $\mathrm{GNI})$

\begin{tabular}{|c|c|c|c|c|c|c|c|c|}
\hline \multirow{2}{*}{ ADB Regional Member } & \multicolumn{4}{|c|}{ Total External Debt } & \multicolumn{4}{|c|}{ External Debt, Public and Publicly Guaranteed } \\
\hline & 2000 & 2005 & 2010 & 2017 & 2000 & 2005 & 2010 & 2017 \\
\hline \multirow{2}{*}{\multicolumn{9}{|c|}{ Developing ADB Member Economies }} \\
\hline & \\
\hline Afghanistan & $\ldots$ & $13.8(2006)$ & 15.2 & 12.1 & $\ldots$ & $13.0(2006)$ & 12.4 & 9.8 \\
\hline Armenia & 51.8 & 38.6 & 64.9 & 85.9 & 34.8 & 18.1 & 26.3 & 43.6 \\
\hline Azerbaijan & 31.8 & 19.4 & 14.6 & 39.1 & 15.9 & 12.9 & 7.7 & 32.4 \\
\hline Georgia & 57.5 & 33.2 & 77.9 & 109.8 & 40.1 & 23.7 & 29.0 & 42.4 \\
\hline Kazakhstan & 75.7 & 84.7 & 92.6 & 118.4 & 21.3 & 4.2 & 3.0 & 14.7 \\
\hline Kyrgyz Republic & 150.5 & 95.1 & 91.7 & 111.2 & 94.8 & 70.2 & 54.5 & 53.3 \\
\hline Pakistan & 45.2 & 30.4 & 34.1 & 26.3 & 37.2 & 26.9 & 23.6 & 18.7 \\
\hline Tajikistan & 138.4 & 50.3 & 51.1 & 71.3 & 91.6 & 37.1 & 25.9 & 37.5 \\
\hline Turkmenistan & 96.3 & 15.3 & 2.6 & 1.9 & 83.3 & 11.6 & 1.7 & 0.6 \\
\hline Uzbekistan & 36.5 & 32.4 & 19.3 & 35.0 & 27.8 & 25.4 & 8.4 & 13.6 \\
\hline \multicolumn{9}{|l|}{ East Asia } \\
\hline China, People's Republic of & 12.2 & 12.5 & 12.1 & 14.0 & 7.9 & 3.7 & 1.6 & 1.7 \\
\hline Hong Kong, China & 120.3 & 257.7 & 376.5 & $444.5(2018)$ & & & & $\ldots$ \\
\hline Korea, Republic of & 23.6 & 17.4 & 31.1 & $25.5(2018)$ & 9.1 & 4.3 & 10.5 & \\
\hline Mongolia & 84.8 & 56.5 & 89.7 & 285.5 & 73.6 & 51.2 & 27.0 & 76.3 \\
\hline Taipei,China & 10.3 & 22.5 & 22.1 & 31.9 (2018) & 0.0 & 0.1 & 1.7 & 0.1 \\
\hline \multicolumn{9}{|l|}{ South Asia } \\
\hline Bangladesh & 28.3 & 25.5 & 21.6 & 18.1 & 27.2 & 24.1 & 17.2 & 12.0 \\
\hline Bhutan & 48.2 & 81.3 & 62.4 & 113.3 & 46.1 & 78.7 & 61.4 & 110.8 \\
\hline India & 22.1 & 15.1 & 17.7 & 19.8 & 17.5 & 6.7 & 6.1 & 7.5 \\
\hline Maldives & 34.2 & 32.0 & 40.3 & 32.2 & 31.1 & 26.5 & 27.6 & 28.2 \\
\hline Nepal & 52.2 & 39.1 & 23.5 & 20.1 & 51.2 & 38.2 & 21.8 & 17.1 \\
\hline Sri Lanka & 57.8 & 46.9 & 38.6 & 59.1 & 49.6 & 40.1 & 29.3 & 38.0 \\
\hline \multicolumn{9}{|l|}{ Southeast Asia } \\
\hline Brunei Darussalam & & $\ldots$ & 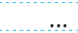 & & $\ldots$ & & & \\
\hline Cambodia & 55.1 & 46.1 & 35.7 & 57.2 & 52.4 & 44.4 & 26.8 & 30.7 \\
\hline Indonesia & 93.5 & 52.3 & 27.0 & 36.0 & 45.4 & 28.6 & 14.1 & 19.9 \\
\hline Lao People's Democratic Republic & 152.4 & 122.8 & 98.2 & 90.8 & 149.0 & 88.2 & 56.2 & 52.5 \\
\hline Malaysia & 48.7 & 47.3 & 54.2 & $69.6(2016)$ & 22.2 & 25.1 & 25.1 & $22.8(2016)$ \\
\hline Myanmar & 70.1 & 60.8 & 20.6 & 24.5 & 63.9 & 53.7 & 17.4 & 22.9 \\
\hline Philippines & 61.6 & 48.0 & 27.2 & 19.4 & 35.5 & 28.9 & 18.7 & 9.4 \\
\hline Singapore & 16.0 & & & & & & & \\
\hline Thailand & 64.4 & 32.3 & 32.5 & 29.8 & 23.8 & 7.0 & 4.9 & 5.6 \\
\hline Viet Nam & 38.5 & 32.8 & 40.3 & 48.8 & 34.9 & 28.7 & 29.4 & 24.3 \\
\hline \multicolumn{9}{|l|}{ The Pacific } \\
\hline Cook Islands ${ }^{\mathrm{a}}$ & 64.3 & 37.4 & 41.0 & $18.8(2018)$ & $\because$ & $\ldots$ & $\ldots$ & $\ldots$ \\
\hline Fiji & 11.3 & 9.9 & 20.0 & 18.7 & 10.1 & 6.1 & 14.0 & 15.2 \\
\hline Kiribatia & $7.1(2001)$ & 7.1 & 6.3 & 11.8 & $\ldots$ & $\ldots$ & $\ldots$ & $\ldots$ \\
\hline Marshall Islands & 70.5 & 50.9 & 52.1 & 30.5 & $\ldots$ & $\ldots$ & $\ldots$ & $\ldots$ \\
\hline Micronesia, Federated States of & 26.4 & 23.9 & 27.9 & $20.8(2016)$ & 1 & $\ldots$ & $\ldots$ & $\ldots$ \\
\hline \multicolumn{9}{|l|}{ Nauru } \\
\hline Niue & $\ldots$ & $\ldots$ & $\ldots$ & $\ldots$ & $\ldots$ & $\ldots$ & $\ldots$ & $\ldots$ \\
\hline Palau & 40.0 & 32.3 & 36.2 & $31.1(2018)$ & $\ldots$ & $\ldots$ & $\ldots$ & $\ldots$ \\
\hline Papua New Guinea & 70.4 & 41.3 & 45.7 & 85.6 & 44.0 & 27.9 & 8.0 & 10.6 \\
\hline Samoa & 51.7 & 38.6 & 52.0 & 53.5 & $48.8(2001)$ & 39.1 & 48.0 & 51.0 \\
\hline Solomon Islands & 35.9 & 40.3 & 46.5 & 28.6 & 27.7 & 34.7 & 25.2 & 7.9 \\
\hline Timor-Leste & 0.0 & 0.0 & 0.0 & 1.9 & 0.0 & 0.0 & 0.0 & 1.6 \\
\hline Tonga & 36.7 & 34.0 & 40.3 & 39.1 & 32.2 & 30.3 & 37.6 & 36.3 \\
\hline Tuvalu & 29.0 & $45.7(2006)$ & 49.1 & 45.4 & & & $\ldots$ & $\ldots$ \\
\hline Vanuatu & 43.3 & 27.2 & 26.3 & 46.0 & 28.2 & 19.5 & 15.2 & 34.1 \\
\hline
\end{tabular}

$\ldots=$ data not available, $0.0=$ magnitude is less than half of unit employed, $\mathrm{ADB}=$ Asian Development Bank, $\mathrm{GNI}=$ gross national income.

a For total external debt as a percentage of GNI, gross domestic product is used in lieu of GNI.

Sources: World Bank. International Debt Statistics Online. http://data.worldbank.org/data-catalog/international-debt-statistics (accessed 19 July 2019 ); and Asian Development Bank estimates using economy sources. 
Table 2.4.22: Total External Debt of Developing ADB Member Economies (\% of exports of goods, services, and primary income)

\begin{tabular}{|c|c|c|c|c|c|c|c|c|c|}
\hline ADB Regional Member & 2000 & 2005 & 2010 & 2012 & 2013 & 2014 & 2015 & 2016 & 2017 \\
\hline \multicolumn{10}{|l|}{ Developing ADB Member Economies } \\
\hline \multicolumn{10}{|l|}{ Central and West Asia } \\
\hline Afghanistan & & & 89.0 & 110.6 & 162.7 & 119.6 & 147.9 & 187.1 & 186.7 \\
\hline Armenia & 182.6 & 101.3 & 193.5 & 189.5 & 196.7 & 188.8 & 222.0 & 228.8 & 192.4 \\
\hline Azerbaijan & 72.9 & 26.9 & 25.2 & 28.9 & 29.0 & 36.1 & 64.6 & 81.2 & 72.2 \\
\hline Georgia & 183.7 & 89.1 & 191.5 & 170.8 & 161.9 & 169.3 & 206.8 & 223.1 & 181.3 \\
\hline Kazakhstan & 123.0 & 139.8 & 174.7 & 144.4 & 160.5 & 176.9 & 277.6 & 357.3 & 287.1 \\
\hline Kyrgyz Republic & 328.5 & 234.4 & 181.2 & 170.9 & 176.8 & 219.9 & 307.6 & 325.8 & 313.3 \\
\hline Pakistan & 326.5 & 172.1 & 218.5 & 194.2 & 189.9 & 197.9 & 224.9 & 262.6 & 286.0 \\
\hline Tajikistan & $163.0(2002)$ & 89.0 & 158.3 & 130.8 & 130.3 & 162.7 & 203.2 & 235.5 & 216.2 \\
\hline Turkmenistan & 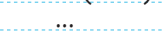 & $\ldots$ & $\cdots$ & & & $\ldots$ & $\ldots$ & & \\
\hline Uzbekistan & $\ldots$ & $\ldots$ & $\ldots$ & & & $\ldots$ & & 127.6 & 118.0 \\
\hline \multicolumn{10}{|l|}{ East Asia } \\
\hline China, People's Republic of & 71.9 & 34.9 & 42.1 & 48.6 & 57.9 & 65.5 & 51.3 & 58.4 & 63.8 \\
\hline Hong Kong, China a & 76.8 & 121.2 & 149.2 & 145.6 & 152.0 & 166.2 & 168.8 & 177.6 & 190.4 \\
\hline Korea, Republic of a & 64.7 & 46.6 & 62.6 & 55.6 & 56.4 & 56.3 & 59.5 & 60.4 & 58.9 \\
\hline Mongolia & 153.3 & 93.6 & 173.2 & 345.0 & 423.4 & 345.4 & 422.4 & 453.7 & 410.0 \\
\hline Taipei,China & 19.3 & 35.9 & 29.9 & 29.2 & 38.4 & 39.6 & 39.1 & 45.2 & 42.4 \\
\hline \multicolumn{10}{|l|}{ South Asia } \\
\hline Bangladesh & 214.0 & 163.4 & 123.5 & 102.8 & 100.2 & 99.6 & 103.4 & 102.8 & 120.1 \\
\hline Bhutan & & $188.8(2006)$ & 154.0 & 194.2 & 233.9 & 270.6 & 269.1 & 346.9 & 353.1 \\
\hline India & 161.9 & 75.6 & 81.1 & 86.5 & 89.1 & 91.8 & 108.1 & 102.2 & 101.0 \\
\hline Maldives & 43.4 & 73.1 & 45.6 & 35.7 & 30.9 & 32.1 & 30.6 & 36.6 & 39.2 \\
\hline Nepal & 212.5 & 224.2 & 212.7 & 175.1 & 159.5 & 142.2 & 154.8 & 167.2 & 165.7 \\
\hline Sri Lanka & 141.7 & 141.9 & 189.8 & 260.5 & 258.5 & 250.2 & 257.3 & 265.4 & 260.1 \\
\hline \multicolumn{10}{|l|}{ Southeast Asia } \\
\hline Brunei Darussalam & & & & & & 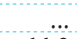 & & & \\
\hline Cambodia & 102.8 & 67.6 & 62.7 & 72.0 & 68.8 & 66.0 & 71.1 & 76.3 & 73.1 \\
\hline Indonesia & 197.1 & 146.5 & 117.6 & 118.2 & 127.8 & 145.8 & 175.8 & 186.8 & 177.0 \\
\hline Lao People's Democratic Republic & 493.1 & 430.1 & 284.0 & 249.8 & 259.1 & 231.6 & 252.2 & 259.6 & 248.6 \\
\hline Malaysia & 36.7 & 38.9 & 57.2 & 73.7 & 72.8 & 74.0 & 86.0 & 94.5 & \\
\hline Myanmar & 290.9 & 189.9 & 129.7 & 115.7 & 99.8 & 99.2 & 101.6 & 103.0 & 106.4 \\
\hline Philippines & 189.8 & 152.4 & 106.7 & 92.4 & 86.9 & 92.1 & 93.5 & 87.4 & 74.4 \\
\hline Singapore & 104.5 & 87.6 & & & $\ldots$ & $\ldots$ & $\ldots$ & $\ldots$ & $\ldots$ \\
\hline Thailand & 92.8 & 44.4 & 45.7 & 47.0 & 46.9 & 46.7 & 46.2 & 42.1 & 40.6 \\
\hline Viet Nam & 73.1 & 50.1 & 56.0 & 49.4 & 45.8 & 44.8 & 44.8 & 45.2 & 45.7 \\
\hline \multicolumn{10}{|l|}{ The Pacific } \\
\hline Cook Islands & $\cdots$ & & 61.3 & 45.8 & 35.6 & 39.3 & 32.8 & 27.2 & 24.9 \\
\hline Fiji & 19.0 & 17.9 & 32.2 & 31.4 & 33.9 & 35.6 & 37.2 & 39.5 & 36.0 \\
\hline Kiribati & 16.3 & 17.6 & 14.9 & 11.1 & 9.8 & 7.4 & 15.8 & 23.5 & 21.0 \\
\hline Marshall Islands a & 141.1 & 98.0 & 98.9 & 70.7 & 66.4 & 68.9 & 63.0 & 63.7 & 52.7 \\
\hline Micronesia, Federated States of & 100.3 & 98.2 & 91.8 & 69.3 & 65.7 & 65.9 & 52.0 & 49.0 & $\ldots$ \\
\hline Nauru & $\ldots$ & $\ldots$ & $\ldots$ & $\ldots$ & $\ldots$ & $\ldots$ & $\ldots$ & $\ldots$ & $\ldots$ \\
\hline Niue & & & & & & $\ldots$ & & & $\ldots$ \\
\hline Palau & 82.4 & 64.0 & 62.5 & 48.4 & 43.1 & 43.0 & 35.1 & 46.0 & 51.7 \\
\hline Papua New Guinea & 98.2 & 51.3 & 98.2 & 217.7 & 337.3 & 227.4 & 238.7 & 230.1 & 169.0 \\
\hline Samoa & & 114.8 & 161.1 & 177.7 & 179.4 & 184.4 & 182.6 & 162.7 & 154.5 \\
\hline Solomon Islands & 121.3 & 108.1 & 68.9 & 35.0 & 33.7 & 30.5 & 35.9 & 40.3 & 53.6 \\
\hline Timor-Leste & & & 0.0 & 1.9 & 2.5 & 3.6 & 6.4 & 4.5 & 5.7 \\
\hline Tonga & & 167.6 & 283.9 & 190.4 & 171.0 & 200.0 & 137.5 & 130.9 & 121.3 \\
\hline Tuvalua & 85.9 & $54.9(2006)$ & 65.0 & 36.7 & 61.7 & 87.3 & 82.2 & 68.5 & 71.4 \\
\hline Vanuatu & 63.9 & 49.0 & 48.9 & 46.2 & 47.6 & 44.8 & 74.7 & 68.2 & $\ldots$ \\
\hline
\end{tabular}

... = data not available, $\mathrm{ADB}=$ Asian Development Bank.

a External debt as a percentage of exports of goods, services, and primary income was derived using balance-of-payments data.

Sources: $\quad$ World Bank. International Debt Statistics Online. http://data.worldbank.org/data-catalog/international-debt-statistics (accessed 19 July 2019); and Asian Development Bank estimates using economy sources. 
Table 2.4.23: Total Debt Service Paid by Developing ADB Member Economies

\begin{tabular}{|c|c|c|c|c|c|c|c|c|}
\hline \multirow[t]{2}{*}{ ADB Regional Member } & \multicolumn{4}{|c|}{$\begin{array}{l}\text { Debt Service Payment } \\
\text { (\$ million) }\end{array}$} & \multicolumn{4}{|c|}{$\begin{array}{l}\text { Debt Service Payment } \\
\text { (\% of exports of goods, services, and primary income) }\end{array}$} \\
\hline & 2000 & 2005 & 2010 & 2017 & 2000 & 2005 & 2010 & 2017 \\
\hline \multicolumn{9}{|l|}{ Developing ADB Member Economies } \\
\hline \multicolumn{9}{|l|}{ Central and West Asia } \\
\hline Afghanistan & 0 & $11(2006)$ & 10 & 54 & & & 0.4 & 4.0 \\
\hline Armenia & 48 & 142 & 969 & 1,451 & 8.7 & 7.3 & 29.7 & 27.0 \\
\hline Azerbaijan & 138 & 242 & 415 & 2,252 & 6.4 & 2.9 & 1.4 & 10.7 \\
\hline Georgia & 126 & 195 & 803 & 2,555 & 12.7 & 8.1 & 17.5 & 29.4 \\
\hline Kazakhstan & 3,392 & 13,158 & 39,474 & 27,966 & 32.4 & 41.9 & 57.9 & 47.9 \\
\hline Kyrgyz Republic & 178 & 143 & 557 & 778 & 30.2 & 14.8 & 24.5 & 29.9 \\
\hline Pakistan & 2,871 & 2,466 & 4,310 & 6,739 & 28.4 & 12.5 & 15.0 & 22.8 \\
\hline Tajikistan & 66 & 73 & 695 & 711 & $\ldots$ & 5.8 & 30.9 & 26.1 \\
\hline Turkmenistan & 472 & 310 & 155 & 46 & $\ldots$ & $\ldots$ & $\ldots$ & \\
\hline Uzbekistan & 907 & 795 & 618 & 1,941 & $\ldots$ & $\ldots$ & $\ldots$ & 12.9 \\
\hline \multicolumn{9}{|l|}{ East Asia } \\
\hline China, People's Republic of & 26,610 & 27,469 & 51,992 & 204,171 & 13.1 & 3.4 & 3.0 & 7.6 \\
\hline Hong Kong, China & & & & $\ldots$ & & & & $\ldots . .$. \\
\hline Korea, Republic of & 22,905 & 7,224 & 2,843 & & 11.0 & 2.1 & 0.5 & \\
\hline Mongolia & 41 & 45 & 239 & 3,868 & 6.6 & 3.0 & 7.0 & 56.2 \\
\hline Taipei,China a, b & 45 & 11,006 & 3,630 & $9,218(2018)$ & 0.0 & 4.6 & 1.1 & $2.1(2018)$ \\
\hline \multicolumn{9}{|l|}{ South Asia } \\
\hline Bangladesh & 773 & 812 & 1,129 & 2,168 & 10.6 & 7.2 & 5.2 & 5.5 \\
\hline Bhutan & 7 & 7 & 87 & 79 & & 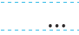 & 14.4 & 10.5 \\
\hline India & 10,668 & 23,922 & 24,413 & 51,160 & 17.1 & 14.9 & 6.8 & 10.1 \\
\hline Maldives & 20 & 31 & 81 & 122 & 4.2 & 6.3 & 4.0 & 3.5 \\
\hline Nepal & 103 & 120 & 188 & 254 & 7.6 & 8.5 & 10.6 & 8.5 \\
\hline Sri Lanka & 791 & 441 & 1,408 & 4,086 & 12.1 & 5.5 & 12.3 & 21.2 \\
\hline \multicolumn{9}{|l|}{ Southeast Asia } \\
\hline \multicolumn{9}{|l|}{ Brunei Darussalam } \\
\hline Cambodia & 13 & 30 & 65 & 638 & 0.7 & 0.7 & 1.1 & 3.9 \\
\hline Indonesia & 16,696 & 20,281 & 31,569 & 67,981 & 22.8 & 20.9 & 18.7 & 34.0 \\
\hline Lao People's Democratic Republic & 41 & 136 & 302 & 780 & 8.0 & 17.8 & 13.1 & 13.4 \\
\hline Malaysia & 6,441 & 9,381 & 5,575 & $10,385(2016)$ & 5.6 & 5.6 & 2.4 & $4.9(2016)$ \\
\hline Myanmar & 20 & 24 & 249 & 792 & 1.0 & 0.6 & 3.2 & 5.2 \\
\hline Philippines & 7,066 & 9,528 & 11,461 & 11,111 & 22.9 & 24.7 & 18.7 & 11.3 \\
\hline Singapore & & & & & & & & \\
\hline Thailand & 14,013 & 18,044 & 10,965 & 15,057 & 16.3 & 13.7 & 4.7 & 4.7 \\
\hline Viet Nam & 1,306 & 946 & 1,873 & 13,545 & 7.5 & 2.6 & 2.3 & 5.9 \\
\hline \multicolumn{9}{|l|}{ The Pacific } \\
\hline Cook Islands $s^{\mathrm{a}, \mathrm{b}}$ & 4 & 4 & 3 & 7 & & & 2.0 & 2.4 \\
\hline Fiji & 26 & 15 & 26 & 58 & 2.6 & 0.9 & 1.4 & 2.3 \\
\hline Kiribati ${ }^{\mathrm{b}}$ & 1 & 1 & 1 & 1 & 1.7 & 1.9 & 0.9 & 0.5 \\
\hline Marshall Islands ${ }^{\mathrm{b}}$ & 22 & 4 & 9 & 8 & 29.8 & 4.8 & 8.1 & 5.0 \\
\hline Micronesia, Federated States of ${ }^{b}$ & 23 & 2 & 5 & $6(2016)$ & 36.1 & 3.9 & 5.3 & 3.9 (2016) \\
\hline Nauru & $\ldots$ & $\ldots$ & $\ldots$ & $\ldots$ & $\ldots \ldots$ & $\ldots . .$. & $\ldots$ & $\ldots \ldots$ \\
\hline Niue & $\ldots$ & $\ldots$ & $\ldots$ & $\ldots$ & $\ldots \ldots$ & - & $\ldots$ & $\ldots$ \\
\hline Palau & & & & & & & & \\
\hline Papua New Guinea & 305 & 308 & 812 & 2,787 & 12.9 & 8.4 & 13.3 & 27.1 \\
\hline Samoa & 6 & 6 & 11 & 26 & & 3.9 & 5.3 & 8.9 \\
\hline Solomon Islands & 9 & 14 & 21 & 26 & 7.1 & 9.1 & 6.2 & 3.9 \\
\hline Timor-Leste & 0 & 0 & 0 & 1 & $\ldots$ & & 0.0 & 0.1 \\
\hline Tonga & 5 & 5 & 5 & 14 & $\ldots$ & 9.8 & 9.3 & 9.9 \\
\hline Tuvalu & & & $\ldots$ & & & & & \\
\hline Vanuatu & 3 & 3 & 6 & 10 & 1.6 & 1.6 & 1.7 & $2.1(2016)$ \\
\hline
\end{tabular}

$\ldots=$ data not available, 0 or $0.0=$ magnitude is less than half of unit employed, $\$=$ United States dollars; $A D B=$ Asian Development Bank.

a Refers to principal repayments on long-term debt plus interest on short-term and long-term debt.

b Debt service payment as a percentage of exports of goods, services, and primary income was derived using balance-of-payments data.

Sources: World Bank. International Debt Statistics Online. http://data.worldbank.org/data-catalog/international-debt-statistics (accessed 19 July 2019 ); and Asian Development Bank estimates using economy sources. 
Table 2.4.24: International Tourist Arrivals ${ }^{a}$ ('000)

\begin{tabular}{|c|c|c|c|c|c|c|c|}
\hline ADB Regional Member & 2000 & 2005 & 2010 & 2015 & 2016 & 2017 & $2018^{*}$ \\
\hline \multicolumn{8}{|l|}{ Developing ADB Member Economies } \\
\hline Central and West Asia ${ }^{\mathrm{b}}$ & 3,404 & 5,514 & 7,947 & 15,116 & 10,799 & 13,017 & $\ldots$ \\
\hline Afghanistan & $\ldots$ & $\ldots$ & $\ldots$ & $\ldots$ & & & \\
\hline Armenia & 45 & 319 & 687 & 1,192 & 1,260 & 1,495 & 1,652 \\
\hline Azerbaijan & $576(2002)$ & 693 & 1,280 & 1,922 & 2,045 & 2,454 & \\
\hline Georgia & 387 & $\ldots$ & 1,067 & 3,012 & 3,297 & 4,069 & 4,757 \\
\hline Kazakhstan & 1,471 & 3,143 & 2,991 & $4,560(2014)$ & & & $\ldots$ \\
\hline Kyrgyz Republic & 59 & 319 & 855 & 3,051 & 3,853 & 4,568 & $\cdots$ \\
\hline Pakistan & 557 & 798 & 907 & $965(2014)$ & $\ldots$ & & $\ldots$ \\
\hline Tajikistan & 4 & $\ldots$ & 160 & 414 & 344 & 431 & 1,250 \\
\hline Turkmenistan & 3 & $\ldots$ & $\ldots$ & $\ldots$ & $\ldots$ & $\ldots$ & $\ldots$ \\
\hline Uzbekistan & 302 & 242 & $\ldots$ & $\ldots$ & & & $\ldots$ \\
\hline East Asia & 48,126 & 71,322 & 90,571 & 107,630 & 114,159 & 113,170 & 119,106 \\
\hline China, People's Republic of & 31,229 & 46,809 & 55,665 & 56,886 & 59,270 & 60,740 & 62,900 \\
\hline Hong Kong, China & 8,814 & 14,773 & 20,085 & 26,686 & 26,553 & 27,885 & 29,263 \\
\hline Korea, Republic of & 5,322 & 6,023 & 8,798 & 13,232 & 17,242 & 13,336 & 15,347 \\
\hline Mongolia & 137 & 339 & 456 & 386 & $\begin{array}{r}11,242 \\
404\end{array}$ & 40 & $\begin{array}{r}10,34 ! \\
529\end{array}$ \\
\hline Taipei,China & 2,624 & 3,378 & 5,567 & 10,440 & 10,690 & 10,740 & 11,067 \\
\hline South Asiab & 4,187 & 5,460 & 8,169 & 17,653 & 19,700 & 21,270 & $\ldots$ \\
\hline Bangladesh & 199 & 208 & 303 & 643 & 830 & 1,026 & \\
\hline Bhutan & 8 & 14 & 41 & 155 & 210 & 255 & $27 \%$ \\
\hline India & 2,649 & 3,919 & 5,776 & 13,284 & 14,570 & 15,543 & \\
\hline Maldives & 467 & 395 & 792 & 1,234 & 1,286 & 1,390 & 1,484 \\
\hline Nepal & 464 & 375 & 603 & 539 & 753 & 940 & 1,173 \\
\hline Sri Lanka & 400 & 549 & 654 & 1,798 & 2,051 & 2,116 & 2,334 \\
\hline Southeast Asia ${ }^{b}$ & 35,458 & 48,971 & 70,431 & 104,181 & 110,706 & 120,392 & 96,984 \\
\hline Brunei Darussalam & $\begin{array}{r}\ldots,+100 \\
\ldots\end{array}$ & 126 & 214 & 218 & 219 & 259 & 278 \\
\hline Cambodia & & 1,333 & 2,508 & 4,775 & 5,012 & 5,602 & 6,201 \\
\hline Indonesia & 5,064 & $\begin{array}{l}1,303 \\
5,002\end{array}$ & 7,003 & 9,963 & 11,072 & 12,948 & \\
\hline Lao People's Democratic Republic & 191 & 672 & 1,670 & 3,543 & 3,315 & 3,257 & 3,770 \\
\hline Malaysia & 10,222 & 16,431 & 24,577 & 25,721 & 26,757 & 25,948 & 25,832 \\
\hline Myanmar & 208 & 660 & 792 & 4,681 & 2,907 & 3,443 & \\
\hline Philippines & 1,992 & 2,623 & 3,520 & 5,361 & 5,967 & 6,621 & 7,128 \\
\hline Singapore & 6,062 & 7,079 & 9,161 & 12,052 & 12,914 & 13,909 & \\
\hline Thailand & 9,579 & 11,567 & 15,936 & 29,923 & 32,530 & 35,483 & 38,277 \\
\hline Viet Nam & 2,140 & 3,478 & 5,050 & 7,944 & 10,013 & 12,922 & 15,498 \\
\hline The Pacific ${ }^{b}$ & 759 & 1,112 & 1,351 & 1,652 & 1,666 & 1,711 & $\ldots$ \\
\hline Cook Islands & 73 & 88 & 104 & 125 & 146 & 161 & 169 \\
\hline Fiji & 294 & 545 & 632 & 755 & 792 & 843 & 870 \\
\hline Kiribati & 5 & 4 & 5 & 4 & 6 & 6 & $\ldots$ \\
\hline Marshall Islands & 5 & 9 & 5 & 6 & 10 & 6 & $\cdots$ \\
\hline Micronesia, Federated States of & 21 & 19 & 45 & 31 & 30 & $\ldots$ & $\cdots$ \\
\hline Nauru & 58 & 81 & $\ldots$ & $\ldots$ & $\ldots$ & $\cdots$ & $\ldots$ \\
\hline Niue & & $\ldots$ & 6 & 8 & 8 & 10 & $\ldots$ \\
\hline Palau & 58 & 81 & 85 & 164 & 138 & 123 & 116 \\
\hline Papua New Guinea & 58 & 69 & 140 & 201 & 156 & 143 & $\ldots$ \\
\hline Samoa & 88 & 102 & 122 & 128 & 134 & 146 & \\
\hline Solomon Islands & 5 & 9 & 21 & 22 & 22 & 26 & 28 \\
\hline Timor-Leste & $\ldots$ & $\ldots$ & 40 & 62 & 66 & 74 & 75 \\
\hline Tonga & 35 & 42 & 47 & 54 & 61 & 62 & $\ldots$ \\
\hline Tuvalu & 1 & 1 & 2 & 2 & 2 & 2 & $\ldots$ \\
\hline Vanuatu & 58 & 62 & 97 & 90 & 95 & 109 & 116 \\
\hline Developed ADB Member Economies & 11,475 & 14,544 & 16,918 & 30,226 & 35,678 & 41,061 & 44,124 \\
\hline Australia & 4,931 & 5,463 & 5,872 & 7,450 & 8,269 & 8,815 & 9,246 \\
\hline Japan & 4,757 & 6,728 & 8,611 & 19,737 & 24,039 & 28,691 & 31,192 \\
\hline New Zealand & 1,787 & 2,353 & 2,435 & 3,039 & 3,370 & 3,555 & 3,686 \\
\hline DEVELOPING ADB MEMBER ECONOMIES ${ }^{b}$ & 91,934 & 132,379 & 178,469 & 246,232 & 257,030 & 269,560 & 230,388 \\
\hline ALL ADB REGIONAL MEMBERS & 103,409 & 146,923 & 195,387 & 276,458 & 292,708 & 310,621 & 274,512 \\
\hline WORLD & 676,655 & 808,570 & 951,522 & $1,195,053$ & $1,240,866$ & $1,327,800$ & $1,402,789$ \\
\hline
\end{tabular}

... = data not available, $\mid$ = marks break in the series, ${ }^{*}=$ provisional or preliminary, $\mathrm{ADB}=$ Asian Development Bank.

a For Australia; Japan; the Kyrgyz Republic; the Republic of Korea; Taipei,China; Tajikistan; and Viet Nam: Data refer to international visitor arrivals at frontiers (including tourists and same-day visitors). For the rest of the economies: Data refer to international tourist arrivals at frontiers (overnight visitors only, i.e., excluding same-day visitors).

b For reporting economies only.

Source: $\quad$ United Nations World Tourism Organization. 2019. World Tourism Barometer and Statistical Annex, May 2019. Volume 17; and past volumes. 
Table 2.4.25: International Tourism Receipts (\$ million)

\begin{tabular}{|c|c|c|c|c|c|c|c|}
\hline ADB Regional Member & 2000 & 2005 & 2010 & 2015 & 2016 & 2017 & $2018^{*}$ \\
\hline \multicolumn{8}{|l|}{ Developing ADB Member Economies } \\
\hline Central and West Asia ${ }^{\mathrm{a}}$ & 679 & 1,528 & 3,631 & 7,470 & 8,607 & 10,097 & 10,862 \\
\hline Afghanistan & $\ldots$ & $-\ldots$ & 75 & 79 & 49 & 2 & \\
\hline Armenia & 38 & 223 & 646 & 936 & 968 & 1,120 & 1,208 \\
\hline Azerbaijan & 63 & 78 & 657 & 2,309 & 2,714 & 3,012 & 2,634 \\
\hline Georgia & 97 & 241 & 659 & 1,868 & 2,111 & 2,704 & 3,222 \\
\hline Kazakhstan & 356 & 701 & 1,005 & 1,534 & 1,549 & 1,781 & 2,255 \\
\hline Kyrgyz Republic & 15 & 73 & 160 & 426 & 432 & $\begin{array}{r} \pm, 101 \\
429\end{array}$ & \\
\hline Pakistan & 81 & 182 & 306 & 317 & 322 & 352 & 390 \\
\hline Tajikistan & $2(2002)$ & 2 & 2 & 1 & 4 & 8 & 9 \\
\hline \multicolumn{8}{|l|}{ Turkmenistan } \\
\hline Uzbekistan & 27 & 28 & 121 & $\cdots$ & 458 & 689 & 1,144 \\
\hline East Asia & 32,707 & 50,550 & 87,307 & 110,966 & 108,301 & 97,977 & 106,573 \\
\hline China, People's Republic of & 16,231 & 29,296 & 45,814 & 44,969 & 44,432 & 38,559 & 40,386 \\
\hline Hong Kong, China & 5,868 & 10,294 & 22,200 & 36,150 & 32,846 & 33,339 & 36,703 \\
\hline Korea, Republic of & 6,834 & 5,806 & 10,328 & 15,214 & 17,332 & 13,368 & 15,319 \\
\hline Mongolia & 36 & 177 & 244 & 246 & 316 & 396 & 461 \\
\hline Taipei,China & 3,738 & 4,977 & 8,721 & 14,387 & 13,375 & 12,315 & 13,704 \\
\hline South Asia & 4,247 & 8,974 & 17,244 & 27,288 & 29,202 & 35,104 & 35,557 \\
\hline Bangladesh & 50 & 75 & 81 & 150 & 214 & 337 & \\
\hline Bhutan & 10 & 19 & 40 & 94 & 91 & 103 & 102 \\
\hline India & 3,460 & 7,493 & 14,490 & 21,013 & 22,427 & 27,365 & 28,568 \\
\hline Maldives & 321 & 826 & 1,713 & 2,569 & 2,506 & 2,744 & 3,028 \\
\hline Nepal & 158 & 132 & 344 & 481 & 446 & 630 & \\
\hline Sri Lanka & 248 & 429 & 576 & 2,981 & 3,518 & 3,925 & 3,859 \\
\hline Southeast Asia & 25,502 & 34,986 & 68,423 & 108,628 & 116,925 & 130,557 & 138,726 \\
\hline Brunei Darussalam & $155(2001)$ & 191 & $\ldots$ & 147 & 144 & 177 & \\
\hline Cambodia & 304 & 840 & 1,519 & 3,131 & 3,208 & 3,636 & 4,362 \\
\hline Indonesia & 4,975 & 4,522 & 6,958 & 10,761 & 11,206 & 13,139 & 14,110 \\
\hline Lao People's Democratic Republic & 114 & 147 & 382 & 724 & 716 & 761 & \\
\hline Malaysia & 5,011 & 8,847 & 18,115 & 17,584 & 18,075 & 18,323 & 19,143 \\
\hline Myanmar & 162 & 67 & 72 & 2,120 & 2,197 & 1,969 & \\
\hline Philippines & 2,156 & 2,287 & 2,645 & 5,272 & 5,143 & 6,986 & 7,461 \\
\hline Singapore & 5,142 & 6,209 & 14,178 & 16,617 & 18,944 & 19,738 & 20,528 \\
\hline Thailand & 7,483 & 9,576 & 20,104 & 44,922 & 48,792 & 56,938 & 63,042 \\
\hline Viet Nam & $\ldots$ & 2,300 & 4,450 & 7,350 & 8,500 & 8,890 & 10,080 \\
\hline The Pacific ${ }^{a}$ & 416 & 839 & 1,292 & 1,653 & 1,505 & 1,585 & $\ldots$ \\
\hline Cook Islands & 36 & 91 & 111 & 154 & 179 & 183 & \\
\hline Fiji & 189 & 485 & 634 & 805 & 863 & 926 & 956 \\
\hline Kiribati & 3 & 4 & 4 & 2 & 3 & 4 & 20 \\
\hline Marshall Islands & 3 & 3 & 4 & 1 & 5 & $\ldots$ & $\cdots$ \\
\hline Micronesia, Federated States of & 17 & 16 & 24 & 25 & $\ldots$ & $\cdots$ & $\cdots$ \\
\hline Nauru & $\ldots$ & $\ldots$ & $\ldots$ & $\ldots$ & $\ldots$ & $\ldots$ & $\ldots$ \\
\hline Niue & & & & & & & $\ldots$ \\
\hline Palau & 53 & 60 & 73 & 149 & 141 & 116 & \\
\hline Papua New Guinea & 7 & 4 & 2 & 2 & 1 & 2 & $\ldots$ \\
\hline Samoa & 41 & 73 & 132 & 142 & 148 & 166 & $\ldots$ \\
\hline Solomon Islands & 4 & 2 & 44 & 51 & 56 & 67 & $\ldots$ \\
\hline Timor-Leste & $\ldots$ & $\ldots$ & 31 & 51 & 58 & 73 & $\ldots$ \\
\hline Tonga & 7 & 15 & 16 & 43 & 51 & 48 & 48 \\
\hline Tuvalu & $\ldots$ & 1 & $\ldots$ & $\ldots$ & $\ldots$ & $\ldots$ & $\ldots$ \\
\hline Vanuatu & 56 & 85 & 217 & 228 & $\ldots$ & $\ldots$ & $\ldots$ \\
\hline Developed ADB Member Economies & 14,934 & 31,526 & 52,305 & 68,587 & 77,539 & 86,379 & 97,154 \\
\hline Australia & 9,289 & 18,423 & 32,584 & 34,246 & 37,040 & 41,732 & 45,035 \\
\hline Japan & 3,373 & 6,630 & 13,199 & 24,982 & 30,679 & 34,054 & 41,115 \\
\hline New Zealand & 2,272 & 6,473 & 6,522 & 9,359 & 9,820 & 10,593 & 11,004 \\
\hline $\begin{array}{l}\text { DEVELOPING ADB MEMBER ECONOMIES a } \\
\text { ALLADB REGIONAL MEMBERS }\end{array}$ & $\begin{array}{l}63,550 \\
78,484\end{array}$ & $\begin{array}{r}96,877 \\
128,403\end{array}$ & $\begin{array}{l}177,897 \\
230,202\end{array}$ & $\begin{array}{l}256,005 \\
324,592\end{array}$ & $\begin{array}{l}264,540 \\
342,079\end{array}$ & $\begin{array}{l}275,320 \\
361,699\end{array}$ & $\begin{array}{l}292,722 \\
389,876\end{array}$ \\
\hline WORLD & 475,510 & 703,779 & 975,302 & $1,222,092$ & $1,246,391$ & $1,345,624$ & $1,447,749$ \\
\hline
\end{tabular}

... = data not available, ${ }^{*}=$ provisional or preliminary, $\$=$ United States dollars, ADB = Asian Development Bank.

a For reporting economies only.

Source: $\quad$ United Nations World Tourism Organization. 2019. World Tourism Barometer and Statistical Annex, May 2019. Volume 17; and past volumes. 


\section{Transport and Communications}

Transport and Communications features a discussion on air passenger traffic and carrier departures, as well as internet usage and penetration rates in Asia and the Pacific. Other data topics covered in the statistical tables include container port traffic; road and rail networks; motor vehicle ownership, injuries, and fatalities; fixed telephone subscriptions; and mobile telephone subscriptions.

\section{Asia and the Pacific is the world's busiest region for air passenger air traffic}

Asia and the Pacific is the busiest region in the world in terms of air passenger traffic, as measured by the UN International Civil Aviation Organization. The region accounted for about $34 \%$ of global air passenger traffic in 2017, with an increase of nearly $11 \%$ over 2016. By comparison, Europe accounted for about $27 \%$ of global air passenger traffic in 2017 , North America about 23\%, the Middle East about 9\%, Latin America and the Caribbean about 5\%, and Africa about 2\% (ICAO 2017).
This growth in air passenger traffic across Asia and the Pacific is reflected in the significant growth in air carrier departures in ADB developing member economies. In 31 of the 38 regional economies with available data, air carrier departures increased from 2000 to 2017 (Table 2.5.6). The economies with the highest average annual growth rates in air carrier departures over this period were Bangladesh (51.8\%), Vanuatu (48.3\%), and Viet Nam (47.8\%). The most notable average annual declines in air carrier departures were observed in Fiji $(-3.6 \%)$, Turkmenistan $(-2.9 \%)$, and Uzbekistan $(-1.6 \%)$.

Figure 2.5.1: Air Carrier Departures by Subregion within Asia and the Pacific ('000)

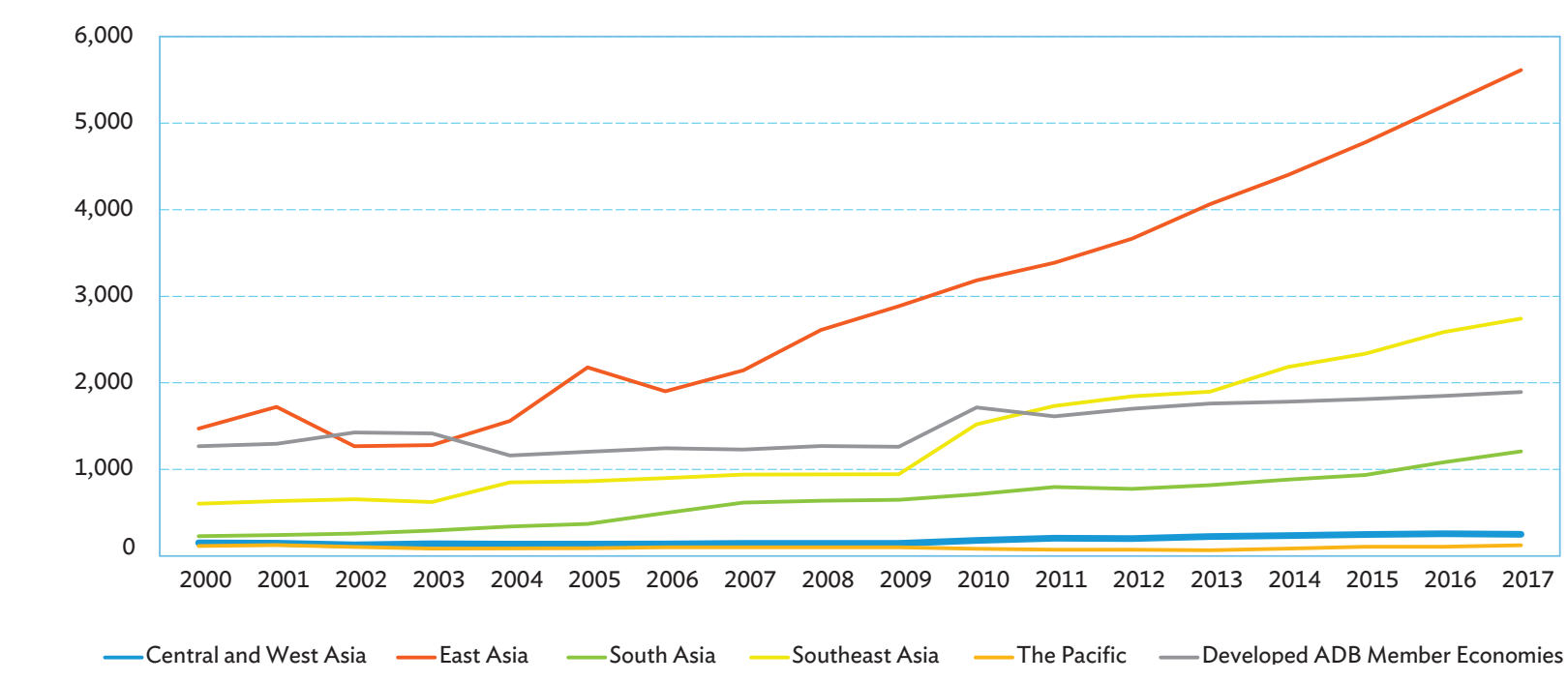

ADB $=$ Asian Development Bank.

Note: This chart treats unavailable data for economies as 0 for calculating the total number of take offs by subregion

Source: Table 2.5.6, Key Indicators for Asia and the Pacific 2019. 
The developing member economies with the most air carrier departures in 2017 were the PRC (4.36 million); India (1.03 million); Indonesia (0.92 million); Taipei,China (0.51 million); and the Republic of Korea (0.50 million). By contrast, the most air carrier departures in 2000 were in Taipei,China (0.59 million); the PRC (0.57 million); the Republic of Korea (0.23 million); India (0.20 million); and Malaysia (0.17 million).

In terms of the subregions, annual growth in air carrier departures was most pronounced in South Asia (25.1\%), Southeast Asia (20.8\%), and East Asia (16.6\%) as shown in Figure 2.5.1. Much lower annual growth rates were observed in Central and West Asia (3.8\%), ADB's developed member economies (2.9\%), and the Pacific (0.5\%).

\section{Internet use is spreading across Asia and the Pacific, with nearly half of all households connected to the internet in 2017; yet, a gender digital divide persists}

According to the International Telecommunications Union, the proportion of households in Asia and the Pacific with internet access rose from about $28 \%$ in 2010 to more than $48 \%$ by 2017 . However, a gender gap persists in terms of internet penetration rates for men and women in Asia and the Pacific. In 2017, the rates for males and females were $47.9 \%$ and $39.7 \%$, respectively (ITU 2017).

From 2010 to 2017, of the 46 regional economies with available data, the largest gains in terms of internet users per 100 population were in Kazakhstan (44.8), Brunei Darussalam (41.9), and Armenia (39.7) as can be observed in Figure 2.5.2.

The eight economies with the highest internet use penetration rates per 100 population in 2017 were all high-income economies: the Republic of Korea (95.1); Brunei Darussalam (94.9); Taipei,China
Figure 2.5.2: Proportion of Internet Users in Select Economies of Asia and the Pacific (per 100 population)

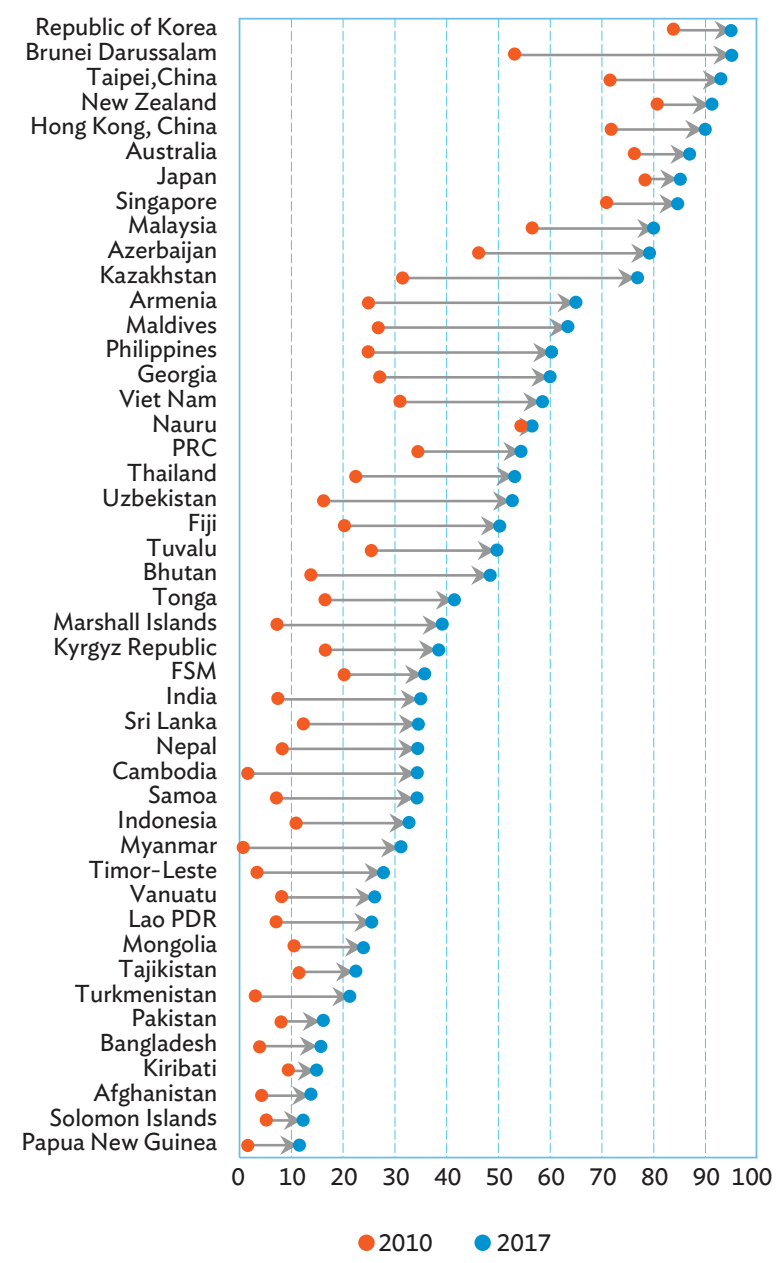

FSM = Federated States of Micronesia, Lao PDR = Lao People's Democratic Republic, PRC $=$ People's Republic of China.

Note: $\quad$ Only economies with available data for both 2010 and 2017 are included.

Source: $\quad$ Table 2.5.9, Key Indicators for Asia and the Pacific 2019.

Click here for figure data

(92.8); New Zealand (90.8); Hong Kong, China (89.4); Australia (86.5); Japan (84.6); and Singapore (84.4).

\section{Data Issues and Comparability}

Issues with the data organization, collection, compilation, and dissemination affect the availability, quality, and timeliness of road statistics. Some subregions, especially the Pacific, have incomplete or 
no data. The most recent road data are usually $2-3$ years old at the time of review.

Most data on telephone and internet subscriptions come from questionnaires sent by the International Telecommunication Union to participating economies. Other information and reports are sourced from national ministries in charge of telecommunications, and staff estimates. 
Table 2.5.1: Road Indicators-Network ${ }^{\mathrm{a}}$

$(\mathrm{km})$

\begin{tabular}{|c|c|c|c|c|c|c|c|}
\hline ADB Regional Member & Primary & Class I & Class II & Class III & Below III & Other & Year $^{b}$ \\
\hline \multicolumn{8}{|l|}{ Developing ADB Member Economies } \\
\hline \multicolumn{8}{|l|}{ Central and West Asia } \\
\hline Afghanistan & - & 10 & 2,549 & - & 1,461 & - & 2015 \\
\hline Armenia & - & 147 & 721 & 58 & 40 & - & 2013 \\
\hline Azerbaijan & - & 544 & 905 & - & - & - & 2017 \\
\hline Georgia & - & 90 & 1,058 & - & - & - & 2017 \\
\hline Kazakhstan & - & 557 & 5,407 & 6,389 & 475 & - & 2010 \\
\hline Kyrgyz Republic & - & - & 303 & 1,324 & 136 & - & 2013 \\
\hline Pakistan & 357 & 1,116 & 275 & 2,442 & 1,138 & - & 2015 \\
\hline Tajikistan & - & 20 & 978 & - & 914 & - & 2015 \\
\hline Turkmenistan & - & 60 & - & 2,120 & 24 & - & 2008 \\
\hline Uzbekistan & - & 1,195 & 1,101 & 670 & - & - & 2008 \\
\hline \multicolumn{8}{|l|}{ East Asia } \\
\hline China, People's Republic of & 8,437 & 230 & 1,855 & 321 & 5 & - & 2015 \\
\hline Hong Kong, China & & & & $\ldots$ & $\ldots$ & $\ldots$ & \\
\hline Korea, Republic of & 457 & 423 & 40 & - & - & - & 2017 \\
\hline Mongolia & - & 8 & 2,593 & 233 & 1,480 & - & 2017 \\
\hline Taipei,China & $\ldots$ & $\ldots$ & $\ldots$ & $\ldots$ & $\ldots$ & $\ldots$ & \\
\hline \multicolumn{8}{|l|}{ South Asia } \\
\hline Bangladesh & - & 321 & 1,680 & 44 & 5 & - & 2017 \\
\hline Bhutan & - & 7 & 116 & - & 47 & - & 2017 \\
\hline India & 90 & 7,067 & 1,071 & 3,556 & 117 & - & 2015 \\
\hline Maldives & $\ldots$ & & & & & $\ldots$ & \\
\hline Nepal & $\ldots$ & - & 218 & 1,082 & 13 & - & 2013 \\
\hline Sri Lanka & - & 60 & 545 & 45 & - & - & 2017 \\
\hline \multicolumn{8}{|l|}{ Southeast Asia } \\
\hline Brunei Darussalam & $\ldots$ & $\ldots$ & $\ldots$ & & $\ldots$ & $\ldots$ & \\
\hline Cambodia & - & - & 633 & 1,321 & - & - & 2017 \\
\hline Indonesia & 409 & 603 & 3,045 & - & - & 34 & 2010 \\
\hline Lao People's Democratic Republic & - & - & 244 & 2,307 & 306 & - & 2010 \\
\hline 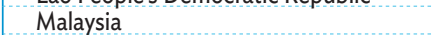 & 795 & 61 & 817 & - & - & - & 2010 \\
\hline Myanmar & - & 320 & 575 & 1,702 & 1,928 & - & 2015 \\
\hline Philippines & - & 665 & 2,048 & 687 & - & - & 2017 \\
\hline Singapore & 13 & 6 & - & - & - & - & 2015 \\
\hline Thailand & 572 & 4,075 & 848 & 27 & - & - & 2017 \\
\hline Viet Nam & - & 1,202 & 1,915 & - & - & - & 2017 \\
\hline \multicolumn{8}{|l|}{ The Pacific } \\
\hline Cook Islands & $\ldots$ & $\ldots$ & $\ldots$ & $\ldots$ & $\ldots$ & $\ldots$ & \\
\hline Fiji & $\ldots$ & $\ldots$ & $\ldots$ & $\ldots$ & $\ldots$ & $\ldots$ & \\
\hline Kiribati & $\ldots$ & $\ldots$ & $\ldots$ & $\ldots$ & $\ldots$ & $\ldots \ldots$ & \\
\hline Marshall Islands & $\ldots . .$. & $\ldots$ & $\ldots$ & $\ldots$ & $\ldots$ & .... & \\
\hline Micronesia, Federated States of & $\ldots$ & $\ldots$ & $\ldots$ & $\ldots$ & $\ldots$ & $\ldots$ & \\
\hline \multirow{2}{*}{\multicolumn{8}{|c|}{ Niue }} \\
\hline & & & & & & & \\
\hline Palau & $\ldots$ & $\ldots$ & $\ldots$ & $\ldots$ & $\ldots$ & $\ldots \ldots$ & \\
\hline Papua New Guinea & $\ldots$ & $\ldots$ & $\ldots$ & $\ldots$ & $\ldots$ & $\ldots$ & \\
\hline Samoa & $\ldots$ & $\ldots$ & $\ldots$ & $\ldots$ & $\ldots$ & $\ldots$ & \\
\hline Solomon Islands & $\ldots$ & $\ldots$ & $\ldots$ & $\ldots$ & $\ldots$ & $\ldots$ & \\
\hline Timor-Leste & $\ldots$ & $\ldots$ & $\ldots$ & $\ldots$ & $\ldots$ & $\ldots$ & \\
\hline Tonga & $\ldots$ & $\ldots$ & $\ldots$ & $\ldots$ & $\ldots$ & $\ldots$ & \\
\hline Tuvalu & $\cdots$ & $\cdots$ & $\ldots$ & $\ldots$ & $\ldots$ & $\ldots$ & \\
\hline Vanuatu & $\cdots$ & $\ldots$ & $\cdots$ & $\ldots$ & $\ldots$ & $\ldots$ & \\
\hline \multicolumn{8}{|l|}{ Developed ADB Member Economies } \\
\hline Australia & & $\ldots$ & $\ldots$ & $\ldots$ & $\ldots$ & $\ldots$ & \\
\hline Japan & 1,138 & - & - & - & - & - & 2015 \\
\hline New Zealand & $\ldots$ & $\ldots$ & $\ldots$ & $\ldots$ & $\ldots$ & $\ldots$ & \\
\hline
\end{tabular}

... = data not available, - = magnitude equals zero, $\mathrm{ADB}=$ Asian Development Bank, $\mathrm{km}=$ kilometer.

a The road network refers to the Asian Highway that consists of highway routes of international importance within Asia, including highway routes substantially crossing more than one subregion; highway routes within subregions that connect neighboring subregions; and highway routes located within member states that provide access to (a) capital cities; (b) main industrial and agricultural centers; (c) major air, sea, and river ports; (d) major container terminals and depots; and (e) major tourist attractions. "Primary" class in the classification refers to access-controlled motorways. Access-controlled motorways are used exclusively by automobiles. Motorcycles, bicycles, and pedestrians will not be allowed to enter the motorway to ensure traffic safety and the high running speed of automobiles.

Class I refers to asphalt, cement, or concrete roads with four or more lanes.

Class II refers to double bituminous-treated roads with two lanes.

Class III is regarded as the minimum desirable standard usually described as a two-lane (narrow) road.

Roads classified below Class III are road sections below the minimum desirable standard.

b The year data was received by the Secretariat of the United Nations Economic and Social Commission for Asia and the Pacific.

Source: United Nations Economic and Social Commission for Asia and the Pacific (ESCAP). ESCAP Online Statistical Database. http://data.unescap.org/escap_stat/ (accessed 24 July 2019). 
Table 2.5.2: Road Indicators-Vehicles

\begin{tabular}{|c|c|c|c|c|c|c|c|}
\hline \multirow{3}{*}{ ADB Regional Member } & \multicolumn{7}{|c|}{ Number of Registered Vehicles, 2016} \\
\hline & \multirow[b]{2}{*}{ Total } & \multirow[b]{2}{*}{$\begin{array}{l}\text { (per } 1,000 \\
\text { people) }\end{array}$} & \multicolumn{5}{|c|}{ By type $^{a}$} \\
\hline & & & $\begin{array}{l}\text { Four-Wheeled } \\
\text { Vehicles }\end{array}$ & $\begin{array}{l}\text { Two- and Three- } \\
\text { Wheeled Vehicles }\end{array}$ & Heavy Trucks & Buses & Others \\
\hline \multirow{2}{*}{\multicolumn{8}{|c|}{$\begin{array}{l}\text { Developing ADB Member Economies } \\
\text { Central and West Asia }\end{array}$}} \\
\hline & & & & & & & \\
\hline Afghanistan & $655,357(2013)$ & 25.2 & 407,608 & 68,090 & 81,416 & 20,589 & 77,654 \\
\hline Armenia & $300,091(2010)$ & 98.6 & 247,723 & 28 & 40,924 & 11,396 & \\
\hline Azerbaijan & $1,330,551$ & 136.4 & $1,136,983$ & 3,290 & 141,525 & 30,958 & 17,795 \\
\hline Georgia & $1,126,470$ & 302.2 & 919,199 & 63,083 & 93,497 & 50,691 & - - \\
\hline Kazakhstan & $4,383,120$ & 246.3 & $3,835,609$ & 9,692 & 439,167 & 98,652 & - \\
\hline Kyrgyz Republic & $993,000(2015)$ & 168.4 & & & & & \\
\hline Pakistan & $18,352,500$ & 93.9 & $2,835,400$ & $13,538,200$ & 259,900 & 229,200 & $1,489,800$ \\
\hline Tajikistan & 439,972 & 50.9 & 380,496 & 4,546 & 39,261 & 15,669 & $-\quad-\quad-$ \\
\hline Turkmenistan & $\ldots$ & $\ldots$ & $\ldots$ & $\ldots$ & $\ldots$ & $\ldots$ & $\ldots$ \\
\hline Uzbekistan & $\ldots$ & $\ldots$ & $\ldots$ & $\ldots$ & $\ldots$ & $\ldots$ & $\cdots$ \\
\hline \multicolumn{8}{|l|}{ East Asia } \\
\hline China, People's Republic of & $294,694,457$ & 213.1 & $\ldots$ & $\ldots$ & $\ldots$ & $\ldots$ & \\
\hline Hong Kong, China & & & & & & & \\
\hline Korea, Republic of & $25,680,967$ & 501.6 & $17,338,160$ & $2,180,688$ & $3,492,173$ & 892,539 & $1,777,407$ \\
\hline Mongolia & 841,537 & 272.4 & 547,299 & 42,751 & 175,648 & 6,823 & 69,016 \\
\hline Taipei,China d, e & $21,704,365(2017)$ & 921.4 & $6,763,422$ & $13,755,582$ & $1,086,382$ & 34,188 & 64,791 \\
\hline \multicolumn{8}{|l|}{ South Asia } \\
\hline Bangladesh & $2,879,708$ & 17.9 & 613,149 & $1,980,246$ & 158,379 & 64,608 & 63,326 \\
\hline Bhutane & $86,981(2017)$ & 119.6 & 56,232 & 9,786 & 12,891 & 681 & 7,391 \\
\hline India & $210,023,289(2015)$ & 163.7 & $38,523,053$ & $154,297,746$ & $4,461,059$ & $1,970,786$ & $10,770,645$ \\
\hline Maldives & 92,983 & 196.8 & 14,314 & $\quad 75,053$ & 3,438 & $\quad 178$ & $2-1-$ \\
\hline Nepal & $2,339,169(2015)$ & 83.7 & 187,014 & $1,547,312$ & 56,250 & 52,388 & 496,205 \\
\hline Sri Lanka & $6,795,469$ & 320.5 & 717,674 & $4,815,617$ & 762,912 & 104,104 & 395,162 \\
\hline \multicolumn{8}{|l|}{ Southeast Asia } \\
\hline Brunei Darussalam & $349,279(2010)$ & 903.0 & & & & & \\
\hline Cambodia & $3,751,715$ & 246.0 & 97,239 & $2,714,193$ & 57,321 & 5,972 & 876,990 \\
\hline Indonesia & $128,398,594$ & 496.3 & & & & & \\
\hline Lao People's Democratic Republic & $1,850,020$ & 280.9 & 370,043 & $1,422,869$ & 52,443 & 4,665 & - \\
\hline Malaysia & $27,613,120$ & 873.8 & $13,123,638$ & $12,677,041$ & $1,191,310$ & 59,977 & 561,154 \\
\hline Myanmare & $6,381,136(2017)$ & 119.5 & 516,707 & $5,391,505$ & 59,680 & 28,383 & 384,861 \\
\hline Philippines & $9,251,565$ & 89.6 & $3,434,329$ & $5,329,770$ & 407,357 & 29,794 & 50,315 \\
\hline Singapore & 933,534 & 166.5 & 727,533 & 142,439 & 45,224 & 18,338 & - \\
\hline Thailand & $37,338,139$ & 553.5 & $15,003,774$ & $20,497,296$ & $1,055,717$ & 157,799 & 623,553 \\
\hline Viet Nam & $50,666,855$ & 546.6 & $3,033,527$ & $47,131,928$ & $\cdots$ & $\ldots$ & 501,400 \\
\hline \multicolumn{8}{|l|}{ The Pacific } \\
\hline Cook Islands & $12,453(2014)$ & 676.8 & 5,085 & 6,846 & 491 & 31 & - \\
\hline Fiji & 110,763 & 0.1 & & & & & $\ldots$ \\
\hline Kiribati & $3,706(2017)$ & 32.8 & 2,547 & 757 & 4 & 398 & - \\
\hline Marshall Islands & $2,116(2013)$ & 39.5 & 1,917 & 52 & 26 & 63 & 58 \\
\hline Micronesia, Federated States of & 5,673 & 55.4 & 5,436 & 25 & 55 & 62 & 95 \\
\hline Nauru & $\ldots$ & $\ldots$ & $\ldots$ & $\ldots$ & $\ldots$ & $\ldots$ & $\ldots$ \\
\hline Niue & & & & $\ldots$ & 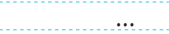 & $\ldots$ & $\ldots$ \\
\hline Palau & $7,102(2013)$ & 408.2 & & & & & $\ldots$ \\
\hline Papua New Guinea & 100,993 & 11.9 & 66,017 & 1,289 & 22,072 & 11,615 & - \\
\hline Samoa & 25,235 & 128.8 & 23,557 & 95 & 1,184 & 326 & 73 \\
\hline \multicolumn{8}{|l|}{ Solomon Islands } \\
\hline Timor-Leste & $146,596(2016)$ & 115.6 & 24,438 & 108,409 & 1,120 & 207 & 12,422 \\
\hline Tonga & $8,154(2012)$ & 79.4 & 6,039 & 184 & 1,882 & 49 & - \\
\hline Tuvalu & & $\ldots$ & & $\ldots$ & $\ldots$ & $\ldots$ & $\ldots$ \\
\hline Vanuatu & & & $\ldots$ & $\ldots$ & $\ldots$ & 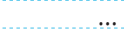 & \\
\hline \multicolumn{8}{|l|}{ Developed ADB Member Economies } \\
\hline Australia & $18,326,236$ & 757.6 & $16,946,125$ & 828,965 & 430,997 & 96,582 & 23,567 \\
\hline Japan & $81,602,046$ & 642.6 & $\ldots$ & $\ldots$ & $\ldots . . .$. & $\ldots$ & $\ldots$ \\
\hline New Zealand & $3,656,300$ & 779.1 & $\ldots$ & ... & $\ldots$ & $\ldots$ & $\ldots$ \\
\hline
\end{tabular}

... = data not available, - = magnitude equals zero; $\mathrm{ADB}=$ Asian Development Bank.

a Figures refer to the same year indicated in the column for "Total" unless otherwise specified.

b Calculated by dividing the total number of registered vehicles by the midyear population in thousands.

c The "per 1,000 people" calculation used end-of-year population data instead of midyear data.

d The "Heavy Trucks" category includes a combination of heavy and light trucks.

e For 2017, data only covers 1 January to April 30.

Sources: World Health Organization. 2018. Global Status Reporton Road Safety 2018. Geneva. For number of registered vehicles per 1,000 people in 2016: Asian Development Bank estimates. For Armenia and Brunei Darussalam: World Health Organization. 2013. Global Status Report on Road Safety 2013. Geneva. For Taipei,China: Government of Taipei,China, Directorate-General of Budget, Accounting and Statistics. 2018. Statistical Yearbook 2017. Nantou City. https://eng. dgbas.gov. tw/public/data/dgbas03/bs2/yearbook_eng/Yearbook2017.pdf (accessed 26 July 2019). 
Transport

Table 2.5.3: Road Indicators-Safety

\begin{tabular}{|c|c|c|c|c|c|c|c|}
\hline \multirow{2}{*}{ ADB Regional Member } & \multicolumn{2}{|c|}{$\begin{array}{l}\text { Estimated Road Traffic } \\
\text { Deaths, } 2016\end{array}$} & \multicolumn{5}{|c|}{$\begin{array}{l}\text { Road User Deaths, } 2016 \\
(\%)\end{array}$} \\
\hline & Total & $\begin{array}{c}\text { Death Rate } \\
\text { (per } 100,000 \text { population) }\end{array}$ & $\begin{array}{l}\text { Four-Wheeled } \\
\text { Vehicles }\end{array}$ & $\begin{array}{l}\text { Two- and Three- } \\
\text { Wheeled Vehicles }\end{array}$ & Cyclists & Pedestrians & Others \\
\hline \multirow{2}{*}{\multicolumn{8}{|c|}{$\begin{array}{l}\text { Developing ADB Member Economies } \\
\text { Central and West Asia }\end{array}$}} \\
\hline & & & & & & & \\
\hline Afghanistan & 5,230 & 15 & & & & & \\
\hline Armenia & 499 & 17 & 59.6 & 1.5 & 0.4 & 34.8 & 3.7 \\
\hline Azerbaijan & 845 & 9 & 51.8 & 0.9 & 0.9 & 42.0 & 4.3 \\
\hline Georgia & 599 & 15 & 44.9 & 0.5 & 0.7 & 26.5 & 27.4 \\
\hline Kazakhstan & 3,158 & 18 & 59.8 & 4.3 & 1.7 & 30.9 & 3.3 \\
\hline Kyrgyz Republic & 916 & 15 & 27.6 & 2.1 & 0.2 & 40.0 & 30.0 \\
\hline Pakistan & 27,582 & 14 & & $\ldots$ & & & $\ldots$ \\
\hline Tajikistan & 1,577 & 18 & 57.4 & $\ldots$ & 2.3 & 40.3 & - \\
\hline Turkmenistan & 823 & 15 & $\ldots \ldots$ & $\ldots$ & $\ldots . .$. & $\ldots \ldots$ & $\ldots$ \\
\hline Uzbekistan & 3,617 & 12 & $\ldots \ldots$ & $\ldots$ & $\ldots$ & $\ldots$ & $\ldots$ \\
\hline \multicolumn{8}{|l|}{ East Asia } \\
\hline China, People's Republic of & 256,180 & 18 & $\ldots$ & $\ldots$ & $\ldots$ & $\ldots$ & $\ldots$ \\
\hline Hong Kong, China & & & $\ldots$ & & & & \\
\hline Korea, Republic of & 4,990 & 10 & & 20.5 & 5.9 & 39.9 & 33.7 \\
\hline Mongolia & 499 & 17 & 39.3 & 18.6 & 1.2 & 28.7 & 12.2 \\
\hline Taipei,China & $\ldots$ & $\ldots$ & $\ldots$ & $\ldots$ & $\ldots$ & $\ldots$ & $\ldots$ \\
\hline \multicolumn{8}{|l|}{ South Asia } \\
\hline Bangladesh & 24,954 & 15 & $\ldots$ & $\ldots$ & $\ldots$ & $\ldots$ & $\ldots$ \\
\hline Bhutan & 139 & 17 & & & $\ldots$ & $\ldots$ & $\ldots$ \\
\hline India & 299,091 & 23 & 17.9 & 39.6 & 1.7 & 10.4 & 30.4 \\
\hline Maldives & 4 & 1 & - & 75.0 & - & 25.0 & - \\
\hline Nepal & 4,622 & 16 & . & & 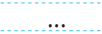 & & \\
\hline Sri Lanka & 3,096 & 15 & 6.2 & 50.8 & 8.1 & 29.2 & 5.7 \\
\hline \multicolumn{8}{|l|}{ Southeast Asia } \\
\hline Brunei Darussalam & & & & & & & \\
\hline Cambodia & 2,803 & 18 & 6.2 & 73.5 & 2.3 & 9.6 & 8.4 \\
\hline Indonesia & 31,726 & 12 & 4.9 & 73.6 & 3.2 & 15.5 & 2.7 \\
\hline Lao People's Democratic Republic & 1,120 & 17 & $\ldots$ & $\ldots$ & $\ldots$ & $\ldots \ldots$ & $\ldots$ \\
\hline Malaysia & 7,374 & 24 & 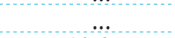 & 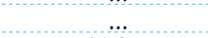 & $\ldots$ & 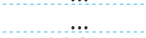 & $\ldots$ \\
\hline Myanmar & 10,540 & 20 & 10.8 & 64.8 & 3.1 & 14.2 & 7.1 \\
\hline Philippines & 12,690 & 12 & 0.3 & 4.7 & 0.1 & 1 & 93.9 \\
\hline Singapore & 155 & 3 & 7.8 & 44.0 & 14.2 & 33.3 & 0.7 \\
\hline Thailand & 22,491 & 33 & 12.3 & 74.4 & 3.5 & 7.6 & 2.3 \\
\hline Viet Nam & 24,970 & 26 & $\ldots$ & $\ldots$ & $\ldots$ & $\ldots$ & $\ldots$ \\
\hline \multicolumn{8}{|l|}{ The Pacific } \\
\hline Cook Islands & 3 & 17 & 20.0 & 80.0 & - & - & - \\
\hline Fiji & 86 & 10 & 63.3 & & … & 36.7 & - \\
\hline Kiribati & 5 & 4 & 40.0 & 20.0 & - & 40.0 & - \\
\hline Marshall Islands & $\ldots$ & $\ldots$ & & $\ldots \ldots$ & … & & .... \\
\hline Micronesia, Federated States of & 2 & 2 & 50.0 & - & - & 50.0 & - \\
\hline Nauru & $\ldots$ & $\ldots$ & $\ldots$ & $\cdots$ & $\ldots$ & $\ldots$ & $\ldots$ \\
\hline Niue & $\ldots . .$. & $\ldots . .$. & $\ldots \ldots$ & $\ldots$ & $\ldots$ & $\ldots \ldots$ & $\ldots$ \\
\hline Palau & & $\ldots$ & 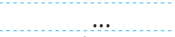 & $\ldots$ & $\ldots$ & $\ldots$ & - \\
\hline Papua New Guinea & 1,145 & 14 & 52.5 & $\ldots$ & & 47.5 & - \\
\hline Samoa & 22 & 11 & 41.2 & - & 5.9 & 47.1 & 5.9 \\
\hline Solomon Islands & 104 & 17 & $\ldots$ & $\ldots$ & $\ldots$ & $\ldots$ & $\ldots$ \\
\hline Timor-Leste & 161 & 13 & & $\ldots$ & ... & ... & $\ldots$ \\
\hline Tonga & 18 & 17 & 66.7 & - & - & 27.8 & 5.6 \\
\hline Tuvalu & $\ldots$ & $\ldots$ & $\ldots$ & $\ldots$ & ... & $\ldots$ & $\ldots$ \\
\hline Vanuatu & 43 & 16 & $\ldots$ & $\ldots$ & $\ldots$ & $\ldots$ & $\ldots$ \\
\hline \multicolumn{8}{|l|}{ Developed ADB Member Economies } \\
\hline Australia & 1,351 & 6 & 60.9 & 19.3 & 2.2 & 14.0 & 3.5 \\
\hline Japan & 5,224 & 4 & 32.4 & 17.2 & 15.1 & 35.0 & 1.0 \\
\hline New Zealand & 364 & 8 & 68.5 & 15.9 & 1.5 & 7.6 & 6.4 \\
\hline
\end{tabular}

$\ldots=$ data not available, - = magnitude equals zero; $\mathrm{ADB}=$ Asian Development Bank.

Source: $\quad$ World Health Organization. 2018. Global Status Report on Road Safety 2018. Geneva. 
Table 2.5.4: $\quad$ Rail Indicators

\begin{tabular}{|c|c|c|c|c|c|c|c|c|}
\hline \multirow[t]{2}{*}{ ADB Regional Member } & \multicolumn{4}{|c|}{$\begin{array}{l}\text { Rail Lines, Total Route } \\
(\mathrm{km})\end{array}$} & \multicolumn{4}{|c|}{$\begin{array}{l}\text { Rail Network, Length per Land Area } \\
\qquad\left(\mathrm{km} \text { per } \mathrm{km}^{2} \mathrm{c} 000\right)\end{array}$} \\
\hline & 2000 & 2005 & 2010 & 2017 & 2000 & 2005 & 2010 & 2017 \\
\hline \multicolumn{9}{|l|}{ Developing ADB Member Economies } \\
\hline \\
\hline Afghanistan & & & & & & & & \\
\hline Armenia & 843.0 & $711.0(2004)$ & 826.07 & 685.6 & 29.6 & $29.7(2006)$ & 29.0 & 24.1 \\
\hline Azerbaijan & $2,116.0$ & $2,122.0$ & $2,079.1$ & $2,132.0$ & 25.6 & 25.7 & 25.2 & 25.8 \\
\hline Georgia & $1,562.0$ & $1,336.0$ & $1,566.4$ & $1,285.0$ & 22.5 & 19.2 & 22.5 & 18.5 \\
\hline Kazakhstan & $13,545.0$ & $14,204.0$ & $14,184.1$ & $16,040.3$ & 5.0 & 5.3 & 5.3 & 5.9 \\
\hline Kyrgyz Republic & 417.0 & 417.0 & 417.2 & 424.0 & 2.2 & 2.2 & 2.2 & 2.2 \\
\hline Pakistan & $7,791.0$ & $7,791.0$ & $7,791.0$ & $7,791.0$ & 10.1 & 10.1 & 10.1 & 10.1 \\
\hline Tajikistan & 533.0 & 617.0 & 620.7 & 620.0 & 3.8 & 4.4 & 4.4 & 4.5 \\
\hline Turkmenistan & $2,521.0$ & $2,529.0$ & $3,115.0$ & $3,840.0$ & 5.4 & 5.4 & 6.6 & 8.2 \\
\hline Uzbekistan & $3,645.0$ & $4,014.0$ & $4,227.2$ & $4,642.0$ & 8.6 & 9.4 & 9.9 & 10.9 \\
\hline \multicolumn{9}{|l|}{ East Asia } \\
\hline China, People's Republic of & $58,656.0$ & $62,200.0$ & $66,239.0$ & $67,278.0$ & 6.2 & 6.6 & 7.2 & 7.2 \\
\hline Hong Kong, China & & & & & & & & \\
\hline Korea, Republic of & $3,123.0$ & $3,392.0$ & $3,618.3$ & $4,191.7$ & 32.4 & 35.0 & 37.2 & 43.0 \\
\hline Mongolia & $1,810.0$ & $1,810.0$ & $1,814.0$ & $1,810.0$ & 1.2 & 1.2 & 1.2 & 1.2 \\
\hline Taipei,China & $1,190.0$ & $1,336.0$ & $1,743.0$ & $1,835.0$ & 33.2 & 37.2 & 48.6 & 51.1 \\
\hline \multicolumn{9}{|l|}{ South Asia } \\
\hline Bangladesh & $2,745.0$ & $2,855.0$ & $2,835.0$ & & 21.1 & 21.9 & 21.8 & $\ldots$ \\
\hline \multicolumn{9}{|l|}{ Bhutan } \\
\hline India & $62,759.0$ & $63,485.0$ & $63,974.0$ & $67,368.0$ & 21.1 & 21.4 & 21.5 & 22.7 \\
\hline Maldives & $\ldots$ & & $\ldots$ & & $\ldots$ & $\ldots$ & $\ldots$ & $\ldots$ \\
\hline \multicolumn{9}{|l|}{ Nepal } \\
\hline Sri Lanka & & $1,463.0(2007)$ & $1,148.3(2011)$ & $1,561.7(2016)$ & & $23.3(2007)$ & $18.3(2011)$ & $24.9(2016)$ \\
\hline \multicolumn{9}{|l|}{ Southeast Asia } \\
\hline Brunei Darussalam & & & 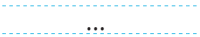 & $\ldots$ & $\ldots$ & $\cdots$ & $\ldots$ & $\ldots$ \\
\hline Cambodia & 601.0 & $650.0(2004)$ & & $\cdots$ & 3.4 & $3.7(2004)$ & & $\cdots$ \\
\hline Indonesia & $\ldots$ & $3,370.0(2006)$ & $4,684.0(2010)$ & $\ldots$ & $\ldots$ & $1.9(2006)$ & 2.6 & $\ldots$ \\
\hline \multicolumn{9}{|l|}{ Lao People's Democratic Republic } \\
\hline Malaysia & $1,636.0$ & $1,667.0$ & $2,209.7$ & 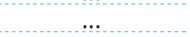 & 5.0 & 5.1 & 6.7 & $\ldots$ \\
\hline \multicolumn{9}{|l|}{ Myanmar } \\
\hline Philippines & $\ldots$ & $\cdots$ & $479.0(2008)$ & $509.0(2016)$ & $\ldots$ & $\ldots$ & $1.6(2008)$ & $1.7(2016)$ \\
\hline Singapore & & $\ldots$ & & & & & & \\
\hline Thailand & $4,044.0$ & $4,429.0(2007)$ & $4,458.0$ & & 7.9 & $8.7(2007)$ & 8.7 & $\ldots$ \\
\hline Viet Nam & $3,142.0$ & $3,147.0$ & $2,576.6$ & $2,367.0$ & 10.1 & 10.1 & 8.3 & 7.6 \\
\hline \multicolumn{9}{|l|}{ The Pacific } \\
\hline Cook Islands & $\ldots$ & $\ldots$ & $\ldots$ & $\ldots$ & $\ldots$ & $\ldots$ & $\ldots$ & $\ldots$ \\
\hline Fiji & $\ldots$ & $\ldots$ & $\ldots$ & $\ldots$ & $\ldots$ & $\ldots$ & $\ldots$ & $\ldots$ \\
\hline Kiribati & $\ldots$ & $\ldots$ & $\ldots$ & $\ldots$ & $\ldots$ & $\ldots$ & $\ldots$ & $\ldots$ \\
\hline Marshall Islands & $\ldots$ & $\ldots$ & $\ldots$ & $\cdots$ & $\cdots$ & $\cdots$ & $\ldots$ & $\ldots$ \\
\hline Micronesia, Federated States of & $\ldots$ & $\ldots$ & $\ldots$ & $\ldots$ & $\ldots$ & $\cdots$ & $\ldots$ & $\ldots$ \\
\hline Nauru & $\ldots$ & $\ldots$ & $\ldots$ & $\ldots$ & $\ldots$ & $\ldots$ & $\ldots$ & $\ldots$ \\
\hline Niue & $\ldots$ & $\ldots$ & $\ldots$ & $\ldots$ & $\ldots$ & $\ldots$ & (n) & $\ldots$ \\
\hline Palau & $\ldots$ & $\ldots$ & $\ldots$ & $\ldots$ & $\ldots$ & $\cdots$ & (n) & $\ldots$ \\
\hline Papua New Guinea & $\ldots$ & $\ldots$ & $\ldots$ & $\ldots$ & $\ldots$ & $\ldots$ & $\ldots$ & $\ldots$ \\
\hline Samoa & $\ldots$ & $\ldots$ & $\ldots$ & $\ldots$ & $\ldots$ & $\ldots$ & $\ldots$ & $\ldots$ \\
\hline Solomon Islands & $\ldots$ & $\ldots$ & $\ldots$ & $\ldots$ & $\ldots$ & $\ldots$ & $\ldots$ & $\ldots$ \\
\hline Timor-Leste & $\ldots$ & $\ldots$ & $\ldots$ & $\ldots$ & $\ldots$ & $\ldots$ & $\ldots$ & $\ldots$ \\
\hline Tonga & $\ldots$ & $\ldots$ & $\ldots$ & $\ldots$ & $\cdots$ & $\ldots$ & $\ldots$ & $\ldots$ \\
\hline Tuvalu & $\ldots$ & $\ldots$ & $\ldots$ & $\ldots$ & $\ldots$ & $\ldots$ & $\ldots$ & $\ldots$ \\
\hline Vanuatu & $\cdots$ & $\ldots$ & $\cdots$ & $\cdots$ & $\cdots$ & $\cdots$ & $\cdots$ & $\ldots$ \\
\hline \multicolumn{9}{|l|}{ Developed ADB Member Economies } \\
\hline Australia & $9,499.0$ & $9,528.0$ & $8,615.4$ & & 1.2 & 1.2 & 1.1 & $\ldots$ \\
\hline Japan & $29,799.0$ & $20,052.3$ & $20,140.3$ & $16,976.4$ & 81.8 & 55.0 & 55.2 & 46.6 \\
\hline New Zealand & $\ldots$ & $\ldots$ & $\ldots$ & $\ldots$ & $\ldots$ & $\ldots$ & $\ldots$ & $\ldots$ \\
\hline
\end{tabular}

$\ldots$ = data not available; $\mathrm{ADB}=$ Asian Development Bank; $\mathrm{km}=$ kilometer $\mathrm{km}^{2}=$ square kilometer.

Sources: World Bank. World Development Indicators. http://data.worldbank.org/indicator (accessed 25 July 2019) and Asian Development Bank estimates. For Taipei,China: National Development Council. 2018. Statistical Data Book. https://ws.ndc.gov.tw/Download.ashx?u=LzAwMS9hZG1pbmlzdHJhdG9yLzExL3 JlbGZpbGUvNTgxNy8zMTc2MS82NDA0ZDUzOC1kZDc1LTQ0ZmMtYWYwMS1jODRkN2IxMjFIYjMucGRm\&n=VGFpd2FuIFN0YXRpc3RpY2FsIERhdGEg Qm9vayAyMDE4LnBkZg\%3d\%3d\&icon=..pdf (accessed 26 July 2019). 
Transport

Table 2.5.5: $\quad$ Railways-Passengers Carried and Goods Transported

\begin{tabular}{|c|c|c|c|c|c|c|c|c|}
\hline \multirow[t]{2}{*}{ ADB Regional Member } & \multicolumn{4}{|c|}{$\begin{array}{l}\text { Passengers Carried } \\
\text { (passenger-km million) }\end{array}$} & \multicolumn{4}{|c|}{$\begin{array}{l}\text { Goods Transported } \\
\text { ( } t-k m \text { million) }\end{array}$} \\
\hline & 2000 & 2005 & 2010 & 2017 & 2000 & 2005 & 2010 & 2017 \\
\hline \multirow{2}{*}{\multicolumn{9}{|c|}{$\begin{array}{l}\text { Developing ADB Member Economies } \\
\text { Central and West Asia }\end{array}$}} \\
\hline & & & & & & & & \\
\hline Afghanistan & & & & & & & & \\
\hline Armenia & 47 & 27 & 50 & 25 & 354 & 654 & 346 & 689 \\
\hline Azerbaijan & 493 & 878 & 917 & 467 & 5,770 & $10,374(2007)$ & 8,250 & 4,633 \\
\hline Georgia & 453 & 720 & 654 & 597 & 3,912 & 6,127 & 6,228 & 2,963 \\
\hline Kazakhstan & 10,215 & 12,129 & 15,448 & 19,241 & 124,983 & 171,855 & 213,174 & 206,258 \\
\hline Kyrgyz Republic & 44 & $60(2006)$ & ) $\quad 99$ & 43 & 337 & $752(2007)$ & $\quad 738$ & 935 \\
\hline Pakistan & 18,495 & 24,238 & 20,619 (2011) & 22,476 & 3,612 & 5,014 & $1,757(2011)$ & 5,031 \\
\hline Tajikistan & 73 & $52(2006$ & ) $\quad 33$ & 28 & 1,326 & $1,274(2007)$ & 808 & 165 \\
\hline Turkmenistan & 943 & $1,435(2006)$ & ) 1,811 & 2,340 & 7,588 & $10,441(2006)$ & 11,765 & 13,327 \\
\hline Uzbekistan & 2,163 & 2,012 & 2,905 & 4,294 & 15,441 & 18,007 & 22,282 & 22,940 \\
\hline \multicolumn{9}{|l|}{ East Asia } \\
\hline China, People's Republic of & 441,468 & 583,320 & 791,158 & 685,213 & $1,333,606$ & $1,953,336$ & $2,451,185$ & $2,146,466$ \\
\hline Hong Kong, China & & & & & & & & \\
\hline Korea, Republic of & 28,097 & 31,004 & 33,012 & 21,935 & 10,621 & 10,108 & 9,452 & 8,229 \\
\hline Mongolia & 1,070 & $1,289(2006)$ & ) $\quad 2,440$ & 973 & 4,293 & $8,361(2007)$ & 20,574 & 13,493 \\
\hline Taipei,China & $12,269(2001)$ & $19,066(2008)$ & 20,931 & 29,004 & $1,010(2001)$ & $933(2008)$ & 873 & 515 \\
\hline \multicolumn{9}{|l|}{ South Asia } \\
\hline Bangladesh & 3,941 & 4,164 & 7,305 & $\ldots$ & 777 & 817 & 710 & \\
\hline \multicolumn{9}{|l|}{ Bhutan } \\
\hline India & 430,666 & 575,702 & 903,465 & $1,149,835$ & 305,201 & 407,398 & 600,548 & 620,175 \\
\hline Maldives & & & $\ldots . .$. & $\ldots$ & $\ldots . .$. & $\ldots$ & $\ldots$ & $\ldots$ \\
\hline Nepal & 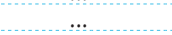 & & & 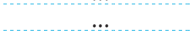 & 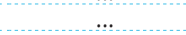 & 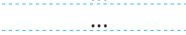 & 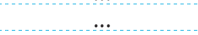 & 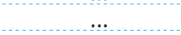 \\
\hline Sri Lanka & 3,208 & 4,358 & $4,574(2011)$ & $7,407(2015)$ & $127(2003)$ & 135 & $154(2011)$ & 127 (2015) \\
\hline \multicolumn{9}{|l|}{ Southeast Asia } \\
\hline \multicolumn{9}{|l|}{ Brunei Darussalam } \\
\hline Cambodia & 45 & 45 & & & $92(2003)$ & & & $\ldots$ \\
\hline \multirow{2}{*}{\multicolumn{9}{|c|}{ Lao People's Democratic Republic }} \\
\hline & & & & & & & & \\
\hline Malaysia & 1,220 & 2,152 & 2,415 & 2,029 & 916 & 1,177 & 1,483 & 1,234 \\
\hline Myanmar & 4,451 & $4,163(2004)$ & $\ldots$ & & 1,222 & $885(2004)$ & $\ldots$ & $\ldots$ \\
\hline Philippines & 123 & $83(2004)$ & $\ldots$ & $384(2016)$ & $\ldots$ & $1(2004)$ & 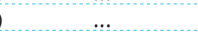 & \\
\hline Singapore & & & & & & & & \\
\hline Thailand & 9,935 & 9,195 & 8,187 & 9,195 & 2,247 & 4,037 & 2,701 & \\
\hline Viet Nam & 3,200 & 4,558 & 4,378 & 3,657 & 1,921 & 2,928 & 3,901 & 3,574 \\
\hline \multicolumn{9}{|l|}{ The Pacific } \\
\hline \multicolumn{9}{|l|}{ Cook Islands } \\
\hline Fiji $\quad \ldots$ & $\ldots$ & $\ldots$ & $\ldots$ & $\ldots$ & $\ldots$ & $\ldots$ & $\ldots$ & $\ldots$ \\
\hline \multicolumn{9}{|l|}{ Kiribati } \\
\hline \multicolumn{9}{|l|}{ Marshall Islands } \\
\hline \multicolumn{9}{|l|}{ Micronesia, Federated States of } \\
\hline Nauru & $\ldots$ & $\ldots$ & $\ldots$ & $\ldots \ldots$ & $\ldots$ & $\ldots \ldots$ & $\ldots$ & $\ldots \ldots$ \\
\hline Nive & & & & & & & & \\
\hline Palau & $\ldots \ldots$ & $\ldots$ & $\ldots \ldots$ & $\ldots$ & $\ldots$ & $\ldots \ldots$ & $\ldots \ldots$ & $\ldots \ldots$ \\
\hline Papua New Guinea & $\ldots . . .$. & $\ldots \ldots$ & $\ldots$ & $\ldots \ldots$ & $\ldots . .$. & $\ldots \ldots$ & & \\
\hline Samoa & $\ldots \ldots$ & $\ldots$ & $\ldots \ldots$ & $\ldots$ & $\ldots$ & $\ldots$ & $\ldots$ & $\ldots \ldots$ \\
\hline Solomon Islands & $\ldots \ldots$ & $\ldots \ldots$ & $\ldots \ldots$ & $\ldots \ldots$ & $\ldots \ldots$ & $\ldots \ldots$ & $\ldots \ldots$ & $\ldots \ldots$ \\
\hline Timor-Leste & $\ldots \ldots$ & $\ldots$ & $\ldots \ldots$ & $\ldots \ldots$ & $\ldots \ldots$ & $\ldots \ldots$ & $\ldots$ & $\ldots$ \\
\hline Tonga & $\ldots$ & $\ldots$ & $\ldots \ldots$ & $\ldots . .$. & $\ldots$ & $\ldots$ & $\ldots$ & $\ldots \ldots$ \\
\hline Tuvalu & & & & $\ldots$ & $\ldots \ldots$ & $\ldots \ldots$ & $\ldots \ldots$ & $\ldots \ldots$ \\
\hline Vanuatu & $\ldots$ & $\ldots$ & $\ldots$ & $\ldots$ & $\ldots$ & $\ldots$ & $\ldots$ & $\ldots$ \\
\hline ADB Member Econ & & & & & & & & \\
\hline Australia & 1,265 & 1,290 & 1,500 & & 33,592 & 46,164 & 64,172 & \\
\hline Japan & 240,657 & 245,957 & 244,591 & 197,254 & 21,800 & 22,632 & 20,255 & 21,265 (2016) \\
\hline New Zealand & & $\ldots$ & $\ldots$ & $\ldots$ & 4,078 & & & \\
\hline
\end{tabular}

$\ldots=$ data not available; $\mathrm{ADB}=$ Asian Development Bank; $\mathrm{km}=$ kilometer; $\mathrm{t}=$ metric ton.

Sources: World Bank. World Development Indicators. http://data.worldbank.org/indicator (accessed 25 July 2019). For Taipei,China: Government of Taipei,China, DirectorateGeneral of Budget, Accounting and Statistics. 2018. Statistical Yearbook 2017. Nantou City. https://eng.dgbas.gov.tw/public/data/dgbas03/bs2/yearbook_eng/ Yearbook2017.pdf (accessed 26 July 2019). 
Table 2.5.6: $\quad$ Air Transport

\begin{tabular}{|c|c|c|c|c|c|c|c|c|c|c|c|c|}
\hline \multirow[t]{2}{*}{ ADB Regional Member } & \multicolumn{4}{|c|}{$\begin{array}{c}\text { Carrier Departure Worldwide } \\
\text { (takeoffs) }\end{array}$} & \multicolumn{4}{|c|}{$\begin{array}{c}\text { Freight } \\
\text { (t-km million) }\end{array}$} & \multicolumn{4}{|c|}{$\begin{array}{l}\text { Passenger Carried } \\
\text { ('000) }\end{array}$} \\
\hline & 2000 & 2005 & 2010 & 2017 & 2000 & 2005 & 2010 & 2017 & 2000 & 2005 & 2010 & 2017 \\
\hline \multirow{2}{*}{\multicolumn{13}{|c|}{ Developing ADB Member Economies }} \\
\hline & \multicolumn{12}{|c|}{ Central and West Asia } \\
\hline Afghanistan & 3,409 & & 21,677 & 23,682 & 7.8 & & 108.0 & 25.1 & 150 & & 1,999 & 1,859 \\
\hline Armenia & 4,406 & 5,939 & 8,761 & & 8.8 & 7.0 & 6.0 & & 298 & 556 & 705 & \\
\hline Azerbaijan & 8,012 & 12,470 & 9,885 & 25,365 & 47.2 & 11.9 & 7.8 & 751.1 & 546 & 1,134 & 797 & 2,331 \\
\hline Georgia & 1,906 & 4,673 & 2,803 & 4,985 & 2.0 & 2.8 & 0.9 & 0.3 & 118 & 249 & 164 & 323 \\
\hline Kazakhstan & 8,041 & 17,302 & 33,483 & 65,009 & 11.8 & 15.8 & 42.4 & 49.3 & 461 & 1,160 & 3,098 & 5,653 \\
\hline Kyrgyz Republic & 6,051 & 5,228 & 7,371 & 27,097 & 3.7 & 2.0 & 1.3 & 0.0 & 241 & 226 & 376 & 1,127 \\
\hline Pakistan & 63,956 & 48,905 & 64,932 & 66,346 & 340.3 & 407.9 & 333.0 & 249.9 & 5,294 & 5,364 & 6,588 & 9,920 \\
\hline Tajikistan & 3,953 & 6,987 & 5,710 & 5,283 & 2.0 & 3.7 & 1.0 & 4.0 & 168 & 479 & 617 & 796 \\
\hline Turkmenistan & 21,858 & 14,094 & 3,221 & 11,068 & 11.9 & 10.1 & 6.2 & 6.0 & 1,284 & 1,654 & 301 & 1,280 \\
\hline Uzbekistan & 30,075 & 22,183 & 22,924 & 21,730 & 79.6 & 71.6 & 153.7 & 126.8 & 1,745 & 1,639 & 2,114 & 2,582 \\
\hline \multicolumn{13}{|l|}{ East Asia } \\
\hline China, People's Republic of & 572,921 & $1,349,269$ & $2,377,789$ & $4,359,033$ & $3,900.1$ & $7,579.4$ & $17,193.9$ & $23,323.6$ & 61,892 & 136,722 & 266,293 & 551,235 \\
\hline Hong Kong, China & 79,182 & 122,705 & 158,255 & 243,518 & $5,111.5$ & $7,763.9$ & $10,373.4$ & $12,415.2$ & 14,378 & 20,230 & 28,348 & 45,580 \\
\hline Korea, Republic of & 226,910 & 221,424 & 280,427 & 496,326 & $7,651.3$ & $7,432.6$ & $12,942.7$ & $11,002.2$ & 34,331 & 33,888 & 36,988 & 84,045 \\
\hline Mongolia & 6,200 & 5,332 & 6,528 & 5,277 & 8.4 & 6.1 & 3.9 & 8.4 & 254 & 295 & 391 & 603 \\
\hline Taipei,China $^{\mathrm{a}}$ & 586,560 & 479,499 & 360,409 & 509,181 & 1.3 & 1.8 & 2.3 & 2.4 & 48,407 & 44,268 & 41,091 & 65,979 \\
\hline \multicolumn{13}{|l|}{ South Asia } \\
\hline Bangladesh & 6,313 & 7,399 & 19,300 & 61,902 & 193.9 & 183.5 & 164.4 & 61.7 & 1,331 & 1,634 & 1,819 & 3,786 \\
\hline Bhutan ${ }^{\mathrm{b}}$ & 1,138 & 2,467 & 3,053 & 7,927 & 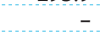 & 0.3 & 0.4 & 0.8 & 34 & 49 & 182 & 293 \\
\hline India & 198,426 & 330,484 & 623,197 & $1,029,961$ & 547.7 & 774.0 & $1,631.0$ & $2,407.3$ & 17,299 & 27,879 & 64,374 & 139,822 \\
\hline Maldives ${ }^{c}$ & 5,970 & 4,520 & 4,971 & 33,904 & 13.2 & 0.0 & & 7.7 & 315 & 82 & 1,025 & 1,486 \\
\hline Nepal & 12,130 & 6,255 & 45,990 & 33,767 & 17.0 & 6.9 & 6.5 & 6.0 & 643 & 480 & 918 & 780 \\
\hline Sri Lanka & 5,206 & 19,712 & 20,921 & 41,272 & 255.7 & 310.4 & 339.0 & 398.6 & 1,756 & 2,818 & 3,008 & 5,342 \\
\hline \multicolumn{13}{|l|}{ Southeast Asia } \\
\hline Brunei Darussalam & 12,739 & 11,808 & 12,333 & 10,743 & 140.2 & 134.1 & 148.5 & 132.6 & 864 & 978 & 1,263 & 1,172 \\
\hline Cambodiab & & 3,207 & 5,105 & 14,372 & & 1.2 & 0.0 & 0.9 & & 169 & 278 & 1,305 \\
\hline Indonesia & 159,027 & 320,724 & 520,932 & 916,471 & 408.5 & 439.8 & 665.7 & $1,056.0$ & 9,916 & 26,836 & 59,384 & 110,253 \\
\hline Lao People's Democratic Republic & 6,411 & 9,002 & 11,374 & 9,731 & 1.7 & 2.5 & 0.1 & 1.5 & 211 & 293 & 444 & 1,196 \\
\hline Malaysia & 169,263 & 176,152 & 302,185 & 432,454 & $1,863.8$ & $2,577.6$ & $2,564.7$ & $1,261.6$ & 16,561 & 20,369 & 34,239 & 58,189 \\
\hline Myanmar & 10,329 & 26,460 & 20,485 & 65,028 & 0.8 & 2.7 & 2.1 & 5.5 & 438 & 1,504 & 924 & 2,854 \\
\hline Philippines & 44,547 & 58,944 & 205,318 & 369,158 & 289.9 & 322.7 & 460.2 & 756.9 & 5,756 & 8,057 & 22,575 & 44,087 \\
\hline Singapore & 71,042 & 77,119 & 131,722 & 213,198 & $6,004.9$ & $7,571.3$ & $7,121.4$ & $7,006.9$ & 16,704 & 17,744 & 24,860 & 37,680 \\
\hline Thailand & 101,591 & 124,347 & 201,306 & 445,736 & $1,712.9$ & $2,002.4$ & $2,938.7$ & $2,393.3$ & 17,392 & 18,903 & 28,781 & 71,192 \\
\hline Viet Nam & 28,999 & 54,415 & 109,176 & 264,548 & 117.3 & 230.2 & 426.9 & 453.3 & 2,878 & 5,454 & 14,378 & 42,593 \\
\hline \multicolumn{13}{|l|}{ The Pacific } \\
\hline \multicolumn{13}{|l|}{ Cook Islands } \\
\hline Fiji & 57,776 & 41,886 & 26,127 & 22,075 & 90.8 & 92.1 & 77.1 & 102.6 & 586 & 871 & 1,259 & 1,558 \\
\hline Kiribati & & & & 5,005 & & & & & & & & 67 \\
\hline Marshall Islandsc & 2,324 & 3,083 & 3,480 & 2,756 & 0.2 & 0.3 & & 0.7 & 16 & 26 & & 47 \\
\hline Micronesia, Federated States of & $\ldots$ & $\ldots$ & & $\ldots$ & $\ldots$ & $\ldots$ & $\ldots$ & $\ldots$ & $\ldots$ & $\ldots$ & $\ldots$ & $\ldots$ \\
\hline Nauru & & & 342 & 842 & & & 6.3 & 7.9 & & & 30 & 45 \\
\hline Niue & $\cdots$ & $\ldots$ & $\ldots$ & $\ldots$ & $\ldots$ & $\ldots$ & $\ldots$ & $\ldots$ & $\ldots$ & $\ldots$ & $\ldots$ & . \\
\hline \multicolumn{13}{|l|}{ Palau } \\
\hline Papua New Guinea & 27,512 & 19,606 & 32,741 & 53,696 & 22.3 & 21.1 & 28.5 & 29.2 & 1,100 & 819 & 1,405 & 1,865 \\
\hline Samoac & 10,877 & 11,439 & 12,492 & 13,433 & 2.2 & 1.8 & 0.0 & 0.0 & 164 & 267 & 271 & 135 \\
\hline Solomon Islands & 11,481 & 12,318 & 7,388 & 14,365 & 1.0 & 0.8 & 2.5 & 3.8 & 75 & 91 & 143 & 428 \\
\hline Timor-Leste & & & $\ldots$ & $\ldots$ & $\ldots$ & $\ldots$ & $\cdots$ & $\ldots$ & $\ldots$ & $\ldots$ & $\ldots$ & \\
\hline Tonga $^{d}$ & 3,814 & 5,255 & & & 0.0 & 0.0 & & & 52 & 75 & & \\
\hline \multicolumn{13}{|l|}{ Tuvalu } \\
\hline Vanuatu & 1,402 & 1,580 & 17,212 & 12,920 & 1.8 & 1.8 & 0.2 & 2.3 & 102 & 112 & 248 & 339 \\
\hline \multicolumn{13}{|l|}{ Developed ADB Member Economies } \\
\hline Australia & 382,514 & 342,509 & 572,906 & 672,349 & $1,730.7$ & $2,444.6$ & $2,938.3$ & $1,982.6$ & 32,578 & 44,657 & 60,641 & 74,257 \\
\hline Japan & 645,087 & 651,858 & 934,487 & $1,035,522$ & $8,672.0$ & $8,549.2$ & $7,698.8$ & $10,684.6$ & 109,123 & 102,279 & 109,617 & 123,898 \\
\hline New Zealand & 240,046 & 209,469 & 207,872 & 184,762 & 817.1 & 781.5 & 468.6 & $1,336.0$ & 10,781 & 11,952 & 13,295 & 16,272 \\
\hline
\end{tabular}

$\ldots=$ data not available, $0.0=$ magnitude is less than half of unit employed, $\mathrm{ADB}=$ Asian Development Bank, $\mathrm{km}=\mathrm{kilometer}, \mathrm{t}=$ metric ton.

a Carried departure worldwide is based on the number of aircraft movements, both domestic and international. Freight is based on million ton.

b For the freight indicator, data for 2000 refer to 2002 .

c For all indicators, data for 2010 refer to 2009.

d For all indicators, data for 2005 refer to 2004.

Sources: World Bank. World Development Indicators. http://databank.worldbank.org/data/reports.aspx?source=world-development-indicators (accessed 24 July 2019). For Taipei,China: Government of Taipei,China, Directorate-General of Budget, Accounting and Statistics. 2018. Statistical Yearbook 2017. Nantou City. https://eng.dgbas.gov.tw/public/data/dgbas03/bs2/yearbook_eng/Yearbook2017.pdf (accessed 26 July 2019). 
Transport

Table 2.5.7: Container Port Traffic

(teu '000)

\begin{tabular}{|c|c|c|c|c|c|c|c|c|c|c|c|c|c|}
\hline ADB Regional Member & 2000 & 2005 & 2006 & 2007 & 2008 & 2009 & 2010 & 2012 & 2013 & 2014 & 2015 & 2016 & 2017 \\
\hline \multicolumn{14}{|c|}{ Developing ADB Member Economies } \\
\hline \multicolumn{14}{|l|}{ Central and West Asia } \\
\hline \multicolumn{14}{|l|}{ Afghanistan } \\
\hline \multicolumn{14}{|l|}{ Armenia } \\
\hline \multicolumn{14}{|l|}{ Azerbaijan } \\
\hline Georgia & $\ldots$ & $\ldots$ & . & 185 & 254 & 182 & 210 & 210 & 226 & 256 & 222 & 222 & 222 \\
\hline \multicolumn{14}{|l|}{ Kazakhstan } \\
\hline \multicolumn{14}{|l|}{ Kyrgyz Republic } \\
\hline Pakistan & $\ldots$ & 1,686 & 1,777 & 1,936 & 1,938 & 2,058 & 2,149 & 2,222 & 2,262 & 2,535 & 2,756 & 2,756 & 2,986 \\
\hline \multicolumn{14}{|l|}{ Tajikistan } \\
\hline Turkmenistan & & $\ldots$ & & & & & & & & & & & \\
\hline \multicolumn{14}{|l|}{ Uzbekistan } \\
\hline \multicolumn{14}{|l|}{ East Asia } \\
\hline China, People's Republic of & 41,000 & 67,245 & 84,811 & 103,823 & 115,942 & 108,800 & 142,970 & 166,511 & 175,936 & 186,679 & 195,277 & 199,552 & 213,720 \\
\hline Hong Kong, China & & 22,602 & 23,539 & 23,998 & 24,494 & 21,040 & 23,600 & 23,100 & 22,290 & 22,300 & 20,114 & 19,580 & 20,770 \\
\hline Korea, Republic of & 9,030 & 15,113 & 15,514 & 17,086 & 17,418 & 15,700 & 19,456 & 22,618 & 23,711 & 24,819 & 25,354 & 26,153 & $3 \quad 27,427$ \\
\hline Mongolia & & & & & & & & & & & & & \\
\hline Taipei,China & & 12,791 & 13,102 & 13,720 & 12,971 & 11,352 & 12,937 & 13,878 & 14,047 & 15,050 & 14,492 & 14,885 & 14,865 \\
\hline \multicolumn{14}{|l|}{ South Asia } \\
\hline Bangladesh & 456 & 809 & 902 & 978 & 1,091 & 1,182 & 1,350 & 1,427 & 1,489 & 1,643 & 2,045 & 2,377 & 2,587 \\
\hline Bhutan & & & & & & & & & & & & & \\
\hline India & 2,451 & 4,982 & 6,141 & 7,398 & 7,672 & 8,014 & 8,923 & 10,072 & 10,626 & 11,323 & 11,882 & 12,086 & 13,259 \\
\hline Maldives & & $\ldots$ & $\ldots$ & 48 & 54 & 56 & 50 & 55 & 80 & 84 & 84 & 82 & 83 \\
\hline Nepal & & & & & & & & & & $\ldots$ & & & \\
\hline Sri Lanka & 1,733 & 2,455 & 3,079 & 3,687 & 3,687 & 3,464 & 4,100 & 4,321 & 4,310 & 4,908 & 5,185 & 5,550 & 6,000 \\
\hline \multicolumn{14}{|l|}{ Southeast Asia } \\
\hline Brunei Darussalam & & $\ldots$ & 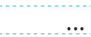 & & 90 & 86 & 93 & 109 & 122 & 128 & 128 & 125 & 125 \\
\hline Cambodia & & & & 253 & 259 & 208 & 224 & 224 & 230 & 342 & 392 & 400 & 485 \\
\hline Indonesia & 3,798 & 5,503 & 4,316 & 6,583 & 7,405 & 7,255 & 9,692 & 11,543 & 11,862 & 11,620 & 11,979 & 12,479 & 13,860 \\
\hline \multicolumn{14}{|l|}{ Lao People's Democratic Republic } \\
\hline Malaysia & 4,642 & 12,198 & 13,419 & 14,829 & 16,094 & 15,923 & 18,142 & 20,898 & 21,377 & 22,645 & 24,260 & 24,570 & 24,719 \\
\hline Myanmar & & & & 170 & 180 & 164 & 335 & 474 & 567 & 717 & 827 & 1,026 & 1,070 \\
\hline Philippines & 3,032 & 3,634 & 3,676 & 4,351 & 4,471 & 4,307 & 5,087 & 5,642 & 5,826 & 6,176 & 7,210 & 7,621 & 8,197 \\
\hline Singapore & 17,100 & 23,192 & 24,792 & 28,768 & 30,891 & 26,593 & 29,147 & 32,347 & 33,388 & 34,688 & 31,710 & 32,668 & 33,600 \\
\hline Thailand & 3,179 & 5,115 & 5,574 & 6,339 & 6,726 & 5,898 & 7,553 & 8,414 & 8,891 & 9,420 & 9,522 & 9,940 & 10,732 \\
\hline Viet Nam & 1,190 & 2,537 & 3,000 & 4,009 & 4,394 & 4,937 & 5,968 & 8,362 & 8,967 & 10,189 & 11,479 & 11,853 & 3 12,284 \\
\hline \multicolumn{14}{|l|}{ The Pacific } \\
\hline Cook Islands & & $\ldots$ & $\ldots$ & $\ldots$ & $\ldots$ & $\cdots$ & $\ldots$ & $\ldots$ & $\cdots$ & $\ldots$ & & $\ldots$ & \\
\hline Fiji & & $\ldots$ & $\ldots$ & & $\ldots$ & & 87 & 82 & 88 & 260 & 89 & 89 & 89 \\
\hline Kiribati & & $\cdots$ & $\ldots$ & $\ldots$ & $\ldots$ & $\ldots$ & $\ldots$ & $\ldots$ & $\ldots$ & $\ldots$ & $\ldots$ & $\ldots$ & \\
\hline Marshall Islands & & $\cdots$ & $\cdots$ & $\cdots$ & & $\ldots$ & $\ldots$ & $\ldots$ & $\ldots$ & $\cdots$ & & & \\
\hline Micronesia, Federated States of & & $\cdots$ & $\cdots$ & & $\ldots$ & $\cdots$ & $\cdots$ & $\ldots$ & $\cdots$ & $\cdots$ & $\cdots$ & $\cdots$ & \\
\hline Nauru & & $\cdots$ & $\cdots$ & $\begin{array}{l}\cdots \\
\cdots\end{array}$ & $\cdots$ & $\ldots$ & $\cdots$ & $\ldots$ & $\ldots$ & $\cdots$ & $\ldots$ & $\ldots$ & \\
\hline Niue & & & & & & & & & & & & & \\
\hline Palau & & & & $\ldots$ & $\ldots$ & & & & & & & $\ldots$ & \\
\hline Papua New Guinea & & $\cdots$ & $\ldots$ & 282 & 255 & 262 & 283 & 279 & 279 & 279 & 279 & 279 & 276 \\
\hline Samoa & & $\cdots$ & $\cdots$ & & $\ldots$ & $\ldots$ & $\ldots$ & 23 & 24 & 27 & 28 & 28 & 28 \\
\hline Solomon Islands & $\ldots$ & $\ldots$ & $\ldots$ & & $\ldots$ & $\ldots$ & $\ldots$ & $\ldots$ & $\ldots$ & $\ldots$ & $\ldots$ & $\ldots$ & \\
\hline Timor-Leste & & $\ldots$ & $\ldots$ & & $\ldots$ & $\ldots$ & $\ldots$ & & & $\ldots$ & $\ldots$ & $\ldots$ & \\
\hline Tonga & & & & & & & & & & & & $\ldots$ & \\
\hline Tuvalu & & $\ldots$ & $\ldots$ & $\ldots$ & $\ldots$ & $\ldots$ & $\ldots$ & $\ldots$ & $\ldots$ & $\ldots$ & $\ldots$ & $\ldots$ & \\
\hline Vanuatu & & $\ldots$ & $\ldots$ & $\cdots$ & $\cdots$ & $\ldots$ & $\ldots$ & $\ldots$ & $\cdots$ & $\cdots$ & $\ldots$ & $\ldots$ & \\
\hline Devel & & & & & & & & & & & & & \\
\hline Australia & 3,543 & 5,191 & 5,742 & 6,290 & 6,102 & 6,200 & 6,412 & 7,251 & 7,180 & 7,405 & 7,634 & 7,690 & 7,694 \\
\hline Japan & 13,100 & 17,055 & 18,470 & 19,165 & 18,944 & 16,286 & 19,548 & 20,834 & 21,050 & 21,139 & 20,577 & 20,785 & 21,904 \\
\hline New Zealand & 1,067 & 1,603 & 1,807 & 2,312 & 2,318 & 2,325 & 2,526 & 2,822 & 2,891 & 3,003 & 3,173 & 3,165 & 3,227 \\
\hline
\end{tabular}

... = data not available, - = magnitude equals zero, $\mathrm{ADB}=$ Asian Development Bank, teu = twenty-foot equivalent unit.

Sources: $\quad$ World Bank. World Development Indicators. http://data.worldbank.org/indicator (accessed 24 July 2019). For Taipei,China for 2005-2007: United Nations Conference on Trade and Development. 2008 and 2010. Review of Maritime Transport. New York, New York: United Nations Publications. For Taipei,China for 2010-2017: United Nations Conference on Trade and Development. UNCTADstat. http://unctadstat.unctad.org/EN/Index.html (accessed 24 July 2019). 
Table 2.5.8: Access to Fixed Telephone, Mobile Phones, and Internet ('000)

\begin{tabular}{|c|c|c|c|c|c|c|}
\hline \multirow{2}{*}{ ADB Regional Member } & \multicolumn{2}{|c|}{ Telephone Subscribers } & \multicolumn{2}{|c|}{ Mobile Phone Subscribers } & \multicolumn{2}{|c|}{ Fixed Broadband Subscribers } \\
\hline & 2000 & 2017 & 2000 & 2017 & 2000 & 2017 \\
\hline \multicolumn{7}{|l|}{ Developing ADB Member Economies } \\
\hline \multicolumn{7}{|l|}{ Central and West Asia } \\
\hline Afghanistan & 29.0 & 118.8 & $25.0(2002)$ & $23,929.7$ & $0.2(2004)$ & 29.4 \\
\hline Armenia & 533.4 & 505.2 & 17.5 & $3,488.5$ & $0.0(2001)$ & 315.3 \\
\hline Azerbaijan & 801.2 & $1,688.3$ & 420.4 & $10,127.0$ & $1.0(2002)$ & $1,805.2$ \\
\hline Georgia & 508.8 & 713.8 & 194.7 & $5,502.4$ & $0.4(2001)$ & 770.9 \\
\hline Kazakhstan & $1,834.2$ & $3,686.6$ & 197.3 & $26,693.3$ & $1.0(2003)$ & $2,576.1$ \\
\hline Kyrgyz Republic & 376.1 & 362.3 & 9.0 & $7,369.9$ & $0.0(2002)$ & 258.0 \\
\hline Pakistan & $3,053.5$ & $2,940.2$ & 306.5 & $144,525.6$ & $14.6(2005)$ & $1,829.7$ \\
\hline Tajikistan & 218.5 & 479.0 & 1.2 & $9,904.0$ & $0.0(2003)$ & 6.0 \\
\hline Turkmenistan & 364.4 & 682.0 & 7.5 & $9,377.0$ & & 5.0 \\
\hline Uzbekistan & $1,655.0$ & $3,444.3$ & 53.1 & $24,265.5$ & $2.8(2003)$ & $3,320.2$ \\
\hline \multicolumn{7}{|l|}{ East Asia } \\
\hline China, People's Republic of & $144,829.0$ & $193,757.0$ & $85,260.0$ & $1,469,882.5$ & 22.7 & $394,190.0$ \\
\hline Hong Kong, China & $3,925.8$ & $4,249.4$ & $5,447.3$ & $18,394.8$ & 444.5 & $2,658.1$ \\
\hline Korea, Republic of & $25,863.0$ & $26,844.7$ & $26,816.4$ & $63,658.7$ & $3,870.0$ & $21,195.9$ \\
\hline Mongolia & 117.5 & 292.6 & 154.6 & $3,886.2$ & $0.0(2001)$ & 285.1 \\
\hline Taipei,China & $12,642.2$ & $13,565.1$ & $17,873.8$ & $28,777.4$ & 229.0 & $5,713.6$ \\
\hline \multicolumn{7}{|l|}{ South Asia } \\
\hline Bangladesh & 491.3 & 707.6 & 279.0 & $150,945.0$ & $43.7(2007)$ & $7,300.5$ \\
\hline Bhutan & 14.1 & 21.4 & 0.0 & 730.6 & & 16.7 \\
\hline India & $32,436.1$ & $23,234.7$ & $3,577.1$ & $1,168,902.3$ & $50.0(2001)$ & $17,856.0$ \\
\hline Maldives & 24.4 & 20.4 & 7.6 & 900.1 & $0.2(2002)$ & 36.5 \\
\hline Nepal & 266.9 & 861.3 & 10.2 & $36,096.4$ & $1.0(2006)$ & 503.2 \\
\hline Sri Lanka & 767.4 & $2,603.2$ & 430.2 & $28,199.1$ & $0.3(2001)$ & $1,220.5$ \\
\hline \multicolumn{7}{|l|}{ Southeast Asia } \\
\hline Brunei Darussalam & 80.5 & 72.0 & 95.0 & 544.7 & $1.9(2001)$ & 41.2 \\
\hline Cambodia & 30.9 & 132.9 & 130.5 & $18,573.0$ & $0.1(2002)$ & 133.6 \\
\hline Indonesia & $6,662.6$ & $11,053.3$ & $3,669.3$ & $435,193.6$ & 4.0 & $6,215.9$ \\
\hline Lao People's Democratic Republic & 40.9 & $1,125.5$ & 12.7 & $3,711.8$ & $0.0(2003)$ & 27.2 \\
\hline Malaysia & $4,628.0$ & $6,578.2$ & $5,121.7$ & $42,338.5$ & $4.0(2001)$ & $2,687.8$ \\
\hline Myanmar & 271.4 & 556.1 & 13.4 & $47,946.7$ & $0.2(2005)$ & 111.6 \\
\hline Philippines & $3,061.4$ & $4,163.3$ & $6,454.4$ & $115,825.0$ & $10.0(2001)$ & $3,399.3$ \\
\hline Singapore & $1,946.0$ & $1,991.7$ & $2,747.4$ & $8,381.9$ & 69.0 & $1,475.7$ \\
\hline Thailand & $5,591.1$ & $3,466.0$ & $3,056.0$ & $121,530.0$ & $1.6(2001)$ & $8,208.0$ \\
\hline Viet Nam & $2,542.7$ & $4,385.4$ & 788.6 & $120,016.2$ & $1.1(2002)$ & $11,269.9$ \\
\hline \multicolumn{7}{|l|}{ The Pacific } \\
\hline Cook Islands & & & & & & \\
\hline Fiji & 86.4 & 76.0 & 55.1 & $1,033.9$ & $7.0(2005)$ & 12.1 \\
\hline Kiribati & 3.4 & 0.8 & 0.3 & 46.1 & $0.3(2005)$ & 0.1 \\
\hline Marshall Islands & 4.0 & 0.0 & 0.4 & 16.0 & $\ldots$ & 1.0 \\
\hline Micronesia, Federated States of & 9.6 & 6.9 & $\ldots$ & 23.1 & $0.0(2003)$ & 3.8 \\
\hline Nauru & 1.8 & 0.0 & 1.2 & 10.0 & & $1.0(2010)$ \\
\hline Niue & 1.1 & $1.0(2015)$ & 0.4 & $\ldots$ & ... & $\ldots$ \\
\hline Palau & $6.9(2002)$ & $7.2(2015)$ & $2.5(2002)$ & $23.7(2015)$ & $0.1(2004)$ & $1.2(2015)$ \\
\hline Papua New Guinea & 64.8 & 158.0 & 8.6 & 4.0 & $3.0(2008)$ & 18.0 \\
\hline Samoa & 8.5 & 8.5 & 2.5 & 124.2 & $0.0(2004)$ & 1.7 \\
\hline Solomon Islands & 7.7 & 7.4 & 1.2 & 465.3 & $0.2(2004)$ & 1.2 \\
\hline Timor-Leste & $2.0(2003)$ & 2.4 & $20.1(2003)$ & $1,556.6$ & $0.0(2003)$ & 3.3 \\
\hline Tonga & 9.7 & 14.7 & 0.2 & 107.9 & $0.0(2002)$ & 3.0 \\
\hline Tuvalu & 0.7 & 2.0 & $0.5(2004)$ & 8.0 & $0.1(2004)$ & 0.5 \\
\hline Vanuatu & 6.6 & 4.5 & 0.4 & 228.0 & $0.0(2003)$ & 4.5 \\
\hline \multicolumn{7}{|l|}{ Developed ADB Member Economies } \\
\hline Australia & $10,050.0$ & $8,460.0$ & $8,562.0$ & $27,553.0$ & $122.8(2001)$ & $7,922.0$ \\
\hline Japan & $61,957.1$ & $63,954.5$ & $66,784.4$ & $172,790.0$ & 854.7 & $40,532.5$ \\
\hline New Zealand & $1,831.0$ & $1,790.0$ & $1,542.0$ & $6,400.0$ & 4.7 & $1,583.0$ \\
\hline
\end{tabular}

$\ldots=$ data not available, 0.0 = magnitude is less than half of unit employed, - = magnitude equals zero, $\mathrm{ADB}=$ Asian Development Bank.

Source: International Telecommunication Union. World Telecommunication/ICT Indicators Database. http://www.itu.int/en/ITU-D/Statistics/Pages/stat/default. aspx (accessed 24 July 2019). 
Table 2.5.9: $\quad$ Access to Fixed Telephone, Mobile Phones, and Internet (per 100 people)

\begin{tabular}{|c|c|c|c|c|c|c|c|c|c|c|c|c|c|c|c|c|}
\hline \multirow{2}{*}{ ADB Regional Member } & \multicolumn{4}{|c|}{ Fixed Telephone } & \multicolumn{4}{|c|}{ Mobile Cellular } & \multicolumn{4}{|c|}{ Fixed Broadband } & \multicolumn{4}{|c|}{ Internet Users ${ }^{\mathrm{a}}$} \\
\hline & 2000 & 2005 & 2010 & 2017 & 2000 & 2005 & 2010 & 2017 & 2000 & 2005 & 2010 & 2017 & 2000 & 2005 & 2010 & 2017 \\
\hline \multicolumn{17}{|l|}{ Developing ADB Member Economies } \\
\hline \multicolumn{17}{|l|}{ Central and West Asia } \\
\hline Afghanistan ${ }^{\mathrm{b}}$ & 0.1 & 0.2 & 0.1 & 0.3 & - & 4.8 & 35.5 & 67.4 & & 0.0 & 0.0 & 0.1 & 0.0 & 1.2 & 4.0 & 13.5 \\
\hline Armenia & 17.4 & 19.9 & 20.6 & 17.2 & 0.6 & 10.7 & 134.3 & 119.0 & & 0.1 & 3.3 & 10.8 & 1.3 & 5.3 & 25.0 & 64.7 \\
\hline Azerbaijan & 9.9 & 12.8 & 16.7 & 17.2 & 5.2 & 26.3 & 100.7 & 103.0 & & 0.0 & 5.3 & 18.4 & 0.1 & 8.0 & 46.0 & 79.0 \\
\hline Georgia & 10.8 & 12.7 & 26.3 & 18.2 & 4.1 & 26.2 & 94.0 & 140.7 & & 0.1 & 4.3 & 19.7 & 0.5 & 6.1 & 26.9 & 59.7 \\
\hline Kazakhstan & 12.2 & 17.4 & 24.7 & 20.3 & 1.3 & 34.7 & 118.3 & 146.6 & & 0.0 & 5.3 & 14.2 & 0.7 & 3.0 & 31.6 & 76.4 \\
\hline Kyrgyz Republic & 7.6 & 8.7 & 9.0 & 6.0 & 0.2 & 10.7 & 97.3 & 121.9 & $\therefore$ & 0.0 & 0.4 & 4.3 & 1.0 & 10.5 & 16.3 & 38.0 \\
\hline Pakistan & 2.2 & 3.4 & 3.6 & 1.5 & 0.2 & 8.3 & 58.2 & 73.4 & & 0.0 & 0.5 & 0.9 & 1.3 & 6.3 & 8.0 & 15.5 \\
\hline Tajikistan & 3.5 & 4.1 & 4.8 & 5.4 & 0.0 & 3.9 & 77.7 & 111.0 & $\ldots$ & $\ldots$ & 0.1 & 0.1 & 0.0 & 0.3 & 11.6 & 22.0 \\
\hline Turkmenistan & 8.1 & 8.4 & 10.2 & 11.8 & 0.2 & 2.2 & 62.9 & 162.8 & $\ldots$ & & 0.0 & 0.1 & 0.1 & 1.0 & 3.0 & 21.3 \\
\hline Uzbekistan & 6.7 & 6.8 & 6.6 & 10.8 & 0.2 & 2.7 & 73.2 & 76.0 & & 0.0 & 0.4 & 10.4 & 0.5 & 3.3 & 15.9 & 52.3 \\
\hline \multicolumn{17}{|l|}{ East Asia } \\
\hline China, People's Republic of & 11.3 & 26.5 & 21.6 & 13.7 & 6.6 & 29.8 & 63.2 & 104.3 & 0.0 & 2.8 & 9.3 & 28.0 & 1.8 & 8.5 & 34.3 & 54.3 \\
\hline Hong Kong, China & 58.9 & 55.6 & 62.1 & 57.7 & 81.7 & 125.1 & 196.3 & 249.8 & 6.7 & 24.3 & 30.9 & 36.1 & 27.8 & 56.9 & 72.0 & 89.4 \\
\hline Korea, Republic of & 54.6 & 49.1 & 57.6 & 52.7 & 56.6 & 78.7 & 102.5 & 124.9 & 8.2 & 25.0 & 34.7 & 41.6 & 44.7 & 73.5 & 83.7 & 95.1 \\
\hline Mongoliac & 4.9 & 6.2 & 7.1 & 9.5 & 6.4 & 22.1 & 92.5 & 126.4 & 0.0 & 0.1 & 2.8 & 9.3 & 1.3 & 9.0 & 10.2 & 23.7 \\
\hline Taipei,China & 57.9 & 64.1 & 71.1 & 57.4 & 81.8 & 98.1 & 120.5 & 121.8 & 1.0 & 19.2 & 23.0 & 24.2 & 28.1 & 58.0 & 71.5 & 92.8 \\
\hline \multicolumn{17}{|l|}{ South Asia } \\
\hline Bangladesh & 0.4 & 0.7 & 0.8 & 0.4 & 0.2 & 6.3 & 44.6 & 91.7 & & 0.0 & 0.3 & 4.4 & 0.1 & 0.2 & 3.7 & 15.0 \\
\hline Bhutan & 2.5 & 5.0 & 3.6 & 2.6 & - & 5.5 & 54.2 & 90.5 & & & 1.2 & 2.1 & 0.4 & 3.8 & 13.6 & 48.1 \\
\hline India & 3.1 & 4.4 & 2.9 & 1.7 & 0.3 & 7.9 & 61.1 & 87.3 & 0.0 & 0.1 & 0.9 & 1.3 & 0.5 & 2.4 & 7.5 & 34.5 \\
\hline Maldives ${ }^{f}$ & 8.7 & 10.1 & 7.8 & 4.7 & 2.7 & 63.9 & 135.6 & 206.3 & 0.1 & 1.0 & 4.3 & 8.4 & 2.2 & 6.9 & 26.5 & 63.2 \\
\hline Nepals & 1.1 & 1.9 & 3.1 & 2.9 & 0.0 & 0.9 & 34.0 & 123.2 & & 0.0 & 0.2 & 1.7 & 0.2 & 0.8 & 7.9 & 34.0 \\
\hline Sri Lankae & 4.1 & 6.4 & 17.7 & 12.5 & 2.3 & 17.2 & 85.9 & 135.1 & 0.0 & 0.1 & 1.1 & 5.8 & 0.6 & 1.8 & 12.0 & 34.1 \\
\hline \multicolumn{17}{|l|}{ Southeast Asia } \\
\hline Brunei Darussalame & 24.2 & 23.0 & 20.6 & 16.8 & 28.5 & 63.8 & 111.9 & 127.1 & 0.6 & 2.2 & 5.6 & 9.6 & 9.0 & 36.5 & 53.0 & 94.9 \\
\hline Cambodia & 0.3 & 0.2 & 2.5 & 0.8 & 1.1 & 8.0 & 57.0 & 116.0 & 0.0 & 0.0 & 0.2 & 0.8 & 0.0 & 0.3 & 1.3 & 34.0 \\
\hline Indonesia & 3.1 & 6.0 & 16.9 & 4.2 & 1.7 & 20.7 & 87.1 & 164.9 & 0.0 & 0.0 & 0.9 & 2.4 & 0.9 & 3.6 & 10.9 & 32.3 \\
\hline Lao People's Democratic Republic & 0.8 & 1.6 & 1.7 & 16.4 & 0.2 & 11.4 & 64.1 & 54.1 & & 0.0 & 0.1 & 0.4 & 0.1 & 0.9 & 7.0 & 25.5 \\
\hline Malaysia & 20.0 & 17.0 & 16.4 & 20.8 & 22.1 & 76.2 & 120.4 & 133.9 & 0.0 & 1.9 & 7.5 & 8.5 & 21.4 & 48.6 & 56.3 & 80.1 \\
\hline Myanmar & 0.6 & 1.0 & 1.0 & 1.0 & 0.0 & 0.3 & 1.2 & 89.8 & & 0.0 & 0.0 & 0.2 & 0.0 & 0.1 & 0.3 & 30.7 \\
\hline Philippines ${ }^{\mathrm{h}}$ & 3.9 & 3.9 & 3.6 & 4.0 & 8.3 & 40.3 & 88.7 & 110.4 & 0.0 & 0.1 & 1.9 & 3.2 & 2.0 & 5.4 & 25.0 & 60.1 \\
\hline Singapore & 49.7 & 41.1 & 39.3 & 34.9 & 70.2 & 97.6 & 145.5 & 146.8 & 1.8 & 14.6 & 26.4 & 25.8 & 36.0 & 61.0 & 71.0 & 84.4 \\
\hline Thailande & 8.9 & 10.8 & 10.2 & 5.0 & 4.9 & 46.6 & 106.7 & 176.0 & 0.0 & 0.8 & 4.8 & 11.9 & 3.7 & 15.0 & 22.4 & 52.9 \\
\hline Viet Nam & 3.2 & 10.1 & 16.2 & 4.6 & 1.0 & 11.4 & 126.1 & 125.6 & 0.0 & 0.2 & 4.1 & 11.8 & 0.3 & 12.7 & 30.7 & 58.1 \\
\hline \multicolumn{17}{|l|}{ The Pacific } \\
\hline Cook Islands & & & & & & & & & & & & & & & & \\
\hline Fiji & 10.7 & 13.7 & 15.1 & 8.4 & 6.8 & 24.9 & 81.2 & 114.2 & & 0.9 & 2.7 & 1.3 & 1.5 & 8.5 & 20.0 & 50.0 \\
\hline Kiribati & 4.0 & 4.5 & 8.2 & 0.7 & 0.4 & 0.7 & 10.3 & 39.6 & & 0.3 & 0.8 & 0.1 & 1.8 & 4.0 & 9.1 & 14.6 \\
\hline Marshall Islands & 7.7 & 10.6 & & 4.5 & 0.9 & 1.3 & 29.3 & 30.1 & & & 2.4 & 1.9 & 1.5 & 3.9 & 7.0 & 38.7 \\
\hline Micronesiak Federated States of & 9.0 & 11.7 & 8.2 & 6.6 & 0.1 & 13.3 & 26.6 & 21.9 & & 0.0 & 1.0 & 3.6 & 3.7 & 11.9 & 20.0 & 35.3 \\
\hline Naurul & 17.9 & 17.8 & - & - & 12.0 & & 61.8 & 38.0 & & & 9.5 & & 3.0 & & 54.0 & 57.0 \\
\hline Niue & 55.3 & 62.4 & 61.3 & 61.4 & 21.6 & 37.9 & & & & & & & 26.5 & 51.7 & 77.0 & \\
\hline Palau ${ }^{m}$ & 35.4 & 40.1 & 34.1 & 33.8 & 12.6 & 30.4 & 70.9 & 111.5 & & 0.5 & 1.2 & 5.7 & & 27.0 & & \\
\hline Papua New Guinea & 1.2 & 1.0 & 1.7 & 1.9 & 0.2 & 1.2 & 26.9 & 48.7 & & & 0.1 & 0.2 & 0.8 & 1.7 & 1.3 & 11.2 \\
\hline Samoa & 4.9 & 10.8 & 4.3 & 4.3 & 1.4 & 13.3 & 48.3 & 363.2 & & 0.0 & 0.1 & 0.9 & 0.6 & 3.4 & 7.0 & 33.6 \\
\hline Solomon Islands & 1.9 & 1.6 & 1.6 & 1.2 & 0.3 & 1.3 & 21.9 & 76.1 & & 0.1 & 0.5 & 0.2 & 0.5 & 0.8 & 5.0 & 11.9 \\
\hline Timor-Leste & . & 0.2 & 0.3 & 0.2 & & 3.2 & 42.6 & 120.1 & & 0.0 & 0.0 & 0.3 & 0.0 & 0.1 & 3.0 & 27.5 \\
\hline Tongaf & 9.9 & 13.6 & 29.8 & 13.6 & 0.2 & 29.6 & 52.1 & 99.9 & 0.0 & 0.6 & 1.1 & 2.8 & 2.4 & 4.9 & 16.0 & 41.2 \\
\hline Tuvalu & 7.0 & 8.9 & 11.4 & 17.9 & - & 13.0 & 15.2 & 271.5 & & 1.5 & 2.3 & 4.0 & 5.2 & & 25.0 & 49.3 \\
\hline Vanuatu & 3.6 & 3.3 & 3.0 & 1.6 & 0.2 & 6.1 & 71.9 & 82.5 & & 0.0 & 0.2 & 1.6 & 2.1 & 5.1 & 8.0 & 25.7 \\
\hline \multicolumn{17}{|l|}{ Developed ADB Member Economies } \\
\hline Australia & 52.7 & 50.0 & 48.0 & 34.6 & 44.9 & 91.0 & 101.7 & 112.7 & 0.6 & 10.0 & 24.9 & 32.4 & 46.8 & 63.0 & 76.0 & 86.5 \\
\hline Japan & 48.6 & 45.2 & 51.0 & 50.2 & 52.4 & 75.2 & 95.9 & 135.5 & 0.7 & 18.2 & 26.5 & 31.8 & 30.0 & 66.9 & 78.2 & 84.6 \\
\hline New Zealand & 47.4 & 41.8 & 43.0 & 38.0 & 40.0 & 85.4 & 107.8 & 136.0 & 0.1 & 7.8 & 25.0 & 33.6 & 47.4 & 62.7 & 80.5 & 90.8 \\
\hline
\end{tabular}

... = data not available, $0.0=$ magnitude is less than half of unit employed, - = magnitude equals zero, $A D B=$ Asian Development Bank.

a The reference population differs across countries. For example, some countries refer to population of people aged 6 years and older, some refer to 7 years and older, and others refer to ages from 16 to 74 years. The details are provided in the documentation of the International Telecommunication Union.

b For fixed telephone, the figure for 2005 refers to 2003. For internet users, the figure for 2000 refers to 2001.

c For fixed broadband, the figure for 2000 refers to 2001. For internet users, the figure for 2005 refers to 2007.

d For fixed broadband, the figure for 2005 refers to 2007.

e For fixed broadband, the figure for 2000 refers to 2001.

$f$ For fixed broadband, the figure for 2000 refers to 2002.

$g$ For fixed broadband, the figure for 2005 refers to 2006.

h For fixed broadband, the figure for 2000 refers to 2001 and the figure for 2010 refers to 2011.

i For fixed telephone, the figure for 2005 refers to 2006. For fixed broadband, the figure for 2000 refers to 2002.

j For fixed telephone, the figure for 2005 refers to 2004 and the figure for 2017 refers to 2014. For mobile celluar, the figure for 2010 refers to 2014 . For fixed broadband, the figure for 2010 refers to 2013 .

k For mobile cellular, the figure for 2000 refers to 2002

I For fixed telephone, the figure for 2017 refers to 2014. For internet users, the figure for 2000 refers to 2001 and the figure for 2010 refers to 2011.

$\mathrm{m}$ For fixed telephone, the figure for 2000 refers to 2002. For moblie cellular, the figure for 2000 refers to 2002 and the figure for 2017 refers to 2015.

Source: International Telecommunication Union. World Telecommunication/ICT Indicators Database. http://www.itu.int/en/ITU-D/Statistics/Pages/stat/default. aspx (accessed 24 July 2019). 


\section{Energy and Electricity}

Energy and Electricity comprises statistics on energy demand, supplies and uses of primary energy, and electricity consumption and generation. The discussion focuses on trends across the region in energy efficiency, global share of energy production, and energy imports.

\section{All five of Asia and the Pacific's most populous economies increased their energy efficiency between 2000 and 2016.}

From 2000 to 2016, Asia and the Pacific's five most populous economies-the PRC, India, Indonesia, Pakistan, and Bangladesh-all increased their energy efficiency, measured by the amount of GDP per unit use of energy (i.e., one petajoule), as seen in Figure 2.6.1. The largest increases in GDP per petajoule among these five economies were in India ( $\$ 76.1$ million at constant $2011 \mathrm{PPP})$, Bangladesh ( $\$ 73.7$ million), and the PRC (\$57.5 million).
In absolute terms, the most energy efficient among the top five most populous economies in 2016 were Bangladesh (\$290.2 million at constant 2011 PPP per petajoule) and Indonesia (\$280.5 million). The global average for GDP per unit of energy use in 2016 was $\$ 204.0$ million at constant 2011 PPP. For regional developing member economies, the average was \$190.9 million at constant 2011 PPP. For ADB's three developed member economies in Asia and the Pacific, the average was $\$ 251.0$ million at constant 2011 PPP.

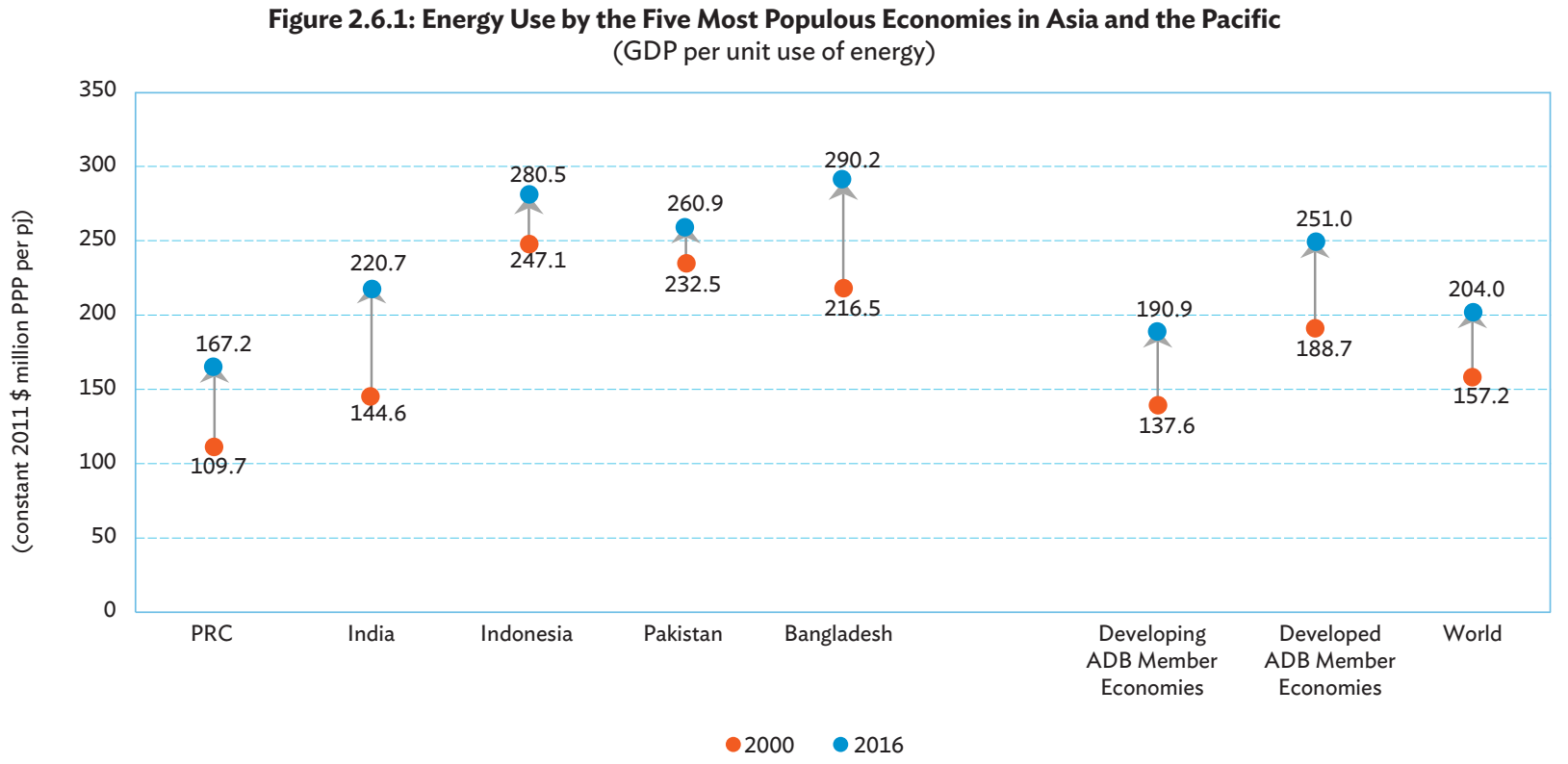

$\$=$ United States dollars, ADB = Asian Development Bank, GDP = Gross Domestic Product, PJ = petajoule, PPP = purchasing power parity, $\mathrm{PRC}=$ People's Republic of China. Source: $\quad$ Table 2.6.3, Key Indicators for Asia and the Pacific 2019. 


\section{The PRC is becoming a global energy production powerhouse}

Asia and the Pacific's energy production comprised $33.7 \%$ of the global total in 2016, compared with $24.6 \%$ in 2000 (Figure 2.6.2, Table 2.6.4). The increase during the review period was mainly driven by expanded energy production in the PRC, which saw its global share of energy production rise from $9.9 \%$ in 2000 to $16.6 \%$ in 2016 .

The PRC accounted for $49.3 \%$ of energy generated in Asia and the Pacific in 2016, up from $40.2 \%$ in 2000 . The region's next largest energy producers, and their respective shares of regional production, were India (12.1\% in 2016 , down from $15.5 \%$ in 2000 ), Indonesia (9.8\% in 2016 , up from $8.0 \%$ in 2000), and Australia (8.5\% in 2016, down from $9.6 \%$ in 2000).

\section{Nearly two-thirds of regional economies were net energy importers in 2016.}

In 2016, 14 regional economies were net energy exporters, while 29 were net energy importers. Compared with their respective status in 2000 (or the earliest year for which data are available), the Lao People's Democratic Republic, Mongolia, and Timor-Leste had all switched from being net energy importers to being net energy exporters by 2016 . Conversely, Viet Nam, which had been a net energy exporter in 2000, was a net energy importer in 2016.

The oil- and gas-rich economies of Timor-Leste, Brunei Darussalam, and Azerbaijan led the region in terms of energy exports as a share of domestic energy use in 2016 (Figure 2.6.3). Energy exports from Timor-Leste in 2016 were equivalent to $1,412.5 \%$ of the economy's domestic energy use. For Brunei Darussalam and Azerbaijan, these percentages were $410.5 \%$ and $305.9 \%$, respectively.

Figure 2.6.2: Energy production by global region and by economy in Asia and the Pacific, 2016 (petajoules, \%)

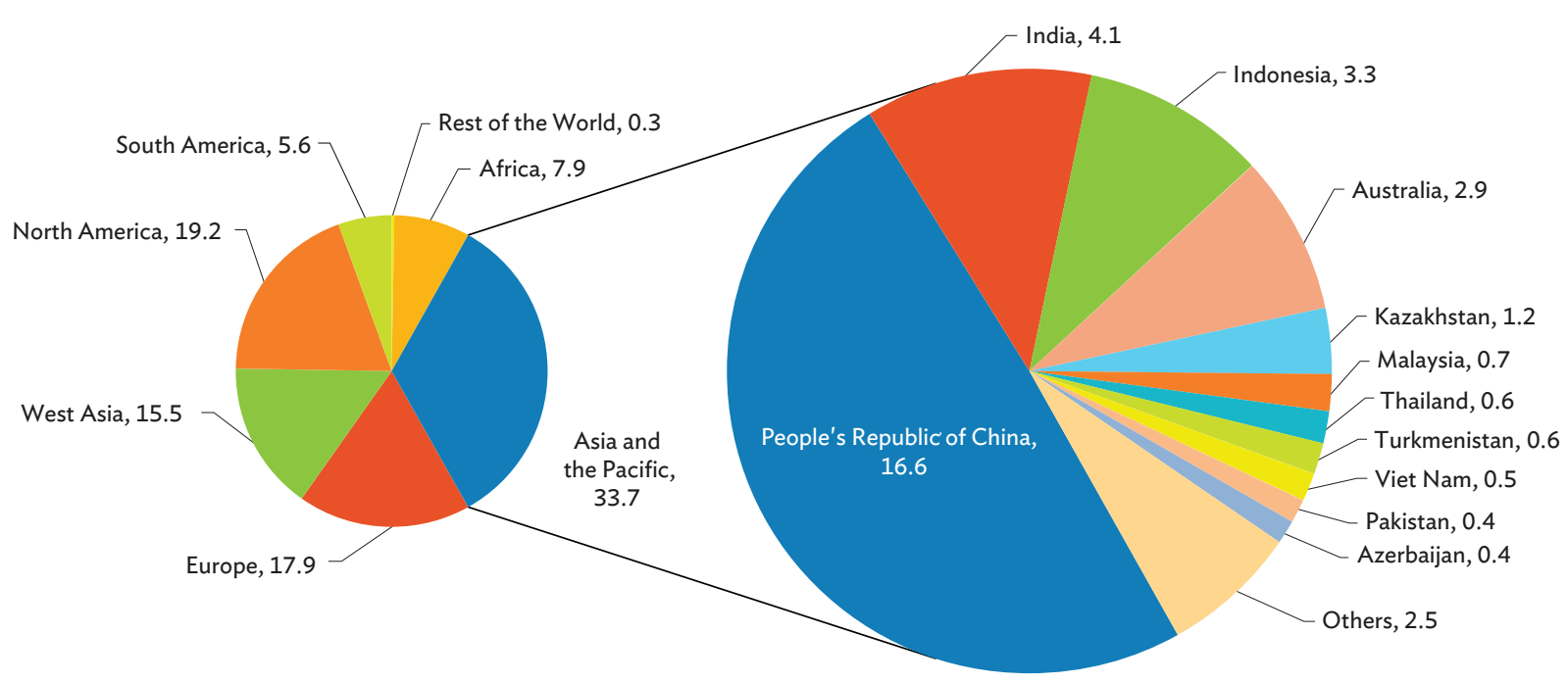


Figure 2.6.3: Net Energy Imports as Share of Energy Use in Select Economies of Asia and the Pacific

(\%)

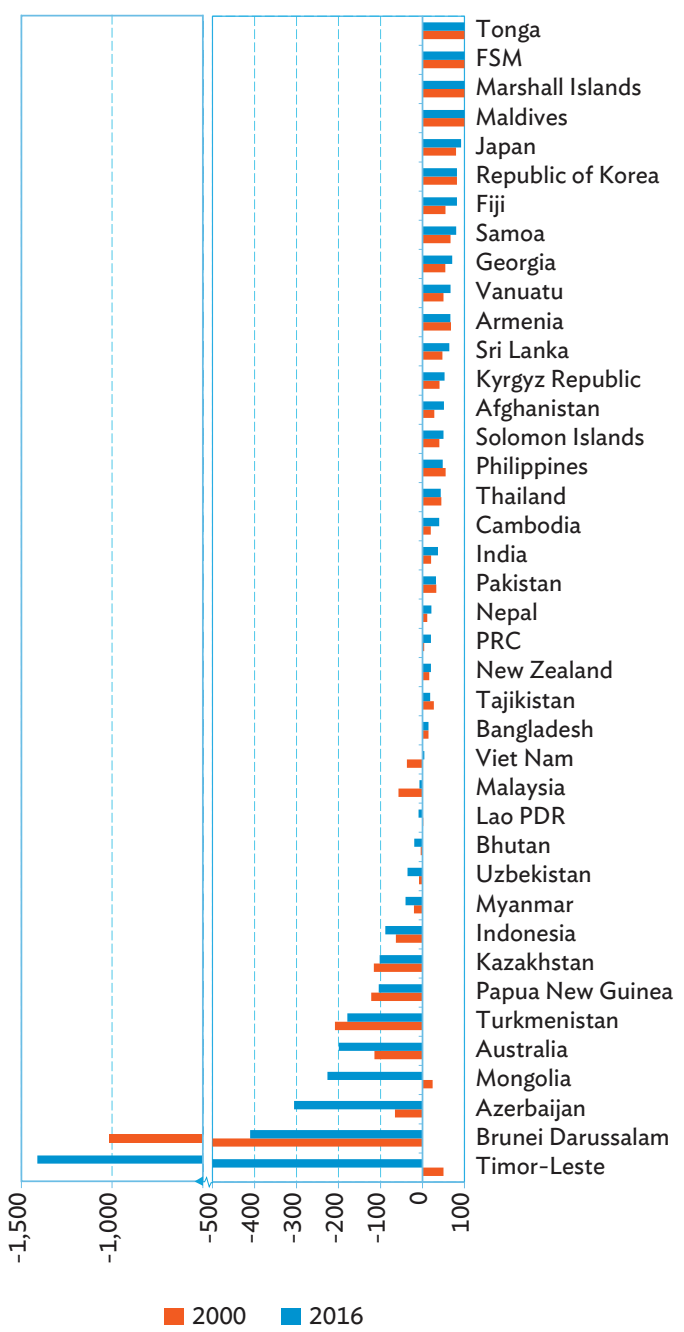

FSM = Federated States of Micronesia, Lao PDR = Lao People's Democratic Republic, PRC $=$ People's Republic of China.

Note: The chart includes economies with available data for 2000 (or the earliest year) and 2016. For Timor-Leste, the earliest year for which data are vailable is 2002.

Source: Table 2.6.4, Key Indicators for Asia and the Pacific 2019.

\section{Data Issues and Comparability}

Energy data are compiled by the United Nations Statistics Division (UNSD) using standard procedures that follow the definitions of the United Nations International Recommendations for Energy Statistics. ${ }^{4}$ The UNSD Annual Questionnaire on Energy Statistics to the UN member economies is the primary source of information. Additional sources of information for the UNSD energy database include national, regional, and international statistical publications. These include, but are not limited to, publications from the International Energy Agency, the Statistical Office of the European Communities (Eurostat), the International Atomic Energy Agency, the Organization of the Petroleum Exporting Countries, and the Organización Latinoamericana de Energía. The UNSD prepares estimates where official data are incomplete or inconsistent. For the indicator on GDP per unit use of energy, the energy statistics adopt the territory principle, while national accounts are being compiled on the residency principle, which could be a potential source of inconsistency, although in practice differences are not huge (UN 2016).

Data for the household electrification indicator are lacking. Data are posted over a varied range of years, i.e., different starting and ending years, depending on data availability. These data may therefore not be comparable, limiting possibilities for analysis.

Click here for figure datc

The island economies of the Federated States of Micronesia, Maldives, the Marshall Islands, and Tonga relied on imports for $100 \%$ of their energy use in both 2000 and 2016.

4 For the full definitions of the International Recommendations for Energy Statistics, go to https://unstats.un.org/UNSD/energy/ires/. 
Table 2.6.1: $\quad$ Electricity Production and Sources

\begin{tabular}{|c|c|c|c|c|c|c|c|c|c|c|}
\hline \multirow{3}{*}{ ADB Regional Member } & \multirow{2}{*}{\multicolumn{2}{|c|}{$\begin{array}{c}\text { Total Electricity } \\
\text { Production (billion kWh) }\end{array}$}} & \multicolumn{8}{|c|}{ Sources of Electricity (\% of total) } \\
\hline & & & \multicolumn{2}{|c|}{ Combustible Fuels ${ }^{\mathrm{a}}$} & \multicolumn{2}{|c|}{ Hydropower } & \multicolumn{2}{|r|}{ Solar } & \multicolumn{2}{|c|}{ Others ${ }^{b}$} \\
\hline & 2000 & 2016 & 2000 & 2016 & 2000 & 2016 & 2000 & 2016 & 2000 & 2016 \\
\hline \multicolumn{11}{|l|}{ Developing ADB Member Economies } \\
\hline \multicolumn{11}{|l|}{ Central and West Asia } \\
\hline Afghanistan & 0.7 & $1.1(2017)$ & 25.0 & $15.3(2017)$ & 75.0 & $84.7(2017)$ & - & - & - & - \\
\hline Armenia & 6.0 & $7.8(2017)$ & 45.2 & $37.0(2017)$ & 21.2 & $29.2(2017)$ & - & 0.0 & 33.7 & $33.8(2017)$ \\
\hline Azerbaijan & 18.7 & 25.0 & 91.8 & 91.9 & 8.2 & 7.9 & - & 0.1 & - & 0.1 \\
\hline Georgia & 7.4 & $11.5(2017)$ & 21.1 & 19.4 (2017) & 78.9 & $79.9(2017)$ & - & - & - & - \\
\hline Kazakhstan & 51.6 & 106.6 & 85.4 & 88.8 & 14.6 & 10.9 & - & 0.1 & - & 0.3 \\
\hline Kyrgyz Republic & 16.0 & 13.3 & 14.4 & 13.3 & 85.6 & 86.7 & - & - & - & - \\
\hline Pakistan & 65.8 & 123.1 & 70.1 & 66.0 & 29.3 & 26.1 & - & - & 0.6 & 7.9 \\
\hline Tajikistan & 14.2 & $18.1(2017)$ & 2.3 & $5.6(2017)$ & 97.7 & $94.4(2017)$ & - & - & - & - \\
\hline Turkmenistan & 9.8 & 22.5 & 100.0 & 100.0 & - & - & - & - & - & - \\
\hline Uzbekistan & 46.9 & 58.3 & 87.5 & 79.7 & 12.5 & 20.3 & - & - & - & - \\
\hline \multicolumn{11}{|l|}{ East Asia } \\
\hline China, People's Republic of & $1,355.6$ & $6,142.5$ & 82.4 & 72.2 & 16.4 & 19.4 & - & 1.0 & 1.2 & 7.3 \\
\hline Hong Kong, China & 31.3 & $37.0(2017)$ & 100.0 & $100.0(2017)$ & - & 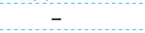 & - & $\ldots$ & $\ldots$ & $\ldots$ \\
\hline Korea, Republic of & 290.1 & 562.6 & 60.5 & 68.5 & 1.9 & 1.2 & 0.0 & 0.9 & 37.6 & 29.3 \\
\hline Mongolia & 2.9 & 5.7 & 100.0 & $100.0(2017)$ & - & - & - & - & - & - \\
\hline Taipei,China & 184.8 & $273.6(2018)$ & $\ldots$ & 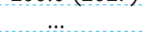 & $\cdots$ & $\cdots$ & $\cdots$ & $\ldots$ & $\cdots$ & $\cdots$ \\
\hline \multicolumn{11}{|l|}{ South Asia } \\
\hline Bangladesh & 15.8 & 64.3 & 94.0 & 98.9 & 6.0 & 0.9 & - & 0.3 & - & 0.0 \\
\hline Bhutan & 1.8 & 8.0 & - & - & 100.0 & 100.0 & - & - & - & 0.0 \\
\hline India & 560.8 & $1,432.4$ & 83.4 & 83.0 & 13.3 & 8.6 & - & 0.9 & 3.3 & 7.6 \\
\hline Maldives & 0.1 & 0.6 & 100.0 & 99.2 & - & - & - & 0.8 & - & $\ldots$ \\
\hline Nepal & 1.7 & 4.2 & 1.6 & - & 98.4 & 99.8 & - & 0.0 & - & 0.1 \\
\hline Sri Lanka & 7.0 & 14.4 & 54.0 & 67.7 & 46.0 & 29.4 & 0.0 & 0.5 & 0.0 & 2.4 \\
\hline \multicolumn{11}{|l|}{ Southeast Asia } \\
\hline Brunei Darussalam & 2.8 & 4.3 & 100.0 & 100.0 & - & - & - & 0.0 & - & - \\
\hline Cambodia & 0.3 & 5.6 & 85.9 & 53.1 & 14.1 & 46.8 & - & 0.1 & - & - \\
\hline Indonesia & 99.5 & 233.4 & 83.5 & 86.2 & 13.8 & 9.2 & - & 0.0 & 2.7 & 4.6 \\
\hline Lao People's Democratic Republic & 4.0 & 25.1 & 9.1 & 28.4 & 90.9 & 71.6 & - & 0.0 & - & - \\
\hline Malaysia & 69.2 & 156.7 & 89.3 & 87.0 & 10.7 & 12.8 & - & 0.2 & - & - \\
\hline Myanmar & 5.1 & 17.9 & 63.0 & 45.5 & 37.0 & 54.5 & - & & - & - \\
\hline Philippines & 45.3 & 93.4 (2017) & 57.1 & $76.2(2017)$ & 17.2 & $10.3(2017)$ & - & $1.3(2017)$ & 25.6 & $12.2(2017)$ \\
\hline Singapore & 31.7 & 51.6 & 100.0 & 100.0 & - & - & - & - & - & - \\
\hline Thailand & 106.1 & 191.3 & 94.3 & 94.4 & 5.7 & 3.6 & - & 1.8 & 0.0 & 0.2 \\
\hline Viet $\mathrm{Nam}$ & 26.6 & 191.6 (2017) & 45.2 & 53.5 (2017) & 54.8 & $46.4(2017)$ & - & - & - & 0.1 (2017) \\
\hline \multicolumn{11}{|l|}{ The Pacific } \\
\hline Cook Islands & 0.0 & 0.0 & 100.0 & 90.7 (2017) & - & - & - & $9.3(2017)$ & - & - \\
\hline Fiji & 0.7 & 0.9 & 39.8 & 46.6 & 60.2 & 53.0 & - & - & - & 0.4 \\
\hline Kiribati & 0.0 & 0.0 & 100.0 & 84.0 & - & - & - & 16.0 & - & - \\
\hline Marshall Islands & 0.1 & 0.1 & 100.0 & 97.7 & - & - & - & 2.3 & - & - \\
\hline Micronesia, Federated States of & 0.1 & 0.1 & 99.8 & 96.9 & - & 0.2 & 0.2 & 3.0 & - & - \\
\hline Nauru & 0.0 & 0.0 & 100.0 & 98.9 & - & - & - & 1.1 & - & - \\
\hline Niue & 0.0 & 0.0 & 100.0 & 97.9 & - & - & - & 2.1 & - & - \\
\hline Palau & 0.1 & 0.1 & 100.0 & 100.0 & - & - & - & - & - & - \\
\hline Papua New Guinea & 2.4 & 4.4 & 52.9 & 67.9 & 39.2 & 22.6 & - & - & 7.8 & 9.4 \\
\hline Samoa & 0.1 & 0.1 & 50.4 & 67.5 & 49.6 & 22.0 & - & 10.4 & - & 0.1 \\
\hline Solomon Islands & 0.1 & 0.1 & 100.0 & 97.9 & - & - & - & 2.1 & - & - \\
\hline Timor-Leste & $0.1(2002)$ & 0.4 & $100.0(2002)$ & 100.0 & - & - & - & $\ldots$ & - & - \\
\hline Tonga & 0.0 & 0.1 & 100.0 & 92.1 & - & - & - & 7.8 & - & 0.0 \\
\hline Tuvalu & 0.0 & 0.0 & 100.0 & 63.0 & - & - & - & 37.0 & - & - \\
\hline Vanuatu & 0.0 & 0.1 & 100.0 & 79.5 & - & 9.9 & - & 2.8 & - & 7.8 \\
\hline \multicolumn{11}{|l|}{ Developed ADB Member Economies } \\
\hline Australia & 210.2 & 256.6 & 92.0 & 86.9 & 8.0 & 6.0 & 0.0 & 2.4 & 0.0 & 4.8 \\
\hline Japan & $1,070.3$ & $1,058.0$ & 58.6 & 82.6 & 9.0 & 8.0 & 0.0 & 4.8 & 32.3 & 4.5 \\
\hline New Zealand & 39.2 & 43.0 & 29.8 & 17.3 & 62.3 & 59.8 & - & 0.1 & 7.8 & 22.6 \\
\hline
\end{tabular}

$\ldots=$ data not available, - = magnitude equals zero, 0.0 = magnitude is less than half of unit employed, $A D B=A s i a n$ Development Bank, $\mathrm{kWh}=\mathrm{kilowatt}-\mathrm{hour}$.

a Electricity from combustible fuels refers to the production of electricity from the combustion of fuels that are capable of igniting or burning, which would include coal, natural gas, oil, and other combustible fuels.

b Includes chemical heat, geothermal, nuclear, tide, other marine electricity, wind, wave, and other sources of energy.

Sources: United Nations. Energy Statistics Database. http://data.un.org/Explorer.aspx?d=EDATA (accessed17 July2019). For Taipei,China: Government of Taipei,China; Directorate-General of Budget, Accounting and Statistics; Official communication, 17 May 2018. 
Table 2.6.2: $\quad$ Electric Power Consumption and Electrification

\begin{tabular}{|c|c|c|c|c|}
\hline \multirow[t]{2}{*}{ ADB Regional Member } & \multicolumn{2}{|c|}{$\begin{array}{l}\text { Electric Power Consumption } \\
\text { (per capita kWh) }\end{array}$} & \multicolumn{2}{|c|}{$\begin{array}{l}\text { Household Electrification Rate } \\
\text { ( } \% \text { of households) }\end{array}$} \\
\hline & 2000 & 2016 & 2000 & 2016 \\
\hline \multicolumn{5}{|l|}{ Developing ADB Member Economies } \\
\hline \multicolumn{5}{|l|}{ Central and West Asia } \\
\hline Afghanistan & 30 & 123 & $25.0(2005)$ & $71.5(2015)$ \\
\hline Armenia & 1,170 & 1,815 & 98.9 & 100.0 \\
\hline Azerbaijan & 1,914 & 2,117 & $99.5(2006)$ & \\
\hline Georgia & 1,542 & 2,817 & $\ldots$ & $\ldots$ \\
\hline Kazakhstan & 2,773 & 4,275 & & \\
\hline Kyrgyz Republic & 1,891 & 1,715 & $100.0(2002)$ & $99.8(2012)$ \\
\hline Pakistan & 320 & 469 & $89.2(2006)$ & $92.7(2018)$ \\
\hline Tajikistan & 2,146 & 1,499 & $99.0(2002)$ & $99.2(2017)$ \\
\hline Turkmenistan & 1,526 & 2,602 & 99.6 & 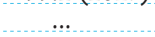 \\
\hline Uzbekistan & 1,669 & 1,526 & $99.7(2002)$ & \\
\hline \multicolumn{5}{|l|}{ East Asia } \\
\hline China, People's Republic of & 993 & 3,867 & $\ldots$ & $\ldots$ \\
\hline Hong Kong, China & 5,446 & $5,930(2017)$ & . & $\ldots$ \\
\hline Korea, Republic of & 5,597 & 10,345 & & $\ldots$ \\
\hline Mongolia & 970 & 1,910 (2017) & 67.3 & $\ldots$ \\
\hline Taipei,China & 7,956 & 11,212 (2018) & $\ldots$ & $\ldots$ \\
\hline \multicolumn{5}{|l|}{ South Asia } \\
\hline Bangladesh & 98 & 335 & 32.0 & $62.4(2014)$ \\
\hline Bhutan & 675 & 2,727 & $41.1(2003)$ & $72.0(2007)$ \\
\hline India & 300 & 809 & $67.9(2006)$ & 88.2 \\
\hline Maldives & 487 & 1,247 & 83.8 & $99.8(2017)$ \\
\hline Nepal & 54 & 181 & $24.6(2001)$ & 90.5 \\
\hline Sri Lanka & 290 & 600 & & $\ldots$ \\
\hline \multicolumn{5}{|l|}{ Southeast Asia } \\
\hline Brunei Darussalam & 7,561 & 8,690 & & \\
\hline Cambodia & 29 & 384 & 16.6 & $56.1(2014)$ \\
\hline Indonesia & 374 & 825 & $90.7(2003)$ & $96.0(2012)$ \\
\hline Lao People's Democratic Republic & 120 & 714 (2017) & $46.3(2002)$ & $\ldots$ \\
\hline Malaysia & 2,637 & 4,694 & & \\
\hline Myanmar & 70 & 292 & $47.0(2002)$ & 55.6 \\
\hline Philippines & 469 & 497 (2017) & $76.6(2003)$ & $92.7(2017)$ \\
\hline Singapore & 7,233 & 8,672 & 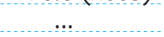 & $+x-1$ \\
\hline Thailand & 1,558 & 2,816 & & \\
\hline Viet Nam & 284 & 1,706 & $89.1(2002)$ & $96.1(2005)$ \\
\hline \multicolumn{5}{|l|}{ The Pacific } \\
\hline Cook Islands & 1,389 & 1,867 (2017) & $97.0(2006)$ & 99.5 \\
\hline Fiji & 749 & 965 & & $84.0(2009)$ \\
\hline Kiribati & 169 & 218 & $\ldots$ & $92.6(2015)$ \\
\hline Marshall Islands & 1,517 & 1,320 & $\ldots$ & $90.0(2011)$ \\
\hline Micronesia, Federated States of & 705 & 418 & n & $72.8(2013)$ \\
\hline Nauru & 2,902 & 1,770 & $100.0(2002)$ & $100.0(2013)$ \\
\hline Niue & & & & 98.7 \\
\hline Palau & 4,481 & 4,000 & $99.0(2005)$ & $98.3(2015)$ \\
\hline Papua New Guinea & 390 & 483 & & $19.5(2010)$ \\
\hline Samoa & 516 & 690 & $98.0(2006)$ & 96.4 \\
\hline Solomon Islands & 139 & 145 & $14.0(2005)$ & $55.1(2015)$ \\
\hline Timor-Leste & $52(2002)$ & 273 & $27.0(2002)$ & $38.0(2009)$ \\
\hline Tonga & 369 & 527 & $89.0(2006)$ & 97.0 \\
\hline Tuvalu & 309 & 722 & $94.0(2005)$ & 97.3 \\
\hline Vanuatu & 224 & 235 & $\ldots$ & 57.8 \\
\hline \multicolumn{5}{|l|}{ Developed ADB Member Economies } \\
\hline Australia & 9,390 & 9,478 & $\ldots$ & $\ldots$ \\
\hline Japan & 7,533 & 7,725 & $\ldots$ & $\ldots$ \\
\hline New Zealand & 9,016 & 8,348 & $\ldots$ & $\ldots$ \\
\hline
\end{tabular}

$\ldots=$ data not available, $\mathrm{ADB}=$ Asian Development Bank, $\mathrm{kWh}=$ kilowatt-hour.

Sources: $\quad$ For Electric Power Consumption: United Nations. Energy Statistics Database. http://data.un.org/Explorer.aspx?d=EDATA (accessed 17 July 2019); and for Taipei,China: Asian Development Bank estimates using economy source. For Household Electrification Rate: World Bank. International Development Association Results Measurement System. http://data.worldbank.org/data-catalog/IDA-results-measurement. (accessed17 July2019); United States Agency for International Development. Demographic and Health Surveys Program. STAT Compiler. http://www.statcompiler.com/ (accessed 17 July 2019); and Secretariat of the Pacific Community. National Minimum Development Indicators. http://www.spc.int/nmdi/MdiHome.aspx (accessed 17 July 2019 ). 


\section{Energy}

Table 2.6.3: Use of Energy

\begin{tabular}{|c|c|c|c|c|c|c|c|c|}
\hline \multirow[t]{2}{*}{ ADB Regional Member } & \multicolumn{4}{|c|}{$\begin{array}{l}\text { Energy Use } \\
(P J)\end{array}$} & \multicolumn{4}{|c|}{$\begin{array}{c}\text { GDP per Unit Use of Energy } \\
\text { (constant } 2011 \text { million PPP per PJ) }\end{array}$} \\
\hline & 2000 & 2005 & 2010 & 2016 & 2000 & 2005 & 2010 & 2016 \\
\hline \multirow{2}{*}{\multicolumn{9}{|c|}{ Developing ADB Member Economies }} \\
\hline & \multicolumn{8}{|c|}{ Central and West Asia } \\
\hline Afghanistan & $32(2002)$ & 36 & 137 & 143 & $717.7(2002)$ & 783.2 & 356.1 & 434.7 \\
\hline Armenia & 84 & 105 & 119 & 131 & 106.9 & 152.1 & 162.1 & 182.9 \\
\hline Azerbaijan & 485 & 573 & 486 & 598 & 76.4 & 119.8 & 302.1 & 263.2 \\
\hline Georgia & 120 & 135 & 140 & 204 & 119.8 & 151.6 & 188.8 & 169.1 \\
\hline Kazakhstan & 1,560 & 2,352 & 3,363 & 3,335 & 94.9 & 103.1 & 97.5 & 125.1 \\
\hline Kyrgyz Republic & 101 & 114 & 115 & 162 & 100.6 & 107.3 & 132.2 & 124.0 \\
\hline Pakistan & 2,082 & 2,642 & 3,094 & 3,597 & 232.5 & 233.8 & 236.1 & 260.9 \\
\hline Tajikistan & 141 & 148 & 143 & 166 & 52.3 & 78.9 & 112.6 & 145.3 \\
\hline Turkmenistan & 625 & 805 & 951 & 1,158 & 38.5 & 38.4 & 53.2 & 76.5 \\
\hline Uzbekistan & 2,130 & 2,050 & 1,809 & 1,574 & 29.2 & 39.3 & 67.0 & 119.0 \\
\hline \multicolumn{9}{|l|}{ East Asia } \\
\hline China, People's Republic of & 42,461 & 68,833 & 101,618 & 118,484 & 109.7 & 108.0 & 125.0 & 167.2 \\
\hline Hong Kong, China & 570 & 579 & 544 & 590 & 397.8 & 481.5 & 621.2 & 676.7 \\
\hline Korea, Republic of & 7,854 & 8,764 & 10,441 & 11,762 & 124.2 & 140.3 & 144.1 & 152.6 \\
\hline Mongolia & 87 & 104 & 164 & 294 & 128.3 & 146.9 & 127.5 & 116.9 \\
\hline Taipei,China & $\ldots$ & $\ldots$ & $\ldots$ & $\ldots$ & $\cdots$ & $\ldots$ & $\ldots$ & $\ldots$ \\
\hline \multicolumn{9}{|l|}{ South Asia } \\
\hline Bangladesh & 998 & 1,191 & 1,493 & 1,864 & 216.5 & 232.4 & 248.9 & 290.2 \\
\hline Bhutan & 44 & 48 & 57 & 66 & 46.1 & 61.9 & 82.0 & 99.8 \\
\hline India & 19,808 & 22,706 & 29,193 & 36,886 & 144.6 & 172.4 & 188.2 & 220.7 \\
\hline Maldives & 6 & 9 & 13 & 21 & 456.5 & 328.5 & 336.6 & 294.8 \\
\hline Nepal & 349 & 388 & 446 & 536 & 104.7 & 111.3 & 120.3 & 124.5 \\
\hline Sri Lanka & 296 & 324 & 360 & 467 & 351.6 & 390.3 & 478.6 & 519.7 \\
\hline \multicolumn{9}{|l|}{ Southeast Asia } \\
\hline Brunei Darussalam & 73 & 76 & 136 & 124 & 374.6 & 398.6 & 230.2 & 245.0 \\
\hline Cambodia & 142 & 144 & 223 & 317 & 118.5 & 181.5 & 161.9 & 172.4 \\
\hline Indonesia & 4,970 & 7,087 & 8,322 & 10,021 & 247.1 & 218.3 & 245.8 & 280.5 \\
\hline Lao People's Democratic Republic & 58 & 68 & 100 & 244 & 228.3 & 263.6 & 263.5 & 168.2 \\
\hline Malaysia & 1,959 & 2,745 & 2,965 & 3,527 & 193.0 & 173.7 & 200.1 & 227.1 \\
\hline Myanmar & 538 & 619 & 663 & 836 & 111.9 & 178.2 & 281.5 & 335.6 \\
\hline Philippines & 1,551 & 1,469 & 1,631 & 2,126 & 212.4 & 280.7 & 321.6 & 351.5 \\
\hline Singapore & 756 & 805 & 1,109 & 910 & 279.0 & 331.9 & 334.5 & 521.9 \\
\hline Thailand & 3,075 & 4,067 & 4,945 & 5,794 & 188.1 & 185.4 & 183.3 & 187.0 \\
\hline Viet Nam & 1,262 & 1,756 & 2,319 & 3,006 & 163.0 & 163.5 & 168.2 & 183.7 \\
\hline \multicolumn{9}{|l|}{ The Pacific } \\
\hline Cook Islands & 1 & 1 & 1 & 1 & & & & \\
\hline Fiji & 22 & 24 & 21 & 33 & 246.1 & 254.3 & 301.1 & 237.1 \\
\hline Kiribati & 1 & 1 & 1 & 1 & 167.9 & 180.8 & 180.3 & 230.4 \\
\hline Marshall Islands & 2 & 2 & 2 & 2 & 75.5 & 84.2 & 91.2 & 99.0 \\
\hline Micronesia, Federated States of & 2 & 2 & 2 & 2 & 167.5 & 172.8 & 170.8 & 172.0 \\
\hline Nauru & 1 & 1 & 1 & 1 & & $\ldots$ & 66.1 & 169.0 \\
\hline Niue & - & - & - & - & & & & \\
\hline Palau & 3 & 3 & 3 & 3 & 78.6 & 92.4 & 81.6 & 101.4 \\
\hline Papua New Guinea & 99 & 126 & 141 & 184 & 154.5 & 135.1 & 160.9 & 175.2 \\
\hline Samoa & 3 & 3 & 4 & 5 & 251.8 & 320.0 & 251.4 & 230.9 \\
\hline Solomon Islands & 5 & 6 & 6 & 6 & 149.9 & 131.6 & 164.6 & 217.7 \\
\hline Timor-Leste & & 4 & 4 & 8 & & $1,617.3$ & $2,461.9$ & $1,153.1$ \\
\hline Tonga & 1 & 2 & 2 & 2 & 451.3 & 249.9 & 259.5 & 285.3 \\
\hline Tuvalu & - & - & - & - & & & & \\
\hline Vanuatu & 2 & 2 & 3 & 3 & 261.2 & 273.2 & 232.2 & 257.5 \\
\hline Developed ADB Member Economies & 26,942 & 27,355 & 27,187 & 24,245 & 188.7 & 200.4 & 207.2 & 251.0 \\
\hline Australia & 4,540 & 4,762 & 5,417 & 5,451 & 149.3 & 166.9 & 168.9 & 198.0 \\
\hline Japan & 21,655 & 21,847 & 20,938 & 17,845 & 198.4 & 208.5 & 218.7 & 271.2 \\
\hline New Zealand & 747 & 746 & 832 & 949 & 145.1 & 176.9 & 168.6 & 176.6 \\
\hline DEVELOPING ADB MEMBER ECONOMIES & 94,359 & 130,919 & 177,290 & 209,194 & 137.7 & 140.7 & 154.1 & 190.9 \\
\hline ALL ADB REGIONAL MEMBERS ${ }^{\mathrm{a}}$ & 121,301 & 158,274 & 204,477 & 233,439 & 149.0 & 151.0 & 161.2 & 197.1 \\
\hline WORLD & 404,363 & 463,300 & 517,492 & 551,579 & 157.2 & 165.2 & 176.9 & 204.0 \\
\hline
\end{tabular}

... = data not available, - = magnitude equals zero, $\$$ = United States dollars, $\mathrm{ADB}=$ Asian Development Bank, GDP = gross domestic product, $\mathrm{PJ}=$ petajoule, $\mathrm{PPP}=$ purchasing power parity.

a Includes only reporting economies with data corresponding to the year heading.

Sources: $\quad$ For Energy Use: United Nations Statistics Division. Official communication, 25 July 2019. For GDP per Unit Use of Energy: Asian Development Bank estimates. 
Table 2.6.4: Energy Production and Imports

\begin{tabular}{|c|c|c|c|c|c|c|c|c|}
\hline \multirow[t]{2}{*}{ ADB Regional Member } & \multicolumn{4}{|c|}{$\begin{array}{l}\text { Energy Production } \\
\text { (PJ) }\end{array}$} & \multicolumn{4}{|c|}{$\begin{array}{l}\text { Energy Imports, Net } \\
\text { (\% of energy use) }\end{array}$} \\
\hline & 2000 & 2005 & 2010 & 2016 & 2000 & 2005 & 2010 & 2016 \\
\hline \\
\hline & \multicolumn{8}{|c|}{ Central and West Asia } \\
\hline Afghanistan & 18 & 23 & 41 & 70 & 28.0 & 36.1 & 70.1 & 51.0 \\
\hline Armenia & 27 & 36 & 52 & 44 & 67.9 & 65.7 & 56.3 & 66.4 \\
\hline Azerbaijan & 803 & 1,155 & 2,759 & 2,427 & -65.6 & -101.6 & -467.7 & -305.9 \\
\hline Georgia & 55 & 53 & 58 & 60 & 54.2 & 60.7 & 58.6 & 70.6 \\
\hline Kazakhstan & 3,367 & 5,131 & 6,770 & 6,737 & -115.8 & -118.2 & -101.3 & -102.0 \\
\hline Kyrgyz Republic & 60 & 61 & 53 & 77 & 40.6 & 46.5 & 53.9 & 52.5 \\
\hline $\begin{array}{l}\text { Pakistan } \\
\text { Pak }\end{array}$ & 1,403 & 2,020 & 2,253 & 2,438 & 32.6 & 23.5 & 27.2 & 32.2 \\
\hline Tajikistan & 103 & 115 & 115 & 136 & 27.0 & 22.3 & 19.6 & 18.1 \\
\hline Turkmenistan & 1,928 & 2,584 & 1,982 & 3,230 & -208.5 & -221.0 & -108.4 & -178.9 \\
\hline Uzbekistan & 2,307 & 2,446 & 2,309 & 2,134 & -8.3 & -19.3 & -27.6 & -35.6 \\
\hline \multicolumn{9}{|l|}{ East Asia } \\
\hline China, People's Republic of & 40,783 & 63,831 & 88,642 & 94,591 & 4.0 & 7.3 & 12.8 & 20.2 \\
\hline \multicolumn{9}{|l|}{ Hong Kong, China } \\
\hline Korea, Republic of & 1,420 & 1,776 & 1,855 & 2,117 & 81.9 & 79.7 & 82.2 & 82.0 \\
\hline Mongolia & 66 & 138 & 655 & 959 & 24.1 & -32.7 & -299.4 & -226.2 \\
\hline \multicolumn{9}{|l|}{ Taipei,China } \\
\hline \multicolumn{9}{|l|}{ South Asia } \\
\hline Bangladesh & 857 & 1,027 & 1,304 & 1,597 & 14.1 & 13.8 & 12.7 & 14.3 \\
\hline Bhutan & 46 & 53 & 73 & 79 & -4.5 & -10.4 & -28.1 & -19.7 \\
\hline India & 15,763 & 18,212 & 22,888 & 23,301 & 20.4 & 19.8 & 21.6 & 36.8 \\
\hline Maldives & - & - & - & 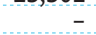 & 100.0 & 100.0 & 100.0 & 100.0 \\
\hline Nepal & 310 & 349 & 384 & 422 & 11.2 & 10.1 & 13.9 & 21.3 \\
\hline Sri Lanka & 156 & 163 & 184 & 169 & 47.3 & 49.7 & 48.9 & 63.8 \\
\hline \multicolumn{9}{|l|}{ Southeast Asia } \\
\hline Brunei Darussalam & 813 & 848 & 775 & 633 & $-1,013.7$ & $-1,015.8$ & -469.9 & -410.5 \\
\hline Cambodia & 114 & 105 & 152 & 191 & 19.7 & 27.1 & 31.8 & 39.7 \\
\hline Indonesia & 8,129 & 11,351 & 16,854 & 18,885 & -63.6 & -60.2 & -102.5 & -88.5 \\
\hline Lao People's Democratic Republic & 57 & 64 & 98 & 267 & 1.7 & 5.9 & 2.0 & -9.4 \\
\hline $\begin{array}{l}\text { Malaysia } \\
\text { lats }\end{array}$ & 3,082 & 3,770 & 3,450 & 3,787 & -57.3 & -37.3 & -16.4 & -7.4 \\
\hline Myanmar & 648 & 927 & 969 & 1,175 & -20.4 & -49.8 & -46.2 & -40.6 \\
\hline Philippines & 695 & 762 & 924 & 1,106 & 55.2 & 48.1 & 43.3 & 48.0 \\
\hline Singapore & & & 25 & 28 & & & 97.7 & 96.9 \\
\hline Thailand & 1,700 & 2,144 & 2,952 & 3,283 & 44.7 & 47.3 & 40.3 & 43.3 \\
\hline Viet Nam & 1,733 & 2,612 & 2,747 & 2,880 & -37.3 & -48.7 & -18.5 & 4.2 \\
\hline \multicolumn{9}{|l|}{ The Pacific } \\
\hline Cook Islands & & & & - & & & & 100.0 \\
\hline $\mathrm{Fiji}$ & 10 & 9 & 5 & 6 & 54.5 & 62.5 & 76.2 & 81.8 \\
\hline Kiribati & - & - & 1 & 1 & 100.0 & 100.0 & - & - \\
\hline Marshall Islands & - & - & - & - & 100.0 & 100.0 & 100.0 & 100.0 \\
\hline Micronesia, Federated States of & - & - & - & - & 100.0 & 100.0 & 100.0 & 100.0 \\
\hline Nauru & $\ldots$ & $-(2006)$ & - & - & $\ldots$ & $100.0(2006)$ & 100.0 & 100.0 \\
\hline Niue & - & - & - & - & $\ldots$ & $\ldots$ & $\ldots$ & $\ldots$ \\
\hline Palau & 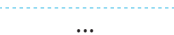 & $\ldots$ & $\cdots$ & $\ldots$ & & ... & $\ldots$ & $\cdots$ \\
\hline Papua New Guinea & 220 & 174 & 95 & 376 & -122.2 & -38.1 & 32.6 & -104.3 \\
\hline Samoa & 1 & 1 & 1 & 1 & 66.7 & 66.7 & 75.0 & 80.0 \\
\hline Solomon Islands & 3 & 3 & 3 & 3 & 40.0 & 50.0 & 50.0 & 50.0 \\
\hline Timor-Leste & $2(2002)$ & 201 & 186 & 121 & $50.0(2002$ & $-4,925.0$ & $-4,550.0$ & $-1,412.5$ \\
\hline Tonga & - & - & - & - & 100.0 & 100.0 & 100.0 & 100.0 \\
\hline Tuvalu & & & $\cdots$ & ... & & & & \\
\hline Vanuatu & 1 & 1 & 1 & 1 & 50.0 & 50.0 & 66.7 & 66.7 \\
\hline Developed ADB Member Economies & 14,738 & 16,282 & 18,586 & 18,561 & & & & \\
\hline Australia & 9,731 & 11,451 & 13,606 & 16,322 & -114.3 & -140.5 & -151.2 & -199.4 \\
\hline Japan & 4,379 & 4,260 & 4,211 & 1,481 & 79.8 & 80.5 & 79.9 & 91.7 \\
\hline New Zealand & 628 & 571 & 769 & 758 & 15.9 & 23.5 & 7.6 & 20.1 \\
\hline DEVELOPING ADB MEMBER ECONOMIES & 86,680 & 122,145 & 161,615 & 173,332 & & & & \\
\hline ALL ADB REGIONAL MEMBERS ${ }^{a}$ & 101,418 & 138,427 & 180,201 & 191,893 & & & & \\
\hline WORLD & 412,155 & 476,738 & 530,597 & 568,988 & & & & \\
\hline
\end{tabular}

... = data not available, - = magnitude equals zero, $\mathrm{ADB}=$ Asian Development Bank, $\mathrm{PJ}$ = petajoule.

a Includes only reporting economies with data corresponding to the year heading.

Sources: $\quad$ For Energy Production: United Nations Statistics Division. Official communication, 25 July 2019. For Net Energy Imports: Asian Development Bank estimates. 


\section{Energy}

Table 2.6.5: Retail Prices of Fuel Energy

$(\$ / L)$

\begin{tabular}{|c|c|c|c|c|c|c|c|c|}
\hline \multirow{2}{*}{ ADB Regional Member } & \multicolumn{4}{|c|}{ Gasoline (Premium) } & \multicolumn{4}{|c|}{ Diesel } \\
\hline & 2000 & 2005 & 2010 & 2018 & 2000 & 2005 & 2010 & 2018 \\
\hline \multirow{2}{*}{\multicolumn{9}{|c|}{$\begin{array}{l}\text { Developing ADB Member Economies } \\
\text { Central and West Asia }\end{array}$}} \\
\hline & & & & & & & & \\
\hline Afghanistan & & & $\cdots$ & $\ldots$ & 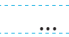 & $\cdots$ & $\ldots$ & \\
\hline Armenia & 0.51 & 0.73 & 1.01 & 0.93 & 0.34 & 0.60 & 0.92 & 0.95 \\
\hline Azerbaijan & & & & & & & $\ldots$ & \\
\hline Georgia & 0.52 & $0.46(2003)$ & 1.03 & 0.94 & 0.38 & 0.70 & 1.00 & 0.96 \\
\hline Kazakhstan & 0.35 & 0.47 & 0.58 & 0.45 & 0.30 & 0.39 & 0.53 & 0.56 \\
\hline Kyrgyz Republic & $\ldots$ & $\ldots$ & $\ldots$ & $\ldots$ & & & $\ldots$ & \\
\hline Pakistan & 0.48 & 0.82 & 0.80 & $0.73(2016)$ & 0.22 & 0.54 & 0.83 & $0.77(2016)$ \\
\hline Tajikistan & $\ldots$ & $\cdots$ & $\ldots$ & 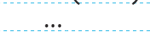 & $\ldots$ & $\ldots$ & $\ldots$ & 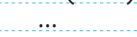 \\
\hline Turkmenistan & $\ldots$ & $\ldots$ & $\ldots$ & $\ldots$ & & & $\ldots$ & $\ldots$ \\
\hline Uzbekistan & 0.44 & $0.33(2004)$ & $\cdots$ & $\cdots$ & $\cdots$ & (n) & $\cdots$ & $\cdots$ \\
\hline \multicolumn{9}{|l|}{ East Asia } \\
\hline China, People's Republic of & $\cdots$ & $\cdots$ & $\cdots$ & $\ldots$ & & & & \\
\hline Hong Kong, China & 1.32 & 1.60 & 1.75 & 1.93 & 0.80 & 1.00 & 1.25 & 1.72 \\
\hline Korea, Republic of & 1.10 & 1.40 & 1.48 & 1.44 & 0.54 & 1.05 & 1.30 & 1.26 \\
\hline Mongolia & 0.33 & 0.56 & 1.01 & 0.66 & 0.38 & $0.81(2006)$ & 0.96 & 0.98 \\
\hline Taipei,China & 0.57 & 0.73 & 0.94 & 0.93 & 0.41 & 0.59 & 0.82 & 0.86 \\
\hline \multicolumn{9}{|l|}{ South Asia } \\
\hline Bangladesh & $\ldots$ & $\ldots$ & $\ldots$ & $\ldots$ & $\ldots$ & $\ldots$ & $\ldots$ & $\ldots$ \\
\hline Bhutan & $\ldots$ & $\ldots$ & $\ldots$ & $\ldots$ & $\ldots$ & $\ldots$ & $\ldots$ & $\ldots$ \\
\hline India & 0.58 & 0.86 & 1.05 & $\ldots$ & 0.32 & 0.64 & 0.83 & $\ldots$ \\
\hline Maldives & $\ldots$ & $\ldots$ & $\ldots$ & $\ldots$ & & & & $\ldots$ \\
\hline Nepal & 0.58 & 0.87 & 1.22 & 1.00 & 0.33 & 0.58 & 0.95 & 0.85 \\
\hline Sri Lanka & 0.65 & 0.80 & 1.02 & 0.77 & 0.32 & 0.50 & 0.65 & 0.62 \\
\hline \multicolumn{9}{|l|}{ Southeast Asia } \\
\hline Brunei Darussalam & $\ldots$ & $\ldots$ & $\ldots$ & $\ldots$ & $\ldots$ & $\ldots$ & $\ldots$ & $\ldots$ \\
\hline Cambodia & $\ldots$ & $\ldots$ & & $\ldots$ & $\ldots$ & & $\ldots$ & $\ldots$ \\
\hline Indonesia & 0.14 & 0.30 & 0.50 & $0.62(2017)$ & 0.07 & 0.27 & 0.50 & \\
\hline Lao People's Democratic Republ & & & & & & & & \\
\hline Malaysia & 0.29 & 0.40 & 0.67 & $0.59(2017)$ & 0.18 & 0.29 & 0.57 & $0.53(2017)$ \\
\hline Myanmar & $\ldots$ & $1.84(2007)$ & 1.41 & 0.67 & & $1.62(2007)$ & 1.37 & 0.67 \\
\hline Philippines & 0.37 & 0.57 & 0.96 & 1.03 & 0.28 & 0.51 & 0.76 & 0.81 \\
\hline Singapore & 0.82 & 0.92 & 1.35 & 1.83 & 0.33 & 0.56 & 0.89 & 1.16 \\
\hline Thailand & 0.39 & 0.59 & 1.12 (2009) & $\ldots$ & 0.32 & 0.50 & 0.90 & 0.88 \\
\hline Viet Nam & $\ldots$ & $\ldots$ & $0.99(2011)$ & $\ldots$ & $\ldots$ & $\ldots$ & $0.93(2011)$ & $0.68(2015)$ \\
\hline \multicolumn{9}{|l|}{ The Pacific } \\
\hline Cook Islands & $\ldots$ & $\ldots$ & $\ldots$ & $\ldots$ & $\ldots$ & $\ldots$ & $\ldots$ & $\ldots$ \\
\hline Fiji & $\ldots$ & $\ldots$ & $\ldots$ & $\ldots$ & $\ldots$ & $\ldots$ & $\ldots$ & $\ldots$ \\
\hline Kiribati & $\ldots$ & $\ldots$ & $\ldots$ & $\ldots$ & $\ldots$ & $\ldots$ & $\ldots$ & $\ldots$ \\
\hline Marshall Islands & $\ldots$ & $\ldots$ & $\ldots$ & $\ldots$ & $\ldots$ & $\ldots$ & $\ldots$ & $\ldots$ \\
\hline Micronesia, Federated States of & $\ldots$ & $\ldots$ & $\ldots$ & $\ldots$ & $\ldots$ & n & $\cdots$ & n \\
\hline Nauru & $\ldots$ & $\ldots$ & $\ldots$ & $\ldots$ & $\ldots$ & - & $\ldots$ & n \\
\hline Niue & $\cdots$ & $\cdots$ & & & & & & \\
\hline Palau & $\ldots$ & $\ldots$ & $\ldots$ & $\ldots$ & $\ldots$ & $\ldots$ & $\ldots$ & $\ldots$ \\
\hline Papua New Guinea & $\ldots$ & $\ldots$ & $\ldots$ & $\ldots$ & $\ldots$ & $\ldots$ & $\ldots$ & 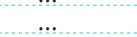 \\
\hline Samoa & $\cdots$ & $\cdots$ & $\ldots$ & $\cdots$ & $\ldots$ & 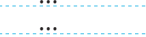 & $\cdots$ & $\ldots$ \\
\hline Solomon Islands & $\ldots$ & $0.86(2007)$ & 1.14 & 1.12 & & $0.86(2007)$ & 1.15 & 1.15 \\
\hline Timor-Leste & $\cdots$ & $\ldots$ & $\ldots$ & $\ldots$ & $\ldots$ & $\ldots$ & $\ldots$ & $\ldots$ \\
\hline Tonga & $\cdots$ & $\cdots$ & $\ldots$ & $\ldots$ & $\ldots$ & $\ldots$ & $\ldots$ & $\ldots$ \\
\hline Tuvalu & $\ldots$ & $\ldots$ & $\ldots$ & $\ldots$ & $\ldots$ & $\ldots$ & $\ldots$ & $\ldots$ \\
\hline Vanuatu & 0.78 & 1.23 & 1.50 & $\cdots$ & $\cdots$ & $\cdots$ & $\cdots$ & $\cdots$ \\
\hline \multicolumn{9}{|l|}{ Developed ADB Member Economies } \\
\hline Australia & 0.49 & 0.82 & 1.09 & 0.97 & & 0.87 & 1.09 & 1.01 \\
\hline Japan & 1.05 & 1.23 & 1.64 & 1.45 & 0.76 & 0.91 & 1.28 & 1.16 \\
\hline New Zealand & 0.51 & 0.97 & 1.34 & 1.55 & 0.33 & 0.64 & 0.85 & 0.99 \\
\hline
\end{tabular}

.. = data not available, $\$=$ United States dollars, $\mathrm{ADB}=$ Asian Development Bank, $\mathrm{L}=$ liter.

Source: Economy sources. 


\section{Environment}

Environment includes a discussion on deforestation and greenhouse gas emissions. Indicators related to land use, forest resources, air and water pollution, and per capita freshwater resources are presented in the statistical tables.

\section{The amount of forested land is declining in about one-third of Asia and Pacific economies.}

An estimated 1.6 billion people use forests for all or part of their livelihoods, while millions more depend on forest resources for clean air and fresh water. By absorbing and storing massive amounts of carbon dioxide $\left(\mathrm{CO}_{2}\right)$, forests play a crucial role in the fight against climate change. ${ }^{5}$

In 2016,15 of the 46 regional economies with available data reported an increase in total forested land, 14 economies reported a decrease, and 17 reported no change (Table 2.7.2).

The region's highest rates of deforestation in 2016 were in Pakistan (2.9\%), Myanmar (1.9\%), and Timor-Leste (1.6\%) as shown in Figure 2.7.1. The highest rates of negative deforestation (i.e., reforestation) occurred in the Philippines (-3.0\%), Azerbaijan (-2.3\%), and the Lao People's Democratic Republic (-1.0\%).
Figure 2.7.1: Deforestation Rates in Select Economies of Asia and the Pacific, 2016

(\%)

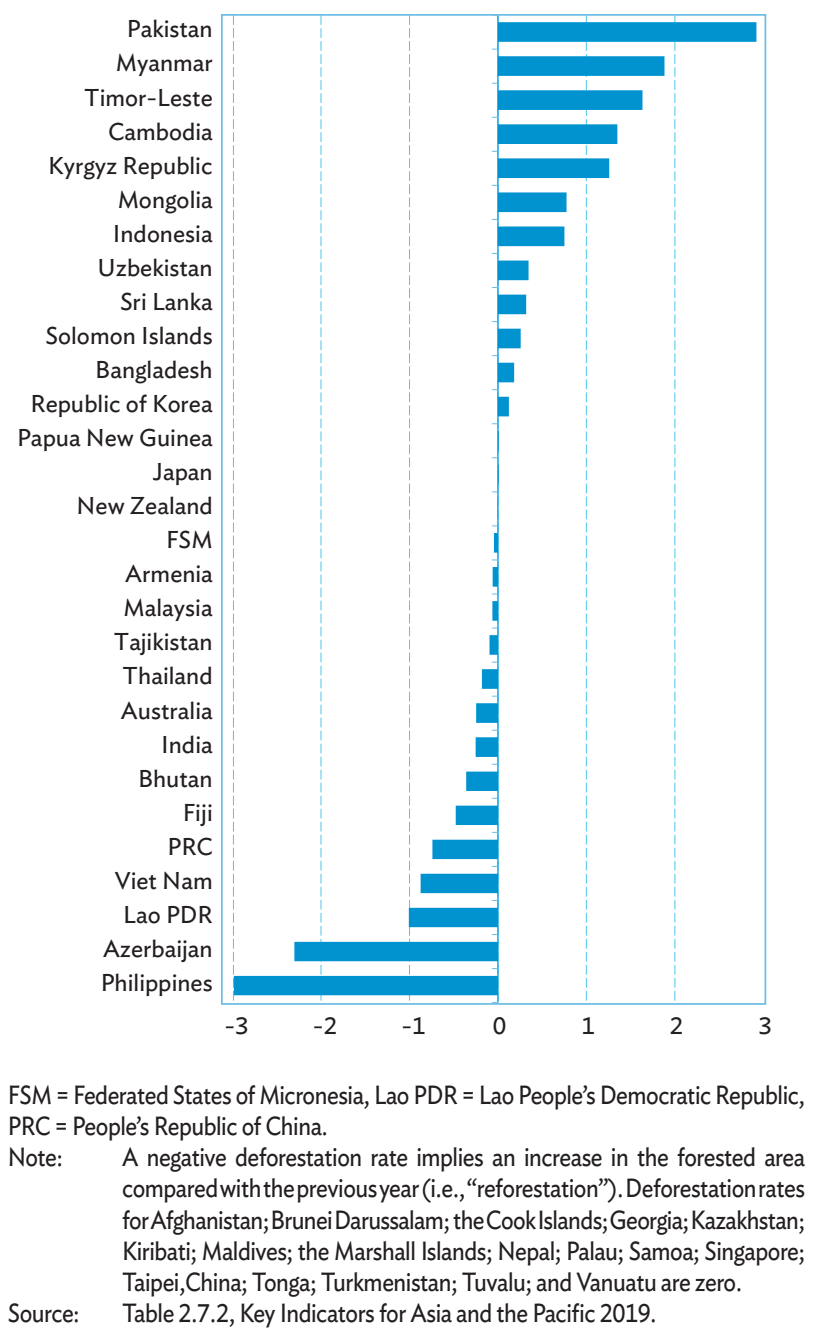

5 For more information about the role of forests in the Earth's environment, go to https://www.un-redd.org/forest-facts. 


\section{Carbon emissions per capita increased in about $85 \%$ of Asia and Pacific economies between 2000 and 2014.}

In 2014, Asia and the Pacific accounted for nearly half (47.7\%) of all global $\mathrm{CO}_{2}$ emissions. The region's highest emitters were the PRC (28.5\% of global emissions), India (6.2\%), Japan (3.4\%), the Republic of Korea (1.6\%), and Indonesia (1.3\%). Together, these five economies accounted for more than $90 \%$ of the region's total emissions (ADB 2018). Rising living standards in Asia and the Pacific have been associated with rising $\mathrm{CO}_{2}$ emissions as power generation and the use of energy-consuming goods, such as cars and air-conditioning units, increase (ADB 2013).

From 2000 to 2014, only 7 of the 47 regional economies with available data were successful in reducing $\mathrm{CO}_{2}$ emissions on a per capita basis (Figure 2.7.2). Among this group, the largest reductions occurred in Nauru (3.9 thousand tons of $\mathrm{CO}_{2}$ emissions per capita), Australia (1.9 thousand tons), and Singapore (1.9 thousand tons). The largest increases occurred in Brunei Darussalam (7.8 thousand tons of $\mathrm{CO}_{2}$ emissions per capita), Kazakhstan (6.4 thousand tons), and the PRC (4.8 thousand tons).

\section{Data Issues and Comparability}

Data on greenhouse gases (GHGs) have been compiled from the Emissions Database for Global Atmospheric Research, a joint project of the European Commission Joint Research Centre and the Netherlands Environmental Assessment Agency. This database applies a technology-based emissions factor approach consistently for all economies. It utilizes a consistent set of activity data for calculating various substances, GHGs, and air pollutants; and relies on the spatial allocation of emissions on a 0.1-degree by 0.1-degree grid.

There may be substantial uncertainty in data for individual economies-especially for methane, nitrous
Figure 2.7.2: Change in Carbon Dioxide Emissions in Select Economies of Asia and the Pacific, 2000-2014 (t'000 per capita)

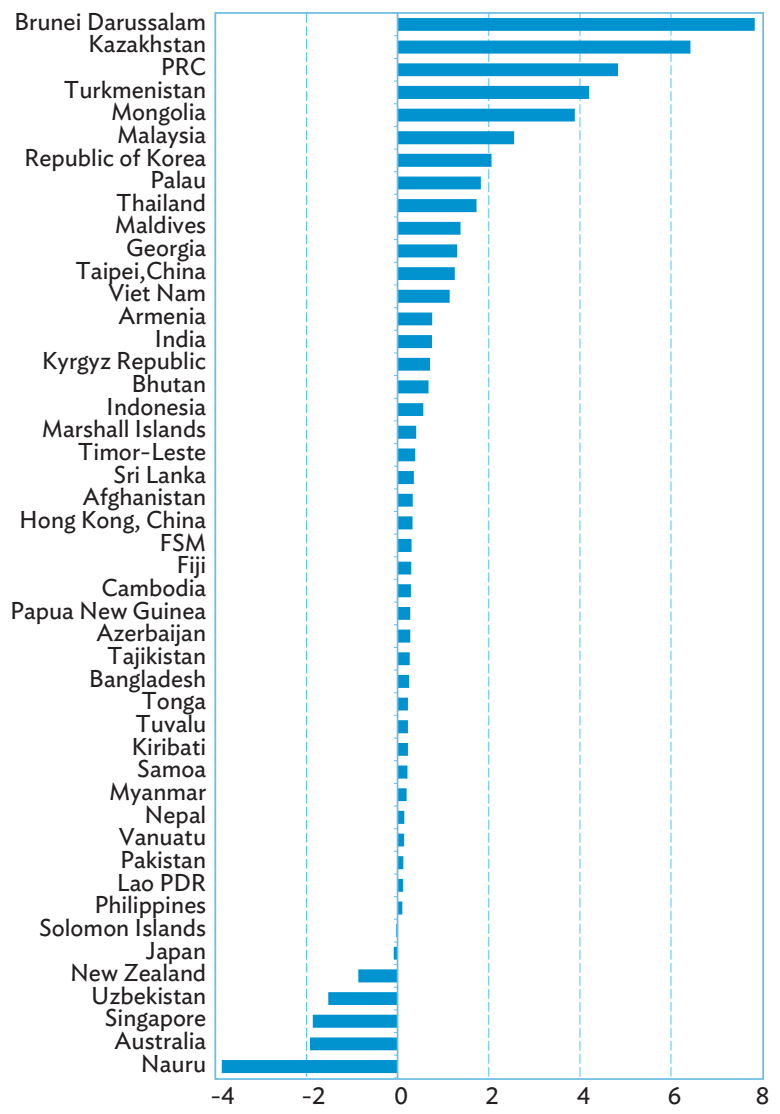

$\mathrm{t}=$ metric ton, FSM = Federated States of Micronesia, Lao PDR = Lao People's Democratic Republic, PRC = People's Republic of China.

Note: Onlyeconomies with available data for both 2000 and 2014 are included. For Taipei,China, data refer to 2001 and 2015.

Source: $\quad$ ADB estimates using Table 2.7.2 and Table 2.1.1, Key Indicators for Asia and the Pacific 2019.

Click here for figure data

oxide, and other GHGs-due to the limited accuracy of international activity data and the emission factors selected for calculating emissions on an economy level. However, since Intergovernmental Panel on Climate Change methodologies are consistently used, and data are based on international information sources, there is sound basis for comparability. ${ }^{6}$

The Food and Agriculture Organization of the UN monitors land use and forestry data, using its own expert sources, country reports, satellite imagery, and official data gathered through questionnaires conducted by the organization.

6 For more information on the methodologies of the Emissions Database for Global Atmospheric Research, go to http://edgar.jrc.ec.europa.eu/ methodology.php. 
Table 2.7.1: $\quad$ Agriculture Land Use

(\% of total land area)

\begin{tabular}{|c|c|c|c|c|c|c|c|c|c|c|c|c|}
\hline \multirow{2}{*}{ ADB Regional Member } & \multicolumn{4}{|c|}{ Agricultural Land } & \multicolumn{4}{|c|}{ Arable Land } & \multicolumn{4}{|c|}{ Permanent Cropland } \\
\hline & 2000 & 2005 & 2010 & 2016 & 2000 & 2005 & 2010 & 2016 & 2000 & 2005 & 2010 & 2016 \\
\hline \multicolumn{13}{|l|}{ Developing ADB Member Economies } \\
\hline \multicolumn{13}{|l|}{ Central and West Asia } \\
\hline Afghanistan & 57.8 & 58.1 & 58.1 & 58.1 & 11.8 & 12.0 & 11.9 & 11.8 & 0.1 & 0.2 & 0.2 & 0.3 \\
\hline Armenia & 46.5 & 56.4 & 60.9 & 58.9 & 15.8 & 16.0 & 15.8 & 15.7 & 1.3 & 1.8 & 1.9 & 2.0 \\
\hline Azerbaijan & 57.4 & 57.6 & 57.7 & 57.7 & 22.1 & 22.3 & 22.8 & 24.2 & 2.9 & 2.7 & 2.8 & 2.9 \\
\hline Georgia & 43.2 & 36.3 & 35.4 & 34.5 & 11.4 & 6.8 & 5.7 & 5.0 & 3.9 & 1.6 & 1.8 & 1.6 \\
\hline Kazakhstan & 79.8 & 78.6 & 80.4 & 80.4 & 11.2 & 10.6 & 10.6 & 10.9 & 0.1 & 0.0 & 0.0 & 0.0 \\
\hline Kyrgyz Republic & 55.9 & 56.0 & 55.3 & 55.0 & 7.1 & 6.7 & 6.7 & 6.7 & 0.3 & 0.4 & 0.4 & 0.4 \\
\hline Pakistan & 47.6 & 46.7 & 45.7 & 47.8 & 40.3 & 39.1 & 38.1 & 40.3 & 0.9 & 1.0 & 1.1 & 1.0 \\
\hline Tajikistan & 32.7 & 33.4 & 34.0 & 34.1 & 5.6 & 5.4 & 5.3 & 5.3 & 0.7 & 0.8 & 1.0 & 1.0 \\
\hline Turkmenistan & 75.5 & 74.2 & 72.4 & 72.0 & 4.1 & 4.3 & 4.1 & 4.1 & 0.1 & 0.1 & 0.1 & 0.1 \\
\hline Uzbekistan & 64.2 & 62.9 & 62.7 & 62.9 & 10.5 & 10.3 & 10.2 & 10.3 & 0.8 & 0.8 & 0.8 & 0.9 \\
\hline \multicolumn{13}{|l|}{ East Asia } \\
\hline China, People's Republic of & 55.6 & 55.1 & 54.8 & 56.2 & 12.6 & 12.0 & 11.4 & 12.7 & 1.2 & 1.3 & 1.5 & 1.7 \\
\hline Hong Kong, China & 6.7 & 6.7 & 5.2 & 4.8 & 4.8 & 4.8 & 3.3 & 2.9 & 1.0 & 1.0 & 1.0 & 1.0 \\
\hline Korea, Republic of & 20.5 & 19.4 & 18.2 & 17.4 & 17.8 & 17.0 & 15.5 & 14.6 & 2.1 & 1.9 & 2.1 & 2.3 \\
\hline Mongolia & 84.0 & 73.0 & 73.1 & 71.5 & 0.8 & 0.4 & 0.4 & 0.4 & 0.0 & 0.0 & 0.0 & 0.0 \\
\hline Taipei,China & 24.0 & 23.5 & 23.0 & 22.4 & 17.5 & 17.0 & 16.9 & 16.6 & 6.5 & 6.5 & 6.1 & 5.8 \\
\hline \multicolumn{13}{|l|}{ South Asia } \\
\hline Bangladesh & 72.2 & 71.5 & 71.0 & 70.6 & 64.1 & 60.8 & 59.9 & 59.6 & 3.5 & 6.1 & 6.5 & 6.4 \\
\hline Bhutan & 13.3 & 15.6 & 13.6 & 13.6 & 2.7 & 4.4 & 2.6 & 2.6 & 0.5 & 0.5 & 0.3 & 0.2 \\
\hline India & 60.9 & 60.6 & 60.4 & 60.4 & 54.1 & 53.6 & 52.8 & 52.6 & 3.1 & 3.4 & 4.1 & 4.4 \\
\hline Maldives & 30.0 & 30.0 & 26.3 & 26.3 & 10.0 & 10.0 & 13.0 & 13.0 & 16.7 & 16.7 & 10.0 & 10.0 \\
\hline Nepal & 29.6 & 29.3 & 28.8 & 28.7 & 16.4 & 15.9 & 15.2 & 14.7 & 0.8 & 0.9 & 1.1 & 1.5 \\
\hline Sri Lanka & 37.5 & 40.0 & 41.8 & 43.7 & 14.6 & 17.5 & 19.1 & 20.7 & 15.9 & 15.5 & 15.6 & 15.9 \\
\hline \multicolumn{13}{|l|}{ Southeast Asia } \\
\hline Brunei Darussalam & 1.9 & 2.1 & 2.5 & 2.7 & 0.4 & 0.4 & 0.8 & 0.9 & 0.8 & 0.9 & 1.1 & 1.1 \\
\hline Cambodia & 27.0 & 30.3 & 30.9 & 30.9 & 21.0 & 21.0 & 21.5 & 21.5 & 0.8 & 0.9 & 0.9 & 0.9 \\
\hline Indonesia & 26.0 & 28.6 & 30.7 & 31.5 & 11.3 & 12.7 & 13.0 & 13.0 & 8.6 & 9.9 & 11.6 & 12.4 \\
\hline Lao People's Democratic Republic & 7.8 & 8.6 & 9.6 & 10.3 & 4.0 & 5.0 & 6.1 & 6.6 & 0.4 & 0.4 & 0.6 & 0.7 \\
\hline $\begin{array}{l}\text { Malaysia } \\
\text { S }\end{array}$ & 21.1 & 21.7 & 22.5 & 26.3 & 2.6 & 2.9 & 2.6 & 2.7 & 17.6 & 18.0 & 19.0 & 22.7 \\
\hline Myanmar & 16.5 & 17.2 & 19.2 & 19.5 & 15.2 & 15.4 & 16.5 & 16.7 & 0.9 & 1.4 & 2.2 & 2.4 \\
\hline Philippines & 37.7 & 38.1 & 40.6 & 41.7 & 16.9 & 16.8 & 17.8 & 18.7 & 15.8 & 16.3 & 17.8 & 17.9 \\
\hline Singapore & 1.8 & 1.1 & 1.1 & 0.9 & 1.5 & 1.0 & 0.9 & 0.8 & 0.3 & 0.1 & 0.1 & 0.1 \\
\hline Thailand & 38.8 & 38.4 & 41.2 & 43.3 & 30.6 & 29.8 & 30.8 & 32.9 & 6.6 & 7.1 & 8.8 & 8.8 \\
\hline Viet Nam & 28.2 & 32.4 & 34.7 & 39.3 & 19.9 & 20.5 & 20.8 & 22.6 & 6.2 & 9.8 & 11.9 & 14.6 \\
\hline \multicolumn{13}{|l|}{ The Pacific } \\
\hline Cook Islands & 20.0 & 11.4 & 5.6 & 6.3 & 7.5 & 5.2 & 2.9 & 4.2 & 12.5 & 6.2 & 2.7 & 2.1 \\
\hline Fiji & 23.4 & 23.4 & 23.3 & 23.3 & 9.3 & 9.3 & 9.0 & 9.0 & 4.5 & 4.5 & 4.7 & 4.7 \\
\hline Kiribati & 42.0 & 42.0 & 42.0 & 42.0 & 2.5 & 2.5 & 2.5 & 2.5 & 39.5 & 39.5 & 39.5 & 39.5 \\
\hline Marshall Islands & 66.7 & 72.2 & 72.2 & 63.9 & 5.6 & 11.1 & 11.1 & 11.1 & 44.4 & 44.4 & 44.4 & 36.1 \\
\hline Micronesia, Federated States of & 32.1 & 32.1 & 31.4 & 31.4 & 3.6 & 3.6 & 2.9 & 2.9 & 24.3 & 24.3 & 24.3 & 24.3 \\
\hline Nauru & 20.0 & 20.0 & 20.0 & 20.0 & - & - & - & - & 20.0 & 20.0 & 20.0 & 20.0 \\
\hline Nive & 18.5 & 18.5 & 19.2 & 19.2 & 3.8 & 3.8 & 3.8 & 3.8 & 10.8 & 10.8 & 11.5 & 11.5 \\
\hline Palau & 10.9 & 10.9 & 10.9 & 10.9 & 2.2 & 2.2 & 2.2 & 2.2 & 4.3 & 4.3 & 4.3 & 4.3 \\
\hline Papua New Guinea & 2.2 & 2.3 & 2.6 & 2.6 & 0.5 & 0.5 & 0.7 & 0.7 & 1.4 & 1.3 & 1.5 & 1.5 \\
\hline Samoa & 17.0 & 14.8 & 12.4 & 12.4 & 4.9 & 3.9 & 2.8 & 2.8 & 11.0 & 9.5 & 7.8 & 7.8 \\
\hline Solomon Islands & 2.7 & 3.2 & 3.8 & 3.9 & 0.5 & 0.6 & 0.7 & 0.7 & 2.0 & 2.3 & 2.9 & 2.9 \\
\hline Timor-Leste & 22.7 & 25.9 & 25.0 & 25.6 & 8.1 & 11.4 & 10.1 & 10.4 & 4.5 & 4.4 & 4.8 & 5.0 \\
\hline Tonga & 41.7 & 41.7 & 44.4 & 45.8 & 20.8 & 20.8 & 23.6 & 25.0 & 15.3 & 15.3 & 15.3 & 15.3 \\
\hline Tuvalu & 66.7 & 56.7 & 60.0 & 60.0 & - & - & - & - & 66.7 & 56.7 & 60.0 & 60.0 \\
\hline Vanuatu & 14.4 & 15.0 & 15.3 & 15.3 & 1.6 & 1.6 & 1.6 & 1.6 & 9.3 & 9.9 & 10.3 & 10.3 \\
\hline \multicolumn{13}{|l|}{ Developed ADB Member Economies } \\
\hline Australia & 59.3 & 57.9 & 51.9 & 48.2 & 6.2 & 6.4 & 5.5 & 6.0 & 0.0 & 0.0 & 0.1 & 0.0 \\
\hline Japan & 14.4 & 12.9 & 12.6 & 12.3 & 12.3 & 12.0 & 11.7 & 11.5 & 1.0 & 0.9 & 0.9 & 0.8 \\
\hline New Zealand & 58.5 & 44.5 & 43.3 & 40.5 & 5.7 & 1.6 & 1.9 & 2.2 & 0.2 & 0.2 & 0.3 & 0.3 \\
\hline
\end{tabular}

- = magnitude equals zero, 0.0 = magnitude is less than half of unit employed, $A D B=A$ sian Development Bank.

Source: $\quad$ Food and Agriculture Organization of the United Nations. FAOSTAT Database. http://www.fao.org/faostat/en/\#data/RL (accessed 21 May 2019). 
Table 2.7.2: Deforestation and Pollution

\begin{tabular}{|c|c|c|c|c|c|c|}
\hline \multirow[t]{2}{*}{ ADB Regional Member } & \multicolumn{2}{|c|}{$\begin{array}{l}\text { Deforestation Rate }{ }^{\mathrm{a}} \\
\text { (average } \% \text { change) }\end{array}$} & \multicolumn{2}{|c|}{$\begin{array}{l}\text { Carbon Dioxide Emissions }{ }^{b} \\
\left(t^{\mathrm{C}} 000\right)\end{array}$} & \multicolumn{2}{|c|}{$\begin{array}{l}\text { Nitrous Oxide Emissions } \\
\text { (t } \mathrm{t} 000 \mathrm{CO}_{2} \text { equivalent) }\end{array}$} \\
\hline & 2000 & 2016 & 2000 & 2014 & 2000 & 2012 \\
\hline \multicolumn{7}{|l|}{ Developing ADB Member Economies } \\
\hline \multicolumn{7}{|l|}{ Central and West Asia } \\
\hline Afghanistan & - & - & 774 & 9,809 & 3,317 & 3,424 \\
\hline Armenia & 0.06 & -0.06 & 3,465 & 5,530 & 462 & 1,023 \\
\hline Azerbaijan & -0.23 & -2.30 & 29,508 & 37,488 & 2,030 & 2,673 \\
\hline Georgia & -0.03 & - & 4,536 & 8,988 & 2,437 & 2,352 \\
\hline Kazakhstan & 0.17 & - & 118,099 & 248,315 & 14,865 & 17,822 \\
\hline Kyrgyz Republic & -0.26 & 1.26 & 4,635 & 9,608 & 1,452 & 1,567 \\
\hline Pakistan & 1.91 & 2.92 & 106,449 & 166,298 & 26,350 & 30,651 \\
\hline Tajikistan & -0.05 & -0.10 & 2,237 & 5,189 & 1,110 & 1,848 \\
\hline Turkmenistan & - & - & 37,539 & 68,423 & 3,046 & 4,924 \\
\hline Uzbekistan & -0.52 & 0.35 & 121,829 & 105,214 & 9,610 & 13,192 \\
\hline \multicolumn{7}{|l|}{ East Asia } \\
\hline China, People's Republic of & -1.13 & -0.74 & $3,405,180$ & $10,291,927$ & 414,138 & 587,166 \\
\hline Hong Kong, China & & & 40,440 & 46,223 & 513 & 476 \\
\hline Korea, Republic of & 0.13 & 0.12 & 447,561 & 587,156 & 18,576 & 14,979 \\
\hline Mongolia & 0.69 & 0.77 & 7,506 & 20,840 & 5,058 & 3,548 \\
\hline Taipei,China & - & $-(2017)$ & $230,022(2001)$ & $271,013(2015)$ & $3,845(2001)$ & $4,506(2015)$ \\
\hline \multicolumn{7}{|l|}{ South Asia } \\
\hline Bangladesh & 0.18 & 0.18 & 27,869 & 73,190 & 20,770 & 26,683 \\
\hline Bhutan & -0.38 & -0.36 & 396 & 1,001 & 281 & 555 \\
\hline India & -0.22 & -0.25 & $1,031,853$ & $2,238,377$ & 207,700 & 239,755 \\
\hline Maldives & - & - & 451 & 1,335 & 12 & 27 \\
\hline Nepal & 2.30 & - & 3,069 & 8,031 & 4,232 & 4,598 \\
\hline SriLanka & 0.42 & 0.32 & 10,238 & 18,394 & 2,044 & 2,174 \\
\hline \multicolumn{7}{|l|}{ Southeast Asia } \\
\hline Brunei Darussalam & 0.40 & - & 4,712 & 9,109 & 395 & 342 \\
\hline Cambodia & 1.20 & 1.35 & 1,977 & 6,685 & 3,295 & 16,685 \\
\hline Indonesia & 1.89 & 0.75 & 263,419 & 464,176 & 94,933 & 93,139 \\
\hline Lao People's Democratic Republic & 0.67 & -1.01 & 939 & 1,955 & 3,265 & 8,987 \\
\hline Malaysia & 0.36 & -0.06 & 125,734 & 242,821 & 13,822 & 15,310 \\
\hline Myanmar & 1.23 & 1.88 & 10,088 & 21,632 & 31,300 & 26,783 \\
\hline Philippines & -0.68 & -2.99 & 73,307 & 105,654 & 12,365 & 12,762 \\
\hline Singapore & - & - & 49,006 & 56,373 & 6,635 & 1,909 \\
\hline Thailand & -1.80 & -0.18 & 181,271 & 316,213 & 18,677 & 30,833 \\
\hline Viet Nam & -2.06 & -0.87 & 53,645 & 166,911 & 19,746 & 34,494 \\
\hline \multicolumn{7}{|l|}{ The Pacific } \\
\hline Cook Islands & -0.47 & - & & & & \\
\hline Fiji & -0.28 & -0.48 & 843 & 1,170 & 343 & 344 \\
\hline Kiribati & - & - & 29 & 62 & 3 & 4 \\
\hline Marshall Islands & - & - & 77 & 103 & 0 & 0 \\
\hline Micronesia, Federated States of & -0.05 & -0.05 & 125 & 150 & 11 & 11 \\
\hline Nauru & $\ldots \ldots$ & $\ldots . .$. & 84 & 48 & 0 & 0 \\
\hline Nive & & $\ldots$ & & & & \\
\hline Palau & -0.38 & - & 249 & 260 & 0 & 0 \\
\hline Papua New Guinea & 0.01 & 0.01 & 2,666 & 6,318 & 1,613 & 1,234 \\
\hline Samoa & -2.46 & - & 143 & 198 & 37 & 40 \\
\hline Solomon Islands & 0.25 & 0.26 & 150 & 202 & 2,425 & 2,656 \\
\hline Timor-Leste & 1.29 & 1.63 & - & 469 & 164 & 226 \\
\hline Tonga & - & - & 95 & 121 & 22 & 22 \\
\hline Tuvalu & - & - & 7 & 11 & 1 & 1 \\
\hline Vanuatu & - & - & 84 & 154 & 118 & 109 \\
\hline \multicolumn{7}{|l|}{ Developed ADB Member Economies } \\
\hline Australia & -0.02 & -0.25 & 329,443 & 361,262 & 75,581 & 54,247 \\
\hline Japan & 0.03 & 0.01 & $1,220,528$ & $1,214,048$ & 30,411 & 24,911 \\
\hline New Zealand & -0.48 & -0.00 & 32,981 & 34,664 & 11,549 & 11,880 \\
\hline
\end{tabular}


Table 2.7.2: Deforestation and Pollution (continued)

\begin{tabular}{|c|c|c|c|c|}
\hline \multirow[t]{2}{*}{ ADB Regional Member } & \multicolumn{2}{|c|}{$\begin{array}{l}\text { Methane Emissions } \\
\left(\mathrm{t}^{\prime} 000 \mathrm{CO}_{2} \text { equivalent }\right)\end{array}$} & \multicolumn{2}{|c|}{$\begin{array}{l}\text { Other Greenhouse Gases }{ }^{c} \\
\left.\text { ( } \mathrm{t}^{\prime} 000 \mathrm{CO}_{2} \text { equivalent }\right)\end{array}$} \\
\hline & 2000 & 2012 & 2000 & 2012 \\
\hline \multicolumn{5}{|l|}{ Developing ADB Member Economies } \\
\hline \multicolumn{5}{|l|}{ Central and West Asia } \\
\hline Afghanistan & 9,384 & 13,763 & 126 & 349 \\
\hline Armenia & 2,565 & 3,426 & 112 & 710 \\
\hline Azerbaijan & 9,955 & 19,955 & 464 & 1,142 \\
\hline Georgia & 4,137 & 5,019 & 3 & 227 \\
\hline Kazakhstan & 38,779 & 71,350 & 14,065 & 30,363 \\
\hline Kyrgyz Republic & 3,486 & 4,291 & 93 & 68 \\
\hline Pakistan & 117,125 & 158,337 & 757 & 1,159 \\
\hline Tajikistan & 3,304 & 5,408 & 798 & 367 \\
\hline Turkmenistan & 21,241 & 22,009 & 124 & 595 \\
\hline Uzbekistan & 37,233 & 47,333 & 298 & 989 \\
\hline \multicolumn{5}{|l|}{ East Asia } \\
\hline China, People's Republic of & $1,043,400$ & $1,752,290$ & 104,677 & 251,254 \\
\hline Hong Kong, China & 2,695 & 3,147 & 155 & 150 \\
\hline Korea, Republic of & 30,916 & 32,625 & 14,934 & 8,968 \\
\hline Mongolia & 9,218 & 6,257 & 26,233 & $2,216(2010)$ \\
\hline Taipei,China & $12,215(2001)$ & $5,449(2015)$ & $6,304(2001)$ & $3,052(2015)$ \\
\hline \multicolumn{5}{|l|}{ South Asia } \\
\hline Bangladesh & 89,247 & 105,142 & 686 & 1,329 \\
\hline Bhutan & 1,032 & 1,770 & 644 & 488 \\
\hline India & 561,733 & 636,396 & 56,626 & 153,658 \\
\hline Maldives & 34 & 52 & & \\
\hline Nepal & 21,206 & 23,982 & 2,443 & 7,995 \\
\hline Sri Lanka & 9,606 & 11,864 & 441 & 91 \\
\hline \multicolumn{5}{|l|}{ Southeast Asia } \\
\hline Brunei Darussalam & 3,882 & 4,539 & 101 & 427 \\
\hline Cambodia & 14,985 & 35,915 & 23,021 & 73,300 \\
\hline Indonesia & 170,032 & 223,316 & 63,048 & 2,556 \\
\hline Lao People's Democratic Republic & 7,219 & 15,011 & 13,588 & 136,841 \\
\hline $\begin{array}{l}\text { Malaysia } \\
\text { Pll }\end{array}$ & 29,309 & 34,271 & 5,144 & 3,866 \\
\hline Myanmar & 66,942 & 80,637 & 78,176 & 406,274 \\
\hline Philippines & 49,911 & 57,170 & 12,487 & 3,891 \\
\hline Singapore & 1,684 & 2,386 & $1,889(2001)$ & 3,299 \\
\hline Thailand & 83,564 & 106,499 & 8,756 & 45,556 \\
\hline Viet $\mathrm{Nam}$ & 75,430 & 113,564 & 5,782 & 25,707 \\
\hline \multicolumn{5}{|l|}{ The Pacific } \\
\hline Cook Islands & & & & \\
\hline Fiji & 705 & 715 & 9 & 52 \\
\hline Kiribati & 13 & 16 & - & - \\
\hline Marshall Islands & 6 & 8 & $\ldots$ & $\ldots$ \\
\hline Micronesia, Federated States of & 28 & 30 & $\ldots$ & $\ldots$ \\
\hline Nauru & 3 & 3 & $\ldots$ & \\
\hline Nive & $\ldots$ & $\ldots$ & $\ldots$ & $\ldots$ \\
\hline Palau & 1 & 1 & & \\
\hline Papua New Guinea & 2,001 & 2,143 & 1,949 & 2,188 \\
\hline Samoa & 116 & 133 & -0 & 0 \\
\hline Solomon Islands & 1,394 & 1,449 & 0 & 0 \\
\hline Timor-Leste & 450 & 732 & - & -0 \\
\hline Tonga & 58 & 61 & -0 & $\ldots$ \\
\hline Tuvalu & 3 & 3 & -0 & 0 \\
\hline Vanuatu & 267 & 254 & 0 & -0 \\
\hline \multicolumn{5}{|l|}{ Developed ADB Member Economies } \\
\hline Australia & 128,133 & 125,588 & 520,911 & 174,653 \\
\hline Japan & 47,496 & 38,957 & 51,527 & 71,746 \\
\hline New Zealand & 26,584 & 28,658 & 1,506 & 1,764 \\
\hline
\end{tabular}

$\ldots=$ data not available, $-=$ magnitude equals zero, -0 or $0=$ magnitude is less than half of unit employed, $A D B=$ Asian Development Bank, $\mathrm{CO}_{2}=$ carbon dioxide, $\mathrm{t}=$ metric ton .

a Rate refers to percentage change over previous year. A negative value indicates that the deforestation rate is decreasing (i.e., reforestation).

b Data from the World Bank are expressed in kilotons, while data provided in the table are expressed in thousands of metric tons, using a conversion factor of 1 kiloton = 1,000 metric tons.

c Other greenhouse gas emissions refer to hydrofluorocarbons, perfluorocarbons, and sulphur hexafluoride.

Sources: $\quad$ Food and Agriculture Organization of the United Nations. FAOSTAT Database. http://www.fao.org/faostat/en/\#data/RL (accessed 25 July 2019 ); and World Bank. World Development Indicators Online. http://data.worldbank.org/indicator (accessed 25 July 2019). For Taipei,China: Government of Taipei,China, DirectorateGeneral of Budget, Accounting and Statistics. Statistical Yearbook 2017. https://eng.dgbas.gov.tw/public/data/dgbas03/bs2/yearbook_eng/Yearbook2017.pdf (accessed 22 May 2019). 
Table 2.7.3: $\quad$ Freshwater Resources

\begin{tabular}{|c|c|c|c|c|}
\hline \multirow{3}{*}{ ADB Regional Member } & \multicolumn{2}{|c|}{ Internal Renewable Freshwater Resources } & \multirow{3}{*}{$\begin{array}{c}\text { Annual Freshwater } \\
\text { Withdrawals } \\
\left(\mathrm{m}^{3} \text { billion }\right)\end{array}$} & \multirow{3}{*}{$\frac{\text { Water Productivity }}{\left(\text { constant } 2010 \$ \text { per m}^{3}\right)}$} \\
\hline & ( $m^{3}$ billion per year) & $\left(m^{3}\right.$ per inhabitant per year) & & \\
\hline & 2017 & $2017^{b}$ & & \\
\hline \multicolumn{5}{|l|}{ Developing ADB Member Economies } \\
\hline Central and West Asia & 370 & 1,155 & & \\
\hline Afghanistan & 47 & 1,327 & $20(2000)$ & \\
\hline Armenia & 7 & 2,341 & $3(2017)$ & $3.5(2015)$ \\
\hline Azerbaijan & 8 & 826 & $13(2017)$ & $4.4(2012)$ \\
\hline Georgia & 58 & 14,859 & $2(2008)$ & $6.2(2008)$ \\
\hline Kazakhstan & 64 & 3,535 & $21(2016)$ & $7.4(2010)$ \\
\hline Kyrgyz Republic & 49 & 8,094 & $8(2006)$ & $0.5(2006)$ \\
\hline Pakistan & 55 & 279 & $184(2008)$ & $0.9(2008)$ \\
\hline Tajikistan & 63 & 7,114 & $11(2006)$ & $0.4(2006)$ \\
\hline Turkmenistan & 1 & 244 & $28(2004)$ & $0.4(2004)$ \\
\hline Uzbekistan & 16 & 512 & $53(2016)$ & $0.5(2005)$ \\
\hline East Asiac & 2,913 & 1,948 & & \\
\hline China, People's Republic of & 2,813 & 1,952 & $594(2015)$ & $15.0(2015)$ \\
\hline \multicolumn{5}{|l|}{ Hong Kong, China } \\
\hline Korea, Republic of & 65 & 1,272 & $29(2005)$ & $30.8(2005)$ \\
\hline Mongolia & 35 & 11,313 & $0(2016)$ & $12.3(2009)$ \\
\hline Taipei, China & \multicolumn{4}{|c|}{ Taipei,China } \\
\hline South Asia & 1,880 & 1,209 & & \\
\hline Bangladesh & 105 & 638 & $36(2008)$ & $2.9(2008)$ \\
\hline Bhutan & 78 & 96,582 & $0(2008)$ & $3.9(2008)$ \\
\hline India & 1,446 & 1,080 & $648(2010)$ & $2.6(2010)$ \\
\hline Maldives & 0 & 69 & & \\
\hline Nepal & 198 & 6,763 & $9(2006)$ & $1.4(2006)$ \\
\hline Sri Lanka & 53 & 2,529 & $13(2005)$ & $3.2(2005)$ \\
\hline \multicolumn{5}{|l|}{ Southeast Asia } \\
\hline Brunei Darussalam & 9 & 19,827 & & \\
\hline Cambodia & 121 & 7,535 & $2(2006)$ & $4.1(2006)$ \\
\hline Indonesia & 2,019 & 7,648 & $223(2016)$ & $4.0(2000)$ \\
\hline Lao People's Democratic Republic & 190 & 27,763 & $3(2005)$ & $1.4(2005)$ \\
\hline Malaysia & 580 & 18,341 & $11(2005)$ & $18.3(2005)$ \\
\hline Myanmar & 1,003 & 18,793 & $33(2000)$ & $0.5(2000)$ \\
\hline Philippines & 479 & 4,565 & $85(2016)$ & $2.3(2009)$ \\
\hline Singapore & 1 & 105 & & \\
\hline Thailand & 225 & 3,252 & $57(2007)$ & $5.5(2007)$ \\
\hline Viet Nam & 359 & 3,762 & $82(2005)$ & $1.0(2005)$ \\
\hline \multirow{2}{*}{\multicolumn{5}{|c|}{$\begin{array}{l}\text { The Pacific } \\
\text { Cook Islands }\end{array}$}} \\
\hline & & & & \\
\hline Fiji & 29 & 31,530 & $0(2005)$ & $35.7(2005)$ \\
\hline Kiribati & $\ldots$ & $\ldots$ & $\ldots$ & $\ldots . .$. \\
\hline Marshall Islands & $\ldots$ & & $\ldots$ & $\ldots$ \\
\hline Micronesia, Federated States of & $\ldots$ & $\ldots$ & $\ldots$ & $\ldots$ \\
\hline Nauru & $\ldots$ & $\ldots$ & $\ldots$ & $\ldots$ \\
\hline Nive & $\ldots$ & $\ldots$ & $\ldots$ & $\ldots$ \\
\hline Palau & $\ldots$ & ....... & $\ldots$ & $\ldots$ \\
\hline Papua New Guinea & 801 & 97,079 & $0(2005)$ & $27.3(2005)$ \\
\hline Samoa & & & $\ldots \quad-\ldots$ & $\ldots$ \\
\hline Solomon Islands & 45 & 73,123 & & \\
\hline Timor-Leste & 8 & 6,339 & $1(2004)$ & $1.6(2004)$ \\
\hline Tonga & $\ldots$ & & & \\
\hline Tuvalu & 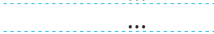 & & $\ldots$ & $\ldots$ \\
\hline Vanuatu & 10 & 36,206 & $\ldots$ & $\ldots$ \\
\hline Developed ADB Member Economies & 1,249 & 7,974 & & \\
\hline Australia & 492 & 20,123 & $16(2016)$ & $78.4(2015)$ \\
\hline Japan & 430 & 3,373 & $81(2009)$ & $67.4(2009)$ \\
\hline New Zealand & 327 & 69,486 & $5(2010)$ & $28.2(2010)$ \\
\hline DEVELOPING ADB MEMBER ECONOMIESc & 11,040 & 2,740 & & \\
\hline ALL ADB REGIONAL MEMBERSC & 12,289 & 2,936 & & \\
\hline
\end{tabular}

$\ldots=$ data not available, 0 = magnitude is less than half of unit employed, $\$=$ United States dollars, $A D B=$ Asian Development Bank, $\mathrm{m}^{3}=$ cubic meter.

a Gross domestic product in constant 2010 United States dollars per cubic meter of total freshwater withdrawal.

b Regional aggregates are weighted averages estimated using population.

c For reporting economies only.

Sources: Food and Agriculture Organization of the United Nations. AQUASTAT Database. http://www.fao.org/nr/water/aquastat/data/query/index.html (accessed 25 July 2019); and World Bank. World Development Indicators Online. http://data.worldbank.org/indicator (accessed 25 July 2019). 


\section{Government and Governance}

Government and Governance presents statistics on government taxes, revenues, and expenditure; government net lending/net borrowing; and government expenditures on health, education, and social protection. The section also includes data on the time and cost required to register a new business in each economy, as well as the latest global rankings for Transparency International's Corruption Perceptions Index. The discussion here focuses on government taxes as a share of GDP, as well as the number of days required to start a business.

\section{In 2018, the share of taxes collected by government as a proportion of GDP was $20 \%$ or higher in around one third of the 23 economies with available data}

Government taxes comprise value-added tax, sales tax, import duties, income tax, profit tax, property tax, capital gains tax, and compulsory social security charges, among others. The total government tax take as a share of GDP was $20.0 \%$ or higher in 8 of the 23 economies with available data for 2018 (Figure 2.8.1).

From 2017 to 2018, the proportion of government taxes to GDP rose in 13 of the 23 reporting economies. In 8 economies, there was a decrease in the proportion of government taxes to GDP, and in 2 economies the proportion remained unchanged. The largest increases during the review period were observed in Tonga (4.9 percentage points), Mongolia (2.6 percentage points), and Uzbekistan (2.4 percentage points). The largest decreases were observed in Nauru ( -5.4 percentage points), Bangladesh ( -1.7 percentage points), and Maldives (-1.1 percentage points).
Figure 2.8.1: Government Taxes as a Proportion of Gross Domestic Product in Select Economies of Asia and the Pacific

(\%)

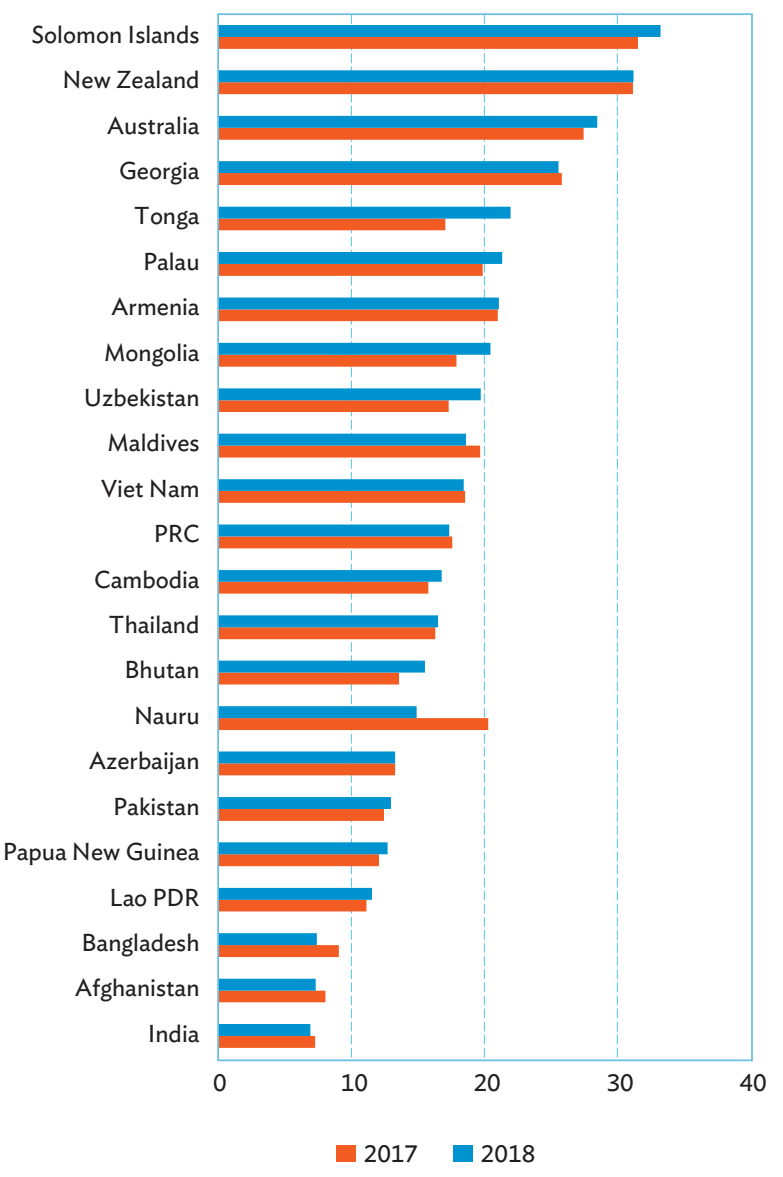

Lao PDR = Lao People's Democratic Republic, PRC = People's Republic of China. Note: Only economies with data for both 2017 and 2018 are included in the chart. Data refer to general government, except for Bangladesh, Bhutan, Cambodia, India, the Lao People's Democratic Republic, Maldives, Nauru, Palau, Solomon Islands, Tonga, and Viet Nam, where data refer to central government.

Source: Table 2.8.2, Key Indicators for Asia and the Pacific 2019. 
Economies in Asia and the Pacific are spurring entrepreneurial activity by reducing the number of days required to start a business.

Reducing the amount of time required to start a business can act as an incentive to entrepreneurial activity. Shorter start-up times are associated with simplified registration procedures and reduced opportunities for bribes (World Bank 2019b).

From 2005 to 2018, of the 37 regional economies with available data, 30 reduced the number of days required to start a business, 4 reported an increase, and 3 had no change (Figure 2.8.2). On a subregional basis, the average number of days required to start a business were reduced as follows: Southeast Asia (25.8 days), the Pacific (25.6 days), South Asia (22.8 days), Central and West Asia (33.0 days), and East Asia (20.5 days). Among ADB's developed member economies in Asia and the Pacific, the average reduction was 2.8 days.

By individual economy, the largest reductions from 2005 to 2018 were achieved in Timor-Leste (154.0 days), Brunei Darussalam (116.0 days), and Azerbaijan (109.5 days). The three most populous economies of the region achieved significant reductions in the number of days required to start a business between 2013 and 2018 for which data are available-the PRC (from 32.4 to 8.6 days), India (from 32.7 to 16.5 days), and Indonesia (from 75.5 to 19.6 days).

The high-income economies of New Zealand (0.5 days); Hong Kong, China (1.5 days); and Singapore (1.5 days) had the shortest amount of time required to start a business among the 37 economies reporting for 2018 (Figure 2.8.2). The longest delays in starting a business in 2018 were incurred in the Lao People's Democratic Republic (174.0 days), Cambodia (99.0 days), and Papua New Guinea (41.0 days).

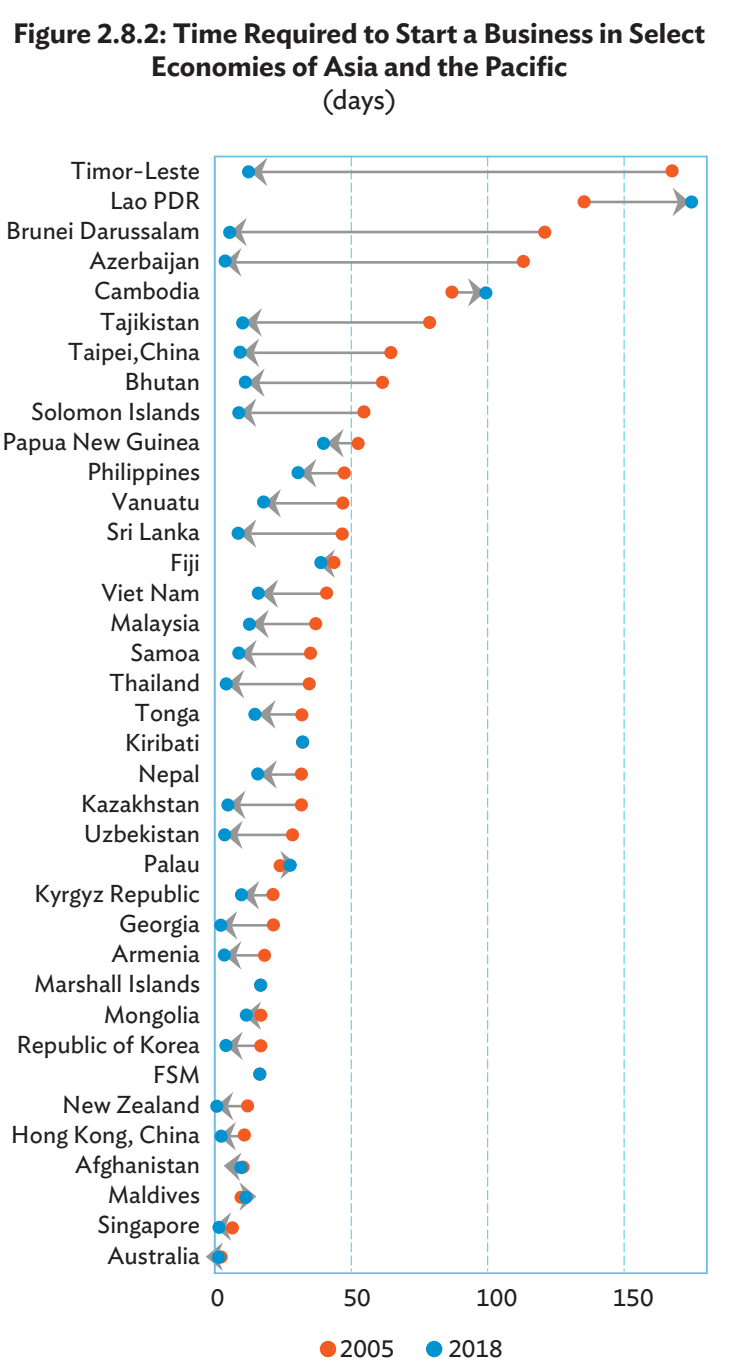
FSM= Federated States of Micronesia, Lao PDR = Lao People's Democratic Republic.
$\begin{array}{ll}\text { Note: } & \text { Only economies with data for both } 2005 \text { and } 2018 \text { are included in the } \\ \text { chart. Initial year for Brunei Darussalam is } 2006 .\end{array}$
Source: $\quad$ Table 2.8.6, Key Indicators for Asia and the Pacific 2019.

Click here for figure data

\section{Data Issues and Comparability}

Most economies generally follow the IMF's Government Finance Statistics (GFS) guidelines, with some economies still using the 1986 version, while others have switched to the 2001 or 2014 GFS guidelines. The comparability of the data is limited by variations in the concepts and definitions used in different versions of the GFS framework. 
Furthermore, there is no single framework for an extended time series available in most economies using the 2014 guidelines, with most economies recording their transactions on a cash basis (and a few on an accrual basis).

Data on government expenditures and revenue are derived from economy sources and are therefore not standard throughout Asia and the Pacific. Data refer to general government for some economies, and central government for other economies.
Statistics on the time and cost for registering new businesses, and on perceived corruption, are taken from nonofficial sources. Common procedures are used in all economies, and the researchers producing these data have refined their procedures over several surveys. However, because of the subjective nature of many of the data, they can only be used to give a broad idea of trends, levels, and rankings. Therefore, small changes from one year to the next should be interpreted with caution. 
Table 2.8.1: Government Net Lending/Net Borrowing ${ }^{a}$ (\% of GDP)

\begin{tabular}{|c|c|c|c|c|c|c|c|c|c|}
\hline ADB Regional Member & 2010 & 2011 & 2012 & 2013 & 2014 & 2015 & 2016 & 2017 & 2018 \\
\hline \multirow{2}{*}{\multicolumn{10}{|c|}{$\begin{array}{l}\text { Developing ADB Member Economies } \\
\text { Central and West Asia }\end{array}$}} \\
\hline & & & & & & & & & \\
\hline Afghanistan & 0.8 & -1.2 & -0.6 & & -1.8 & -1.3 & 0.5 & -0.4 & - \\
\hline Armenia & $\begin{array}{r}-5.0 \\
\end{array}$ & -2.8 & -1.5 & -1.5 & $\begin{array}{r}-1.9 \\
\end{array}$ & -4.8 & -5.5 & -4.8 & -1.6 \\
\hline Azerbaijan & -10.8 & -13.0 & -13.1 & -13.6 & -13.4 & -12.4 & -5.5 & -6.3 & -9.0 \\
\hline $\begin{array}{l}\text { Georgia } \\
\text { Kazakhstan }\end{array}$ & $\begin{array}{r}-4.5 \\
5.0\end{array}$ & $\begin{array}{r}-0.9 \\
8.3\end{array}$ & $\begin{array}{r}-0.6 \\
6.0\end{array}$ & $\begin{array}{r}-1.1 \\
5.0\end{array}$ & $\begin{array}{r}-2.0 \\
3.5\end{array}$ & $\begin{array}{l}-1.1 \\
-2.2\end{array}$ & $\begin{array}{r}-1.4 \\
-2.8\end{array}$ & $\begin{array}{l}-0.9 \\
-3.0\end{array}$ & $\begin{array}{l}-0.8 \\
\ldots\end{array}$ \\
\hline Kyrgyz Republic & -4.8 & -4.8 & -6.5 & -0.8 & 0.0 & -1.0 & -3.7 & -2.6 & \\
\hline Pakistanc & -6.0 & -6.4 & -8.6 & -8.1 & -4.7 & -5.2 & -4.5 & -5.8 & -6.5 \\
\hline Tajikistan & -7.1 & -5.8 & -3.4 & -5.4 & -3.8 & -7.8 & -10.4 & $\ldots$ & \\
\hline $\begin{array}{l}\text { Turkmenistan } \\
\text { Uzbekistan }\end{array}$ & 2.01 & 3.5 & 6.4 & 1.5 & 0.9 & -0.7 & $\ldots$ & 15 & 3 \\
\hline \multirow{2}{*}{\multicolumn{10}{|c|}{ East Asia }} \\
\hline & & & & & & & & & \\
\hline $\begin{array}{l}\text { China, People's Republic of } \\
\text { Hong Kong, China }\end{array}$ & $\begin{array}{r}-1.6 \\
4.1\end{array}$ & $\begin{aligned}-1.1 \\
3.8\end{aligned}$ & $\begin{array}{r}-1.6 \\
3.5\end{array}$ & $\begin{array}{r}-1.9 \\
0.7\end{array}$ & $\begin{array}{r}-1.8 \\
4.2\end{array}$ & $\begin{array}{r}-3.4 \\
1.4\end{array}$ & $\begin{array}{r}-3.8 \\
4.7\end{array}$ & $\begin{array}{l}-3.1 \\
6.3\end{array}$ & $\begin{array}{r}-4.2 \\
\ldots\end{array}$ \\
\hline Korea, Republic of & & & 1.1 & 1.4 & 1.3 & 1.2 & 2.5 & 2.6 & \\
\hline Mongolia & -3.2 & -11.8 & -15.5 & -8.3 & -11.5 & -10.9 & -23.0 & -11.1 & -4.1 \\
\hline Taipei,China & -2.6 & -1.5 & -2.8 & -1.0 & -0.8 & 0.2 & -0.3 & -0.1 & . \\
\hline \multicolumn{10}{|l|}{ South Asia } \\
\hline Bangladesh ${ }^{c}$ & -1.7 & -0.9 & -0.5 & -1.3 & -2.3 & -2.2 & -2.7 & -3.0 & -1.9 \\
\hline Bhutanc & 1.5 & -2.0 & -1.1 & -4.0 & 3.6 & 1.4 & -1.0 & -3.3 & -0.3 \\
\hline Indiad & -4.8 & -5.9 & -4.9 & -4.5 & -4.1 & -3.9 & -3.5 & -3.5 & -3.4 \\
\hline Maldives & -12.9 & -5.8 & -6.7 & -3.5 & -2.4 & -6.7 & -10.4 & -3.0 & -5.5 \\
\hline Nepale & -1.4 & -1.0 & -0.6 & 1.7 & 1.8 & 1.1 & $\begin{array}{r}0.7 \\
1.4\end{array}$ & -3.1 & \\
\hline Sri Lanka & -6.3 & -5.8 & -5.3 & -5.3 & -5.6 & -7.6 & -5.3 & -5.4 & -5.3 \\
\hline \multicolumn{10}{|l|}{ Southeast Asia } \\
\hline Brunei Darussalam & 15.6 & 25.6 & 15.7 & 10.1 & -0.7 & -14.5 & -21.7 & -9.9 & \\
\hline Cambodia & -4.5 & -5.4 & -4.4 & -2.7 & -1.3 & -0.9 & -0.4 & -1.0 & 0.2 \\
\hline Indonesia & -0.6 & -0.7 & -1.5 & -1.8 & -2.6 & -3.0 & -1.9 & -2.0 & \\
\hline Lao People's Democratic Republics & -0.9 & -0.9 & -0.7 & -4.9 & -3.3 & -3.7 & -4.9 & -4.4 & -6.0 \\
\hline Malaysia & -5.0 & -4.6 & -4.4 & -3.8 & -3.3 & -3.1 & -3.0 & -2.9 & \\
\hline Myanmar & & & -4.4 & -3.2 & -2.5 & -4.4 & -3.0 & -3.1 & $\ldots$ \\
\hline Philippines & -3.5 & -1.8 & -1.9 & -1.2 & -0.5 & -1.3 & -2.3 & -2.2 & $\ldots$ \\
\hline Singapored & 7.5 & 9.1 & 8.5 & 8.1 & 7.1 & 4.2 & 5.1 & 7.7 & $\dddot{2}$ \\
\hline Thailands & -0.7 & -0.6 & -0.8 & 0.6 & -0.7 & 0.1 & 0.4 & -0.3 & 0.3 \\
\hline Viet $\mathrm{Nam}^{\mathrm{h}}$ & -2.1 & -0.5 & -3.4 & -5.0 & -4.4 & -4.3 & -4.2 & -3.5 & -3.5 \\
\hline \multicolumn{10}{|l|}{ The Pacific } \\
\hline Cook Islands & 2.9 & 9.6 & 0.8 & 14.2 & -2.9 & -7.8 & 1.4 & 8.7 & $\ldots$ \\
\hline Fiji & -2.6 & -1.7 & -1.4 & -0.9 & -2.4 & -2.0 & -0.8 & -0.9 & \\
\hline Kiribatic & & -6.9 & 3.5 & 20.3 & 44.7 & 56.1 & 21.6 & 17.0 & $\ldots$ \\
\hline Marshall Islands 8 & 0.3 & 2.1 & -0.7 & 0.7 & 2.8 & 2.8 & 4.0 & 4.5 & $\ldots$ \\
\hline Micronesia, Federated States of & 0.5 & -0.6 & 0.9 & 2.9 & 11.2 & 10.4 & 7.3 & 14.6 & \\
\hline Nauruc & 0.1 & $\ldots$ & 7.9 & 1.5 & 25.0 & 8.9 & 23.5 & 10.4 & 9.0 \\
\hline $\begin{array}{l}\text { Niue } \\
\text { Palaug }\end{array}$ & & 88 & & 51 & & 100 & 9 & & \\
\hline $\begin{array}{l}\text { Palaug } \\
\text { Papua New Guinea }\end{array}$ & 10.0 & 8.8 & 9.3 & 5.1 & 8.1 & 10.0 & 9.2 & $\begin{array}{r}7.8 \\
-24\end{array}$ & $\begin{array}{r}8.2 \\
-25\end{array}$ \\
\hline Samoa ${ }^{c}$ & & & -8.1 & -3.9 & -4.8 & -3.7 & 0.7 & $\begin{array}{l}-2.4 \\
-0.6\end{array}$ & \\
\hline Solomon Islands & 7.3 & 7.9 & 6.0 & 4.5 & 2.7 & 1.0 & -4.1 & -2.9 & 1.9 \\
\hline Timor-Leste & $\ldots$ & & & -3.3 & -11.8 & 3.8 & -6.9 & 5.5 & \\
\hline Tongac & $\ldots$ & $\ldots$ & & & & & 2.7 & 4.4 & 3.0 \\
\hline Tuvalu & $\ldots$ & .... & 11.5 & 26.6 & 29.0 & 40.0 & 4.8 & &. \\
\hline Vanuatu & $\ldots$ & $\ldots$ & -1.6 & -0.2 & 1.2 & 6.9 & 2.5 & 1.9 & $\ldots$ \\
\hline \multicolumn{10}{|l|}{ Developed ADB Member Economies } \\
\hline Australia ${ }^{c}$ & -5.5 & -4.8 & -4.3 & -2.7 & -2.9 & -2.9 & -2.7 & -2.3 & -1.1 \\
\hline Japand ${ }^{d}$ & -8.9 & -9.0 & -8.2 & -7.2 & -5.0 & -3.4 & -3.4 & -2.8 & 1.1 \\
\hline New Zealandc & -3.4 & -7.5 & -2.7 & -1.9 & -0.9 & -0.1 & 0.6 & 1.2 & 1.1 \\
\hline
\end{tabular}

... = data not available, $\mid$ = marks break in series, - = magnitude equals zero, $\mathrm{ADB}=$ Asian Development Bank, $\mathrm{GDP}=$ gross domestic product.

a In general, economies follow the guidelines of the International Monetary Fund on Government Finance Statistics (GFS). Some economies still use the 1986 version of the GFS guidelines, while others have switched to the 2001 or 2014 guidelines. The comparability of the data in this table is limited by variations in the concepts and definitions used in different versions of the GFS framework. Data refer to government net lending/net borrowing as classified in the GFS 2001 or GFS 2014 framework, except for Bhutan; Brunei Darussalam; India, Maldives; Nauru; Pakistan; the People's Republic of China; Taipei,China; Tajikistan; Turkmenistan; and Viet Nam, where data refer to overall budgetary surplus/deficit as classified in the GFS 1986 framework. Data refer to general government, except for Bangladesh; Bhutan; Brunei Darussalam; Cambodia; the Cook Islands; the Federated States of Micronesia; Fiji; India; the Lao People's Democratic Republic; Malaysia; Maldives; the Marshall Islands; Nauru; Nepal; Palau; the Philippines; Solomon Islands; Sri Lanka; Taipei,China; Timor-Leste; Tonga; Tuvalu; Vanuatu; and Viet Nam, where data refer to central government. For Azerbaijan: Data are based on the state budget. For Cambodia: Data refer to central government excluding extra budgetary central government. For the Kyrgyz Republic: For 2010-2013, data refer to central government. For Pakistan: Data refer to the consolidated federal and provincial governments. For the People's Republic of China: Data refer to consolidated central and local governments. For Turkmenistan: For 2010, data refer to central government.

b For 2005-2011, GFS data are based on fiscal year beginning 21 March. For 2012, data cover 9 months from 21 March to 20 December. For 2013 onward, data are based on fiscal year ending 20 December. National accounts data for 2005-2017 are based on fiscal year beginning 21 March, and for 2018 on fiscal year ending 20 December.

c Data are based on fiscal year ending 30 June.

d Data are based on fiscal year beginning 1 April.

e Data are based on fiscal year ending 15 July.

$f$ For 2005 onward, data are based on fiscal year beginning 1 April. Data are derived as excess of revenue over expenditure (ordinary plus charged) less the sum of contribution to a development fund, contribution to a government trust fund, and capital and currency adjustments.

g Data are based on fiscal year ending 30 September.

$\mathrm{h}$ Taxes include local government taxes.

Sources: $\quad$ Economy sources. For Fiji; Hong Kong, China; Kiribati (2011-2013 and 2017); the Kyrgyz Republic; Nepal; and Sri Lanka (2010-2013): International Monetary Fund. Government Finance Statistics. https://data.imf.org/ (accessed May-June 2019). For Nauru: International Monetary Fund. Staff Country Reports. Republic of Nauru: 2017 Article IV. http://www.imf.org/en/Publications/CR/Issues/2017/04/03/Republic-of-Nauru-2017-Article-IV-Consultation-Press-Release-Staff-Report-andStatement-by-44794 (accessed 6 June 2019). 
Table 2.8.2: Government Taxes ${ }^{a}$

(\% of GDP)

\begin{tabular}{|c|c|c|c|c|c|c|c|c|c|}
\hline ADB Regional Member & 2010 & 2011 & 2012 & 2013 & 2014 & 2015 & 2016 & 2017 & 2018 \\
\hline \multirow{2}{*}{\multicolumn{10}{|c|}{ Developing ADB Member Economies }} \\
\hline & & & & & & & & & \\
\hline Afghanistan ${ }^{\mathrm{b}}$ & 9.2 & 8.7 & 7.4 & 7.5 & 6.7 & 7.2 & 7.1 & 8.1 & 7.3 \\
\hline Armenia & 17.7 & 17.8 & 19.2 & 22.0 & 22.2 & 21.3 & 21.5 & 21.0 & 21.1 \\
\hline Azerbaijan & 12.4 & 12.3 & 12.7 & 13.2 & 14.2 & 16.2 & 14.9 & 13.3 & 13.3 \\
\hline Georgia & 23.5 & 25.2 & 25.5 & 24.8 & 24.8 & 25.2 & 25.8 & 25.8 & 25.6 \\
\hline Kazakhstan & 19.6 & 21.7 & 16.9 & 19.5 & 17.8 & 13.6 & 12.4 & 14.2 & \\
\hline Kyrgyz Republic & 15.0 & 16.1 & 18.1 & 17.6 & 20.4 & 19.7 & 19.5 & 19.6 & \\
\hline Pakistanc & 10.0 & 9.4 & 10.2 & 9.8 & 10.2 & 11.0 & 12.4 & 12.5 & 13.0 \\
\hline Tajikistan & 18.0 & 19.5 & 19.6 & 20.8 & 22.7 & 21.9 & 20.6 & $\ldots$ & $\ldots$ \\
\hline Turkmenistan & $\ldots$ & 17.5 & 20.2 & 17.7 & 17.0 & 15.6 & & & \\
\hline Uzbekistan & $\ldots$ & $\ldots$ & $\ldots$ & 21.1 & 20.4 & 20.3 & 20.0 & 17.3 & 19.7 \\
\hline \multicolumn{10}{|l|}{ East Asia } \\
\hline China, People's Republic of & 17.8 & 18.4 & 18.7 & 18.6 & 18.6 & 18.2 & 17.6 & 17.6 & 17.4 \\
\hline Hong Kong, Chinad & 13.5 & 14.2 & 13.7 & 13.4 & 15.5 & 14.4 & 13.6 & 14.3 & $\ldots$ \\
\hline Korea, Republic of & & & 18.0 & 17.3 & 17.3 & 17.6 & 18.4 & 19.0 & \\
\hline Mongolia & 24.2 & 24.3 & 21.1 & 21.9 & 19.1 & 17.7 & 16.0 & 17.9 & 20.5 \\
\hline Taipei,China & 7.6 & 8.4 & 8.4 & 8.0 & 8.4 & 8.7 & 8.9 & 8.8 & $\ldots$ \\
\hline \multicolumn{10}{|l|}{ South Asia } \\
\hline Bangladesh ${ }^{c}$ & 10.2 & 10.6 & 10.3 & 9.7 & 9.6 & 8.9 & 8.8 & 9.1 & 7.4 \\
\hline Bhutan ${ }^{c}$ & 13.3 & 13.6 & 15.1 & 14.6 & 13.5 & 13.9 & 13.1 & 13.6 & 15.5 \\
\hline India ${ }^{d}$ & 7.3 & 7.2 & 7.5 & 7.3 & 7.3 & 6.9 & 7.2 & 7.3 & 6.9 \\
\hline Maldives & 8.8 & 12.1 & 15.5 & 17.5 & 19.1 & 19.4 & 19.6 & 19.7 & 18.6 \\
\hline Nepale & 13.4 & 13.3 & 13.9 & 15.3 & 15.9 & 16.7 & 18.7 & 21.0 & $\ldots$ \\
\hline Sri Lanka & 11.3 & 11.3 & 10.4 & 10.5 & 10.1 & 12.4 & 12.2 & 12.4 & . \\
\hline \multirow{2}{*}{\multicolumn{10}{|c|}{$\begin{array}{l}\text { Southeast Asia } \\
\text { Brunei Darussalam }\end{array}$}} \\
\hline & & & & & & & & & \\
\hline Cambodia & 7.3 & 7.6 & 11.6 & 12.1 & 14.6 & 14.6 & 14.8 & 15.8 & 16.8 \\
\hline Indonesia & 12.1 & 12.2 & 12.5 & 12.5 & 12.1 & 12.0 & 11.6 & 11.2 & \\
\hline Lao People's Democratic Republics & 13.8 & 14.3 & 13.6 & 13.7 & 13.8 & 13.5 & 12.9 & 11.1 & 11.5 \\
\hline Malaysia & 13.3 & 14.8 & 15.6 & 15.3 & 14.8 & 14.1 & 13.6 & 13.0 & $\ldots$ \\
\hline Myanmar & & & 6.6 & 7.3 & 7.8 & 7.5 & 7.8 & 7.2 & \\
\hline Philippines & 12.1 & 12.4 & 12.9 & 13.3 & 13.6 & 13.6 & 13.7 & 14.2 & $\ldots$ \\
\hline Singapore ${ }^{d}$ & 12.8 & 13.1 & 13.6 & 13.3 & 13.6 & 13.1 & 13.4 & 14.2 & \\
\hline Thailands & 16.1 & 17.7 & 16.8 & 18.4 & 17.3 & 17.6 & 16.8 & 16.3 & 16.5 \\
\hline Viet $\mathrm{Nam}^{\mathrm{h}}$ & 22.4 & 22.3 & 19.0 & 19.1 & 18.2 & 18.0 & 17.9 & 18.6 & 18.5 \\
\hline \multicolumn{10}{|l|}{ The Pacific } \\
\hline Cook Islands ${ }^{c}$ & 27.0 & 26.4 & 23.8 & 28.1 & 25.3 & 23.5 & 26.3 & 26.0 & $\ldots$ \\
\hline Fiji & 21.8 & 23.0 & 23.2 & 23.6 & 22.7 & 23.7 & 23.5 & 25.0 & $\ldots$ \\
\hline Kiribatic & & 18.3 & 19.0 & 18.6 & 18.4 & 22.7 & 25.5 & 22.8 & $\ldots$ \\
\hline Marshall Islandsg & 16.8 & 16.5 & 15.7 & 15.8 & 17.0 & 13.5 & 17.5 & 17.9 & $\ldots$ \\
\hline Micronesia, Federated States of & 12.0 & 12.0 & 11.6 & 12.1 & 19.0 & 12.4 & 12.9 & 17.7 & \\
\hline Nauruc & & & 8.1 & 15.3 & 14.9 & 18.8 & 22.5 & 20.3 & 14.9 \\
\hline Niue & & & & & & & & & \\
\hline Palaus & 17.0 & 18.0 & 18.5 & 18.6 & 19.3 & 20.2 & 19.7 & 19.9 & 21.4 \\
\hline Papua New Guinea & & & & & & & & 12.1 & 12.7 \\
\hline Samoa ${ }^{c}$ & & & 20.9 & 23.5 & 24.9 & 23.6 & 24.3 & 25.0 & \\
\hline Solomon Islands & 28.4 & 32.5 & 33.8 & 33.7 & 32.7 & 32.8 & 30.3 & 31.6 & 33.3 \\
\hline Timor-Leste & $\ldots$ & $\ldots$ & $\ldots$ & 1.9 & 3.1 & 4.0 & 6.3 & 5.6 & \\
\hline Tongac & & & & & & & 20.3 & 17.1 & 22.0 \\
\hline Tuvalu & $\ldots$ & & 28.5 & 34.7 & 30.1 & 33.1 & 28.0 & & $\ldots$ \\
\hline Vanuatu & $\ldots$ & $\ldots$. & 16.5 & 17.2 & 17.3 & 16.3 & 16.3 & 17.1 & $\ldots$ \\
\hline \multicolumn{10}{|l|}{ Developed ADB Member Economies } \\
\hline Australia ${ }^{\mathrm{C}}$ & 25.6 & 25.3 & 26.0 & 27.0 & 27.1 & 27.3 & 27.8 & 27.5 & 28.5 \\
\hline Japand & 15.7 & 16.4 & 16.7 & 17.4 & 18.7 & 18.8 & 18.5 & 19.0 & \\
\hline New Zealandc & 29.1 & 28.6 & 29.3 & 30.5 & 29.6 & 30.7 & 30.9 & 31.2 & 31.2 \\
\hline
\end{tabular}

... = data not available, $\mid$ = marks break in series, $\mathrm{ADB}=$ Asian Development Bank, GDP = gross domestic product.

a In general, economies follow the guidelines of the International Monetary Fund on Government Finance Statistics (GFS). Some economies still use the 1986 version of the GFS guidelines, while others have switched to the 2001 or 2014 guidelines. The comparability of the data in this table is limited by variations in the concepts and definitions used in different versions of the GFS framework. Data refer to government taxes as classified in the GFS 2001 or GFS 2014 framework, except for Bhutan; Brunei Darussalam; India, Maldives; Nauru; Pakistan; the People's Republic of China; Taipei,China; Tajikistan; Turkmenistan; and Viet Nam, where data refer to tax revenue as classified in the GFS 1986 framework. Data refer to general government, except for Bangladesh; Bhutan; Brunei Darussalam; Cambodia; the Cook Islands; the Federated States of Micronesia; Fiji; India; the Lao People's Democratic Republic; Malaysia; Maldives; the Marshall Islands; Nauru; Nepal; Palau; the Philippines; Solomon Islands; Sri Lanka; Taipei,China; Timor-Leste; Tonga; Tuvalu; Vanuatu; and Viet Nam, where data refer to central government. For Azerbaijan: Data are based on the state budget. For Cambodia: Data refer to central government excluding extra budgetary central government. For the Kyrgyz Republic: For 2010-2013, data refer to central government. For Pakistan: Data refer to the consolidated federal and provincial governments. For the People's Republic of China: Data refer to consolidated central and local governments. For Turkmenistan: For 2010, data refer to central government.

b For 2005-2011, GFS data are based on fiscal year beginning 21 March. For 2012, data cover 9 months from 21 March to 20 December. For 2013 onward, data are based on fiscal year ending 20 December. National accounts data for 2005-2017 are based on fiscal year beginning 21 March, and for 2018 on fiscal year ending 20 December.

c Data are based on fiscal year ending 30 June.

d Data are based on fiscal year beginning 1 April.

e Data are based on fiscal year ending 15 July.

$f$ For 2005 onward, data are based on fiscal year beginning 1 April. Data are derived as excess of revenue over expenditure (ordinary plus charged) less the sum of contribution to a development fund, contribution to a government trust fund, and capital and currency adjustments.

$g$ Data are based on fiscal year ending 30 September.

h Taxes include local government taxes.

Sources: $\quad$ Economy sources. For Fiji; Hong Kong, China; Kiribati (2011-2013 and 2017); the Kyrgyz Republic; Nepal; and Sri Lanka (2010-2013): International Monetary Fund. Government Finance Statistics. https://data.imf.org/ (accessed May-June 2019). For Nauru: International Monetary Fund. Staff Country Reports. Republic of Nauru: 2017 Article IV. http://www.imf.org/en/Publications/CR/Issues/2017/04/03/Republic-of-Nauru-2017-Article-IV-Consultation-Press-Release-Staff-Report-andStatement-by-44794 (accessed 6 June 2019). 
Table 2.8.3: Government Revenue

(\% of GDP)

\begin{tabular}{|c|c|c|c|c|c|c|c|c|c|}
\hline ADB Regional Member & 2010 & 2011 & 2012 & 2013 & 2014 & 2015 & 2016 & 2017 & 2018 \\
\hline \multirow{2}{*}{\multicolumn{10}{|c|}{$\begin{array}{l}\text { Developing ADB Member Economies } \\
\text { Central and West Asia }\end{array}$}} \\
\hline & & & & & & & & & \\
\hline Afghanistan $\mathrm{b}$ & 23.6 & 22.5 & 19.0 & 26.9 & 24.1 & 23.9 & 25.2 & 24.6 & 26.9 \\
\hline Armenia & 23.2 & 24.0 & 24.4 & 24.2 & 24.4 & 23.8 & 23.8 & 22.9 & 23.1 \\
\hline Azerbaijan & 26.9 & 30.1 & 31.6 & 33.5 & 31.2 & 32.2 & 29.0 & 23.5 & 28.2 \\
\hline Georgia & 28.3 & 28.2 & 28.9 & 27.7 & 27.9 & 28.2 & 28.4 & 28.9 & 28.8 \\
\hline Kazakhstan & 25.5 & 27.6 & 26.3 & 24.2 & 23.2 & 17.6 & 17.6 & 20.4 & \\
\hline Kyrgyz Republic & 22.6 & 24.1 & 25.0 & 25.11 & 35.4 & 35.6 & 33.1 & 33.9 & \\
\hline Pakistan & 14.2 & 12.5 & 12.8 & 13.3 & 14.5 & 14.4 & 15.0 & 15.5 & 15.2 \\
\hline Tajikistan & 19.3 & 21.1 & 21.5 & 22.7 & 25.1 & 25.0 & 23.4 & & \\
\hline Turkmenistan & 15.8 & 18.1 & 21.0 & 18.4 & 17.9 & 16.6 & 11.7 & 14.9 & 14.1 \\
\hline Uzbekistan & & & & 30.3 & 29.0 & 27.6 & 27.5 & 24.3 & 27.8 \\
\hline \multicolumn{10}{|l|}{ East Asia } \\
\hline China, People's Republic of & 20.2 & 21.3 & 21.8 & 21.8 & 21.9 & 22.2 & 21.6 & 21.0 & 20.4 \\
\hline Hong Kong, China ${ }^{d}$ & 22.3 & 23.8 & 23.5 & 21.5 & 23.6 & 21.7 & 24.6 & 25.8 & $\ldots$ \\
\hline Korea, Republic of & & & 33.3 & 32.3 & 32.3 & 32.2 & 32.6 & 33.2 & \\
\hline Mongolia & 32.0 & 32.2 & 29.3 & 31.0 & 28.2 & 25.8 & 24.4 & 26.1 & 28.7 \\
\hline Taipei,China & 10.7 & 11.8 & 11.0 & 11.5 & 10.9 & 11.6 & 11.1 & 11.1 & $\ldots$ \\
\hline \multicolumn{10}{|l|}{ South Asia } \\
\hline Bangladesh & 13.0 & 13.9 & 13.7 & 12.9 & 11.5 & 10.6 & 10.2 & 10.5 & 8.3 \\
\hline Bhutan $^{c}$ & 27.4 & 20.8 & 20.7 & 20.0 & 19.7 & 19.9 & 17.8 & 18.6 & 21.4 \\
\hline Indiad & 10.6 & 9.0 & 9.3 & 9.4 & 9.3 & 9.2 & 9.4 & 9.1 & 8.8 \\
\hline Maldives & 19.3 & 22.6 & 22.0 & 23.3 & 26.4 & 26.4 & 27.0 & 26.6 & 25.1 \\
\hline Nepale & 18.1 & 18.5 & 18.7 & 19.5 & 20.6 & 21.1 & 23.3 & 24.4 & \\
\hline Sri Lanka & 13.0 & 13.2 & 12.2 & 12.0 & 11.5 & 13.3 & 14.1 & 13.7 & 13.4 \\
\hline \multicolumn{10}{|l|}{ Southeast Asia } \\
\hline Brunei Darussalam ${ }^{f}$ & 49.0 & 55.3 & 46.8 & 37.9 & 31.1 & 24.2 & 17.7 & 26.1 & \\
\hline Cambodia & 13.8 & 12.5 & 16.3 & 17.9 & 19.1 & 18.5 & 19.8 & 20.4 & 21.6 \\
\hline Indonesia & 16.6 & 16.8 & 17.0 & 16.9 & 16.8 & 15.1 & 14.4 & 14.1 & \\
\hline Lao People's Democratic Republic & 21.7 & 21.5 & 20.8 & 20.9 & 20.9 & 20.3 & 16.2 & 13.9 & 15.0 \\
\hline Malaysia & 19.4 & 20.3 & 21.4 & 20.9 & 19.9 & 18.6 & 17.0 & 16.1 & \\
\hline Myanmard & & & 9.8 & 11.2 & 13.9 & 11.8 & 11.7 & 10.7 & \\
\hline Philippines & 13.4 & 14.0 & 14.5 & 14.8 & 15.1 & 15.4 & 15.2 & 15.6 & \\
\hline Singapore & 16.8 & 17.0 & 17.5 & 17.2 & 18.0 & 18.0 & 18.5 & 20.5 & \\
\hline Thailands & 20.6 & 21.3 & 20.4 & 22.2 & 21.3 & 22.1 & 21.5 & 20.9 & 21.5 \\
\hline Viet Nam ${ }^{\mathrm{h}}$ & 26.7 & 25.5 & 22.3 & 22.8 & 22.0 & 23.5 & 24.3 & 25.6 & 25.6 \\
\hline \multicolumn{10}{|l|}{ The Pacific } \\
\hline Cook Islands ${ }^{c}$ & 38.3 & 40.6 & 39.0 & 42.2 & 38.8 & 39.7 & 39.2 & 38.8 & \\
\hline Fiji & 24.3 & 25.6 & 25.6 & 26.1 & 25.9 & 27.4 & 26.1 & 27.9 & $\ldots$ \\
\hline Kiribatic & & 64.4 & 77.9 & 92.2 & 112.1 & 127.8 & 99.9 & 104.3 & $\ldots$ \\
\hline Marshall Islands & 60.0 & 57.0 & 50.8 & 53.5 & 58.6 & 57.9 & 61.9 & 70.0 & 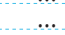 \\
\hline Micronesia, Federated States of 8 & 67.7 & 64.8 & 66.2 & 62.6 & 65.7 & 66.3 & 69.1 & 79.1 & $\cdots$ \\
\hline Nauruc & 39.2 & $\ldots$ & 31.9 & 39.1 & 60.0 & 64.7 & 94.1 & 92.6 & 74.7 \\
\hline \multicolumn{10}{|l|}{ Niue } \\
\hline Palaus & 46.7 & 45.2 & 45.0 & 41.2 & 43.8 & 41.0 & 41.5 & 40.2 & 44.7 \\
\hline Papua New Guinea & $\ldots \ldots$ & $\ldots$ & & & & & & 15.2 & 17.1 \\
\hline Samoa & & & 30.2 & 31.7 & 36.0 & 32.0 & 32.6 & 34.0 & \\
\hline Solomon Islands & 36.5 & 42.4 & 43.9 & 44.8 & 42.6 & 44.7 & 38.8 & 39.3 & 41.3 \\
\hline Timor-Leste & $\ldots \ldots$ & $\ldots$ & $\ldots$ & 15.6 & 21.3 & 47.0 & 58.1 & 52.4 & \\
\hline Tongac & 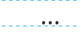 & & & & & & 26.1 & 22.6 & 29.9 \\
\hline Tuvalu & $\ldots$ & $\ldots$ & 105.3 & 123.3 & 140.4 & 184.0 & 161.5 & & \\
\hline Vanuatu & $\ldots \ldots$ & $\ldots \ldots$ & 21.8 & 21.4 & 23.4 & 31.1 & 30.8 & 30.9 & $\ldots$ \\
\hline \multicolumn{10}{|l|}{ Developed ADB Member Economies } \\
\hline Australiac & 32.3 & 31.7 & 32.3 & 33.7 & 33.7 & 34.2 & 34.8 & 34.5 & 35.6 \\
\hline Japand & 30.2 & 31.5 & 32.0 & 33.1 & 34.9 & 35.6 & 35.4 & 35.7 & \\
\hline New Zealand ${ }^{c}$ & 36.9 & 38.3 & 36.7 & 37.8 & 36.7 & 37.5 & 37.6 & 37.6 & 37.3 \\
\hline
\end{tabular}

... = data not available, $\mid$ = marks break in series, $\mathrm{ADB}=$ Asian Development Bank, $\mathrm{GDP}=$ gross domestic product.

a In general, economies follow the guidelines of the International Monetary Fund on Government Finance Statistics (GFS). Some economies still use the 1986 version of the GFS guidelines, while others have switched to the 2001 or 2014 guidelines. The comparability of the data in this table is limited by variations in the concepts and definitions used in different versions of the GFS framework. Data refer to government revenue as classified in the GFS 2001 or GFS 2014 framework, except for Bhutan; Brunei Darussalam; India, Maldives; Nauru; Pakistan; the People's Republic of China; Taipei,China; Tajikistan; Turkmenistan; and Viet Nam, where data refer to total government revenue as classified in the GFS 1986 framework. Data refer to general government, except for Bangladesh; Bhutan; Brunei Darussalam; Cambodia; the Cook Islands; the Federated States of Micronesia; Fiji; India; the Lao People's Democratic Republic; Malaysia; Maldives; the Marshall Islands; Nauru; Nepal; Palau; the Philippines; Solomon Islands; Sri Lanka; Taipei, China; Timor-Leste; Tonga; Tuvalu; Vanuatu; and Viet Nam, where data refer to central government. For Azerbaijan: Data are based on the state budget. For Cambodia: Data refer to central government excluding extra budgetary central government. For the Kyrgyz Republic: For 2010-2013, data refer to central government. For Pakistan: Data refer to the consolidated federal and provincial governments. For the People's Republic of China: Data refer to consolidated central and local governments. For Turkmenistan: For 2010, data refer to central government.

b For 2005-2011, GFS data are based on fiscal year beginning 21 March. For 2012, data cover 9 months from 21 March to 20 December. For 2013 onward, data are based on fiscal year ending 20 December. National accounts data for 2005-2017 are based on fiscal year beginning 21 March, and for 2018 on fiscal year ending 20 December.

c Data are based on fiscal year ending 30 June.

d Data are based on fiscal year beginning 1 April.

e Data are based on fiscal year ending 15 July.

$f$ For 2005 onward, data are based on fiscal year beginning 1 April. Data are derived as excess of revenue over expenditure (ordinary plus charged) less the sum of contribution to a development fund, contribution to a government trust fund, and capital and currency adjustments.

$g$ Data are based on fiscal year ending 30 September.

$\mathrm{h}$ Taxes include local government taxes.

Sources: $\quad$ Economy sources. For Fiji; Hong Kong, China; Kiribati (2011-2013 and 2017); the Kyrgyz Republic; Nepal; and Sri Lanka (2010-2013): International Monetary Fund. Government Finance Statistics. https://data.imf.org/ (accessed May-June 2019). For Nauru: International Monetary Fund. Staff Country Reports. Republic of Nauru: 2017 Article IV. http://www.imf.org/en/Publications/CR/Issues/2017/04/03/Republic-of-Nauru-2017-Article-IV-Consultation-Press-Release-Staff-Report-andStatement-by-44794 (accessed 6 June 2019). 
Table 2.8.4: Government Expenditure ${ }^{a}$ $(\%$ of GDP)

\begin{tabular}{|c|c|c|c|c|c|c|c|c|c|}
\hline ADB Regional Member & 2010 & 2011 & 2012 & 2013 & 2014 & 2015 & 2016 & 2017 & 2018 \\
\hline \multirow{2}{*}{\multicolumn{10}{|c|}{ Developing ADB Member Economies }} \\
\hline & & & & & & & & & \\
\hline Afghanistan ${ }^{\mathrm{b}}$ & 29.5 & 25.5 & 24.7 & 23.9 & 25.5 & 25.4 & 28.2 & 27.4 & 26.8 \\
\hline Armenia & 28.2 & 26.8 & 25.9 & 25.7 & 26.3 & 28.6 & 29.3 & 27.7 & 24.7 \\
\hline Azerbaijan & 37.7 & 43.2 & 44.7 & 47.1 & 44.6 & 44.6 & 34.4 & 29.8 & 37.2 \\
\hline Georgia & 32.8 & 29.1 & 29.5 & 28.8 & 29.8 & 29.3 & 29.8 & 29.7 & 29.6 \\
\hline Kazakhstan & 20.4 & 19.3 & 20.3 & 19.1 & 19.8 & 19.8 & 20.5 & 23.4 & \\
\hline Kyrgyz Republic & 27.5 & 29.0 & 31.5 & 25.9 & 35.4 & 36.5 & 36.9 & 36.5 & \\
\hline Pakistanc ${ }^{c}$ & 20.4 & 18.9 & 21.2 & 19.8 & 20.4 & 20.2 & 20.3 & 21.6 & 21.6 \\
\hline Tajikistan & 25.1 & 27.4 & 25.1 & 28.5 & 28.8 & 33.6 & 33.8 & & \\
\hline Turkmenistan & 13.8 & 14.6 & 14.7 & 16.9 & 17.0 & 17.3 & 14.1 & 17.7 & 13.5 \\
\hline Uzbekistan & $+\ldots$ & 17.0 & $\ldots$ & 25.4 & 24.7 & 24.3 & 23.6 & 22.8 & 24.6 \\
\hline \multicolumn{10}{|l|}{ East Asia } \\
\hline China, People's Republic of & 21.8 & 22.4 & 23.4 & 23.6 & 23.7 & 25.6 & 25.4 & 24.7 & 24.5 \\
\hline Hong Kong, Chinad & 18.1 & 20.0 & 20.0 & 20.8 & 19.3 & 20.3 & 19.9 & 19.5 & $\ldots$ \\
\hline Korea, Republic of & & & 32.2 & 30.9 & 31.0 & 31.1 & 30.2 & 30.7 & \\
\hline Mongolia & 35.2 & 44.0 & 44.8 & 39.3 & 39.8 & 36.8 & 47.3 & 37.1 & 32.8 \\
\hline Taipei, China & 13.3 & 13.3 & 13.7 & 12.5 & 11.7 & 11.4 & 11.4 & 11.2 & $\ldots$ \\
\hline \multicolumn{10}{|l|}{ South Asia } \\
\hline Bangladesh ${ }^{c}$ & 14.8 & 14.8 & 14.2 & 14.2 & 13.7 & 12.7 & 12.9 & 13.4 & 10.2 \\
\hline Bhutan ${ }^{c}$ & 35.6 & 34.8 & 35.8 & 34.7 & 29.0 & 27.6 & 29.4 & 31.3 & 32.3 \\
\hline India ${ }^{d}$ & 15.4 & 14.9 & 14.2 & 13.9 & 13.4 & 13.1 & 12.9 & 12.5 & 12.2 \\
\hline Maldives & 33.2 & 31.3 & 29.8 & 27.0 & 29.1 & 34.0 & 37.3 & 30.1 & 31.3 \\
\hline Nepale & 19.5 & 19.5 & 19.3 & 17.8 & 18.8 & 20.1 & 21.9 & 27.5 & \\
\hline Sri Lanka & 19.3 & 19.0 & 17.5 & 17.3 & 17.0 & 20.9 & 19.5 & 19.1 & 18.7 \\
\hline \multicolumn{10}{|l|}{ Southeast Asia } \\
\hline Brunei Darussalam & 33.3 & 29.7 & 31.0 & 27.8 & 31.8 & 38.7 & 39.4 & 36.0 & \\
\hline Cambodia & 18.3 & 17.9 & 20.7 & 20.6 & 20.5 & 19.4 & 20.2 & 21.4 & 21.4 \\
\hline Indonesia & 17.2 & 17.5 & 18.4 & 18.7 & 18.5 & 17.8 & 16.9 & 16.5 & \\
\hline Lao People's Democratic Republics & 22.7 & 22.4 & 21.5 & 25.7 & 24.2 & 24.1 & 21.1 & 18.3 & 21.0 \\
\hline Malaysia & 24.4 & 25.0 & 25.8 & 24.7 & 23.2 & 21.7 & 20.0 & 19.0 & $\ldots$ \\
\hline Myanmar & & & 14.2 & 14.4 & 16.4 & 16.2 & 14.7 & 13.7 & \\
\hline Philippines & 16.9 & 15.8 & 16.4 & 16.1 & 15.6 & 16.7 & 17.4 & 17.9 & $\ldots$ \\
\hline Singapored & 9.3 & 7.9 & 9.0 & 9.2 & 10.9 & 13.8 & 13.5 & 12.8 & \\
\hline Thailands & 21.3 & 21.9 & 21.2 & 21.6 & 22.0 & 21.9 & 21.1 & 21.2 & 21.2 \\
\hline Viet Nam & 27.2 & 25.4 & 28.2 & 28.8 & 26.4 & 28.2 & 28.7 & 29.2 & 29.2 \\
\hline \multicolumn{10}{|l|}{ The Pacific } \\
\hline Cook Islands c & 35.5 & 31.0 & 35.7 & 28.0 & 41.7 & 47.5 & 37.8 & 30.1 & $\ldots$ \\
\hline Fiji & 27.0 & 27.3 & 27.0 & 26.9 & 28.4 & 29.4 & 28.0 & 26.5 & $\cdots$ \\
\hline Kiribatic & & 71.3 & 74.5 & 71.9 & 67.4 & 71.7 & 78.3 & 87.4 & $\ldots$ \\
\hline Marshall Islands & 59.8 & 54.9 & 51.5 & 52.8 & 55.8 & 55.2 & 57.9 & 65.5 & $\ldots$ \\
\hline Micronesia, Federated States of 8 & 67.2 & 65.4 & 65.3 & 59.8 & 54.5 & 55.9 & 61.8 & 64.5 & \\
\hline Nauruc $^{c}$ & 83.6 & $\ldots . .$. & 44.7 & 57.4 & 51.8 & 72.3 & 91.6 & 99.9 & 94.5 \\
\hline Niue & $\ldots$ & $\ldots \ldots$ & $\ldots$ & ....... & $\ldots$ & $\ldots . .$. & $\ldots . .$. & $\ldots$ & $\ldots \ldots$ \\
\hline Palaus & & & $\ldots$ & $\ldots$ & $\ldots$ & $\ldots$ & $\ldots . .$. & $\ldots$ & $\ldots$ \\
\hline Papua New Guinea & $\ldots$ & $\ldots$ & & & & & & 17.6 & 19.6 \\
\hline Samoa ${ }^{\mathrm{C}}$ & & & 38.3 & 35.7 & 40.8 & 35.7 & 31.9 & 34.7 & \\
\hline Solomon Islands & 29.1 & 34.4 & 37.9 & 40.2 & 39.9 & 43.7 & 42.9 & 42.1 & 39.3 \\
\hline Timor-Leste & $\ldots$ & $\ldots . .$. & $\ldots . .$. & 18.9 & 33.1 & 43.2 & 65.0 & 46.9 & \\
\hline Tongac & & & & & & & 23.4 & 18.2 & 26.8 \\
\hline Tuvalu & $\ldots \ldots$ & $\ldots \ldots$ & 92.0 & 93.3 & 106.7 & 117.0 & 121.9 & & \\
\hline Vanuatu & $\ldots$ & $\ldots$. & 23.4 & 21.6 & 22.2 & 24.2 & 28.4 & 29.1 &. \\
\hline \multicolumn{10}{|l|}{ Developed ADB Member Economies } \\
\hline Australiac & 37.8 & 36.5 & 36.7 & 36.4 & 36.6 & 37.2 & 37.4 & 36.9 & 36.7 \\
\hline Japand & 39.1 & 40.4 & 40.2 & 40.4 & 39.8 & 39.0 & 38.8 & 38.5 & \\
\hline New Zealandc & 40.3 & 45.7 & 39.4 & 39.7 & 37.7 & 37.7 & 37.0 & 36.4 & 36.2 \\
\hline
\end{tabular}

... = data not available, $\mid$ = marks break in series, $\mathrm{ADB}=$ Asian Development Bank, GDP = gross domestic product.

a In general, economies follow the guidelines of the International Monetary Fund on Government Finance Statistics (GFS). Some economies still use the 1986 version of the GFS guidelines, while others have switched to the 2001 or 2014 guidelines. The comparability of the data in this table is limited by variations in the concepts and definitions used in different versions of the GFS framework. Data refer to government expenditure as classified in the GFS 2001 or GFS 2014 framework, except for Bhutan; Brunei Darussalam; India, Maldives; Nauru; Pakistan; the People's Republic of China; Taipei,China; Tajikistan; Turkmenistan; and Viet Nam, where data refer to total government expenditure as classified in the GFS 1986 framework. Data refer to general government, except for Bangladesh; Bhutan; Brunei Darussalam; Cambodia; the Cook Islands; the Federated States of Micronesia; Fiji; India; the Lao People's Democratic Republic; Malaysia; Maldives; the Marshall Islands; Nauru; Nepal; Palau; the Philippines; Solomon Islands; Sri Lanka; Taipei,China; Timor-Leste; Tonga; Tuvalu; Vanuatu; and Viet Nam, where data refer to central government. For Azerbaijan: Data are based on the state budget. For Cambodia: Data refer to central government excluding extra budgetary central government. For the Kyrgyz Republic: For 2010-2013, data refer to central government. For Pakistan: Data refer to the consolidated federal and provincial governments. For the People's Republic of China: Data refer to consolidated central and local governments. For Turkmenistan: For 2010, data refer to central government.

b For 2005-2011, GFS data are based on fiscal year beginning 21 March. For 2012, data cover 9 months from 21 March to 20 December. For 2013 onward, data are based on fiscal year ending 20 December. National accounts data for 2005-2017 are based on fiscal year beginning 21 March, and for 2018 on fiscal year ending 20 December.

c Data are based on fiscal year ending 30 June.

d Data are based on fiscal year beginning 1 April.

e Data are based on fiscal year ending 15 July.

$f$ For 2005 onward, data are based on fiscal year beginning 1 April. Data are derived as excess of revenue over expenditure (ordinary plus charged) less the sum of contribution to a development fund, contribution to a government trust fund, and capital and currency adjustments.

$g$ Data are based on fiscal year ending 30 September.

h Taxes include local government taxes.

Sources: $\quad$ Economy sources. For Fiji; Hong Kong, China; Kiribati (2011-2013 and 2017); the Kyrgyz Republic; Nepal; and Sri Lanka (2010-2013): International Monetary Fund. Government Finance Statistics. https://data.imf.org/ (accessed May-June 2019). For Nauru: International Monetary Fund. Staff Country Reports. Republic of Nauru: 2017 Article IV. http://www.imf.org/en/Publications/CR/Issues/2017/04/03/Republic-of-Nauru-2017-Article-IV-Consultation-Press-Release-Staff-Report-andStatement-by-44794 (accessed 6 June 2019). 
Table 2.8.5: Government Expenditure by Economic Activity (\% of GDP)

\begin{tabular}{|c|c|c|c|c|c|c|c|c|c|c|}
\hline \multirow{2}{*}{ ADB Regional Member } & \multicolumn{3}{|c|}{ Health } & \multicolumn{3}{|c|}{ Education } & \multicolumn{4}{|c|}{ Social Protection } \\
\hline & 2010 & 2015 & 2018 & 2010 & 2015 & 2018 & 2010 & 2015 & & 18 \\
\hline \multirow{2}{*}{\multicolumn{11}{|c|}{$\begin{array}{l}\text { Developing ADB Member Economies } \\
\text { Central and West Asia }\end{array}$}} \\
\hline & & & & & & & & & & \\
\hline Afghanistan ${ }^{\mathrm{b}}$ & 1.7 & 1.2 & 1.7 & 4.4 & 3.5 & 3.2 & 1.3 & 1.4 & 2.2 & \\
\hline Armenia & 1.6 & 1.7 & 1.3 & 3.2 & 2.9 & 2.5 & 7.1 & 7.7 & 7.0 & \\
\hline Azerbaijan & 1.0 & 1.3 & 0.9 & 2.8 & 3.0 & 2.5 & 2.6 & 3.4 & 2.7 & \\
\hline Georgia & 2.2 & 2.9 & 3.0 & 2.9 & 3.4 & 3.8 & 6.9 & 7.8 & 7.1 & \\
\hline Kazakhstan & 2.5 & 2.1 & $2.6(2017)$ & 3.5 & 3.3 & $3.4(2017)$ & 4.5 & 4.5 & 4.7 & (2017) \\
\hline Kyrgyz Republic & 2.81 & 3.5 & 3.4 (2017) & 2.11 & 7.0 & $7.2(2017)$ & 4.81 & 10.8 & 10.0 & (2017) \\
\hline Pakistan & & & & & & & & & & \\
\hline Tajikistan & 1.4 & 2.1 & 2.2 & 4.0 & 5.2 & 5.6 & 3.5 & 5.4 & 4.5 & \\
\hline Turkmenistan & $\ldots$ & & & $\ldots$ & & & $\ldots$ & & & \\
\hline Uzbekistan & $\ldots$ & 2.5 & 2.3 & $\ldots$ & 6.0 & 5.4 & $\ldots$ & 7.4 & 6.3 & \\
\hline \multicolumn{11}{|l|}{ East Asia } \\
\hline China, People's Republic of & 1.2 & 1.7 & 1.7 & 3.0 & 3.8 & 3.6 & 2.2 & 2.8 & 3.0 & \\
\hline Hong Kong, China ${ }^{c}$ & 2.4 & 3.2 & $2.9(2017)$ & 3.5 & 3.4 & $3.5(2017)$ & 2.4 & 2.9 & 2.8 & (2017) \\
\hline Korea, Republic of & 0.2 & 0.3 & $0.2(2017)$ & 2.8 & 3.0 & $3.2(2017)$ & 4.3 & 5.3 & 5.4 & (2017) \\
\hline Mongolia & 2.5 & 2.5 & 2.5 & 5.1 & 3.0 & 2.8 & 11.1 & 7.6 & 7.4 & \\
\hline Taipei,China & 0.2 & 0.1 & $0.1(2017)$ & 1.7 & 1.5 & $1.5(2017)$ & 3.1 & 3.3 & 3.4 & (2017) \\
\hline \multicolumn{11}{|l|}{ South Asia } \\
\hline Bangladesh $^{\mathrm{d}}$ & 0.8 & 0.7 & $0.3(2017)$ & 2.0 & 2.0 & $2.5(2017)$ & 0.9 & 0.7 & 0.8 & (2017) \\
\hline Bhutand & 3.0 & 2.6 & 2.8 & 6.7 & 5.5 & 6.2 & 3.1 & 3.0 & 1.9 & \\
\hline Indiac & $1.0(2011)$ & 1.2 & $1.3(2016)$ & $4.4(2011)$ & 4.4 & $4.6(2016)$ & $1.4(2011)$ & 1.8 & 1.8 & (2016) \\
\hline Maldives & 3.0 & 3.5 & & 5.0 & 4.7 & & 1.7 & 5.2 & & \\
\hline Nepale & 1.5 & 1.4 & $1.7(2017)$ & 3.9 & 3.7 & $4.1(2017)$ & 0.8 & 0.7 & 1.4 & (2017) \\
\hline SriLanka & 1.2 & 1.6 & $1.5(2017)$ & 1.6 & 2.1 & $1.9(2017)$ & 1.7 & 2.6 & 2.0 & (2017) \\
\hline \multicolumn{11}{|l|}{ Southeast Asia } \\
\hline Brunei Darussalam ${ }^{c}$ & 1.8 & & & 3.6 & & & 0.8 & & & \\
\hline Cambodia & 1.3 & 1.3 & 1.2 & 1.6 & 2.0 & 2.5 & 0.5 & 0.8 & 0.9 & \\
\hline Indonesia & 1.0 & 1.1 & $1.4(2017)$ & 3.4 & 3.3 & $2.7(2017)$ & 0.1 & 0.3 & 1.2 & (2017) \\
\hline Lao People's Democratic Republ & & & & & & & $\ldots$ & $\ldots$ & $\ldots$ & \\
\hline Malaysia & 2.0 & 2.0 & $1.9(2017)$ & 6.1 & 4.8 & $4.4(2017)$ & & & & \\
\hline Myanmarc & $0.7(2012)$ & 1.0 & $0.8(2017)$ & $1.5(2012)$ & 2.1 & $1.8(2017)$ & $0.4(2012)$ & 0.8 & 0.8 & (2017) \\
\hline Philippines $^{f}$ & 0.3 & 0.8 & 1.0 & 2.5 & 2.9 & 4.1 & 1.7 & 1.4 & 2.6 & \\
\hline Singapore ${ }^{c}$ & 1.2 & 2.1 & $2.2(2017)$ & 3.0 & 2.9 & $2.8(2017)$ & 1.1 & 1.8 & 1.0 & (2017) \\
\hline Thailands & $\ldots$ & 1.1 & 1.3 & $\ldots$ & 3.8 & 3.1 & $\ldots$ & 2.5 & 3.0 & \\
\hline Viet Nam & $\ldots$ & $\ldots$ & $\ldots$ & $\ldots$ & $\ldots$ & .... & $\ldots$ & $\ldots$ & ... & \\
\hline \multicolumn{11}{|l|}{ The Pacific } \\
\hline Cook Islands ${ }^{\mathrm{d}}$ & 3.9 & 3.0 & $2.7(2017)$ & 4.0 & 3.5 & $2.7(2017)$ & 3.9 & 4.2 & 3.7 & (2017) \\
\hline Fiji & $\ldots$ & & & $\ldots$ & & & $\ldots$ & $\ldots$ & $\ldots$ & \\
\hline Kiribati $^{\mathrm{d}}$ & & 9.9 & $11.2(2017)$ & & 9.9 & $11.0(2017)$ & ... & 1.4 & 1.3 & (2017) \\
\hline Marshall Islands & 7.8 & 7.6 & $12.0(2017)$ & 19.6 & 16.7 & $15.5(2017)$ & - & - & 3.6 & (2017) \\
\hline Micronesia, Federated States of & $\ldots$ & $\ldots$ & $\ldots$ & $\ldots$ & $\ldots$ & $\ldots$ & $\ldots$ & $\ldots$ & $\ldots$ & \\
\hline Nauru & $\ldots$ & $\ldots$ & $\ldots$ & $\ldots$ & $\ldots . . .$. & $\ldots$ & $\ldots$ & $\ldots$ & $\ldots$ & \\
\hline Niue & $\ldots$ & $\ldots$ & $\ldots$ & $\ldots$ & $\ldots$ & $\ldots$ & $\ldots$ & $\ldots$ & $\ldots$ & \\
\hline Palau & $\ldots$ & $\ldots$ & $\ldots$ & $\ldots$ & $\ldots$ & $\ldots$ & $\ldots$ & $\ldots$ & $\ldots$ & \\
\hline Papua New Guinea & & & & & & & $\ldots$ & & ... & \\
\hline Samoa ${ }^{\mathrm{d}}$ & 3.6 & 5.4 & 3.8 & 5.8 & 4.5 & 4.5 & 1.1 & 2.1 & 1.2 & \\
\hline Solomon Islands & & & & & & & & & & \\
\hline Timor-Leste & 0.9 & 1.9 & $2.2(2017)$ & 1.7 & 3.4 & $3.8(2017)$ & 3.6 & 6.0 & 6.2 & (2017) \\
\hline Tonga & & & & & & & & & & \\
\hline Tuvalu & $8.5(2012)$ & 9.4 & $9.6(2016)$ & $16.0(2012)$ & 23.2 & $20.4(2016)$ & $6.1(2012)$ & 18.3 & 9.1 & (2016) \\
\hline Vanuatu & $2.9(2011)$ & 2.4 & $2.1(2017)$ & $6.2(2011)$ & 5.4 & $5.6(2017)$ & $0.0(2011)$ & 0.1 & 0.0 & (2017) \\
\hline \multicolumn{11}{|l|}{ Developed ADB Member Economies } \\
\hline Australiad & 6.7 & 6.8 & 7.0 & 5.9 & 5.4 & 5.4 & 9.9 & 10.4 & 9.6 & \\
\hline$J_{a p a n}{ }^{c}$ & 6.9 & 7.4 & 7.4 (2017) & 2.8 & 2.6 & $2.5(2017)$ & 2.2 & 2.5 & 2.6 & (2017) \\
\hline New Zealand & 7.0 & 6.9 & 6.6 & 6.8 & 6.3 & 5.7 & 12.5 & 11.5 & 10.6 & \\
\hline
\end{tabular}

... = data not available, - = magnitude equals zero, 0.0 = magnitude is less than half of unit employed, $\mathrm{ADB}=\mathrm{Asian}$ Development Bank, GDP = gross domestic product.

a In general, economies follow the guidelines of the International Monetary Fund on Government Finance Statistics (GFS). Some economies still use the 1986 version of the guidelines, while others have switched to the 2001 or 2014 guidelines. The comparability of the data in this table is limited by variations in the concepts and definitions used in different versions of the GFS framework. The table refers to government expenditure by economic activity as classified in the GFS 2001 or GFS 2014 framework, except for Bhutan; Brunei Darussalam; Maldives; the People's Republic of China; and Taipei,China, where data refer to health, education, and social security and welfare, as classified in the GFS 1986 framework. Data refer to general government, except for Bangladesh; Bhutan; Brunei Darussalam; Cambodia; the Cook Islands; Malaysia; Maldives; the Marshall Islands; Nepal; the People's Republic of China; the Philippines; Samoa; Sri Lanka; Taipei,China; Timor-Leste; Tuvalu; and Vanuatu, where data refer to central government. For the Kyrgyz Republic: Data for 2010-2013 refer to expenditure of the budgetary central government, while data for 2014 onward refer to expenditure of the general government.

b For 2005-2011, GFS data are based on fiscal year beginning 21 March. For 2012, data cover 9 months from 21 March to 20 December. For 2013 onward, data are based on fiscal year ending 20 December. National accounts data for 2005-2017 are based on fiscal year beginning 21 March, and for 2018 on fiscal year ending 20 December.

c Data are based on fiscal year beginning 1 April.

d Data are based on fiscal year ending 30 June.

e Data are based on fiscal year ending 15 July.

$f$ For 2000-2013, data on education include expenditure on recreation, culture, and religion.

$g$ Data are based on fiscal year ending 30 September.

Source: Economy sources. 
Table 2.8.6: Indicators for Business Startups

\begin{tabular}{|c|c|c|c|c|c|c|}
\hline \multirow[t]{2}{*}{ ADB Regional Member } & \multicolumn{3}{|c|}{$\begin{array}{c}\text { Cost of Business Startup Procedure } \\
\text { (\% of GNI per capita) }\end{array}$} & \multicolumn{3}{|c|}{$\begin{array}{l}\text { Time Required to Start Business } \\
\text { (days) }\end{array}$} \\
\hline & 2005 & 2010 & 2018 & 2005 & 2010 & 2018 \\
\hline \multicolumn{7}{|l|}{ Developing ADB Member Economies } \\
\hline Central and West Asia ${ }^{a}$ & 28.0 & 11.3 & 4.5 & 40.1 & 12.9 & 7.1 \\
\hline Afghanistan & 75.2 & 26.7 & 6.4 & 9.5 & 9.5 & 8.5 \\
\hline Armenia & 6.1 & 3.1 & 0.8 & 18.0 & 14.0 & 3.5 \\
\hline Azerbaijan & 12.3 & 3.1 & 1.3 & 113.0 & 8.0 & 3.5 \\
\hline Georgia & 13.7 & 5.0 & 2.2 & 21.0 & 3.0 & 2.0 \\
\hline Kazakhstan & 9.9 & 1.0 & 0.3 & 31.0 & 25.0 & 5.0 \\
\hline Kyrgyz Republic & 10.4 & 3.7 & 1.9 & 21.0 & 14.0 & 10.0 \\
\hline Pakistan & & & 6.8 & & & 16.5 \\
\hline Tajikistan & 85.1 & 36.9 & 18.0 & 79.0 & 16.0 & 11.0 \\
\hline \multicolumn{7}{|l|}{ Turkmenistan } \\
\hline Uzbekistan & 11.5 & 10.8 & 3.1 & 28.0 & 14.0 & 4.0 \\
\hline East Asia ${ }^{a}$ & 8.3 & 6.0 & 3.9 & 27.5 & 13.0 & 7.0 \\
\hline China, People's Republic of & . & & 0.4 & & & 8.6 \\
\hline Hong Kong, China & 3.4 & 2.0 & 1.1 & 11.0 & 6.0 & 1.5 \\
\hline Korea, Republic of & 15.7 & 14.7 & 14.6 & 17.0 & 14.0 & 4.0 \\
\hline Mongolia & 9.6 & 3.2 & 1.3 & 17.0 & 17.0 & 11.0 \\
\hline Taipei,China & 4.4 & 4.0 & 1.9 & 65.0 & 15.0 & 10.0 \\
\hline South Asia ${ }^{a}$ & 37.7 & 24.0 & 12.5 & 37.0 & 31.8 & 14.3 \\
\hline Bangladesh & & & 21.2 & & & 19.5 \\
\hline Bhutan & 16.9 & 6.1 & 3.5 & 62.0 & 46.0 & 12.0 \\
\hline India & & & 14.4 & & & 16.5 \\
\hline Maldives & 14.0 & 9.4 & 4.0 & 9.0 & 12.0 & 12.0 \\
\hline Nepal & 69.9 & 46.6 & 22.2 & 31.0 & 31.0 & 16.5 \\
\hline Sri Lanka & 50.0 & 33.9 & 9.4 & 46.0 & 38.0 & 9.0 \\
\hline Southeast Asia ${ }^{a}$ & 50.9 & 41.4 & 12.7 & 63.8 & 55.6 & 38.0 \\
\hline Brunei Darussalam & $8.9(2006)$ & 13.6 & 1.2 & $121.5(2006)$ & 108.5 & 5.5 \\
\hline Cambodia & 276.1 & 127.5 & 47.4 & 87.0 & 102.0 & 99.0 \\
\hline Indonesia & & & 6.1 & & & 19.6 \\
\hline Lao People's Democratic Republic & 25.6 & 13.3 & 6.6 & 135.0 & 86.0 & 174.0 \\
\hline Malaysia & 26.6 & 17.5 & 11.6 & 37.5 & 17.5 & 13.5 \\
\hline Myanmar & & 157.7( & 24.8 & & $77.0(2012)$ & 14.0 \\
\hline Philippines & 23.9 & 22.1 & 20.3 & 47.0 & 37.0 & 31.0 \\
\hline Singapore & 0.9 & 0.7 & 0.4 & 6.0 & 2.5 & 1.5 \\
\hline Thailand & 17.3 & 7.7 & 3.1 & 35.0 & 34.0 & 4.5 \\
\hline Viet Nam & 27.6 & 12.1 & 5.9 & 41.0 & 36.0 & 17.0 \\
\hline \multirow{2}{*}{\multicolumn{7}{|c|}{$\begin{array}{l}\text { The Pacific } \\
\text { Cook Islands }\end{array}$}} \\
\hline & & & & & & \\
\hline Fiji & 28.4 & 23.8 & 15.9 & 44.0 & 44.0 & 40.0 \\
\hline Kiribati & 40.3 & 47.1 & 36.1 & 31.0 & 31.0 & 31.0 \\
\hline Marshall Islands & 22.4 & 17.6 & 10.6 & 17.0 & 17.0 & 17.0 \\
\hline Micronesia, Federated States of & 127.6 & 137.8 & 141.7 & 16.0 & 16.0 & 16.0 \\
\hline \multirow{2}{*}{\multicolumn{7}{|c|}{ Niue }} \\
\hline & & & & & & \\
\hline Palau & 4.7 & 5.7 & 2.9 & 24.0 & 28.0 & 28.0 \\
\hline Papua New Guinea & 27.7 & 27.0 & 20.5 & 52.0 & 52.0 & 41.0 \\
\hline Samoa & 46.4 & 9.8 & 7.3 & 35.0 & 9.0 & 9.1 \\
\hline Solomon Islands & 135.5 & 78.5 & 28.1 & 55.0 & 55.0 & 9.0 \\
\hline Timor-Leste & 125.4 & 5.7 & 0.6 & 167.0 & 110.0 & 13.0 \\
\hline Tonga & 11.7 & 7.0 & 6.5 & 32.0 & 25.0 & 16.0 \\
\hline \multicolumn{7}{|l|}{ Tuvalu } \\
\hline Vanuatu & 83.5 & 48.2 & 42.0 & 47.0 & 47.0 & 18.0 \\
\hline Developed ADB Member Economies ${ }^{\mathrm{a}}$ & 1.1 & 0.6 & 2.8 & 7.5 & 1.5 & 4.7 \\
\hline Australia & 1.9 & 0.7 & 0.7 & 3.0 & 2.5 & 2.5 \\
\hline Japan & & & 7.5 & & & 11.2 \\
\hline New Zealand & 0.2 & 0.4 & 0.2 & 12.0 & 0.5 & 0.5 \\
\hline DEVELOPING ADB MEMBER ECONOMIES ${ }^{a}$ & 42.0 & 27.5 & 14.0 & 46.0 & 33.8 & 19.6 \\
\hline ALL ADB REGIONAL MEMBERS ${ }^{a}$ & 39.7 & 26.1 & 13.2 & 43.9 & 32.1 & 18.6 \\
\hline WORLD & 84.5 & 45.1 & 23.9 & 50.7 & 35.7 & 20.1 \\
\hline
\end{tabular}

... = data not available, $\mathrm{ADB}=$ Asian Development Bank, $\mathrm{GNI}$ = gross national income.

a Arithmetic average of reporting economies only.

Source: World Bank. Doing Business Online. http://data.worldbank.org/indicator (accessed 9 July 2019). 
Table 2.8.7: $\quad$ Corruption Perceptions Index ${ }^{a}$

\begin{tabular}{|c|c|c|c|c|c|c|c|c|c|c|c|c|}
\hline ADB Regional Member & 2000 & 2005 & 2010 & 2012 & 2013 & 2014 & 2015 & 2016 & 2017 & 2018 & Rank in $2017^{b}$ & Rank in $2018^{b}$ \\
\hline \multicolumn{13}{|l|}{ Developing ADB Member Economies } \\
\hline \multicolumn{13}{|l|}{ Central and West Asia } \\
\hline Afghanistan & & 2.5 & 1.4 & 8 & 8 & 12 & 11 & 15 & 15 & 16 & 177 & 172 \\
\hline Armenia & 2.5 & 2.9 & 2.6 & 34 & 36 & 37 & 35 & 33 & 35 & 35 & 107 & 105 \\
\hline Azerbaijan & 1.5 & 2.2 & 2.4 & 27 & 28 & 29 & 29 & 30 & 31 & 25 & 122 & 152 \\
\hline Georgia & $2.4(2002)$ & 2.3 & 3.8 & 52 & 49 & 52 & 52 & 57 & 56 & 58 & 46 & 41 \\
\hline Kazakhstan & 3.0 & 2.6 & 2.9 & 28 & 26 & 29 & 28 & 29 & 31 & 31 & 122 & 124 \\
\hline Kyrgyz Republic & & 2.3 & 2.0 & 24 & 24 & 27 & 28 & 28 & 29 & 29 & 135 & 132 \\
\hline Pakistan & $2.3(2001)$ & 2.1 & 2.3 & 27 & 28 & 29 & 30 & 32 & 32 & 33 & 117 & 117 \\
\hline Tajikistan & $\ldots$ & 2.1 & 2.1 & 22 & 22 & 23 & 26 & 25 & 21 & 25 & 161 & 152 \\
\hline Turkmenistan & $\ldots$ & 1.8 & 1.6 & 17 & 17 & 17 & 18 & 22 & 19 & 20 & 167 & 161 \\
\hline Uzbekistan & 2.4 & 2.2 & 1.6 & 17 & 17 & 18 & 19 & 21 & 22 & 23 & 157 & 158 \\
\hline \multicolumn{13}{|l|}{ East Asia } \\
\hline China, People's Republic of & 3.1 & 3.2 & 3.5 & 39 & 40 & 36 & 37 & 40 & 41 & 39 & 77 & 87 \\
\hline Hong Kong, China & 7.7 & 8.3 & 8.41 & 77 & 75 & 74 & 75 & 77 & 77 & 76 & 13 & 14 \\
\hline Korea, Republic of & 4.0 & 5.0 & 5.4 & 56 & 55 & 55 & 56 & 53 & 54 & 57 & 51 & 45 \\
\hline Mongolia & & 3.0 & 2.7 & 36 & 38 & 39 & 39 & 38 & 36 & 37 & 103 & 93 \\
\hline Taipei,China & 5.5 & 5.9 & 5.8 & 61 & 61 & 61 & 62 & 61 & 63 & 63 & 29 & 31 \\
\hline \multicolumn{13}{|l|}{ South Asia } \\
\hline Bangladesh & $0.4(2001)$ & 1.7 & 2.4 & 26 & 27 & 25 & 25 & 26 & 28 & 26 & 143 & 149 \\
\hline Bhutan & $\ldots$ & $6.0(2006)$ & 5.7 & 63 & 63 & 65 & 65 & 65 & 67 & 68 & 26 & 25 \\
\hline India & 2.8 & 2.9 & 3.3 & 36 & 36 & 38 & 38 & 40 & 40 & 41 & 81 & 78 \\
\hline Maldives & $\ldots$ & $3.3(2007)$ & 2.3 & $\ldots$ & $\ldots$ & $\ldots$ & $\ldots$ & 36 & 33 & 31 & 112 & 124 \\
\hline Nepal & & 2.5 & 2.2 & 27 & 31 & 29 & 27 & 29 & 31 & 31 & 122 & 124 \\
\hline Sri Lanka & $3.7(2002)$ & 3.2 & 3.21 & 40 & 37 & 38 & 37 & 36 & 38 & 38 & 91 & 89 \\
\hline \multicolumn{13}{|l|}{ Southeast Asia } \\
\hline Brunei Darussalam & $\ldots$ & & 5.51 & 55 & 60 & & & 58 & 62 & 63 & 32 & 31 \\
\hline Cambodia & & 2.3 & 2.1 & 22 & 20 & 21 & 21 & 21 & 21 & 20 & 161 & 161 \\
\hline Indonesia & 1.7 & 2.2 & 2.8 & 32 & 32 & 34 & 36 & 37 & 37 & 38 & 96 & 89 \\
\hline Lao People's Democratic Republic & $\ldots$ & 3.3 & 2.1 & 21 & 26 & 25 & 25 & 30 & 29 & 29 & 135 & 132 \\
\hline Malaysia & 4.8 & 5.1 & 4.41 & 49 & 50 & 52 & 50 & 49 & 47 & 47 & 62 & 61 \\
\hline Myanmar & $\ldots$ & 1.8 & 1.4 & 15 & 21 & 21 & 22 & 28 & 30 & 29 & 130 & 132 \\
\hline Philippines & 2.8 & 2.5 & 2.4 & 34 & 36 & 38 & 35 & 35 & 34 & 36 & 111 & 99 \\
\hline Singapore & 9.1 & 9.4 & 9.3 & 87 & 86 & 84 & 85 & 84 & 84 & 85 & 6 & 3 \\
\hline Thailand & 3.2 & 3.8 & 3.5 & 37 & 35 & 38 & 38 & 35 & 37 & 36 & 96 & 99 \\
\hline Viet Nam & 2.5 & 2.6 & 2.71 & 31 & 31 & 31 & 31 & 33 & 35 & 33 & 107 & 117 \\
\hline \multicolumn{13}{|l|}{ The Pacific } \\
\hline Cook Islands & $\ldots$ & $\ldots$ & $\ldots$ & $\ldots$ & $\ldots$ & $\ldots$ & $\ldots$ & $\ldots$ & $\ldots$ & $\ldots$ & $\ldots$ & $\ldots$ \\
\hline Fiji & $\ldots$ & 4.0 & $\ldots$ & $\ldots$ & $\ldots$ & $\ldots$ & $\ldots$ & $\ldots$ & $\ldots$ & $\ldots$ & $\ldots$ & $\ldots$ \\
\hline Kiribati & $\ldots$ & $3.3(2007)$ & 3.21 & $\ldots$ & $\ldots$ & $\ldots$ & $\ldots$ & $\cdots$ & $\ldots$ & $\ldots$ & $\ldots$ & $\ldots$ \\
\hline Marshall Islands & $\ldots$ & ... & $\ldots$ & $\ldots$ & $\ldots$ & $\ldots$ & $\cdots$ & $\ldots$ & $\ldots$ & $\ldots$ & $\ldots$ & $\ldots$ \\
\hline Micronesia, Federated States of & $\ldots$ & $\ldots$ & $\ldots$ & $\cdots$ & $\cdots$ & $\ldots$ & $\ldots$ & $\cdots$ & $\cdots$ & $\cdots$ & $\ldots$ & $\ldots$ \\
\hline Nauru & $\cdots$ & $\ldots$ & $\ldots$ & $\cdots$ & $\ldots$ & $\ldots$ & $\ldots$ & $\ldots$ & $\ldots$ & $\ldots$ & $\ldots$ & $\ldots$ \\
\hline Niue & $\cdots$ & $\ldots$ & $\ldots$ & $\cdots$ & $\ldots$ & $\ldots$ & $\ldots$ & $\cdots$ & $\ldots$ & $\ldots$ & $\ldots$ & $\ldots$ \\
\hline Palau & $\ldots$ & $\ldots$ & $\ldots$ & $\ldots$ & $\ldots$ & $\ldots$ & $\ldots$ & $\ldots$ & $\ldots$ & $\ldots$ & $\ldots$ & $\ldots$ \\
\hline Papua New Guinea & $\ldots$ & 2.3 & 2.1 & 25 & 25 & 25 & 25 & 28 & 29 & 28 & 135 & 138 \\
\hline Samoa & ... & $4.5(2007)$ & 4.1 & $\ldots$ & $\ldots$ & 52 & $\ldots$ & $\ldots$ & $\ldots$ & $\ldots$ & $\ldots$ & $\ldots$ \\
\hline Solomon Islands & $\ldots$ & $2.8(2007)$ & 2.8 & $\ldots$ & $\ldots$ & $\ldots$ & $\ldots$ & 42 & 39 & 44 & 85 & 70 \\
\hline Timor-Leste & & $2.6(2006)$ & 2.5 & 33 & 30 & 28 & 28 & 35 & 38 & 35 & 91 & 105 \\
\hline Tonga & $\cdots$ & $1.7(2007)$ & 3.0 & & $\ldots$ & $\ldots$ & $\ldots$ & $\ldots$ & $\ldots$ & $\ldots$ & $\ldots$ & $\ldots$ \\
\hline Tuvalu & $\cdots$ & $\ldots$ & $\ldots$ & $\cdots$ & $\ldots$ & $\ldots$ & $\cdots$ & $\cdots$ & $\ldots$ & $\ldots$ & $\ldots$ & $\ldots$ \\
\hline Vanuatu & $\ldots$ & $3.1(2007)$ & 3.61 & $\cdots$ & $\ldots$ & $\ldots$ & $\ldots$ & $\cdots$ & 43 & 46 & 71 & 64 \\
\hline \multicolumn{13}{|l|}{ Developed ADB Member Economies } \\
\hline Australia & 8.3 & 8.8 & 8.7 & 85 & 81 & 80 & 79 & 79 & 77 & 77 & 13 & 13 \\
\hline Japan & 6.4 & 7.3 & 7.8 & 74 & 74 & 76 & 75 & 72 & 73 & 73 & 20 & 18 \\
\hline New Zealand & 9.4 & 9.6 & 9.3 & 90 & 91 & 91 & 88 & 90 & 89 & 87 & 1 & 2 \\
\hline
\end{tabular}

... = data not available, $\mid$ = marks break in the series, $\mathrm{ADB}=$ Asian Development Bank.

a For 2000-2011, scores relate to perceptions of the degree of corruption as seen by business people and country analysts, and are not comparable over time; scores range from 0 (highly corrupt) to 10 (very clean). From 2012 onward, an updated methodology was used to calculate scores, and these are presented on a scale from 0 (highly corrupt) to 100 (very clean). Due to the differences in methodology, scores prior to 2012 should not be compared with scores from 2012 onward.

b Based on the Transparency International Index, an economy's rank indicates its position relative to the Corruption Perceptions Index of other economies of the world; 2017 and 2018 rankings compare 180 economies.

Source: $\quad$ Transparency International. Corruption Perception Index 2018. https://www.transparency.org/cpi2018 (accessed 23 May 2019 ). 


\section{References}

ADB. 2013. Asian Development Outlook 2013. Manila.

ADB. 2018. Key Indicators for Asia and the Pacific 2018. Manila.

ADB. 2019. Asian Development Outlook 2019: Strengthening Disaster Reliance. Manila.

International Civil Aviation Organization (ICAO). 2017. The World of Air Transport 2017. Montreal. https://www.icao.int/annual-report-2017/ Pages/the-world-of-air-transport-in-2017. aspx.

International Telecommunications Union (ITU). 2017. ICT Facts and Figures 2017. Geneva. https://www.itu.int/en/ITU-D/Statistics/ Documents/facts/ICTFactsFigures2017.pdf.
UN. 2016. Energy Statistics Compilers Manual. New York.

UN. 2019a. Department of Economic and Social Affairs, Population Division. World Population Prospects, 2019 Revision. New York. https:// population.un.org/wpp/Publications/Files/ WPP2019_Highlights.pdf.

UN. 2019b. Conference on Trade and Development. World Investment Report 2019. Geneva.

World Bank. 2019a. Migration and Development Brief 31. Washington, DC.

World Bank. 2019b. Doing Business 2019: Training for Reform. Washington, DC. https://www. worldbank.org/content/dam/doingBusiness/ media/Annual-Reports/English/DB2019report_web-version.pdf. 

PART III

\section{Global Value Chains}




\section{The Evolving Dynamics of Domestic Value-Added in Asia}

\section{Snapshot}

- Domestic value-added via forward linkages measures the amount of domestic value-added that is generated from the production of total exports. It can be used to describe the evolving dynamics of production networks within Asia and the Pacific.

- The share of domestic value-added flowing to and from Asia increased from 2000 to 2018, highlighting the increasing role of the region as a source of, and destination for, domestic value-added. Meanwhile, Asia's connection to North America, as measured by domestic value-added flows, had diminished by 2018.

- Intraregional trade matters for Asia, with the region retaining up to $33.5 \%$ of its generated domestic value-added within its own economies in 2018. This share of intraregional outflows is equivalent to $39.0 \%$ of total value-added inflows to Asia.

- While dynamics vary by sector, by 2018, the People's Republic of China had surpassed other subregions and individual economies as Asia's source hub for intraregional domestic value-added outflows when considering all sectors. Meanwhile, Southeast Asia plus Fiji emerged as the region's largest destination for intraregional domestic value-added inflows.

Global value chain (GVC) statistics have been included in Key Indicators for Asia and the Pacific (Key Indicators) since 2015. This flagship publication began by highlighting the GVC statistics of 11 Asian economies and covered the years 2000, 2005, and 2011. In Key Indicators 2016, the GVC statistical assessment expanded to 13 Asian economies and covered 2008 and 2015, while the 2017 edition embraced 23 economies of the Asia and Pacific region and covered 2014-2016. In Key Indicators 2018, GVC statistics were presented for 25 economies from across the region, assessing the years 2010 and 2017.

Across its first 4 years, the GVC chapter of Key Indicators has featured some insightful analyses of the importance of value chains to international trade and commerce. Key Indicators 2015 documented the exponential growth in trade in intermediates in 11 Asian economies, while the 2016 edition discussed the increasing localization of production in 13 Asian economies. Key Indicators 2017 emphasized the increase in the domestic content in exports as a mitigating factor to the global trade slowdown. A year later, in Key Indicators 2018, some stylized facts were presented to highlight the participation of Asian economies in GVCs, using the decomposition developed by Wang, Wei, and Zhu (2018). It presented variations in forward and backward GVC participation across economies, across sectors, and over time.

In 2019, Key Indicators utilizes domestic valueadded via forward linkages (DVA $\_$) to discuss the evolution of global value chains in Asia. DVA F m measures the amount of domestic value-added that is generated from the production of total exports (Wang, Wei, and Zhu 2018). The discussion encompasses 25 economies of Asia and the Pacific included in the 2019 release of the ADB multi-regional input-output tables (MRIOTs), and covers 2000 and 2007-2018. The MRIOTs provide a 35-sector breakdown for each economy. However, for simplicity, the analysis in this chapter aggregates results into 5 major sectors. ${ }^{1}$

1 The data presented in this Part III are not official statistics. Production and trade data from various sources were integrated into the input-output economic analysis framework and adjusted as required to conform to specific macroeconomic concepts. As such, data and statistics presented here could differ from relevant official statistics. 


\section{Asia's Role in Sending and Receiving Domestic Value-Added in Exports}

Figure 3.1.1 uses DVA _F to shed light on Asia's role as a source of, and destination for, domestic value-added generated in exports production across the world.

A growing share of the world's total DVA F is from Asia. In 2000, Asia's share in the world's total DVA F was $23.0 \%$. At $35.7 \%$, Japan was the largest contributor to Asia's domestic value-added generation, followed by the People's Republic of China (PRC), which contributed 16.8\% of Asia's total. From 2001 to 2018, Asia's share in the world's total DVA_F increased to $30.2 \%$. Additionally, the PRC overtook Japan as the leading source of DVA F in Asia. By 2018, the PRC was generating $44.2 \%$ of Asia's total DVA F, while only $13.8 \%$ of that total was generated in Japan.
Likewise, Asia's role as a destination for DVA_F has also grown. In 2000, less than $19.7 \%$ of total world DVA F w went to Asia. By 2018, this share had grown to $26.0 \%$. Of the total domestic value-added that was sent to Asia in 2000, 28.7\% went to Japan, while only $14.2 \%$ went to the PRC. In 2018, by contrast, the PRC was the biggest destination for DVA F in Asia, receiving $32.8 \%$ of the region's total. Japan was the second largest single destination for DVA_F sent to Asia, receiving $15.3 \%$ of the total.

Figure 3.1.1 also shows that Asia plays a larger role as an exporter of value-added than as an importer of value-added. Across all years, in 2000 and 2007-2018, the share of world DVA F generated in Asia is bigger than the share of world DVA $F$ that is sent to Asia.

Figure 3.1.1: Asia's Role in the Global Transfer of Domestic Value-Added in Exports
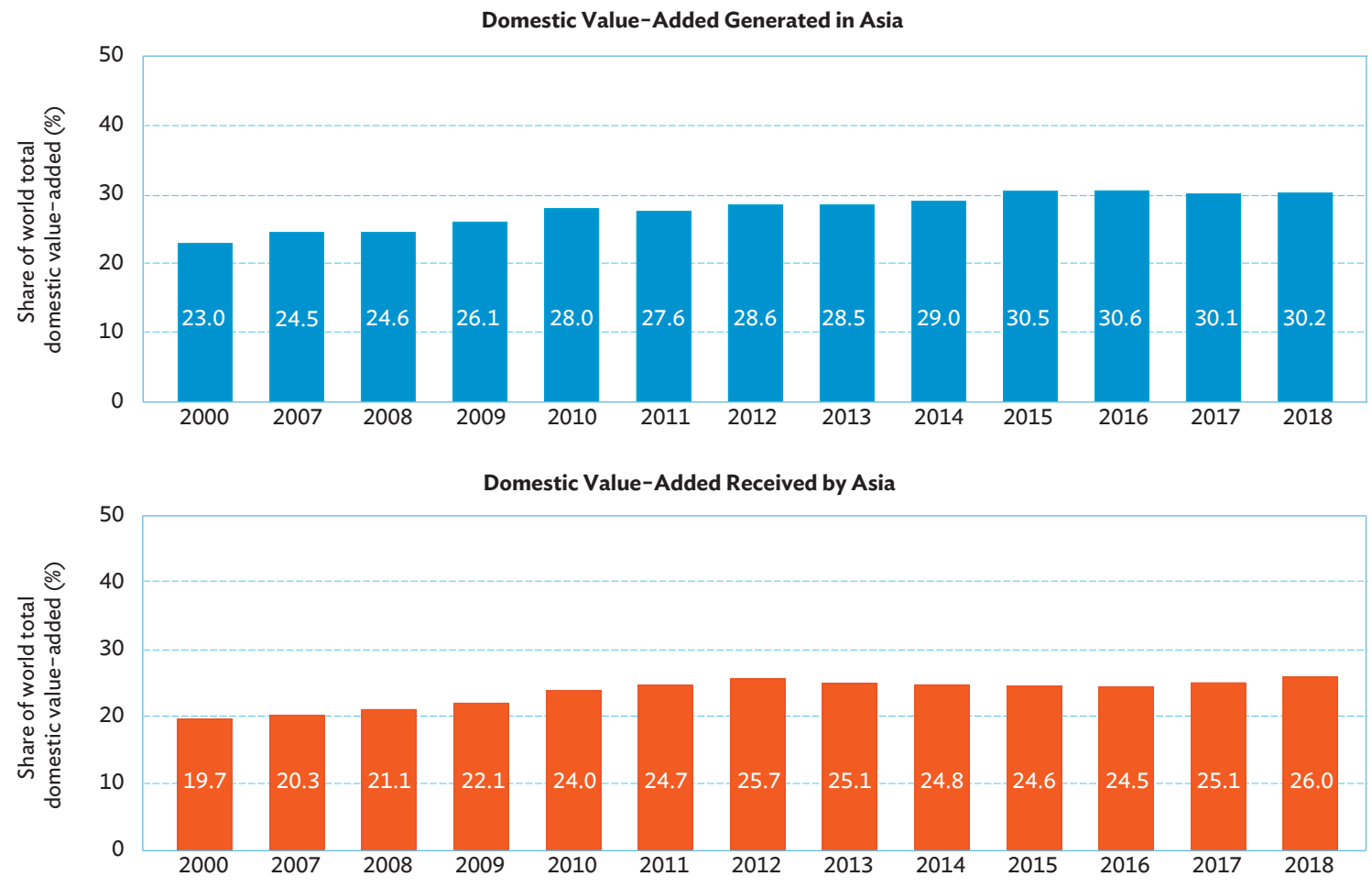

Source: $\quad$ Asian Development Bank estimates based on Wang, Wei, and Zhu (2018) using Asian Development Bank Multi-Regional Input-Output Tables (2000, 2007-2018). 
Where Does Asia's Domestic ValueAdded Go?

The first part of Figure 3.1.2 shows domestic valueadded generated in Asia's production of exports, and breaks it down by destination.

A large proportion of DVA $F$ originating from Asia flows to economies within the region. The share of Asia's total DVA F that is sent within Asia has been fairly stable, from $32.0 \%$ in 2000 to $33.5 \%$ in 2018 . The share of DVA $\mathrm{F}$ from Asia that goes to Europe has also been stable at $15.4 \%$ in 2000 and $16.4 \%$ by 2018 .
On the other hand, significant changes can be seen in the shares of domestic value-added flowing from Asia to North America (defined here as the United States and Canada) and to the rest of the world (defined here as economies in the ADB MRIOTs that are not in Asia, Europe, or North America). The proportion of DVA_F sent from Asia to North America decreased substantially, from $21.3 \%$ in 2000 to $13.4 \%$ in 2018. Meanwhile, the proportion of Asia's total DVA $F$ that was sent to the rest of the world grew from $31.3 \%$ in 2000 to $36.7 \%$ in 2018 .

Figure 3.1.2: Transfer of Domestic Value-Added in Exports by Region

Destination for Domestic Value-Added Generated in Asia

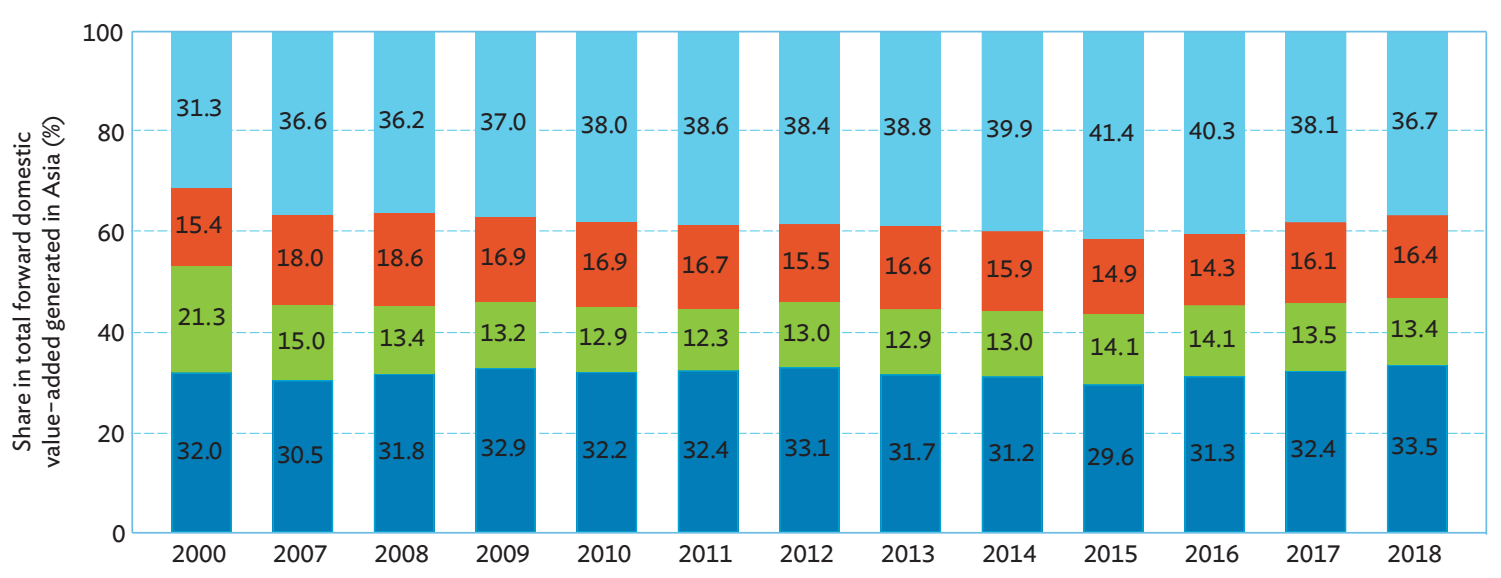

Source of Domestic Value-Added Received by Asia

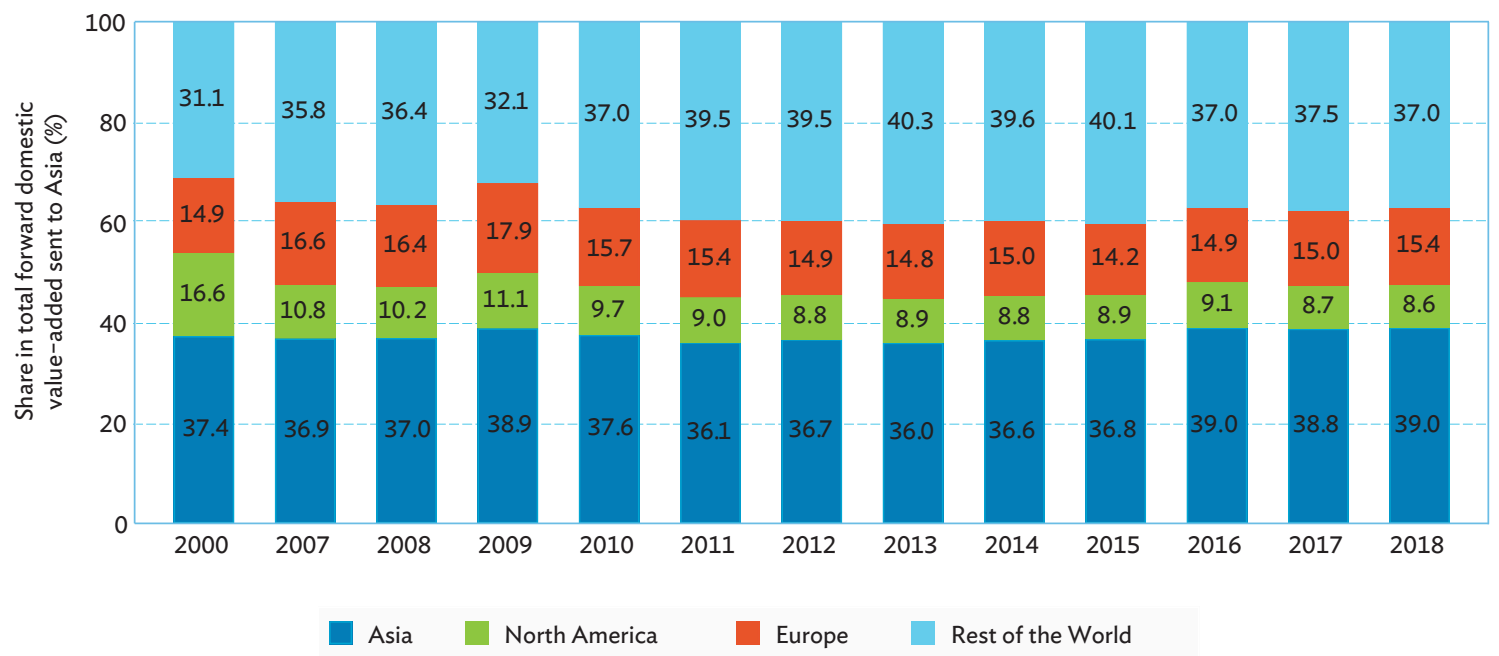

Source: $\quad$ Asian Development Bank estimates based on Wang, Wei, and Zhu (2018) using Asian Development Bank Multi-Regional Input-Output Tables (2000, 2007-2018). 
Where Does the Domestic ValueAdded Received by Asia Come From?

The second part of Figure 3.1.2 presents domestic value-added in exports sent to Asia, and breaks it down by source.

The largest sources of domestic value-added sent to Asia are Asia itself and economies across the rest of the world. By 2018, the share of DVA F received by Asia from within Asia was $39.0 \%$, while the share from the rest of the world was $37.4 \%$. The share of domestic value-added sent to Asia from within Asia remained fairly stable over the period assessed, ranging from a low of $36.0 \%$ in 2013 to a high of $39.0 \%$ in both 2016 and 2018. On the other hand, the share of DVA_F sent to Asia from the rest of the world has fluctuated, ranging from a low of $31.1 \%$ in 2000 to a high of $40.3 \%$ in 2013.

North America's proportion of the total domestic value-added that is sent to Asia appears to be in decline. From $16.6 \%$ in 2000 , this figure fell to $8.6 \%$ in 2018. Meanwhile, Europe's contribution to domestic value-added sent to Asia remained fairly constant over the period assessed, from $14.9 \%$ in 2000 to $15.4 \%$ in 2018.

In summary, Figure 3.1.1 underlines the global importance of Asia as both a source of domestic value-added sent to other parts of the globe, and as a destination for domestic value-added generated around the world. Figure 3.1.2 highlights the declining role of North America as a destination for DVA $F$ generated in Asia, and as a source of DVA F F received by Asia.

\section{The Evolving Dynamics of Domestic Value-Added within Asia}

A focus on DVA F F flows within Asia can give insights into the evolving role of Asian subregions as sources of, and destinations for, intraregional DVA F. The
Sankey diagrams below are used to demonstrate how DVA $F$ flows from source (on the left axis) to destination (on the right axis). The sizes of the nodes are proportional to each nodes' share of total DVA_F flows. The thickness of the arcs connecting the nodes is proportional to the value of the flow of DVA_F.

For simplicity, economies in Asia have been organized into four subregions: Central \& West Asia, East Asia, South Asia, and Southeast Asia plus Fiji. India, Japan, and the PRC are reported separately from the subregions to which they would otherwise belong. Central \& West Asia includes Kazakhstan, the Kyrgyz Republic, and Pakistan. East Asia includes Hong Kong, China; Mongolia; the Republic of Korea; and Taipei,China. Fiji is grouped with economies from Southeast Asia, namely Brunei Darussalam, Cambodia, Indonesia, the Lao People's Democratic Republic, Malaysia, the Philippines, Singapore, Thailand, and Viet Nam. South Asia includes Bangladesh, Bhutan, Maldives, Nepal, and Sri Lanka.

Figure 3.1.3 shows that, in 2000, Japan was the largest single source of DVA F outflows within the region, exceeding even the combined contributions of the four economies making up East Asia. In that year, $46.1 \%$ of Japan's DVA F sent within Asia went to East Asia, 33.3\% went to Southeast Asia plus Fiji, and $17.4 \%$ went to the PRC. Following Japan as sources of intraregional DVA F in 2000 are East Asia and Southeast Asia plus Fiji, which accounted for $23.5 \%$ and $21.3 \%$ of total Asian DVA F outflow to the region, respectively.

In terms of intraregional DVA $F$ inflows in 2000, East Asia was the largest destination for DVA $F$ from other parts of Asia, absorbing $30.0 \%$ of these inflows. Japan was the largest source of DVA_F inflows into East Asia. Southeast Asia plus Fiji came a close second as a destination for intraregional DVA_F flows. In 2000, 26.5\% of intraregional DVA $F$ inflows went to Southeast Asia plus Fiji, with Japan also being this subregion's main source of intraregional DVA F inflows. 
Figure 3.1.3: Intraregional Flow of Asia's Domestic Value-Added Generated in Exports, All Sectors

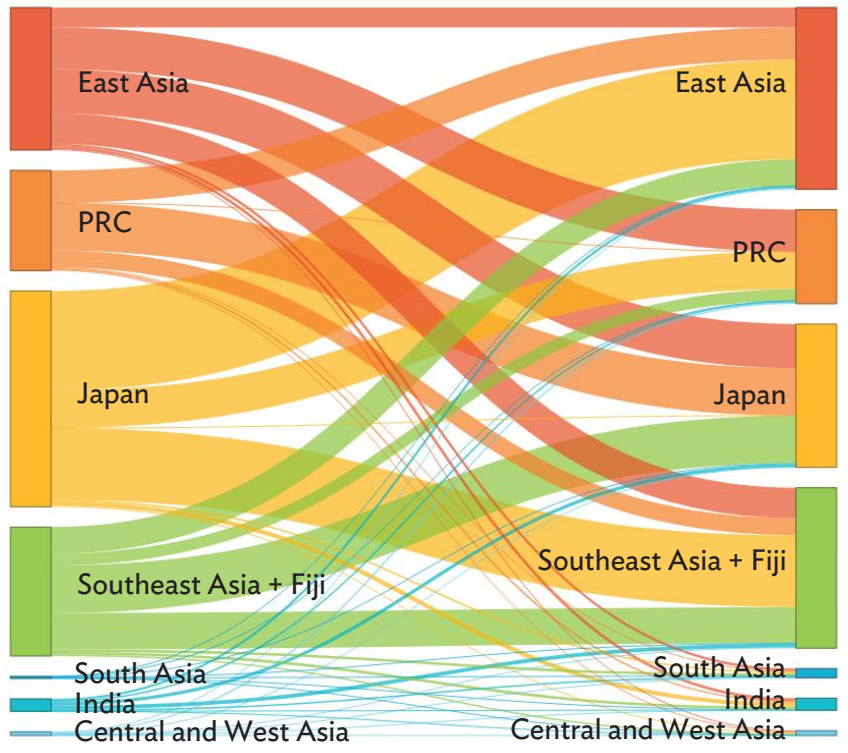

2000

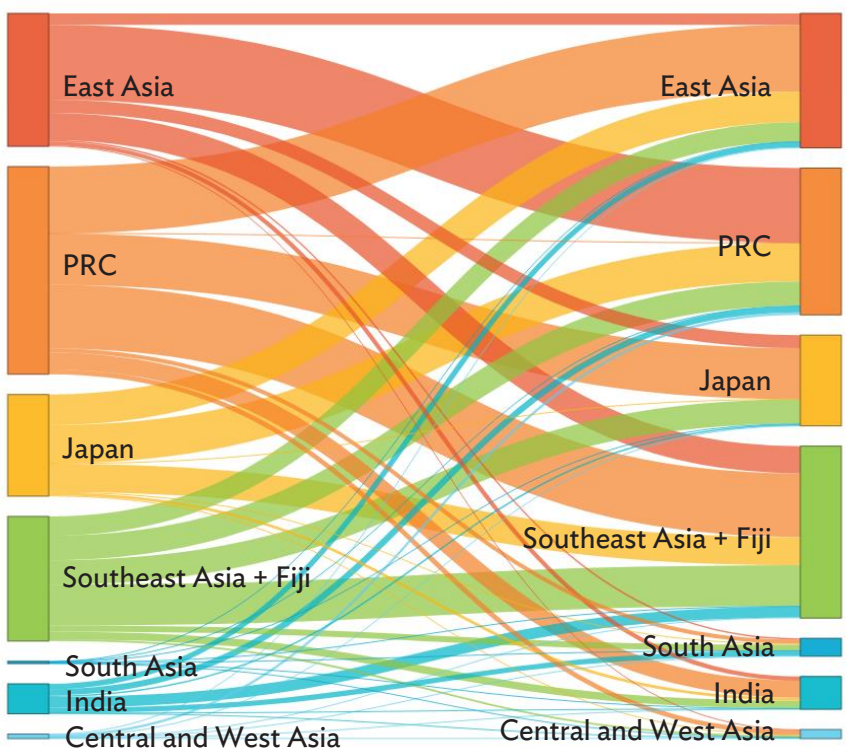

2018

PRC $=$ People's Republic of China

Source: Asian Development Bank estimates based on Wang, Wei, and Zhu (2018) using Asian Development Bank Multi-Regional Input-Output Tables (2000, 2007-2018).

By 2018, Asia's top source of, and destination for, intraregional DVA $F$ had changed. The PRC became the largest source of intraregional DVA_F, accounting for $34.4 \%$ of total DVA F flowing within Asia. The PRC's top destination for DVA F within the region also changed, from Japan in 2000 to East Asia and followed by Southeast Asia plus Fiji in 2018, reflecting the PRC's stronger links to the latter subregion. Moreover, data for 2018 show that India became an important intraregional destination for DVA $F$ from the PRC.

Meanwhile, Japan's contribution to intraregional DVA_F outflows decreased by 18.8 percentage points from 2000 to 2018. While its proportion of total intraregional DVA_F outflows stood at only $16.8 \%$ in 2018 , Japan's outflows were more diversified. Southeast Asia plus Fiji and East Asia also observed smaller shares of total intraregional DVA $F$ outflows in 2018. India's increasing role as a source of intraregional DVA FF was also noticeable, with a large portion of its DVA_F being sent to Southeast Asia plus Fiji.
A look at the destinations for intraregional DVA $\angle$ in 2018 shows that Southeast Asia plus Fiji became the largest destination within Asia. Most intraregional DVA $F$ flowing into Southeast Asia plus Fiji came from the PRC, followed by Southeast Asia plus Fiji itself. While Japan was once the top source of intraregional DVA_F inflows to Southeast Asia plus Fiji, by 2018 it was only the third biggest source for that subregion. In 2018, the PRC was the second largest destination for intraregional DVA_F inflows, with $51.0 \%$ of those inflows coming from East Asia.

Overall, a comparison between 2000 and 2018 shows that the PRC has overtaken Japan as a source of, and destination for, intraregional DVA $\_$. Moreover, in 2018, the PRC was playing a larger role as an exporter of intraregional DVA $F$ than as an importer of intraregional DVA_F. Meanwhile, Southeast Asia plus Fiji has always been a larger exporter of intraregional DVA_F than an importer of intraregional DVA_F. 
In summary, Asia has different hubs of intraregional DVA_F. As a source of intraregional DVA $F$, the PRC emerges as the hub. In terms of destination for intraregional DVA_F, Southeast Asia plus Fiji can be defined as Asia's hub.

There are differences when looking at intraregional DVA F flows by sector. Source and destination hubs also vary according to which sector is being examined and they change over time. Figure 3.1.4 shows results specific to the primary sector, while Figure 3.1.5 and Figure 3.1.6 show results for the low-technology industrial sector and the mediumto high-technology industrial sector, respectively. Figure 3.1.7 and Figure 3.1.8 demonstrate the flows of intraregional DVA_F for the business services sector and the personal and public services sector, respectively.

\section{Primary sector}

In 2000, Southeast Asia plus Fiji was Asia's major generator of primary sector intraregional DVA_F, accounting for $51.4 \%$ of the region's total, compared to the PRC's $30.1 \%$. Almost half (49.9\%) of the intraregional DVA $\_$F generated in Southeast Asia plus Fiji's production of primary sector exports was sent to Japan, while $19.7 \%$ was sent to East Asia, and $16.8 \%$ was sent within the subregion. The PRC was Asia's second largest generator of primary sector intraregional DVA_F in 2000 and its main destinations within Asia were Japan (48.6\%), East Asia (29.6\%), and Southeast Asia plus Fiji (18.4\%).

Japan was the biggest destination for primary sector intraregional DVA_F in 2000, with $46.5 \%$ of Asia's total intraregional inflows. Most primary sector intraregional DVA F sent to Japan was generated in Southeast Asia plus Fiji and the PRC at $55.2 \%$ and $31.5 \%$, respectively. The next two biggest destinations in 2000 were East Asia and Southeast Asia plus Fiji, with both having similar DVA F F inflow breakdowns.
By 2018, the PRC had overtaken Southeast Asia plus Fiji as Asia's largest source of intraregional DVA $F$ generated in primary sector exports. It generated $46.3 \%$ of intraregional DVA $\angle$ F in the primary sector, of which $38.5 \%$ went to Southeast Asia plus Fiji, 26.5\% went to East Asia, and 23.1\% went to Japan. Meanwhile, Southeast Asia plus Fiji's primary sector DVA_F outflows had become more diversified by 2018. In 2000, almost half of its intraregional DVA $\mathrm{F}$ in the primary sector was sent to Japan (49.9\%), but this share has gone down to $25.3 \%$ in 2018 as increasing proportions of intraregional DVA $F$ generated in the subregion were sent to the subregion itself (30.8\%), East Asia (16.3\%) and the PRC (16.3\%).

The roles of East Asia and Japan as producers also shrank in the period from 2000 to 2018, while India's role grew slightly. India exported a smaller share of its primary sector DVA_F to Japan in 2018 than in 2000, with Southeast Asia plus Fiji becoming its top intraregional destination in 2018.

Southeast Asia plus Fiji had become Asia's top destination for intraregional primary sector DVA_F by 2018, receiving $33.7 \%$ of intraregional DVA $\_$F in the primary sector. A bulk of its inflows (52.9\%) came from the PRC and 35.4\% came from within the subregion itself. Japan (21.5\%) and East Asia (20.4\%) were the second and third biggest destinations for primary sector intraregional DVA_F inflows in 2018.

Overall, in terms of the primary sector, Asia's source hubs for intraregional DVA_F shifted from Southeast Asia plus Fiji in 2000 to the PRC in 2018, although Southeast Asia plus Fiji remained a major contributor for the region. On the other hand, the main destination hub within Asia shifted from Japan in 2000 to Southeast Asia plus Fiji in 2018. 
Figure 3.1.4: Intraregional Flow of Asia's Domestic Value-Added Generated in Exports, Primary Sector

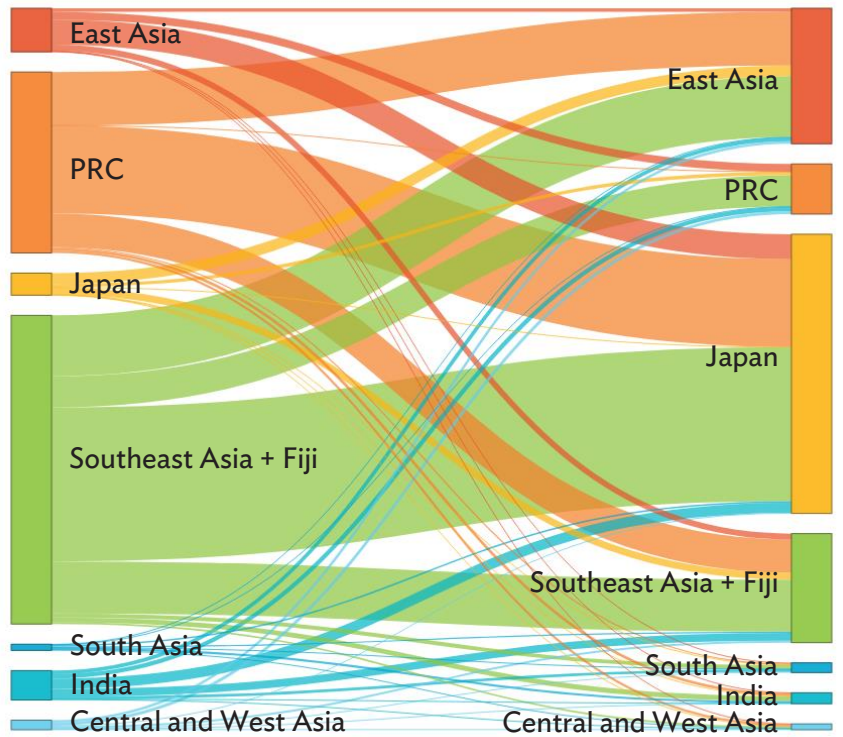

2000

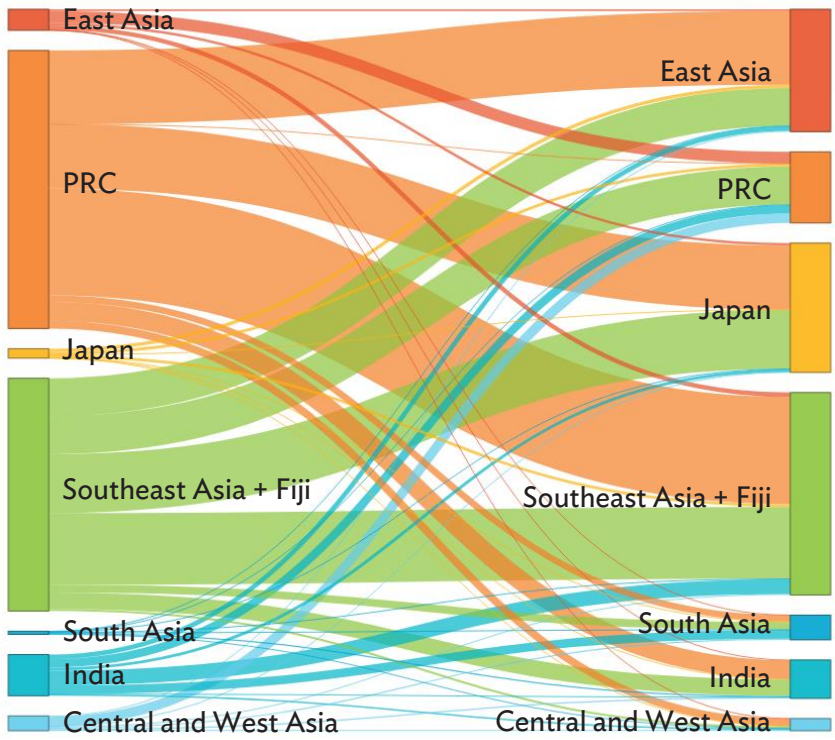

2018

PRC = People's Republic of China

Source: Asian Development Bank estimates based on Wang, Wei, and Zhu (2018) using Asian Development Bank Multi-Regional Input-Output Tables (2000, 2007-2018).

\section{Low-technology industrial sector}

In 2000, the major sources of, and destinations for, intraregional DVA_F flows in the low-technology industrial sector were the PRC, Japan, East Asia, and Southeast Asia plus Fiji.

The sources of intraregional DVA F generated in the sector were more or less evenly distributed in 2000, with the PRC contributing 27.8\%, Japan contributing $27.4 \%$, East Asia contributing $21.3 \%$, and Southeast Asia plus Fiji contributing $20.3 \%$ of Asia's total. The PRC was a major source of low-technology industrial intraregional DVA $F$ for Japan, East Asia, and Southeast Asia plus Fiji, while Japan was a key source for East Asia, Southeast Asia plus Fiji, and the PRC. Within Asia, East Asia sent most of its low-technology DVA $F$ to the PRC, Japan, Southeast Asia plus Fiji, and within the subregion itself. Lastly, Southeast Asia plus Fiji's was a major source for Japan, itself, East Asia, and the PRC.
Looking at intraregional destinations for lowtechnology industrial DVA_F in 2000, Japan was the largest, receiving $31.5 \%$ of total intraregional inflows. Most of Japan's low-technology intraregional DVA F F at this time came from the PRC, followed by Southeast Asia plus Fiji and East Asia. Meanwhile, East Asia was the second largest intraregional destination in 2000, absorbing $26.7 \%$ of Asia's total low-technology industrial DVA_F, most of it coming from Japan.

By 2018, the PRC had emerged as Asia's source hub, generating $42.2 \%$ of low-technology industrial intraregional DVA F and replacing Japan as the top source. Southeast Asia plus Fiji was the second largest source in 2018 , generating $24.8 \%$ of the total. At the same time, the contribution of Japan and East Asia to lowtechnology industrial DVA F declined considerably.

In terms of intraregional destinations in 2018, Southeast Asia plus Fiji became the largest receiver of Asia's low-technology industrial DVA F. Other 
Figure 3.1.5: Intraregional Flow of Asia's Domestic Value-Added Generated in Exports, Low-Technology Industrial Sector

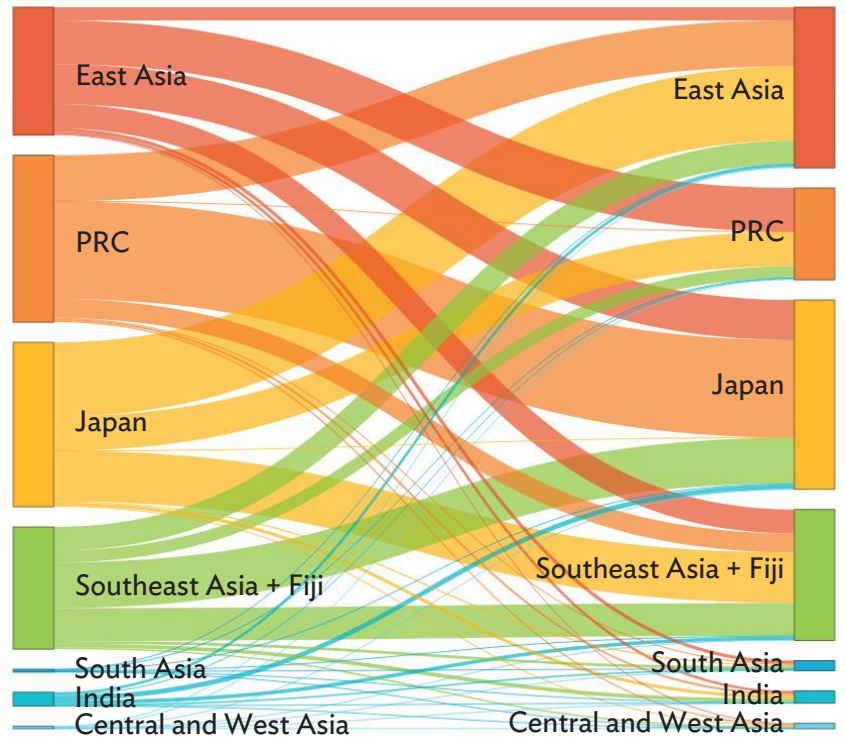

2000

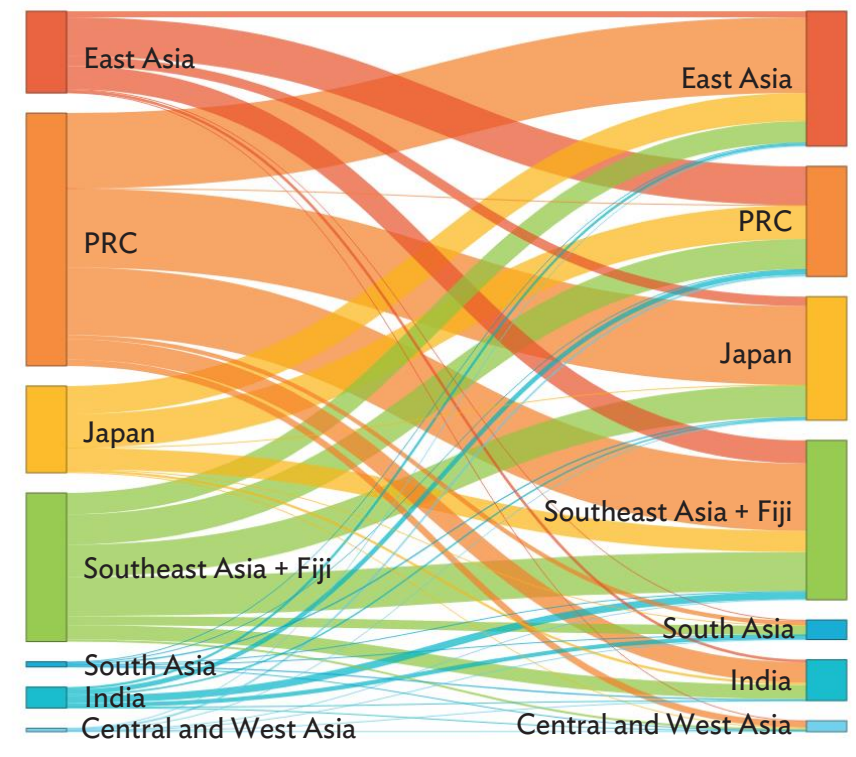

2018

PRC = People's Republic of China

Source: Asian Development Bank estimates based on Wang, Wei, and Zhu (2018) using Asian Development Bank Multi-Regional Input-Output Tables (2000, 2007-2018).

noticeable changes in the low-technology industrial sector were the growth in the shares of intraregional DVA F received by India and by economies in South Asia and Central \& West Asia. The combined share of these three destinations was only at $4.6 \%$ in 2000 , but it grew to $11.9 \%$ in 2018.

\section{Medium- to high-technology industrial sector}

In 2000, Asia's largest intraregional source of medium- to high-technology industrial DVA_F was by far Japan (45.3\%), while its largest destination was East Asia (31.2\%).

By 2018, Japan's role as the region's major source had been assumed by East Asia, with that subregion and the PRC increasing their intraregional contributions to total medium- to high-technology DVA_F generation to $32.4 \%$ and $28.8 \%$, respectively. Japan's share had been reduced to $22.4 \%$ by that time.
From the destination perspective, over $60.0 \%$ of the sector's intraregional DVA $\mathrm{F}$ in 2000 flowed into East Asia and Southeast Asia plus Fiji, while another 35.3\% was received by the PRC and Japan combined. In 2018, the PRC was the region's top destination of medium- to high-technology industrial DVA $F$, absorbing $33.4 \%$ of the total intraregional inflows in the sector.

For the medium- to high-technology manufacturing sector, the two largest intraregional DVA F flows in 2000 were from Japan to East Asia and from Japan to Southeast Asia plus Fiji. These two flows made up $35.7 \%$ of the sector's intraregional DVA F flows. In 2018, the two largest intraregional DVA F flows were from East Asia to the PRC and from Japan to the PRC, amounting to a combined $29.5 \%$ of total intraregional DVA_F flows.

Also worth noting is the increase in medium- to high-technology industrial DVA F received by India, 
Figure 3.1.6: Intraregional Flow of Asia's Domestic Value-Added Generated in Exports, Medium- to High-Technology Industrial Sector

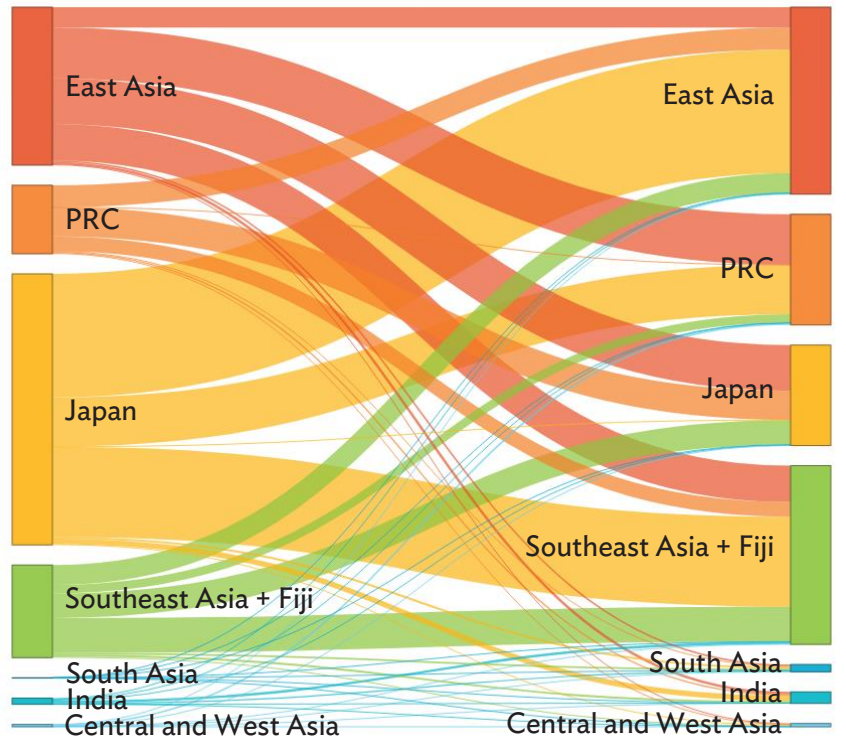

2000

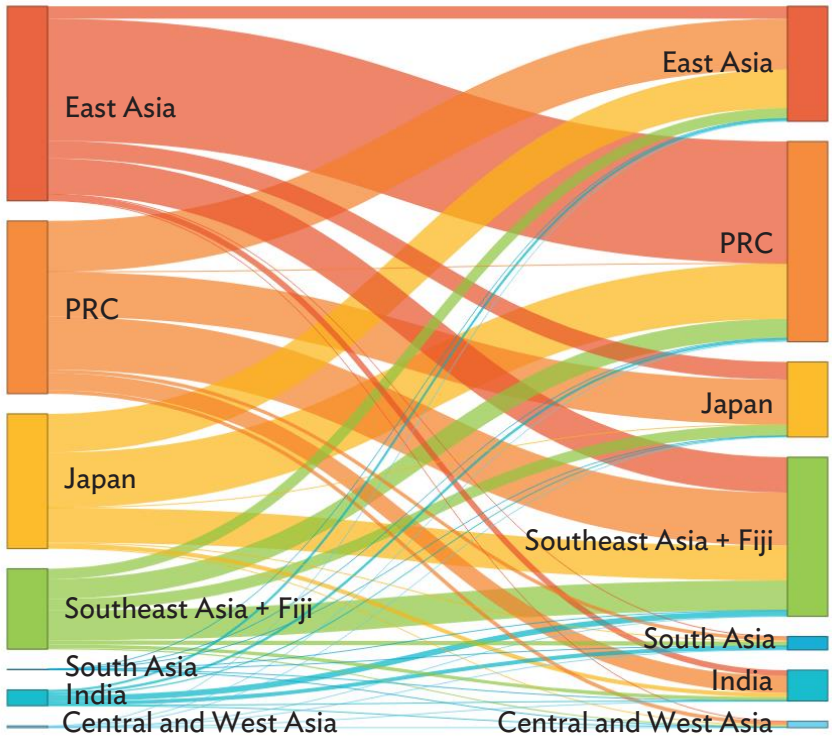

2018

PRC = People's Republic of China

Source: $\quad$ Asian Development Bank estimates based on Wang, Wei, and Zhu (2018) using Asian Development Bank Multi-Regional Input-Output Tables (2000, 2007-2018).

South Asia, and Central \& West Asia by 2018. Most of the inflows of this DVA_F to India came from the PRC.

In summary, the results highlight Japan's decreasing role as a source of DVA $F$ in the mediumto high-technology industrial sector within Asia. In 2000, Japan was Asia's main hub in terms of DVA_F generation, but the Sankey diagram for 2018 implies that the region is diversifying its source of DVA $F$ in this sector. Moreover, unlike the scenarios in the primary and low-technology industrial sectors, the PRC emerged as a destination hub for intraregional DVA $F$ generated in the medium- to high-technology industrial sector.

\section{Business services sector}

Japan was Asia's source hub of intraregional DVA \&F in the business services sector in 2000. Its economy generated $37.2 \%$ of Asia's intraregional DVA F for this sector, $47.5 \%$ of which was sent to East Asia and another $34.4 \%$ of which went to Southeast Asia plus Fiji. These two major destinations for Japan's intraregional DVA $\mathrm{F}$ in business services were also the biggest recipients of Asia's total intraregional DVA F flows for the sector in 2000: East Asia absorbing 32.4\% and Southeast Asia plus Fiji absorbing 27.0\%.

By 2018, Japan's and East Asia's roles as the source hubs of intraregional flows in business services had diminished, as other economies boosted their DVA F generation in the sector. Particularly, the PRC and Southeast Asia plus Fiji became the two largest sources of intraregional DVA F flows for the sector, respectively contributing $33.8 \%$ and $21.3 \%$ to the sector's total intraregional outflows.

On the destination side, the share of business services intraregional DVA $\angle F$ received by the PRC noticeably increased, growing from $13.9 \%$ in 2000 to $20.0 \%$ in 2018. Meanwhile, the shares received by East 
Figure 3.1.7. Intraregional Flow of Asia's Domestic Value-Added Generated in Exports, Business Services Sector

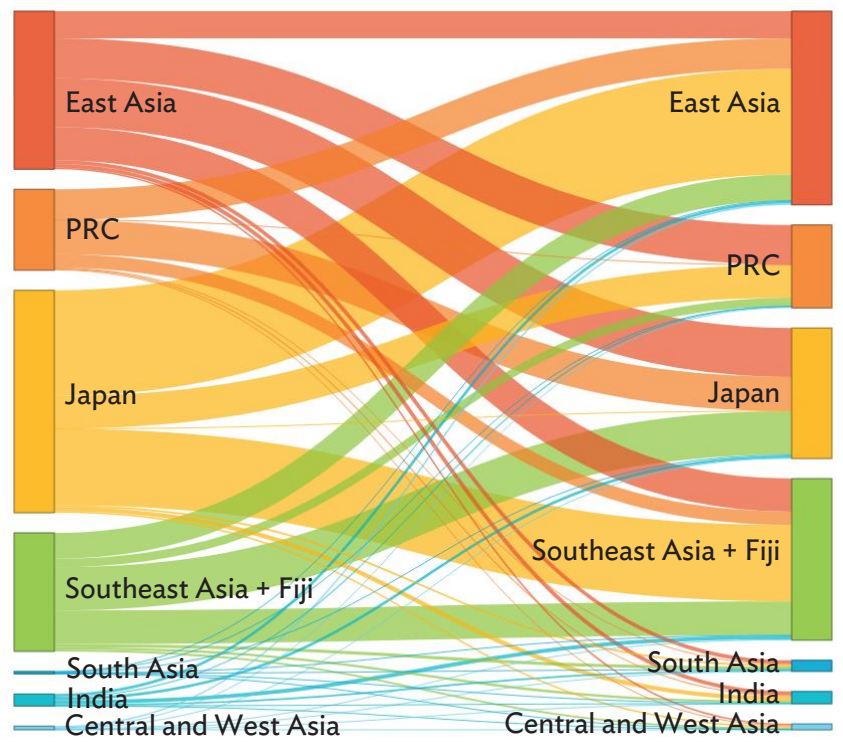

2000

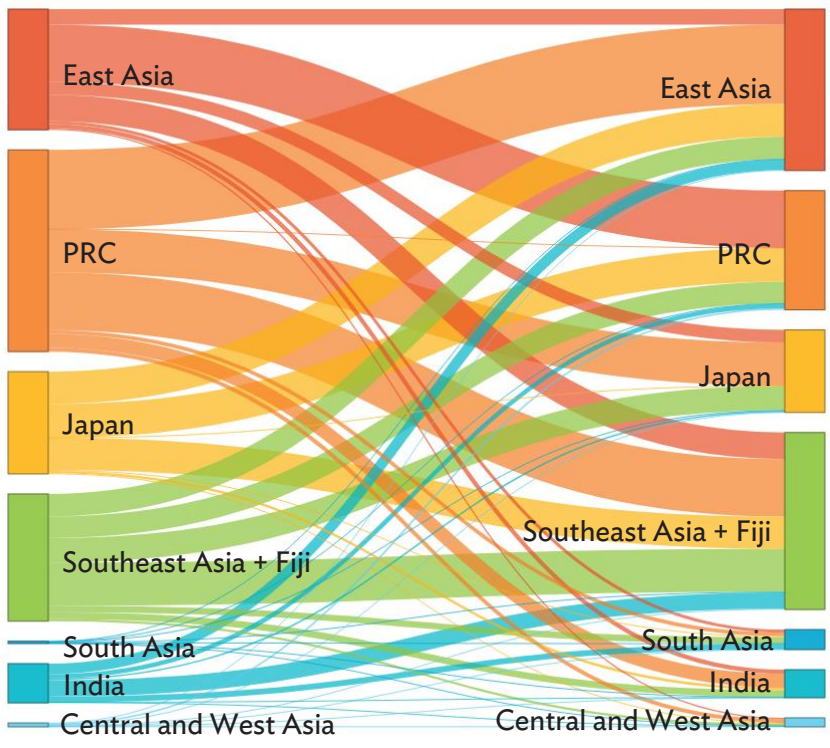

2018

PRC = People's Republic of China

Source: $\quad$ Asian Development Bank estimates based on Wang, Wei, and Zhu (2018) using Asian Development Bank Multi-Regional Input-Output Tables (2000, 2007-2018).

Asia and Japan decreased by 5.4 and 8.0 percentage points, respectively, from 2000 to 2018. Intuitively, as the PRC's economy grew through the early part of the millennium, more business services were being demanded to support the growing economic activity.

Overall, the business services sector in Asia saw a shift in sources of intraregional DVA $\_F$ and a persistence in destination hubs over time. In 2000, intraregional DVA $F$ outflows in the sector came mostly from Japan and East Asia. By 2018, the contributions of the PRC and Southeast Asia plus Fiji to intraregional DVA F outflows had expanded. While the PRC absorbed a considerable amount of intraregional inflows in 2018, East Asia and Southeast Asia remained the destination hubs of business services intraregional DVA F flows.

\section{Personal and public services sector}

Japan was Asia's leader in terms of intraregional DVA F $F$ generation in the personal and public services sector in 2000. At this time, Japan's intraregional DVA $F$ flows in the sector went to East Asia, Southeast Asia plus Fiji, and the PRC, representing $17.5 \%, 13.6 \%$, and $8.3 \%$ of total intraregional outflows, respectively.

By 2018, Japan's position as the leading source in the sector had been assumed by the PRC, while the outflows of intraregional DVA_F were also more evenly distributed between East Asia, Japan, Southeast Asia plus Fiji, and India (which is positioned as a key source of intraregional DVA FF compared to its contribution in other sectors). The largest single outflow in 2018 was sent from India to the PRC, representing $11.9 \%$ of total intraregional outflows. 
Figure 3.1.8: Intraregional Flow of Asia's Domestic Value-Added Generated in Exports, Personal and Public Services Sector

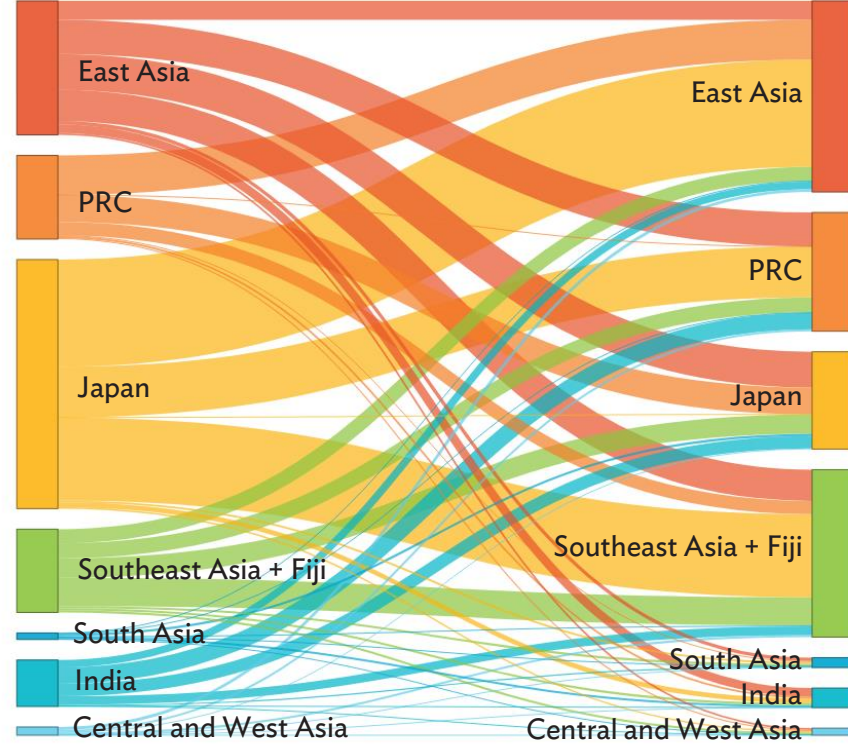

2000

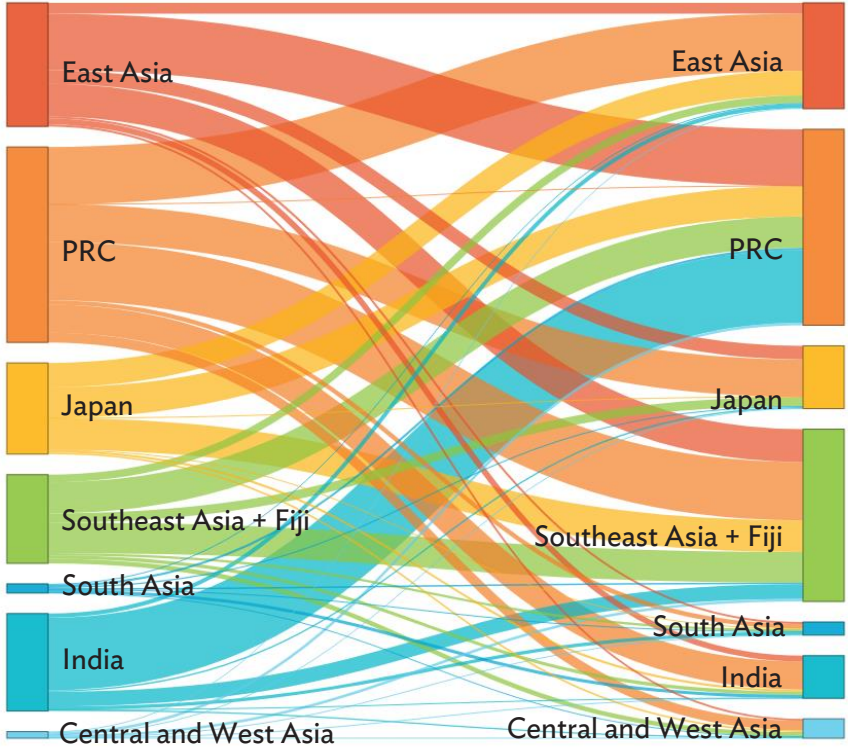

2018

PRC $=$ People's Republic of China

Source: Asian Development Bank estimates based on Wang, Wei, and Zhu (2018) using Asian Development Bank Multi-Regional Input-Output Tables (2000, 2007-2018).

In terms of the sector's intraregional DVA_F inflows, East Asia and Southeast Asia plus Fiji were the top two destinations in 2000. By 2018, East Asia's share in the region's total personal and public services intraregional DVA_F inflows had fallen, as was the case with Japan's share. Those two shares combined fell from $47.2 \%$ of total sectoral intraregional DVA_F flows in 2000 to $27.6 \%$ in 2018. Surpassing Southeast Asia plus Fiji as the top destination for intraregional DVA $F$ in the sector was the PRC.

In short, the PRC has become a dominant player in intraregional DVA $F$ flows in the personal and public services sector. The source hub shifted from Japan in 2000 to the PRC in 2018. The destination hub changed from East Asia in 2000 to the PRC in 2018, with Southeast Asia plus Fiji remaining a major destination of personal and public services sector intraregional DVA_F inflows.

\section{Conclusion}

The analysis in this chapter shows that Asia's role as a source of, and destination for, domestic valueadded in exports increased from 2000 to 2018. DVA $F$ generated in Asia went up from $23.0 \%$ of the world's total in 2000 to $30.2 \%$ in 2018 . Moreover, an increasing share of world DVA $F$ was absorbed by Asia. In 2000 , the region received $19.7 \%$ of the world's total DVA_F, and this has risen to $26.0 \%$ of total DVA F by 2018. Comparing Asia's share in world DVA $F$ generation against its share in world DVA F absorption, it can be said that the region plays a larger role as an exporter of domestic value-added than as an importer of value-added.

In 2018, almost a third of the DVA F generated in Asia stayed within the region. This represented $39.0 \%$ of the total domestic value-added that was sent 
to the region. It is therefore clear that intraregional trade matters for Asia. The data also show that Asia's connection to North America is weakening, as represented by the declining shares of DVA $F$ that the region sends to North America, and by North America's shrinking share of DVA F inflows into Asia.

Focusing on intraregional trade, the PRC has surpassed Japan and took over as the region's leading source of intraregional DVA F, while Southeast Asia plus Fiji is now larger than East Asia as a destination for intraregional DVA F. The changing dynamics and patterns of intraregional DVA $\mathrm{F}$ flows can vary by sector, but the growth of the PRC as a source and the persistence of Southeast Asia plus Fiji as a major destination is evident across all five sectors assessed here.

\section{References}

Asian Development Bank. Key Indicators for Asia and the Pacific. Manila (4 years: 2015-2018).

Asian Development Bank. 2000, 2007-2018. Multiregional Input-Output Tables.

Z. Wang, S. Wei, and K. Zhu. 2018. Quantifying International Production Sharing at the Bilateral and Sector Levels. NBER Working Paper No. 19677. Cambridge, MA: National Bureau of Economic Research. 
Global Value Chain Tables for Economies of Asia and the Pacific

\begin{tabular}{|c|c|c|c|c|c|}
\hline \multirow[b]{2}{*}{ ADB Regional Member } & Fynorts & VAX G & BDV $B$ & FVA & DRC \\
\hline & (\$ million) & \multicolumn{4}{|c|}{ (\% share in exports) } \\
\hline \multicolumn{6}{|l|}{ Bangladesh } \\
\hline 2008 & 338.39 & 92.05 & 0.07 & 5.91 & 1.97 \\
\hline 2018 & 518.39 & 92.47 & 0.09 & 6.15 & 1.29 \\
\hline \multicolumn{6}{|l|}{ Bhutan } \\
\hline 2008 & 106.48 & 94.37 & 0.01 & 4.94 & 0.68 \\
\hline 2018 & 114.07 & 92.96 & 0.01 & 6.47 & 0.57 \\
\hline \multicolumn{6}{|l|}{ Brunei Darussalam } \\
\hline 2008 & $5,742.14$ & 93.74 & 0.01 & 4.12 & 2.13 \\
\hline 2018 & $3,476.43$ & 87.97 & 0.01 & 8.06 & 3.97 \\
\hline \multicolumn{6}{|l|}{ Cambodia } \\
\hline 2008 & 374.62 & 89.92 & 0.14 & 6.93 & 3.02 \\
\hline 2018 & $1,083.54$ & 89.32 & 0.22 & 6.73 & 3.72 \\
\hline \multicolumn{6}{|l|}{ China, People's Republic of } \\
\hline 2008 & $23,336.67$ & 86.30 & 2.53 & 7.26 & 3.91 \\
\hline 2018 & $29,476.22$ & 89.97 & 2.74 & 4.80 & 2.49 \\
\hline \multicolumn{6}{|l|}{ Fiji } \\
\hline 2008 & 55.08 & 69.06 & 0.01 & 26.10 & 4.84 \\
\hline 2018 & 202.83 & 74.60 & 0.01 & 21.46 & 3.94 \\
\hline \multicolumn{6}{|l|}{ Hong Kong, China } \\
\hline 2008 & 91.73 & 51.29 & 0.26 & 32.25 & 16.20 \\
\hline 2018 & 114.11 & 60.57 & 0.22 & 28.40 & 10.81 \\
\hline \multicolumn{6}{|l|}{ India } \\
\hline 2008 & $20,874.68$ & 93.22 & 0.63 & 4.21 & 1.95 \\
\hline 2018 & $24,219.99$ & 94.10 & 0.92 & 3.46 & 1.52 \\
\hline \multicolumn{6}{|l|}{ Indonesia } \\
\hline 2008 & $39,409.50$ & 92.38 & 0.80 & 4.19 & 2.62 \\
\hline 2018 & $53,853.96$ & 88.33 & 1.21 & 6.12 & 4.34 \\
\hline \multicolumn{6}{|l|}{ Japan } \\
\hline 2008 & $2,677.27$ & 59.09 & 1.36 & 25.17 & 14.38 \\
\hline 2018 & $3,611.63$ & 60.32 & 1.36 & 24.93 & 13.39 \\
\hline \multicolumn{6}{|l|}{ Kazakhstan } \\
\hline 2008 & $37,320.47$ & 85.28 & 0.12 & 8.84 & 5.76 \\
\hline 2018 & $26,849.79$ & 90.14 & 0.08 & 5.38 & 4.40 \\
\hline \multicolumn{6}{|l|}{ Korea, Republic of } \\
\hline 2008 & 681.64 & 82.02 & 0.39 & 14.94 & 2.66 \\
\hline 2018 & 919.36 & 82.18 & 0.78 & 13.09 & 3.96 \\
\hline \multicolumn{6}{|l|}{ Kyrgyz Republic } \\
\hline 2008 & 163.73 & 85.94 & 0.02 & 11.27 & 2.76 \\
\hline 2018 & 303.62 & 79.76 & 0.10 & 15.91 & 4.23 \\
\hline \multicolumn{6}{|l|}{ Lao People's Democratic Republic } \\
\hline 2008 & 743.10 & 84.64 & 0.01 & 10.07 & 5.29 \\
\hline 2018 & $1,675.22$ & 89.32 & 0.06 & 7.55 & 3.07 \\
\hline
\end{tabular}


Table 3.2.1a: continued

\begin{tabular}{|c|c|c|c|c|c|}
\hline \multirow{2}{*}{ ADB Regional Member } & Exports & VAX_G & RDV_B & FVA & PDC \\
\hline & (\$ million) & \multicolumn{4}{|c|}{ (\% share in exports) } \\
\hline \multicolumn{6}{|l|}{ Malaysia } \\
\hline 2008 & $18,279.10$ & 91.11 & 0.26 & 5.61 & 3.02 \\
\hline 2018 & $15,115.99$ & 86.40 & 0.78 & 8.01 & 4.81 \\
\hline \multicolumn{6}{|l|}{ Maldives } \\
\hline 2008 & 19.44 & 56.36 & 0.01 & 37.19 & 6.43 \\
\hline 2018 & 39.46 & 58.30 & 0.01 & 33.94 & 7.75 \\
\hline \multicolumn{6}{|l|}{ Mongolia } \\
\hline 2008 & $1,713.82$ & 74.44 & 0.01 & 16.26 & 9.30 \\
\hline 2018 & $5,611.65$ & 75.09 & 0.01 & 18.22 & 6.68 \\
\hline \multicolumn{6}{|l|}{ Nepal } \\
\hline 2008 & 75.93 & 92.18 & 0.05 & 7.11 & 0.66 \\
\hline 2018 & 75.64 & 91.04 & 0.08 & 8.41 & 0.48 \\
\hline \multicolumn{6}{|l|}{ Pakistan } \\
\hline 2008 & $1,026.92$ & 95.80 & 0.13 & 3.19 & 0.89 \\
\hline 2018 & $2,202.50$ & 96.60 & 0.11 & 2.68 & 0.62 \\
\hline \multicolumn{6}{|l|}{ Philippines } \\
\hline 2008 & $1,463.20$ & 89.75 & 0.19 & 7.18 & 2.87 \\
\hline 2018 & $1,718.85$ & 90.55 & 0.23 & 6.83 & 2.39 \\
\hline \multicolumn{6}{|l|}{ Singapore } \\
\hline 2008 & 128.28 & 59.01 & 0.10 & 34.31 & 6.58 \\
\hline 2018 & 33.38 & 64.74 & 0.10 & 26.09 & 9.07 \\
\hline \multicolumn{6}{|l|}{ Sri Lanka } \\
\hline 2008 & 478.14 & 89.96 & 0.06 & 7.77 & 2.21 \\
\hline 2018 & 833.74 & 89.44 & 0.03 & 8.88 & 1.65 \\
\hline \multicolumn{6}{|l|}{ Taipei,China } \\
\hline 2008 & $1,517.44$ & 70.98 & 0.09 & 25.94 & 2.98 \\
\hline 2018 & $1,690.25$ & 76.31 & 0.13 & 19.36 & 4.20 \\
\hline \multicolumn{6}{|l|}{ Thailand } \\
\hline 2008 & $3,503.27$ & 84.89 & 0.38 & 10.33 & 4.40 \\
\hline 2018 & $10,896.53$ & 87.35 & 0.20 & 9.37 & 3.08 \\
\hline \multicolumn{6}{|l|}{ Viet Nam } \\
\hline 2008 & $9,186.97$ & 74.31 & 0.19 & 18.82 & 6.67 \\
\hline 2018 & $21,582.55$ & 62.26 & 1.23 & 27.54 & 8.97 \\
\hline
\end{tabular}

$0.00=$ magnitude is less than half of unit employed, $\$=$ United States dollars, FVA $=$ foreign value-added, PDC $=$ pure double counted terms, RDV_B = domestic value-added first exported then returned home, $V A X \_G=$ domestic value-added absorbed abroad.

Source: ADB Multi Region Input-Output Tables Database. 


\begin{tabular}{|c|c|c|c|c|c|}
\hline \multirow{2}{*}{ ADB Regional Member } & Exports & VAX_G & RDV_B & FVA & PDC \\
\hline & (\$ million) & \multicolumn{4}{|c|}{ (\% share in exports) } \\
\hline \multicolumn{6}{|l|}{ Bangladesh } \\
\hline 2008 & $13,165.14$ & 81.44 & 0.02 & 16.59 & 1.94 \\
\hline 2018 & $30,780.11$ & 83.39 & 0.04 & 14.78 & 1.79 \\
\hline \multicolumn{6}{|l|}{ Bhutan } \\
\hline 2008 & 235.81 & 84.88 & 0.00 & 11.10 & 4.03 \\
\hline 2018 & 309.14 & 82.87 & 0.00 & 11.25 & 5.88 \\
\hline \multicolumn{6}{|l|}{ Brunei Darussalam } \\
\hline 2008 & 42.87 & 68.15 & 0.01 & 25.13 & 6.71 \\
\hline 2018 & 111.81 & 58.91 & 0.01 & 34.55 & 6.54 \\
\hline \multicolumn{6}{|l|}{ Cambodia } \\
\hline 2008 & $2,470.62$ & 62.66 & 0.00 & 34.85 & 2.49 \\
\hline 2018 & $6,213.53$ & 64.81 & 0.01 & 32.71 & 2.48 \\
\hline \multicolumn{6}{|l|}{ China, People's Republic of } \\
\hline 2008 & $362,219.77$ & 84.75 & 0.54 & 12.86 & 1.84 \\
\hline 2018 & $621,135.34$ & 89.27 & 1.17 & 8.06 & 1.50 \\
\hline \multicolumn{6}{|l|}{ Fiji } \\
\hline 2008 & 190.63 & 73.09 & 0.00 & 22.34 & 4.57 \\
\hline 2018 & 501.82 & 73.87 & 0.00 & 22.12 & 4.01 \\
\hline \multicolumn{6}{|l|}{ Hong Kong, China } \\
\hline 2008 & $7,806.17$ & 57.18 & 0.07 & 33.06 & 9.69 \\
\hline 2018 & $7,211.08$ & 47.12 & 0.07 & 44.38 & 8.43 \\
\hline \multicolumn{6}{|l|}{ India } \\
\hline 2008 & $37,943.29$ & 82.32 & 0.28 & 14.48 & 2.91 \\
\hline 2018 & $85,694.44$ & 87.32 & 0.30 & 10.36 & 2.03 \\
\hline \multicolumn{6}{|l|}{ Indonesia } \\
\hline 2008 & $55,887.16$ & 81.35 & 0.22 & 14.74 & 3.69 \\
\hline 2018 & $101,845.06$ & 78.40 & 0.17 & 16.98 & 4.46 \\
\hline \multicolumn{6}{|l|}{ Japan } \\
\hline 2008 & $44,857.60$ & 82.17 & 1.71 & 10.52 & 5.60 \\
\hline 2018 & $53,193.78$ & 81.54 & 1.23 & 11.77 & 5.45 \\
\hline \multicolumn{6}{|l|}{ Kazakhstan } \\
\hline 2008 & $1,586.26$ & 81.45 & 0.14 & 13.79 & 4.62 \\
\hline 2018 & $1,542.36$ & 84.94 & 0.32 & 11.86 & 2.88 \\
\hline \multicolumn{6}{|l|}{ Korea, Republic of } \\
\hline 2008 & $33,791.40$ & 68.84 & 0.39 & 21.90 & 8.87 \\
\hline 2018 & $41,683.97$ & 70.09 & 0.57 & 20.36 & 8.98 \\
\hline \multicolumn{6}{|l|}{ Kyrgyz Republic } \\
\hline 2008 & 196.11 & 59.75 & 0.03 & 32.79 & 7.43 \\
\hline 2018 & 256.30 & 67.81 & 0.03 & 27.76 & 4.40 \\
\hline \multicolumn{6}{|l|}{ Lao People's Democratic Republic } \\
\hline 2008 & 229.39 & 88.40 & 0.01 & 8.84 & 2.76 \\
\hline 2018 & $3,375.41$ & 89.77 & 0.02 & 7.79 & 2.42 \\
\hline \multicolumn{6}{|l|}{ Malaysia } \\
\hline 2008 & $41,269.46$ & 69.95 & 0.14 & 21.88 & 8.03 \\
\hline 2018 & $47,960.66$ & 62.99 & 0.16 & 28.03 & 8.83 \\
\hline
\end{tabular}


Table 3.2.1b: continued

\begin{tabular}{|c|c|c|c|c|c|}
\hline \multirow{2}{*}{ ADB Regional Member } & Exports & VAX_G & RDV_B & FVA & PDC \\
\hline & (\$ million) & \multicolumn{4}{|c|}{ (\% share in exports) } \\
\hline \multicolumn{6}{|l|}{ Maldives } \\
\hline 2008 & 35.57 & 57.93 & 0.01 & 28.01 & 14.05 \\
\hline 2018 & 341.48 & 58.77 & 0.00 & 33.05 & 8.18 \\
\hline \multicolumn{6}{|l|}{ Mongolia } \\
\hline 2008 & 150.51 & 78.42 & 0.01 & 16.69 & 4.88 \\
\hline 2018 & 178.88 & 69.31 & 0.03 & 23.41 & 7.24 \\
\hline \multicolumn{6}{|l|}{ Nepal } \\
\hline 2008 & 243.92 & 77.35 & 0.02 & 20.66 & 1.98 \\
\hline 2018 & 253.26 & 73.03 & 0.04 & 24.19 & 2.75 \\
\hline \multicolumn{6}{|l|}{ Pakistan } \\
\hline 2008 & $10,881.98$ & 90.67 & 0.08 & 6.95 & 2.30 \\
\hline 2018 & $14,666.02$ & 91.89 & 0.09 & 6.25 & 1.77 \\
\hline \multicolumn{6}{|l|}{ Philippines } \\
\hline 2008 & $12,285.20$ & 83.26 & 0.07 & 13.92 & 2.75 \\
\hline 2018 & $15,376.28$ & 84.53 & 0.11 & 12.86 & 2.49 \\
\hline \multicolumn{6}{|l|}{ Singapore } \\
\hline 2008 & $7,211.76$ & 41.76 & 0.07 & 47.19 & 10.97 \\
\hline 2018 & $10,832.82$ & 54.40 & 0.07 & 38.00 & 7.53 \\
\hline \multicolumn{6}{|l|}{ Sri Lanka } \\
\hline 2008 & $3,716.59$ & 78.24 & 0.02 & 18.79 & 2.96 \\
\hline 2018 & $6,899.54$ & 84.54 & 0.01 & 13.70 & 1.75 \\
\hline \multicolumn{6}{|l|}{ Taipei,China } \\
\hline 2008 & $21,222.35$ & 54.91 & 0.13 & 32.19 & 12.77 \\
\hline 2018 & $23,679.74$ & 58.87 & 0.14 & 29.53 & 11.46 \\
\hline \multicolumn{6}{|l|}{ Thailand } \\
\hline 2008 & $27,907.45$ & 71.88 & 0.18 & 22.23 & 5.71 \\
\hline 2018 & $44,742.74$ & 77.00 & 0.14 & 17.72 & 5.15 \\
\hline \multicolumn{6}{|l|}{ Viet Nam } \\
\hline 2008 & $22,308.23$ & 69.42 & 0.04 & 26.56 & 3.98 \\
\hline 2018 & $95,023.80$ & 59.90 & 0.06 & 33.84 & 6.20 \\
\hline
\end{tabular}

$0.00=$ magnitude is less than half of unit employed, $\$=$ United States dollars, FVA $=$ foreign value-added, PDC = pure double counted terms, RDV_B = domestic value-added first exported then returned home, VAX_G = domestic value-added absorbed abroad.

Source: ADB Multi Region Input-Output Tables Database. 


\begin{tabular}{|c|c|c|c|c|c|}
\hline \multirow{2}{*}{ ADB Regional Member } & Exports & VAX_G & RDV_B & FVA & PDC \\
\hline & (\$ million) & \multicolumn{4}{|c|}{ (\% share in exports) } \\
\hline \multicolumn{6}{|l|}{ Bangladesh } \\
\hline 2008 & 437.51 & 83.46 & 0.09 & 12.41 & 4.04 \\
\hline 2018 & 655.83 & 84.64 & 0.04 & 14.49 & 0.84 \\
\hline \multicolumn{6}{|l|}{ Bhutan } \\
\hline 2008 & 117.74 & 77.64 & 0.02 & 20.10 & 2.24 \\
\hline 2018 & 85.30 & 80.20 & 0.01 & 18.07 & 1.71 \\
\hline \multicolumn{6}{|l|}{ Brunei Darussalam } \\
\hline 2008 & $3,345.81$ & 92.96 & 0.01 & 4.77 & 2.27 \\
\hline 2018 & $2,952.44$ & 89.43 & 0.01 & 7.34 & 3.22 \\
\hline \multicolumn{6}{|l|}{ Cambodia } \\
\hline 2008 & 31.89 & 67.36 & 0.04 & 23.96 & 8.64 \\
\hline 2018 & 110.87 & 69.18 & 0.04 & 25.37 & 5.41 \\
\hline \multicolumn{6}{|l|}{ China, People's Republic of } \\
\hline 2008 & $906,218.76$ & 71.63 & 1.67 & 20.30 & 6.40 \\
\hline 2018 & $1,603,200.92$ & 77.87 & 3.17 & 13.78 & 5.18 \\
\hline \multicolumn{6}{|l|}{ Fiji } \\
\hline 2008 & 25.49 & 59.20 & 0.01 & 32.77 & 8.03 \\
\hline 2018 & 55.30 & 61.20 & 0.00 & 35.27 & 3.53 \\
\hline \multicolumn{6}{|l|}{ Hong Kong, China } \\
\hline 2008 & $6,993.56$ & 26.00 & 0.04 & 49.30 & 24.66 \\
\hline 2018 & $11,353.30$ & 22.24 & 0.02 & 57.74 & 19.99 \\
\hline \multicolumn{6}{|l|}{ India } \\
\hline 2008 & $77,400.96$ & 62.79 & 0.49 & 22.50 & 14.22 \\
\hline 2018 & $171,380.59$ & 74.39 & 0.53 & 17.55 & 7.54 \\
\hline \multicolumn{6}{|l|}{ Indonesia } \\
\hline 2008 & $53,993.70$ & 75.32 & 0.43 & 16.87 & 7.38 \\
\hline 2018 & $77,088.29$ & 66.99 & 0.35 & 22.61 & 10.05 \\
\hline \multicolumn{6}{|l|}{ Japan } \\
\hline 2008 & $607,682.84$ & 77.99 & 1.23 & 14.54 & 6.24 \\
\hline 2018 & $696,067.45$ & 75.23 & 0.91 & 17.12 & 6.74 \\
\hline \multicolumn{6}{|l|}{ Kazakhstan } \\
\hline 2008 & $12,979.44$ & 85.19 & 0.24 & 8.79 & 5.79 \\
\hline 2018 & $12,036.45$ & 91.29 & 0.20 & 4.82 & 3.69 \\
\hline \multicolumn{6}{|l|}{ Korea, Republic of } \\
\hline 2008 & $390,437.58$ & 57.99 & 0.37 & 29.92 & 11.72 \\
\hline 2018 & $581,976.81$ & 61.41 & 0.43 & 27.42 & 10.74 \\
\hline \multicolumn{6}{|l|}{ Kyrgyz Republic } \\
\hline 2008 & 594.47 & 56.58 & 0.01 & 28.68 & 14.73 \\
\hline 2018 & 575.95 & 75.97 & 0.01 & 16.13 & 7.89 \\
\hline \multicolumn{6}{|l|}{ Lao People's Democratic Republic } \\
\hline 2008 & 8.32 & 45.87 & 0.02 & 36.19 & 17.93 \\
\hline 2018 & 44.87 & 80.05 & 0.06 & 13.18 & 6.71 \\
\hline \multicolumn{6}{|l|}{ Malaysia } \\
\hline 2008 & $72,095.77$ & 63.90 & 0.29 & 21.60 & 14.22 \\
\hline 2018 & $79,526.61$ & 53.21 & 0.42 & 30.14 & 16.23 \\
\hline
\end{tabular}


Table 3.2.1c: continued

\begin{tabular}{|c|c|c|c|c|c|}
\hline \multirow{2}{*}{ ADB Regional Member } & Exports & VAX_G & RDV_B & FVA & PDC \\
\hline & (\$ million) & \multicolumn{4}{|c|}{ (\% share in exports) } \\
\hline \multicolumn{6}{|l|}{ Maldives } \\
\hline 2008 & 1.07 & 60.83 & 0.01 & 33.84 & 5.32 \\
\hline 2018 & 5.99 & 68.36 & 0.00 & 27.55 & 4.09 \\
\hline \multicolumn{6}{|l|}{ Mongolia } \\
\hline 2008 & 51.98 & 66.94 & 0.01 & 20.81 & 12.25 \\
\hline 2018 & 125.01 & 73.67 & 0.01 & 19.76 & 6.56 \\
\hline \multicolumn{6}{|l|}{ Nepal } \\
\hline 2008 & 92.31 & 62.50 & 0.08 & 31.72 & 5.70 \\
\hline 2018 & 102.57 & 58.35 & 0.11 & 37.01 & 4.52 \\
\hline \multicolumn{6}{|l|}{ Pakistan } \\
\hline 2008 & 969.27 & 75.96 & 0.09 & 17.98 & 5.97 \\
\hline 2018 & $1,667.93$ & 78.44 & 0.10 & 17.34 & 4.12 \\
\hline \multicolumn{6}{|l|}{ Philippines } \\
\hline 2008 & $32,928.51$ & 49.98 & 0.10 & 29.57 & 20.34 \\
\hline 2018 & $28,413.44$ & 49.58 & 0.19 & 31.80 & 18.42 \\
\hline \multicolumn{6}{|l|}{ Singapore } \\
\hline 2008 & $133,314.31$ & 28.70 & 0.07 & 48.96 & 22.26 \\
\hline 2018 & $207,365.04$ & 36.57 & 0.11 & 46.48 & 16.83 \\
\hline \multicolumn{6}{|l|}{ Sri Lanka } \\
\hline 2008 & 723.13 & 65.92 & 0.04 & 25.17 & 8.87 \\
\hline 2018 & 537.30 & 50.63 & 0.03 & 40.05 & 9.30 \\
\hline \multicolumn{6}{|l|}{ Taipei,China } \\
\hline 2008 & $221,339.21$ & 49.77 & 0.21 & 30.84 & 19.18 \\
\hline 2018 & $287,430.37$ & 52.66 & 0.26 & 30.12 & 16.96 \\
\hline \multicolumn{6}{|l|}{ Thailand } \\
\hline 2008 & $86,623.55$ & 51.36 & 0.26 & 32.60 & 15.78 \\
\hline 2018 & $104,159.38$ & 53.91 & 0.21 & 33.64 & 12.24 \\
\hline \multicolumn{6}{|l|}{ Viet Nam } \\
\hline 2008 & $5,571.60$ & 62.82 & 0.10 & 26.28 & 10.79 \\
\hline 2018 & $41,596.58$ & 43.80 & 0.08 & 36.22 & 19.90 \\
\hline
\end{tabular}

$0.00=$ magnitude is less than half of unit employed, $\$=$ United States dollars, FVA $=$ foreign value-added, PDC $=$ pure double counted terms, RDV_B = domestic value-added first exported then returned home, VAX_G = domestic value-added absorbed abroad.

Source: ADB Multi Region Input-Output Tables Database. 


\begin{tabular}{|c|c|c|c|c|c|}
\hline \multirow{2}{*}{ ADB Regional Member } & Exports & VAX_G & RDV_B & FVA & PDC \\
\hline & (\$ million) & \multicolumn{4}{|c|}{ (\% share in exports) } \\
\hline \multicolumn{6}{|l|}{ Bangladesh } \\
\hline 2008 & $1,921.39$ & 95.86 & 0.05 & 3.00 & 1.09 \\
\hline 2018 & $2,311.31$ & 96.31 & 0.12 & 2.47 & 1.09 \\
\hline \multicolumn{6}{|l|}{ Bhutan } \\
\hline 2008 & 63.08 & 73.64 & 0.00 & 21.01 & 5.35 \\
\hline 2018 & 219.67 & 82.34 & 0.00 & 13.28 & 4.38 \\
\hline \multicolumn{6}{|l|}{ Brunei Darussalam } \\
\hline 2008 & 569.44 & 74.86 & 0.00 & 19.02 & 6.12 \\
\hline 2018 & 448.96 & 73.29 & 0.01 & 19.53 & 7.17 \\
\hline \multicolumn{6}{|l|}{ Cambodia } \\
\hline 2008 & $1,258.52$ & 81.03 & 0.01 & 14.81 & 4.16 \\
\hline 2018 & $3,320.72$ & 80.54 & 0.01 & 14.83 & 4.62 \\
\hline \multicolumn{6}{|l|}{ China, People's Republic of } \\
\hline 2008 & $237,154.45$ & 85.92 & 1.96 & 8.51 & 3.60 \\
\hline 2018 & $455,895.60$ & 89.52 & 3.64 & 4.47 & 2.37 \\
\hline \multicolumn{6}{|c|}{ Fiji } \\
\hline 2008 & 746.60 & 67.22 & 0.01 & 27.78 & 4.99 \\
\hline 2018 & $1,737.95$ & 72.63 & 0.01 & 22.20 & 5.17 \\
\hline \multicolumn{6}{|l|}{ Hong Kong, China } \\
\hline 2008 & $122,562.16$ & 74.18 & 0.14 & 20.55 & 5.13 \\
\hline 2018 & $187,584.58$ & 75.73 & 0.16 & 19.56 & 4.55 \\
\hline \multicolumn{6}{|l|}{ India } \\
\hline 2008 & $105,866.03$ & 87.85 & 0.74 & 8.24 & 3.16 \\
\hline 2018 & $117,204.45$ & 93.31 & 0.59 & 4.66 & 1.45 \\
\hline \multicolumn{6}{|l|}{ Indonesia } \\
\hline 2008 & $9,033.30$ & 87.90 & 0.30 & 8.76 & 3.03 \\
\hline 2018 & $13,175.41$ & 87.45 & 0.29 & 9.16 & 3.10 \\
\hline \multicolumn{6}{|l|}{ Japan } \\
\hline 2008 & $203,055.59$ & 87.43 & 1.49 & 7.91 & 3.17 \\
\hline 2018 & $158,944.42$ & 90.83 & 0.96 & 5.53 & 2.67 \\
\hline \multicolumn{6}{|l|}{ Kazakhstan } \\
\hline 2008 & $18,605.46$ & 87.32 & 0.39 & 9.26 & 3.03 \\
\hline 2018 & $15,218.99$ & 90.78 & 0.56 & 6.23 & 2.42 \\
\hline \multicolumn{6}{|l|}{ Korea, Republic of } \\
\hline 2008 & $55,289.22$ & 79.14 & 0.54 & 14.49 & 5.84 \\
\hline 2018 & $83,176.89$ & 82.17 & 0.50 & 12.47 & 4.87 \\
\hline \multicolumn{6}{|l|}{ Kyrgyz Republic } \\
\hline 2008 & 544.82 & 63.09 & 0.01 & 29.17 & 7.73 \\
\hline 2018 & 431.87 & 70.02 & 0.02 & 22.43 & 7.53 \\
\hline \multicolumn{6}{|l|}{ Lao People's Democratic Republic } \\
\hline 2008 & 109.49 & 79.88 & 0.01 & 14.09 & 6.02 \\
\hline 2018 & 897.23 & 87.02 & 0.02 & 9.65 & 3.31 \\
\hline \multicolumn{6}{|l|}{ Malaysia } \\
\hline 2008 & $36,864.23$ & 77.55 & 0.19 & 16.39 & 5.87 \\
\hline 2018 & $35,829.33$ & 74.60 & 0.27 & 18.34 & 6.79 \\
\hline
\end{tabular}


Table 3.2.1d: continued

\begin{tabular}{|c|c|c|c|c|c|}
\hline \multirow{2}{*}{ ADB Regional Member } & Exports & VAX_G & RDV_B & FVA & PDC \\
\hline & (\$ million) & \multicolumn{4}{|c|}{ (\% share in exports) } \\
\hline \multicolumn{6}{|l|}{ Maldives } \\
\hline 2008 & $1,341.86$ & 67.60 & 0.00 & 24.54 & 7.85 \\
\hline 2018 & $3,002.09$ & 64.38 & 0.00 & 27.29 & 8.32 \\
\hline \multicolumn{6}{|l|}{ Mongolia } \\
\hline 2008 & 491.62 & 75.96 & 0.01 & 18.57 & 5.47 \\
\hline 2018 & 820.45 & 78.34 & 0.04 & 15.97 & 5.66 \\
\hline \multicolumn{6}{|l|}{ Nepal } \\
\hline 2008 & 364.37 & 82.97 & 0.02 & 13.26 & 3.75 \\
\hline 2018 & 531.93 & 78.97 & 0.05 & 17.09 & 3.89 \\
\hline \multicolumn{6}{|l|}{ Pakistan } \\
\hline 2008 & $2,612.58$ & 92.41 & 0.10 & 5.58 & 1.91 \\
\hline 2018 & $5,083.23$ & 93.33 & 0.11 & 5.16 & 1.39 \\
\hline \multicolumn{6}{|l|}{ Philippines } \\
\hline 2008 & $14,646.65$ & 90.22 & 0.11 & 7.42 & 2.25 \\
\hline 2018 & $33,179.01$ & 90.25 & 0.16 & 7.20 & 2.38 \\
\hline \multicolumn{6}{|l|}{ Singapore } \\
\hline 2008 & $114,405.78$ & 58.10 & 0.09 & 31.59 & 10.22 \\
\hline 2018 & $235,952.41$ & 54.49 & 0.12 & 34.12 & 11.27 \\
\hline \multicolumn{6}{|l|}{ Sri Lanka } \\
\hline 2008 & $3,006.16$ & 86.05 & 0.03 & 11.24 & 2.68 \\
\hline 2018 & $6,224.95$ & 89.12 & 0.02 & 8.59 & 2.27 \\
\hline \multicolumn{6}{|l|}{ Taipei,China } \\
\hline 2008 & $46,541.78$ & 77.33 & 0.31 & 15.52 & 6.84 \\
\hline 2018 & $79,081.81$ & 78.42 & 0.33 & 14.96 & 6.29 \\
\hline \multicolumn{6}{|l|}{ Thailand } \\
\hline 2008 & $17,603.81$ & 78.32 & 0.27 & 16.38 & 5.03 \\
\hline 2018 & $87,145.81$ & 84.64 & 0.15 & 12.19 & 3.02 \\
\hline \multicolumn{6}{|l|}{ Viet Nam } \\
\hline 2008 & $7,399.11$ & 77.39 & 0.06 & 18.28 & 4.27 \\
\hline 2018 & $29,713.37$ & 73.76 & 0.10 & 21.20 & 4.95 \\
\hline
\end{tabular}

$0.00=$ magnitude is less than half of unit employed, $\$=$ United States dollars, FVA $=$ foreign value-added, PDC = pure double counted terms, RDV_B = domestic value-added first exported then returned home, VAX_G = domestic value-added absorbed abroad.

Source: ADB Multi Region Input-Output Tables Database. 


\begin{tabular}{|c|c|c|c|c|c|}
\hline \multirow[b]{2}{*}{ ADB Regional Member } & Fynorts & VAX G & PDY R & & \\
\hline & (\$ million) & \multicolumn{4}{|c|}{ (\% share in exports) } \\
\hline \multicolumn{6}{|l|}{ Bangladesh } \\
\hline 2008 & 321.38 & 96.58 & 0.02 & 2.87 & 0.52 \\
\hline 2018 & $2,292.50$ & 96.71 & 0.07 & 2.43 & 0.79 \\
\hline \multicolumn{6}{|l|}{ Bhutan } \\
\hline 2008 & 4.32 & 86.60 & 0.00 & 11.07 & 2.33 \\
\hline 2018 & 25.91 & 84.98 & 0.00 & 11.90 & 3.12 \\
\hline \multicolumn{6}{|l|}{ Brunei Darussalam } \\
\hline 2008 & 92.14 & 90.44 & 0.00 & 8.09 & 1.47 \\
\hline 2018 & 56.10 & 83.25 & 0.00 & 15.38 & 1.37 \\
\hline \multicolumn{6}{|l|}{ Cambodia } \\
\hline 2008 & 85.35 & 79.46 & 0.01 & 15.00 & 5.53 \\
\hline 2018 & 121.29 & 80.69 & 0.02 & 15.31 & 3.99 \\
\hline \multicolumn{6}{|l|}{ China, People's Republic of } \\
\hline 2008 & $11,855.53$ & 87.49 & 0.61 & 9.80 & 2.10 \\
\hline 2018 & $18,896.06$ & 92.03 & 1.32 & 5.41 & 1.23 \\
\hline \multicolumn{6}{|l|}{ Fiji } \\
\hline 2008 & 15.99 & 81.35 & 0.01 & 14.70 & 3.93 \\
\hline 2018 & 51.88 & 86.28 & 0.01 & 12.95 & 0.76 \\
\hline \multicolumn{6}{|l|}{ Hong Kong, China } \\
\hline 2008 & 958.03 & 85.87 & 0.18 & 10.94 & 3.01 \\
\hline 2018 & $1,292.53$ & 86.56 & 0.15 & 10.17 & 3.11 \\
\hline \multicolumn{6}{|l|}{ India } \\
\hline 2008 & $10,500.45$ & 94.22 & 0.02 & 5.64 & 0.12 \\
\hline 2018 & $12,006.52$ & 97.94 & 0.01 & 2.03 & 0.02 \\
\hline \multicolumn{6}{|l|}{ Indonesia } \\
\hline 2008 & $1,638.51$ & 89.10 & 0.21 & 9.00 & 1.69 \\
\hline 2018 & $2,178.61$ & 91.04 & 0.12 & 7.57 & 1.27 \\
\hline \multicolumn{6}{|l|}{ Japan } \\
\hline 2008 & $3,250.32$ & 92.91 & 0.90 & 4.87 & 1.32 \\
\hline 2018 & $3,400.89$ & 93.24 & 0.45 & 5.39 & 0.92 \\
\hline \multicolumn{6}{|l|}{ Kazakhstan } \\
\hline 2008 & 605.55 & 83.48 & 0.04 & 15.20 & 1.29 \\
\hline 2018 & 302.35 & 93.13 & 0.04 & 6.24 & 0.60 \\
\hline \multicolumn{6}{|l|}{ Korea, Republic of } \\
\hline 2008 & $6,059.60$ & 82.84 & 0.80 & 11.19 & 5.17 \\
\hline 2018 & $4,953.84$ & 84.55 & 0.39 & 12.22 & 2.84 \\
\hline \multicolumn{6}{|l|}{ Kyrgyz Republic } \\
\hline 2008 & 182.15 & 77.06 & 0.00 & 18.99 & 3.94 \\
\hline 2018 & 260.09 & 85.85 & 0.00 & 11.27 & 2.88 \\
\hline \multicolumn{6}{|l|}{ Lao People's Democratic Republic } \\
\hline 2008 & 1.69 & 85.49 & 0.00 & 13.91 & 0.61 \\
\hline 2018 & 182.47 & 91.31 & 0.01 & 7.44 & 1.23 \\
\hline \multicolumn{6}{|l|}{ Malaysia } \\
\hline 2008 & $1,904.65$ & 75.27 & 0.11 & 18.59 & 6.03 \\
\hline 2018 & $1,882.24$ & 76.04 & 0.08 & 22.00 & 1.88 \\
\hline
\end{tabular}


Table 3.2.1e: continued

\begin{tabular}{|c|c|c|c|c|c|}
\hline \multirow{2}{*}{ ADB Regional Member } & Exports & VAX_G & RDV_B & FVA & PDC \\
\hline & (\$ million) & \multicolumn{4}{|c|}{ (\% share in exports) } \\
\hline \multicolumn{6}{|l|}{ Maldives } \\
\hline 2008 & 17.61 & 75.57 & 0.01 & 19.66 & 4.77 \\
\hline 2018 & 99.61 & 76.98 & 0.01 & 16.83 & 6.18 \\
\hline \multicolumn{6}{|l|}{ Mongolia } \\
\hline 2008 & 4.22 & 83.33 & 0.01 & 10.93 & 5.73 \\
\hline 2018 & 20.35 & 76.36 & 0.01 & 20.62 & 3.01 \\
\hline \multicolumn{6}{|l|}{ Nepal } \\
\hline 2008 & 307.68 & 91.47 & 0.02 & 6.51 & 2.00 \\
\hline 2018 & 470.75 & 88.83 & 0.07 & 9.03 & 2.06 \\
\hline \multicolumn{6}{|l|}{ Pakistan } \\
\hline 2008 & 912.06 & 94.31 & 0.03 & 5.21 & 0.45 \\
\hline 2018 & $1,366.55$ & 95.21 & 0.03 & 4.43 & 0.32 \\
\hline \multicolumn{6}{|l|}{ Philippines } \\
\hline 2008 & 432.49 & 89.17 & 0.11 & 7.54 & 3.18 \\
\hline 2018 & $1,571.10$ & 88.67 & 0.11 & 8.27 & 2.94 \\
\hline \multicolumn{6}{|l|}{ Singapore } \\
\hline 2008 & $1,365.45$ & 74.43 & 0.17 & 18.04 & 7.36 \\
\hline 2018 & $1,764.75$ & 79.42 & 0.15 & 14.04 & 6.38 \\
\hline \multicolumn{6}{|l|}{ Sri Lanka } \\
\hline 2008 & 66.59 & 83.28 & 0.03 & 11.47 & 5.22 \\
\hline 2018 & 532.81 & 89.47 & 0.01 & 9.13 & 1.39 \\
\hline \multicolumn{6}{|l|}{ Taipei,China } \\
\hline 2008 & $1,229.35$ & 84.14 & 0.11 & 14.30 & 1.45 \\
\hline 2018 & $1,547.80$ & 83.81 & 0.11 & 14.82 & 1.26 \\
\hline \multicolumn{6}{|l|}{ Thailand } \\
\hline 2008 & $2,219.64$ & 82.94 & 0.10 & 15.37 & 1.59 \\
\hline 2018 & $7,891.71$ & 87.67 & 0.09 & 11.15 & 1.09 \\
\hline \multicolumn{6}{|l|}{ Viet Nam } \\
\hline 2008 & 249.78 & 84.41 & 0.03 & 14.69 & 0.88 \\
\hline 2018 & $2,089.97$ & 75.95 & 0.05 & 22.59 & 1.42 \\
\hline
\end{tabular}

$0.00=$ magnitude is less than half of unit employed, $\$=$ United States dollars, FVA $=$ foreign value-added, PDC $=$ pure double counted terms, RDV_B = domestic value-added first exported then returned home, VAX_G = domestic value-added absorbed abroad.

Source: ADB Multi Region Input-Output Tables Database. 


\begin{tabular}{|c|c|c|c|c|c|}
\hline \multirow{2}{*}{ ADB Regional Member } & \multirow{2}{*}{$\begin{array}{l}\text { Exports } \\
\text { (\$ million) }\end{array}$} & VAX_G & RDV_B & FVA & PDC \\
\hline & & \multicolumn{4}{|c|}{ (\% share in exports) } \\
\hline \multicolumn{6}{|l|}{ Bangladesh } \\
\hline 2008 & $16,183.80$ & 83.73 & 0.03 & 14.37 & 1.87 \\
\hline 2018 & $36,558.14$ & 85.19 & 0.05 & 13.10 & 1.66 \\
\hline \multicolumn{6}{|l|}{ Bhutan } \\
\hline 2008 & 527.43 & 83.84 & 0.01 & 13.05 & 3.10 \\
\hline 2018 & 754.09 & 84.01 & 0.01 & 11.91 & 4.07 \\
\hline \multicolumn{6}{|l|}{ Brunei Darussalam } \\
\hline 2008 & $9,792.41$ & 92.23 & 0.01 & 5.34 & 2.42 \\
\hline 2018 & $7,045.74$ & 87.15 & 0.01 & 8.97 & 3.88 \\
\hline \multicolumn{6}{|l|}{ Cambodia } \\
\hline 2008 & $4,221.00$ & 70.93 & 0.02 & 25.91 & 3.14 \\
\hline 2018 & $10,849.95$ & 72.29 & 0.03 & 24.37 & 3.31 \\
\hline \multicolumn{6}{|l|}{ China, People's Republic of } \\
\hline 2008 & $1,540,785.17$ & 77.26 & 1.46 & 16.46 & 4.83 \\
\hline 2018 & $2,728,604.14$ & 82.64 & 2.77 & 10.77 & 3.82 \\
\hline \multicolumn{6}{|l|}{ Fiji } \\
\hline 2008 & $1,033.78$ & 68.42 & 0.01 & 26.61 & 4.96 \\
\hline 2018 & $2,549.77$ & 73.06 & 0.01 & 22.22 & 4.72 \\
\hline \multicolumn{6}{|l|}{ Hong Kong, China } \\
\hline 2008 & $138,411.64$ & 70.85 & 0.13 & 22.65 & 6.37 \\
\hline 2018 & $207,555.60$ & 71.87 & 0.15 & 22.46 & 5.52 \\
\hline \multicolumn{6}{|l|}{ India } \\
\hline 2008 & $252,585.42$ & 80.05 & 0.56 & 13.11 & 6.29 \\
\hline 2018 & $410,505.99$ & 84.34 & 0.50 & 11.08 & 4.07 \\
\hline \multicolumn{6}{|l|}{ Indonesia } \\
\hline 2008 & $159,962.18$ & 82.48 & 0.44 & 12.46 & 4.62 \\
\hline 2018 & $248,141.33$ & 77.60 & 0.46 & 15.87 & 6.07 \\
\hline \multicolumn{6}{|l|}{ Japan } \\
\hline 2008 & $861,523.63$ & 80.43 & 1.31 & 12.77 & 5.49 \\
\hline 2018 & $915,218.17$ & 78.31 & 0.94 & 14.78 & 5.97 \\
\hline \multicolumn{6}{|l|}{ Kazakhstan } \\
\hline 2008 & $71,097.18$ & 85.70 & 0.21 & 9.10 & 4.99 \\
\hline 2018 & $55,949.93$ & 90.44 & 0.24 & 5.68 & 3.65 \\
\hline \multicolumn{6}{|l|}{ Korea, Republic of } \\
\hline 2008 & $486,259.44$ & 61.49 & 0.40 & 27.35 & 10.76 \\
\hline 2018 & $712,710.88$ & 64.53 & 0.44 & 25.14 & 9.89 \\
\hline \multicolumn{6}{|l|}{ Kyrgyz Republic } \\
\hline 2008 & $1,681.29$ & 64.14 & 0.01 & 26.57 & 9.28 \\
\hline 2018 & $1,827.83$ & 75.45 & 0.03 & 18.52 & 5.99 \\
\hline \multicolumn{6}{|l|}{ Lao People's Democratic Republic } \\
\hline 2008 & $1,092.00$ & 84.66 & 0.01 & 10.42 & 4.92 \\
\hline 2018 & $6,175.19$ & 89.22 & 0.03 & 8.03 & 2.72 \\
\hline \multicolumn{6}{|l|}{ Malaysia } \\
\hline 2008 & $170,413.22$ & 71.36 & 0.23 & 18.79 & 9.62 \\
\hline 2018 & $180,314.83$ & 63.08 & 0.35 & 25.29 & 11.28 \\
\hline
\end{tabular}


Table 3.2.1f: continued

\begin{tabular}{|c|c|c|c|c|c|}
\hline \multirow{2}{*}{ ADB Regional Member } & Exports & VAX_G & RDV_B & FVA & PDC \\
\hline & (\$ million) & \multicolumn{4}{|c|}{ (\% share in exports) } \\
\hline \multicolumn{6}{|l|}{ Maldives } \\
\hline 2008 & $1,415.57$ & 67.30 & 0.00 & 24.75 & 7.94 \\
\hline 2018 & $3,488.63$ & 64.13 & 0.00 & 27.63 & 8.23 \\
\hline \multicolumn{6}{|l|}{ Mongolia } \\
\hline 2008 & $2,412.15$ & 74.85 & 0.01 & 16.84 & 8.30 \\
\hline 2018 & $6,756.34$ & 75.31 & 0.02 & 18.12 & 6.56 \\
\hline \multicolumn{6}{|l|}{ Nepal } \\
\hline 2008 & $1,084.21$ & 83.02 & 0.03 & 14.15 & 2.80 \\
\hline 2018 & $1,434.15$ & 80.32 & 0.06 & 16.67 & 2.95 \\
\hline \multicolumn{6}{|l|}{ Pakistan } \\
\hline 2008 & $16,402.81$ & 90.60 & 0.08 & 7.05 & 2.27 \\
\hline 2018 & $24,986.22$ & 91.88 & 0.09 & 6.36 & 1.67 \\
\hline \multicolumn{6}{|l|}{ Philippines } \\
\hline 2008 & $61,756.06$ & 67.36 & 0.10 & 20.52 & 12.01 \\
\hline 2018 & $80,258.69$ & 74.73 & 0.16 & 17.01 & 8.09 \\
\hline \multicolumn{6}{|l|}{ Singapore } \\
\hline 2008 & $256,425.58$ & 42.44 & 0.08 & 40.99 & 16.49 \\
\hline 2018 & $455,948.40$ & 46.44 & 0.12 & 39.76 & 13.69 \\
\hline \multicolumn{6}{|l|}{ Sri Lanka } \\
\hline 2008 & $7,990.62$ & 80.81 & 0.02 & 15.81 & 3.36 \\
\hline 2018 & $15,028.33$ & 85.67 & 0.02 & 12.10 & 2.22 \\
\hline \multicolumn{6}{|l|}{ Taipei,China } \\
\hline 2008 & $291,850.12$ & 54.80 & 0.22 & 28.40 & 16.59 \\
\hline 2018 & $393,429.97$ & 58.44 & 0.27 & 26.93 & 14.37 \\
\hline \multicolumn{6}{|l|}{ Thailand } \\
\hline 2008 & $137,857.72$ & 60.31 & 0.25 & 27.59 & 11.85 \\
\hline 2018 & $254,836.17$ & 70.95 & 0.17 & 21.77 & 7.10 \\
\hline \multicolumn{6}{|l|}{ Viet Nam } \\
\hline 2008 & $44,715.69$ & 71.01 & 0.08 & 23.50 & 5.41 \\
\hline 2018 & $190,006.28$ & 58.99 & 0.20 & 31.55 & 9.27 \\
\hline
\end{tabular}

$0.00=$ magnitude is less than half of unit employed, $\$=$ United States dollars, FVA $=$ foreign value-added, PDC $=$ pure double counted terms, RDV_B $=$ domestic value-added first exported then returned home, $V A X \_G=$ domestic value-added absorbed abroad.

Source: ADB Multi Region Input-Output Tables Database. 


\begin{tabular}{|c|c|c|c|c|c|}
\hline \multirow{2}{*}{ ADB Regional Member } & VAX_G & DVA_B & DVA_F & VAX_B & VAX_F \\
\hline & \multicolumn{5}{|c|}{ Value-Added Export Measure to Gross Exports Ratio (\%) } \\
\hline \multicolumn{6}{|l|}{ Bangladesh } \\
\hline 2008 & 92.05 & 92.14 & 576.35 & 92.05 & 576.17 \\
\hline 2018 & 92.47 & 92.58 & 614.35 & 92.47 & 614.03 \\
\hline \multicolumn{6}{|l|}{ Bhutan } \\
\hline 2008 & 94.37 & 94.38 & 103.02 & 94.37 & 103.01 \\
\hline 2018 & 92.96 & 92.97 & 101.77 & 92.96 & 101.76 \\
\hline \multicolumn{6}{|l|}{ Brunei Darussalam } \\
\hline 2008 & 93.74 & 93.75 & 115.11 & 93.74 & 115.10 \\
\hline 2018 & 87.97 & 87.97 & 121.78 & 87.97 & 121.78 \\
\hline \multicolumn{6}{|l|}{ Cambodia } \\
\hline 2008 & 89.92 & 90.06 & 160.15 & 89.92 & 160.01 \\
\hline 2018 & 89.32 & 89.56 & 130.93 & 89.32 & 130.71 \\
\hline \multicolumn{6}{|l|}{ China, People's Republic of } \\
\hline 2008 & 86.30 & 89.34 & 795.09 & 86.30 & 780.55 \\
\hline 2018 & 89.97 & 92.91 & $1,060.01$ & 89.97 & $1,028.86$ \\
\hline \multicolumn{6}{|l|}{ Fiji } \\
\hline 2008 & 69.06 & 69.07 & 138.08 & 69.06 & 138.07 \\
\hline 2018 & 74.60 & 74.61 & 106.92 & 74.60 & 106.91 \\
\hline \multicolumn{6}{|l|}{ Hong Kong, China } \\
\hline 2008 & 51.29 & 51.55 & 41.54 & 51.29 & 41.35 \\
\hline 2018 & 60.57 & 60.81 & 56.72 & 60.57 & 56.52 \\
\hline \multicolumn{6}{|l|}{ India } \\
\hline 2008 & 93.22 & 93.87 & 145.23 & 93.22 & 144.32 \\
\hline 2018 & 94.10 & 95.07 & 181.09 & 94.10 & 179.81 \\
\hline \multicolumn{6}{|l|}{ Indonesia } \\
\hline 2008 & 92.38 & 93.23 & 131.05 & 92.38 & 130.14 \\
\hline 2018 & 88.33 & 89.61 & 133.29 & 88.33 & 132.01 \\
\hline \multicolumn{6}{|l|}{ Japan } \\
\hline 2008 & 59.09 & 60.50 & 185.77 & 59.09 & 182.29 \\
\hline 2018 & 60.32 & 61.75 & 178.10 & 60.32 & 175.28 \\
\hline \multicolumn{6}{|l|}{ Kazakhstan } \\
\hline 2008 & 85.28 & 85.40 & 72.87 & 85.28 & 72.76 \\
\hline 2018 & 90.14 & 90.22 & 75.55 & 90.14 & 75.47 \\
\hline \multicolumn{6}{|l|}{ Korea, Republic of } \\
\hline 2008 & 82.02 & 82.47 & 615.83 & 82.02 & 612.36 \\
\hline 2018 & 82.18 & 83.05 & 659.56 & 82.18 & 655.35 \\
\hline \multicolumn{6}{|l|}{ Kyrgyz Republic } \\
\hline 2008 & 85.94 & 85.96 & 120.59 & 85.94 & 120.56 \\
\hline 2018 & 79.76 & 79.87 & 64.54 & 79.76 & 64.47 \\
\hline \multicolumn{6}{|l|}{ Lao People's Democratic Republic } \\
\hline 2008 & 84.64 & 84.64 & 80.81 & 84.64 & 80.81 \\
\hline 2018 & 89.32 & 89.38 & 102.76 & 89.32 & 102.69 \\
\hline \multicolumn{6}{|l|}{ Malaysia } \\
\hline 2008 & 91.11 & 91.43 & 227.88 & 91.11 & 227.24 \\
\hline 2018 & 86.40 & 87.27 & 196.85 & 86.40 & 195.72 \\
\hline
\end{tabular}


Table 3.2.2a: continued

\begin{tabular}{|c|c|c|c|c|c|}
\hline \multirow{2}{*}{ ADB Regional Member } & VAX_G & DVA_B & DVA_F & VAX_B & VAX_F \\
\hline & \multicolumn{5}{|c|}{ Value-Added Export Measure to Gross Exports Ratio (\%) } \\
\hline \multicolumn{6}{|l|}{ Maldives } \\
\hline 2008 & 56.36 & 56.37 & 476.05 & 56.36 & 476.02 \\
\hline 2018 & 58.30 & 58.31 & 200.75 & 58.30 & 200.74 \\
\hline \multicolumn{6}{|l|}{ Mongolia } \\
\hline 2008 & 74.44 & 74.45 & 67.39 & 74.44 & 67.38 \\
\hline 2018 & 75.09 & 75.10 & 55.54 & 75.09 & 55.53 \\
\hline \multicolumn{6}{|l|}{ Nepal } \\
\hline 2008 & 92.18 & 92.23 & 178.84 & 92.18 & 178.77 \\
\hline 2018 & 91.04 & 91.12 & 208.30 & 91.04 & 208.15 \\
\hline \multicolumn{6}{|l|}{ Pakistan } \\
\hline 2008 & 95.80 & 95.93 & 525.26 & 95.80 & 524.76 \\
\hline 2018 & 96.60 & 96.70 & 386.78 & 96.60 & 386.39 \\
\hline \multicolumn{6}{|l|}{ Philippines } \\
\hline 2008 & 89.75 & 89.96 & 344.45 & 89.75 & 344.02 \\
\hline 2018 & 90.55 & 90.79 & 363.22 & 90.55 & 362.64 \\
\hline \multicolumn{6}{|l|}{ Singapore } \\
\hline 2008 & 59.01 & 59.09 & 53.15 & 59.01 & 53.06 \\
\hline 2018 & 64.74 & 64.89 & 123.45 & 64.74 & 123.26 \\
\hline \multicolumn{6}{|l|}{ Sri Lanka } \\
\hline 2008 & 89.96 & 90.02 & 147.15 & 89.96 & 147.07 \\
\hline 2018 & 89.44 & 89.47 & 148.06 & 89.44 & 148.02 \\
\hline \multicolumn{6}{|l|}{ Taipei,China } \\
\hline 2008 & 70.98 & 71.04 & 115.30 & 70.98 & 115.05 \\
\hline 2018 & 76.31 & 76.43 & 122.36 & 76.31 & 122.11 \\
\hline \multicolumn{6}{|l|}{ Thailand } \\
\hline 2008 & 84.89 & 85.29 & 207.57 & 84.89 & 206.87 \\
\hline 2018 & 87.35 & 87.59 & 165.93 & 87.35 & 165.62 \\
\hline \multicolumn{6}{|l|}{ Viet Nam } \\
\hline 2008 & 74.31 & 74.54 & 108.94 & 74.31 & 108.75 \\
\hline 2018 & 62.26 & 63.60 & 105.04 & 62.26 & 103.97 \\
\hline
\end{tabular}

DVA_B $=$ domestic value-added exports by backward industrial linkages, DVA_F = domestic value-added exports by forward industrial linkages, VAX_B = value-added exports by backward industrial linkages, VAX_F = value-added exports by forward industrial linkages, VAX_G = domestic valueadded absorbed abroad.

Source: ADB Multi Region Input-Output Tables Database. 


\begin{tabular}{|c|c|c|c|c|c|}
\hline \multirow{2}{*}{ ADB Regional Member } & VAX_G & DVA_B & DVA_F & VAX_B & VAX_F \\
\hline & \multicolumn{5}{|c|}{ Value-Added Export Measure to Gross Exports Ratio (\%) } \\
\hline \multicolumn{6}{|l|}{ Bangladesh } \\
\hline 2008 & 81.44 & 81.46 & 40.62 & 81.44 & 40.61 \\
\hline 2018 & 83.39 & 83.43 & 47.87 & 83.39 & 47.85 \\
\hline \multicolumn{6}{|l|}{ Bhutan } \\
\hline 2008 & 84.88 & 84.88 & 92.92 & 84.88 & 92.92 \\
\hline 2018 & 82.87 & 82.87 & 80.15 & 82.87 & 80.15 \\
\hline \multirow{2}{*}{\multicolumn{6}{|c|}{ Brunei Darussalam }} \\
\hline & & & & & \\
\hline 2008 & 68.15 & 68.15 & 155.49 & 68.15 & 155.48 \\
\hline 2018 & 58.91 & 58.91 & 55.57 & 58.91 & 55.56 \\
\hline \multicolumn{6}{|l|}{ Cambodia } \\
\hline 2008 & 62.66 & 62.66 & 49.41 & 62.66 & 49.40 \\
\hline 2018 & 64.81 & 64.81 & 50.14 & 64.81 & 50.14 \\
\hline \multicolumn{6}{|l|}{ China, People's Republic of } \\
\hline 2008 & 84.75 & 85.16 & 62.48 & 84.75 & 61.77 \\
\hline 2018 & 89.27 & 90.37 & 63.66 & 89.27 & 62.30 \\
\hline \multicolumn{6}{|l|}{ Fiji } \\
\hline 2008 & 73.09 & 73.09 & 55.56 & 73.09 & 55.56 \\
\hline 2018 & 73.87 & 73.87 & 57.01 & 73.87 & 57.00 \\
\hline \multicolumn{6}{|l|}{ Hong Kong, China } \\
\hline 2008 & 57.18 & 57.22 & 56.37 & 57.18 & 56.28 \\
\hline 2018 & 47.12 & 47.13 & 49.77 & 47.12 & 49.69 \\
\hline \multicolumn{6}{|l|}{ India } \\
\hline 2008 & 82.32 & 82.56 & 50.61 & 82.32 & 50.35 \\
\hline 2018 & 87.32 & 87.59 & 47.88 & 87.32 & 47.65 \\
\hline \multicolumn{6}{|l|}{ Indonesia } \\
\hline 2008 & 81.35 & 81.54 & 47.40 & 81.35 & 47.26 \\
\hline 2018 & 78.40 & 78.54 & 46.55 & 78.40 & 46.44 \\
\hline \multicolumn{6}{|l|}{ Japan } \\
\hline 2008 & 82.17 & 83.99 & 138.62 & 82.17 & 136.18 \\
\hline 2018 & 81.54 & 82.85 & 128.10 & 81.54 & 126.42 \\
\hline \multicolumn{6}{|l|}{ Kazakhstan } \\
\hline 2008 & 81.45 & 81.56 & 206.51 & 81.45 & 206.05 \\
\hline 2018 & 84.94 & 85.22 & 119.03 & 84.94 & 118.65 \\
\hline \multicolumn{6}{|l|}{ Korea, Republic of } \\
\hline 2008 & 68.84 & 69.26 & 74.59 & 68.84 & 74.14 \\
\hline 2018 & 70.09 & 70.69 & 95.77 & 70.09 & 95.05 \\
\hline \multicolumn{6}{|l|}{ Kyrgyz Republic } \\
\hline 2008 & 59.75 & 59.78 & 46.14 & 59.75 & 46.12 \\
\hline 2018 & 67.81 & 67.84 & 53.64 & 67.81 & 53.62 \\
\hline \multicolumn{6}{|l|}{ Lao People's Democratic Republic } \\
\hline 2008 & 88.40 & 88.40 & 72.19 & 88.40 & 72.18 \\
\hline 2018 & 89.77 & 89.78 & 74.34 & 89.77 & 74.33 \\
\hline \multicolumn{6}{|l|}{ Malaysia } \\
\hline 2008 & 69.95 & 70.08 & 30.75 & 69.95 & 30.68 \\
\hline 2018 & 62.99 & 63.13 & 29.95 & 62.99 & 29.85 \\
\hline
\end{tabular}


Table 3.2.2b: continued

\begin{tabular}{|c|c|c|c|c|c|}
\hline \multirow{2}{*}{ ADB Regional Member } & VAX_G & DVA_B & DVA_F & VAX_B & VAX_F \\
\hline & \multicolumn{5}{|c|}{ Value-Added Export Measure to Gross Exports Ratio (\%) } \\
\hline \multicolumn{6}{|l|}{ Maldives } \\
\hline 2008 & 57.93 & 57.94 & 200.90 & 57.93 & 200.88 \\
\hline 2018 & 58.77 & 58.77 & 156.19 & 58.77 & 156.18 \\
\hline \multicolumn{6}{|l|}{ Mongolia } \\
\hline 2008 & 78.42 & 78.43 & 59.41 & 78.42 & 59.40 \\
\hline 2018 & 69.31 & 69.34 & 171.99 & 69.31 & 171.95 \\
\hline \multicolumn{6}{|l|}{ Nepal } \\
\hline 2008 & 77.35 & 77.36 & 53.16 & 77.35 & 53.15 \\
\hline 2018 & 73.03 & 73.06 & 58.45 & 73.03 & 58.41 \\
\hline \multicolumn{6}{|l|}{ Pakistan } \\
\hline 2008 & 90.67 & 90.75 & 33.02 & 90.67 & 32.99 \\
\hline 2018 & 91.89 & 91.98 & 33.30 & 91.89 & 33.27 \\
\hline \multicolumn{6}{|l|}{ Philippines } \\
\hline 2008 & 83.26 & 83.33 & 60.97 & 83.26 & 60.91 \\
\hline 2018 & 84.53 & 84.64 & 67.60 & 84.53 & 67.50 \\
\hline \multicolumn{6}{|l|}{ Singapore } \\
\hline 2008 & 41.76 & 41.81 & 46.97 & 41.76 & 46.88 \\
\hline 2018 & 54.40 & 54.44 & 73.67 & 54.40 & 73.52 \\
\hline \multicolumn{6}{|l|}{ Sri Lanka } \\
\hline 2008 & 78.24 & 78.25 & 58.74 & 78.24 & 58.72 \\
\hline 2018 & 84.54 & 84.55 & 66.21 & 84.54 & 66.20 \\
\hline \multicolumn{6}{|l|}{ Taipei,China } \\
\hline 2008 & 54.91 & 55.02 & 49.75 & 54.91 & 49.61 \\
\hline 2018 & 58.87 & 58.99 & 66.09 & 58.87 & 65.88 \\
\hline \multicolumn{6}{|l|}{ Thailand } \\
\hline 2008 & 71.88 & 72.04 & 55.94 & 71.88 & 55.76 \\
\hline 2018 & 77.00 & 77.13 & 64.40 & 77.00 & 64.26 \\
\hline \multicolumn{6}{|l|}{ Viet Nam } \\
\hline 2008 & 69.42 & 69.45 & 43.64 & 69.42 & 43.61 \\
\hline 2018 & 59.90 & 59.93 & 40.20 & 59.90 & 40.15 \\
\hline
\end{tabular}

DVA_B = domestic value-added exports by backward industrial linkages, DVA_F = domestic value-added exports by forward industrial linkages, VAX_B = value-added exports by backward industrial linkages, VAX_F = value-added exports by forward industrial linkages, VAX_G = domestic valueadded absorbed abroad.

Source: ADB Multi Region Input-Output Tables Database. 


\begin{tabular}{|c|c|c|c|c|c|}
\hline \multirow{2}{*}{ ADB Regional Member } & VAX_G & DVA_B & DVA_F & VAX_B & VAX_F \\
\hline & \multicolumn{5}{|c|}{ Value-Added Export Measure to Gross Exports Ratio (\%) } \\
\hline \multicolumn{6}{|l|}{ Bangladesh } \\
\hline 2008 & 83.46 & 83.56 & 122.95 & 83.46 & 122.88 \\
\hline 2018 & 84.64 & 84.67 & 130.74 & 84.64 & 130.68 \\
\hline \multicolumn{6}{|l|}{ Bhutan } \\
\hline 2008 & 77.64 & 77.66 & 30.05 & 77.64 & 30.04 \\
\hline 2018 & 80.20 & 80.22 & 48.71 & 80.20 & 48.71 \\
\hline \multirow{2}{*}{\multicolumn{6}{|c|}{ Brunei Darussalam }} \\
\hline & & & & & \\
\hline 2008 & 92.96 & 92.97 & 48.60 & 92.96 & 48.59 \\
\hline 2018 & 89.43 & 89.44 & 47.11 & 89.43 & 47.10 \\
\hline \multicolumn{6}{|l|}{ Cambodia } \\
\hline 2008 & 67.36 & 67.40 & 96.63 & 67.36 & 96.59 \\
\hline 2018 & 69.18 & 69.22 & 93.63 & 69.18 & 93.57 \\
\hline \multicolumn{6}{|l|}{ China, People's Republic of } \\
\hline 2008 & 71.63 & 73.23 & 46.88 & 71.63 & 45.89 \\
\hline 2018 & 77.87 & 80.96 & 43.84 & 77.87 & 42.22 \\
\hline \multicolumn{6}{|l|}{ Fiji } \\
\hline 2008 & 59.20 & 59.21 & 68.51 & 59.20 & 68.50 \\
\hline 2018 & 61.20 & 61.20 & 75.00 & 61.20 & 74.99 \\
\hline \multicolumn{6}{|l|}{ Hong Kong, China } \\
\hline 2008 & 26.00 & 26.00 & 8.27 & 26.00 & 8.26 \\
\hline 2018 & 22.24 & 22.21 & 4.63 & 22.24 & 4.62 \\
\hline \multirow{2}{*}{\multicolumn{6}{|c|}{ India }} \\
\hline & & & & & \\
\hline 2008 & 62.79 & 63.26 & 43.64 & 62.79 & 43.31 \\
\hline 2018 & 74.39 & 74.91 & 38.50 & 74.39 & 38.24 \\
\hline \multicolumn{6}{|l|}{ Indonesia } \\
\hline 2008 & 75.32 & 75.74 & 53.99 & 75.32 & 53.70 \\
\hline 2018 & 66.99 & 67.32 & 45.88 & 66.99 & 45.65 \\
\hline \multicolumn{6}{|l|}{ Japan } \\
\hline 2008 & 77.99 & 79.18 & 51.96 & 77.99 & 51.17 \\
\hline 2018 & 75.23 & 76.11 & 49.41 & 75.23 & 48.83 \\
\hline \multirow{2}{*}{\multicolumn{6}{|c|}{ Kazakhstan }} \\
\hline & & & & & \\
\hline 2018 & 91.29 & 91.48 & 67.47 & 91.29 & 67.33 \\
\hline \multicolumn{6}{|l|}{ Korea, Republic of } \\
\hline 2008 & 57.99 & 58.34 & 42.78 & 57.99 & 42.50 \\
\hline 2018 & 61.41 & 61.82 & 45.44 & 61.41 & 45.12 \\
\hline \multicolumn{6}{|l|}{ Kyrgyz Republic } \\
\hline 2008 & 56.58 & 56.59 & 51.80 & 56.58 & 51.79 \\
\hline 2018 & 75.97 & 75.98 & 75.48 & 75.97 & 75.46 \\
\hline \multicolumn{6}{|l|}{ Lao People's Democratic Republic } \\
\hline 2008 & 45.87 & 45.88 & 137.87 & 45.87 & 137.85 \\
\hline 2018 & 80.05 & 80.11 & 208.85 & 80.05 & 208.77 \\
\hline \multicolumn{6}{|l|}{ Malaysia } \\
\hline 2008 & 63.90 & 64.18 & 38.83 & 63.90 & 38.66 \\
\hline 2018 & 53.21 & 53.62 & 36.55 & 53.21 & 36.27 \\
\hline
\end{tabular}


Table 3.2.2c: continued

\begin{tabular}{|c|c|c|c|c|c|}
\hline \multirow{2}{*}{ ADB Regional Member } & VAX_G & DVA_B & DVA_F & VAX_B & VAX_F \\
\hline & \multicolumn{5}{|c|}{ Value-Added Export Measure to Gross Exports Ratio (\%) } \\
\hline \multicolumn{6}{|l|}{ Maldives } \\
\hline 2008 & 60.83 & 60.83 & 388.78 & 60.83 & 388.76 \\
\hline 2018 & 68.36 & 68.36 & 161.81 & 68.36 & 161.80 \\
\hline \multicolumn{6}{|l|}{ Mongolia } \\
\hline 2008 & 66.94 & 66.95 & 69.18 & 66.94 & 69.17 \\
\hline 2018 & 73.67 & 73.68 & 106.10 & 73.67 & 106.08 \\
\hline \multicolumn{6}{|l|}{ Nepal } \\
\hline 2008 & 62.50 & 62.58 & 49.98 & 62.50 & 49.93 \\
\hline 2018 & 58.35 & 58.47 & 58.66 & 58.35 & 58.57 \\
\hline \multicolumn{6}{|l|}{ Pakistan } \\
\hline 2008 & 75.96 & 76.06 & 66.90 & 75.96 & 66.83 \\
\hline 2018 & 78.44 & 78.54 & 69.24 & 78.44 & 69.16 \\
\hline \multicolumn{6}{|l|}{ Philippines } \\
\hline 2008 & 49.98 & 50.08 & 31.08 & 49.98 & 31.02 \\
\hline 2018 & 49.58 & 49.76 & 34.62 & 49.58 & 34.50 \\
\hline \multicolumn{6}{|l|}{ Singapore } \\
\hline 2008 & 28.70 & 28.74 & 23.86 & 28.70 & 23.80 \\
\hline 2018 & 36.57 & 36.62 & 26.99 & 36.57 & 26.91 \\
\hline \multicolumn{6}{|l|}{ Sri Lanka } \\
\hline 2008 & 65.92 & 65.96 & 64.63 & 65.92 & 64.60 \\
\hline 2018 & 50.63 & 50.65 & 68.52 & 50.63 & 68.50 \\
\hline \multicolumn{6}{|l|}{ Taipei,China } \\
\hline 2008 & 49.77 & 49.98 & 40.98 & 49.77 & 40.81 \\
\hline 2018 & 52.66 & 52.91 & 45.92 & 52.66 & 45.69 \\
\hline \multicolumn{6}{|l|}{ Thailand } \\
\hline 2008 & 51.36 & 51.62 & 32.52 & 51.36 & 32.36 \\
\hline 2018 & 53.91 & 54.12 & 35.30 & 53.91 & 35.18 \\
\hline \multicolumn{6}{|l|}{ Viet Nam } \\
\hline 2008 & 62.82 & 62.93 & 67.12 & 62.82 & 67.02 \\
\hline 2018 & 43.80 & 43.88 & 42.92 & 43.80 & 42.80 \\
\hline
\end{tabular}

DVA_B $=$ domestic value-added exports by backward industrial linkages, DVA_F = domestic value-added exports by forward industrial linkages, VAX_B = value-added exports by backward industrial linkages, VAX_F = value-added exports by forward industrial linkages, VAX_G $=$ domestic valueadded absorbed abroad.

Source: ADB Multi Region Input-Output Tables Database. 


\begin{tabular}{|c|c|c|c|c|c|}
\hline \multirow{2}{*}{ ADB Regional Member } & VAX_G & DVA_B & DVA_F & VAX_B & VAX_F \\
\hline & \multicolumn{5}{|c|}{ Value-Added Export Measure to Gross Exports Ratio (\%) } \\
\hline \multicolumn{6}{|l|}{ Bangladesh } \\
\hline 2008 & 95.86 & 95.92 & 239.05 & 95.86 & 238.97 \\
\hline 2018 & 96.31 & 96.44 & 387.45 & 96.31 & 387.21 \\
\hline \multicolumn{6}{|l|}{ Bhutan } \\
\hline 2008 & 73.64 & 73.64 & 116.40 & 73.64 & 116.39 \\
\hline 2018 & 82.34 & 82.34 & 96.24 & 82.34 & 96.24 \\
\hline \multicolumn{6}{|l|}{ Brunei Darussalam } \\
\hline 2008 & 74.86 & 74.86 & 108.36 & 74.86 & 108.36 \\
\hline 2018 & 73.29 & 73.30 & 90.73 & 73.29 & 90.72 \\
\hline \multicolumn{6}{|l|}{ Cambodia } \\
\hline 2008 & 81.03 & 81.03 & 84.61 & 81.03 & 84.61 \\
\hline 2018 & 80.54 & 80.55 & 92.33 & 80.54 & 92.31 \\
\hline \multicolumn{6}{|l|}{ China, People's Republic of } \\
\hline 2008 & 85.92 & 88.30 & 148.33 & 85.92 & 145.34 \\
\hline 2018 & 89.52 & 93.51 & 188.74 & 89.52 & 182.09 \\
\hline \multicolumn{6}{|l|}{ Fiji } \\
\hline 2008 & 67.22 & 67.23 & 65.56 & 67.22 & 65.55 \\
\hline 2018 & 72.63 & 72.63 & 72.90 & 72.63 & 72.89 \\
\hline \multicolumn{6}{|l|}{ Hong Kong, China } \\
\hline 2008 & 74.18 & 74.32 & 72.99 & 74.18 & 72.86 \\
\hline 2018 & 75.73 & 75.89 & 74.13 & 75.73 & 73.98 \\
\hline \multicolumn{6}{|l|}{ India } \\
\hline 2008 & 87.85 & 88.62 & 102.39 & 87.85 & 101.59 \\
\hline 2018 & 93.31 & 93.91 & 153.14 & 93.31 & 152.22 \\
\hline \multicolumn{6}{|l|}{ Indonesia } \\
\hline 2008 & 87.90 & 88.21 & 256.58 & 87.90 & 255.48 \\
\hline 2018 & 87.45 & 87.75 & 273.11 & 87.45 & 272.01 \\
\hline \multicolumn{6}{|l|}{ Japan } \\
\hline 2008 & 87.43 & 89.01 & 150.07 & 87.43 & 147.58 \\
\hline 2018 & 90.83 & 91.87 & 182.08 & 90.83 & 179.99 \\
\hline \multicolumn{6}{|l|}{ Kazakhstan } \\
\hline 2008 & 87.32 & 87.72 & 121.52 & 87.32 & 121.09 \\
\hline 2018 & 90.78 & 91.36 & 132.87 & 90.78 & 132.27 \\
\hline \multicolumn{6}{|l|}{ Korea, Republic of } \\
\hline 2008 & 79.14 & 79.79 & 170.09 & 79.14 & 168.99 \\
\hline 2018 & 82.17 & 82.76 & 164.62 & 82.17 & 163.54 \\
\hline \multicolumn{6}{|l|}{ Kyrgyz Republic } \\
\hline 2008 & 63.09 & 63.10 & 68.71 & 63.09 & 68.69 \\
\hline 2018 & 70.02 & 70.04 & 98.59 & 70.02 & 98.55 \\
\hline \multicolumn{6}{|l|}{ Lao People's Democratic Republic } \\
\hline 2008 & 79.88 & 79.89 & 133.14 & 79.88 & 133.13 \\
\hline 2018 & 87.02 & 87.04 & 117.33 & 87.02 & 117.31 \\
\hline \multicolumn{6}{|l|}{ Malaysia } \\
\hline 2008 & 77.55 & 77.74 & 103.44 & 77.55 & 103.14 \\
\hline 2018 & 74.60 & 74.88 & 109.88 & 74.60 & 109.39 \\
\hline
\end{tabular}


Table 3.2.2d: continued

\begin{tabular}{|c|c|c|c|c|c|}
\hline \multirow{2}{*}{ ADB Regional Member } & VAX_G & DVA_B & DVA_F & VAX_B & VAX_F \\
\hline & \multicolumn{5}{|c|}{ Value-Added Export Measure to Gross Exports Ratio (\%) } \\
\hline \multicolumn{6}{|c|}{ 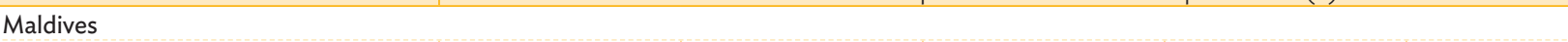 } \\
\hline 2008 & 67.60 & 67.61 & 57.03 & 67.60 & 57.03 \\
\hline 2018 & 64.38 & 64.39 & 49.52 & 64.38 & 49.52 \\
\hline & \multicolumn{5}{|c|}{ Mongolia } \\
\hline 2008 & 75.96 & 75.97 & 103.01 & 75.96 & 103.00 \\
\hline 2018 & 78.34 & 78.37 & 180.29 & 78.34 & 180.24 \\
\hline \multicolumn{6}{|l|}{ Nepal } \\
\hline 2008 & 82.97 & 82.99 & 103.94 & 82.97 & 103.92 \\
\hline 2018 & 78.97 & 79.01 & 92.58 & 78.97 & 92.52 \\
\hline \multicolumn{6}{|l|}{ Pakistan } \\
\hline 2008 & 92.41 & 92.51 & 168.92 & 92.41 & 168.75 \\
\hline 2018 & 93.33 & 93.44 & 141.67 & 93.33 & 141.50 \\
\hline \multicolumn{6}{|l|}{ Philippines } \\
\hline 2008 & 90.22 & 90.35 & 125.37 & 90.22 & 125.18 \\
\hline 2018 & 90.25 & 90.43 & 96.38 & 90.25 & 96.17 \\
\hline \multicolumn{6}{|l|}{ Singapore } \\
\hline 2008 & 58.10 & 58.23 & 62.48 & 58.10 & 62.37 \\
\hline 2018 & 54.49 & 54.66 & 61.90 & 54.49 & 61.76 \\
\hline \multicolumn{6}{|l|}{ Sri Lanka } \\
\hline 2008 & 86.05 & 86.08 & 96.29 & 86.05 & 96.26 \\
\hline 2018 & 89.12 & 89.14 & 98.14 & 89.12 & 98.12 \\
\hline \multicolumn{6}{|l|}{ Taipei,China } \\
\hline 2008 & 77.33 & 77.70 & 116.37 & 77.33 & 115.91 \\
\hline 2018 & 78.42 & 78.79 & 97.67 & 78.42 & 97.26 \\
\hline \multicolumn{6}{|l|}{ Thailand } \\
\hline 2008 & 78.32 & 78.60 & 172.18 & 78.32 & 171.50 \\
\hline 2018 & 84.64 & 84.79 & 104.20 & 84.64 & 103.96 \\
\hline \multicolumn{6}{|l|}{ Viet Nam } \\
\hline 2008 & 77.39 & 77.45 & 108.50 & 77.39 & 108.40 \\
\hline 2018 & 73.76 & 73.85 & 108.06 & 73.76 & 107.86 \\
\hline
\end{tabular}

DVA_B $=$ domestic value-added exports by backward industrial linkages, DVA_F = domestic value-added exports by forward industrial linkages, VAX_B = value-added exports by backward industrial linkages, VAX_F = value-added exports by forward industrial linkages, VAX_G $=$ domestic valueadded absorbed abroad.

Source: ADB Multi Region Input-Output Tables Database. 


\begin{tabular}{|c|c|c|c|c|c|}
\hline \multirow{3}{*}{ ADB Regional Member } & $\mathrm{VAX} G$ & DVA R & DVA F & & \\
\hline & \multirow{2}{*}{\multicolumn{5}{|c|}{ Value-Added Export Measure to Gross Exports Ratio (\%) }} \\
\hline & & & & & \\
\hline \multicolumn{6}{|l|}{ Bangladesh } \\
\hline 2008 & 96.58 & 96.61 & 350.46 & 96.58 & 350.36 \\
\hline 2018 & 96.71 & 96.79 & 149.60 & 96.71 & 149.51 \\
\hline \multicolumn{6}{|l|}{ Bhutan } \\
\hline 2008 & 86.60 & 86.61 & 107.47 & 86.60 & 107.46 \\
\hline 2018 & 84.98 & 84.98 & 64.54 & 84.98 & 64.54 \\
\hline \multicolumn{6}{|l|}{ Brunei Darussalam } \\
\hline 2008 & 90.44 & 90.44 & 122.74 & 90.44 & 122.74 \\
\hline 2018 & 83.25 & 83.25 & 82.86 & 83.25 & 82.86 \\
\hline \multicolumn{6}{|l|}{ Cambodia } \\
\hline 2008 & 79.46 & 79.47 & 91.86 & 79.46 & 91.85 \\
\hline 2018 & 80.69 & 80.70 & 117.87 & 80.69 & 117.84 \\
\hline \multicolumn{6}{|l|}{ China, People's Republic of } \\
\hline 2008 & 87.49 & 88.06 & 205.06 & 87.49 & 201.71 \\
\hline 2018 & 92.03 & 93.33 & 314.38 & 92.03 & 304.72 \\
\hline \multicolumn{6}{|l|}{ Fiji } \\
\hline 2008 & 81.35 & 81.37 & 115.76 & 81.35 & 115.74 \\
\hline 2018 & 86.28 & 86.29 & 99.41 & 86.28 & 99.40 \\
\hline \multicolumn{6}{|l|}{ Hong Kong, China } \\
\hline 2008 & 85.87 & 86.09 & 393.42 & 85.87 & 392.68 \\
\hline 2018 & 86.56 & 86.74 & 482.12 & 86.56 & 481.19 \\
\hline \multicolumn{6}{|l|}{ India } \\
\hline 2008 & 94.22 & 94.21 & 113.42 & 94.22 & 113.22 \\
\hline 2018 & 97.94 & 97.94 & 149.35 & 97.94 & 148.98 \\
\hline \multicolumn{6}{|l|}{ Indonesia } \\
\hline 2008 & 89.10 & 89.29 & 132.67 & 89.10 & 132.19 \\
\hline 2018 & 91.04 & 91.16 & 144.49 & 91.04 & 144.10 \\
\hline \multicolumn{6}{|l|}{ Japan } \\
\hline 2008 & 92.91 & 93.86 & 510.76 & 92.91 & 502.46 \\
\hline 2018 & 93.24 & 93.70 & 511.39 & 93.24 & 505.45 \\
\hline \multicolumn{6}{|l|}{ Kazakhstan } \\
\hline 2008 & 83.48 & 83.47 & 79.01 & 83.48 & 78.92 \\
\hline 2018 & 93.13 & 93.15 & 89.47 & 93.13 & 89.40 \\
\hline \multicolumn{6}{|l|}{ Korea, Republic of } \\
\hline 2008 & 82.84 & 83.84 & 173.07 & 82.84 & 171.78 \\
\hline 2018 & 84.55 & 84.98 & 317.63 & 84.55 & 315.56 \\
\hline \multicolumn{6}{|l|}{ Kyrgyz Republic } \\
\hline 2008 & 77.06 & 77.06 & 59.47 & 77.06 & 59.47 \\
\hline 2018 & 85.85 & 85.85 & 71.43 & 85.85 & 71.43 \\
\hline \multicolumn{6}{|l|}{ Lao People's Democratic Republic } \\
\hline 2008 & 85.49 & 85.49 & 67.72 & 85.49 & 67.72 \\
\hline 2018 & 91.31 & 91.32 & 73.64 & 91.31 & 73.64 \\
\hline \multicolumn{6}{|l|}{ Malaysia } \\
\hline 2008 & 75.27 & 75.36 & 80.17 & 75.27 & 80.01 \\
\hline 2018 & 76.04 & 76.07 & 96.16 & 76.04 & 95.87 \\
\hline
\end{tabular}


Table 3.2.2e: continued

\begin{tabular}{|c|c|c|c|c|c|}
\hline \multirow{2}{*}{ ADB Regional Member } & VAX_G & DVA_B & DVA_F & VAX_B & VAX_F \\
\hline & \multicolumn{5}{|c|}{ Value-Added Export Measure to Gross Exports Ratio (\%) } \\
\hline \multicolumn{6}{|l|}{ Maldives } \\
\hline 2008 & 75.57 & 75.58 & 109.29 & 75.57 & 109.28 \\
\hline 2018 & 76.98 & 76.99 & 129.06 & 76.98 & 129.05 \\
\hline \multicolumn{6}{|l|}{ Mongolia } \\
\hline 2008 & 83.33 & 83.34 & 451.55 & 83.33 & 451.49 \\
\hline 2018 & 76.36 & 76.37 & 258.70 & 76.36 & 258.65 \\
\hline \multicolumn{6}{|l|}{ Nepal } \\
\hline 2008 & 91.47 & 91.49 & 68.27 & 91.47 & 68.25 \\
\hline 2018 & 88.83 & 88.91 & 62.57 & 88.83 & 62.52 \\
\hline \multicolumn{6}{|l|}{ Pakistan } \\
\hline 2008 & 94.31 & 94.34 & 90.55 & 94.31 & 90.52 \\
\hline 2018 & 95.21 & 95.24 & 89.41 & 95.21 & 89.37 \\
\hline \multicolumn{6}{|l|}{ Philippines } \\
\hline 2008 & 89.17 & 89.29 & 123.89 & 89.17 & 123.73 \\
\hline 2018 & 88.67 & 88.79 & 105.55 & 88.67 & 105.38 \\
\hline \multicolumn{6}{|l|}{ Singapore } \\
\hline 2008 & 74.43 & 74.67 & 168.81 & 74.43 & 168.46 \\
\hline 2018 & 79.42 & 79.67 & 123.88 & 79.42 & 123.62 \\
\hline \multicolumn{6}{|l|}{ Sri Lanka } \\
\hline 2008 & 83.28 & 83.31 & 315.67 & 83.28 & 315.58 \\
\hline 2018 & 89.47 & 89.48 & 112.12 & 89.47 & 112.10 \\
\hline \multicolumn{6}{|l|}{ Taipei,China } \\
\hline 2008 & 84.14 & 84.22 & 275.78 & 84.14 & 274.91 \\
\hline 2018 & 83.81 & 83.87 & 259.72 & 83.81 & 258.90 \\
\hline \multicolumn{6}{|l|}{ Thailand } \\
\hline 2008 & 82.94 & 83.02 & 95.46 & 82.94 & 95.24 \\
\hline 2018 & 87.67 & 87.75 & 85.86 & 87.67 & 85.74 \\
\hline \multicolumn{6}{|l|}{ Viet Nam } \\
\hline 2008 & 84.41 & 84.43 & 111.05 & 84.41 & 110.98 \\
\hline 2018 & 75.95 & 75.98 & 78.20 & 75.95 & 78.07 \\
\hline
\end{tabular}

DVA_B $=$ domestic value-added exports by backward industrial linkages, DVA_F = domestic value-added exports by forward industrial linkages, VAX_B = value-added exports by backward industrial linkages, VAX_F = value-added exports by forward industrial linkages, VAX_G = domestic valueadded absorbed abroad.

Source: ADB Multi Region Input-Output Tables Database. 


\begin{tabular}{|c|c|c|c|c|c|}
\hline \multirow{3}{*}{ ADB Regional Member } & & & & & \\
\hline & VAX_G & DVA_B & DVA_F & VAX_B & VAX_F \\
\hline & \multicolumn{5}{|c|}{ Value-Added Export Measure to Gross Exports Ratio (\%) } \\
\hline \multicolumn{6}{|l|}{ Bangladesh } \\
\hline 2008 & 83.73 & 83.76 & 83.76 & 83.73 & 83.73 \\
\hline 2018 & 85.19 & 85.24 & 85.24 & 85.19 & 85.19 \\
\hline \multicolumn{6}{|l|}{ Bhutan } \\
\hline 2008 & 83.84 & 83.85 & 83.85 & 83.84 & 83.84 \\
\hline 2018 & 84.01 & 84.02 & 84.02 & 84.01 & 84.01 \\
\hline \multirow{2}{*}{\multicolumn{6}{|c|}{ Brunei Darussalam }} \\
\hline & & & & & \\
\hline 2008 & 92.23 & 92.24 & 92.24 & 92.23 & 92.23 \\
\hline 2018 & 87.15 & 87.15 & 87.15 & 87.15 & 87.15 \\
\hline \multicolumn{6}{|l|}{ Cambodia } \\
\hline 2008 & 70.93 & 70.95 & 70.95 & 70.93 & 70.93 \\
\hline 2018 & 72.29 & 72.32 & 72.32 & 72.29 & 72.29 \\
\hline \multicolumn{6}{|l|}{ China, People's Republic of } \\
\hline 2008 & 77.26 & 78.71 & 78.71 & 77.26 & 77.26 \\
\hline 2018 & 82.64 & 85.41 & 85.41 & 82.64 & 82.64 \\
\hline \multicolumn{6}{|l|}{ Fiji } \\
\hline 2008 & 68.42 & 68.43 & 68.43 & 68.42 & 68.42 \\
\hline 2018 & 73.06 & 73.06 & 73.06 & 73.06 & 73.06 \\
\hline \multicolumn{6}{|l|}{ Hong Kong, China } \\
\hline 2008 & 70.85 & 70.98 & 70.98 & 70.85 & 70.85 \\
\hline 2018 & 71.87 & 72.02 & 72.02 & 71.87 & 71.87 \\
\hline \multicolumn{6}{|l|}{ India } \\
\hline 2008 & 80.05 & 80.61 & 80.61 & 80.05 & 80.05 \\
\hline 2018 & 84.34 & 84.84 & 84.84 & 84.34 & 84.34 \\
\hline \multicolumn{6}{|l|}{ Indonesia } \\
\hline 2008 & 82.48 & 82.92 & 82.92 & 82.48 & 82.48 \\
\hline 2018 & 77.60 & 78.06 & 78.06 & 77.60 & 77.60 \\
\hline \multicolumn{6}{|l|}{ Japan } \\
\hline 2008 & 80.43 & 81.74 & 81.74 & 80.43 & 80.43 \\
\hline 2018 & 78.31 & 79.25 & 79.25 & 78.31 & 78.31 \\
\hline \multicolumn{6}{|l|}{ Kazakhstan } \\
\hline 2008 & 85.70 & 85.91 & 85.91 & 85.70 & 85.70 \\
\hline 2018 & 90.44 & 90.68 & 90.68 & 90.44 & 90.44 \\
\hline \multicolumn{6}{|l|}{ Korea, Republic of } \\
\hline 2008 & 61.49 & 61.89 & 61.89 & 61.49 & 61.49 \\
\hline 2018 & 64.53 & 64.97 & 64.97 & 64.53 & 64.53 \\
\hline \multicolumn{6}{|l|}{ Kyrgyz Republic } \\
\hline 2008 & 64.14 & 64.15 & 64.15 & 64.14 & 64.14 \\
\hline 2018 & 75.45 & 75.48 & 75.48 & 75.45 & 75.45 \\
\hline \multicolumn{6}{|l|}{ Lao People's Democratic Republic } \\
\hline 2008 & 84.66 & 84.66 & 84.66 & 84.66 & 84.66 \\
\hline 2018 & 89.22 & 89.25 & 89.25 & 89.22 & 89.22 \\
\hline \multicolumn{6}{|l|}{ Malaysia } \\
\hline 2008 & 71.36 & 71.59 & 71.59 & 71.36 & 71.36 \\
\hline 2018 & 63.08 & 63.43 & 63.43 & 63.08 & 63.08 \\
\hline
\end{tabular}


Table 3.2.2f: continued

\begin{tabular}{|c|c|c|c|c|c|}
\hline \multirow{2}{*}{ ADB Regional Member } & VAX_G & DVA_B & DVA_F & VAX_B & VAX_F \\
\hline & \multicolumn{5}{|c|}{ Value-Added Export Measure to Gross Exports Ratio (\%) } \\
\hline \multicolumn{6}{|l|}{ Maldives } \\
\hline 2008 & 67.30 & 67.30 & 67.30 & 67.30 & 67.30 \\
\hline 2018 & 64.13 & 64.14 & 64.14 & 64.13 & 64.13 \\
\hline \multicolumn{6}{|l|}{ Mongolia } \\
\hline 2008 & 74.85 & 74.86 & 74.86 & 74.85 & 74.85 \\
\hline 2018 & 75.31 & 75.32 & 75.32 & 75.31 & 75.31 \\
\hline \multicolumn{6}{|l|}{ Nepal } \\
\hline 2008 & 83.02 & 83.05 & 83.05 & 83.02 & 83.02 \\
\hline 2018 & 80.32 & 80.38 & 80.38 & 80.32 & 80.32 \\
\hline \multicolumn{6}{|l|}{ Pakistan } \\
\hline 2008 & 90.60 & 90.68 & 90.68 & 90.60 & 90.60 \\
\hline 2018 & 91.88 & 91.97 & 91.97 & 91.88 & 91.88 \\
\hline \multicolumn{6}{|l|}{ Philippines } \\
\hline 2008 & 67.36 & 67.46 & 67.46 & 67.36 & 67.36 \\
\hline 2018 & 74.73 & 74.90 & 74.90 & 74.73 & 74.73 \\
\hline \multicolumn{6}{|l|}{ Singapore } \\
\hline 2008 & 42.44 & 42.53 & 42.53 & 42.44 & 42.44 \\
\hline 2018 & 46.44 & 46.55 & 46.55 & 46.44 & 46.44 \\
\hline \multicolumn{6}{|l|}{ Sri Lanka } \\
\hline 2008 & 80.81 & 80.83 & 80.83 & 80.81 & 80.81 \\
\hline 2018 & 85.67 & 85.69 & 85.69 & 85.67 & 85.67 \\
\hline \multicolumn{6}{|l|}{ Taipei,China } \\
\hline 2008 & 54.80 & 55.02 & 55.02 & 54.80 & 54.80 \\
\hline 2018 & 58.44 & 58.70 & 58.70 & 58.44 & 58.44 \\
\hline \multicolumn{6}{|l|}{ Thailand } \\
\hline 2008 & 60.31 & 60.56 & 60.56 & 60.31 & 60.31 \\
\hline 2018 & 70.95 & 71.12 & 71.12 & 70.95 & 70.95 \\
\hline \multicolumn{6}{|l|}{ Viet Nam } \\
\hline 2008 & 71.01 & 71.09 & 71.09 & 71.01 & 71.01 \\
\hline 2018 & 58.99 & 59.19 & 59.19 & 58.99 & 58.99 \\
\hline
\end{tabular}

DVA_B $=$ domestic value-added exports by backward industrial linkages, DVA_F = domestic value-added exports by forward industrial linkages, $V A X \_B=$ value-added exports by backward industrial linkages, VAX_F = value-added exports by forward industrial linkages, VAX_G $=$ domestic valueadded absorbed abroad.

Source: ADB Multi Region Input-Output Tables Database. 


\begin{tabular}{|c|c|c|}
\hline \multirow{2}{*}{ ADB Regional Member } & 2008 & 2018 \\
\hline & \multicolumn{2}{|c|}{ (ratio) } \\
\hline \multicolumn{3}{|l|}{ Bangladesh } \\
\hline Business Services Sector & 0.51 & 0.24 \\
\hline Low-Technology Manufacturing Sector & 5.24 & 5.31 \\
\hline Medium- and High-Technology Manufacturing Sector & 0.06 & 0.04 \\
\hline Personal Services Sector & 1.11 & 2.97 \\
\hline Primary Sector & 0.19 & 0.14 \\
\hline \multicolumn{3}{|l|}{ Bhutan } \\
\hline Business Services Sector & 0.51 & 1.09 \\
\hline Low-Technology Manufacturing Sector & 2.88 & 2.58 \\
\hline Medium- and High-Technology Manufacturing Sector & 0.47 & 0.25 \\
\hline Personal Services Sector & 0.46 & 1.63 \\
\hline Primary Sector & 1.79 & 1.54 \\
\hline \multicolumn{3}{|l|}{ Brunei Darussalam } \\
\hline Business Services Sector & 0.25 & 0.24 \\
\hline Low-Technology Manufacturing Sector & 0.03 & 0.10 \\
\hline Medium- and High-Technology Manufacturing Sector & 0.71 & 0.92 \\
\hline Personal Services Sector & 0.52 & 0.38 \\
\hline Primary Sector & 5.20 & 5.03 \\
\hline \multicolumn{3}{|l|}{ Cambodia } \\
\hline Business Services Sector & 1.27 & 1.14 \\
\hline Low-Technology Manufacturing Sector & 3.77 & 3.61 \\
\hline Medium- and High-Technology Manufacturing Sector & 0.02 & 0.02 \\
\hline Personal Services Sector & 1.13 & 0.53 \\
\hline Primary Sector & 0.79 & 1.02 \\
\hline \multicolumn{3}{|l|}{ China, People's Republic of } \\
\hline Business Services Sector & 0.66 & 0.62 \\
\hline Low-Technology Manufacturing Sector & 1.51 & 1.44 \\
\hline Medium- and High-Technology Manufacturing Sector & 1.23 & 1.29 \\
\hline Personal Services Sector & 0.43 & 0.33 \\
\hline Primary Sector & 0.13 & 0.11 \\
\hline \multicolumn{3}{|l|}{ Fiji } \\
\hline Business Services Sector & 3.07 & 2.54 \\
\hline Low-Technology Manufacturing Sector & 1.19 & 1.24 \\
\hline Medium- and High-Technology Manufacturing Sector & 0.05 & 0.05 \\
\hline Personal Services Sector & 0.86 & 0.96 \\
\hline Primary Sector & 0.47 & 0.81 \\
\hline \multicolumn{3}{|l|}{ Hong Kong, China } \\
\hline Business Services Sector & 3.77 & 3.37 \\
\hline Low-Technology Manufacturing Sector & 0.36 & 0.22 \\
\hline Medium- and High-Technology Manufacturing Sector & 0.11 & 0.12 \\
\hline Personal Services Sector & 0.39 & 0.29 \\
\hline Primary Sector & 0.01 & 0.01 \\
\hline \multicolumn{3}{|l|}{ India } \\
\hline Business Services Sector & 1.78 & 1.06 \\
\hline Low-Technology Manufacturing Sector & 0.97 & 1.32 \\
\hline Medium- and High-Technology Manufacturing Sector & 0.64 & 0.92 \\
\hline Personal Services Sector & 2.32 & 1.39 \\
\hline Primary Sector & 0.73 & 0.60 \\
\hline \multicolumn{3}{|l|}{ Indonesia } \\
\hline Business Services Sector & 0.24 & 0.20 \\
\hline Low-Technology Manufacturing Sector & 2.25 & 2.59 \\
\hline Medium- and High-Technology Manufacturing Sector & 0.70 & 0.68 \\
\hline Personal Services Sector & 0.57 & 0.42 \\
\hline Primary Sector & 2.18 & 2.21 \\
\hline
\end{tabular}




\begin{tabular}{|c|c|c|}
\hline \multirow{2}{*}{ ADB Regional Member } & 2008 & 2018 \\
\hline & \multicolumn{2}{|c|}{ (ratio) } \\
\hline \multicolumn{3}{|l|}{ Japan } \\
\hline Business Services Sector & 1.00 & 0.65 \\
\hline Low-Technology Manufacturing Sector & 0.34 & 0.37 \\
\hline Medium- and High-Technology Manufacturing Sector & 1.47 & 1.68 \\
\hline Personal Services Sector & 0.21 & 0.18 \\
\hline Primary Sector & 0.03 & 0.04 \\
\hline \multicolumn{3}{|l|}{ Kazakhstan } \\
\hline Business Services Sector & 1.11 & 1.01 \\
\hline Low-Technology Manufacturing Sector & 0.14 & 0.17 \\
\hline Medium- and High-Technology Manufacturing Sector & 0.38 & 0.47 \\
\hline Personal Services Sector & 0.47 & 0.26 \\
\hline Primary Sector & 4.65 & 4.89 \\
\hline \multicolumn{3}{|l|}{ Korea, Republic of } \\
\hline Business Services Sector & 0.48 & 0.43 \\
\hline Low-Technology Manufacturing Sector & 0.45 & 0.37 \\
\hline Medium- and High-Technology Manufacturing Sector & 1.68 & 1.80 \\
\hline Personal Services Sector & 0.69 & 0.33 \\
\hline Primary Sector & 0.01 & 0.01 \\
\hline \multicolumn{3}{|l|}{ Kyrgyz Republic } \\
\hline Business Services Sector & 1.38 & 0.88 \\
\hline Low-Technology Manufacturing Sector & 0.75 & 0.88 \\
\hline Medium- and High-Technology Manufacturing Sector & 0.74 & 0.69 \\
\hline Personal Services Sector & 6.04 & 6.74 \\
\hline Primary Sector & 0.86 & 1.69 \\
\hline \multicolumn{3}{|l|}{ Lao People's Democratic Republic } \\
\hline Business Services Sector & 0.43 & 0.54 \\
\hline Low-Technology Manufacturing Sector & 1.35 & 3.45 \\
\hline Medium- and High-Technology Manufacturing Sector & 0.02 & 0.02 \\
\hline Personal Services Sector & 0.09 & 1.40 \\
\hline Primary Sector & 6.03 & 2.77 \\
\hline \multicolumn{3}{|l|}{ Malaysia } \\
\hline Business Services Sector & 0.92 & 0.74 \\
\hline Low-Technology Manufacturing Sector & 1.56 & 1.68 \\
\hline Medium- and High-Technology Manufacturing Sector & 0.88 & 0.97 \\
\hline Personal Services Sector & 0.62 & 0.49 \\
\hline Primary Sector & 0.95 & 0.86 \\
\hline \multicolumn{3}{|l|}{ Maldives } \\
\hline Business Services Sector & 4.04 & 3.21 \\
\hline Low-Technology Manufacturing Sector & 0.16 & 0.62 \\
\hline Medium- and High-Technology Manufacturing Sector & 0.00 & 0.00 \\
\hline Personal Services Sector & 0.69 & 1.35 \\
\hline Primary Sector & 0.12 & 0.12 \\
\hline \multicolumn{3}{|l|}{ Mongolia } \\
\hline Business Services Sector & 0.87 & 0.45 \\
\hline Low-Technology Manufacturing Sector & 0.40 & 0.17 \\
\hline Medium- and High-Technology Manufacturing Sector & 0.04 & 0.04 \\
\hline Personal Services Sector & 0.10 & 0.14 \\
\hline Primary Sector & 6.30 & 8.47 \\
\hline \multicolumn{3}{|l|}{ Nepal } \\
\hline Business Services Sector & 1.43 & 1.38 \\
\hline Low-Technology Manufacturing Sector & 1.45 & 1.11 \\
\hline Medium- and High-Technology Manufacturing Sector & 0.18 & 0.16 \\
\hline Personal Services Sector & 15.81 & 15.55 \\
\hline Primary Sector & 0.62 & 0.54 \\
\hline
\end{tabular}


Table 3.2.3a: continued

\begin{tabular}{|c|c|c|}
\hline \multirow{2}{*}{ ADB Regional Member } & 2008 & 2018 \\
\hline & \multicolumn{2}{|c|}{ (ratio) } \\
\hline \multicolumn{3}{|l|}{ Pakistan } \\
\hline Business Services Sector & 0.68 & 0.76 \\
\hline Low-Technology Manufacturing Sector & 4.28 & 3.70 \\
\hline Medium- and High-Technology Manufacturing Sector & 0.12 & 0.15 \\
\hline Personal Services Sector & 3.10 & 2.59 \\
\hline Primary Sector & 0.55 & 0.90 \\
\hline \multicolumn{3}{|l|}{ Philippines } \\
\hline Business Services Sector & 1.01 & 1.54 \\
\hline Low-Technology Manufacturing Sector & 1.28 & 1.21 \\
\hline Medium- and High-Technology Manufacturing Sector & 1.11 & 0.78 \\
\hline Personal Services Sector & 0.39 & 0.93 \\
\hline Primary Sector & 0.21 & 0.22 \\
\hline \multicolumn{3}{|l|}{ Singapore } \\
\hline Business Services Sector & 1.90 & 1.93 \\
\hline Low-Technology Manufacturing Sector & 0.18 & 0.15 \\
\hline Medium- and High-Technology Manufacturing Sector & 1.09 & 1.00 \\
\hline Personal Services Sector & 0.30 & 0.18 \\
\hline Primary Sector & 0.00 & 0.00 \\
\hline \multicolumn{3}{|l|}{ Sri Lanka } \\
\hline Business Services Sector & 1.60 & 1.54 \\
\hline Low-Technology Manufacturing Sector & 3.00 & 2.89 \\
\hline Medium- and High-Technology Manufacturing Sector & 0.19 & 0.08 \\
\hline Personal Services Sector & 0.46 & 1.68 \\
\hline Primary Sector & 0.53 & 0.57 \\
\hline \multicolumn{3}{|l|}{ Taipei,China } \\
\hline Business Services Sector & 0.68 & 0.75 \\
\hline Low-Technology Manufacturing Sector & 0.47 & 0.38 \\
\hline Medium- and High-Technology Manufacturing Sector & 1.58 & 1.61 \\
\hline Personal Services Sector & 0.23 & 0.19 \\
\hline Primary Sector & 0.05 & 0.04 \\
\hline \multicolumn{3}{|l|}{ Thailand } \\
\hline Business Services Sector & 0.54 & 1.27 \\
\hline Low-Technology Manufacturing Sector & 1.30 & 1.11 \\
\hline Medium- and High-Technology Manufacturing Sector & 1.31 & 0.90 \\
\hline Personal Services Sector & 0.90 & 1.47 \\
\hline Primary Sector & 0.23 & 0.44 \\
\hline \multicolumn{3}{|l|}{ Viet Nam } \\
\hline Business Services Sector & 0.70 & 0.58 \\
\hline Low-Technology Manufacturing Sector & 3.21 & 3.15 \\
\hline Medium- and High-Technology Manufacturing Sector & 0.26 & 0.48 \\
\hline Personal Services Sector & 0.31 & 0.52 \\
\hline Primary Sector & 1.82 & 1.16 \\
\hline
\end{tabular}

Source: ADB Multi Region Input-Output Tables Database. 


\begin{tabular}{|c|c|c|}
\hline \multirow{2}{*}{ ADB Regional Member } & 2008 & 2018 \\
\hline & \multicolumn{2}{|c|}{ (ratio) } \\
\hline \multicolumn{3}{|l|}{ Bangladesh } \\
\hline Business Services Sector & 0.84 & 0.67 \\
\hline Low-Technology Manufacturing Sector & 3.06 & 3.58 \\
\hline Medium- and High-Technology Manufacturing Sector & 0.14 & 0.11 \\
\hline Personal Services Sector & 2.32 & 2.82 \\
\hline Primary Sector & 0.92 & 0.72 \\
\hline \multicolumn{3}{|l|}{ Bhutan } \\
\hline Business Services Sector & 0.41 & 0.78 \\
\hline Low-Technology Manufacturing Sector & 3.84 & 2.96 \\
\hline Medium- and High-Technology Manufacturing Sector & 0.29 & 0.25 \\
\hline Personal Services Sector & 0.29 & 0.68 \\
\hline Primary Sector & 1.59 & 1.30 \\
\hline \multicolumn{3}{|l|}{ Brunei Darussalam } \\
\hline Business Services Sector & 0.17 & 0.15 \\
\hline Low-Technology Manufacturing Sector & 0.06 & 0.08 \\
\hline Medium- and High-Technology Manufacturing Sector & 0.65 & 0.87 \\
\hline Personal Services Sector & 0.35 & 0.19 \\
\hline Primary Sector & 4.70 & 4.89 \\
\hline \multicolumn{3}{|l|}{ Cambodia } \\
\hline Business Services Sector & 0.89 & 0.91 \\
\hline Low-Technology Manufacturing Sector & 3.16 & 3.01 \\
\hline Medium- and High-Technology Manufacturing Sector & 0.04 & 0.05 \\
\hline Personal Services Sector & 0.73 & 0.47 \\
\hline Primary Sector & 1.29 & 1.28 \\
\hline \multicolumn{3}{|l|}{ China, People's Republic of } \\
\hline Business Services Sector & 0.72 & 0.86 \\
\hline Low-Technology Manufacturing Sector & 1.45 & 1.29 \\
\hline Medium- and High-Technology Manufacturing Sector & 1.26 & 1.16 \\
\hline Personal Services Sector & 0.56 & 0.65 \\
\hline Primary Sector & 0.98 & 0.95 \\
\hline \multicolumn{3}{|l|}{ Fiji } \\
\hline Business Services Sector & 1.72 & 1.59 \\
\hline Low-Technology Manufacturing Sector & 1.16 & 1.16 \\
\hline Medium- and High-Technology Manufacturing Sector & 0.09 & 0.09 \\
\hline Personal Services Sector & 0.73 & 0.71 \\
\hline Primary Sector & 0.69 & 0.83 \\
\hline \multicolumn{3}{|l|}{ Hong Kong, China } \\
\hline Business Services Sector & 2.27 & 2.17 \\
\hline Low-Technology Manufacturing Sector & 0.35 & 0.18 \\
\hline Medium- and High-Technology Manufacturing Sector & 0.02 & 0.01 \\
\hline Personal Services Sector & 1.07 & 1.07 \\
\hline Primary Sector & 0.00 & 0.00 \\
\hline \multicolumn{3}{|l|}{ India } \\
\hline Business Services Sector & 1.33 & 1.20 \\
\hline Low-Technology Manufacturing Sector & 0.73 & 0.89 \\
\hline Medium- and High-Technology Manufacturing Sector & 0.60 & 0.73 \\
\hline Personal Services Sector & 1.64 & 1.32 \\
\hline Primary Sector & 0.96 & 0.89 \\
\hline \multicolumn{3}{|l|}{ Indonesia } \\
\hline Business Services Sector & 0.43 & 0.43 \\
\hline Low-Technology Manufacturing Sector & 1.55 & 1.85 \\
\hline Medium- and High-Technology Manufacturing Sector & 0.79 & 0.70 \\
\hline Personal Services Sector & 0.46 & 0.42 \\
\hline Primary Sector & 2.50 & 2.63 \\
\hline
\end{tabular}


Table 3.2.3b: continued

\begin{tabular}{|c|c|c|}
\hline \multirow{2}{*}{ ADB Regional Member } & 2008 & 2018 \\
\hline & \multicolumn{2}{|c|}{ (ratio) } \\
\hline \multicolumn{3}{|l|}{ Japan } \\
\hline Business Services Sector & 1.08 & 0.93 \\
\hline Low-Technology Manufacturing Sector & 0.68 & 0.71 \\
\hline Medium- and High-Technology Manufacturing Sector & 1.61 & 1.83 \\
\hline Personal Services Sector & 0.66 & 0.61 \\
\hline Primary Sector & 0.05 & 0.06 \\
\hline \multicolumn{3}{|l|}{ Kazakhstan } \\
\hline Business Services Sector & 0.92 & 0.93 \\
\hline Low-Technology Manufacturing Sector & 0.42 & 0.27 \\
\hline Medium- and High-Technology Manufacturing Sector & 0.44 & 0.62 \\
\hline Personal Services Sector & 0.22 & 0.14 \\
\hline Primary Sector & 2.86 & 2.83 \\
\hline \multicolumn{3}{|l|}{ Korea, Republic of } \\
\hline Business Services Sector & 0.78 & 0.69 \\
\hline Low-Technology Manufacturing Sector & 0.65 & 0.65 \\
\hline Medium- and High-Technology Manufacturing Sector & 2.00 & 2.20 \\
\hline Personal Services Sector & 0.97 & 0.87 \\
\hline Primary Sector & 0.09 & 0.09 \\
\hline \multicolumn{3}{|l|}{ Kyrgyz Republic } \\
\hline Business Services Sector & 0.86 & 0.72 \\
\hline Low-Technology Manufacturing Sector & 0.65 & 0.75 \\
\hline Medium- and High-Technology Manufacturing Sector & 1.03 & 1.22 \\
\hline Personal Services Sector & 2.81 & 3.45 \\
\hline Primary Sector & 1.18 & 1.01 \\
\hline \multicolumn{3}{|l|}{ Lao People's Democratic Republic } \\
\hline Business Services Sector & 0.39 & 0.45 \\
\hline Low-Technology Manufacturing Sector & 1.39 & 3.45 \\
\hline Medium- and High-Technology Manufacturing Sector & 0.04 & 0.07 \\
\hline Personal Services Sector & 0.03 & 0.62 \\
\hline Primary Sector & 4.17 & 2.21 \\
\hline \multicolumn{3}{|l|}{ Malaysia } \\
\hline Business Services Sector & 0.78 & 0.80 \\
\hline Low-Technology Manufacturing Sector & 0.81 & 0.95 \\
\hline Medium- and High-Technology Manufacturing Sector & 0.83 & 0.98 \\
\hline Personal Services Sector & 0.35 & 0.40 \\
\hline Primary Sector & 2.19 & 1.84 \\
\hline \multicolumn{3}{|l|}{ Maldives } \\
\hline Business Services Sector & 2.00 & 1.55 \\
\hline Low-Technology Manufacturing Sector & 0.58 & 1.81 \\
\hline Medium- and High-Technology Manufacturing Sector & 0.02 & 0.02 \\
\hline Personal Services Sector & 0.56 & 1.47 \\
\hline Primary Sector & 0.62 & 0.25 \\
\hline \multicolumn{3}{|l|}{ Mongolia } \\
\hline Business Services Sector & 0.70 & 0.68 \\
\hline Low-Technology Manufacturing Sector & 0.38 & 0.46 \\
\hline Medium- and High-Technology Manufacturing Sector & 0.07 & 0.10 \\
\hline Personal Services Sector & 0.30 & 0.26 \\
\hline Primary Sector & 4.11 & 4.34 \\
\hline \multicolumn{3}{|l|}{ Nepal } \\
\hline Business Services Sector & 1.05 & 1.00 \\
\hline Low-Technology Manufacturing Sector & 1.12 & 0.97 \\
\hline Medium- and High-Technology Manufacturing Sector & 0.18 & 0.20 \\
\hline Personal Services Sector & 6.52 & 6.54 \\
\hline Primary Sector & 0.97 & 0.97 \\
\hline
\end{tabular}




\begin{tabular}{|c|c|c|}
\hline \multirow{2}{*}{ ADB Regional Member } & 2008 & 2018 \\
\hline & \multicolumn{2}{|c|}{ (ratio) } \\
\hline \multicolumn{3}{|l|}{ Pakistan } \\
\hline Business Services Sector & 0.74 & 0.73 \\
\hline Low-Technology Manufacturing Sector & 1.87 & 1.61 \\
\hline Medium- and High-Technology Manufacturing Sector & 0.16 & 0.19 \\
\hline Personal Services Sector & 1.55 & 1.36 \\
\hline Primary Sector & 2.33 & 2.63 \\
\hline \multicolumn{3}{|l|}{ Philippines } \\
\hline Business Services Sector & 1.10 & 1.24 \\
\hline Low-Technology Manufacturing Sector & 1.39 & 1.31 \\
\hline Medium- and High-Technology Manufacturing Sector & 0.88 & 0.63 \\
\hline Personal Services Sector & 0.36 & 0.71 \\
\hline Primary Sector & 0.78 & 0.74 \\
\hline \multicolumn{3}{|l|}{ Singapore } \\
\hline Business Services Sector & 1.63 & 1.61 \\
\hline Low-Technology Manufacturing Sector & 0.24 & 0.28 \\
\hline Medium- and High-Technology Manufacturing Sector & 1.05 & 1.02 \\
\hline Personal Services Sector & 0.59 & 0.26 \\
\hline Primary Sector & 0.00 & 0.00 \\
\hline \multicolumn{3}{|l|}{ Sri Lanka } \\
\hline Business Services Sector & 1.12 & 1.11 \\
\hline Low-Technology Manufacturing Sector & 2.62 & 2.69 \\
\hline Medium- and High-Technology Manufacturing Sector & 0.26 & 0.11 \\
\hline Personal Services Sector & 0.91 & 1.19 \\
\hline Primary Sector & 0.70 & 0.68 \\
\hline \multicolumn{3}{|l|}{ Taipei,China } \\
\hline Business Services Sector & 0.84 & 0.78 \\
\hline Low-Technology Manufacturing Sector & 0.51 & 0.51 \\
\hline Medium- and High-Technology Manufacturing Sector & 2.03 & 2.21 \\
\hline Personal Services Sector & 0.59 & 0.45 \\
\hline Primary Sector & 0.07 & 0.06 \\
\hline \multicolumn{3}{|l|}{ Thailand } \\
\hline Business Services Sector & 0.90 & 1.17 \\
\hline Low-Technology Manufacturing Sector & 1.45 & 1.20 \\
\hline Medium- and High-Technology Manufacturing Sector & 1.21 & 0.78 \\
\hline Personal Services Sector & 0.71 & 0.96 \\
\hline Primary Sector & 0.56 & 0.71 \\
\hline \multicolumn{3}{|l|}{ Viet Nam } \\
\hline Business Services Sector & 0.63 & 0.67 \\
\hline Low-Technology Manufacturing Sector & 2.37 & 2.57 \\
\hline Medium- and High-Technology Manufacturing Sector & 0.42 & 0.61 \\
\hline Personal Services Sector & 0.24 & 0.37 \\
\hline Primary Sector & 2.02 & 1.43 \\
\hline
\end{tabular}

Source: ADB Multi Region Input-Output Tables Database. 


\begin{tabular}{|c|c|c|c|c|c|c|}
\hline \multicolumn{7}{|c|}{ Table 3.2.4.a: Vertical Specialization, Disaggregated-Bangladesh } \\
\hline & Exports & VS & FVA_FIN & FVA_INT & DDC & FDC \\
\hline & (\$ million) & (\% of gross exports) & \multicolumn{4}{|c|}{ (\% of VS) } \\
\hline \multicolumn{7}{|c|}{ Agriculture, Hunting, Forestry and Fishing } \\
\hline 2008 & 336.48 & 7.91 & 12.95 & 62.04 & 0.26 & 24.75 \\
\hline 2018 & 511.74 & 7.49 & 28.27 & 54.47 & 0.29 & 16.97 \\
\hline \multicolumn{7}{|c|}{ Textiles and Textile Products } \\
\hline 2008 & $12,416.59$ & 18.81 & 77.71 & 11.93 & 0.06 & 10.29 \\
\hline 2018 & $29,725.79$ & 16.76 & 76.42 & 12.70 & 0.15 & 10.73 \\
\hline \multicolumn{7}{|c|}{ Wholesale Trade and Commission Trade, Except of Motor Vehicles and Motorcycles } \\
\hline 2008 & 363.45 & 3.40 & 11.75 & 42.12 & 0.19 & 45.95 \\
\hline 2018 & 484.15 & 4.17 & 14.36 & 36.46 & 0.22 & 48.96 \\
\hline
\end{tabular}

$\$=$ United States dollars, DDC = domestic value-added double counted in exports, $F D C=$ foreign value-added double counted in exports, FVA_FIN = foreign value-added in exports for final consumption, FVA_INT = foreign value-added in intermediate exports, VS = vertical specialization. Source: ADB Multi Region Input-Output Tables Database.

\begin{tabular}{|c|c|c|c|c|c|c|}
\hline & Exports & VS & FVA_FIN & FVA_INT & DDC & FDC \\
\hline & (\$ million) & (\% of gross exports) & \multicolumn{4}{|c|}{ (\% of VS) } \\
\hline \multicolumn{7}{|c|}{ Agriculture, Hunting, Forestry and Fishing } \\
\hline 2008 & 87.81 & 4.57 & 32.24 & 53.45 & 0.02 & 14.29 \\
\hline 2018 & 51.82 & 3.57 & 37.13 & 53.25 & 0.01 & 9.61 \\
\hline \multicolumn{7}{|c|}{ Electricity, Gas and Water Supply } \\
\hline 2008 & 200.22 & 12.68 & 1.45 & 64.18 & 0.01 & 34.36 \\
\hline 2018 & 276.44 & 16.27 & 1.23 & 61.86 & 0.01 & 36.91 \\
\hline \multicolumn{7}{|c|}{ Inland Transport } \\
\hline 2008 & 27.33 & 28.48 & 49.42 & 37.46 & 0.01 & 13.12 \\
\hline 2018 & 61.34 & 24.23 & 31.11 & 47.21 & 0.00 & 21.68 \\
\hline
\end{tabular}

$\$=$ United States dollars, DDC = domestic value-added double counted in exports, $F D C=$ foreign value-added double counted in exports, FVA_FIN = foreign value-added in exports for final consumption, FVA_INT = foreign value-added in intermediate exports, VS = vertical specialization . Source: ADB Multi Region Input-Output Tables Database.

\begin{tabular}{|c|c|c|c|c|c|c|}
\hline & Exports & VS & FVA_FIN & FVA_INT & DDC & FDC \\
\hline & (\$ million) & (\% of gross exports) & \multicolumn{4}{|c|}{ (\% of VS) } \\
\hline \multicolumn{7}{|c|}{ Air Transport } \\
\hline 2008 & 207.28 & 30.32 & 50.43 & 34.41 & 0.03 & 15.13 \\
\hline 2018 & 23.02 & 42.16 & 35.44 & 36.33 & 0.01 & 28.22 \\
\hline \multicolumn{7}{|c|}{ Coke, Refined Petroleum and Nuclear Fuel } \\
\hline 2008 & $3,220.03$ & 6.70 & 4.53 & 65.28 & 0.04 & 30.15 \\
\hline 2018 & $2,875.89$ & 9.99 & 6.52 & 62.25 & 0.01 & 31.23 \\
\hline \multicolumn{7}{|c|}{ Mining and Quarrying } \\
\hline 2008 & $5,740.09$ & 6.24 & 0.09 & 65.82 & 0.05 & 34.04 \\
\hline 2018 & $3,454.15$ & 11.93 & 0.35 & 66.34 & 0.01 & 33.30 \\
\hline
\end{tabular}

$\$=$ United States dollars, DDC = domestic value-added double counted in exports, $F D C=$ foreign value-added double counted in exports, FVA_FIN = foreign value-added in exports for final consumption, FVA_INT = foreign value-added in intermediate exports, VS = vertical specialization.

Source: ADB Multi Region Input-Output Tables Database.

\begin{tabular}{|c|c|c|c|c|c|c|}
\hline & Exports & VS & FVA_FIN & FVA_INT & DDC & FDC \\
\hline & (\$ million) & (\% of gross exports) & \multicolumn{4}{|c|}{ (\% of VS) } \\
\hline \multicolumn{7}{|c|}{ Hotels and Restaurants } \\
\hline 2008 & 681.06 & 16.47 & 59.15 & 26.65 & 0.01 & 14.19 \\
\hline 2018 & $1,404.68$ & 17.33 & 56.81 & 26.36 & 0.02 & 16.81 \\
\hline \multicolumn{7}{|c|}{ Textiles and Textile Products } \\
\hline 2008 & $2,259.81$ & 37.98 & 89.39 & 4.94 & 0.00 & 5.66 \\
\hline 2018 & $5,621.83$ & 35.73 & 84.16 & 9.64 & 0.00 & 6.19 \\
\hline \multicolumn{7}{|c|}{ Wholesale Trade and Commission Trade, Except of Motor Vehicles and Motorcycles } \\
\hline 2008 & 327.23 & 22.19 & 22.65 & 45.10 & 0.01 & 32.24 \\
\hline 2018 & $1,143.43$ & 20.62 & 30.37 & 37.66 & 0.03 & 31.95 \\
\hline
\end{tabular}

$\$=$ United States dollars, DDC = domestic value-added double counted in exports, FDC = foreign value-added double counted in exports, FVA_FIN = foreign value-added in exports for final consumption, FVA_INT = foreign value-added in intermediate exports, VS = vertical specialization.

Source: ADB Multi Region Input-Output Tables Database. 


\begin{tabular}{|c|c|c|c|c|c|c|}
\hline & Exports & Vs & & IY IT & & \\
\hline & (\$ million) & (\% of gross exports) & \multirow{2}{*}{\multicolumn{4}{|c|}{ (\% of VS) }} \\
\hline \multicolumn{3}{|c|}{ Basic Metals and Fabricated Metal } & & & & \\
\hline 2008 & $122,193.53$ & 22.19 & 15.52 & 46.29 & 5.39 & 32.79 \\
\hline 2018 & $190,846.81$ & 18.31 & 22.79 & 43.47 & 5.67 & 28.08 \\
\hline \multicolumn{7}{|c|}{ Electrical and Optical Equipment } \\
\hline 2008 & $483,100.83$ & 31.26 & 61.98 & 16.27 & 3.42 & 18.33 \\
\hline 2018 & $860,708.64$ & 21.58 & 53.41 & 20.10 & 5.91 & 20.58 \\
\hline \multicolumn{7}{|c|}{ Textiles and Textile Products } \\
\hline 2008 & $164,533.50$ & 13.85 & 79.58 & 10.32 & 1.26 & 8.85 \\
\hline 2018 & $266,740.74$ & 8.36 & 75.72 & 12.38 & 1.96 & 9.94 \\
\hline
\end{tabular}

$\$=$ United States dollars, DDC = domestic value-added double counted in exports, FDC = foreign value-added double counted in exports, FVA_FIN = foreign value-added in exports for final consumption, FVA_INT = foreign value-added in intermediate exports, VS = vertical specialization.

Source: ADB Multi Region Input-Output Tables Database.

\begin{tabular}{|c|c|c|c|c|c|c|}
\hline & Exports & VS & FVA_FIN & FVA_INT & DDC & FDC \\
\hline & (\$ million) & (\% of gross exports) & \multicolumn{4}{|c|}{ (\% of VS) } \\
\hline \multicolumn{7}{|c|}{ Agriculture, Hunting, Forestry and Fishing } \\
\hline 2008 & 38.32 & 18.72 & 36.53 & 49.36 & 0.01 & 14.11 \\
\hline 2018 & 132.68 & 17.62 & 38.57 & 44.64 & 0.01 & 16.77 \\
\hline \multicolumn{7}{|c|}{ Food, Beverages and Tobacco } \\
\hline 2008 & 140.86 & 28.15 & 25.55 & 57.23 & 0.01 & 17.21 \\
\hline 2018 & 354.47 & 27.24 & 48.94 & 36.65 & 0.01 & 14.40 \\
\hline \multicolumn{7}{|c|}{ Textiles and Textile Products } \\
\hline 2008 & 18.14 & 16.19 & 79.03 & 14.75 & 0.00 & 6.22 \\
\hline 2018 & 48.18 & 14.67 & 77.35 & 15.44 & 0.01 & 7.21 \\
\hline
\end{tabular}

$\$=$ United States dollars, DDC = domestic value-added double counted in exports, FDC = foreign value-added double counted in exports, FVA_FIN = foreign value-added in exports for final consumption, FVA_INT = foreign value-added in intermediate exports, VS = vertical specialization

Source: ADB Multi Region Input-Output Tables Database.

\begin{tabular}{|c|c|c|c|c|c|c|}
\hline & \multicolumn{6}{|c|}{ Table 3.2.4.g: Vertical Specialization, Disaggregated-Hong Kong, China } \\
\hline & Exports & VS & FVA_FIN & FVA_INT & DDC & FDC \\
\hline & (\$ million) & (\% of gross exports) & \multicolumn{4}{|c|}{ (\% of VS) } \\
\hline \multicolumn{7}{|c|}{ Air Transport } \\
\hline 2008 & $10,753.51$ & 42.47 & 12.76 & 53.27 & 0.50 & 33.46 \\
\hline 2018 & $15,530.05$ & 33.86 & 22.52 & 47.82 & 0.54 & 29.11 \\
\hline \multicolumn{7}{|c|}{ Retail Trade, Except of Motor Vehicles and Motorcycles; Repair of Household Goods } \\
\hline 2008 & $14,308.98$ & 11.16 & 61.33 & 29.24 & 0.52 & 8.91 \\
\hline 2018 & $19,624.49$ & 10.61 & 68.06 & 22.46 & 0.55 & 8.93 \\
\hline \multicolumn{7}{|c|}{ Wholesale Trade and Commission Trade, Except of Motor Vehicles and Motorcycles } \\
\hline 2008 & $70,779.38$ & 26.85 & 50.96 & 35.99 & 0.38 & 12.66 \\
\hline 2018 & $110,944.68$ & 27.06 & 54.27 & 30.93 & 0.41 & 14.39 \\
\hline
\end{tabular}

$\$=$ United States dollars, DDC = domestic value-added double counted in exports, $F D C=$ foreign value-added double counted in exports, FVA_FIN = foreign value-added in exports for final consumption, FVA_INT = foreign value-added in intermediate exports, VS = vertical specialization

Source: ADB Multi Region Input-Output Tables Database.

\begin{tabular}{|c|c|c|c|c|c|c|}
\hline & Exports & VS & FVA_FIN & FVA_INT & DDC & FDC \\
\hline & (\$ million) & (\% of gross exports) & \multicolumn{4}{|c|}{ (\% of VS) } \\
\hline \multicolumn{7}{|c|}{ Chemicals and Chemical Products } \\
\hline 2008 & $15,279.64$ & 29.32 & 10.95 & 52.69 & 0.69 & 35.67 \\
\hline 2018 & $31,124.17$ & 17.00 & 11.11 & 51.13 & 0.83 & 36.93 \\
\hline \multicolumn{7}{|c|}{ Renting of Machinery and Equipment and Other Business Activities } \\
\hline 2008 & $62,272.04$ & 12.01 & 24.20 & 48.25 & 0.74 & 26.80 \\
\hline 2018 & $77,353.52$ & 4.29 & 49.74 & 29.95 & 1.10 & 19.21 \\
\hline \multicolumn{7}{|c|}{ Textiles and Textile Products } \\
\hline 2008 & $15,734.69$ & 15.07 & 68.82 & 16.20 & 0.25 & 14.73 \\
\hline 2018 & $32,503.56$ & 10.60 & 64.09 & 19.48 & 0.34 & 16.08 \\
\hline
\end{tabular}

$\$=$ United States dollars, DDC = domestic value-added double counted in exports, FDC = foreign value-added double counted in exports, FVA_FIN = foreign value-added in exports for final consumption, FVA_INT = foreign value-added in intermediate exports, VS = vertical specialization.

Source: ADB Multi Region Input-Output Tables Database. 


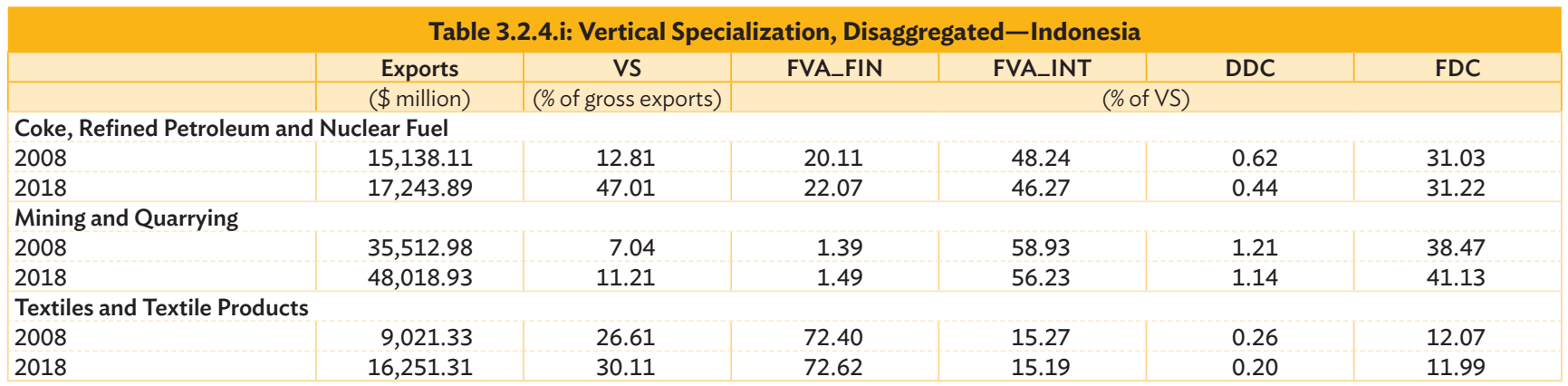

$\$=$ United States dollars, DDC = domestic value-added double counted in exports, FDC = foreign value-added double counted in exports, FVA_FIN = foreign value-added in exports for final consumption, FVA_INT = foreign value-added in intermediate exports, VS = vertical specialization.

Source: ADB Multi Region Input-Output Tables Database.

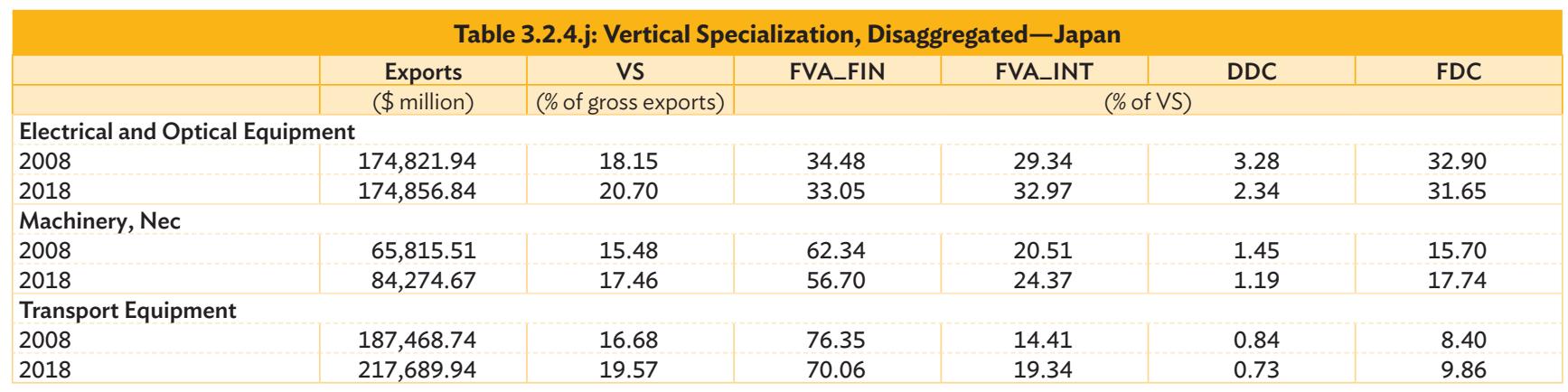

$\$=$ United States dollars, DDC = domestic value-added double counted in exports, FDC = foreign value-added double counted in exports, FVA_FIN = foreign value-added in exports for final consumption, FVA_INT $=$ foreign value-added in intermediate exports, VS $=$ vertical specialization .

Source: ADB Multi Region Input-Output Tables Database.

\begin{tabular}{|c|c|c|c|c|c|c|}
\hline \multicolumn{7}{|c|}{ Table 3.2.4.k: Vertical Specialization, Disaggregated-Kazakhstan } \\
\hline & Exports & VS & FVA_FIN & FVA_INT & DDC & FDC \\
\hline & (\$ million) & (\% of gross exports) & \multirow{2}{*}{\multicolumn{4}{|c|}{ (\% of VS) }} \\
\hline \multicolumn{4}{|c|}{ Basic Metals and Fabricated Metal } & & & \\
\hline 2008 & $7,641.83$ & 11.21 & 0.55 & 45.29 & 0.67 & 53.48 \\
\hline 2018 & $9,114.52$ & 7.95 & 6.85 & 37.38 & 0.43 & 55.34 \\
\hline \multicolumn{7}{|c|}{ Coke, Refined Petroleum and Nuclear Fuel } \\
\hline 2008 & $4,103.30$ & 18.42 & 24.60 & 47.39 & 0.31 & 27.69 \\
\hline 2018 & $1,575.41$ & 6.88 & 36.86 & 42.82 & 0.30 & 20.01 \\
\hline \multicolumn{7}{|c|}{ Mining and Quarrying } \\
\hline 2008 & $35,899.30$ & 14.95 & 1.78 & 58.43 & 0.54 & 39.25 \\
\hline 2018 & $25,750.38$ & 9.75 & 3.57 & 49.86 & 0.40 & 46.16 \\
\hline
\end{tabular}

$\$=$ United States dollars, DDC = domestic value-added double counted in exports, $F D C=$ foreign value-added double counted in exports, FVA_FIN = foreign value-added in exports for final consumption, FVA_INT = foreign value-added in intermediate exports, VS = vertical specialization.

Source: ADB Multi Region Input-Output Tables Database.

\begin{tabular}{|c|c|c|c|c|c|c|}
\hline & Exports & VS & FVA_FIN & FVA_INT & DDC & FDC \\
\hline & (\$ million) & (\% of gross exports) & \multirow{2}{*}{\multicolumn{4}{|c|}{ (\% of VS) }} \\
\hline \multicolumn{4}{|c|}{ Electrical and Optical Equipment } & & & \\
\hline 2008 & $141,978.97$ & 35.59 & 39.39 & 26.12 & 1.20 & 33.29 \\
\hline 2018 & $244,916.40$ & 31.53 & 35.02 & 33.03 & 1.67 & 30.27 \\
\hline \multicolumn{7}{|c|}{ Textiles and Textile Products } \\
\hline 2008 & $14,903.61$ & 29.04 & 21.70 & 41.94 & 0.81 & 35.56 \\
\hline 2018 & $18,096.13$ & 27.99 & 20.36 & 39.89 & 0.93 & 38.82 \\
\hline \multicolumn{7}{|c|}{ Transport Equipment } \\
\hline 2008 & $90,978.29$ & 34.56 & 77.39 & 14.51 & 0.24 & 7.87 \\
\hline 2018 & $101,412.83$ & 33.18 & 73.47 & 16.33 & 0.33 & 9.87 \\
\hline
\end{tabular}

$\$=$ United States dollars, DDC = domestic value-added double counted in exports, $F D C=$ foreign value-added double counted in exports, FVA_FIN = foreign value-added in exports for final consumption, FVA_INT = foreign value-added in intermediate exports, VS = vertical specialization.

Source: ADB Multi Region Input-Output Tables Database. 


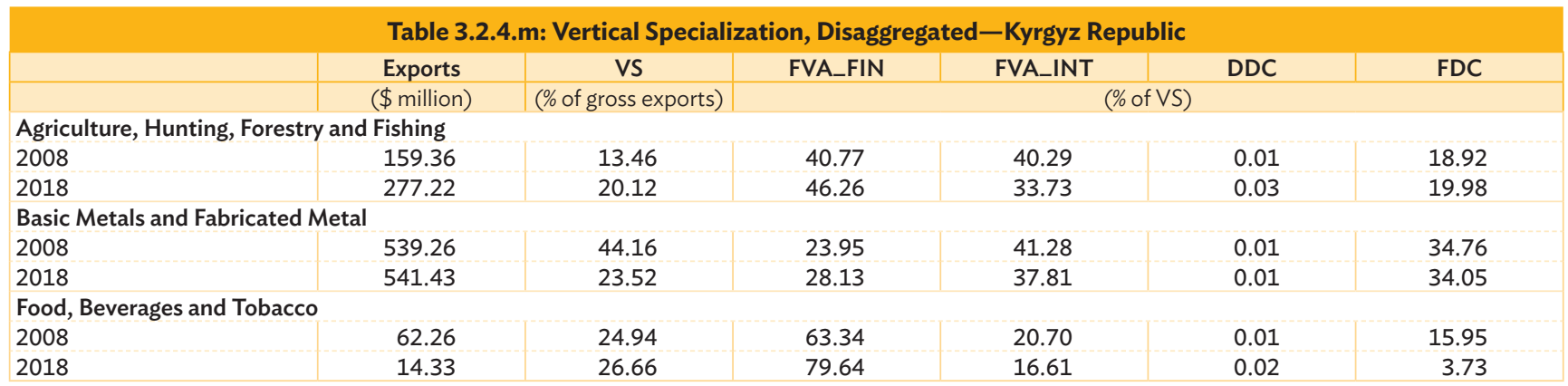

$\$=$ United States dollars, DDC = domestic value-added double counted in exports, FDC = foreign value-added double counted in exports, FVA_FIN = foreign value-added in exports for final consumption, FVA_INT = foreign value-added in intermediate exports, VS = vertical specialization.

Source: ADB Multi Region Input-Output Tables Database.

\begin{tabular}{|c|c|c|c|c|c|c|}
\hline & Exports & VS & FVA_FIN & FVA_INT & DDC & FDC \\
\hline & (\$ million) & (\% of gross exports) & \multicolumn{4}{|c|}{ (\% of VS) } \\
\hline \multicolumn{7}{|c|}{ Agriculture, Hunting, Forestry and Fishing } \\
\hline 2008 & 65.67 & 3.69 & 7.06 & 61.05 & 0.01 & 31.88 \\
\hline 2018 & 609.01 & 3.24 & 8.46 & 47.04 & 0.09 & 44.42 \\
\hline \multicolumn{7}{|c|}{ Electricity, Gas and Water Supply } \\
\hline 2008 & 78.87 & 8.02 & 12.92 & 55.63 & 0.01 & 31.44 \\
\hline 2018 & $2,197.53$ & 6.52 & 16.75 & 54.39 & 0.02 & 28.83 \\
\hline \multicolumn{7}{|c|}{ Retail Trade, Except of Motor Vehicles and Motorcycles; Repair of Household Goods } \\
\hline 2008 & 43.93 & 13.75 & 23.52 & 45.99 & 0.00 & 30.48 \\
\hline 2018 & 374.19 & 9.49 & 34.64 & 40.90 & 0.01 & 24.44 \\
\hline
\end{tabular}

$\$=$ United States dollars, DDC = domestic value-added double counted in exports, FDC = foreign value-added double counted in exports, FVA_FIN = foreign value-added in exports for final consumption, FVA_INT = foreign value-added in intermediate exports, VS = vertical specialization

Source: ADB Multi Region Input-Output Tables Database.

\begin{tabular}{|c|c|c|c|c|c|c|}
\hline & Exports & VS & FVA_FIN & FVA_INT & DDC & FDC \\
\hline & (\$ million) & (\% of gross exports) & \multicolumn{4}{|c|}{$(\%$ of VS) } \\
\hline \multicolumn{7}{|c|}{ Electrical and Optical Equipment } \\
\hline 2008 & $28,208.83$ & 46.29 & 29.63 & 25.38 & 0.82 & 44.18 \\
\hline 2018 & $47,166.02$ & 47.74 & 26.21 & 32.35 & 0.72 & 40.72 \\
\hline \multicolumn{7}{|c|}{ Machinery, Nec } \\
\hline 2008 & $1,439.81$ & 39.24 & 39.31 & 31.82 & 0.39 & 28.48 \\
\hline 2018 & $1,862.47$ & 44.60 & 14.60 & 49.68 & 0.38 & 35.35 \\
\hline \multicolumn{7}{|c|}{ Mining and Quarrying } \\
\hline 2008 & $14,984.49$ & 7.41 & 0.27 & 59.35 & 1.32 & 39.06 \\
\hline 2018 & $9,931.14$ & 10.11 & -5.37 & 49.14 & 1.76 & 54.47 \\
\hline
\end{tabular}

$\$=$ United States dollars, DDC = domestic value-added double counted in exports, $F D C=$ foreign value-added double counted in exports, FVA_FIN = foreign value-added in exports for final consumption, FVA_INT = foreign value-added in intermediate exports, VS = vertical specialization

Source: ADB Multi Region Input-Output Tables Database.

\begin{tabular}{|c|c|c|c|c|c|c|}
\hline \multicolumn{7}{|c|}{ Table 3.2.4.p: Vertical Specialization, Disaggregated-Maldives } \\
\hline & Exports & VS & FVA_FIN & FVA_INT & DDC & FDC \\
\hline & (\$ million) & (\% of gross exports) & \multirow{2}{*}{\multicolumn{4}{|c|}{ (\% of VS) }} \\
\hline \multicolumn{4}{|c|}{ Air Transport } & & & \\
\hline 2008 & 19.15 & 44.55 & 7.17 & 73.17 & 0.00 & 19.66 \\
\hline 2018 & 142.21 & 39.10 & 35.43 & 54.55 & 0.01 & 10.01 \\
\hline \multicolumn{7}{|c|}{ Hotels and Restaurants } \\
\hline 2008 & $1,246.27$ & 32.62 & 39.79 & 37.60 & 0.00 & 22.60 \\
\hline 2018 & $2,550.06$ & 36.36 & 41.01 & 35.34 & 0.01 & 23.65 \\
\hline \multicolumn{7}{|c|}{ Other Supporting and Auxiliary Transport Activities; Activities of Travel Agencies } \\
\hline 2008 & 15.55 & 21.36 & 27.43 & 47.68 & 0.00 & 24.88 \\
\hline 2018 & 78.02 & 26.39 & 29.06 & 41.69 & 0.01 & 29.24 \\
\hline
\end{tabular}

$\$=$ United States dollars, DDC = domestic value-added double counted in exports, $F D C=$ foreign value-added double counted in exports, FVA_FIN = foreign value-added in exports for final consumption, FVA_INT = foreign value-added in intermediate exports, VS = vertical specialization.

Source: ADB Multi Region Input-Output Tables Database. 


\begin{tabular}{|c|c|c|c|c|c|c|}
\hline & Exports & VS & FVA_FIN & FVA_INT & DDC & FDC \\
\hline & (\$ million) & (\% of gross exports) & \multirow{2}{*}{\multicolumn{4}{|c|}{ (\% of VS) }} \\
\hline \multicolumn{4}{|c|}{ Inland Transport } & & & \\
\hline 2008 & 81.69 & 31.08 & 28.07 & 51.57 & 0.01 & 20.35 \\
\hline 2018 & 137.89 & 37.27 & 23.69 & 57.14 & 0.01 & 19.16 \\
\hline \multicolumn{7}{|c|}{ Mining and Quarrying } \\
\hline 2008 & $1,516.30$ & 27.41 & 1.28 & 61.38 & 0.01 & 37.33 \\
\hline 2018 & $5,382.16$ & 25.45 & 2.17 & 70.92 & 0.03 & 26.88 \\
\hline \multicolumn{7}{|c|}{ Textiles and Textile Products } \\
\hline 2008 & 69.31 & 21.12 & 49.42 & 25.02 & 0.00 & 25.56 \\
\hline 2018 & 47.55 & 30.12 & 11.82 & 53.12 & 0.01 & 35.05 \\
\hline
\end{tabular}

$\$=$ United States dollars, DDC = domestic value-added double counted in exports, $F D C=$ foreign value-added double counted in exports, FVA_FIN = foreign value-added in exports for final consumption, FVA_INT = foreign value-added in intermediate exports, VS = vertical specialization.

Source: ADB Multi Region Input-Output Tables Database.

\begin{tabular}{|c|c|c|c|c|c|c|}
\hline & Exports & Vs & & FVA_INI & & rDC \\
\hline & (\$ million) & (\% of gross exports) & \multirow{2}{*}{\multicolumn{4}{|c|}{ (\% of VS) }} \\
\hline \multicolumn{6}{|c|}{ Agriculture, Hunting, Forestry and Fishing } & \\
\hline 2008 & 74.27 & 7.71 & 40.81 & 51.53 & 0.02 & 7.64 \\
\hline 2018 & 72.56 & 8.76 & 52.58 & 42.20 & 0.01 & 5.21 \\
\hline \multicolumn{7}{|c|}{ Food, Beverages and Tobacco } \\
\hline 2008 & 73.06 & 13.87 & 70.02 & 26.27 & 0.01 & 3.70 \\
\hline 2018 & 67.27 & 15.40 & 42.13 & 46.84 & 0.01 & 11.02 \\
\hline \multicolumn{7}{|c|}{ Retail Trade, Except of Motor Vehicles and Motorcycles; Repair of Household Goods } \\
\hline 2008 & 92.65 & 7.40 & 29.16 & 43.04 & 0.01 & 27.80 \\
\hline 2018 & 139.16 & 8.63 & 32.10 & 40.21 & 0.01 & 27.68 \\
\hline
\end{tabular}

$\$=$ United States dollars, DDC = domestic value-added double counted in exports, FDC = foreign value-added double counted in exports, FVA_FIN = foreign value-added in exports for final consumption, FVA_INT $=$ foreign value-added in intermediate exports, VS $=$ vertical specialization .

Source: ADB Multi Region Input-Output Tables Database.

\begin{tabular}{|c|c|c|c|c|c|c|}
\hline & Exports & VS & FVA_FIN & FVA_INT & DDC & FDC \\
\hline & (\$ million) & (\% of gross exports) & \multicolumn{4}{|c|}{ (\% of VS) } \\
\hline \multicolumn{7}{|c|}{ Inland Transport } \\
\hline 2008 & 702.97 & 15.18 & 33.47 & 50.03 & 0.02 & 16.47 \\
\hline 2018 & $1,403.40$ & 13.05 & 37.26 & 46.10 & 0.02 & 16.61 \\
\hline \multicolumn{7}{|c|}{ Retail Trade, Except of Motor Vehicles and Motorcycles; Repair of Household Goods } \\
\hline 2008 & 948.93 & 5.54 & 46.70 & 34.58 & 0.05 & 18.68 \\
\hline 2018 & $1,569.43$ & 5.03 & 47.95 & 35.23 & 0.05 & 16.77 \\
\hline \multicolumn{7}{|c|}{ Textiles and Textile Products } \\
\hline 2008 & $8,280.53$ & 9.30 & 47.33 & 26.13 & 0.03 & 26.51 \\
\hline 2018 & $10,923.32$ & 8.01 & 49.79 & 26.68 & 0.03 & 23.50 \\
\hline
\end{tabular}

$\$=$ United States dollars, DDC = domestic value-added double counted in exports, $F D C=$ foreign value-added double counted in exports, FVA_FIN = foreign value-added in exports for final consumption, FVA_INT = foreign value-added in intermediate exports, VS = vertical specialization.

Source: ADB Multi Region Input-Output Tables Database.

\begin{tabular}{|c|c|c|c|c|c|c|}
\hline & Exports & VS & FVA_FIN & FVA_INT & DDC & FDC \\
\hline & (\$ million) & (\% of gross exports) & \multicolumn{4}{|c|}{ (\% of VS) } \\
\hline \multicolumn{7}{|c|}{ Electrical and Optical Equipment } \\
\hline 2008 & $22,572.95$ & 54.69 & 20.35 & 32.58 & 0.38 & 46.70 \\
\hline 2018 & $19,077.94$ & 54.07 & 31.57 & 27.78 & 0.27 & 40.38 \\
\hline \multicolumn{7}{|c|}{ Machinery, Nec } \\
\hline 2008 & $3,337.74$ & 42.16 & 74.19 & 15.19 & 0.03 & 10.58 \\
\hline 2018 & $1,888.97$ & 43.84 & 75.65 & 13.39 & 0.03 & 10.93 \\
\hline \multicolumn{7}{|c|}{ Textiles and Textile Products } \\
\hline 2008 & $1,152.50$ & 25.45 & 84.18 & 7.92 & 0.02 & 7.88 \\
\hline 2018 & $1,063.53$ & 26.09 & 75.03 & 10.10 & 0.04 & 14.82 \\
\hline
\end{tabular}

$\$=$ United States dollars, DDC = domestic value-added double counted in exports, $F D C=$ foreign value-added double counted in exports, FVA_FIN = foreign value-added in exports for final consumption, FVA_INT = foreign value-added in intermediate exports, VS = vertical specialization. Source: ADB Multi Region Input-Output Tables Database. 


\begin{tabular}{|c|c|c|c|c|c|c|}
\hline & Eynortc & Vs & CYA CIN & EYA INT & r & \\
\hline & (\$ million) & (\% of gross exports) & \multirow{2}{*}{\multicolumn{4}{|c|}{ (\% of VS) }} \\
\hline \multicolumn{4}{|c|}{ Coke, Refined Petroleum and Nuclear Fuel } & & & \\
\hline 2008 & $47,477.59$ & 85.36 & 35.30 & 32.01 & 0.31 & 32.38 \\
\hline 2018 & $60,863.33$ & 84.03 & 41.11 & 34.38 & 0.46 & 24.04 \\
\hline \multicolumn{7}{|c|}{ Electrical and Optical Equipment } \\
\hline 2008 & $52,295.91$ & 69.02 & 40.95 & 25.70 & 0.42 & 32.93 \\
\hline 2018 & $80,083.25$ & 60.99 & 36.35 & 30.04 & 0.68 & 32.93 \\
\hline \multicolumn{7}{|c|}{ Wholesale Trade and Commission Trade, Except of Motor Vehicles and Motorcycles } \\
\hline 2008 & $36,999.20$ & 34.24 & 23.16 & 56.29 & 0.46 & 20.09 \\
\hline 2018 & $92,310.49$ & 40.21 & 23.52 & 54.57 & 0.74 & 21.17 \\
\hline
\end{tabular}

$\$=$ United States dollars, DDC = domestic value-added double counted in exports, FDC = foreign value-added double counted in exports, FVA_FIN = foreign value-added in exports for final consumption, FVA_INT = foreign value-added in intermediate exports, VS = vertical specialization.

Source: ADB Multi Region Input-Output Tables Database.

\begin{tabular}{|c|c|c|c|c|c|c|}
\hline & Exports & VS & FVA_FIN & FVA_INT & DDC & FDC \\
\hline & (\$ million) & (\% of gross exports) & \multicolumn{4}{|c|}{ (\% of VS) } \\
\hline \multicolumn{7}{|c|}{ Agriculture, Hunting, Forestry and Fishing } \\
\hline 2008 & 382.56 & 10.79 & 38.59 & 39.03 & 0.02 & 22.36 \\
\hline 2018 & 650.35 & 11.50 & 58.19 & 26.95 & 0.01 & 14.85 \\
\hline \multicolumn{7}{|c|}{ Inland Transport } \\
\hline 2008 & 885.84 & 18.87 & 35.40 & 48.55 & 0.01 & 16.03 \\
\hline 2018 & $2,359.48$ & 14.27 & 33.64 & 49.01 & 0.02 & 17.33 \\
\hline \multicolumn{7}{|c|}{ Other Community, Social and Personal Services } \\
\hline 2008 & 66.59 & 16.69 & -17.64 & 86.38 & 0.03 & 31.23 \\
\hline 2018 & 523.00 & 10.69 & 45.05 & 41.74 & 0.02 & 13.19 \\
\hline
\end{tabular}

$\$=$ United States dollars, DDC = domestic value-added double counted in exports, FDC = foreign value-added double counted in exports, FVA_FIN = foreign value-added in exports for final consumption, FVA_INT = foreign value-added in intermediate exports, VS = vertical specialization

Source: ADB Multi Region Input-Output Tables Database.

\begin{tabular}{|c|c|c|c|c|c|c|}
\hline & Exports & VS & FVA_FIN & FVA_INT & DDC & FDC \\
\hline & (\$ million) & (\% of gross exports) & \multicolumn{4}{|c|}{$(\%$ of VS) } \\
\hline \multicolumn{7}{|c|}{ Electrical and Optical Equipment } \\
\hline 2008 & $115,872.72$ & 42.43 & 23.51 & 34.86 & 1.15 & 40.48 \\
\hline 2018 & $163,738.48$ & 41.74 & 18.41 & 42.17 & 1.40 & 38.02 \\
\hline \multicolumn{7}{|c|}{ Textiles and Textile Products } \\
\hline 2008 & $8,433.89$ & 43.61 & 30.75 & 36.15 & 0.31 & 32.79 \\
\hline 2018 & $7,931.22$ & 40.36 & 23.87 & 40.61 & 0.34 & 35.18 \\
\hline \multicolumn{7}{|c|}{ Wholesale Trade and Commission Trade, Except of Motor Vehicles and Motorcycles } \\
\hline 2008 & $26,369.52$ & 12.50 & 24.96 & 44.91 & 1.03 & 29.09 \\
\hline 2018 & $43,079.10$ & 13.34 & 30.07 & 42.97 & 0.85 & 26.11 \\
\hline
\end{tabular}

$\$=$ United States dollars, DDC = domestic value-added double counted in exports, $F D C=$ foreign value-added double counted in exports, FVA_FIN = foreign value-added in exports for final consumption, FVA_INT = foreign value-added in intermediate exports, VS = vertical specialization

Source: ADB Multi Region Input-Output Tables Database.

\begin{tabular}{|c|c|c|c|c|c|c|}
\hline & Exports & VS & FVA_FIN & FVA_INT & DDC & FDC \\
\hline & (\$ million) & (\% of gross exports) & \multicolumn{4}{|c|}{ (\% of VS) } \\
\hline \multicolumn{7}{|c|}{ Basic Metals and Fabricated Metal } \\
\hline 2008 & $47,195.53$ & 52.07 & 9.99 & 56.60 & 0.39 & 33.02 \\
\hline 2018 & $48,431.32$ & 44.24 & 14.69 & 55.84 & 0.44 & 29.02 \\
\hline \multicolumn{7}{|c|}{ Food, Beverages and Tobacco } \\
\hline 2008 & $11,002.08$ & 29.04 & 54.51 & 33.08 & 0.16 & 12.25 \\
\hline 2018 & $20,488.10$ & 21.57 & 57.71 & 29.37 & 0.21 & 12.71 \\
\hline \multicolumn{7}{|c|}{ Textiles and Textile Products } \\
\hline 2008 & $5,806.75$ & 27.28 & 69.96 & 15.12 & 0.11 & 14.81 \\
\hline 2018 & $7,305.76$ & 26.84 & 51.52 & 21.51 & 0.18 & 26.79 \\
\hline
\end{tabular}

$\$=$ United States dollars, DDC = domestic value-added double counted in exports, $F D C=$ foreign value-added double counted in exports, FVA_FIN = foreign value-added in exports for final consumption, FVA_INT = foreign value-added in intermediate exports, VS = vertical specialization.

Source: ADB Multi Region Input-Output Tables Database. 


\begin{tabular}{|c|c|c|c|c|c|c|}
\hline & Exports & VS & FVA_FIN & FVA_INT & DDC & FDC \\
\hline & (\$ million) & (\% of gross exports) & \multicolumn{4}{|c|}{ (\% of VS) } \\
\hline \multicolumn{7}{|c|}{ Agriculture, Hunting, Forestry and Fishing } \\
\hline 2008 & $2,803.16$ & 20.93 & 33.17 & 49.51 & 0.19 & 17.13 \\
\hline 2018 & $9,450.53$ & 34.28 & 39.94 & 44.61 & 0.27 & 15.18 \\
\hline \multicolumn{7}{|c|}{ Food, Beverages and Tobacco } \\
\hline 2008 & $10,004.24$ & 26.08 & 62.46 & 29.67 & 0.06 & 7.80 \\
\hline 2018 & $36,444.90$ & 38.61 & 55.40 & 30.80 & 0.13 & 13.68 \\
\hline \multicolumn{7}{|c|}{ Mining and Quarrying } \\
\hline 2008 & $6,383.81$ & 27.49 & 0.48 & 70.39 & 0.27 & 28.86 \\
\hline 2018 & $12,132.03$ & 38.25 & 3.96 & 65.08 & 0.62 & 30.34 \\
\hline
\end{tabular}

$\$=$ United States dollars, DDC = domestic value-added double counted in exports, FDC = foreign value-added double counted in exports, FVA_FIN = foreign value-added in exports for final consumption, FVA_INT = foreign value-added in intermediate exports, VS = vertical specialization. Source: ADB Multi Region Input-Output Tables Database. 


\section{Definitions}



This section contains the definitions of statistical indicators that are covered in Part I - Sustainable Development Goals (SDGs), Part II - Regional Trends and Tables, and Part III - Global Value Chains (GVCs). The definitions are taken mostly from the Asian Development Bank's Development Indicators Reference Manual, including websites and publications of international and private organizations such as the Food and Agriculture Organization of the United Nations (FAO); International Labour Organization (ILO); International Monetary Fund (IMF); International Telecommunication Union (ITU); Organisation for Economic Co-operation and Development (OECD); Transparency International; United Nations Children's Fund (UNICEF); United Nations
Educational, Scientific and Cultural Organization (UNESCO); United Nations Population Division (UNPD); United Nations Statistics Division (UNSD); World Bank; World Health Organization (WHO); and United Nations World Tourism Organization (UNWTO). The definitions for GVCs are taken from ADB's Key Indicators for Asia and the Pacific 2015. The SDG indicators are arranged according to their respective goals and targets before they are defined, while the indicators for the Regional Trends and Tables are grouped according to their themes and subtopics before they are defined. In many instances, the indicators themselves, rather than their growth rates or ratios to another indicator, are defined.

\section{Sustainable Development Goals}

\begin{tabular}{|c|c|c|}
\hline Goals and Targets & Statistical Indicators & Definition \\
\hline \multicolumn{3}{|c|}{ Goal 1. End poverty in all its forms everywhere } \\
\hline \multirow[t]{2}{*}{$\begin{array}{l}\text { Target 1.1: By } 2030, \\
\text { eradicate extreme poverty } \\
\text { (currently measured as } \\
\text { people living on less than } \\
\$ 1.90 \text { a day) for all people } \\
\text { everywhere. }\end{array}$} & $\begin{array}{l}\text { 1.1.1.a: Proportion of the } \\
\text { population living below the } \\
\text { international poverty line, by } \\
\text { sex, age, employment status, } \\
\text { and geographical location } \\
\text { (urban or rural) }\end{array}$ & $\begin{array}{l}\text { Proportion of the population living on less than } \$ 1.90 \text { a day, measured at } \\
2011 \text { international prices, adjusted for purchasing power parity (PPP). } \\
\text { Note: } \\
\text { The PPP conversion factor for private consumption is the number of units } \\
\text { of a country's currency required to buy the same amount of goods and/or } \\
\text { services in the domestic market as a United States (US) dollar would buy } \\
\text { in the US. }\end{array}$ \\
\hline & $\begin{array}{l}\text { 1.1.1.b: Proportion of the } \\
\text { employed population living } \\
\text { below the international } \\
\text { poverty line, by sex }\end{array}$ & $\begin{array}{l}\text { Proportion of the employed population living in households with per } \\
\text { capita consumption or income below the international poverty line of } \\
\$ 1.90 \text {. } \\
\text { Note: } \\
\text { The proportion of working poor in total employment (also known as } \\
\text { the working poverty rate) combines data on household income or } \\
\text { consumption with labor force framework variables measured at the } \\
\text { individual level, and sheds light on the relationship between household } \\
\text { poverty and employment. The numbers are International Labour } \\
\text { Organization modeled estimates. } \\
\text { Employed persons refer to all persons of working age who, during a short } \\
\text { reference period such as a day or a week, performed work for others in } \\
\text { exchange for pay or profit. }\end{array}$ \\
\hline $\begin{array}{l}\text { Target 1.2: By 2030, reduce } \\
\text { at least by half the proportion } \\
\text { of men, women, and children } \\
\text { of all ages living in poverty in } \\
\text { all its dimensions, according } \\
\text { to national definitions. }\end{array}$ & $\begin{array}{l}\text { 1.2.1: Proportion of the } \\
\text { population living below the } \\
\text { national poverty line, by } \\
\text { sex, age, and geographical } \\
\text { location (urban or rural) }\end{array}$ & $\begin{array}{l}\text { Percentage of the total population living below the national poverty line. } \\
\text { Note: } \\
\text { National poverty rates are defined at country-specific poverty lines } \\
\text { in local currencies, which are different in real terms across countries } \\
\text { and different from the international poverty line of } \$ 1.90 \text { a day. Thus, } \\
\text { national poverty rates cannot be compared across countries or with the } \\
\text { poverty rate of } \$ 1.90 \text { a day. }\end{array}$ \\
\hline
\end{tabular}




\begin{tabular}{|c|c|c|}
\hline Goals and Targets & Statistical Indicators & Definition \\
\hline \multicolumn{3}{|c|}{ Goal 2. End hunger, achieve food security and improved nutrition, and promote sustainable agriculture } \\
\hline $\begin{array}{l}\text { Target 2.1: By } 2030 \text {, end } \\
\text { hunger and ensure access by } \\
\text { all people, in particular the } \\
\text { poor and people in vulnerable } \\
\text { situations, including infants, } \\
\text { to safe, nutritious, and } \\
\text { sufficient food all year round. }\end{array}$ & $\begin{array}{l}\text { 2.1.1: Prevalence of } \\
\text { undernourishment }\end{array}$ & $\begin{array}{l}\text { Proportion of the population whose habitual food consumption is } \\
\text { insufficient to provide the dietary energy levels that are required to } \\
\text { maintain a normal active and healthy life. } \\
\text { Note: } \\
\text { Undernourishment is defined as the condition by which a person has } \\
\text { access, on a regular basis, to amounts of food that are insufficient to } \\
\text { provide the energy required for conducting a normal, healthy, and active } \\
\text { life, given his or her own dietary energy requirements. }\end{array}$ \\
\hline \multirow{3}{*}{$\begin{array}{l}\text { Target 2.2: By 2030, end } \\
\text { all forms of malnutrition, } \\
\text { including achieving, by } 2025 \text {, } \\
\text { the internationally agreed } \\
\text { targets on stunting and } \\
\text { wasting in children under } \\
5 \text { years of age, and address } \\
\text { the nutritional needs of } \\
\text { adolescent girls, pregnant and } \\
\text { lactating women, and older } \\
\text { persons. }\end{array}$} & $\begin{array}{l}\text { 2.2.1: Prevalence of } \\
\text { stunting-height for age } \\
<-2 \text { standard deviation from } \\
\text { the median of World Health } \\
\text { Organization (WHO) Child } \\
\text { Growth Standards-among } \\
\text { children under } 5 \text { years of age }\end{array}$ & $\begin{array}{l}\text { Prevalence of stunting-height-for-age }<-2 \text { standard deviation from the } \\
\text { median of WHO Child Growth Standards-among children under } 5 \text { years } \\
\text { of age. } \\
\text { Note: } \\
\text { Stunting refers to the impaired growth and development that children } \\
\text { experience from poor nutrition, repeated infection, and inadequate } \\
\text { psychosocial stimulation. }\end{array}$ \\
\hline & $\begin{array}{l}\text { 2.2.2.a: Prevalence of } \\
\text { malnutrition-weight } \\
\text { for height <-2 standard } \\
\text { deviation from the median } \\
\text { of WHO Child Growth } \\
\text { Standards-among children } \\
\text { under } 5 \text { years of age } \\
\text { (wasting) }\end{array}$ & $\begin{array}{l}\text { Prevalence of wasting-weight for height }<-2 \text { standard deviation from the } \\
\text { median of WHO Child Growth Standards - among children under } 5 \text { years } \\
\text { of age. } \\
\text { Note: } \\
\text { Child wasting refers to a child who is too thin for his or her height, and is } \\
\text { the result of recent rapid weight loss or the failure to gain weight. }\end{array}$ \\
\hline & $\begin{array}{l}\text { 2.2.2.b: Prevalence of } \\
\text { malnutrition-weight } \\
\text { for height }>+2 \text { standard } \\
\text { deviation from the median } \\
\text { of WHO Child Growth } \\
\text { Standards-among children } \\
\text { under } 5 \text { years of age } \\
\text { (overweight) }\end{array}$ & $\begin{array}{l}\text { Prevalence of overweight-weight for height }>+2 \text { standard deviation from } \\
\text { the median of WHO Child Growth Standards-among children under } 5 \\
\text { years of age. } \\
\text { Note: } \\
\text { Child overweight refers to a child who is too heavy for his or her height. }\end{array}$ \\
\hline $\begin{array}{l}\text { Target 2.a: Increase } \\
\text { investment, including through } \\
\text { enhanced international } \\
\text { cooperation, in rural } \\
\text { infrastructure, agricultural } \\
\text { research and extension } \\
\text { services, technology } \\
\text { development, and plant } \\
\text { and livestock gene banks in } \\
\text { order to enhance agricultural } \\
\text { productive capacity in } \\
\text { developing countries, in } \\
\text { particular least developed } \\
\text { countries. }\end{array}$ & $\begin{array}{l}\text { 2.a.1: The agriculture } \\
\text { orientation index for } \\
\text { government expenditures }\end{array}$ & $\begin{array}{l}\text { The Agriculture Orientation Index for Government Expenditures is } \\
\text { defined as the agriculture share of government expenditure, divided by } \\
\text { the agriculture value-added share of gross domestic product (GDP), } \\
\text { where "agriculture" refers to the agriculture, forestry, fishing, and hunting } \\
\text { sector. The measure is a currency-free index, calculated as the ratio } \\
\text { of these two shares. National governments are requested to compile } \\
\text { government expenditures according to the international Classification } \\
\text { of Functions of Government and agriculture value-added share of GDP } \\
\text { according to the System of National Accounts. } \\
\text { Note: } \\
\text { Government expenditure is all expense and acquisition of nonfinancial } \\
\text { assets associated with supporting a particular sector, as defined in } \\
\text { the Government Finance Statistics Manual } 2014 \text { developed by the } \\
\text { International Monetary Fund. }\end{array}$ \\
\hline
\end{tabular}




\begin{tabular}{|c|c|c|}
\hline Goals and Targets & Statistical Indicators & Definition \\
\hline & $\begin{array}{l}\text { 2.a.2: Total official flows } \\
\text { (official development } \\
\text { assistance plus other official } \\
\text { flows) to the agriculture } \\
\text { sector }\end{array}$ & $\begin{array}{l}\text { Gross disbursements of total official development assistance (ODA) and } \\
\text { other official flows from all donors to the agriculture sector. } \\
\text { Note: } \\
\text { The Development Assistance Committee (DAC) defines ODA as those } \\
\text { flows to countries and territories on the DAC List of ODA Recipients and } \\
\text { to multilateral institutions which are (i) provided by official agencies, } \\
\text { including state and local governments, or by their executive agencies; } \\
\text { (ii) each transaction is administered with the promotion of the economic } \\
\text { development and welfare of developing countries as its main objective; } \\
\text { and (iii) each transaction is concessional in character and conveys a grant } \\
\text { element of at least } 25 \% \text { (calculated at a rate of discount of 10\%). } \\
\text { Other official flows are defined as transactions by the official sector, } \\
\text { which do not meet the conditions for eligibility as ODA, either because } \\
\text { they are not primarily aimed at development or because they are not } \\
\text { sufficiently concessional. They also exclude officially supported export } \\
\text { credits. }\end{array}$ \\
\hline \multicolumn{3}{|c|}{ Goal 3. Ensure healthy lives and promote well-being for all at all ages } \\
\hline \multirow[t]{2}{*}{$\begin{array}{l}\text { Target 3.1: By } 2030 \text {, reduce } \\
\text { the global maternal mortality } \\
\text { ratio to less than } 70 \text { per } \\
100,000 \text { live births. }\end{array}$} & $\begin{array}{l}\text { 3.1.1: Maternal mortality } \\
\text { ratio }\end{array}$ & $\begin{array}{l}\text { Number of maternal deaths during a given time period per } 100,000 \text { live } \\
\text { births during the same time period. } \\
\text { Note: } \\
\text { The term maternal deaths refers to the annual number of female deaths } \\
\text { from any cause related to, or aggravated by, pregnancy or its management } \\
\text { (excluding accidental or incidental causes) during pregnancy and } \\
\text { childbirth or within } 42 \text { days of termination of pregnancy, irrespective of } \\
\text { the duration and site of the pregnancy, expressed per 100,000 live births, } \\
\text { for a specified time period. }\end{array}$ \\
\hline & $\begin{array}{l}\text { 3.1.2: Proportion of births } \\
\text { attended by skilled health } \\
\text { personnel }\end{array}$ & $\begin{array}{l}\text { Percentage of deliveries attended by health personnel trained in providing } \\
\text { lifesaving obstetric care, including giving the necessary supervision, care, } \\
\text { and advice to women during pregnancy, labor, and the post-partum } \\
\text { period; conducting deliveries on their own; and caring for newborns. } \\
\text { Traditional birth attendants, even if they receive a short training course, } \\
\text { are not included. } \\
\text { Note: } \\
\text { Having a skilled attendant at the time of delivery is an important lifesaving } \\
\text { intervention for both mothers and babies. Not having access to this key } \\
\text { assistance is detrimental to women's health and gender empowerment } \\
\text { because it could cause the death of the mother or long-lasting disability, } \\
\text { especially in marginalized settings. }\end{array}$ \\
\hline \multirow[t]{2}{*}{$\begin{array}{l}\text { Target 3.2: By } 2030 \text {, end } \\
\text { preventable deaths of } \\
\text { newborns and children } \\
\text { under } 5 \text { years of age, with all } \\
\text { countries aiming to reduce } \\
\text { neonatal mortality to at least } \\
\text { as low as } 12 \text { per } 1,000 \text { live } \\
\text { births and under- } 5 \text { mortality } \\
\text { to at least as low as } 25 \text { per } \\
1,000 \text { live births. }\end{array}$} & 3.2.1: Under-5 mortality rate & $\begin{array}{l}\text { The probability of a child born in a specific year or period dying before } \\
\text { reaching the age of } 5 \text { years, if subject to age specific mortality rates of } \\
\text { that period, expressed per } 1,000 \text { live births. } \\
\text { Note: } \\
\text { The under- } 5 \text { mortality rate as defined here is, strictly speaking, not a rate } \\
\text { (i.e., the number of deaths divided by the number of population at risk } \\
\text { during a certain period of time) but a probability of death derived from a } \\
\text { life table and expressed as a rate per } 1,000 \text { live births. }\end{array}$ \\
\hline & $\begin{array}{l}\text { 3.2.2: Neonatal mortality } \\
\text { rate }\end{array}$ & $\begin{array}{l}\text { Probability that a child born in a specific year or period will die during the } \\
\text { first } 28 \text { completed days of life, if subject to age-specific mortality rates of } \\
\text { that period, expressed per } 1,000 \text { live births. } \\
\text { Note: } \\
\text { Neonatal deaths (deaths among live births during the first } 28 \text { completed } \\
\text { days of life) may be subdivided into early neonatal deaths, occurring } \\
\text { during the first } 7 \text { days of life, and late neonatal deaths, occurring after the } \\
\text { seventh day but before the } 28 \text { th completed day of life. }\end{array}$ \\
\hline
\end{tabular}




\begin{tabular}{|c|c|c|}
\hline Goals and Targets & Statistical Indicators & Definition \\
\hline \multirow{3}{*}{$\begin{array}{l}\text { Target 3.3: By 2030, end } \\
\text { the epidemics of AIDS, } \\
\text { tuberculosis, malaria, and } \\
\text { neglected tropical diseases; } \\
\text { and combat hepatitis, water- } \\
\text { borne diseases, and other } \\
\text { communicable diseases. }\end{array}$} & $\begin{array}{l}\text { 3.3.1: Number of new } \\
\text { HIV infections per } 1,000 \\
\text { uninfected population, by } \\
\text { sex, age, and key populations }\end{array}$ & $\begin{array}{l}\text { Number of new HIV infections per } 1,000 \text { person-years among the } \\
\text { uninfected population. }\end{array}$ \\
\hline & $\begin{array}{l}\text { 3.3.2: Tuberculosis incidence } \\
\text { per } 100,000 \text { population }\end{array}$ & $\begin{array}{l}\text { Estimated number of new and relapse tuberculosis cases (all forms of } \\
\text { tuberculosis, including cases in people living with HIV) arising in a given } \\
\text { year, expressed as a rate per } 100,000 \text { population. }\end{array}$ \\
\hline & $\begin{array}{l}\text { 3.3.3: Malaria incidence per } \\
\text { 1,000 population }\end{array}$ & The number of new cases of malaria per 1,000 people at risk each year. \\
\hline \multirow[t]{2}{*}{$\begin{array}{l}\text { Target 3.4: By } 2030 \text {, } \\
\text { reduce by one third } \\
\text { premature mortality from } \\
\text { noncommunicable diseases } \\
\text { through prevention and } \\
\text { treatment, and promote } \\
\text { mental health and well-being. }\end{array}$} & $\begin{array}{l}\text { 3.4.1: Mortality rate } \\
\text { attributed to cardiovascular } \\
\text { disease, cancer, diabetes, or } \\
\text { chronic respiratory disease }\end{array}$ & $\begin{array}{l}\text { Probability of dying between the ages of } 30 \text { and } 70 \text { years from } \\
\text { cardiovascular diseases, cancer, diabetes, or chronic respiratory diseases; } \\
\text { defined as the percentage of } 30 \text {-year-old people who would die before } \\
\text { their } 70 \text { th birthday from cardiovascular disease, cancer, diabetes, or } \\
\text { chronic respiratory disease, assuming that a person would experience } \\
\text { current mortality rates at every age and he or she would not die from any } \\
\text { other cause of death (e.g., injuries or HIV/AIDS). } \\
\text { Note: } \\
\text { Probability of dying refers to the likelihood that an individual would die } \\
\text { between two ages given current mortality rates at each age, calculated } \\
\text { using life table methods. The probability of death between two ages may } \\
\text { be called a mortality rate. }\end{array}$ \\
\hline & 3.4.2: Suicide mortality rate & $\begin{array}{l}\text { The number of suicide deaths in a year, divided by the population and } \\
\text { multiplied by } 100,000 \text {. } \\
\text { Note: } \\
\text { The number of suicide deaths refers to crude suicide rates (per } 100,000 \\
\text { population). }\end{array}$ \\
\hline $\begin{array}{l}\text { Target 3.6: By } 2020 \text {, halve } \\
\text { the number of global deaths } \\
\text { and injuries from road traffic } \\
\text { accidents. }\end{array}$ & $\begin{array}{l}\text { 3.6.1: Death rate due to road } \\
\text { traffic injuries }\end{array}$ & Number of road traffic fatal injury deaths per 100,000 population. \\
\hline \multirow{2}{*}{$\begin{array}{l}\text { Target 3.7: By 2030, ensure } \\
\text { universal access to sexual } \\
\text { and reproductive health } \\
\text { care services, including for } \\
\text { family planning, information } \\
\text { and education, and the } \\
\text { integration of reproductive } \\
\text { health into national strategies } \\
\text { and programs }\end{array}$} & $\begin{array}{l}\text { 3.7.1: Proportion of women } \\
\text { of reproductive age (15-49 } \\
\text { years) who have their need } \\
\text { for family planning satisfied } \\
\text { by modern methods }\end{array}$ & $\begin{array}{l}\text { The percentage of women of reproductive age ( } 15-49 \text { years) who desire } \\
\text { either to have no (additional) children or to postpone the next child, and } \\
\text { who are currently using a modern contraceptive method. }\end{array}$ \\
\hline & $\begin{array}{l}\text { 3.7.2: Adolescent birth rate } \\
\text { (15-19 years) per } 1,000 \\
\text { women in that age group }\end{array}$ & $\begin{array}{l}\text { Annual number of births to females aged } 15-19 \text { years per } 1,000 \text { females } \\
\text { in the respective age group. }\end{array}$ \\
\hline $\begin{array}{l}\text { Target 3.8: Achieve universal } \\
\text { health coverage, including } \\
\text { financial risk protection; } \\
\text { access to quality essential } \\
\text { healthcare services; and } \\
\text { access to safe, effective, } \\
\text { quality, and affordable } \\
\text { essential medicines and } \\
\text { vaccines for all }\end{array}$ & $\begin{array}{l}\text { 3.8.1: Coverage of essential } \\
\text { health services (defined } \\
\text { as the average coverage of } \\
\text { essential services based } \\
\text { on tracer interventions } \\
\text { that include reproductive, } \\
\text { maternal, newborn and child } \\
\text { heath, infectious disease, } \\
\text { noncommunicable diseases, } \\
\text { and service capacity and } \\
\text { access, among the general } \\
\text { and the most disadvantaged } \\
\text { population) }\end{array}$ & $\begin{array}{l}\text { The indicator is an index reported on a unitless scale of } 0 \text { to } 100 \text {, which is } \\
\text { calculated as the geometric mean of } 14 \text { tracer indicators of health service } \\
\text { coverage. } \\
\text { Note: } \\
\text { The index of health service coverage is computed as the geometric means } \\
\text { of tracer indicators. The tracer indicators are organized by four broad } \\
\text { categories of service coverage: (i) reproductive, maternal, newborn, and } \\
\text { child health, (ii) infectious diseases, (iii) noncommunicable diseases, and } \\
\text { (iv) service capacity and access. }\end{array}$ \\
\hline
\end{tabular}




\begin{tabular}{|c|c|c|}
\hline Goals and Targets & Statistical Indicators & Definition \\
\hline \multirow[t]{2}{*}{$\begin{array}{l}\text { Target 3.9: By 2030, } \\
\text { substantially reduce the } \\
\text { number of deaths and } \\
\text { illnesses from hazardous } \\
\text { chemicals and air, water, } \\
\text { and soil pollution and } \\
\text { contamination. }\end{array}$} & $\begin{array}{l}\text { 3.9.1: Mortality rate } \\
\text { attributed to household and } \\
\text { ambient air pollution }\end{array}$ & $\begin{array}{l}\text { Expressed as the number of deaths and death rate. Death rates are } \\
\text { calculated by dividing the number of deaths by the total population (or } \\
\text { indicated if a different population group is used, e.g., children under } 5 \\
\text { years). } \\
\text { Note: } \\
\text { Evidence from epidemiological studies has shown that exposure to air } \\
\text { pollution is linked to, among others, the important diseases taken into } \\
\text { account in this estimate: } \\
\text { - acute respiratory infections in young children (estimated under } 5 \text { years } \\
\text { of age); } \\
\text { - cerebrovascular diseases (stroke) in adults (estimated above } 25 \text { years } \\
\text { of age); } \\
\text { - ischemic heart diseases in adults (estimated above } 25 \text { years of age); } \\
\text { - chronic obstructive pulmonary disease in adults (estimated above } 25 \\
\text { years of age); and } \\
\text { - lung cancer in adults (estimated above } 25 \text { years of age). }\end{array}$ \\
\hline & $\begin{array}{l}\text { 3.9.2: Mortality rate } \\
\text { attributed to unsafe water, } \\
\text { unsafe sanitation, and lack } \\
\text { of hygiene-exposure to } \\
\text { unsafe water, sanitation, } \\
\text { and hygiene for all (WASH) } \\
\text { services }\end{array}$ & $\begin{array}{l}\text { Number of deaths from unsafe water, unsafe sanitation, and lack of } \\
\text { hygiene - exposure to unsafe water, sanitation and hygiene for all } \\
\text { (WASH) services-in a year, divided by the population, and multiplied by } \\
100,000 \text {. }\end{array}$ \\
\hline \multicolumn{3}{|c|}{ Goal 4. Ensure inclusive and equitable quality education and promote lifelong learning opportunities for all } \\
\hline $\begin{array}{l}\text { Target 4.2: By } 2030 \text {, ensure } \\
\text { that all girls and boys have } \\
\text { access to quality early } \\
\text { childhood development, care, } \\
\text { and preprimary education, } \\
\text { so that they are ready for } \\
\text { primary education. }\end{array}$ & $\begin{array}{l}\text { 4.2.2: Participation rate in } \\
\text { organized learning ( } 1 \text { year } \\
\text { before the official primary } \\
\text { entry age), by sex }\end{array}$ & $\begin{array}{l}\text { Percentage of children in the given age range who participate in one } \\
\text { or more organized learning programs, including programs which offer } \\
\text { a combination of education and care. Participation in early childhood } \\
\text { education and primary education are both included. The age range } \\
\text { will vary by country, depending on the official age for entry to primary } \\
\text { education. } \\
\text { Note: } \\
\text { An organized learning program is one that consists of a coherent set } \\
\text { or sequence of educational activities designed with the intention of } \\
\text { achieving predetermined learning outcomes or the accomplishment of a } \\
\text { specific set of educational tasks. Early childhood and primary education } \\
\text { programs are examples of organized learning programs. } \\
\text { The official primary entry age is the age at which children are obliged to } \\
\text { start primary education, according to national legislation or policies. }\end{array}$ \\
\hline
\end{tabular}




\begin{tabular}{|c|c|c|}
\hline Goals and Targets & Statistical Indicators & Definition \\
\hline $\begin{array}{l}\text { Target 4.c: By } 2030 \text {, } \\
\text { substantially increase } \\
\text { the supply of qualified } \\
\text { teachers, including through } \\
\text { international cooperation for } \\
\text { teacher training in developing } \\
\text { countries, especially least } \\
\text { developed countries and } \\
\text { small island developing states. }\end{array}$ & $\begin{array}{l}\text { 4.c.1.a: Proportion of } \\
\text { teachers in preprimary } \\
\text { education who have received } \\
\text { at least the minimum } \\
\text { organized teacher training } \\
\text { 4.c.1.b: Proportion of } \\
\text { teachers in primary } \\
\text { education who have received } \\
\text { at least the minimum } \\
\text { organized teacher training } \\
\text { 4.c.1.c: Proportion of } \\
\text { teachers in lower secondary } \\
\text { education who have received } \\
\text { at least the minimum } \\
\text { organized teacher training } \\
\text { 4.c.1.d: Proportion of } \\
\text { teachers in upper secondary } \\
\text { education who have received } \\
\text { at least the minimum } \\
\text { organized teacher training }\end{array}$ & $\begin{array}{l}\text { Percentage of teachers by level of education taught (preprimary, primary, } \\
\text { lower secondary, and upper secondary education) who have received at } \\
\text { least the minimum organized pedagogical teacher training pre-service and } \\
\text { in-service required for teaching at the relevant level in a given country. } \\
\text { Note: } \\
\text { Number of teachers in a given level of education who are trained is } \\
\text { expressed as a percentage of all teachers in that level of education. } \\
\text { A teacher is trained if they have received at least the minimum organized } \\
\text { pedagogical teacher training pre-service and in-service required for } \\
\text { teaching at the relevant level in each country. }\end{array}$ \\
\hline \multicolumn{3}{|c|}{ Goal 5. Achieve gender equality and empower all women and girls } \\
\hline $\begin{array}{l}\text { Target 5.3: Eliminate all } \\
\text { harmful practices, such } \\
\text { as child, early, and forced } \\
\text { marriage, and female genital } \\
\text { mutilation. }\end{array}$ & $\begin{array}{l}\text { 5.3.1: Proportion of women } \\
\text { aged } 20-24 \text { years who were } \\
\text { married or in a union before } \\
\text { age } 15 \text { and before age } 18\end{array}$ & $\begin{array}{l}\text { Proportion of women aged } 20-24 \text { years who were married or in a union } \\
\text { before age } 15 \text { and before age } 18 . \\
\text { Note: } \\
\text { Both formal (i.e., marriages) and informal unions are covered under } \\
\text { this indicator. Informal unions are generally defined as those in which } \\
\text { a couple lives together (i.e., cohabits) for some time, intends to have } \\
\text { a lasting relationship, but for which there has been no formal civil or } \\
\text { religious ceremony. }\end{array}$ \\
\hline $\begin{array}{l}\text { Target 5.5: Ensure women's } \\
\text { full and effective participation } \\
\text { in, and equal opportunities } \\
\text { for leadership at, all levels of } \\
\text { decision-making in political, } \\
\text { economic, and public life. }\end{array}$ & $\begin{array}{l}\text { 5.5.1: Proportion of seats } \\
\text { held by women in national } \\
\text { parliaments }\end{array}$ & $\begin{array}{l}\text { The proportion of seats held by women in national parliaments, as of } \\
1 \text { February of reporting year, is currently measured as the number of } \\
\text { seats held by women members in single or lower chambers of national } \\
\text { parliaments, expressed as a percentage of all occupied seats. } \\
\text { Note: } \\
\text { National parliaments can be bicameral or unicameral. This indicator } \\
\text { covers the single chamber in unicameral parliaments and the lower } \\
\text { chamber in bicameral parliaments. It does not cover the upper chamber } \\
\text { of bicameral parliaments. Seats are usually won by members in general } \\
\text { parliamentary elections. Seats may also be filled by nomination, } \\
\text { appointment, indirect election, rotation of members, and by-election. } \\
\text { Seats refer to the number of parliamentary mandates, or the number of } \\
\text { members of parliament. }\end{array}$ \\
\hline & $\begin{array}{l}\text { 5.5.2: Proportion of women } \\
\text { in managerial positions }\end{array}$ & $\begin{array}{l}\text { Proportion of females in the total number of persons employed in senior } \\
\text { and middle management. Senior and middle management correspond } \\
\text { to major group } 1 \text { in International Standard Classification of Occupations } \\
\text { (ISCO)-08 and ISCO-88, minus category } 14 \text { in ISCO-08 (hospitality, } \\
\text { retail, and other services managers) and minus category } 13 \text { in ISCO- } \\
88 \text { (general managers), since these comprise mainly managers of small } \\
\text { enterprises. } \\
\text { Note: } \\
\text { The indicator provides information on the proportion of women who are } \\
\text { employed in decision-making and managerial roles in government, large } \\
\text { enterprises, and institutions, thus providing some insight into women's } \\
\text { power in decision-making and in the economy (especially compared to } \\
\text { men's power in those areas). }\end{array}$ \\
\hline
\end{tabular}




\begin{tabular}{|c|c|c|}
\hline Goals and Targets & Statistical Indicators & Definition \\
\hline \multicolumn{3}{|c|}{ Goal 6. Ensure availability and sustainable management of water and sanitation for all } \\
\hline $\begin{array}{l}\text { Target 6.1: By } 2030 \text {, achieve } \\
\text { universal and equitable } \\
\text { access to safe and affordable } \\
\text { drinking water for all. }\end{array}$ & $\begin{array}{l}\text { 6.1.1: Proportion of } \\
\text { population using safely } \\
\text { managed drinking water } \\
\text { services }\end{array}$ & $\begin{array}{l}\text { Proportion of population using an improved basic drinking water source } \\
\text { that is located on premises, available when needed, and free of fecal (and } \\
\text { priority chemical) contamination. } \\
\text { Note: } \\
\text { Improved drinking water sources include the following: piped water into a } \\
\text { dwelling, yard, or plot; public taps or standpipes; boreholes or tubewells; } \\
\text { protected dug wells; protected springs; packaged water; delivered water; } \\
\text { and rainwater. } \\
\text { "Located on premises": A water source is considered to be located on } \\
\text { premises if the point of collection is within the dwelling, yard, or plot. } \\
\text { "Available when needed": Households that are able to access sufficient } \\
\text { quantities of water when needed. } \\
\text { "Free from fecal (and priority chemical) contamination": Water that } \\
\text { complies with relevant national or local standards. } \\
\text { In the absence of such standards, reference is made to the WHO } \\
\text { Guidelines for Drinking Water Quality (http://www.who.int/water_ } \\
\text { sanitation_health/dwq/guidelines/en/). } \\
\text { E. coli or thermotolerant coliforms are the preferred indicator for } \\
\text { microbiological quality, and arsenic and fluoride are the priority chemicals } \\
\text { for global reporting. } \\
\text { The WHO/UNICEF Joint Monitoring Programme (JMP) for Water } \\
\text { Supply, Sanitation, and Hygiene estimates access to basic services for } \\
\text { each country, separately in urban and rural areas, by fitting a regression } \\
\text { line to a series of data points from household surveys and censuses. } \\
\text { This approach was used to report on use of 'improved water' sources for } \\
\text { Millennium Development Goal monitoring. The JMP is evaluating the } \\
\text { use of alternative statistical estimation methods as more data become } \\
\text { available. } \\
\text { The JMP } 2017 \text { update and SDG baselines report describes in more detail } \\
\text { how data on availability and quality from different sources can be combined } \\
\text { with data on use of different types of supplies, as recorded in the current } \\
\text { JMP database, to calculate the safely managed drinking water services } \\
\text { indicator (https://washdata.org/report/jmp-2017-report-final). }\end{array}$ \\
\hline
\end{tabular}




\begin{tabular}{|c|c|c|}
\hline Goals and Targets & Statistical Indicators & Definition \\
\hline $\begin{array}{l}\text { Target 6.2: By } 2030 \text {, achieve } \\
\text { access to adequate and } \\
\text { equitable sanitation and } \\
\text { hygiene for all, and end open } \\
\text { defecation, paying special } \\
\text { attention to the needs of } \\
\text { women and girls and those in } \\
\text { vulnerable situations. }\end{array}$ & $\begin{array}{l}\text { 6.2.1.a: Proportion of } \\
\text { population using safely } \\
\text { managed sanitation services }\end{array}$ & $\begin{array}{l}\text { The proportion of population using a basic sanitation facility, including } \\
\text { a handwashing facility with soap and water, that is not shared with other } \\
\text { households and where excreta is safely disposed in situ or treated off-site. } \\
\text { Note: } \\
\text { Improved sanitation facilities include flush or pour-flush toilets to sewer } \\
\text { systems, septic tanks or pit latrines, ventilated improved pit latrines, pit } \\
\text { latrines with a slab, and composting toilets. } \\
\text { "Safely disposed in situ": When pit latrines and septic tanks are not } \\
\text { emptied, the excreta may still remain isolated from human contact and } \\
\text { can be considered safely managed. For example, with the new SDG } \\
\text { indicator, households that use twin pit latrines or safely abandon full pit } \\
\text { latrines and dig new facilities (a common practice in rural areas) would be } \\
\text { counted as using safely managed sanitation services. } \\
\text { "Treated offsite": Not all excreta from toilet facilities conveyed in sewers } \\
\text { (as wastewater) or emptied from pit latrines and septic tanks (as fecal } \\
\text { sludge) reach a treatment site. For instance, a portion may leak from } \\
\text { the sewer itself or, due to broken pumping installations, be discharged } \\
\text { directly to the environment. Similarly, a portion of the fecal sludge } \\
\text { emptied from containers may be discharged into open drains, to open } \\
\text { ground or water bodies, rather than being transported to a treatment } \\
\text { plant. And finally, even once the excreta reach a treatment plant, a } \\
\text { portion may remain untreated due to dysfunctional treatment equipment } \\
\text { or inadequate treatment capacity, and be discharged to the environment. } \\
\text { For the purposes of SDG monitoring, adequacy of treatment will initially } \\
\text { be assessed based on the reported level of treatment. } \\
\text { "A handwashing facility with soap and water": A handwashing facility is } \\
\text { a device to contain, transport, or regulate the flow of water to facilitate } \\
\text { handwashing. }\end{array}$ \\
\hline $\begin{array}{l}\text { Target 6.4: By } 2030 \text {, } \\
\text { substantially increase } \\
\text { water-use efficiency across } \\
\text { all sectors and ensure } \\
\text { sustainable withdrawals } \\
\text { and supply of freshwater to } \\
\text { address water scarcity and } \\
\text { substantially reduce the } \\
\text { number of people suffering } \\
\text { from water scarcity. }\end{array}$ & $\begin{array}{l}\text { 6.4.2: Level of water stress; } \\
\text { freshwater withdrawal as } \\
\text { a proportion of available } \\
\text { freshwater resources }\end{array}$ & $\begin{array}{l}\text { Ratio of total freshwater withdrawn by all major sectors to total renewable } \\
\text { freshwater resources, after taking into account environmental water } \\
\text { requirements. } \\
\text { Note: } \\
\text { Total freshwater withdrawal is the volume of freshwater extracted } \\
\text { from its source (rivers, lakes, aquifers) for agriculture, industries, and } \\
\text { municipalities. Freshwater withdrawal includes primary freshwater (not } \\
\text { withdrawn before), secondary freshwater (previously withdrawn and } \\
\text { returned to rivers and groundwater, such as discharged wastewater and } \\
\text { agricultural drainage water) and fossil groundwater. Main sectors, as } \\
\text { defined by International Standard Industrial Classification standards, } \\
\text { include agriculture, forestry and fishing, manufacturing, electricity } \\
\text { industry, and services. Environmental water requirements are the } \\
\text { quantities of water required to sustain freshwater and estuarine } \\
\text { ecosystems. This indicator is also known as water withdrawal intensity. } \\
\text { Total renewable freshwater resources are expressed as the sum of internal } \\
\text { and external renewable water resources. } \\
\text { Internal renewable water resources are defined as the long-term average } \\
\text { annual flow of rivers and recharge of groundwater, generated from } \\
\text { endogenous precipitation, for a given country. } \\
\text { External renewable water resources refer to the flows of water entering } \\
\text { the country, taking into consideration the quantity of flows reserved to } \\
\text { upstream and downstream countries through agreements or treaties. }\end{array}$ \\
\hline
\end{tabular}




\begin{tabular}{|c|c|c|}
\hline Goals and Targets & Statistical Indicators & Definition \\
\hline $\begin{array}{l}\text { Target 6.a: By 2030, expand } \\
\text { international cooperation and } \\
\text { capacity-building support } \\
\text { to developing countries in } \\
\text { water- and sanitation-related } \\
\text { activities and programs, } \\
\text { including water harvesting, } \\
\text { desalination, water efficiency, } \\
\text { wastewater treatment, } \\
\text { recycling, and reuse } \\
\text { technologies. }\end{array}$ & $\begin{array}{l}\text { 6.a.1: Amount of water- and } \\
\text { sanitation-related ODA that } \\
\text { is part of a government- } \\
\text { coordinated spending plan }\end{array}$ & $\begin{array}{l}\text { Proportion of total water- and sanitation-related ODA disbursements } \\
\text { that are included in a government's budget. } \\
\text { Note: } \\
\text { The amount of water- and sanitation-related ODA is a quantifiable } \\
\text { measurement as a proxy for "international cooperation and capacity } \\
\text { development support" in financial terms. } \\
\text { A low value of this indicator (near 0\%) would suggest that international } \\
\text { donors are investing in water- and sanitation-related activities and } \\
\text { programs in the country, outside the purview of the national government. } \\
\text { A high value (near } 100 \% \text { ) would indicate that donors are aligned with } \\
\text { the national government and national policies and plans for water and } \\
\text { sanitation. }\end{array}$ \\
\hline \multicolumn{3}{|c|}{ Goal 7. Ensure access to affordable, reliable, sustainable, and modern energy for all } \\
\hline \multirow[t]{2}{*}{$\begin{array}{l}\text { Target 7.1: By } 2030 \text {, ensure } \\
\text { universal access to affordable, } \\
\text { reliable, and modern energy } \\
\text { services. }\end{array}$} & $\begin{array}{l}\text { 7.1.1: Proportion of } \\
\text { population with access to } \\
\text { electricity }\end{array}$ & $\begin{array}{l}\text { Percentage of the population with access to electricity. } \\
\text { Note: } \\
\text { Access to electricity addresses major critical issues in all the dimensions } \\
\text { of sustainable development. The target has a wide range of social and } \\
\text { economic impacts, including facilitating development of household- } \\
\text { based income-generating activities and lightening the burden of } \\
\text { household tasks. }\end{array}$ \\
\hline & $\begin{array}{l}\text { 7.1.2: Proportion of } \\
\text { population with primary } \\
\text { reliance on clean fuels and } \\
\text { technology }\end{array}$ & $\begin{array}{l}\text { Number of people using clean fuels and technologies for cooking, } \\
\text { heating, and lighting, divided by total population reporting any cooking, } \\
\text { heating, or lighting, and expressed as a percentage. "Clean" is defined by } \\
\text { the official emission rate targets and specific fuel recommendations (i.e., } \\
\text { against unprocessed coal and kerosene) included in the WHO guidelines } \\
\text { for indoor air quality: household fuel combustion. }\end{array}$ \\
\hline $\begin{array}{l}\text { Target 7.2: By 2030, increase } \\
\text { substantially the share of } \\
\text { renewable energy in the } \\
\text { global energy mix. }\end{array}$ & $\begin{array}{l}\text { 7.2.1: Renewable energy } \\
\text { share in total final energy } \\
\text { consumption }\end{array}$ & $\begin{array}{l}\text { Percentage of final consumption of energy that is derived from renewable } \\
\text { resources. } \\
\text { Note: } \\
\text { Renewable energy consumption includes consumption of energy derived } \\
\text { from hydro, solid biofuels, wind, solar, liquid biofuels, biogas, geothermal, } \\
\text { marine sources, and waste. Total final energy consumption is calculated } \\
\text { from national balances and statistics as total final consumption minus } \\
\text { nonenergy use. }\end{array}$ \\
\hline $\begin{array}{l}\text { Target 7.3: By 2030, } \\
\text { double the global rate of } \\
\text { improvement in energy } \\
\text { efficiency. }\end{array}$ & $\begin{array}{l}\text { 7.3.1: Energy intensity } \\
\text { measured in terms of primary } \\
\text { energy and GDP }\end{array}$ & $\begin{array}{l}\text { Energy supplied to the economy per unit value of economic output. } \\
\text { Note: } \\
\text { Total energy supply, as defined by the International Recommendations } \\
\text { for Energy Statistics, is made up of production, plus net imports, minus } \\
\text { international marine and aviation bunkers plus-stock changes. GDP is } \\
\text { the measure of economic output. For international comparison purposes, } \\
\text { GDP is measured in constant terms at PPP. }\end{array}$ \\
\hline \multicolumn{3}{|c|}{ Goal 8. Promote sustained, inclusive, and sustainable economic growth, full and productive employment, and decent work for all } \\
\hline $\begin{array}{l}\text { Target 8.1: Sustain per- } \\
\text { capita economic growth in } \\
\text { accordance with national } \\
\text { circumstances and, in } \\
\text { particular, at least 7\% GDP } \\
\text { growth per annum in the least } \\
\text { developed countries. }\end{array}$ & $\begin{array}{l}\text { 8.1.1: Annual growth rate of } \\
\text { real GDP per capita }\end{array}$ & $\begin{array}{l}\text { Percentage change in the real GDP per capita between } 2 \text { consecutive } \\
\text { years. } \\
\text { Note: } \\
\text { Real GDP per capita is calculated by dividing GDP at constant prices by } \\
\text { the population of a country or area. The data for real GDP is measured in } \\
\text { constant US dollars to facilitate the calculation of country growth rates } \\
\text { and aggregation of the country data. }\end{array}$ \\
\hline
\end{tabular}




\begin{tabular}{|c|c|c|}
\hline Goals and Targets & Statistical Indicators & Definition \\
\hline $\begin{array}{l}\text { Target 8.2: Achieve } \\
\text { higher levels of economic } \\
\text { productivity through } \\
\text { diversification, technological } \\
\text { upgrading, and innovation, } \\
\text { including through a focus on } \\
\text { high-value-added and labor- } \\
\text { intensive sectors. }\end{array}$ & $\begin{array}{l}\text { 8.2.1: Annual growth rate } \\
\text { of real GDP per employed } \\
\text { person }\end{array}$ & $\begin{array}{l}\text { Annual percentage change in real GDP per employed person. } \\
\text { Note: } \\
\text { With the real GDP per employed person being a measure of labor } \\
\text { productivity, this indicator represents a measure of labor productivity } \\
\text { growth. It therefore provides information on the evolution, efficiency, and } \\
\text { quality of human capital in the production process. }\end{array}$ \\
\hline $\begin{array}{l}\text { Target 8.5: By } 2030 \text {, } \\
\text { achieve full and productive } \\
\text { employment and decent } \\
\text { work for all women and men, } \\
\text { including for young people } \\
\text { and persons with disabilities, } \\
\text { and equal pay for work of } \\
\text { equal value. }\end{array}$ & $\begin{array}{l}\text { 8.5.2: Unemployment rate, } \\
\text { by sex and age }\end{array}$ & $\begin{array}{l}\text { Percentage of persons in the labor force who are unemployed. } \\
\text { Note: } \\
\text { Unemployed persons are defined as all those of working age (usually } \\
\text { persons aged } 15 \text { and above) who were not in employment, carried out } \\
\text { activities to seek employment during a specified recent period, and were } \\
\text { currently available to take up employment given a job opportunity, where: } \\
\text { (i) "not in employment" is assessed with respect to the short reference } \\
\text { period for the measurement of employment; } \\
\text { (to "seek employment" refers to any activity when carried out, during } \\
\text { a specified recent period comprising the past } 4 \text { weeks or } 1 \text { month, for } \\
\text { the purpose of finding a job or setting up a business or agricultural } \\
\text { undertaking; } \\
\text { (iii) the point when the enterprise starts to exist should be used to } \\
\text { distinguish between search activities aimed at setting up a business } \\
\text { and the work activity itself, as evidenced by the enterprise's } \\
\text { registration to operate or by when financial resources become } \\
\text { available, the necessary infrastructure or materials are in place, or } \\
\text { the first client or order is received, depending on the context; and } \\
\text { (iv) "currently available" serves as a test of readiness to start a job } \\
\text { in the present, assessed with respect to a short reference period } \\
\text { comprising that used to measure employment (depending on } \\
\text { national circumstances, the reference period may be extended to } \\
\text { include a short subsequent period not exceeding } 2 \text { weeks in total, so } \\
\text { as to ensure adequate coverage of unemployment situations among } \\
\text { different population groups). }\end{array}$ \\
\hline $\begin{array}{l}\text { Target 8.6: By } 2020 \text {, } \\
\text { substantially reduce the } \\
\text { proportion of youth not in } \\
\text { employment, education, or } \\
\text { training. }\end{array}$ & $\begin{array}{l}\text { 8.6.1: Proportion of youth } \\
\text { (aged } 15-24 \text { years) not in } \\
\text { education, employment, or } \\
\text { training }\end{array}$ & $\begin{array}{l}\text { Proportion of youth (aged } 15-24 \text { years) who are not in education, } \\
\text { employment, or training, also known as "the NEET rate". It conveys the } \\
\text { number of young persons not in education, employment, or training as a } \\
\text { percentage of the total youth population. }\end{array}$ \\
\hline $\begin{array}{l}\text { Target 8.7: Take immediate } \\
\text { and effective measures to } \\
\text { eradicate forced labor, end } \\
\text { modern slavery and human } \\
\text { trafficking, and secure the } \\
\text { prohibition and elimination } \\
\text { of the worst forms of child } \\
\text { labor, including recruitment } \\
\text { and use of child soldiers, and, } \\
\text { by } 2025, \text { end child labor in all } \\
\text { its forms. }\end{array}$ & $\begin{array}{l}\text { 8.7.1: Proportion of children } \\
\text { aged } 5-17 \text { years engaged in } \\
\text { child labor }\end{array}$ & $\begin{array}{l}\text { The number of children aged 5-17 years reported to be in child labor } \\
\text { during the reference period (usually the week prior to the survey). The } \\
\text { proportion of children in child labor is calculated as the number of } \\
\text { children in child labor, divided by the total number of children in the } \\
\text { population. }\end{array}$ \\
\hline
\end{tabular}




\begin{tabular}{|c|c|c|}
\hline Goals and Targets & Statistical Indicators & Definition \\
\hline \multirow[t]{2}{*}{$\begin{array}{l}\text { Target 8.10: Strengthen the } \\
\text { capacity of domestic financial } \\
\text { institutions to encourage and } \\
\text { expand access to banking, } \\
\text { insurance, and financial } \\
\text { services for all. }\end{array}$} & $\begin{array}{l}\text { 8.10.1: Number of } \\
\text { commercial bank branches } \\
\text { and ATMs per } 100,000 \\
\text { adults }\end{array}$ & $\begin{array}{l}\text { The number of commercial bank branches per } 100,000 \text { adults refers } \\
\text { to the number of commercial banks branches reported by the central } \\
\text { bank or the main financial regulator of the country every year. To make it } \\
\text { comparable, this number is presented as a reference per } 100,000 \text { adults } \\
\text { in the respective country. } \\
\text { The number of ATMs per } 100,000 \text { adults, refers to the number of ATMs } \\
\text { in the country for all types of institutions, such as commercial banks, } \\
\text { non-deposit-taking microfinance institutions, deposit-taking micro } \\
\text { finance institutions, credit unions, financial cooperatives, and others. } \\
\text { This information is reported every year by the central bank or the main } \\
\text { financial regulator of the country. To make it comparable, this number is } \\
\text { presented as a reference per } 100,000 \text { adults in the respective country. }\end{array}$ \\
\hline & $\begin{array}{l}\text { 8.10.2: Proportion of adults } \\
\text { (aged } 15 \text { years and older) } \\
\text { with an account at a bank or } \\
\text { other financial institution or } \\
\text { with a mobile-money service } \\
\text { provider }\end{array}$ & $\begin{array}{l}\text { Percentage of adults (aged } 15+\text { ) who report having an account (of their } \\
\text { own or held with someone else) at a bank or another type of financial } \\
\text { institution or have personally used a mobile-money service in the past } \\
12 \text { months. }\end{array}$ \\
\hline \multicolumn{3}{|c|}{ Goal 9. Build resilient infrastructure, promote inclusive and sustainable industrialization, and foster innovation } \\
\hline \multirow{4}{*}{$\begin{array}{l}\text { Target 9.1: Develop quality, } \\
\text { reliable, sustainable, and } \\
\text { resilient infrastructure, } \\
\text { including regional and } \\
\text { transborder infrastructure, } \\
\text { to support economic } \\
\text { development and human } \\
\text { well-being, with a focus on } \\
\text { affordable and equitable } \\
\text { access for all. }\end{array}$} & $\begin{array}{l}\text { 9.1.a: Passenger volume by } \\
\text { road transport, measured } \\
\text { in millions of passenger- } \\
\text { kilometers }\end{array}$ & \multirow{4}{*}{$\begin{array}{l}\text { Passenger and freight volumes are the sums of the passenger and freight } \\
\text { volumes reported for the road and rail carriers in terms of number of } \\
\text { people and metric tons of cargo, respectively. } \\
\text { Note: } \\
\text { The International Transport Forum collects data on transport (rail and } \\
\text { road) statistics on annual basis from all its member countries. Data } \\
\text { are collected from transport ministries, statistical offices, and other } \\
\text { institutions designated as official data sources. Although there are clear } \\
\text { definitions for all the terms used in this survey, countries might have } \\
\text { different methodologies to calculate passenger-kilometers and ton- } \\
\text { kilometers. Methods could be based on traffic or mobility surveys, using } \\
\text { very different sampling methods and estimating techniques, which could } \\
\text { affect the comparability of the statistics. }\end{array}$} \\
\hline & $\begin{array}{l}\text { 9.1.b: Freight volume by } \\
\text { road transport, measured in } \\
\text { millions of ton-kilometers }\end{array}$ & \\
\hline & $\begin{array}{l}\text { 9.1.c: Passenger volume } \\
\text { by rail transport, measured } \\
\text { in millions of passenger- } \\
\text { kilometers }\end{array}$ & \\
\hline & $\begin{array}{l}\text { 9.1.d: Freight volume by } \\
\text { rail transport, measured in } \\
\text { millions of ton-kilometers }\end{array}$ & \\
\hline \multirow{2}{*}{$\begin{array}{l}\text { Target 9.2: Promote } \\
\text { inclusive and sustainable } \\
\text { industrialization and, } \\
\text { by } 2030, \text { significantly } \\
\text { raise industry's share of } \\
\text { employment and GDP, in line } \\
\text { with national circumstances, } \\
\text { and double its share in least } \\
\text { developed countries. }\end{array}$} & $\begin{array}{l}\text { 9.2.1: Manufacturing value } \\
\text { added as a proportion of } \\
\text { GDP and per capita }\end{array}$ & $\begin{array}{l}\text { Manufacturing value added (MVA) as a proportion of GDP is a ratio } \\
\text { between MVA and GDP, both reported in constant } 2010 \text { US dollars. } \\
\text { MVA per capita is calculated by dividing MVA in constant } 2010 \text { US } \\
\text { dollars by the population of a country or area. }\end{array}$ \\
\hline & $\begin{array}{l}\text { 9.2.2: Manufacturing } \\
\text { employment as a proportion } \\
\text { of total employment }\end{array}$ & Share of manufacturing employment in total employment. \\
\hline $\begin{array}{l}\text { Target 9.4: By 2030, upgrade } \\
\text { infrastructure and retrofit } \\
\text { industries to make them } \\
\text { sustainable, with increased } \\
\text { resource-use efficiency and } \\
\text { greater adoption of clean } \\
\text { and environmentally sound } \\
\text { technologies and industrial } \\
\text { processes, with all countries } \\
\text { taking action in accordance } \\
\text { with their respective } \\
\text { capabilities. }\end{array}$ & $\begin{array}{l}\text { 9.4.1: Carbon dioxide }\left(\mathrm{CO}_{2}\right) \\
\text { emissions per unit of value } \\
\text { added }\end{array}$ & $\begin{array}{l}\mathrm{CO}_{2} \text { emissions per unit value added is an indicator calculated as ratio } \\
\text { between } \mathrm{CO}_{2} \text { emissions from fuel combustion and the value added of } \\
\text { associated economic activities. The indicator can be calculated for the } \\
\text { whole economy (total } \mathrm{CO}_{2} \text { emissions to GDP) or for specific sectors, } \\
\text { notably the manufacturing sector ( } \mathrm{CO}_{2} \text { emissions from manufacturing } \\
\text { industries per MVA). } \\
\mathrm{CO}_{2} \text { emissions per unit of GDP are expressed in kilograms of } \mathrm{CO}_{2} \text { per } \\
\mathrm{Constant}_{2010} \mathrm{US} \text { dollar PPP GDP. } \mathrm{CO}_{2} \text { emissions from manufacturing } \\
\text { industries per unit of MVA are measured in kilograms of } \mathrm{CO}_{2} \text { equivalent } \\
\text { per unit of MVA in constant } 2010 \text { US dollars. }\end{array}$ \\
\hline
\end{tabular}




\begin{tabular}{|c|c|c|}
\hline Goals and Targets & Statistical Indicators & Definition \\
\hline \multirow{2}{*}{$\begin{array}{l}\text { Target 9.5: Enhance } \\
\text { scientific research and } \\
\text { upgrade the technological } \\
\text { capabilities of industrial } \\
\text { sectors in all countries, } \\
\text { in particular developing } \\
\text { countries, including, by 2030, } \\
\text { encouraging innovation } \\
\text { and substantially increasing } \\
\text { the number of research } \\
\text { and development (R\&D) } \\
\text { workers per } 1 \text { million people } \\
\text { and public and private R\&D } \\
\text { spending. }\end{array}$} & $\begin{array}{l}\text { 9.5.1: R\&D expenditure as a } \\
\text { proportion of GDP }\end{array}$ & Amount of R\&D expenditure divided by the total output of the economy. \\
\hline & $\begin{array}{l}\text { 9.5.2: Researchers (full- } \\
\text { time equivalent) per million } \\
\text { inhabitants }\end{array}$ & Number of R\&D workers per 1 million people. \\
\hline $\begin{array}{l}\text { Target 9.a: Facilitate } \\
\text { sustainable and resilient } \\
\text { infrastructure development } \\
\text { in developing countries } \\
\text { through enhanced financial, } \\
\text { technological, and technical } \\
\text { support to African countries, } \\
\text { least developed countries, } \\
\text { landlocked developing } \\
\text { countries, and small island } \\
\text { developing states. }\end{array}$ & $\begin{array}{l}\text { 9.a.1: Total official } \\
\text { international support (ODA } \\
\text { plus other official flows) to } \\
\text { infrastructure }\end{array}$ & $\begin{array}{l}\text { Gross disbursements of total ODA and other official flows from all donors } \\
\text { in support of infrastructure. }\end{array}$ \\
\hline $\begin{array}{l}\text { Target 9.b: Support domestic } \\
\text { technology development, } \\
\text { research, and innovation } \\
\text { in developing countries, } \\
\text { including by ensuring a } \\
\text { conducive policy environment } \\
\text { for, among other things, } \\
\text { industrial diversification } \\
\text { and value addition to } \\
\text { commodities. }\end{array}$ & $\begin{array}{l}\text { 9.b.1: Proportion of } \\
\text { medium- and high-tech } \\
\text { industry value added in total } \\
\text { value added }\end{array}$ & $\begin{array}{l}\text { Ratio of the value added by medium- and high-tech (MHT) industry to } \\
\text { total MVA. } \\
\text { Note: } \\
\text { Industrial development generally entails a structural transition from } \\
\text { resource-based and low-tech activities to MHT activities. A modern, } \\
\text { highly complex production structure offers better opportunities for skills } \\
\text { development and technological innovation. MHT activities are also the } \\
\text { high-value addition industries of manufacturing with higher technological } \\
\text { intensity and labor productivity. Increasing the share of MHT sectors also } \\
\text { reflects the impact of innovation. }\end{array}$ \\
\hline \multirow{3}{*}{$\begin{array}{l}\text { Target 9.c: Significantly } \\
\text { increase access to } \\
\text { information and } \\
\text { communications technology } \\
\text { and strive to provide universal } \\
\text { and affordable access to the } \\
\text { Internet in least developed } \\
\text { countries by } 2020 \text {. }\end{array}$} & $\begin{array}{l}\text { 9.c.1.a: Proportion of the } \\
\text { population covered by } \\
\text { narrowband ( } 2 G) \text { mobile } \\
\text { networks }\end{array}$ & \multirow{3}{*}{$\begin{array}{l}\text { Proportion of the population covered by a mobile network, broken down } \\
\text { by technology, refers to the percentage of inhabitants living within range } \\
\text { of a mobile-cellular signal, irrespective of whether or not they are mobile- } \\
\text { phone subscribers or users. This is calculated by dividing the number of } \\
\text { inhabitants within range of a mobile-cellular signal by the total population } \\
\text { and multiplying by } 100 . \\
\text { Note: } \\
\text { Coverage refers to Long-Term Evolution (LTE), broadband (3G), and } \\
\text { narrowband ( } 2 \mathrm{G} \text { ) mobile-cellular technologies: } \\
2 \mathrm{G} \text { mobile population coverage refers to the percentage of inhabitants } \\
\text { within range of a mobile networks with access to data communications } \\
\text { (e.g. Internet) at downstream speeds below } 256 \text { Kbit/s. This includes } \\
\text { mobile-cellular technologies such as general packet radio service, code } \\
\text { division multiple access } 20001 x \text {, and most enhanced data for global } \\
\text { system for mobile communications evolution implementations. } \\
3 G \text { population coverage refers to the percentage of inhabitants that } \\
\text { are within range of at least a } 3 G \text { mobile-cellular signal, irrespective of } \\
\text { whether or not they are subscribers. } \\
\text { LTE population coverage refers to the percentage of inhabitants that live } \\
\text { within range of LTE/LTE-Advanced, mobile WiMAX/WirelessMAN or } \\
\text { other more advanced mobile-cellular networks, irrespective of whether or } \\
\text { not they are subscribers. }\end{array}$} \\
\hline & $\begin{array}{l}\text { 9.c.1.b: Proportion of the } \\
\text { population covered by } 3 G \\
\text { mobile networks }\end{array}$ & \\
\hline & $\begin{array}{l}\text { 9.c.1.c: Proportion of the } \\
\text { population covered by LTE } \\
\text { mobile networks }\end{array}$ & \\
\hline
\end{tabular}




\begin{tabular}{|c|c|c|}
\hline Goals and Targets & Statistical Indicators & Definition \\
\hline \multicolumn{3}{|c|}{ Goal 10. Reduce inequality within and among countries } \\
\hline \multirow[t]{2}{*}{$\begin{array}{l}\text { Target 10.1: By } 2030 \text {, } \\
\text { progressively achieve and } \\
\text { sustain income growth of the } \\
\text { bottom } 40 \% \text { of the population } \\
\text { at a rate higher than the } \\
\text { national average. }\end{array}$} & $\begin{array}{l}\text { 10.1.1.a: Growth rates of } \\
\text { household expenditure or } \\
\text { income per capita among } \\
\text { the bottom } 40 \% \text { of the } \\
\text { population }\end{array}$ & $\begin{array}{l}\text { The growth rate in the welfare aggregate of the bottom } 40 \% \text { of the } \\
\text { population is calculated as the annualized average growth rate in per } \\
\text { capita real consumption or income of the bottom } 40 \% \text { of the income } \\
\text { distribution in a country from household surveys over a period of } \\
\text { approximately } 5 \text { years. }\end{array}$ \\
\hline & $\begin{array}{l}\text { 10.1.1.b: Growth rates of } \\
\text { household expenditure or } \\
\text { income per capita }\end{array}$ & $\begin{array}{l}\text { The national average growth rate in the welfare aggregate is calculated } \\
\text { as the annualized average growth rate in per capita real consumption or } \\
\text { income of the total population in a country from household surveys over a } \\
\text { period of approximately 5years. }\end{array}$ \\
\hline \multicolumn{3}{|c|}{ Goal 11. Make cities and human settlements inclusive, safe, resilient, and sustainable } \\
\hline $\begin{array}{l}\text { Target 11.1: By 2030, ensure } \\
\text { access for all to adequate, } \\
\text { safe, and affordable housing } \\
\text { and basic services, and } \\
\text { upgrade slums. }\end{array}$ & $\begin{array}{l}\text { 11.1.1: Proportion of the } \\
\text { urban population living in } \\
\text { slums, informal settlements, } \\
\text { or inadequate housing }\end{array}$ & $\begin{array}{l}\text { The proportion of the urban population living in slums, informal } \\
\text { settlements, or inadequate housing to total urban population is currently } \\
\text { being measured by the proportion of the urban population living in slums } \\
\text { and informal settlements. This indicator has been monitored for the } \\
\text { past } 17 \text { years by United Nations (UN)-Habitat in mostly developing } \\
\text { countries, with a new component-inadequate housing or affordability- } \\
\text { that applies largely to the developed countries. By integrating these two } \\
\text { components, the indicator is now universal and can be monitored in both } \\
\text { developing and developed regions. The inadequate housing component } \\
\text { allows capturing housing informality in more developed countries and } \\
\text { wealthier urban contexts. } \\
\text { Note: } \\
\text { This indicator is expected to be a composite one, with the main } \\
\text { components being slums or informal settlements, and the added } \\
\text { component being affordability defining inadequate housing. }\end{array}$ \\
\hline $\begin{array}{l}\text { Target } 11.5: \text { By } 2030, \\
\text { significantly reduce the } \\
\text { number of deaths and the } \\
\text { number of people affected, } \\
\text { and substantially decrease } \\
\text { the direct economic losses } \\
\text { relative to global GDP caused } \\
\text { by disasters, including } \\
\text { water-related disasters, with } \\
\text { a focus on protecting the } \\
\text { poor and people in vulnerable } \\
\text { situations. }\end{array}$ & $\begin{array}{l}\text { 11.5.2: Direct economic } \\
\text { loss in relation to global } \\
\text { GDP, damage to critical } \\
\text { infrastructure, and number } \\
\text { of disruptions to basic } \\
\text { services, attributed to } \\
\text { disasters }\end{array}$ & $\begin{array}{l}\text { Direct economic loss is the monetary value of total or partial destruction } \\
\text { of physical assets existing in the affected area. Direct economic loss is } \\
\text { nearly equivalent to physical damage. } \\
\text { Note: } \\
\text { The original national disaster loss databases usually register physical } \\
\text { damage value (housing unit loss, infrastructure loss, etc.), which } \\
\text { needs conversion to a monetary value according to the United Nations } \\
\text { International Strategy for Disaster Reduction methodology. The } \\
\text { converted global value is divided by global GDP (inflation adjusted, } \\
\text { constant US dollars) calculated from the World Bank Development } \\
\text { Indicators. }\end{array}$ \\
\hline $\begin{array}{l}\text { Target 11.6: By } 2030 \text {, } \\
\text { reduce the adverse per capita } \\
\text { environmental impact of } \\
\text { cities, including by paying } \\
\text { special attention to air quality } \\
\text { and municipal and other } \\
\text { waste management. }\end{array}$ & $\begin{array}{l}\text { 11.6.2: Annual mean levels } \\
\text { of fine particulate matter } \\
\text { (PM), e.g., PM2.5 and } \\
\text { PM10, in cities, measured in } \\
\text { total (population weighted) } \\
\text { micrograms per cubic meter }\end{array}$ & $\begin{array}{l}\text { The mean annual concentration of fine suspended particles of less than } \\
2.5 \text { microns in diameters (PM2.5) is a common measure of air pollution. } \\
\text { Note: } \\
\text { The mean is a population-weighted average for urban population in a } \\
\text { country and is expressed in micrograms per cubic meter. }\end{array}$ \\
\hline
\end{tabular}




\begin{tabular}{|c|c|c|}
\hline Goals and Targets & Statistical Indicators & Definition \\
\hline \multicolumn{3}{|c|}{ Goal 12. Ensure sustainable consumption and production patterns } \\
\hline \multirow[t]{2}{*}{$\begin{array}{l}\text { Target 12.2: By } 2030 \text {, } \\
\text { achieve the sustainable } \\
\text { management and efficient } \\
\text { use of natural resources. }\end{array}$} & $\begin{array}{l}\text { 12.2.1: Material footprint, } \\
\text { material footprint per capita, } \\
\text { and material footprint per } \\
\text { GDP }\end{array}$ & $\begin{array}{l}\text { Material footprint is the attribution of global material extraction to } \\
\text { domestic final demand of a country. The total material footprint is the } \\
\text { sum of the material footprint for biomass, fossil fuels, metal ores, and } \\
\text { nonmetal ores. This indicator is calculated as raw material equivalent } \\
\text { of imports plus domestic extraction minus raw material equivalents of } \\
\text { exports. A global multi-regional input-output framework is employed for } \\
\text { the attribution of the primary material needs of final demand. }\end{array}$ \\
\hline & $\begin{array}{l}\text { 12.2.2: Domestic material } \\
\text { consumption, domestic } \\
\text { material consumption } \\
\text { per capita, and domestic } \\
\text { material consumption per } \\
\text { GDP }\end{array}$ & $\begin{array}{l}\text { Domestic material consumption (DMC) is a standard material flow } \\
\text { accounting indicator and reports the apparent consumption of materials } \\
\text { in a national economy. } \\
\text { Note: } \\
\text { DMC reports the amount of materials used in a national economy. DMC } \\
\text { is a territorial (production side) indicator. DMC also presents the amount } \\
\text { of material that needs to be handled within an economy, which is either } \\
\text { added to material stocks of buildings and transport infrastructure, or } \\
\text { used to fuel the economy as material throughput. DMC describes the } \\
\text { physical dimension of economic processes and interactions. It can also be } \\
\text { interpreted as long-term waste equivalent. }\end{array}$ \\
\hline
\end{tabular}

Goal 13. Take urgent action to combat climate change and its impacts

Target 13.1: Strengthen resilience and adaptive capacity to climate-related hazards and natural disasters in all countries. 13.1.1.a: Number of persons affected by disasters

13.1.1.b: Number of deaths due to disasters

13.1.2: Number of countries that adopt and implement national disaster risk reduction strategies in line with the Sendai Framework for Disaster Risk Reduction 2015-2030

Number of people who were directly affected by disasters per 100,000 population.

Note:

Directly affected means people who have suffered injury, illness, or other health effects; who were evacuated, displaced, or relocated; or have suffered direct damage to their livelihoods, economic, physical, social, cultural, and/or environmental assets.

The number of people who died during a disaster, or directly after, or as a direct result of the hazardous event.

Number of countries that adopt and implement national disaster risk reduction strategies in line with the Sendai Framework for Disaster Risk Reduction 2015-2030.

Note:

The score of adoption and implementation of national disaster risk reduction strategies in line with the Sendai Framework was developed to monitor progress and achievement against Indicator 13.1.2. The score indicates compliance of alignment of national strategies with the Sendai Framework, based on self-assessments of the country and using 10 criteria for monitoring the progress of national disaster risk reduction strategies.

\section{Goal 14. Conserve and sustainably use the oceans, seas, and marine resources for sustainable development}

Target 14.5: By 2020, conserve at least $10 \%$ of coastal and marine areas, consistent with national and international law and based on the best available scientific information.

\subsection{1: Coverage of} protected areas in relation to marine areas
The indicator measures the coverage of protected areas in relation to marine areas and shows temporal trends in the mean percentage of important sites for marine biodiversity (i.e., those that contribute significantly to the global persistence of biodiversity or key biodiversity areas) that are wholly covered by designated protected areas.

Note:

The International Union for Conservation of Nature (IUCN) defines a protected area as "a clearly defined geographical space, recognized, dedicated and managed, through legal or other effective means, to achieve the long-term conservation of nature with associated ecosystem services and cultural values." 


\begin{tabular}{|c|c|c|}
\hline Goals and Targets & Statistical Indicators & Definition \\
\hline \multicolumn{3}{|c|}{$\begin{array}{l}\text { Goal 15. Protect, restore, and promote sustainable use of terrestrial ecosystems, sustainably manage forests, combat } \\
\text { desertification, halt and reverse land degradation, and halt biodiversity loss }\end{array}$} \\
\hline \multirow{2}{*}{$\begin{array}{l}\text { Target 15.1: By 2020, } \\
\text { ensure the conservation, } \\
\text { restoration, and sustainable } \\
\text { use of terrestrial and inland } \\
\text { freshwater ecosystems } \\
\text { and their services, in } \\
\text { particular forests, wetlands, } \\
\text { mountains, and drylands, in } \\
\text { line with obligations under } \\
\text { international agreements. }\end{array}$} & $\begin{array}{l}\text { 15.1.1: Forest area as a } \\
\text { proportion of total land area }\end{array}$ & Size of forest cover in relation to total land area. \\
\hline & $\begin{array}{l}\text { 15.1.2: Proportion } \\
\text { of important sites for } \\
\text { terrestrial and freshwater } \\
\text { biodiversity that are covered } \\
\text { by protected areas, by } \\
\text { ecosystem type }\end{array}$ & $\begin{array}{l}\text { Proportion of important sites for terrestrial and freshwater biodiversity } \\
\text { that are covered by protected areas shows temporal trends in the } \\
\text { mean percentage of each important site for terrestrial and freshwater } \\
\text { biodiversity (i.e., those that contribute significantly to the global } \\
\text { persistence of biodiversity) that is covered by designated protected areas. }\end{array}$ \\
\hline $\begin{array}{l}\text { Target 15.4: By 2030, ensure } \\
\text { the conservation of mountain } \\
\text { ecosystems, including their } \\
\text { biodiversity, in order to } \\
\text { enhance their capacity to } \\
\text { provide benefits that are } \\
\text { essential for sustainable } \\
\text { development }\end{array}$ & $\begin{array}{l}\text { 15.4.1: Coverage by } \\
\text { protected areas of } \\
\text { important sites for mountain } \\
\text { biodiversity }\end{array}$ & $\begin{array}{l}\text { Coverage by protected areas of important sites for mountain biodiversity } \\
\text { shows temporal trends in the mean percentage of each important site } \\
\text { for mountain biodiversity (i.e., those that contribute significantly to the } \\
\text { global persistence of biodiversity) that is covered by designated protected } \\
\text { areas. } \\
\text { Note: } \\
\text { Protected areas, as defined by the IUCN (IUCN; Dudley 2008), are } \\
\text { clearly defined geographical spaces, recognized, dedicated, and managed, } \\
\text { through legal or other effective means, to achieve the long-term } \\
\text { conservation of nature with associated ecosystem services and cultural } \\
\text { values. Importantly, a variety of specific management objectives are } \\
\text { recognized within this definition, spanning conservation, restoration, and } \\
\text { sustainable use: "(i) Category la: Strict nature reserve; (ii) Category Ib: } \\
\text { Wilderness area; (iii) Category II: National park; (iv) Category III: Natural } \\
\text { monument or feature; (v) Category IV: Habitat/species management } \\
\text { area; (vi) Category V: Protected landscape/seascape; (vii) Category VI: } \\
\text { Protected area with sustainable use of natural resources." }\end{array}$ \\
\hline $\begin{array}{l}\text { Target 15.5: Take urgent } \\
\text { and significant action to } \\
\text { reduce the degradation of } \\
\text { natural habitats, halt the } \\
\text { loss of biodiversity and, by } \\
2020, \text { protect and prevent } \\
\text { the extinction of threatened } \\
\text { species. }\end{array}$ & 15.5.1: Red List Index & $\begin{array}{l}\text { The Red List Index measures changes in aggregate extinction risk across } \\
\text { groups of species. It is based on genuine changes in the number of species } \\
\text { in each category of extinction risk on the IUCN Red List of Threatened } \\
\text { Species (IUCN 2015), which is expressed as changes in an index ranging } \\
\text { from } 0 \text { to } 1 . \\
\text { Note: } \\
\text { The Red List Index value ranges from } 1 \text { (all species are categorized } \\
\text { as "Least Concern") to } 0 \text { (all species are categorized as "Extinct"), } \\
\text { indicating how far the set of species has moved overall toward extinction. } \\
\text { Threatened species are those listed on The IUCN Red List of Threatened } \\
\text { Species in the categories Vulnerable, Endangered, or Critically } \\
\text { Endangered (i.e., species that are facing a high, very high, or extremely } \\
\text { high risk of extinction in the wild in the medium-term future). }\end{array}$ \\
\hline \multicolumn{3}{|c|}{$\begin{array}{l}\text { Goal 16. Promote peaceful and inclusive societies for sustainable development; provide access to justice for all; and build } \\
\text { effective, accountable, and inclusive institutions at all levels }\end{array}$} \\
\hline $\begin{array}{l}\text { Target 16.1: Significantly } \\
\text { reduce all forms of violence } \\
\text { and related death rates } \\
\text { everywhere. }\end{array}$ & $\begin{array}{l}\text { 16.1.1: Number of victims } \\
\text { of intentional homicide per } \\
100,000 \text { population, by sex } \\
\text { and age }\end{array}$ & $\begin{array}{l}\text { Total count of victims of intentional homicide divided by the total } \\
\text { population, expressed per } 100,000 \text { population. } \\
\text { Intentional homicide is defined as the unlawful death inflicted upon a } \\
\text { person with the intent to cause death or serious injury (International } \\
\text { Classification of Crime for Statistical Purposes, ICCS 2015). Population } \\
\text { refers to total resident population in a given country in a given year. } \\
\text { Note: } \\
\text { This indicator is widely used at national and international levels to } \\
\text { measure the most extreme form of violent crime, providing a direct } \\
\text { indication of lack of security. }\end{array}$ \\
\hline
\end{tabular}




\begin{tabular}{|c|c|c|}
\hline Goals and Targets & Statistical Indicators & Definition \\
\hline $\begin{array}{l}\text { Target 16.3: Promote the } \\
\text { rule of law at the national } \\
\text { and international levels, and } \\
\text { ensure equal access to justice } \\
\text { for all. }\end{array}$ & $\begin{array}{l}\text { 16.3.2: Unsentenced } \\
\text { detainees as a proportion of } \\
\text { the overall prison population }\end{array}$ & $\begin{array}{l}\text { Total number of persons held in detention who have not yet been } \\
\text { sentenced, as a percentage of the total number of persons held in } \\
\text { detention, on a specified date. }\end{array}$ \\
\hline $\begin{array}{l}\text { Target 16.5: Substantially } \\
\text { reduce corruption and bribery } \\
\text { in all their forms. }\end{array}$ & $\begin{array}{l}\text { 16.5.2: Proportion of } \\
\text { businesses that had at least } \\
\text { one contact with a public } \\
\text { official and that paid a bribe } \\
\text { to a public official, or were } \\
\text { asked for a bribe by those } \\
\text { public officials during the } \\
\text { previous } 12 \text { months }\end{array}$ & $\begin{array}{l}\text { Proportion of firms that were asked for a gift or informal payment when } \\
\text { meeting with tax officials. } \\
\text { Note: } \\
\text { This indicator aims to ascertain whether or not firms have been solicited } \\
\text { for gifts or informal payments (i.e., bribes) when meeting with tax } \\
\text { officials. Paying taxes are required of formal forms in most countries, and } \\
\text { the rationale for this indicator is to measure the incidence of corruption } \\
\text { during this routine interaction. }\end{array}$ \\
\hline $\begin{array}{l}\text { Target 16.9: By } 2030 \text {, } \\
\text { provide legal identity, } \\
\text { including birth registration, } \\
\text { for all. }\end{array}$ & $\begin{array}{l}\text { 16.9.1: Proportion of } \\
\text { children under } 5 \text { years } \\
\text { of age whose births have } \\
\text { been registered with a civil } \\
\text { authority, by age }\end{array}$ & $\begin{array}{l}\text { Proportion of children under } 5 \text { years of age whose births have been } \\
\text { registered with a civil authority. }\end{array}$ \\
\hline \multicolumn{3}{|c|}{ Goal 17. Strengthen the means of implementation and revitalize the Global Partnership for Sustainable Development } \\
\hline $\begin{array}{l}\text { Target 17.4: Assist } \\
\text { developing countries in } \\
\text { attaining long-term debt } \\
\text { sustainability through } \\
\text { coordinated policies aimed at } \\
\text { fostering debt financing, debt } \\
\text { relief, and debt restructuring, } \\
\text { as appropriate, and address } \\
\text { the external debt of highly } \\
\text { indebted poor countries to } \\
\text { reduce debt distress }\end{array}$ & $\begin{array}{l}\text { 17.4.1: Debt service as a } \\
\text { proportion of exports of } \\
\text { goods and services }\end{array}$ & $\begin{array}{l}\text { Percentage of debt services (principle and interest payments) to the } \\
\text { exports of goods and services. Debt services covered in this indicator } \\
\text { refer only to public and publicly guaranteed debt. }\end{array}$ \\
\hline $\begin{array}{l}\text { Target 17.9: Enhance } \\
\text { international support for } \\
\text { implementing effective and } \\
\text { targeted capacity-building } \\
\text { in developing countries to } \\
\text { support national plans to } \\
\text { implement all the Sustainable } \\
\text { Development Goals, including } \\
\text { through North-South, } \\
\text { South-South, and triangular } \\
\text { cooperation. }\end{array}$ & $\begin{array}{l}\text { 17.9.1: Dollar value of } \\
\text { financial and technical } \\
\text { assistance (including through } \\
\text { North-South, South-South, } \\
\text { and triangular cooperation) } \\
\text { committed to developing } \\
\text { countries }\end{array}$ & $\begin{array}{l}\text { Gross disbursements of total ODA and other official flows from all donors } \\
\text { for capacity-building and national planning. } \\
\text { Note: } \\
\text { ODA refers to "those flows to countries and territories on the } \\
\text { Development Assistance Committee List of ODA Recipients and to } \\
\text { multilateral institutions which are (i) provided by official agencies, } \\
\text { including state and local governments, or by their executive agencies; and } \\
\text { (ii) each transaction is administered with the promotion of the economic } \\
\text { development and welfare of developing countries as its main objective; } \\
\text { and is concessional in character and conveys a grant element of at least } \\
\text { 25\% (calculated at a rate of discount of 10\%). } \\
\\
\text { Other official flows (excluding officially supported export credits) } \\
\text { are defined as transactions by the official sector that do not meet the } \\
\text { conditions for eligibility as ODA, either because they are not primarily } \\
\text { aimed at development or because they are not sufficiently concessional. }\end{array}$ \\
\hline
\end{tabular}




\begin{tabular}{|c|c|c|}
\hline Goals and Targets & Statistical Indicators & Definition \\
\hline $\begin{array}{l}\text { Target 17.18: By } 2020, \\
\text { enhance capacity-building } \\
\text { support to developing } \\
\text { countries, including for least } \\
\text { developed countries and } \\
\text { small island developing states, } \\
\text { to increase significantly the } \\
\text { availability of high-quality, } \\
\text { timely, and reliable data } \\
\text { disaggregated by income, } \\
\text { gender, age, race, ethnicity, } \\
\text { migratory status, disability, } \\
\text { geographic location, and } \\
\text { other characteristics relevant } \\
\text { in national contexts. }\end{array}$ & $\begin{array}{l}\text { 17.18.3: Number of } \\
\text { countries with a national } \\
\text { statistical plan that is } \\
\text { fully funded and under } \\
\text { implementation, by source of } \\
\text { funding }\end{array}$ & $\begin{array}{l}\text { Count of countries that are either (i) implementing a strategy, } \\
\text { (ii) designing a strategy, or (iii) awaiting adoption of a strategy in the } \\
\text { current year. } \\
\text { Note: } \\
\text { The indicator is based on the annual Status Report on National Strategies } \\
\text { for the Development of Statistics. In collaboration with its partners, } \\
\text { PARIS21 reports on country progress in designing and implementing } \\
\text { national statistical plans. } \\
\text { This indicator can be disaggregated by geographical area. Regional-level } \\
\text { aggregates are based on the total count of national strategies. }\end{array}$ \\
\hline \multirow{2}{*}{$\begin{array}{l}\text { Target 17.19: By } 2030, \\
\text { build on existing initiatives } \\
\text { to develop measurements } \\
\text { of progress on sustainable } \\
\text { development that } \\
\text { complement GDP, and } \\
\text { support statistical capacity- } \\
\text { building in developing } \\
\text { countries. }\end{array}$} & $\begin{array}{l}\text { 17.19.1: Dollar value of all } \\
\text { resources made available } \\
\text { to strengthen statistical } \\
\text { capacity in developing } \\
\text { countries }\end{array}$ & $\begin{array}{l}\text { US dollar value of ongoing statistical support in developing countries. } \\
\text { Note: } \\
\text { The indicator is based on the Partner Report on Support to Statistics, } \\
\text { which is designed and administered by PARIS21 to provide a snapshot of } \\
\text { the US dollar value of ongoing statistical support in developing countries. }\end{array}$ \\
\hline & $\begin{array}{l}\text { 17.19.2: Number of } \\
\text { countries that have } \\
\text { conducted at least one } \\
\text { population and housing } \\
\text { census in the past } 10 \text { years }\end{array}$ & $\begin{array}{l}\text { Countries that have conducted at least one population and housing } \\
\text { census in the past } 10 \text { years. This includes countries that compile their } \\
\text { detailed population and housing statistics from population registers, } \\
\text { administrative records, sample surveys, other sources, or a combination } \\
\text { of those sources. }\end{array}$ \\
\hline
\end{tabular}




\section{Regional Trends and Tables}

\begin{tabular}{|c|c|}
\hline Indicator & Definition \\
\hline \multicolumn{2}{|l|}{ PEOPLE } \\
\hline \multicolumn{2}{|l|}{ Population } \\
\hline Midyear Population & $\begin{array}{l}\text { Estimates of the midyear de facto population. De facto population includes all persons } \\
\text { physically present in the country during the census day, including foreign, military, } \\
\text { and diplomatic personnel and their accompanying household members; and transient } \\
\text { foreign visitors in the country or in harbors. }\end{array}$ \\
\hline Growth Rates in Population & $\begin{array}{l}\text { Number of people added to (or subtracted from) a population over a given period of } \\
\text { time because of natural increase and net migration, expressed as a percentage of the } \\
\text { population at the given period of time. }\end{array}$ \\
\hline Net International Migration Rate & $\begin{array}{l}\text { Number of immigrants minus the number of emigrants over a period, divided by the } \\
\text { person-years lived by the population of the receiving country over that period. It is } \\
\text { expressed as net number of migrants per } 1,000 \text { population. }\end{array}$ \\
\hline $\begin{array}{l}\text { Urban Population } \\
\text { (as \% of total population) }\end{array}$ & $\begin{array}{l}\text { Population living in urban areas, defined in accordance with the national definition or } \\
\text { as used in the most recent population census. Because of national differences in the } \\
\text { characteristics that distinguish urban from rural areas, the distinction between urban } \\
\text { and rural populations is not amenable to a single definition that would be applicable } \\
\text { to all countries. National definitions are most commonly based on size of locality. } \\
\text { Population that is not urban is considered rural. } \\
\text { The estimated population living in urban areas at midyear as a percentage of the total } \\
\text { midyear population in a country. }\end{array}$ \\
\hline Age Dependency Ratio & $\begin{array}{l}\text { Ratio of the nonworking-age population to the working-age population. Since countries } \\
\text { define working age differently, a straightforward application of the definition will lead } \\
\text { to noncomparable data. The Asian Development Bank therefore uses the following } \\
\text { United Nations definition that can be calculated directly from an age distribution: } \\
\qquad \frac{\text { Population aged }(0-14)+(65 \text { and over }) \text { years }}{\text { Population aged }(15-64) \text { years }} \times 100\end{array}$ \\
\hline \multicolumn{2}{|l|}{ Labor Force and Employment } \\
\hline Labor Force Participation Rate & $\begin{array}{l}\text { Percentage of the labor force to the working-age population. The labor force is the sum } \\
\text { of those employed and unemployed but seeking work. The labor force participation rate } \\
\text { measures the extent of the economically active working-age population in an economy. } \\
\text { It provides an indication of the relative size of the supply of labor available for the } \\
\text { production of goods and services in the economy. It must be noted that the definition } \\
\text { of working-age population varies across countries. }\end{array}$ \\
\hline Employment in Agriculture & $\begin{array}{l}\text { Employment in agriculture, including forestry and fishing, that corresponds to division } \\
1 \text { (International Standard of Industrial Classification [ISIC] revision 2), tabulation } \\
\text { categories A and B (ISIC revision 3), and category A of ISIC revision } 4 \text {. }\end{array}$ \\
\hline Employment in Industry & $\begin{array}{l}\text { Employment in industry includes mining and quarrying; manufacturing; electricity, } \\
\text { gas, steam, and air-conditioning supply; water supply; sewage, waste management, } \\
\text { and remediation activities; and construction. }\end{array}$ \\
\hline Employment in Mining and Quarrying & $\begin{array}{l}\text { Employment in mining and quarrying that corresponds to division } 2 \text { (ISIC revision 2), } \\
\text { tabulation category C (ISIC revision 3), and category B of ISIC revision } 4 \text {. }\end{array}$ \\
\hline Employment in Manufacturing & $\begin{array}{l}\text { Employment in manufacturing that corresponds to division } 3 \text { (ISIC revision 2), tabulation } \\
\text { category D (ISIC revision 3), and category C of ISIC revision } 4 .\end{array}$ \\
\hline $\begin{array}{l}\text { Employment in Electricity, Gas, Steam, } \\
\text { and Air-Conditioning Supply; Water } \\
\text { Supply; Sewerage, Waste Management and } \\
\text { Remediation Activities }\end{array}$ & $\begin{array}{l}\text { Employment in electricity, gas, steam, and air-conditioning supply; water supply; } \\
\text { sewerage, waste management, and remediation activities that corresponds to division } \\
4 \text { (ISIC revision 2), tabulation category E (ISIC revision } 3 \text { ), and categories D and E of } \\
\text { ISIC revision } 4 \text {. }\end{array}$ \\
\hline Employment in Construction & $\begin{array}{l}\text { Employment in construction that corresponds to division } 5 \text { (ISIC revision 2), tabulation } \\
\text { category F (ISIC revisions 3), and category F of ISIC revision } 4 \text {. }\end{array}$ \\
\hline
\end{tabular}




\begin{tabular}{|c|c|}
\hline Indicator & Definition \\
\hline Employment in Service & $\begin{array}{l}\text { Employment in service includes wholesale and retail trade; repair of motor vehicles and } \\
\text { motorcycles; accommodation and food service activities; transportation and storage; } \\
\text { information and communication; financial and insurance activities; real estate activities; } \\
\text { and other services. }\end{array}$ \\
\hline $\begin{array}{l}\text { Employment in Wholesale and } \\
\text { Retail Trade; Repair of Motor } \\
\text { Vehicles and Motorcycles }\end{array}$ & $\begin{array}{l}\text { Employment in wholesale and retail trade; repair of motor vehicles and motorcycles } \\
\text { that corresponds to division } 6 \text { (subdivisions } 61 \text { and } 62 \text {, ISIC revision 2); tabulation } \\
\text { category G (ISIC revision 3); and category G of ISIC revision } 4 \text {. }\end{array}$ \\
\hline $\begin{array}{l}\text { Employment in Accommodation } \\
\text { and Food Service Activities }\end{array}$ & $\begin{array}{l}\text { Employment in accommodation and food service activities that corresponds to division } \\
6 \text { (subdivision } 63 \text {, ISIC revision 2); tabulation category H (ISIC revision 3); and category } \\
\text { I of ISIC revision } 4 \text {. }\end{array}$ \\
\hline $\begin{array}{l}\text { Employment in Transportation } \\
\text { and Storage }\end{array}$ & $\begin{array}{l}\text { Employment in transport and storage that corresponds to division } 7 \text { (subdivision } 71 \text {, } \\
\text { ISIC revision 2); tabulation category I (sub-categories } 60-63 \text {, ISIC revision 3); and } \\
\text { category } \mathrm{H} \text { of ISIC revision } 4 \text {. }\end{array}$ \\
\hline $\begin{array}{l}\text { Employment in Information and } \\
\text { Communication }\end{array}$ & $\begin{array}{l}\text { Employment in information and communication that corresponds to division } 7 \\
\text { (subdivision } 72 \text {, ISIC revision 2); tabulation category I (subcategory } 64 \text {, ISIC revision } \\
\text { 3); and category J of ISIC revision } 4 \text {. }\end{array}$ \\
\hline $\begin{array}{l}\text { Employment in Financial and } \\
\text { Insurance Activities }\end{array}$ & $\begin{array}{l}\text { Employment in financial and insurance activities that corresponds to division } 8 \\
\text { (subdivisions } 81-82 \text {, ISIC revision } 2 \text { ), tabulation category J (ISIC revision } 3 \text { ), and } \\
\text { category K of ISIC revision } 4 \text {. }\end{array}$ \\
\hline $\begin{array}{l}\text { Employment in Real Estate } \\
\text { Activities }\end{array}$ & $\begin{array}{l}\text { Employment in real estate activities that corresponds to division } 8 \text { (subdivision } 83 \text {, } \\
\text { ISIC revision 2); tabulation category K (subcategory 70, ISIC revision 3); and category } \\
\text { L of ISIC revision } 4 \text {. }\end{array}$ \\
\hline Employment in Other Services & $\begin{array}{l}\text { Employment in other services that corresponds to divisions } 9 \text { and } 0 \text { (ISIC revision } 2 \text { ), } \\
\text { tabulation categories } L \text { to } Q \text { (ISIC revision } 3 \text { ), and categories } M \text { to } U \text { of ISIC revision } 4 \text {. }\end{array}$ \\
\hline \multicolumn{2}{|l|}{ Poverty Indicators } \\
\hline $\begin{array}{l}\text { Proportion of Population below } \\
\$ 1.90 \text { a Day (2011 PPP) }\end{array}$ & $\begin{array}{l}\text { Percentage of the population living on less than } \$ 1.90 \text { a day at } 2011 \text { purchasing power } \\
\text { parity (PPP). }\end{array}$ \\
\hline $\begin{array}{l}\text { Proportion of Population below } \\
\$ 3.20 \text { a Day (2011 PPP) }\end{array}$ & Percentage of the population living on less than $\$ 3.20$ a day at 2011 PPP. \\
\hline $\begin{array}{l}\text { Income Ratio of Highest } 20 \% \text { to } \\
\text { Lowest } 20 \%\end{array}$ & $\begin{array}{l}\text { Income or consumption share that accrues to the richest } 20 \% \text { of the population, divided } \\
\text { by the income or consumption share of the lowest } 20 \% \text { of the population. }\end{array}$ \\
\hline Gini Coefficient or Index & $\begin{array}{l}\text { Measure of the degree to which an economy's income distribution diverges from perfect } \\
\text { equal distribution. A value of zero (0) implies perfect equality while a value of one (1) } \\
\text { implies perfect inequality. }\end{array}$ \\
\hline Human Development Index & $\begin{array}{l}\text { Composite index of long and healthy life (measured by life expectancy at birth), } \\
\text { knowledge (measured by expected years of schooling and mean years of schooling), } \\
\text { and decent standard of living (measured by gross national income per capita in United } \\
\text { States [US] PPP dollars). }\end{array}$ \\
\hline \multicolumn{2}{|l|}{ Social Indicators } \\
\hline Life Expectancy at Birth & $\begin{array}{l}\text { Number of years that a newborn is expected to live if prevailing patterns of mortality } \\
\text { at the time of his or her birth are to stay the same throughout his or her life. }\end{array}$ \\
\hline Crude Birth Rate & $\begin{array}{l}\text { Ratio of the total number of live births in a given period to the midyear total population } \\
\text { of the same period, expressed per } 1,000 \text { people. }\end{array}$ \\
\hline Crude Death Rate & $\begin{array}{l}\text { Ratio of the number of deaths occurring within a given period to the midyear total } \\
\text { population of the same period, expressed per } 1,000 \text { people. }\end{array}$ \\
\hline Total Fertility Rate & $\begin{array}{l}\text { Number of children that would be born to a woman if she were to live to the end of her } \\
\text { childbearingyears and bear children in accordance with current age-specific fertility rates. }\end{array}$ \\
\hline $\begin{array}{l}\text { Primary Education Completion } \\
\text { Rate }\end{array}$ & $\begin{array}{l}\text { Total number of new entrants in the last grade of primary education, regardless of age, } \\
\text { expressed as a percentage of the total population at the theoretical entrance age to the } \\
\text { last grade of primary education. This indicator is also known as "gross intake ratio to } \\
\text { the last grade of primary." The ratio can exceed } 100 \% \text { due to overaged and underaged } \\
\text { children who enter primary school late, early, and/or repeat grades. }\end{array}$ \\
\hline
\end{tabular}




\begin{tabular}{|c|c|}
\hline Indicator & Definition \\
\hline Adult Literacy Rate & $\begin{array}{l}\text { The percentage of the population aged } 15 \text { years and older who can both read and write } \\
\text { (with understanding) a short simple statement on his or her everyday life. Generally, } \\
\text { literacy also encompasses numeracy, i.e., the ability to make simple arithmetic } \\
\text { calculations. }\end{array}$ \\
\hline Primary Pupil-Teacher Ratio & $\begin{array}{l}\text { Average number of pupils (students) per teacher at the primary level of education in a } \\
\text { given school year. This indicator is used to measure the level of human resources input } \\
\text { in terms of number of teachers in relation to the size of the primary pupil population. }\end{array}$ \\
\hline Secondary Pupil-Teacher Ratio & $\begin{array}{l}\text { Average number of pupils (students) per teacher at the secondary level of education in } \\
\text { a given school year. This indicator is used to measure the level of human resources input } \\
\text { in terms of number of teachers in relation to the size of the secondary pupil population. }\end{array}$ \\
\hline Physicians & $\begin{array}{l}\text { Physicians, including general and specialist medical practitioners, expressed in terms } \\
\text { of the number per } 1,000 \text { people. }\end{array}$ \\
\hline Hospital Beds & $\begin{array}{l}\text { In-patient beds for both acute and chronic care available in public, private, general, } \\
\text { and specialized hospitals and rehabilitation centers expressed in terms of the number } \\
\text { per } 1,000 \text { people. }\end{array}$ \\
\hline Number of Adults Living with HIV & $\begin{array}{l}\text { All adults, defined as men and women aged } 15 \text { years and older, with HIV infection, } \\
\text { whether or not they have developed symptoms of AIDS, estimated to be alive at the } \\
\text { end of a specific year. }\end{array}$ \\
\hline \multicolumn{2}{|l|}{ ECONOMY AND OUTPUT } \\
\hline \multicolumn{2}{|l|}{ National Accounts } \\
\hline Gross Domestic Product & $\begin{array}{l}\text { Unduplicated market value of the total production activity of all resident producer units } \\
\text { within the economic territory of a country during a given period. It is calculated without } \\
\text { makingdeductions for depreciation of fabricated assets or for depletion and degradation } \\
\text { of natural resources. Transfer payments are excluded from the calculation of gross } \\
\text { domestic product (GDP). GDP can be calculated using the production, expenditure, } \\
\text { and income approaches. } \\
\text { Production-based GDP is the sum of the gross value added by all resident producers } \\
\text { in the economy, plus any taxes and minus any subsidies not included in the value of } \\
\text { the products. Gross value added is the net output of an industry after adding up all } \\
\text { outputs and subtracting intermediate inputs. } \\
\text { Income-based GDP is the sum of the compensation of employees, mixed income, } \\
\text { operating surplus, consumption of fixed capital, and taxes, less subsidies on production } \\
\text { and imports. } \\
\text { Expenditure-based GDP is the sum of final consumption expenditure of households, } \\
\text { nonprofit institutions serving households, and the government; gross capital formation; } \\
\text { and exports minus imports of goods and services. } \\
\text { GDP can be measured at current prices (the prices of the current reporting period), } \\
\text { and constant prices (obtained by expressing values in terms of a base period and chain } \\
\text { volume measure). }\end{array}$ \\
\hline GDP at PPP & $\begin{array}{l}\text { Measures obtained by using PPP to convert the GDP into a common currency, and by } \\
\text { valuing them at a uniform price level. They are the spatial equivalent of a time series } \\
\text { of GDP for a single country expressed at constant prices. At the level of GDP, they are } \\
\text { used to compare the economic size of countries. }\end{array}$ \\
\hline GDP at Current US Dollar & $\begin{array}{l}\text { GDP at local currency units are obtained from the economy sources and are converted } \\
\text { to US dollars using the official exchange rates from the International Monetary Fund } \\
\text { (IMF). The exchange rates used are expressed as the average rate for a period of time } \\
\text { (average of period), calculated as annual averages based on the monthly averages (local } \\
\text { currency units relative to the US dollar). }\end{array}$ \\
\hline GDP per Capita at PPP & GDP at PPP, divided by the midyear population. \\
\hline
\end{tabular}




\begin{tabular}{|c|c|}
\hline Indicator & Definition \\
\hline GNI per Capita, Atlas Method & $\begin{array}{l}\text { The gross national income (GNI) converted to US dollars using the World Bank Atlas } \\
\text { method, divided by the midyear population. GNI is the sum of value added by all resident } \\
\text { producers, plus any product taxes (less subsidies) not included in the valuation of output, } \\
\text { plus net receipts of primary income (compensation of employees and property income) } \\
\text { from abroad. GNI, calculated in national currency, is usually converted to US dollars } \\
\text { at official exchange rates for comparisons across economies, although an alternative } \\
\text { rate is used when the official exchange rate is judged to diverge by an exceptionally } \\
\text { large margin from the rate actually applied in international transactions. To smooth } \\
\text { fluctuations in prices and exchange rates, a special Atlas method of conversion is used } \\
\text { by the World Bank. This applies a conversion factor that averages the exchange rate } \\
\text { for a given year and the } 2 \text { preceding years, adjusted for differences in rates of inflation } \\
\text { between the country, and through } 2000 \text {, the G-5 countries (France, Germany, Japan, } \\
\text { the United Kingdom, and the US). From } 2001 \text {, these countries include the Euro area, } \\
\text { Japan, the United Kingdom, and the US. }\end{array}$ \\
\hline GDP per Capita at Current US Dollar & GDP at current US dollar value, divided by the midyear population. \\
\hline Agriculture Value Added & $\begin{array}{l}\text { The gross output of the agriculture sector, less the corresponding value of intermediate } \\
\text { consumption. The industrial origin of value added is determined by ISIC revision 4, where } \\
\text { agriculture corresponds to ISIC Section A and includes agriculture, forestry, and fishing. }\end{array}$ \\
\hline Industry Value Added & $\begin{array}{l}\text { The gross output of industry sectors, less the corresponding value of intermediate } \\
\text { consumption. The industrial origin of value added is determined by ISIC revision } 4 \text {, } \\
\text { where industry corresponds to ISIC Sections B-F and includes mining and quarrying (B); } \\
\text { manufacturing(C); electricity, gas, steam, and air-conditioningsupply (D); water supply; } \\
\text { sewerage, waste management, and remediation activities (E); and construction (F). }\end{array}$ \\
\hline Services Value Added & 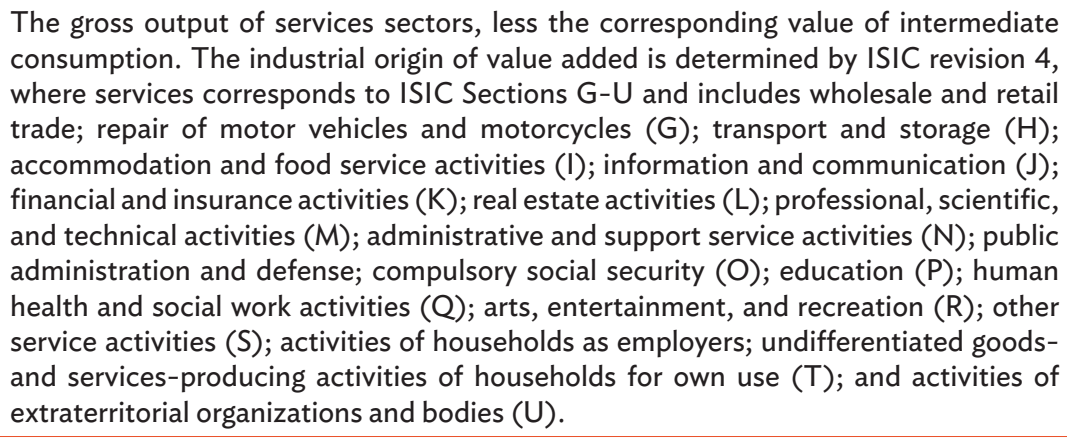 \\
\hline $\begin{array}{l}\text { Household Consumption } \\
\text { Expenditure }\end{array}$ & $\begin{array}{l}\text { Market value of all goods and services, including durable products (such as cars, } \\
\text { washing machines, and home computers), purchased or received as income in kind by } \\
\text { households. It excludes purchases of dwellings, but includes imputed rent for owner- } \\
\text { occupied dwellings. It also includes payments and fees to governments to obtain permits } \\
\text { and licenses. The expenditure of nonprofit institutions serving households is generally } \\
\text { included for most economies. }\end{array}$ \\
\hline $\begin{array}{l}\text { Government Consumption } \\
\text { Expenditure }\end{array}$ & $\begin{array}{l}\text { Includes all current outlays on purchases of goods and services (including wages and } \\
\text { salaries of government employees). It also includes most expenditure on national } \\
\text { defense and security, but excludes government military expenditures that are part of } \\
\text { public investment. }\end{array}$ \\
\hline Gross Capital Formation & $\begin{array}{l}\text { Total value of gross fixed capital formation, changes in inventories, and acquisitions less } \\
\text { disposals of valuables. Gross fixed capital formation is the total value of a producer's } \\
\text { acquisitions, less disposals of tangible goods (such as buildings) and intangible goods } \\
\text { (such as computer software) that are intended for use in production during several } \\
\text { accounting periods, plus certain specified expenditure on services that add to the value } \\
\text { of nonproduced assets. Changes in inventories are changes in stocks of produced goods } \\
\text { and goods for intermediate consumption, and the net increase in the value of work in } \\
\text { progress. Valuables are goods (such as precious metals and works of art) that are not } \\
\text { used in production, but are acquired as stores of value in the expectation that they will } \\
\text { retain or increase their value over time. }\end{array}$ \\
\hline Exports of Goods and Services & $\begin{array}{l}\text { Consist of sales, bartering, or gifts or grants of goods and services from residents to } \\
\text { nonresidents. The treatment of exports in the System of National Accounts is generally } \\
\text { identical with that in the balance of payments accounts as described in the IMF's } \\
\text { Balance of Payments Manual. }\end{array}$ \\
\hline
\end{tabular}




\begin{tabular}{|c|c|}
\hline Indicator & Definition \\
\hline Imports of Goods and Services & $\begin{array}{l}\text { Consist of purchases, bartering, or receipts of gifts or grants of goods and services } \\
\text { by residents from nonresidents. The treatment of imports in the System of National } \\
\text { Accounts is generally identical with that in the balance of payments accounts as } \\
\text { described in the IMF's Balance of Payments Manual. }\end{array}$ \\
\hline Gross Domestic Saving & $\begin{array}{l}\text { Difference between GDP and final consumption expenditure, where final consumption } \\
\text { expenditure is the sum of the final consumption of household, nonprofit institutions } \\
\text { serving households, and the government. }\end{array}$ \\
\hline \multicolumn{2}{|l|}{ Production } \\
\hline Agriculture Production Index & $\begin{array}{l}\text { Relative level of the aggregate volume of agricultural production for each year in } \\
\text { comparison with the base period. It is based on the sum of price-weighted quantities } \\
\text { of different agricultural commodities produced after deductions of quantities used as } \\
\text { seed and feed weighted in a similar manner. The resulting aggregate therefore represents } \\
\text { disposable production for any use, except as seed and feed. }\end{array}$ \\
\hline Manufacturing Production Index & $\begin{array}{l}\text { An index covering production in manufacturing. The exact coverage, the weighting } \\
\text { system, and the methods of calculation vary from country to country, but the divergences } \\
\text { are less important than, for example, in the case of price and wage indexes. }\end{array}$ \\
\hline \multicolumn{2}{|l|}{ MONEY, FINANCE, AND PRICES } \\
\hline \multicolumn{2}{|l|}{ Prices } \\
\hline Consumer Price Index & $\begin{array}{l}\text { An index that measures changes in prices against a reference period of a basket of goods } \\
\text { and services purchased by households. Based on the purpose of the consumer price } \\
\text { index, different baskets of goods and services can be selected. For macroeconomic } \\
\text { purposes, a broad-based basket is used to represent the relative price movement of } \\
\text { household final consumption expenditure. }\end{array}$ \\
\hline $\begin{array}{l}\text { Food and Nonalcoholic } \\
\text { Beverages Price Index }\end{array}$ & $\begin{array}{l}\text { An index that covers food and nonalcoholic beverages purchased by the household } \\
\text { mainly for consumption or preparation at home including services for food processing for } \\
\text { own consumption. The index corresponds to Classification of Individual Consumption } \\
\text { by Purpose (COICOP) Version } 1999 \text { division } 01 \text {. Excluded are food and nonalcoholic } \\
\text { beverages that are provided as part of a food-servingservice under hotels and restaurants } \\
\text { (COICOP division 11). }\end{array}$ \\
\hline $\begin{array}{l}\text { Alcoholic Beverages, Tobacco, } \\
\text { and Narcotics Price Index }\end{array}$ & $\begin{array}{l}\text { An index that covers the purchase of alcoholic beverages, tobacco, and narcotics, } \\
\text { regardless of where these are consumed, but not provided as part of a food-and- } \\
\text { beverage-serving service under hotels and restaurants. Services for the production of } \\
\text { alcohol for own consumption are also included. The index corresponds to COICOP } \\
\text { division } 02 \text {. Excluded are alcoholic beverages purchased for immediate consumption } \\
\text { in hotels, restaurants, cafes, bars, kiosks, street vendors, automatic vending machines, } \\
\text { etc. classified under restaurants, cafes, and the like (COICOP Group 11.1.1). }\end{array}$ \\
\hline Clothing and Footwear Price Index & $\begin{array}{l}\text { An index that covers all clothing materials, garments, articles and accessories, footwear } \\
\text { and related services, including cleaning, repair, and hire of clothing and footwear, } \\
\text { and the purchase of secondhand clothing and footwear. The index corresponds to } \\
\text { COICOP division } 03 \text {. }\end{array}$ \\
\hline $\begin{array}{l}\text { Housing, Water, Electricity, Gas, and Other } \\
\text { Fuels Price Index }\end{array}$ & $\begin{array}{l}\text { An index that covers goods and services for the use of the house or dwelling and its } \\
\text { maintenance and repair; the supply of water and miscellaneous services related to the } \\
\text { dwelling; and energy used for heating or cooling. The index corresponds to COICOP } \\
\text { division 04. }\end{array}$ \\
\hline $\begin{array}{l}\text { Furnishings, Household Equipment, and } \\
\text { Routine Household Maintenance Price } \\
\text { Index }\end{array}$ & $\begin{array}{l}\text { An index that covers a wide range of products to equip the house or dwelling and the } \\
\text { household durables, semidurables, and nondurables as well as some household services. } \\
\text { Includes all kinds of furniture (including lightning equipment, household textiles, } \\
\text { glassware, tableware and household utensils), major and smaller electric household } \\
\text { appliances, tools and equipment for house and garden, and goods for routine household } \\
\text { maintenance. The index also includes the repair, installation, and rental services of } \\
\text { the goods. Domestic services by paid staff in private service, supplied by enterprises } \\
\text { or self-employed persons, window-cleaning and disinfecting services, as well as dry- } \\
\text { cleaning and laundering of household textiles and carpets, are also included. The index } \\
\text { corresponds to COICOP division } 05 \text {. }\end{array}$ \\
\hline
\end{tabular}




\begin{tabular}{|c|c|}
\hline Indicator & Definition \\
\hline Health Price Index & $\begin{array}{l}\text { An index that covers health services provided during an overnight stay, services that } \\
\text { do not require an overnight stay, diagnostic imaging services, medical laboratory } \\
\text { services, patient emergency transportation, and emergency rescue services. The index } \\
\text { also includes medicines and health products, covering all products that are separately } \\
\text { invoiced from health services, except when administered under the direct supervision } \\
\text { of a health care professional during an overnight stay. The index corresponds to } \\
\text { COICOP division } 06 \text {. }\end{array}$ \\
\hline Transport Price Index & $\begin{array}{l}\text { An index that covers four main categories of goods and services for transportation: } \\
\text { (i) purchase of vehicles covers motor cars, motor cycles, bicycles, and animal-drawn } \\
\text { vehicles; (ii) goods and services for the operation of the personal transport equipment } \\
\text { cover parts and accessories for personal transport equipment, fuels and lubricants, and } \\
\text { the repair and maintenance of personal transport equipment including expenditures for } \\
\text { parking spaces in garages or in public places, expenditures for tolls, and expenditures to } \\
\text { acquire a driving certificate; (iii) transport services provided by the market, structured } \\
\text { by the mode of transport; and (iv) transport services of goods covers postal and courier } \\
\text { services, removal and storage services, and the delivery of any kinds of goods when } \\
\text { charged separately. Theindex corresponds to COICOP division 07. It excludes purchases } \\
\text { of recreational vehicles such as camper vans, caravans, trailers, aeroplanes, and boats } \\
\text { that are classified under the Recreation and Culture Price Index. }\end{array}$ \\
\hline Communication Price Index & $\begin{array}{l}\text { An index that covers three main groups of goods and services: (i) information and } \\
\text { communication equipment, including equipment for the capture, recording, and } \\
\text { reproduction of sound and vision; software; and information and communication } \\
\text { services; (ii) information and communication services including telephones and other } \\
\text { communication services, internet access services, television and radio licenses, fee and } \\
\text { subscription services including streaming services of films and music; and (iii) repair, } \\
\text { maintenance, and rental of information and communication equipment. The index } \\
\text { corresponds to COICOP division } 08 \text {. }\end{array}$ \\
\hline Recreation and Culture Price Index & $\begin{array}{l}\text { An index that covers a wide range of goods and services for recreation, sport, and } \\
\text { culture and is structured into eight groups: (i) recreation durables such as photographic } \\
\text { equipment, other major durables for recreation, such as camper vans, boats, yachts, } \\
\text { aeroplanes, and the like; (ii) nonmajor durable recreational goods such as games and } \\
\text { toys, including video game computers, celebration articles, equipment for sport, } \\
\text { camping, and open-air recreation; (iii) garden products and plants and flowers and } \\
\text { purchases of pets and expenditures for pets, excluding veterinary services; (iv) } \\
\text { recreational services cover rental, maintenance, and repair of goods, veterinary and } \\
\text { other services for pets, recreational and leisure services, such as amusement parks, } \\
\text { games of chanceandexpenditures for sporting services, both expenditures for practicing } \\
\text { sports as well as expenditures for attendance of sport events; (v) cultural goods such } \\
\text { as musical instruments and audio-visual media; (vi) cultural services such as cinemas, } \\
\text { theatres, concerts, museums, and other cultural sites, and photographic services; (vii) } \\
\text { newspapers, all kinds of books, stationery and drawing materials; and (viii) package } \\
\text { holidays that include transportation, accommodation, food provision, or tour guide. } \\
\text { The index corresponds to COICOP division 09. }\end{array}$ \\
\hline Education Price Index & $\begin{array}{l}\text { An index that covers educational services only. It includes: (i) education by radio } \\
\text { or television broadcasting as well as e-learning and correspondence courses; (ii) } \\
\text { admission and registration fees as well as tuition fees; and (iii) other education-related } \\
\text { fees such as camps and/or field trips, course fees, diploma fees, examination fees, } \\
\text { graduation fees, laboratory fees, physical education fees, etc. The index corresponds } \\
\text { to COICOP division 10. It excludes expenditures on other education-related goods } \\
\text { and services such as school uniforms, education support services, such as health-care } \\
\text { services, transport services (except in the case of excursions that are part of the normal } \\
\text { school program), text books and academic journals, stationery, catering services, and } \\
\text { accommodation services. }\end{array}$ \\
\hline Restaurants and Hotels Price Index & $\begin{array}{l}\text { An index that covers services provided by restaurants, cafes, and similar facilities, either } \\
\text { with full or limited- or self-service, or by canteens, cafeterias, or refectories at work } \\
\text { or at school and other educational establishment's premises. It also includes catering } \\
\text { services and accommodation services. The index corresponds to COICOP division } 11 .\end{array}$ \\
\hline
\end{tabular}




\begin{tabular}{|c|c|}
\hline Indicator & Definition \\
\hline $\begin{array}{l}\text { Miscellaneous Goods and } \\
\text { Services Price Index }\end{array}$ & $\begin{array}{l}\text { An index that covers insurance and financial services. It also includes personal care, } \\
\text { prostitution, personal effects not elsewhere classified, social protection, financial } \\
\text { services not elsewhere classified, and other services not elsewhere classified. The index } \\
\text { corresponds to COICOP division } 12 \text {. }\end{array}$ \\
\hline Wholesale Price Index & $\begin{array}{l}\text { A measure that reflects changes in the prices paid for goods at various stages of } \\
\text { distribution up to the point of retail. It can include prices of raw materials for intermediate } \\
\text { and final consumption, prices of intermediate or unfinished goods, and prices of finished } \\
\text { goods. The goods are usually valued at purchasers' prices. }\end{array}$ \\
\hline Producer Price Index & $\begin{array}{l}\text { A measure of the change in the prices of goods and services, either as they leave their } \\
\text { place of production or as they enter the production process. A measure of the change } \\
\text { in the prices received by domestic producers for their outputs or of the change in the } \\
\text { prices paid by domestic producers for their intermediate inputs. }\end{array}$ \\
\hline GDP Deflator & $\begin{array}{l}\text { A measure of the annual rate of price change in the economy as a whole for the period } \\
\text { shown, obtained by dividing GDP at current prices by GDP at constant prices. }\end{array}$ \\
\hline \multicolumn{2}{|l|}{ Money and Finance } \\
\hline Money Supply & $\begin{array}{l}\text { Refers to the total amount of money in circulation in a specific country. Money supply } \\
\text { can be measured in different ways: } \\
M 1 \text { (Narrow Money) is a measure of money supply that includes all coins and notes } \\
\text { (M0) as well as personal money in current accounts. M2 (Intermediate Money) is the } \\
\text { sum of } M 1 \text { and personal money in deposit accounts. M3 (Broad Money) is the sum of } \\
M 2 \text { and government and other deposits. According to the Organization for Economic } \\
\text { Co-operation and Development, M3 includescurrency, deposits with an agreed maturity } \\
\text { of up to } 2 \text { years, deposits redeemable at notice of up to } 3 \text { months and repurchase } \\
\text { agreements, money market fund shares or units, and debt securities up to } 2 \text { years. } \\
\text { Not all countries publish the same types of aggregates, and even when aggregates are the } \\
\text { same name (e.g., M1, M2, M3, etc.), their asset composition often differs significantly. } \\
\text { Cross-country differences in national definitions of lowered-ordered aggregates also } \\
\text { arise from differences in the maturity categories of nontransferable deposits included } \\
\text { in a particular money aggregate. For example, the definition of } M 2 \text { in one country may } \\
\text { include time deposits with maturities of } 1 \text { year or less, whereas another country's } M 2 \\
\text { definition may include time deposits with maturities of } 2 \text { years or less. } \\
\text { When the monetary policystrategy consists of monetary aggregate targeting, the choice } \\
\text { of the definition of the targeted aggregate is guided mainly by two considerations. The } \\
\text { aggregate should be sufficiently sensitive to interest rate changes for the central bank } \\
\text { to be able to control it and display a stable relationship over time to the movement of } \\
\text { the overall price level. }\end{array}$ \\
\hline Interest Rate on Savings Deposits & Rate paid by commercial and similar banks for savings deposits. \\
\hline Interest Rate on Time Deposits & Rate paid by commercial and similar banks for time deposits. \\
\hline Lending Interest Rate & $\begin{array}{l}\text { Bank rate that usually meets the short-and medium-term financing needs of the private } \\
\text { sector. This rate is normally differentiated according to creditworthiness of borrowers } \\
\text { and objectives of financing. }\end{array}$ \\
\hline Yield on Short-Term Treasury Bills & Rate at which short-term securities are issued or traded in the market. \\
\hline Domestic Credit Provided by Banking Sector & $\begin{array}{l}\text { Includes all credits to various sectors on a gross basis, except credit to the central } \\
\text { government, which is net. The banking sector includes monetary authorities, deposit } \\
\text { money banks, and other banking institutions for which data are available (including } \\
\text { institutions that do not accept transferable deposits but do incur such liabilities as time } \\
\text { and savings deposits). Examples of other banking institutions are savings and mortgage } \\
\text { loan institutions and building and loan associations. }\end{array}$ \\
\hline $\begin{array}{l}\text { Ratio of Bank Nonperforming Loans to Total } \\
\text { Gross Loans }\end{array}$ & $\begin{array}{l}\text { Value of nonperforming loans divided by the total value of the loan portfolio (including } \\
\text { nonperformingloans before the deduction of loan loss provisions). The amount recorded } \\
\text { as nonperforming should be the gross value of the loan as recorded in the balance sheet, } \\
\text { not just the amount that is overdue. }\end{array}$ \\
\hline Stock Market Price Index & $\begin{array}{l}\text { Index that measures changes in the prices of stocks traded in the stock exchange. The } \\
\text { price changes of the stocks are usually weighted by their market capitalization. }\end{array}$ \\
\hline
\end{tabular}




\begin{tabular}{|c|c|}
\hline Indicator & Definition \\
\hline Stock Market Capitalization & $\begin{array}{l}\text { The share price multiplied by the number of shares outstanding (including their various } \\
\text { classes) for listed domestic companies. Investment funds, unit trusts, and companies } \\
\text { whose only business goal is to hold shares of other listed companies are excluded. Data } \\
\text { are end-of-yearvalues converted to US dollars using correspondingend-of-year foreign } \\
\text { exchange rates. Also known as market value. }\end{array}$ \\
\hline \multicolumn{2}{|l|}{ Exchange Rates } \\
\hline Official Exchange Rate & $\begin{array}{l}\text { The exchange rate determined by national authorities or the rate determined in the } \\
\text { legally sanctioned exchange market. It is calculated as an annual average based on the } \\
\text { monthly averages (local currency units relative to the US dollar). }\end{array}$ \\
\hline Purchasing Power Parity Conversion Factor & $\begin{array}{l}\text { Number of units of country B's currency that are needed in country B to purchase the } \\
\text { same quantity of an individual good or service, which one unit of country A's currency } \\
\text { can purchase in country A. }\end{array}$ \\
\hline Price Level Index & $\begin{array}{l}\text { Ratio of the relevant PPP to the exchange rate. It is expressed as an index on a base of } \\
\text { 100. A price level index (PLI) greater than } 100 \text { means that, when the national average } \\
\text { prices are converted at exchange rates, the resulting prices tend to be higher on average } \\
\text { than prices in the base country (or countries) of the region (and vice versa). At the } \\
\text { level of GDP, PLIs provide a measure of the differences in the general price levels of } \\
\text { countries. PLIs are also referred to as comparative price levels. }\end{array}$ \\
\hline \multicolumn{2}{|l|}{ GLOBALIZATION } \\
\hline \multicolumn{2}{|l|}{ Balance of Payments } \\
\hline Trade in Goods Balance & Difference between exports and imports of goods. \\
\hline Trade in Services Balance & Difference between exports and imports of services. \\
\hline Current Account Balance & Sum of net exports of goods, services, net income, and net current transfers. \\
\hline $\begin{array}{l}\text { Workers' Remittances and Compensation } \\
\text { of Employees, Receipts }\end{array}$ & $\begin{array}{l}\text { Consist of } \\
\text { (i) Current transfers from migrant workers who are residents of the host country to } \\
\text { recipients in their country of origin. To count as a resident, the worker must have } \\
\text { been living in the host country for more than } 1 \text { year. } \\
\text { (ii) Compensation of employees of migrants who have lived in the host country for } \\
\text { less than } 1 \text { year. } \\
\text { (iii) Migrants' transfers, defined as the net worth of migrants who are expected to } \\
\text { remain in the host country for more than } 1 \text { year, which are transferred from one } \\
\text { country to another at the time of migration. }\end{array}$ \\
\hline Foreign Direct Investment & $\begin{array}{l}\text { Refers to net inflows of investment to acquire a lasting management interest ( } 10 \% \\
\text { or more of voting stock) in an enterprise operating in an economy other than that of } \\
\text { the investor. It is the sum of equity capital, reinvestment of earnings, other long-term } \\
\text { capital, and short-term capital as shown in the balance of payments. }\end{array}$ \\
\hline \multicolumn{2}{|l|}{ External Trade } \\
\hline Merchandise Exports or Imports & $\begin{array}{l}\text { Covering all movable goods, with a few specified exceptions, the ownership of which } \\
\text { changes between a resident and a foreigner. For merchandise exports, it represents } \\
\text { the value of the goods and related distributive services at the customs frontier of the } \\
\text { exporting economy, i.e., the free on board (FOB) value. Merchandise imports, on the } \\
\text { other hand, are reported in cost, insurance, and freight (CIF) values. }\end{array}$ \\
\hline Trade in Goods & Sum of merchandise exports and merchandise imports. \\
\hline \multicolumn{2}{|l|}{ Direction of Trade } \\
\hline $\begin{array}{l}\text { Direction of Trade: Merchandise Exports } \\
\text { and Imports }\end{array}$ & $\begin{array}{l}\text { The direction of trade represents the value of merchandise exports and imports } \\
\text { disaggregated according to a country's primary trading partners. Imports are reported } \\
\text { on a CIF basis and exports are reported on an FOB basis, with the exception of a few } \\
\text { countries for which imports are also available FOB. Time series data includes estimates } \\
\text { derived from reports of partner countries for nonreporting and slow-reporting countries. }\end{array}$ \\
\hline
\end{tabular}




\begin{tabular}{|c|c|}
\hline Indicator & Definition \\
\hline \multicolumn{2}{|l|}{ International Reserves } \\
\hline International Reserves & $\begin{array}{l}\text { External assets that are readily available to, and controlled by, monetary authorities for } \\
\text { meeting balance-of-payments financing needs, for intervention in exchange markets to } \\
\text { affect the currency exchange rate, and for other related purposes (such as maintaining } \\
\text { confidence in the currency and the economy, and serving as a basis for foreign borrowing). } \\
\text { Consist of monetary gold, special drawing rights holdings, reserve position in the IMF, } \\
\text { currency and deposits, securities (including debt and equity securities), financial } \\
\text { derivatives, and other claims (loans and other financial instruments). }\end{array}$ \\
\hline Ratio of International Reserves to Imports & $\begin{array}{l}\text { International reserves outstanding at the end of the year as a proportion of imports } \\
\text { of goods from the balance of payments during the year, where imports of goods are } \\
\text { expressed in terms of a monthly average. It is a useful measure for reserve needs of } \\
\text { countries with limited access to capital markets. }\end{array}$ \\
\hline \multicolumn{2}{|l|}{ Capital Flows } \\
\hline Net Official Development Assistance & $\begin{array}{l}\text { Concessional flows to developing economies and multilateral institutions provided by } \\
\text { official agencies, including state and local governments, or by their executing agencies, } \\
\text { administered with the objective of promoting the economic development and welfare } \\
\text { of developing economies, and containing a grant element of at least } 25 \% \text {. Net flow } \\
\text { takes into account principal repayments for loans, offsetting entries for forgiven debt, } \\
\text { and recoveries made on grants. }\end{array}$ \\
\hline Net Other Official Flows & $\begin{array}{l}\text { Official sector transactions with countries on the Development Assistance Committee } \\
\text { List of Official Development Assistance Recipients, which do not meet the conditions } \\
\text { for eligibility as official development assistance, either because they are not primarily } \\
\text { aimed at development, or because they have a grant element of less than } 25 \% \text {. The } \\
\text { Development Assistance Committee list of recipients of official development assistance } \\
\text { is available at http://www.oecd.org/dac/financing-sustainable-development/ } \\
\text { development-finance-standards/daclist.htm. Net flow takes into account principal } \\
\text { repayments forloans, offsettingentries forforgiven debt, and recoveries made on grants. }\end{array}$ \\
\hline Net Private Flows & $\begin{array}{l}\text { Sum of direct investment and portfolio investment. } \\
\text { Direct investment is a category of international investment made by a resident entity } \\
\text { in one economy (direct investor) with the objective of establishing a lasting interest } \\
\text { in an enterprise that is resident in an economy other than that of the investor (direct } \\
\text { investment enterprise). "Lasting interest" implies the existence of a long-term } \\
\text { relationship between the direct investor and the enterprise and a significant degree of } \\
\text { influence by the direct investor on the management of the direct investment enterprise. } \\
\text { Direct investment involves both the initial transaction between the two entities and all } \\
\text { subsequent capital transactions between them and among affiliated enterprises, both } \\
\text { incorporated and unincorporated. } \\
\text { Portfolio investment is the category of international investment that covers investment } \\
\text { in equity and debt securities, excluding any such instruments that are classified as direct } \\
\text { investment or reserve assets. }\end{array}$ \\
\hline Aggregate Net Resource Flows & Sum of net official development assistance, net other official flows, and net private flows. \\
\hline \multicolumn{2}{|l|}{ External Indebtedness } \\
\hline Total External Debt & $\begin{array}{l}\text { Debt owed to nonresidents repayable in currency, goods, or services. It is the sum } \\
\text { of public, publicly guaranteed, and private nonguaranteed long-term debt, use of } \\
\text { IMF credit, and short-term debt. Short-term debt includes all debt having an original } \\
\text { maturity of } 1 \text { year or less and interest in arrears on long-term debt. }\end{array}$ \\
\hline Public and Publicly Guaranteed Debt & $\begin{array}{l}\text { Comprises long-term external obligations of public debtors, including the national } \\
\text { government, political subdivisions (or an agency of either), and autonomous public } \\
\text { bodies, and external obligations of private debtors that are guaranteed for repayment } \\
\text { by a public entity. }\end{array}$ \\
\hline External Debt as a Percentage of GNI & $\begin{array}{l}\text { Total external debt as a percentage of GNI. } \\
\text { GNI is the sum of value added by all resident producers plus any product taxes (less } \\
\text { subsidies) not included in the valuation of output, plus net receipts of primary income } \\
\text { (compensation of employees and property income) from abroad. }\end{array}$ \\
\hline
\end{tabular}




\begin{tabular}{|c|c|}
\hline Indicator & Definition \\
\hline $\begin{array}{l}\text { External Debt as a Percentage of Exports of } \\
\text { Goods and Services and Primary Income }\end{array}$ & $\begin{array}{l}\text { Total external debt as a percentage of exports of goods, services, and primary income. } \\
\text { Exports of goods, services, and primary income constitute the total value of exports of } \\
\text { goods and services, receipts of compensation of nonresident workers, and investment } \\
\text { income from abroad. }\end{array}$ \\
\hline Total Debt Service Paid & $\begin{array}{l}\text { The sum of principal repayments and interest actually paid in currency, goods, or services } \\
\text { on long-term debt, interest paid on short-term debt, and repayments (repurchases } \\
\text { and charges) to the IMF. }\end{array}$ \\
\hline $\begin{array}{l}\text { Total Debt Service Paid as a Percentage of } \\
\text { Exports of Goods and Services and Primary } \\
\text { Income }\end{array}$ & Total debt service paid as a percentage of exports of goods, services, and primary income. \\
\hline \multicolumn{2}{|l|}{ Tourism } \\
\hline International Tourist Arrivals & $\begin{array}{l}\text { The number of tourists (overnight visitors) who travel to a country other than that in } \\
\text { which they usually reside, and outside their usual environment, for a period not exceeding } \\
12 \text { months, and whose main purpose of visit is other than the activity remunerated } \\
\text { from within the country visited. In some cases, data may also include same-day visitors } \\
\text { when data on overnight visitors are not available separately. Data refer to the number } \\
\text { of arrivals and not to the number of people. }\end{array}$ \\
\hline International Tourism, Receipts & $\begin{array}{l}\text { The receipts earned by a destination country from inbound tourism and covering all } \\
\text { tourism receipts resulting from expenditures made by visitors from abroad. These include } \\
\text { lodging, food and drinks, fuel, transport in the country, entertainment, shopping, etc. } \\
\text { This concept includes receipts generated by overnight visits as well as by same-day trips. } \\
\text { It does, however, exclude the receipts related to international transport by contracted } \\
\text { residents of the other countries (for instance ticket receipts from foreigners travelling } \\
\text { with a national company). }\end{array}$ \\
\hline \multicolumn{2}{|l|}{ TRANSPORT AND COMMUNICATIONS } \\
\hline \multicolumn{2}{|l|}{ Transport } \\
\hline Road Traffic Deaths & $\begin{array}{l}\text { Death caused by a road traffic crash and occurring within } 24 \text { hours (the Federated States } \\
\text { of Micronesia, Kiribati, Solomon Islands, Timor-Leste, Tonga ); } 7 \text { days (Azerbaijan, } \\
\text { Bhutan, the People's Republic of China, Tajikistan, Turkmenistan, Viet Nam); } 30 \text { days } \\
\text { (Armenia, Australia, Cambodia, Fiji, India, Indonesia, Japan, Kazakhstan, the Republic } \\
\text { of Korea, the Lao People's Democratic Republic, Malaysia, Mongolia, Myanmar, Nepal, } \\
\text { New Zealand, Papua New Guinea, Singapore, Sri Lanka, Uzbekistan); unlimited time } \\
\text { period (Afghanistan, the Cook Islands, Georgia, Maldives, the Philippines, Samo, } \\
\text { Thailand); within a year (the Kyrgyz Republic); no definition for other countries. }\end{array}$ \\
\hline Road Network & $\begin{array}{l}\text { Refers to the Asian Highway that consists of highway routes of international importance } \\
\text { within Asia, including highway routes substantially crossing more than one subregion; } \\
\text { highway routes within subregions that connect neighboring subregions; and highway } \\
\text { routes located within member states that provide access to: (a) capital cities; (b) main } \\
\text { industrial and agricultural centers; (c) major air, sea, and river ports; (d) major container } \\
\text { terminals and depots; and (e) major tourist attractions. }\end{array}$ \\
\hline Motor Vehicles & Include cars, buses, freight vehicles, and two- and three-wheeled vehicles. \\
\hline Container Port Traffic & $\begin{array}{l}\text { Measures the flow of containers from land to sea transport modes, and vice versa, in 20- } \\
\text { foot equivalent units, a standard-size container. Data refer to coastal shipping as well as } \\
\text { international journeys. Transshipment traffic is counted as two lifts at the intermediate } \\
\text { port (once to offload and again as an outbound lift) and includes empty units. }\end{array}$ \\
\hline Air Transport, Passengers Carried & $\begin{array}{l}\text { Air passengers carried include both domestic and international aircraft passengers of } \\
\text { air carriers registered in the country. }\end{array}$ \\
\hline $\begin{array}{l}\text { Air Transport, Carrier Departures } \\
\text { Worldwide }\end{array}$ & $\begin{array}{l}\text { Registered carrier departures worldwide are domestic takeoffs and takeoffs abroad of } \\
\text { air carriers registered in the country. }\end{array}$ \\
\hline Air Transport, Freight & $\begin{array}{l}\text { Air freight is the volume of freight, express, and diplomatic bags carried on each flight } \\
\text { stage (operation of an aircraft from takeoff to its next landing), measured in metric } \\
\text { tons multiplied by kilometers traveled. }\end{array}$ \\
\hline Rail Lines & $\begin{array}{l}\text { Rail lines are the length of railway route available for train service, irrespective of the } \\
\text { number of parallel tracks. }\end{array}$ \\
\hline Rail Network & Length of rail lines divided by the land area. \\
\hline
\end{tabular}




\begin{tabular}{|c|c|}
\hline Indicator & Definition \\
\hline Railways, Passengers Carried & $\begin{array}{l}\text { Passengers carried by railway are the number of passengers transported by rail multiplied } \\
\text { by kilometers traveled. }\end{array}$ \\
\hline Railways, Goods Transported & $\begin{array}{l}\text { Goods transported by railway are the volume of goods transported by railway, measured } \\
\text { in metric tons multiplied by kilometers traveled. }\end{array}$ \\
\hline \multicolumn{2}{|l|}{ Communications } \\
\hline Telephone Subscribers & $\begin{array}{l}\text { Fixed-telephone subscriptions refer to the sum of active number of analogue fixed } \\
\text { telephone lines, voice-over-IP subscriptions, fixed wireless local loop subscriptions, } \\
\text { ISDN voice-channel equivalents, and fixed public payphones. }\end{array}$ \\
\hline Mobile Phone Subscribers & $\begin{array}{l}\text { The proportion of individuals who used a mobile telephone in the } 3 \text { months prior to } \\
\text { data collection. } \\
\text { A mobile (cellular) telephone refers to a portable telephone subscribing to a public } \\
\text { mobile telephone service using cellular technology, which provides access to the PSTN. } \\
\text { This includes analogue and digital cellular systems and technologies such as IMT-2000 } \\
\text { (3G) and IMT- Advanced. Users of both postpaid subscriptions and prepaid accounts } \\
\text { are included. }\end{array}$ \\
\hline Fixed-Broadband Subscribers & $\begin{array}{l}\text { Fixed-broadband subscriptions refer to fixed subscriptions to high-speed access to the } \\
\text { publicinternet (a TCP/IP connection), at downstream speeds equal to, or greater than, } \\
256 \text { kilobits per second. This includes cable modem, DSL, fiber-to-the-home/building, } \\
\text { other fixed (wired)- broadband subscriptions, satellite broadband and terrestrial fixed } \\
\text { wireless broadband. This total is measured irrespective of the method of payment. } \\
\text { It excludes subscriptions that have access to data communications (including the } \\
\text { Internet) via mobile-cellular networks. It should include fixed WiMAX and any other } \\
\text { fixed wireless technologies. It includes both residential subscriptions and subscriptions } \\
\text { for organizations. }\end{array}$ \\
\hline Internet Users & $\begin{array}{l}\text { The frequency of internet use by individuals who used the internet from any location } \\
\text { in the } 3 \text { months prior to data collection. } \\
\text { The internet can be used via a personal computer, digital tablet device, mobile or cell } \\
\text { phone, personal digital assistant, games machine, digital television, etc. }\end{array}$ \\
\hline \multicolumn{2}{|l|}{ ENERGY AND ELECTRICITY } \\
\hline \multicolumn{2}{|l|}{ Energy } \\
\hline GDP per Unit of Energy Use & $\begin{array}{l}\text { The ratio of GDP to total energy use (measured per petajoule) with GDP converted } \\
\text { to } 2011 \text { constant international dollars using PPP rates. An international dollar has the } \\
\text { same purchasing power over GDP as a US dollar has in the US. }\end{array}$ \\
\hline Energy Production & $\begin{array}{l}\text { Primary energy production that is the capture or extraction of fuels or energy from } \\
\text { natural energy flows, the biosphere, and natural reserves of fossil fuels within the national } \\
\text { territory in a form suitable for use. Inert matter removed from the extracted fuels and } \\
\text { quantities reinjected, flared, or vented are not included. The resulting products are } \\
\text { referred to as primary products. }\end{array}$ \\
\hline Energy Use & $\begin{array}{l}\text { Energy production plus imports minus exports, minus international marine bunkers, } \\
\text { minus international aviation bunkers, minus stock changes. Also referred to as energy } \\
\text { supply. }\end{array}$ \\
\hline Energy Imports, Net & Energy imports, net estimated as energy use less production, both measured in petajoules. \\
\hline \multicolumn{2}{|l|}{ Electricity } \\
\hline Electricity Production & $\begin{array}{l}\text { Gross production, which is the sum of the electrical energy production by all the } \\
\text { generating units and/or installations concerned (including pumped storage), measured } \\
\text { at the output terminals of the main generators. Also referred to as electricity generation. }\end{array}$ \\
\hline
\end{tabular}




\begin{tabular}{|c|c|}
\hline Indicator & Definition \\
\hline Sources of Electricity & $\begin{array}{l}\text { Refers to the different types of technology and/or processes for the generation or } \\
\text { production of electricity, including: (i) electricity from combustible fuels, which refers } \\
\text { to the production of electricity from the combustion of fuels that are capable of igniting } \\
\text { or burning, i.e., reacting with oxygen to produce a significant rise in temperature; (ii) } \\
\text { hydroelectricity, which refers to electricity produced from devices driven by fresh, } \\
\text { flowing, or falling water; (iii) nuclear electricity, which refers to electricity generated } \\
\text { by nuclear plants; and (iv) other electricity, which includes solar, wind, wave, tidal, } \\
\text { other marine electricity, geothermal, electricity generated from chemical heat, and } \\
\text { electricity from other sources not elsewhere specified. }\end{array}$ \\
\hline Electric Power Consumption Per Capita & $\begin{array}{l}\text { Total electricity consumption divided by midyear population, where consumption refers } \\
\text { to energy-industries-own-use and final consumption. Energy-industries-own-use refers } \\
\text { to the consumption of electricity for the direct support of the production and preparation } \\
\text { for use of fuels and energy. Final consumption refers to the consumption of electricity } \\
\text { by manufacturing, construction and nonfuel mining, transport, and households and } \\
\text { other consumers (nonenergy use being irrelevant for electricity). }\end{array}$ \\
\hline Household Electrification Rate & Percentage of households with an electricity connection. \\
\hline \multicolumn{2}{|l|}{ ENVIRONMENT } \\
\hline \multicolumn{2}{|l|}{ Land } \\
\hline Agricultural Land or Area & $\begin{array}{l}\text { Land area that is arable, under permanent crops, and/or under permanent meadows } \\
\text { and pastures. }\end{array}$ \\
\hline Arable Land & $\begin{array}{l}\text { Land under temporary agricultural crops (double-cropped areas are counted only once), } \\
\text { temporary meadows for mowing or pasture, land under market, and kitchen gardens } \\
\text { and land temporarily fallow (less than } 5 \text { years). The abandoned land resulting from } \\
\text { shifting cultivation is not included. Data for arable land are not meant to indicate the } \\
\text { amount of land that are potentially cultivable. }\end{array}$ \\
\hline Permanent Cropland & $\begin{array}{l}\text { Land cultivated with long-term crops that do not have to be replanted for several } \\
\text { years (such as cocoa and coffee); land under trees and shrubs producing flowers, } \\
\text { such as roses and jasmine; and nurseries (except those for forest trees, which should } \\
\text { be classified under "forestry"). Permanent meadows and pastures are excluded from } \\
\text { land under permanent crops. }\end{array}$ \\
\hline Deforestation Rate & $\begin{array}{l}\text { Rate of permanent conversion of natural forest area into other uses, including } \\
\text { shifting cultivation, permanent agriculture, ranching, settlements, and infrastructure } \\
\text { development. Deforested areas do not includeareas logged but intended for regeneration } \\
\text { or areas degraded by fuel-wood gathering, acid precipitation, or forest fires. A negative } \\
\text { rate indicates reforestation or increase in forest area. }\end{array}$ \\
\hline \multicolumn{2}{|l|}{ Pollution } \\
\hline Carbon Dioxide Emissions & $\begin{array}{l}\text { Carbon dioxide emissions, largely by-products of energy production and use, account } \\
\text { for the largest share of greenhouse gases, which are associated with global warming. } \\
\text { Anthropogenic carbon dioxide emissions result primarily from fossil fuel combustion } \\
\text { and cement manufacturing. In combustion, different fossil fuels release different } \\
\text { amounts of carbon dioxide for the same level of energy used: oil releases about } 50 \% \\
\text { more carbon dioxide than natural gas, while coal releases about twice as much. Cement } \\
\text { manufacturing releases about half a metric ton of carbon dioxide for each metric ton of } \\
\text { cement produced. Data for carbon dioxide emissions include gases from the burning } \\
\text { of fossil fuels and cement manufacture but excludes emissions from land use such as } \\
\text { deforestation. }\end{array}$ \\
\hline Nitrous Oxide Emissions & $\begin{array}{l}\text { Nitrous oxide emissions are mainly from fossil fuel combustion, fertilizers, rainforest } \\
\text { fires, and animal waste. Nitrous oxide is a powerful greenhouse gas, with an estimated } \\
\text { atmospheric lifetime of } 114 \text { years, compared with } 12 \text { years for methane. The per- } \\
\text { kilogram global warming potential of nitrous oxide is nearly } 310 \text { times that of carbon } \\
\text { dioxide within } 100 \text { years. }\end{array}$ \\
\hline Methane Emissions & $\begin{array}{l}\text { Methane emissions are those stemming from human activities such as agriculture and } \\
\text { from industrial methane production. A kilogram of methane is } 21 \text { times as effective at } \\
\text { trapping heat in the earth's atmosphere as a kilogram of carbon dioxide within } 100 \text { years. }\end{array}$ \\
\hline Other Greenhouse Gases & By-product emissions of hydrofluorocarbons, perfluorocarbons, and sulfur hexafluoride. \\
\hline
\end{tabular}




\begin{tabular}{|c|c|}
\hline Indicator & Definition \\
\hline \multicolumn{2}{|l|}{ Freshwater } \\
\hline Internal Renewable Water Resources & $\begin{array}{l}\text { Internal renewable water resources (IRWR) refer to the long-term average annual flow } \\
\text { of rivers and recharge of aquifers generated from endogenous precipitation. Double- } \\
\text { counting of surface water and groundwater resources is avoided by deducting the } \\
\text { overlap from the sum of the surface water and groundwater resources. } \\
\text { IRWR in billion cubic meters per year refers to surface water produced internally, plus } \\
\text { groundwater produced internally deducted by the overlap between surface water and } \\
\text { groundwater. IRWR in cubic meters per inhabitant per year is calculated as total annual } \\
\text { IRWR divided by total population. }\end{array}$ \\
\hline Annual Freshwater Withdrawals & $\begin{array}{l}\text { Sum of surface water withdrawal and groundwater withdrawal. } \\
\text { Total water withdrawal summed by sector deducted by: desalinated water produced, } \\
\text { direct use of treated wastewater, and direct use of agricultural drainage water. }\end{array}$ \\
\hline Water Productivity & $\begin{array}{l}\text { Water productivity is the ratio of the net benefits from crop, forestry, fishery, livestock, } \\
\text { and mixed agricultural systems to the amount of water used to produce those benefits. It is } \\
\text { calculated as GDP in constant US dollar prices, divided by annual total water withdrawal. }\end{array}$ \\
\hline \multicolumn{2}{|l|}{ GOVERNMENT AND GOVERNANCE } \\
\hline \multicolumn{2}{|l|}{ Government Finance } \\
\hline Government Net Lending / Net Borrowing & $\begin{array}{l}\text { Net lending }(+) / \text { net borrowing }(-) \text { is a summary measure indicating the extent to which } \\
\text { government is either putting financial resources at the disposal of other sectors in the } \\
\text { economy or abroad, or utilizing the financial resources generated by other sectors in } \\
\text { the economy or resources from abroad. It may be viewed as an indicator of the financial } \\
\text { impact of government activity on the rest of the economy and the rest of the world. } \\
\text { Net lending (+) / net borrowing (-) is a balancing item calculated as the net operating } \\
\text { balance (revenue minus expense) minus the net investment in nonfinancial assets. It } \\
\text { is also equal to the net acquisition of all financial assets minus the net incurrence of all } \\
\text { liabilities from transactions. } \\
\text { For economies following the IMF's Government Finance Statistics } 1986 \text { framework, } \\
\text { the indicator refers to the overall budgetary surplus/deficit measured as the difference } \\
\text { between total revenue (including grants) and total expenditure (including net lending). }\end{array}$ \\
\hline Government Taxes & $\begin{array}{l}\text { Taxes are compulsory, unrequited amounts receivable by government units from } \\
\text { institutional units. Certain compulsory receivables, such as fines, penalties, and most } \\
\text { social security contributions are not considered to be taxes. } \\
\text { For economies following the IMF's Government Finance Statistics } 1986 \text { framework, } \\
\text { tax revenues are compulsory transfers to the central government for public purposes, } \\
\text { which includes social security contributions. }\end{array}$ \\
\hline Government Revenue & $\begin{array}{l}\text { Government revenue is an increase in net worth resulting from a transaction. Revenue } \\
\text { transactions have counterpart entries either in an increase in assets or in a decrease } \\
\text { in liabilities, thereby increasing net worth. General government units have four types } \\
\text { of revenue: (i) compulsory levies in the form of taxes and certain types of social } \\
\text { contributions; (ii) property income derived from the ownership of assets; (iii) sales of } \\
\text { goods and services; and (iv) other transfers receivable from other units. } \\
\text { Foreconomies following the IMF's Government FinanceStatistics } 1986 \text { framework, total } \\
\text { revenue (including grants) consists of current and capital revenues. Current revenue is } \\
\text { the revenue accruing from taxes as well as all current nontax revenues, except transfers } \\
\text { received from foreign governments and international institutions. Capital revenue } \\
\text { constitutes the proceeds from the sale of nonfinancial capital assets. }\end{array}$ \\
\hline
\end{tabular}




\begin{tabular}{|c|c|}
\hline Indicator & Definition \\
\hline Government Expenditure & $\begin{array}{l}\text { Government expenditure is the sum of expense and the net investment in nonfinancial } \\
\text { assets. } \\
\text { Expense is a decrease in net worth resulting from a transaction. The major types of } \\
\text { expense are compensation of employees, use of goods and services subsidies, grants, } \\
\text { social benefits, and other expense. The acquisition of a nonfinancial asset by purchase } \\
\text { or barter is not an expense because it has no effect on net worth. Similarly, amounts } \\
\text { payable on loans extended and repayments on loans incurred arenot classified as expense. } \\
\text { Nonfinancial assets are economic assets other than financial assets. Nonfinancial assets } \\
\text { are stores of value and provide benefits either through their use in the production of } \\
\text { goods and services or in the form of property income and holding gains. These assets } \\
\text { are classified as fixed assets, inventories, valuables, and nonproduced assets. } \\
\text { For economies following the IMF's Government Finance Statistics } 1986 \text { framework, } \\
\text { total expenditure (including net lending) consists of current and capital expenditures. } \\
\text { Current expenditure comprises purchases of goods and services by the central } \\
\text { government, transfers to noncentral government units and to households, subsidies } \\
\text { to producers, and interest on public debt. Capital expenditure covers outlays for the } \\
\text { acquisition or construction of capital assets and for the purchase of intangible assets, } \\
\text { as well as capital transfers to domestic and foreign recipients. Loans and advances for } \\
\text { capital purposes are also included. }\end{array}$ \\
\hline Government Expenditure on Education & $\begin{array}{l}\text { Government expenditure on education includes expenditure on services provided to } \\
\text { individual pupils and students as well as expenditure on services provided on acollective } \\
\text { basis. Expenditure on education is allocated to preprimary and primary education, } \\
\text { secondary education, postsecondary nontertiary education, tertiary education, } \\
\text { subsidiary services to education, education not definable by level, and research and } \\
\text { development (R\&D) education. } \\
\text { For economies following the IMF's Government Finance Statistics } 1986 \text { framework, the } \\
\text { indicator refers to government expenditure on education affairs and services. }\end{array}$ \\
\hline Government Expenditure on Health & $\begin{array}{l}\text { Government expenditure on health includes expenditure on services provided to } \\
\text { individual persons and services provided on a collective basis. Expenditure on health is } \\
\text { allocated to medical products, appliances, and equipment; outpatient services; hospital } \\
\text { services; public health services; R\&D health; and health not elsewhere classified. } \\
\text { For economies following the Government Finance Statistics } 1986 \text { framework, the } \\
\text { indicator refers to government expenditure on health affairs and services. }\end{array}$ \\
\hline Government Expenditureon Social Protection & $\begin{array}{l}\text { Government expenditure on social protection includes expenditure on services and } \\
\text { transfers provided to individual persons and households as well as expenditure on } \\
\text { services provided on a collective basis. Expenditure on social protection is allocated to } \\
\text { sickness and disability, old age, survivors, family and children, unemployment, housing, } \\
\text { social exclusion not elsewhere classified, and R\&D social protection. } \\
\text { For economies following the IMF's Government Finance Statistics } 1986 \text { framework, } \\
\text { the indicator refers to government expenditure on social security and welfare affairs } \\
\text { and services. }\end{array}$ \\
\hline
\end{tabular}




\begin{tabular}{|c|c|}
\hline Indicator & Definition \\
\hline \multicolumn{2}{|l|}{ Governance } \\
\hline Cost of Business Start-Up Procedure & $\begin{array}{l}\text { Cost to register a business normalized by presenting it as a percentage of GNI per } \\
\text { capita. It includes all official fees and fees for legal or professional services if such } \\
\text { services are required by law or commonly used in practice. Fees for purchasing and } \\
\text { legalizingcompanybooks are included ifthese transactions are required bylaw. Although } \\
\text { value-added tax registration can be counted as a separate procedure, value-added tax } \\
\text { is not part of the incorporation cost. Company law, commercial codes, and specific } \\
\text { regulations and fee schedules are used as sources for calculating costs. In the absence } \\
\text { of fee schedules, a government officer's estimate is taken as an official source. In the } \\
\text { absence of a government officer's estimate, estimates by incorporation experts are } \\
\text { used. If several incorporation experts provide different estimates, the median reported } \\
\text { value is applied. In all cases, the cost excludes bribes. }\end{array}$ \\
\hline Time Required to Start Up a Business & $\begin{array}{l}\text { Number of calendar days needed to complete the procedures to legally operate a } \\
\text { business. If a procedure can be accelerated at additional cost, the fastest procedure, } \\
\text { independent of cost, is chosen. }\end{array}$ \\
\hline Corruption Perceptions Index & $\begin{array}{l}\text { Ranks countries and territories based on how corrupt or otherwise their public sector is } \\
\text { perceived to be. It is a composite index-a combination of polls-drawingon corruption- } \\
\text { related data collected by a variety of reputable institutions. The index reflects the views } \\
\text { of observers from around the world, including experts living and working in the countries } \\
\text { and territories evaluated. From } 2000 \text { to } 2011 \text {, scores ranged from } 10 \text { (highly clean) to } \\
0 \text { (highly corrupt). From } 2012 \text { onwards, calculation of the score has used an updated } \\
\text { methodology and is now presented on a } 100 \text { (very clean) to } 0 \text { (highly corrupt) scale. } \\
\text { Due to this difference in methodology, scores from years prior to and including } 2011 \\
\text { should not be compared with scores from } 2012 \text { onward. A country's rank indicates its } \\
\text { position relative to the other countries or territories included in the index. It is important } \\
\text { to keep in mind that a country's rank can change simply because new countries enter } \\
\text { the index or others drop out. }\end{array}$ \\
\hline
\end{tabular}




\section{Global Value Chains}

\begin{tabular}{|c|c|}
\hline Indicator & Definition \\
\hline Business Services Sector & $\begin{array}{l}\text { Consists of the sectors: Sale, Maintenance, and Repair of Motor Vehicles and Motorcycles; } \\
\text { Retail Trade, Except of Motor Vehicles and Motorcycles; Repair of Household Goods; Hotels and } \\
\text { Restaurants; Inland Transport; Water Transport; Air Transport; Other Supporting and Auxiliary } \\
\text { Transport Activities; Activities of Travel Agencies; Post and Telecommunications; Financial } \\
\text { Intermediation; Real Estate Activities; Renting of Machinery and Equipment; and Other Business } \\
\text { Activities. }\end{array}$ \\
\hline $\begin{array}{l}\text { Domestic Value-Added via Backward } \\
\text { Linkages (DVA_B) }\end{array}$ & $\begin{array}{l}\text { Value-added that is originated from all domestic sectors that are embedded in the exports of a } \\
\text { particular sector in the source economy, regardless of where it is ultimately absorbed. }\end{array}$ \\
\hline $\begin{array}{l}\text { Domestic Value-Added via Forward } \\
\text { Linkages (DVA_F) }\end{array}$ & $\begin{array}{l}\text { Domestic value-added that is exported via all forward linkages, regardless of where it is ultimately } \\
\text { absorbed. Alternatively, this refers to domestic value-added that is originated from a particular } \\
\text { sector and ultimately embodied in exports (regardless of where these exports are finally consumed). }\end{array}$ \\
\hline $\begin{array}{l}\text { Domestic Value-Added Absorbed } \\
\text { Abroad (VAX_G) }\end{array}$ & All domestic value-added embodied in gross exports and ultimately absorbed abroad. \\
\hline $\begin{array}{l}\text { Domestic Value-Added First Exported } \\
\text { then Returned Home (RDV_B) }\end{array}$ & $\begin{array}{l}\text { Domestic value-added that is first exported, but then returned to the home economy for domestic } \\
\text { consumption. This would happen, for example, when the Philippines exports electronic parts to } \\
\text { the People's Republic of China for the final assembly of laptops, which are then returned to the } \\
\text { Philippines for consumer purchase. }\end{array}$ \\
\hline Foreign Value-Added (FVA) & Imported inputs of goods and services in the overall exports of an economy. \\
\hline Global Value Chains (GVCs) & $\begin{array}{l}\text { A network of interlinked stages of production for goods and services that straddles international } \\
\text { borders. Typically, a GVC involves combining imported and domestically produced goods and } \\
\text { services into products that are then exported for use as intermediates in the subsequent stage } \\
\text { of production or as final consumption products. }\end{array}$ \\
\hline GVC Participation & $\begin{array}{l}\text { There are various ways to measure the participation of economies in GVCs. A simple metric is } \\
\text { the share of foreign value-added in total exports. It reflects the extent to which an economy uses } \\
\text { foreign inputs in producing exports. A more rigorous measure is vertical specialization. }\end{array}$ \\
\hline Low-Technology Industrial Sector & $\begin{array}{l}\text { Consists of the sectors: Food, Beverages, and Tobacco; Textiles and Textile Products; Leather, } \\
\text { Leather Products, and Footwear; Wood and Products of Wood and Cork; Pulp, Paper, Paper } \\
\text { Products, Printing, and Publishing; Rubber and Plastics; Manufacturing, NEC; Recycling; Electricity, } \\
\text { Gas, and Water Supply; and Construction. }\end{array}$ \\
\hline $\begin{array}{l}\text { Medium- and High-Technology } \\
\text { Industrial Sector }\end{array}$ & $\begin{array}{l}\text { Consists of the sectors: Coke, Refined Petroleum, and Nuclear Fuel; Chemicals and Chemical } \\
\text { Products; Other Nonmetallic Minerals; Basic Metals and Fabricated Metals; Machinery, NEC; } \\
\text { Electrical and Optical Equipment; and Transport Equipment. }\end{array}$ \\
\hline Personal and Public Services Sector & $\begin{array}{l}\text { Consists of the sectors: Public Administration and Defense; Compulsory Social Security; Education; } \\
\text { Health and Social Work; Other Community, Social, and Personal Services; and Private Households } \\
\text { with Employed persons. }\end{array}$ \\
\hline Primary Sector & Consists of the sectors: Agriculture, Hunting, Forestry, and Fishing; and Mining and Quarrying. \\
\hline Pure Double-Counted Terms (PDC) & $\begin{array}{l}\text { In a GVC, some goods or services may cross the same national border on three or } \\
\text { more occasions. }\end{array}$ \\
\hline Revealed Comparative Advantage (RCA) & $\begin{array}{l}\text { Traditional method: Introduced by Bela Balassa, this index represents the relative advantage an } \\
\text { economy has in the export of any given good or service. An economy is said to have an RCA in a } \\
\text { product if it exports more than its "fair share", or a share that is equal to or greater than the share } \\
\text { of the product to total world trade. } \\
\text { Value-added method: Based on Wang, WeiandZhu (2018), this measure is similar to the traditional } \\
\text { RCA method, except that it is based on DVA_F rather than gross exports. An economy is said to } \\
\text { have an RCA in a product if its DVA_F matches or exceeds the share of the product's DVA_F in } \\
\text { total global value-added in exports. }\end{array}$ \\
\hline $\begin{array}{l}\text { Value-Added Exports via Backward } \\
\text { Linkages (VAX_B) }\end{array}$ & $\begin{array}{l}\text { Value-added that is originated from all domestic sectors and ultimately absorbed abroad via the } \\
\text { exports of a particular sector in the source economy. For example, the domestic value-added } \\
\text { of Japanese automobile exports includes that of all Japanese sectors (e.g., business services, } \\
\text { computers) used as inputs. }\end{array}$ \\
\hline
\end{tabular}




\begin{tabular}{|l|l|}
\hline Indicator & \multicolumn{1}{c|}{ Definition } \\
\hline $\begin{array}{l}\text { Value-Added Exports via Forward } \\
\text { Linkages (VAX_F) }\end{array}$ & $\begin{array}{l}\text { Domestic value-added that is originated from a particular sector and ultimately absorbed abroad } \\
\text { via the exports of all sectors in the source economy. For example, besides direct export, the } \\
\text { value-added of the Japanese business services sector may be exported as an input to Japanese } \\
\text { automobiles. This indicator is useful in understanding the contribution of a given sector to the } \\
\text { economy's aggregate exports. }\end{array}$ \\
\hline
\end{tabular}




\section{Key Indicators for Asia and the Pacific 2019}

The Key Indicators for Asia and the Pacific 2019, the 50th edition of this series, includes the latest available economic, financial, social, and environmental indicators for the 49 regional members of the Asian Development Bank. It presents the latest key statistics on development issues concerning the economies of Asia and the Pacific to a wide audience, including policy makers, development practitioners, government officials, researchers, students, and the general public.

Part I of this issue presents the current status of economies of Asia and the Pacific with respect to the Sustainable Development Goals based on selected indicators from the global indicator framework. Part II comprises statistical indicators that capture economic, financial, social, and environmental developments. Part III presents key statistics and stylized facts on the phenomenon of global value chains.

This publication is available at www.kidb.adb.org along with the country tables that are only available online.

\section{About the Asian Development Bank}

ADB is committed to achieving a prosperous, inclusive, resilient, and sustainable Asia and the Pacific, while sustaining its efforts to eradicate extreme poverty. Established in 1966, it is owned by 68 members -49 from the region. Its main instruments for helping its developing member countries are policy dialogue, loans, equity investments, guarantees, grants, and technical assistance. 